DEPARTMENT OF THE INTERIOR

Frankin K. Lane, Secretary

United States Geological Survey

George OTIS Smith, Director

Professional Paper 101

\title{
GEOLOGY AND PALEONTOLOGY
}

OF THE

\section{RATON MESA AND OTHER REGIONS IN \\ COLORADO AND NEW MEXICO}

PAPERS BY

WILLIS T. LEE

AND

F. H. KNOWLTON

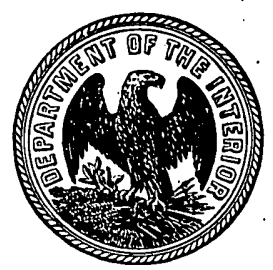

WASHINGTON

GOVIRNMENT PRINTING OFFIOE

1917 



\section{CONTENTS.}

Geology of the Raton Mesa and other regions in Colorado and New Mexico, by W. T. Lee.

Chapter 1. Introduction.

Need of investigation....

Purpose of investigation....................

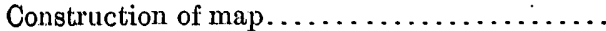

Methods of observation.....................

Principles of correlation....................

Physical versus paleontologic criteria...... Cretaceous quiescence versus Tertiary violence...........................

. Cause versus results of change............

Physiography, climate, and land life......

Diastrophism........................

Conclusions in brief......................

Previous investigations....................

Bibliography

Chapter 2. General geography and geology.......

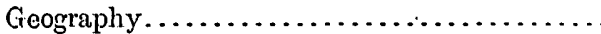

Location and extent of the Raton Mesa

region.............................

Access.............................

Relation of coal fields to mountain and

plain............................

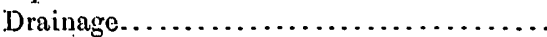

Topography...........................

Character of rock exposures.............

Geology

General features..........

Pre-Cretaceous formations................

Cretaceous (?) system.................

Morrison formation................

Cretaceous system.....................

Purgatoire formation and Dakota sandstone.........................

Benton, Niobrara, and Pierre formations.........................

Trinidad sandstone................. Definition .................. Character and continuity........ Age.......................

Vermejo formation...................

Name and type section...........

Thickness and extent.............

Character.....................

Sandstone. ................

Shale......................

Coal......................

Summary.................

Derivation of sediments.........

Fossils.

Post-Cretaceous unconformity....

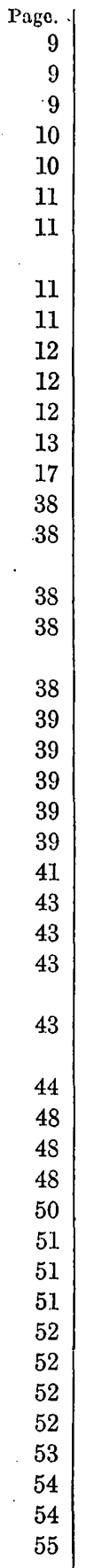

Chrapter 2. General geography and geology-Con. Geology-Continued.

Tertiary system.......................

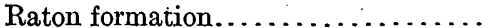

Name and type locality ..........

Thickness and extent............

Character and distribution.......

Range.....................

Basal conglomerate.

Lower coal zone.............

Cliffs or "barren series"......

Upper coal zone..............

Measure of post-Cretaceous erosion.

Local unconformities...........

Fossils and age relations...........

Poison Canyon formation..............

Geologic history .......................

Pre-Paleozoic time...................

Paleozoic events......................

Mesozoic events......................

Triassic and Jurassic time ............

Cretaceous time....................

Post-Cretaceous uplift and erosion.........

Cenozoic events.......................

Tertiary seclimentation and erosion..

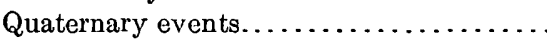

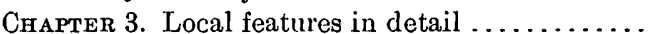

Method of presentation....................

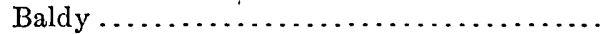

Baldy to Ute Park.........................

Ute Park..............................

Cimarron River...........................

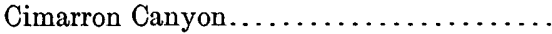

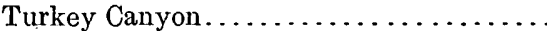

Cimarron..........................

Cimarron to Van Bremmér Canyon...........

Ponil Canyon.........................

Encenoso Creek..........................

Cerrososo Canyon......................

Van Bremmer Creek....................

Dawson area...........................

Dawson...........................

Saltpeter Creek.........................

Saltpeter Mountain. . . . . . . . . . . . . .

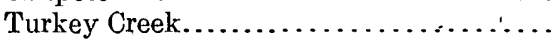

Koehler area

Curtis Creek.................... $\quad 89$

Koehler............................ 90

Van Houten area....................... 94

Van Houten......................... 94

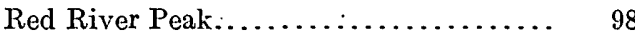


CONTENTS.

Chapter 3. Local features in detail-Continued.

Canadian Canyon and Gardiner...............

General features......................

Cottonwood Canyon...................

Sugarloaf Mountain

North wall of Canadian Canyon to Gardiner

Dillon Canyon area.....................

General features......................

Blossburg...........................

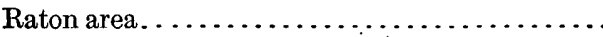

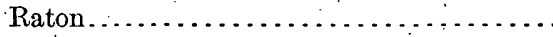

Bartlett Mesa........................

Sugarite Canyon.....................

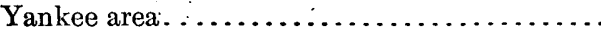

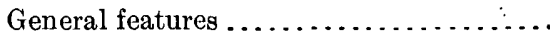

Mouth of Sugarite Canyon..............

Yankee mines...........................

Johnson Mesa.........................

Horseshoe and Barilla mesas............

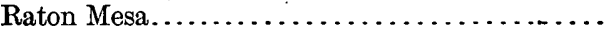

San Francisco Canyon...................

Gray Creek........................

Engle.............................

Morley dome............................

Purgatoire Valley area......................

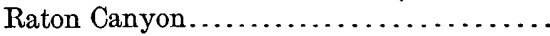

Sopris

Purgatoire Canyon. .................. 126

Trinidad,......................... 127

Powell Arroyo . . . . . . . . . . ........... 127

Bowen......................... 128

Berwind-Aguilar area.................. 130

General features..................... 130

Bowen......................... 130

Majestic......................... $\quad 131$

Berwind......................... 132

Berwind to Aguilar................. 132

Gonzales Canyon, Colo................ 133

Walsenburg area, Colo . . . . . . . . . . ...... 137

General features.................... 137

Cuchara River................... 137

Pictou and Maitland................. 139

Shumway......................... 140

Vermejo Canyon, N. Mex............... 141

General features.................... 141

Salyers Creek....................... 142

Vermejo Park....................... 143

Gonzales Canyon, N. Mex................ 148

Hogback area.......................... 148

General features.................... 148

Rito Leandro..................... $\quad 149$

San Francisco Pass.
Chapter 3. Local features in detail-Continued.

Tercio Park ........................... 152

General features.................... 152

Cuatro.......................... 153

Tercio........................... 153

Cornell............................ 156

Stonewall area........................ 156

Stonewall Gap.................. $\quad 157$

North Fork of Purgatoire River.......... 157

La Veta district..................... 158

General features.................... 158

Cuchara River..................... $\quad 159$

Chapter 4. Correlation of formations with those of

other regions......................... 162

Canon City field . . ..................... 162

Previous investigations.............. 162

Local features in detail. .............. 163

Radiant..................... 163

Bluff Springs................... 163

Coal Creek...................... 163

Rockvale...................... 164

Williamsburg.................... 165

Northern part of field............ 166

Alkali Gap..................... 166

Littell mine ..................... 167

Age relations........................ $\quad 167$

Pierre shale.................... $\quad 167$

Trinidad sandstone................ 167

Vermejo formation............. 168

Arapahoe(?) and Denver(?) formations. $\quad 168$

Summary.................... 168

Gulf region........................... 170

Colorado Springs area and Denver Basin...... $\quad 170$

Areas west of the Rocky Mountains........... 171

Field investigations............... 171

Geologic formations................... $\quad 172$

General features ............... 172

Dakota (?) sandstone. . ............ 172

Mancos shale...................... 172

Mesaverde formation................ 178

Lewis shale..................... 183

"Laramie" formation............... 183

Tertiary and later formations........ 184

Local features in detail. .............. $\quad 185$

Durango........................ 185

Monero and Dulce.............. 189

Cabezon.......................... 192

Casa Salazar..................... $194^{\circ}$

Rio Puerco field................... 195

Tijeras field...................... 198

Hagan field.................... 201

Ċerrillos field................... 206

Chapter 5. Summary of stratigraphic and structural relations............................... 218 
Fossil rloras of the Vermejo and Raton rormations of Colorado and New Mexico, by F. H. Knowlton.

Chapter 1. Introduction.........

Previous paleobotanic work. ............... Synonyms and changes of interpretation..... The Vermejo flora.

$$
\text { Stratigraphy. }
$$

General considerations..............

Species...

Floras of the Canon City and Raton Mesa fields

Floras of the Vermejo and Raton formations ....................... Vermejo and Laramie floras of the Denver Basin ................. Species transgressing the great unconformity 'elsewhere.

Biologic considerations................

Ecologic considerations..................

The Raton flora .........................

Stratigraphic considerations...............

Ecologic considerations.................

Age of the Raton formation..................

Crapryer 2. Flora of the Vermejo formation.........

Thallophyta.

Fungi..............................

Algae.

Pteridophyta.........................

Filicaies.

Polypodiaceae..................

Osmundaceae....................

Gleicheniaceae..................

Schizaeaceae ....................

Spermatophyta.........................

Coniferrles.........................

Brachyphyllaceae................

Pinaceae.......................

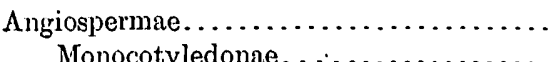

Monocotyledonae................

Pandanales....................

Typhaceae...............

Palmaceae..................

Scitaminales.................

Cannaceae.................

Dicotyledonae......................

Juglandales. .................. Juglandaceae..............

Myricales...................... Myricaceae.................

Salicales................... Salicaceae................

Fagales...................... Fagaceae................

Urticales. . . . . . . . . . . . . . . Moraceae................. Credneriaceae . .............

Ranales..................... Iauraceae................ Magnoliaceae..............
Page.

223

223

226

226

226

226

227

230

230

231

232

232

233

235

235

239

240

242

242

242

242

244

244

244

246

247

248

249

249

249

253

253

253
253

253

254

254 .

255

255

256

256

257.

257

259

259

259

259

267

268

268

269
Chapter 2. Flora of the Vermejo formation-Con. Spermatophyta-Continued.

Angiospermae-Continued.

Dicotyledonae-Continued.

Rosales....................

Platanaceae?............

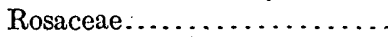

Papilionaceae

Sapindales. . . . . . . . . . . . . . $\quad 271$

Celastraceae............ .271

Rhamnales................ 271

Rhamnaceae............. 271

Malvales.................... 272

Sterculiaceae............. 272

Vitaceas................. 274

Ebenales....................... 275

Ebenaceae............... 275

Gentianales.................. 275

Oleaceae?............... 275

Rubiales.................. 275

Caprifoliaceae........... 275

Incertae sedis......................... 278

Chapter 3. Flora of the Raton formation....... 284

Pteridophyta....................... 284

Filicales........................... 284

Polypodiaceae.................. 284

Schizaeaceae.................. 285

Spermatophyta......................... 286

Angiospermae..................... 286

Monocotyledonae.............. 286

Naiadales.................. 286

Alismaceae?............. 286

Graminales................ 287

Poaceae............... 287

Arecales................. 287

Palmaceae................ 287

Dicotyledonae................... 292

Juglandales.................. 292

Juglandaceae. . . . . . . . . . . . 292

Salicales.................... 296

Salicaceae.............. 296

Fagales..................... 297

Fagaceae................ 297

Urticales. . . . . . . . . . . . . . . 300

Ulmaceae............. 300

Moraceae .............. 300

Aristolochiales. . . . . . . . . . . 307

Aristolochiaceae......... 307

Ranales................. 307

. Nymphaeaceae.......... 307

Magnoliaceae............ 309

Lauraceae................. 316

Rosales................... $\quad 320$

Hamamelidaceae........... 320

Platanaceae............. 321

Rosaceae............... 325

Leguminosae. . . . . . . . . 326 
CONTENTS.

Chapter 3. Flora of the Raton formation-Contd. Spermatophyta-Continued.

Angiospermae-Continued.

Dicotyledonae-Continued.

Geraniales....................

Rutaceae................. 328

Euphorbiaceae?............ 328

Sapindales.................. 328

Anacardiaceae............. 328

Celastraceae............. 329

Aceraceae. . . . .......... $\quad 330$

Sapindaceae............. 330

Rhamnales ................. $\quad 332$

Rhamnaceae............... 332

Malvales................. 336

Tiliaceae................ 336

Sterculiaceae..............

Vitaceae.................

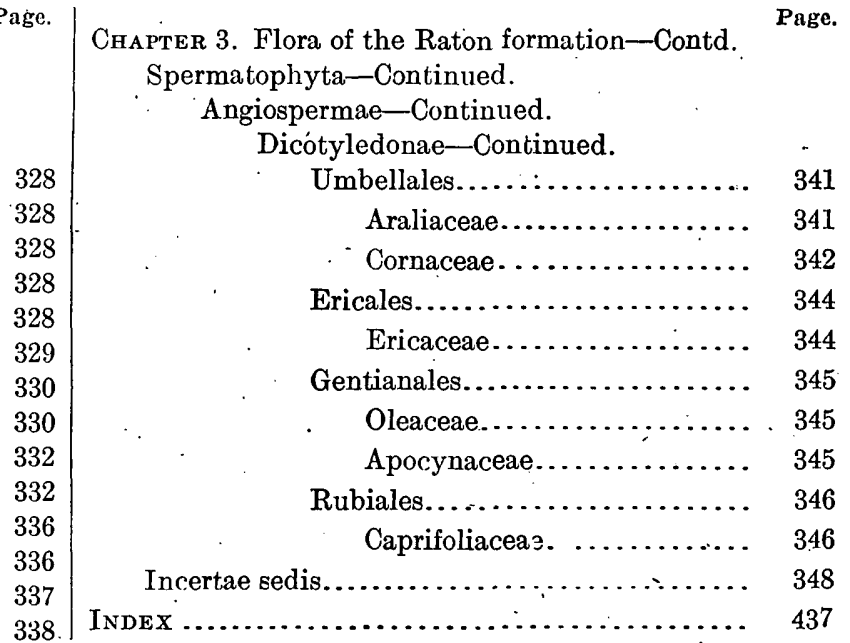




\section{ILLUSTRATIONS.}

Padte I. Map of the Raton Mesa region, Colorado and New Mexico..... In pocket.

II. Sections along lines A-B to I-J, Plate I, map of Raton Mesa region................ In pocket.

III. Breaks of the mesa east of Dawson, N. Mex.....................

IV. Sections showing relations of the Trinidad sandstone to the Pierre shale and Vermejo formation....

$\mathrm{V}$. Short columnar sections in the Raton coal field, N. Mex., between Ute Park and Sugarite Canyon. .

VI. Cliffs in the north wall of Cimarron Canyon, N. Mex...............

VII. A, Unconformity between the Vermejo and Raton formations in Ponil Canyon, N. Mex.; $B$, North wall of canyon at Koehler, $N$. Mex.......................

VIII. Rocks near Van Houten, N. Mex..

IX. Structural relations of formations at Willow mine, Van Houten, $\mathrm{N}$. Mex.: $A$, North wall of canyon at the mine; $B$, One of the openings of the mine..............

$\mathrm{X}$. Columnar sections in the Raton coal field, N. Mex.................

XI. $A$, Goat Fill at Raton, N. Mex.; $B$, Cliff in north slope of Johnson Mesa south of Yankee, N. Mex.

XII. Columnar sections in the eastern part of the Trinidad coal field, Colo.........................

XIII. South wall of Purgatoire Canyon, near Sopris, Colo..............

XIV. $A$, A characteristic outcrop of the Trinidad sandstone about 4 miles north of Trinidad, Colo.: $B$, Relation of the Vermejo to neighboring formations in the north wall of Purgatoire Canyon, near Sopris, Colo.

38

48

56

68

XV. Geologic sections and drill records in the Trinidad coal field, Colo..

XVI. A, Structural relations shown in the north wall of Santa Clara Canyon, Colo., at the eastern margin of the Trinidad coal field; $B$, Ëastern margin of the Trinidad coal field, near Shumway, Colo......
Plate XVII. Columinar sections in the western part of the Raton coal field, $\mathrm{N}$. Mex......................

XVIII. Coal in the basal conglomerate of the Raton formation, Vermejo Canyon, N. Mex.: $A$, Irregularly shaped masses of coal; $B$, Rounded pebble of coal surrounded by pebbles of siliceous rock; $C$, Pebbles of coal embedded in conglomeratic sandstone

XIX. $A$, North wall of Tercio Park, Cornell, Colo.; $B$, Hogback in Vermejo Gap, N. Mex............

XX. The Stonewall on Purgatoire River.

XXI. Map of Canon City coal field, Colo..........................

XXII. Columnar sections measured in the Canon City coal field, Colo.

XXIII. Escarpment at the eastern margin of Canon City coal field, worth of Rockvale, Colo.

XXIV. Rockvale sandstone member of the Vermejo formation near Brookside, Colo.....................

XXV. $A$, Lewis shale and "Laramie" formation near Dulce, N. Mex.; $B$, Mancos shale and the basal sandstone of the Mesaverde formation near El Vado, N. Mex.; $C$, Top of Mancos shale and basal sandstone of the Mesaverde formation at Cabezon, N. Mex........

XXVI. $A$, Cabezon Butte, a large volcanic plug from Cabezon, N. Mex.; $B$, Volcanic plug about a mile west of Casa Salazar; N. Mex; C, Volcanic plug north of Casa Salazar, N. Mex.....................

XXVII. $A$, Punta de la Mesa, near San Ygnacio, N. Mex.; B, West slope of Prieta Mesa, about 5 miles south of Casa Salazar, N. Mex.; $C$, Valley of Rio Puerco north of San Francisco, N. Mex.

XXVIII. $A$, Coal-bearing portion of Mesaverde formation at Hagan, $\mathrm{N}$. Mex.; $B$, Fossil wood in Tertiary deposits near Pina Vititos, N. age.

142 
Plate XXIX. $A$, Top of Mancos shale and basal sandstone of Mesaverde formation west of Madrid, N. Mex.; $B$, Eastward - dipping formations north of Galisteo Creek, N. Mex.; $C$, Sandstone concretions in the Galisteo sandstone, near Madrid, N. Mex ................... 214

XXX-LIII. Flora of the Vermejo formation. $352-375$

LIV-CIII. Flora of the Raton formation... 376-435

Figure 1. Pierre shale and younger formations in Cimarron Canyon, N. Mex......... . 72

2. Point of mesa near Koehler, N. Mex., showing the relations of the rock formations ...

-3. Sketch showing unconformity at the base of the Raton formation in Willow mine, near Van Houten, N. Mex.

4. Diagrams showing irregularities in coal bed in Willow mine, near Van Houten, N. Mex.

5. Fault in coal of Willow mine near:Van Houten, N. Mex................

6: Sketch showing unconformity at the base of the Raton formation in Willow mine near Van Houten, N. Mex. . . . .

7. Sketch showing unconformity at the base of the Raton formation near Red River Peak, N. Mex...............
Page.

Figure 8. Sketch showing unconformity at the base of the Raton formation in Cottonwood Canyon, N. Mex...........

9. Columnar sections measured in the La Veta district, Colo.................

10. Sketch section showing the unconformable relations between the Vermejo and Poison Canyon formations near Oakdale, Colo . . . ...............

11. Diagram showing correlation of formations in the coal fields east of the Rocky Mountains with those of the Gulf region.

12. Map of parts of Colorado, New Mexico, Utah, Arizona, and Wyoming, showing the positions of the coal fields described

Page.

100

158

16. Sketch section through the Raton Mesa and San Juan River regions at the Colorado-New Mexiço boundary, showing the occurrence of a postCretaceous unconformity on both sides of the Rocky Mountains....... 


\section{GEOLOGY OF THE RATON MESA AND OTHER REGIONS IN COLORADO AND NEW MEXICO. \\ By Wrilis T. Lee.

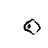

CHAPTER 1.-INTRODUCTION.

NEED OF INVESTIGATION.

For many years evidence has been accumulating that coal occurs at serieral horizons in the Cretaceous strata of the Rocky Mountain region. Coal-bearing formations once supposed to be of Laramie age have, on further examination, been referred to other horizons; and the question has now arisen whether the coal measures of the Raton Mesa region, which have long been called Laramie, are equivalent in age to the so-called Laramie of other fields and especially to the typical Laramie of the Denver Basin. The Raton Mesa region is about 80 miles from the Denver Basin, one small field, the Canon City coal field, lying between. It is also about 90 miles from the San Juan Basin, west of the Rocky Mountains, in which there are two coal-bearing formations, the Mesaverde and the "Laramie." The "Laramie" of the San Juan Basin has been regarded by some geologists as essentially equivalent to the Laramie of the Denver Basin, but the validity of this correlation has recently been questioned. ${ }^{235}$ (The "superior" figures here and elsewhere refer to entries in the bibliography, pp. 17-37.)

Hayden, Lesquereux, and others regarded all the coal-bearing rocks of the Raton Mesa region as Tertiary, but later geologists have regarded them as Cretaceous and have correlated them with the Laramie of the Denver Basin, although it has been known for many years that most of the fossil plants from this region are specifically different from those found in the Laramie of the Denver region. No satisfactory explanation of this discrepancy was suggested until the writer ${ }^{215}$ announced that the so-called Laramie of the Raton field is divisible into two formations, the lower of which contains a flora that is older than that of the Laramie of the Denver Basin and the. upper a post-Laramie flora. About the same time Washburne ${ }^{226}$ collected from the lower group of coal-bearing rocks in the Canon City field, which were then supposed to be of Laramie age, fossil plants that Knowlton regarded as older than Laramie. Several questions then became pertinent: Are the two coalbearing formations of the Raton field widely separated in time or is the unconformity local? Is the lower formation to be correlated with the Laramie of the Denver Basin or with the Mesaverde of the San Juan Basin or with neither, and is it to be correlated with a part or with all of the coal measures of the Canon City field? Is the upper formation equivalent in age to the Denver or to the Arapahoe formation or to neither?. In order to answer these and similar questions the investigations described in this paper were undertaken.

\section{PURPOSE OF INVESTIGATION.}

As the geologic relations in the Raton Mesa region are the principal object of this discussion, attention is first directed mainly to that region, its relation to the Canon City and other fields being reserved for later sections of this paper. The main purpose of the investigation was to trace, if possible, the unconformity found in the coal measures of the Raton field ${ }^{215}$ throughout the Raton Mesa region and to. collect evidence of its geologic significance. This led to several lines of research. Sections were measured for the purpose of determining whether the irregularities in thickness of the lower coal measures are due mainly to deposition 'or mainly to erosion followirg deposition, and data were collected 
to determine whether these rocks were consolidated or unconsolidated when the erosion took place. Data were also collected to determine the relative amount of erosion.

The rocks of both the upper and the lower coal measures contain great numbers of fossil plants, and large collections of them were made. The. stratigraphic position of each collection was determined, especially with reference to the unconformity, in order that the data thus obtained might be definitely applied in correlating the formations with those of other fields and in determining. the time represented by the unconformity. Some of the species found here have been described from other places; and these furnish a means of correlating the formations in which they are found with those of other fields. Others are new to science, and these are described by F. H. Knowlton. (See pp. 223-435.). The double purpose, therefore, is accomplished of making such correlations as are possible by means of previously identified species, and of establishing a new section which will be of use in future investigations. Few fossils other than plants occur in the coal measures of the Raton Mesa region, but fossil invertebrates were collected from the marine Cretaceous rocks below the coal measures in order that their evidence might be considered together with that of the plants, the lithology, and the structure in establishing the stratigraphic succession and time relations of the formations.

The results obtained in the Raton Mesa region and in the Canon City field during the season of 1910 rendered it desirable to examine in a similar manner the isolated coal fields of central and western New Mexico, in the hope of obtaining information that would lead to the correlation of the coal measures of the Raton Mesa region with those of the San Juan Basin. This was done during the summer of 1911 and the results published ${ }^{235}$ the following year. These results aid materially in accomplishing one of the principal purposes of the paper, namely in fixing the coal-bearing formations of the Raton Mesa region in their proper places in the time scale.

\section{CONSTRUCTION OF MAP.}

The map of the Raton Mesa region used in this paper has been constructed from Land Office data, United States Geological Survey topographic sheets, mine maps, and railroad and private surveys. The base for the Colorado portion was constructed from the township plats of the General Land Office by G. B. Richardson ${ }^{225}$ and the topography of this portion was adapted from the atlas sheets of the United States Geological Survey. The base for the New Mexico portion outside the Maxwell land grant was constructed from the township plats of the General Land Office and from private surveys, and that for the portion inside the grant was adapted from the map of Colfax County, N. Mex., and from private surveys, the records of which are in the possession of the St. Louis, Rocky Mountain \& Pacific Coal Co., whose headquarters are at Raton, N. Mex. No detailed topographic maps of this portion of New Mexico were available at the time of investigation, although topographic work has been oarried on near Raton since that time, and the only topography available for the main part of the Raton field was that shown on a manuscript sketch map on the scale of 12 miles to the inch. From this map the topography shown on the map in this paper has been adapted. For the reasons just stated, the topography of the New Mexico portion, though it gives the general configuration of the field, is by no means so accurate as that of the Trinidad field. (See Pl. I, in pocket.)

\section{METHODS OF OBSERVATION.}

In the absence of topographic maps sufficiently detailed for the purposes of the investigation it was necessary to devise some way of showing graphically the structural relation of the lower coal measures (Vermejo formation) to the upper coal measures (Raton formation). (See pp. 51, 56.) This was done by measuring. sections at short intervals along the outcrop and platting them to scale for comparison. Those in the eastern part of the region, where the rocks lie nearly horizontal and outcrop in the steep sides of mesas, were measured with Locke level, and are shown in the several plates of sections. (See Pls. V, X, XII, XV, XVII.) A large number of diamond-drill records were also obtained. Some of these are shown in the plates of sections, but most of them were furnished by coal companies which stipulated that. their details should not be made known.

Along the western margin of the region, where the rocks are upturned at the outcrop, 
considerable care was necessary in order to obtain the true thickness. On steep slopes the vertical distances were measured by Locke level and records were kept of the dip and strike, the direction of the measurement, and the angle of the surface slope. From these data were constructed the sections as published. On gentle slopes the horizontal distances were measured with tapeline as an additional check in computing true thicknesses. The writer believes that in this way the sections were made sufficiently accurate to show adequately the variations in the thickness of the Vermejo formation, and to show rather convincingly that the surface upon which the Raton formation was deposited was far from boing a plain such as would be expected to result from continuous deposition of sediments, or, in other words, that it was a surface of erosion. (See sections in Pl. II, in pocket.)

The coal beds throughout the Trinidad field and to a less extent those in the Raton field have, been extensively prospected for many years and have been mined productively in many places. The success of the investigation described in this paper is very largely due to this development. Many important faots have been obtained from mine maps and records, from surveys of coal lands, and from records of drill holes and mine shafts that show the number, thickness, and locations of the coal beds. A large proportion of the fossil plants on which the correlations of the coal measures depend were obtained from the mines.

\section{PRINCIPLES OF CORRELATION.}

Some of the conclusions reached by the writer of this paper differ radically from those held by some geologists and depend for their validity on the interpretation placed on the observed phenomena. For this reason it may be well briefly to state some of the fundamental principles that have governed the writer in the placing of the Cretaceous-Tertiary boundary. These are probably so well known that little need be said of them.

Physical versus paleontologic criteria.-The conflict botween the structuralist and the paleontologist is nearly as old as the science of geology, and until the several lines of evidence are less conflioting than they are at present, harmony in geologic classification seems hopeless. Each thinker must weigh the evidence and decide for himself. Geikie said of the Cretaceous-Tertiary boundary of. Europe that "the lithologic sequence, being the more obvious, was first established before it was confirmed and extended by a recognition of the value of the evidence of organic remains." During the last century the study of organic remains as a means of determining the limits of geologic time divisions has received more attention than lithologic sequence. Recently, however, emphasis is being laid on structure and other physical phenomena. Chamberlin, Ulrich, and others are emphasizing this in America and Haug and others in Europe. It is significant in this connection to note that Haug places the base of the Tertiary below the Montien because of an unconformity there in spite of certain Cretaceous forms of life contained in the Montien.

Cretaceous quiescence versus Tertiary violence.-There is no evidence of any notable orogenic movement during the Cretaceous period in the area described in this paper. So far as crustal movements are concerned it was a period of inaction. But in this same region the Tertiary period was one of great orogenic and epirogenic movements, of great changes in the physiographic conditions of the continent, and of oonsequent changes in climite and life. The writer maintains that the disturbance which' brought a long period of quiescence to a close and inaugurated a new order of things is more significant in determining the beginning of a new period than later disturbances which are often more plainly recorded. He therefore maintains that in the area described in this paper the first unconformity above rocks of undoubted Cretaceous age marks the proper Cretaceous-Tertiary boundary. In this respect he differs from some geologists, who seem to placie emphasis on the culmination rather than on the inception of orogenic movement.

Cause versus results of change.-In determining the point of separation between Cretacoous and Tertiary time the cause of the change in physiographic conditions, whether it can be determined or not, is important, for it must precede any obvious result. This cause was operative long before the oldest Tertiary sediments were laid down. The Cretaceous sea had been mainly or entirely expelled from the interior of North America. Mountains had been 
upheaved in the areas abandoned by the sea, and these had been deeply eroded. For these reasons the writer maintains that some of the time represented by the post-Cretaceous unconformity is a part of Tertiary time and that Tertiary rocks may yet be found that are older than those of the Raton formation. (Some geologists urge the recognition in the Rocky Mountain region of a group of formations intermediate between Cretaceous and Tertiary. If their suggestion is adopted the later part of the time represented by the post-Cretaceous unconformity should constitute the first epoch of the new period.)

Physiography, climate, and land life.-The great changes in North America that resulted in the withdrawal of the sea and the upheaval of mountains in its place naturally caused great changes in climate, and therefore in plant and animal life. It is not to be expected, however, that the changes would be accomplished suddenly, or in all places at the same time. Hardy types would survive for a time or adapt themselves to the new conditions. Others would emigrate and their places be taken by immigrants. It is probable that the changes in climate would affect the plants and the land animals earlier than the aquatic forms. Applying this principle to the problem of the Cretaceous-Tertiary boundary, it is found that the unconformity here described as the delimiting plain marks a conspicuous change in the plant life, and that the first part of the succeeding period witnessed the extinction of the dinosaurs, one of the dominant types of Cretaceous time, and the introduction of the modern mammalian types.

Diastrophism.--The principles of diastrophism that have recently been elucidated by Chamberlin, Ulrich, and others, and that seem to be rapidly gaining ground as criteria for an ultimate basis of time divisions, are especially applicable in intercontinental correlation of late Cretaceous and early Tertiary formations. The general withdrawal of oceanic waters from continental areas at the close of the Cretaceous seems to indicate a cause world-wide in its effect, and therefore to indicate that the withdrawal of the sea from Europe: and from America was synchronous. If further observation establishes this synchronism a means will be afforded of more exact intercontinental correlation than is possible by any class of organisms. Applying this principle to the Cretaceous-Tertiary boundary of the West, we find that although some of the vertebrates, notably the dinosaurs, and some of the invertebrates, mostly of fresh-water type, stand in opposition, as now.interpreted by some geologists, the evidence of diastrophism is in perfect accord with that of the fossil plants and mammals.

\section{CONCLUSIONS IN BRIEF.}

The principal conclusions arrived at in this paper are as follows:

The coal-bearing rocks of the Raton Mesa region, which have formerly been referred to the Laramie, constitute two distinct formations, separated in time by a period of erosion.

The lower formation, to which the name Vermejo is here applied, contains a Montana flora. It is distinct from the Laramie flora of the Denver Basin, and proves that the Vermejo formation is older than Laramie, and that it is more closely related to the Mesaverde of western New Mexico than to any other formation yot examined.

The coal-bearing rocks of the Canon City field are correlated by lithology, stratigraphic position, and fossil plants with the Vermejo of the Raton Mesa region and are designated by the same-name. The character of the invertebrates found in the Vermejo of the Canon Cit $y$ field in the midst of the plant-bearing beds suggests that this formation is approximately equivalent in age to the Fox Hills of the Denver Basin.

The upper formation of the Raton Mesa region, to which the name Raton is here applied, is Eocene in age and contains a flora distinct from that of the Laramie of the Denver Basin but similar to that of the postLaramie formations of that basin and to that of the Eocene Wilcox group of the Gulf Coast.

The unconformity between the Vermejo and Raton formations represents a time interval comparable to that described as separating the Laramie from the Arapahoe of the Denver Basin. Separating, as it does, the youngest Cretaceous of the region from the oldest Eocene, it represents post-Cretaceous erosion and is correlated with the post-Laramie unconformity of the Denver Basin.

West of the Rocky Mountains, in northern New Mexico. and southern Colorado. there are 
two coal-bearing formations separated by a marine shale. The older-the Mesaverdecontains a fauna of lower Montana age and a flora similar to that of the Vermejo and other formations of Montana age. The youngerthe "Laramie" - contains in its basal member (Pictured Cliffs sandstone) a marine fauna of Montana age and in its higher beds brackishwater and fresh-water shells that seem to indicate later time. The fresh-water beds contain a flora that indicates Montana age.

The coal-bearing rocks of the Cerrillos, Hagan, Tijeras, and. Rio Puerco fields are essentially equivalent in age to the Mesaverde of the San Juan Basin.

In all the coal fields west of the mountains rocks of unquestioned Cretaceous age are.separated by an unconformity from younger beds whose age has not been determined beyond question, but which, on the basis of broad structural relations, are regarded as Tertiary by the writer, who correlates the unconformity with the post-Cretaceous unconformity of the eastern mountain front. ${ }^{245}$

\section{PREVIOUS INVESTIGATIONS.}

In the following review and in the annotated list of publications on pages 17-34 an attempt is made to bring together the principal facts that have hitherto influenced opinion regarding the age of the coal beds in the several coal fields here described. The reviews necessarily are incomplete, for the subject of the geologic age of the coal-bearing rocks of the southern Rocky Mountain areas is so intimately connected with investigations of those farther north, and also with investigations of certain noncoal-bearing formations, that a complete review would be little short of a history of Rocky Mountain stratigraphy. Many papers containing only slight reference to the fields here described are omitted, as are also papers of a purely commercial nature, but it is the writer's intention to include all the available publications that the geologist will find immediately useful in a study of the formations described. A few papers that deal especially with these formations and have had the most influence in shaping opinion regarding them are discussed below.

Coal in the Raton Mesa region was discovered in $1821^{1}$ by members of the exploring party in charge of S. H. Long. Little more than an announcement of its occurrence is found in the literature for more than 25 years, but in 1846 Emory ${ }^{6}$ examined the coal beds near Trinidad and Raton and Abert ${ }^{4}$ collected fossil plants from rocks associated with the coal near Trinidad. The coal had previously been regarded by some as indicating the western outcrop of the Carboniferous coal measures, but Bailey, ${ }^{5}$ who examined the fossil plants collected by Abert, announced that the coal beds are younger than Carboniferous. Thus the discussion of the age of the coal beds of the Raton Mesa region, which is not yet settled to the satisfaction of all geologists, began about 65 years ago.

About 1854 Hayden began a study on upper Missouri River of the coal-bearing formations which he called the Lignitic group and which he referred to the Tertiary. Later," the Tertiary age of the rocks was questioned and about the year $1865^{17,18,19}$ the coal beds of the Raton.Mesa region became involved in the discussion, probably because of Hayden's assumption that the coal beds extending from Montana to New Mexico were of essentially the same age and parts of one great group now separated by erosion. This assumption was later modified and finally proved to be false, but its influence persisted for a long time. In 1865 R. E. Owen ${ }^{16}$ found, near the top of Raton Pass, fossil plants which he states are "in shale of Cretaceous age," and three years later John L. Le Conte ${ }^{20}$ made the statement that these rocks are of "middle Cretaceous" age. He found coal-bearing rocks in the Raton field in the vicinity of Yankee, and farther west he examined them from Trinidad, Colo., southward to Cimarron, N. Mex., a distance of about 50 miles. Near Trinidad he found marine Cretaceous shells near the coal-bearing rocks, probably in the Trinidad sandstone, and fossil plants associated with the coal, which he regarded as Cretaceous, although Lesquereux later described them as Tertiary. Le Conte discussed the question of age and gave reasons for placing the coal beds of the Cerrillos field low in the Cretaceous, the coals of the Raton Mesa region in the "middle Cretaceous," those of the Denver Basin (Laramie) in the youngest Cretaceous or oldest Tertiary. Hayden's Lignitic group of the Missouri River region he conceded to be Tertiary. Apparently the observations of Le Conte and Owen had little weight with Hayden and his followers, and Lesquereux ${ }^{24,25,26}$ maintained that the fossil 
plants collected near Trinidad by Le Conte were of Eocene age. In the meantime, J. S. Newberry ${ }^{48,65}$ had studied certain coal-bearing rocks in western New Mexico and had found Cretaceous invertebrates above the coal. He had also examined the coal-bearing rocks of the Cerrillos coal field and regarded them as Cretaceous. Although the full account of his work was not published until 1876, his opinion was known and had weight with other investigators.

In 1868 , after a brief examination of the Raton Mesa region, Hayden ${ }^{29}$ referred its coal beds to the Tertiary. At about the same time Lesquereux examined and described as Tertiary the plants which Le Conte had collected near Trinidad and had referred to the Cretaceou's. He also examined the plants collected in the same field by Hayden ${ }^{24}$ and referred them to the Tertiary. Hayden accepted Lesquereux's opinion as to the age of these plants and argued from them that the Raton Mesa coal beds were Tertiary.

In 1872 Lesquereux ${ }^{28}$ described 21 fossil plants from the Raton Mesa region and 9 from the Cerrillos coal field and maintained that they indicated Tertiary age. At that time it was not known that plant-bearing rocks of both Tertiary and Cretaceous age occur in both of these fields, all the plant-bearing rocks being supposed to constitute a single formation. Such fossil localities as are mentioned for the Raton Mesa region indicate that probably all of the plants came from the upper coal measures or Raton formation, now recognized as Eocene. Furthermore, most of the original specimens described by Lesquereux prove on examination to be specifically identical with those collected more recently from the Raton formation. Those from the Cerrillos field are of Tertiary types and probably come from the Galisteo sandstone, which is now known to rest unconformably on the coal-bearing rocks but which was not definitely separated from them until $1912 .{ }^{235}$ As Lesquereux was describing Tertiary plants it is little wonder that he referred the rocks containing them to the 'Tertiary. But the evidence of the plants seems to have had little weight at the time, and the erroneous assumption of Hayden and others (that the coalbearing rocks east of the Rocky Mountains all belonged to one formation) prevailed; and, when the coal formations farther north were called Laramie and referred to the Cretaceous, those of southern Colorado and New Mexico were assumed to be Laramie also. It may be in place in this connection to recall Prof. Newberry's statement ${ }^{116}$ that "much undeserved discredit has fallen upon the remains of plants as criteria of the age of strata, and much mischief and confusion have followed the error of Dr. Hayden in uniting with the Laramie the totally distinct and independent Fort Union formation." The same confusion prevailed in the Denver Basin previous to 1896, when the work resulting in the Denver monograph ${ }^{133}$ proved that the Laramie is definitely separable from the Denver and Arapahoe formations: The confusion of Cretaceous and post-Cretaceous formations and the commingling of Cretaceous and Tertiary floras have persisted in southern Colorado and New Mexico to the present time. Preliminary announcements have been made by the writer, ${ }^{215}$ but the full data for the separation are presented in this paper for the first time.

During $1873 \cdot$ J. J. Stevenson ${ }^{50}$ visited the Canon City coal field and found, above some of the coal beds, marine fossils which induced him to refer the coal beds to the Cretaceous; and a year later $\mathrm{Cope}^{35}$ announced that Cretaceous dinosaurs occur in northeastern Colorado in beds which Hayden and Lesquereux had referred to the Tertiary. Hayden replied that as early às $1869^{39}$ he had pointed out that some of the coal beds of western Colorado, New Mexico, and elsewhere are of Cretaceous age and argued that since the coal-bearing rocks began to accumulate in the Cretaceous and continued into the Tertiary they should be regarded as "transition beds," but Lesquereux seems to have consistently maintained the position, based on the evidence of the fossil plants, that the coal beds of the West are all Tertiary. Cope ${ }^{34}$ about the same time attributed to Hayden essentially the same opinion that Lie Conte had expressed, namely, that the Cerrillos coal beds are older than the Canon City coals (which had been correlated with those of the Raton Mesa region), and that both were older than the Lignitic group, but stated that Hayden referred all three groups to the Tertiary. Newberry, ${ }^{46,47}$ on the other hand, maintained that all of the plant-bearing coal beds of New Mexico which he had exam- 
ined were Cretaceous, and was inclined to place all of Hayden's Lignitic group in the Cretaceous.

In 1876 Hayden $^{01,02}$ published a review of the Lignitic group, which he still referred to the Eocene and called "Lignitic or Laramie." He correlated the coal beds of the Raton Mesa fields with those of the Canon City and Denver: fields, and argued that they are transitional betwoen Cretaceous and Tertiary. It should be noted in this connection that very little was then known regarding the age of the Raton Mesa coals aside from the fact that they contained fossil leaves which Le. Conte regarded as Cretaceous and Lesquereux as Tertiary. Apparently these beds were included in the controversy over the Lignitic group principally because of the assumption that all of the coal beds along the eastern front of the Rocky Mountains were of the same age. During the same year (1876) appeared N'ewberry's delayed roport, ${ }^{05}$ in which he argued that the coal beds of northwestern New Mexico are in rocks of Cretaceous age. About the same time, also, St. John ${ }^{07}$ described the geology of the Raton conl field. He assumed, as other geologists had done, that the coal beds all belonged to one formation and followed Hayden and Lesquereux in referring them to the Tertiary. From rocks near Cimarron he collected marine invertebrates, which were said to be of Fox Hills nge ${ }^{80}$ but Fox Hills as then used included the Pierre. From these same beds were obtained most of the Pierre fossils from the Raton field named in the present paper.

In 1877 Endlich ${ }^{73}$ published a description of the coal-bearing rocks of the Raton Mesa region and referred them all to the post-Cretaceous on the mistaken assumption that the Trinidad sandstone rested unconformably on Colorndo shale, whereas it is now well known that it rests conformably on the Pierre. Hayden, ${ }^{20}$ after his early reconnaissance in this region, stated that the coal-bearing rocks rested on Cretaceous No. 2 (Benton); and Endlich appears to have accepted this statement and to have thought that he had found confirmatory evidence of its truth in certain structural relations in the Trinidad field. He was obviously in error in this, as has been proved by later investigators, but Hayden accepted this supposed unconformity as upholding his own contention that the coal beds of the Raton Mesa region are younger than Cretaceous. Conkling ${ }^{72}$ described the geology of the Raton field and noted the basal conglomerate of the Raton formation in Vermejo Canyon but attached no special significance to it.

In 1878 Lesquereux ${ }^{81}$ published his work on . the Tertiary fiorn in which he correlated the coal measures of the Cerrillos, Raton Mesa, and Canon City fields with those near Denver and elsewhere, and referred them to the Tertiary. However, the next year, J. J. Stevenson, who had previously examined the Canon City coal field and found evidence of the Cretaceous age of the coals, began a study of the Raton Mesa region and described the coal-bearing rocks as Laramie. He found above the lowest coal beds some of the same fossils that he had previousuy found associated with the coal in the Cronyon City field, and he naturally concluded that they proved the equivalency of the formations. $\mathrm{He}$ found Halymenites major Lesquereux and Cardium-like shells above the lowest coal in the Raton field and described the basal conglomerate of the Raton formation, although he failed to note its significance and seems to have confused it with the conglomerate of the Poison Canyon formation, which he observed farther north. His reference of the coal-bearing rocks to the Laramie seems to have been accepted by his contemporaries.

After Stevenson's time little advance was made in knowledge of the geology of the Raton Mesa region for about 18 years. Many brief references were made to the coal beds and many minor contributions were issued during this time (see pp. 26-29), but it was not until 1899 that any notable paper was published. . In 1899, however, R. C. Hills ${ }^{143}$ published the Elmoro folio, in which the coal-bearing rocks are all mapped as one formation and referred, without statement of reasons, to the Laramie. The Trinidad sandstone is referred to the Fox Hills and the underlying shale to the Pierre.

The Walsenburg folio ${ }^{148}$ appeared during the $\cdot$ following year and the Spanish Peaks folio ${ }^{151}$ in 1901. These folios were published by the United States Geological Survey and fixed the stamp of approval of that organization on the reference of all of the coal-bearing rocks to the Laramie. This reference was not openly challenged until the present writer ${ }^{215}$ discovered in 1908 that the coal-bearing rocks in the Raton field are separable into two unconformable 
formations. A few fossil plants collected at that time from the lower formation were regarded by Knowlton as probably older than Laramie but could not be definitely determined by him withoutmore and better material. Otherfossilplants - collected from the upper formation (Raton) (where they are more abundant and better preserved than those that had been collected up to that time from the lower or Vermejo formation) were identified by Knowlton as being closely related to those of the post-Cretaceous formations of the Denver Basin, thus corroborating the writer's conclusion, reached from a study of the stratigraphic and structural relations, that the two coal-bearing formations of the Raton field are separated by a time break of considerable magnitude.

While the writer was working in the Raton coal field G. B. Richardson ${ }^{225}$ was examining the Trinidad field. He found a conglomerate in some places within the coal-bearing rocks, and collected fossil plants from beds both above and below it. At that time, however, it had not been clearly demonstrated that this conglomerate marked an unconformity, and Richardson in his report avoided the question of the age relations and retained the old nomenclature, using the word "Laramie" in quotations.

The writer did no geologic work in the Raton Mesa region in 1909, but during the following year he began the observations described in this paper and traced the unconformity, previously found in the Raton field, around both the Raton and Trinidad coal fields, collecting fossil plants from both the Vermejo and Raton formations. These fossils are described by Knowlton in this volume (pp. 223-435).

The subdivision of the coal-bearing rocks of the Raton field into two formations was foreshadowed as early as 1877 , when A. R. Conkling ${ }^{72}$ published a geologic section, measured in Vermejo Canyon, that showed a conglomerate (the basal conglomerate of the Raton formation) about 110 feet above the top of the Trinidad sandstone. Later, Stevenson ${ }^{80}$ noted the same conglomerate and described it accurately from several places between the towns of Cimarron and Van Houten, but he seems to have confused it with the conglomerate of the Poison Canyon formation which overlies the Raton formation. However, nothing is said in these reports of the significance of this conglomerate, and its occurrence in the midst of the coal-bearing rocks seems to have made little impression on the minds of geologists who were familiar with it and to have escaped the notice of readers of the reports. Hills seems to have attached little significance to it in the Trinidad field, for he makes no mention of it in his folios. When the present writer announced that this conglomerate marked an unconformity, it was recalled that Hills, in the Spanish Peaks folio, ${ }^{151}$ had used the name "parting sandstone" for a certain bed separating two groups of coal-bearing rocks, and it was supposed that this sandstone might be the basal conglomerate. of the Raton formation. Later, however, when the conglomerate was traced around the Trinidad field, it was found at a considerable distance above the "parting sandstone." In answer to an inquiry by the writer, Mr. Hills states that his "parting sandstone" is not the conglomerate and kindly furnished the records of six drill holes in the vicinity of Hastings, all of which show the conglomerate considerably above his "parting-sandstone."

In :1912 Richardson ${ }^{234}$ announced that the Dawson arkose, a formation of recognized Eocene age, is probably equivalent to the Denver and Arapahoe formations, which have long been regarded as doubtfully Cretaceous. The following year the present writer ${ }^{238}$ announced the discovery of dinosaurs in the Dawson arkose, thus strengthening its correlation with the Denver and Arapahoe formations. At the same time Knowlton ${ }^{239}$ showed that the fossil plants correlate the Raton formation of the Raton Mesa region with the Dawson, Denver, and Arapahoe on the north and with the Eocene Wilcox group of the Gulf Coast on the south.

After the present paper was practically completed and the results had been somewhat generally made known through preliminary announcements, several papers were published dealing with various phases of one of the principal problems, viz, the position and character of the boundary between Cretaceous and Tertiary in the Rocky Mountain region. Among these may be mentioned two important contributions from the Gulf region, one by Stephenson, ${ }^{24}$ who describes a general unconformity separating Cretaceous from Tertiary beds in the Gulf States, the other by Berry ${ }^{250}$ describing the flora of the Tertiary formations of the 
Gulf region. The question was discussed for the Rocky Mountain region at the meeting of the Geological Society of America at Princeton, N. J., in $1913,{ }^{243}$ and a paper ${ }^{248}$ in which the question has a conspicuous place has since then been published by the present writer. . In preparing that paper the writer had at his disposal all the information given in the present one.

\section{BIBLIOGRAPHY.}

The following list shows the principal pubiications that contain information relative to the formations in southern Colorado and northern New Mexico here described as well as some other publications to which references are made. The arrangement is chronologic, and notes are given calling attention to information used in this paper. The absence of notes means either that the publication contains no original information or that no specific use is here made of it. The prefixed numbers are used in the text of this paper instead of footnote references. Placed as they are, in chronologic order, the publications listed constitute a brief history of the investigation of the region described.

This paper does not primarily consider the economic resources of the coal fields, so that little attention has been given to purely economic reports, but the list includes some economic papers that contain geologic information. On the other hand, it does not include many publications that make casual.reference to the coal fields but give little definite information. The list is intended to contain all publications that give real geologic information concerning the coal measures here described.

\section{1.}

1. JAmes, Edwin, Geological sketches of the Mississippi Valley: Acad. Nat. Sci. Philadelphia Jour., vol. 2, pp. 326-329, pl.

The paper is a preliminary account of Maj. Long's expedition, the full account of which was published in 1823. The existence of coal along the east front of the Rocky Mountains is announced, and coal is said to exist (p. 328) in the "southern section" (probably the Raton Mesa region).

1823.

2. JAMes, Edwin, Map of the country drained by the Mississippi; western section.

Account of an expedition from Pittsburg to the Rocky Mountains in the years 1819-20 by Maj. S. H. Long, atlas, $4^{\circ}$, Philadelphia.

$47019^{\circ}-17-2$
3. Lona, S. H., Account of an expedition from Pittsburg to the Rocky Mountains, performed in the years 1819-20; compiled by Edward James, vol. 1, 5, 503 pages; vol. 2, 442 pages, atlas, of 11 sheets, Philadelphia.

The coal formation of the Canon City field is described (p. 44), and the statement is made that - coal generally is found along the mountain front wherever the gray sandstone is met with (pp. $399,405)$.

\section{8.}

4. Abert, J. W., Report on examination of New Mexico in the years 1846-47: Rept. Sec. War, Senate Doc. 23, 1st sess., 30th Cong., pp. 3-130, 24 plates, map; Ex. Doc. No. 41, 30th Cong., 1st sess., pp. 417-546.

Coal was found near Trinidad, Colo. (p. 22), and fossil plants were collected which were later examined by Bailey. Abert had crossed the coal fields the previous year but apparently had not noted the occurrence of the coal (p. 37). Coal was found in the Cerrillos field and on the Rio Puerco. From the Rio Puerco coal beds, at Poblozon, Abert collected fossils which Bailey determined as Cretaceous (p. 547).

5. BaILEY, J. W., Notes concerning the minerals and fossils collected by Lieut. J. W. Abert while engaged in the geographical examination of New Mexico: Rept. Sec. War, Senate Ex. Doc. No. 23, 30th Cong., 1.st sess., pp. 131-132; 3 pls.; Ex. Doc. No. 41, 30th Cong., 1st sess., pp. 547-548. ReviewedAm. Jour. Sci., 2d ser., vol. 6, pp. 389-392.

The fossil plants collected by Abert near Trinidad are described and three of them are figured. The conclusion is reached (p. 131) that the coal is younger than Carboniferous.

The Cretaceous fossils collected by Abert at Poblozon in the Rio Puerco coal field, N. Mex., are described. Poblozon is a few miles north of San Ygnacio.

6. EMory, W. H., Notes of a military reconnaissance from Fort Leavenworth, in Missouri, to San Diego, in California, including parts of the Arkansas, Del Norte, and Gila rivers: Senate Ex. Doc. No. 7, 30th Cong., 1st sess., pp. 5-126.

In 1846 Lieut. Emory found coal.in the Trinidad field (p. 19) and also near Raton (p. 20).

7. TAYLOR, R. C., Statistics of coal. The geographical and geological distribution of mineral combustibles or fossil fuel, including also notices and localities of the various mineral bituminous substances employed in the arts and manufactures (etc.), clxviii, 754 pages, plates, maps, Philadelphia. Second edition edited by S. S. Haldeman, xx, 640 pages, plates, maps, Philadelphia, 1855.

A summary of early discoveries is given (pp. 174-176).

8. Wislizenus, A., Memoir of a tour to northern Mexico, connected with Doniphan's expedition in 1846 and 1847, 141 pages, 3 maps. Also Senate Doc. 26, 30th Cong., 1st sess. Abstract in Am. Jour. Sci.; $2 \mathrm{~d}$ ser., vol., 6, pp. 376-386. Geographisches Jahrbuch von Dr. Berghaus (Gotha), 1850. 
In 1846 Dr. Wislizenus visited Placer Mountain (Cerrillos field). He found petrified wood (p. 29) but apparently did not find the coal, although he refers to coal in the Raton field and on the Rio Puerco. On his geologic sketch map coal is shown in the Raton region (p. 138): Coal is reported near Cadena, Mexico (lat. $26^{\circ} \mathrm{N}$., long. $105^{\circ} \mathrm{oW}$.).

$$
\text { - } 1850 .
$$

9. Simpson, J. H., Journal of a military reconnaissance from Santa $\mathrm{Fe}, \mathrm{N}$. Mex., to the Navajo country.

Reports of the Secretary of War, with reconnaissance of routes from San Antonio to El Paso, by Johnson and others [etc.]: Senate Ex. Doc. No. 64, 31st Cong., 1st sess., pp. 146-148.

Coal was found in 1849 on the Rio Puerco north of Cabezon and at several localities farther west in northwestern New Mexico (pp. 72, 146-147).

\section{3.}

10. Hrтchcock, Edward, Notes upon the specimens of rocks and minerals collected. Exploration of the Red River of Louisiana in 1852, by Marcy, Senate Doc. 54, 32d Cong., 2d sess., pp. 163-178, Washington, 1853. (Another edition, pp. 140-155, 1854.)

The paper contains a review of the occurrence of coal previously described (p. 165).

\section{5.}

11. Marcou, Jules, Résumé of a geological reconnaissance, extending from Napoleon, at the junction of the Arkansas with the Mississippi, to the Pueblos de Los Angeles, in California: Report of exploration for railway route to the Pacific Ocean, near thirtyfifth parallel, by Whipple, vol. 4, pp. 40-48, $8^{\circ}$, House Doc. 129. Also explorations for a railway route from the Mississippi' to the Pacific, vol. 3, pt. 4 ; route near the thirty-fifth parallel, explored by Whipple. Report of the geology of the route, by Blake, pp. 165-175, pl., $4^{\circ}$ [House Ex. Doc. No. 91, 33d Cong., 2d sess.; also Senate Ex. Doc. No. 78, Washington, 1856].

The Cretaceous coal beds near Tijeras (Tigeras of Marcou) seem to be confused with Carboniferous coal beds which occur in the Sandia Mountains near by (p. 45). The Cretaceous rocks underlying the coal beds near Galisteo. are described (p. 46).

\section{6.}

12. BLAKE, W. P., Report on the geology of the route: Explorations for a railroad route from the Mississippi to the Pacific, vol. 3, pt. 4; route near the thirty-fifth parallel, explored by Whipple, 116 pages, maps, plates, $4^{\circ}$, House Ex. Doc. No. 91, 33d Cong., 2d sess. Includes report on fossils by. J. Hall, pp. 99-105, pls.

The Cretaceous' age of the rocks examined by Abert at Poblozon, on the Rio Puerco, is accepted (p. 34), and Whipple and Marcou are quoted as reporting coal on the Rio Puerco and near Laguna and Cebolleta (p. 36) in rocks which are regarded as Cretaceous.

\section{0.}

13. BLAKE, W. P.; Observations on the geology of the Rocky Mountain chain in the vicinity of Santa Fe, N. Mex. [abstract]: Am. Assoc. Proc., vol. 13, pp. 314-319.

The anthracite coal found in 1857 near Cerrillos is described ( $\mathrm{p} .315)$.

\section{1.}

14. BLAKE, W. P., Observations on the mineral resources of the Rocky Mountain chain near Santa Fe and the probable extent southward of the Rocky Mountain gold field: Boston Soc. Nat. Hist. Proc., vol. 7, pp. 64-70.

The occurrence of anthracite coal near Cerrillos, examined in 1.857 , is described. In the same connection the author refers to the Carboniferous coal beds at Santa Fe.

15. Newrerry, J. S., Geological report: Report upon the Colorado River of the West, explored in 1857 and 1858 by Lieut. Joseph C. Ives, pt. 3, 154 pp., 6 pls., $4^{\circ}$ [Senate Ex. Doc. -, 36th Cong., 1st sess.]: Abstract in Am. Jour. Sci., 2d ser., vol. 33, pp. 394-403.

Some of the coal near Moqui is described as Jurassic (p. 85) and some as Cretaceous, the latter associated with fossil plants similar to those of the Dakota sandstone of Kansas and Nebraska. The Cretaceous coal of this author occurs both east and west of Fort Defiance [in the San Juan Basin] (p. 100). Carboniferous fossils were obtained from the coal measures at Santa $\mathrm{Fe}$ and samples of the anthracite from the vicinity of Cerrillos were obtained, but that locality was not visited.

\section{5.}

16. OWEN, R. E., and Cox, E. T., Report on the mines of New Mexico, 60 pp. Abstract in Am. Jour. Sci., 2d ser., vol. 40, pp. 391-392.

The occurrence of coal in the Canon City field in the Raton Mesa region, in the Rio Puerco field, and near Fort Craig, on the Rio Grande, is mentioned (pp. 23-40). Anthracite regarded by these authors as Carboniferous in age is reported at Placer Mountain (Cerrillos field).

1867. -

17. Hayden, F. V., First Annual Report of the United States Geological Survey of the Territories, embracing Nebraska, 64 pp. Abstract on Iignite formation: Am. Jour. Sci., $2 \mathrm{~d}$ ser., vol. 45, pp. 198-208.

The coal measures of the Rocky Mountains are reported as extending southward to the Raton Mesa region and are referred to the Tertiary (p. 170, p. 56 of First, Second, and Third Ann. Repts. printed together in 1873).

1868.

18. HAyden, F. V., Rocky Mountain coal beds: Am. Jour. Sci., 2d ser., vol. 45, pp. 101-102.

Brief reference is made to the coal beds "all along the foot of the mountains from Pole Creek 
far south into New Mexico." They are included with the author's Tertiary lignites.

19. ElAYDEN, F.V., Notes on the lignite deposits of the West: Am. Jour. Sci., 2d ser.; vol. 45, pp. 198-208.

Brief reference is made to the New Mexico coal described by Le Conte (pp. 199, 202). A report by Lesquereux is quoted giving the descriptions of fossil plants, among which are those collected by Le Conte at Raton Pass and on the Purgatoire River (p. 207). Lesquereux, however, refrains from expressing an opinion regarding the age of these fossils, but Hayden uses them in his argument that the coal beds are of Tertiary age. He expresses the opinion (p. 205) that there are "no valuable beds of lignite west of the Mississippi in formations older than the Tertiary."

20. Ine Conte, J. L., Notes on the geology of the survey for the extension of the Union Pacific Railway from Smoky Hill River, Kans., to the Rio Grande, 76 pages, $8^{\circ}$, Philadelphia.

Coal is reported near Tijeras, N. Mex. (p. 34); at Tierra Amarilla, about 120 miles northwest of Santa Fe, N. Mex. (p. 36); and in the Rio Puerco field west of Albuquerque, N. Mex. (p. 41).

The anthracite near Cerrillos is described and also the occurrence of fossil plants in rocks associated with it (pp. 38-40). The coal is referred to the Cretaceous and is said to be older than the so-called Marshall formation (Laramie) of the Denver Basin (p. 38).

Coal was found in Manco del Burro Pass [near - Yankee, N. Mex.], and the coal beds near Trinidad, Wootten, Raton, Vermejo Canyon, and Van Bremmer Canyon were examined. From certain fossil plants and shells found near Trinidad the author concludes that the coal is of "middle Cretaceous" age. Compared with other coalbearing rocks, he places the Cerrillos coal beds low in the Cretaceous; the Raton Mesa coal beds next higher; the Denver coal beds [Laramie] in the youngest Cretaceous or oldest Tertiary; and the Missouri River coal beds in the Tertiary.

21. Cretaceous coals in New Mexico: Am. Jour. Sci., 2d ser., vol. 45, p. 136.

The coal beds near Cerrillos are correlated with those described by Newberry in the lower part of the Cretaceous of northwestern New Mexico.

"Unmetamorphosed coal from the coal mine 8 miles east of San Antonio and the Rio Grande" [probably in the Carthage field] also is mentioned (p. 1.36).

1870.

22. RAYMOND, R. W., Statistics of mines and mining in the States and Territories west of the Rocky Mountains. House Ex. Doc. No: 207, 41st Cong., 2d sess., pp. 1-805.

The coal beds of several localities in New Mexico are described, including those near Fort Craig, Fort Wingate, Taos, the Rio Puerco field, the Cerrillos field, and the Raton Mesa region, including Vermejo, Raton, and Purgatoire River.
1871.

23. Newierry, J. S., On the age of some western lignites: New York Lyceum Nat. Hist. Proc., vol. 1, p. 252.

The coal beds near Cerrillos are referred to the Cretaceous.

24. Lesquereux, Leo, On the fossil plants of the Cretaceous and Tertiary formations of Kansas and Nebraska: U. S. Geol. Survey Terr. [Fourth Ann.] Rept., pp. 370-385.

Under the title "Tertiary fossil plants" the author names several from Purgatoire Canyon, Raton Pass, and other localities.

$187 \%$.

25. Lesquereux, Leo, Tertiary flora of North America: U. S. Geol. and Geog. Survey Terr. [Fifth Ann.] Rept., pp. 304-318.

A list of fossil plants is given, including several from the Raton Mesa region, which the author regards as indicative of Eocene age.

26. - An enumeration with descriptions of some Tertiary fossil plants from specimens procured in the explorations of Dr. F. V. Hayden in 1870: U. S. Geol. Survey Terr. [Fifth Ann.] Rept., pp. 1-22.

Descriptions are given of 21 species of fossil plants from Fishers Peak and Raton Mountains (pp: 12-16). The author correlates the plantbearing rock of Raton Mesa with those at Evanston, Wyo., and with the Tertiary of the Mississippi Valley (p. 19). It is probable that most, if not all, of these plants came from beds above the unconformity. In this region there is little chance that fossil plants from below the unconformity would be collected before the mines were opened, for these fossils occur in soft shale which weathers quickly on exposure.

Descriptions are given of 9 species of plants from Placer Mountain (Cerrillos field), pp. 16-17. It was supposed that these plants came from the coal measures, now believed to be of Mesaverde age, but the locality within the field is not definitely indicated. It seems probable that they may have come from the Galisteo sandstone, now believed to be of Tertiary age. The plants named are of Tertiary types as follows:

Populus balsamoides Göppert.

Quercus platanea (?) Heer.

Ficus tiliaefolia Heer.

Platanus guillelmae Heer.

Cinnamomum mississippiense Lesquereux.

Magnolia.

Carpolithes spirales Lesquereux.

Carpolithes compositus Lesquereux.

Carpolithes mexicanus Lesquereux.

1873.

27. Clark, R. N., The Tertiary coal beds of Canyon City, Colo.: Am. Inst. Min. Eng. Trans., vol. 1, pp. 293-296, pl.; (a) p. 90. 
28. Frazer, Persifor, Jr., Mines and minerals of Colorado: U. S. Geol. Survey Terr. First, Second, and Third Ann. Repts., pp. 201-228.

29. Hayden, F. V., Geological report: U. S. Geol. Survey Terr. First, Second, and Third Ann. Repts., pp 103-199. Abstracts Am. Naturalist, vol. 4, pp. 119-121, 1871; Am. Jour. Sci., 2d ser., vol. 49, pp. 258-263, 1869. (The Third Annual Report was published as a preliminary field report in 1869.)

In this report the author notes in the Canon City field (p. 49) the presence of the Cretaceous beds up to No. 5 (Fox Hills) and states that No. 5 is capped by a rusty yellow sandstone that is regarded as the lowest bed of the coal formation, which he refers to the Tertiary. Hayden's No. 5 is the transition zone below what is now known as the Trinidad sandstone, and this sandstone is the one he describes as the lowest bed of the Tertiary and correlates with the base of the coal formation of the "Laramie Plains" and also of the "Raton Mountains" (p. 50).

Below this sandstone he found Baculites ovatus and other shells which he regarded as "plainly No. 5." He expresses the opinion that the coal beds of Wyoming, eastern Colorado, and the Rio Grande are of the same age and are remnants of the same coal basin. He refers to Tertiary beds east of Spanish Peaks (p. 53) and describes the coal beds and the fossil plants near Trinidad (p. 54), correlating the beds with those at Canon City, but states that the coal beds referred to the Tertiary in Raton Mountains rest on Cretaceous No. 2 (Benton), thus making the coal measures unconformable on the Cretaceous shale.

The coal beds near Cerrillos are described, and fossil plants were found which Hayden thinks are identical with some found in "Raton Mountains" (pp. 67-68). He "regards all the coal beds of the West, including those at Cerrillos, as lower Tertiary" (p. 89).

In a summary (p. 90) he refers again to the Canon City coal beds; the Raton Hills, where he names the coal beds the Raton Hills group; and to the Placer Mountain (Cerrillos) coal beds.

A list of fossil plants described by Lesquereux in 1868 is given (pp: 95-97). Hayden admits (p. 90) that the Cerrillos coal beds may be older than those of the Raton Mesa region. The beds now known as the Galisteo sandstone are correlated with the "Monument Creek group" of the Denver region, which is now separated into the Dawson arkose and the Castle Rock conglomerate.

30. Hitchcock, C. H., and Blake, W. P., Geological map of the United States: Statistics of mines and mining in the States and Territories west of the Rocky Mountains, [Fifth Ann.] Rept. Statistical atlas of the United States, based on the results of the ninth census (1870), by F. A. Walker, Pls. XIII, XIV, folio, Washington, 1874. Petermann's Mittheilungen, vol. 21, pl. 16, $4^{\circ}, 1875$. Special Rept. of Smithsonian Inst. for the Centennial, Washington, 1876. Atlas of the United States and the world, by Gray, folio, Philadelphia, 1877. Reproduced (probably) by F. Ratzel, Die Ver- einigten Staaten von Nord-Amerika, vol. 1, . München, 1878.

Canon City coal is referred to (pp. 302-305).

31. Lesquereux, Leo, On the age of certain beds of Wyoming referred to the Tertiary by Prof. Hayden and to the Cretaceous by others: Am. Jour. Sci., 3d ser., vol. 5, pp. 308-309.

Slight reference is made to the Trinidad field.

32. Lignitic formations and fossil flora: U. S. Geol. Survey Terr. Sixth Ann. Rept., pp. 317-427. Abstracts in Am. Jour. Sci.,.3d ser., vol. 6, pp. 441-450; Am. Naturalist, vol. 8, pp. 217-218, 1874.

Canon City.-A section of the coal-bearing rocks, measured by Nelson Clark, is given (p.323); and the lowest sandstone is correlated with the sandstone of the Trinidad field, now known as the Trinidad sandstone. Fossil plants, supposed to be of Eocene age, were found in the higher beds of the section and fucoids in the sandstone near the base.

Trinidad field.-A section of the coal-bearing rocks near Trinidad is given (p. 319). The shale below the sandstone, now known as Trinidad sandstone, is referred to No. 4 (Pierre), whereas Hayden previously had called it No. 2 (Benton). Fossils from this sandstone and from the coal-bearing rocks are named, and the formations are regarded as equivalent to those at Canon City, Colo., and at Cerrillos, N. Mex., and the coals of all three fields are referred to the Eocene (p. 409). Coal in Tijeras Canyon; near San Felipe, 12 miles from the Rio Grande; in Rio Puerco field; and elsewhere in New Mexico is mentioned (p. 363).

The Placer Mountain coals (Cerrillos field) are correlated with those at Raton, N. Mex., and at Canon City, Colo.

33. Macfarlane, James, Coal regions of America, their topography, geology, and development, xvi, 676 pages, 25 maps, New York; 2d.ed., New York; 3d ed., xvi, 700 pages, maps, plates, New York, 1877. Includes map of Pennsylvania by J. P. Lesley, frontispiece.

The coal fields of southern Colorado and New Mexico are included with others only in a general way. The author refers the coal beds to the Cretaceous (p. 6) and states (p. 535) that the coal beds along the base of the Rocky Mountains [including the southern fields] were formed during the Cretaceous and early Tertiary.

1874.

34. Cope, E. D., On the mutual relations of the Cretaceous and Tertiary formations: Report on the vertebrate paleontology of Colorado, U. S. Geol. and Geog. Survey Terr. Seventh Ann. Report, pp. 427-533, pl.

The literature of "The Fort Union or Lignitic Group" is reviewed. In this "group" were included (p. 432) the Placer Mountain (Cerrillos coal beds, which the author refers to the Cretaceous "near No. 5" (Fox Hills). The opinion is expressed that the Cerrillos coal beds are older than those at Canon City, Colo., and that both are older than Hayden's Lignitic group. 
35. Cope, E. D., On the Cretaceous age of the lignites of the West: $\Lambda$ cad. Nat. Sci. Philadelphia Proc., vol. 26, pp. 10-11, 12-13. Remarks by Le Conte and Frazer, p. 11.

Announcement is made that dinosaur bones found in northeast Colorado prove that the coal beds referred by Hayden and Lesquereux to the Tertiary are of Cretaceous age. [John Le Conte had referred the coal beds farther south to the Cretaceous in 1.867.]

36. - Notes on the Eocene and Pliocene lacustrine formations of New Mexico, including descriptions of certain new species of Vertebrata: U. S. Geog. Surveys W. 100th Mer. Ann. Rept. (Chief Eng. Ann. Rept., 1874, App. FF, pp. 115-130). Abstract in Am. Jour. Sci., 3d ser., vol. 9, p. 151, 1875 .

The Eocene in the vicinity of Chama River is described as resting unconformably upon coalbearing rocks which occur below fossiliferous Cretaceous [the Mesaverde of later writers] (p.116).

37. Review of the Vertebrata of the Cretaceous period found west of the Mississippi River: U. S. Geol. and Geog. Survey Terr. Bull.; vol. 1 [1st sér:], No. 2, pp. 5-48.

Hayden's reference of the "Placer Mountain" (Cerrillos) coal beds to the base of his Tertiary Lignitic group is quoted and the statement is made that "they are nearer to No. 5" (Fox Hills).

Former publications dealing with the age of the Canon City and Placer Mountain coals are reviewed (pp. 5-48).

38. $\mathrm{I}_{\mathrm{A}} \mathrm{YDEN}, \mathrm{F} . \mathrm{V}$. [General report]: U: S. Geol. and Geog. Survey Terr. [Seventh] Ann. Rept., pp. 17-82. Abstract in Am. Naturalist, vol. 9, pp. 173-177, 1875

Hayden shows (p. 27) that the fossil plants of his Lignitic group indicate Tertiary age, although the vertebrate remains, according to Cope, indicate Cretaceous age, but that as early as 1869 he admitted that at Coalville and elsewhere some of the coal is Cretaceous and adds: "I am more convinced that farther south in New Mexico, Arizona, and Utah, there are coal beds of undoubted Cretaceous age." He further argues that Cope and Marsh are not justified in maintaining that the "entire lignitic group" is Cretaceous from the vertebrate evidence then at hand.

39. - Remarks on age of lignitic group: U. S. Geol. and Geog. Survey Terr. Bull,; vol. 1 [1st ser.], No. 2, pp. 1-2.

As a preface to Cope's paper in this bulletin Hayclen shows that in 1.869 he pointed out that the coal beds at Coalville, Utah, are probably Cretaceous and adds that the, greater portion of these in southern Utah, New Mexico, and Arizona are "of undoubted Cretaceous age." He argues that' the coal-bearing rocks whose accumulation began in the Cretaceous continued as transitional beds into the Tertiary, and that there is no marked break within them.

40. Lesquereux, Leo, The lignitic formation and its fossil flora: U. S. Geel. and Geog. Survey Terr. [Seventh] Ann. Rept., pp. 366-425.
The question of age of the coal beds is discussed and names are given of the fossil plants from many places including the Cerrillos and Raton Mesa coal fields.

41. Lesquereux, Leo, On the formation of the lignite beds of the Rocky, Mountain region: Am. Jour. Sci., 3d ser., vol. 7, pp. 29-31.

The author gives facts opposing the theory that the coal of the Raton Mesa region, Canon City, and elsewhere was formed from drifted material.

42. - On the age of the lignitic formations of the Rocky Mountains: Am. Jour. Sci., 3d ser., vol. 7, pp. 546-557.

The author discusses the age of the western coal beds and repeats his previous reference of them to the Tertiary.

43. Loew, OsCar, A new fossil resin-"wheelerite": Am. Jour. Sci., 3d ser., vol. 7, 571-572.

Resin was found in "Cretaceous lignite beds" near Nacimiento, N. Mex. An analysis of the resin is given.

44. Marvine, A. R., Report of Middle Park division: U. S. Geol. and Geog. Survey Terr. [Seventh] Ann. Rept., pp. 83-192.

45. Newberry, J. S., On circles of deposition in secondary sedimentary rock, American and foreign: New York Lyceum Nat. Hist. Proc., 2d ser., pp. 122-124. Discussed by Wurtz and Day, idem, pp. 124, 125.

46. - [On the lignite flora of the far west]: New York Lyceum Nat. Hist. Proc., 2d ser., pp. 78-79.

The author criticizes an article by Lesquereux, who referred the western coals to the Eocene, and shows that in Arizona and western New Mexico marine invertebrates of Cretaceous age occur above the coal.

47. On the lignites and plant beds of western America: Am. Jour. Sci., 3d ser., vol. 7, pp. $399-404$.

The author answers the argument of Lesquereux contained in an article in Hayden's report for 1872 and dissents from his views. He asserts that all of the plant-bearing coal beds in New Mexico are of Cretaceous age and is inclined to the opinion that those farther north are of the same age.

He refers (p. 404) to an "Echo Canyon conglomerate" above the coal beds and suggests that it may mark the division between Cretaceous and Tertiary.

48. Prout, H. G. [General description of country]: Report of a reconnaissance in the Ute country, made in 1873, by Ruffner: $42 \mathrm{~d}$ Cong., lst sess., House Ex. Doc. No. 193, pp. 6-5i.

49. RAYMOND, R. W., Remarks on the occurrence of anthracite in New Mexico: Am. Inst. Min. Eng. Trans., vol. 2, pp. 140-142.

The author discusses the age of coal beds near Cerrillos and the chemical character of the coal. He accepts Newberry's reference of the coal beds to the Cretaceous.

50. Stevenson, J. J. [Age of western lignite]: New York Lyceum Nat. Hist. Proc., vol. 2, pp. 93-94.

The writer argues for the Cretaceous age of the Canon. City coal and shows that Halymenites 
occurs both below and within the coal-bearing rocks. He compares these beds with those of New Mexice, which he claims are admitted to be Cretaceous, and with beds containing Halymenites and marine shells at Platteville, Colo., above [Laramie] coal.

\section{5.}

51. Cope, E. D., Report on the geology of that part of northwestern New Mexico examined during the field season of 1874: U. S. Geog. Surveys W. 100th Mer. Ann. Rept. 1875 (Chief Eng. Ann. Rept., pt. 2, App. LI), pp. 981-1017, pls. (Published also separately, pp. 1-196.)

Cretaceous beds, Nos. 3 and 4, are described (pp. 996-997) east of Sandia Mountains [near Hagan]. The author's discussion of the relation of these rocks to the Galisteo sandstone indicates that he regarded the coal beds which are above the marine Cretaceous as No. 4 [Pierre] or younger [although according to Stevenson he placed them in No. 3].

The coal beds extending from Nacimiento Mountains northward are described and referred to Cretaceous No. 3. Marine invertebrates were found above these beds (p. 1000).

A section is given in which coal is shown in Cretaceous No. 3, at Cristone, overlain by rocks of marine origin with fossils supposed to indicate Cretaceous No. 4 (pp. 1007-1008). The author states that "this lignite bed extends throughout the region west of the Rocky Mountains wherever No. 3 occurs, and is the bed which has been mistaken for the true lignite, or No. 6 of some geologists."

52. On the Cretaceous beds of the Galisteo: Acad. Nat. Sci. Philadelphia Proc. for 1875 [vol. 27], pp. 359-360.

The author discusses Stevenson's paper on "Geological relations of the lignitic groups of the Cretaceous," and refers the Galisteo sandstone to the Triassic on the supposition that former observers had inverted the section.

53. - The geology of New Mexico: Acad. Nat. Sci. Philadelphia Proc. [vol. 27], pp. 263-267. Am. Jour. Sci., 3d ser., vol. 10, pp. 152-153.

Reference is made to the age of the Galisteo sandstone (p. 264).

A section of the rocks west of the Sierra Madre is given, including both Cretaceous and Tertiary formations (p. 267).

54. The classification and distribution of the Cretaceous deposits of the West: Vertebrata of the Cretaceous formations of the West, U. S. Geol. Survey Terr. Rept., vol. 2, pp. 15-41, $4^{\circ}$.

55. Howell, E. E., Report on the geology of portions of Utah, Nevada, Arizona, and New Mexico, examinəd in 1872 and 1873: U. S. Geog. and Geol. Surveys W. 100th Mer. Rept., vol. 3, Geology, pp. $227-301,4^{\circ}$.

Coal measures in Arizona, Utah, and western New Mexico are correlated (pp. 275-280) with those "east of Mount Taylor" [the southeastern part of the San Juan Basin].
56. Loew, Oscar, Report upon the mineralogical, agricultural, and chemical conditions observed in portions of Colorado, New Mexico, and Arizona [including analyses of soils and a chapter on "The eruptive rocks of Arizona and New Mexico"]: U. S. Geog. and Geol. Surveys W. 100th Mer. Rept., vol. 3, Geology, pp. 569-661, $4^{\circ}$.

An analysis of the anthracite from Placer Mountain (Cerrillos field) is given; also an analysis of bituminous coal from the Rio. Puerco near Nacimiento (pp. 632-635).

The anthracite coal is said (p. 635) to have been mined "40 years ago" [i. e., about 1835]. It is regarded as "probably Carboniferous." Information is given of coal at Elizabethtown, N. Mex., and near Trinidad and Canon City, Colo. (p. 634).

57. - Geological and mineralogical report on portions of Colorado and New Mexico: U. S. Geog. Surveys W. 100th Mer., Ann. Rept. 1875 (Chief Eng. Ann. Rept. 1875, pt. 2, App. LL, pp. 1017-1036, published also separately, pp. 1-196).

Cretaceous coal measures west of Nacimiento Mountains are described; also (p. 1027) those of the Rio Puerco field (pp. 1023-1026).

The anthracite at Placer Mountain was examined; also the coal in Tijeras Canyon and at other New Mexico localities (p. 1028).

58. Stevenson, J. J., Geology of a portion of Colorado explored and surveyed in 1873: U. S. Geol. and Geog. Surveys W. 100th Mer. Rept., vol. 3, Geology pp. 303-50], $4^{\circ}$. Review by J. D. D[ana], Am. Jour. Sci., 3d ser., vol.11, p. 412, 1876.

The coal-bearing rocks of the Canon City field are described (pp. 393-398) as Upper Cretaceous, and three divisions of them are made-a highest division 250 feet thick, conglomeratic at the top; a middle division 175 feet thick, consisting of shale and beds of coal; and a lower division, 350 feet thick [apparently including the sandstone herein (p. 165) named the Rockvale member, in which were found Halymenites and impressions of shells].

\section{6.}

59. Conkuing, A. R., Report on the geology of the mountain ranges from La Veta Pass to the head of the Pecos: U. S. Geog. Surveys W. 100th Mer., Ann. Rept. 1876 (Chief Eng. Ann. Rept. 1876, App. JJ), pp. 199-202.

60. Engleman, H., The brown coals of Utah and adjoining Territories: Am. Inst. Min. Eng. Trans., vol. 4, pp. 298-308.

61. Hayden, F. V!, General report: U. S. Geol. and Geog. Survey Terr. [Eighth] Ann. Rept., pp. 19-58, pls. Abstract in Am. Jour. Sci., 3d ser., vol. 11, p. 496.

In chapter 1 a general review is given of the "Lignitic group," which the author still regards as lower Eocene; and he adds that "it is somewhat doubtful whether the age will ever be decided positively to the satisfaction of all."

Chapter 2 describes the Lignitic group, as examined at Canon City, etc. Hayden reviews the previous work and argues that the transition from the marine to the fresh-water formations should 
mark the passage from Cretaceous to Tertiary. He correlates the coal measures of the Canon City field with those of the Raton Mesa and Denver regions. He refers (p. 45) to the coal-bearing. rocks as the Lignitic or Laramie group.

62. HAYDen, I. V., Notes on the Lignitic group of eastern Colorado and portions of Wyoming: U. S. Geol. and Geog. Survey Terr. Bull., vol. 1, 2d ser., pp. 401-41.1. Reviewed in Am. Jour. Sci., 3d ser., vol. 11, pp. 147-1.49.

The paper is a general discussion of the geologic age of the coal beds in which are involved those of the Raton Mesa region, Canon City, and elsewhere.

63. Lesquereux, Leo, On the Tertiary flora of the North American Iignitic, considered as evidence of the age of the formation: U. S. Geol. and Geog. Survey Terr. [Eighth] Ann. Rept., pp. 271-315.

64. MeEk, IF. B., Descriptions of the Cretaceous fossils collected on the San Juan exploring expedition under Macomb: Report of expedition from Santa Fe, N. Mex., to the junction of the Grand and Green rivers of the Great Colorado of the West, in 1859, under the command of Capt. J. N. Macomb; pp. 119-133, plates, $4^{\circ}$

The fossils described in this report were collected by Newberry in 1859 from the Cretaceous rocks of western New Mexico and Colorado.

Meek agrees with Newberry in correlating the "Lower Cretaceous" of the latter with the Dakota of the Upper Missouri Cretaceous section; the "Middle Cretaceous" with the Benton and Niobrara formations; and the "Upper Cretaceous," except the highest beds, which were regarded as probably Tertiary, with Pierre and Fox Fills (pp. 121-122).

65. Newberry, J. S., Geological report: Report of expedition from Santa Fe, N. Mex., to the junction of the Grand and Green rivers of the Great Colorado of the West, in 1859, under the command of Capt. J. N. Macomb, pp. 9-118, map, plates, $4^{\circ}$

The Cretaceous is subdivided into three groups: The lowest or "Lower Cretaceous" includes the Dakota of other writers; the "Middle Cretaceous" is made equivalent to Benton and Niobrara; and the "Upper Cretaceous" to the Pierre and Fox Hills (including beds at the top that later proved to be Tertiary).

"Triassic rocks containing * * * silicified trunks of coniferous trees" are reported east of Cerrillos (p. 38). [The silicified trees east of Cerrillos described by later writers are in the Galisteo sandstcne.]

Near the mouth of Galisteo Creek fossil leaves said to be Cretaceous were found in yellow sandstone below the marine Cretaceous shale (p. 51). The description seems to indicate that these may be below the Dakota sandstone of the present paper.]

The coal beds at the base of Placer Mountain [the Mesaverde near Madrid] are referred to "Middle Cretaceous" and the bituminous coal is described as changed to anthracite by igneous intrusion.
In northern New Mexico [north of Jemez Mountains] the three subdivisions of the Cretaceous were recognized and traced westward through southwestern Colorado (pp. 67-71). The rocks near Sierra del Navajo (near the ColoradoNew Mexico line) are described as "Middle Cretaceous" and "Upper Cretaceous" [the Mesaverde, Lewis, and "Laramie" formations of later writers].

The "brown sandstone and beds of lignite". near Nacimiento are referred to "Middle Cretaceous" (p. 117). [These are clearly the Mesaverde formation of later writers.]

66. Strevenson, J. J., On the geological relations of the Lignitic groups of the far West: Am. Philos. Soc. Proc., vol. 14, pp. 447-475.

The paper is a general summary of facts bearing on the controversy as to the age of the Rocky Mountain coal beds. The author concludes by placing the Lignitic group in the Cretaceous.

67. St. Jон,, O. H., Notes on the geology of northeastern New Mexico: U. S. Geol. and Geog. Survey Terr. Bull., vol. 2, pp. 279-308, pls. 42-49. Abstract in Am. Jour. Sci., 3d ser., vol. 13, p. 219.

The Raton coal field is described and good maps and sketches presented. St. John here accepts Hayden's reference of the coal to the Tertiary and describes the concretionary fossiliferous layer near the top of the shale underlying the coal measures, the fossils from which are described at Fox Hills in a later publication. [From the same beds were obtained most of the invertebrates that constitute the Pierre fauna of the Raton field in the present paper.]

68. Williams, S. G., Notes on the geology of some lacalities near Canon City, Fremont County, Colo.: U. S. Geol. and Geog. Survey Terr. Bull., vol. 1, 2d ser., pp. 249-251.

- A section of rocks about 1,000 feet thick is given, including seven coal beds.

\section{7}

69. Cope, E. D., Report on the extinct Vertebrata obtained in New Mexico by parties of the expedition of 1874: U. S. Geog. Surveys W. 100th Mer. Rept., vol. 4, Paleontology, 370 pp., pìs. $22-83,4^{\circ}$. Abstract in Am. Jour. Sci., 3d ser., vol. 15, p. 56 , 1878.

The Cretaceous west of Nacimiento and Gallinas Mountains is described and a cross section given showing coal in "Cretaceous No. 3" [probably the Mesaverde coal], succeeded after a covered interval by Puerco (pp. 1-13).

The relations of the Eocene to the Cretaceous are discussed at some length (pp. 13-5j).

72. Conklina, A. R., Report on the foothilis' facing the plains from latitude $35^{\circ} 30^{\prime}$ to $38^{\circ}$, approximately: U. S. Geog. Surveys W. 100th Mer., Ann. Rept. 1877 (Chief Eng. Ann. Rept. 1877, App. NN, pp. 1298-1303)

The coal beds between Cimarron, N. Mex., and Trinidad, Colo., are described. Cretaceous shells were found below the coal and fossil plants in the coal measures. A section was measured in 
Vermejo Canyon showing a conglomerate about 110 feet above the sandstone now known as the Trinidad. [This conglomerate is the base of what is now known as the Raton formation.]

The coal mines near Trinidad are described. The author gives (pp. 1301-1303) a translation of a paper published at The Hague in 1874 describing the Maxwell land grant. It contains descriptions of the coal beds in Ponil Canyon, Vermejo Valley, and Cottonwood Canyon, in New Mexico, and at Trinidad, Walsenburg, and elsewhere in Colorado.

73. ENDLICH, F. M., Report as geologist of the southeastern division: U. S. Geol. and Geog. Survey Terr. Ninth Ann. Rept., pp. 103-235. Abstract in Am. Jour. Sci., 3d ser., vol. 14, p. 421.

Laramie(?) rocks are described as lying between the Fox Hills and the Puerco in western New Mexico (p. 189).

Chapter V (pp. 194-215) describes post-Cretaceous beds of the Trinidad region.

The coal beds seem to lie conformably on the Cretaceous, although the author considers the possibility that they are really unconformable. Several sections, maps, and sketches are given. A cross section (XIV) shows the essential features as they are known at the present time, notably a lower and an upper group of coal beds. Endlich believed (p. 198) that the lower group of coals together with the basal sandstone (later named Trinidad) disappeared westward and was not present at the western margin of the field (see section XXI), from which he argues that the coal formation really is unconformable on the Cretaceous shale, which he calls Colorado shale, including in it all rocks between Dakota and Fox Hirls. Descriptions and analyses are given of the coal from the Trinidad, Canon City, and other coal fields.

He argues (p. 206) that No. 5 (Fox Hills) is absent from the Trinidad field and that the coalbearing rocks rest unconformably on the Cretaceous. He concludes (p. 211) that the coal beds of Trinidad and Canon City should not be considered Cretaceous or Tertiary but should form a transition group between the two.

74. Macfarlane, James, Coal regions of America, their topography, geology, and development, xvi, 676 pp., 25 maps, New York, 1873; 2d ed., New York; 3d ed., xvi, 700 pp., maps, pls., New York, 1877.

The author describes the coal beds of the Cerrillos field and mentions those of the Rio Puerco, Raton, and other New Mexico fields (pp. 72-76).

75. Hayden, F. V., Letter [on general results]: U. . S. Geol. and Geog. Survey Terr. Ninth Ann. Rept., pp. 1-28. Abstract in Am. Naturalist, vol. 10, pp. 161-162, 1876.

Hayden refers (p. 4) to Endlich's work contained in this volume and asserts that the observations there described prove that the coal at Trinidad is not Cretaceous.

76. - U. S. Geol. and Geog. Survey Terr. Geological and geographical atlas of Colorado and portions of adjacent territory, folio 22 , double folio atlas sheets. (2d ed. corrected to date, 1881.)
Detailed geologic sheets, by Endlich, W. H. Holmes, Peale, Marvine, and C. A. White.

The marine shale (apparently both Mancos and Lewis of later writers) in northern New Mexico west of the Rocky Mountains is mapped as Colorado shale. The coal-bearing rocks [apparently including both Mesaverde and "Laramie," and probably including also some of the Tertiary] are mapped as Fox Hills. The Wasatch is mapped as resting on Fox Hills at the eastern margin of the San Juan Basin and on Laramie farther to the west near Durango and elsewhere. The Cretaceous formations mapped are Dakota; Colorado, including Benton and Niobrara; Fox Hills, including Pierre and Fox Hills proper; and Laramie. In the Canon City and Raton Mesa regions the coal-bearing rocks are designated as Laramie and the shale underlying them as Colorado. No Pierre or Fox Hills is indicated in either of these regions.

77. Pотter; W. B., The character and composition of the lignite coals of Colorado: Am. Inst. Min. Eng. Trans., vol. 5, pp. 365-375.

Descriptions and chemical properties are given of coal from the Trinidad, Raton, and Canon City coal fields, and elsewhere, also of graphite from Raton.

78. WHITE, C. A., Report upon the invertebrate fossils collected in portions of $\mathrm{New}$ Mexico and Arizona by parties of the expeditions of 1871, 1872,1873, and 1874: U. S. Geog. Surveys W. 100th Mer. Rept., vol. 4, Paleontology, p. 1, 219 pages, pls. 1-21, $4^{\circ}$. Abstract in Am. Jour. Sci., 3d ser., vol. 12, pp. $62-63,1876$.

1878.

79. Evdich, F. M., Catalogue of minerals found in Colorado: U. S. Geol. and Geog. Survey Terr. Tenth Ann. Rept., pp. 133-159.

80. Hayden, F. V., Remarks on lignitic formation of the West: U. S. Geol. Survey Terr. Rept., vol. 7, Contributions to the fossil flora of the Western Territories, p. 2, the Tertiary flora, by Leo Lesquereux, pp. iii-ix, $4^{\circ}$.

The author defines Lignitic group (p. 4) as the "coal-bearing strata lying above the Fox Hills group - and embraced in the divisions Laramie and Fort Union groups." The name "Lignitic" is abandoned because of the occurrence of coal at lower horizons.

81. Lesquereux, Leo, The Tertiary flora: U. S. Geol. and Geog. Survey Terr. Rept., vol. 7; The lignitic formations of North America, pt. 1, pp. 1-31; Distribution of Tertiary fossil plants, pt. 2, pp. 33-301; Age of the lignitic formations, etc., pt. 3, pp. 309$366 ; 65$ pls., $4^{\circ}$. Reviewed by E. D. Cope, Am. Naturalist, vol. 12, pp. 243-246.

The geology of the various localities from which fossil plants were obtained is outlined, including Canon City; the Raton Mesa region, and Cerrillos.

The fossil plants from Placière (Cerrillos) are included in the Tertiary flora, and the rocks containing them correlated with the coal measures of the Raton Mesa, Canon City, Denver, and other fields (p. 314). 
1879.

82. Cops, E. D., The relations of the horizons of extinct Vertebrata of Europe and North America: U. S. Geol. and Geog. Survey Terr. Bull., vol. 5, pp. 33-54.

Puerco (?) is shown as occurring above Laramie (p. 50).

"The Puerco marls * * * first observed by me [Cope] in New Mexico in 1874" were referred by Endlich in 1875 (p. 52) "to the lowest place in the Tertiary series, but the absence of fossils renders it difficult to conclude whether they belong here or in the Laramie series."

83. Miller, S. A., North American Mesozoic and Cenozoic geology and paleontology: Cincinnati Soc. Nat. Fist. Jour., vol. 2, pp. 140-161, 223-244, 1879; vol. 3 , pp. 9-32, 79-118, 165-202, 245-288, 1880; vol. 4, pp. 3-46, 93-144, 183-234, 1881. Also issued 338 pp., Cincinnati, 1881.

84. Stevenson, J. J., Report on a special geological party operating in. Colorado and New Mexico from Spanish Peaks to the south, field season of 1878 (and 1879): U. S. Geog. Surveys 100th Mer. Ann. Rept., 1879 (Chief Eng. Ann. Rept. 1879, App. OO, pp. 271-281).

The Raton Mesa region is described and a generalized section given in which appear 32 coal beds [many of which are now known to be parts of essentially the same beds]. A Cardium is reported from the coal beds; also Halymenites was found in rocks above the sandstone now known as Trinidad (p. 279).

85. - Geology of Galisteo Creek, New Mexico: Am. Jour. Sci., 3d ser., vol. 18, pp. 471-475.

The coal beds north of Placer Mountain (Cerrillos field) are referred to the Laramie, and the underlying shale exposed near the town of Galisteo, to the Pierre, Niobrara, and Benton (p. 471).

"The Galisteo group" is described as lying unconformably on beds ranging from Laramie to Dakota. [This probably is not the Galisteo sandstone of other writers.]

86. White, C. A., Report on the paleontological field work for the season of 1877: U. S. Geol. and Geog. Survey Terr. Eleventh Ann. Rept., pp. 161-272. Abstracts in Am. Naturalist, vol. 12, pp: 103-106, 1878; Am. Jour. Sci., 3d ser., vol. 15, p. 59, 1878.

A list is given (pp. 267-268) of fossils collected by 0 . H. St. John near Cimarron, said to come from the Fox Hills, which as used by White included the Pierre. Apparently they are from the zone of limestone concretions 100 to 400 feet below the base of the Trinidad sandstone, in what is now regarded as Pierre. The greater part of the paper is devoted to the fields north of those described in this paper.

1881.

87. Lesquereux, Leo, Remarks on the Cretaceous and Tertiary flora of the Western Territories: Am. Naturalist, vol. 16, pp. 102-108.

8S. Stevenson, J. J., Note on the Laramie group of southern New Mexico: Am. Jour. Sci., 3d ser., vol. 22, pp. 370-372.
See No. 89 (below), p. 223.

The statement is made (p. 370) that the Laramie (so called) is practically continuous from Galisteo Creek southward for $\mathbf{1 5 0}$ miles. [This is an error probably arising from the fact that coal occurs near "San Pedro" about 10 miles south of the Galisteo and also near another "San Pedro" about 150 miles to the south. The coal near San Pedro and San Antonio referred to by J. M. Robinson, whom Stevenson quotes, is probably the coal of the Tijeras field, but it is not certain how much of the description refers to this field and how much to the Carthage field near the "San Pedro" farther to the south.]

Ostrea congesta was observed "high up in the Laramie" of the Cerrillos field; and Ostrea glabra, Anomia, Corbula (3 species), Camptonectes (?), and Tellina (?) were obtained from the coal measures near San Pedro [probably from the Tijeras field] and identified by R. P. Whitfield (p. 371).

89. Stevenson, J. J., Report upon geological examinations in southern Colorado and northern New Mexico during the years 1878 and 1879: U. S. Geog. Surveys W. 100th Mer. Rept., vol. 3, suppl., 420 pp., pl., 3 maps, $4^{\circ}$. (The maps were issued in 1877 to accompany folio geologic atlas of the surveys west of the 100th meridian.)

A review is given of former explorations and investigations. Chapter 9 contains a description of "the Laramie group" of the Raton Mesa and Cerrillos coal fields.

A conglomerate is described in the Raton field (p. 124), but the conglomerate at the north end (which belongs to the formation later named Poison Canyon) seems to be confused with the older conglomerate exposed in Cimarron Canyon. The older conglomerate (which belongs to the Raton formation of the present report) containing "many pebbles of gneiss and quartzite" is described in the southern part of the Raton field (p. 125). It was noted on Crow Creek (Van Houten) where "its under surface is covered with a close mat of small cylindrical bodies 1 inch long and one-fifth of an inch in diameter. They may be casts of fucoids." (See also p. 264.) It is further stated that "at most localities a variable sandstone overlies the 'Trinidad coal bed'-or second thick bed of coal above the base of the coal measures (see section on p. 105)-and contains some conglomerate layers, fossil plants, and a Cardium-like shell, similar to shells found in the Trinidad sandstone, was found in the coal-bearing rocks in Ponil Canyon. Fish teeth and a Cardium like the one named above were found in Ponil Canyon in the Trinidad sandstone" (p. 126).

"The "Galisteo coal field"' (Cerrillos field) is briefly described and a detailed section of the coal-bearing rocks near the "western edge of the area" is given, and the rocks referred to the Laramie (pp. 126-130).

The subdivisions of Lower, Middle, and Upper Cretaceous are adopted, but "Upper Cretaceous" 
is here made equivalent to No. 5 (Fox Hills) and a part of No. 4 (Pierre), and "Middle Cretaceous" is made to include part of No. 4 (p. 132). On the maps. "Middle Cretaceous" is designated as Colorado.

The coal beds of the Galisteo area are correlated directly with those of southern Colorado (Trinidad field) and with those of northern Colorado (Denver field) and Wyoming (p. 133).

The writer states that Newberry regarded the coal beds near. Chama and farther to the north and west as younger than the Galisteo coal beds (p. 145). The Galisteo coal beds are correlated with Newberry's Upper Cretaceous of the Chama region [Newberry himself had referred them to "Middle Cretaceous"].

Cope's description of the rocks near Chama in the Wheeler reports (Nos. 36 and 51 of this list) is quoted as proof that Cope was describing the Upper Cretaceous of Newberry. Stevenson uses this for correlating with his Laramie.

Inoceramus and Ostrea were found in the Laramie (so called) of the Galisteo area (p. 155).

His Galisteo group is referred to the Tertiary (pp. 159-162). [The description and the mapping indicate that Stevenson's Galisteo is quite different from the Galisteo of other authors and is probably younger, for it lies with marked angular unconformity on the older rocks. The Galisteo sandstone of other authors is evidently regarded by Stevenson as a part of his Laramie (see author's fig. 49).]

Detailed descriptions and sections of the coalbearing rocks are given (pp. 328-346).

Chapter 10 contains a discussion of the relations of the Laramie and a conclusion that it belongs in the Cretaceous.

Chapters 13 and 14 contain sections of the coal beds of the Raton Mesa region and detailed descriptions.

Pennsylvania fossils were found on South Fork of Purgatoire River with red sandstone above and below them (p. 223).

Conglomerate [the basal conglomerate of the Raton formation] is shown in a section measured in Vermejo Canyon (p. 249).

- A detailed section is given of the coal measures in the hogback 1. mile north of. Vermejo Gap (pp. 258-259). The coal-bearing rocks are shown to be about 213 feet thick with 12 beds of coal 3 inches or more in thickness. The highest sandstone of the section [obviously the basal conglomerate of the Raton formation] is correlated [erroneously] with the cliff-making sandstone above the coal beds in Vermejo Canyon near Dawson.

90. Stevenson, J. J., U. S. Geog. Surveys W. 100th Mer., atlas, 1881. For geology of New Mexico localities, see atlas sheets Nos. 69 (B), 69 (D), 70 (A), 70 (C), 77 (B), 78 (D).

The coal-bearing rocks are mapped as Laramie and the shale under them as Colorado.
1882.

91. Cope, E. D., The Tertiary formation of the central region of the United States: Am. Naturalist, vol. .16, pp. 177, 195, pl.

The coal beds near Gallinas Mountains, N. Mex., are mentioned (p. 180) and a section farther north including the coal measures near the ColoradoNew Mexico line is described (p. 181). (See also U. S. Geol. and Geog. Survey Terr. [Seventh] Ann. Rept., 1875, opp. p. 189.)

92. Stevenson, J. J., Notes on the coal field near Canyon City, Colorado: Am. Philos. Soc. Proc., vol. 19, pp. 505-521, 1882. Abstract in Am. Jour. Sci., 3̀d ser., vol. 23, p. 152 .

Several detailed geologic sections and a generalized section showing the occurrence of 13 beds of coal are given. Palm leaves were found in the shaft' of the Rockvale mine between Halymenitesbearing sandstones (p. 511). The record of a bore hole is given, showing six beds of coal below the sandstone, herein named Rockvale sandstone.

Reference is made to the Trinidad and Cerrillos coal fields.

1883.

93. Lesquereux, Leo, Contributions to the fossil flora of the western Territories; part 3, The Cretaceous and Tertiary floras: U. S. Geol. Survey Terr. Rept., vol. 8 , xii, 283 pp., 59 pls., $4^{\circ}$.

Lists and descriptions of fossil plants from the Cerrillos, Raton, Mesa, and other.coal fields are given (pp. 115-126).

94. White, C. A., Late observations concerning the molluscan fauna and the geographical extent of the Laramie group: Am. Jour. Sci., 3d ser., vol. 25, pp. 207-209.

Fossil shells occurring between Mexico and the Saskatchewan are described. The author criticizes a statement regarding the molluscan fauna of the Laramie in Geikie's textbook and throws doubt on Stevenson's observations that marine fossils were collected from the Laramie.

1884.

95. Cope, E. D., The Vertebrata of the Tertiary formations of the West: U.S. Geol. Survey Terr. Rept., vol. 3, xxxv, 1009 pp., 75 pls, $4^{\circ}$. Reviewed in Science, vol. 5. pp. 467-469, 1885.

In the table of formations Puerco and Laramie are included under post-Cretaceous (p. 42), although it is stated (p. 4) that the Puerco belongs to the "Tertiary rather than the post-Cretaceous"; and Fox Hills is used as a group name to include the Pierre and Fox Hills proper. A cross section west of Gallinas Mountains is given, showing "lignite." below the so-called Fox Hills.

96. Emmons, S. F., Address of the president (sketch of geology of the Rocky Mountain district): Colorado Sci. Soc. Proc:, vol. 1, pp. 3-12. 
1885.

96. Cops, E. D., Relations of the Puerco and Laramie deposits: Am. Naturalist, vol. 19, pp. 985-986. .

Observations from David Beldwin's notes are quoted, supplementing previous observations by the writer and others. The Taramie (so-called) is said to overlie the Fox Hills, to be 2,000 feet thick at Animas City, N. Mex., and to contain characteristic dinosaurs. The Puerco is said to overlie the Laramie with apparent conformity but is faunally distinct. It is sometimes included "with the Laramie in post-Cretaceous series."

97. Durron, C. E., Mount Taylor and the Zuni plateau: U. S. Geol. Survey Sixth Ann. Rept., pp. 105198, pls. 11-12. Abstracts in Am. Jour. Sci., 3d ser., vol. 34 , pp. 155-157, 1887. Science, vol. 10, pp. 317-318, 1887.

98. Emmons, S. F., Geological sketch of the Rocky Mountain division: Tenth Census, vol: 13, statistics and technology of the precious metals, pp. $60-104,4^{\circ}$

99. Savage, J., Notes on the geology of the Spanish Peaks: Kansas Acad. Sci. Trans., vol. 9, pp. 1.13-114.

100. S'Tevenson. J. J., Some notes respecting metamorphism: Am. Philos. Soc. Proc., vól. 22, pp. 161166. Abstract in Am. Jour. Sci., 3d ser., vol. 29, p. 4.14 .

Bricf reference is made to the anthracite coal of Placer Mountain (Cerrillos field) and to the metamorphosed coal near Trinidad and near Raton (p. 166). Several sections are given of the Raton coal bed.

101. Wario, L. F., Synopsis of the flora of the Laramie group: U. S. Geol. Survey Sixth Ann. Rept., pp. 399-557, pls. 31-65. Abstracts in Am. Naturalist, vol. 21, pp. 1011-1012, 1887. Am. Geologist, vol. 2, pp. 56-58, 1888. Review in Science, vol. 10 , pp. $150-151,1887$.

A historical review of opinion regarding the Laramie is given. A list of fossil plants includes some from the Raton Mesa region.

\section{6.}

102. Whrte, C. A., On the relation of the Laramie molluscan fauna to that of the succeeding fresh-water Eocene and other groups: U. S. Geol. Survey Bull. 34, pp. 39.L-442, 5 pls. . Abstract in Science, vol. 10, pp. 126-127, 1888. Pop. Sci. Monthly, vol. 33, p. $420,1888$.

The relation of Laramie (so-called) and Puerco is discussed and some of the invertebrates from the Puerco near Nacimiento are described.

1887.

703. Lesquereux, Leo, Prof. L. F. Ward's synopsis of the flora of the Laramie group: Am. Jour. Sci., $3 d$ ser., vol. 34 , pp. 487-488.

104. Rigas, R. B., "Naturil coke" from Purgatory Canon, N. Mex. (Colo.): In U. S. Geol. Survey Bull. 42, p. 147.
1888.

105. Inlseng, M. C., Report on oil fields of Fremont County: Colorado School of Mines Rept. of field work and analyses, 1886, pp. 67-80, pl.

\section{9.}

106. Hinls, R. C., The recently discovered Tertiary beds of the Huerfano River basin, Colorado: Colorado Sci. Soc. Proc., vol. 3, pt. 1, pp. 148-164.

107. - Address: The field for original work on the Rocky Mountains: Colorado Sci. Soc. Proc., vol. 3, pp. 168-184.

109. Strevenson, J. J., The Mesozoic rocks of southern Colorado and northern New Mexico: Am. Geologist, vol. 3, pp. 391-397.

The coal-bearing rocks of the Canon City, Trinidad, Raton, and Galisteo (Cerrillos) coal fields are referred to the Laramie (pp. 391-392). Rocks of Fox Fills age are supposed to occur below the coal near Canon City and Trinidad, Colo., but to thin out farther to the south, and are "supposed to be absent" in the Galisteo area.

110. WARD, L. F., The gengraphical distribution of fossil plants: U. S. Geol. Survey Eighth Ann. Rept., pp. 663-960, pl. lxi.

Colorado and New Mexico (pp. 911-916).

The discoveries of fossil plants in the Rio Puerco, Cerrillos, Raton Mesa, and other coal fields are reviewed.

1890.

111. Cope, E. D. [Remarks on the age and stratigraphic components of the Laramie group]: Geol. Soc. America Bull., vol. 1, p. 532. Am. Naturalist, vol. 24, p. 569 .

The Puerco, containing "about 100 species of mammalia, " is said to rest on the Laramie, which also contains some mammals and dinosaurs of Cretaceous age.

112. Emmons, S. F., Orographic movements in the Rocky Mountains: Geol. Soc. America Bull., vol. 1, pp. 245-286. Abstract in Am. Naturalist, vol. 24, pp. 211-212.

"I have laid stress upon the importance of the movement at the close of the coal-bearing Laramie in the Rocky Mountain region, and I desire to protest against what seems to be a tendency among those who are studying the paleontology of the region to give little weight to it, or even to neglect it altogether, in their determination of horizons. It is unquestionably one of the most important events in the orographical history of the entire Cordilleran system. With the exception of the great unconformity between the Archæan and all overlying sediments * * * no movement has left such definite evidence as that which followed the deposition of the coalbearing rocks to which the name Laramie has by universal consent been applied"' (p. 285).

113. - Colorado: Macfarlane's Geol. Railway Guide, 2d ed., pp. 289, 297-308. 
114. Hriss, R. C., Additional note on the Huerfano beds: Colorado Sci. Soc. Proc., vol. 3, pp. 21.7-223.

115. - Additional notes on the eruptions of the Spanish Peaks region: Colorado Sci. Soc. Proc., vol. 3, pp. 224-227.

116. Newberry, J. S., The Laramie group, its geologic relation, its economic importance, and its fauna and flora: New York Acad. Sci. Trans., vol. 9, pp. 27-32. Abstract (by author) in Geol. Soc. America Bull., vol. 1, pp. 524-527, 527-528, with discussion by J. B. Tyrrell, L. F. Ward, J. J. Stevenson, and E. D. Cope, pp. 527-532. Other abstracts in Am. Geologist, vol. 5, p. 118; Am. Naturalist, vol. 24 , pp. $856-857$.

Casual reference is made to southern Colorado and northern New Mexico coal fields.

A discussion of the Laramie problem is given, in which it is shown that confusion has arisen from grouping together formations of totally different age.

"Much undeserved discredit has * * * fallen upon the remains of plants as criteria of the age of strata and much mischief and confusion have followed the error of Dr. Hayden in uniting with the Laramie the totally distinct and independent Fort Union formation" (p. 28).

117. Stevenson, J. J. [Remarks on the differentiation of the Colorado group in Colorado and New Mexico]: Geol. Soc. America Bull., vol. 1; p. 532. Am. Naturalist, vol. 24, pp. 568-569. Discussion of paper by J. S. Newberry on "The Laramie group."

Reference is made to the Canon City, Raton Mesa, and central New Mexico coal fields. The writer states that the Fox Hills thins out to the south in New Mexico, but that the other Cretaceous formations continue around the mountains to the Rio Grande. [These formations are not known to exist over a large area at the southern end of the mountains, and although they may have been continuous at one time, they are far from being continuous now.]

118. VAN Diest, P. H., Remarks on the plication of the coal measures in southeastern Colorado and northeastern - New Mexico: Colorado Sci. Soc. Proc., vol. 3, pp. 185-190.

Some of the structural features of the Raton coal field are described and the presence of "nutlike lumps of coal" in the basal conglomerate of what is now known as the Raton formation near Yermejo Park is announced.

119. WARD, L. F. [Remarks on the age of the Laramie group]: Geol. Soc. America Bull., vol. 1, pp. 529-532. Am. Naturalist, vol. 24, pp. 564-568. Discussion of paper by J. S. Newberry on "The Laramie group."

1891.

120. Eldoridge, G. H., The Florence oil fields, Colorado: Eng. and Min. Jour., vol. 52, p. 422.

121. HiLls, R. C., Orographic and structural features of Rocky Mountain geology: Colorado Sci. Soc. . Proc., vol. 3, pp. 362-458, pl.
122. HiLls, R. C., Types of past eruptions in the Rocky Mountains: Colorado Sci. Soc. Proc., vol. 4, pp. 14-32.

123. - Address of the retiring president: Colorado Sci. Soc. Proc., vol. 3, pt. 3, pp. 359-458.

For "the Laramie movement," see p. 380. Among the post-Laramie beds are included the. Poison Canyon of the Raton Mesa region and the conglomeratic sandstones of the Canon City field.

124. Lakes, Arthor, The fuel resources of Colorado: Am. Geologist, vol. 8, pp. 7-1.9.

\section{2.}

125. Cross, Whitman, Post-Laramie deposits of Colorado: Am. Jour. Sci., 3d ser., vol. 44, pp. 19-42.

The Denver and Arapahoe formations are described as separated from the Laramie by a long period of important orographic disturbances (p. 20). "Great angular unconformity exists between the Laramie and the Poison Canyon beds" (p. 21). The conglomeratic beds of the Canon City field are correlated with the Denver and Arapahoe (p. 25). The Animas formation. near Durango is described among the post-Laramie formations (pp. 25-27).

126. EldDidare, G. H., The Florence oil field, Colorado: Am. Inst. Min. Eng. Trans., vol. 20, pp. 442-462.

127. Hills, R. C., Coal fields of Colorado: U. S. Geol.. Survey Mineral Resources, 1892, pp. 319-365, 1893.

1893.

128. Emmons, S. F., Excursion to the Canyon of the Colorado-Itinerary, Denver, Colo., to Albuquerque, N. Mex.: Cong. géol. internat., 5th sess., Compt: rend., pp. 464-468.

The reference of the coal beds near Ortiz in the. Cerrillos field to the Laramie is accepted. Coal measures of the Raton Mesa fields are referred to.

129. — Idem, Itinerary, Canyon City to Colorado. Springs, Colo.: Cong. geol. internat., 5th sess., Compt. rend., pp. $428-429$.

Describes the geology along the railroad between these points.

130. Knowlton, F. H., Annotated list of fossil plants of the Bozeman, Mont., coal field, with table of distribution and description of new species: The Laramie and the overlying Livingston formation in Montana: U. S. Geol. Survey Bull. 105, pp. 43-63, pls. v-vi. Abstracts in Am. Jour. Sci., 3d ser., vol. 44, p. 334, 1892; Washington Biol. Soc. Proc., vol. 7, pp. 153-154, 1892.

The localities and the collectors of the material on which the paper is based are mentioned. A - list of species and descriptions of new species are. given, also a table showing their geologic distribution. Brief reference is made to the Laramie: (so-called) of the Raton Mesa region.

1894.

131. Hollick, Arthur, A new fossil Nelumbo from theLaramie group at Florence, Colo.: Torrey Bot. Club Bull., vol. 21, pp. 307-310. 
1895.

132. Osborn, H. F., and Earle, Charles, Fossil mammals of the Puerco beds: Am. Mus. Nat. Hist. Bull., vol. 7, pp. 1-70, figs. 1-21.

The coal beds below the Puerco are assumed to be Laramie, and the Puerco is said to contain "several Laramie reptiles" (p. 4).

1896.

133. Emmons, S. F., Cross, Whitman, and Eldridge, G. H., Geology of the Denver Basin in Colorado: U. S. Geol. Survey Mon. 27, 1896.

134. Strevenson, J. J., The Cerrillos coal fields near Santa Ire, New Mexico: New York Acad. Sci. Trans., vol. 15, pp. 105-122. Abstracts in Geol. Soc. America 13ull., vol. 7, pp. 525-527; Science, new ser., vol. 3, pp. 392-394.

The statement is reiterated that the Fox Hills of the Rocky Mountain region is not represented in this area and the coal beds are assumed to be Laramie (p. 111). Sections of the coal-bearing rocks are given, the characteristics of the coal are described, and several analyses of the coal are given. The metamorphosis of the bituminous coal into anthracite is discussed.

1897.

135. Flemina, J. W. [Coal mines of New Mexico]: Rept. Governor of New Mexico to Secretary of Interior, Washington, 1897, pp. 91-115.

The report contains a geologic section of the rocks exposed near Madrid in the Cerrillos coal field. Coal mines in northern New Mexico, near Monero, are referred to.

1898.

136. Flemina, J.,W. [Coal mines of New Mexico]: Rept. of Governor of New Mexico to Secretary of Interior, Washington, 1898, pp. 56-86.

The report contains a geologic section of rocks exposed near Madrid in the Cerrillos coal field. The mines at Monero are described, where three beds of coal ranging in thickness from 3 feet 6 inches to 3 feet 10 inches have been opened.

137. Hosed, R. M., Anthracite in the Rockies: Mines and Minerals, vol. 18, pp. 529-533, 5 figs.; vol. 19, pp. 7-9, 2 figs.

138. Herrick, C. I., The geology of the San Pedro and the Albuquerque districts [N. Mex.]: Denison Univ, Sci. Lab. Bull., vol. 11, pp. 93-116, pl. 13.

The coal-bearing rocks outcropping on the Rio Puerco (p. 97) and those of the Tijeras field (pp. 108-109) are described as Cretaceous.

The coal beds of the Cerrillos field at Waldo, Madrid, and Omera are briefly mentioned ( $p$. 112). A sketch map of the geologic formations accompanies the paper.

139. Newberny, J. S., The later extinct floras of North America; edited by Arthur Hollick: U. S. Geol. Survey Mon. 35, 151 pp., pls. 1-58.

Descriptions of fossil plants from the Raton Mesa and Canon City coal fields are included.
140. Spencer, A. C., The Upper Cretaceous section in southwestern Colorado: Abstract in Science, new ser., vol. 7, p. 143 .

The statement is made that above the Dakota "comes a series of shales, known to embrace the Benton, Niobrara, and a part of the Pierre which can not be divided on lithologic grounds. The upper part of the section $* * *$ consists of massive sandstones in which both the Fox Hills equivalent and that of the Iaramie may prove to be present." No mention is made of the shale later named Lewis.

1899.

141. Cross, Whitman, U. S. Geol. Survey Geol. Atlas, La Plata folio (No. 60).

The coal-bearing rocks of the La Plata quadrangle in southwestern Colorado are described as the Mesaverde formation and as underlain by Mancos shale and overlain by Lewis shale, the latter about 2,000 feet thick (pp. 4, 5). The occurrence of coal-bearing rocks above the Lewis is noted, but doubt is cast upon the correctness of their reference to the Laramie.

The lower part of the Mancos shale (p. 5) contains the following characteristic Benton fossils:

Gryphaea newberryi.

Ostrea lugubris.

Ostrea congesta.

Inoceramus labiatus.

Inoceramus fragilis.

Inoceramus dimidius.

Prionocyclus macombi.

Baculites gracilis.

Scaphites warreni.

Anatina sp.?

Plicatula n. sp.

The upper part of the Mancos contains the following Pierre fossils [These have been reexamined by T. W. Stanton and the list given below was prepared by him to replace that given in the La Plata folio]:

Inoceramus barabini Morton (?).

Inoceramus sagensis Owen.

Inoceramus sp.

Syncyclonema rigida Hall and Meek.

Scaphites sp.

Baculites asper Morton (?). .

Baculites ovatus Say (?).

Baculites sp.

Arca sp. (?)

Turritella sp.

142. Flemina, J. W. [Coal mines of New Mexico]: Rept. of Governor of New Mexico to Secretary of Interior, Washington, 1899, pp. 164-209.

The coal mines near Madrid in the Cerrillos field are described and the geologic relations of the coal beds shown by columnar section. The mines at Monero are also described.

143. Hruls, R. C.; U. S. Geol. Survey Geol. Atlas, Elmoro, folio (No. 58). 
A part of the Trinidad coal field is described. The coal-bearing rocks are all referred, without statement of reasons, to the Laramie, the Trinidad sandstone to the Fox Hills, and the shale beneath it to the Pierre.

144. Lakes, Arthur, Coal fields of Colorado: Mines and Minerals, vol. 19, pp. 541-543, 4 figs.

1900.

145. Fleming, J. W., Report of the mine inspector for the Territory of New Mexico: Rept. of Governor of New Mexico to Secretary of Interior, Washington, 1900, pp. 279-314.

146. Herrick, C. L., and Johnson, D. W., The geology of the Albuquerque sheet [New Mexico]: Denison Univ. Sci. Lab. Bull., vol. 11, art. 9, pp. 175239, pls. 27-58. New Mexico Univ. Hadley Lab. Bull., vol. 2, pt. 1, pp. 1-67, 32 pls., colored geologic map in pocket; (a) p. 177.

A gastropod zone is described as occurring about 40 feet above the Dakota sandstone, followed upward by the Tres Hermanos sandstone and by a concretion zone which "abounds in large ammonite shells and large species of Pinna and Baculites" (pp. 187-188). This zone was recognized near Cabezon, about 20 miles to the northwest, and near Una de Gato (Hagan field), about 30 miles to the east. These three zones are close together, and from them, in the Rio Puerco, Hagan, and Tijeras fields, the following fossils were collected:

Ostrea translucida Meek and Hayden.

Exogyra laeviuscula Roemer.

Exogyra columbella Meek.

Mactra ? subquadrata Herrick and Johnson.

Tapes cyrimeriformis Stanton.

Caryates veta Whitfield.

Pholadomya subventricosa Meek and Hayden.

Liopistha concentrica Stanton.

Camptonectes symmetricus Herrick and Johnson.

Dosinia sp.

Chemnitzia sp.

Sigaretus textilis Stanton.

Baculites gracilis Shumard?

Prionotropis woolgari Mantell.

A thick shale [the principal part of the Mancos shale] occurs above the concretion zone, but its thickness is not given. Apparently the space occupied by it is represented by the hiatus in the section from east of Prieta Mesa, given in plate 22. [Johnson has stated personally to the present writer that the shale between the "concretion zone" and the "cephalopod zone" was roughly estimated at 1,000 feet.] A cephalopod zone is stated to occur about 100 feet from the top of this shale. [The present writer found this zone to be about 300 feet from the top], and above it the Punta de la Mesa sandstone (the basal member of the yellow sandstones described as the "Prieta series"), now known to be. a member of the Mancos shale. These sandstones, together with the cephalopod zone, were regarded as Fox Hills. From them the following fossils were collected:

Ostrea lugubris Conrad.

Ostrea sannionensis White.

Gryphaea vesicularis Lamarck.

Inoceramus fragilis Hall and Meek.

Pinna petrina White.

Rostellites ambigua Stanton.

Buchiceras swallovi Shumard.

Sphenodiscus lenticularis Owen.

Placenticeras placenta De Kay.

Placenticeras costata Herrick and Johnson.

Pholadomya subventricosa

Scaphites nodosus Meek and Hayden.

Scaphites sp.

The upper part of the "Prieta series" contains marine shells said to be of Fox Hills age and fossil plants "not identifiable with familiar Laramie species." The following fossils were collected from these coal-bearing rocks in the Rio Puerco, Hagan, and Tijeras fields:

Ostrea prudentia White.

Ostrea franklini Coquand?

Exogyra texana Roemer.

(?) Exogyra winchelli White.

Tellina ? perlata Herrick and Johnson.

Tellina equilateralis Meek.

Idonearca? depressa White.

Cardium pauperculum Meek.

Cardium sp.

Legumen ? appressum Conrad.

Chemnitzia coalvillensis Meek.

Gyrodes depressa Meek.

Pyropsis bairdi Meek and Hayden.

Rostellites dalli Stanton.

Volutomorpha? nova-mexicana Herrick and Johnson:

Baculites asper Morton.

Shark's teeth.

Plants.

Tertiary beds "with remains of vertebrates which we presume to be representatives of lower Tertiary strata" lie stratigraphically above the coal-bearing rocks on the Rio Puerco (p. 17).

147. Herrick, C. L., Report of a geological reconnaissance in western Socorro and Valencia counties, N.Mex.: Am. Geologist, vol. 25, pp. 331-346, pls. 8-60.

This paper supplements to some extent the information given in the description of the Albuquerque sheet. A section measured east of Prieta Mesa is given in which the cephalopod zone is placed only about 100 feet above the Tres Hermanos sandstone (p. 338). [This cephalopod zone seems to be the concretion zone of Herrick and Johnson.] The coal-bearing sandstones and shales (Mesaverde formation) are about 1,600 feet thick and are overlain by Tertiary.

148. Hilus, R. C., U. S. Geol. Survey Geol. Atlas, Walsenburg folio (No. 68)

149. Meade, Frank, Coal mines of Pictou, Colo.: Mines and Minerals, vol. 21, pp. 1-3, 2 figs.

The coal beds are referred to as Laramie and contain numerous fossil plants. A cross section of the rocks is given which is significant in show- 
ing a discrepancy in dip between the coal beds and the overlying sandstone, although the significance of this relation is not explained.

1901.

150. Herrick, C. L., Applications of geology to economic problems in New Mexico: Internat. Min. Cong. Proc., 4th sess., pp. 61-64.

Attention is called to the fact that some of the New Mexico coal-bearing rocks formerly supposed to be Laramie contain Ostrea glabra and are overlain by marine Cretaceous beds "with fossils like those of the upper Fox Hills group" (p. 64).

151. Frtrs, R. C., U. S. Geol. Survey Geol. Atlas, Spanish Peaks folio (No. 71)

For geology, see Elmoro folio. [The Morley coal is placed in the section about 800 feet above the base of what is called Laramie in the folio, whereas the coal at Morley is now known to be the lowest bed of the Vermejo formation elevated by a local dome. This coal seems to have been correlated with beds which in other places occur near the middle of the coal measures.]

152. Lakes, Anthur, The Cerrillos anthracite mines: Mines and Minerals, vol. 21, pp. 341-342.

153. The geology of the oil fields of Colorado: Colorado School of Mines Bull., vol. 1, pp. 221226.

154. Sherrdan, J. E., Report of the mine inspector for the Territory of New Mexico: Rept. of Governor of New.Mexico to Secretary of Interior, Washington, pp. 309-351.

\section{2.}

155. Lakkes, Arthur, The Spanish peaks; coal region in söuthern Colorado; an illustration of the effects of volcanic action on coal seams: Mines and Minerals, vol. 22, pp. 463-464, 4 figs.

156. The coal, graphite, and oil fields of Raton, N. Mex; the location and geological character; the coal mines: Mines and Minerals, vol. 22, pp. 350-352, 5 figs.

157. LeE, W. T.; Note on the Carboniferous of the Sangre de Cristo Range, Colo.: Jour. Geology, vol. 10, pp. 392-396.

158. The Morrison shales of southern Colorado and northern New Mexico: Jour. Geology, vol. 10, pp. $36-58,7$ figs.; (a) p. 44 ; (b) p. 45 .

The Exeter sandstone is named and described in this paper.

159. - Canyons of southeastern Colorado: Jour. Geography, vol. 1, pp. 357-370, 12 figs.

Includes sections of the strata cut by some of the canyons described.

160. Storrs, L. S., The Rocky Mountain coal fields: U. S. Geol. Survey Twenty-second Ann. Rept., pt. 3, pp. 415-471, 2 pls., 1 fig.

The coal beds of the San Juan Basin and of the Cerrillos and Hagan fields are referred to the Laramie and the coal of the latter two is said to lie "under the Tertiary beds."
1903.

161. Johnson, D. W., The geology of the Cerrillos Hills, New Mexico; Part I, General geology; Part II, Paleontology; Part III, Petrography: School of Mines Quart., vol. 24, pt. 1, pp. 303-350, 7 pls., 7 figs.; pp. 456-500, 10 pls., 6 figs., 1903; pt. 2, pp. 173-246, 14 pls., 1903; vol. 25, pt. 3, pp. 69-98, 5 pls., 1904; (a) p. 339, fig. 5 .

The report results from the work done in 18991902.

"Among others, the following propositions are" supported. ***

"The *** Santa $\mathrm{Fe}$ marls of Hay$\operatorname{den} * * *$ represent the time from the early Loup Fork Tertiary to the Recent period.

"The Galisteo group of Hayden consists of red beds of late Cretaceous, probably Laramie age. $* * *$

"The coal series, or Madrid group, is of Fox Hills age.

"Fort-Pierre, Fort Benton,. and probably Dakota and Jura-Triassic beds are also present in the district" (vol. 24, p. 306).

The Galisteo sandstone is referred doubtfully to the Laramie and is described as consisting of red sedimentary rocks similar lithologically to the older "Red Beds" and lying conformably [(?) see discussion on this point in the present paper] upon the beds called Madrid coal group (Mesaverde formation of the present paper). They contain fossil wood which, according to F. H. Knowlton, indicates a species of Quercus and is evidently of Upper Cretaceous or later age (vol. 24, pp. 336-338).

The "Madrid coal group" is described (pp. 338-344) as 1,500 to 2,000 feet thick. The coal is said to be in the lower part of this "group." The author's figure 5 makes the base of the "group" rest upon the lowest sheet of intrusive igneous rock at Madrid, and places the rocks below this sheet in the Pierre. [This would place in the Pierre below the "Madrid coal group" a considerable thickness of sandstone and several thin beds of coal which obviously belong in the "Madrid" (Mesaverde) or coalbearing formation.] The base of the "Madrid" is obviously drawn but little below the coals that have been. mined, for the writer states (p. 340) that "the coal in the lower portion of Madrid group has proven of great interest to geologists, and so -many references have been made to it," etc.

The Pierre is described as consisting of shale and sandstone (pp. 344-347). - A section (p. 346) places 162 feet of sandstone above the dark shale (Mancos) in the Pierre.

No undoubted Niobrara was found, but the Benton and Dakota are reported (p. 347).

The economic features of the coal are described (pp. 477-493). Fossil plants, identified by Knowlton (p. 178, Paleontology) as Ficus rham- 
noides Knowlton, Ficus uncata Lesquereux, Quercus? sp., and Aralia? sp. were found above the highest coal bed east of Madrid.

In some places fossils characteristic of the Colorado and Montana groups seem to occur together (p. 182).

The following faunas of the Cerrillos region are described :

$$
\text { Pierre fauna. }
$$

Lingula subspatulata Hall and Meek. Ostrea anomioides var. nanus Johnson. ?Ostrea congesta Conrad.

Inoceramus simpsoni Meek.

Inoceramus vanuxemi Meek and Hayden Inoceramus balchii Meek and Hayden. Inoceramus cripsi var. barabini Morton. Inoceramus irregularis Johnson. Inoceramus sp.

Endocostea typica Whitfield.

Endocostea brooksi Johnson.

Arca madridensis Johnson.

Trigonarca obliqua Meek.

Nucula subplana Meek and Hayden. Astarte evansi (Hall and Meek) Whitfield. Protocardia rara Evans and Shumard. Cyprimeria? sulcata Johnson.

Solen cuneatus Gabb.

Corbula nematophora var. fitchi Johnson.

Natica sp.

Turritella galisteoensis Johnson.

Rostellaria? texana Conrad.

Tritonium kanabense Stanton.

Admetopsis? elevata Johnson.

Helicoceras pariense White.

Baculites anceps Lamarck.

Baculites sp.

Placenticeras placenta De Kay.

Placenticeras? sp.

Placenticeras? intermedium Johnson.

Placenticeras? rotundatum Johnson.

Stantonoceras guadaloupae Roemer.

Beryx sp.

\section{Benton fauna.}

Ostrea lugubris Conrad.

Inoceramus fragilis Hall and Meek.

Inoceramus labiatus Schlotheim.

Inoceramus dimidius White.

Aucella strongi Johnson.

Acmaea cerillosensis Johnson.

Scurria coniformis Johnson.

Rostellites dalli var. wellsi Johnson.

Rostellites ambigua Stanton.

Prionocyclus wyomingensis Meek.

Prionocyclus macombi Meek.

Prionocyclus sp.

- Prionotropis woolgari Mantell.

Scaphites warreni Meek and Hayden.

Beryx sp.

Baculites anceps Lamarck.

162. Lakes, Arthur, The Trinidad or El Moro coal region of Colorado: Mines and Minerals, vol. 23, pp. 254-256.
163. Lakes, Arthur, Aguilar coal and oil district; a description of the geology, the thickness and - quality of the coal veins, and the indications of oil: Mines and Minerals, vol. 23, pp. 196-198, 4 figs.

164. Lee, H. A., Colorado: Rept. State Bur. Mines, 1901-2, 310 pp., map, Denver.

165. McLaughlin, J. E., Barela Mesa coal field, Colorado: Mines and Minerals, vol. 24, p. 139, 1 fig.

The author describes the coal measures in the eastern part of the Raton Mesa field and gives a section showing ten beds of coal, nine of which are 3 feet or more in thickness. Illustrations are given of the irregularity in the thickness of the coal.

166. Merriam, L. B., The development of a new coal field in Colorado: Western Soc. Eng. Jour., vol. 8 , no. 6 , pp. $617-637$.

167. RegGan, A. B., Geology of the Jemez-Albuquerque region, New Mexico: Am. Geologist, vol. 31, pp. $67-111,7$ pls. See also Indiana Acad. Sci. Proc., 1902, pp. 197-198.

A geologic sketch map showing the distribution of the formations from Cabezon eastward to Hagan is given.

The author's Fox Hills includes the sandy rocks below the coal; and the coal-bearing rocks, 500 feet thick, are described as "Fort Union or Laramie" (p. 79). His Fox Hills and Fort Union constitute the Fox Hills of Herrick and Johnson and the Mesaverde of later writers.

The colored sediments lying unconformably on the coal-bearing rocks south of San Isidro (in the Rio Puerco field) are referred to the Puerco (p. 81).

1904.

168. Hosea, R. M., Tercio and Cuatro mines. A description of the coal washing and coking plants of the Colorado Fuel and Iron Company at Tercio and Cuatro [Colo.]: Mines and Minerals, vol. 25 , pp. 218-223, 6 figs.

169. The Primero mines: Mines and Minerals, vol. 24, pp. 521-526.

170. Jones, F. A., New Mexico mines and minerals, World's Fair edition, Santa Fe, N. Mex., The New Mexican Printing Co., 349 pp., 50 figs.

171. KeYES, C. R., Unconformity of the Cretaceous on older rocks in central New Mexico: Am. Jour. Sci., 4th ser., vol. 18, pp. 360-362, 2 figs.

Cretaceous sandstones (2,000 feet thick) lying above rocks of Montana age (presumably the coal-bearing sandstones described in this paper as Mesaverde) are referred to the Laramie.

172. - The Hagan coal field [New Mexico]: Eng. and Min. Jour., vol. 78, pp. 670-671, 3 figs.

The Hagan coal field is described with sketch maps and geologic sections.

A detailed section is given of the coal-bearing rocks. measured at the Hagan mine, in which eight beds of coal occur. Another section is given as measured in the Coyote field (Sloan. mine). Four analyses of the Hagan coal are given and the fuel values compared with those of other New Mexico coals. 
173. Tha Kes, Arthur, The coal fields of Colorado: Colorado School of Mines Bull., vol. 2, no. 2, pp. 11-23, 2 figs.

174. The Walsenburg coal district of Coloradu: Abstract in Mines and Minerals, vol. 24, pp. 339-341.

175. Srentdan, J. E., Annual report of the mine inspector for the Territory of New Mexico: Ann. Rept. U. S. Mine Inspector for New Mexico Terr. to Secretary of Interior, 1904, $79 \mathrm{pp}$.

1905.

176. Darton, N. H., Preliminary report on the geology and underground-water resources of the central Great Plains: U. S. Geol. Survey Prof. Paper 32, 433 pp., 72 pls., 18 figs.

177. Fenneman, N. M., The Florence (Colo.) oil field: U. S. Geol. Survey Bull. 260, pp. 436-440.

178. Jupd, E. W., New coal developments in northern New Mexico: Eng. and Min. Jour., vol. 80, pp. 300-301.

179. Lakes, Arthur, The Rocky Mountain coal fields. Min. Reporter, vol. 51, pp. 5-7, 2 figs.

180. The coal field of Colorado: Min. Reporter, vol. 51 , pp. 73-74, 3 figs.

181. — Coal along the eastern foothills: Min. Reporter, vol. 51, pp. 127-128.

182. The geology and coal deposits of the Spanish Peaks district: Min. Reporter, vol. 51, pp. 184-185, 4 figs.

183. Coals of the southern Colorado or the Walsenburg and Trinidad region: Min. Reporter, vol. 51, pp. 234-235, 1 fig.

184. - Sketch of the economic resources of the foothills of the front range of Colorado: Min. Reporter, vol. 51, pp. 522-524, 1 fig.

185. The Occidental and other coal mines of i.Tuerfano County, Colorado. A description of the geology and development of the region: Mines and Minerals, vol. 25, pp. 473-474, 3 figs.

Several geologic sections are given by which the coal beds of the Occidental mine at the western margin of the Trinidad coal field are correlated with those of the Walsenburg district.

186. Plumb, C. H., The Tercio coal mining district, Colorado: Drury. Coll., Bradley Geol. Field Station Bull., vol. 1, pp. 94-100.

187. Stranton, T. W., Morrison formation and its relation with the Comanche series and the Dakota formation: Jour. Geology, vol. 13, pp. 657-669.

Some of the rocks in northeastern New Mexico and southeastern Colorado; heretofore called Dakota, are shown on fossil evidence to be Comanche (p. 664).

Near Canon City, Colo., the shale which separates the two sandstones of the so-called Dakota sandstone was found to contain a Comanche fauna (p. 666).

188. Sheridan, J. E., Annual report of the mine inspector for the Territory of New Mexico: U. S. Mine Inspector for N. Mex. Terr. Ann. Rept. to Secretary of Interior, 1905.

Describes the Cerrillos and Una del Gato (Hagan) coal fields (pp. 40-48).

$47019^{\circ}-17-3$
189. Underhill, James, Correlation of Colorado geological formations: Min. Reporter, vol. 52, pp. 496-497.

1906.

190. Chamberlin, T. C., and Salisbura, R. D., Geology, vol. 3, 624 p̀., 270 figs.

191. Darton, N. H., Geology and underground waters of the Arkansas Valley in eastern Colorado: U. S. Geol. Survey Prof. Paper 52, 90 pp., 27 pls., 2 figs.

192. Griffith, William, Kinds and occurrence of anthracite coal: Min. Mag., vol. 13, No. 3, pp. 214-221.

193. Jones, F. A., Mineral resources of New Mexico: Am. Min. Cong. Eighth Ann. Sess., pp. 135-143.

194. Keyes, C. R., Orotaxial significance of certain unconformities: Am. Jour. Sci., 4th ser., vol. 21, pp. 296-300, 2 figs.

195. G Geological section of New Mexico: Science, new ser., vol. 23, pp. 921-922.

196. Lakes, Arthur, Colorado anthracite. The field of the State and the influence of eruptive rocks in metamorphosing the bituminous deposits: Mines and Minerals, vol. 26, No. 6, pp. 275-276, 2 figs.

197. LEE, W. T., The Engle coal field, New Mexico: U. S. Geol. Survey Bull. 285, p. 240.

The coal beds of the Engle field contain numerous plant remains and rest on rocks containing a Benton fauna. [Lying on the coal measures (unconformably, as has been determined since this paper was published) are red sedimentary rocks similar in general appearance to the Galisteo sandstone of the Cerrillos, field.] Triceratops bones were found in these red rocks. The correlation of the coal measures with those at Cerrillos and Raton is suggested.

198. Merrilu, G. P., Contributions to the history of American geology: U. S. Nat. Mus. Ann. Rept. 1904, pp. 189-733, 37. pls., 141 figs.

Several brief sketches are given of the men who worked in the fields described in this paper and of the results obtained by them. Chapter $\mathrm{X}$ is devoted to the Laramie question.

199. Ritter, E. A., Les bassins lignitifères et houillers des Montagnes Rocheuses: Annales des mines, 10th ser., vol. 10, livr. 7, pp. 5-84.

200. Schrader, F. C., The Durango-Gallup coal field of Colorado and New Mexico: U. S. Geol. Survey Bull. 285, pp. 24l-258.

A map is presented outlining the principal part of the San Juan Basin. Five groups of coal beds are shown: (1) a Colorado coal group in the southwestern part of the field; (2) a lower Montana coal group-"relation to the Mesaverde unknown."-occurring also in the southwestern part of the field; (3) a Mesaverde coal group occurring in the northern and eastern parts of the field; (4) an upper Montana coal group-" relation to the Mesaverde unknown"-ccurring in the south and southeastern parts of the field; and (5) a Laramie? coal group occurring in the northern and northeastern parts. 
The Laramie? coal group is shown as extending from Colorado as far south as Gallinas Mountains, N. Mex., and is the same as the Laramie of other writers; the Mesaverde coal group extends as far south as Puerco River. The upper Montana coal group occurs in the southeastern part of the field near Cabezon and is included in the Mesaverde formation of the later writers. The other coal groups occur only west of the area described by the present writer.

The Chico Arroyo district, extending from Sierra Nacimiento to Mount Taylor, contains coal-bearing rocks 2,000 to 3,000 feet thick, which are said to contain fossils which indicate that they are younger than Mesaverde (p. 251). These constitute the upper Montana coal group. [The Mesaverde coal group and the upper Montana coal group of Schrader together constitute the Mesaverde formation of Gardner and of the present writer.]

201. Sheridan, J. E., Present conditions and future pros' pects of the coal-mining industry in New Mexico: Ann. Rept. U. S. Mine Inspector for New Mexico Terr. to Governor of New Mexico, 134 pp., Santa Fe.

The coal mines at Monero are described. Three beds of coal, varying from 3 to 4 feet in thickness, are said to be worked (pp. 66-69).

The mines in the Cerrillos and Una del Gato (Hagan) fields are briefly described (pp. 70-78).

202. - Report of the mine inspector for the Territory of New Mexico to the Secretary of the Interior for the year ended June 30, 1906, 87. pp.

\section{7.}

203. Campbell, M. R., The Una del Gato coal field, Sandoval County, N. Mex.: U. S. Geol. Survey Bull. 316, pp. 427-430, 1 fig.

The Una del Gato (Hagan) field is described principally from an economic point of view. A section of the rocks measured by C. R. Keyes near Sloan mine is given. The coals are correlated with those of the Cerrillos field, and the statement is made that "it is highly probable that they are Laramie."

204. JUDD, E. K., New development in coal fields of New $y^{\prime 2}$ Mexico: Eng. and Min. Jour., vol. 84, pp. 8-11, 6 figs.

205. LAKES, ARTHUR, Sketch of the oil fields of Colorado: Min. World, vol. 26, p. 684.

206. LeE, W. T., Note on the red beds of the Rio Grande region in central New Mexico: Jour. Geology, vol. 15, No. 1, pp. 52-58.

Coal-bearing rocks near Elephant Butte, N. Mex., are described (p. 57) as underlying red beds containing bones of Triceratops, which suggests late Cretaceous age. Red beds of similar appearance near Cerrillos, N. Mex., known as Galisteo sandistone; have also been regarded as late Cretaceous, and the correlation of the two is suggested.

207. Shaler, M. K., A reconnaissance survey of the western part of the Durango-Gallup coal field of Colo- rado and New Mexico: U. S. Geol. Survey Bull. 316 , pp. 376-426, 2 pls.

The paper deals with the geology. of the western part of the San Juan Basin. Coal was found in the Dakota, the Mancos, the Mesaverde, and the so-called Laramie.

208. Sheridan, J. E., Report of the mine inspector for the Territory of New Mexico to the Secretary of the Interior for the fiscal year ended June 30, 1907, $48 \mathrm{pp}$.

1908.

209. CAMpBell, M. R., Coal fields of the United States (map, with explanations), U. S. Geol. Survey.

210. Jones, F. A., Epitome of the economic geology of New Mexico, published by direction of the New Mexico Bureau of Immigration, $47 \mathrm{pp}$.

211. Shrmer, H. W., and Blodgett, M. E., The stratigraphy of the Mount Taylor region, New Mexico: Am. Jour. Sci., 4th ser., vol. 25, pp. 53-67, 4 figs. This paper is a report on observations made in 1906 in the Rio Puerco valley, south of Cabezon.

The gastropod zone near the base of the Cre- taceous, the concretion (Septaria) zone, and the cephalopod zone of Herrick and Johnson were recognized, but most of the fossils collected are from the latter two zones.

1909.

212. Gardner, J. H., The coal field between Gallina and Raton Spring, New Mexico, in the San Juan coal region: U. S. Geol. Survey Bull. 341, pp. 335-351, 1 pl. (map).

Two coal-bearing formations southwest of Nacimiento Mountains are described. They are the Mesaverde, which includes Schrader's upper Montana coal group, and the Laramie (so called). These are separated by Lewis shale, which is said to be 2,000 feet thick near Gallina and only 250 feet thick on the Arroyo Torreons, about 30 miles to the southwest. Several geologic sections are given, showing the relations of the coal beds to other rocks.

"At a point 10 miles north of Gallina a part of the formation [Mancos shale] becomes arenaceous and forms a hogback in the shale valley. This.sandy bed is about 30 feet thick and about 275 feet below the top of the formation. It is no doubt the beginning of the sandstone and shale formation that increases in thickness toward the south and is coal bearing on the south side of the [San Juan] Basin" (p. 338).

213. LEE, W. T., The correlation of sections lithologically similar: Abstract in Science, new ser., vol. 29, p. 239.

214. - On the occurrence of coal changed to coke and graphite in the Raton, N. Mex., coal field: Abstract in Science, new ser., vol. 29, pp. 198-199.

215. Unconformity in the so-called Laramie of the Raton coal field, New Mexico: Geol. Soc. America Bull., vol. 20, pp. 357-368, 3 pls., 1 fig. 
The paper presents evidenee that the coalbearing rocks of the Raton field are divisible into two formations, the lower older than Laramie and the upper of post-Laramie age.

216. Lee, W. T., The Manzano group of the Rio Grande valley, New Mexico: U. S. Geol. Survey Bull. 389; (a) pp.18-19; (b) p. 37.

The paper includes geologic sections of the older rocks up to and including the Dakota sandstone in the Cerrillos and Hagan fields.

217. Shrridan, J. E., The coal mines and plant of the Stag Canyon Fuel Co:, Dawson, N. Mex.: Am. Inst. Min. Eng. Bull. 30, pp. 537-564, 15 figs.

'Two workable coal beds and two or three thin beds are described (p. 539). The Dawson mines are on the lowest coal, which in the mines ranges from 6 to 11 feet in thickness.

218. Stranton, T. W., The age and stratigraphic relations of the "Leratops beds" of Wyoming and Montana: Washington Acad. Sci. Proc., vol. 11, pp. 239-293.

The paper gives the names of invertebrates from the Laramie (so called) of southwest Colorado (p. 274).

219. Strennetr, D. B., The production of precious stones in 1908: U. S. Geol. Survey Mineral Resources, 1908; (a) p. 807

1910.

220. Darton, N. H., A reconnaissance of parts of northwestern New Mexico and northern Arizona: U.S. Geol. Survey Bull. 435, 88 pp., 17.pls., 8 figs.

The geology along the Santa Fe Railway from Albuquerque westward is described. The Cretaceous is stated to consist of the following formations given in descending order: Laramie formation, coal bearing; Lewis shale; Mesaverde formation, coal bearing; Mancos shale, locally coal bearing; Dakota sandstone.

Gardner's results are accepted for the Nacimiento region and Herrick and Johnson's for the Rio Puerco region (p. 58). Herrick's section in the Rio Puerco valley (p. 338) is quoted with several changes, and the reference of the coalbearing rocks, including the Punta de la Mesa sandstone to the Fox Hills is accepted. A section of rocks exposed at Laguna west of the Rio Puerco coal field was measured. The following fossils occur about 550 feet above the base of this section:

Exogyra columbella Meek.

Gryphaea sp., probably a variety of G. newberryi.

Avicula gastrodes Meek?

Cardium, Panopea, Turritella, Rostellites, and Fusus sp.

About 100 feet lower in the section the following Benton species were collected:

- Exogyra columbella Meek.

Pecten sp:

Pinna petrina White.

Inoceramus?, Leda, Cardium, and Lucina? sp.
Isocardia n. sp.

Cyprimeria? sp.

Corbula sp.

Liopistha (Psilomyra) concentrica Stanton. Turritella whitei Stanton.

'Tritonium kanabense Stanton.

Actaeon, Cinulia, Turrilites?, or Heteroceras sp.

221. Gardner, J. H., Isolated coal fields in Santa Fe and San Miguel counties, New Mexico: U. S. Geol. Survey Bull. 381, pp. 447-451.

A part of this paper is devoted to the "Omara coal field" and the coal beds at the Omara mine are correlated with those near Madrid. [These localities are at opposite extremities of the Cerrillos field.]

222. - The coal field between San Mateo and Cuba, New Mexico: U. S. Geol. Survey Bull. 381, pp. $461-473,1$ pl. (map).

The coal-bearing formations of the southeastern part of the San Juan Basin are described as Mesaverde and "Laramie." A detailed section of the Mesaverde on Arroyo Torreones (p. 470) shows a thickness of 1,328 feet.

The statement is made (p. 462) that the Mesaverde "is now known to encircle the San Juan Basin. The same is true of the overlying conformable Lewis shale and 'Laramie' formation."

223. The Puerco and Torrejon formations of the Nacimiento group: Jour. Geology, vol. 18, No. 8 , pp. 702-741, 3 pls., 8 figs.

The Tertiary and late Cretaceous formations of the San Juan Basin west of Nacimiento Mountains are described.

The Tertiary beds were found to rest unconformably on the "Laramie" and the Mesaverde formation is separated from the "Laramie" by the Lewis shale.

224. Lindgren, Waldemar, Graton, L. C., and Gordon, C. H., The ore deposits of New Mexico: U. S. Geol. Survey Prof. Paper 68, 361 pp., 22 pls., 33 figs.

Brief references are made in many places to the coal-bearing formations of New Mexico.

225. Richardson, G. B., The Trinidad coal field, Colorado: U. S. Geol. Survey Bull. 381, pp. 379-446, 2 pls. (map and sections), 9 figs.; (a) p. 123; (b) p. 104; (c) p. 128 .

The author describes the general geology, the occurrence of the coal beds, and the character of the coals. The occurrence of a conglomerate in the midst of the coal-bearing rocks is recognized, but its significance is not pointed out. The coalbearing rocks are not subdivided and their age is left an open question. The coal beds are all referred to the "Laramie."

226. Washburne, C. W., The Canon City coal field, Colorado: U. S. Geol. Survey Bull. 381, pp. 341-378; (a) p. 365.

The author describes the general geology, the occurrence of the coal beds, and the character of the coals. Geologic sections, are given, 
including the rocks from the Pierre shale to the Denver (?) formation. The coal measures are all referred to the Laramie, although a Montana flora was found in the lower part. [A few poorly. preserved plants from the upper part were supposed to indicate Laramie age, but better material collected and studied since that time proves that the whole formation is Montana in age.]

227. Washburne, C. W., The Florence oil field, Colorado: U. S. Geol. Survey Bull. 381, pp. 517-544, also separately (U. S. Geol. Survey Bull. 381-D).

1911.

228. LeE, W. T., Further evidence of an unconformity in the so-called Laramie of the Raton coal field, New Mexico: Abstract in Geol. Soc. America Bull., vol. 22, p. 717.

.The unconformity in the midst of the coalbearing rocks of the Raton coal field was traced around the Raton and Trinidad coal fields.

229. Correlation of rocks in the isolated coal fields around the southern end of the Rocky Mountains in New Mexico. (The preliminary announcement of the results contained in this paper was made at the Washington meeting of the Geological Society of America in 1911.)

230. Criteria for an unconformity in the so-called Laramie of the Raton Mesa coal fields of New Mexico and Colorado: Abstract in Science, new ser., vol. 33, pp. 355-356.

231. Lakes, Arthur, Geology of the La Veta coal field: Mines and Minerals, vol. 31, pp. 466-468

\section{2.}

232. Willis, Bailey, Geologic map of North America (published in 1911) to accompany Index to the stratigraphy of North America: U. S. Geol. Survey Prof. Paper 71.

The reference on the map of the rocks now known as the Vermejo formation to the Montana and of the rocks now known as the Raton formation to "earliest Tertiary or latest Cretaceous" (in which is included Denver, Arapahoe, etc.) is based on the information given in detail in the present paper.

233. Stose, G. W., U. S. Geol. Survey Geol. Atlas, Apishapa folio (No. 186).

The two sandstones, separated hy shale at the base of the Cretaceous section of this quadrangle, have until recently been called Dakota. The name Dakota is now restricted to the upper sandstone and the lower one, including the shale parting, is called the Purgatoire formation and is referred on fossil evidence to the Lower Cretaceous series (Comanche).

234. Richardoson, G. B., The Monument Creek group: Geol. Soc. America Bull., vol. 23, pp. 267-276.

The Monument Creek of former writers is here separated into two formations-the Dawson arkose (assigned to the Eocene) and the Castle Rock conglomerate (assigned to the Oligocene). Regarding the age relations of the Dawson arkose the writer says (p. 268): "Stratigraphic relation- ships indicate that the Arapahoe and Denver formations are equivalent to the lower part of the Dawson arkose, and this evidence is paleontologically supported." Knowlton states that the fossil plants from the Dawson arkose "are undoubtedly Denver in age" (p. 272). "It is evident that the Dawson arkose together with its associated unconformities represents the time between the Laramie and the Oligocene" (p. 274). "In the light of present knowledge, therefore, it seems plausible that the Arapahoe and Denver formations are the equivalent of the lower part of the Dawson arkose": (p. 275). A saving clause is added, that "it is not claimed that final correlations have been established, but nevertheless previously unsuspected relationships are indicated" (p. 274).

Of the stratigraphic relations it is said (p. 274) that "the lower part of the Dawson arkose seems to pass along the strike into the Arapahoe and Denver formations; that the Dawson and Arapahoe can not be separated lithologically even at the type locality of the Arapahoe on the bluffs of Willow Creek; and that the Denver and Dawson apparently merge into each other." It is further stated (p. 275) that "the evidence [of certain vertebrates] implies the correlation of the lower part of the Monument Creek of Hayden [the lower part of the Dawson arkose] and the 'post-Laramie' of the Denver Basin" [the Arapahoe and Denver formations].

235. LEE; W. T., Stratigraphy of the coal fields of northern central New Mexico: Geol. Soc. America Bull., vol. 23 , pp. 571-686.

The results presented in this paper have been amplified by more recent observations and are incorporated in the present paper; hence the abstract is omitted in this connection. Some of the results were used in a paper by the same writer, entitled "The Cerrillos coal field, Santa Fe County, New Mexico": U. S. Geol. Survey Bull. 531, pp. 285-312, 1913; (a) p. 617 .

236. Graphite near Raton, New Mexico: U. S Geol. Survey Bull. 530, pp. 371-374, also separately (U. S. Geol. Survey Bull. 530-I, pp. 3-6).

The graphite results from the metamorphosis, by intrusion of igneous rock, of the bituminous coal mined a few miles away, and analyses of this coal are given together with that of the graphite.

237: C Coal fields of Grand Mesa and the West Elk Mountains, Colorado: U. S. Geol. Survey Bull. 510 .

1913.

238. LEE, W. T., Recent discovery of dinosaurs in the Tertiary: Am. Jour. Sci., 4th ser., vol. 35, pp. 531-534.

Dinosaur bones were found near Colorado Springs, Colo., in the Dawson arkose in associations that are regarded as proving the Tertiary age of these dinosaurs.

239. Kivowlton, F. H., A paleontological study of the coal-bearing rocks of the Raton Mesa region of 
Colorado and New Mexico: Am. Jour. Sci., 4th ser., vol. 35, pp. 526-530.

(This paper is a preliminary announcement of conclusions based on the details given in F. H. Knowlton's part of the present paper.)

240. Georae, R. D., Geologic map of Colorado: Colorado Geol. Survey, Boulder, Colo.

The formation names Vermejo and Raton first proposed for the present report are used on the Colorado map.

1.914.

241. LEE, W. T., Use of physiography in the study of Rocky Mountain stratigraphy: Washington Acad. Sci. Jour., vol. 4, pp. 8-9.

Reasons are given for believing that the interior Cretaceous sea extended uninterruptedly over the Rocky Mountain region of Colorado and northern New Mexico and that the present mountains date from the beginning of the Tertiary period.

242. Stephenson, L. W., The Cretaceous-Eocene contact in the Atlantic and Gulf coastal plain: U. S. Geol. Survey Prof. Paper 90, pp. 155-182, 1915. Abstract in Washington Acad. Sci. Jour., vol. 4, pp. 111-12, 1914.

The Cretaceous-Eocene contact is described as an unconformity of regional extent, which represents a long period of time.

243. Symposium on the close of the Cretaceous and the opening of Eocene time in North America: Geol. Soc. America Bull., vol. 25, pp. 321-402; includes the following papers:

Osborn, H. F., Close of the Cretaceous and opening of Eocene time in North America, pp. 321-323.

Knowlton, F. H., Cretaceous-Tertiary boundary in the Rocky Mountain region, pp. 325-340.

Stanton, T. W., Boundary between Cretaceous and Tertiary in North America as indicated by strat:graphy and invertébrate faunas, pp. 341-354.

Brown, Barnum, Cretaceous Eocene correlation in New Mexico, Wyoming, Montana, Alberta, pp. 355-380.

Matthew, W. D., Evidence of the Paleocene vertebrate fauna on the Cretaceous-Tertiary problem, pp. 381-402.
244. Sinclair, W. J., and Granger, Walter, Paleocene deposits of the San Juan Basin, New Mexico: Am. Mus. Nat. Hist. Bull, vol. 33, pp. 297316.

1915.

245. Richardson, G. B., Description of the Castle Rock quadrangle, Colorado: U. S. Geol. Survey Geol. Atlas, Castle.Rock folio (No. 198).

246. Ransome, F. I., Problems of American geology, New Haven, Yale University Press, London, etc.

247. HeRoy, W. B.; The relation of the Upper Cretaceous formations of southern Wyoming and northeastern Colorado: Washington Acad. Sci. Jour., vol. 5, pp. 330-331.

The equivalency of the so-called Fox Hills sandstone of the Denver Basin with the typical Fox Hills in northern South Dakota is questioned and the writer concludes that "the 'Fox Hills' of the Denver Basin is apparently equivalent to the lower Mesaverde (Parkman). of southern Wyoming."

\section{6 .}

248. Frndey, G. I., Description of the Colorado Springs quadrangle, Colorado: U. S. Geol. Survey Geol. Atlas, Colorado Springs folio'(No. 203).

249. LEE, W. T., Relation of the Cretaceous formations to the Rocky Mountains in Colorado and New Mexico: U. S. Geol. Survey Prof. Paper 95, pp. 27-58 (Prof. Paper 95-C).

Although published first this paper was written after the present one was finished and makes use of the facts gathered for the latter and of the principles developed during its preparation.

250. Berry, E. W., The lower Eocene floras of southeastern North America: U. S. Geol. Survey Prof. Paper 91.

250. Bauer, C. M., Gilmore, C. W.; Stanton, T. W., and Knowlton, F. H., Contributions to the geology and paleontology of San Juan County, N. Mex.: U. S. Geol. Survey Prof. Paper 98, pp. 271-353; (a) p. 281; (b) p. 310; (c) p. 331. 


\section{CHAPTER 2.-GENERAL GEOGRAPHY AND GEOLOGY.}

\section{GEOGRAPHY. \\ LOCATION AND EXTENT OF THE RATON MESA REGION.}

The Raton Mesa region, a highly dissected plateau situated east of the Rocky Mountains, comprises the Raton coal field in northern New Mexico and the Trinidad coal field in southern Colorado. It has a north and south extent of about 85. miles and stretches from the foothills eastward to a maximum width of about 50 miles at the interstate boundary. The coal-bearing area is subtriangular in outline and contains nearly 2,500 square miles of coal land. It has been called the Raton Mesa region because of the group of high table-lands commonly known as the Raton Mesas that are included in its easterncentral part. These, together with the divide extending from Bartlett Mesa westward to the mountains, have sometimes been called the Raton "Mountains," but as the highlands result from the erosion of an uplifted peneplained area, large portions of which still remain as flat-topped mesas, it is obvious that "mesas" rather than "mountains" is the appropriate designation: The area has been called the Raton Mesa "region" because it consists of two coal fields which, although geologically identical (the coal-bearing rocks being continuous throughout both), are geographically more or less distinct and are well known in commercial circles as separate fields. The divide formed by the Raton Mesas is practically on the boundary between New Mexico and Colorado, so that the political subdivision agrees with the geographic and commercial subdivisions of the region.

\section{ACCESS.}

The main lines of the Atchison, Topeka \& Santa Fe Railway, the Colorado \& Southern Railway, the Denver \&. Rio Grande Railroad, and the Chicago, Rock Island \& El Paso Railway enter the Raton Mesa region. In addition to these main lines spurs and local roads connect the several mining towns, so that approach is relatively easy to all of the developed parts of the region. There are several towns of considerable size along the eastern margin of the Trinidad field and a few similarly situated in the Raton field.

\section{RELATION OF COAL FIELDS TO MOUNTAIN AND} PLAIN.

The coal-bearing rocks form a plateau which constitutes a topographic province intermediate between the high mountains to the west and the Great Plains to the east. In most places along the western margin of the region the plateau is separated from the mountains by a structural valley (see Pl. XX, p. 156) formed on the soft beds of upturned shales that range in age from Benton to Pierre. East of this valley the hard rocks of the coal measures, also upturned, form a hogback because of their superior resistance to erosion. But east of this hogback the coalbearing rocks lie nearly horizontal and, being harder than the underlying rocks, have withstood erosion and remained as highlands while the areas farther east were being more uniformly degraded.

The eastern extremity of the coal-bearing rocks is characterized by a steep escarpment which forms a conspicuous topographic feature. At the southern end of the Raton field this escarpment attains a maximum altitude of nearly 1,000 feet. Farther north its altitude is somewhat less; but in New Mexico, between Cimarron and Raton, it would probably average not less than 500 feet. North and east of Raton it joins the high mesas which rise to a maximum altitude of more than 2,000 feet above the general level of the plains. From the nearly level plain the cliffs rise so abruptly (see Pl. III) that some observers have likened them to sea cliffs formed by undercutting waves. Although this interpretation is obviously erroneous it recalls a vivid mental picture of existing conditions.

The eastern margin of the Trinidad field is marked by cliffs similar to those of the Raton field but in general less prominent; although the extremes are greater. .A maximum differ- 


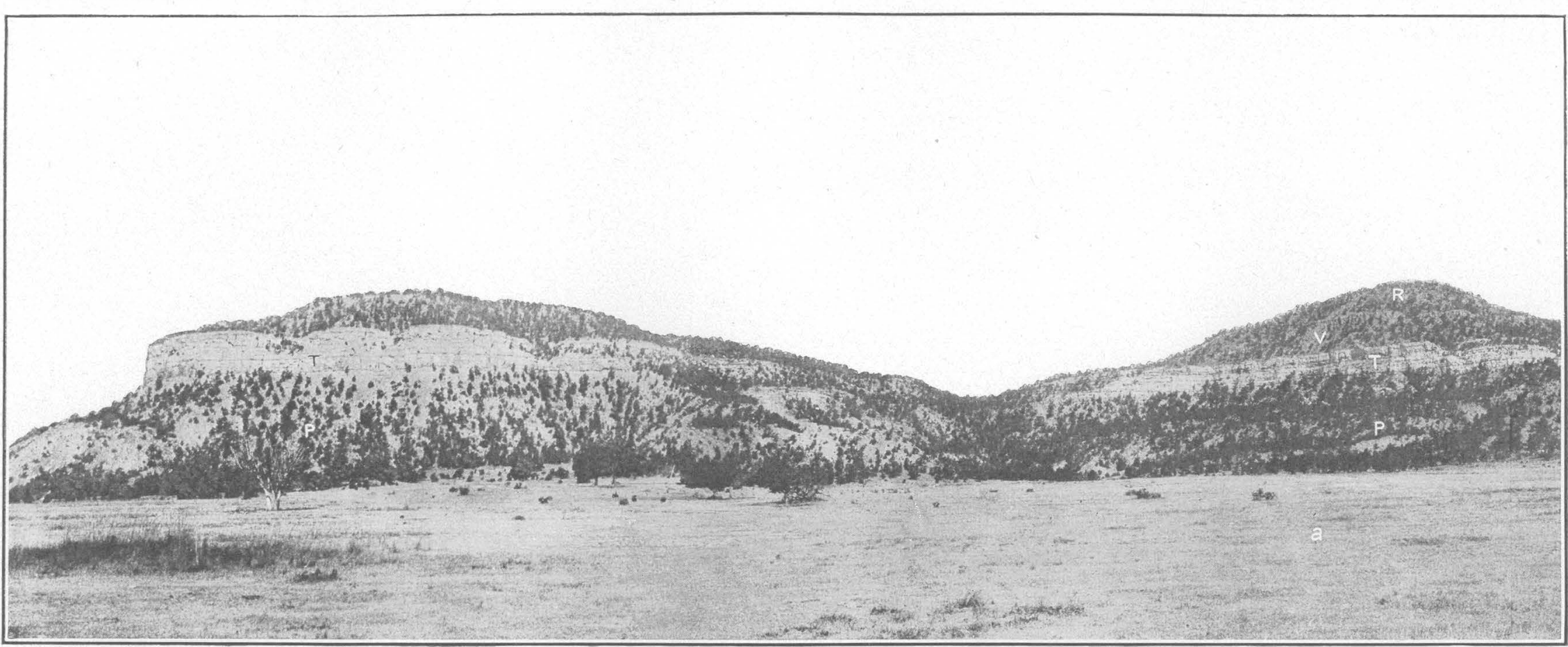

BREAKS OF THE MESA EAST OF DAWSON, N. MEX.

A characteristic view at the eastern edge of the Raton coal field. a, Western limit of the Great Plains; P, Pierre shale; T, Trinidad sandstone; V, Vermejo formation; $R$, Raton formation. 
.nce in altitude occurs near Trinidad, where the north end of Raton Mesa, known as. Fishers בeak, rises something more than 3,500 feet above the plain. North of Trinidad an escarpment similar to that east of Dawson, N. Mex. (Pl. III) is more or less prominent nearly to Walsenburg but is inconspicuous farther north.

In the center of the Trinidad field the continuity of the sedimentary formations is interrupted by the intrusive igneous rocks of the Spanish Peaks, and it is due largely to the protection of these rocks that the younger sedimentaries have not been removed by erosion.

\section{DRAINAGE.}

The Raton Mesa region lies at the western extremity of the Great Plains in a semiarid region; and the precipitation in its eastern part is principally in the form of torrential showers commonly known as cloud-bursts. Farther west toward the mountains the rainfall increases in amount. A few streams that cross the region rise in the mountains and flow at all seasons of the year, but most of them are practically dry except in times of flood. The perennial streams have cut narrow and relatively straight canyons that are especially conspicuous in the Raton field. The streams that depend for their water supply on the torrential showers have cut short, precipitous canyons, many of which are tortuous and branching.

\section{TOPOGRAPHY.}

The character of the drainage resulting from the position of the Raton Mesa region between high mountains and semiarid plains, together with the character of the rocks, has given rise to many topographic forms. But as this paper deals with a special phase of stratigraphy and not with the general geology of the region no attempt will here be made to describe these forms further than is essential for an understanding of the geologic relations of the formations. For this purpose the principal topographic forms are those that expose the rocks to view, chief among which are the mesas, canyons; escarpments, and hogbacks.

The Raton Mesa region as a whole is, as already stated, a plateau more or less deeply dissected by erosion into a complex of sharp ridges, deep canyons, and flat-topped mesas.
The region was once peneplained, and the nearly level surface was partly covered by sheets of basaltic lava that formed the hard layers now found at the tops of the mesas. The softer rocks were eroded away faster than the harder ones, but in some places the thick sheets of basalt have effectively preserved them.

\section{CHARACTER OF ROCK EXPOSURES}

The character of the exposures of rock in the canyons and along the margins of the plateau is of the greatest importance for the purposes of this paper. The several illustrations show the nature of the outcrops, and the detailed sections indicate that in many places the rocks are well exposed. The character of the exposure naturally differs with the rocks, but the southward-facing slopes generally present better exposures than the northward-facing slopes, which are covered with vegetation in many places. This is especially true of the north slopes of the Raton Mesas, which are so densely forested that the rocks are very imperfectly exposed, and of many places along the western margin of the region, where vegetation flourishes in the moist atmosphere near the mountains.

\section{GEOLOGY.}

\section{GENERAL FEATURES.}

The core of the mountains west of the Raton Mesa region consists of crystalline rock, probably of pre-Cambrian age. Also, in some places there are thick beds of rocks, more or less metamorphosed, that are apparently preCambrian but are younger than the crystallines of the mountain core. These are obviously of sedimentary origin. The next younger rocks observed are the red beds, the oldest fossils of which indicate Carboniferous age; but still lower rocks in which no fossils have been found may be older than Carboniferous. In the Raton Mesa region the red beds lie in contact with the ancient crystalline rocks in some places and with the metamorphosed sedimentary rocks in other places. Farther south they rest on limestone of Pennsylvanian age. They are the so-called "Red Beds" of the Rocky Mountains, and above them occur the Cretaceous and Tertiary rocks in the order shown in the table. 
Geologic formations of the Raton Mesa region.

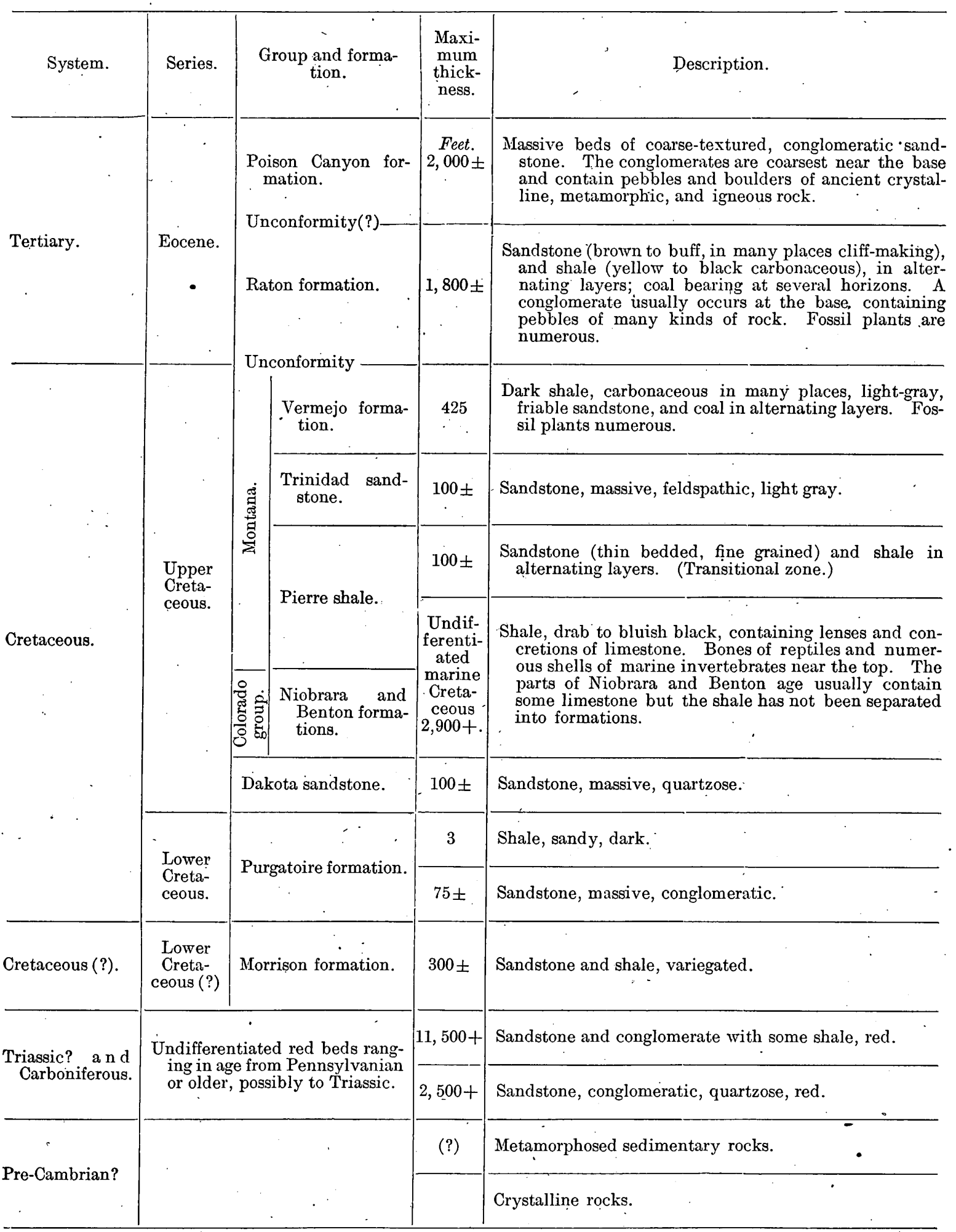


PRE-CRETACEOUS FORMATIONS.

Relatively little is known of the older formations of the Culebra Range in the Raton Mesa region, and few observations were made on them by the present writer. The core of the mountains consists of crystalline rock and the foothills of relatively old sedimentary rocks. These are of interest here only in so far as they are the source of the sediments composing the younger formations and in so far as their thickness indicates the amount of erosion that must have taken place before certain pebbles found in the basal conglomerate of the Raton formation could have been formed. The older formations were observed somewhat hurriedly in four places, namely, south of Vermejo Peak and west of Van Bremmer Park; in the canyon of South Fork of Purgatoire River; north of Culebra Peak, which lies west of Stonewall; and in Huerfano Park, a few miles northwest of the area mapped.

In the first of these places the red beds consist principally of sandstone and conglomerate in which are boulders of igneous and metamorphic rock some of which are 2 feet in diameter. The red beds here appear to be many thousands of feet thick, but doubtless this thickness is due in some measure to duplication by faulting.

In the canyon of South Fork of Purgatoire River the sedimentary rocks are upturned nearly vertical and the canyon has been cut nearly at right angles to their strike, thus affording a good opportunity for measuring their thickness. The linear measurements were made with tapeline, the direction of each measurement being taken with hand compass and the altitudes with aneroid barometer. Corrections for direction of measurement, dip, strike, and altitude were made in the office. The results are as follows:

Geologic section measured on South Fork of Purgatoire River, in southern Colorado.

Sandstone (Dakota), massive, quartzitic......... Shale, fine grained, sandy, dark (Purgatoire forma-

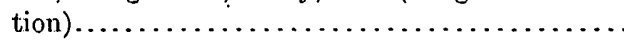
Sandstone, conglomeratic (Purgatoire formation).. Not exposed . ........................... Shale and sandstone (Morrison formation), variegated; red agates near base.................. Not exposed
Sandstone, conglomeratic, with some shale (red beds). From top to bottom this series of beds contains many coarse conglomerates composed of pebbles which measure up to 8 inches or more in diameter and which consist of many varieties of crystalline and metamorphic rock......... 11, 537

Sandstone, dark red, more or less quartzose, much harder than the red beds above. Small pebbles occur in many places throughout the formation and in some places there are well-defined conglomerates, but few pebbles more thian half an inch in diameter were seen. Similar rocks occur about 10 miles farther north below rocks from which Pennsylvanian fossils were collected.... 2, 2,508 Crystalline rock.

No fossils were found in any of the rocks of this section, and their correlation is based on stratigraphic position and lithologic character. Apparently the red beds are here in contact with the crystalline rocks, but about 10 miles farther north ${ }^{157}$ a considerable thickness of shale and limestone occurs between the two. Where these rocks were observed south of Vermejo Peak the conglomerates are much coarser than they are on the South Fork where the section was measured.

Several years ago some of the older rocks north of Culebra Peak were observed by the writer and a short section measured near their base was published, ${ }^{157}$ together with a list of fossils that prove their Pennsylvanian age. Near this locality there are fossiliferous limestones within the red beds, ${ }^{89}$ but no fossils were collected from them by the present writer. The red beds of this locality contain conglomerates, but on the whole they are much less conglomeratic than those farther south. The section and fossils ${ }^{157}$ are as follows:

Section measured at the crest of the Sangre de Cristo or Culebra Range, between Middle and North forks of Purgatoire River, Colo.

Conglomerate, hard, quartzitic.

.............. 10

Shale, dark................................. 5

Limestone, fossiliferous...................... 2

Sandstone, red, with bands of red shale and irregular masses of limestone....................... 1.2

Sandstone, greenish, argillaceous.............. 4

Sandstone, pink, argillaceous above, conglomeratic

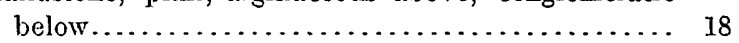

Limestone, fossiliferous.................... 4

Sandstone, deep red, conglomeratic at the base, shaly

near the top. ......................... 10 


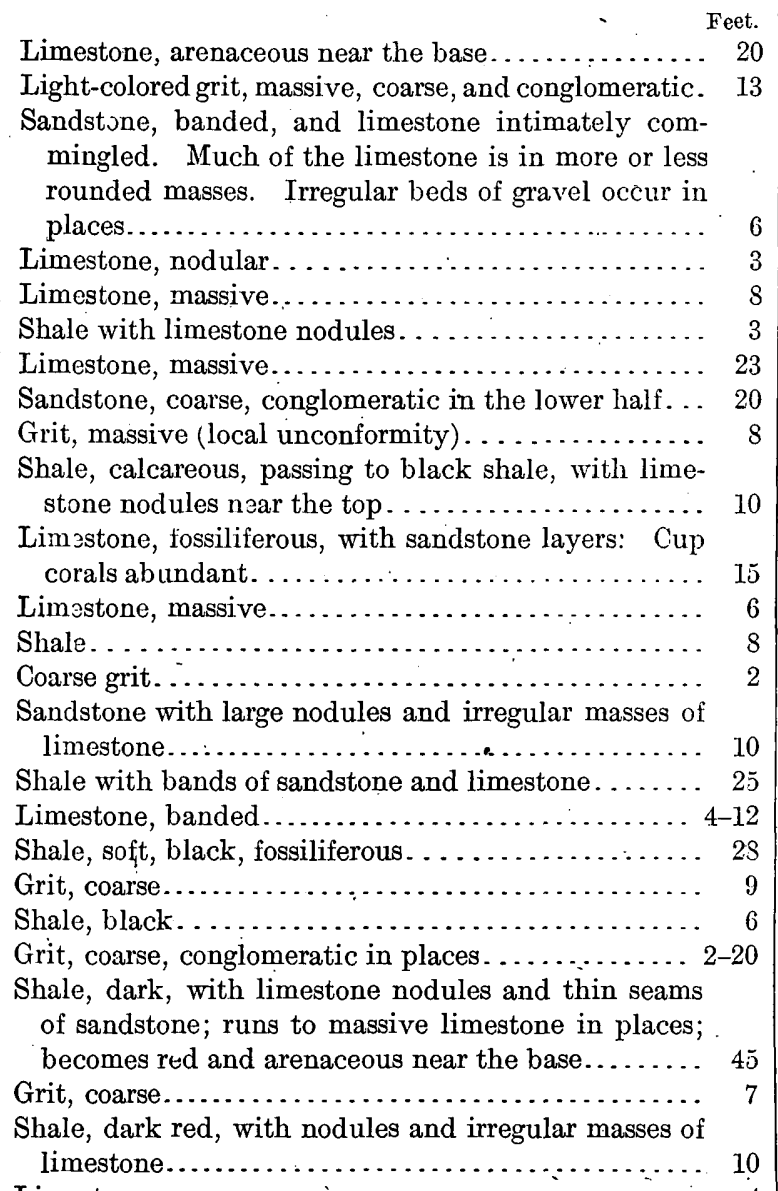

Limestone.............................. 4

Shale, red to black micaceous, with bands of sandstone near the base and limestone nodules near the top. .

Grit, coarse......................... 10

Grit, red, and conglomerate $\ldots \ldots \ldots \ldots \ldots \ldots \ldots \ldots \ldots$ ?

Crystalline rocks of the mountains.

Fossils collected at the crest of the range between Middle and North forks of Purgatoire River, Colo., mainly from the 28-foot fossiliferous shale of the foregoing section.

[Identified by Stuart Weller.]

Zaphrentis, sp. undet.

Orbiculoidea convexa Shumard.

Orbiculoidea missouriensis Shumard.

Chonetes mesoloba Norwood and Pratten.

Productus longispinus Sowerby.

Productus costatus Sowerby.

Productus cora D'Orbigny.

Spirifer cameratus Morton.

Spirifer rockymontana Marcou.

Reticularia perplexa McChesney.

Seminula argentea Shepard.

Aviculipecten carboniferus Stevens.

Astartella concentrica McChesney.

Nucula ventricosa Hall.

Nuculana bellistriata Stevens.
Pelecypod (genera and sp. undet.).

Bellerophon percarinatus Conrad.

Bellerophon carbonarius Cox.

Bellerophon montfortianus Norwood and Pratten.

Bellerophon sp. undet.

Rotella verrucelifera White.

Soleniscus brevis White.

Soleniscus sp. undet.

Sphaerodoma texana Shumard.

Sphaerodoma sp. undet.

Trachydomia wheeleri Swallow var.

Naticopsis altonensis McChesney.

Naticopsis altonensis var. gigantea Meek and

Worthen.

Pleurotomaria perizomata White.

Pleurotomaria (several small species undet.).

Murchisonia copei White.

Orthoceras sp. undet.

Syringopora sp.

Campophyllum torquium Owen.

Straparollus catilloides Conrad.

Fossils from the same locality, found as loose fragments; horizons not determined.

Derbya crassa Meek and Hayden.

Hustedia mormoni Marcou.

Allorisma subcuneata Meek and Hayden.

Schizodus wheeleri Swallow.

- Bellerophon (large sp. undet.).

Temnocheilus winslowi Meek and Worthen.

Phillipsia sp.

Large fish spine.

A brief visit to the red beds in Huerfano Park, a few miles north of the northern end of the Trinidad coal field, showed them to be many hundreds of feet thick. The base of the formation was not seen. The rocks consist mainly of coarse-grained sandstone, but contain layers of conglomerate, and at one horizon near the middle of the series include an earthy limestone a few feet thick, from which the following fossils were collected:

Fossils from the red beds in Huerfano Park, Colo.

$$
\text { - [Identified by G. H. Girty.] }
$$

Lophophyllum profundum?

Lioclema? sp.

Derbya bennetti.

Marginifera aff. M. wabashensis.

Marginifera sp.

Productus inflatus?

Spirifer bóonensis.

Squamularia perplexa?

Ambocoelia planiconvexa.

Spiriferina kentuckyensis:

Composita subtilita.

Cliothyridina orbicularis.

Astartella varica? 
Of these fossils Girty says "the geologic age is clearly Pennsylvanian, and compared with the New Mexico section ${ }^{218}$ they would be Magdalena rather than Manzano."

\section{CRETACEOUS (?). SYSTEM.}

MORRISON FORMATION.

Between the red beds and the conglomeratic sandstone of Lower Cretaceous age (here correlated on stratigraphic evidence with the Purgatoire formation of the Apishapa quadrangle ${ }^{233}$ ) lies 782 feet of rock, only 150 feet of which is exposed to view. The exposed rocks are lithologically similar to those of the Morrison formation found elsewhere in the Rocky Mountain region, and although no fossils :were found in them the writer has no hesitancy in referring them on lithologic and stratigraphic evidence to the Morrison. A shaly zone near the base of the exposure contains red agates similar to those found in the Morrison near Canon City, where they are cut into gems. Sterrett ${ }^{210}$ describes these gem agates as follows:

The silica is evidently a deposit from solution and often occurs in concentric bands of different colors. The seams bearing this agate-like material are usually only a few inches thick and have a clay filling in the internodular spaces.

J. D. Endicott has obtained some agate from Garden Park, 8 miles north of Canon City, Colo., similar to the above, but he states that it came from the inside of fossil dinosaur bones. Some of it has a peculiar structure that may be the original bone structure. This agate has brightred, yellow, and gray colors and makes a beautiful curio gem for watch charms when polished. $\mathrm{Mr}$. Endicott also obtains agates with peculiar structure from the Curio Hill locality, 8 miles southeast of Canon City. These agates are translucent, with blood-red spots through them either in layers or bands or more or less regularly distributed through the mass. 'The latter pattern has been called St. Stephen stone. Mr. Endicott has cut a small quantity of translucent bluish chalcedony found at Thirty-one Mile Mountain, 7 miles west of Guffy, Colo. This chalcedony has an agate structure showing faint banding. The blue color is of a light shade, though pronounced. It is not the bright blue found in the blue chrysoprase or copper-stained chalcedony of Globe, Ariz. The effect of the cut gem is very pleasing. Another variety of chalcedony found in Colorado by Mr. Endicott has an amethystine color. This cuts to a pretty cabochon gem. These fancy agates and chalcedony gems are delicately marked and have beautiful colors. They should be in large demand for the tourist trade and also for wider sale when people become acquainted with them.

These agates were noted in the Morrison ${ }^{158 a}$ several years ago and more recently have been observed in so many places that the writer has come to regard them as one of the diagnostic features of the Morrison of southern Colorado and northern New Mexico. ${ }^{1}$

Sedimentary rocks of variegated color, such as are characteristic of the Morrison, were observed in the foothills throughout the Raton Mesa region wherever the rocks are well exposed. They were seen at Stonewall, on both branches of South Fork of Purgatoire River, and on the main branches of the Vermejo. In the southern part of the region the sedimentary formations have been so obscured by faulting and by intrusions of igneous rock that further observations are necessary before it can be confidently asserted that the Morrison is present there. But in view of the known uniformity in the character and thickness of this formation over wide areas in southern Colorado and northern New Mexico, together with its occurrence far south of the region at Las Vegas ${ }^{216 a}$ and in Galisteo Canyon, ${ }^{216 b}$ it seems safe to assume that the Morrison underlies the entire Raton Mesa region.

\section{CRETACEOUS SYSTEM.}

\section{PURGATOIRE FORMATION AND DAKOTA} SANDSTONE.

In many places throughout the Rocky Mountain region the Dakota has been described as consisting of two sandstones separated by a layer of shale which is often referred to as the "Dakota fire clay." These two sandstones are well developed in the Raton Mesa region and together they form a prominent ridge commonly known as the Dakota hogback: On South Fork of Purgatoire River (see section, p. 41) the lower sandstone is 50 feet thick and the upper one 95 feet. The lower sandstone is hard, massive, and conglomeratic; the upper is not conglomeratic where observed but is quartzitic, very hard, and forms the crest of the ridge. The relations of these two sandstones and the intervening shale have been recognized north of the Raton Mesa region in the vicinity of Canon

1 Since this report was written the writer has learned that similar agates occur in northern Colorado in rocks which were formerly classed as basal Morrison but which prove to be the southward extension of the Sundance formation or marine Jurassic. The agate-bearing rocks of northern Colorado appear to lie above fossiliferous marine Jurassic rocks and unconformably below typical Morrison beds. These facts suggest that the agate-bearing rocks of southern Colorado, near the base of what is now called the Morrison, may prove to be equivalent in age to the marine Jurassic, like the similar rocks in northern Colorado. 
City, ${ }^{187}$ east of the Raton Mesa region in Huerfano Canyon, ${ }^{232}$ in Apishapa Canyon, ${ }^{233}$ in Purgatoire Canyon, ${ }^{187}$ in Cimarron Canyon, ${ }^{187}$ farther south on the Canadian, ${ }^{187}$ and at Las Vegas. ${ }^{216}$

It has been known since the publication of Stanton's paper ${ }^{187}$ that the shale separating the two sandstones correlates with the Washita, which some geologists but not all regard as Lower Cretaceous. This sandstone, together with the shale above it, has been named the Purgatoire formation. Although no fossils were found in the Raton Mesa region in either of the sandstones of the hogback or in the shale separating them the writer feels confident in correlating the lower sandstone and the shale with the Purgatoire formation of the Apishapa quadrangle and in referring the upper sandstone to the Dakota.

\section{BENTON, NIOBRARA, AND PIERRE} FORMATIONS.

The marine Cretaceous shale and limestone formations of southern Colorado have been described in several publications and are fairly well known. Few observations were made by the writer on the Benton and Niobrara or on the older Pièrre in the Raton Mesa region, all of which are of interest in the present investigation only in so far as they aid in measuring post-Cretaceous erosion or shed light on the age of the coal-bearing formations. For measuring the erosion their thickness is important, but so far as age is concerned neither they nor any of the rocks below the fossiliferous zone near the top of the Pierre shale.call for much consideration.

The marine Cretaceous rocks in southern Colorado are separable into several formations, having an aggregate thickness of about 2,500 feet in the Elmoro quadrangle, ${ }^{143}$ but the formations seem to be less well defined toward the south and no attempt was made by the writer to determine their limits in the Raton field. In some places in this field the horizon of the Greenhorn limestone is represented by a few feet of limestone, but the limestone of the Niobrara group which is prominent farther north has not been found. So far as observed in the Raton Mesa region the rocks between the Dakota and the Trinidad sandstone consist almost wholly of shale. Although the total thickness of this shale has never been measured it is known to be more than 3,000 feet-near Raton, where a well was drilled in it to a depth of 2,700 feet (see locality 82, p. 108) and probably about the same in Vermejo Park, where well data prove that it measures more than 2,500 feet at locality 123. This shale occupies a broad valley lying between the ridge at the western margin of the coal fields and the Dakota hogback still farther to the west. Its thickness here has not been measured, but can scarcely be less than 3,000 feet and may be much more. However, for the purposes of this paper the thickness shown by the drill will be used.

The marine Cretaceous shale is more or less. fossiliferous throughout, but few fossils have been collected in the Raton Mesa region from the lower part. These are as follows:

Marine invertebrates from the lower (Benton) part of the Cretaceous shale of the Raton Mesa region.

[Identified by $\mathrm{T}$. W. Stanton.]

Baculites asper Morton?

Coilopoceras novimexicanum Hyatt.

Inoceramus dimidius White.

Inoceramus fragilis Hall and Meek.

Inoceramus labiatus Schlotheim.

Inoceramus sp.

Ostrea lugubris Conrad,

Ostrea sp.

Prionocyclus wyomingensis Meek.

Scaphites ventricosus Meek and Hayden.

Invertebrates' were collected from the upper part of the Pierre shale in many places. They are most abundant in the southern part of the Raton field, where they occur in limestone concretions 100 to 400 feet below the top of the shale. A few were collected by the writer, and some also by G. B. Richardson's party in the Trinidad field. The localities at which collections were made are indicated on the map (PI. I, in pocket) by numerals which denote the lot numbers under which the collections are stored in the United States National Museum. A complete list of these fossils is given in the. following table of species. Concerning the age of the invertebrates Stanton says that the fauna is a meager one and that; although "typical of the Pierre shale, it has a considerable stratigraphic range within it. From this material it is not possible to recognize definite restricted zones." 
Fossils collected from Pierre shale and Trinidad sandstone in the Raton Mesa region.

[Identified by T. W. Stanton. The number at the top of each column refers to the locality (PI. I, in pocket) at which the fossils were collected. For fuller information as to occurrence see "Local features

\begin{tabular}{|c|c|c|c|c|c|c|c|c|c|c|c|c|c|c|c|c|c|c|c|c|c|c|c|c|c|c|c|c|c|c|c|c|c|c|c|c|c|c|c|}
\hline \multirow{3}{*}{$\begin{array}{l}. \\
.\end{array}$} & \multirow[b]{3}{*}{ ' } & \multicolumn{27}{|c|}{ Pierre snale. } & \multirow{2}{*}{\multicolumn{11}{|c|}{ Trinidad sandstone. }} \\
\hline & & \multicolumn{13}{|c|}{ Eastern part of Raton field. } & \multicolumn{5}{|c|}{ Vermejo Park. } & \multicolumn{9}{|c|}{ Trinidad field. } & & & & & & & & & & & \\
\hline & & $\dot{9}$ & : & . & 总 & 营 & 密 & 宙 & 过 & 苞 & 害 & 串 & & $\dot{b}$ & 象 & $\frac{\dot{0}}{3}$ & 总 & 敢 & 突 & 客 & 章 & 苑 & 章 & 帘 & $\mid \begin{array}{l}\text { 范 } \\
\text { : } \\
\text { : }\end{array}$ & 空 & 葋 & 䆛 & 窎 & \begin{tabular}{l}
$\infty$ \\
0 \\
0 \\
\hdashline
\end{tabular} & 密 & 㻤 & 总 & 窟 & 总 & 离 & $\dot{\bar{B}}$ & 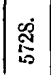 & 密 \\
\hline
\end{tabular}

\section{Ancyloceras sp}

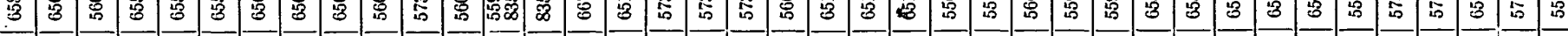

Anomia sp........

vicula sp............................... A vicula nebrascana Evans and

Baculites compressus Say................

Chlamys nebrascensis Meek an Crassatelites cimarronensis white. Crenella sp............................ cucullaea sp. Fasciolaria sp........................ Heteroceras cheyenne...................

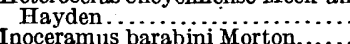
Inoceramus barabini Morton........... Inoceramus sagensis Owen.....................
Inoceramus vanuxemi Meek an Leda sp Yoldia) scitula Meek and Hayden?
egumen? $\mathrm{xp}$. (Cymelia) undata Mee and Hayden................ Lucina sp... actra sp........ M. den............

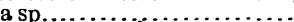
Margarita nebrascensis Meek and Martesia? sp

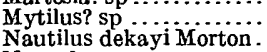

Nemodon sp.......................................

Nucula planimarginata Meek and
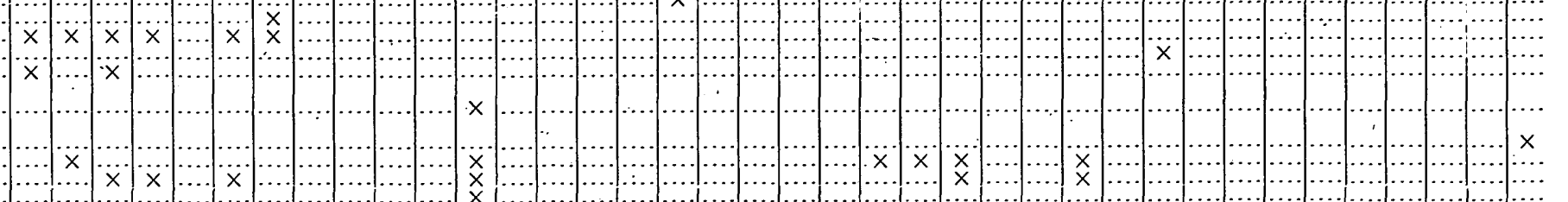
Fossils collected from Pierre shale and Trinidad sandstone in the Raton Mesa region-Continued.

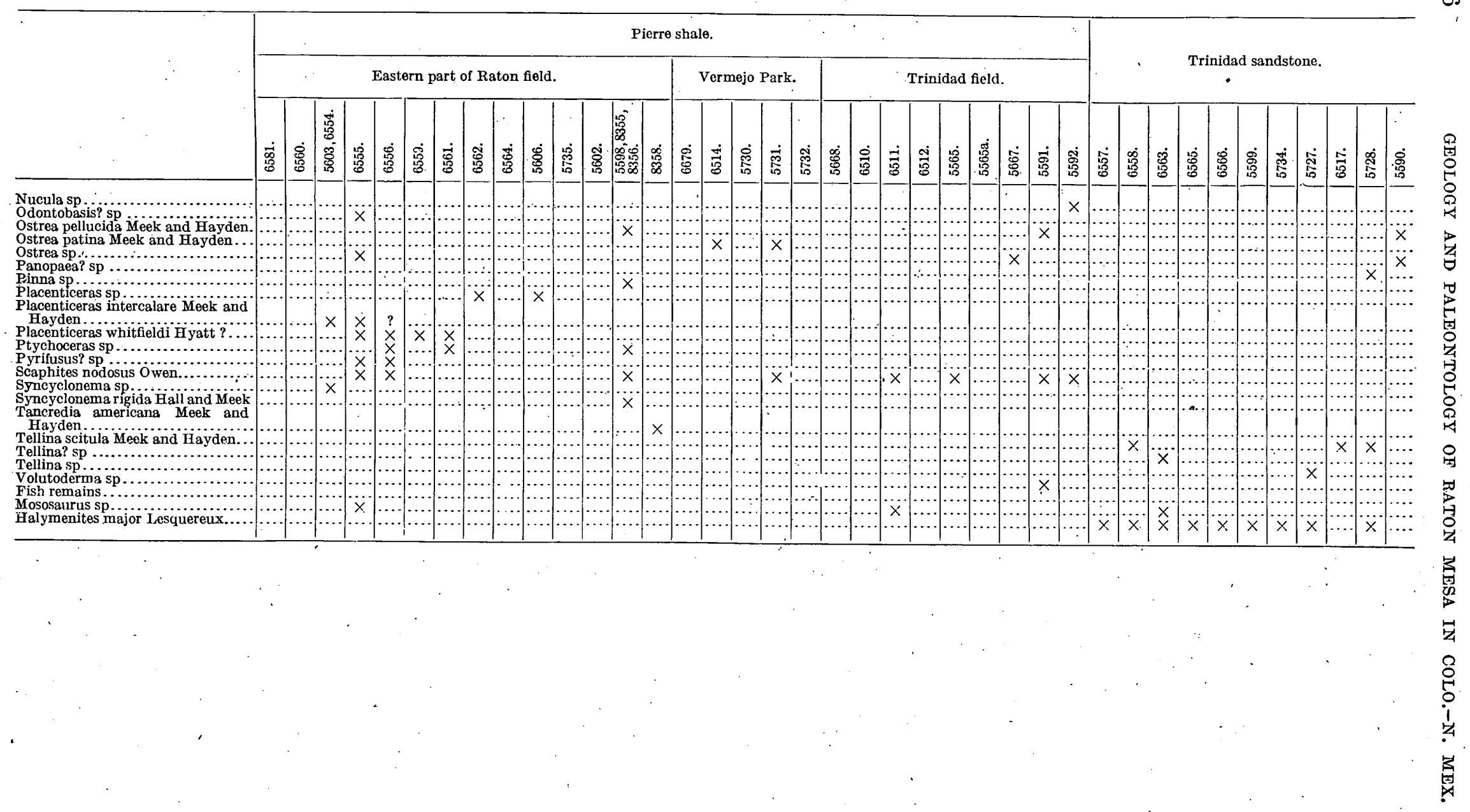


The fossil lots of the foregoing table are briefly described as follows. The locality numbers refer to the permanent lot numbers of the Mesozoic fossil invertebrates of the United States Geological Survey under which the fossils are stored in the United States National Museum, and to the map (Pl. I, in pocket).

6581. Baldy mine, about 6 miles northwest of Ute Park, N. Mex.; at top of Pierre shale.

6560. North wall of Ute Park, N. Mex.; about 150 feet below top of Pierre shale.

5603 and 6554. Cimarron Canyon, about 7 miles west of Cimarron City, N. Mex.; about 100 feet below top of Pierre shale.

6555. North wall of Cimarron Canyon, about 4 miles northwest of Cimarron; 100 feet below top of Pierre shale. 6556. Point of mesa northwest of Cimarron, N. Mex. 200 feet below top of Pierre shale.

6559. Cerrososo Canyon; N. Mex.; about 100 feet below top of Pierre shale.

6561. Point of mesa west of Cimarron; 400 to 500 feet below top of Pierre shale.

6562. Point of mesa between Cerrososo and Van Bremmer canyons, N. Mex.; near top of Pierre shale.

6564. North wall of Van Bremmer Canyon, N. Mex. about a mile from its mouth; near top of Pierre shale.

5606. Western slope of Saltpeter Mountain, about 4 miles southeast of Dawson, N. Mex.; near top of Pierre shale.

5735. Half a mile north of Koehler, N. Mex.; near top of Pierre shale.

5602. Red River Peak, N. Mex.; 400 feet below top of

Pierre shale.

5598 and 8355. Raton, N. Mex.; 50 feet below top of

Pierre shale.

8356. Brickyard at Raton, N. Mex.; about 150 feet below top of Pierre shale.

8358. Koehler, N. Mex., in Trinidad sandstone.

6679. Vermejo Park, N. Mex., at the Bartlett ranch; several hundred feet below top of Pierre shale:

6514. Vermejo Park, N. Mex., 2 miles north of Vermejo post office; about 100 feet below top of Pierre shale. (Collected by T. W. Stanton.)

5730. Vermejo Park, N. Mex., near eastern extremity, in the north wall; at top of Pierre shale.

5731. Vermejo Park, N. Mex., near eastern extremity; about 300 feet below top of Pierre shale.

5732. Eastern extremity of Vermejo Park, N. Mex.; near top of Pierre shale.

5668. Three miles southeast of Trinidad, Colo.; 100 feet below top of Pierre shale.

6510. One mile northeast of Trinidad, Colo., in a railroad cut, several hundred feet below top of Pierre shale.

6511. About 2 miles northeast of Trinidad, Colo.; several hundred feet below top of Pierre shale.

6512. One mile south of Bowen, Colo.; near top of Pierre shale.
5565. One mile south of Bowen, Colo.; 150 feet below top of Pierre shale. (Collected by G. B. Richardson's party.) ${ }^{1}$ 5565a. Same locality as 5565; 275 feet below top of Pierre shale. (Collected by G. B. Richardson's party.) 5667. Shale quarry, 2 miles north of Trinidad, Colo.; 50 feet below top of Pierre shale. (Collected by G. B. Richardson's party.)

5591. One and three-fourths miles east of Monson, Colo., 500 feet south of Santa Clara Creek; in upper part of Pierre shale. (Collected by G. B. Richardson's party.)

5592. Two and one-fourth miles east of Monson, Colo., south of Santa Clara Creek; in upper part of Pierre shale. (Collected by G. B. Richardson's party.)

6557. Point of mesa northwest of Cimarron, N. Mex., in slide rock; at base of Trinidad sandstone.

6558. Ponil Canyon, N. Mex., a mile east of the forks of the canyon; in Trinidad sandstone.

6563. Van Bremmer Canyon, N. Mex., a mile from its mouth, in slide rock; at base of Trinidad sandstone.

6565. North wall of Van Bremmer Canyon, N. Mex. (same locality as 6564); at top of Trinidad sandstone.

6566. Point of mesa northeast of Saltpeter Mountain, at locality 28 , in slide rock; at base of Trinidad sandstone. 5599. One mile south of Raton, N. Mex.; in Trinidad sandstone.

5734. Eastern extremity of Vermejo Park; near top of Trinidad sandstone.

5727. Vermejo Park, N. Mex., at mouth of Spring Canyon, in Trinidad sandstone.

6517. Vermejo Park, N. Mex., half a mile southeast of Vermejo post office; near top of Trinidad sandstone. (Collected by T. W. Stanton.)

5728. South of San Francisco Pass, N. Mex., at locality 129; from top of Trinidad sandstone or base of Vermejo formation.

5590. Railroad cut half a mile east of Pryor mine, near Rouse, Colo.; in lower part of Trinidad sandstone. (Collected by G. B. Richardson's party.)

Cimarron has been known as a prolific fossil locality since 1876, when O. H. St. John collected a large number of invertebrates, a list of which was later published by White. ${ }^{80}$ St. John's locality is not given very definitely, but a comparison of the species in White's list with those collected by the writer near Cimarron from the upper part of the Pierre shale (see table, pp. 45-46) shows that the two collections came from essentially the same horizon. St. John's list is given below for comparison.

Fossils collected by 0 . H. St. John near Cimarron, N. Mex. Caryophyllia johannis White.

Ostrea congesta Conrad?

Ostrea sp.

Anomia sp.

1 This party was made up of G. B. Richardson, J. H. Gardner, D. E. Winchester, and J. B. Mertie 
Camptonectes sp:

Pteria linguiformis Evans and Shumard.

Inoceramus barabini Morton.

Inoceramus vanuxemi Meek and Hayden.

Inoceramus erectus Meek?

Crassatella (Pachythaerus) cimarronensis White?

Trapizium sp.

Idonearca shumardi Meek and Hayden.

Callista pellucida Meek and Hayden.

Teredo? sp.

Anisomyon alveolus Meek and Hayden.

Margarita sp.

Lunatia sp.

Turritella sp.

Aporrhais biangulata Meek and Hayden.

Spironema sp.

Pyramidella sp.

Turbonilla (Chemnitzia) sp.

Fasciolaria (Piestochilus) sp.

Baculites ovatus Say.

Scaphites nodosus Owen?

Placenticeras placenta De Kay.

Serpula sp.

White states in his report ${ }^{86}$ that these fossils indicate Fox Hills age, but Fox Hills, as he then (1879) used the term, included the Pierre shale. Twenty years later (1899) R.C. Hills ${ }^{143}$ referred the Trinidad sandstone to the Fox Hills. It seems proper, therefore, to call attention here to the fact that the Fox Hills of White is not the Trinidad sandstone but the upper part of the shale which underlies this sandstone and which now is called Pierre.

\section{TRINIDAD SANDSTONE.} DEFINITION.

The Trinidad sandstone was first described as a formation in 1899 by R.C. Hills, ${ }^{143}$ who defined it from the coal field lying east of Trinidad, Colo., as a light-gray sandstone 70 to 80 feet thick (called "Upper Trinidad") and a series of thin layers of sandstone and shale about 75 feet thick (called "Lower Trinidad"). The rocks persist with slight variation throughout the Trinidad coal field and over much of the Raton field, but the definition requires modification before it applies to the Trinidad sandstone of the southern part of the Raton field. "The "Upper Trinidad" of Hills had previously.been included in the coal measures, as the similar sandstone in the Denver Basin ${ }^{133}$ is included at the present time, and was sometimes called the basal sands tone of the coal measures and sometimes the Halymenites sandstone because of the great number of Halymenites major Lesquereux that it contains.

The "Lower Trinidad" of Hills is a group of transitional beds, a few feet to $200^{-}$feet or more in thickness, that separate the typical Pierre shale from the massive "Upper Trinidad" sandstone. It consists of thin layers of darkgray, fine-grained sandstone, alternating with layers of shale that differ but little from the underlying Pierre shale. It is not clearly separable from the underlying shale, either in its physical character or in its faunal relations, the variation in thickness being due mainly to the irregularity of the base, while its separation from the overlying massive sandstone is usually rather sharp. It is doubtful whether the transitional beds. should be included in a formation with the overlying sandstone or regarded as a part of the underlying shale. However, for the purpose of this paper Trinidad sandstone is used to designate the massive sandstone or "Upper Trinidad" of Hills, and the sandy series or "Lower Trinidad" is called the transitional zone and is included in the top of the Pierre shale.

CHaRaCTER AND CONTINOITY.

The Trinidad sandstone as thus defined is a massive feldspathic sandstone, usually harder than the rocks immediately above and below it, so that in the eastern parts of the Raton Mesa region, where the rocks are nearly horizontal, it forms a conspicuous shelf. (See Pl. $\mathrm{XIV}, A$, p. 125.) Many other illustrations in this paper (particularly. Pl. III, p. 38) show the characteristic appearance of this sandstone. Along the western margin of the field where the rocks are upturned the Trinidad does not form a conspicuous topographic feature because of the dominating influence of harder rocks stratigraphically above it; and in the northern part of the Trinidad field it does not form a conspicuous cliff. It is well known throughout the Trinidad field, and there is little doubt that it constitutes a single continuous stratum of rock. But this can not be asserted for the Trinidad sandstone of the Raton coal field.

At the northern end of the Ratón field the Trinidad is as conspicuous as it is at its type locality near Trinidad, but it is not so well known over wide areas because mining devel- 


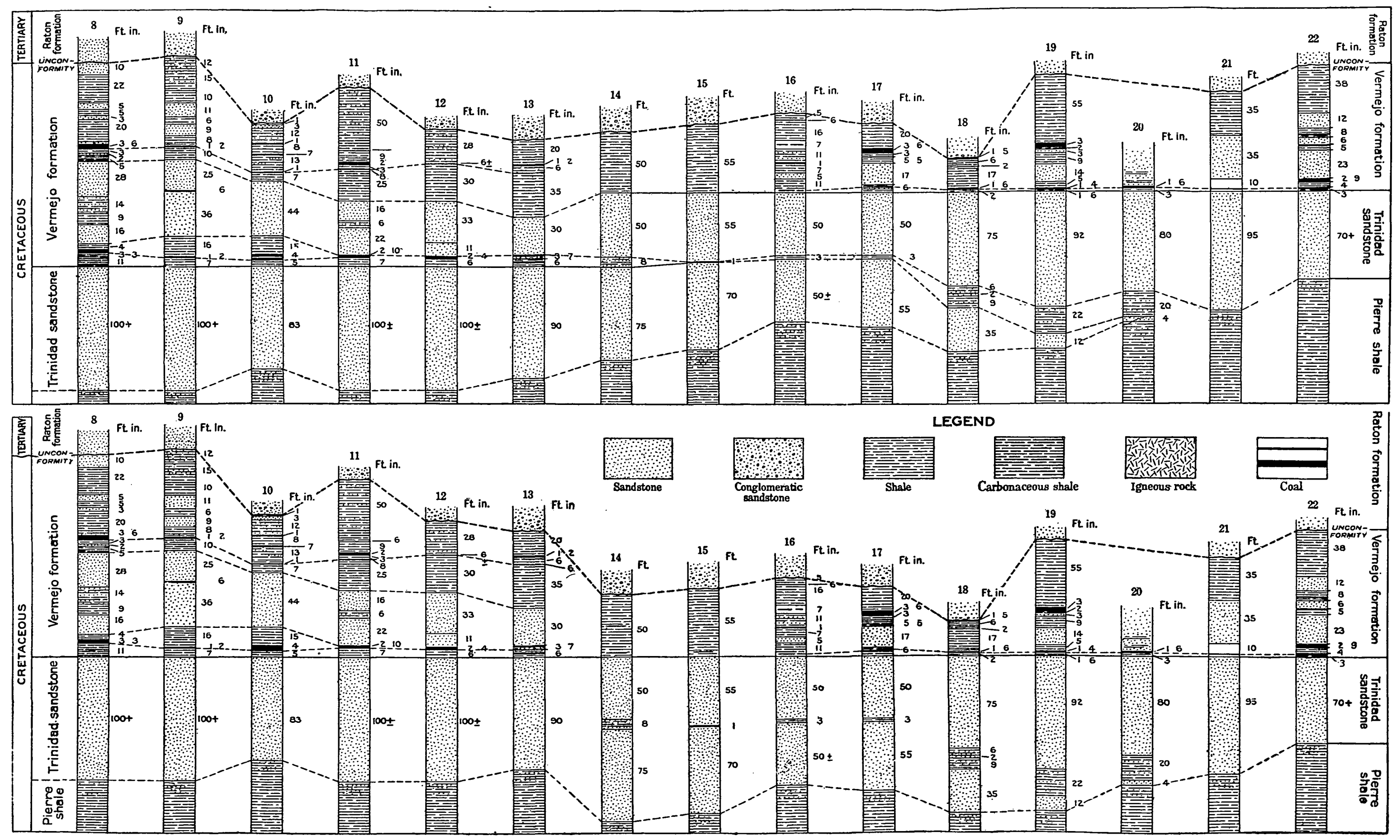

SECTIONS SHOWING RELATIONS OF THE TRINIDAD SANDSTONE TO THE PIERRE SHALE AND VERMEJO FORMATION.

The upper group shows the true relations of the beds; the lower group shows the former erroneous interpretation of the relations. 
opment has not been so extensively carried on as in the Trinidad field. The cliff-making sandstone in the vicinity of Raton is obviously the same as the Trinidad of the type locality, and this has been traced as a practically continuous layer southward beyond Dawson a distance of 40 miles or more. South of Dawson, however, the cliff that farther north is formed in most places by a single mass of sandstone consists of two sandstones separated by a thin shale, which thickens toward the south, becomes carbonaceous, and finally includes a bed of coal. The upper sandstone also changes in character toward the south, becoming soft and shaly in some places, so that it does not form a part of the "Trinidad cliff." The lower sandstone, on the other hand, increases in thickness and becomes the "Trinidad cliff" of the southern part of the field. (See Pl. IV.)

The sandstone cliff is so conspicuous throughout the Raton field, so uniform in character, and with few exceptions so well exposed, that heretofore it has been regarded as a perfectly continuous formation. A coal bed usually occurs a few feet above it, which, in the northern part of the field, where mining has been carried on somewhat extensively, is known as the Raton coal bed. South of Dawson, where no mining and little prospecting has been done, the first coal above the sandstone cliff is locally called the Raton bed on the assumption that it is the same coal that occurs above the cliff in the northern part of the field. Because of this usage the relations may be described in greater detail than would otherwise be necessary.

Several of the sections measured south of Dawson in the critical area where the change occurs have been plotted to the same scale and grouped in Plate IV in such manner as to illustrate the relations of the two members of the Trinidad sandstone to each other and to the neighboring formations. The upper group of this plate shows the correlation of the sections which the author regards as correct. The lower group shows the same sections arranged in accordance with the conception that has prevailed heretofore but which the author regards as erroneous. Apparently the error has been due to the impression, which the writer formerly shared, that the sandstone cliff was in reality as continuous as it appears to be from a distance, and that the lowest coal in all parts of the field represented essentially the same bed: However, this grouping is shown to be untenable in the vicinity of Ponil Canyon (sections 12 to $15, \mathrm{Pl}$. IV), where the cliff consists of two sandstones about equally thick, both of which contain Halymenites major Lesquereux and which are separated by the thin bed of coal previously referred to. It was in this canyon that Stevenson ${ }^{84}$ found a Cardium above the lowest bed of coal. In tracing this coal bed northward, however, it is found to become thin and finally disappear. Also the lower sandstone thins to the north and finally disappears while the upper one thickens. There are places in this critical area between Ponil Canyon and Dawson in which the beds can not be followed continuously at the outcrop on account of brush and slide rock, but the evidence at hand indicates that the sandstone of the Trinidad cliff of the southern part of the Raton field thins out south of Dawson near locality 20 and that it is slightly older than the Trinidad sandstone farther north; and further that the lowest coal bed south of Ponil Canyon (localities 8 to 13 , inclusive) is older than the lowest coal farther north (localities 17 to 22, inclusive). Furthermore, south of Ponil Canyon (localities 8 to 13) there is above the lowest coal a zone of coal-bearing shale that seems to be the southward extension of the Raton or lowest coal bed farther north. It follows, if exact horizons are traced, that the Trinidad sandstone of the southern part of the Raton coal field is not the exact equivalent of the Trinidad sandstone of the type locality. The transitional beds below the - Trinidad of the southern end of the field probably correspond in age with the top of the Pierre shale farther north; the cliff-making sandstone to the transitional beds; and the lowest coal-bearing rocks of the south to the massive Trinidad sandstone of the type area. These relations are best shown by the correlation lines in Plate IV.

The cliff-making sandstone in all parts of the Raton Mesa region represents the last stage in the filling of the Cretaceous sea, and the coal measures above this sandstone represent the swamp conditions that prevailed after the retreat of the sea. According to the somewhat general usage heretofore employed the cliff- 
making sandstone is here referred to the Trinidad and the coal beds to the Vermejo, even though it be known that the lower part of the Vermejo at the southern end of the Raton field is the exact equivalent in time of the Trinidad sandstone farther north.

\section{AGE.}

The geologic age of the Trinidad sandstone has been a matter for considerable speculation, and it is doubtful whether it is yet beyond the speculative stage. By some geologists it has been regarded as Fox Hills because of its stratigraphic position between the Pierre shale and the coal-bearing rocks which heretofore have been referred to the Laramie. In the Elmoro folio, published in 1899, Hills ${ }^{143}$ states that "it is uncertain what part of the Fox Hills group * * * is represented" by the Trinidad; in the Walsenburg folio, ${ }^{148}$ published a year later, he states that it "probably corresponds to the upper portion of the Fox Hills formation"; and in the Spanish Peaks folio, ${ }^{151}$ published in 1901, he states that "the Trinidad sandstone [note change from formation] represents some part, or possibly the whole, of the Fox Hills group, but on account of its relation to the Laramie [Vermejo and Raton formations of the present paper], and the thickening of the lower zone of the formation northward, it is presumably the upper portion only." The only direct evidence of age offered by Hills is an undetermined species of Baculites from the so-called "Lower Trinidad" and the Halymenites major Lesquereux, then supposed to be a characteristic Fox Hills fossil, from the so-called "Upper Trinidad."

G. B. Richardson, in 1910,225 followed Hills's later usage and described the Trinidad sandstone as consisting of an upper massive member and a lower thin-bedded member and collected from it several fossils named in the following list. With the exception of Halymenites major Lesquereux, Richardson's fossils came from the "Lower Trinidad," or the transitional zone of this paper. Those in the same list from the Raton field came from the massive sandstone of the southern part of the field, which, although there called Trinidad sandstone, is probably the exact time equivalent of the "Lower Trinidad" or transitional beds of the Trinidad field, as has just been explained.
Fossils from the Trinidad sandstone and underlying transitional beds.

[Identified by.T. W.Stanton. For descriptions of localities, see pp.66-161:] Anomia? sp. ${ }^{1}$

Avicula nebrascana Evans and Shumard.2

Chlamys nebrascensis Meek and Hayden. ${ }^{2}$

Inoceramus barabini Morton. ${ }^{3}$

Inoceramus sagensis Owen. ${ }^{1}$

Inoceramus sp. ${ }^{1}$

Legumen? sp. ${ }^{1}$

Macțra warrenana Meek and Hayden?'

Mactra sp. ${ }^{1}$

Mytilus? sp. ${ }^{1}$

Ostrea pellucida Meek and Hayden. ${ }^{2}$

Ostrea sp. ${ }^{2}$

Panopaea? sp. ${ }^{1}$

Tancridia americana Meek and Hayden. ${ }^{1}$

Tellina scitula Meek and Hayden. ${ }^{1}$

Tellina sp. ${ }^{1}$

Tellina? sp. ${ }^{1}$

Fish bones and scales. ${ }^{1}$

Halymenites major Lesquereux. ${ }^{3}$

These fossils would be included in a list of Fox Hills species; but they do not give conclusive evidence of Fox Hills age. Halymenites major Lesquereux occurs in the Fox Hills, but it has also been found in rocks that are much older than Fox Hills. Stanton, who identified the invertebrates, states that some of them, such as Avicula nebrascana, Inoceramus barabini, and Inoceramus sagensis, have a wide range in time, while others, such as Ostrea pellucida, Chlamys nebrascensis, and Mactra warrenana, are more restricted and are known only in the upper part of the Pierre and in the Fox Hills. Of the eight forms specifically identified, six range downward into the Pierre; leaving only two, one of which is doubtfully identified, that occur only -in the Trinidad. Evidence presented later (p. 168). tends to correlate the Vermejo of the Canon City field with the Fox Hills and to place the Trinidad well down in the Montana. Evidence from the fossils found in the Raton Mesa region has the same tendency. On the whole, the fossils of the Trinidad sandstone indicate that its age is upper Montana but apparently are not-sufficient for more exact correlation. However, inasmuch as the Trinidad sandstone lies beneath the Vermejo formation, whose fossils prove its Montana age, it seems probable

\footnotetext{
1 From Raton field (collected from the massive sandstono or Trinidad proper).

2 From Trinidad field (collected principally from the transitional zone which is now included in the Pierre).

${ }^{3}$ From Raton and Trinidad fields.
} 
that the Trinidad should be placed as far down in the time scale as the lower part of the Fox Hills, if not somewhat lower.

\section{VERMEJO FORMATION. \\ NAME AND TYPE SECTION.}

The name Vermejo formation was originally proposed, for use in this paper, for the coal measures lying immediately above the Trinidad sandstone, but owing to delay in the completion of the paper the name was first used elsewhere, 238.230 the formation being correlated according to the evidence herein presented. This was permitted because it seemed desirable to use the principal conclusions without waiting for the details.

The Vermcjo formation consists of coalbearing sandstone and shale, principally of fresh-water origin. The type locality of the formation is in Vermejo Park, N. Mex.; where the rocks are well exposed and have a maximum thickness of about 375 feet. Three sections were measured in Vermejo Park at localities 123,124 , and 125 (see pp. 143-146). The rocks are better exposed at locality 123 than they are in the other places, and this may be regarded as the type locality of the Vermejo formation. The section is as follows:

Section of rocks measured at locality 129, at the southeastern extremity of Vermejo Park, N. Mex. [For graphic section see P1. XxII, p. 164.]

Raton formation:

Conglomerate (top eroded away)

Ft. in. Unconformity.

Vermejo formation:

Coal.........................

Shale, black, carbonaceous at top.......

Sandstone, yellow, massive, fine grained, containing Ficus speciosissima Ward, Pterospermites undulatus Knowlton, Sequoia obovata Knowlton, Sabal montana Knowlton, Zizyphus paliurifolius Knowlton ..........................

Covered............................

Shale, drab, somewhat sandy........... Coal.

Sandstone and sbale, not continuously exposed ........................

Sandstone, white, massive, very friable.. Coal (streak).

Shale, drab...................................
Sandstone, yellow to white, massive, coarse grained.......................

Shale, very sandy $. . . \ldots \ldots \ldots \ldots \ldots . . . . .$.

Sandstone, yellowish white, massive, coarse grained, fossiliferous............. Coal..........................
Vermejo formation-Continued. Shale, sandy, with thin sandstone...... $41 \quad 0$ Coal..........................

Shale, sandy......................... 150 Coal .......................... 36

Shale, yellow, sandy............... $17 \quad 0$ Coal......................... $\quad 10$

Shale, drab........................ $\quad 7 \quad 0$ Coal........................ 4

Shale, drab........................ $21 \quad 0$

Sill of igneous rock, much altered, contains coke...................., 60 Coal,.altered to coke at top......... $3 \quad 4$

Not exposed...................... $19 \quad 0$ Coal....................... $\quad 1 \cdot 6$ Sandstone, shaly, friable............ $38 \quad 0$ $370+$ $100 \pm$

Trinidad sandston

Pierre shale:

Transitional zone.

Shale (possibly including rocks older than Pierre; lower 2,300 feet penetrated by drill). Near the top were found Ancyloceras sp., Inoceramus barabini Morton, Inoceramus sagensis Owen, Inoceramus vanuxemi Meek and Hayden, Mactra sp., Ostrea patina Meek and Hayden, Scaphites nodosus Owen............ 2,530+

$$
3,020 \pm
$$

The Vermejo formation rests conformably on the Trinidad sandstone and there seems to have been no time break between them. In most places the lowest bed of the Vermejo is shale, and the line of separation between it and the Trinidad sandstone can be drawn definitely, but where the lowest bed is sandstone, as at locality 123 (p. 143), exact demarcation is not easy, although the doubtful zone is in few places more than a few feet thick. $\begin{array}{llll}3 & 0 & \text { is } \\ 3 & 0 & \text { The upper limit of the Vermejo formation is }\end{array}$ well marked, and the massive basal conglomerate of the Raton formation rests unconformably on it. At locality 123 the conglomerate rests on coal, but a few hundred feet away it rests on shale, and still farther away on sandstone. THICKNESS AND EXTENT.

The Vermejo formation has its greatest observed thickness in the western part of the Raton Mesa region near the interstate boundary and thins toward the south, the east, and the north. All of the sections measured in the central western part of the region show considerable thicknesses of it (see Pl. XVII, p. 195), but it reaches a maximum of nearly 400 feet at Cornell, Colo. (locality 133, Pl. I, in pocket). 10 Between this locality and Spanish Peaks, a 
distance of 20 miles, the thickness does not vary greatly, but north of Spanish Peaks it thins sharply to a minimum observed thickness of about 31 feet on Cuchara River. (See fig. 9, p. 158.)

Toward the south the Vermejo formation was not found in Van Bremmer Park, possibly because of the absence of good exposures; and it was not observed for about 7 miles to the south. Beyond this to Baldy Peak (locality 1, Pl. I) the exposures are good and the Vermejo does not occur; and from Baldy Peak to locality 4, in Ute Park, a distance of about 6 miles, no rocks that can be referred to it were found. In Ute Park the Vermejo appears as a wedge that bluntly thickens to 150 feet or more in Cimarron Canyon. Thence, northeastward along the edge of the Raton field, its thickness is variable, as shown in detail in Plate V (p. 56). It thins and disappears east of Koehler and was not found at the outcrop between Koehler and Van Houten but is present a little farther to the west, where it is exposed in the canyons and where it was penetrated by drill and in mine shafts. It is absent from Red River Peak but is present farther north, where it was observed in the canyon walls, mine prospects, etc. East of Raton it thins out and has not been observed in the Raton field east of locality 81 .

In the Trinidad field the easternmost locality in which the Vermejo was recognized is in San Francisco Canyon (locality 94). Farther east the outcrop is obscured by brush. From locaIity 94 westward it gradually increases in thickness to a maximum of more than 200 feet but is irregular (see Pl. XII, p. 118), reaching a minimum at Bowen, Colo. (locality 109); of less than 50 feet. North of Bowen it is less variable. (See Pl. XV, p. 132.)

\section{CHARACTER.}

Sandstone.-The sandstones of the Vermejo formation ordinarily do not form prominent topographic features. In the northern part of the Trinidad field a cliff-making sandstone occurs near the middle of the Vermejo (see $\mathrm{Pl}$ : $\mathrm{XVI}, B, \mathrm{p} .136$ ), and farther south there is a sandstone at about the same horizon that Hills has called the "parting sandstone." But in 'most places throughout the Raton. Mesa region the sandstones of the Vermejo are soft and friable and disintegrate about as readily as the shale that is associated with them. In many places, although the sandstones seem, when fresh, to be well consolidated, they weather readily to a loose granular mass. Attempts to use these sandstones as building material have failed because of their rapid disin tegration. In general appearance they do not differ notably from the underlying Trinidad sandstone, and in the southern part of the Raton field those in the lower part of the Vermejo can not be distinguished readily from the Trinidad. The sandstones are usually light gray in color, and although they are doubtless somewhat lenticular the lenses are so broad and thin that the observer receives the impression that the bedding is very regular. In some places it contrasts sharply with the obviously lenticular character of some of the sandstones in the overlying Raton formation.

Shale.-In most places the Vermejo consists principally of shale and shaly sandstone, much of which is carbonaceous and in which are found numerous seams or thin beds of coal. This shale varies in color from coal black through various shades of buff and tan. No doubt the different layers of shale, as well as those of sandstone, are lenticular, although few distinct lenses have been traced out. If it be granted that the thicknesses of the rocks and their descriptions in these sections and records are correct, it seems necessary to assume lenticularity. This character becomes obvious when an attempt is made to correlate individual members of sections and of drill records. However, because most of the sandstones are shaly and most of the shales are sandy, and because no two observers would describe them in exactly the same terms, the descriptions both of the drill records and of the sections measured at the surface are likely to show greater variations than actually exist.

Coal.-Coal beds occur at many horizons throughout the Vermejo formation. Indeed, they are so numerous in some places that it is difficult definitely to correlate those of contiguous localities unless the individual beds are actually traced at the outcrop or unless carefully measured sections and drill prospects are made close together. The coal beds probably furnish the most reliable data in explanation of the variations in thickness of the Vermejo. There seem to be good reasons for believing that the Vermejo coals were formed in swamps lying little above sea level, and that a bed of 
coal represents a surface that was practically level during the time that the vegetable matter from which the coal was formed was accumulated. This conception scarcely admits of the postulate of extreme lenticularity of the Vermejo beds, and where sections of this formation measured close together differ notably in thickness and in the number of the coal beds these differences may be due, at least in part, to removal of the higher beds during post-Vermejo erosion rather than to extreme lenticularity, which seems to be a necessary assumption in case erosion be not admitted.

On the other hand, it is perfectly well established that some of the bodies of sandstone and shale are in the form of broad lenses and that some of the coal beds also are lenticular and that others coalesce to form a single bed. There are beds of coal that have been worked in mines or prospected along the outcrop to points where they were too thin to be worked profitably. There are many places where shale or sandstone partings in the coal increase laterally to considerable proportions. Richardson ${ }^{225 a}$ has described a notable instance where a thick bed of conl is split into two thinner beds which in less than half a mile became separated by 30 feet of sandstone and shale. No doubt many similar cases will be found as mining progresses, but where one notable exception of this kind is found there are probably scores of places where the coal beds, although somewhat variable in thickness, are continuous for long distances and where the intervals between them are relatively regular. Decision of the question whether the coal beds of the Vermejo are more lenticular than those of other fields must await a much more detailed study than has yet been given them, but from such facts as are now known it seems probable that although the variations in the thickness of the Vermejo formation and in the number of the coal beds may be due in some measure to the lenticularity of the beds, it is due in many places to erosion following the deposition of these beds-that is, to post-Cretaceous erosion.

Summary.-In general, the Vermejo formation consists of shale, much of which is cârbonaceous; high-grade coking, bituminous coal, and light-grny, friable, granular sandstone. Except for differences in induration the formation is relatively uniform in character throughout the Raton Mesa region, in this re- spect contrasting sharply with the overlying Raton formation, which varies in character from place to place and is notably coarser near the mountains in the western part of the Raton. Mesa region than in the eastern part.

The general differences between these two formations is perhaps best described by stating the writer's conception of their origin. As the rocks of the Raton formation consist mainly of thick beds of sandstone and conglomerate near the mountains and become thinner and the material finer away from the mountains (see p. 58), it seems obvious that the sediments were derived from the area to the west now occupied by the southern part of the Rocky Mountains and at no great distance from their present resting place. In marked contrast with this the sediments, of the Vermejo formation were obviously derived from some area either so low lying or at such a distance from the Raton Mesa region that no material coarser than sand of medium-sized grains found its way into them. The uniform character of the rocks throughout a region 50 miles east and west and 90 miles north and south suggests the probability that the source of the sediments was far away. It may seem on first thought that as the Vermejo formation is thickest in the western part of the region and thins toward the east the sediments must have come from the west. However, the lithologic character: of the rocks does not warrant this reasoning, and a critical examination of the geologic sections in the various parts of the region seems to. prove that the observed differences in thickness are due principally to erosion.

The conception as just stated is in harmony with the known physical conditions existing in the Rocky Mountain region during Cretaceous time and with the changes that inaugurated Tertiary time. It seems to be generally conceded by geologists who are familiar with this region that in early Cretaceous. time the area now occupied by the Rocky Mountains was one of very low relief, if not. actually base-leveled. It is certain that the Cretaceous formations extended originally over much of the area now occupied by the Rocky Mountains, and isolated remnants preserved in protected parts of the mountains indicate that the whole area may have been subinerged by the Cretaceous sea. ${ }^{249}$ This postulate is wholly in agreement with such data as have been 
obtained in the vicinity of the mountains in northern New Mexico and southern Colorado. The Cretaceous formations are comparable in thickness and in lithologic character on either side of the mountains, and sedimentary rocks above the Dakota sandstone, ranging in thickness from 1,000 to more than 3,000 feet, give little indication that they were derived from land masses in the Rocky Mountain region rather than from lands at greater distances. As Cretaceous formations, comparable to each other in thickness, lithologic character, and stratigraphic succession, occur on either side of the mountains separated by less than 90 miles, it seems reasonable to assume that they may once have extended continuously over the area now occupied by these mountains. Although minor warpings of the surface may have caused differences in the thickness of the sediments or even "slight emergences in some places no orogenic disturbances in the southern part of the Rocky Mountains before the close of the Cretaceous period left any unmistakable imprint in the stratigraphic record. At the close of the Cretaceous came the first great uphearal of the mountains, marked in this region by the unconformity between the Vermejo and Raton formations; and the evidence derived from the younger rocks indicates geographic conditions very different from those that prevailed while the sediments of the Vermejo were being deposited.

\section{DERIVATION OF SEDIMENTS.}

The question has been raised as to the source of the Vermejo sediments. As the formation occurs near the base of the present mountains there is a temptation to regard the material as derived from the mountain area. But if this area furnished the material some clear evidence of that fact should be found-and thus far it has not been found. The sediments have essentially the same characteristics in all -parts of the Raton Mesa region. The sandstones of the Vermejo are not coarser nor more massive near the mountains than they are far from them; nor is the proportion of coarse -material greater near the mountains in the western part of the region than in the eastern part. After comparing the material in the field with that of the Raton formation, which was obviously derived from the area now occupied by the mountains, the writer is inclined to doubt such a derivation for the Vermejo sedimentary rocks and to believe that these, like those of similar mid-Cretaceous formations of the Rocky Mountain region, were derived from the continental land masses that existed during Cretaceous time both east and west of the interior Cretaceous sea. This belief is strengthened and to some extent engendered by the theory presented by the writer in a recent paper ${ }^{240}$ that highlands did not exist in the Rocky Mountain region in Colorado and New Mexico during the Upper Cretaceous epoch and that these mountains began their existence with the Tertiary.

$$
\text { FossIrs. }
$$

Aside from the fossil seaweeds, Halymenites major Lesquereux and a Cardium $^{84}$ found above the lowest bed of coal in the southern part of the Raton field, the fossils thus far found in the Vermejo formation are land plants. Because of poor exposures due to the easy disintegration of the rocks few of these plants were found at the outcrop, nearly all of the best collections being obtained from the rock dumps of coal mines. A list, complete so far as is known at this writing; may be found in the table below. Plants found in the Canon City field that will be described later are inserted here in order to bring together the whole Vermejo flora.

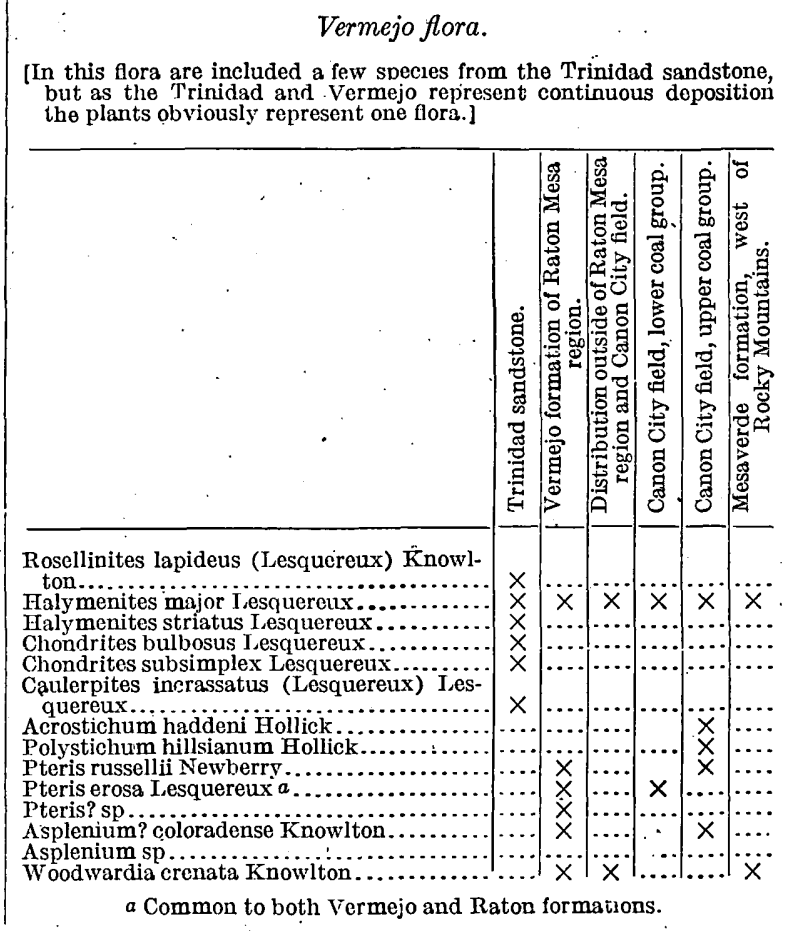


Vermejo flora-Continued.

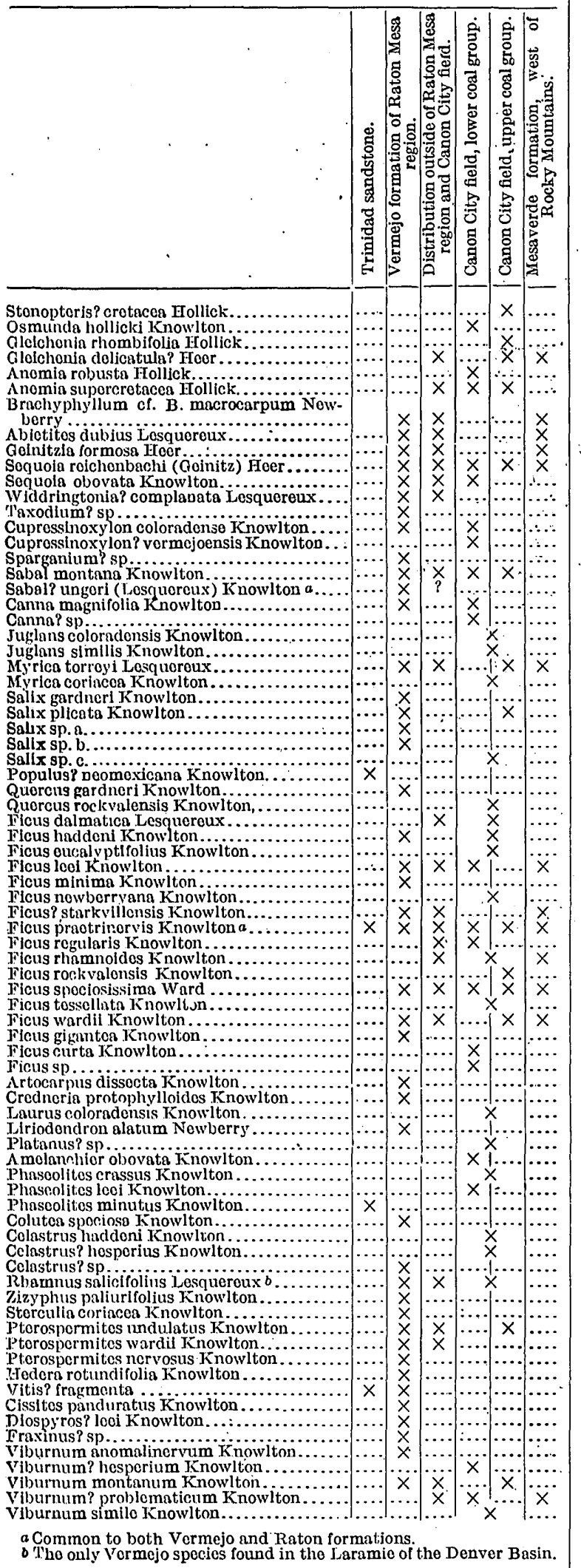

Vermejo flora-Continued.

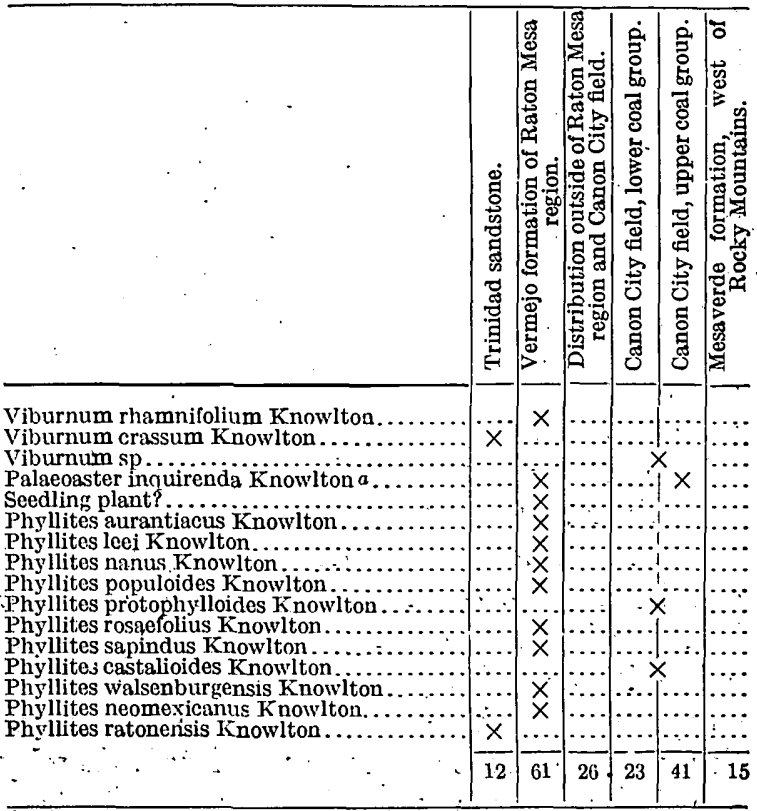

a Common to both Vermejo and Raton formations.

POST-CRETACEOUS UNCONFORMTYY

Evidence of the post-Vermejo unconformity; which the writer regards as a part of the general post-Cretaceous unconformity of the southern Rocky Mountain region, was obtained at many of the localities described in detail in other parts of this paper. In some places wellmarked angularity was noted between the planes of bedding of the two formations. The most conspicuous example of this is in Ute Park, where the base of the Raton formation transgresses the Vermejo formation, the Trinidad sandstone, and a considerable thickness of Pierre shale. ' (See Pl. V, p. 56.) Well-marked angularity was observed in Cottonwood Canyon, N. Mex., near locality 48 (fig. 8, p. 100), and in the Willow mine at Van Houten, N. Mex. (fig. 3, p. 96). At many other localities less conspicuous angularity was noted. However, in many places throughout the Raton Mesa region the stratification of the Vermejo is so nearly parallel to that of the Raton formation that it is quite impossible to determine whether a slight angularity marks the horizon of a general unconformity or constitutes a mere local unconformity such as is somewhat common in the younger beds of the region.

At many of the localities examined in detail the evidence of erosion at the top of the Vermejo is unmistakable. Certain easily recog- 
nizable beds, such as coal, when traced laterally, disappear abruptly at the line of unconformity; and in some places the Vermejo formation thins sharply or disappears entirely in a manner best explained by erosion. The relations of the Vermejo formation to the younger rocks is fully described on pages 66161. The stratigraphic and structural relations are indicated graphically in the several plates of sections (Pl. V; Pl. X, p. 108; Pl.XV, p. 132; and Pl. XVII, p. 142), and can best be understood from study of these plates.

The lithology of the Vermejo formation is sufficiently different from that of the Raton formation to indicate to a close observer, even without the aid of other data, that they should not be included in a single formation; and this physical evidence of unconformity is abundantly supported by the evidence of the two fossil floras, which are practically unrelated, thereby showing that the unconformity represents a long interval of time. They prove, according to Knowlton, that the Vermejo formation is Montana in age and that the Raton formation is Tertiary. The length of time represented by the unconformity as indicated by the fossil plants is commensurate with that indicated by the observed structural relations and by the character of the basal conglomerate of the Raton formation. (See p. 58.) In short, the unconformity seems to represent all of Laramie and perhaps some of late Montana time, for rocks of Montana age have been eroded away.

If this erosion resulted from uplift in the Rocky Mountain region, as is postulated in this paper, it must have been accomplished by streams of relatively high gradient, and the resulting surface would naturally be more or less uneven. This feature is shown graphically in Plates V, X, XV, and XVII, from which it appears that erosion cut deeper in some places than in others. In the southwestern part of the Raton field, north of Ute Park, it cut well down into the Pierre shale; in the eastern part of this field between. Koehler and Red River Peak it cut in some places down to the Trinidad sandstone; and from the mesa region of Raton it removed all rocks that may have existed above the Trinidad. These are the only areas in the Raton Mesa region where the Vermejo is known to have been entirely removed. These areas (see Pl. I, in pocket) are in line from southwest to northeast, and this fact suggests rather strongly that they may be parts of the valley of one of the major streams of early Tertiary time, and that this stream emerged from the mountains at the southern end of the Raton field in the vicinity of Baldy Peak and was flowing in a general northeasterly direction when deposition of sediment was resumed.

\section{- TERTIARY SYSTEM. \\ RATON FORMATION. \\ NAME AND TYPE LOCALITY.}

Raton formation is the name given to the upper coal measures of the Raton Mesa region and includes all of the stratified rocks between the Vermejo and the Poison Canyon formations. The name was first used by Hayden ${ }^{20 a}$ to indicate all of the coal-bearing rocks which he observed near Raton Mesa. As used by him it included the beds now assigned to the Vermejo formation, but as the Vermejo is not conspicuously exposed along the route traversed by Hayden and as most of the rocks that he called Raton Hills group belong to the coal-bearing formation above the Vermejo the name Raton has been adopted for this formation.

The type area of the Raton formation is the high mesa region between Trinidad, Colo., and Raton, N. Mex., erroneously called mountains, that culminates in Fishers Peak, a sharp projecting point of the highest mesa. No complete section of the rocks is exposed in the slopes of this highest mesa, called Raton Mesa, but in the side of Bartlett Mesa north of the town of Raton, from locality 75 (see Pl. I, in pocket) to the southern point of the mesa, these rocks are well exposed (see section on pp. 106-107 and Pl. X, p. 108), and a fairly complete section was measured with Locke level.

The details of the coal-bearing portion of this formation, given below, were obtained from the records of diamond-drill holes put down near Brilliant, N. Mex. The rocks above those penetrated by the drill are mainly coarse arkosic sandstone which seems to grade upward into the Poison Canyon formation. The two coal beds penetrated near the bottom of the hole are in the Vermejo formation, but the position of the Vermejo-Raton contact was not determined. Below the coal the drill entered the Trinidad sandstone. The succession of beds is as follows: 


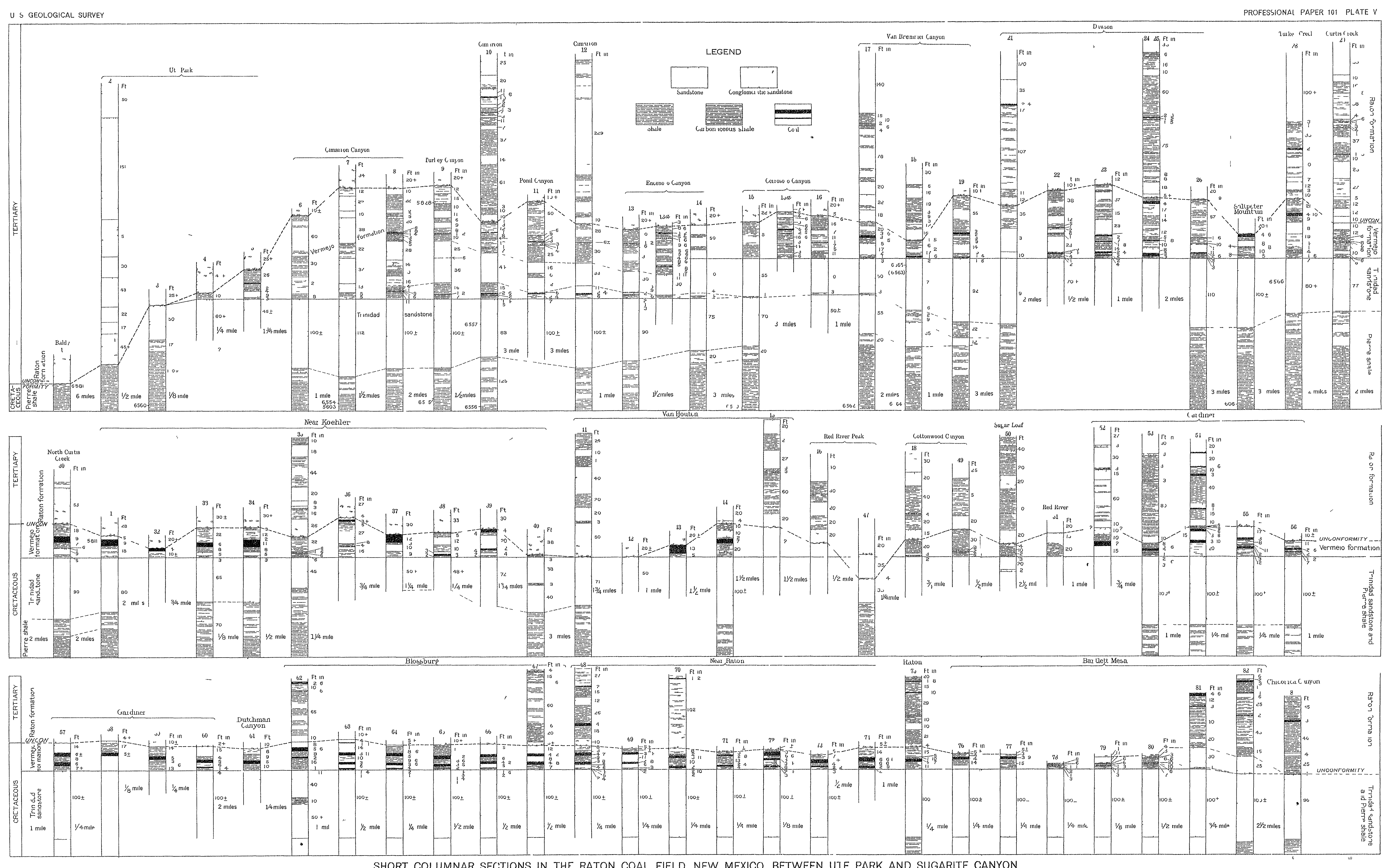


Rocks penetrated by diamond drill near Brilliant, N. Mex.

Surface soil

Sandstone.

Sandstone and shale, alternating layers

Sliale... Coal.

Shale........

Sandstone.

Coal

Shale...... Coal.

Shale.....

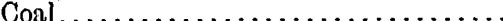

Shale and sandstone.

Coal. . .

Shale...

Coal.

Shale. ...

Shale, sandy.

Coal.

Shale...

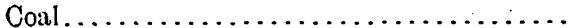

Shale...

Sandstone.

Shale..

Coal ..............

Shale

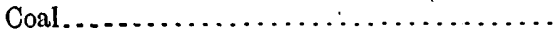

Shale.

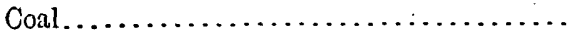

Shale, sandy

Sandstone.

Shale, sandy Coal..

Sanclstone.

Shale.. Coal..

Shale, sandy

Sandistone.

Sandstone and shale, alternating layers......... Coal...

Shale and sandstone........................ Coal.

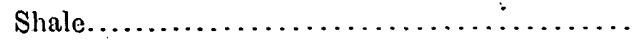
Coal.

Shale................................. Coal.............................. Shale............................... Coal. .

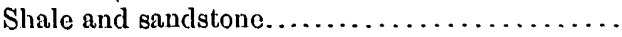
Coal.

Shale.

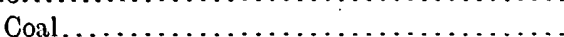

Shale, sandy Coal.

Shale...

Coal.

Shale.

Coal.

$37 \quad 10$

203

3
Shale.

Coal...........

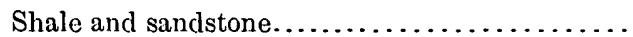

Coal...............................

Shat.

Coal.

Shale

Cont.

Shale.............................

Coal...............................

Shale...............................

Coal ...............................

Shale..............................

Coal..............................

Sandstone.........................

Coal ................................

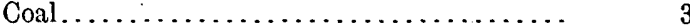

Shale............................. 3

Coal.............................. 3

Shale............................... $24 \quad 0$

Sandstone............................. $17 \quad 0$

Shale............................... 110

Coal.......................... 6

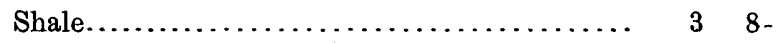

Coal............................ 7

Shale..............................

Coal................................ 3

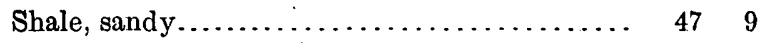

Coal............................ 6

Shale and sandstone, alternating layers......... $14 \quad 0$

Sandstone............................. $143 \quad 0$

Shale, sandy.......................... $22 \quad 0$

Sandstone........................... $71 \quad 0$

Shale; sandy............................ $25 \quad 0$

Sandstone............................. $37 \quad 6$

Coal............................. 21

Sandstone and shale..................... $51 \quad 9$

Coal............................. 5

Shale................................. $20 \quad 3$

Sandstone............................. 180

Sandstone and shale..................... $16 \quad 0$

Igneous rock........................... $50 \quad 0$

Sandstone and shale....................... 350

Coal.............................. $2 \quad 0$

Shale............................. 17

Coal............................. \& 1

Shale and sandstone...................... 74

. Coal............................... $3 \quad 10$

Shale................................. 19

Sandstone (Trinidad) $\ldots \ldots \ldots \ldots \ldots \ldots \ldots \ldots \ldots, \quad 49 \quad 8$

3
3

In Raton Mesa the top of the Raton formation is about 2,000 feet higher than its base and probably at no other locality in the region is so great a thickness of this formation preserved. If the strata were horizontal, this distance would indicate the thickness of the formation. At locality No. 75, near Raton, the 
formation is about 1,140 feet thick, and in the western part of the region, at Tercio, Colo., it is about 1,650 feet thick. Unlike the Vermejo, the Raton formation is essentially continuous throughout the region, the only interruptions in its continuity being such slight ones as those at Morley and in Vermejo Park, where the strata were domed and the rocks removed by erosion 'from the crests. The outline of the Raton Mesa region, shown on the map ( $\mathrm{Pl}$. I, in pocket), is essentially. the boundary of the Raton formation.

\section{CHARACTER AND DISTRIBUTION.}

Range.-The rocks of the Raton formation vary in character from coal and carbonaceous shale to sandy shale, sandstone, and conglomerate. In most places the rocks weather to yellowish brown. Most of the conglomerate occurs at the base of the formation, but in the southwestern part of the Raton field conglomerates were found far above the base. Coal occurs throughout the formation, but the principal beds are gouped so that at least two coalbearing zones are recognizable-a lower one, in which the coals are only locally of commercial importance and an upper one in which several thick beds occur.

Basal conglomerate. - The base of the Raton formation in nearly all parts of the Raton Mesa region is conglomeratic. In the western part of the region this conglomerate contains much arkosic material, is several hundred feet thick, and is coarse, massive, and resistant, but it thins and becomes finer grained toward the east. It varies greatly from place to place in thickness and in character, and in some places it can be distinguished from the sandstones higher in the formation only by the closest observation. In the vicinity of Raton it is represented by a thin quartzose sandstone in which only a very few small pebbles have been found; also, near Trinidad, Colo., there are many places where it is difficult to determine the line separating the Raton formation from the Vermejo; but in the western part of the region south of Spanish Peaks, in the southern and eastern parts as far north as Canadian River, and in the eastern part of the Trinidad field north of the city of Trinidad there is little difficulty in recognizing the conglomeratic sandstone that constitutes the base of the Raton formation.
The basal conglomerate consists of a matrix of firmly cemented sand, usually more or less quartzose, in which are embedded pebbles consisting mainly of quartz, quartzite; and chert varying in size from small grains to masses. 6 inches in diameter. The pebbles are unevenly distributed-in places in irregular masses many feet thick, in places in small "pockets," and in places singly. In character the pebbles are varied-near Yermejo Park and elsewhere were found some of coal; and in the hogback farther west and north were found pebbles apparently from the Trinidad sandstone; quartzose sandstone similar to the Dakota; conglomeratic sandstone similar to the conglomerates of the Purgatoire formation; petrified wood that may have come from the Vermejo or from the $\mathrm{Da}$ kota; red sandstone that could have come only from the red beds stratigraphically below the Dakota; cherty limestones with impressions of crinoid stems, such as are found in the limestone below the red beds; pebbles containing horn corals, such as are found in the limestones of the Pennsylvanian rocks (p. 42); quartz; quartzite; jasper; several sorts of cherts; igneous rocks, some of which are coarsely crystalline, like the granites of the mountains to the west and some fine grained, like those found in dikes of the mountain region; and pebbles of feldspar up to half an inch or more in diameter, most of them kaolinized, but some of them still retaining their original form sufficiently to show cleavage faces.

The character of the conglomerate strengthens the postulate (p. 56) that one of the main streams of early Tertiary time entered the Raton: Mesa region from the southwest near Baldy Peak, and indicates that this stream probably carried much of the sediment that formed the Raton beds. In the southwestern part of the Raton field the pebbles attain their maximum size and the conglomerates their maximum thickness. The sandstones farther to the east and south, which lie above the lowest conglomerate (see Pl. VI, p. 68) and which are in part equivalents of the higher conglomeratic beds to the northwest, are much thicker and more massive than sandstones at the same horizon in the eastern parts of the field. In brief, the Raton formation is coarsest and thickest in the southwestern part of the field and becomes thinner, finer grained, and more shaly toward the northwest. 
Lower coal zone.-In many places in the east- Upper Cretaceous formations extended conern part of the Raton Mesa region a zone of coal- tinuously over it have already been given in bearing shale occurs in the lower part of the this paper (p. 37) and have been more comRaton formation. This is perhaps best known. pletely stated in a separate publication. ${ }^{249}$ east of Raton, where several mines have been According to the measurements (see p. 41) opened on the thickest coal (here known as the Sugarite bed), which occurs about 100 feet above the base of the Raton formation. This zone of coal-bearing shale is known to extend southward beyond Dawson, and it is rather definitely identifiable in the eastern part of the Trinidad field, but in the western and extreme southern part of the Raton Mesa region it was not recognized. Its place there seems to be occupied by sandstone or perhaps even by conglomerate.

Cliffs or "barren series." -A series of beds consisting principally of coarse-grained sandstone occurs above the lower coal zone and outcrops in the cliffs that form an almost continuous escarpment along the eastern margin of the Raton field and in the precipitous walls of most of the canyons. (See Pl. VI, p. 68, and Pl. VIII, p. 94.) In the Trinidad field these sandstones are recognizable in the measured sections and the drill records, but they do not form -a conspicuous escarpment as they do in the Raton field. These rocks are 600 feet or more in thickness in the southern part of the Raton field but thin northward to 200 or 300 feet. Because no coal of commercial importance has been found in them they are locally known as the "barren series." In the western and extreme southern parts of the region this series blends with the underlying conglomerate. (See Pl. X, p. 108; and Pl. XVII, p. 142.)

Upper coal zone.-The principal coals of the Raton formation occur in a series of alternating sandstones and shales above the "barren series." This upper coal zone is recognizable quite generally throughout the Raton Mesa region. The lowest coal beds in the zone have been developed at Yankee and at Brilliant in the Raton field, and the higher beds are known in prospect openings made in many places throughout the eastern part of this field. In the Trinidad field these upper coals àre mined at Primero, Segundo, Delagua, Rugby, and elsewhere.

MEASURE OF POST-CRETACEOUS EROSION.

Some of the author's reasons for believing that the southern Rocky Mountain region was submerged by the Cretaceous sea and that the of the several formations now exposed in the foothills along the mountains the conglomerate at the base of the Raton formation is stratigraphically more than 18,000 feet above the crystalline and metamorphic rocks that furnished most of the pebbles found in it. If it could be demonstrated that the older sedimentary formations were conformable and once extended continuously over the now uplifted area, this figure might be accepted as an adequate measure of the post-Cretaceous erosion, but they are not conformable with each other and there is doubt as to their original distribution. However, the Upper Cretaceous sedimentary rocks are conformable throughout and in order that pebbles of sandstones from the Dakota and from the still older red beds might be incorporated in the conglomerate there must have been differential uplift and erosion of more than 4,000 feet. It is probable that the erosion was much greater than this, but it is perhaps unsafe to make the figure larger, for it is practically certain that the crystalline rocks of the mountain area near by were exposed at the surface during the formation of the red beds and that. they furnished the boulders of granite and of other crystalline and metamorphic rocks found in these red beds. It is equally certain, however, that the highlands had been reduced to low relief previous to the deposition of the Morrison formation, for no material coarser than sand has been observed in the Morrison in the Raton Mesa region, though there must have been highlands at no great distance to furnish the pebbles found in the Purgatoire. No fragmental material coarser than sand has been found in the Upper Cretaceous of this region. above the Dakota, and the rocks consist principally of shale.

Cross has estimated ${ }^{133}$ that during the period of post-Cretaceous erosion in the Denver Basin 14,000 feet of sedimentary rocks were cut away. Computed in a similar way the amount of post-Cretaceous erosion in the Raton Mesa region would seem to be at least as great. But this method of measuring the amount of erosion seems open to criticism. However, although a definite measure of the uplift and erosion may not be possible, the known facts 
seem to prove that the post-Cretaceous unconformity in the Raton Mesa region represents a period of erosion whose duration is comparable to that of post-Cretaceous erosion in the Denver Basin.

\section{LOCAL UNCONFORMITIES.}

In some places local unconformities occur within the Raton formation." A rather conspicuous one was observed in the canyon of the Purgatoire near Weston and another in the canyon of the Canadian. The beds of the Raton formation are so lenticular in some places that exact correlations of individual beds in the measured sections is difficult.

FOSSILS AND AGE RELATIONS.

The Raton formation in all parts of the Raton Mesa region contains great numbers of fossil plants, of which 150 have been described and are named in the following table of fossil plants. A large number of these plants occur in the Wilcox group of the Gulf coast-a group known to be of Eocene age not only because of its fossil plants but because of its invertebrate fauna and its position above a formation (Midway) that contains distinctively Eocene invertebrates and which in turn lies unconformably on rocks of Cretaceous age. ${ }^{242}$

The relation of the Raton flora to the Arapahoe, Denver, Dawson, Fort Union, Midway, and Wilcox floras is discussed by Knowlton in the accompanying paper and need not be repeated here. Berry ${ }^{250}$ has shown that these floras are closely allied to each other, that they are early Tertiary in age, and that they are essentially synchronous with the basal Eocene of Europe. The paleontology is in perfect accord with the structure in indicating the early Tertiary age of the Raton formation.

\section{Raton flora.}

[A few of the species of this list are described from specimens from th Poison Canyon formation, but as the same species occur in the Rato formation these are properly included in the Raton flora.]

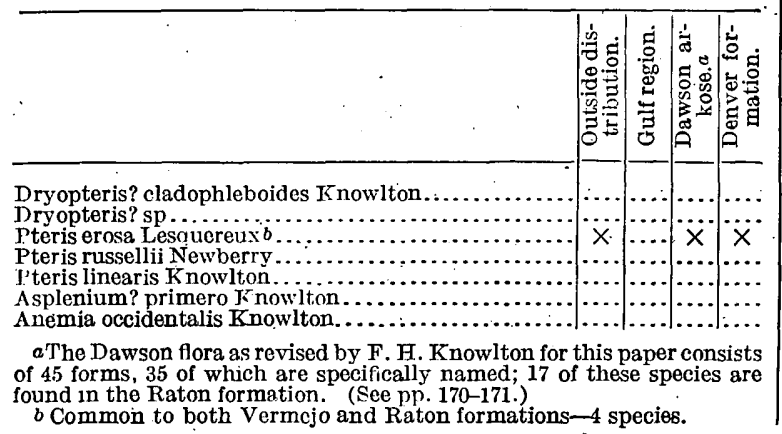

Raton flora-Continued.

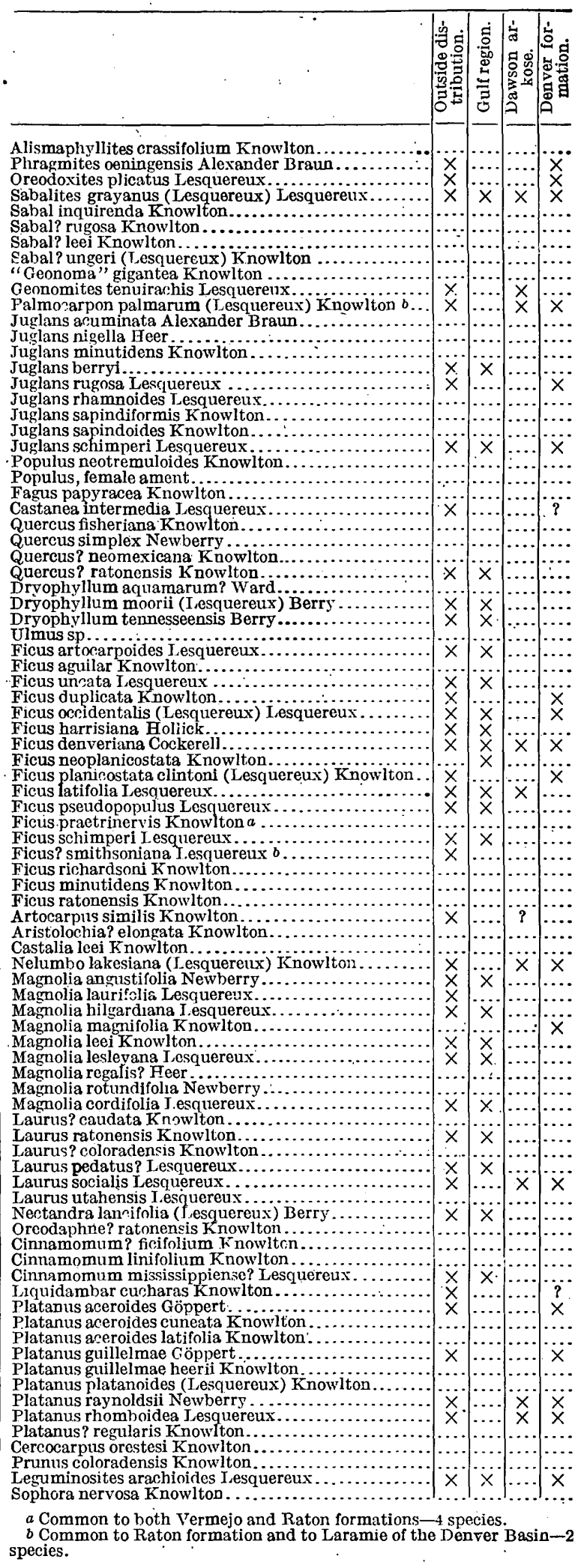


Raton flora-Continued.

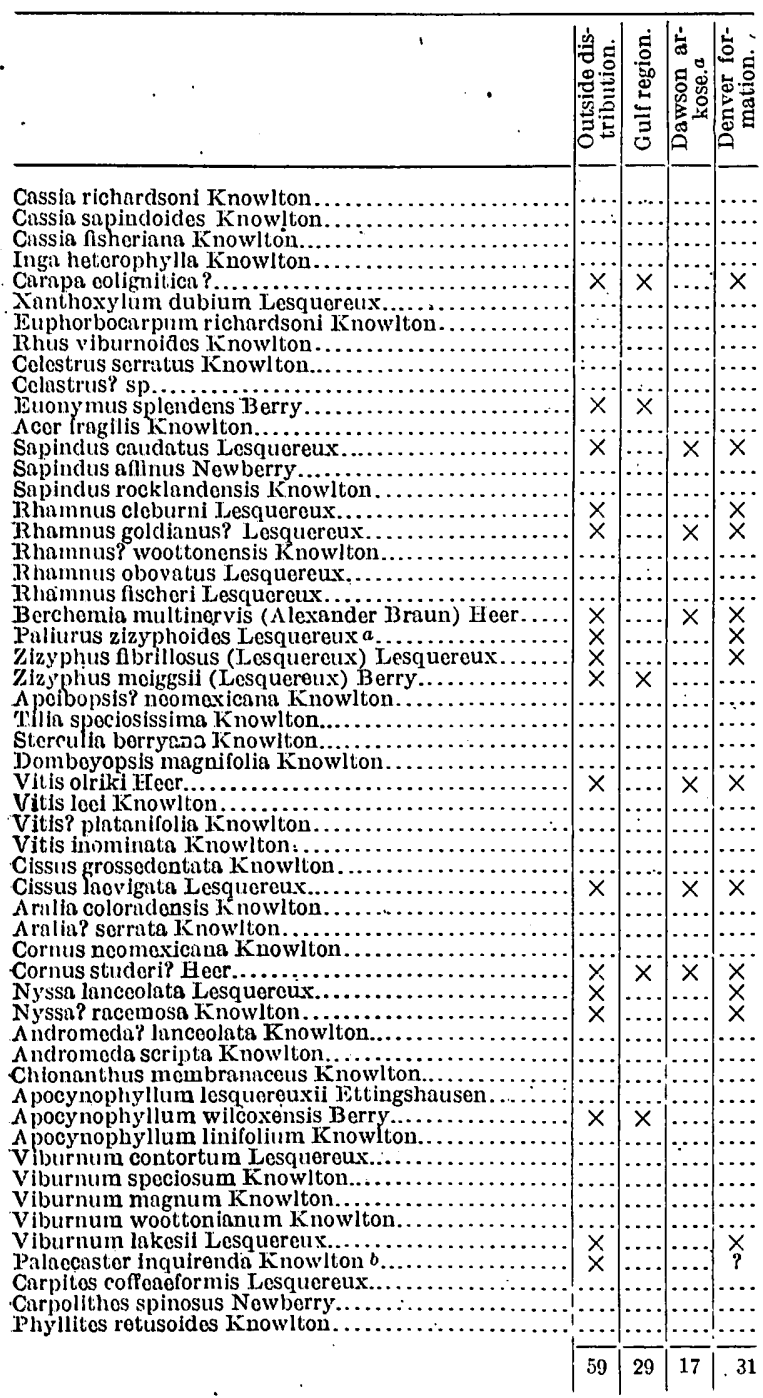

$a$ Common to Raton formation and to Laramie of the Denver Basin2 spocies.

Common to both Vermejo and Raton formations-4 species.

POISON CANYON FORMATION.

The Poison Canyon formation is only incidentally involved in the subjects discussed in this paper. However, because of its relation to the underlying Raton formation, and because it contains certain fossil plants that are also included in the Raton flora, some mention of it seems necessary. It has been correlated with the Denver formation, principally because of lithologic resemblances and supposed stratigraphic position. While working in the Trinidad field, the members of Richardson's party found several fossil plants in these rocks that proved to be specifically identical with those in the Denver formation. However, it was found later that these species occur also in the Raton formation and that the fossil floras show little difference in age between the Raton and the Poison Canyon formations. Furthermore, as the Poison Canyon beds have not been examined with sufficient care to determine their variations in character and appearance, it is not always possible to ascertain whether the rocks at a given locality belong to the Raton or to the Poison Canyon formation. However, the two formations have generally been regarded as unconformable with each other, although difficulty has been found in tracing the contact. It seems possible that the Poison Canyon and Raton formations may differ but little in age and that their physical differences may be due to local variations in the conditions of sedimentation, as Richardson ${ }^{234}$ has suggested for the Arapahoe, Denver, and Dawson formations of the Denver region. Although a general discussion of the relation of the Poison Canyon to the Raton formation is beyond the scope of the present paper, the foregoing statement will explain why some of the fossil plants collected from the Poison Canyon formation are appropriately included in the Raton flora. Several collections preserved in the National Museum are labeled as coming from the Poison Canyon near the line of contact with the Raton formation. The species represented in these collections are identical with those from the Raton formation; but some of them are better preserved and have been used for illustration in the accompanying paper by Knowlton. The locality at which each lot of fossils was obtained is indicated by the lot number on the map (Pl. I, in pocket), and all the information at hand concerning each lot is given on pages $66-161$.

\section{GEOLOGIC HISTORY.}

\section{PRE-PALEOZOIC TIME.}

A brief account of the principal geologic events that have been recorded in the Raton Mesa region may be of service in clarifying some of the relations described. The oldest rocks of the region are the crystallines of preCambrian age that constitute the core of the Culebra Range. Some of the finer-grained crystalline rocks may represent ancient sediments, but the coarse-grained granites probably resulted from the slow cooling of a liquid 
magma below the surface of the earth and were exposed at the surface only when they were elevated and the overlying rocks removed by erosion.

\section{PALEOZOIC EVENTS.}

During a great part of the Paleozoic era, when large areas of North America were covered with epicontinental seas which shifted in position from time to time and in which were deposited the sediments of the several formations of early Paleozoic age, the Raton Mesa region either remained above sea level or was cleared by later erosion of such early Paleozoic sediments as may have accumulated there. The latter alternative is the more probable, for small remnants of sedimentary rocks formed in Cambrian and Ordovician seas are found along the mountain front north of this region and larger remnants south of it. Also, in central New Mexico there are remnants of sedimentary formations of Devonian and early Carboniferous (Mississippian) age, the latter extending northward into Colorado. In early Pennsylvanian time considerable portions of the southern Rocky Mountain region were above sea level and nonmarine deposits accumulated in many places. These contain thin beds of coal, with which are found plants iepresenting an early Pennsylvanian (Pottsville) flora. . Central Colorado and areas farther north remained above sea level, but southern Colorado and New Mexico sank beneath the sea and accumulated a thick limestone formation. In the mountains west of the Raton Mesa region the limestone layers seem to interfinger with coarser material indicative of near-shore conditions. Later in Pennsylvanian time this limestone was brought above sea level and eroded to some extent, so that in some places pebbles of it are found in the conglomerates of the younger sedimentary rocks. These rocks, which also have been classed as Pennsylvanian, are in part the red beds of the southern part of the Rocky Mountain region. ${ }^{1}$ Some of these were deposited in the sea and contain marine shells. Others consist of coarse sand and conglomerate and may represent upland accumulation. On the whole they represent a long, complicated history that has not yet been fully worked out.

\footnotetext{
1 Since this account was written evidence has been obtained that the red beds here assigned to the Pennsylvanian are probably Permian, hence the unconformity and conglomerate here referred to as midPennsylvanian probably mark the base of the Permian of this region.
}

The detritus from the highlands that probably occupied about the same place as the present Rocky Mountains was carried to the lowlands. by streams and deposited there in part as alluvial wash. Some of it was carried beyond these lowlands to shallow shifting bodies of water, some of which may have been saline lakes and others were arms of the sea. These waters evaporated, leaving in some places layers of salt and gypsum interbedded in places with shale and in other places with limestone, both of which contain shells of marine or brackishwater mollusks. The red bed accumulation continued through Permian and into Triassic time. The salt and gypsum beds of Pennsylvanian, possibly also of Permian age occur south of the Raton Mesa region but not north of it.

\section{MESOZOIC EVENTS.}

TRIASSIC AND JURASSIC TIME.

Little is known of the plane of separation between Paleozoic and Mesozoic in this part of the continent, but it is certain that some of the fine-grained sedimentary rocks of the upper part of the red beds accumulated during the Triassic periods of waters that were fresh enough in some places to be inhabited by unios and belodonts. Triassic sedimentation was interrupted by a movement that domed the strata in some places in northeastern New Mexico, ${ }^{158}$ and probably also lifted the mountain region to some extent. Renewed erosion planed off the tops of the domes. Beds of sand covered the truncated edges of the older strata and hardened into the Exeter sandstone, which may be of Jurassic age, though no fossils have been found in it: It is well exposed in the walls of the canyons east and south of the Raton Mesa region. There are some reasons for believing that the Wingate sandstone of northwestern New Mexico and the La Plata sandstone of southwestern Colorado were formed about the same time and under similar conditions.

In early Cretaceous time, or possibly in late Jurassic, although the writer deems this inprobable, the streams of this region, as well as those of the whole Rocky Mountain region from New Mexico to Montana and from Utah to Kansas, spread out sediments that were variable in color and ranged in composition from limy mud to fine-grained sand and in 
some places even to conglomerate. These beds consolidated into the Morrison formation, which underlies the Raton Mesa region and crops out on all sides of it. In some places it contains fresh-water shells and the remains of land mammals, and in other places the bones of gigantic dinosaurs that lived in the swamps and streams and on the shores of the shallow temporary lakes. The mountains that furnished the coarse sediments in late Pennsylvanian or Permian time had been worn down, and the sediments of the Morrison formation were deposited over most of the area formerly occupied by them.

The stream deposition of Morrison time was probably accompanied by the slow subsidence of a large area that included the Rocky Mountain region. This movement culminated later in the occupation of the interior by the sea. Late in the Lower Cretaceous Morrison sediments of varied constitution and color were covered with sediments that have uniform constitution and color over a wide range. The first of this new material was light-colored, relatively pure quartz sand and fine conglomerate, followed by dark shale in places. These deposits hardened into the Purgatoire formation. They denote a great change in the physical conditions of the region, but possibly no great lapse of time, for in few places has any indication of a lapse in time been found between the Purgatoire and the underlying Morrison. The change denotes the advance of the sea over an area which had formerly been occupied by marshy lowlands lying but little above sea level and therefore a change from stream deposition to marine deposition. The subsidence, possibly accompanied also by. a rise of the sea level, had progressed at the close of this epoch far enough to allow the sea water from the Gulf of Mexico to invade the interior as far at least as the present mountain front and probably much farther. The truncated edge of the Purgatoire formation, there upturned, indicates that it once extended considerably farther, ${ }^{248}$ possibly to the west side of the mountains, where similar sediments may prove to be of Lower Cretaceous age, although no direct evidence of this correlation has yet been found.

The Purgatoire formation was covered in turn by the Dakota sandstone, the oldest of the formations now generally acknowledged to bə of Upper Cretaceous age. A time interval may be represented by the contact of the Purgatoire and the Dakota, but there is little eridence of an interval of intersystemicimportance. in the Rocky Mountains. At the beginning of the Upper Cretaceous epoch the Rocky Mountain region had been planed down nearly to sea level. ${ }^{248}$ This region was included in the subsiding area, and the sands of the Dakota were widely distributed over it. Continued subsidence, accompanied; perhaps, by continued rise of sea level, resulted in the formation of the broad interior basin of Upper Cretaceous time. In this basin were deposited the sands, muds, and limy ooze, which hardened into the marine formations of Upper Cretaceous age, and on its shores were accumulated the beds of peat which later formed the Upper Cretaceous coals. The rate of sedimentation in this basin was comparable with the rate of subsidence, and probably at no time was the sea very deep. In many places it was so shallow that sediments were distributed somewhat uniformly over large areas of its floor, probably by the action of waves and currents. Many times during the Upper Cretaceous epoch portions of the basin extending well toward its center were filled with sediments to the limit of marine deposition, and on these low-lying lands grew the luxuriant vegetation which accumulated in broad swamps as muck and peat. ${ }^{24 \theta}$

The coal beds and other features indicating nearness to land in the southern Rocky Mountain region in early Upper Cretaceous time are found mainly in central New Mexico and in western Colorado. In the Raton Mesa region open-sea conditions prevailed until after the middle of the Montana epoch. By this time the filling of the basin with sediments derived mainly from the west and southwest had proceeded to such an extent that shore conditions were established in the Raton Mesa region: The sediments delivered by the streams were washed by the waves and currents of the sea, and the sands were deposited near the shore. These hardened into the Trinidad sandstone.

When the sands of the Trinidad had filled the sea in this region to the limit of marine deposition, coastal swamps developed, in which accumulated the vegetable matter of the Vermejo coal beds. The later Cretaceous events of this region are not known, for the 
evidence of them has been destroyed by erosion; but farther north, near Canon City, Vermejo fresh-water sedimentation, interrupted at times by temporary incursions of the sea, continued until a thickness of 1,000 feet or more of strata had accumulated, and farther north, in the-Denver Basin, the sediments of a formation generally regarded as still younger, the Laramie, were deposited. If rocks of Laramie age were ever formed in the Raton Mesa region, they were removied by later erosion.

\section{POST-CRETACEOUS UPLIFT AND EROSION.}

Cretaceous sedimentation was terminated in the Rocky Mountain region by a general withdrawal of the sea waters from the continent. This was probably due in part, but not wholly, to a general lowering of sea level, possibly because of some readjustment in the interior of the earth that increased the capacity of the ocean basins. The withdrawal of the water was accompanied by a differential movement of the rocks which left the mountain region above sea level. The resulting erosion gave rise to the post-Laramie unconformity of the Denver region, the post-Vermejo unconformity of southern Colorado and New Mexico, and the post-Cretaceous unconformity of the Gulf coast. These are probably local manifestations of a general post-Cretaceous erosion which affected the whole southern Rocky Mountain region and may in time be found to have affected other regions. The diastropic movement that resuscitated the mountains whose roots had been buried beneath the Cretaceous strata changed the Rocky Mountain region from an area of general downwarping to an area of general upwarping and resulted in many local orogenic movements and in the extrusion of andesitic and other lavas. These seem to be parts of the world-wide changes in the distribution of land and sea which have been regarded as appropriately closing the Mesozoic . and opening the Cenozoic era.

Although the post-Cretaceous uplift in the Rocky Mountain region had great significance in that it marked the close of a long period of quiescent conditions and inaugurated a period characterized by great mountain-making movements and intense volcanic activity; it was probably less in actual magnitude than some of the uplifts which followed.' However, the differential uplift must have amounted to several thousand feet, for the Cretaceous beds that had covered the mountains were eroded from them in some places and the pre-Cretaceous rocks were exposed. All rocks younger than the Vermejo which may have been formed in the Raton Mesa region, were removed, and the Vermejo itself was reduced to a maximum thickness of about 400 feet in the western part of the region and removed entirely from the eastern part.

\section{CENOZOIC EVENTS.}

TERTIARY SEDIMENTATION AND EROSION.

The post-Cretaceous uplift and erosion were followed in the Raton Mesa region by the accumulation in early Tertiary time of the stream and swamp deposits that constitute the Raton formation. This deposition may have been caused in part by a subsidence of this region, but if so it was not sufficient to allow marine waters to return, for no marine beds have ever been found in the Tertiary formations of the Raton Mesa region. At first the streams deposited sand and gravel derived from the highlands to the west; but later they deposited finer sediments, mainly mud, over their broad flood plains, on which grew numerous semitropical plants that supplied the vegetable matter for the coal beds of the Raton formation.

Tertiary rocks younger than Raton wero formed in this region and were later eroded away. Remnants of them remain in the northern part, where they form the Poison Canyon; Cuchera, and Huerfano formations. These were later cut by intrusive igneous rocks of the Spanish Peaks irruption. At about the same time broad low flexures were formed east of the mountains. Sometime within the Tertiary, probably near the middle of the period, sedimentation was brought to a close in the Raton Mesa region, and the latter part of the period was occupied in producing a peneplain which beveled all the Tertiary beds previously formed and all of the Cretaceous down to the Dakota sandstone. On this plain thin beds of gravel were deposited, supposedly in late Tertiary time, and over them were poured great floods of molten basalt, remnants of which still remain as the hard cap rock of the mesas which extend from the Raton Mesa region eastward to the border of Oklahoma and Texas. 


\section{QUATERNARY EVENTS.}

Some years ago, when it was supposed that the flows of basaltic lava in the Raton Mesa region resulted from a single period of eruption, it was supposed that the eruption occurred in mid-Tertiary time. Since then much evidence has been brought forward to prove that the Quaternary period was much longer than was formerly supposed. The length of Quaternary time as measured by the general degradation of the plains surrounding the mesas is comparable to that which in northern Montana has left mesas covered with Pleistocene till standing 1,000 feet or more above the surrounding country. A length of Quaternary time as great or even greater is indicated in western Colorado by Pleistocene deposits on the divides between canyons tributary to the Grand Canyon of the Colorado.

It is possible that the Quaternary was introduced in the Rocky Mountain region by a notable orogenic disturbance, and that ore of the results of this disturbance was the outpouring in many places of basaltic lavas. Thus the outpouring of the mesa lavas may mark the opening of the Quaternary period. This possibility, finds support in the fact that. after the first great flow in the Raton Mesa region the same kind of basaltic lava was extruded in this region again and again down to a time so recent that the youngest cinder cones and flows show little alteration. These periods of eruption alternating with periods of degradation have resulted in the steplike character of the lava-covered mesas.

$47019^{\circ}-17-5$ 


\section{CHAPTER 3.-LOCAL FEATURES IN DETAIL.}

METHOD OF PRESENTATION.

In arranging the details given in this paper it was found that place names were wanting in so many areas that it seemed best to. designate - the localities described by numbers. (See map, Pl. I, in pocket.) These localities are described in order from the southwestern extremity of the region east and north around its eastern margin; then in Vermejo Canyon across the Raton field and thence along the western margin. Most of the observations were made near the outcrops of the coal beds.

Because little information has been published heretofore regarding the geology of the Raton field many details have been included which in a better-known region might seem to be out of place in the consideration of a special phase of the geology. In the Trinidad field the general geology has long been known from the folio publications of R. C. Hills, ${ }^{143,148.151}$ and many of the details of the coal deposits have been described more recently by G. B. Richardson, ${ }^{225}$ hence in the present paper the descriptions of localities in this field are confined more exclusively to the structural relations of the formations and to their geologic age.

BALDY.

LOCALITY 1.

Baldy is a gold-mining camp located at the southwestern extremity of the Raton coal field high on the side of Baldy Peak, an eminence caused by extensive intrusions of igneous rock which have upturned and lifted some of the sedimentary rocks. Remnants of these rocks still remain on the top of the mountain at altitudes of about 12,500 feet. The rocks exposed here are Pierre shale and the basal conglomerate of the Raton formation.

The Pierre shale is very thick near this locality, but the zone of fossiliferous limestone concretions that occur in Ute Park, a few miles to the southeast and that is found generally throughout the southern part of the Raton coal field near the top of the Pierre, was not found at Baldy. Several shells of the species Inoceramus vanuxemi (U.S. Geol. Survey fossil locality 6581) were found in the rocks of the dump from the gold mine which is described below. The shells came from the top of the shale, as represented here, but in many other places throughout the Raton coal field this species was found only below the zone of concretions several hundred feet below the top of the Pierre shale. This species is known to have a great vertical range, and therefore is not a good horizon marker. However, at several places in the Raton field where the full thickness of 'the shale is represented and where fossil shells were collected, this species was not found in the upper 400 feet or more, and its presence immediately below the conglomerate at Baldy adds force to the conclusion that the erosion represented by the unconformity separating them carried away not only all rocks younger than the Pierre that may have existed there, but also several hundred feet of the Pierre itself.

Neither the Trinidad sandstone nor the Vermejo formation occurs near Baldy, and the conglomeratic sandstone at the base of the Raton formation lies with irregular base on the Pierre shale. Here, as elsewhere, this sandstone is coarse grained and contains irregular masses of conglomerate consisting principally of siliceous pebbles. The conglomeratic parts are coarsest near the base but vary greatly in character from place to place. The porous conglomerate seems to have transmitted percolating waters in ages past and, lying as it does directly upon the relatively impervious shale, its base naturally served as a passageway. Apparently the waters carried gold in solution and deposited it in interstices of the conglomerate and crevices of the shale. At the time of investigation this gold was being mined at Baldy. The mine entries are driven on the unconformity and the gold is found in the upper few feet of shale and in vein material near the base of the conglomerate. In some of the mine openings small masses and irregular seams of coal, probably due to the carbonization of wood or other vegetable matter buried in the gravel, occur in the conglomerate. This coal also has been found to contain gold in appreciable quantities. 
The contact of the conglomerate with the Pierre shale was followed for about 5 miles north of Baldy. Throughout this distance the conglomerate lies with obvious unconformity on the shale and is variable in character. It is mainly coarse grained, massive, and arkosic. The pebbles consist principally of quartzite, although a number of coarse-grained granitic rocks were seen. They vary in size from small grains to masses 6 to 7 inches in diameter.

\section{BALDY TO UTE PARK}

Between Baldy and Ute Park, a distance of about 6 miles, the conglomerate was seen in several places resting on the Pierre shale. This relation is well shown northwest of Ute station in the canyon through which the wagon road passes from Ute Park to Ponil Creek, where the following fossil plants belonging to the Raton flora were found several hundred feet above the base of the Raton formation. (U. S. Geol. Survey fossil locality 5830):

Fossil plants collected northwest of Ute Park, N. Mex.

[U. S. Geol. Survey fossil locality 5830.1

Cinnamomum mississippiense? Lesquereux.

Dombeyopsis magnifolia Knowlton.

Magnolia angustifolia Newberry.

Palmocarpum palmarum (Lesquereưx) Knowlton. Sabal? ungeri (Lesquereux) Knowlton.

\section{UTE PARK.}

Uto. Park is an opening among the hills at the southwestern extremity of the Raton field, occupied in the center by soft Pierre shale and surrounded by hills of harder rock. West and south of the park these hills consist principally of igneous rock, but north and east of it they consist chiefly of the hard, conglomeratic sandstone of the Raton formation.

\section{LOCALI'TY 2.}

In the north wall of Ute Park, at locality 2, the Pierre shale is exposed at the foot of the slope. The basal conglomerate of the Raton formation lies above it, but the contact of the two was not seen. However, in view of the relations known to exist on either side of this locality, the conglomerate is plotted (section 2, $\mathrm{Pl}$. V) as resting unconformably on the shale. No rocks referable to the Trinidad sandstone or to the Vermejo formation occur at this locality.

The conglomeratic part of the Raton is more than 400 feet thick and underlies the finer- grained sandstone and shale that contain the fossil plants. The rocks in this 400 feet are coarse grained throughout but are not uniformly conglomeratic. A massive conglomerate occurs at the base and finer-grained rocks about 112 feet thick above it, succeeded by two conspicuous conglomerates separated by 151. feet of sandstone. Some of the layers and lenticular masses of pebbles in the basal conglomerate are 10 to 15 feet thick, and the pebbles, which consist mainly of quartz and quartzite, have a maximum diameter of $4 \frac{1}{2}$ inches or more. The section follows:

Section of Raton formation measured at locality 2, Ute Park, N. Mex.

[For graphic section see Pls. V (p. 56) and X (p. 108).]

Sandstone and shale, coal bearing, fossiliferous (several hundred feet).

Sandstone, yellow, massive, coarse grained, cliffmaking, conglomeratic in places; pebbles 1 inch in maximum diameter. . . ................ 50

Sandstone, coarse grained, yellow; contains fossil plants. . . . . . . . ...................... $15 i$

Sandstone, white, coarse grained, massive, cliffmaking; conglomeratic in places........... 55

Covered............................ 30

Sandstone, gray to yellow, fine grained, massive; somewhat friable. . . . . . . . . . . . . . . . . 43

Covered.............................. 22

Sandstone, gray, massive.................. 17

Sandstone, conglomeratic, with pebbles mostly of quartz, having a maximum diameter of $4 \frac{1}{2}$ inches.

\section{LOCALITY 3.} Feet. 50 55 政 43 $45+$

In the north wall of Ute Park about half a mile southeast of locality 2 the rocks are not well exposed, but the conglomerate was found in several places, resting, not on the Pierre shale as it does farther west, but on a gray sandstone. At locality 3 the rocks near this sandstone are well exposed and the short section given below was measured:

Section of rocks measured at locality 8 , Ute Park, N. Mex. [For graphic section see PI. V, p. 56.]

Raton formation: Feet. Conglomerate, resting with uneven base on. sandstone........................ $25+$

Unconformity.

Trinidad sandstone:

Sandstone, containing Halymenites major Lesquereux..................... 50

Pierre shale:

Sandstone, shaly, transitional zone. . . . . . 17

Shale, fossiliferous. . . . . . . . . . 
The basal conglomerate of the Raton formation here rests unconformably upon the white. Trinidad sandstone. Below the sandy transitional zone of the Pierre 150 feet of typical Pierre shale carrying concretions of limestone containing fossil invertebrates is exposed at the foot of the slope. No attempt was made to secure a complete collection, but the following species were taken from a single concretion about 150 feet below the top of the shale:

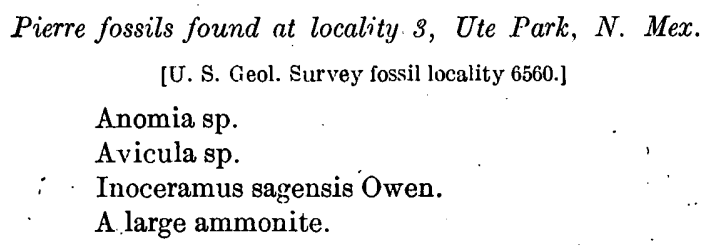

Between the shale and the overlying massive sandstone is a series of thin sandstones separated by shale which throughout the Raton Mesa region constitutes the transitional zone between the typical Pierre shale and the Trinidad sandstone. "The light-colored sandstone above this zone at locality 3 contains great numbers of the fossil fucoids, Halymenites major Lesquereux, which are usually abundant in the Trinidad sandstone. No rocks were found at this locality that can be referred to the Vermejo formation. These were doubtless eroded away during the post-Cretaceous erosion, for the basal conglomerate of the Raton formation was traced eastward and found to overlie the Vermejo. 'This conglomerate is the same as that described at locality 2 and is equally thick and massive. Only its base is included in the section.

\section{LOCALITY 4.}

In the north wall of Ute Park, about oneeighth mile southeast of locality 3 , the rocks both above and below the unconformity are well exposed and the structural relations are plainly discernible. The Pierre shale is exposed at the foot of the slope, but the top of this shale and the base of the Trinidad sandstone are not exposed. However, the upper 60 feet of the Trinidad was examined and was found to contain the characteristic fusoid, Halymenites major Lesquereux. Carbonaceous shale 10 feet thick; which obviously belongs to the Vermejo formation, occurs above this sandstone, and on it the basal conglomerate of the Raton formation rests unconformably. The massive sandstone cliffs described at locality 2 occur above the basal conglomerate, but only enough of the lower part of the Raton is included in the following section to show its relations to the underlying formation.

Section of rocks measured at locality 4, Ute Park, N. Mex. [For graphic section see Pl. v, p. 56. ]

Raton formatiòn:

Sandstone, conglomeratic, with irregular layers and lenses of pebbles consisting mainly of quart $z$ and quartzite................. $45+$ Unconformity.

Vermejo formation: Shale, drab, carbonaceous............. 10

Trinidad sandstone:

Sandstone, massive, yellowish white; contains Halymenites major Lesquereux. . ......... $\mathrm{BO}+$

Pierre shale:

Transitional zone.

Shale. Feet.

LOCALITY 5 .

In the north wall of the park, a mile northeast of Ute station, the upper part of the Trinidad sandstone, 45 feet thick, is exposed beneath beds of sandstone and shale 44 feet thick that obviously belong to the Vermejo formation. No coal was found at this locality, but the records of certain prospects made several years ago show that a 6-inch bed of coal occurs 16 feet above the top of the Trinidad sandstone, and a 12-inch bed of shaly coal 28 feet above the Trinidad. The conglomerate at the base of the Raton rests on the Vermejo unconformably. The following section was measured:

Section of rocks measured at locality 5, Ute Park, N. Mex.

[For graphic section see Pl. V, p. 56.]

$$
\text { [For graphic section see Pl. V, p. 56.] }
$$

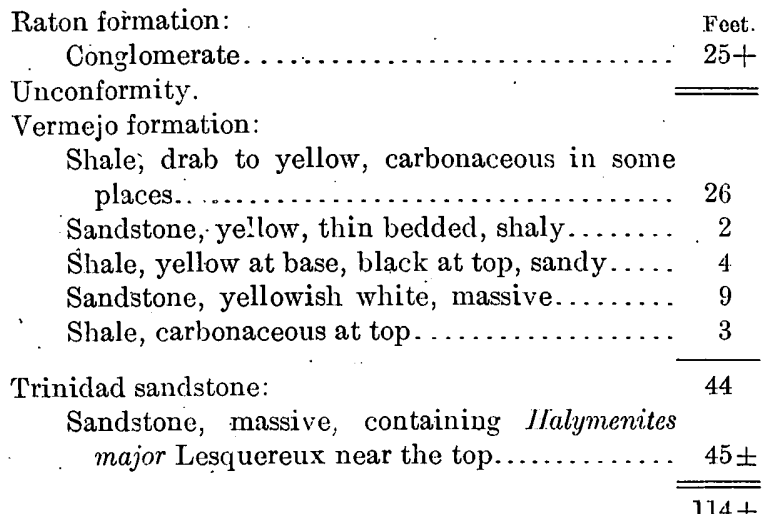

The conglomerate, which is here 44 feet above the top of the Trinidad sandstone, is only 10 feet above that sandstone a quarter of a mile to the northwest. A little farther northwest it rests on this sandstone and about a mile away it rests on the Pierre shale. In 


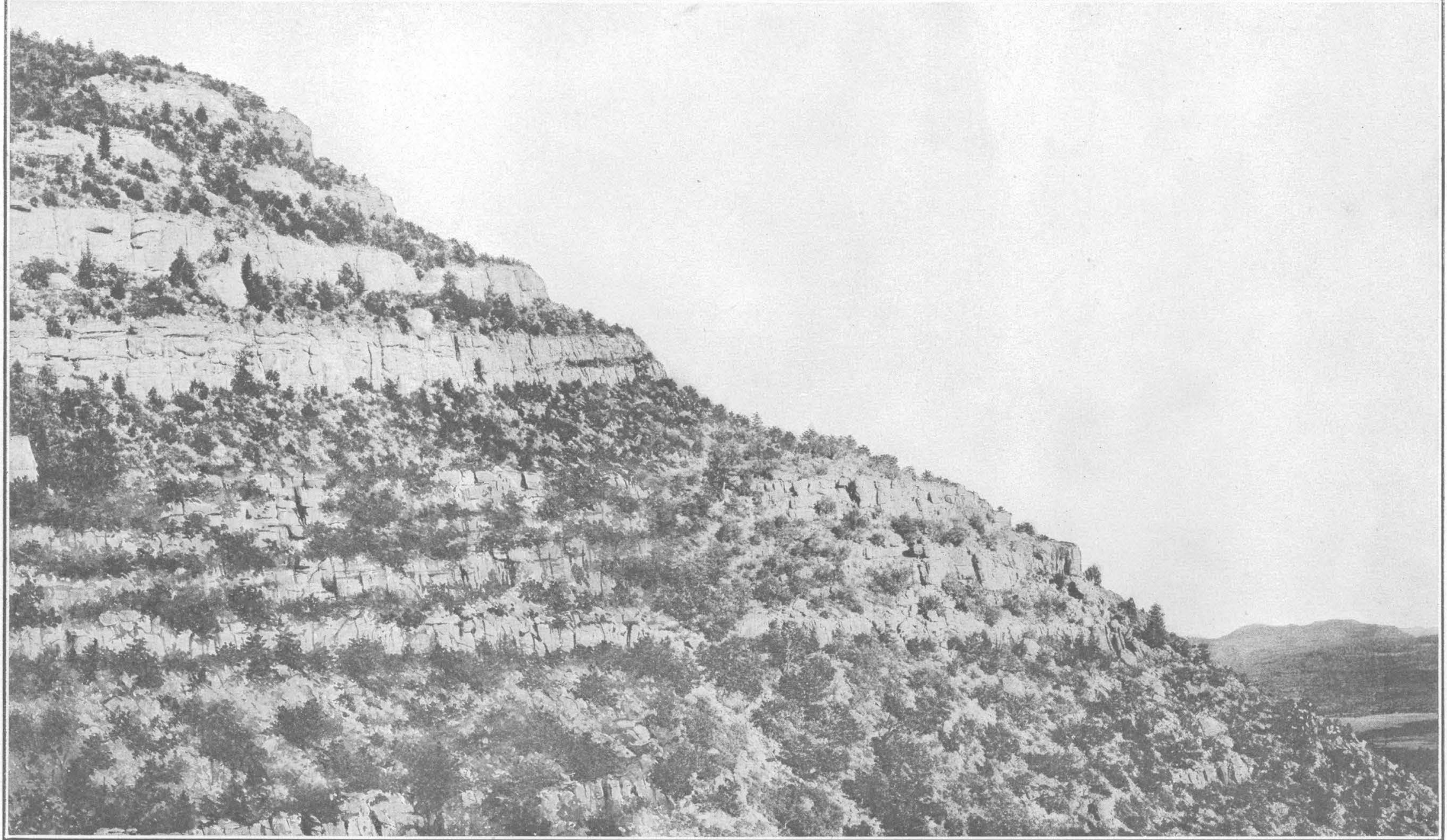

CLIFFS IN THE NORTH WALL OF CIMARRON CANYON, N. MEX.

Showing the sandstones of the lower part of the Raton formation. 
other words, within a distance of about a mile the base of the Raton formation transgresses the eroded edges of the Vermejo formation, the Trinidad sandstone, and the upper part of the Pierre shale. East of this locality the northeastward dip carries all the rocks except those of the Raton formation beneath the bed of Cimarron River, where they are covered by younger rocks for about $1 \frac{1}{2}$ miles. They reappear farther downstream.

\section{CIMARRON RIVER.}

East of Ute Park Cimarron River has eroded a deep canyon through the conl measures and, except for a short space between localities 5 and 6 , has cut downward into the Pierre shale. The canyon walls, which rise precipitously to a maximum height of -about 1,000 feet, consist principally of well-indurated cliff-forming sandstone. (See Pl. VI.) South of the Cimarron the rocks are poorly exposed, but in the north wall of the canyon they are well exposed and nearly all of the observations described were made there.

\section{CHMARRON CANYON.}

LOCALITY 6.

At the point in Cimarron Canyon east of Ute Park where the top of the Trinidad sandstone reappears from benenth the river a shale and sandstone formation 110 feet thickthe Vermejo-occurs between the top of the Trinidad sandstone and the base of the Raton formation. About half a mile farther downstream $\Omega$ section was measured in the north wall of the canyon. The Trinidad sandstone at this locality is about 100 feet thick, forms a conspicuous.cliff, and contains the characteristic fossil Halymenites major Lesquereux. Its upper part is stained dark brown or black, and a line denoting its upper limit in the section below was drawn at the horizon where the massive sandstone gives place to carbonaceous shale. The rocks above the Trinidad consist of shale and light-colored granular sandstone that obviously belong to the Vermejo formation but that show no indication of coal. On these rocks the basal conglomerate of the Raton formation rests with uneven base. Only the lower part of the Raton was measured here. The section follows:
Section of rocks measured at locality 6, Cimarron Canyon, N. $\mathrm{Mex}$.

[For graphic section see Pl. v, p. 56.]

Raton formation:

Feet. Conglomerate, resting with uneven base on . . shale $\ldots \ldots \ldots \ldots \ldots \ldots \ldots \ldots \ldots \ldots \ldots, 10 \pm \ldots$ Unconformity.

Vermejo formation:

Sandstone and shale, not con tinuously exposed.. 60 .

Shale, with layers of shaly sandstone......... 30

Sandstone, with partings of shale.......... 25 .

Shale, carbonaceous (horizon of lowest coal).. 8

Trinidad sandstore: $\quad$.

Sandstone, containing Halymenites _major Lesquereux......................... $100: t$

LOCALITY 7

$\overline{\overline{233} \pm}$

About a mile farther downstream a section was measured at locality 7 , in the north wall of the canyon, here nearly 1,000 feet high. The section includes the top of the Pierre shale, the Trinidad sandstone, the Vermejo formation, and the lower part of the Raton formation. The canyon wall is very precipitous and the greater part of it is formed by the cliffs of massive sandstone that constitute the lower part of the Raton. (See Pl. VI.) The lower part of the wall does not differ in character from that shown in figure 1 (p. 72); which illustrates the general character of the rocks farther downstream. The section follows:

Section of rocks measured at locality 7 , Cimarron Canyon, N. Mex.

[For graphic section see PIs. V (p. 56) and X (p. 108).]

Raton formation: leet

Sandstone, coarse grained, massive cliff-making. . 180

Sandstone, locally conglomeratic.............. 90

Sandstone, with partings of shale. ........... 1.03

Sandstone, locally conglomeratic.............. 196

Shale, sandy, carbonaceous, with thin seams of

coal........................... 26

Sandstone, cliff-making, conglomeratic, with siliceous pebbles 1 inch in maximum diameter. ... 34

Unconformity.

$\begin{array}{r}34 \\ 629 \\ \hline\end{array}$

Vermejo formation:

Shale, gray, sandy .................. 12

Sandstone, brown; massive, coarse grained, friable 22

Covered.............................. 10

Sandstone, gray, massive, coarse grained, soft and friable......................... 38

Shale, drab to black, carbonaceous, not continuously exposed....................... 22

Sandstone, gray, massive, and friable.......... 37

Sandstone, thin bedded.................. 13 
Vermejo formation-Continued. Feet. Shale, brown, carbonaceous................ 5

Sandstone, with partings of shale........... 5

Trinidad sandstone:

Sandstone, greenish drab near the top, weathering to dark brown; contains Halymenites major Lesquereux......................... 112

Pierre shale:

Transitional zone.

Shale, fossiliferous.

The bed of the river is about 20 feet below the top of the Pierre shale at this locality and a good exposure of it. was found in the north bank. ' It contains globular concretions of brittle limestone a few inches to 2 feet or more in diameter, and from these the following invertebrates were collected:

Pierre shells collected at locality 7, Cimarron Canyon, N. Mex.

[U. S. Geol. Survey fossil localities 6554 and 5603.]

Anomia sp.

Baculites ovatus Say.

Heteroceras sp.

Inoceramus barabini Morton.

Inoceramus sagensis Owen.

Leda sp.

Lunatia sp.

Placenticeras intercalare Meek and Hayden.

Syncyclonema sp.

The Trinidad sandstone forms a conspicuous cliff and is a little thicker at this locality than is common. The upper part of it is dark and very hard, contrasting sharply. with the overlying rocks, which are relatively soft. The Vermejo formation is about 164 feet thick, as compared with 123 feet a mile to the northwest and 10 feet or less 3 miles to the northwest. It consists of light-colored, soft, granular sandstone and shale, which is carbonaceous in some places but is not known to contain coal. This apparent absence may, however, be due to poor exposures, for a little more than a mile to the southeast the formation contains 3 beds of coal.

The basal. conglomerate of the Raton formation rests with uneven base on the Vermejo. It consists of a massive, coarse-grained, quartzose sandstone, in which are included irregular masses of pebbles up to an inch or more in diameter composed mainly of siliceous rock. It has the aspect and general character of the conglomerate in Ute Park but is not so thick. The higher conglomerates correspond in a general way to the second and third conglomerates of the section measured in the park at locality 2. (See p. 67:)

About 50 feet above the base of the Raton formation thin beds of coal were found in a sandy shale. This occurrence is significant, for farther west this shaly zone is not known to be coal bearing. However, it thickens to the east and north. Thin beds of coal were observed in it in many places, and these become more and more prominent until in the northeastern part of the Raton field the largest, or Sugarite, coal bed attains considerable economic importance.

\section{IOCALITY 8.}

In the north wall of Cimarron Canyon, about 6 miles northwest of Cimarron, at locality 8, $1 \frac{1}{2}$ miles southeast of locality 7 ; the rocks of the Vermejo formation are well exposed and offer one of the best sections of the formation in the southern part of the Raton coal field. Several hundred feet of Pierre shale is exposed in the lower part of the canyon wall. A zone of fossiliferous limestone concretions, described elsewhere (p. 73) as occurring near the top of this shale, was noted, but no fossils were collected from it at this locality. The Trinidad sandstone occurs in characteristic development and contains great numbers of very perfectly preserved Halymenites major Lesquereux. The section follows:

Section of rocks measured at locality 8 , Cimarron Canyon, N. Mex.

[For graphic section see Pl. V, p. 56.]

Raton formation:

Sandstone, massive, quartzose, with sparkling grains and contorted laminae; rests with uneven base on shale and sandstone; contains no pebbles but is continuous laterally with conglomerate................ 20+

Unconformity.

Vermejo formation:

Sandstone, friable; contains fossil plants.... $10 \quad 100$

Shale, drab to black................. $22^{-} 0$

Sandstone, soft, friable ................. $5 \quad 50$

Shale............................ 50

Sandstone, soft, friable.................. 30

Shale, with thin sandstone at base........ $20 \quad 0$ Coal ........................ 6

Coal, with seams of shale............ $\quad 1 \quad 8$

Coal........................... 14

Shale, black to drab................ $3 \quad 0$

Sandstone, yellow, shaly................. $2 \quad 0$

Shale, black, carbonaceous............... 5 5 0

Sandstone, white, massive, friable......... $\quad 28 \quad 0$

Sandstone and shale, alternating layers..... $14 \quad 0$ 


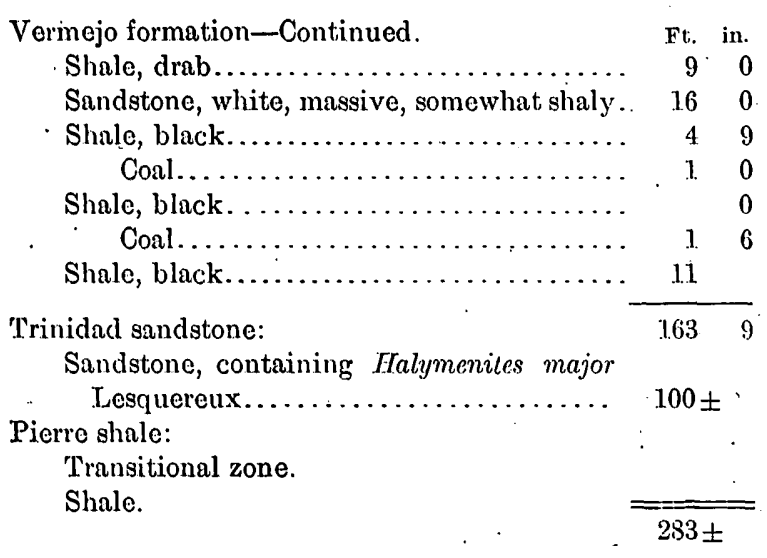

The section was measured in a small gulch where all of the surface débris had been washed away, leaving the native rocks perfectly exposed. The Vermejo is about 163 feet thick and contains two beds of coal, both of which have been opened by prospectors. A short distance farther west the lower coal bed is considerably thicker than at this locality, the lower bench measuring 3 feet 6 inches and the upper one 5 inches. Farther southeast, between localities 8 and 9 , the lowest bed has been prospected in several places and found to vary but little in character. The maximum observed thickness is 3 feet 9 inches. A few poorly preserved fossil plants were found in the highest sandstone of the Vermejo formation. They appeared to belong to the same species as those found in other places in the Vermejo, but none was collected.

On the fossiliferous sandstone, a massive quartzose sandstone rests with uneven base. Lithologically it is identical with the conglomeratic sandstone at the base of the Raton formation in other places, but no pebbles were found in it at this locality. However, it was traced laterally for a short distance and there found to be conglomeratic. The rocks higher in the section consist mainly of cliff-making sandstones, but they were not here examined in detail.

\section{TURKEY CANYON. LOCALITY 9.}

About 2 miles southeast of locality 8 there is a small break in the north wall of Cimarron Canyon known as Turkey Canyon, through which a road leads to the highlands north of the Cimarron. In the east wall of this canyon' close to the wagon road the Vermejo and closely associated formations are well exposed, and the following section was measured:

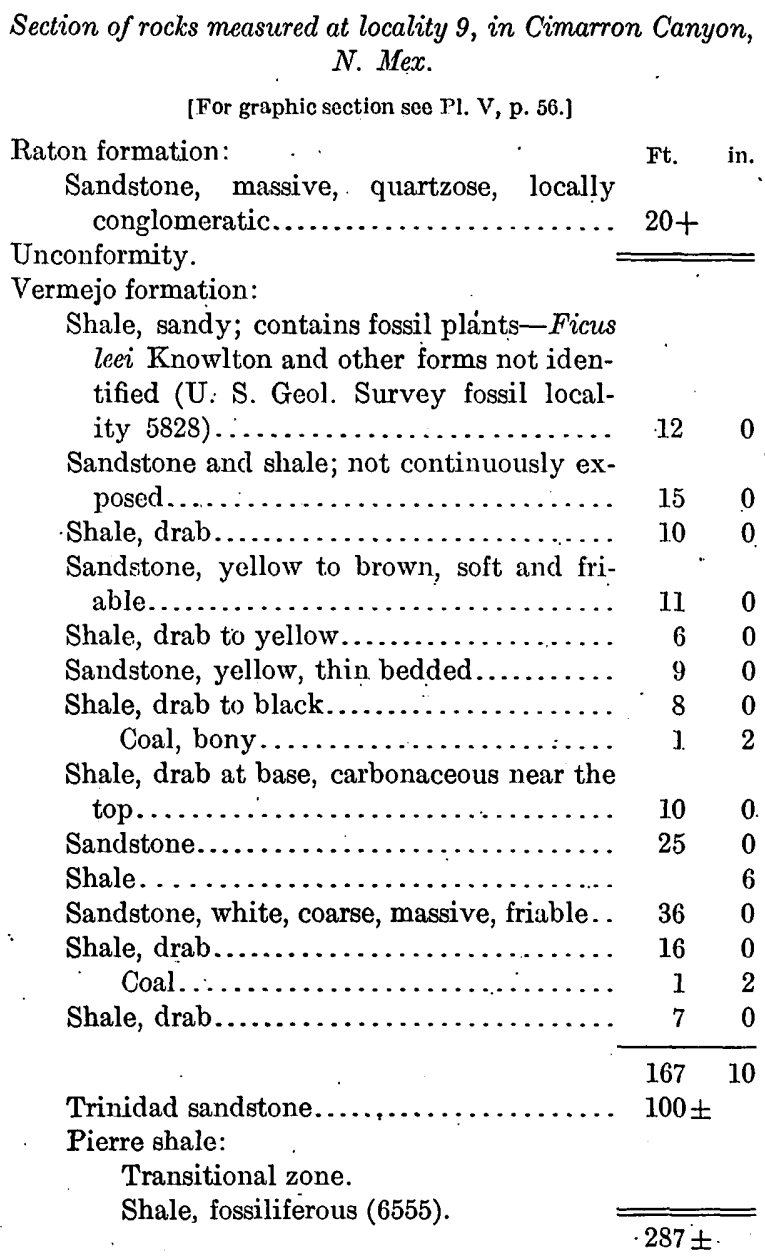

The upper part of the Pierre shale, 200 feet or more in thickness, is well exposed in the east wall of Turkey Canyon and is very fossiliferous. Most of the shells are embedded in concretions of limestone, but some of them occur separately in the shale. Large ammonites are especially abundant, and some of them attain a diameter of more than 2 feet. One which was dug out entire measured 26 inches across and was by no means the largest found. Most of the ammonites occur in the centers of limestone concretions and it is difficult to extract the larger ones unbroken. The following species of invertebrates were obtained at this locality 100 feet or more below the top of the Pierre shale:

Pierre fossils collected in Turkey Canyon, northwest of Cimarron, N. Mex.

[U. S. Geol. Survey fossil locality 6555. ]

Anomia sp.

Avicula sp.

Baculites compressus Say.

Crassatellites cimarronensis White. 
Inoceramus oblongus Meek.

Inoceramus sagensis Owen.

Lima sp.

Liopistha (Cymella) undata Meek and Hayden.

Lucina sp.

Nemodon sp.

Odontobasis? sp.

Ostrea sp.

Placenticeras intercalare Meek and Hayden var. Placenticeras whitfieldi Hyatt?

Pyrifusus? sp.

Scaphites nodosus Owen.

The Trinidad sandstone is typically developed at this locality but was not examined in detail. Its thickness was estimated. The Vermejo formation has practically the same thickness here as at localities 7 and 8. Apparently this formation thins most rapidly from southwest to northeast: The localities described in Cimarron Canyon are in a line nearly

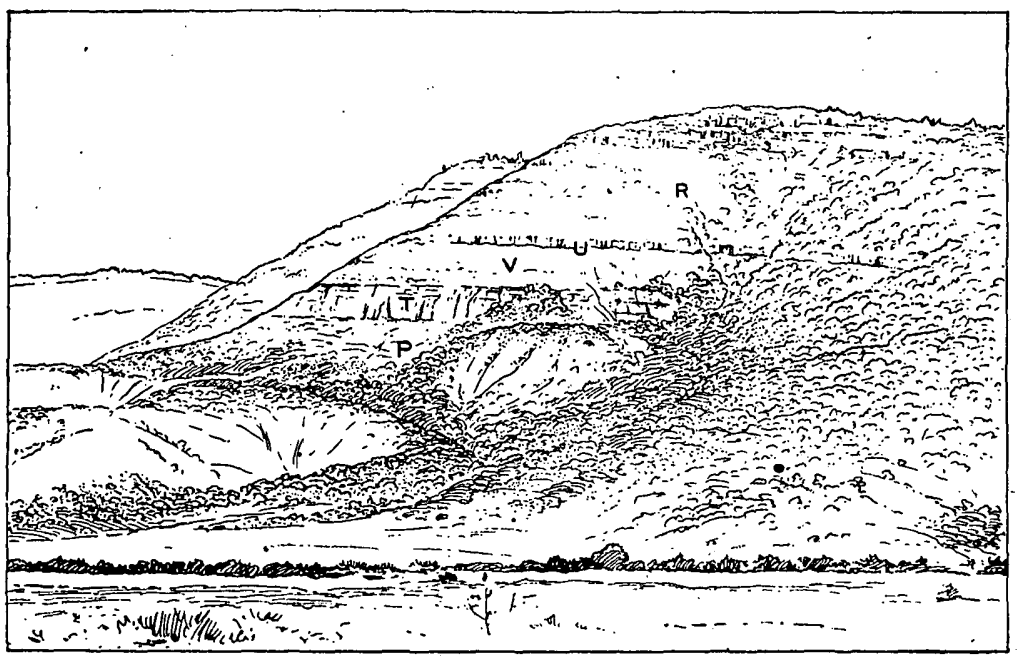

FIGURE 1.-Pierre shale and younger formations in Cimarron Canyon; N. Mex. P, Pierre shale $\mathrm{T}$, Trinidad sandstone; $\mathrm{V}$, Vermejo formation; $\mathrm{U}$, unconformity between the Vermejo and Raton formations; R, Raton formation.

at right angles to this direction, and probably for this reason the formation along this river does not change in thickness so rapidly as it would if the line of outcrop trended in some other direction.

The rocks of the Vermejo consist of lightcolored granular sandstone and shale, in which two beds of coal are found at practically the horizons of the two coals described at locality 8. The higher coal seems to be of relatively little importance near this locality. Although 14 inches thick where the section was measured it is bony, and about one-fourth mile farther south it is only 8 inches thick. The lower bed also seems to be irregular in thickness near this locality, measuring only a few inches where the outcrop crosses Turkey Canyon. About 2 miles farther southeast, however, between localities 9 and 10, it has been opened in nine places; and the coal, as reported by. Orestes St. John, is relatively regular in character. and reaches a maximum thickness of a little more than 4 feet. In some places between these two localities igneous rock has been intruded in or near the bed and has: coked the coal.

A few fossil plants belonging to the Vermejo flora were found in the sandstone and sandy shale. near the top of the formation, as noted in the section.

At this locality a sandstone about 62 feet thick lying above the coal-bearing shale at the base of the Vermejo resembles the Trinidad sandstone much more closely than it resembles the sandstone at higher horizons, although it is softer than the Trinidad and does not stand as a cliff in the sides of the canyon. A sandstone similarly located in the section was noted in several places east and north of this locality, and, but for the fact that coal occurs below it, would have been included with the Trinidad. It is the' southward continuation of the upper part of the Trinidad sandstone as developed farther northeast (see Pl. V, p. 56), and the reasons for including it in the Vermejo at this and neighboring localities are stated on page 49 . Doubtless some of the sandstones of the lower part of the Vermejo farther west are to be correlated with this sandstone, but the correlation can not now be made with confidence.

\section{CIMARRON.}

LOCALITY 10.

East of locality 9 the rocks are especially well exposed in the north wall of the canyon. (See fig. 1.) Great barren slopes are formed on the-Pierre shale, and the Trinidad sandstone stands out as a conspicuous white cliff high in the side of the canyon. The outcrop of the Vermejo is characterized here, as elsewhere, by a relatively smooth slope, above which the basal conglomerate of the Raton formation appears 
in a low but well-marked cliff. The following section was measured in the side of the canyon:

Section of rocks measured near Cimarron City, N. Mex., at locality 10.

[For graphic soction seo Pl. V, p. 56.]

Raton formation:

Sandstone, yellow, massive, cliff making, shale partings near top...................

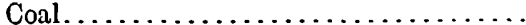

Sandstone, yellow, thin bedded............

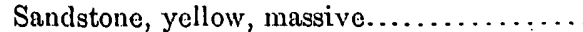

Shale, yellow, sandy Coal.....

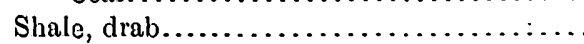

Sandstone, yellow, fine grained, massive....

Sandistone, yellowish white, massive, locally conglomeratic......................

Sandstone, yellow, thin bedded and shaly at base.............................

Sandstone, yellowish white, conglomeratic, pebbles up to $\frac{1}{2}$ inch in diameter.......... Coal........................... 1

Shale, drab to yellow, sandy ............ 10

Sandstone, yellowish white, massive........

Shale, drab......................... Coal

Shale, drab to black....................

Sandstone, yellow, fine grained, shaly, thin bedded..............................

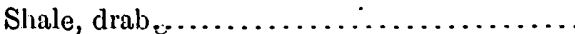

Sandstone, yellowish white, massive, fine grained............................

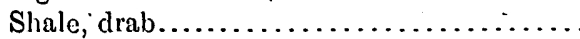

Sandstone, white, massive.................

Shale, drab.........................

Sandstone, yellow, fine grained, massive...

Shale, drab in color......................

Conglomerate, white, coarse grained, quartzose, ground mass, with thick beds of siliceous pebbles up to 2 inches in diameter; base irregular.

Unconformity.

Vermejo formation:

Shale, gray to yellow, sandy $. . . \ldots \ldots \ldots . .$.

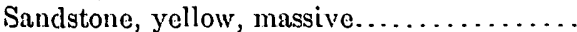

Shale, gray to yellow, sandy ...............

Coal, bony............................

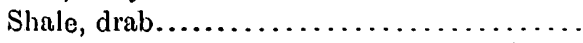
Conl.

Shale with partings of shaly sandstone......

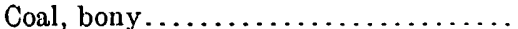

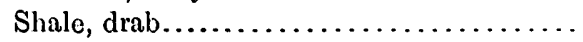

Sandstone, white, friable, massive........

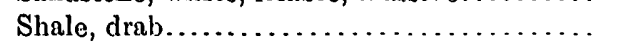

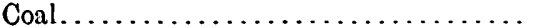

Shale............................

Coal ............................

Shale, drab at base, carbonaceous at top....
Trinidad sandstone:

Ft. in.

Sandstone containing Halymenites major Lesquereux.......................... $83 \quad 0$

Pierre shale:
$\quad$ Sandstone and shale, transitional beds...... $125 \quad 0$

Shale, fossiliferous $(6556) \ldots \ldots \ldots \ldots \ldots \ldots \ldots .350 \quad 0$

\begin{tabular}{ll}
475 & 0 \\
\hline \hline $971 \quad 7$
\end{tabular}

The zone of fossiliferous limestone concretions lies about 200 feet below the top of the Pierre shale and has yielded a large collection of fossils. Another collection was made at about the same horizon half a mile farther east. Ammonites are very abundant. Several bones and teeth of a mososaur were found near the base of the shale slope, and the largest Inoceramus shells come from the same horizon. The Nautilus and some of the smaller ammonites were found near the top of the shale. The invertebrates from these two localities are as follows:

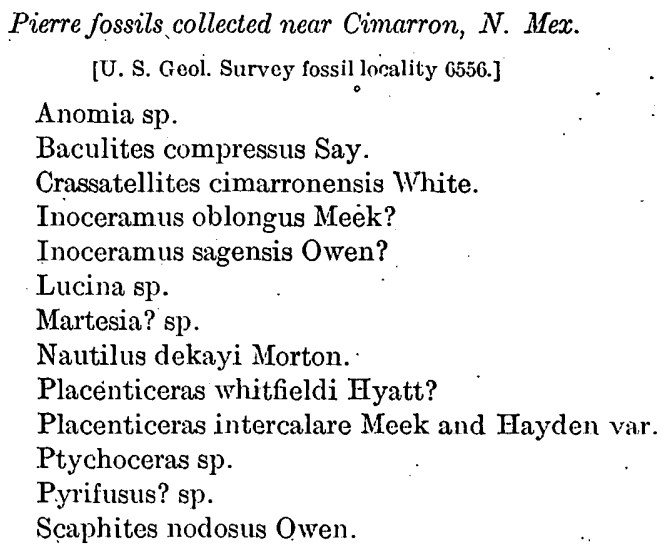

The alternating sandstones and shales of the transitional zone at the top of the Pierre are thicker at this locality than is common. The messive part of the Trinidad sandstone is a little thinner. It contains the usucl Halymenites major Lesquereux, and half a mile east of locality 10 it yielded, in addition to Halymenites, two shells, Mactra warrenana Meek and Hayden and an undescribed species of Inoceramus, which were found in slide rock at the base of the Trinidad sandstone (U. S. Geol. Survey fossil locality 6557) in such a position that they must have come from this sandstone.

The Vermejo formation contains at its base the same coal-bearing shale that was found at the last two localities described, and the coal bed attains considerable prominence. This 
coal has been prospected in many places between localities 10 and 11 , and the records show that it attains considerable thicknesses in some places, the greatest reported thickness being nearly 5 feet. Above the coal-bearing shale is the sandstone described (p. 49) as probably equivalent to the upper part of the Trinidad sandstone as developed farther north.

At this locality, near the horizon of the higher coal, as described in the sections, there are three thin beds of coal. Below this horiżon the section corresponds closely with that measured at locality 9, except that it seems to lack the upper 60 feet of the Vermejo; This difference in thickness is in agreement with the evidence of erosion observed at the top of the formation. The upper surface of the Vermejo is irregular, with rather sharp depressions 4 feet or more in depth, and the Vermejo beds are locally tilted to a maximum of about $5^{\circ}$ and truncated, and their eroded edges are traversed by the base of the Raton formation.

The basal conglomerate of the Raton is only 10 feet thick at this locality, but it is so very hard and resistant that it not only forms a prominent cliff but, where it lies above shale or soft sandstone, juts out as an overhanging cliff. The rocks above the basal conglomerate consist largely of shale, but another conglomerate lies near the top of the section and four thin beds of coal were found, some of which may be equivalent to the coals found in similar positions farther north; these, however, had no apparent bearing on the principal problem under investigation and received little attention.

About 3 miles west of Cimarron invertebrates were collected at a horizon in the Pierre shale slightly lower than that of the collections from Cimarron Canyon. They occur near the foot of a barren slope on the south side of the mesa west of Cimarron 400 to 500 feet below the base of the Trinidad sandstone. Bones and teeth of a mososaur were also found at this locality.

Invertebrates collected 400 to 500 feet below the top of the Pierre shale 8 miles west of Cimarron, $N$. Mex. [U. S. Geol. Survey fossil locality 6561.]

Anomia sp.

Baculites compressus Say.

Crassatellites cimarronensis White.

Fasciolaria (Piestochilus) sp.
Inoceramus oblongus Meek.

Inoceramus sagensis Meek.

Inoceramus vanuxemi Meek and Hayden?

Lucina occidentalis (Morton)?

Nautilus dekayi Morton.

Placenticeras whitfieldi Hyatt?

Ptychoceras sp.

CIMARRON TO VAN BREMMER CANYON.

Along the southeastern margin of the Raton coal field the coal beds outcrop in precipitous cliffs that overlook relatively level plains formed on the Pierre shale. The coal measures are deeply dissected, and the rocks, which lie nearly horizontal, are well exposed in many places. The sections described were all measured by Locke level in the best exposed portions of the escarpment.

\section{ponil Canyon. \\ LOCALITY 11.}

The outcrops of the various formations were observed around the eastern end of the mesa northwest of Cimarron, and examined in several places in Ponil Canyon. A section of the Vermejo formation was measured at locality 11 in the east wall of Ponil Canyon, where the Trinidad sandstone passes beneath the level of the river, 3 miles northeast of the place where the last section was measured. (The line representing the top of the Trinidad would cross the river at this locality, but the line used on the map (Pl. I, in pocket) to mark the boundary of the coal field is the line of outcrop of the upper coal bed. The rocks here lie nearly horizontal and the few feet intervening between the top of the Trinidad and the coal is sufficient to throw the boundary line considerably farther upstream than would the line marking the top of the Trinidad.) The section follows:

Section of rocks measured at locality 11, Ponil Canyon, N. Mex.

[ For graphic section see Pl. V, p. 56.]

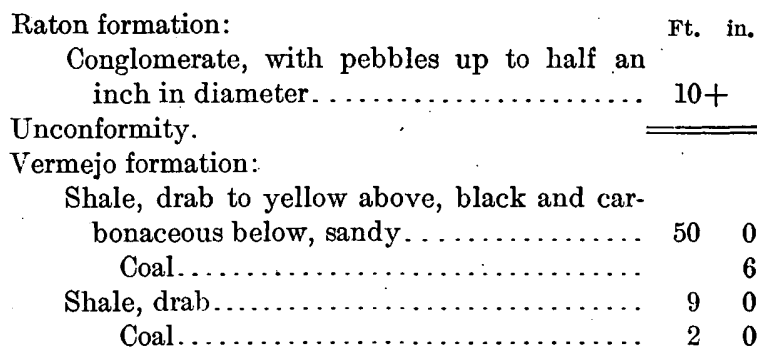




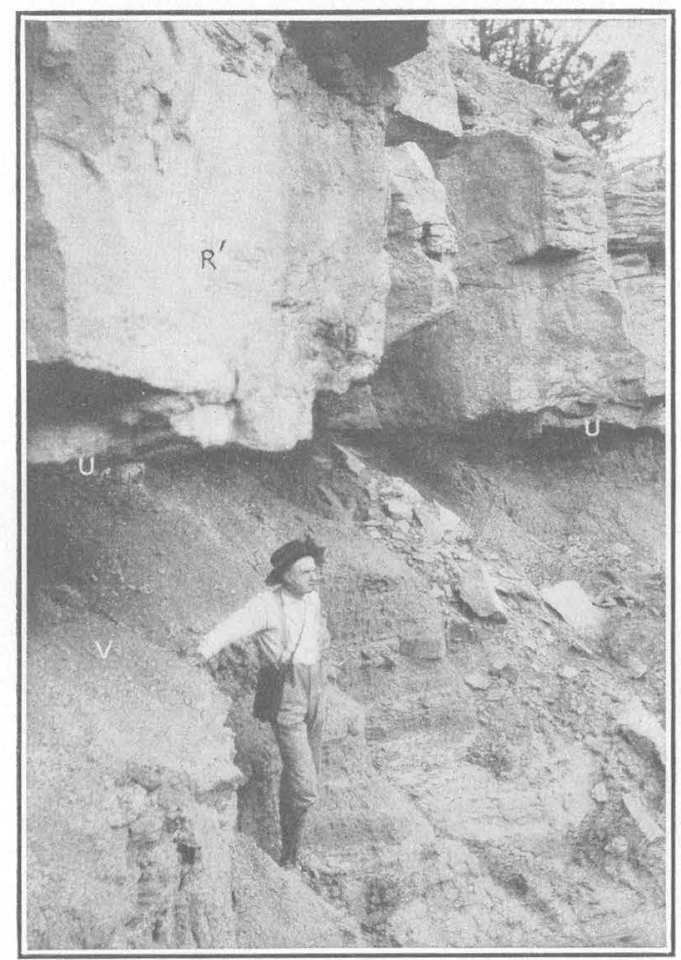

A. UNCONFORMITY BETWEEN THE VERMEJO AND RATON FORMATIONS, PONIL CANYON, N. MEX.

$V$, Vermejo formation; U, unconformity between the Vermejo and Raton formations; $R^{\prime}$, basal conglomerate of the Raton formation.

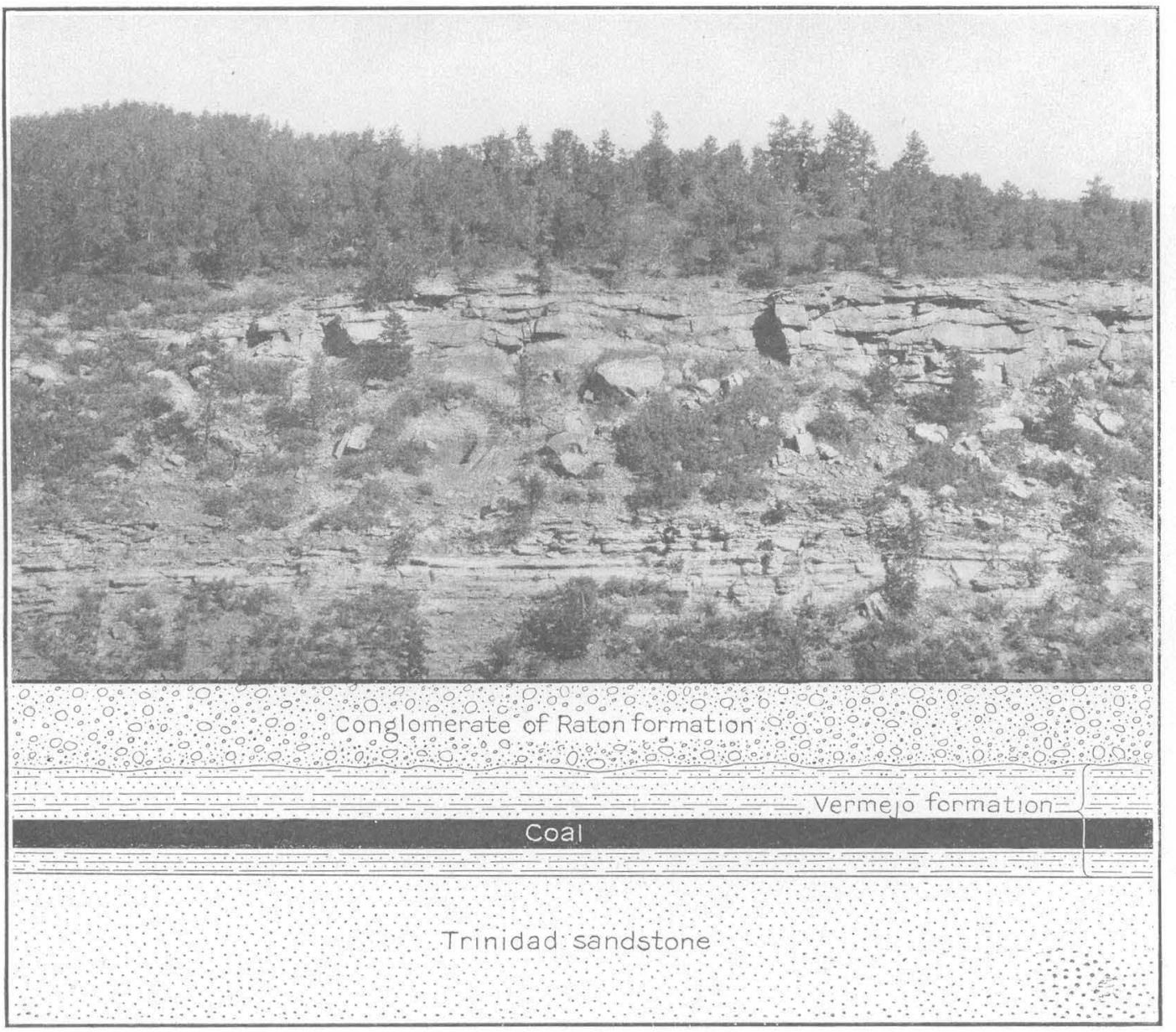

B. NORTH WALL OF CANYON AT KOEHLER, N. MEX.

Showing the relation of the Vermejo formation to the Trinidad sandstone and Raton formation. 


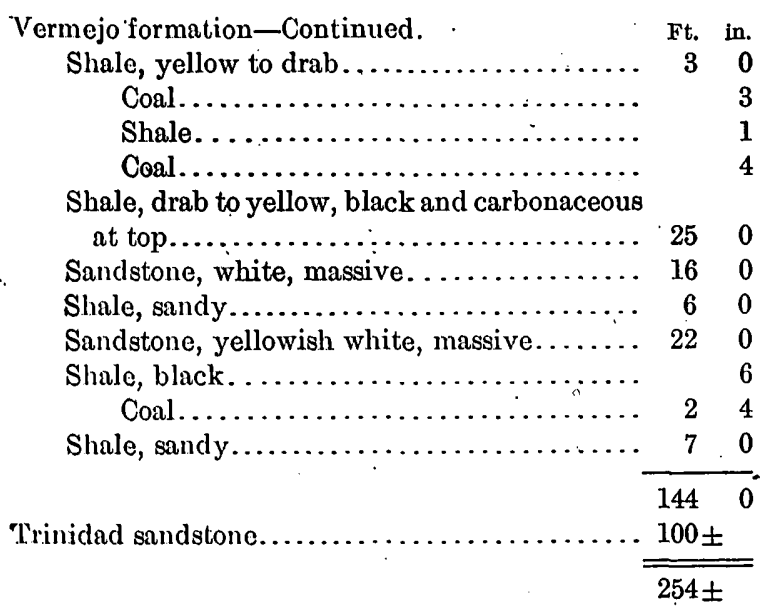

The two principal coal beds of this section are well developed, and the intervening sandstone previously described as being probably equivalent to the upper part of the Trinidad sandstone as developed farther north is here almost indistinguishable from the undoubted Trinidad underlying it. Good measurements were obtained of all of the coal beds. 'In the lowest, 2 feet 4 inches thick, the coal is of fairly good quality where its outcrop crosses the Ponil. Near the mouth of Chase Creek it is 2 feet 11 inches thick; and between Chase and Templeton Canyon it is 2 to 3 feet thick but is more or less slaty.

Above the higher group of coals, the rocks, about 50 feet thick, consist principally of shale and soft shaly sandstone and contrast rather sharply with the rocks at the top of the Vermejo formation a quarter of a mile farther west. These shales are overlain unconformably by the massive conglomeratic sandstone that constitutes the base of the Raton formation.

About a mile west of locality 11 , at the mouth of a small side gulch, the upper part of the Vermejo formation is exposed even more perfectly than it is in the east wall of Ponil Canyon, but the base is covered. The upper part is much more sandy than it is at locality 11 , and in some places the sandstone is full of fossil plants. Ficus leei Knowlton, Salix sp. b, Sequoia obovata Knowlton, Sequoia reichenbachi (Geinitz) Heer, and Sabal? ungeri (Lesquereux) Knowlton were collected a few feet below the top of the Vermejo formation (U. S. Geol. Survey fossil locality 5829). This formation seems to be also fossiliferous in Dean
Canyon, which was not entered by the writer, but which furnished some of the plants collected by St. John and included in the Vermejo flora.

The basal conglomerate of the Raton formation is about 15 feet thick at this locality and is massive and very resistant. It rests with obvious unconformity on the soft beds of the Vermejo, and these, being so much softer than the conglomerate, have weathered from beneath it and left it as an overhanging cliff. (See Pl. VII, A.) The higher rocks of the Raton formation were not examined near locality 11 , but at the forks of Ponil Creek, about 2 miles farther northwest, they consist mainly of coarsegrained massive sandstones that form cliffs 300 to 400 feet high. These rocks were searched for fossils, but only imperfect impressions of leaves were found.

\section{LOCALITY 12.}

The next section toward the east examined in detail was in the south wall of the easternmost point of the mesa north of Ponil Creek, at locality 12, nearly 3 miles southeast of locality 11 . The side of the mesa is very precipitous, and several hundred feet of the top of the Pierre shale is exposed in the lower part of the wall. The shale is fossiliferous, but no fossils were collected. The Trinidad sandstone is characteristically developed and appears as a prominent cliff in the side of the mesa. No fossils were collected from it at this locality, but in the north wall of Ponil Canyon, 2 miles farther west (U. S. Geol. Survey fossil locality 6558), Halymenites major Lesquereux, Anomia? sp., and Tellina scitula Meek and Hayden were collected from it.

The Vermejo formation is 110 feet thick at this locality as compared with 144 feet at locality 11 , the difference seeming to be due to the absence of certain rocks at the top of the formation at the latter locality. From the Trinidad sandstone up to the higher coal the two sections are very much alike. The lowest coal bed is about 2 feet 4 inches thick, and the coal appears to be of fairly good quality. Half a mile farther east this bed is 2 feet 8 inches thick. Only one higher bed of coal about 6 inches thick was fourid, but other beds corresponding to those found about this horizon in section 11 
probably occur in the poorly exposed rocks above the 6 -inch bed. The-section follows:

Section of rocks measured at locality No. 12, mouth of -Ponil Canyon, N. Mex.

[For graphic section see Pl. v, p. 56.]

Raton formation: Ft. in.

Sandstone, yellow, massive, cliff making... 175 r 0

Sandstone and shale, not continuously exposed....................... 0

Conglomerate, pebbles up to half an inch in diameter....................... $10 \quad 0$

Unconformity.

Vermejo formation:

Covered, but chiefly shale............. $28 \quad 0$

Coal ............................

Shale, drab....................... $30 \quad 0$

Sandstone, white, massive; not continu-

ously exposed................... $33 \quad 0$

Covered............................ 110

Coal......................... 2. 4

Shale, drab to yellow, sandy............ $6 \quad 6$

Trinidad sandstone: $110 \quad 10 \pm$

Sandstone, containing Halymenites major Lesquereux....................... 100土

Pierre shale:

Transitional zone.

Shale, fossiliferous.

$624 \pm$

The conglomerate at the base of the Raton formation is much less conspicuous at this locality than it is farther west. It contains siliceous pebbles and rests with uneven base on the softer rocks of the Vermejo formation. The cliffs rise about 400 feet above the conglomerate and are composed mainly of massive sandstone, but details were not obtained of this part of the section. The coal outcrops at a horizon a little above the top of the section and a short distance back from the edge of the cliff. For this reason it was not included in the section.

\section{ENCENOSO CREEK.}

LOCALITY 13.

About a mile east of locality 12 and 2 miles south of Encenoso Canyon, in the north wall of a small recession in the cliff, a short section was measured (locality 13). The upper part of the Pierre shale is exposed and the Trinidad sandstone was found characteristically developed. It is 90 feet thick, forms a prominent cliff, and is separated as usual from the typical Pierre shale by thin-bedded sandstones and shales. No indication was found of a shale parting, such as appears near the middle of the Trinidad in sections to follow. The lower coal of the Vermejo formation; which is a bed of considerable thickness in Cimarron and Ponil canyons, seems to thin toward the north and at this locality is only a few inches thick and is coked by an intrusion of igneous rock. However, in the point of the mesa a few hundred yards farther north a coal bed 3 feet or more in thickness was found. But whether it is the lower coal previously described or a higher one was not satisfactorily determined. The shale and shaly sandstone associated with this lowest bed of coal, both at this locality and farther to the south, are yellowish brown and have a mottled appearance different from that of any other bed in the section. This character becomes important at this locality: because it helps in correlating these beds with those of the next localities described. The 30 -foot sandstone above this coal bed is more prominent here than it isfarther to the south, and it contained many impressions of Halymenites major Lesquereux. These fossils throughout the Raton Mesa region are characteristic of the Trinidad sandstone, and their presence in the sandstone above the lower coal at this locality is one of the reasons for correlating it with the upper part of the Trinidad farther north. The upper coal bed of the Vermejo formation found at the several localities farther south is well developed here.

The base of the Raton formation is readily determined because of the conglomeratic sandstone that here rests unconformably on the Vermejo. A section of the Vermejo was measured here on the rocks above it. The section follows:

Section of rocks measured at locality 19,2 miles south of Encenoso Creek, N. Mex.

[For graphic section see Pl: V, p. 46.]

Raton formation:

Ft. in. Conglomerate, with siliceous pebbles up to one-half inch in diameter.............. $20+$

Unconformity.

Vermejo formation:

Shale, drab....................... $20 \quad 0$

Coal, bony.................... 12

Shale, drab at base, carbonaceous and black

at top.......................... $6 \quad 0$

Shale, drab; not continuously exposed ..... $35 \quad 0$

Sandstone, light-colored, massive, similar in character to the Trinidad sandstone; contains many impressions of Halymenites major Leśquereux.................... 30 
Vermejo formation-Continued.

Shale, black.

Coke, with columnar structure.............

Sill of igneous intrisive rock.............

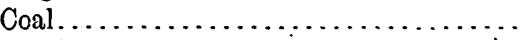

Shale, drab to black, mottled.............

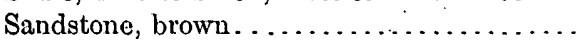

Shale, brown to yellow, sandy, mottled...

Trinidad sandstone:

Sandstone, containing Halymenites major l.esquereux.........................

Pierre shale:

Transitional \%one.

Shale.

It is a matter of considerable importance in correlating the sections in this region that the various beds at locality 13 should be traced continuously northward through Encenoso and Cerrososo canyons, but unfortunately this could not be done because of the brushy condition of the surface. In the south-side gulch tributary to Encenoso Canyon; between localities 13 and 13a, the upper part of- the Trinidad sandstone and the overlying bed of coal is exposed, and at locality 13a a considerable thickness of higher rocks is exposed. These places were not visited by the writer but were examined by Orestes St. John, and the following section is taken from his report to the Raton Coal Co.

Section of rocks measured by Orestes St. John at locality 18a, Encenoso Canyon; N. Mex.

[For graphic section see ??1. V, p. 56.]

Sandstone, massive, buff-colored.

Sandstone, rusty, nodular.

Shale, saindy.

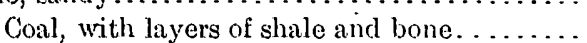

Shale, drab to black, sandy ...............

Sandstone, shaly ....................

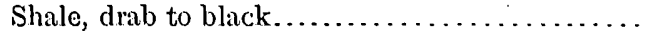

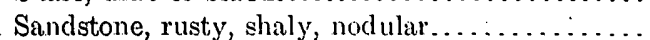

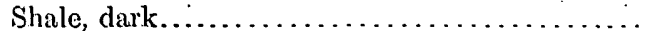

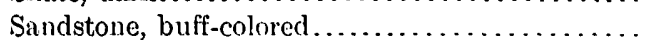

Shale, drab to black...................

Sandstone, buff-colored, soft...............

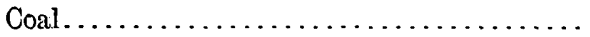

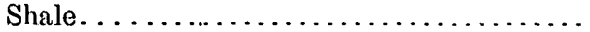

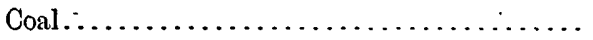

Shale. . . . . . . . . . . . . . . . . . . . . .

Sandstone [Trinidad, upper part] .............

Shale, brown ................

Sandstone ['Trinidad, lower part]. 2

1.09土

Critical comparison of this section with those previously described and inspection of the columnar sections of Plate V (p. 56) show that the lowest sandstone is obviously the Trinidad of section 13 and the lower sandstone of the Trinidad of section 14. The 5 feet of brown shale seems to correspond to the lowest coal-bearing shale of the localities farther south (which was only a few inches thick at locality 13) and to be associated with brown and yellow shale. The 30-foot or upper sandstone is obviously the same as the upper sandstone of the Trinidad at. locality 14 and as the Halymenites-bearing sandstone above the lowest coal bed in section 13. The lowest coal of section 13 a was not found at other localities near Encenoso Canyon, probably because of poor exposures and the correlation of the higher beds with those of neighboring sections is provisional and their probable relations are best indicated by the plotted sections of Plate V (p. 56).

\section{LOCALITY 14.}

In the Encenoso embayment, north of locality 13 , the rocks are covered with brush and débris in many places along the outcrop, but at locality 14 , about $1 \frac{1}{2}$ miles northeast of locality 13 and nearly 2 miles east of locality $13 \mathrm{a}$, they are well enough exposed at critical places to make possible their correlation with those described farther south. The following section was measured in the projecting point of the mesa north of Encenoso Creek.

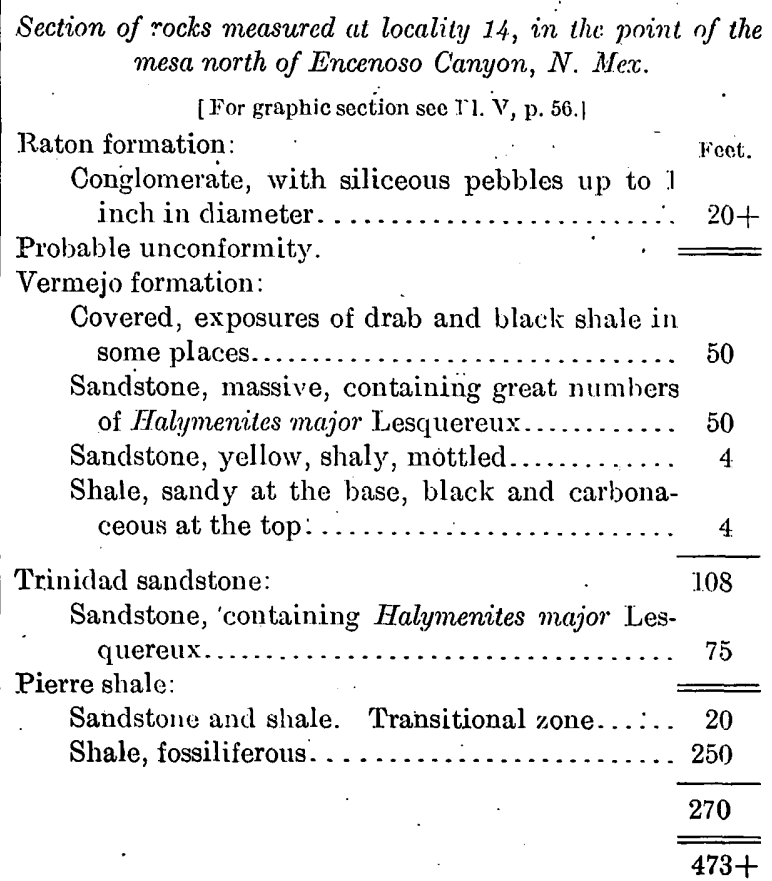


The Pierre shale occupies the lower half of the slope and contains fossils, but none were collected. The Trinidad sandstone occurs as a prominent cliff, and although it is little thinner it is otherwise unchanged from its condition farther south. Above this sandstone there is a 4 -foot bed of black carbonaceous shale, which, from a little distance, might easily be mistaken for coal. This shale is overlain by yellowish mottled sandy shale similar to that associated with the lowest coal at locality 13 .

Above this carbonaceous bed, which evidently marks the horizon of the lower coal bed of locality 13 and the lowest shale of locality 13a, there is a 50 -foot sandstone which is nearly as resistant as the underlying sandstone. It has a yellowish tint but is otherwise like the typical Trinidad sandstone of other localities and contains great numbers of Halymenites major Lesquereux, the characteristic fossil of the Trinidad throughout the Raton Mesa region. The rocks between this sandstone and the overlying conglomerate are very imperfectly exposed, and although no coal was found, the occurrence of black carbonaceous shale at the surface indicates that coal corresponding in position to the upper bed (locality 13) may be found here.

The base of the Raton formation consists of conglomeratic sandstone 20 feet or more in thickness, which forms a broad shelf and caps the mesa at this point. It is hard and resists erosion to such an extent that it stands out in the sides of the mesa as a prominent cliff.

\section{Cerrososo CANYoN}

LOCALITY 15.

Between the forks of Cerrososo Creek, about 3 miles northwest of locality 14 , the Trinidad sandstone and the basal conglomerate of the Raton formation are well exposed in precipitous cliffs. The Pierre shale forms barren slopes and is fossiliferous, but only one species, Placenticeras whitfieldi Hyatt?, was collected (U. S. Geol. Survey fossil locality 6559). These ammonites are especially abundant at this locality and occur in limestone concretions 100 feet or more below the top of the formation. The following section was measured at this locality:
Section of rocks measured at locality 15, forks of Cerrososo Canyon, N: Mex.

[For graphic section see Pl. V, p. 56.]

Raton formation:

Sandstone, conglomeratic, with pebbles up to 1 inch in diameter in lower 10 feet........ $22+$ Unconformity.

Vermejo formation and Trinidad sandstone:

Shale, not continuously exposed............ 55

Sandstone (Trinidad), containing Halymenites major Lesquereux. It is the sandstone which constitutes the top of the Trinidad farther north and which overlies the lowest coal farther to the south................. 55

Shale, dark drab to yellowish brown, and carbonaceous in some places.............. 1 Sandstone (Trinidad), containing Halymenites major Lesquereux................... 70

Pierre shale:

Sandstone and shale. Transitionäl zone.

Shale, fossiliferous (6559) 200

The Trinidad sandstone is unusually thick at this locality if all of the massive sandstone above the Pierre shale be included. It consists of two parts. separated by a thin layer of shale: The lower part is 70 feet thick and contains the fossil fucoid Halymenites major Lesquereux characteristic of the Trinidad sandstone. This sandstone is obviously the same as the 75-foot sandstone of locality 14 . Unfortunately' the rocks in the south wall of Cerrososo Canyon are not well exposed, and although there is a strong presumption that the foot of shale at the top of this sandstone corresponds to the carbonaceous shale which separates the two thick plates of sandstone at locality 14 , it can not be confidently asserted that this correlation is correct. However, the shale at both places has the same peculiar brownish-yellow color and holds the same stratigraphic position.

The higher sandstone is a little less resistant than the lower and forms a less precipitous cliff, but otherwise it does not differ notably from the lower. Apparently it is to be correlated with the sandstone which overlies the lower coal bed farther to the south. (See Pl. V, p. 56.)

The rocks intervening between this upper sandstone and the overlying conglomerate consist mainly of shale but are not continuously exposed. Probably they contain one or 
more beds of coal, but no coal was observed at the outcrop. The records of certain prospects opened several years ago indicate that coal occurs in this vicinity, probably in this 55-foot shale series. In the gulch between localities 14 and 15, about a mile south of locality 15, a 3 -foot bed of carbonaceous shale and thin seams of coal occur near the base of the shale series. In the south fork of Cerrososo Canyon, at the point where the outcrop of the Trinidad sandstone crosses the creek, there is a similar bed of carbonaceous shale and coal. In the north fork of Cerrososo Canyon this carbonaceous shale and three higher beds of coal are exposed. In the records of these prospects St. John gives the following section, measured in the north fork about half a mile north of locality 15 :

Section of rocks reported by Orestes St. John at locality 15a, Cerrososo Canyon, N. Mex.

[For graphic soction seo PI. v, p. 56.]

Sandstone.............

Ft. in.

Sandstone, buff-colore

Coal.

Shale, brown to drab.....................

Coal.............................. 6

Shale, drab, sandy $\ldots \ldots \ldots \ldots \ldots \ldots \ldots \ldots \ldots .5 \ldots \ldots$

Coal.............................. $2 \quad 5$

Shale, dark, with thin seams of coal.............. $16 \quad 6$

Sandstone, rusty..................... 30

Shale, dark, with thin seams of coal........... $14 \quad 0$

Sandstone, buff-colored ..................... $3 \pm$

Shale, brown, with streaks of coal in upper part.... $66_{0}$

Sandstone, rusty $\ldots \ldots \ldots \ldots \ldots \ldots \ldots \ldots \ldots \ldots \ldots$

Sandstone [Trinidad], gray.

Apparently the gray sandstone at the base of this section and the rusty layer at its top constitute the upper massive sandstone described at locality 15 , and the coal-bearing shales correspond in position to the shale series between the sandstone and the overlying conglomerate. The writer has not seen this section, and he is not certain that the sandstone at the top of St. John's section is the conglomerate of section 15, but it corresponds closely to it in stratigraphic position and is provisionally correlated with it. (See Pl. V, p. 56.)

The conglomeratic sandstone at the base of the Raton formation at locality 15 is hard, massive, coarse grained, and resistant. Its upper part has been eroded, but 22 feet of it still remains. Because of its superior hardness it forms a bench in the side of the mesa that is readily recognized. No observations were made near this locality on the rocks of higher horizons.

\section{LOCALITY 16.}

About a mile west of the easternmost prominent point of the mesa north of Cerrososo Creek and about 3 miles southeast of locality $15 \mathrm{a}$ and 2 miles from locality 14 the following section was measured (locality 16). The Pierre shale is covered with brush and slide rock and no observations were made on it. The base of the Trinidad is not exposed, but the formation was found to consist of two sandstones, each about 50 feet thick and each containing the fossil fucoid characteristic of the Trinidad. The two sandstones are separated by 3 feet of sandy shale, which probably represents the lowest bed of corl farther south. There is no doubt here such as existed at the localities farther south regarding what shall be included in the Trinidad. The top or upper sandstone is clearly what was originally described as Trinidad. In the sections described hereafter this upper Halymenites-bearing sandstone constitutes the Trinidad, and the Vermejo formation is described as consisting of the rocks intervening between this sandstone and the overiying conglomerate, although these rocks obviously represent only the upper part of the Vermejo as described farther to the south. The section follows:

Section of rocks measured at locality 16, north wall of Cerrososo Canyon, N. Mex.

[For graphic section see PI. v, p. 56.]

Raton formation

Conglomerate, with pebbles one-fourth inch in diameter, resting with uneven base upon shale............................ $20+$

Unconformity. $=$

Vermejo formation:

Shale, light-colored................. $5 \quad 0$

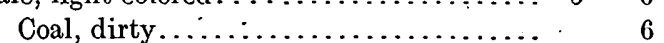

Shale, drab......................... $16 \quad 0$

Covered (coal blossom)................ $7 \quad 0$

Shale and thin-bedded sandstone......... 110 Coal........................... 1 , 0

Shale. . . . . . . . . ............ $7 \quad 0$

Sandstone, white, friable, granular....... 50 .

Shale, buff-colored to black, with thin seams of coal ............. 
Trinidad sandstone: Sandstone containing Halymenites major Lesquereux........................ 50

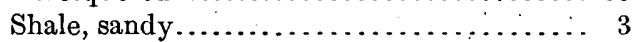

Sandstone containing Halymenites major Lesquereux.

$\frac{\frac{.250 \pm}{103 \pm}}{186 \pm}$

The Vermejo formation, about 63 feet thick, is coal bearing at this locality, and the coal beds correspond in position with those of other localities on either side. The coal beds have been prospected in a branch of Cerrososo Canyon west of locality 16 . At the head of this branch, about a mile northwest of locality 16 , St. John reports $1 \frac{1}{2}$ feet of coal about 4 feet above the basal (Trinidad) sandstone, but in a section which he measured a few hundred feet farther east he found no coal at this horizon. His section of the lower part of the Vermejo formation follows:

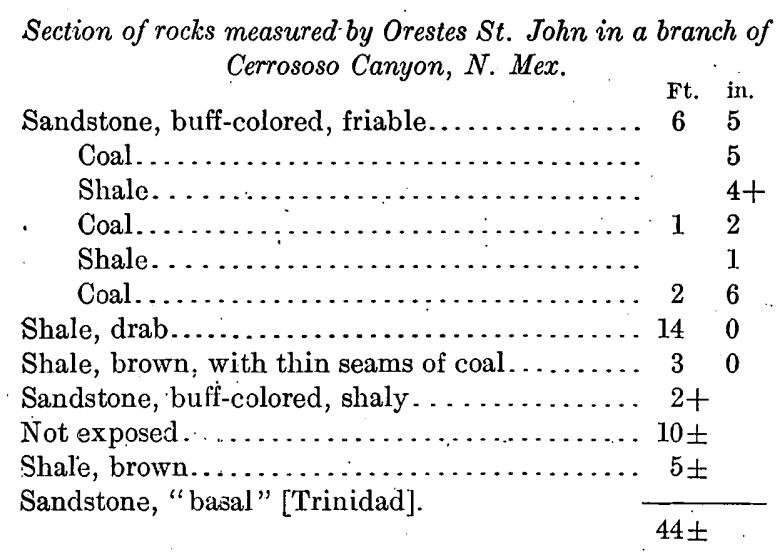

In the gulch halfway between this locality and locality $16 \mathrm{St}$. John reports the occurrence of only thin seams of coal at the lowest coal horizon and no vestige of the higher coal; but at locality 16 , only half a mile farther southeast, two beds of coal lie above the thin seams of the lowest horizon. It is not known whether the absence of coal in certain places is due to nondeposition or to post-Vermejo erosion or is only apparent, being so reported through some misinterpretation of horizons. More detailed observations are necessary in this vicinity before the various sections can be definitely correlated.

\section{VAN BREMMER CREEK.}

LOCALITY 17.

South of Van Bremmer Creek, about a mile east of locality 16 , the rocks are well exposed

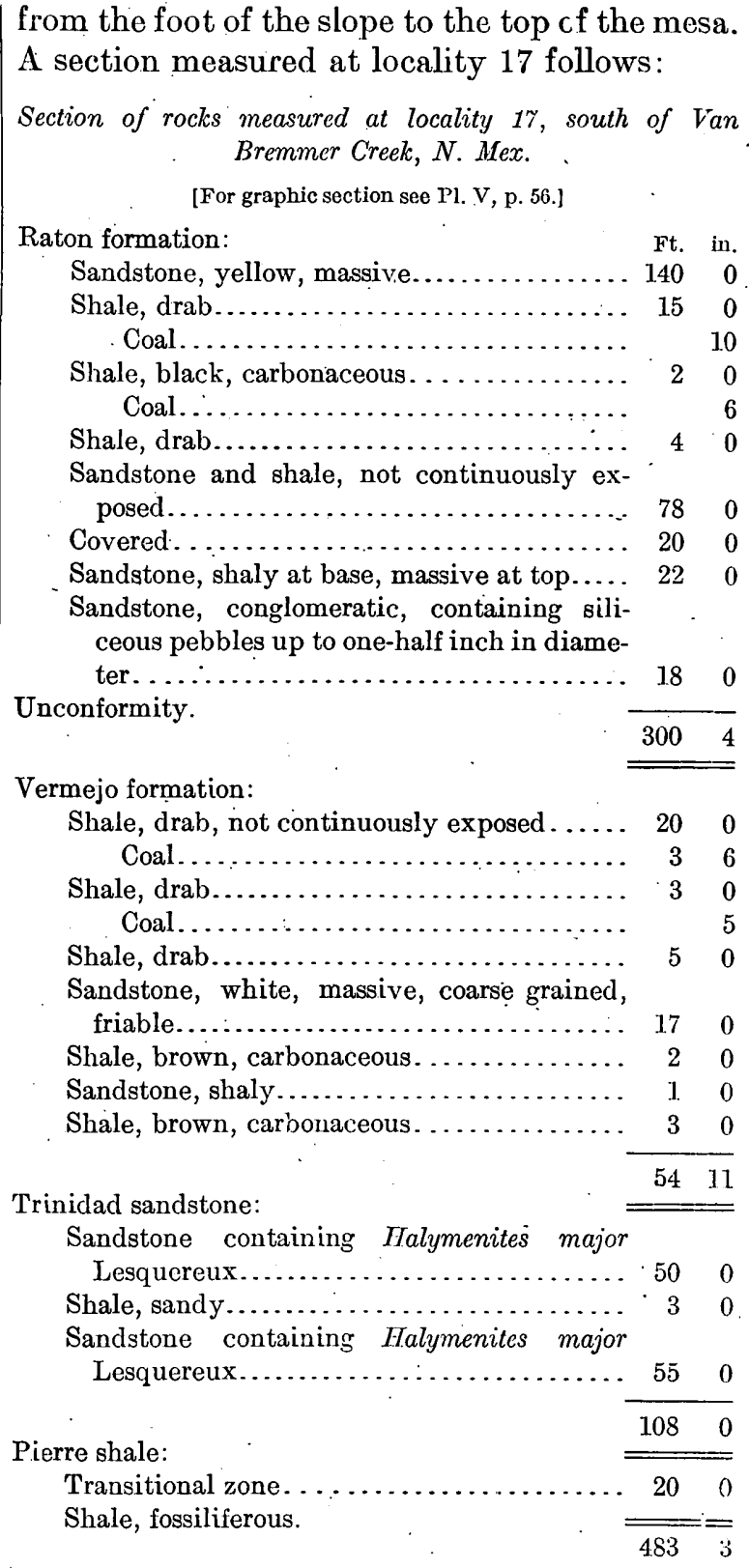

The Pierre shale is characteristically exposed and contains fossiliferous limestone concretions 100 to 200 feet below the top. From one of these concretions Anomia sp., Anisomyon? sp., Inoceramus sagensis Owen, and Placenticeras sp. were obtained (U. S. Geol. Survey fossil locality 6562). The Trinidad here consists of two sandstones separated by 3 feet of sandy shale (see locality 16); both contain the characteristic fucoids.

The Vermejo formation is thinner here than it is at locality 16 , and the 6 -inch bed of coal near the top of that section is not represented. The horizon of the lowest coal is marked by 
the presence of carbonaceous shale, and a thick bed of coal occurs near the middle of the formation.

The lowest stratum of the Raton formation. consists of a conglomeratic sandstone that rests with uneven base on the shale of the Vermejo. The rocks above this basal conglomerate consist of shale and soft shaly sandstone, which contrin a bed of coal at about the same horizon as the one at locality 10. (See p. 72.). Also, coal occurs at about the same horizon in several of the scctions measured north of this locality. The edge of the mesa is formed here by a massive sandstone 140 feet thick-one of the group of sandstones that form conspicuous cliffs all along the eastern margin of the Raton coal field from Cimarron to Raton.

The Vermejo beds were traced north of locality 17 , but for about 3 miles no good exposure of them was found. Near the point where the line of outcrop of the lowest conl bed crosses Hackberry Canyon a bed of coal, reported to be 5 feet thick, with a slaty band near the middle, has been opened. The base of the Vermejo formation is somewhat in doubt at this point, but it is probable that this coal bed corresponds to that occurring about the middle of the Vermejo at locality 17.

\section{IOCALITY 18.}

In the north wall of Van Bremmer Canyon at locality 18 , about 2 miles north of locality 17 , the rocks from the upper part of the Pierre shale to a point above the base of the Raton formation are well exposed. The zone of limestone concretions that usually occurs in this field in the upper part of the Pierre is here about 100 feet below the top of this shale, and the concretions contain an unusually large. number of ainmonites, with which are associated Fasciolaria sp. (U. S. Geol. Survey fossil locality 6564). . It was not possible, at the time of investigation, to make a full collection of these fossils at this locality.

The Trinidad, which is exposed as a precipitous cliff at locality 18 , consists of two sandstones separated by shale; as described in soveral of the preceding sections. The lower sandstone is here only 35 feet thick, as compared with 75 to 100 feet farther south. The shale separating the two is thicker than it is in the sections previously described but has

$$
47019^{\circ}-17-6
$$

the same yellowish-brown mottled aspect that was noted in all of these sections. It is worthy of note that as the lower sandstone thins toward the north the upper one thickens and is here 75 feet thick. The fossil fucoids characteristic of the Trinidad occur in both parts; and several shells of Inoceramus sagensis Owen were found near the top of the upper one (U. S. Geol. Survey fossil locality 6565). Tellina? sp., Mactra warrenana Meek and Hayden?, and scales and vertebrae of fishes were found (U. S. Geol. Survey fossil locality 6563) in blocks of sandstone, which obviously came from the Trinidad. Three beds of coal were found in the Vermejo formation at this locality. The lowest occurs at the horizon of the carbonaceous shale found at the base of the Vermejo in section 17, and the two higher are apparently to be correlated with those of section 17. The basal conglomerate of the Raton formation rests unconformably on the higher beds, which thins out 75 feet east of the point where the section was measured but comes in again farther east. About 175 feet from the point where the section was measured this coal is 2 feet 8 inches thick. This irregularity in occurrence and thickness was obviously caused by the erosion of a relatively thick bed of coal previous to the deposition of the conglomeratic sandstone. The section follows:

Section of rocks measiured at locality 18 , in the north wall of Van Bremmer Canyon, N. Mex.

[For graphic section see Pl. V; p. 56.]

Raton formation:

Ft. in.

Sandstone, yellow, massive, fine grained... $30 \cdot 0$

Shale, drab......................... 50

Sandstone, yellowish white, coarse grained, friàble, massive.................... $16 \quad 0$

$\begin{array}{llll}\text { Shale, with thin-bedded shaly sandstone.... } & 19 & 0\end{array}$

Sandstone, white to yellow, massive, fine grained.......................... 30

Shale, yellow to drab.................. 990

Shale, black, carbonaceous, 'with thin seams of coal......................... 30

Shale, yellow, sandy................... $12 \quad 0$

Sandstone, white, massive, coarse, quartzose in some places; locally conglomeratic..... $16 \quad 0$

Unconformity.

Vermejo formation:

Coal. About 75 feet to east the overlying sandstone cuts out the coal and rests unconformably on the shale; 100 feet farther east this coal bed is 32 inches thick..................... 


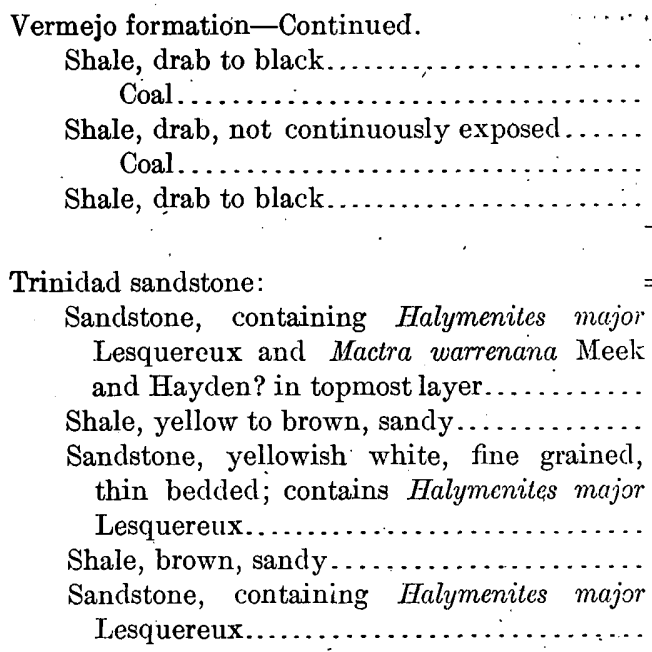

\section{IOCALITY 19.}

The nextsection in orderalong the outcrop was measured on the north slope of the point of the mesa north of Van Bremmer Creek at locality 19, about a mile east of locality 18 . The top of the Pierre shale is exposed at the foot of the slope, but no details of it were obtained. The Trinidad consists of two sandstones, as described in several sections farther south, but at this locality the lower is only 12 feet thick as compared, with 35 feet a mile farther west. The shale separating the two is 22 feet thick, as compared with 17 feet a mile to the west and with only 3 feet $2 \frac{1}{4}$ miles to the southwest (locality 17). However, the lower sandstone is identical in character and appearance with the typical Trinidad of other localities. The shale between the two sandstones has the yellowish-brown appearance already described. The upper sandstone is 92 feet thick and is the typical Trinidad sandstone that forms the escarpment farther, north. The section follows:

Section of rocks measured at locality 19 , north of Van Bremmer Canyon, N. Mex.

$$
\text { [For graphic sestion see P1. } \dot{y}, \text { p. } 56 .]
$$

Raton formation:

Sandstone, massive, coarse grained, hard, quartzose..........................

Probable unconformity.

Vermejo formation:

Shale, not continuously exposed........... $55 \quad 0$ Cioal.

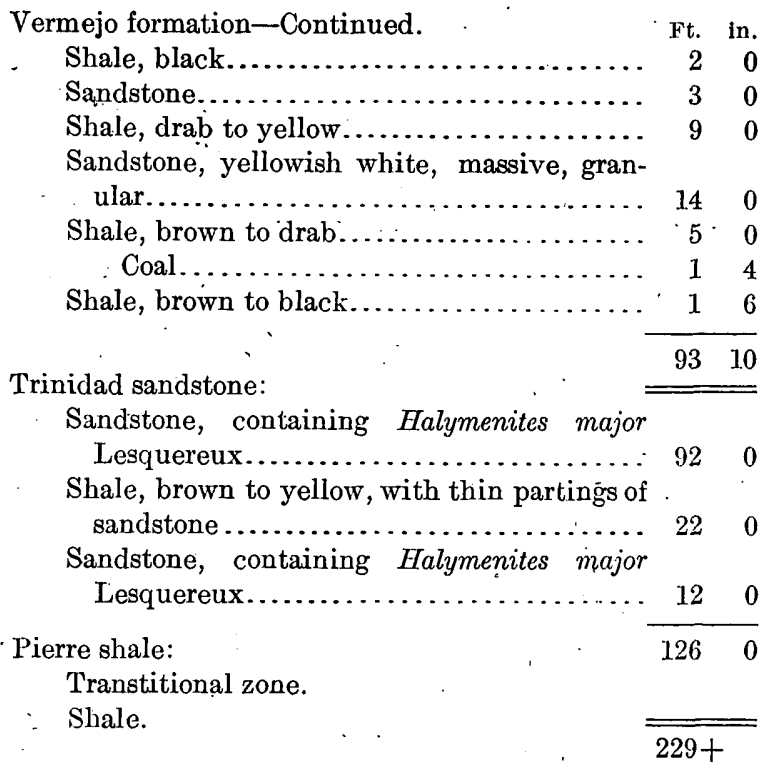

The Vermejo formation, which is only 28 feet thick at locality 18 , a mile to the west, is here about 93 feet thick. The rocks consist principally of shale. Two coal beds were found at horizons which indicate that they are the same as the beds at locality 18 . The upper part of the formation, 55 feet thick, is not well exposed.

The Raton formation, only the base of which was examined, consists of hard, coarse-grained quartzose sandstone that is lithologically identical with the conglomeratic sandstone described in many other places in the region, except that no pebbles were found in it.

\section{DAWSON AREA.}

Dawson is a mining town in Vermejo Canyon. The coal measures of the area near it are deeply dissected and the rocks are well exposed in many places. The coal beds have been opened in mines and prospects, and much exact information was obtained from the records of the Dawson Fuel Co.

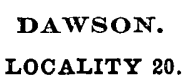

Three miles south of Dawson and about $1 \frac{3}{4}$ miles north of locality 19, a. short section including the Trinidad sandstone was measurod at locality 20. The lower sandstone of the Trinidad, as described farther south, practically thins out at this locality, being probably represented by the 4-foot sandstone of the section and not being certainly recognized farther 
north. The shale between it and the higher sandstone has the general appearance of that described farther south as separating the: two parts of the Trinidad, but at this"locality it takes on the character of the transitional rocks near the top of the Pierre shale. The lower bed of coal in the Vermejo formation was found at this locality, but the higher beds were not seen, owing to a covering of brush and boulders from the overlying conglomeratic sandstone. The section follows:

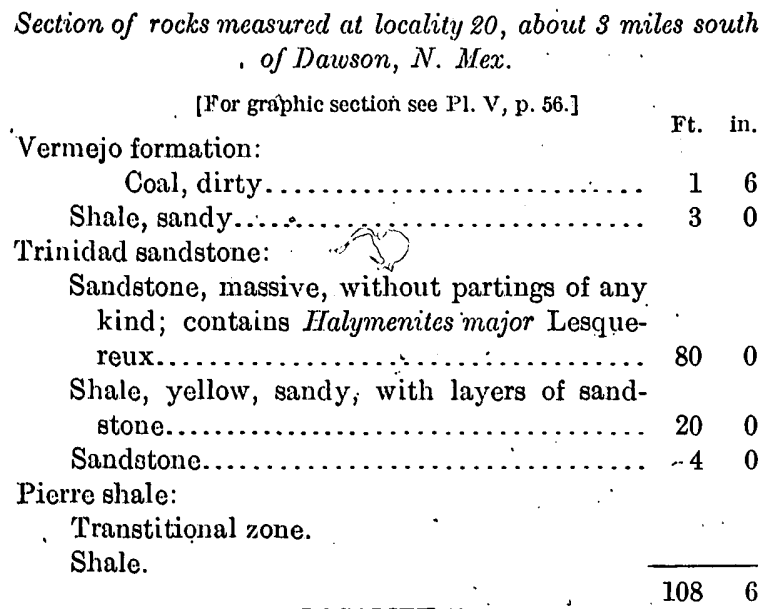
LOCALITY 21.

In Lacy Canyon, south of Dawson, an attempt was made to examine the coal-bearing rocks at locality 21 , about $1 \frac{1}{2}$ miles north of locaitity 20 ; but although some of the rocks are well exposed the Vermejo beds are badly covered with surface débris. The lower part of the Thinidad described at several localities farther south is not recognizable here. The thin sandstones and shale at the base of the Trinidad are yellowish brown and evidently represent the shale that separates the two parts of this formation farther south. The section follows:

Section of rocks measured at locality 21 , about $1 \frac{1}{2}$ miles south of Dauison, N. Mex.

[For graphic section see P1. V, p. 56.]

Raton formation:

Sandstone, yellow, massive............... 120

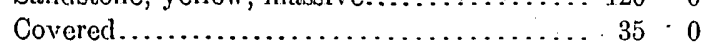

Coal............................. 24

Shale, sandy, not continuously exposed..... 17

Sandstone, with partings of shale........... 107

Sandstone, yellow, shaly................ 11

Sandstone, coarse grained, massive, quartzose 12

Probable unconformity.

$304 \quad 4$

Vermejo formation:

Shale, yellow, sandy, not continuously exposed.......................... 35
Vermejo formation-Continued. Ft. in. Sandstone, white, massive, granular........ $35 \quad 0$ Covered............................ 10.0.

Trinidad sandstone:

800

Sandstone, containing Halymenites major Lesquereux. The lower 20 feet is yellower than the rest, but there is no line of separation............................ 950

Pierre shale:

Transitional zone.

Shale.

The Vermejo formation at locality 21 is about 80 feet thick, but few details of it could be obtained. Coal "blossom" was found near the base of the formation, but no measurement of the coal bed could be made. However, a coal bed supposed to be the lowest was opened near this locality several years ago, and is shown by the records in possession of the Dawson Fuel Co. to vary in thickness from 3 to 6 feet.

A 35-foot sandstone above this lower coal bed resembles very closely the sandstone found in the lower part of the Vermejo formation in Ponil and Cimarron canyons, where it was described as probably equivalent to the upper part of the Trinidad sandstone. It is massive, white, and granular, and it weathers readily. Sandstone of similar character was noted in many places throughout the Raton Mesa region, and in this region occurs only in the Vermejo formation. A coal bed probably exists above this sandstone in the Vermejo formation corresponding in position with the principal coal of the localities on either side (Pl. V), but it was not found.

The top of the Vermejo formation is not so easily determined at this locality as it was farther south. A 12-foot sandstone above the undoubted Vermejo beds is similar in some respects to the conglomeratic sandstone that usually occurs at the base of the Raton formation, but no pebbles were found in it, nor was any conglomeratic sandstone observed at a higher horizon. The rocks above this sandstone have the yellowish color characteristic of the Raton formation. A coal bed of considerable thickness, lying 147 feet above the supposed base of the Raton, corresponds in a general way to coal beds at localities 10 and 17 to the south and 25 to the north; but all are too little known to permit exact correlations.

Above this upper bed of coal the rocks con0 sist mainly of the hard massive sandstone that 
forms more or less conspicuous cliffs throughout the Raton Mesa region.

\section{LOCALITY 22.}

In the west wall of Vermejo Canyon, about a mile northwest of Dawson and about 2 miles north of locality 21 , the rocks were examined and a section of the Vermejo formation measured (locality 22). 'The upper 70 feet of the "Trinidad sandstone is exposed beneath 150 feet or more of the Vermejo formation overlain by a conglomeratic sandstone. The higher rocks are not well exposed. The section follows:

Section of rocks measured at locality 22, in the south wall of Vermejo Canyon, about 1 mile northwest of Dawson, N. Mex.

$$
\text { [For graphic section see Pl. V, p. 56.] }
$$

Raton formation:

Sandstone, coarse grained, quartzose, locally conglomeratic .................... $10+$

\section{Unconformity.}

Vermejo formation:

Shale, with thin beds of coal not continuously exposed..................... 38

Sandstone, yellow, massive.............. 12

Shale, drab.........................

Coal..............................

Shale, drab to black.

Sandstone, yellowish white, massive, friable.

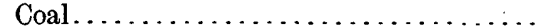

\$hale. ............................

Sandstone, white, massive, friable..........

Shale, black. . . . . . . . . . . . . . . . . Coal ........

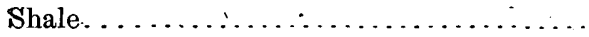

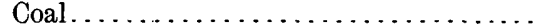

Shale, black, carbonaceous.............

Trinidad sandstone:

Sandstone, containing Halymenites major

Lesquereux.

ior $70+$

The lowest bed of coal in the Vermejo, which is 3 to 6 feet thick farther south is probably represented here by the two thin beds of coal separated by 4 feet of shale. The thicknesses given in the section are from surface measurements, and probably show less coal than really exists. In an old opening on this bed, a few hundred feet farther south, the coal is 6 feet thick. Sheridan ${ }^{217}$ states that in the developed area of the Dawson mines this coal bed ranges in thickness from 6 to 11 feet.

The white friable sandstone described from locality 21 occurs in this section above the lowest bed of coal and is a little thinner than it is at that locality. Above it lie two coal beds, which are apparently thinner at the surface, where the measurements were made than they are back from the outcrop. One of them was found to be 3 feet thick a few hundred feet farther south. They are probably to be correlated with those holding a similar position farther south and also with those at localities 23 to 25. (See p. 86.)

The upper part of the Vermejo formation is not so well exposed as the lower part. Some indications of coal but no thick beds were found. This seems somewhat singular when the section is compared with that at locality 25 , less than a mile to the east, where a 4-foot bed of coal occurs near the top of the Vermejo formation. On the one hand, it is possible that this bed is represented by a thin seam of coal not here recorded; and, on the other hand, it is possible that this bed was eroded away previous to the deposition of the conglomeratic sandstone at the base of the Raton formation.

The basal sandstone of the Raton is well developed. At localities 20 and 21 no pebbles were found in this sandstone, but here siliceous pebbles up to one-fourth inch in diameter were found in small pockets near the base. The sandstone is massive, coarse grained, quartzose, and lies with uneven base on the shale of the Vermejo formation. It is only 10 feet thick where the section was measured, but it reaches 40 feet a little farther south. Its under surface is covered in some places with peculiar markings resembling worm borings, and these same markings were found on the under side of the basal conglomerate at Koehler, Van Houten, and other places where the conglomerate rests on beds of coal.

\section{LOCALITY 23}

Another section of the Vermejo formation was measured in the west wall of Vermejo Canyon at the mouth of a small gulch known as Cook Canyon, one-half mile north of locality 22. The top of the Trinidad sandstone is exposed, and the overlying coal beds have been opened. The measurements given in the following section were made in the prospect openings. Coal is mined near this locality on both sides of the canyon. The upper part of the Vermejo formation is not so well exposed as the lower part, and, although a thin bed of coal was observed in it, there is little chance 
that it includes a thick bed such as was found at locality 25 . (See p. 86.) The basal sandstone of the Raton formation is well represented and has the same character as the conglomerate at locality 22. The section follows:

Section of rocks measured. at locality 29 , about 2 miles north- west of Dawson, N.'Mex.

$$
\text { [For graphic section sco T'l. v, p. 56.] }
$$

Raton formation:

Sandstone, massive, quartzose; locally conglomeratic........................ $12 \quad 0$

Unconformity.

Vermejo formation:

Shale and sändstone, not continuously exposed; 2 inches 'of coal near the top......

Shale, with thin layers of sandstone.........

Sandstone, white, granular.............. 23

Shale......

Coal.

Shale.

Shale, with thin beds of sandstone.......... 1

Coal.............................

Shale................................

Coal............................

Shale.

Trinidad sandstone.

For a considerable distance above the basal conglomerate the rocks are principally shale, above which lie massive cliff-making sandstones. These contain fossil plants, but few of them were collected near Dawson. Near the mouth of Stout Canyon blocks of conglomeratic sandstone, well up in the sides of the canyon, may have been carried there by streams before the canyons were as deep as they are now, but it seems more probable that they were derived from some bed in the cliff-making sandstones at a horizon corresponding to one of the upper conglomerates of the Cimarron Canyon region, about 15 miles to the southwest.

\section{LOCALITY 23a.}

A diamond-drill hole, bored several years ago in Vermejo Canyon at locality 23a, near the mouth of Stout Creek, passed through a considerable thickness of the Raton formation, including the basal conglomerate, and penetrated well into, if not entirely through, the Vermejo formation. A gray sandstone at the bottom of the hole is supposed to be the Trinidad sandstone, and the coal near the bottom to be the main bed at the base of the Vermejo. (See Pl. XVII, p. 142.) However, this lowest sandstone may be the sandstone above the lowest coal, which at locality 21 is 35 feet thick and at locality 22 is 23 feet thick. It is so nearly like the Trinidad sandstone that the difference could scarcely be detected in a drill core. If the sandstone is the one above the lowest coal the Vermejo formation would appear to thicken toward the northwest as it should do in view of the fact that, at the mouth of Salyers Creek, about 5 miles upstream from Stout Canyon, the formation is about 200 feet thick (section 122, Pl. XVII). The rocks penetrated by the drill are as follows:

Record of a diamond-drill boring at locality 2sa in Vermejo Canyon, about 4 miles northwest of Dawson, N. Mex.

[For graphiç sestion see Pl..XVII, $\dot{p}$. 56.]

Raton formation:

Surface débris _.... Ft. ir.

Shale............................... 20

Shale, sandy, and ironstone............... 5 (t)

Sandstone, white................... 8.

Shale, gray....................... 18 .

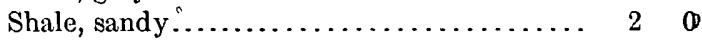

Sandstone.......................... $3 \quad 0$

Ironstone........................... $\quad 2 \quad 0$

Sandstone......................... $7 \quad 0$

Ironstone.............................

Sandstone, gray, with hard ironstone concretions.............................. $5 \quad 9$

Ironstone.......................... 5 5

Shale, gray, soft................... $29 \quad 0$

Sandstone, gray .................... 7

Ironstone, green ......................... 10

Shale, drab, sandy .................. $12 \quad 0$

Sandstone, gray, dark pebbles in the central part............................ 1

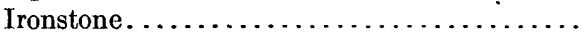

Sandstone, hard, containing black pebbles ..

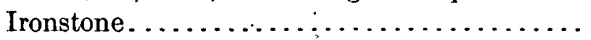

Sandstone, drab, shaly.................

Sandstone, gray, coarse grained, with streaks of black ironstone and gray shale; contains pebbles and particles of coal near the base.

Vermejo formation:

Sandstone, gray, fine grained

Shale, drab, black at base................ Coal............................

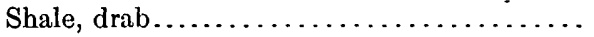

Shale with ironstones...................

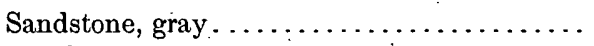

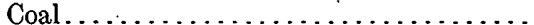

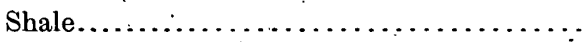

Coal, bony in some places..............

Shale, sandy, with ironstone concretions....

Sandstone, gray.

\begin{tabular}{rr}
16 & 0 \\
\hline 159 & 2 \\
\hline \hline 16 & 0 \\
7 & 0 \\
& 4 \\
1 & 8 \\
20 & 0 \\
3 & 6 \\
1 & 6 \\
6 & 8 \\
4 & 4 \\
11 & 0 \\
20 & 0 \\
\hline 92 & 0 \\
\hline \hline 251 & 2
\end{tabular}


Sabal? ungeri (Lesquereux) Knowlton, Cinnamomum tiniffolium Knowlton, and Dryophyllum 'moorii" (Lesquereux) Berry were found at' Iocality 23 a near the base of the Raton fờmâtión (U.'S. Geol. Survey fossil locality $5827)$. $\therefore$ ist:

\section{LOCALITIES 24 AND 25.}

In the north wall of Vermejo Canyon, opposite locality 22 , a section was measured from the river to the top of the mesa at locality 24. However, the Vermejo formation is better exposed about one-fourth mile farther down stream, at locality 25 , where the details of this formation presented in the following section were obtained:

Section of rocks measured at localities 24 and 25 , in the north wall of Vermejo Canyon, about 1 mile northwest of Dawson, N. Mex

[For graphic section see Pls. V, p. 56, and X, p. 108.]

Raton formation:

Sandstone, coarse, massive, cliff making 125 in.

Sandstone, shaly................... 20

Sandstone, massive.................. 35

Shale, black, with thin seams of coal . . . . . 6

Shale and shaly sandstone.............. 16

Sandstone, massive, cliff making........ 10

Shale, with thin seams of coal............ 60

Coal. .....................

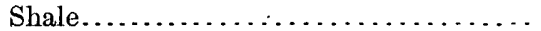

Coal.

Shale, carbonaceous in some places; and with

thin beds of impure sandstone.......... 75

Sandstone, massive, cross-bedded......... 8

Shale, with sandstone nodules..............

Sandstone, irregular, mainly soft, friable, sur-

face weathers cavernous. ............. $18 \quad 0$

Sandstone, conglomeratic............. $5+$

Unconformity.

Vermejo formation:

Shale, buff-colored . . . . . . . . . . . . . . 5,0

Coal.................... $4 \quad 0$

Sandstone, white, friable, with thin beds of

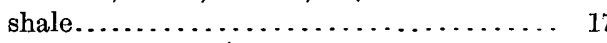

Shale, black, carbonaceous. . . . . . . . . . .

.Shale, buff-colored. . . . . . . . . . . . . . 14

Sandstone, white, friable.................

Sandstone and shale, buff-colored....... 12

Shale, buff-colored. . . . . . . . . . . . . . . . .

Coal . . . . . . . . . . . . . . . . .

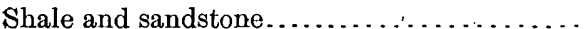

Sandstone, white, granular............

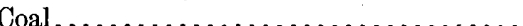

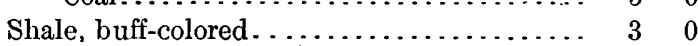

Trinidad sandstone.
Only the top of the Trinidad sandstone is exposed at the base of the section. The principal coal bed lies a few feet above the Trinidad and is 5 feet thick at locality 25 and 6 feet thick at locality 24 . Sheridan ${ }^{217}$ states that this bed, where devieloped in the Dawson mines, ranges in thickness from 6 to 11 feet. At locality 24 several species of fossil plants occur about 25 feet above the base of the Vermejo (U. S. Geol. Survey fossil locality 5153). They are poorly preserved, and only Sequoia obovata Knowlton was definitely identified.

The upper 70 feet of the Vermejo at locality 24 appears at the surface to consist principally of shale with thin beds of coal near the top. At locality 25 considerable sandstone was found with the shale, and a 4-foot bed of coal occurs near the top.

The layer of sandstone, which at locality 24 is probably the base of the Raton formation, is only 2 feet thick but is hard, coarse grained, and quartzose. At locality 25 this sandstone is 5 feet or more in thickness and, in addition to being coarse grained and quartzose, contains small pebbles of quartz and larger pebbles up to half an inch or more in diameter of relatively soft sandstone such as is found in the underlying rocks of the Vermejo.

The Raton formation consists principally of shale for about 175 feet above the basal conglomerate, and a coal bed of considerable thickness occurs about midway of this shaly portion. Still higher the rocks are principally hard, massive, cliff-making sandstone that forms a steep escarpment.

No measurements were made at the surface in Rail Canyon, north of Dawson, but the record of an air shaft 201 feet deep, sunk to mine No. 2 of the Dawson Fuel Co. about $2 \frac{1}{2}$ miles north of the town, was obtained.

Section of rocks penetrated by an air shaft for Dawson mine No. 2 in Rail Canyon near Dawson, N. Mex.

Raton formation: $\quad F t$ in Surface débris..................... 90 Sandstone, gray to yellow ............. $14 \quad 6$ Shale, black ................... $9 . \ldots$ Sandstone, white................. 34 Shale, gray........................ $19 \quad 3$ Sandstone, yellow.................... $13 \quad 8$ Shale, black, with ironstone........... $14 \quad 10$ Sandstone, white, hard............... $21 \quad 3$ $\frac{90 \quad 8}{481+\text {. }}$ 


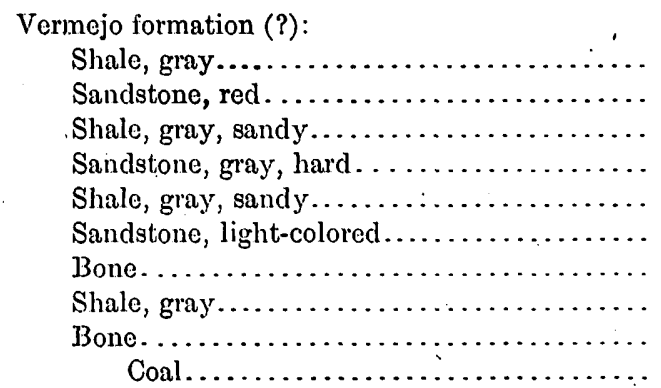

\begin{tabular}{rr|} 
Ft. & in. \\
4 & 0 \\
6 & 5 \\
19 & 1 \\
11. & 0 \\
5 & 7 \\
33 & 6 \\
1 & 6 \\
7 & 6 \\
1. & 0 \\
6 & 0 \\
\hline 95 & 7 \\
\hline \hline 201. & 0 \\
\hline \hline
\end{tabular}

The coal at the bottom of the shaft is obviously the lower bed of the Vermejo, for it is the coal developed in the Dawson mine. The higher or 4-foot bed of coal of locality 25 was not found. Nothing in the record indicates where the top of the Vermejo occurs, but a comparison of the section with that measured at locality 25 indicates that the line between the Vermejo and the Raton formations may perhaps be drawn at the base of the hard white sandstone 21 feet 3 inches thick about 95 feet above the bottom of the shaft.

\section{LOCALITY 26.}

A section was measured at locality 26 , southeast of Dawson, about 2 miles from locality 25. This point of the mesa is very precipitous. The Pierre shale occupies the lower 200 to 300 feet of the slope and the Trinidad sandstone forms a conspicuous white cliff. Above this cliff the relatively soft rocks of the Vermejo formation form a slope that is more or less covered with surface débris, and above these the hard basal sandstone of the Raton formation forms a second cliff less prominent than the Trinidad. The following section was measured:

Section of rocks measured at locality 26, about 2 miles east of Dawson, N. Mex.

[ For graphic section seo Pl. V, p. 56.]

Raton formation:

Sandstone, massive, friable at the base;

coarse grained and quartzose near the top.. $20 \quad 0$ Unconformity.

Vermejo formation: Coal

Shale, drab to yellow, with partings of shaly, yellow sandstone....................

Coal...............................

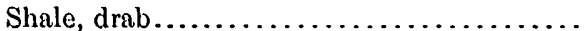

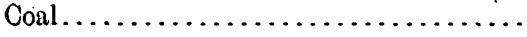

Shale, black. .....................

Sandstone, white, granular, friable....... 11

Coal.

Vermejo formation-Contint:ed.

Shale..

Shale, drab to

to black

$\begin{array}{rr}\text { Fi. in } \\ 3 & 0\end{array}$

1. 0

Trinidad sandstone.

$110 \quad 0$

Pierre shale:

Transitional zone.

Shale.

The main coal bed at the base of the Vermejo is thinner at this locality than was anticipated, in view of the fact that a prospect opening in the west slope of this point showed 5 feet 4 inches of coal and another in the east slope 4 feet 2 inches. The basal sandstone of the Raton formation is hard, quartzose, and otherwise similar to other occurrences of the formation, but no pebbles were found in it at this locality. However, it is the same sandstone that is conglomeratic at localities 22 and 25, for, although it is not everywhere conglomeratic, it is readily traced along the outcrop and there is little chance of mistaking its identity. The higher rooks were not examined.

\section{SALTPETER CREEK.}

In no place in the Raton Mesa region is the Trinidad sandstone more conspicuous than it is in Spring and Saltpeter cany,ons. In Saltpeter Canyon, on the east side of the ridge separating it from Spring Canyon the small cliff above the conspicuous white Trinidad cliff (see PI. III, p. 38) is apparently formed by the basal sandstone of the Raton formation (as was a similar cliff at locality.26). The rocks, however, were not examined in detail.

\section{SALTPETER MOUNTAIN.}

LOCALITY 27.

Saltpeter Mountain is an outlier separated from the main body of the mesa by Saltpeter Canyon and by a gap north of the mountain connecting Saltpeter Canyon with the plains to the east. Section 27 was measured on the east slope about 3 miles southeast of locality 26. The section follows:

Section of rocks measured at locality $2 \%$, in the east slope of Salipeter Mountain. 


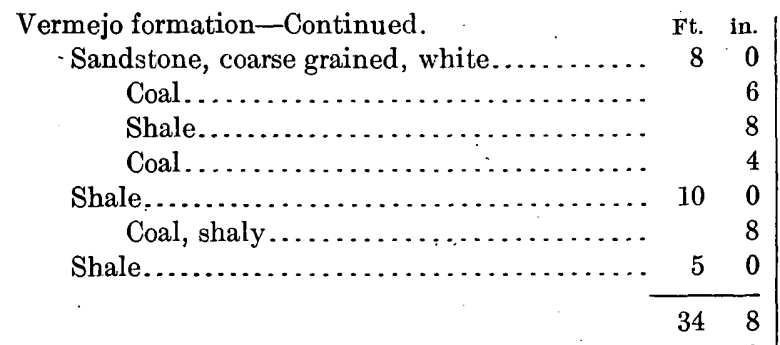

Trinidad sandstone. 100

Pierre shale:

Transitional zone and shale, fossiliferous (5606)

$$
\underline{400+}
$$

About 400 feet of the Pierre shale is well exposed. Fossiliferous limestone concretions, from which Inoceramus sagensis Öwen and Placenticeras sp. were collected (U. S. Geol. Survey fossil locality 5606), occur 100 feet or more from the top. The thickness of the Trinidad sandstone was estimated at 100 feet. No thick bed of coal was found near the base of the Vermejo at the horizon where the main coal of the Dawson area occurs. This bed seems to be represented here by one of the thin beds found near the base of the formation. The thick bed of coal at the top of the Vermejo is apparently to be correlated with one of the thin beds above the main coal of the Dawson area. (See sections 22 to $26, \mathrm{Pl} . \mathrm{V}$, p. 56.)

\section{TURKEY CREEK.}

\section{LOCALITY 28.}

The side of the mesa is precipitous at locality 28 , near the point of the mesa south of Turkey Creek, 3 miles northeast of locality 27. The horizontally bedded rocks, from the Pierre shale to the cliff-making sandstones of the Raton formation, are well exposed. No detailed observations were made on the Pierre shale. The base of the Trinidad sandstone is not exposed, but the formation is more than 80 feet thick and contains the characteristic fossil fucoids.

Two species of invertebrates, Inoceramus sagensis Owen and Mactra warrenana Meek and Hayden.(U. S. Geol. Survey fossil locality 6566) were found in blocks of sandstone that apparently came from the upper part of this sandstone. The section follows:

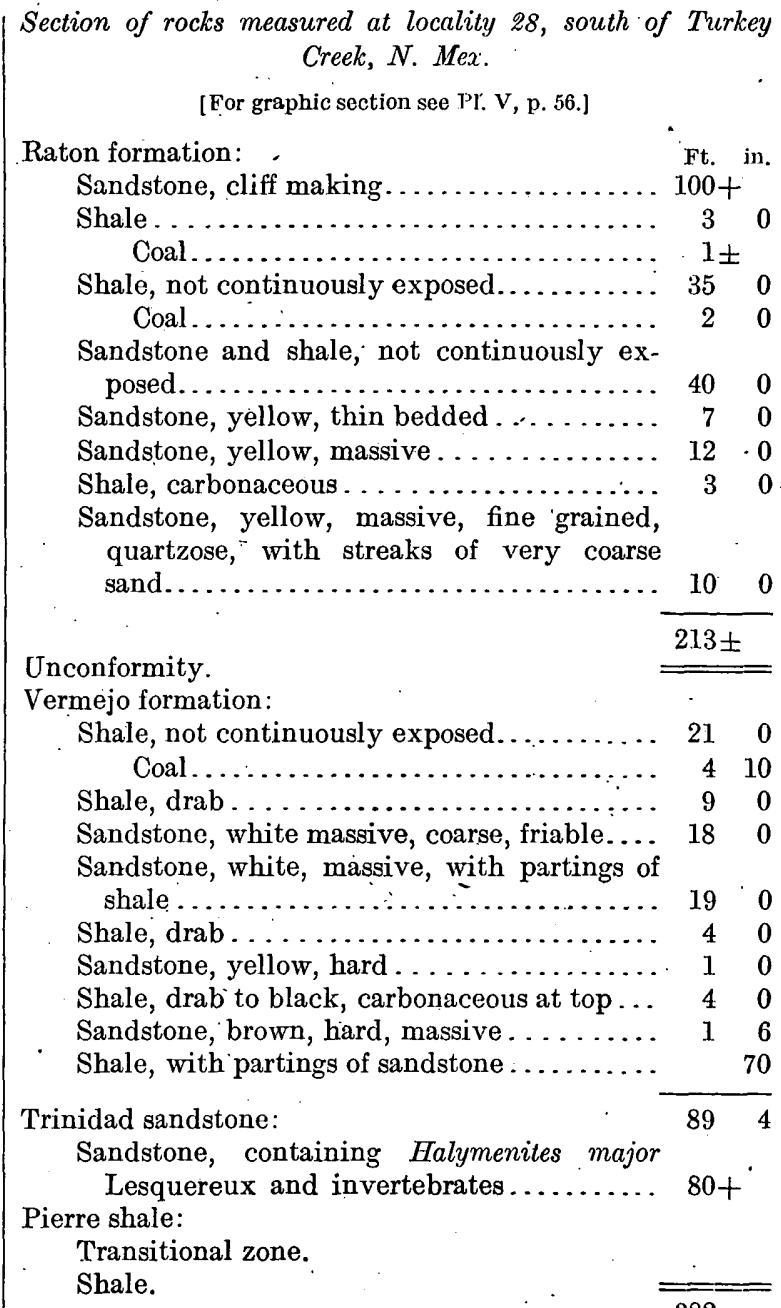

The Vermejo formation -at this locality contains one thick bed of coal, which is probably to be correlated with the coal of locality 27 . Carbonaceous shale near the base may represent the lowest coal bed of the Dawson area, but no coal was found in it. Thin beds of coal were found at this horizon at localities 27 and 29, and the apparent absence of coal here may be due to poor exposures.

The base of. the Raton formation is not conglomerate at locality 28 . The sandstone which probably constitutes the base is massive and quartzose like the basal sandstone at other localities, but it is rather fine grained. However, in this fine-grained mass are irregular masses of coarse sand, which have the general aspect 
of the pockets containing the pebbles in places where the rock is coarser grained.

Two beds of conl were found between this quartzose sandstone and the cliff-making sandstones at the top of the section. No special consideration was given to these beds in the field, but when the sections were plotted to the same scale and compared (see Pl. V, p. 56) these coal beds were found to correspond in a general way with those observed in several other places.

\section{KOEHLER AREA.}

At Koehler is situated one of the large mines of the St. Louis, Rocky Mountain \& Pacific Conl Co. Although the coal measures are not so well exposed in this area as they are in some other places, the relation of the Vermejo to the Raton formation is conspicuously shown. The basal conglomerate of the Raton is thick, coarse, and well indurated and forms a prominent cliff. In some places it lies unconformably on the Vermejo formation, and in other places it transgresses the Vermejo and rests on the Trinidad sandstone.

\section{CURTIS CREER: LOCALITY 29.}

A section extending from the top of the Pierre shale to the cliffs at the top of the mesa was measured at locality 29 in the prominent point between the forks of Curtis Creek, 2 miles northeast of locality 28. The Pierre shale and Trinidad sandstone are characteristically developed. A thin bed of coal was found at the base of the Vermejo formation at the horizon occupied by the main coal developed at Dawson. A higher bed of impure coal may be one that is not represented farther south, or it may be the equivalent of the thick bed found at localities 27 and 28 , although it is considerably lower in the section. The measurements of this section; like those of most of the other sections given in this paper, were made at the surface and are subject to slight correction. In many places where soft shale is overlain by harder rocks these tend to creep downward in the steep sides of the mesa, thus making the shale appear thinner than it really is. This may possibly explain in part the apparent thinness of the Vermejo formation-only 43 feetin this section. On the other hand, the fact that in other places differences in thickness of this formation are known to be due to erosion makes it rational to attribute the thinning at this locality to this cause. The correlation of the main coals with the thick bed described farther to the south, and also with a still thicker bed found farther to the north, is strengthened by the known continuity of the bed in Curtis Canyon, where is has been prospected and found to have an average thickness of about 6 feet. North of locality 29 it thickens. About a mile to the north it contains 6 feet 10 inches, and at locality 30,9 feet of coal. The section follows:

Section of rocks measured at locality 29, north of Curtis Creek, N. Méx.

[For graphic section see Pl. V, p. 56.]

Raton formation: - Ft. in.

Sandstone, yellow, massive, fine grained... $20 \quad 20$

Covered .......................... $55 \quad 0$

Sandstone, yellow, massive, fine grained.... $10 \quad 0$

Shale, sandy ...................... $16 \quad 0$

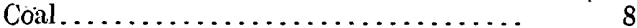

Sandstone, thin bedded, alternating with yellow sandy shale................. $38 \quad 0$

Shale.......................... $4 \quad 0$

Coal........................... 6

Shale, drab.......................... 10

Sandstone, massive, fine grained.......... $3 \quad 0$

Shale, drab to yellow.................. $4 \quad 0$ Coal.......................... 10

Shale, not continuously exposed............. $37 \quad 0$ Coal............................ 15

Shale, yellow to brown.................. $10 \quad 0$

Sandstone, massive, coarse grained.......... $25 \quad 0$

Sandstone, thin bedded, and sandy shale, not continuously exposed ............. $27 \quad 0$

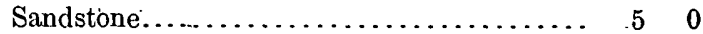

Shale............................... $12 \quad 0$

Sandstone........................... $12 \quad 0$

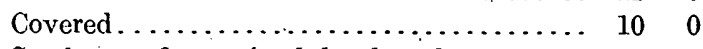

Sandstone, fine grained, hard, and quartzose. $10 \quad 0$

Unconformity.

Vermejo formation:

Shale, brown to black..................

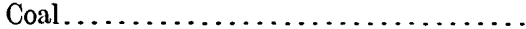

Shale, black, carbonaceous..................

Coal.............................

Shale, brown to black.................

Coal...............................

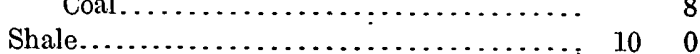

Sandstone, yellowish white.............. $6 \quad 6$

Coal, bony ......................... 6

Shale, brown to black ................ $6 \quad 6 \quad 0$

$43 \quad 0$

Trinidad sand
Pierre shale:

Transitional zone.

Shale. 
No conglomerate was found at the base of the Raton formation, but the sandstone supposed to constitute the base is hard and quartzose like the undoubted basal sandstone at other localities. The coal beds found well up in the section correspond in a general way to the coal beds farther south that have been described as occurring in the Raton formation between the basal conglomerate and the overlying cliff-making sandstones.

\section{LOCALITY 30 .}

Section 30 was measured in the south side of the point of the mesa north of the north fork of Curtis Creek, about 2 miles northeast of locality 29 , which it supplements to some extent, as in it no doubt exists as to the base of the Raton formation. The Vermejo formation is less than 50 feet thick and contains one thick bed of coal and one thin bed. The section follows:

Section of rocks measured at locality 30, north of North Fork of Curtis Creek, N. Mex.

[For graphic section see Pl. V, p. 56.]

Raton formation:

Sandstone and shale; several hundred feet.

Sandstone, massive, coarse grained, base irregular.......................... 53

Unconformity.

Vermejo formation:

Shale, with layers of thin sandstone and ironstone nodules. ......................

Coal............................. 9

Shale, buff-colored..................

coal............................

Shale..................................

Sandstone, white, granular............. 9

Shale, buff-colored. ...............................

. . .

Trinidad sandstone...................... $90 \quad 0$

Pierre shale:

Transitional zone...................... $25 \quad 0$
Shale.

The base of the Raton consists of a thick, coarse-grained, massive sandstone that forms a conspicuous bluff and rests with uneven base on the shales of the Vermejo formation. The cliff-making sandstones at the top of the mesa are conspicuously exposed at this locality, but the shales underlying them are covered with rock débris, and the section above the 53-foot sandstone was not measured. The rocks a few feet above it contain fossil plants, but only one species, Palaeoaster inquirenda Knowlton, which was very perfectly preserved, was collected. This fossil was found in slide rock apparently about 50 feet above the base of the Raton formation. A landslide at this point obscures the relations.

The thick bed of coal in the Vermejo formation has been traced along the outcrop for a considerable distance on either side of this locality and opened in several places. In Waldron Canyon, $1 \frac{1}{2}$ miles northwest of locality 30 , the coal is 8 feet thick and the shale intervening between it and the basal sandstone of the Raton formation is only 5 feet thick. Between this point and locality 31 the coal ranges in thickness from 7 feet to nearly 9 feet.

\section{KOEHLER.}

LOCALITY 31.

At locality 31 , on the first prominent point of the mesa south of Koehler, the Pierre shale and Trinidad sandstone are well exposed. The main bed of coal, 9 feet thick, is 18 feet above the top of the Trinidad. The sandstone 5 feet above the top of this coal is conglomeratic and lies unconformably on the shale that separates it from the coal. A few specimens of Sequoia reichenbachi (Geinitz) Heer (U. S. Geol. Survey fossil locality 5811) were found at the surface in such a position as to indicate that they probably came from the Vermejo formation. The section follows:

Section of rocks measured at locality 31, south of Koehler, N. Mex.

[For graphic section see Pl. V; p. 56.]

Ft. in.

Raton formation:

Sandstone, conglomeratic, coarse grained, quartzose, containing siliceous pebbles up

to $1 \frac{1}{4}$ inches in diameter............... $28 \quad .0$

Unconformity.

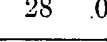

Vermejo formation:

Covered.......................... $55^{5} \quad 0$

Coal............................ 95

- Shale, not continuously exposed........... $18 \quad 0$

320

Trinidad sandstone...................... 80

Pierre shale:

Transitional zone.

Shale.

LOCALITIES 32 TO 35

$\overline{140 \quad 0}$

Four sections of the Vermejo formation were measured near Koehler and can best be described together. The main workings of the 
Koehler mine lie between localities 31 and 32 , south of the southern branch of Crow Canyon, in which Koehler is situated. Two other openings are in the gulch west of locality '33. The mine is in the thick bed of coal shown in sections 30 and 31 . These mines offered opportunities for observation not enjoyed in undeveloped regions.

In the vicinity of Koehler the Vermejo formation becomes very thin and disappears entirely north of locality 40 , and the basal sandstone of the Raton formation becomes very massive and conglomeratic. The shale separating the coal from the conglomerate at locality 31 occurs in some places in the mine and in other places it is absent, allowing the conglomerate to rest directly upon the coal. At locality 32 this coal, which is normally 6 to 12 feet thick in the vicinity of Koehler, is only 4 feet thick, and the conglomerate, with pebbles half an inch or more in dinmeter, rests directly upon it. The under surface of the conglomerate at this locality is covered with the peculiar wormlike markings that have been found in several other places, notably in the mine at Van Houten; on the under surface of the basal conglomerate.

The thinning of the Vermejo formation toward the west is shown in an abandoned mine at locality 33 . In this mine the conglomerate rests upon the coal, which thins in the direction in which the entry was driven, and the mine was abandoned at a point where the conl was less than $2 \frac{1}{2}$ feet thick. In the east wall of the same gulch an opening was made on this same coal bed, and a measurement a few hundred feet from the mouth showed 14 feet of conl separated from the overlying conglomerate by 6 feet of shale. At this locality, therefore, there is a conspicuous and well-marked unconformity by erosion. The following sections, measured at the surface a little farther to the east at localities 33 and 34, show that the rock intervening between the coal bed and the overlying conglomerate attains in places a thickness of at least 22 feet. (See Pl. V, p. 56.)

Section of rocks measured at locality 39 , near Koehler, N. Mex.

[For graphic section seo P!. V, p. 56.]

Raton formation:

Conglomerate; siliceous pebbles up to 1 inch in diameter...................... $30_{ \pm}$ Unconformity.

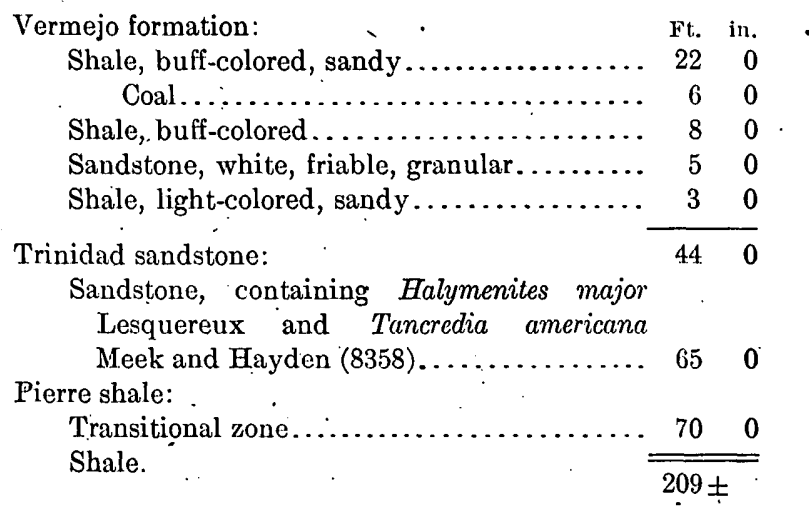

Section of rocks measured at locality $\$ 4$, near Koehler, N. Mex. (220 feet èast of section 39).

[For graphic section sce Pl. v, p. 56.] · Feet.

Raton formation:

Conglomerate, siliceous pebbles up to 1 inch in diameter............................ $30 \pm$

Unconformity.

Vermejo formation :

Shale.............................. 3

Sandstone, shaly....................... 12

Shale............................... 2 Coal............................... 11

Shale.............................. 8

Sandstone............................. 5

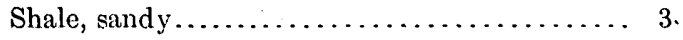

Trinidad sandstone: _. .

Sandstone, containing Halymenites major Lesquereux.

Pierre shale:

Transitional zone.

Shale.

In the side of the canyon north of Koehler (Prairie Crow Canyon) the rocks extending from the upper part of the Pierre shale to the cliff-making sandstones of the Raton formation at the top of the mesa are well exposed (see fig. 2 ), and a section was measured (locality 35). The Pierre shale contains limestone concretions which have a few poorly preserved invertebrates, none of which were collected. The Trinidad sandstone is unusually thin at this locality, but otherwise it is not different from the Trinidad described at neighboring localities. It is here less conspicuous than the basal conglomerate of the Raton formation. The coal bed, which has a maximum observed thickness of 14 feet less than a mile west of this locality, does not appear here, but a bed of ash was found that obviously was derived from its burning. The section follows. 


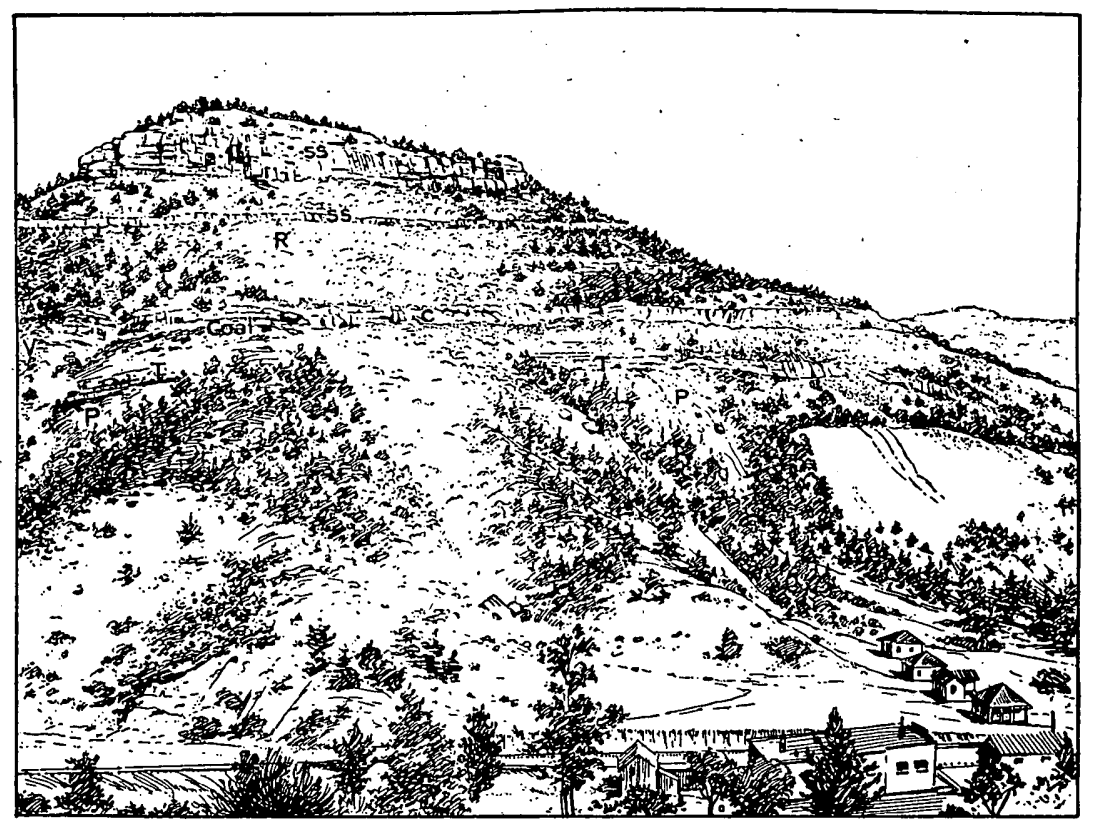

Figure 2.-Point of mesa near Koehler, N. Mex., showing the relations of the rock formations. P, Pierre șhale; T, Trinidad sandstone; $\mathrm{V}$, Vermejo formation; R, Raton formation; SS, sandstone; C, coll, or ash where the coal is burned.

Section of rock measured at locality 35 , north of Koehler, N. Mex.

[For graphic section see I'I. V, p. 50.]

Raton formation:

Sandstone, yellow, massive...............

Covered.................................

Sandstone, yellow, massive............. 15

- Sandstone, yellow, thin bedded, with partings of sandy shale; not continuously exposed.

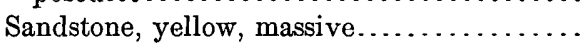

Shale, drab to brown. . . . . . . . . . . . . .

Sandstone, yellow, massive..............

Shale and sandstone, not continuously ex-

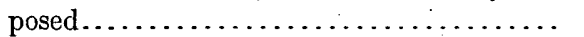

Sandstone.......................... 20

Covered........................... 8

Sandstone..........................

Shale and shaly sandstone...............

Sandstone, conglomeratic, coarse grained, quartzose, with siliceous pebhles up to 1 . inch in diameter.

Unconformity.

Vermejo formation:

Shale and shaly sandstone.............. $22 \quad 0$

Ash (representing burned coal of the bed which a quarter of a mile to the west is 12 feet thick) .......................

Shale...............................

Coal, dirty ........................

Shale, brown to black, sandy..............

Trinidad sandstone:

Sandstone, with shaly partings; contains Halymenites major Lesquereux : . . .........

Pierre shale:

Transitional zone.

Shale.
The basal conglomerate of the Raton formation here forms the prominent cliff shown in figure 2. The higher beds were examined as described in the foregoing section, but no coal was found to correspond with the highest bed described in several of the preceding sections.

\section{LOCALITY 36.}

A section of the Vermejo formation was measured in the north wall of Prairie Crow Canyon, at locality $36,1 \frac{1}{4}$ miles northwest of locality 35 . Only the upper part of the Trinidad sandstone is exposed. The Vermejo is much thicker than it is a mile farther south, at localities 33 and 34, and contains two beds of coal. Although the 8-inch bed near the base of the formation has the stratigraphic position of the main coal the thick bed near the top is supposed to be the one developed in the Koehler mine. Although only 3 feet of coal was found in this bed where the section was measured, the coal is 5 feet thick about one-fourth mile farther west. It is possible that the 27-foot sandstone belongs to the Trinidad, in which case the thick coal bed and the overlying conglomerate would be brought down to a more rational position in the section (see $\mathrm{Pl}$. V, p. 56), but this would necessitate the reference of the 8-inch bed of coal and 20 feet of shale to the Trinidad.

The basal conglomerate of the Raton formation has here practically the same thickness and character as that described at the Koehler mine 
and rests unconformably on the shale which overlies the main coal. The section follows:

Section of rock measured at loculity 36 , northwest of Koehler, N. Mex.

[For graphic section see PI. V, p. 56.]

Raton formation:

Sandstone conglomeratic . ....

Unconformity.

Vermejo formation:

Covered...

Shale............................. 50

Sandstone, white, coarse, massive, shaly toward the top.........................

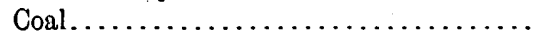

Shale, brown to black..................

Shale and massive sandstone, not continuously exposed

Trinidad sandstone.

LOCAIITY 37.
27.0

40

0 160

598

$86+$
Another section was measured in the north wall of the middle fork of Crow Canyon, at locality 37 , about half a mile southeast of locality 36. A thickness of 50 feet of the Trinidad sandstone is exposed, but the base was not seen. The Vermejo formation is much thinner than at locality 36 , but the lowest shale, 9 feet thick, seems to be the equivalent of the lower 20 feet of the last section, and the 10 feet of white granular sandstone is apparently the equivalent of the 27-foot sandstone of that section; but no coal was observed between the 'shale and this sandstone. The coal bed is evidently continuous with the main coal at locality 36 , and the basal conglomerate of the Raton formation rests here directly upon the corl. The section follows:

Section of rocks measured at locality 37 , northwest of Koehler; N. Mex.

[For graphic soction sec Pl. V, p. 56.]

Raton formation:

Sandstone, conglomeratic...

Unconformity.

Vermejo formation:

$$
\text { Coal.. }
$$

Shale, black, carbonaceous.

Sandstone, white, coarse grained, granular...

Shale, sandy

Irinidad sandstone.

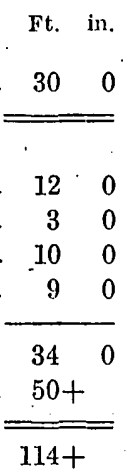

LOCALITY 38.

The main coal bed, which was found to be 12 feet thick at locality 37 , can be traced thence along the outcrop to a point three-fourths of a mile or more to the southeast, where it is 8 to 9 feet thick, but in the point between Prairie Crow Canyon and the canyon of Crow Creek it has been burned in some places. Section 38 was measured on this point, which is about $1 \frac{1}{4}$. miles southeast of locality 37 . The results follow:

Section of rocks measured at lccality $\$ 8$, northwest of Koehler; N. $M e x$.

[For graphic section ses Pl. V, p. 56.]

Raton formation:

Sandstone, coarse grained, conglomeratic, quartzose, with pebbles up to an inch in diameter......................... 33

Unconformity.

Vermejo formation:

Shale................................. 5

Sandstone............................. 12 .

Shale, sandy......................... 10

Sandstone........................... 3

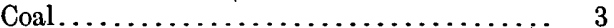

Shale.............................. 2

Trinidad sandstone...................

LOCALITY 39.

In the west wall of Crow Canyon, at locality 39 , the rocks are fairly well exposed, and a short section was measured, but the main coal bed of this region was not found. Two beo's of coal occur here in place of the one found at locality 38 , where the upper bed seems to have been eroded away previous to the deposition of the conglomerate.' The section follows:

Section of rocks measured at locality 39 , in west wall of Crow Canyon, about 3 miles north of Koehler, N. Mex.

$$
\text { [For graphic section see Tl. V, p. 56.] }
$$

Raton formation:

$$
\text { Sandstone, conglomeratic............ } 30
$$

Unconformity.

Vermejo formation:

Coal.......................... .4

Shale....................... 4

Sandstone......................... 20

Coal. ......................... 2

Shale............................. 4

Sandstone............................ 4

Shale................

Trinidad sandstone................. $\begin{array}{r}40 \\ \frac{72}{142}\end{array}$ 
In the same side of the canyon, less than. one-eighth mile northwest of locality 39 , the higher coal is something more than 5 feet thick and is separated from the overlying conglomerate by about 3 feet of shale. No sections were measured in the east'wall of Crow Canyon, but the main coal has been opened in many places and the results, reported by Orestes St. $\mathrm{John}_{,}$have been furnished for this paper by the St. Louis, Rocky Mountain \& Pacific Coal Co. In ten prospect openings north and east of locality 39 the main coal bed ranges in thickness from about 4 feet to more than 12 feet. On Castle and Schomburg creeks the conglomerate rests on the coal. In a drill hole between Castle Creek and Van Houten a 6 -inch shale lies between this conglomerate and the coal; and in the Willow mine, which extends from Willow Canyon to this drill hole, the conglomerate is either on the coal or very close to it. (See p. 96.) A prospect opening in the point east of Schomburg Creek shows the conglomerate resting on the coal, which is here nearly 8 feet thick; but east of this point the coal was not observed. There is no doubt that the coal bed was once continuous in the vicinity of Crow Creek canyon, but it is equally doubtless that it is not continuous at the present time. Through the Crow Creek district. the basal conglomerate of the Raton formation is persistent in character and occurrence and forms a prominent, cliff that is easily traced from place to place. It is clearly unconformable on the Vermejo formation, resting in some places on shale which overlies the main coal, in other places on the coal, and in still other places on beds that normally underlie the coal.

\section{LOCALITY 40.}

East of Schomburg Creek the Vermejo thins, and about half a mile north of locality 40 it is 15 feet thick. A little farther south the conglomerate rests on coal 1 foot 6 inches thick, and still farther south on coal only a few inches thick. Where section 40 was measured the Vermejo formation is about 3 feet thick, and a few hundred feet farther to the east it is absent and the conglomerate rests on the Trinidad sandstone.

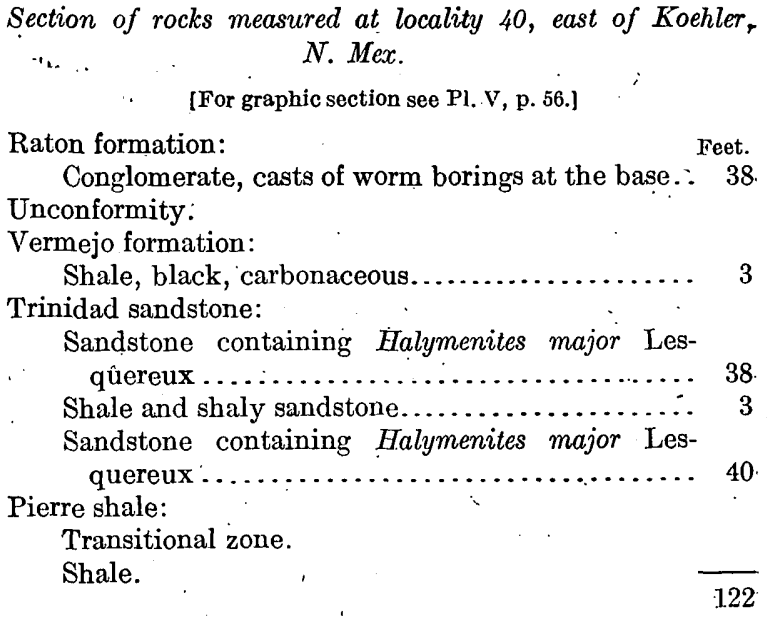

For about half a mile east and north of locality 40 the rocks are well exposed; and the relation of the conglomerate, which rests on the Trinidad except in a few places where a foot or two of dark shale intervenes, is plainly discernible. These irregular masses of shale make. the unconformity between the Trinidad and the basal conglomerate of the Raton very conspicuous, especially where the base of the conglomerate extends diagonally across the edges. of the horizontally bedded shale.

\section{VAN HOUTEN AREA.}

At Van Houten is located the Willow mine, one of the largest producers of the St. Louis, Rocky Mountain \& Pacific Coal Co. The unconformity between the Raton and Vermejo formations is nearly as conspicuous here as it is near Koehler. Indeed, these two areas are. probably the best and most accessible in the Raton field for examining the structural relations of these formations.

\section{VAN HOUTEN. \\ IOCALITY 41.}

For about 2 miles northeast of locality 40 the rocks appear from a distance to be poorly exposed, especially in the Falls Creek embayment, and no attempt was made to examine them; but in an eastward-facing escarpment maintained by the resistant rocks of the Trinidad sandstone and the Raton formation north of Falls Creek, the rocks are well exposed.

The best exposure found between Falls Creek and Willow Creek is at locality 41 , about, 


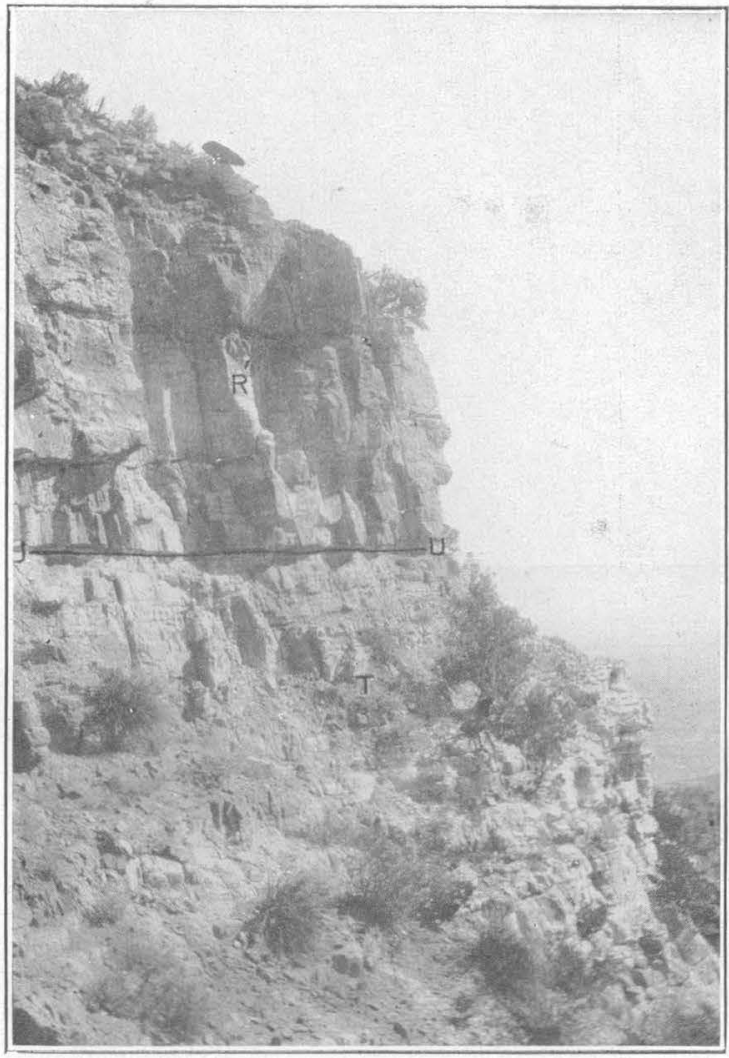

A.

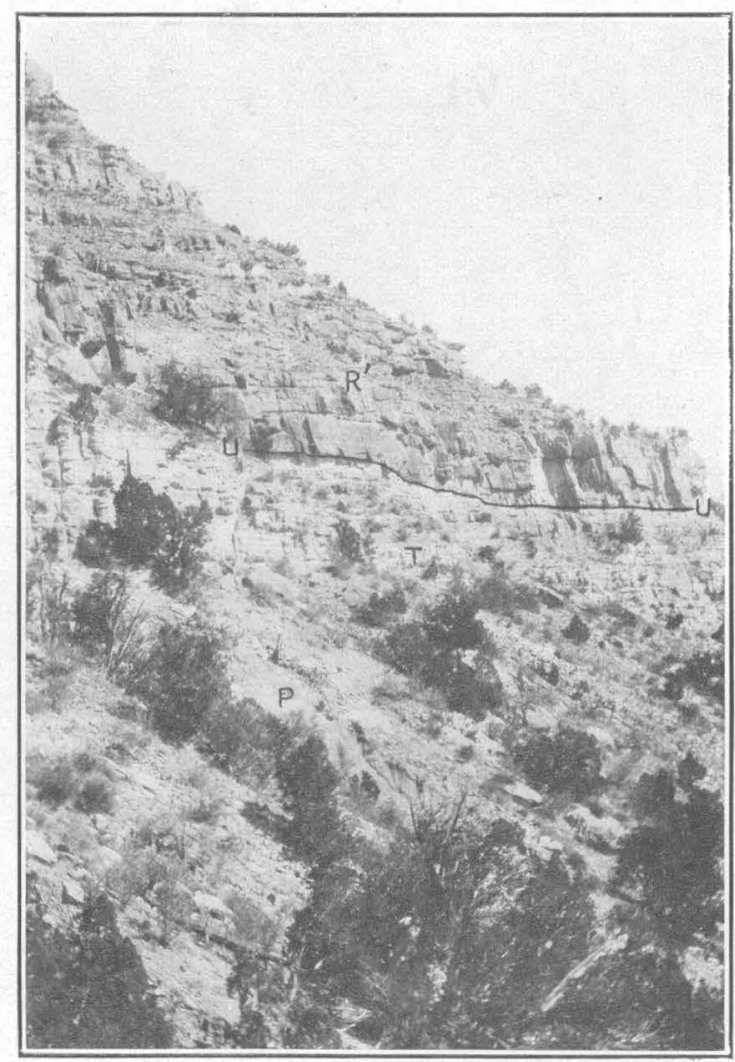

B.

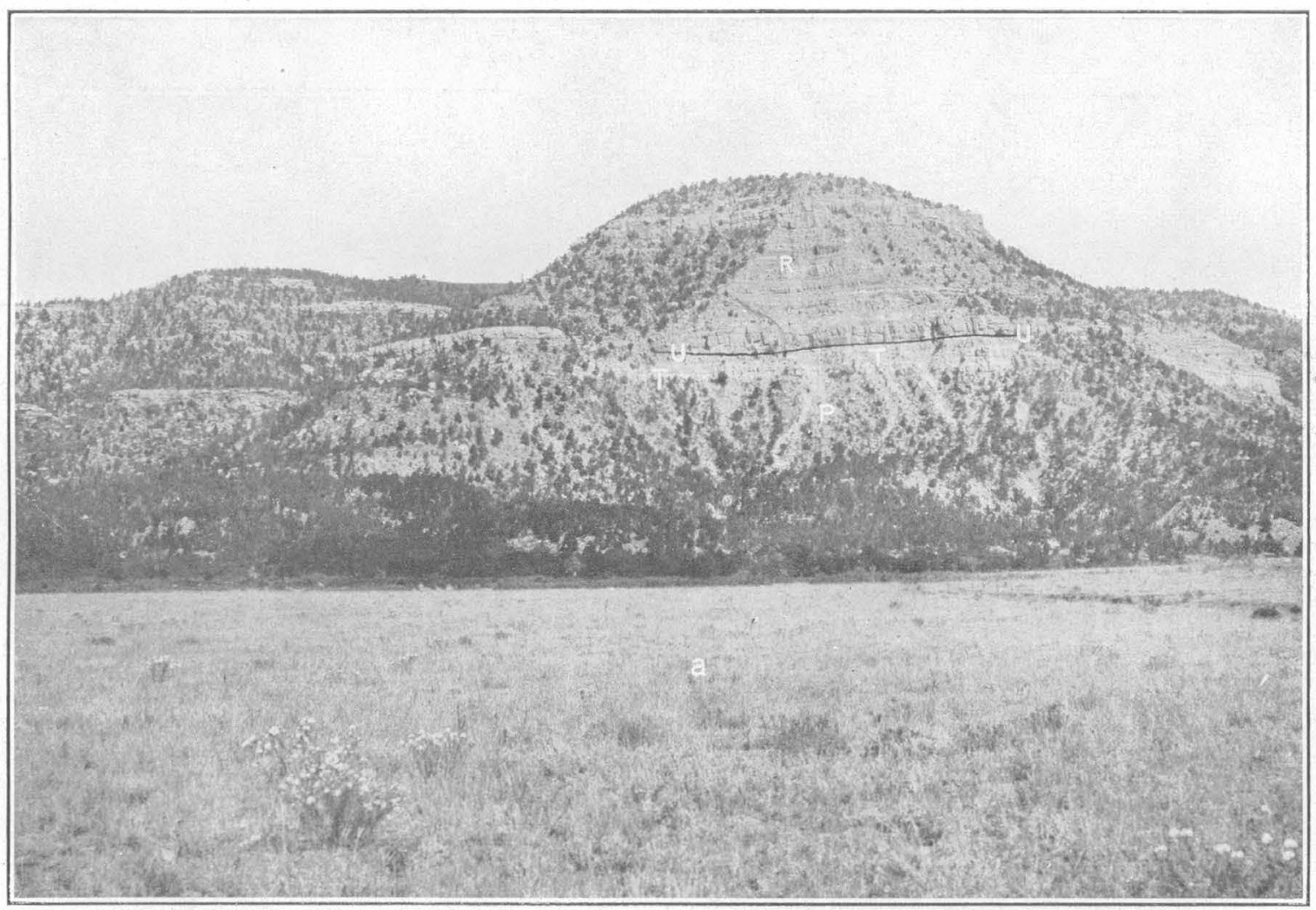

C.

$A,-B$, ROCKS ABOUT 3 MILES SOUTHEAST OF VAN HOUTEN, N. MEX. $C$. GENERAL VIEW OF CLIFFS SHOWN IN NEAR VIEW IN A AND $B$.

The Vermejo formation is absent and the Raton formation rests unconformably upon the Trinidad sandstone. a, The plains; P. Pierre shale; T, Trinidad sandstone; $U$, unconformity; $R^{\prime}$, basal conglomerate of the Raton formation; R, Raton formation. 


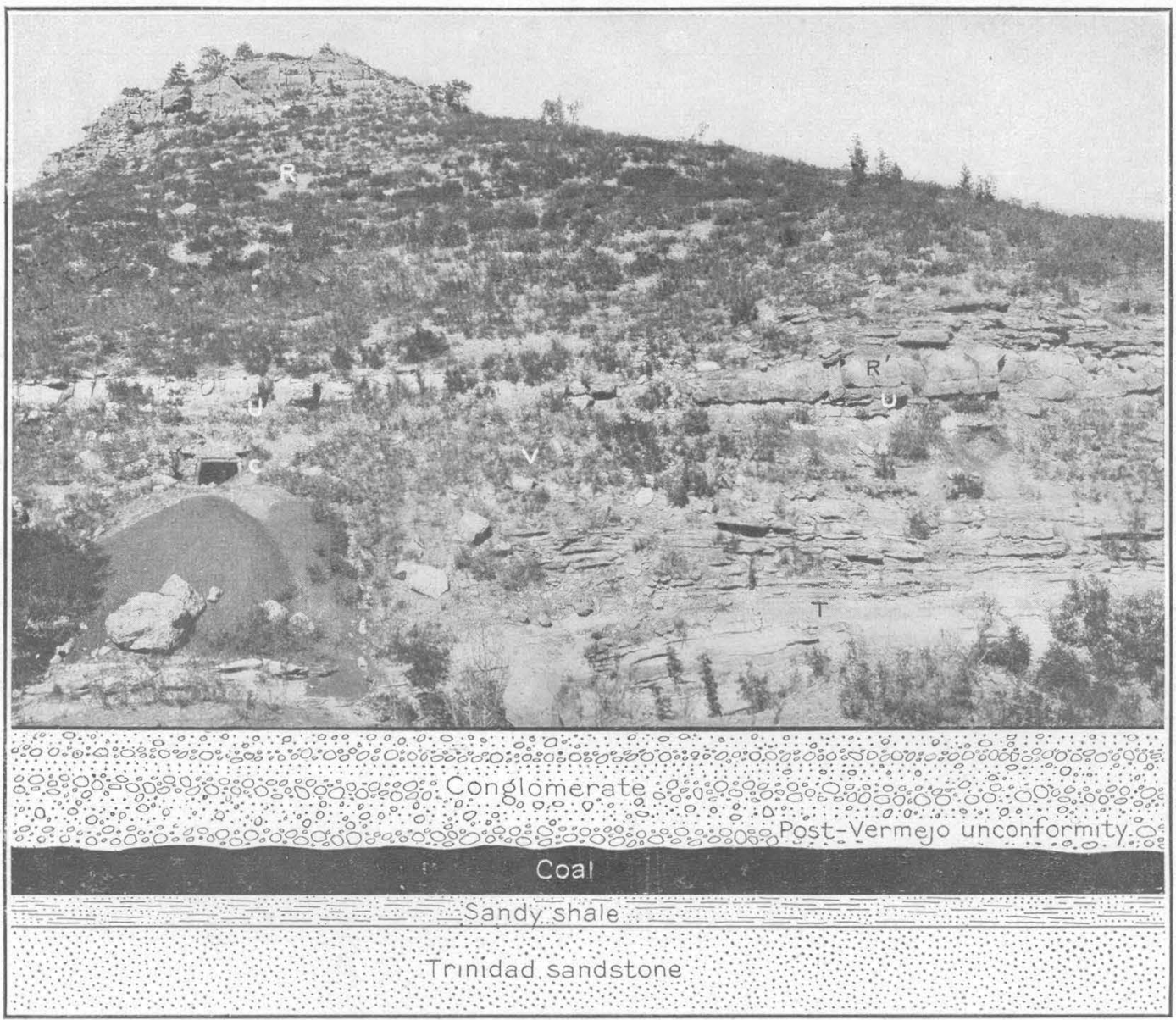

A. NORTH WALL OF CANYON AT THE MINE.

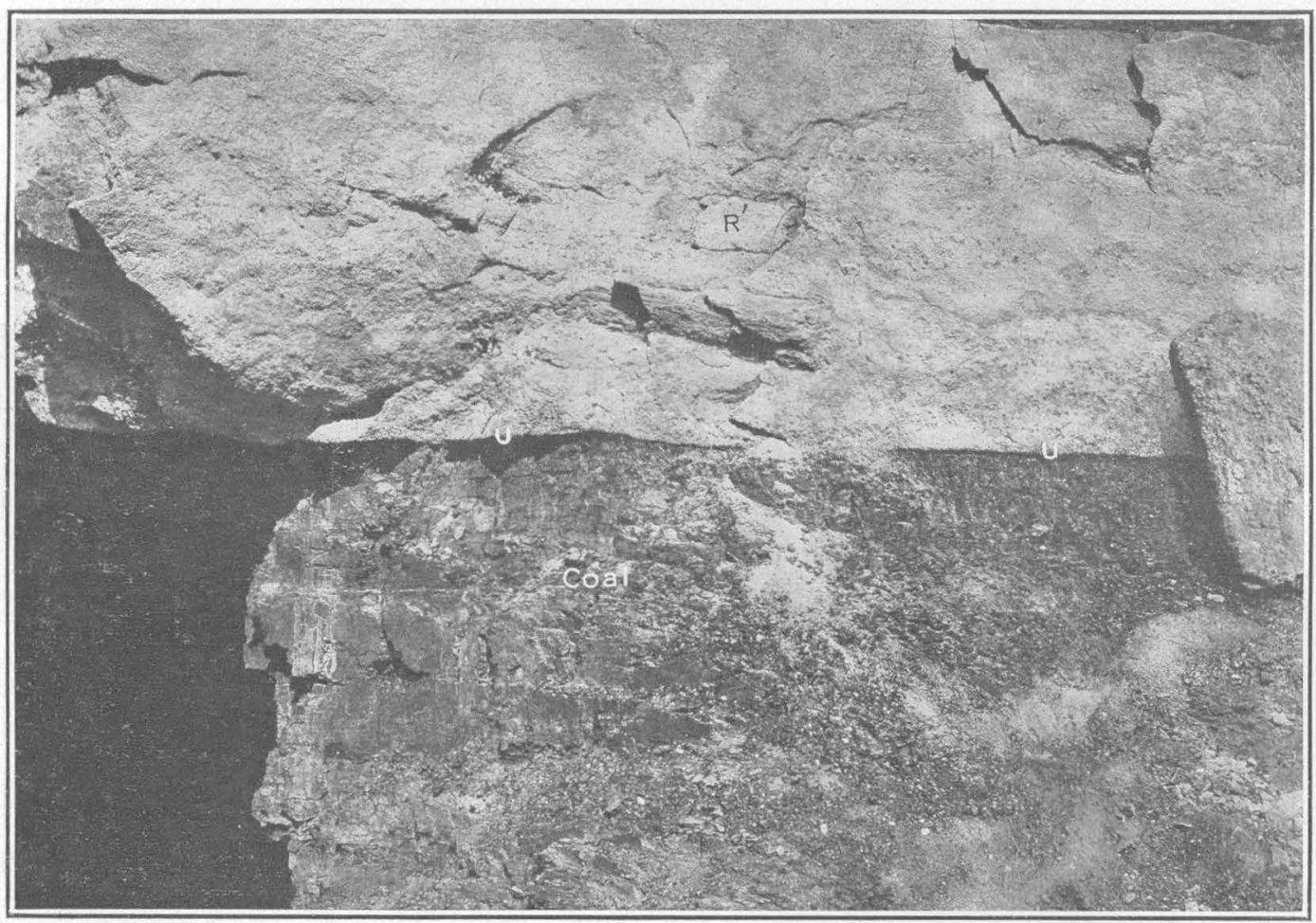

B. ONE OF THE OPENINGS OF THE MINE, SHOWING THE CONGLOMERATE RESTING ON COAL.

Structural Relations of formations at Willow mine, Van Houten, N. MEX.

$T$, Trinidad sandstone: $V$, Vermejo formation: $c$, coal bed in the Vermejo: $U$, unconformity between the Vermejo and the Raton formations; R, Raton formation; R', basal conglomerate of the Raton formation. 
3 miles northeast of locality 40 . The Pierre shale forms long barren slopes at the foot of the mesa, and the overlying transitional beds of alternating sandstone and shale are characteristically developed. The Trinidad sandstone is also normally developed and appears as a white band in the face of the cliff. There are no rocks at this locality that can be referred to the Vermejo, and the basal conglomerate of the Raton formation rests unconformably on the Trinidad sandstone. (See Pl. VIII, $A, B$.)

There are few places in the Raton coal field where the unconformity is so conspicuously exposed as in the escarpment at this' place. In Plate VIII, $C$, the photograph for which was taken from a point half a mile or more from the face of the cliff the line of unconformity would scarcely be distinguished by one unfamiliar with the rocks themselves, but in Plate VIII, $A, B$, which presents nearer views of parts of the same exposure, the line of unconformity is plainly discernible. The horizontally bedded Trinidad sandstone has obviously been eroded and the conglomerate lies diagonally across the truncated layers. The conglomerate is harder than some of the neighboring rocks and in some places juts out beyond the underlying sandstone. Near the point where the photographs reproduced in Plate VIII were taken the following section was measured:

Section of rocks measured at locality 41, in bluffs of mesa about 2 miles southeast of Van Houten, N. Mex.

[For graphic section soe I'ls. V, p. 56 , and X, p. 108.]

Raton formation: Ft. in:

Sandstone, massive, cliff making. ....... 70

Shale, soft, with thin beds of sandstone.... 50

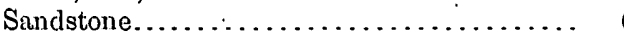

Shale.......................... 8

Sandstone, thinly bedded................ 12

Shale.......................... 12

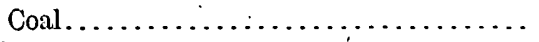

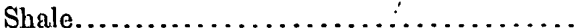

Sandstone, thin bedded near top, massive

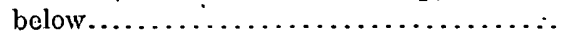

Shale, carbonaceous, with thin beds of coal....

Sandstone...................

Shale, black. . .................. 1

Sandstone, coarse grained, massive, cliff mak-

ing, locally conglomeratic.............

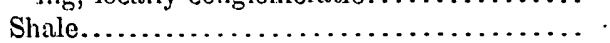

Sandstone, white, coarse grained, friable....

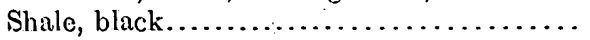

Conglomerate and coarse-grained sandstone. .

Unconformity.
Trinidad sandstone:

Sandstone containing Halymenites major Les-

quereux........................ 71

Pierre shale:

Transitional zone.

Shale.

4516

The basal conglomerate of the Raton formation is here about 50 feet thick and is hard, massive, and resistant. It consists of a matrix of coarse sand in which siliceous pebbles occur in more or less irregular masses. So far as observed, the pebbles are most numerous near the base but are found here and there through a thickness of about 50 feet. At this locality they are not confined to the base of the Raton formation as they appear to be in many places. Also, pebbles were found 130 feet above the base of the formation.

The capping rock of the mesa is the massive cliff-making sandstone that forms an almost continuous escarpment from Cimarron to Raton. The softer shaly beds described from many other localities as occurring between the conglomerate and the overlying cliff-making sandstones are characteristically developed at this locality and carry coal at two horizons. At the lower horizon only thin beds were found, but at the higher a bed occurs 2 feet 6 inches thick. Although this coal bed is about 220 feet above the base of the Raton formation it is probably to be correlated in a general way with the bed described in several of the foregoing sections as occurring 110 to 150 feet above the base of this formation. The absence from this locality of rocks referable to the Vermejo, considered in connection with their occurrence on either side of it and the unusual thickness of the conglomerate; suggests that the conglomerate was deposited in a local depression, perhaps a valley of erosion. The top of the conglomerate may be regarded as a gradéd plain on which the succeeding beds were deposited, and, for purposes of correlating the coal beds above the conglomerate, the vertical distances from this plain to the coal should be considered. With this in mind, it seems very probable that the main coal bed of this section may be the equivalent of the coals holding similar positions farther south. (See Pl. X, p. 108.)

\section{LOCALITY 42.}

For nearly 2 miles north and west of locality 41 the relations of the formations are appar- 
ently unchanged. At locality 42 , in the west wall of the south fork of Willow Canyon, the basal conglomerate of the Raton formation rests on the Trinidad sandstone, but immediately to the north the thin edge of the coalbearing shales of the Vermejo occurs between the conglomerate and the Trinidad, underlying the conglomerate with conspicuous unconformity. (See fig. 3.) At this point small

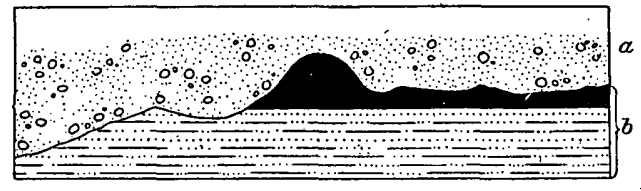

FIGURE 3:-Sketch showing unconformity at the base of the Raton formation in Willow.mine, near Van Houten, N. Mex. a. Conglomerate of the Raton formation, resting on $(b)$ the coal and underlying shale of the Vermejo formation.

fragments of coal were found in the conglomera.te, apparently resulting from erosion of the coal bed. A few hundred feet farther north a bed of coal 6 feet thick occurs between the Trinidad and the conglomerate. This coal is the one mined at Van Houten and the one which, by means of this development, is known to be the same bed of coal as that described from the vicinity of locality 39 and elsewhere in Crow Creek Canyon.

West of locality 42 the coal bed has been penetrated by mine entries over an area $1 \frac{1}{2}$ miles east and west and 2 miles or more north and south. These entries offered an excellent opportunity for observing the relation of the coal bed to the overlying conglomerate. In the part of the mine nearest locality 42 the conglomerate rests on the coal, which ranges in thickness from less than $2 \frac{1}{2}$ feet to about 15 feet. At the time of the investigation mining operations had not been carried beyond the point where the coal is much less than $2 \frac{1}{2}$ feet; but from the relations observed at the surface at locality 42 it is certain that the coal disappears somewhere between this locality and the point where mining operations ceased.

Where the conglomerate rests on the coal the contact is very uneven, evidently due to crosion of the bed previous to the deposition if the conglomerate upon it. This is particularly conspicuous in the part of the mine that lies immediately west of locality 42 ; where there are grivel-filled depressions 2 feet or more in depth in the upper surface of the coal. (See fig. 4.) There are also a grent many dikelike bodies of sandstone and conglomerate in the coal, usually connected with the conglomeratic sandstone that here forms the roof of the mine. An attempt has been made in figure 4 to show the relations of several of these bodies to the coal bed. The drawings are made from sketches and measurements made in the mine. Some of the bodies are more or less irregular (see fig. $4, A$ ) and have the general appearance of dikes; others (ing. 4, $G, H$ ) extend only part way through the coal. Some
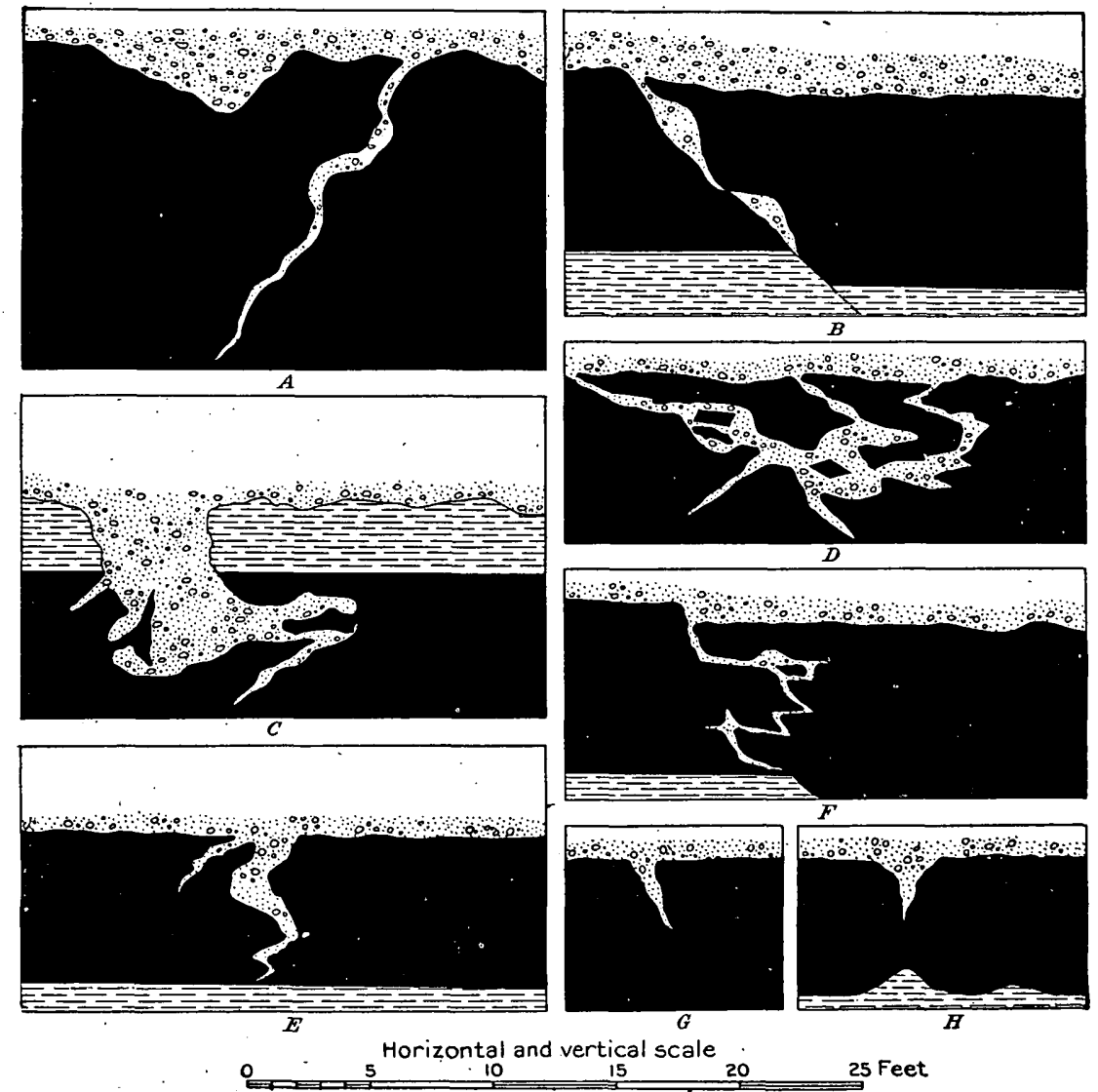

FIGURE 4.-Diagrams showing irregularities in coal bed in Willow mine, near Van Houten, N. Mex. Coal (black) of the Vermejo formation lies beneath the conglomerate of the Raton formaticn. 
are very irregular and complicated in design and range in thickness from a fraction of an inch to 4 or 5 feet. Some of the larger masses are conglomeratic, and in some places (fig. $4, C$ ) considerable masses of conglomerate cut through such shale as may overlie the coal and well into or completely through the coal bed.

In several places (fig. $4, D$ ) detached masses of coal with rough surfaces and sharp angular edges, as if torn from previously consolidated conl, are included in the sand. In two places the sandy inclusions were seen associated with slight displacements by faulting. In one of these (fig. 4, F) the displacement appeared at both the upper and lower surfaces of the coal bed. In another (fig. $4, B$ ) the lower surface showed a throw of a foot or more, but the offset at the upper surface had evidently been eroded away. In no place was the faulting observed to extend to the overlying conglomerate. Another fault in the coal bed is shown in figure 5 .

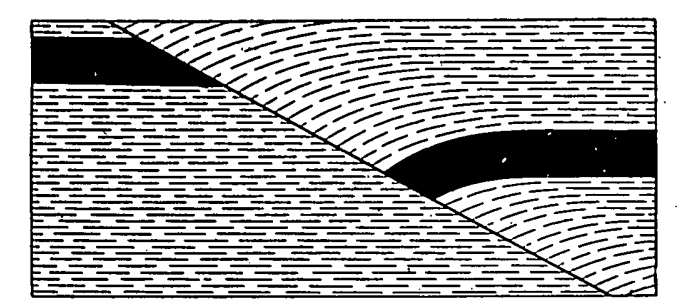

FIGURE 5.-Fault in coal of Willow mine, near Van Houten, N. Mex.

The origin of these dikelike bodies in the coil is not understood, but it is obvious that they are associated in some way with the deposition of the conglomerate. The fact that the conglomerate was deposited upon an eroded surface indicates that the cavities may have been open fissures such as are frequently found in rocks exposed at the surface, and that these fissures were filled at the time the conglomerate was laid down. Furthermore, the fact that the faults are traceable through the coal and into the underlying shale but not into the con"glomerate points to the inference that the cavities may be due to rock movements previous to the consolidation of the conglomerate. The angularity of the blocks of coal included in the masses of sandstone seems to prove that the bed from which they were derived had passed beyond the stage of peat; or, in other words, that it was a bed of consolidated coal when the conglomeratic sandstone found its way into the cavities.

$$
47019^{\circ}-17-7
$$

LOCALITY 43.

A favorable opportunity was afforded at locality 43 , at one of the openings of the Willow coal mine, to examine the relations of the basal conglomerate of the Raton formation to the main coal bed of the Vermejo. At this mine the coal, 13 feet thick, is. overlain by the conglomerate and exposed at the surface: (See Pl. IX, $A, B$.) The upper part of the Trinidad sandstone is somewhat fissile near this locality and grades into the Vermejo through a series of alternating layers of sandstone and shale. In a former publication ${ }^{215}$ the writer included these alternating layers in the Vermejo and drew the line for the top of the Trinidad at the top of the massive sandstone. However, after further examination, he now draws the boundary 5 feet below the bottom of the coal. The section follows:

Section of.rocks measured at locality 49 , near Van Houten, N. Mex.

[For graphic section see Pl. V, p. 56.]

Raton formation:

Conglomerate.......................

Unconformity.

Vermejo formation:

Coal................................ 13

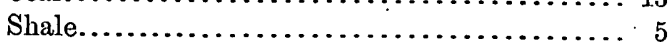

Trinidad sandstone:

Sandstone, fossiliferous near top. $\quad 38 \pm$

The underside of the conglomerate at locality 43 is covered with wormlike bodies, which are probably the casts of worm borings, though their significance is not known. 'Similar mark-

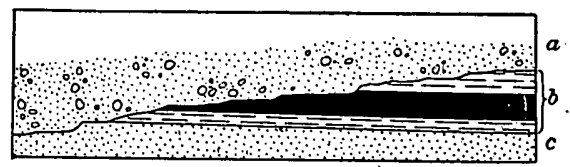

FIGURE. 6.-Sketch showing unconformity at the base of the Raton formation in Willow mine, near Van Houten, N.. Mex. a, Raton formation; $b$, Vermejo formation; $c$, Trinidad sandstone.

ings were found on the underside of the conglomerate at several of the localities previously described: Although no shale separates the conglomerate from the coal at locality 43 , shale appears between these beds a little farther north and is reported by the mining engineers at Van Houten as increasing in thickness toward the north and west. At the northwestern extremity of the mine workings 15 feet of shale was reported between the coal and the conglomerate. (See fig. 6.) 
LOCALITY 44.

The coal of the Vermejo formation has been prospected in many places north and east of Van Houten. It has been considerably disturbed in several places by igneous intrusions which have coked the coal and a little farther to the north have turned it to graphite. In the north wall of North Willow Canyon, at locality 44 , about $1 \frac{1}{2}$ miles northeast of locality 43 , a short section, including the Vermejo, was measured as follows:

Section of rocks measured at locality 44, North Willow Canyon, near Van Houter, N. Mex.

[For graphic section see Pl. V, p. 56.]

Raton formation:

Feet.

. Igneous rock (basalt).................... 20

Conglomerate.......................... 4

Unconformity. 24

Vermejo formation:

Shale, black, carbonaceous................ 10

Igneous rock (basalt)...................... 10

Shale................................ 2

Coal.............................. 7

Shale, with intrusive sheets of igneous rocks..., 20

Trinidad sandstone........................ $100 \pm$

Pierre shale:

Transitional zone.

Shale.

\section{LOCALITY 45}

$\cdot 173 \pm$

For some distance east of locality 44 the conglomerate and overlying beds of the Raton formation are well exposed, but because of the presence of surface débris few satisfactory observations on the lower rocks could be made. At locality 45 , about $1 \frac{1}{2}$ miles from locality 44 , a section was measured from the conglomerate to the cliff-making sandstones at the top of the mesa. The horizon of the main coal bed below the conglomerate was recognized, but the coal is burned at the outcrop. The correlation of the beds at this locality is made on the basis of the conglomerate, which was traced almost continuously along the side of the mesa from locality 44 . The section follows:

Section of rocks measured at locality 45, about 2 miles northeast of Van Houten, N. Mex.

[For graphic section see Pl. V, p. 56.]

Raton formation:

Sandstone, cliff making.

Shale and igneous rock

Sandstone and igneous rock....................

Shale and sandstone in alternating beds...........

Sandstone.
Raton formation-Continued.

Shale................................ 25

Sandstone............................. 27

Igneous rock (basalt) ...................... 3

Shale, carbonaceous, with thin beds of coal...... 3

Shale, with thin beds of sandstone............. 60

Sandstone, conglomeratic at the base........... 20

Unconformity.

Vermejo formation:

Coal, burned at outcrop................. ?

Shale, sandy, carbonaceous, thickness not determined.

Trinidad sandstone.

RED RIVER PEAK.

LOCALITY 46.

Another section extending from the basal conglomerate of the Raton formation to the top of the mesa was measured at locality 46 , about $1 \frac{1}{2}$ miles east of locality 45 . The Trinidad sandstone and the conglomerate were recognized, as was also some carbonaceous shale between them, but no coal was found. It is probable that the coal was eroded away at this locality previous to the formation of the conglomerate, as.it, together with all of the rocks of the Vermejo, was a little farther east. The section follows:

Section of rocks measured at locality 46, half a mile west of Red River Peak, N. Mex.

[For graphic section see Pl. v, p. 56.]

Raton formation:

Igneous rock (diabase) $\ldots \ldots \ldots \ldots \ldots \ldots \ldots \ldots, 15$

Sandstone and igneous rock ............... 50

Shale ................................ 20

Sandstone, cliff making................... 50

Shale, mostly covered ................... 60

Sandstone, white, massive ................. 40

Shale, locally carbonaceous............... 30

Sandstone, cliff making. . . . . . . . . . . . . . . . . 20

Shale, not well exposed ................... 20

Sandstone, cliff making, conglomeratic......... 20

Unconformity.

Vermejo formation:

Shale, locally carbonaceous, thickness not determined.

Trinidad sandstone:

A little way east of locality 46 , in the steep slopes of Red River Peak, the rocks from the top of the Pierre shale to a horizon well up in the Raton formation are well exposed. The Pierre and the Trinidad are characteristically developed, but no rocks were found that can be referred to the Vermejo. The basal conglomerate of the Raton formation rests unconformably upon the Trinidad. This relation 
was observed in several places around Red River Peak: The rocks of the Raton above the conglomerate consist of sandstone and shale, in which have been intruded many sheets of igneous rock.

\section{LOCALITY 47.}

For one-half mile or more north of Red River Peak the basal conglomerate of the Raton formation rests on the Trinidad sandstone and together they form a prominent cliff. The upper part of the Pierre shale is exposed in many places near this locality and is fossiliferous, but only one species (Inoceramus vanuxemi Meek and Hayden), found about 400 feet below the top of the shale (U. S. Geol. Survey fossil locality 5602), was collected. The Trinidad sandstone is present and contains the usual fucoids, but it is much thinner here than it is at neighboring localities where the Vermejo occur above it. At locality 47, about one-half mile northeast of locality 46 , a critical examination was made of the rocks near the contact of the Trinidad and the conglomerate, and the following section measured:

Section of rocks measured at locality $4 \%$, north of Red River Peak, N. Mex.

[For graphic section see Pl. V, p. 56.]

Raton formation:

Sandstone, hard, quartzose, conglomeratic... 20 " 0 Unconformity (?).

Vermejo formation:

Sandstone, yellowish brown, coarse grained, poorly consolidated....................

Shale, sandy, carbonaceous, resembling soil (possibly an old soil horizon, representing. base of Raton formation)...............

Unconformity.

Trinidad sandstone:

Sandstone, soft, friable, greenish in color near the top, apparently from surface weathering, grading downward to white, massive sandstone; contains Halymenites major Les-

Pierre shale: quereux........................ 350

Transitional zone.

Shale. 350

sun

anything seen elsewhere in the Trinidad, may represent an old surface soil. For about 35 feet above this dark layer the rocks consist of sand but do not resemble the Trinidad, nor could any Halymenites be found in them. They are soft, friable, and yellowish-brown in color, like many of the sandstones of the Raton formation, and are notably cross-bedded. (See fig. 7.) Lying on this yellowish friable sand with uneven base is the typical basal conglomerate of the Raton formation.

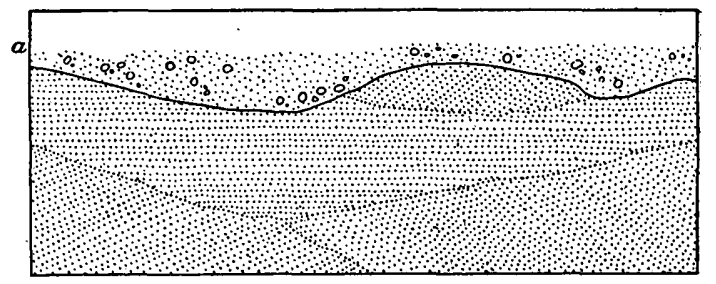

FIGURE 7.-Sketch showing unconformity at the base of the Raton formation near Red River Peak, N. Mex. a, Raton formation overlying beds of doubtful origin that occur between typical Raton and typica! Trinidad.

All things considered it seems probable that the erosion which removed the Vermejo in this vicinity cut deep into the Trinidad sandstone and that the altered aspect of the upper part of this sandstone is due to surface weathering. The writer reached the conclusion in the field that the dark layer above the Trinidad is probably an old soil horizon and nothing has been learned since that time to alter this conclusion. The cross-bedded sand below the conglomerate has the appearance of streamdeposited sand and probably was the first sediment deposited at this locality after the streams that had eroded away the Vermejo beds resumed deposition. For this reason the sands are included in the Raton formation as shown by the correlation lines on Plate V (p. 56).

\section{CANADIAN CANYON AND GARDINER.}

\section{GENERAL FEATURES.}

The canyon of Canadian River (or Red River Canyon, as it is locally called) forms a deep embayment in the coal measures. South of this river igneous rock has been intruded into the coal measures at several horizons and in some places has changed the coal to graphite. However, in the western part of the embayment the coal occurs in normal condition. North of Canadian Canyon the coal beds of the Vermejo formation, locally known as the Raton coal,

The Trinidad sandstone is here only 35 feet thick, as compared with 100 feet or more to both the north and the south. This sandstone is dark near the top and is otherwise different in appearance from the sandstone as usually developed. At the top a thin irregular layer of dark sandy carbonaceous material, unlike 
have been worked for many years at Gardiner. The mine was not in operation at the time of the writer's visit, but the records and a number of drill records were placed at his disposal and aided materially in the interpretation of surface phenomena.

The Raton coal is ordinarily referred to as a coal bed and the assumption that there is a single continuous bed finds some confirmation in the fact that workable coal has been found at about the same horizon at nearly all the localities prospected in the mining district. However, by inspection of a considerable number of mine maps, drill records, and other data, it seems practically certain that the Raton coal consists of a series of close-lying interlocking lenses rather than of one bed.

\section{COTTONWOOD CANYON.}

LOCALITY 48

About a mile north of locality 4, the Trinidad sandstone seems to regain its normal thickness and the Vermejo beds again appear above it. About one-fourth mile farther north, in the point of the mesa just south of Cottonwood Creek, a short section was measured (locality 48). The top of the Trinidad is exposed here, and a few feet.of carbonaceous. shale occurs between it and the basal conglomerate of the Raton formation, but no coal was found and the conglomerate rests unconformably on the shale. The section follows:

Section of rocks measured at locality 48 in Cottonwood Canyon, N. Mex.

[For graphic section see Pl. V, p. 56.]

Raton formation:

Igneous rock $(c$

Igneous rock (basalt) ....................... 20

Shale, not well exposed.................... 40

Shale, carbonaceous, with thin beds of coal...... 4

Shale, partly covered ................... 20

Sandstone, cliff making, conglomeratic at base... 15

Unconformity.

Vermejo formation:

Shale, carbonaceous. $\ldots \ldots \ldots \ldots \ldots \ldots \ldots \ldots .20$

Sandstone, rusty ........................ 3

Shale, carbonaceous..................... 2

Trinidad sandstone........................
In Cottonwood Canyon west of locality 48 the rocks of the Vermejo were seen in many places, but did not everywhere contain coal. $A$ bed 2 feet thick overlain by 20 feet of conglomeratic sandstone was found near the forks of Cottonwood Creek. Half a mile farther west, in the north fork of the canyon, coke and graphite resulting from the metamorphism of the coal were found beneath 15 feet of conglomerate. Over a large area adjoining Cottonwood Canyon the main coal was transformed to graphite by intrusions of igneous rock. Half a mile farther upstream, or a mile west of the forks of the canyon, the writer's assistant (Mr. C. S. Blair) found an exposure of the rocks in which the basal conglomerate of the Raton formation lies across the eroded edges of the Vermejo beds. (See fig. 8.) At one end of the exposure the conglomerate lies on the sandstone, which is shown to belong to the Trinidad by the presence of the characteristic fossil

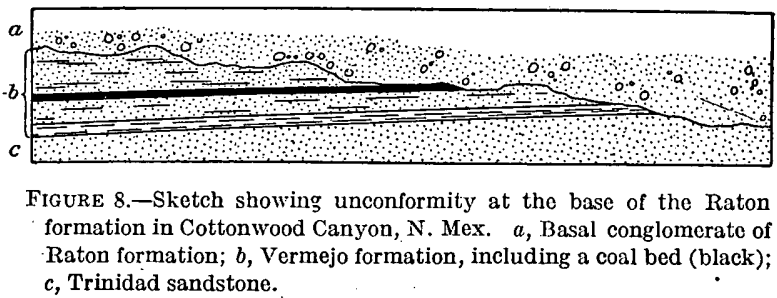

c, Trinidad sandstone.

fucoid Halymenites major Lesquereux. The conglomerate about 20 feet thick lies nearly horizontal, but the underlying beds $\operatorname{dip} 3^{\circ} \mathrm{W}$. The principal coal bed of the Vermejo, which is here 28 feet above the top of the Trinidad sandstone, together with a considerable thickness of the Vermejo overlying the coal, was eroded and the conglomerate deposited across the truncated beds. The occurrence of the coal 28 feet above the Trinidad here explains its absence from section 48 , in which the base of the conglomerate is only 25 .feet above this sandstone.

LOCALITY 49.

A short section was measured in the north wall of Cottonwood Canyon at locality 49 about three-fourths of a mile northwest of locality 48 . The Trinidad sandstone is exposed here and the rocks of the Vermejo were recognized, although the coal once contained in them has been changed to graphite by the intrusion of 
igneous rock. A massive sandstone 20 feet thick probably constitutes the base of the Raton formation, but no pebbles were noted in it. This section and several others in the same general region were examined before the full significance of the structural relations of the formations to each other was known, and in the absence of a well-developed conglomerate the correlation of this section with others (see $\mathrm{Pl} . \mathrm{V}$ ) is open to question. The section is as follows:

Section of rocks measured at locality 49 in north wall near the mouth of Coltonwood Canyon, N. Mex.

[For graphic section see P1. V, p. 56.]

Raton formation:

Feet.

Sandstone, cliff making.

Shale, carbonaceous, with thin beds of friable

sandstone.......................... 55

Sandstone, hard, cliff making. .............. 20

Probable unconformity. . 100

Vermejo formation:

Shale............................... 30

Igneous rock, containing masses of graphite......

Shale, black, carbonaceous. . . ...............

Shale ...............................

Trinidad sandstone.

In Cottonwood Canyon west of this locality the bed of graphite was opened several years ago. $\Lambda$ brief account of it has been published by the present writer. ${ }^{236}$.

\section{SUGARLOAF MOUNTAIN. LOCAIITY 50.}

In a section at locality 50, about one-half mile northeast of locality 49 , a conglomerate was found in its normal relation to the other stratified rocks and, together with the Trinidad sandstone, renders the correlation of this section with neighboring ones relatively certain. The section follows:

Section of rocks measured at locality 50, Sugarloaf Mountain.

$$
\text { [For graphic section see Pl. V, p. 56.] }
$$

Raton formation:

Shale and igneous rock............... 40

Shale, baked ..................... 20

Igneous rock........................ 20

Shale, carbonaceous in places. ............ 60

Sandstone, cliff making, conglomeratic at the-

base......................... 20

Unconformity.
Vermejo formation: Feet.

Igneous rock $\ldots \ldots \ldots \ldots \ldots \ldots \ldots \ldots \ldots \ldots . \ldots \ldots$

Shale. ......................... 10

Igneous rock. ....................... 2

Shale, carbonaceous.................. 3

. . . . . .

Trinidad sandstone:

Sandstone....................... 20

Igneous rock...................... 2

Sandstone.

For a distance of nearly 4 miles northwest of locality 50 the rocks are not well exposed. Several small outcrops were found where intrusive sheets of igneous rock had changed the coal to coke and graphite. However, in Coal Canyon the metamorphosing forces seem to have been less intense and coal is found there in normal condition.

An attempt was made to trace the line of unconformity between the Vermejo and Raton formations in Red River canyon above the mouth of Coal Canyon, but the sedimentary beds have been so much disturbed in places by the intrusion of igneous rock that the attempt was not wholly successful. In several places unconformable relations were noted, but in the absence of a well-developed conglomerate in the beds immediately above the unconformity, it was not satisfactorily demonstrated that these are parts of the general unconformity between the Vermejo and the Raton formations. They may be local unconformities such as are found in many places within the Raton formation. An exposure on the north bank of Canadian River near the mouth of Potato Canyon shows an unconformity very near to where one should occur at the base of the Raton formation, but the line can not be traced continuously and there is doubt as to the exact horizon.

Many remarkably perfect impressions of palm leaves occur in Canadian Canyon. Sabal? leei Knowlton was collected near the mouth of Jones Canyon (U. S. Geol. Survey fossil locality 5235), and Magnolia magnifolia Knowlton, Platanus aceroides Göppert, and Rhamnus cleburni Knowlton were collected in the main canyon about a mile farther downstream (U. S. Geol. Survey fossil locality 5291). The palm leaves were too large to collect in toto. On the face of one block that had fallen from the cliff 
were observed several leaves, the largest of which is 57 inches long. A very perfect specimen of Anemia hesperia Knowlton (6533) was found here later.

\section{NOPTH WALL OF CANADIAN, CANYON TO GARDINER. \\ LOCALITY 51.}

In the north wall of Canadian Canyon the basal conglomerate of the Raton formation was recognized in several places, where it lies unconformably on the Vermejo. At locality 51 it is conspicuously exposed above a thick bed of yellow sand similar to that described north of Red River Peak (locality 47) as belonging probably to the Raton formation. The characteristic rocks of the Vermejo formation are below this bed of sand. Where the following, section was measured igneous rock has been intruded into the coal bed and has changed it to coke and graphite.

Section of rocks measured at locality 51, Canadian Canyon. [For graphic section see Pl. V, p. 56.]

Raton formation:

Sandstone, hard, quartzose, coarse grained, conglomeratic .......................... 20

Sandstone, yellow, coarse grained, friable, poorly. consolidated.

Unconformity.

Vermejo formation:

Shale, carbonaceous, containing coal, coke, graphite, and sheets of intrusive igneous rock...... 20 Trinidad sandstone.

LOCALITIES 52-60.

East of locality 51, in Canadian Canyon, and thence northeastward beyond Raton the base of the Raton formation is only slightly conglomeratic and is not easily followed until its variations are intimately known. There is no question of its identity at locality 51, and its conglomeratic character east of Raton makes its recognition easy there, but between these extremities special care was necessary. In order that no mistake might be made in its identity it was traced step by step through this part of the field, and sections were measured at short intervals along the outcrop from the Trinidad sandstone up to it. The greater number of these sections have been plotted to the same scale and arranged in the order in which they occur along the outcrop in Plate V (p. 56). The numerals above correspond to the location numbers on the map. (See Pl. I, in pocket.) It is probable that all information necessary for the purposes of this paper is given sufficiently definite on this plate of sections, and written descriptions of most of the individual sections will be omitted. They will be described in groups.

The top of the Pierre shale is continuously exposed near Gardiner, but the sections were not extended downward to include it. The Trinidad sandstone is also present in characteristic development, forming a conspicuous white cliff in the side of the mesa. The Vermejo formation ranges in thickness from about 20 to 45 feet and contains one to four beds of coal, which collectively are known as the Raton coal. The basal sandstone of the Raton formation is variable in character, and the beds above it consist of a lower shaly group, in which the Sugarite coal bed of the Raton region occurs, and of an upper group of cliffmaking sandstones, which are the same as the sandstones previously described in several places as forming the top of the mesa.

The sandstone at the base of the Raton formation between Canadian River and Sugarite Canyon east of Raton is inconspicuous and is conglomeratic in only a few places, but in most places it is harder than the sandstones above and below it and is more or less quartzose. It consists of a yellowish-brown matrix of coarse sand, in which are lenses and irregular masses of clean white sand, usually somewhat harder than the matrix. This character was noted at no other horizon and was helpful in tracing the sandstone. From locality 51, where the basal sandstone of the Raton is conglomeratic, this sandstone was traced east and north along the outcrop continuously, except for short intervals where it was covered with brush. At locality 52 the sedimentary rocks are considerably disturbed by intrusions of igneous rock. At locality 53 they are less disturbed, and a section was measured which may be given in detail. No pebbles were found in the basal sandstone in this section, and without careful tracing its identity might easily have been mistaken. The section follows: 


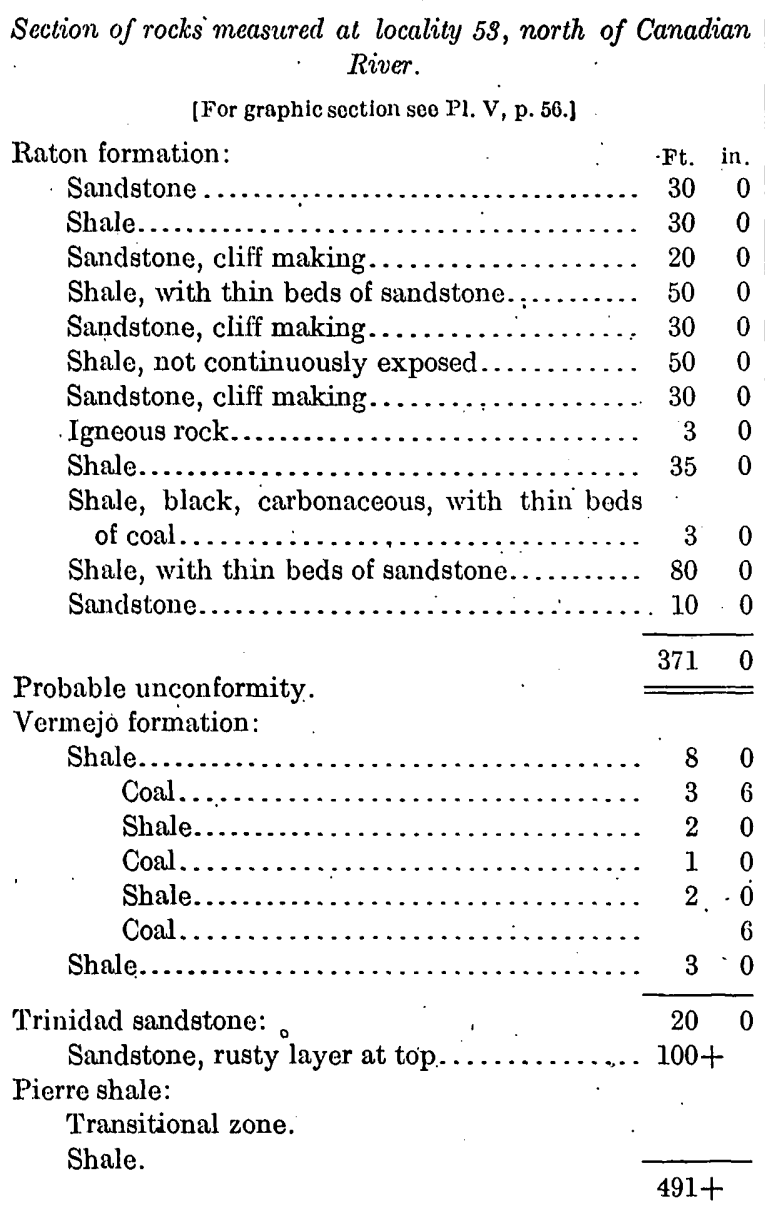

About 1 mile farther east, at locality 54, the same formations were measured, but at this locality the coal-bearing shales above the basal sandstone of the Raton formation are more perfectly exposed, and for the sake of the detail in this part of the section the description is included, as follows:

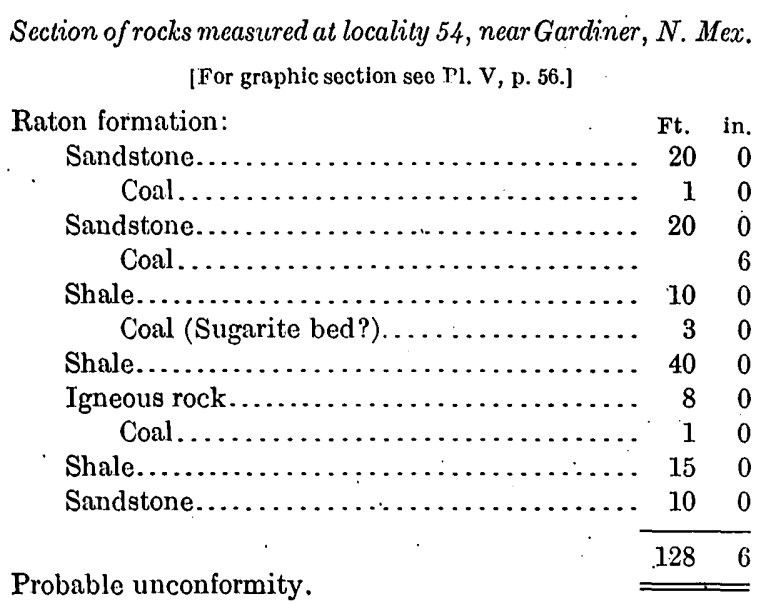

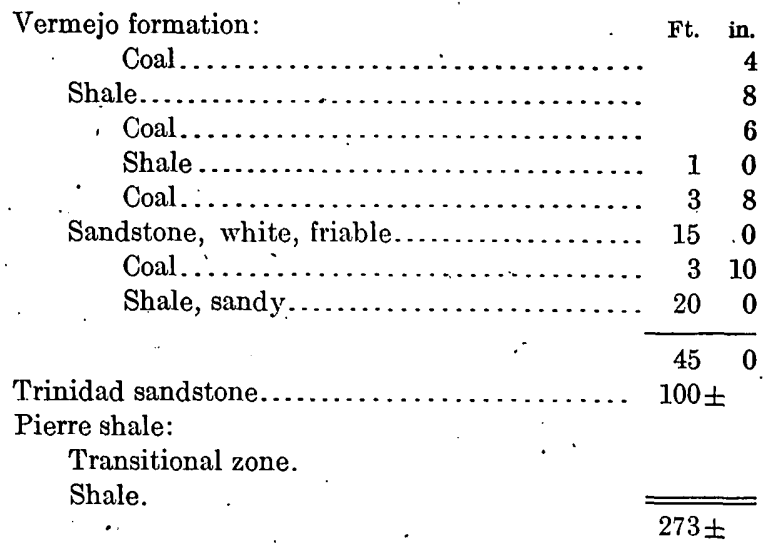

At localities 55 and 56 quartz and chert pebbles up to half an inch in diameter were found in the basal sandstone, but west of locality 56 the rocks are covered with brush at the outcrop and this sandstone was not traced continuously. However, it was identified without difficulty in the north wall of Gardiner Canyon, where it is locally conglomeratic and rests unconformably on the Vermejo, which here contains two thick beds of coal. Four short sections were measured north of Gardiner, and in all of them the conglomerate rests with uneven base on the Vermejo formation.

\section{DILLON CANYON AREA. GENERAL FEATURES.}

In Dillon.Canyon north of Gardiner the coal of the Vermejo formation (the Raton coal) has been extensively mined and many diamonddrill prospects have been put down at considerable distances back from the outcrop. By inspection of the records of the mines and of the drill holes, it appears that in this area.there are one to four beds of coal in the Vermejo formation, and they come and go in a manner that has proved difficult of explanation. Much more detailed examination is necessary before all of the anomalies, even in so restricted and well developed an area as the Dillon Canyon tract, can be satisfactorily explained, but the investigations described in this paper have proved that the absence of some of the coal beds in certain places is due to their removal by erosion previous to the deposition of the younger sediments.

The rocks of the Raton formation are well exposed in Seeley Canyon, and a section of them was measured for the purpose especially 
of comparison with the sections farther to the east which show the stratigraphic position of the higher coal beds. The Seeley Canyon section was measured before the nature of the basal sandstone of the Raton formation was known, and the base can not now be definitely located in the section. For this reason the section is not included in Plate V (p. 56), where the attempt has been made to show the relations of the Raton and Vermejo formations with all possible exactness. It has, however, been included in Plate X (p. 108), where the correlation of the higher beds is emphasized.

A bed of impure coal, probably to be correlated with the Sugarite bed, was found in Seeley Canyon 78 feet above the Raton coal. Near the top of the section, above the cliffmaking sandstones, coal was found which eridently represents the bed opened at Brilliant, a mining town in Dillon Canyon about 4 miles northwest of Blossburg. It is not important for the purpose of this paper to describe this higher coal bed in detail, and it is mentioned only for correlation (see Pl. X, p. 108) with sections measured farther east, in which a bed of coal, known as the Yankee bed, occurs at essentially the same horizon. The section measured in Seeley Canyon follows:

Section of rocks measured in Seeley Canyon, near Blossburg, N. -Mex.

[For graphic section see PI. X, p. 108,]

Sandstones and sandy sháles. . ............ 40 Shale, carbonaceous; with 6 . inches or more of coal

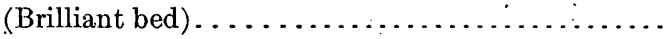

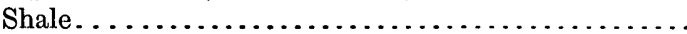

Sandstone, massive, cliff making. ............

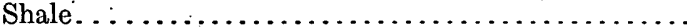

Sandstone, cliff making...................

Sandstone, in thin beds with shale partings. . . . . . .

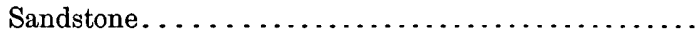

Sill of igneous rock (andesite) $\ldots \ldots \ldots \ldots \ldots \ldots$

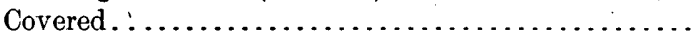

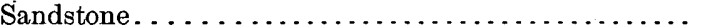

Shale, not well expósed . . . .............. 55

Coal, impure (Sugarite bed) . ............. 3

Shale, with thin beds of sandstone . . . . . . . . . 40

Sill of igneous rock . . . . . . . . . . . . . . . . . . . 2

Shale and sandstone, in alternating beds. . ....... 30

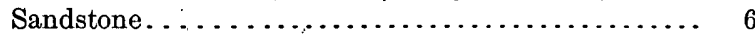

Coal (Raton) $\ldots \ldots \ldots \ldots \ldots \ldots \ldots \ldots \ldots \ldots \ldots$

Shale...........................

Sandstone (Trinidad).
BLÓssBurg.

LOCALITIES 61-67.

About a mile north of Seeley Canyon, at locality 61 , the basal sandstone of the Raton formation is well developed and forms a cliff. It is about 10 feet thick and consists of hard sandstone in which are small pockets of pebbles. It rests unconformably on the sandy shale of the Vermejo formation, which is here only 32 feet thick and contains one bed of coal. The cliff formed by the conglomeratic sandstone is easily recognized in the eastern wall of Dillon Canyon opposite locality 61.

The basal sandstone is readily traceable northward from locality 61 to near the mouth of Coal Canyon, where it disappears beneath the surface, and thence southward in the east wall of Dillon Canyon. Several collections of fossils were made in this vicinity. Sabal? ungeri (Lesquereux) Knowlton was found (U. S. Geol. Survey fossil locality 5150) half a mile southwest of the mouth of Coal Canyon, 300 feet above the base of the Raton formation; and 100 feet higher (U. S. Geol. Survey fossil locality 5147) Sabalites grayanus (Lesquereux) Lesquereux, Juglans schimperi Lesquereux, and Ficus occidentalis Lesquereux were found. At the latter horizon, about one-half mile farther west (U.S. Geol. Survey fossil locality 561)0) were found a few poorly preserved shells of freshwáter species, which were identified as Unio sp. (fragmentary casts), Viviparus sp., and Campeloma? sp. In the north wall of the canyon opposite these localities and 150 feet above the base of the Raton formation (U. S. Geol. Survey fossil locality 5148) Sabal? ungeri (Lesquereux) Knowlton and Palmocarpon palmarum (Lesquereux) Knowlton were found in place; and Magnolia magnifolia Knowlton and Zizyphus fibrillosus (Lesquereux) Lesquereux were collected from slide rock (U. S. Geol. Survey fossil locality 5149). Farther to the northwest, half a mile north of Brilliant (U. S. Geol. Survey fossil locality 5154), Magnolia angustifolia Newberry, Magnolia magnifolia Knowlton, and Carpites coffeaeformis Lesquereux were collected in a small tributary canyon near the top of the Raton formation. At about the same horizon, near the south end of the railway tunnel, the following plants were collected: 
Fossil plants collected at the south end of the Raton tunnel, near the top of the Raton formation.

[U. S. Gool. Survoy fossil localities 5146,5155 , and 5464 .]

Euonymus splendens Berry.

Ficus richardsoni Knowlton.

Ficus harrisiana Hollick.

Sabalites grayanus Lesquereux.

Juglans schimperi Lesquereux.

Magnolia angustifolia Newberry.

Magnolia magnifolia Knowlton.

Platanus aceroides Göppert.

Platanus aceroides latifolia Knowlton.

Platanus guillelmae Göppert.

Rhamnus cleburni Lesquereux.

Sabal? ungeri (Lesquereux) Knowlton.

A section of the rocks was measured at locality 62 in the east wall of Dillon Canyon south of the mouth of Coxe Canyon, $1 \frac{1}{2}$ miles southeast of locality 61 and 1 mile northeast of the section in Seeley Canyon. The Trinidad here consists of two thick sandstones separated by shale in which thin beds of coal occur. The Vermejo formation is about 41 feet thick and contains three beds of coal. The base of the Raton formation is slightly conglomeratic and a coal bed was found above this conglomerate at the horizon of the Sugarite coal. The section is as follows:

Section of rocks measured at locality 62, Dillon Canyon, east of Blossburg, N. Mex.

Raton formation: [For graphic section see Pl. V, p. 56.]

Covered

Shale, carbonaceous, with thin beds of coal... . 5 - 0

Shale............................... 150

Coal.......................... 110

Shale.............................. 150

Coal, with partings of shale (Sugarite bed). $\quad 2 \quad 6$

Shale, sandy ......................... $10 \quad 0$ Coal......................... 6

Shale, not well exposed .................. $65 \quad 0$

Sandstone, locally conglomeratic........... $10 \quad 0$

Unconformity.

Vermejo formation:

Covered . ...........................

Coal...............................

Shale................................

Coal...........................

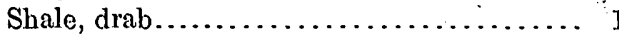

Sandstone.............................

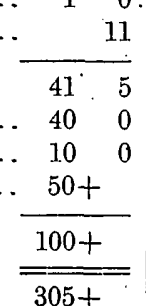

Four short sections and one longer one were measured south and east of Coxe Canyon. (See sections 63 to $67, \mathrm{Pl} . \mathrm{V}$, p. 56.) In all these sections the basal sandstone of the Raton formation is slightly conglomeratic and rests with uneven base on the weaker rocks of the Vermejo. In section 67 two coal beds which occur at about the horizon of the Sugarite coal are probably to be correlated with the two coals near the top of section 62 .

\section{RATON AREA. \\ RATON. \\ LOCALITY 68}

The rocks are well exposed in the point of the mesa southwest of Raton at locality 68 . The Trinidad sandstone is typically developed here and is separated into two parts of nearly equal thickness by a layer of fissile sandstone which contains fossil plants of netted-vein type, as follows:

\section{Fossil plants collected from the Trinidad sandstone.}

[U. S. Geol. Survey fossil locality 5145.]

Phasiolites minutus Knowlton.

Phyllites ratonensis Knowlton.

Populus? neomexicana Knowlton.

Viburnum crassum Knowlton.

Vitis? fragmenta Knowlton.

The Trinidad also contains Halymenites major Lesquereux and Inoceramus barabini Morton at essentially the same horizon (U. S. Geol. Survey fossil locality 5599).

The coal of the Vermejo has been prospected at this locality, and three beds have been opened. The basal sandstone of the Raton is slightly conglomeratic and rests with uneven base on sandy shale. The horizon of the Sugarite coal bed is marked by red rocks, probably oxidized by the burning of the coal. . The following section was measured at this point:

Section of rocks measured at locality 68,1 mile southwest of Raton, $N$. Mex.

[For graphic sections see PI.V, p. 56.]

Raton formation: Ft. in.

Sandstone, brown, and shale, in alternating

layers........................... $25 \quad 0$

Sandstone, cliff making, base irregular..... $32 \quad 0$

Sandstone and shale, not well exposed....... $27 \quad 0$ Coal, burned at outcrop............... ?

Shale............................... 150

Sandstone, massive, with contorted laminae.. $12 \quad 0$

Shale................................\%: $26 \quad 0$

Sandstone........................ $4 \quad 0$

Shale................................ 18 


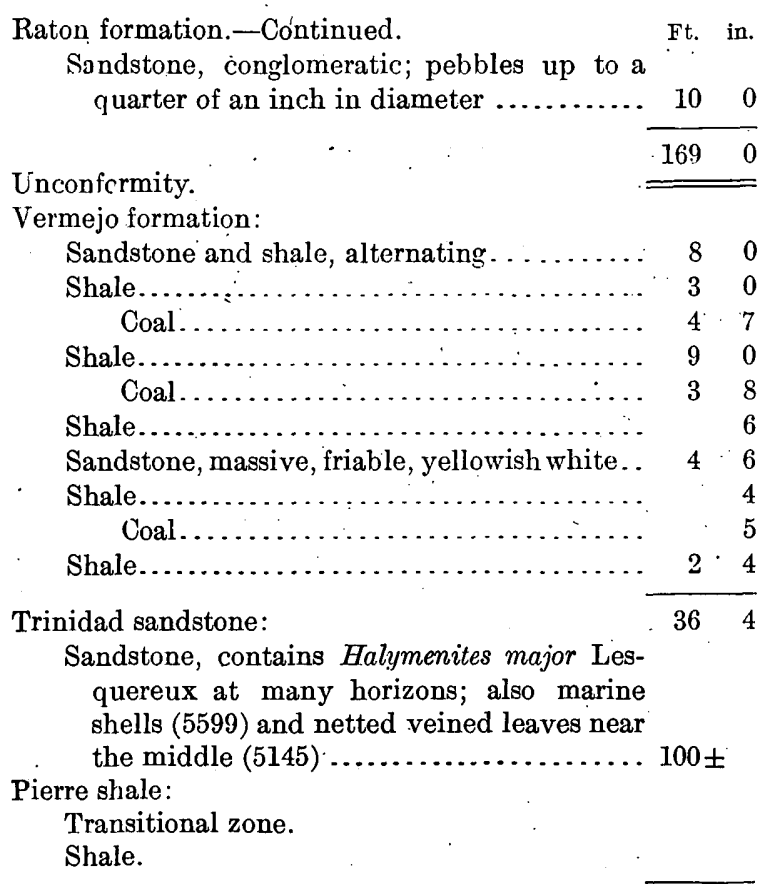

LOCALITIES 69-74.

$305 \pm$

Near Raton, north of locality 58, the upper part of the Pierre shale is well exposed and the Trinidad sandstone above it forms a conspicuous cliff. (SeePl.XI, $A$, p.110.) Invertebrates were found in the Pierre in limestone concretions at the base of Goat Hill, 50 feet below the top of the shale, as follows:

Invertebrates collected from the upper part of the Pierre shale at Raton, N. Mex.

[U. S. Geol. Survey fossil localities 5598 and 8355.]

Ostrea pellucida $\dot{M}$ eek and Hayden.

Syncyclonema rigida (Hall and Meek)?

Inoceramus barabini Morton.

Inoceramus sagensis $\mathrm{Owen}$.

Baculites ovatus Say.

Crenella sp.

Pinna sp.

Leda (Yoldia) scitula Meek and Hayden?

Leda sp.

Scaphites nodosus.

Nucula planimarginata Meek and Hayden?

Dentalium sp.

Undetermined gastropod:

Another collection was made at the brickyard in Raton at a horizon 50 to 100 feet lower.

Pierre invertebrates collected at the brickyard in Raton

[U. S. Geol. Survey fossil locality 8356.]

Ostrea pellucida Meek and Hayden?

Syncyclonema rigida (Hall and Meek)?

Avicula linguiformis Evans and Shumard.

Inoceramus sagensis Owen.

Crenella sp.
Leda (Yoldia) scitula Meek and Hayden?

Lucina sp.

Cardium sp.

Margarita nebrascensis Meek and Hayden?

Nautilus dekayi Morton.

Baculites compressus Say.

Scaphites nodosus Owen.

Ptychoceras sp.

The Vermejo formation is thin but contains the main coal bed of the Raton field. The basal sandstone of the Raton formation was traced continuously in the side of the mesa and short sections were measured at localities 69 to 74, inclusive. (See Pl. V, p. 56.) The sandstone at each locality contains a few small pebbles, and its base is usually uneven, as if it had been deposited on an eroded surface. At locality 70 a coal bed, probably to be correlated with the Sugarite coal, occurs 102 feet above the base of the conglomeratic sandstone.

\section{LOCALITY 75.}

One of the most complete sections in the Raton field was measured near the point of Bartlett Mesa north of Raton, at locality 75, where the side of the mesa is very steep and the rocks well exposed. The capping of basalt has protected from erosion the higher rocks of the Raton formation, which had all been eroded away at the localities previously described. However, even at this locality the youngest rocks of the Raton formation are not present, having been eroded away previous to the outpouring of the basalt upon them. The section follows:

Section of rocks measured near locality 75 , north of Raton, N. Mex.

[For graphic sections see PIs. V, p. 56, and X, p. 108.]

$\mathrm{Ft}$. in

Basalt. ....................... $100+$

Raton formation:

Covered.......................... 50

Shale and sandstone in alternating layers,

fossiliferous $(5152) \ldots \ldots \ldots \ldots \ldots \ldots \ldots \ldots, 50 \quad 0$

Coal............................. I. 0

Shale.............................. 40

Sandstone, massive, cliff making......... 350

Shale............................... $30 \quad 0$ Coal............................. 6

Shale.......................... $30 \quad 0$

Coal............................ 24

Shale............................ 40

Sandstone, cliff making................. $30 \quad 0$

Shale............................. $90 \quad 0$

Sandstone, cliff making.................. $30 \quad 0$

Shale............................ $10 \quad 0$

Coal........................... $4 \quad 10$ 
Raton formation-Continued.

Shale.

Shale, carbonaceous, with thin beds of coal.

Sandstone and shale...................

Coal.........................

Sandstone and shale in alternating layers... Coal.............................

Shale............................

Coal...........................

Shale...........................

Coal, with shale partings.............

Shale..............................

Sandstone, massive, cliff making..........

Shale, carbonaceous....................

Coal.

Shale.............................

Coal............................

Shale...........................

Coal, with shale partings.............

Shale..............................

Sandstone, cliff making.................

Sandstone and shale in alternating layẹrs. .

Shale, carbonaceous, with thin beds of coal.

shale..............................

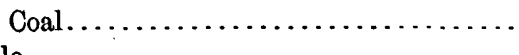

Shale............................

Sandstone, cliff making .................

Shale............................

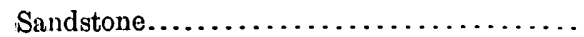

Sandstone and shale in alternating layers....

Sandstone, massive, cliff making..........

Shales and sandstones in alternating layers.

Sandstone..........................

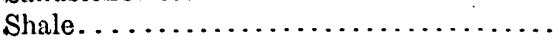

Coal............................

Shale, carbonaceous..................... Coal (Sugarite bed) ................

Shale . . . . . . . . . . . . . . . . . . Coal............................

Shale. .....................................

Shale, black, carbonaceous, with thin beds
of coal near the base.....................

Shale............................

Sandstone............................

Shale.............................

Sandstone, locally conglomeratic.........

Unconformity.

Vermejo formation:

Shale and friable sandstone.............. Coal............................

Shale..........................

Coal.............................

Trinidad sandstone:

Sandstone containing fossil plants near the middle....................... $100 \pm$

Pierre shale:

Transitional zone.

Shale.
Ft. in.

30

200

10

0

18

4

0

0

4

350

300

200

4

16

10

20

350

$30 \quad 0$

600

20

$29 \quad 0$

1. 8

$20 \quad 0$

200

250

120

50

0

(

$\overline{1,377 \pm}$
The Pierre shale is sparingly fossiliferous at this locality, but the shells are contained in concretions of brittle limestone and are so poorly preserved that no collection of them was made. The Trinidad sandstone is characteristically developed and contains the fossil fucoids usually found in this formation. In addition to Halymenites major Lesquereux several netted-veined leaves were found in a layer of fissile shaly sandstone near the middle of the formation, but no specimens sufficiently perfect for identification were obtained. The Vermejo formation is about 33 feet thick and contains one thick bed of coal and one thin bed. The basal sandstone of the Raton formation is only 4 feet thick but is hard and quartzose, and a few small quartz and chert pebbles were found in it. It rests with uneven base on weaker rocks. (See Pls. V, p. 56, and X, p. 108.)

Above the basal sandstone the rocks are principally shaly for about 125 feet, and in this shale occurs the Sugarite and two thin beds of coal. This shaly zone seems to be the same as that first described in Cimarron Canyon at locality 10 (p. 72), nearly 40 miles southwest of Raton, to which attention has been called in the descriptions of several intervening localities. It is not probable that the coals at all of these localities belong to a single bed. Doubtless there are several more or less lenticular bodies, but they lie so nearly at the same horizon that there is a temptation to regard them as belonging to one and the same bed.

Above this zone of coal-bearing shale occurs the series of cliff-making sandstones, the lower part of which has been described in several of the foregoing sections as the cliff-making sandstone at the top of the mesa. At most of the localities previously described only the lowest member of this series was included in the sections, the principal ones having been eroded away where the sections were measured. At locality 75 the entire series is included and is 400 feet or more in thickness. Above the cliff-making sandstones is another series of coal beds, near the base of which is the Yankee coal, and still higher there are several coals not necessary to describe in this paper. Above the highest bed of coal, at the highest horizon from which fossil plants were collected in the 
Raton coal field, were obtained the following species :

Fossil plants collected near the top of the Raton formation, in Bartlett Mesa, north of Raton, N. Mex.

[U. S. Geol. Survey fossil locality No. 5152.]

Ficus denveriana Cockerell.

Platanus rhomboidea Lesquereux.

Vitis olriki Heer.

\section{BARTLETT MESA. LOCALITIES 76-81.}

Several short sections were measured east of locality 75 for the specific purpose of showing the relation of the Raton formation to the underlying rocks. (See Pl. V, p. 56.) The coal of the Vermejo formation (Raton bed) was traced eastward to locality 80 but was not found east of that locality. The basal sandstone of the Raton formation is thin but is hard and quartzose and contains. a few pebbles. But at locality 81 this sandstone thickens to about 30 feet, is coarse grained and massive, contains irregularly shaped bodies of conglomerate, and is separated from the Trinidad sandstone by a thin layer of dark shale. The rocks above this 30-foot sandstone are the same as the coal-bearing shale that contains the Sugarite coal bed at locality 75 (p. 106).

\section{LOCALITY 82.}

A section comparable with that at locality 75 was measured in the southern slope of Bartlett Mesa, starting at locality 82 and extending to the top of the mesa to the east. The Pierre shale is not exposed in the canyon at locality 82 but is included in the section because it was penetrated by a well bored about $1 \frac{1}{2}$ miles to the southeast. The well 'starts at a horizon estimated to be 300 feet below the base of the Trinidad sandstone, and reaches a depth of 2,700 feet, but does not extend entirely through the shale. The absence of limestone indicates either that the limestone of the Niobrara group to the north supposed to exist here was not reached or that there is no limestone in such parts of the Niobrara and Benton formations as may have been penetrated. The section measured at this locality, including the drill record, is as follows:
Section of rocks measured near locality 82, northeast of Raton, N. Mex.

[For graphic section see Pl. X.]

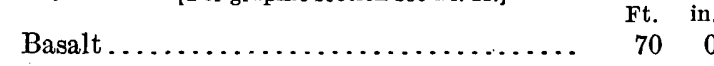

Basaltic breccia.................... 10.0

Raton formation:

$80 \quad 0$

Clay, baked....................... $6 \quad 0$

Sandstone, massive................... . $30 \quad 0$

Covered ........................ $15 \quad 0$

Basalt sill (?), green, weathered ............ $40 \quad 0$

Sandstone, cliff making.............. $30 \quad 0$

Shale........................... $4 \quad 0$

Basalt sill........................ 20

Shale............................ $4{ }_{4} 0$

Sandstone....................... $20 \quad 0$

Shale, sandy ........................ $60 \quad 0$

Shale, not well exposed................ $80 \quad 0$ Coal......................... 10

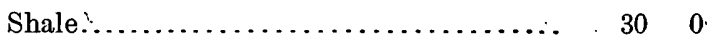

Coal .......................... 30

Shale........................... 450.

Shale, carbonaceous................... 40.

Coal....................... 16

Sandstone, massive, cliff making ........ $30 \quad 0$.

Shale........................... $25 \quad 0$.

Coal, with partings of shale ............ $5 \quad 0$.

Shale and sandstone, alternating layers.... $\quad 90 \quad 0$.

Coal......................... 10

Shale with thin beds of sandstone......... $25 \quad 0$.

Coal with partings of shale.......... $6 \quad 6 \quad 0$.

Shale with thin beds of sandstone.......... $30 \quad 30$.

Shale, carbonaceous................... 30 .

Coal.............................. $\quad 10^{2}$

Shale, carbonaceous.................. $25 \quad 0$.

Coal, lower 3 feet clean, upper 2 feet with partings of shale..............

Shale, carbonaceous....................

Sandstone...........................

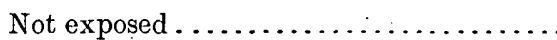

Shale, carbonaceous, with 6 inches of coal

Shale ..........................

Sandstone, massive, cliff making .........

Sandstone, massive..................

Shales and sandstones interbedded........

Shale, carbonaceous at the base..........

Sandstone, massive, cliff making...........

Shale with thin base of sandstone........ .

Shale, carbonaceous at the base..........

Sandstone, massive, cliff making .........

Shale not well exposed . ................

Sandstone

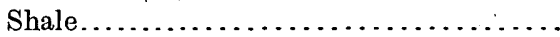
Coal (Sugarite bed).................

Shale, black, carbonaceous............... Coal. .

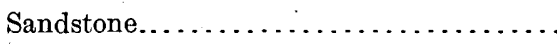

Shales and sandstones, alternating.......
50

150

100

$\begin{array}{ll}60 & 0\end{array}$

60

100

$50 \quad 0$

$20 \cdot 0$

$70 \quad 0$

$20 \quad 0$.

$40 \quad 0$.

$\begin{array}{ll}50 & 0\end{array}$

100

280

150

60

20

30

150

10.

60

$25 \quad 0$ 


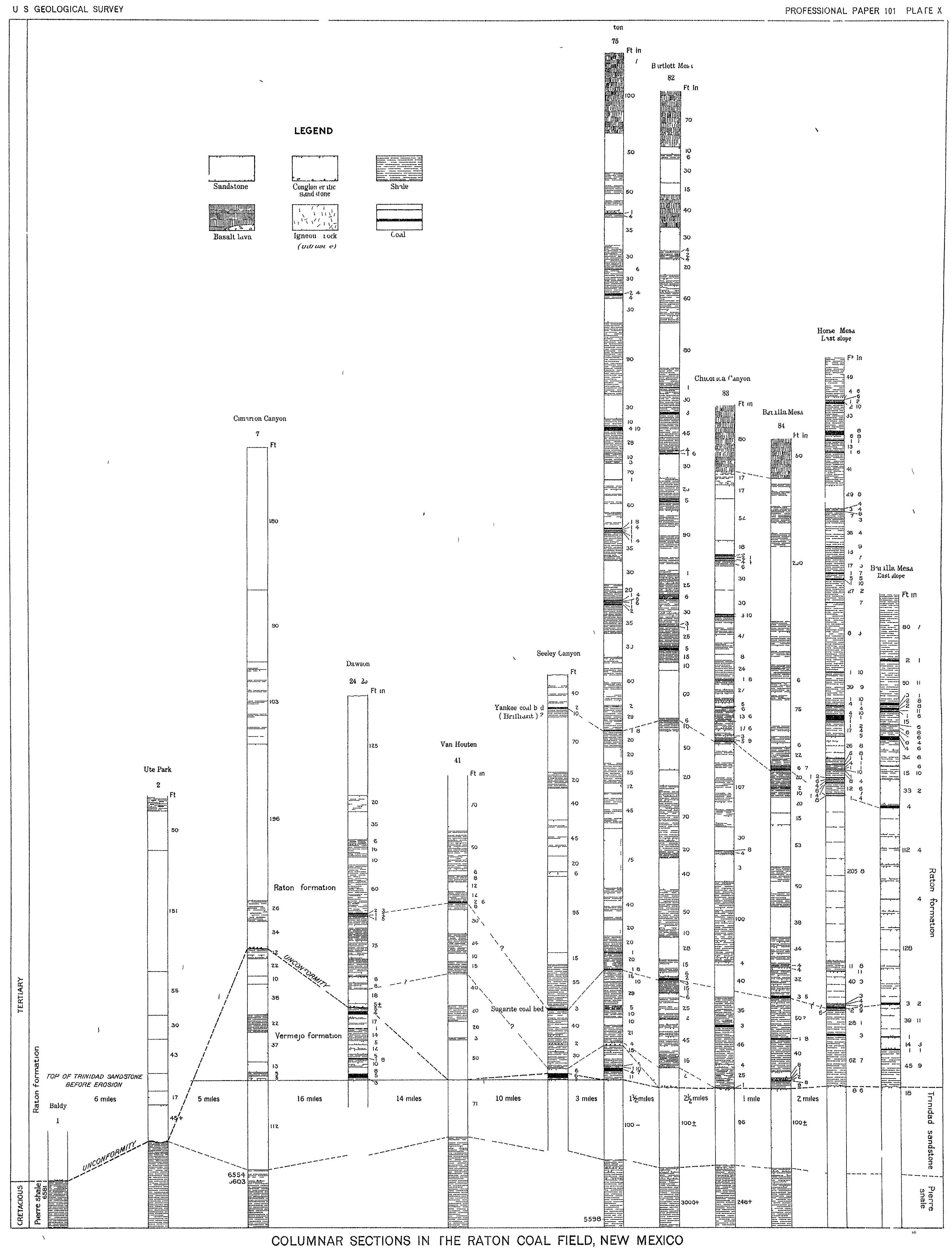


Raton formation-Continued.

Shales, black, carbonaceous.

Sandstones and shales, altornati

Shales, carbonaceous, containing thin bed of coal............................

Sandstone, conglomeratic ................

Unconiormity.

Trinidad sandstone:

Sandstone, white, massive ............ $100 \pm$

Pierre and older (?) shales:

Transition zone.

Shale.

$\frac{3,000+}{4,350 \pm}$

No rocks that can be referred to the Vermejo were found at locality 82. The basal conglomerate of the Raton formation rests directly on the Trinidad sandstone. The coal beds and the various groups of rocks described in section 75 were recognized in this section. (See Pls. V and X.) The formations were traced eastward from this locality and examined in detail. in several places, but no complete section of them was measured between localities 82 and 83 , a distance of about $2 \frac{1}{2}$ miles. The Pierre shale and the Trinidad sandstone continue unchanged in character through this distance, but no rocks were found above the Trinidad that can be referred to the Vermejo formation. For some distance east of locality 81 the basal conglomerate of the Raton formation can be recognized, but still farther east the base loses its conglomeratic character.

The zone of coal-bearing shale above the conglomerate continues eastward with little change in character. The Sugarite coal bed, which was recognized at several places along the outcrop, has been mined for several years at the Sugarite mine, also known as the old Wagon mine, half a mile west of locality 83. The same relations obtain here as at locality 82. In the sections farther east the main or Sugarite conl bed is 90 to 100 feet above the base of the Raton formation, and another thin bed of conl occurs about 15 feet below it. Great numbers of fossil plants belonging to the Raton flora occur in the roof shale of the mine, palm leaves being especially abundant and perfect. Sabal inquirenda Knowlton and Sabal? ungeri (Lesquereux) Knowlton were collected from the roof of the mine (U. S. Geol. Survey fossil locality 5143) by the writer. Acer fragitis Knowlton and Cinnamomum mississippiensis? (Lesquereux) were collected by Knowlton from the same mine.

\section{SUGARITE CANYON.}

LOCALITY 83.

In the southeast point of Bartlett Mesa near the mouth of Sugarite Creek the rocks extending from the upper part of the Pierre shale to the basalt cap of the mesa are well exposed. The following section was measured "at locality 83 , about $2 \frac{1}{2}$ miles from locality 82 . The Pierre-shale is exposed in barren slopes and contains concretions of limestone in which a few poorly preserved fossils were found. The transitional zone near the top of the shale is not prominent at this locality, and in measuring the section it was included with the shale. The section follows:

Section of rocks measured at locality 83, east of Raton, $N$. Mex.

[For graphic section see PI. X.]

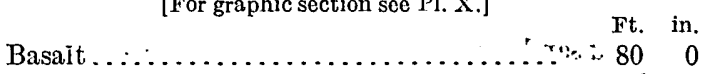

Sand and clay, unconsolidated......... 170

Raton iormation:

$97 \quad 0$

Sandstone, massive, yellow, friable..... $17 \quad 0$

Covered......................... $52 \quad 0$

Sandstone, gray, massive............... $18 \quad 0$

Coal........................ $\quad 2 \quad 0$

Shale......................... 10

Coal $\ldots \ldots \ldots \ldots \ldots \ldots \ldots \ldots \ldots \ldots . \ldots 6$

Shale........................ 17

Coal......................... 110

Shale........................ 1. 6

Coal............................ 10

Shale.......................... 60

Sandstone, gray, coarse grained......... $30 \quad 0$

Covered .......................... $30 \quad 0$

Coal........................ 110

Sandstone..................... $\quad{ }_{6}$

Coal.......................... 16

Shale and sandstone in alternating layers.. . $47 \quad 0$

Sandstone, massive................. $8 \quad 0$

Shale........................... $\quad 24 \quad 0$

Coal........................ 18

Shale, carbonaceous, and sandstone in alter-

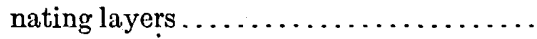

Sandstone, brown $\ldots \ldots \ldots \ldots \ldots \ldots \ldots \ldots$

Shale, leafy ........................

Coal...........................

Shale............................

Coal .............................

Shale, blue ......................

Shale, carbonaceous, with thin beds of coal

Shale and sandstone interbedded..........

Sandstone, massive.

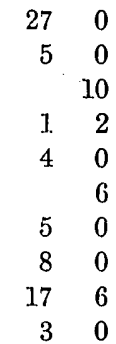


Raton formation-Continued.

Shale, leafy ........................

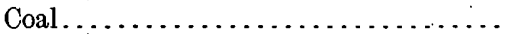

Shale...........................

Coal.

Shale............................

Coal...........................

Sandstone and shale containing ironstone

concretions poorly exposed ...........

Sandstone, gray, massive $: \ldots \ldots \ldots \ldots \ldots$

Coal.............................

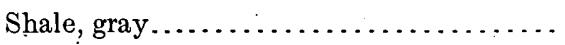

Sandstone; gray, cross-bedded, massive...

Shale, probably with beds of sandstone...

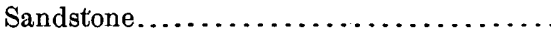

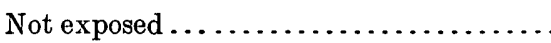

Shale, with thin beds of coal ............ Coal.

Shale.

Sandstone

Shale, with thin beds of coal............ Coal, shaly

Unconformity.

Trinidad sandstone:

Sandstone, massive, white, containing Halymenites major Lesquereux. The. upper 3 feet are rusty brown and nodular; contain fragments of bone.............

Pierre shale:

Transitional zone.

Shale . $248+$

$1,200+$

The Trinidad sandstone is 96 feet thick at locality 83 and does not differ in any notable way from the Trinidad at the localities previously described except that the upper few feet are wholly different from the material below and wholly different in appearance from the material at the top of the formation farther west, where it is overlain by the Vermejo. At this locality the top of the sandstone has a rusty-brown color, is harder than the lower parts, so that it stands out in the sides of the mesai as a well-marked cliff, and is very irregular, suggesting an eroded surface. The hardbrown layer suggests exposure at the surface, during which the sandstone was oxidized and "case" hardened. The same character was noted east of this locality at the several places (see Pl. X) where the Vermejo is not represented and where the Raton rests on the Trinidad sandstone.

The basal sandstone of the Raton formation, which is 25 feet thick at locality 82 but which farther east thins out sharply, was not found at locality 83 , where 25 feet of coal-bearing shale (probably the same as the 15 feet of similar shale above the conglomerate of section 82) rests directly on the Trinidad. A 3-foot bed of coal, found about 75 feet above the Trinidad, may be the thin bed 15 feet below the Sugarite bed; but the rocks are not exposed at the horizon where the Sugarite bed should outcrop.

The cliff-making sandstones above the Sugarite bed are prominent, and above them occur several beds of coal, the lowest of which is called the Yankee coal bed.

In Sugarite Canyon the rocks are so badly covered with surface débris and dense growths of underbrush that they could not be satisfactorily measured. Croppings of coal were observed in many places, and mines have been developed in the Sugarite coal on either side of the canyon, but the beds could not be followed continuously except where prospect openings have been made in them. However, some of the rocks at locality 84 , at the foot of Barilla Mesa in the east wall of Sugarite Canyon, about a mile northeast of locality 83 , are well exposed, and the two sections can be correlated without reasonable doubt. In the roof of the new Sugarite mine opened in the east wall of Sugarite Canyon (6530) the writer found beautifully preserved specimens of Magnolia magnifolia Knowlton, Apocynophyllum wilcoxensis Berry, Palmocarpon palmarum (Lesquereux) Knowlton, and other forms usually found at much higher horizons in the formation (6530). The Magnolia is worthy of special note, being very abundant in the upper part of the Raton formation but rare in the lower part.

YANKEE AREA.

GENERAL FEATURES.

Yankee is a coal-mining town situated in a deep embayment between Barilla Mesa and Johnson Mesa. The Pierre shale and Trinidad sandstone are well exposed, but no rocks referable to the Vermejo formation have been found except at the one locality mentioned below. The Raton formation rests with irregular base (see Pl. XI, B), quartzose in some places, on the Trinidad, with which it forms cliffs. About a mile north of Yankee a prominent shelf, bordered by cliffs, consists of light-colored friable Trinidad sandstone capped by a hard, yellowish-brown sandstone about 10 feet thick. The two sandstones are separated by carbonaceous shale having a maximum thickness of 3 


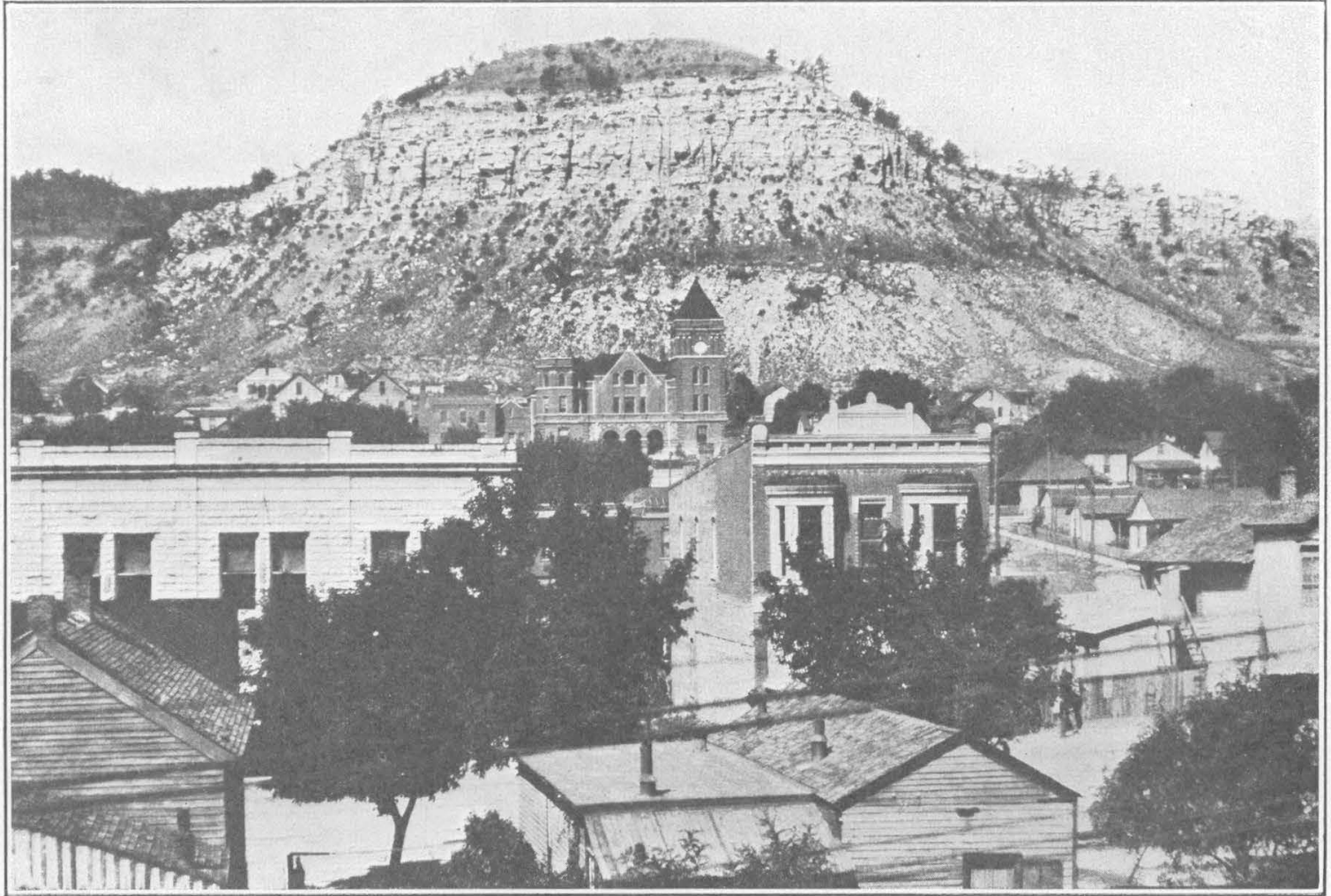

A. GOAT HILL, AT RATON, N. MEX.

Showing cliff of Trinidad sandstone, beneath coal-bearing Vermejo formation and above Pierre shale.

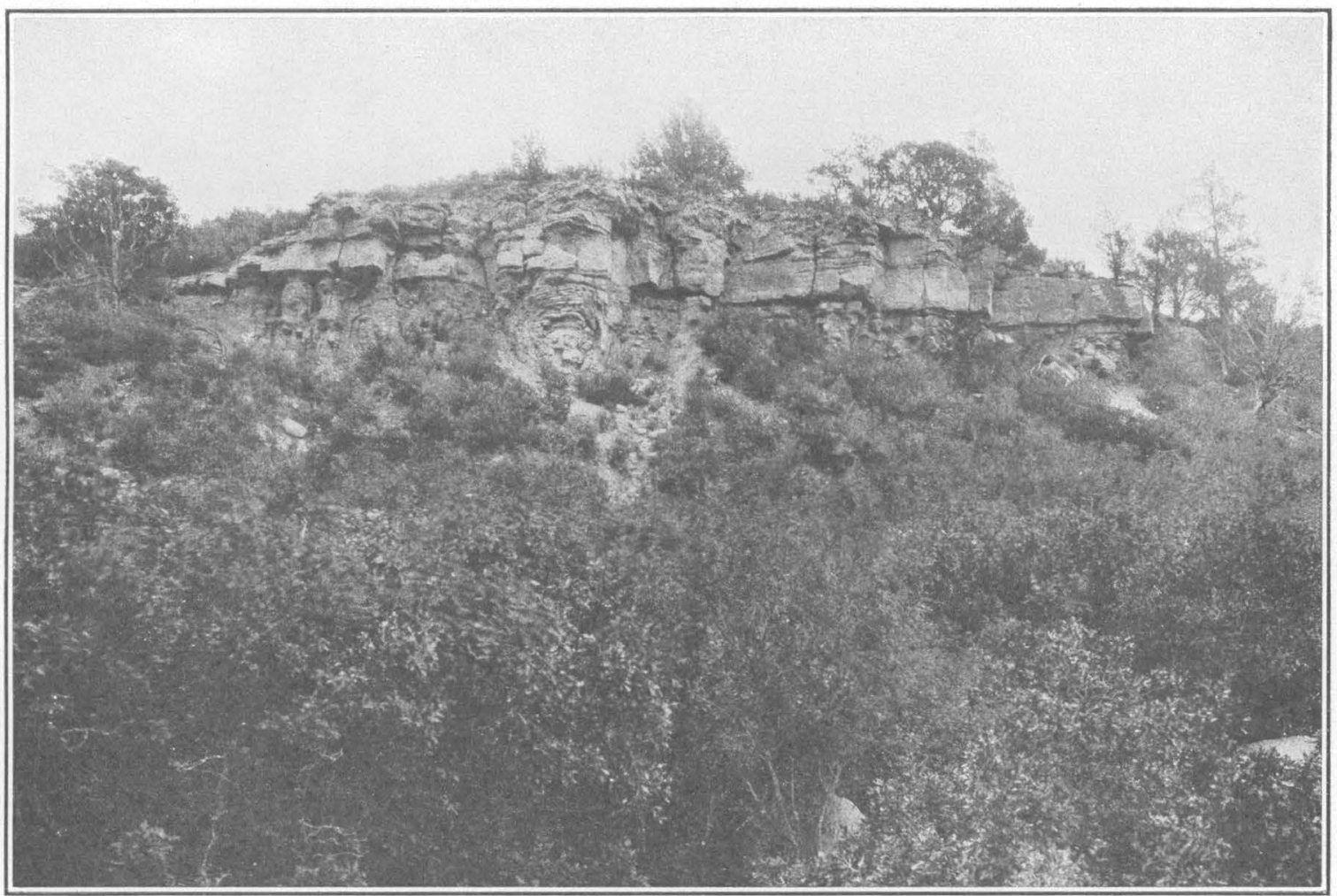

B. CLIFF IN NORTH SLOPE OF JOHNSON MESA SOUTH OF YANKEE, N. MEX.

Showing basal sandstone of Raton formation resting unconformably on Trinidad sandstone. 
feet and containing thin seams of coal. The upper sandstone is obviously the basal layer of the Raton formation, and the carbonaceous shale seems to be an erosional remnant of the Vermejo formation.

A similar occurrence was found in the north side of Johnson Mesa south of Yankee and just east of the volcanic cone. The lowest sandstone of the Raton formation here rests with uneven base directly upon the light-colored friable Trinidad sandstone. (See Pl. "XI, B.) This quartzose sandstone was observed resting unconformably on the Trinidad in similar relation at several localities, notably in the west slope of Johnson Mesa, the east slope of Barilla Mesa south of Rathbun Canyon, and near the Colorado line north of Bear Canyon. In other places the quartzose sandstone was not found, and the shale which normally lies above it rests directly on the Trinidad.

The lowest coal of commercial importance in the Raton formation is the Sugarite bed. It has been opened in several places. The sandstone cliffs of the so-called "barren series" above the Sugarite coal are prominent. The coals above them have been mined near Yankee. The tops of the mesas surrounding Yankee are covered with basalt outpoured as surface flows in late Tertiary or early Quaternery time. In many places the basalt rests on beds of gravel and boulders consisting principally of crystalline and metamorphic rocks. However, since this paper is devoted mainly to the structural and age relations of the Vermejo and Raton formations little will be said of these younger rocks.

\section{MOUTH OF SUGARTTE, CANYON.}

\section{LOCALITY 84.}

At the southwestern extremity of Barilla Mesa, near locality 84, the rocks from the top of the Pierre shale to the Yankee coal bed are well exposed, but the higher beds are badly obscured at the outcrop. No details were obtained of the Pierre shale, and the thickness of the Trinidad sandstone was estimated. Detailed examination began at the top of the Trinidad, which is hard and brownish red in color (as at locality 83) and forms a shelf in the side of the mesa. Above this shelf rests the coal-bearing shale of the Raton formation, which was examined and measured as shown in the following section:
Section of rocks measured at locality 84, in the side of Barilla Mesa, near the mouth of Sugarite Canyon, N. Mex.

$$
\text { [For graphic section see Pl: X.] }
$$

Basalt . $\quad F t$. in

Raton formation:

Shale and sandstone, with beds of coal; not continuously exposed................. $250 \quad 0$

Sandstone........................ $6 \quad 0$

Shale and sandstone, not continuously exposed............................ $75 \quad 0$

Sandstone............................ $6 \quad 0$

Shale, with ironstone concretions and thin beds of coal......................... $22 \quad 0$

Yankee bed:

Coal.......................... 11

Shale.......................... 5

Coal............................ 8

Shale........................... 2

Coal............................ 6

Shale........................... $\quad 2$

Coal........................... 27

Shale.......................... 8

Coal............................ 6

Shale, carbonaceous, with ironstone con-

cretions......................... $20 \quad 0$

Shale, carbonaceous.................... $2 \quad 0$

Shale, carbonaceous, with ironstone con-

cretions........................... 100

Sandstone, cliff making................ $20 \quad 0$

Not exposed.......................... 150

Sandstone, cliff making................ $53 \quad 0$

Shale, not continuously exposed............. $50 \quad 0$

Sandstone, cliff making................ $38 \quad 0$

Sandstone and shale, in alternating layers... 34

Shale, with thin beds of coal ............. 4. 0

Sandstone.......................... $44_{4} 0$

Shale, sandy........................ $32 \quad 0$

Coal (Sugarite bed) $\ldots \ldots \ldots \ldots \ldots \ldots \ldots \quad 3 \quad 5$

Sandstone and shale, in alternating layers, not well exposed..................... 50(?)

Coal............................. 18

Shale.............................. $40 \quad 0$

Sandstone........................... $8 \quad 0$

Shale................................ 10

Sandstone, clean, nodular................ 10

Shale, black, carbonaceous................ 20

Coal.......................... 8

Shale $\ldots \ldots \ldots \ldots \ldots, \ldots$

$\begin{array}{lll}\text { Unconformity. } & & 764 \\ \text { Trinidad sandstone } & . & 100 \pm\end{array}$

Pierre shale:

Transitional zone.

Shale.

No rocks were found that could be referred to the Vermejo formation, and the sudden change in the character of the sedimentaryo rocks from hard oxidized sandstone at the top of the Trinidad to soft shale above is sufficient in itself to suggest the unconformity. which the 
absence of the Vermejo formation proves. A thin bed of coal found about 60 feet above the base of the coal-bearing rocks is probably the 3 -foot bed of coal near the base of section 83 . The thickness of the Sugarite coal bed, which has been opened near this locality, was measured in the opening at the old Hartzell mine, but the rocks between this and the lower thin bed may be less than the 50 feet indicated in the section. The relations of the two beds could not be satisfactorily determined at the point where the measurements were made. The cliffmaking sandstones are well exposed and the Yankee coal bed was found above them, but few details were obtained of the higher beds.

\section{YANKEE MINES.}

GENERAL FEATURES.

East of locality 84 the top of the Pierre shale is exposed in the valley near Yankee. The Trinidad sandstone forms a cliff in several places and is easily recognized, but is not continuously exposed. The coal beds have been opened in several places near Yankee, and although their outcrops can not.be followed continuously there is little doubt of the identity of the beds in the lower part of the sections. The Raton coal, which is the one commonly known as the "main coal". west of Raton, does not exist in the Yankee district and there are no rocks that can be referred to the Vermejo formation. The Sugarite coal bed is the lowest coal of any considerable value in this district and has been opened in many places. $\mathrm{Al}$ though it can not be traced continuously between these openings the author has little hesitancy in drawing the correlation lines connecting the coals at this horizon. (See Pl. X, p. 108.)

The Yankee coal has been exploited at the Yankee mines near locality 85, and the higher beds have been opened near by, but although short sections of the rocks are exposed in many places the only comprehensive section measured at the surface is at locality 86.

The most complete section of the rocks in this part of the field was obtained from the record of a drill hole put down in Horse Mesa, the lobe of Barilla Mesa west of Yankee. The top of the hole is near the rim of the mesa, so that the section includes practically all of the sedimentary rocks below the overlying sheet of basalt. The section follows:
Rocks penetrated by diamond drill in Horse Mtsa.

[For graphic section, see Pl. X.]

Shale, sandy $\ldots \ldots \ldots \ldots \ldots \ldots \ldots \ldots \ldots \ldots .49 .{ }^{\text {Ft. }}$

Sandstone......................... 4

Coal, shaly.................... 6

Shale:..................... 12

Coal.......................... 18

Shale. . . . . . . . . . $\ldots \ldots \ldots \ldots \ldots{ }^{1}$

Coal............................. 10

Shale. . . . . . . . . . . . . . . . . $33{ }_{33} 0$

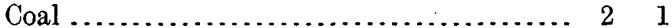

Coal, shaly...................... 11

Coal......................... 2.8

Shale, sandy $\ldots \ldots \ldots \ldots \ldots \ldots \ldots \ldots \ldots \ldots \ldots \ldots \ldots{ }_{6}{ }_{8}$

Coal......................... 1

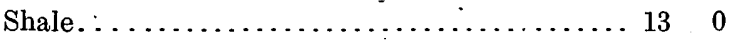

Coal..................... 16

Shale. ...................... 410

Sandstone............................ 29

Coal, shaly .................... 4

Shale........................ 34

Coal........................ 8

Shale..................... 5

Shale, with thin seams of coal............ 14

Shale......................... 5

Coal............................. 3

Shale, sandy...................... 35

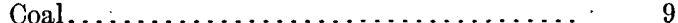

Shale. ......................... 13

Coal. .......................... 7

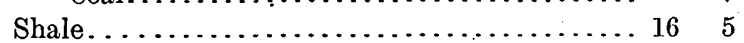

Shale, with thin seams of coal............ 10

Coal. ...................... 17

Shale.......................... $55_{5}$

Coal, shaly.................... 110

Shale............................. 27

Coal..................... 7

Shale........................... 85

Coal . . . . . . . . . . . . . . . 10

Shale, sandy....................... 399

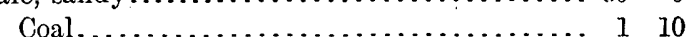

Shale, sandy $\ldots \ldots \ldots \ldots \ldots \ldots \ldots \ldots \ldots \ldots \ldots .41$

Coal....................... 4

Shale..................... $4 \quad 10$

Coal........................... 10

Coal, shaly .................... 1

Coal.......................... 50

Shale. . . . . . . . . . . . . . . . . . 10

Coal. ....................... 12

Shale, sandy $\ldots \ldots \ldots \ldots \ldots \ldots \ldots \ldots \ldots \ldots \ldots \ldots \ldots$

Coal. . . . . . . . . . . . . . . . . . . . . 5

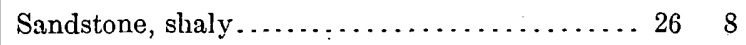
Coal .............................. 5

Shale, sandy ..................... 6

Coal. . . . . .................... 14

Shale......................... 1

Coal. ...................... 11

Shale...................... 10

Coal. ...................... 10

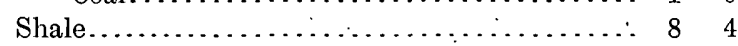

Coal, shaly $\ldots \ldots \ldots \ldots \ldots \ldots \ldots \ldots \ldots \ldots . \ldots \ldots$

Coal. . . . . . 8 . 


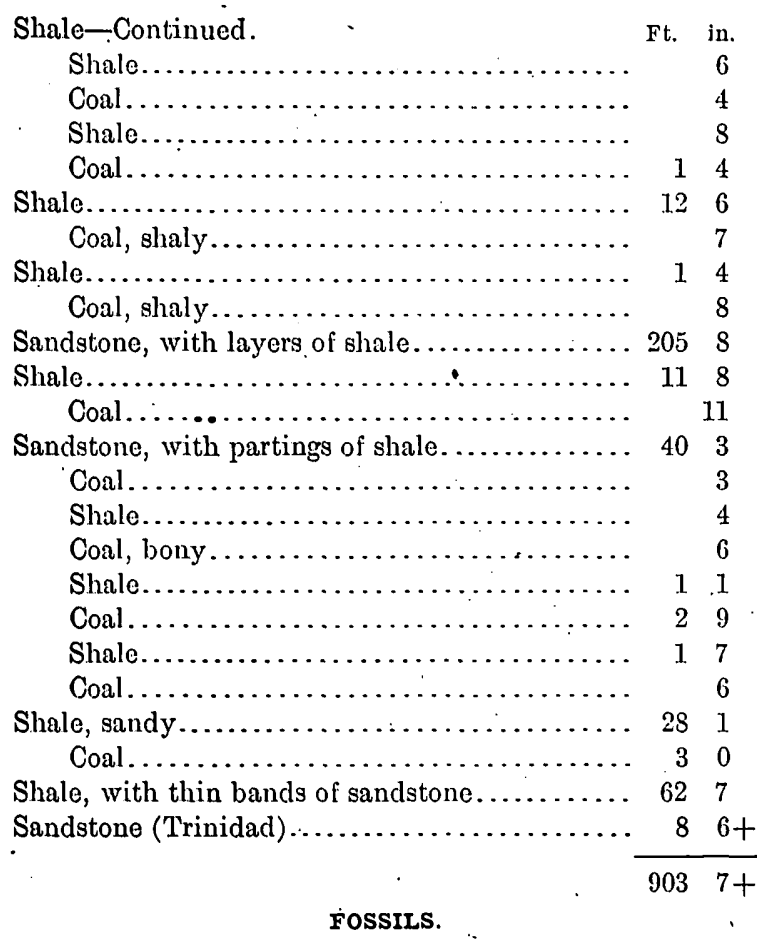

Several small collections of fossil plants were made near Yankee, the localities of which are sufficiently indicated by the United States Geological Survey fossil locality numbers. (See Pl. I, in pocket.) Near the old Honeyfield mine, 75 feet above the base of the Raton formation (5140), Anemia hesperia Knowlton, Laurus ratonensis Knowlton, Ficus ratonensis Knowlton, Quercus? ratonensis Knowlton, and Celastrus? sp. were collected. About 125 feet higher (5141) Platanus guillelmae Göppert was found. A little farther east in the east wall of the gulch near Yankee mine No. 5 (5139) a large palm leaf, Geonomites tenuirachis Lesquereux was found about 100 feet above the base of the Raton formation. Only a small part of the fossil, which measured 33 inches in length and whose rachis extended to the extremity of the part preserved, could be collected. Platanus guillelmae Göppert was found in slide rock 400 feet above the base of the Raton formation (5138); and 50 feet higher (5137) Zizyphus meiggsii (Lesquereux) Berry, Dryopteris? sp., Ficus denveriana Cockerell, and Nyssa? racemosa Knowlton were collected from rock in place. About 50 feet higher (5135) or 500 feet above the base of the Raton Cinnamomum mississippiensis? Lesquereux was found; and from the highest rocks exposed (5134) were col- lected Berchemia multinervis (Alexander Braun) Heer, and Sterculia berryana Knowlton.

Still farther east in the roof of the Raynolds coal mine (5133), at a horizon 600 feet or more above the base of the Raton formation, Juglans sapindiformis Knowlton and Sabal? ungeri (Lesquereux) Knowlton were found. In a gulch a mile southeast of this mine the following species were collected:

Fossil plants collected near Yankee, sec. 29, T. $\$ 2$ N., R. 25 $E$., about 400 feet above the base of the Raton formation.

[U. S. Geol. Survey fossil locality 5142.]

Apeibopsis? neomexicana Knowlton.

Ficus denveriana Cockerell.

Ficus pseudopopulus Lesquereux.

Ficus schimperi Lesquereux.

Juglans rugosa Lesquereux.

Magnolia angustifolia Newberry.

Terminalia hilgardiana (Lesquereux) Berry.

Quercus? neomexicana Knowlton.

Sabal? rugosa Knowlton.

Sabal? ungeri (Lesquereux) Knowlton.

Sapind us caudatus Lesquereux.

Zizyphus fibrillosus (Lesquereux) Lesquereux.

\section{IOCALITY 86.}

The section measured at locality 86 , about a mile northeast of the town of Yankee, extends from the Pierre shale, which is exposed at the bottom of the valley, to the lavas at the top of Barilla Mesa. Little attention was given to the Pierre shale or to the Trinidad sandstone, but the coal-bearing rocks were measured as accurately as the condition of the surface permitted. The section follows:

Section of rocks measured at locality 86, nëar Yankee, N. Mex.

Tertiary (?) rocks: $\quad$ Ft. in.

Basalt............................ 25. 0

Sand and gravel unconsolidated........... $80 \quad 0$

Conglomerate....................... $10^{\circ} 0$

Raton formation:

$115 \quad 0$

Covered...

$60 \cdot 0$

Coal $\ldots \ldots \ldots \ldots \ldots \ldots \ldots \ldots \ldots \ldots, \quad 4$

Shale and sandstone, not continuously ex-

posed........................... 1040

Coal....................... $4 \quad 0$

Not exposed ......................... $8 \quad 0$

Sandstone, yellow.......................... 150

Not exposed........................ $12 \quad 0$

Coal, impure...................... 25

Not exposed.......................... $24 \quad 0$

Coal.............................. 6

Shale.......................... 180

Coal............................. 5

Shale.......................... 350

$$
47019^{\circ}-17 \longrightarrow \mathrm{S}
$$


Raton formation-Continued.

Sandstone, yellow.

Not exposed. Coal.

Not exposed

Shale. Coal (Sperry mine) $\ldots \ldots \ldots \ldots \ldots \ldots \ldots$

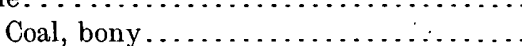

Shale, yellow, and thin bedded at top; gray and massive near base.................

Not exposed . . . . . . . . . . . . . . . . . .

Sandstone, brown, with iron concretions ....

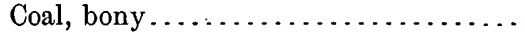

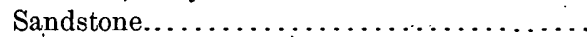

Sandstone and shale, in alternating layers... Coal.........................

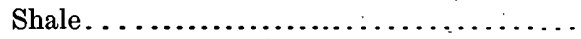

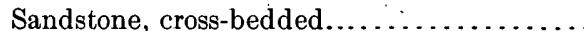
Coal............................

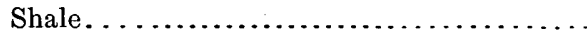

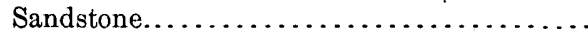

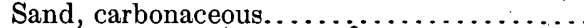

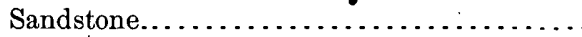

Shale

Sandstone, yellow......................

Sandstone and shale, in alternating layers...

Sandstone, yellow, massive................

Shale and sandstone, in alternating layers.:

Shale, carbonaceous, with thin beds of coal. .

Shale and sandstone, not continuously ex-

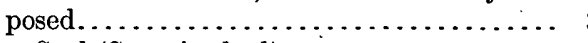
Coal (Sugarite bed) ..................

Shale..............................

Sandstone, friable.................... 12 Coal..............................

Shale and sandstone; not well exposed.....

Unconformity

Trinidad sand

Pierre shale:

Transitional zone.

Shale.

Not only do no rocks of Vermejo age occur at this locality; but no sandstone that can be confidently correlated with the basal conglomerate of the Raton formation was found. The rocks above the Trinidad consist principally of soft shales, some of which are carbonaceous and contain thin beds of coal, interbedded with layers of friable sandstone and lenses of ironstone. A thin bed of coal occurs about 82 feet above the base, and the Sugarite coal bed a little higher. The cliff-making sandstones are recognizable here, but they are not so massive as they are farther west, and three thin beds of coal were found in them. The Yankee coal bed was recognized above the cliffs and has been exploited to some extent in the Sperry mine. Several higher coal beds are included in the section, but they are not specifically used in correlating the formations described in this paper and need not be discussed in detail.

Above the highest bed of coal is a mass of more or less unconsolidated gravel of Tertiary age, on which lies the basalt that forms the cap rock of the mesas.

The higher rocks of this section were traced southeastward around the point of Barilla Mesa to locality 92 . Some of the higher beds of coal have been opened near Norman's ranch on the southern extremity of the mesa, where the following fossil plants were collected:

Fossil plants collected north of Norman's ranch about 50 feet above the base of the Raton formation.

[U. S. Geol: Survey fossil locality 5132 .]

Apocynophyllum lesquereuxii Ettingshausen Cinnamomum mississippiensis? Lesquereux.

Ficus denveriana Cockerell.

Ficus planicostata clintoni (Lesquereux) Knowlton.

Magnolia magnifolia Knowlton.

Platanus guillelmae Göppert.

\section{JOHNSON MESA.}

LOCALITIES 87-91.

The rocks of the lower part of the section measured at locality 86 were traced southward to Johnson Mesa, where several sections were measured but need not be described in detail The Pierre shale is exposed on all sides of the mesa. The Trinidad sandstone occurs in characteristic development south of Yankee and in the west slope of the mesa near localities 87 and 88 but becomes inconspicuous farther south and east. In the southern slope of the mesa it does not form a cliff and its thickness ${ }^{\circ}$ could nowhere be satisfactorily measured. At locality 89 near the eastern limit of its extension it is thin and inconspicuous. In the north slope of the mesa its occurrence is similar to that in the south slope. It is exposed in several places south and east of locality 93 but nowhere does it attain a prominence comparable to that farther west. No rocks that can be referred to the Vermejo were found in Johnson Mesa, where apparently the post-Vermejo erosion carried away not only all rocks of this formation but part of the Trinidad sandstone as well, so that when sedimentation was renewed in early Tertiary time the first deposits accumulated on an uneven surface of Trinidad sandstone. The lowest stratum of these younger deposits is well exposed in several places near localities 87 and 
Ss. It is hard, quartzose, and slightly conglomeratic.

HORSESHOE AND bARILLA mESAS.

$$
\text { LOCALITIES } 92 \text { AND } 93 .
$$

The coal-bearing rocks are well exposed in only a few places east of Barilla Mesa. In the eastern face of Horseshoe Mesa those in the lower part of the Raton formation are exposed in a cliff formed by a landslide at locality 93, and some of the coal beds crop out at locality 92 . But the best section of the rocks east of Barilla Mesa is shown in the following record of a diamond-drill hole put down in the eastern slope of Barilla Mesa:

Rocks penetrated by diamond drill on Barilla Mesa.

$$
\text { [For graphic section sce Pl. X, p. 108.] }
$$

Shale, sandy $\ldots \ldots \ldots \ldots \ldots \ldots \ldots \ldots \ldots \ldots \ldots$

Shale, with thin seams of coal...........

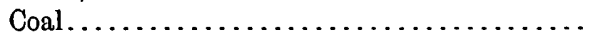

Shale, with thin beds of sandstone......... $50 \quad 11$

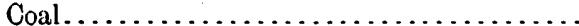

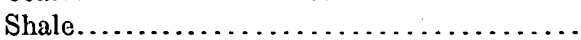

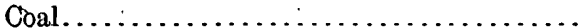

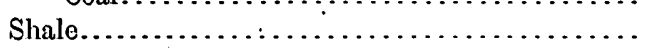

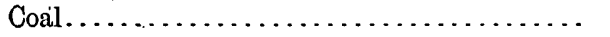

Shale........................ 11

Coal, shaly $\ldots \ldots \ldots \ldots \ldots \ldots \ldots \ldots \ldots \ldots \ldots, 1$

Shale, sandy............................ 15

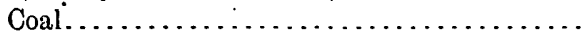

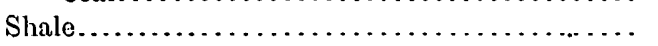

Coal, shaly $\ldots \ldots \ldots \ldots \ldots \ldots \ldots \ldots \ldots \ldots$

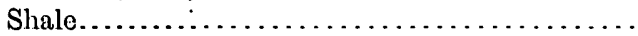

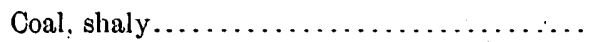

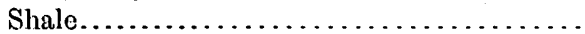

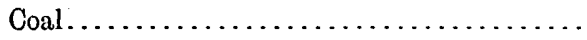

Shale and sandstone..................... 32

Coal, shaly $\ldots \ldots \ldots \ldots \ldots \ldots \ldots \ldots \ldots \ldots$

Shale, sindy $\ldots \ldots \ldots \ldots \ldots \ldots \ldots \ldots \ldots \ldots \ldots$

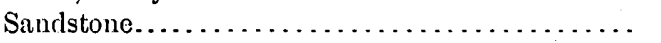

Sandstone, with thin beds of coal.........

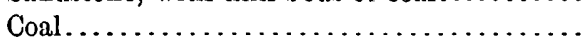

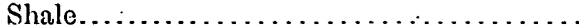

Coal. ..........................

Shale, with thin beds of coal............ 1

Sandstone and shale................... 111

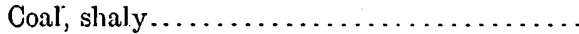

Sandstone and shale...................... 128

Coal.......................... 3

Shale, sandy $. \ldots \ldots \ldots \ldots \ldots \ldots \ldots \ldots \ldots \ldots \ldots \ldots .{ }_{39} 1$

Coal..................... 1.0

Shale........................ 1.4

Coal. ................... 1.

Shale, with sandy layers. . . ............. $45 \quad 9$

Sandstone (Trinidad) ................. $18+$

$638+$

The Pierre shale is characteristically developed; but the Trinidad sandstone, which is normally about 100 feet thick throughout the Raton Mesa region, is here much thinner. It contains the characteristic fossil Halymenites major Lesquereux and does not differ in lithologic character from this sandstone as developed elsewhere. It is possible that the Trinidad never possessed normal thickness at this locality, but it seems more reasonable to attribute its thinness to erosion previous to the deposition on it of the sediments of the Raton formation.

In Bear Canyon north of locality 93 the sides of the mesa are so densely forested that little was learned of the rock formations above the Pierre shale. Still farther north, near the eastern extremity of Barilla Mesa, the Trinidad sandstone is exposed for a short distance, but no satisfactory section of it or of the overlying rocks was measured. However, it is clear that no rocks of Vermejo age occur in this part of the field, and that, except for localities near the State line where a brown quartzose sandstone at the base of the Raton rests with uneven base on the Trinidad, the shales of the Raton formation lie in contact with the Trinidad sandstone as they do in the other places described east of locality 81 .

The north side of Barilla Mesa in Colorado also is densely forested, and the rocks above the Pierre shale are exposed in very few places. Because of this forestation no satisfactory observations were made on them for about 7 miles along the outcrop north of the mesa. About half a mile east of San Francisco Creek, however, the Trinidad sandstone is exposed beneath 25 to 30 feet of coal-bearing rocks that probably belong to the Vermejo formation. The Vermejo (see p. 122) is well developed toward the northwest, in. the vicinity of Trinidad, and it thins toward the east, as in the vicinity of Raton. Its point of disappearance north of the mesa is not known, for this point lies somewhere in the covered area between San Francisco Creek and the eastern point of Barilla Mesa.

\section{RATON MESA}

The north and west slopes of Raton Mesa are densely covered with brush, and in few places are the rocks well exposed. No place was found east of San Francisco Canyon where a section could be measured satisfactorily. It is probable, however, that all of the beds described from the south slope of Barilla Mesa 
may be found here, for the distance between the outcrops on the two sides of the mesa is only a few miles.

The formations were traced along their outcrop northwest of San Francisco Creek and examined wherever the rocks were well exposed. Unfortunately good exposures are rare in this vicinity because of the dense growths of brush that covered the north slope of the mesas. However, a considerable number of prospects have been made with diamond drill between San Francisco Creek and Engle, and these records supplement the information gained from measurements at the surface. . It is not always possible to correlate the beds reported in these drill records with those observed at the outcrop. This may be due to one of several causes, among which may be mentioned (1) the absence of characteristic rocks-comparison being difficult in beds consisting of sandstone, shale, and coal, all of which vary from place to place in thickness and in character; (2) the continuity in the drill record and the lack of continuity in the section measured at the surface, which is likely to emphasize such prominent features as sandstone cliffs and to minimize or even -omit thin beds of soft rock; such as shale and coal that outcrop in soil-covered slopes; and (3) the different viewpoints of the observer, the geologist noting and emphasizing one group of phenomena and the driller paying special attention to quite another group. Thus the drill may have gone through' a conglomeratic sandstone without any reference to its character or significance appearing in the record, or through a plane of unconformity (in passing from one formation to another) without the fact being suspected by the driller. On the other hand, the drill record is likely to show thin beds of coal and shale that are obscured at the surface and that do not appear in the sections measured at the outcrop.

\section{SAN FRANCISCO CANYON.} LOCALITY 94.

A poorly exposed section was examined east of San Francisco Creek (locality 94). The coal beds were opened some years previous to the time of examination, and their thicknesses were measured in the old prospect entries. The Vermejo formation was measured again about one-fourth mile farther east, where the lowest. coal is 2 feet thick and the next higher bed 1 foot thick. A hard sandstone about 40 feet above the top of the Trinidad is probably the basal member of the Raton formation; it is not conglomeratic so far as was observed, but otherwise it is similar in character to the conglomeratic sandstone farther west that is undoubtedly the base of the Raton formation.

Above this sandstone shaly rocks nearly 100 feet thick that contain coal at several horizons occupy the position of the lowest coal-bearing shales of the Yankee district south of Barilla Mesa; and their thickest coal doubtless should be correlated with the Sugarite bed of that district. Above these shaly beds lies a series of thick, massive, cliff-making sandstones similar in thickness and character to those which form the prominent cliffs in the vicinity of Raton and which, in the parlance of this region, constitute the "barren series." Coal beds occur above the cliffs in the same general positions as those exposed in the south slope of the mesa, the lowest of which is known as the Yankee coal. The thickest, or 4-foot, coal bed of the following section is correlated with some confidence with the Yankee bed. 'The higher beds of the Yankee district outcrop in San Francisco Canyon but are so poorly exposed that the measured section was not extended to include them. In all essential characters the section is comparable with those measured in the south slope of Barilla Mesa and indicates that the formations extend through the mesa with little change in character, except that the conglomeratic sandstone which rests on the Trinidad south of the mesa is here separated from that sandstone by 40 feet of the Vermejo formation. The section follows:

Section of rocks measured at locality 94, San Francisco Creek, Colo.

[For graphic section see PI. XII.]

Raton formation: Sandstone......................... $20 \cdot 0$

Shale.............................. $25 \quad 0$ Coal.......................... 196 Shale........................... $15 \quad 0$ Shale, carbonaceous, with thin seams of coal. $2 \quad 0$ Shale, with layers of sandstone.......... $25 \quad 0$ Coal (probably the Yankee bed)........ $4 \quad 0$ Shale............................. $20 \quad 0$ Sandstone.......................... $20 \quad 0$

- Sandstone and sandy shale.............. $90 \quad 0$ Sandstone, cliff making................ $100 \quad 0$ Shale, with thin beds of coal. ........... $40 \quad 0$ Coal (Sugarite bed?)................... . 16 
Raton formation-Continued.

Shale, dark colored. Coal, thin

Shale, carbonaceous, black............... Sandstone, hard, coarse grained, cliff making, probably the base of the Raton formation..

Probable unconformity.

Vermejo formation:

Shale, not well exposed

Coal.

Shale and sandstone, alternating

Coal...

Shale, sandy

Trinidad sandstone.

Pierre shale:

Transitional zone.

Shale.

LOCALITY 95.

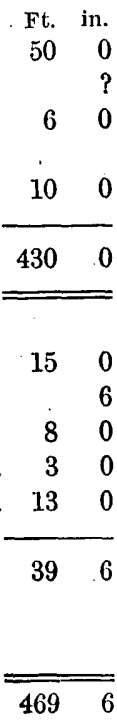

At locality 95, a mile northwest of San Francisco Creek, a short section was measured. The rocks are not well exposed, but some diamonddrill prospecting has been done in the neighborhood, by aid of which it seems possible to recognize both the Raton. and the Vermejo formations. From these records and from such data as were obtained at the outcrop the following section has been constructed:

Section of rocks measured at locality 95, near San Miguel and San Francisco Creek, and penetrated by diamond drill.

$$
\text { [For graphic section see .PI. XII.] }
$$

Raton formation:

Shale..

Sandstone.

Shale...

Sandstone.

Shale...

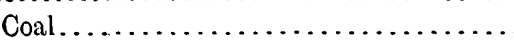

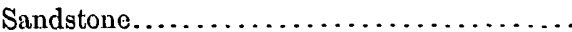

Shale..

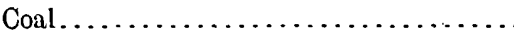

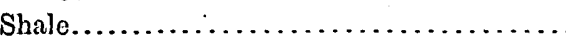

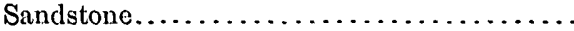

Shale.

Shale.

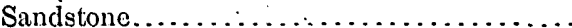

(l)

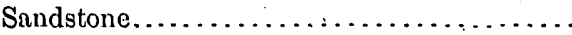

Shale.

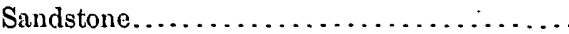

Shale.

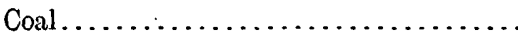

Shale...........................

Coal (Sugarite bed?)..............

Shale. .

Coal. .....................
Raton formation-Continued.

Shale

Coal, bony .................... 10

Shale............................ 180

Sandstone..................... 1111

Coal........................ 5

Shale......................... 18 8

Sandstone........................ 120

Shale......................... 150

Sandstone......................... 1.0

Coal.................... 1

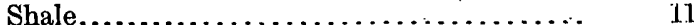

Sandstone (possibly the base of the Raton

formation) $\ldots \ldots \ldots \ldots \ldots \ldots \ldots \ldots \ldots \ldots, 8 \quad 0$

Vermejo formation?:

Shale........................ 33 Coal...................

Shale......................... $66_{4}$

Sandstone...................... 30

Shale...................... 6

Coal ......................

Sandstone....................... $3 \quad 0$

Shale.......................... . 10

Coal. ................ 4

Shale.......................... 111

Coal...................... 10

Shale........................... 101

Coal...................... 10

$39 \quad 1$

Trinidad sandstone.................. 100.

Pierre shale:

Transitional zone.

Shale.

The Trinidad sandstone, which is about 100 feet thick at this locality, was penetrated only 50 feet by the drill. In the Vermejo formation coal was found at the surface at only one horizon, but the drill penetrated one thick bed and several thin ones less than 40 feet above the top of the Trinidad. A sandstone 8 feet thick and 40 feet above the Trinidad at the outcrop is supposed to lie at the base of the Raton formation. It is hard, white, coarse grained, cross-bedded, and mottled near the base, with the inclusions of clay and fragments of carbonized wood that characterize the basal conglomeratic sandstone of the Raton formation in many places throughout the Raton Mesa region. In some places it consists of clean white sand of well-rounded grains which have been cemented, apparently by silica, into a flinty quartzitic mass. In other places this clean white sand contains irregular masses of buff-colored muddy sand which are usually softer than the white portions. Where these softer inclusions occur the rocks weather to an 
uneven craggy surface, this being noted in many places where the basal sandstone is only slightly conglomeratic. There is no mention in the drill records of any character by which the basal sandstone of the Raton formation can be identified, and the correlation of the 8-foot sandstone in section 95 (Pl. XII) with it is provisional. The Sugarite coal and the shales associated with it can be recognized in the drill records, as can also the overlying sandstones which constitute the so-called "barren series." The Yankee coal bed was not penetrated, and if the correlations indicated by the dotted lines in Plate XII are correct this bed occurs at a horizon slightly higher than that represented by the top of the record.

\section{GRAY CREEK. \\ LOCALITY 96.}

No good exposures of the coal-bearing rocks were found between.locality 95 and Gray Creek, about 4 miles to the northwest (locality 96). At Gray Creek the Vermejo formation is well exposed, and three of its coal beds have been opened. At the mouth of Gray Creek mine the base of the Vermejo is not exposed, but the mine superintendent informed the writer that the lowest bed developed in the mine is the same as the one exposed in the gulch about 100 yards east of the mine, where coal was found about 7 feet above the top of the Trinidad sandstone. The thickness of the Vermejo formation, where measured in the west wall of the gulch at Gray Creek, is about 77 feet.

The basal conglomerate of the Raton formation is here 30 feet thick and is characteristically quartzose and conglomeratic in the lower part: Although the pebbles are not numerous several more than half an inch in diameter were found. The conglomerate rests with uneven base upon shale, and the rocks above it are mainly massive, cliff-making sandstones which contrast sharply with the shale and soft sandstone of underlying Vermejo beds: No coal which can be correlated with the Sugarite bed was found at the place where the section was measured. This may be because of poor exposure. Richardson ${ }^{225 b}$ states that within 150 feet above the Trinidad' sandstone in the vicinity of Gray Creek there are from two to six beds of coal more than 2 feet thick. It is possible that one or more of these beds occur near the horizon of the Sugarite coal above the conglomeratic sandstone. On the other hand, all of the large beds observed at the outcrop near Gray Creek occur below the conglomerate. The uneven base of the conglomerate is suggestive of an erosional unconformity and it is possible that some of the six coal beds penetrated in some of the drill prospects may have been eroded. away at locality 96 before the conglomerate was laid down.

Fossil plants found in the rock dump of the Gray Creek mine came from the roof of the 6-foot coal bed (the middle bed of the three mined). The plants belong to the Vermejo flora and are as follows:

Fossil plants collected at Gray Creek, Colo. [U. S. Geol. Survey fossil locality 5710.]

Abietites dubius Lesquereux.

Ficus praetrinervis Knowlton.

Ficus starkvillensis? Knowlton.

Fraxinus? sp.

Viburnum anomalinervum? Knowlton.

The section measured at this locality is as follows:

Section of rocks measured in west wall of the gulch at locality 96, Gray Creek mine, Colo.

[For graphic section see P.I. XII.]

Raton formation:

Sandstone, coarse grained, yellow, in massive thick layers separated by layers of shale (thickness estimated).................... 200+. Sandstone, coarse grained, locally conglomeratic and quartzose near the base............. 30

Unconformity.

Vermejo formation:

Shale with sandstone................... 15

- Coal (this coal varies in the mine from 4 to. . 14 feet in thickness). ............... $4+$

Sandstone and shale in alternating layers, fossiliferous $(5710) \ldots \ldots \ldots \ldots \ldots \ldots \ldots \ldots \ldots . .6 \ldots$

Coal........................... $6 \pm$

Sandstone and shale..................... 25

Coal............................. $5 \pm$

Sandstone, shaly and friable.............. 7

Trinidad sandstone $\ldots \ldots \ldots \ldots \ldots \ldots \ldots, \frac{77}{307}$

A considerable number of drill holes hare been bored in the vicinity of Gray Creek, but a comparison of the records indicates such great variations in the number, character, and thickness of the coal beds that their correlation is quite impossible at the present time, although the large groups can be recognized without difficulty. One record, section 96a (Pl. XII), 


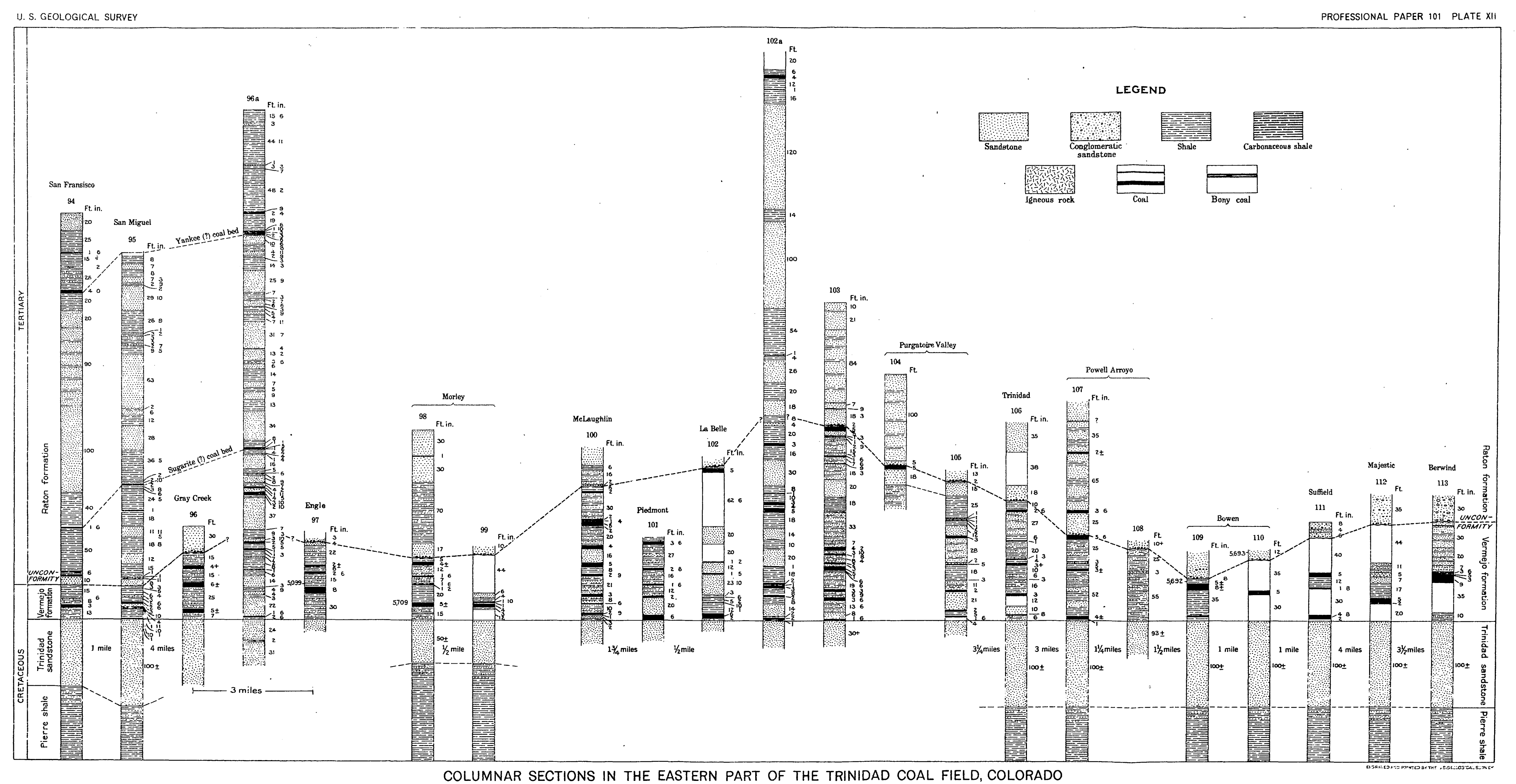


is given in order to show the character and succession of the rocks of the Raton formation, which could not be examined at the outcrop. It is probable that the $37-$ foot sandstone of this record is the basal conglomerate of the Raton formation and that the coals above it are at or near the horizon of the Sugarite bed. The so-called "barren series" appears conspicuously in this record and the lowest coal of the upper group seems to be the Yankee coal bed.

Hills ${ }^{143}$ publishes the records of two diamonddrill prospects made between Gray .Creek and Engleville. He did not make a subdivision of the conl-bearing rocks such as is described in this paper, but it is not difficult to recognize in these two records two of the groups of coal beds here described. A massive sandstone 35 to 38 feet thick that occurs 90 to 100 feet above the lowest conl in Hill's section seems to be the same as the 37-foot sandstone of section No. 96凡. (See Pl. XII.) The principal coal beds occur below this sandstone and are undoubtedly the Vermejo coals of this paper. The highest coal beds of Hill's sections probably belong to the Sugarite group. The sections do not extend high enough to include the rocks at the horizon of the Yankee coal.

\section{ENGLE.}

LOCALITY 97.

For about 3 miles along the outcrop northwest of Gray Creek little was seen of the coalbearing rocks, but about half a mile east of Engleville boulders of conglomerate were observed which seem to have come from the basal conglomerate of the Raton formation, as no other rock in this vicinity is known to be conglomeratic.

A section was measured at Engle (locality 97), about 3 miles northwest of Gray Creek. The lower part of the Vermejo formation is not well exposed but seems to contain no coal. Three.coal beds, the lowest of which is worked in the Engle mine, have been opened at higher horizons in this formation.

The conglomeratic sandstone at the base of the Raton formation was examined in an excavation'near the mouth of Engle mine and at several places east of the mine in cuts along an old tramway. It is irregularly quartzose in some places and is locally conglomeratic. A few quartz pebbles half an inch in diameter were found in it near the mine, but the pebbles are larger and more numerous farther east. The section follows:

Section of rocks measured at locality 97, Engle, Colo. [For graphic section see PI. XII.]

Raton formation: Ft. in. Sandstone, locally conglomeratic; pebbles up to half an inch in diameter........... $3+$ Unconformity. Vermejo formation:

Sandstone, massive, yellow............ i $\quad$ i

Shale, with partings of concretionary sandstone, drab....................... 220 Coal.......................... $2 \pm$

$\begin{array}{llll}\text { Shale, carbonaceous, black................ } & 6 & 0\end{array}$ Coal, bony........................ $2 \quad 0$

Shale, drab, and shaly sandstone........... $15 \quad 0$ Coal........................... \& 80

Shale and sandstone, not continuously exposed.......................... $30 \quad 0$ Trinidad sandstone....................

About $1 \frac{1}{2}$ miles southwest of Engle. a coal bed has been opened in the side of Ratom Mesa at the Fishers Peak mine (mine No. 8, Pl. I, in pocket). This bed is 400 to 500 feet above the Trinidad sandstone and is at or near the horizon of the Yankee coal. From the floor of this mine the following fossil plants were collected by G. B. Richardson:

Fossil plants from the floor of Fishers Peak mine, Colo.

[Collected by G. B. Richardson, U. S. Geol. Survey fossil locality 5099.]

Acer fragilis Knowlton.

Alismaphyllum crassifolium Knowlton.

Cassia fisheriana Knowlton.

Ficus denveriana Cockerell.

Nelumbo lakesiana (Lesquereux) Knowlton.

Pteris linearis Knowlton.

Quercus fisheriana Knowlton.

\section{MORLEY DOME.}

LOCALITIES 98 AND 99.

Unusual interest centered in the structural relations in the vicinity of Morley, which is midway between the localities in the Raton field where evidence of a plane of unconformity within the coal measures was first found and the localities near Trinidad where similar conditions were observed. Morley is 8 miles from the nearest locality described in the Raton field and 6 miles from the nearest locality near Trinidad at which the Vermejo beds are described. A local dome in this vicinity has brought to the surface the upper part of the Pierre shale and the Trinidad 
sandstone as well as the lowest beds of coal. From the center of this dome the strata dip on all sides at an average of àbout $10^{\circ}$. G. B. Richardson ${ }^{225}$ found Halymenites major. Lesquereux in the Trinidad sandstone and Inoceramus in the Pierre shale. He also confirmed Stevenson's assignment ${ }^{89}$ of the. Morley coal to the case of the coal measures and pointed out that it had been incorrectly assigned to a horizon 800 feet above the base. ${ }^{151}$

Near Raton only a few small pebbles were found in the basal sandstone of the Raton formation (p. 106), and the hypothesis was entertained at one time that the conglomerate might thin toward the north and disappear under Raton Mesa in some such manner as it thins toward the east in the Raton field. For these reasons special care was taken to determine if the coal-bearing rocks at. Morley are clearly separable into two formations as they. are in the Raton field. To aid in this determination, as complete a collection as possible of fossil plants was made from the lower part of the coal measures at Morley and equally complete collections were obtained from the higher beds near Wootton: On the evidence thus obtained and on the physical evidence rests the separation of the coal measures into two formations.

Although the rocks of the Vermejo are relatively soft and the exposures correspondingly poor near Morley, two sections were measured, as follows:

Section of rocks measured at locality 98 , half a mile northeast of Morley, Colo.

[For graphic section see Pl. XII.]

Raton formation:

Sandstone, massive, yellowish brown....... 30

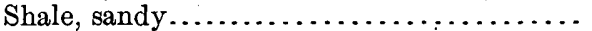

Sandstone, massive, cliff making, white....

Shale and sandstone, not continuously ex-

posed............................

Sandstone, massive, locally conglomeratic at base, quartzitic, white to yellowish brown; weathers to crags having uneven cavernous surfaces....................

Unconformity.

Vermejo formation:

Shale........................... 50

Coal........................... $4 \pm$

Sandstone and shale, thin bedded, yellow. $\therefore \quad 12 \quad 0$

Coal........................ 16

Sandstone and sandy shale, thin bedded, yellow.
Vermejo formation-Continued.

Ft. in.

Shale, carbonaceous, black............... 16

Coal........................... 12

Shale, drab........................ $20 \quad 0$

Coal.......................... $5+$

Shale, sandy, weathering red, with 1 foot of

coal near the middle................ $15 \quad 0$

Trinidad sandstone:

$72 \pm$

Sandstone containing Halymenites major Lesquereux

Pierre shale:

Transitional zone.

Shale containing Inoceramus sp.

\section{$270 \pm$}

Section of rocks measured at locality 99 , half a mile northwest of Morley, Colo.

[For graphic section see.PI. XII.]

Raton formation:

Ft. in.

Sandstone, locally conglomeratic, quartzitic, coarse grained, white; weathers to crags having uneven cavernous surfaces. . . . ........ 10

Unconformity.

Vermejo formation:

Covered.............................44 0

Sandstone, massive, friable, yellow .......... 6

Shale, drab, fossiliferous................ 40

Coal............................. 110

Shale......................... 10

Coal........................... $4 \quad 0$

Shale, reddish brown................... 30

Covered $. . \ldots \ldots \ldots \ldots \ldots \ldots \ldots \ldots \ldots \ldots, 12 \quad 0$

Trinidad sandstone: $75 \quad 10$

Sandstone containing Halymenites major Lesquereux.

Pierre shale:

Transitional zone.

Shale containing Inoceramus sp.

The Morley coal mine has been developed in the lowest bed of the Vermejo formation, 12 to 15 feet above the top of the massive Trinidad sandstone. From rock on the mine dump (U. S. Geol. Survey fossil locality 5709), which according to the superintendent came from the roof of the mine, some very perfect fossil plants of the Vermejo flora-Ficus leei Knowlton, Sequoia obovata Knowlton, and Sabal montana Knowlton-were collected.

For about 75 feet above the top of the Trinidad sandstone there is obviously no break in the sedimentation, but at this horizon there is a hard quartzitic sandstone that varies in thickness from 2 to 17 feet or more. In some places a few pebbles of quartz $\varepsilon$ nd chert up to half an inch in diameter occur in this sandstone, but they are relatively rare, and for its identity more dependence is to be placed on other char$\begin{array}{llll}7 & 0 & \text { acteristics. The rock is made up of relatively }\end{array}$ 
dark, muddy sand which contains irregular masses of clean, harder, and more resistant white sand. This difference in hardness causes the sandstone to weather to a rough, craggy surface. The mottled quartzose character was noted in so many places where the rocks are conglomeratic only at the base of the Raton formation that it is regarded as diagnostic of this basal member.

The conglomeratic sandstone, 17 feet thick at locality 98 , is overlain by 70 teet of poorly exposed sandstone and shale that probably represent the shaly. zone in which the Sugarite coal bed occurs at several of the localities previously described. However, no coal was found in it at this locality. The sandstone at the top of the measured section and those still higher that were not included because of poor exposures doubtless constitute the lower part of the "barren series."

The rocks above the quartzose conglomeratic sands tone are more uniformly fossiliferous than those below. They are well exposed in many places between Morley and Wootton, but the best collections came from horizons near that of the Wootton coal bed. This coal is probably the same as the highest developed in the south slopes of the Raton Mesa and is known to be about 700 feet above the base of the Raton formation. Fossil plants were collected from the Wootton mine; from the rocks 100 to 200 feet above the Wootton horizon west of the mine; from rocks a few feet below it half a mile north of the mine; and from the Turner mine about a mile north of Wootton. These fossils all belong to the Raton flora; in short, all the data; both stratigraphic and paleontologic, agree in separating the coal-bearing rocks at Morley into two formations, the Vermejo and the Raton, as has been done for neighboring regions.

In a railway cut 1 mile south of Morley (U. S. Geol. Survey fossil locality 5715), Platanus aceroides Göppert and Platanus raynoldsii Newberry were found; and from the dump of the Turner mine, on the Wootton coal bed, about $1 \frac{1}{2}$ miles north of Wootton, a large collection was made.

Fossil plants from the Turner mine near Wootton, Colo. [U. S. Geol. Survey fossil locality 5714.]

Andromeda? lanceolata Knowlton.

Cassia sapindoides Knowlton.

Juglans berryi Knowlton.

Juglans minutidens Knowlton.
Juglans rugosa Lesquereux.

Magnolia angustifolia Newberry.

Terminalia lesleyana (Lesquereux) Berry?

Magnolia rotundifolia Newberry.

Magnolia lesleyana Lesquereux?

Prunus coloradensis Knowlton.

Rhamnus cleburni Lesquereux.

Rhamnus? woottonensis Knowlton.

Viburnum woottonianum Knowlton.

In a railway cut, half a mile north of Wootton, at a horizon 50 to 100 feet below the Wootton coal bed, the following plants were collected:

Fossil plants collected near Wootton, Colo..

[U. S. Geol. Survey fossil locality 5711.]

Artocarpus similis Knowlton.

Ficus artocartoides Lesquereux.

Ficus minutidens Knowlton.

Juglans rugosa Lesquereux.

Juglans sapindoides Knowlton.

Phyllites retusoides Knowlton.

Platanus rhomboidea Lesquereux.

Rhamnus cleburni Lesquereux.

Rhamnus goldianus? Lesquereux.

Rhus? viburnoides Knowlton.

Viburnum magnum Knowlton.

In the same cut, 10 rods farther north (U.S. Geol. Survey fossil locality 5713), a large collection was made of very large and perfect fossil leaves of Platanius aceroides latifolia. Knowlton.

On the hillside west of Wootton, between that town and the northend of the Raton tunnel, the following plants were collected from horizons ranging from the Wootton coal bed to about 100 feet above that bed:

Fossil plants collected southwest of Wootton, Colo.

[U. S. Geol. Survey fossil locality j712.]

Artocarpus similis Knowlton.

- Castanea intermedia Lesquereux.

Celastrus serratus Knowlton.

Dryophyllum aquamarum? Ward.

Ficus denveriana Cockerell.

Ficus praetrinervis Knowlton.

Inga heterophylla Knowlton.

Juglans rugosa Lesquereux.

Laurus? caudata Knowlton.

Magnolia angustifolia Newberry.

Magnolia magnifolia Knowlton.

Platanus aceroides Göppert.

Platanus aceroides latifolia Knowlton.

Platanus rhomboidea Lesquereux.

Paliurus zizyphoides Lesquereux.

It may not be out of place to call attention in this connection to the fact that these large collections of fossil plants come from North Raton Creek and that many of the fossils of the old collections from this region, according to the 
brief description given, came "from North Raton Creek." Although this creek flows across the Vermejo formation at Morley and at Starkville the present writer found no fossils in these beds at the surface, all the Vermejo plants -coming from unweathered rock on the mine dumps. On the other hand, the fossil plants of the Raton formation are very abundant at the surface. Furthermore, at the time Hayden, Lesquereux, and others made the early collections the road house for travelers crossing the pass between Trinidad and Raton was at Wootton. It seems altogether probable, therefore, that the plants from "Fishers Peak," "Raton Mountains," "North Raton Creek," etc., which Lesquereux maintained were of Eocene age, came from the vicinity of Wootton.

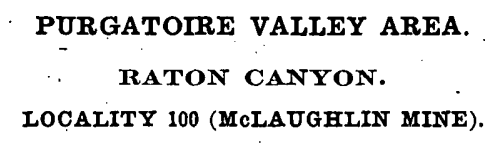

West of Engle the Pierre shale, the Trinidad sandstone, and both coal-bearing formations were observed in many places, but good sections of them were difficult to obtain. Two small collections of invertebrates were made from the Pierre. Inoceramus vanuxemi Meek and Hayden and two undescribed species of Inoceramus were found in a railway cut northeast of Trinidad (U. S. Geol. Survey fossil locality. 6510); and G. B. Richardson found Inoceramus sagensis Owen farther south (U. S. Geol. Survey fossil locality 5668). No fossils were collected from the Trinidad sandstone, but Halymenites major Lesquereux was observed in it; and on Simpsons Rest west of Trinidad Inoceramus and bones supposed to be the remains of a large fish were found in the sandstone. The Vermejo consists of shale and soft sandstone which weather easily and form gentle slopes that are often covered with débris from the harder rocks above them.

The first place west of Engle at which a section was measured is at McLaughlin's coal mine (locality 100), where all the coal beds in the Vermejo formation have been opened. The lower part of the following section is from mine records furnished by Mr. J. E. McLaughlin, who conducted the development work, and the upper part is constructed from measurements made at the surface. In the lowest coal bed were found petrified logs several feet long and 2 feet or more in diameter and stumps, both in an excellent state of preservation. The logs are rounded at the ends and the condition of the sides suggests considerable wear by transportation or otherwise before their final lodgment in the bed where they were found. Several stumps have been found in the coal, but according to Mr. McLaughlin none of them was standing upright. Each was found on its side with roots only a few inches long, as if worn off before the stump found its way into the material that formed the coal. Apparently the logs and stumps were transported from some distance. The surface of some of the logs is full of holes similar to those frequently seen in driftwood at the seashore. The petrified wood in the coal bed (U. S. Geol. Survey fossil locality 5706) has been described as Cupressinoxylon coloradense Knowlton.

The base of the Raton formation is not well marked here. The lowest stratum, about 2 feet thick, is coarse grained, quartzose, and mottled with inclusions of small bits of clay, a character noted at the base of the formation in many places. No pebbles were found in it, though a few hundred feet to the east it contains pockets of small pebbles composed mainly of chert. This sandstone is here about 70 feet higher in the section than the similar sandstone at Engle, 3 miles to the east, and it overlies eight beds of coal in place of the three found at Engle. This is in harmony with the known thickening of the Vermejo formation toward the west. The section follows:

Section of rocks measured at locality 100, McLaughlin's mïne near Starkville, Colo.

[For graphic section see Pl. XII, p. 118.]

Raton formation:

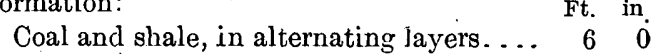

Shale and sandstone, not continuously ex-

posed........................... $16 \quad 0$

Sandstone, locally conglomeratic ........ $\quad 2 \quad 0$

Probable unconformity.

Vermejo formation:

Shale............................... 60

Coal........................ 20

Shale and sandstone................... $30 \quad 0$

Coal............................... 20

Shale.............................. 14

Coal.......................... 5

Shale............................. 20

Shale and sandstone, not differentiated.... $20 \quad 0$ Coal................................ 40

Sandstone........................ $16 \quad 0$

Coal, with partings of shale............. 5 5 0 


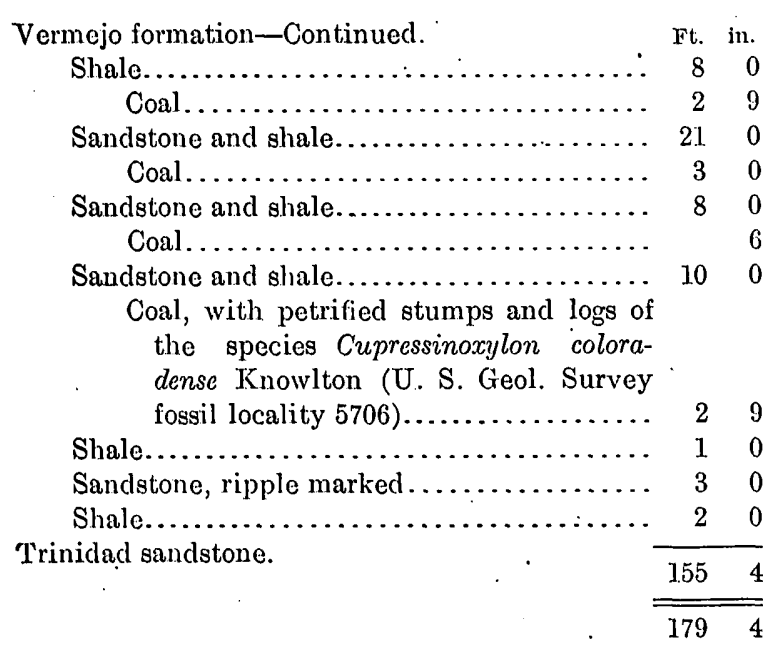

The basal sandstone of the Raton formation was observed in several places about a mile south of the McLaughlin mine in the vicinity of Starkville, and at one place about a mile south of the mine it was found to be plainly conglomeratic. A few fossils belonging to the Vermejo flora were obtained from the rock. dump of the Starkville mine (mine No. 10, Pl. I, in pocket), and plants belonging to the Raton flora were found in several places in the rocks above the conglomerate; but few were collected.

Fossil plants from mine at Starkville, Colo.

[U. S. Gcol. Survey fossil locality 5707.]

Ficus praetrinervis Knowlton.

Ficus? starkvillensis Knowlton.

Sabal montana Knowlton.

Sequoia reichenbachi (Geinitz) Heer.

Sequoia obovata Knowlton.

The fossils found in the Raton formation near Starkville are poorly preserved and few were collected. Cinnamomum linifolium Knowlton was obtained near the base of the formation (U. S. Geol. Survey fossil locality 5796) and Magnolia angustifolia Newberry from about 200 fect above the base (U. . S. Geol. Survey fossil locality 5797).

\section{SOPRIS. \\ LOCALITY 101 (PIEDMONT MINE).}

Between Starkville and the Piedmont mine (locality No. 101) the rocks are not well exposed. The short section of the Vermejo formation given below was obtained from the records of J. E. McLaughlin, who opened this mine. This section seems to include less than half of the thickness of the Vermejo formation.

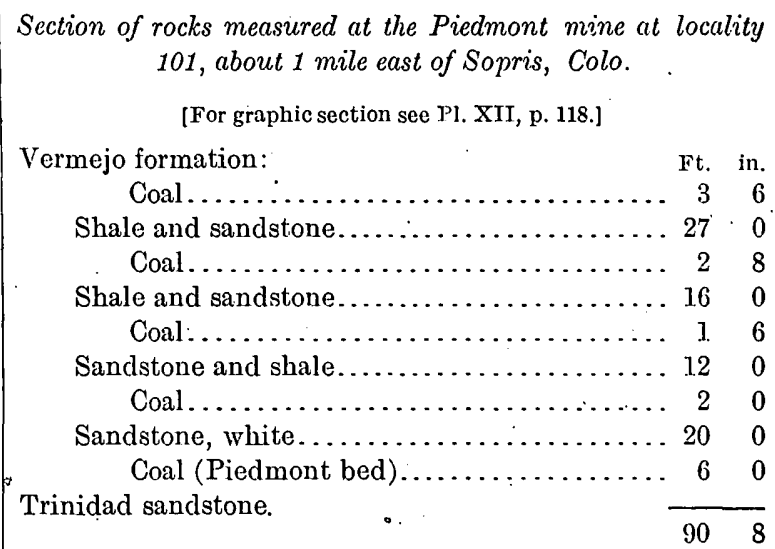

At the La Belle mine, about half a mile southwest of the Piedmont mine, a coal bed 5 feet thick, known as the Sopris coal, has been opened, which, according to measurements made by the mine engineers, is separated from the Trinidad sandstone by an interval of 171 feet. Near the mouth of the mine the basal conglomerate of the Raton formation was observed a few feet above this coal bed. The conglomerate consists of a groundmass of dark muddy sand in which are embedded irregular masses of clay shale, small bits of carbonized wood (dull black, like charcoal), larger fragments of bright vitreous coal, like that on which the conglomerate rests, and pebbles of chert an inch or more in diameter.

Section of rocks measured in La Belle mine at locality 102, near Sopris, Colo.

[For graphic section șee Pl. XII, p. 118.]

Raton formation:

Conglomerate.

Unconformity.

Vermejo formation: Ft. in.

Coal, overlain by thin shale............ $\quad 5 \quad r$

Not exposed ........................... $62 \quad 6$

Sandstone.............................. $20 \quad 0$

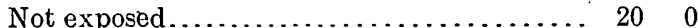

Coal............................ 12

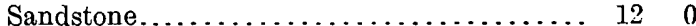

Coal.............................. 15

Sandstone.......................... $23 \quad 10$

Shale............................. $3 \quad 0$

Coal........................... 6

Shale............................... $6 \quad 6$

Coal .......................... 10

Shale............................... $12 \quad 1$

Coal (Piedmont bed) $\ldots \ldots \ldots \ldots \ldots \ldots, \quad 6 \quad 0$

Shale.............................. $2_{2} 0$

Trinidad sandstone. $\quad . \quad \overline{176 \quad 6}$ 
No satisfactory observations were made at the outcrop near Sopris, but many diamonddrill holes have been put down near by, and these, if correctly interpreted, show that the Sopris coal bed occurs 170 to 200 feet above the Trinidad sandstone, the altitude varying according to location. No mention of the conglomeratic sandstone is made in the drill records and its position in section 102a of Plate XII (p. 118) can not be definitely fixed. Its occurrence at the La Belle mine above the Sopris coal and its occurrence above the same bed west of Sopris indicate that it will probably be found near Sopris in a similar position. This section is included in Plate XII not so much for the purpose of showing the positions of the lower coal beds, which are equally well shown in neighboring localities where the line of separation between the Vermejo and the Raton formations can be drawn, as for the purpose of showing the occurrence of the so-called "barren series," which here consists mainly of sandstone, and the occurrence above it of coal beds which are probably to be correlated in a general way with the Yankee and Brilliant coals of the Raton field to the south.

Hills has published ${ }^{151}$ the record of a bore hole near Sopris which is comparable with the sections published in this paper, except that it does not recognize two coal-bearing formations. Apparently, his 24-foot sandstone, near the top of the section, is the lowest member of the Raton formation, although no mention is made of its being conglomeratic. This is not strange in view of the fact that in the vicinity of Sopris the base of the Raton is only locally conglomeratic, and the drill might easily go through it without revealing its conglomeratic character. This sandstone is about 260 feet above the Trinidad as compared with 255 feet in section 102a of Plate XII and 247 feet in-section 103. The highest coal bed, probably the Sopris coal, is 260 feet above the Trinidad as compared with 220 feet in section 102a and 240 feet in section 103.

About a mile west of Sopris in a railroad cut the conglomeratic sandstone is coarse and massive. The rock consists of a groundmass of muddy sand in. which are embedded small masses of clay shale, bits of carbonized wood, and pebbles, mainly of chert, up to 2 inches in diameter. The most. conspicuous occurrence of this conglomerate near Sopris is in the first south-side gulch west of the town near mine No. 16 of the accompanying map. In the railroad cut just west of this gulch the sandstone is not so coarsely conglomeratic, but rests unconformably on the Vermejo. (See Pl. XIII, $A, B$.) A small fault with a throw of about 4 feet at this point displaces the Vermejo beds but, so far as could be determined, not the overlying conglomerate. (See Pl. XIII, B.) Apparently the faulting took place before the conglomerate was deposited.

Farther.west the rocks are well exposed in several places. The basal sandstone of the Raton formation was traced in the south wall of Purgatoire Canyon for more than a mile before it was again found to be notably conglomeratic; but west of Long Canyon, at the point where the line of outcrop of the Sopris coal crosses the Purgatoire River, near mine No. 22 (Pl. I, in pocket), this conglomerate is 10 feet above the coal bed. The following fossil plants belonging to the Raton flora were obtained from the overlying rocks 50 to 150 feet above the conglomerate:

Fossil plants from Purgatoire Canyon south of Cokedale, Colo.

[U. S. Geol. Survey fossil localities 5704 and 5795.]

Magnolia angustifolia Newberry. Magnolia lesleyana (Lesquereux'). Nyssa lanceolata Lesquereux. Palmocarpon palmarum (Lesquereux) Knowlton. Sabal? ungeri (Lesquereux) Knowlton.

Fossil wood, which has not yet been described, was collected from the rock dump of McLaughlin mine No. 22.

At Primero a good collection of fossil plants was made, principally from the rock dump of the mine: The coal is one of the higher beds of the Raton formation, lying probably 600 feet or more above the base of the formation.

Fossil plants from Primero, Colo.

[U. S. Geol. Survey fossil locality 5798 .]

Apocynophyllum wilcoxensis Berry

Asplenium? primero Knowlton.

Celastrus serratus Knowlton.

Juglans acuminata Alexander Braun

Juglans bèryi Knowlton.

Juglans rugosa Lesquereux.

Magnolia leei Knowlton.

Populus neotremuloides Knòwlton.

Sapindus affinis Newberry. 


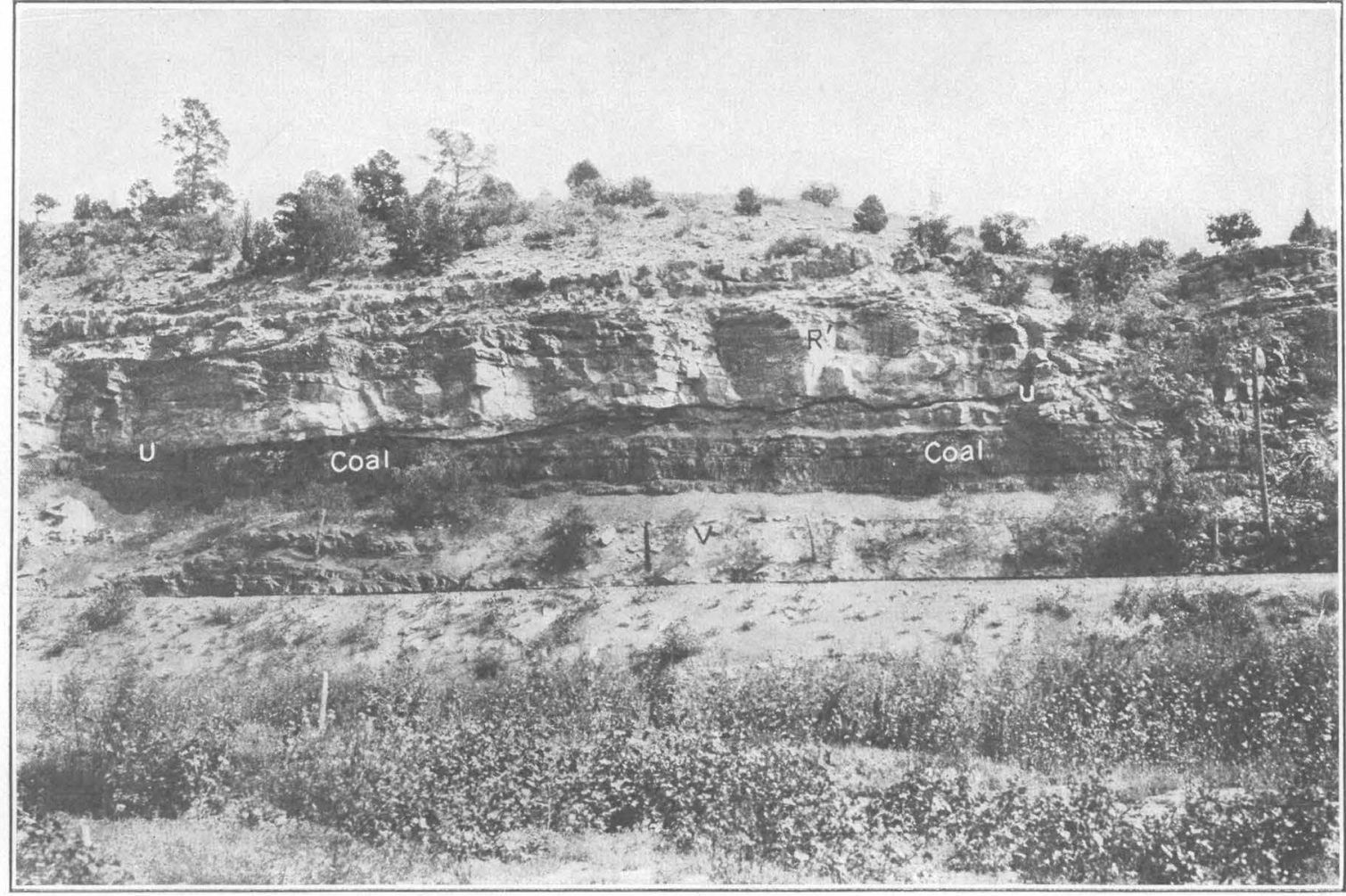

A

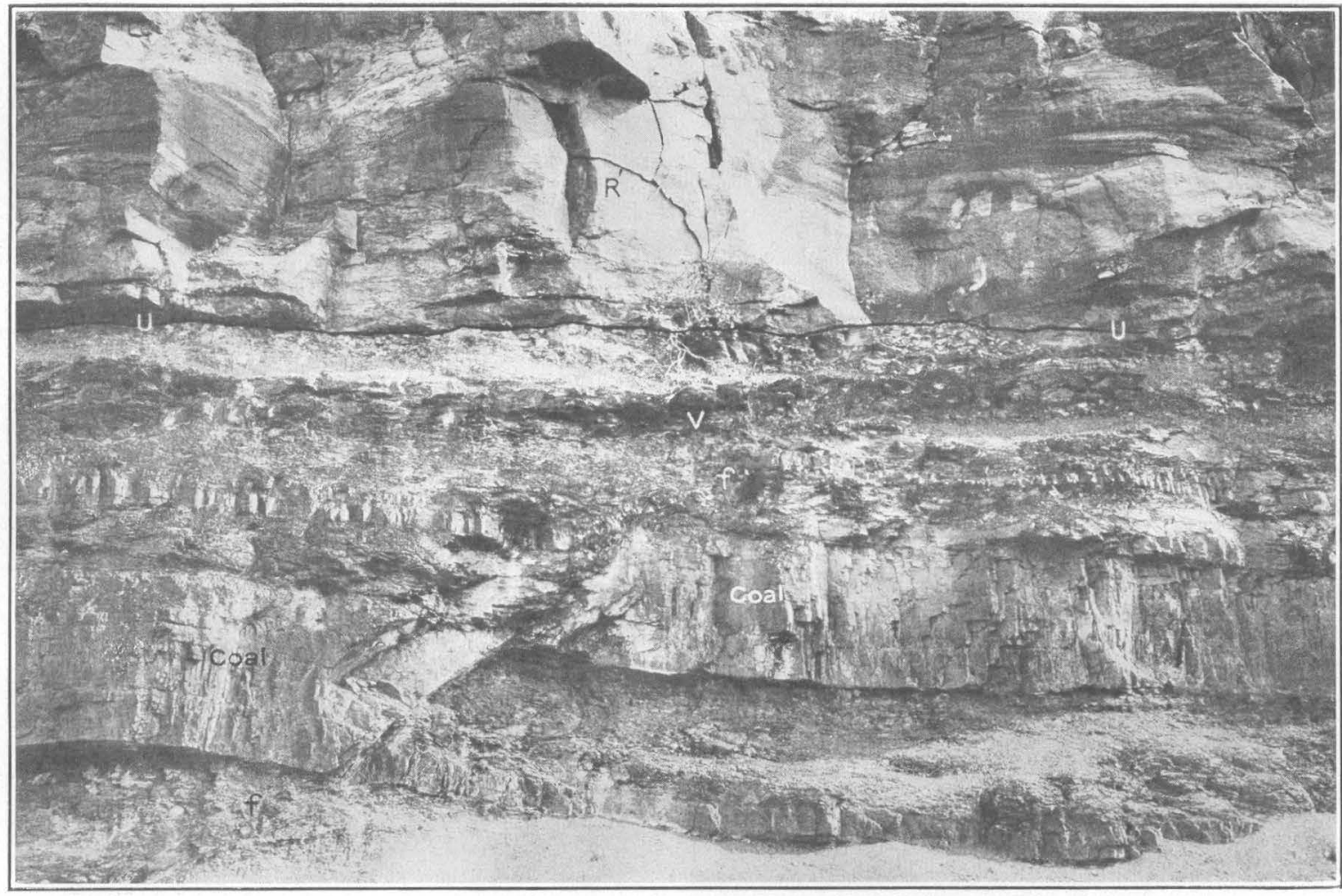

$B$.

SOUTH WALL OF PURGATOIRE CANYON, NEAR SOPRIS, COLO.

$A$, General view; $B$, near view. $V$, Vermejo formation; $U$, unconformity; $R^{\prime}$, basal conglomerate of the Raton formation; $f$, line of fault. 


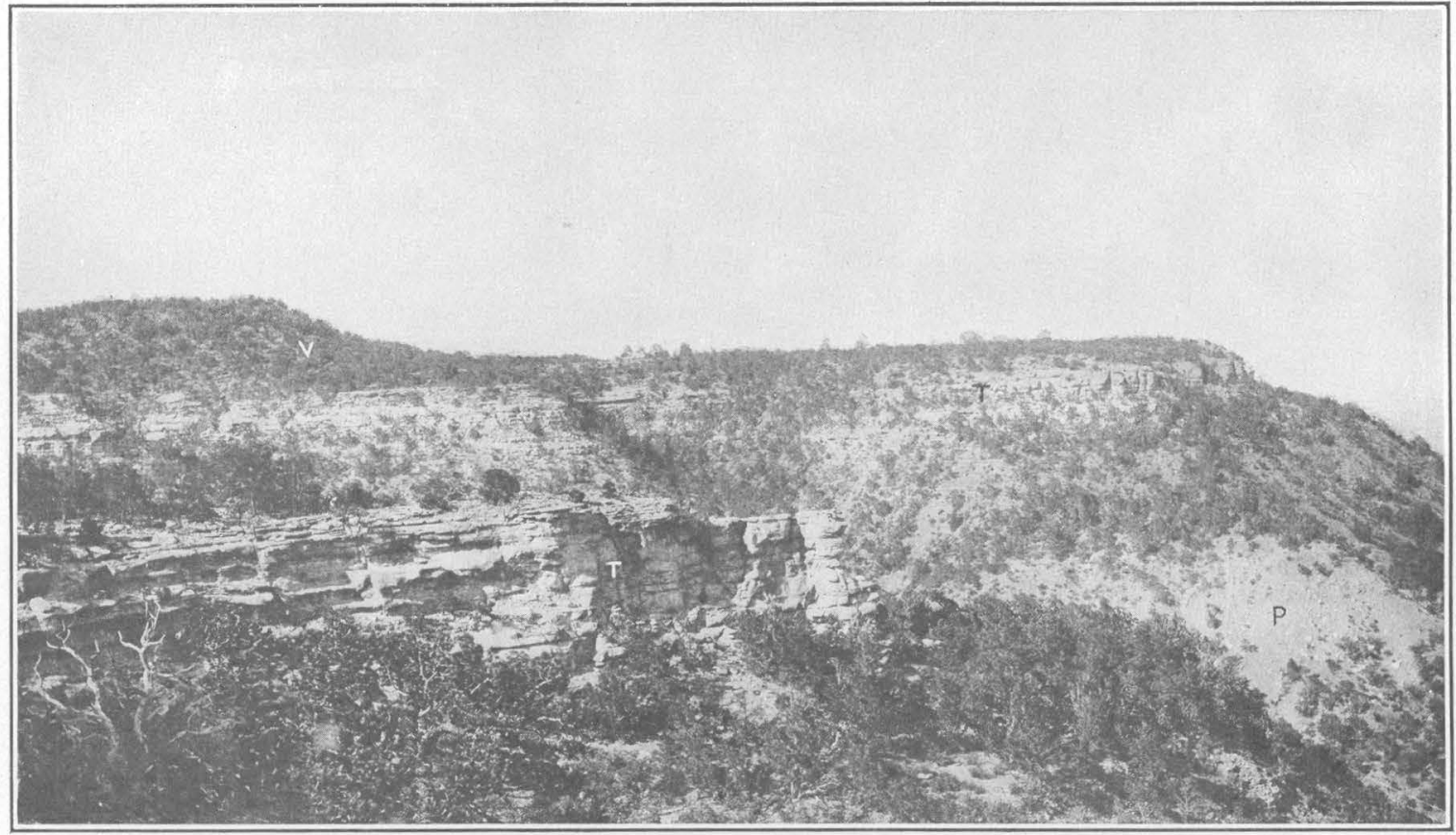

A. A CHARACTERISTIC OUTCROP OF THE TRINIDAD SANDSTONE, ABOUT 4 MILES NORTH OF TRINIDAD, COLO.

P, Pierre shale; T, Trinidad sandstone; V, Vermejo formation.

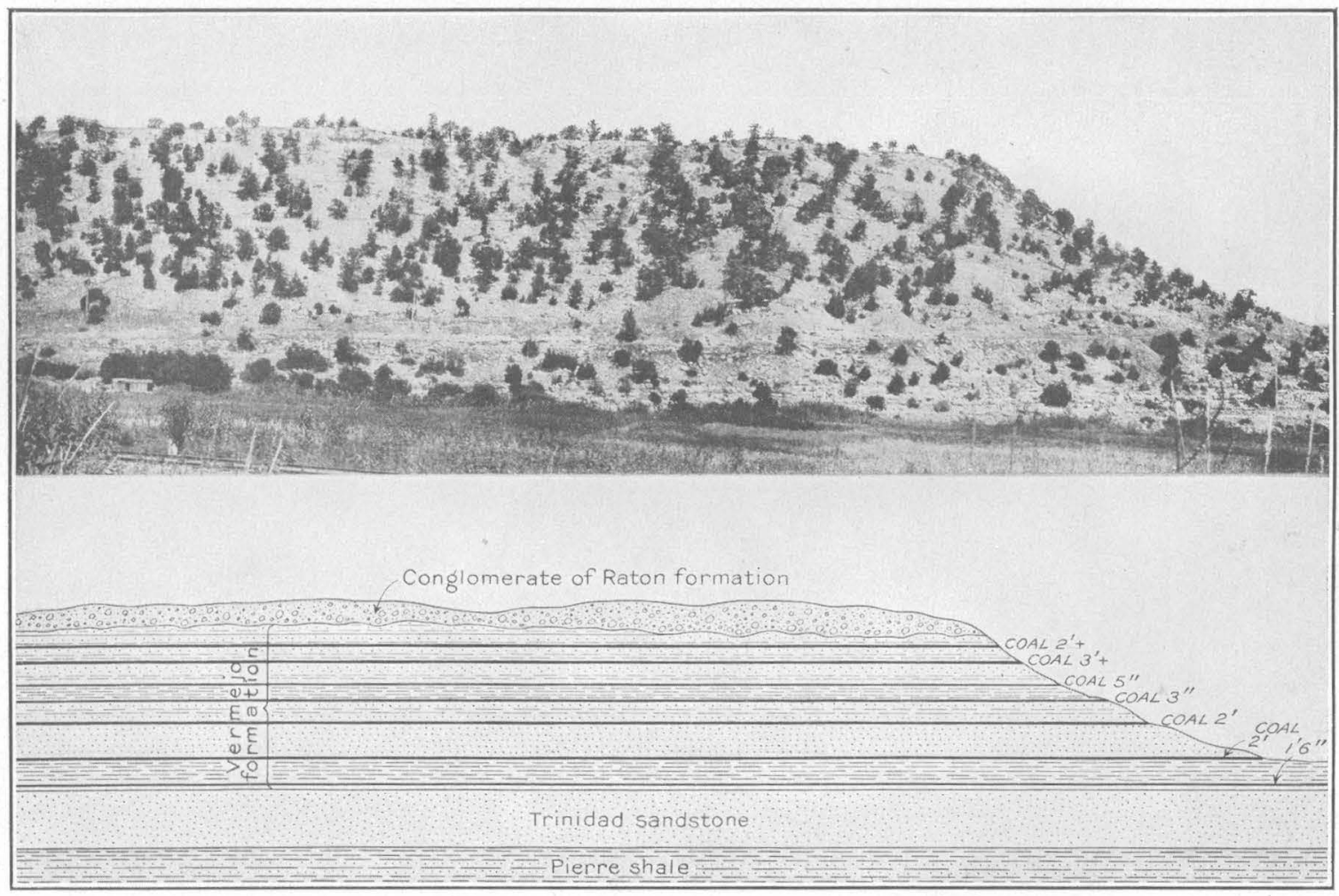

B. RELATION OF tHE VERMEJO TO NEIGHBORING FORMATIONS IN THE NORTH WALL OF PURGATOIRE CANYON, NEAR SOPRIS, COLO. 
REILLY CANYON.

LOCALITY 103

Near the mouth of Reilly Creek conglomerate was observied in several places above the Cokedale coal bed (believed to be the same as the Sopris coal). About a mile west of the mouth of Reilly Creek the conglomerate is 15 feet above this coal bed, but east of the mouth it rests directly upon the coal, with an uneven base that in places cuts well down into the coal. The base of the Vermejo formation is not exposed here, but its thickness is known from many drill prospects in this part of Purgatoire Valley. In the following representative record the 5-foot coal bed, about 240 feet above the Trinidad sandstone, is the one developed in the Cokedale mine, which is known, from observations made at the outcrop, to lie directly under the basal conglomerate of the Raton formation. There is nothing in the drill record to show where the conglomerate occurs, but from the relations observed at the surface it seems probable that the lowest member of the Raton formation is the 18 -foot sandstone above the Cokedale coal.

No satisfactory measurement of the Vermejo formation was obtained west of Reilly Canyon, and it may be in place here to call attention again to the general thickening of this formation westward. From Gray Creek- to Reilly Canyon, a distance of about 10 miles, it increases in a more or less uniform manner from 77 to 247 feet.

Record of rocks penetrated by diamond drill near Purgatoire River, about 7 miles west of Trinidad, Colo.

- [For graphic section see P.!. XII, p. 118.]

Raton formation:

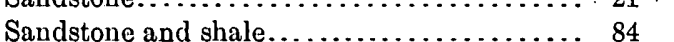

Sandstone....................... 7

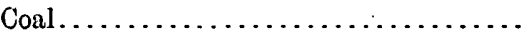

Sandstone (probably conglomeratic). .....

Vermejo formation:

Shale. ......................

Coal (Cokedale bed). .............

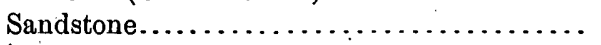

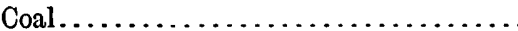

Shale. . . . . . . . . . . . . . . . .

Sandstone and shale............... 20

Coal. .......................

Sandstone and shale.................

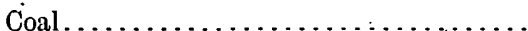

Sandstone and shale.

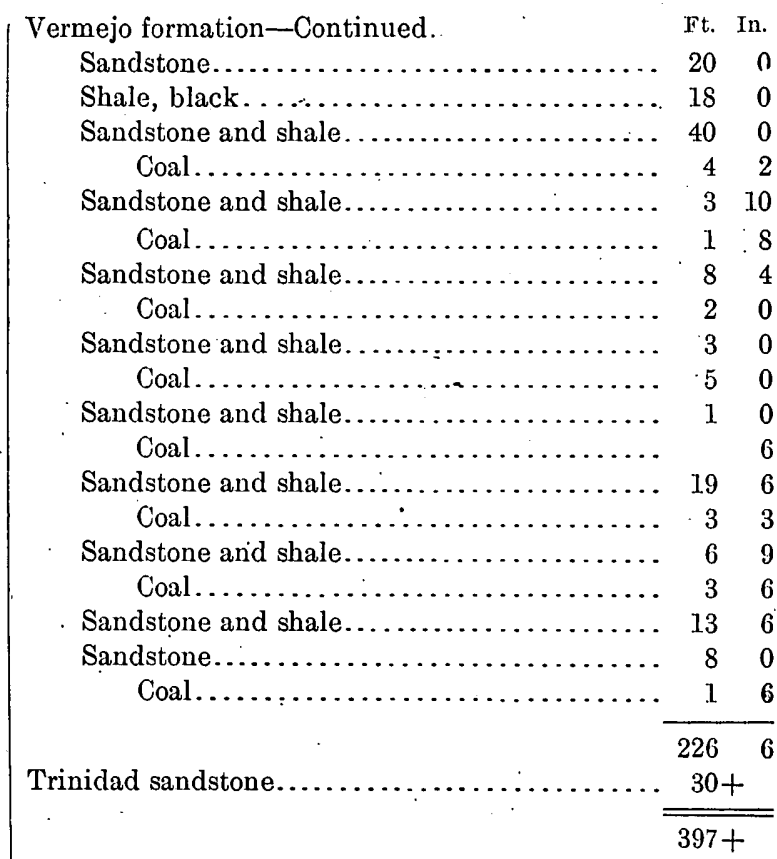

Fossil plants belọnging to the Vermejo flora were collected from the rock dump of the Cokedale mine (U. S. Geol. Survey fossil locality 5698). Very perfect specimens of Ficus speciosissima Ward were found and with them fragments of palms. In the roof of the mine a nearly perfect impression of a palm leaf 3 feet wide and about 4 feet long (including the stem) was found. The rachis was traceable through half the length of the leaf. . From a photograph the species is determined as probably Sabal? ungeri (Lesquereux) Knowlton.

Several small collections of fossil plants belonging in the Raton flora were made near Cokedale from the lower 200 feet of the formation. The location of the collections is indicated on Plate I (in pocket). The lots are combined as follows:

Fossil plants collected from the lower part of the Raton formation near Cokedale, Colo:

[U. s. Geol. Survey fossil localities $5699,5103,5104,5700,5701,5702,5703$.]

Anemia hesperia Knowlton.

Apocynophyllum wilcoxensis Berry.

Aralia coloradensis Knowlton.

Aralia? serrata Knowlton.

Artocarpus similis Knowlton.

Ficus praetrinervis Knowlton.

Magnolia hilgardiana (Lesquereux) Berry.

Magnolia magnifolia Knowlton.

Platanus aceroides Göppert.

Platanus raynoldsii Newberry.

Sabal? ungeri (Lesquereux) Knowlton.

Vitis? platanifolia Knowlton.

Viburnum speciosum Knowlton. 
PURGATOIRE CANYON. LOCALITY 104.

In the north wall of Purgatoire Canyon, near Sopris, the basal conglomerate of the Raton formation is more or less conspicuous and is easily followed, but the underlying beds of coal and shale are more difficult to trace because of rock débris and soil on the slopes along the outcrop of these weaker rocks. At locality 104, 11 miles east of Reilly Canyon, the conglomerate lies unconformably upon coal, but apparently this coal is not the same bed as that exposed beneath the conglomerate near the mouth of Reilly Canyon. The rocks above the conglomerate consist mainly of yellow sandstones, but were not examined in detail. Those below the conglomerate consist of the coal-bearing shales and soft sandstones characteristic of the Vermejo formation but are not exposed well enough for satisfactory measurement. The thickness of the Vermejo beds could not be ascertained here, but the following short section is given for comparison with the more complete one measured at locality 105 :

Section of rocks measured at locality 104 in the north wall of Purgatoire Canyon about 1 mile northwest of Sopris, Colo.

[For graphic section see PI. XII, p. 118.]

Raton formation:

Sandstone, yellow, flaggy; fossiliferous

Sandstone, conglomeratic

Unconformity.

Vermejo formation:

Coal and carbonaceous shale.............

Sandstone, white, coarse grained; friable...... 18

Shale, black, and coal-bearing sandstone.

LOCALITY 105

Feet: $100+$

5

105

$\begin{array}{r}5 \\ 18 \\ \hline 23 \\ \hline 128+\end{array}$
、

At locality 105 , opposite Sopris, a section
cluding the Trinidad sandstone, the Vermejo formation, and the basal conglomerate of the Raton formation is well exposed in the north wall of Purgatoire Canyon. The Vermejo formation is here 161 feet thick and contains seven beds of coal. The bed underlying the conglomerate at locality 104 was not found here and was probably eroded away before the disposition of the conglomerate. The Vermejo beds thin toward the east in Purgatoire Canyon, and in the 3 miles between Reilly Canyon and locality 105 the thickness has decreased from 247 to 161 feet and the number of coal beds from 11 to 7 .
The conglomerate, which is exceptionally coarse in places, lies unconformably on the lower beds, is quartzose; very hard, and, because of its resistance to erosion, forms a broad shelf, the edge of which is shown at the top in Plate XIV, $B$. It varies considerably in thickness and character within short distances. In some places it is an ordinary sandstone, not notably different from other sandstones in the same region. In other places it consists of an admixture of clean white sand and muddy sand, such as characterizes the base of the Raton formation in many places throughout the Raton Mesa region, and yields large boulders with rough, craggy surface, similar to those previously described from Morley. (See p. 119.)

The pebbles contained in this rock give probably the best proof that it belongs at the base of the Raton formation. They have a maximum diameter of about an inch, consist mainly of quartz and chert, and are very irregularly distributed. In some places they are found in small pockets or lenticular masses a few inches to a foot or more thick, and in other places. they are scattered sparsely through a considerable thickness of the rock mass, but they are usually found at or near the base of the sandstone. The section follows:

Section of rocks measured at locality 105 in the north wall of Purgatoire River opposite Sopris, Colo.

[For graphic section see P1. XII, p. 118.]

Raton formation: $\quad$ Ft. in.

Sandstone, locally conglomeratic.......... $13 \quad .0$

Unconformity.

Vermejo formation:

Shale, sandy....................... $2 \quad 0$

Sandstone, white..................... $15 \quad 0$

Shale, drab.............................25 0

Sill of igneous rock, decomposed.......... $\quad 1 \quad 0$

Coke.......................... 10

Sill, decomposed ..................... 110

Coke............................ 10

Shale, drab...................... $5 \quad 0^{\prime}$

Sandstone, yellow, thin bedded............ 12 Coal. ........................... 30

Sandstone, thin bedded, with partings of shale............................ $28 \quad 0$

Sill of igneous rock.................... 28 Coal....................... 5.

Shale, drab.......................... 180. Coal.......................... 3 .

Sandstone, thin bedded, with partings of sandy shale...................... 110 Coal........................... $2 \cdot 0$

Sandstone, white, massive, soft, very friable, rather coarse grained............... $21 \quad 0$

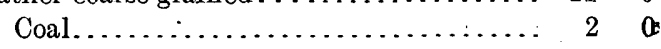




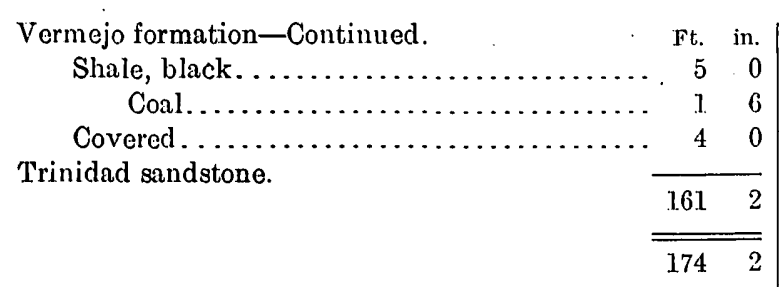

Fossil wood not yet described was found at this locality about 50 feet above the base of the Vermejo formation.

\section{TRINIDAD. \\ LOCALITY 106}

The Vermejo formation, containing several beds of coal, was observed in Colorado Canyon about 2 miles north of locality 105 but was not examined in detail. Also, the basal conglomerate of the Raton formation was found in this canyon above the highest observed coal. These beds were followed thence eastward along the outcrop to an abandoned mine (No. 20, Pl. I, in pocket) 3 miles in a straight line from locality 105 , where the last section was. measured. Here the base of the Raton formation consists of a sandstone that is hard and quartzose and otherwise similar to the basal sandstone in many other places but that was not observed to be conglomeratic. The following section was measured on the east side of the ridge separating this old mine from locality 106:

Section of rocks measired at locality 106, northwest of Trinidad, Colo.

[For graphic section see Pl. XII, p. 118.]

Raton formation:

Sandstone, yellow, massive, cliff making,

fossiliferous..........................

Covered . . . . . . . . . . . . . . . . . . . .

Sandstone, massive, coarse grained, prominent ledge (probably the conglomeratic sandstone of neighboring sections) ...... $18 \quad 0$

Vermejo formation:

Shale, drab.

Coal.

Sandstone, yellow, shaly, thin bedded......

Shale, drab............................

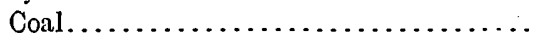

Shale, drab to yellow, sandy.............. Coal................................

Shale, drab...........................

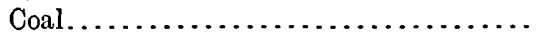

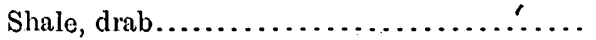

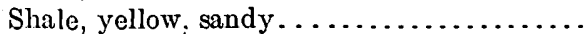

Coal.............................

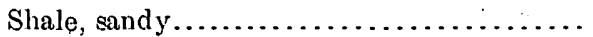

Coal............................

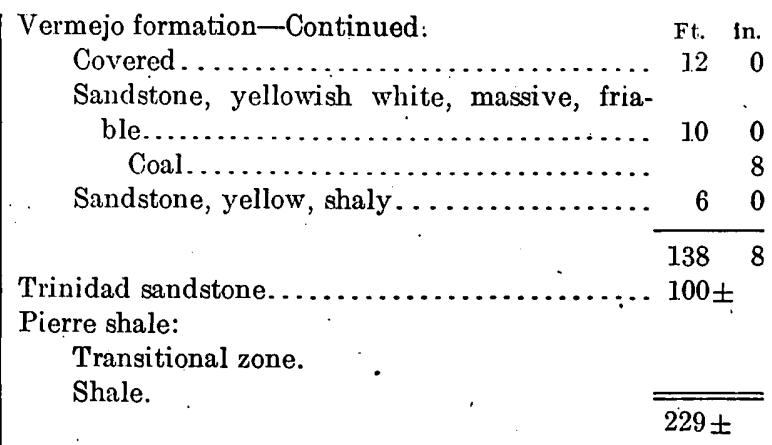

Vermejo formation-Continued:

Sandstone, yellowish white, massive, fria-

ble........................... 100

Coal............................ 8

Sandstone, yellow, shaly.................. $6 \quad 0$

Trinidad sandstone. . ..................... $100 \pm$

Pierre shale:

Transitional zone.

Shale.

G. B. Richardson found Palmocarpon palmarum (Lesquereux) Knowlton near the base of the Raton formation (U. S. Geol. Survey fossil locality 5097) at this locality; and the present writer collected the following species from the same formation about 200 feet above the base of the Raton formation:

Fossil plants from the Ralon formation at locality 106, west of Trinidad, Colo.

[U. S. Geol. Survey fossil locality 5697.]

Anemia hesperia Knowlton.

Ficus schimperi Lesquereux.

Juglans rugosa Lesquereux.

Magnolia angustifolia Newberry.

Magnolia cordifolia Lesquerenx.

Magnolia lesleyana (Lesquereux) Berry.

Magnolia magnifolia Knowlton.

Sabal? ungeri (Lesquereux) Knowlton.

At about the same horizon 3 miles farther northwest (U. S. Geol. Survey fossil locality 5100) Richardson found Juglans nigella Heer; and about one-half mile south of this locality (U. S. Geol. Survey fossil locality 5098) he found Abietites dubius Lesquereux and Rhamnus salicifolius? Lesquereux near the top of the Vermejo formation.

POWELL ARROYO.

$$
\text { LOCALITY } 107 .
$$

Three miles farther north, in Powell Arroyo, at locality 107 , a mine has recently been opened in one of the lowest beds of coal. The section given below was measured by the superintendent in charge of the development work. The measurements from the base of the coal measures up to the conglomerate were verified by the writer in the field, except that none of the higher coals was found. They are included in the section as it was reported by the superintendent. From this section it appears that the Vermejo formation is here about 98 feet thick as compared with 247 feet in the Purgatoire Valley and that the coal beds are correspondingly fewer in number. 
Section of rocks measured in Powell Arroyo at locality 10\%, northwest of Trinidad, Colo.

[For graphic section see PI. XII, p. 118.]

Raton formation:

Sandstone (not measured). Coal (streak).

Sandstone and shale....................... $35 \quad 0$

Coal, dirty...................... $2 \pm$

Sandstone and shale.................... $65 \quad 0$

Coal............................. 36

Sandstone, locally conglomeratic at base ..... . $\quad 25 \quad 0$

Unconformity.

Vermejo formation:

Coal ..............................

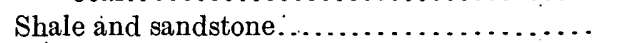

Basalt................................

Shale.............................

Coal.

Shale and sandstone.................... 52.0

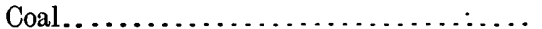

Shale.

$130 \quad 6$

$\begin{array}{ll}5 & 6\end{array}$

$\begin{array}{ll}25 & 0\end{array}$

300

500

10

$98 \quad 6$

Trinidad sandstone

$100 \pm$

Pierre shale:

Transitional zone.

Shale.

$329 \pm$

Near this locality Richardson's party collected

Brachyphyllum cf. B. macrocarpum Newberry, Abietites dubius Lesquereux; and a form doubtfully identified as Pàlmocarpon palmarum Lesquereux near the top of the Vermejo (U. S. Geol. Survey fossil locality 5110) and the following list of fossil plants from the Raton formation:

Fossil plants collected in Powell Arroyo, northwest of Trinidad, Colo.

[U. S. Geol. Survey fossil localities 5111, 5695, and 5112.]

Apocynophyllum wilcoxensis Berry. Magnolia magnifolia Knowlton.

Palmocarpon palmarum Lesquereux.

Sabal? ungeri (Lesquereux) Knowlton.

Ulmus sp.

LOCALITY 108.

At an abandoned mine (No. 50, Pl. I, in pocket) in the gulch about a mile east of locality 107 a small collection of fossil plants was made. This mine is located on the highest coal bed of the Vermejo formation, a few feet below the conglomerate sandstone that constitutes the base of the Raton formation. Volcanic rock has been intruded into the sedimentary rocks at this locality and has disturbed them to some extent, but near the mouth of the gulch, about one-fourth mile south of the old mine, the con- glomeratic sandstone is well developed and the Vermejo is about 83 feet thick, as shown in the section. Surface indications of coal were found at three horizons, and doubtless the three coals shown in section 107 occur here, but their thicknesses were not determined.

Section of rocks measured in Powell Arroyo at locality 108 north of Trinidad, Colo.

[For graphic section see P1. XII, p. 118.]

Raton formation:

Sandstone, coarse grained, quartzose, with contorted laminae, contains pebbles of quartz and chert up to a quarter of an inch in diameter... 10+

Unconformity.

Vermejo formation:

Sandstone and shale, coal bearing........... 25

Sheet of igneous rock ................... 3

Sandstone and shale, coal bearing............. 55

Trinidad sandstone....................... $\overline{\overline{93 \pm}}$

Fossil plants of the Vermejo formation identified as Sequoia reichenbachi (Geinitz) Heer and Ficus wardii Knowlton were collected from the roof shale of the old mine (U. S. Geol. Survey fossil locality No. 5694).

\section{BOWEN.}

LOCALITY 109

Two miles farther east the coal-bearing rocks were examined near Bowen, at locality 109. The lower 35 feet of the Vermejo formation is not well exposed at this locality. The superintendent of the mine informed the writer that a coal bed 18 to 20 inches thick occurs near the base, but its exact position in the section was not determined. This doubtless is the coal that is opened in Powell Arroyo, at locality 107, near the base of the Vermejo. The coal developed in the Bowen mine is 35 feet above the top of the Trinidad sandstone, and is the only coal of any considerable thickness at this locality. Near the mine opening a few feet of shale and a thin bed of coal occur between the main coal and an overlying sandstone, which is massive and coarse grained and rests with uneven base on the shale. It is mottled with inclusions of clay, as in many places in the basal member of the Raton formation, and it contains fragments of carbonized wood. The quartzose character is inconspicuous here but in some places near the mine pebbles about one-fourth inch in diameter were found in it. 
In some parts of the mine a sandstone, which may be the conglomeratic sandstone just described, rests on the main coal. In other parts of the mine shale separates this sandstone from. the conl. Fossil plants (Myrica torreyi Lesquereux, Ficus speciosissima Ward, and Sabal? ungeri (Lesquereux) Knowltọn) were collected from the roof shale and from the mine dump (U. S. Geol. Survey fossil locality 5692). These belong in the Vermejo flora. An unidentified palm and other fragments of fossil leavesseemed to belong in the Raton flora. As the top of the coal marks the line of separation it is probable that plants of both floras "mày be found in the mine dump.

The rocks above the conglomerate are fairly well exposed near the Bowen mine and were soarched for coal beds, but no coal was found. The rocks consist mainly of massive sandstone, such as occurs throughout the Raton Mesa region in the lower part of the Raton formation, and their assignment to that formation is confirmed by the occurrence in them of fossil plants belonging to the Raton flora. The section follows:

Section of rocks measured at locality 109, Bowen, Colo. [For graphic section see PI. XII, p. 118.]

Raton formation: Ft. . in.

Sandstone, friable and white in some places, hard and quartzose in other places, locally conglomeratic, and mottled with inclusions of clay and pieces of charcoal. Unconformity.

Vermejo formation:

Coal............................

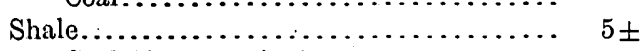
Coal (Bowen mine) ................. $8 \pm$ Shale, with 18 to 20 inches of coal near base. 35

Trinidad sandstone $48 \pm$ Pierre shale: Transitional zone.

Shale.

A well-exposed section one-half mile south of Bowen mine was examined by G. B. Richardson, ${ }^{225}$ who has furnished the following section for use in this report:

Section of rocks measured by G. B. Richardson half a mile south of Bowen, Colo.

Sandstone, brown, soft, massive

Ft. in.

Sandstone and shale, buff-colored, thin bedded,

fossiliferous........................... 165

Sandstone, light brown, fossiliferous........... 20

Coal..

$47019^{\circ}-17-9$

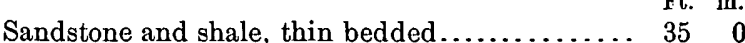

Coal and carbonaceous shale............... $12 \quad 0$

Sandstone and shale, thin bedded, in alternating layers; three thin beds of coal near the middle and thinner-bedded, light-brown sandstone at the base..................... $70 \quad 0$

Sandstone (Trinidad) containing Halymenites major Lesquereux........................ $75 \quad 0$

Sandstone and shale in alternating layers grading into the massive sandstone above and into the shale below. (Included in Pierre shale.)... 1250 Shale (Pierre).

$$
572+
$$

Richardson made no attempt to separate the coal-bearing rocks into two formations, but the conditions observed at neighboring localities leave little doubt that the 20 -foot sandstone denotes the base of the Raton formation. This locality was somewhat hurriedly examined by the writer a year before the investigation was made that resulted in the separation of the coal-bearing rocks in this vicinity into two formations, and it was noted that this sandstone had contorted laminae and was coarse grained and cross-bedded. It varies considerably in thickness within short distances, and in some places rests with uneven base on shale. It forms a well-marked shelf in the side of the mesa. In the rocks below this sandstone was found a fossil conifer, Sequoia obovata Knowlton, a species that occurs very generally in the Vermejo formation. In the 20 -foot sandstone were found two species of palm, one with broad stem and one with narrow stem such as were found in many places near the base of the Raton, and immediately above this sandstone a considerable number of plants belonging to the Raton flora." According to Richardson's measurement this sandstone is 117 feet above the Trinidad sandstone, somewhat more than would be expected in view of the fact that at locality 108, about 2 miles to the west, the conglomerate with which it is provisionally correlated is only 85 feet above the Trinidad, and at Bowen mine, one-half mile to the north, it is less than 50 feet. This difference may be due in some measure to difference of opinion as to what constitutes the top of the Trinidad sandstone. The writer included in the Trinidad the sandy layers between the massive sandstone and the lowest bed of coal, which Richardson seems to refer to the coal measures.

... The fossil plants collected mainly by G. B. Richardson's party above the 20-foot sand- 
stone all belong to the Raton flora and are as follows:

Fossil plants collected near Bowen, Colo.

[U. S. Geol. Survey fossil localities 5794, 5102, 5094, and 5496.]

Alismaphyllum crassifolium Knowlton.

Anemia hesperia Knowlton.

Cinnamomum mississippiensis? Lesquereux.

Magnolia hilgardiana (Lesquereux).

Palaeoaster inquirenda Knowlton.

Palmocarpon palmarum (Lesquereux) Knowlton.

Sabal? leei Knowlton.

Sabal? ungeri (Lesquereux) Knowlton.

The Pierre shale is well exposed south of Bowen, where it yielded several small collections of fossils at localities denoted on Plate I (in pocket) by the United. States Geological Survey fossil locality numbers.

5565. Invertebrates near Bowen, Colo., from a horizon 150 feet below the top of the Pierre shale (collected by G. B. Richardson's party).

Baculites compressus Say.

Inoceramus sagensis Owen.

Scaphites nodosus Owen.

5565a. Invertebrates from a horizon 275 feet below the top of the Pierre shale, near Bowen, Colo. (collected by G. B. Richardson's party).

Baculites compressus Say.

Baculites ovatus Say.

Inoceramus barabini Morton.

Inoceramus sagensis Owen.

Inoceramus vanuxemi Meek and Hayden?

5667. Invertebrates from the Pierre shale at a quarry north of Trinidad, Colo. (collected by G. B. Richardson's party).

Inoceramus barabini Morton:

,

Inoceramus vanuxemi Meek and Hayden?

Ostrea sp.

6511. Pierre fossils collected near the fair grounds, about 2 miles northeast of Trinidad, Colo. Inoceramus sagensis Owen.

Inoceramus vanuxemi Meek and Hayden?

Scaphites nodosus Owen.

Mososaurus sp.

6512. Invertebrates from the top of the Pierre shale, about 1 mile south of Bowen, Colo.

Baculites ovatus Say.

Inoceramus sagensis Owen.

The Trinidad sandstone is probably as oonspicuous between Trinidad and Bowen as it is anywhere in the Raton Mesa region. It forms a broad shelf, which is usually terminated by a precipitous cliff. (See Pl. XIV, $A$, p. 125.)

\section{BERWIND-AGUILAR AREA.}

GENERAL FEATURES.

The eastern escarpment of the Trinidad coal field, which attains its greatest prominence in the vicinity of Bowen, Colo., becomes less prominent farther north. The Trinidad sand- stone sinks lower in the cliffs and in the northern part of the Berwind-Aguilar area approaches the general level of the plain to the east of it. (See.Pl. XIV, $A$, p. 125.) Many of the details of the coal beds and the rocks associated with them have been presented by Richardson. ${ }^{225}$ Throughout most of this area the conglomerate at the base of the Raton formation is well developed and is usually conspicuous at the outcrop. Also, it is readily recognizable in the records of the diamond-drill holes, many of which have been put down north of this locality. The drill records indioate the thickness and character of the rocks penetrated with greater accuracy and detail than are obtainable by measurements at the outcrop. For these reasons sections were measured less frequently in the central part of the Trinidad field than in the southern parts, the observations being directer mainly toward tracing the conglomerate and establishing its relations to the underlying rocks.

$$
\begin{aligned}
& \text { Bowen. } \\
& \text { Locality } 110 .
\end{aligned}
$$

For about one-half mile along the outcrop north of Bowen mine the relation of the conglomerate at the base of the Raton formation to the underlying shale was not satisfactorily determined because of surface débris. There are some indications that the coal bed on which the conglomerate rests in some parts of the Bowen mine is absent a short distance north of this mine, but this was not determined satisfactorily because of the brush and slide rock which obscure the outorop. In a prospect entry at the supposed horizon of the coal, about one-fourth mile northwest of the mine, only shale was encountered. However, at locality 110 , about a mile north of the Bowen mine, the main coal bed was found about 30 feet above the top of the Trinidad sandstone, and the conglomerate about 35 feet above the coal. The Vermejo formation, which reached a minimum thickness of less than 50 feet near Bowen, here thickens to 70 feet, and continues to thicken for some distance to the north. (See Pl. XII, p. 118.)

The base of the Raton formation at locaiity 110 consists of a conglomeratic sandstone which was found to be 12 feet thick. It is coarse grained and massive and contains great numbers of pebbles one-fourth inch or more in 
diameter. Above this conglomerate there is a sheet of igneous rock, and this is overlain by sandstone and shale containing Ficus denveriana Cockerell, Ficus' pseudopopulus Lesquereux, Magnolia hilgardiana Lesquereux, and palms (U. S. Geol. Survey fossil localities Nos. 5101 and 5693). The palm leaves are numerous and well preserved but are so large that they were not collected. The section follows:

Section of rocks measured at locality 110, about a mile northwest of Bowen, Colo.

[For graphic section see Pl. XII, p. 118.]

Raton formation:

Sandstone, conglomeratic, with pebbles up to one-fourth inch in diameter............. 12

Unconformity.

Fect.

Vermejo formation:

Covered ............................ 35

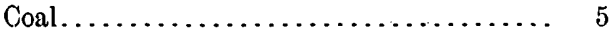

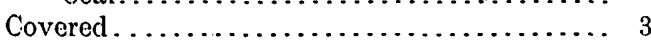

70

Trinidad sandstone

Pierre shale:

Transitional zone.

Shale.

LOCALITY 111 (SUFFIELD MINE).

At the Suffield mine, locality 111, about 2 miles north of the Bowen mine, a section of the Vermejo formation was measured and found to contain at least three beds of coal. The formation is underlain by the Trinidad sandstone and the Pierre shale, which are conspicuously exposed in the steep sides of the mesa and overlain by conglomerate similar to that at locality 110. The section follows:

Section of rocks measured at locality 111, Suffield mine, Colo. Raton formation: [For graphic sestion see PI. XII, p. 118.]

Sill of igneous rock....................... 4

Conglomerate, with pebbles up to one-fourth inch in diameter.

Unconformity.

Vermejo formation:

Covered................................. $40 \quad 0$

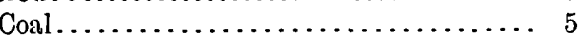

Shale, brown ......................... 12

Coal............................ 1

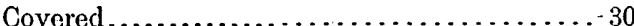

Coal................................ 4

Covered . .

Trinidad sundstone.

Pierre shale:

Transitional zone.

Shale.
MAJESTIC.

LOCALITY 112.

North of Suffield mine the basal conglomerate of the Raton formation forms a more or less conspicuous shelf that is easily recognizable. The outcrop of the Trinidad sandstone is even more conspicuous, and it was deemed unnecessary to make detailed measurements for about 4 miles northwest of locality 111 .

At the Forbes mine, south of Majestic, the conglomerate is 22 feet thick and rather finegrained, the pebbles seldom attaining an observed diameter of more than one-fourth inch. Its base is 122 feet above the top of the Trinidad sandstone. The highest coal in the Vermejo formation is worked at this locality and is a few feet below the base of the conglomerate. From the rock dump of the mine the following fossil plants were collected, all of which belong in the Vermejo flora:

Fossil plants from the dump of mine 6 at Forbes, Colo.

[U. S. Geol. Survey fossil locality 5691.]

Ficus praetrinervis Knowlton.

Ficus speciosissima Ward.

Ficus starkvillensis Knowlton.

Myrica torreyi Lesquereux.

Sabal montana Knowlton.

Sequoia obovala Knowlton.

Near Majestic, in the north wall of the canyon at locality 112 , some of the rocks are well exposed and the Vermejo was found to be about 110 feet thick. Here as elsewhere the weak rocks of this formation break down easily and form slopes that become more or less covered with soil and brush. The overlying sandstone is typically conglomeratic, coarse grained, massive, and feldspathic, and in some places is perhaps better described as a conglomeratic arkose. The section follows:

Section of rocks measured at locality 112, near Majestic, Colo.

[For graphic section see PI. XII, p. 118.]

Raton formation:

Conglomerate, with pebbles up to half an inch in diameter....................... 35

Unconformity.

Vermejo formation:

Covered

Sandstone, very shaly and thin bedded, with partings of shale.......................

Sill of igneous rock................... 5

Sandstone, hard, nodular, brown............ 7

Shale, drab........................ 17

Coal.............................. 5 
- Vermejo formation-Continued Shale, carbonaceous, black Covered. 2 ..................................

Trinidad sandstone

Pierre shale:

Transitional zone.

Shale.

\section{BERWIND.}

$246 \pm$

LOCALITY 113.

The next locality north of Majestic at which a section was measured is near Tabasco mine at locality 113, about half a mile north of Berwind and $3 \frac{1}{2}$ miles northwest of locality 112 . The basal conglomerate of the Raton formation is 30 feet thick at this locality and is massive and feldspathic, with numerous pebbles up to an inch in diameter. Its lower surface is uneven and rests with obvious unconformity upon the softer beds below. A fairly good exposure of the Vermejo indicates that it is slightly thicker here than it is farther south. Only one thick bed of coal was observed where the section was measured, but Richardson ${ }^{225}$ found two beds in Road Canyon south of Tabasco, and doubtless a lower one is present in the unexposed interval near the base of the Vermejo in the following section:

Section of rocks measured at locality 11s, near Berwind, Colo.

$$
\text { [For graphic section see Pl. XII, p. 118.] }
$$

Raton formation:

Conglomerate, many pebbles up to 1 inch in diameter..................... $30 \quad 0$

Unconformity.

Vermejo formation:

Sandstone, thin bedded, with partings of shale. A thin bed of coal coked by a sill of igneous rock occurs near the top...... 30

Sandstone, soft and friable, with partings of sandy shale, yellowish white......... $20 \quad 0$

Sill of igneous rock. .................... 7

Shale, black...................... 3

Coal

Shale, black......................

Coal............................ 9

Covered.......................... 35

Shale, sandy and locally carbonaceous...... $10 \quad 0$

Trinidad sandstone.

1152

. $\overline{\overline{245+}}$

Several fossil plants of the Raton flora were collected by the party under G. B. Richardson 1 to 4 miles southwest of Berwind from rocks that are said to be at the base of the Poison
Canyon. The flora is not distinctive of the Poison Canyon formation, for the species occur -also in the Raton. Furthermore it does not seem tọ be possible to draw a definite line of separation in all places at the present time between the Raton and Poison Canyon formations. For these reasons these plants are for present purposes included in the Raton flora. They are as follows:

Fossil plants collected southwest of Berwind, Colo.

[U. S. Gẹol. Survey fossil localitiẹs 5095, 5107, and 5120.]

Ȧristolochia? elongata Knowlton.

Cassia richardsoni Knowlton.

Ficus pseudopopulus Lesquereux.

Magnolia lesleyana Lesquereux.

Platanus aceroides latifolia Knowlton.

Platanus guillelmae Göppert.

Rhamnus cleburni Lesquereux.

South of Apishapa River, about 6 miles farther west (Pl. I, in pocket), the same party. collected plants from a horizon 400 feet above what they regarded as the base of the Poison Canyon formation. These are Poison Canyon species and are inserted here, as they do not seem to differ notably from those found in the Raton formation. They are as follows:

Fossil plants collected 7 miles southwest of Berwind, Colo.

[U. S. Geol. Survey fossil localities 5121 and 5045.]

Ficus denveriana Cockerell.

Ficus latifolia Lesquereux.

Leguminosites? arachioides Lesquereux.

Palmocarpon palmarum (Lesquereux) Knowlton.

\section{BERWIND TO AGUILAR.}

, LOCALITIES 114-118.

Between Berwind and Aguilar, a distance of about 6 miles, the formations from Pierre shale to Raton formation, inclusive, were observed in several places. The Trinidad sandstone forms a conspicuous cliff and the basal conglomerate of the Raton formation was located without difficulty at every locality observed. No sections were measured at the outcrop because of the abundance of more accurate data furnished by the diamond-drill borings. Unfortunately, the confidential nature of this information makes it impossible to publish the location of individual borings. However, five records (Nos. 114-118, Pl. XV) have been so selected that they probably give an adequate conception of the thickness of the Vermejo beds and their relation to the underlying and overlying rocks. In addition to these records 


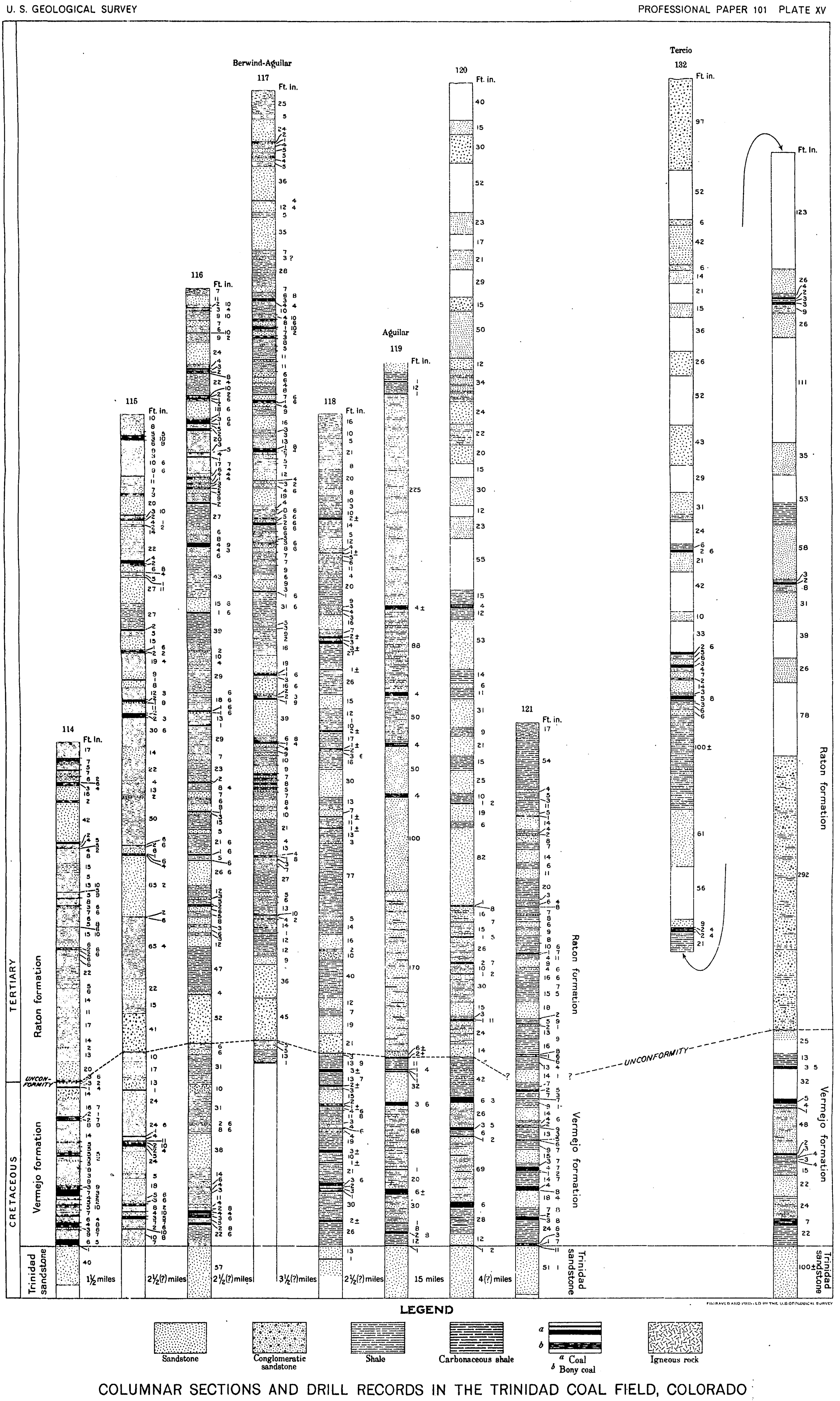


three others in the same general region have been published by Hills. ${ }^{151}$.

A brief explanation may be included here relative to the correlations of these records. with each other and with sections measured elsewhere. It is evident, for example, that the position of the base of the Vermejo formation is a matter of interpretation. In section 114, for example, the $40+$ feet of sandstone at the base is probably the Trinidad, but it might possibly be the 38-foot sandstone which lies above the lowest coal in section 116: Again, in section 115, the 7-foot sandstone at the base may be a part of the Trinidad or it may possibly be a higher sandstone. However, a prominent conglomerate is present in all five sections, and there is little chance of mistake in correlating the sections on the assumption that it is a continuous bed. If this correlation is correct, the thickness of the Vermejo formation is here 200 to 230 feet or more.

It has been seen that near Berwind, at locality 113 , the Vermejo beds measure only 115 feet at the outcrop. The drill borings were made at considerable distances back from the outcrop-in the direction toward which the Vermejo formation thickens. About 20 miles farther southwest, at locality 136 , it is 345 feet thick. The increase in thickness from 115 feet at the outcrop to 230 feet in the drill holes is what might naturally be expected. Furthermore, near Aguilar, at locality 119, the thickness of this formation is nearly as great at the outcrop as it is in any of the drill holes described.

At Delagua, west of Hastings, a mine has been opened in the Raton formation on a bed that is estimated to be about 850 feet above the Trinidad sandstone, 225 or something more than 600 feet above the base of the Raton formation. A collection of plants was made from the rock dump of this mine, as follows:

Fossil plants from Delagua, Colo.

[U. S. Gool. Survey fossil locality 5690.]

Artocarpus similis Knowlton.

Laurus socialis Lesquereux.

Magnolia angustifolia Newberry.

Magnolia magnifolia Knowlton.

Platanus aceroides latifolia Knowlton.

Zizyphus fibrillosus (Lesquereux) Lesquereux.

A few miles farther west, near Abeton, north of the Apishapa (Pl. I, in pocket) several collections of fossils were made:
Fossil plants collected north of the wagon road one-half mile west of Abeton, 100 feet below the top of the Raton formation.

[U. S. Geol. Survey fossil locality 5086.]

Cinnamomum? ficifolium Knowlton.

Ficus denveriana Cockerell.

Juglans nigella Heer.

Juglans rugosa Lesquereux.

Magnolia angustifolia Newberry.

Magnolia magnifolia Knowlton.

About a mile farther northeast, at a horizon 100 feet or more lower than the last (U. S. Geol. Survey fossil locality 5688), Cinnamomum mississippiensis? Lesquereux and Zizyphus fibrillosus (Lesquereux) Lesquereux were found.

About a mile northwest of Trujillo (U. S. Geol. Survey fossil locality 5687) Artocarpus similis Knowlton, Maynolia magnifolia Knowlton, and Oreodaphne? ratonensis Knowlton were found 100 feet below the top of the Raton formation; and $1 \frac{1}{2}$ miles farther northwest (U. S. Geol. Survey fossil locality 5124) Richardson's party obtained Aristolochia? elongata Knowlton and Ficus pseudopopulus Lesquereux about 400 feet above the base of the Poison Canyon formation.

In the north wall of Apishapa Canyon, about $3 \frac{1}{2}$ miles southwest of Aguilar, the following fossil plants were found near a coal bed that is believed to be the same as that developed at Delagua.

Fossil plants collected,southwest of Aguilar, Colo.

[U. S. Gegl. Survey fossil locality 5689.]

Cissus laevigata Lesquereux.

Ficus denveriana Cockerell.

Ficus uncata Lesquereux.

Magnolia angustifolia Newberry.

Magnolia magnifolia Knowlton.

gonzales canyon, colo. LOCALITY 119.

Near the mouth of Gonzales Canyon, about a mile west of Aguilar, the rocks irom the Pierre shale to the Raton formation are well exposed, and a section of them was measured at locality 119. A. G. Broadhead has spent several years in prospecting the coals in this vicinity, and the section measured by him agrees in general with that measured by the writer and his assistant but includes more details, especially regarding the number and position of the coal beds. For this reason Mr. Broadhead's section is given below. On the other hand, Mr. Broadhead laid special emphasis on the number of coal beds and the thickness of the 
coal and paid little attention to the character of the intervening rocks. For this reason these rocks are described as sandstone and shale with little attempt at differentiating them.

Section of rocks measured at locality 119, near Aguilar, Colo.

Measurements furnished by A. G. Broadhead, who has prospected all of the coal beds near this locality. For graphic section see Pl. XV, p. 132.]

Raton formation:

Sandstone and shale. $\quad$ Ft. in. Coal....................... 10

Shale........................ $12 \quad 0$ Coal......................... 10

Sandstone, shaly in some places......... $225 \quad 0$ Coal......................... $4 \pm$

Sandstone and shale................ $88 \quad 0$ Coal.......................... 40

Shale and sandstone, fossiliferous........ $50 \quad 0$ Coal, with thin partings of sandstone.... $4 \quad 0$

Sandstone, hard, white. ............. 50. Coal, dirty ................... $4 \quad 0$

Sandstone, massive, forms cliff........... 100

Sandstone, with thin layers of shale and 7 or 8 thin beds of coal................. 170

Conglomerate, variable in thickness and character; contains pebbles up to onehalf inch in diameter.............. $6 \pm$

Unconformity.

Vermejo formation:

Coal, variable in thickness; absent in some places................... $2 \pm$

Shale.

Coal. ...................... 14

Shale........................ 10

Coal.......................... 10

Sandstone.............................. 320

Coal (Robinson bed), varies in thickness from 1 foot to 4 feet............... 36

Sandstone and shale............... $68 \quad 0$

Coal ............................ 10

Sandstone and shale................. 20. 0 Coal....................... $6 \pm$

Shale and sandstone................ $30 \quad 0$ Coal........................ 10

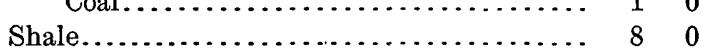
Coal, mostly burned............... $2 \quad 8$

Shale........................ 12, 0

Graphite (?)................... 10

Trinidad sandstone:

Sandstone containing Halymenites major Lesquereux ........................ 920士

The Pierre shale and Trinidad sandstone are characteristically developed at this locality, as everywhere in the Raton Mesa region. The Trinidad forms a prominent cliff, near the middle of which there is a zone of hard, flaggy, ripple-marked sandstone similar to that in the zone near the middle of this formation at Raton and elsewhere, which contains fossil plants, carbonaceous shale, and thin seams of coal. Halymenites major Lesquereux is very abundant above this zone, and with it are found large concretions of sandstone that are harder and darker than the mass in which they are embedded. The massive character of the formation continues unchanged to the top, where the transition to the carbonaceous shale and coal of the Vermejo formation is very abrupt.

The Vermejo is about 200 feet thick and consists of the shale and relatively soft sandstone that characterize this formation throughout the region. Sandstone constitutes a considerable part of the formation, but it is the customary soft granular variety which disintegrates almost as readily as the shale, so that the slope at the outcrop of this formation is smooth and often covered with soil.

The base of the Raton formation is marked by a hard, massive, conglomeratic sandstone which varies in. thickness from 3 to 30 feet in the one-fourth mile or so of the outcrop observed and contains pebbles mostly of quartz and chert up to 2 inches in diameter. It lies unconformably on the Vermejo, in some places on coal which varies in thickness from 2 feet or more to zero, and in other places on the shale which normally underlies this coal bed. The conglomerate is overlain by a sandy shale which contains several thin beds of coal and seems to correspond in a general way with the coalbearing shale which has been noted in many places throughout the eastem part of the Raton Mesa region and which farther south contains the Sugarite coal. This shale is overlain by the cliff-making sandstones of the so-called "barren series." However, from the fact that the rocks are shaly above the conglomerate it does not follow that they are at all like the shaly sandstones of the ${ }^{\circ}$ Vermejo formation. The aspect of the slope above the conglomerate is very different from that below. Above this conglomerate the sandstones are hard and form more or less well-defined cliffs that contrast sharply with the smooth regular slope at the outcrop of the Vermejo.

Several thick beds of coal outcrop above the cliffs of the "barren series." On three of them mines have been opened 330 to 475 feet above the base of the Raton formation. The rock waste from all three of these mines is dumped 
in the same place, and from this dump a large collection of fossil plants was obtained, as follows:

Fossil plants from the Green Canyon mines in Gonzales Canyon near Aguilar, Colo.

[U. S. Geol. Survey fossil locality 5684.]

Apocynophyllum linifolium Knowlton. Chionan thus membranaceus Knowlton.

Ficus aguilar Knowlton.

Ficus duplicata Knowlton.

Ficus schimperi Lesquereux.

Juglans schimperi Lesquereux.

Laurus pedatus? (Lesquereux).

Magnolia angustifolia Newberry.

Magnolia magnifolia Knowlton.

Magnolia rotundifolia Newberry.

Nectandra lancifolia (Lesquereux) Berry.

Populus neotremuloides Knowlton.

Fagus papyracea Knowlton.

Magnolia cordifolia Lesquereux.

Populus, female ament.

Rhamnus goldianụs? Lesquereux.

Vitis leei Knowlton.

There are coal beds at horizons higher than those indicated in the section, but these had not been developed at the time of investigation, and their position in the formation is not known further than that they are near the top of it. The rocks associated with these coals are fossiliferous and Richardson's party collected Ficus denveriana Cockerell, Magnolia angustifolia Newberry, Magnolia hilgardiana Newberry, Magnotia magnifolia Knowlton, and Platanus aceroides latifolia Knowlton from them (U.S. Geol. Survey fossil localities Nos. 5118, 5122, and 5123). The same party obtained a good collection of plants from the Poison Canyon formation about 2 miles west of the Green Canyon mine. Of these plants Knowlton says that although the previously described species are all found in the Denver formation, with which the Poison Canyon has been directly correlated, they also occur in the Raton formation. They are as follows:

- Fossil plants from the Poison Canyon formation, about 5 miles west of Aguilar, Colo.

[U. S. Geol. Survey fossil locality 5046.]

Cornus studeri? Heer.

Euphorbocarpum richardsoni Knowlton.

Ficus richardsoni Knowlton.

Laurus socialis Lesquereux.

Magnolia laurifolia Lesquereux.
Platanus guillelmae Göppert.

Rhamnus cleburni Lesquereux.

Zizyphus fibrillosus (Lesquereux) Lesquereux.

North of Aguilar the formations were traced along the outcrop and examined in detail in several places, but their structural relations appeared so obvious that it seemed unnecessary to measure sections at short intervals. At the Jewel mine, $1 \frac{1}{2}$ miles north of Aguilar, and at the Rugby mine, about 5 miles north of that town, the conglomerate at the base of the Raton formation was examined in detail. At Rugby it is about 200 feet above the Trinidad sandstone. The coals of both the Raton and the Vermejo formations have been developed here and have been described by Richardson. ${ }^{225}$

The rocks of the Raton formation are very fossiliferous near Rugby, but only one species, Platanus aceroides latifolia Knowlton, was collected (U. S. Geol. Survey fossil locality No. $5696)$.

For several miles north of Rugby the conglomerate is unusually prominent and forms a shelf in the side of the mesa that can be readily recognized even from considerable distances. Near the New Rouse mine, on Santa Clara. Creek, it is 25 feet or more in thickness and consists of pebbles mainly of quartz and chert embedded in a matrix of coarse sand. Many of these pebbles are an inch or more in diameter and some reach a diameter of $2 \frac{1}{2}$ inches. Several beds of coal occur below the conglomerate, the highest of which is reported by the superintendent of the Rouse mine to be about 150 feet above the top of the Trinidad sandstone. The rocks are faulted in the vicinity of this mine. The rocks above the conglomerate are composed mainly of sandstone. At a horizon supposed in the field to be about 100 feet above the base of the Raton formation Ficus gigantea Knowlton and Credneria protophylloides Knowlton, were found near the water tank of the mine (U. S. Geol. Survey fossil locality 5685). . These prove on examination to be Vermejo types of plants and it may be that the horizon was misinterpreted by the writer. This possibility is strengthened by the fact that the rocks near New Rouse have been shown by mining operations to be badly faulted.

The Trinidad sandstone and the Pierre shale are both fossiliferous on Santa Clara Creek. 
From the sandstone Richardson's party collected the following species:

Invertebrates from a railroad cut in the Trinidad sandstone, one-half mile east of Prior mine, near Rouse, Colo.

[U. S. Geol. Survey fossil locality 5590 .]

Ostrea pellucida Meek and Hayden.

Ostrea sp.

Chlamys nebrascensis Meek and Hayden.

Avicula nebrascana Evans and Shumard.

Inoceramus barabini Morton.

The same party collected shells from the upper part of the Pierre shale at two localities, as follows:

Invertebrates from a point 500 feet south of Santa Clara Creek, 13 miles east of Monson, Colo.

, [U. S. Geol. Survey fossil locality 5591.]

Ostrea pellucida Meek and Hayden.

Inoceramus vanuxemi Meek and Hayden?

Cucullaea sp.

Lucina sp.

Volutoderma sp.

Scaphites nodosus Owen var.

Inveriebrates from the south side of Santa Clara Creek, about 21 miles east of Monson, Colo.

[U. S. Geol. Survey fossil locality 5592.]

Nucula sp.

Baculites ovatus Say.

Baculites compressus Say.

Scaphites nodosus Owen.

Heteroceras cheyennense Meek and Hayden?

About a mile north of the New Rouse mine the basal conglomerate of the Raton formation forms a broad shelf, which was determined by barometer to be about 200 feet above the top of the Trinidad sandstone, which is exposed to the east. (See Pl. XVI, A.) Three beds of coal in the Vermejo formation have been opened at the Pryor mine (No. 108, Pl. I, in pocket), about one-fourth mile west of the point shown in this illustration. Their positions in the section are shown by Richardson ${ }^{225}$ as follows:

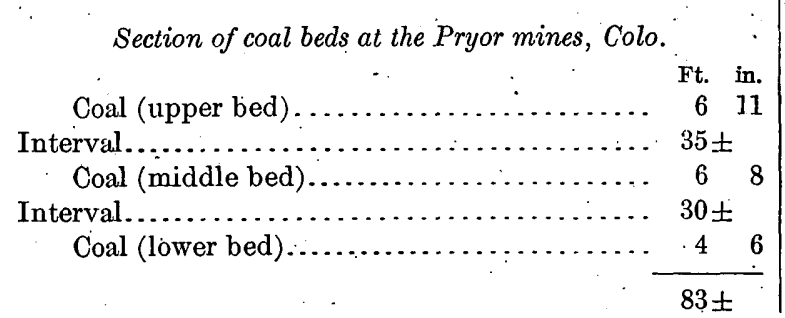

An attempt was made to measure a section of the rocks in a small canyon about 4 miles northwest of the Pryor mines, but the beds are nowhere sufficiently well exposed. Apparently the conglomerate which is so prominent near the Pryor mines loses its massive character in some places and is not conspicuous in. this canyon. However, a little farther north, or about 3 miles south of Walsenburg, it is well developed as a coarse "pudding stone" and forms a prominent ridge.

A collection of fossil plants belonging to the Raton flora was made in this canyon, at a horizon estimated to be about 300 feet above the base of the Raton formation, and is as follows:

Fossil plants collected about 4 miles west of Mayne, Colo.

[U. S. Geol. Survey fossil locality 5683.]

Magnolia angustifolia Newberry.

Nyssa lanceulata Lesquereux.

Quercus simplex Newberry.

Platanus aceroides latifolia Knowlton.

Platanus platanoides (Lesquereux) Knowlton.

About 3 miles farther north the basal conglomerate of the Raton formation attains prominence and several prospect openings have been made in the coal beds below it. About 10 feet above the base of the Vermejo formation (U. S. Geol. Survey fossil locality 5130) Richardson's party found Ficus praetrinervis Knowlton, Ficus wardii Knowlton, and Salix gardneri SKnowlton at the Simpson or Ravenwood mine; and at about the same horizon they found in the roof of the Cameron mine (No. 122, Pl. I) Ficus haddeni Knowlton, Ficus praetrinervis Knowlton, and Salix plicata Knowlton (U. S. Geol. Survey fossil locality 5044). About 1 mile southwest of these localities, at a horizon about 130 feet higher, the same party collected the following:

Fossil plants collected about 190 feet above the base of the Vermejo formation and 50 feet below the overlying conglomerate, 3 miles south of Waisenburg, Colo.

[U. S. Geol. Survey fossil locality 5131.]

Geinitzia formosa Heer.

Phyllites aurantiacus Knowiton.

Quercus gardneri Knowlton.

Widdringtonia? complanata Lesquereux. 


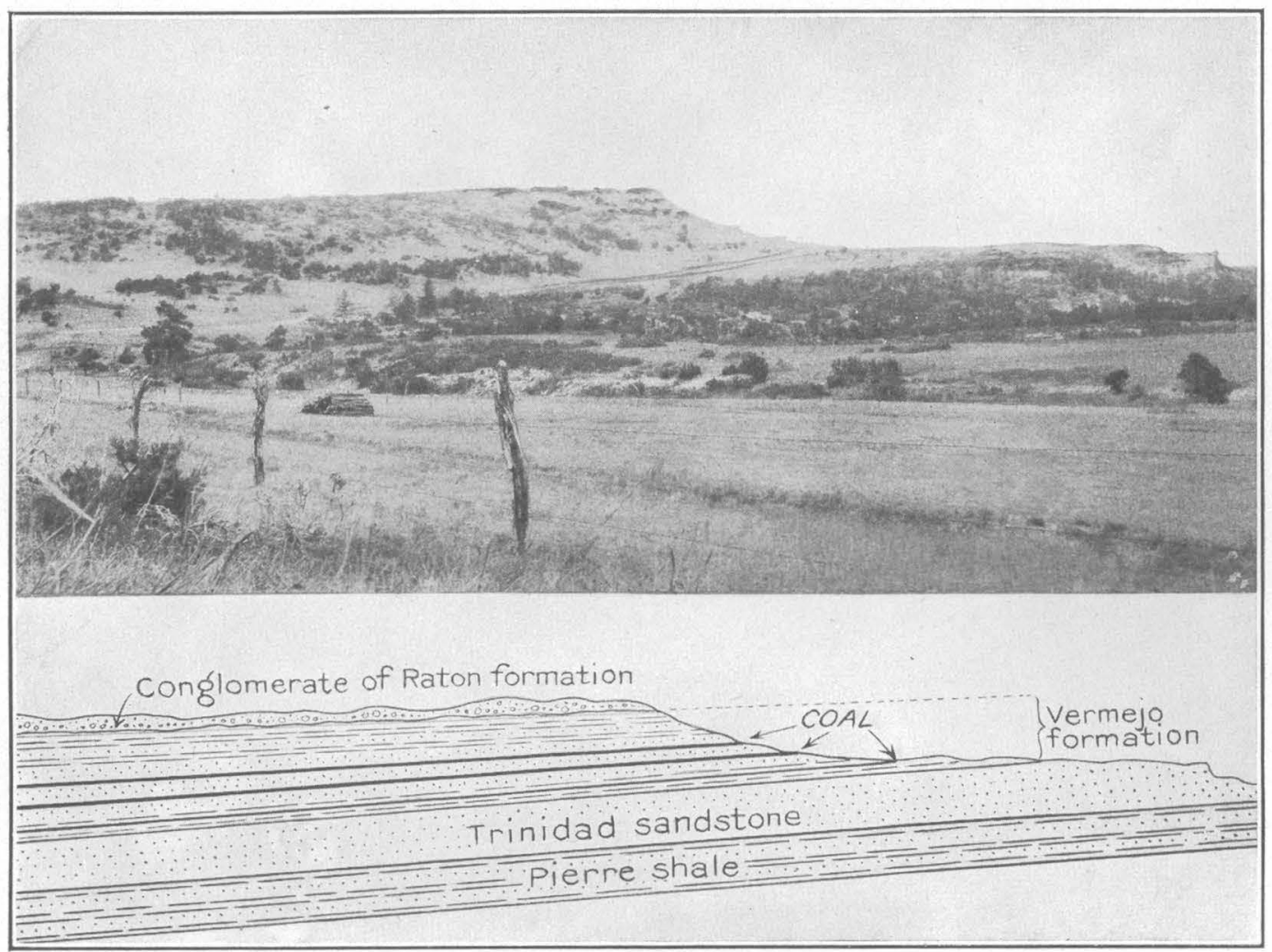

A. STRUCTURAL RELATIONS SHOWN IN THE NORTH WALL OF SANTA CLARA CANYON, COLO., AT THE EASTERN MARGIN OF THE TRINIDAD COAL FIELD.

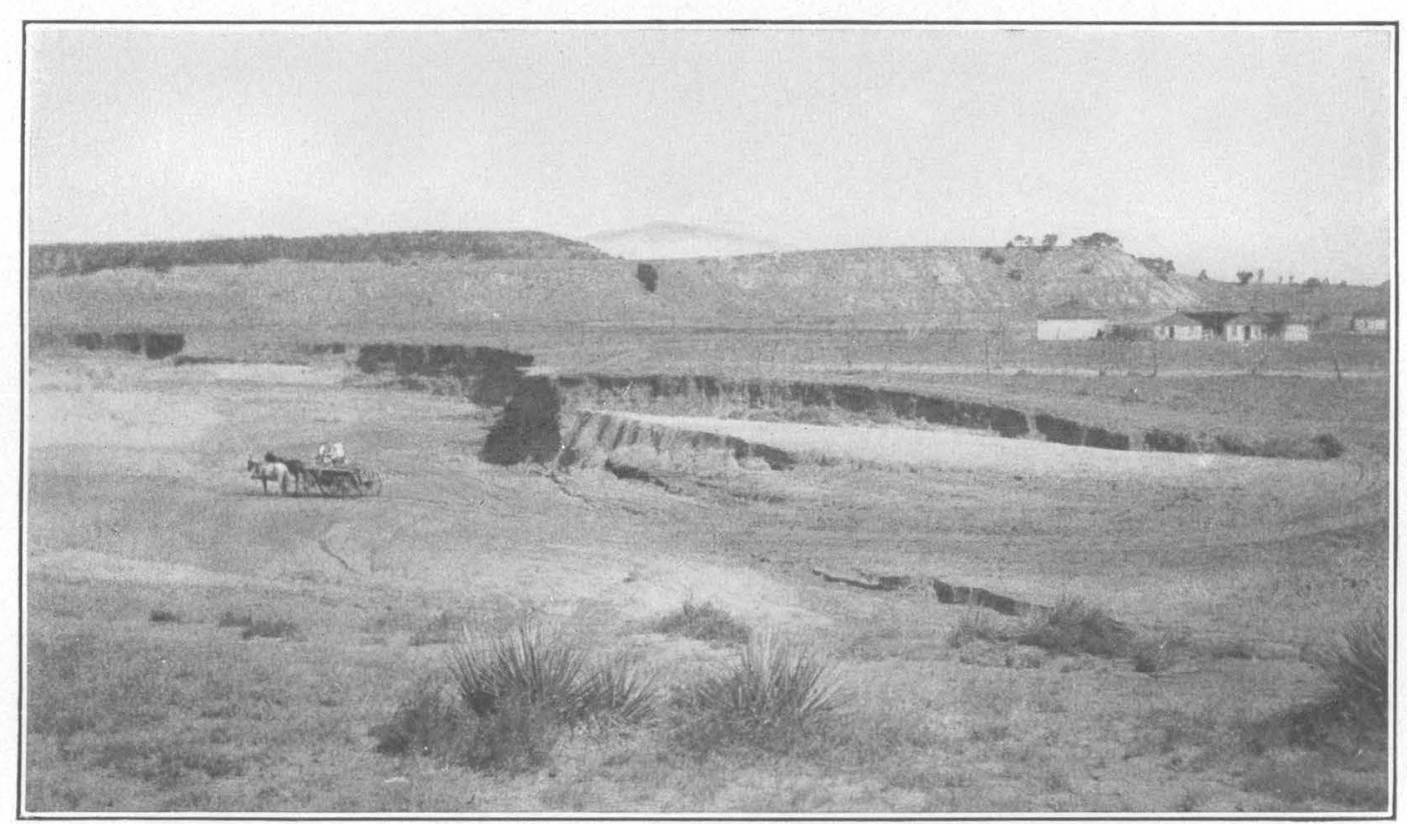

B. EASTERN MARGIN OF TRINIDAD COAL FIELD, NEAR SHUMWAY, COLO. 
WALSENBURG AREA, COLO.

GENERAT FEATURES.

Near Walsenburg the coal-bearing rocks are well exposed on Cuchara River and yielded large collections of fossil plants. Also, a considerable amount of exact information was obtained from the records of the coal companies operating in the Walsenburg district. But north of Walsenburg the coal-bearing rocks are not well exposed and it is not easy in some places to distinguish between the Raton and the Vermejo formations. The escarpment at the margin of the coal field is not prominent (see Pl. XVI, $B$ ), and such cliffs as occur are formed by the harder rocks within the coal measures, and the Trinidad sandstone outcrops in the plain to the east. The basal conglomerate of the Raton formation was traced with confidence only a few miles north of Walsenburg. In the northern part of the Trinidad field the Poison Canyon formation seems to approach close to the Vermejo if, indeed, it does not come in actual contact with it. No clear evidence on this question was obtained by the present writer.

\section{CUChara RIVER.}

LOCALITY 120.

Opportunity was afforded in the valley of Cuchara River southwest of Walsenburg to measure in detail a section of rocks from the Trinidad sandstone to the Poison Canyon formation. The lower 130 feet or more of the Vermejo formation has been penetrated by a shaft at the McAnily mine, one-half mile west of Walsenburg, and the part of the following section below the Robinson coal bed was obtained from the records of this shaft. At the Rockland mine, locality 120, about 2 miles southwest of Walsenburg, a shaft had been sunk previous to the time of investigation, and exact measurements of the rocks penetrated were obtained from the records. The bottom of the shaft reached a coal which the operator supposed to be the Robinson bed, but it remains to be demonstrated whether it is the same as that called the Robinson coal at the McAnily mine. However, for the following section it is assumed to be the same. A coal bed locally known as the Solar coal is exposed in the south bank of the river, and was penetrated near the top of the shaft. From this coal a section was measured at the outcrop in the bluff south of Rockland mine and added to that from the Rockland shaft, the correlation being made by means of the Solar coal. The combined section follows:

Section of rocks measured at locality 120 in the Cuchara Valley, near Walsenburg, Colo.

[The upper part, 600 feet, was measured at the surface in the south wall of Cuchara Canyon; the middle part, between the Solar and the Robinson coal beds, was measured in the shaft of the Rockland mine; the part below the Robinson coal was measured in the shaft of the Mc.Anily mine. For graphic section see P.I. XV, p. 132.]

Poison Canyon (?) formation:

Covered by igneous talus from dike, which forms Unfug Ridge.................

Sandstone, fine grained..................

Sandstone, massive, coarse grained, friable; contains pebbles one-fourth inch in diam-

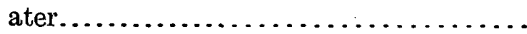

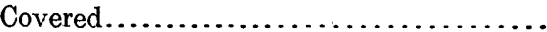

Sandstone, yellow, thin bedded, fossiliferous $(5678) \ldots \ldots \ldots \ldots \ldots \ldots \ldots \ldots$. . . . . . . .

Covered..........................

Sandstone, yellow, thin bedded, fossiliferous.......................

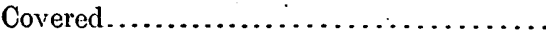

Sandstone, yellow, massive, coarse grained; contains pebbles of quartz and feldspar up to one-fourth inch in diameter.......

Raton formation:

$$
\text { Ft. in. }
$$

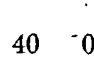

150

$30 \quad 0$

520

230

170

210

290

Sandstone, gray, fine grained, thin bedded.

Sandstone, yellow, massive.............

Sandstone, thin bedded, with partings of sandy shale, fossiliferous...............

Sandstone, yellow, coarse grained, massive.

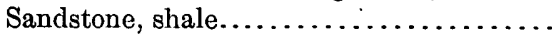

Sandstone, yellow, massive, fossiliferous. .

Covered.........................

Sandstone, yellowish, fine grained.........

Covered..........................

Sandstone, yellow, thin bedded, fossilif-

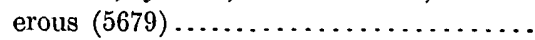

Covered...$\ldots \ldots \ldots \ldots \ldots \ldots \ldots \ldots$

Shale......................... Coal, Solar bed, with three sandy part-

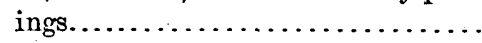

Shale.......................

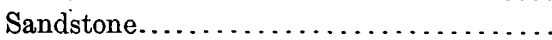

Shale...........................

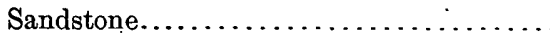

Shale.........................

Sandstone......................

Shale...........................

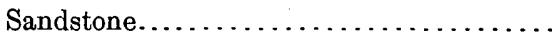

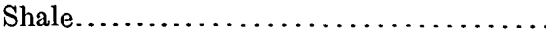

Sandstone.......................

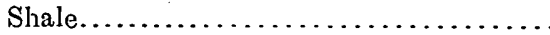

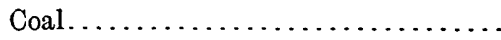

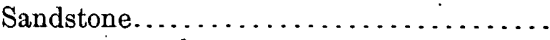

Shale.

\begin{tabular}{cc}
15 & 0 \\
\hline 242 & 0 \\
\hline 50 & 0 \\
12 & 0 \\
34 & 0 \\
24 & 0 \\
22 & 0 \\
20 & 0 \\
15 & 0 \\
30 & 0 \\
12 & 0 \\
& \\
23 & 0 \\
55 & 0 \\
15 & 0
\end{tabular}

$4 \quad 0$

120

530

140

60

11. 0

310

90

$21 \quad 0$

150

250

100

12

190

60 
Raton formation-Continued.

Sandstone.........................

Shale...............................

Coal..........................

Sandstone and shale..................

Coal............................

Sandstone and shale...................

Coal..............................

Sandstone and shale................... Coal...

Sandstone and shale.

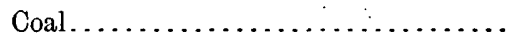

Sandstone and shále...................

Sandstone...........................

Shale...

Coal, bony.......................

Coal............................

Shale............................

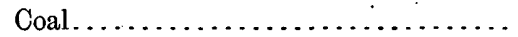

Sandstone and shale.....................

Sandstone, conglomeratic, pebbles of 2 inches maximum diameter, 12 feet were conglomeratic .

Vermejo formation:

Shale, with thin bands of sandstone......

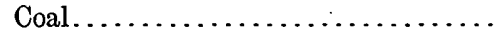

Sandstone and shale, fossiliferous (5676 and 5677). Coal, supposed to be the Robinson bed.

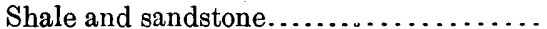
Coal...

Sandstone and shale containing three thin beds of coal, fossiliferous................

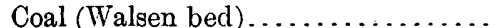

Shale, containing three beds of coal 12 to 14 inches thick. . . . . . . . . . . . . . . .

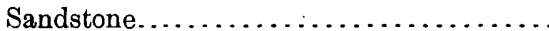
Coal (Cameron bed)....................

Trinidad sandstone.

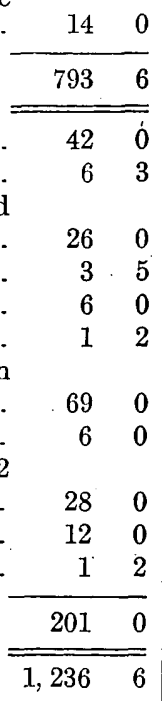

According to this section the Vermejo formation in the vicinity of Walsenburg is about 200 feet thick and consists of coal-bearing sandstone and shale similar to those described elsewhere. It is very fossiliferous in some places. From the rock dump of the McAnily mine a collection of plants was obtained from material said to come from above the Walsen coal bed. However, all of the material from the shaft is contained in this rock dump, and it is possible that some of the fossils came from other horizons, but all belong to the Vermejo flora. They are as follows:

Fossil plants from McAnily mine, near Walsenburg, Colo.

[U. S. Geol. Survey fossil locality 5676.]

Artocarpus dissecta Knowlton.

Cissites panduratus Knowlton.

Ficus minima Knowlton.
Ficus wardii Knowlton.

Liriodendron alatum Newberry.

Myrica torreyi Lesquereux.

Palaeoaster inquirenda Knowlton.

Phyllites leei Knowlton.

Phyllites walsenburgensis Knowlton.

Pterospermites wardii Knowlton.

Sequoia obovata Knowlton.

A large collection of fossil plants of the Vermejo flora was made from the rock dump of the Rockland mine in material which, according to the superintendent's statement, is from above the Robinson coal bed at the base of the shaft. They are as follows:

Fossil plants collected at the Rockland coal mine, about $s$ miles southwest of Walsenburg, Colo.

[U. S. Geol. Survey fossil locality 5677 .]

Asplenium? coloradense Knowlton.

Canna magnifolia Knowlton.

Cissites panduratus Knowlton.

Ficus leei Knowlton.

Myrica torreyi Lesquereux.

Pterospermites nervosus Knowlton.

Sequoia reichenbachi (Geinitz) Heer.

The basal conglomerate of the Raton formation is well developed in the vicinity of Walsenburg but is irregular in thickness and somewhat variable in character. North of the wagon road, about one-fourth mile west of the Walsen mine (No. 123, Pl. I), it consists of a conglomeratic sandstone about 3 feet thick, which is hard and quartzose in some places and relatively soft in other places, so that the weathered surface is rough and craggy. The pebbles, consisting mainly of quartz and chert, are contained in pockets or lenticular masses, and most of them are less than one-half inch in diameter, although some about 2 inches in maximum diameter were found. In some places south of the river, although the sandstone representing the conglomerate is readily identified, no pebbles were found in it for considerable distances. On the other hand, in the shaft of the Rockland mine a thickness of 12 feet of conglomerate was penetrated and reported as "a pudding stone with pebbles up to 2 inches in diameter." From these facts it is evident that this basal conglomerate varies within short distances from a sandstone to a massive conglomerate. It rests with uneven base on the Vermejo formation, and the unconformable relation thus suggested may explain the apparent variation in the thickness of the Vermejo formation in the vicinity of Walsen- 
burg. If the records obtained from the McAnily and Rockland mines are correctly interpreted, this formation is about 200 feet thick. On the other hand, certain drill records in the vicinity of Walsenburg show that a thickness of 240 feet or more intervenes between the conglomerate and the Trinidad sandstone. Also there are discrepancies in the number of coal beds reported. If it is assumed that the number as reported is correct, it is difficult to explain their occurrence without assuming that some of the higher beds of the Vermejo were eroded away in certain places previous to the deposition of the basal conglomerate of the Raton.

The Raton formation is not continuously exposed where the upper part of the section was measured. Several massive sandstones occur, as shown in the section, but in the intervals between them the rocks are covered with soil at the outcrop. Doubtless shale and beds of coal corresponding to some of those penetrated by the diamond drill farther south occur in these poorly exposed intervals. The upper part of the section includes some of the conglomeratic beds which R. C. Hills ${ }^{148}$ maps as Poison Canyon. It is not the purpose of this paper to discuss the relation of the Poison Canyon formation to the Raton formation, but it may be mentioned in passing that certain fossil plants found here (U. S. Geul. Survey fossil locality 5678) above the base of what has been mapped as Poison Canyon are indistinguishable from those in the Raton formation. "They are Magnolia magnifolia Knowlton and palms.

The Raton formation is very fossiliferous near Walsenburg. A large collection was made at a horizon a few feet above the Solar coal in the north bank of Cuchara River, onefourth mile east of the Rockland mine. They are as follows:

Fossil plants collected near the Rockland mine southwest of Walsenburg, Colo.

[U. S. Geol. Survey fossil locality 5679.]

Andromeda scripta Knowlton.

Artocarpus similis Knowlton.

Castalia leei Knowlton.

Cinnamomum mississippiensis? Lesquereux.

Ficus neoplanicostata Knowlton.

- "Geonoma" gigantea Knowlton.

Juglans rugosa Lesquereux.

Liquidambar? cucharas Knowlton.

Magnolia hilgardiana Lesquereux.
Rhamnus cleburni Lesquereux.

Sabal? leei Knowlton.

Sapind us rocklandensis Knowlton.

Tilia speciosissima Knowlton.

Viburnum contortum Lesquereux.

Viburnum magnum Knowlton.

Vitis inominata Knowlton.

PICTOU AND MATtLand.

The prominent cliffs that occur at the eastern margin of the coal field south of Walsenburg are inconspicuous or wholly absent north of that town. The outcrop of the Trinidad sandstone can be traced readily but does not form a continuous cliff, as it does in most parts of the field. The Vermejo formation continues northward apparently undiminished in thickness, but no place was found during the somewhat hasty examination of this part of the field where a detailed section could be measured. The Yermejo coals developed in the vicinity of Walsenburg continue northward and are mined at Pictou and Maitland. In the Pictou mine three thick beds have been opened, but Richardson ${ }^{225 a}$ has shown that two of these coalesce to form a single bed. Some of the peculiarities of structure near. Piotou were noted many years ago. Meade ${ }^{149}$ published in 1900 a cross section of the rocks at this locality in which he indicated a difference in dip between the coal beds and the overlying sandstone but failed to explain its signifioance. At Maitland only two beds of coal have been opened at the mine; but certain drill records show that there are several coal beds in this part of the field. The following section is taken from the record of a hole bored about 4 miles northwest of Walsenburg:

Section of rocks penetrated by diamond drill about \& miles northwest of Walsenburg, Colo.

[For graphic section see No. 121, Pl. XV, p. 132.]

Raton formation:

Shale............................. $54 \quad 0$

Sandstone........................... 40

Shale............................. 50

Sandstone .......................... 30

Shale............................. 1110

Sandstone.......................... 50

Shale............................ 10

Sandstone........................... i4 0

Shale............................ 40

Sandstone............................. 20

Conglomerate......................... 80

Shale............................... $7{ }^{7} 0$

Sandstone.......................... $14 \quad 0$ 


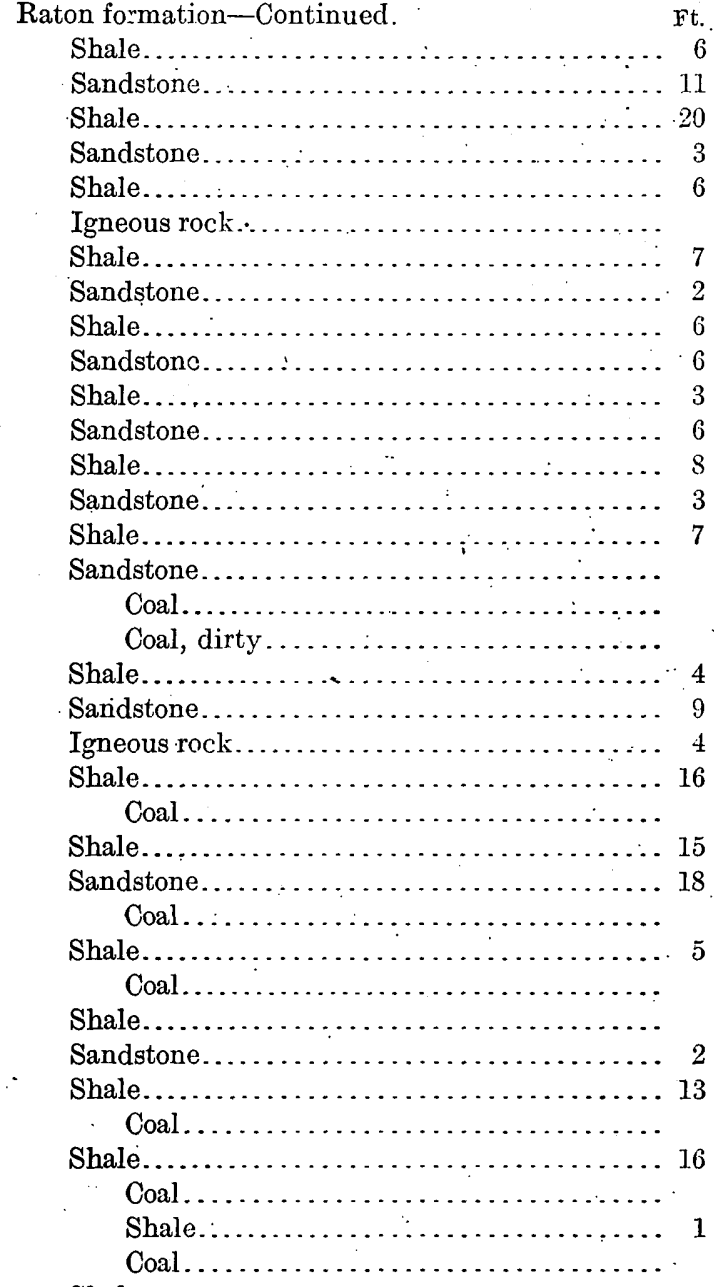

Shale............................ 13

Sandstone (probable base of Raton formation). 14

Vermejo formation(?):

Shale.

Coal...............................

Shale...............................

Coal.............................

Shale............................... 9

Sandstone............................ 14

Shale.................................. . 2

Sandstone............................ 2

Shale............................... 2

Coal.............................

Shale.............................. 13

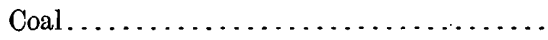

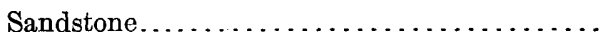

Shale................................ 9

Sandstone............................ 15

Shale.............................. 3

Coal.......................... 4

Shale ................................ 1

Coal. .............................

Shale $\ldots \ldots \ldots \ldots \ldots \ldots \ldots \ldots \ldots \ldots \ldots, 14$

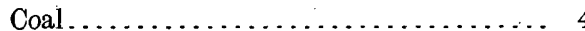

Shale.

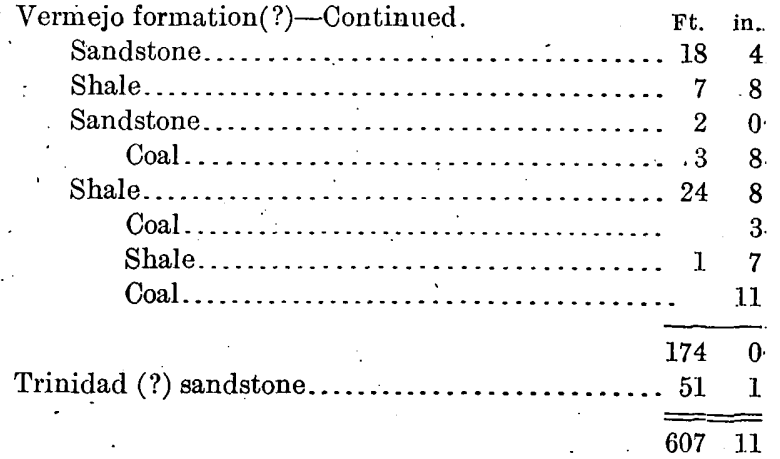

The lowest sandstone of this record is supposed to be the Trinidad, but there is nothing in the record to denote how many of the ceal beds belong to the Vermejo, nor where the top of this formation occurs. However, by comparing it with the section measured near Walsenburg (No. 120), in which the conglomerate is well developed, it seems probable that. the 14-foot sandstone, 173. feet above the top. of the Trinidad, is the base of the Raton formation. (See Pl. XV, p. 132.)

Little is known of the Raton formation north of Walsenburg. In the drill hole just. described a conglomerate was penetrated about 470 feet above the top of the Trinidad sandstone. This is far above the horizon at which the basal conglomerate of the Raton formation is to be expected, and it seems more probable that this conglomerate is either one of local occurrence near the top of the Raton or that it belongs to the Poison Canyon formation, which, without doubt because of erosion of the Raton formation, is known to descend in the section toward the north and west.

\section{SHUMWAY.}

About a mile south of Shumway a part. of the Vermejo formation is well exposed (see Pl. $\mathrm{XVI}, B)$, but no place was observed where a. complete and satisfactory section could be measured. The formation here is divided about midway by a layer of very resistant sandstone (U. S. Geol. Survey fossil locality 5680) that contains fossil palms, Sabal? ungeri (Lesquereux) Knowlton, . and other plants. This resistant layer is more or less persistent. from Maitland northwestward to Strong. The. basal conglomerate of the Raton formation was. not observed closely north of Walsenburg but. seems to outcrop west of the bluffs formed by this sandstone and may form the highest shelf shown in Plate XVI, $B$. At Shumway, a mining. 
town about 6 miles northwest of Walsenburg, the bluff overlooking the town is composed of conglomeratic sandstone 20 to 30 feet thick. It is corrse grained, cross-bedded, and of uneven hardness, and contains irregular masses of pebbles that vary from the size of small peas to one-half inch in diameter. It rests unconformably upon carbonaceous shale and forms a broad shelf with gentle slope. Inasmuch as this conglomerate rests on the coal-bearing shales of the Vermejo formation as the basal conglomerate of the Raton formation does farther south, it seems to represent this conglomerate. However, the lithology is sufficiently different to render this reference doubtful. A few feet above the top of the conglomerate was found a tossil turtle which O. P. Hay identified as Baptemys sp., but the parts necessary for specific determination are wanting.

North of Shumway the Raton formation was not certainly recognized. The Vermejo formation seems to continue with little change in character, but as certain fossil plants appear to cast doubt on the age of the beds the stratigraphic relations of the northern extremity of the field must remain in doubt. Fossil leaves were observed in several places and a few (Artocarpus similis Knowlton and Sophora nervosa Knowlton), which belong in the Raton flora were collected near Strong (U. S. Geol. Survey fossil locality 5682). The coal-bearing rocks are overlain by a conglomeratic sandstone, but nothing was found at the northern end of the field to prove that this is the conglomerate at the base of the Raton formation. In some places it resembles certain parts of the Poison Canyon formation and may belong to that formation. About a mile southeast of Strong the upper part of the coal-bearing rocks is well exposed in a steep bluff, the cap rock of which is conglomeratic. This rock is hard, coarse grained and quartzose, and contains siliceous pebbles one-half inch or more in diameter. In the vicinity of Strong and Tioga the rocks are poorly exposed, and the structural relations were not satisfactorily determined. Apparently rocks belonging to the Poison Canyon formation lie upon the Vermejo, as was found to be the case west of La Veta, about 15 miles southwest of Tioga. This seems to be confirmed by . Fills, ${ }^{148}$, for, according to the mapping in the Walsenburg folio, the coal-bearing rocks are here very thin and the Poison Canyon extends practically to Tioga, which is located on the outcrop of the coal.

\section{VERMEJO CANYON, N. MEX.}

GENERAI FEATURES.

The coal beds can not be followed at the outcrop around the northern end of the Trinidad field to connect with the beds outcropping at the western margin of the field, and in order to make the most satisfactory correlation between the beds exposed in the eastern part of the Raton Mesa region with those exposed. in the western part it is necessary to return to the Raton field, where two drill holes in Vermejo Canyon help to.bridge the gap.

The area lying between the Baldy Mountain (locality 1, p. 66) and Van Bremmer Park, a distance of about 15 miles, was not examined in detail. No doubt places will be found in this area where the structural relations of the sedimentary formations. can be determined, but the rocks are badly obscured by brush and surface débris, and the time at the writer's disposal was not sufficient for the examination of this part of the field. From Van Bremmer Park northward to Rita Leandro, a distance of about 7 miles, the basal conglomerate of the Raton formation appears at the outcrop, but the older formations are so poorly exposed that no satisfactory observations were made on them. The hogback formed by this conglomerate from Rita Leandro northward was not found in Castle Rock Park or in Van Bremmer Park and is not known to occur farther south. Where it is absent; the rock débris from the mountains which rise abruptly to the west obscures the sedimentary rocks along the outcrop in so many places that it seemed best to resort to Vermejo Canyon (where the intervals between good sections are only a few miles) in order to correlate the sections measured along the eastern margin of the field with those measured along the western margin.

As an introduction to this correlation it may be recalled that from Dawson to Van Houten the Vermejo formation ranges in thickness from about 125 feet to nothing, and that in several places throughout the Raton Mesa region this formation has been found to thicken toward the west. It is therefore not surprising to find that at the western margin of the field 
this formation is much thicker than it is along the eastern margin.

In order to show graphically the structural relations of the Vermejo to the Raton formation, section 4, measured near Van Houten and shown graphically in Plate X (p. 108), has been repeated in Plate XVII. From locality 41 to Dawson the Vermejo formation gradually increases in thickness. Northwest of Dawson it is covered with younger rocks, but these have been penetrated by diamond drill in two places in Vermejo Canyon. In one drill hole, near the mouth of Stout Creek (locality 23a, p. 85), a conglomerate was found overlying coalbearing sandstone and shale, and there :; no reasonable doubt that this is the basal conglomerate of the Raton formation and that the underlying rocks are Vermejo. The second boring was made about 5 miles farther up Vermejo River.

\section{SALYERS CREEK. LOCALITY 122.}

In Vermejo Canyon, near the mouth of Salyers Creek, about 9 miles northwest of Dawson and 5 miles from locality $23 \mathrm{a}$, a thick bed of coal outcrops in the sides of the canyon at a stratigraphic horizon slightly above locality 122. This is-obviously one of the upper coals of the Raton formation, and is of assistance in correlating the beds described in the drill record given below with those observed in other parts of the coal field. The drill was started in the floor of the canyon at locality 122 a little below the horizon of this coal bed, and bored to a depth of nearly 1,000 feet, penetrating several beds of coal and a conglomerate that is obviously the basal conglomerate of the Raton formation. Coke and graphite were found near the bottom of the hole, but no intrusive rock was encountered. The occurrence of coke and graphite reminds one of the lowest beds of the Vermejo formation between Van Houten and Cottonwood Canyon, about 18 miles farther east, where the coal over a large area has been changed to graphite by intrusive igneous rock. A sandstone lying below the lowest bed of coke penetrated by the drill (itself penetrated for 15 feet) was thought by the engineers in charge of the work to be the Trinidad, to which it was similar in composition. There seems to be good reason, however, for doubting this interpretation, for if it is correct, the rocks between it and the conglomerate of the Raton (only 155 feet) would represent the full thickness of the Vermejo formation; whereas, in Vermejo Park, only 10 miles northwest of the mouth of Salyers Creek, the Vermejo is about 375 feet thick; and near Dawson, about 7 miles in the opposite direction, it is about 110 feet thick. On the assumption that the Vermejo thins uniformly from Vermejo Park to Dawson it should be about 100 feet thicker at Salyers Creek than is indicated by the drill record, according to this interpretation. On the other hand, the known variations in thickness of this formation weaken this argument and render doubtful the correlation made on Plate XVII.

Although the thickness of the Vermejo formation at this locality may be in doubt, the fact that it is considerable is indisputable. The conglomerate above it is similar in lithologic character and stratigraphic position to the basal conglomerate of the Raton formation as observed at the outcrops to both the east and the west. It is hard and quartzose, and contains siliceous pebbles of considerable size. Some of these observed in the diamond drill core are nearly one-half inch in diameter. The drill record is as follows:

Record of a diamond-drill boring in Vermejo Canyon at locality 122, about 9 miles northwest of Dawson, N. Mex.

$$
\text { [For graphic section see Pl. XVII.] }
$$

Raton formation: $\quad \because \quad$ Ft. in. Surface débris...................... $22 \quad 0$

Sandstone and shale in alternating layers.... $27 \quad 0$

Sandstone........................... $60 \quad 6$

Shale................................ $16 \quad 0$

Sandstone and shale in alternating layers.... $33 \quad 0$ Coal, bony ........................ 3

Sandstone......................... $19 \quad 3$ Coal.............................. 8

Shale........................... 14

Sandstone and shale in alternating layers.... $336 \quad 0$

Coal, bony..................... 4

Shale........................... 3

Coal.......................... i 4

Sandstone........................... 23,0

Shale, sandy....................... 60.0

Sandstone.......................... $18 \quad 0$

- Sandstone and shale in alternating layers.... $156 \quad 0$

Sandstone, conglomeratic................. $4 \quad 0$

Shale.............................. 120

Sandstone, conglomeratic................... $12 \quad 0$

Coal............................ $1 \quad 6$

Sandstone, conglomeratic (base of Raton

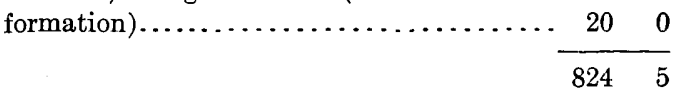

Probable unconformity. 


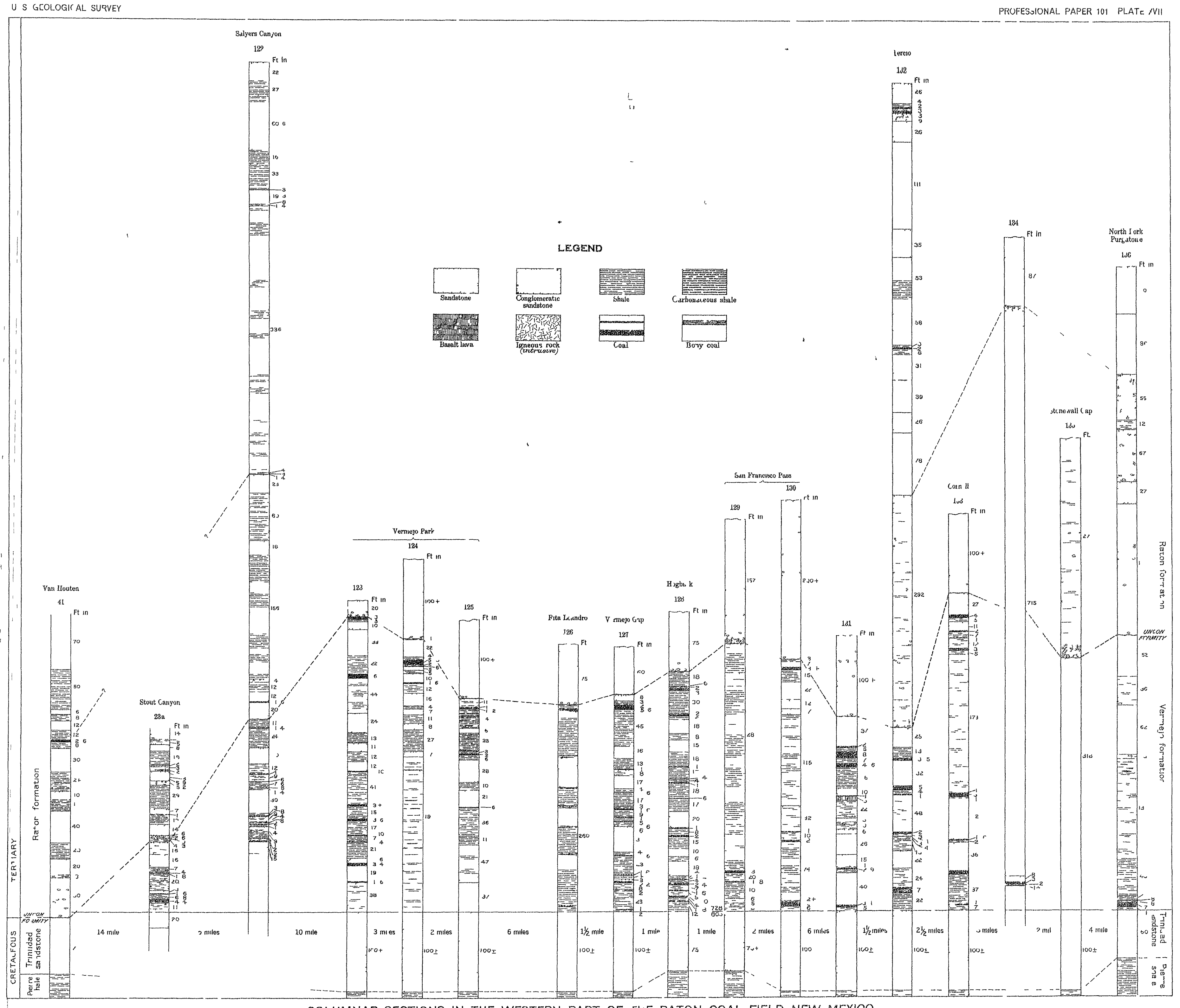

COLUMNAR SECTIONS IN THE WESTERN PART OF THE RATON COAL FIELD, NEW MEXICO 


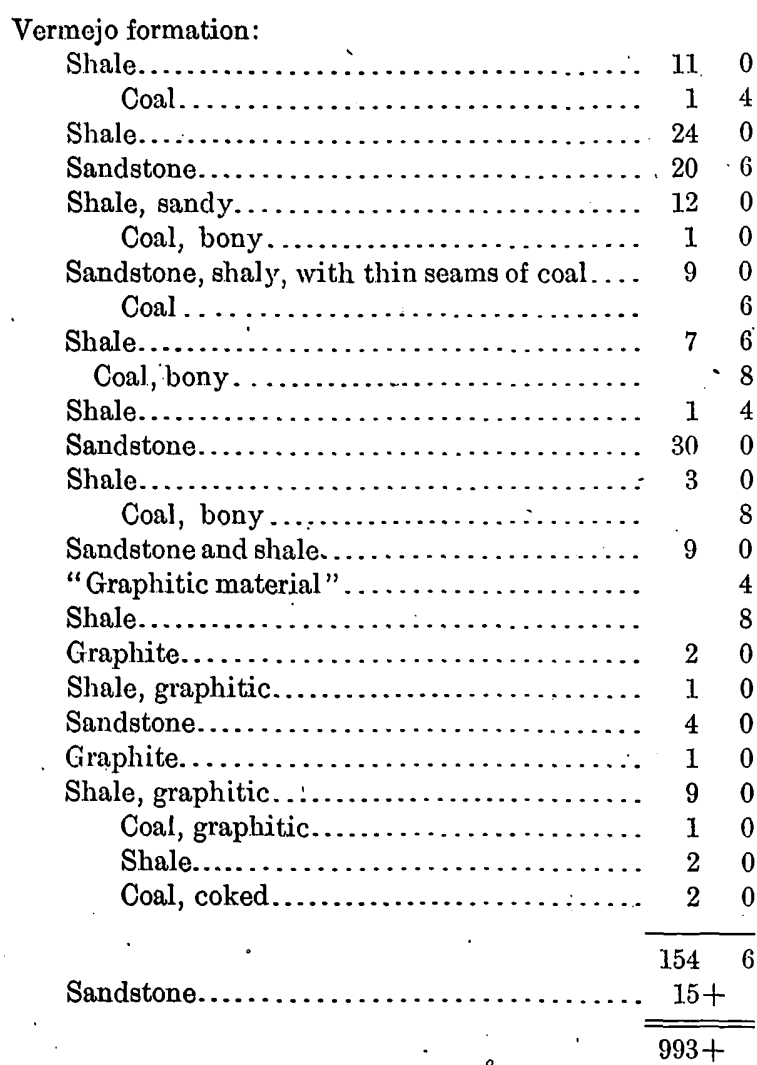

Two collections of fossil plants were made in the Vermejo Valley between locality 122 and Vermejo Park at horizons estimated to be nearly 1,000 feet above the base of the Raton formation. The larger collection is as follows:

Fossil plants collected in Vermejo Valley, N. Mex., near Adams's horse ranch, in sec. 96, T. 30 N., R. 19.E.

[U. S. Gool. Survey fossillocality 5826.]

Aralia? serrata Knowlton.

Cornus neomexicana Knowlton.

Ficus denveriana Cockerell.

Ficus schimperi Lesquereux.

Magnolia angustifolia Newberry.

Magnolia leei Knowlton.

Magnolia magnifolia Knowlton.

Nectandra lancifolia (Lesquereux) Berry.

Platanus aceroides Göppert.

Platanus aceroides latifolia Knowlton.

Platanus guillelmae Göppert.

Quercus simplex Newberry.

Sabal? ungeri (Lesquereux) Knowlton.

Zizyphus fibrillosus (Lesquereux) Lesquereux.

Zizyphus meigsii (Lesquereux) Berry.

A smaller collection was made near the mouth of York Canyon at a horizon a few feet higher than that of the last collection.
Fossil plants collected near the mouth of York Canyon, in Vermejo Valley, N. Mex.

[U. S. Geol. Survey fossil locality 5241.]

Ficus denveriana Cockerell.

Ficus pseudopopulus Lesquereux.

Laurus socialis Lesquereux.

Platanus raynoldsii Newberry.

Platanus rhomboidea Lesquereux.

VERMEJO PARK.

Vermejo Park is an opening formed by the erosion of a dome, in whose center the rocks had been elevated several hundred feet above those at corresponding horizons on all sides. The surface rock in the center of the park is the Pierre shale, which at locality 122,10 miles to the southeast, is more than 1,000 feet below the surface. The park is surrounded by precipitous walls formed by the Trinidad sandstone, the Vermejo formation, and the base of the Raton formation. The continuity of this wall is broken in three places-at the point where Spring Canyon joins the park, at the western extremity (where Vermejo River enters), and at the southeastern extremity (where Vermejo River leaves). At these places detailed sections were measured.

LOCALITY 123.

Between the mouth of Salyers Creek and Vermejo Park several beds of coal outcrop. These are believed to be the coals that outcrop above the "barren series." in the eastern part of the Raton field. Near the southeastern extremity of Vermejo Park, at locality 123, the rocks dip about $4^{\circ} \mathrm{E}$., away from the center of the dome; and the Pierre shale, the Trinidad sandstone, and the Vermejo formation, which are exposed in the park, are covered farther east by the younger rocks. The following section was measured north of Vermejo River, about half a mile from the point where the Trinidad sandstone crosses the river:

Section of rocks measured at locality 123, at southeastern extremity of Vermejo Park, N. Mex.

[For graphic section see PI. XVII.]

Raton formation: $\quad \mathrm{Ft}$. in.

Conglomerate (top eroded away) .......... $\quad 20 \pm$

Unconformity.

Vermejo formation:

$$
\text { Coal...................... } 3 \quad 30
$$

Shale, carbonaceous at top, black........... 30

Sandstone, massive, fine grained, fossiliferous, yellow...................... 10.0 
Vermejo formation-Continued.

Covered

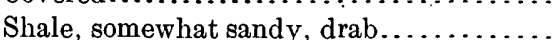
Coal............................

Sandstone and shale; not continuously exposed............................ Sandstone, massive, very friable, white... Coal (streak).

Shale, drab.......

Sandstone, coarse grained, massive, yellow

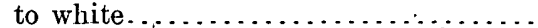

Shale, very sandy.....

Sandstone, massive, coarse grained, iferous, yellowish white................ Coal............................

Shale, sandy, with thin sandstone......... Coal............................

Shale, sandy.......................... Coal............................

Shale, sandy, yellow.

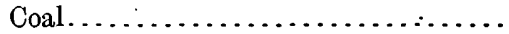

Shale, drab....................... Coal.

Shale, drab

Sill of igneous rock, much altered; contains coke.......................... Coal, altered to coke at top........... Not exposed. Coal..........................

Sandstone, shaly, friable..............

Trinidad sandstone

Pierre shale:

Transitional zone.

Shale, fossiliferous. $(6679,5731,5730,5732$, and 5734) (lower 2,300 feet penetrated by drill). $2,530+$

$3,020 \pm$

The Pierre shale, the oldest formation exposed at this locality, is known from surface measurements and drill records to be at least 2,530 feet thick. At the Bartlett ranch, about half a mile northwest of locality 123 , a well was started 230 feet or more below the base of the Trinidad sandstone, which here forms a conspicuous cliff in the wall of the park. The upper 700 feet of the boring was done with calix drill, and many fossil shells were brought out in the core. One of these, given to the writer by Norman Bartlett, has been identified as Inoceramus vanuxemi Meek and Hayden (U. S. Geol. Survey fossil locality 6679). Below 700 feet a churn drill was used. Nothing but shale was encountered to a depth of 2,300 feet, where work was discontinued. This depth, together with the 230 feet of shale exposed in the wall of the park above the top of the well, makes a thickness of at least 2,530 feet of shale, probably all belonging to the Pierre, for no limeston'e that can be referred to the Niobrara or Benton was reported by the driller. A few species of invertebrates collected at the surface near locality 123 all came from the upper part of the Pierre shale, only a few hundred feet below the Trinidad sandstone. They are as follows:

Fossil shells collected in Vermejo Park, N. Mex., near top of Pierre shale.

[U. S. Geol. Survey fossil localities 5731, 6679, 5730, 5732, 5734.] Ancyloceras sp.

Inoceramus barabini Morton.

Inoceramus sageneis Owen.

Inoceramus vanuxemi Meek and Hayden. Mactra sp.

Ostrea patina Meek and Hayden.

Scaphites nodosus Owen.

The Trinidad sandstone is typically developed in this locality and is about 100 feet thick. It is separated from the typical Pierre shale by a series of thin sandstones separated by layers of shale which constitute the transitional zone that occurs more or less uniformly throughout the Raton Mesa region. The top of the Trinidad sandstone is drawn in the section at the top of the massive part, thus placing 38 feet of shaly sandstone that occurs above it in the Vermejo formation.

The Vermejo formation is about 375 feet thick at this locality, and contains at least ten beds of coal varying in thickness from 4 inches to 6 feet. The sandstones are coarse and light colored, and do not differ notably in general appearance from the Trinidad sandstone. They are relatively soft, weather to a granular mass, and disintegrate almost as easily as the shale that separates them, so that a smooth slope is formed along the outcrop of the Vermejo.

The following-named fossil plants, collected at this locality, 25 feet below the top of the Vermejo formation, are in poor state of preservation, few good specimens being obtainable. However, it is clear that they belong to the Vermejo flora.

Fossil plants collected 25 feet below the top of the Vermejo formation; about 1 mile east of Bartlett's ranch, in the easi wall of Vermejo Park, N. Mex.

[U. S. Geol. Survey fossil locality 5810 .]

Ficus speciosissima Ward.

Pterospermites undulatus Knowlton.

Sequoia obovata Knowlton.

Sabal montana Knowlton.

Zizyphus paliurifolius Knowlton. 
The basal conglomerate of the Raton formation forms the crest of the ridge that incloses the park: The top of this conglomerate is eroded away at this locality, and only 20 feet of it was included in the section. It consists of a matrix of coarse-grained; cross-bedded, massive sandstone, in which are embedded pebbles of quartz, chert, and a variety of igneous and metamorphic rocks. These are very irregularly distributed throughout the rock mass, but are found in greatest abundance near the base. They occur most often in pockets or irregular masses, but in some places are somewhat evenly distributed through the mass. The conglomerate rests with obvious erosional unconformity. on the Vermejo formation. At locality 123 it rests on 3 feet of coal, but a few.rods farther north it rests on shale, no coal being present. No observations were made on the Raton beds above the conglomerate near this locality.

\section{LOCALITY 124.}

No sections were measured in the north wall of Vermejo Park, although the Pierre shale, Trinidad sandstone, Vermejo formation, and the basal conglomerate of the Raton formation are well exposed in many places. The Trinidad sandstone forms a cliff which is readily recognized, and the conglomerate is equally conspicuous, forming the crest-of the ridge inclosing the park. Two of the thickest beds of coal in the Vermejo formation in the north wall were opened about the year 1894, and Orestes St. John, who reported the results, states that 17 openings on the highest bed show an average thickness of about 5 feet 8 inches of corl, and 10 openings on the lowest bed show an average thickness of more than 5 feet of coal. An intermediate bed was prospected in three places and found to contain coal 3 to 5 feet thick.

At the northwestern extremity of Vermejo Park, at locality 124, the rocks dip about $15^{\circ} \mathrm{NW}$., away from the center of the dome. At the point where the Trinidad sandstone crosses Spring Canyon a short section was measured. The top of the Pierre shale is exposed at this locality, but little attention was given to it, though a few fossils (Inoceramus barabini Morton and Ostrea patina Meek and Hayden) were found in the upper 100 feet (U. S. Geol. Survey fossil locality 6514). The
Trinidad sandstone is typically developed and the following fossils were found in it at an old stone quarry in the north wall of the canyon:

Fossils collected from the Trinidad randstone in Spring Canyon.

[U. S. Geol. Survey fossil locality 5727.]

Halymenites major Lesquereux. Mytilus? sp.

Inoceramus sagensis Owen?

Legumen? sp.

Tellina sp.

The Vermejo formation is here about 343 feet thick. The lower part of it is not well exposed, but some of the details of the upper part were obtained. The highest coal has been mined for local consumption for several years from an opening known as the "Dead Easy mine.". Fossil plants were collected from the shale above this coal bed and from a point about 300 feet farther downstream at a slightly higher horizon. These plants are combined as follows:

Fossil plants collected at the top of the Vermejo formation in the south wall of Spring Canyon, in Vermejo Park, N. Mex.

[U. S. Geol. Survey fossil localities $5237,5240,5807$, and 5808.]

Ficus praetrinervis Knowlton.

Ficus speciosissima Ward.

Phyllites vermejoensis Knowlton.

Sterculia coriacea Knowlton.

Taxodium? sp.

Viburnum montanum? Knowlton.

Viburnum rhamnifolium Knowlton.

The section measured at this locality is as follows:

Section of rocks measured at locality 124, northwestern extremity of Vermejo Park, N. Mex., in south wall of Spring Canyon.

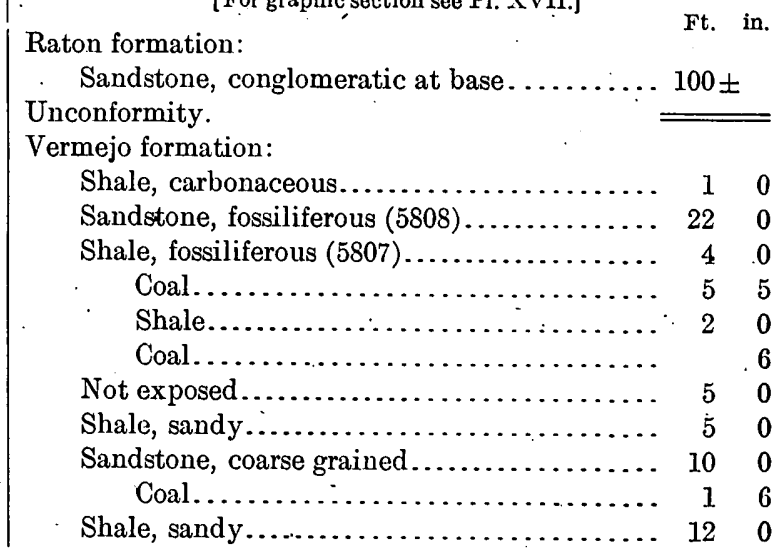


Vermejo formation-Continued.

Sandstone, soft, friable.

Shale, carbonaceous...................... 4 . 4

Sandstone, soft, friable.................. $\quad \dot{7}$

Shale............................. 11

Sandstone.......................... 8

Shale............................. 27

Sandstone.......................... 7

Sandstone and shale, coal bearing, not continuously exposed................... 195

Trinidad sandstone:

Sandstone, fossiliferous $(5727) \ldots \ldots \ldots \ldots \ldots .100 \pm$

Pierre shale:

Transitional zone.

Shale (6514).

The basal conglomerate of the Raton formation is 100 feet or more. in thickness at locality 124 and is unusually massive and coarse at the base, where it consists of little else than siliceous pebbles 1 to 2 inches in diameter. The rocks of the Raton formation above the conglomerate are poorly exposed in Spring Canyon, and no attempt was made to examine them in detail. However, a small collection of fossils belonging to the Raton flora was made at a horizon estimated to be 500 feet stratigraphically above the conglomerate (U. S. Geol. Survey fossil locality 5236). These are identified as Ficus pseudopopulus Lesquereux, Juglans rhamnoides Lesquereux; Palmocarpón palmarum (Lesquereux) Knowlton, and Rhamnus cleburni Lesquereux.

Along the outcrop of the coal beds between Spring Canyon and Vermejo River the coals were opened, about 1894, in six places.' The higher coal averages 6 feet 6 inches in thickness, and the lower 4 feet $7 \frac{1}{2}$. inches. The rocks of the Vermejo do not seem to be well exposed in the south wall of the park, and no attempt was made to examine them. However, the coals are known to occur in the south wall, the highest one reported to be about 4 feet and the lowest about 3 feet 6 inches thick. The basal conglomerate of the Raton is conspicuous at the crest of the ridge.

\section{IOCALITY 125}

On.Vermejo River, at the western extremity of Vermejo Park, a section was measured in the south wall of the canyon at locality 125 , about 2 miles south of locality 124 and 4 miles west of locality 123 . The Pierre shale is exposed in the valley to the east and the Trinidad sandstone, which dips $6^{\circ} \mathrm{W}$., is characteristi- cally developed. At the top of the Trinidad, about half a mile southwest of Vermejo (U. S. Geol. Survey fossil locality 6517), Stanton found Tellina scitula Meek and Hayden and Mactra sp.

The lower part of the Vermejo formation is best exposed in the south wall of the canyon and the upper part in the north wall. For this reason the upper 105 feet of the formation, as represented in the following section, was measured north of the river opposite locality 125 . In both places the top of the formation was accurately determined and the total thickness measured. In the south. wall this thickness was measured as 255 feet, and in the north wall as 260 feet; the thickness of the individual beds, as determined in the two places, sums up about 267 feet. It is clear, therefore, that the accurate thickness of the Vermejo at this locality is not far from 260 feet as compared with 343 feet for this formation 2 miles to the north and 374 feet at locality 123, 4 miles to the east. The section follows:

Section of rocks measured in Vermejo Canyon, at locality 125, about 2 miles west of Vermejo post office, N. Mex.' [For graphic section seo Pl. XVII.]

Raton formation: $\quad \cdot \quad \cdot F \dot{t}$. in.

Conglomerate....................... $100 \pm$

Unconformity.

Vermejo formation:

Sandstone, shaly, yellow................. $11 \quad 0$

Shale, black....................... 10

Coal............................ 12

Shale, carbonaceous, black, with several

seams of coal near the base........... $24 \quad 0$

Sandstone, thin bedded, yellow......... $6 \quad 0$

Shale, carbonaceous, very black, with thin seams of coal...................... $233^{\prime} 0$ Coal (streak).

Shale,............................. $3 \quad 0$

Coal, impure.................... 20

Shale, drab......................... 6

Sandstone, massive, friable, yellow ........ $28 \quad 0$

Shale, drab....................... $10 \quad 0$

Sandstone, soft, friable, massive, gray to

yellow, fossiliferous $(5809) \ldots \ldots \ldots \ldots \ldots$ 21 0

Coal

Shale, sandy.......................... $36 \quad 0$

Sandstone, massive, gray to yellow......... $11 \quad 0$

Saridstone and drab shale............... $47 \quad 0$

Not exposed . . . . . . . . . . . . . . . . $\quad 37 \ldots \ldots$

Trinidad sandstone $\ldots \ldots \ldots \ldots \ldots \ldots \ldots \ldots \ldots \ldots$

Pierre shale:

Transitional zone.

Shale. 


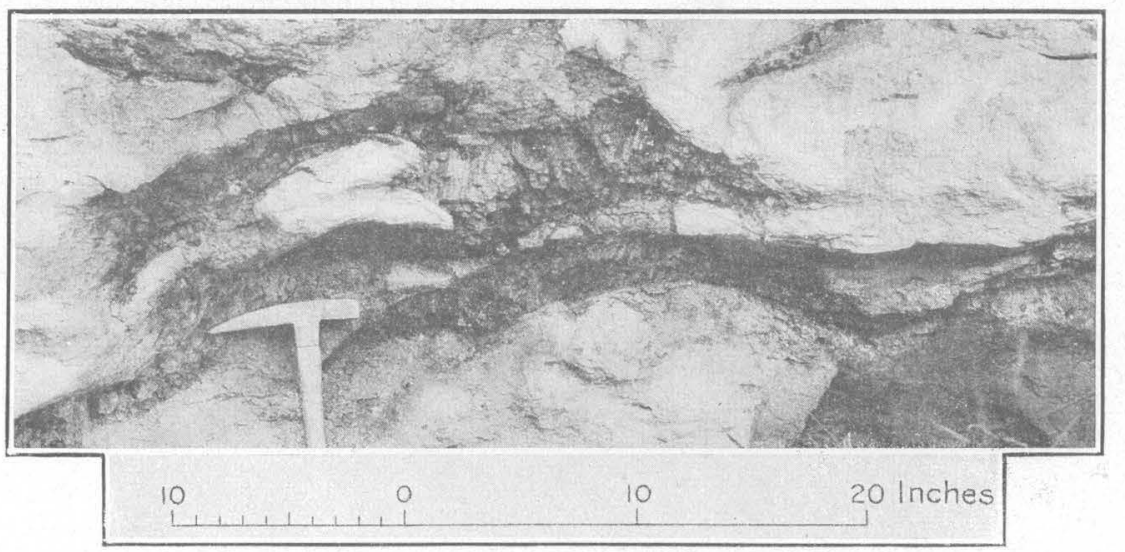

A. IRREGULARLY SHAPED MASSES OF COAL.

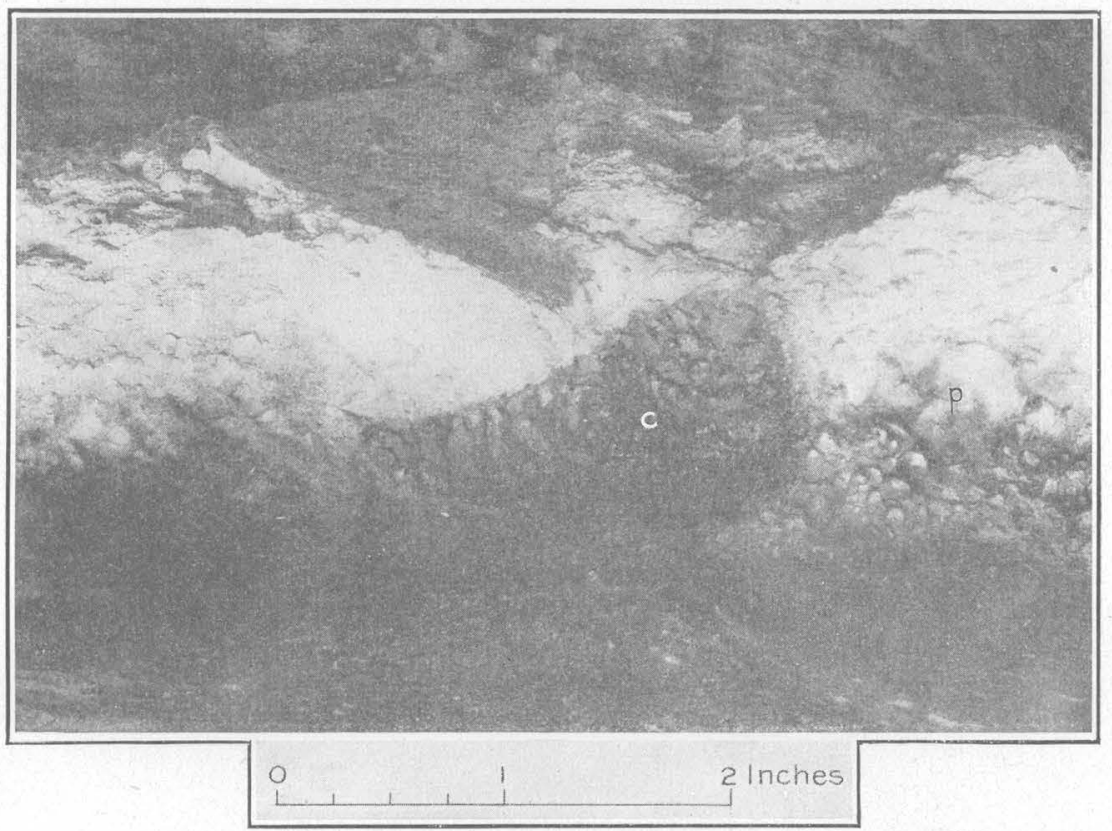

B. ROUNDED PEBBLE OF COAL (c) SURROUNDED BY PEBBLES OF SILICEOUS ROCK (p).

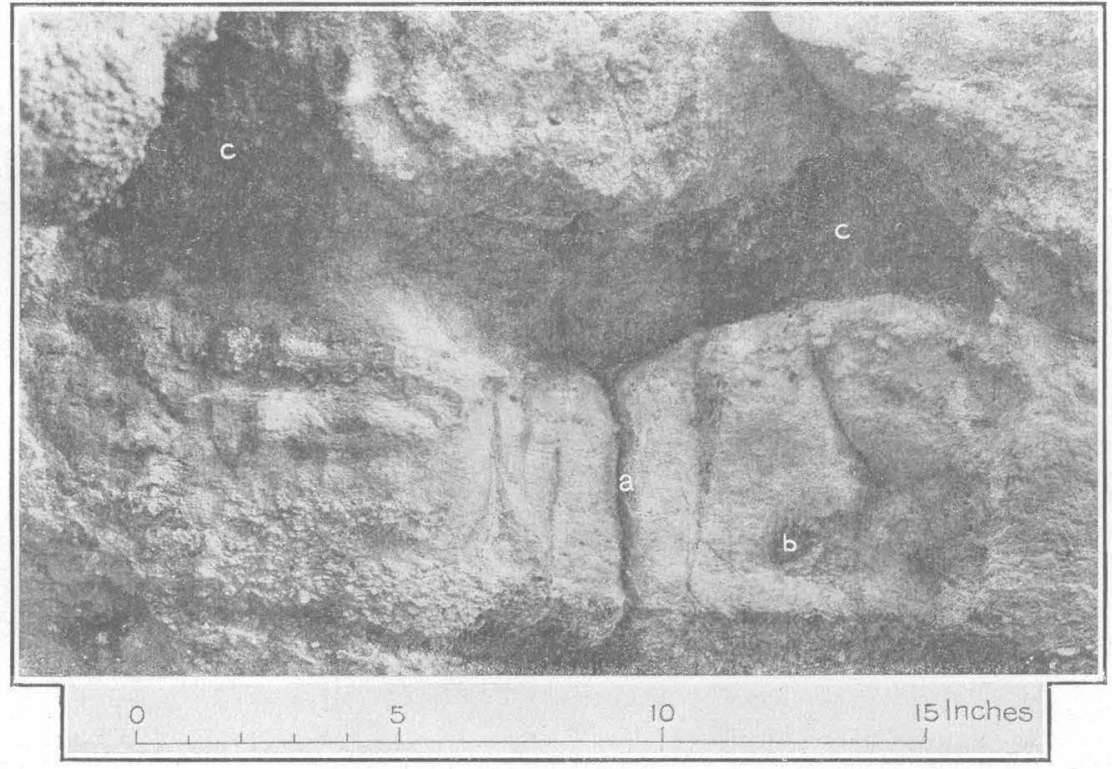

C. PEBbles OF COAL (b, c) EMBEDDED IN CONGLOMERATIC SANDSTONE (a).

Coal in the Basal Conglomerate of the Raton formation, Vermejo

CANYON, N. MEX. 


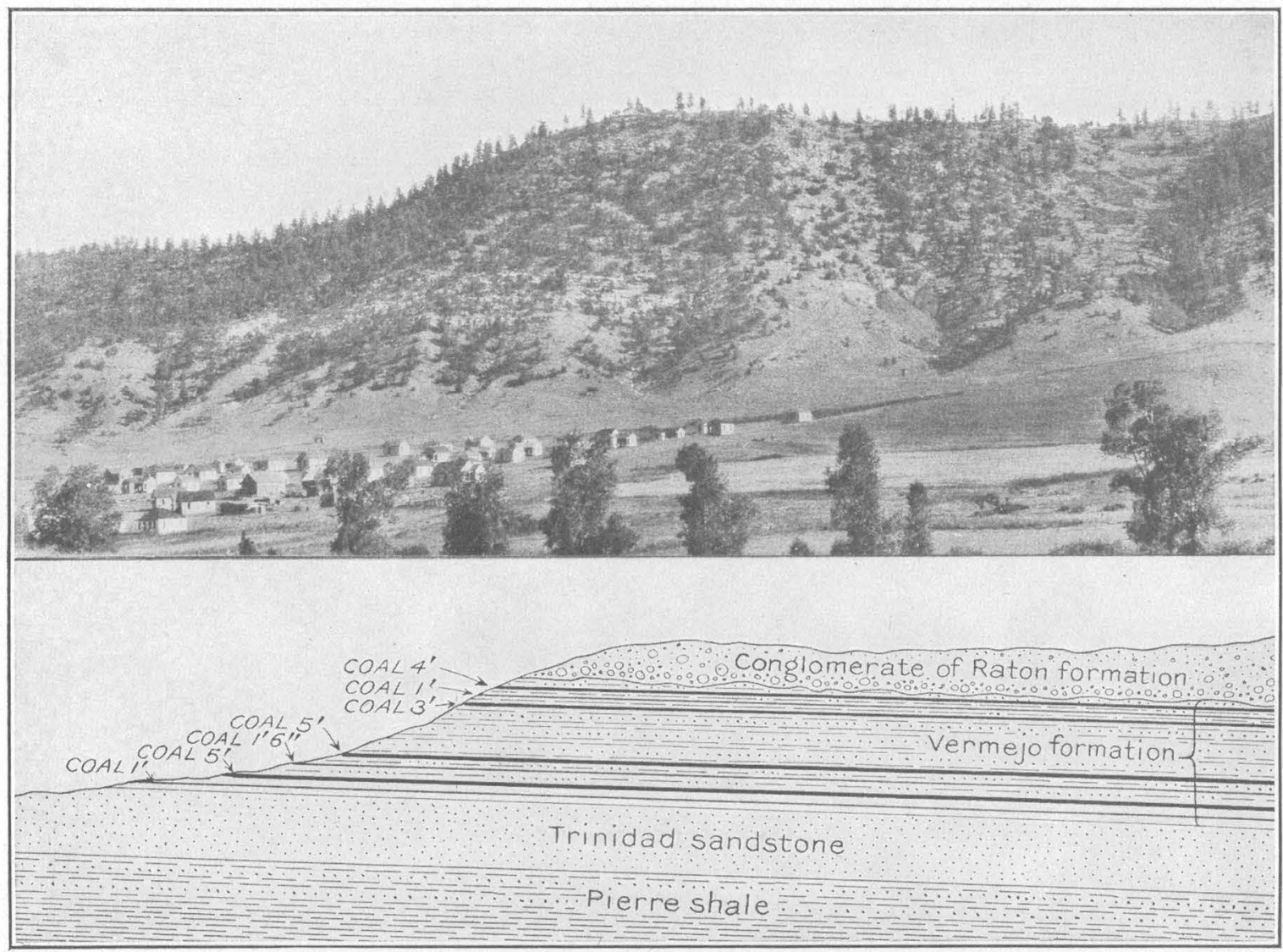

A. NORTH WALL OF TERCIO PARK, CORNELL, COLO. Showing structural relations.

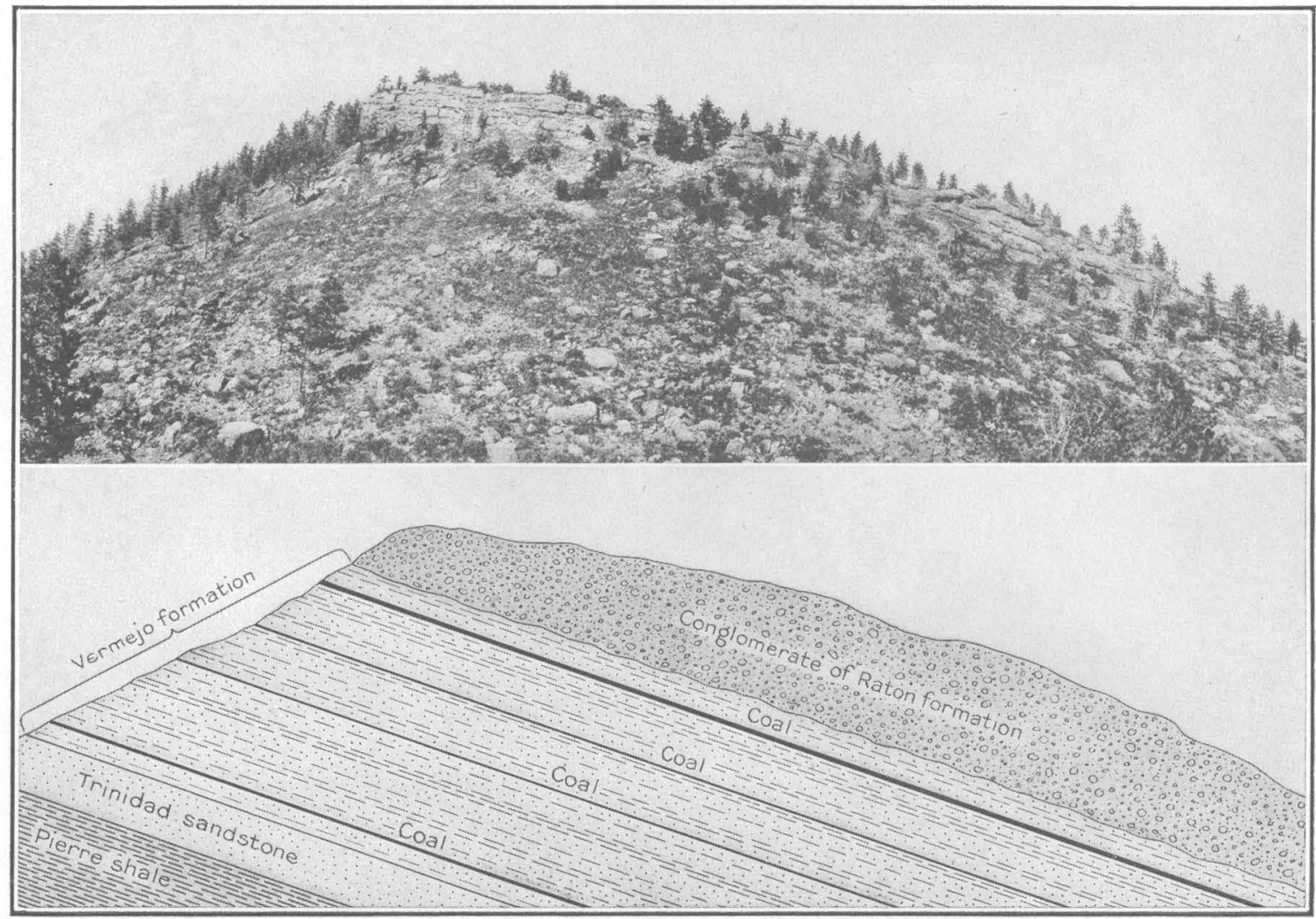

B. HOGBACK IN VERMEJO GAP, N. MEX.

Showing the basal conglomerate of the Raton formation, overlying the Vermejo coal measures. 
Fossil plants were found in the south wall of the canyon at about the middle of the Vermejo and were identified as follows:

\section{Fossil leaves collected near the middle of the Vermejo forma-} tion, in the south wall of Vermejo Canyon.

[U. S. Geol. Survey fossil locality 5809.]

Celastrus? sp.

Colutea speciosa Knowlton.

Diospyros? leei Knowlton.

Phyllites nanus Knowlton.

Phyllites sapindus Knowlton.

Phyllites rosaefolius Knowlton.

Salix sp. a.

The basal conglomerate of the Raton formation is well exposed near this locality, but the rocks above it are obscured by brush and slide rock. They are coal bearing, but the stratigraphic positions of the coal beds were not determined. The conglomerate is massive, quartzose, and cross-bedded. In a small gulch - that enters Vermejo River from the north, near this locality, fragments of coal, first described by Van Diest, ${ }^{118}$ occur embedded in the conglomerate. They are best seen in the east wall of this gulch, where the conglomerate is well exposed and consists of a matrix of coarsegrained cross-bedded sandstone, in which are embedded pebbles of quartz, chert, and a variety of igneous and metamorphic rocks. In some places these pebbles are distributed more or less regularly through the sandstone, and in other places form large irregular masses of "pudding stone." In and near these masses of conglomerate are irregular bodies of shale and coal; most of them are only a few inches in diameter, though the coal fragments range in size from small grains to masses 4 feet long and 6 inches thick. Some of the smaller fragments of coal are rounded, others are irregularly lenticular, and some feather out to streaks that are little more than carbonaceous stains in the conglomeratic sandstone. Some of this conl is inclosed in the hard quartzose conglomerate, there being no shale or carbonaceous material between the vitreous coal and the siliceous pebbles. None of the lumps of conl could be extracted intact from the conglomerate, and an attempt to break off fragments of the rock containing them resulted in the crumbling and loss of the coal. Nor was the attempt to photograph them in place a complete success, because of the difficulty in getting good illumination. (See Pl. XVIII.)

In reaching the conclusions stated below several facts regarding these pebbles of coal have been considered. First, except in a few places where the thin edges feather out, the coal is pure, clean, and bright, with vitreous luster. In other words, it is a genuine coal and contrasts sharply with the masses of carbonaceous shale and fragments of carbonized wood that are contained in the conglomerate together with the coal. Second, some of the smaller pebbles of coal are well rounded, with relatively smooth surface. Third, with few exceptions the large and more irregularly shaped bodies are convex upward. (See Pl. XVIII, A.) Fourth, in addition to the coal, there are numerous fragments of charcoal or carbonized wood such as are found in many places in the Raton field near the base of this conglomerate. These might sometimes be mistaken for coal, but on close examination they prove to be soft, lusterless, and wanting in the structure and cleavage which characterizes the coal.

The possibility that the coal was formed from vegetable matter buried with the conglomerate and later transformed into coal was carefully considered both at the time of the field investigation and later. If the coal were formed from fragments of wood buried in the conglomerate it is difficult to understand why some of these fragments turned to coal and others to charcoal. Furthermore, if these bodies represent vegetable matter buried with the conglomerate the overlying conglomerate should tend to sag, for coal occupies less space than the wood from which it was formed. On the contrary, however, in nearly all of the bodies examined the top of the coal was more or less arched (see Pl. XVIII, $A$ ), and no evidence of crushing was found.

The general confused appearance of the conglomerate, with its inclusions of shale, coal, and charcoal, suggests the caving of a bank undercut by a stream, and it seems probable that the stream which deposited the conglomerate had eroded laterally in the coal-bearing shales of the Vermejo formation at this locality, and that the caving bank supplied the irregular masses of coal and shale which were buried by the gravels practically where they fell. The 
small, well-rounded pebbles of coal may have been transported by the stream for some distance and worn round.

GONZALES CANYON, N. MEX.

Between Vermejo Park and the hogback, about 6 miles to the west, where the rocks are upturned at the foothills, coal-bearing rocks of the Raton formation occupy the trough of the syncline. In Gonzales Canyon three beds of coal were opened many years ago. From such records as are now available, the lowest seems .to range in thickness from 2 to 18 inches, the middle one from 2 to 12 inches, and the highest from 3 to 23 inches. No information was obtained by which these beds can be correlated with those of the eastern part of the field, but comparison with known sections in various parts of the region indicates that they correspond to similar thin beds observed elsewhere near the base of the Raton formation. Also, the degree of dip from either side toward the trough of the syncline, considered in connection with the character of the rocks, inclines the writer to the opinion that these coal beds are the lowest of the Raton coals.

- The rocks contain fossil plants in great abundance, but no collections were made in this part of the field.

\section{HOGBACK AREA}

GENERAL FEATURES.

At the northwestern extremity of the Raton coal field, west of the syncline just described, the coal measures, together with the underlying rocks, are upturned in the foothills of the Sangre de Cristo Mountains and dip $10^{\circ}$ to $30^{\circ} \mathrm{E}$. Here, as in Vermejo Park, the basal conglomerate of the Raton formation forms the crest of the most prominent ridge. This is separated from the mountain front by a broad structural valley eroded in the weak shales of Pierre and Benton age. In the western part of this valley, about 12 miles northwest of Vermejo (U. S. Geol. Survey fossil locality 6515) Stanton found Inoceramus labiatus Schlotheim in a limestone at the horizon of the Greenhorn limestone. At the same locality, but stratigraphically 150 to 200 feet higher (U. S. Geol. Survey fossil locality 6516), he found the upper Benton forms Ostrea lugubris Conrad, Inoceramus fragilis Meek and Hayden?, and Prionocyclus wyomingensis Meek.
The Trinidad sandstone, which forms such a conspicuous shelf along the eastern margin of the Raton Mesa region, is present and has essentially the same thickness and character, but here it assumes a subordinate rôle in shaping the topography, the controlling stratum being the massive resistant conglomerate which seems to be several hundred feet thick. The structural relations of the formations are well shown in the gap occupied by Vermejo River. In this gap the Pierre shale, Vermejo formation, and the basal conglomerate of the Raton formation are well exposed and dip about $12^{\circ} \mathrm{E}$. The general aspect of the rocks and a cross section of the hogback are shown in Plate XIX, $B$. The crest and eastern slope of the ridge are formed by the conglomerate, from which the weaker rocks lying stratigraphically higher have been eroded. The underlying Vermejo forms a characteristic relatively smooth slope, on which boulders of conglomerate lodge and, as in many . other places along the hogback, render examination difficult: However, the underlying rocks are exposed about a. quarter of a mile farther north, where the details in the diagrammatic section were obtained.

The basal conglomerate of the Raton formation in the gap was examined with considerable care, and an effort was made to find as great a variety as possible of the pebbles composing it in the hope that these would give a clue to the region whence the material was derived and would give some indication of the length of time represented by the unconformity between the Vermejo and the Raton formations. The massive part of the conglomerate which forms the crest of the bogback is about 60 feet thick, but a considerable though undetermined thickness has been removed by erosion. What remains is very massive and resistant. Blocks 10 or 15 feet in diameter, consisting chiefly of well-rounded pebbles of siliceous rocks, are numerous along the slope. Pebbles up to 2 inches in diameter are common, and some about 4 inches in diameter were found.

A considerable variety of rock is represented by the pebbles. Some are of relatively soft sandstone that resembles the sandstones of the Vermejo and Trinidad formations. Some are of ferruginous sandstone similar to the so-called ironstones common in the Vermejo. Others were derived from some coarse-grained, quartz- 
ose sandstone or from a quartzose conglomerate similar to the conglomeratic sandstone of the Purgatoire formation, which now outcrops in a prominent hogback west of the coal field, stratigraphically more than 3,000 feet below the conglomerate. There are pebbles of red sandstone 1 to 3 inches in diameter, which could come only from the red beds now exposed in the foothills to the west, 4,000 feet or more stratigraphically below the basal conglomerate of the Raton. There are pebbles of quartz, quartzite, chert, and other metamorphic rocks, with which are included a few small pebbles of a red material resembling jasper. Many of the cherts bear impressions of crinoid stems and some impressions of small shells that could not be generically determined. A few pebbles of granite and several of fine-grained igneous rock supposed to be derived from dikes were found. Several pebbles of feldspar, some of them nearly an inch in diameter, were found so well preserved that their cleavage faces could be determined. However, the feldspar seems to be most abundant in the matrix in which the larger pebbles are embedded and is mostly decomposed. Soft kaolin, which apparently resulted from the decomposition of pebbles of feldspar, was found in some places.

Many fossil leaves were seen in the rocks of the Raton formation east of Vermejo Gap, but none of them was collected except Platanus guillelmae Göppert, which was found in a sandy lnyer in the midst of the conglomerate (U. S. Geol. Survey fossil locality 5239).

\section{RITO LEANDro.}

LOCALITY 126

The southernmost point at which a section was measured on the hogback is at locality 126 , north of Rito Leandro. This locality is about 6 miles west of the point where the Spring Canyon section was measured. The rocks are poorly exposed here, and the principal object in measuring the section was to obtain the thickness of the Vermejo formation and to ascertain its relations to the Trinidad sandstone and to the Raton formation. It consists of shale, coal, and relatively soft sandstone, which do not seem to differ in character from those of the better-exposed sections farther north. The section follows:
Section of rocks measured at locality 126, at the western margin of the Raton coal field, south of Rito Leandro.

[For graphic seation, see Pl. IVII, p. 142.]

Raton formation: Conglomerate....................... $75+$ Unconformity.

Vermejo formation:

Shale, sandstone, and coal, not well exposed.. 260

Trinidad sandstone...................... 100士

Pierre shale:

Transitional zone.

Shale.

$435 \pm$

In the western slope of the hogback, south of Rito Leandro, three of the thickest beds of coal in the Vermejo formation have been opened. No measurement of the lowest could be obtained, but the middle coal is 5 feet thick and the highest is 8 feet 6 inches thick. Still farther south the surface at the outcrop of the Vermejo is badly covered with:brush, and no details of the rocks were obtained. The hogback formed by the basal conglomerate of the Raton formation is traceable for several miles, but it seems to disappear farther south and was not recognized as a separate topographic feature west of Castle Rock Park.

LOCALITY 127.

About half a mile north of Vermejo Gap the rocks are well exposed in a shallow ravine at locality 127 , about $1 \frac{1}{2}$ miles north of locality 126. The typical Pierre shale is exposed at the foot of the slope but was not examined. The zone of sandy transitional beds between the Pierre and the Trinidad sandstone was present, and the thickness of the sandstone was estimated at 100 feet.

The Vermejo formation is here about 272 feet thick as compared with 260 feet $1 \frac{1}{2}$ miles farther south and 374 feet at locality 123, 6 miles to the southeast. It consists of coal, shale, and coarse-grained, friable, light-colored sandstone, similar to that found in many places in this formation throughout the Raton Mesa region. Nine beds of coal range in thickness from a few inches to 5 feet 6 inches. Three of them were opened several years ago in a number of places between this locality and Vermejo Gap. The record of these openings show that the coal in the lowest bed ranges in thickness from 1 foot 6 inches to 2 feet; that the 
middle bed averages about 2 feet 6 inches; and that the highest ranges from 3 feet 6 inches to 6 feet 5 inches. The highest sandstone in the Vermejo formation at this locality contains fossil plants, but no identifiable forms were collected.

The basal conglomerate of the Raton formation at this locality is the same as that at Vermejo Gap. (See Pl: XIX, B.) The section follows:

Section of rocks measured at locality 127 , in the western face of the hogback half a mile north of Vermejo Gap. [For graphic section see Pl. XVII, p..142.]

Raton formation:

Conglomerate, top eroded away (5239) $\therefore . . .6 .60+$

Unconformity.

Vermejo formation:

Sandstone, fossiliferous................. 8

Shale, yellow........................ 30

Shale, carbonaceous.................... 20

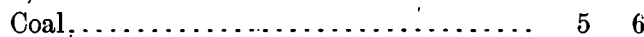

Shale, covered, yellow................. $45 \quad 0$

Sandstone, coarse grained, massive, gray..... 16 . 0

Shale.............................. 130

Coal, impure.................... 1. 0

Shale and sandstone................... $8 \quad 0$

Sandstone, friable, white.................. $17^{0}$

Shale, carbonaceous.................... 40

Shale, carbonaceous near the top............

Shale, carbonaceous....................

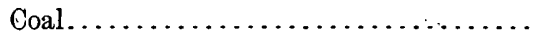

Shale.

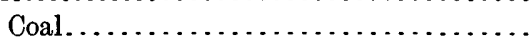

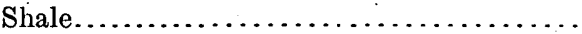

Coal..................................

Shale, sandy.......................

Sandstone, coarse grained, shaly near the

top, white........................ 32

Shale, carbonaceous near top...............

Coal. .........................

Shale, containing ironstone concretions...... 23

Sandstone, brown . . . . . . . . . . . . . . . .

Shale, yellow......................

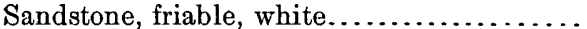

Coal...........................

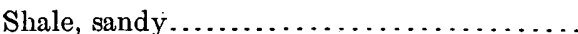

Shale, carbonaceous....................

Shale, sandy, brown..................

Coal........................... .

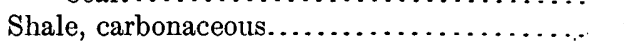

Trinidad sandstone..................... $100 \pm$

Pierre shale:

Transitional zone.

Shale

\section{LOCALITY 128}

A well-exposed section was measured in the west slope of the hogback at locality 128, about a mile north of the section at locality 127 , to which it is very.similar. The Vermejo formation, however, is somewhat thicker and contains fourteen instead of nine beds of coal 4 inches or more in thickness. The section follows:

Section of rocks measured in the hogback at locality 128, about $1 \frac{1}{2}$ miles north of Vermejo Gap.

[For graphic section see PI. XVII, p. 142.]

Raton formation:

Conglomerate with pebbles up to 5 inches in diameter (top eroded away)........... $75+$

Unconformity.

Vermejo formation:

Shale, not well exposed.................. $18 \quad 0$

Coal........................ 6

Shale............................ 20

Coal........................... 30

Shale............................ $30 \quad 0$

Coal......................... 20

Shale............................ 40

Sandstone, white.................... $18 \quad 0$

Shale, sandy ........................ $8 \quad 0$

Sandstone, white..................... 150

Shale.............................. 180

Coal............................. 10

Shale............................ 150

Coal.......................... 4

Shale............................

Coal............................ 12

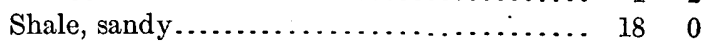

Coal........................... 6

Shale............................ $17 \quad 0$

Sandstone, friable, white, irregular bedding $20 \quad 0$ Coal............................ 146

Shale, sandy $\ldots \ldots \ldots \ldots \ldots \ldots \ldots \ldots \ldots \ldots, 8 \ldots \ldots$ Coal............................. 20

Shale........................... 150

Sandstone.......................... $10 \quad 0$

Shale, with thin beds of sandstone........... $6 \quad 6$

Sandstone, friable, white.................. $18 \quad 0$

Shale.............................. $4 \quad 0$ Coal.......................... $1{ }^{2}$

Shale............................. $4 \quad 0$

- Coal........................... 24

Shale and sandstone.................. $7 \quad 0$ Coal............................. $1{ }^{6}$

Shale and sandstone.................... 50 Coal............................. 110

Shale.............................. 4

Coal.......................... 18

Shale with bands of ironstone.............. $12 \quad 0$ $300 \quad 6$ 
Trinidad sandstone

75 in.

Pierre shale:

Transitional zone.

Shale.

\section{SAN FRANCISCO PASS.} LOCALITY 129.

For a considerable distance north of locality 128 the Vermejo formation is not well exposed, but at locality 129, about quarter of a mile south of the Colorado-New Mexico line the following section of the lower part of the Vermejo, of the Trinidad sandstone, and of the basal conglomerate of the Raton formation was measured:

. Section of rocks measured in the hogback at locality 129, onefourth mile south of the Colorado-New Mexico boundary. [For graphicsection see Pl. XVII; p. 142.]

Raton formation:

Conglomerate and coarse-grained sandstone, . containing pebbles of many kinds of rock including. well-rounded pebbles of coal from the size of small peas up to one-half inch Ft. in. in diameter....................... $157 \quad 0$

Unconformity.

Vermejo formation:

Sandstone and sandy shale not continuously exposed ......................... 285

Coal.......................... $3{ }^{2} 0$

Shale, drab, and sandy shale, not continuously exposed....................... 20

Coal ............................ 18

Shale, carbonaceous.................... in 0

Sandstone, shaly to massive, fossiliferous

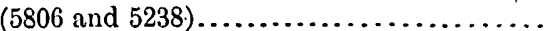

Shale, sandy $\ldots \ldots \ldots, \ldots \ldots \ldots \ldots \ldots \ldots$

Sandstone, shaly:........................

$335 \quad 8$

Trinidad sandstone....................... $75 \pm$

Pierre shale:

Transitional zone.

Shale.

$567 \pm$

The Pierre shale is exposed at the base of the slope, and the massive part of the overlying Trinidad sandstone was found to be ripproximately 75 feet thick. There is some doubt where the line separating the Trinidad sandstone from the Vermejo formation should bo drawn. In neighboring localities where coal and carbonaceous shale occur close to the undoubted Trinidad there is no such difficulty. But at this locality the lowest coal lies 26 feet above the massive part of the Trinidad sandstone and is separated from it by shaly sandstone in which, in a 6-foot sandstone 10 feot above the massive part of the Trinidad; shells belonging to the marine Cretaceous fauna were found. This fauna is sparingly represented in the Trinidad sandstone, and the shells, in the opinion. of T. W. Stanton, who identified them, indicate that this 6-foot bed belongs to the Trinidad. On the other hand, fossil plants that obviously belong to the Vermejo flora occur in the same rock with the shells.

Fossils found between undoubted Trinidad sandstone and the Vermejo formation, at locality 129.

Invertebrates (U. S. Geol. Survey fossil locality 5728):

Tellina scitula Meek and Hayden.

Panopaea? sp.

Several small undetermined shells.

Plants (U. S. Geol. Survey fossil localities 5806 and 5238): Hedera rotundifolia Knowlton.

Phyllites nanus Knowlton.

The association here of Trinidad and Vermejo fossils is in harmony with the facts already described (p: 49) and indicates that there is no sharp distinction between the two formations. They represent practically continuous deposition, the Trinidad representing the last stages of marine deposition and the Vermejo the accumulation of material on lowlying flats lately occupied by. the sea.

Only two beds of coal were found, probably because of imperfect exposures, for from the records of old prospects it appears that three coal beds have been opened in several-places near by. Between locality 128 (to the south) and a point a mile or more north of locality 129 , the lowest bed prospected ranges in thickness from 1 foot 6 inches to 6 feet, the middle bed from 1 foot to 4 feet, and the highest from 2 feet to 6 feet in thickness.

The basal conglomerate of the Raton formation forms a prominent cliff at this locality. It rests with uneven base on the underlying rocks and is obviously unconformable with them. It does not differ greatly in character from the conglomerate described at the localities farther south along the hogback, except that it is not quite so coarse. Probably its most significant feature, showing its relation to the underlying Vermejo, is its content of small pebbles of coal. Several of these were well rounded like pebbles of other kinds of rock in the same bed.

LOCALITY 130 .

North of the Colorado State line the slopes are forested, and good exposures of the rocks are rare. The eastward dip of the rocks grad- 
ually decreases toward the north, and the basal conglomerate of the Raton formation does not form the crest of a ridge, for the overlying rocks are not eroded away as they, are farther south. Nevertheless the slope which to the south forms the western face of the hogback continues and the Vermejo formation outcrops in it, as do also both the underlying and the overlying rocks. A fairly well exposed section was found in a gulch about $1 \frac{1}{2}$ miles north of the State line at locality 130, 2 miles north of locality 129 .

The top of the Pierre shale and the Trinidad - sandstone are exposed, and the thickness of the Trinidad estimated at 100 feet. The Vermejo dips $25^{\circ} \mathrm{E}$. and is exposed along the winding course of the gulch. It appears to be somewhat thicker than it is farther south. Four beds of coal were found in it, but doubtless there are other coals in the wide intervals of poorly exposed rock. The principal coal beds of the Vermejo have been opened along the outcrop in this vicinity, but few of the old prospects were accessible at the time of investigation and the number and character of the coals are best indicated in the vicinity of the Tercio mines, about 6 miles farther east.

The basal conglomerate of the Raton formation is not so coarse at locality $130^{\circ}$ as it is farther south, but otherwise it does not differ in any notable way. It is coarsest at the base, where it contains pebbles irregularly distributed through a matrix of coarse-grained arkose sandstone. Above this basal part lies 200 feet of more or less conglomeratic sandstone or grit, overlain by a considerable, though unmeasured, thickness of grits and coarse-grained sandstones. The section follows:

Section of rocks measured at locality 130, about 4 miles southwest of Torres, Colo. [For graphic section see Pl. XVII, p. 142.]

Raton formation: Conglomerate...................... $200 \quad 0$

Unconformity.

Vermejo formation:

Shale...

Sandstone

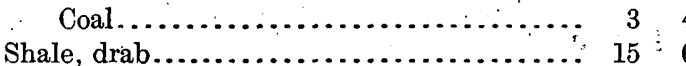

Sandstone, massive, hard, coarse grained, white.............................

Sandstone, thin bedded, yellow............ 12

Sandstone, friable ......................

Shale and friable sandstone, not well exposed ............................. 115
Vermejo formation-Continued. Ft. in. Shale, sandy, not continuously exposed.... $32 \quad 0$ Coal.............................. 10

Shale, sandy........................ $10 \quad 0$ Coal.......................... $2+$

Sandstone and shale, not continuously ex-

posed........................... $74 \quad 0$

Shale............................. 20

Coal........................... 50

Covered at base, shale at top............ $6 \quad 6 \quad 0$ $316+$

Trinidad sandstone..................... $100 \pm$

Pierre shale:

Transitional zone.

Shale.

\section{$616 \pm$}

From this locality northward to Torres, a distance of about 4 miles, the formations described in the last section continue without notable change, but were not examined in detail. West of Torres, in the canyon of South Fork of Purgatoire River, a section was measured (see p.41) which included the rocks from the ancient crystallines of the mountains to those of the Cretaceous.

\section{TERCIO PARK.}

\section{GENERAL FEATURES.}

Tercio Park is an opening similar to Vermejo Park, except that it is not entirely inclosed by the coal measures. It was formed by the erosion of the younger rocks from the crest of a dome and by the exposure of the easily eroded Pierre shale in the center. The crest of the inclosing ridge consists of coarse-grained conglomeratic sandstone of the Raton, in which occur a few layers of sandy shale. The pebbles are largest and most numerous near the base, where in some places they occur in pockets and lenticular masses and in other places are somewhat generally disseminated through a considerable thickness of sandstone. The higher parts are less conglomeratic, but pebbles are common through a thickness of nearly 300 feet. The usual range of pebbles of igneous and metamorphic rocks is present and includes several of special significance. One pebble is of petrified wood; which was obviously silicified before the time of erosion during which the pebble was formed. It may have come from the Vermejo formation or from the Dakota sandstone, both of which contain petrified wood. Several pebbles consist of gray quartzitic sandstone and conglomerate, apparently derived from sandstone of the Purgatoire formation, which is now upturned in a prominent hogback to the 
west. One pebble (found at Tercio) consists of a horn cornl such as have been found in the limestones of the Carboniferous in the mountains to the west. Many of the chert pebbles contain impressions of crinoid stems and of undetermined species of shells. Apparently these cherts also came from the Carboniferous beds, for no limestone that could furnish them is known to occur in the overlying red beds. One pebble was worn from a crystal of feldspar at least an inch in diameter. The slightly decomposed condition of this and other feldspar pebbles seems to indicate that they were derived directly from the crystalline rocks to the west.

\section{CUATRo.}

LOCALITY 130.

No detrils were obtained along the outcrop between locality 130 and Cuatro, 4 miles distant. At Cuatro the dip is opposite that. at locality 130 and the syncline thus formed plunges southward. The coals in the lower part of the Vermejo formation have been mined at Cuntro. The following succession of beds is described by Richardson: ${ }^{225}$

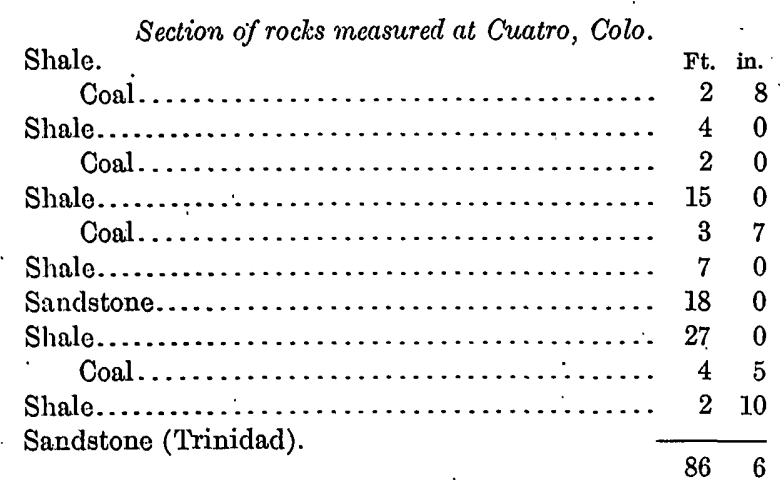

A few fossil plants belonging to the Vermejo flora were found in the lower 50 feet of the coal-bearing rocks (U. S. Geol. Survey fossil locality 5805). They were Ficus praetrinervis Knowlton, Pteris? sp., Sequoia obovata Knowlton, and a curious seedling that has not been named.

\section{LOCALITY 131}

At locality 131, $1 \frac{1}{2}$ miles south of Tercio and about 6 miles east of locality 130 , on the eastern limb of the so-called Tercio anticline, the strata dip about $40^{\circ} \mathrm{E}$. The thicknesses of the Trinidad sandstone and of the conglomerate at the base of the Raton formation were estimated at this locality, but the thickness of the Vermejo formation was measured, and was found to be about 245 feet (about 71 feet less than at locality 130). Six beds of coal varying in thickness from 1 to 8 feet were found, and others doubtless occur in the unexposed intervals near the base, for in the Tercio section beds of coal of considerable thickness occur at horizons that fall within these unexposed intervals. The section follows:

Section of rocks measured at locality.191, at an ahandoned mine about $1 \frac{1}{2}$ miles south of Tercio, Colo.

$$
\text { [For graphic section see Pl. XVII, p. 142.] }
$$

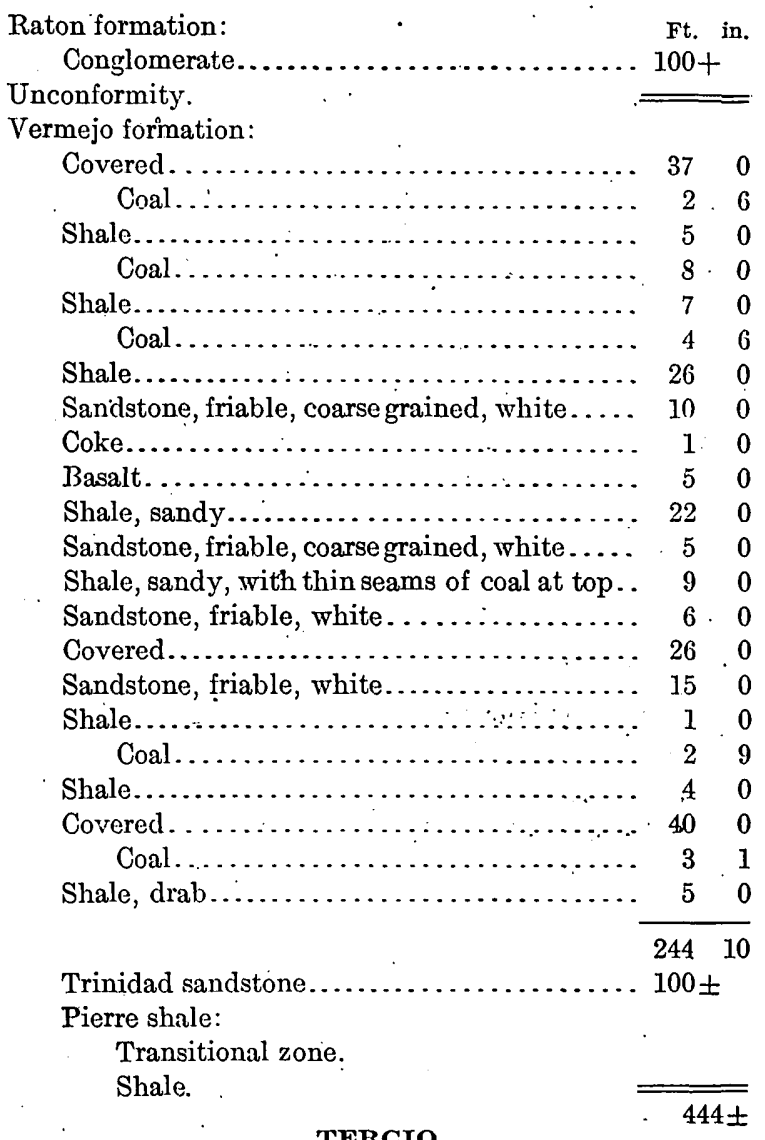

TERCIO.

LOCALITY 132.

At Tercio; $1 \frac{1}{2}$ miles north of locality 131 , the South Fork of Purgatoire River has eroded a narrow canyon through the upturned sedimentary rocks and has exposed the formations from the Pierre shale to the Poison Canyon beds: The beds are tilted steeply toward the east and strike N. $21^{\circ} \mathrm{W}$. The dip of the rocks represented by the lower part of the section is $55^{\circ}$, but farther downstream, where the upper part of the section was. measured, the dip is onty $10^{\circ}$. A farorable opportunity , was afforded here for measuring a section. The Raton 
formation is thicker than it is at many of the localities where sections were measured, probably because it was eroded less deeply before the deposition of the Poison Canyon formation. Inasmuch as the section is the most complete one measured in the western part of the Raton Mesa region, care was taken to extend it to include the base of the Poison Canyon formation. The difficulty met with elsewhere in distinguishing between the Raton and Poison Canyon formations was found here. The line of separation in the following section is drawn at the base of the higher conglomerates. The lower part of the section, showing the relations of the Vermejo formation to that of neighboring localities, has been plotted in Plate XVII (p. 142), and the complete section in Plate $\mathrm{XV}$ (p. 132).

Section of rocks measured at locality 192, on South Fork of Purgatoire River, Tercio, Colo.

[For graphic section see Pls. XV, p. 132, and XVII, p. 142.]

Poison Canyon formation:

Sandstone, coarse grained, conglomeratic, yellowish white.

Covered.

Conglomerate. rather coarse grained, but thin

bedded ....................................... up to three-fourths inch in diameter. . . . . .

Raton formation:

Sandstone, thin bedded, yellow............

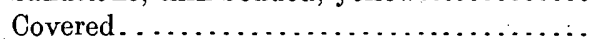

Sandstone, thin bedded, yellow. .........

Covered. . . . . . . ...............

Sandstone, massive, yellow............

Covered. . . . . . . . . . . . . . . . . . .

Sandstone, coarse grained, cliff. making, yellow

Covered. . . . . . . . . . . . . . . . . .

Sandstone, massive, shaly at base, yellow...

Covered. .......................

Shale, drab.

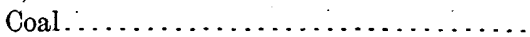

Sandstone, thin bedded, yellow...........

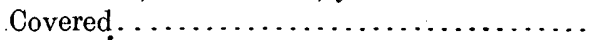

Sandstone, massive, yellowish red........

Covered.

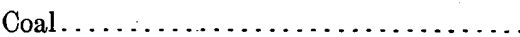

Shale, sandy, yellow . . . . . . . . . . .

Sandstone, massive, yellow. Coal.

Shale.

Sandstone, massive, yellow

Shale............. Coal (streak)

Sandstone, massive.
Raton formation-Continued.

. 30

Coal.................... $2{ }_{6}$

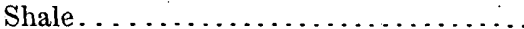

Coal $\ldots \ldots \ldots \ldots \ldots \ldots \ldots \ldots \ldots \ldots \ldots \ldots \ldots, 1{ }_{1}$

Shale........................ 1.0

Coal ................ $\quad 8$

Shale, drab.................... 30

Sandstone, thin bedded, yellow, and sandy shale..................... $6 \quad 0$

Sandstone, coarse grained, weathers to yellowish red.................... 60

Shale and shaly sandstone............. 100 1

- Sandstone, massive, fossiliferous, $\therefore$ yellowish white. .................... 610

Covered ...................... $56 \quad 0$

Sandstone, massive, coarse grained, yellow 90

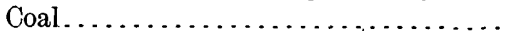

Shale, carbonaceous, black..........

Coal. ........................

Shale, carbonaceous, black..........

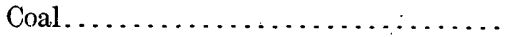

Shale, sandy; yellow................

Covered.......................

Sandstone, massive, white............

Shale, drab....................

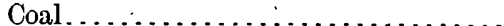

Shale, drab.................... Coal.

Sandstone, shaly, yellow..............

Sandstone, hard, massive, white, fossiliferous (5802)....................

Covered .......................

Sandstone, hard, massive, yellow to gray.

Shale at base, covered above..........

Sandstone, fine grained, hard, massive, yellow to gray, fossiliferous (5803).....

Shale, sandy, yellow . . . . . . . . . . . .

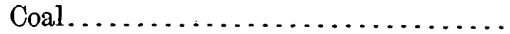

Shale, drab, sandy................

Sandstone, hard, massive, white........

Covered

Sandstone, thin bedded, gray to yellow,

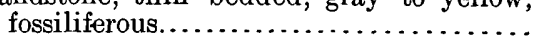

Covered ..........................

Conglomerate; a very coarse grained sandstone, hard and white, with numerous shale partings; contains many pockets of pebbles up to 2 inches in diameter...

Unconformity.

\begin{tabular}{rr}
2920 \\
\hline 1,6564
\end{tabular}

Vermejo formation:

Sandstone, thin bedded, yellow at top, covered below . . . . . . . . . . . . . . . . .

Shale, carbonaceous, black............ Coal with 2-inch parting of bone.....

Covered. Coal. .

Shale, drab. Coal.

Sandstone, thin shale. Coal.

$\begin{array}{rr}25 & 0 \\ 13 & 0 \\ 3 & 5 \\ 32 & 0 \\ 5 & 0 \\ 4 & 0 \\ 1 & 0 \\ . & \\ 48 & 0 \\ 2 & 0\end{array}$


Vermejo formation-Continued.

Shale, sandy.......................

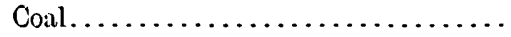

Shale, sandy $\ldots \ldots \ldots \ldots \ldots \ldots \ldots \ldots . . .6$.

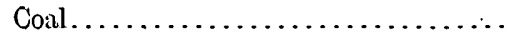

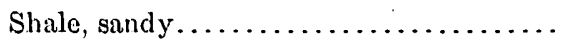

Coal, thickness not determined.

Sandstone, soft, friable, white...........

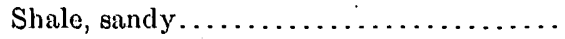

Coal, with three partings of shale and bone...........................

shale............................

Coal, thin.

Trinidad san
Pierre shale:

Transitional zone.

Shale.

$2,189 \pm$

The exact line of separation between the Trinidad sandstone and the Vermejo formation could not be determined where the section was measured, but the maximum possible error is only a few feet. The details of the Vermejo were obtained in a railway cut in the south wall of the canyon, in which an interval of 25 feet appears between the highest carbonaceous shale and the bottom of the basal conglomerate of the Raton formation. The rocks at the base of this interval were not seen, but near the top they consist of thin-bedded sandstone, upon which the conglomerate rests with uneven base. Obviously, at this place the line of separation between the Vermejo and the Raton should be drawn at the top of this sandstone. On the other hand, in the north wall of the canyon, the highest coal has been opened in a mine and is separated from the overlying conglomerate by only a few feet of shale. This coal is clearly the 3-foot 5-inch coal bed of the foregoing section, and the carbonaceous shale is apparently the same as the shale shown in the section above this coal; but the 25foot sandstone found at the top of the Vermejo in the south wall does not occur in the north wall, where the conglomerate lies unconformably upon the shale. The irregularity at the top of the Vermejo thus indicated seems to harmonize with the variation in thickness noted elsewhere. It is 316 feet thick at locality 130 , and thins to 244 feet at locality 131 and to about 230 feet at Tercio (or to 205 feet if the top of the Vermejo formation is drawn at the top of the 13-foot shale in the north wall of the canyon).
The Vermejo formation at this locality yielded a few poorly preserved fossil leaves of the species Myrica torreyi Lesquereux, Phyilites populoides Knowlton, and Sequoia obovata? Knowlton (U. S. Geol. Survey fossil locality 5804). Some of them were found about midway of the formation in the south wall of the canyon and others were'found on the mine dump in rock that came from the opening on the highest coal bed north of the canyon.

The basal conglomerate of the Raton formation is very prominent around Tercio Park, attaining a thickness of $29 \dot{2}$ feet at Tercio. In the eastern part of the field, about 30 miles distant, this great thickness seems to be represented in some places by only a few feet of rock and in other places not at all.

The section resembles somewhat closely those measured in other parts of the coal field. The rocks above the basal conglomerate consist of fine-grained sandstones separated by shale overlain by a zone of poorly exposed, shaly, coal-bearing rocks above which there is a considerable thickness of cliff-making sandstone comparable with the "barren series" of the eastern portions of the field, and a still higher zone of shale and relatively soft sandstone in which occur several beds of coal that correspond in a general way with the upper coals in other parts of the Raton Mesa region. .In other words, if the basal conglomerate be disregarded the character, succession, and thickness of the Raton beds correspond somewhat closely with those found throughout the Raton Mesa region.

Fossil plants belonging to the Raton flora were found at the several horizons indicated in the section but were not found sufficiently well preserved to yield large collections.

Fossil plants collected about 200 feet above the basal conglomerate of the Raton formation, near Tercio, Colo. [U. S. Geol. Survey fossil locality 5803.] Dryopteris? cladophleboides Knowlton. Magnolia angustifolia Newberry. Magnolia magnifolia Knowlton. Oreodoxites plicatus Lesquereux.

Fossil plants collected about 400 feet above the basal conglomerate of the Raton formation, near Tercio, Colo. [U. S. Geol. Survey fossil locality 5802 .]

Juglans rugosa Lesquereux. Platanus aceroides latifolia Knowlton. Platanus guillelmae Göppert.

Platanus guillelmae heerii Knowlton. 


\section{CORNELL.}

LOCALITY 133.

From Tercio northwestward to Cornell, a distance of about $2 \frac{1}{2}$ miles, the formations appear to be relatively regular in thickness and character, but the Vermejo is not well exposed. However, near Cornell a good exposure was found at locality 133 , where a section was measured. The strata dip $5^{\circ}$ NE. (strike N. $60^{\circ}$ W.) and outcrop in the steep wall of Tercio Park. The general aspect of the rocks and a cross section are shown in Plate XIX, $B$ (p. 147). The view is northward, nearly at right angles to the strike, for which reason the strata in the section appear to be nearly horizontal. The Pierre shale is well exposed in the lower part of the slope, and the Trinidad sandstone is typically developed. Its thickness was estimated at 100 feet. The secton follows:

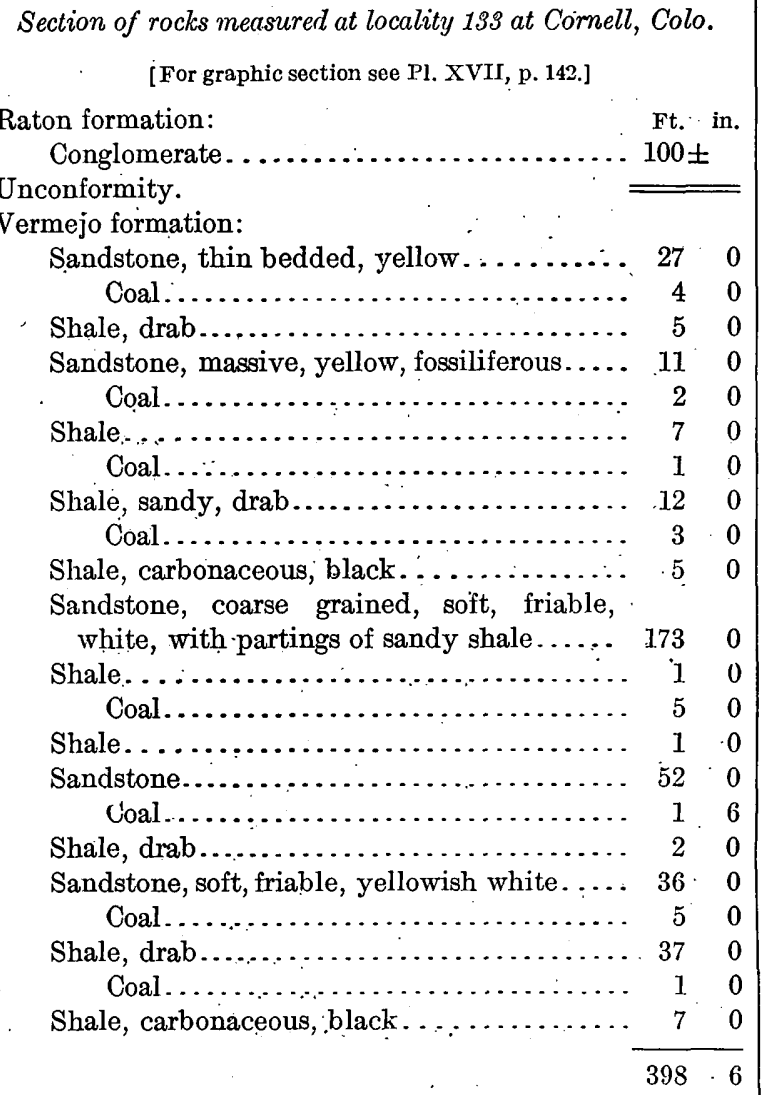

Trinidad, sandstone. . .................... $100 \pm$

Pierre shale:

Transitional zone.

Shale.
Richardson ${ }^{225}$ publishes a section measured near the Cornell mine and states that the interval between the top of the Trinidad sandstone and the base of the conglomerate is about 200 feet. His measurement seems to represent the vertical distance, as it is nearly the same as the vertical distance obtained by the writer's assistant, who measured the section. However, when this vertical distance is corrected for the dip and strike of the rocks, the slope of the hill, and the direction in which the measurements were made, the base of the conglomerate is found to be stratigraphically nearly 400 feet above the Trinidad.

Eight beds of coal, ranging from 1 foot to 5 feet in thickness, were found in the Vermejo formation near Cornell. These are separated into an upper group and a lower group by coarse-grained sandstones in which are thin layers of shale. These sandstones seem to be somewhat local in occurrence for nothing very closely resembling them was found at Tercio. The lower coal group (see Pl. XVII, p. 142) is probably to be correlated with the Vermejo coals at Tercio; but the upper group may not be represented at Tercio at all, the unconformable relation between the Vermejo and Raton formations suggesting that it may have been eroded away previous to the deposition of the Raton formation.

About 100 feet of the conglomerate was measured, but some unknown thickness of it has been eroded away at this locality. It does not differ materially in character from the conglomerate described at Tercio and other places along the western outcrop of the Raton Mesa region. The younger beds of the Raton formation outcrop immediately east of this locality, but no observations were made on them.

\section{STONEWALL AREA.}

For the purposes of this paper the Stonewall area includes the localities described between Tercio Park and Spanish Peaks. The name is derived from the ridge formed by the Dakota sandstone, which is upturned to a nearly vertical position and which, together with the underlying sandstone of Comanche age (Purgatoire formation), forms a wall-like crest. (See Pl. XX.) East of this ridge throughout. 


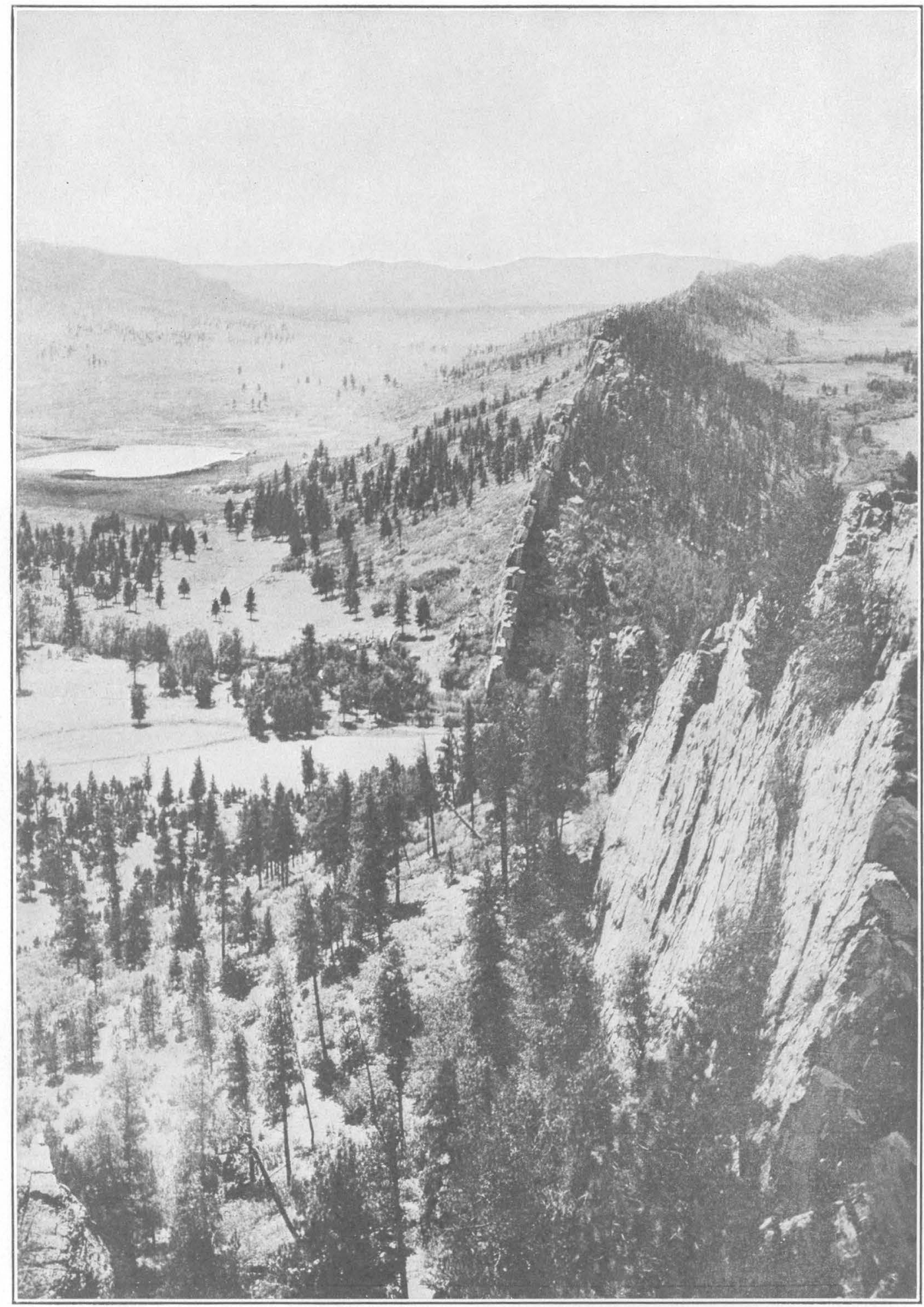

THE STONEWALL ON PURGATOIRE RIVER LOOKING SOUTH.

The valley to the right of the ridge is eroded in the soft shale of the Morrison formation and that to the left in the soft marine Cretaceous shale. The hills in the distance mark the western margin of the coal measures. 
the area a broad structural valley has been worn in the soft Cretaceous shales, east of which the basal conglomerate of the Raton formation rises in a prominent hogback.

\section{NORTH OF CORNELL.}

LOCALITY 134.

Three miles north of Cornell, at locality 134, an attempt was made to measure the thickness of the Vermejo formation. The rocks near the base are not well exposed, but a coal bed, supposed to be the lowest in this formation, was found. Above this bed the rocks are poorly exposed and the base of the conglomerate could not be definitely located. However, the top of this conglomerate was plainly discernible beneath a considerable thickness of the yellowish sandstone characteristic of the Raton formation, and it seemed desirable to fix its position by measuring the section.

Section of rocks measured at locality 192, in hogback, about 2 miles south of Stonewall, Colo.

[ [For graphic section see Pl. XVII, p. 142.]

Sandstone gray to yellow, thin bedded, fossil- Ft. in.

iferous.......................... $87 \quad 0$

Conglomerate at top, covered below; largest

pebbles 3 inclies in diameter............ 7150

Sandstone, friable........................ ${ }^{8} 8$

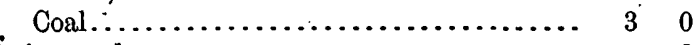

shale, sandy..............................

Coal, base not exposed...................

STONEWALT GAP.

LOCALITY 135.

At locality 135, about 2 miles north of locality 134, the Middle Fork of Purgatoire River has eroded a passage known as Stonewall Gap through the hogback formed by the basal conglomerate of the Raton formation. . The Trinidad sandstone was recognized in this gap, but it is not well exposed. The Vermejo formation is so badly obscured with brush and rock débris that no attempt was made to examine it in detail, though its upper and lower limits were found and its thickness determined as about 318 feet. The basal conglomerate of the Raton formation makes a prominent ridge. The conglomerate is very coarse and massive near the base but contains shaly sandstone at several horizons. It does not differ materially in character from the conglomerate as described from other localities along the western margin of the coal fields. The section is as follows:
Section of rocks measured at locality 135 , on Middle Fork of Purgatoire River at Stonewall, Colo.

[For graphic section see Pl. XVII, p: 142.]

Raton formation:

Conglomerate, with beds of shaly thin-bedded fossiliferous sandstone; pebbles up to 2 inches in diameter. :...................... $275+$ Unconformity.

Vermejo formation:

Covered, coal near base.................... 318

Trinidad sandstone.......................... 100

- $\overline{693+}$

A few fossil plants were collected from the upper part of the Raton formation east of Stonewall (U. S. Geol. Survey fossil localities 5106 and 5114). Richardson's party found Magnolia magnifolia Knowlton, Magnolia lèsleyana Lesquereux, and Sabat? ungeri (Lesquereux) Knowlton.

Farther east, in Wet Canyon, about 4 miles north of Weston, the present writer collected the following species near the top of the Raton formation at two horizons, 50 and 100 feet respectively below a conglomeratic sandstone that seems to be the base of the Poison Canyon formation. However, fossil plants above this conglomerate could not be distinguished in the field from those below. They are as follows:

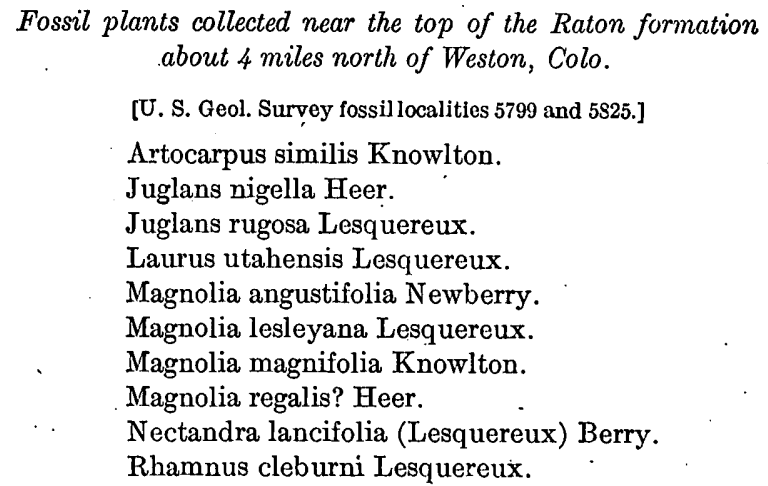

NORTH FORK OF PURGATOIRE RIVER.

\section{IOCALITY 136}

From Stonewall Gap northward to North Fork of Purgatoire River the formations were seen at their outcrop only from a distance. However, they appear to continue without notable variation. At locality 136; about half a mile north of North Fork, a section of the rocks including the Trinidad sandstone, the Vermejo formation, and some of the Raton. formation was measured as follows. Coal was found near the base and doubtless occurs in 
other beds, but poor exposures prevented them from being definitely located.

Section of rocks measured at locality 196 on North Fork of Purgatoire River, about 5 miles north of Stonewall, Colo.

[For graphic section see Pl. XVII, p. 142.]

Raton formation:

Sandstone, white, coarse grained......... $50 \quad$ Ft. 0

Sandstone, yellow, thin bedded.......... 86

Conglomerate.................... 550

Sandstone, gray, shaly, fossiliferous. . . . . 12

Conglomerate.................... 67 0

Sandstone, yellowish, fine grained....... $27 \quad 0$

Conglomerate, pebbles up to 2 inches in diameter..................... 1650

Unconformity

Vermejo formation:

Covered................. $52 \quad 0$

Sandstone, yellow to gray, massive, fossiliferous, with partings of shaly sandstone ......

Sandstone, yellow, shaly, concretionary..... 55

Shale and sandstone, not continuously exposed, coal near the top, fossiliferous..... 130

Shale and thin-bedded yellow sandstone.... 43

Shale, black to brownish red ........... 5

Coal.

Shale

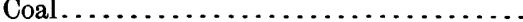

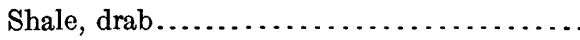

Trinidad sandstone, containing Halymenites ma-

jor Lesquereux.......................

Pierre shale:

Transitional zone.

Shale.

No fossil plants were collected from the Vermejo at this locality, although their presence was noted at several horizons. But Ficus leei Knowlton and Sabal montana Knowlton were found in the roof of an old prospect entry (U. S. Geol. Survey fossil locality 5800) in a coal bed about the middle of the Vermejo formation, south of North Fork. Good specimens of Magnolia magnifolia Knowlton were found in slide rock (U. S. Geol. Survey fossil locality 5801) that evidently came from the Raton formation north of the river.

The Vermejo formation and the basal conglomerate of the Raton were observed for a considerable distance along the outcrop north of North Fork, but no further details were obtained by the writer south of Spanish Peaks. However, Richardson ${ }^{225}$ shows that the coal beds are traceable for about 7 miles north of locality 136. His party collected several fossil plants; most of which belong to the Raton flora, from slide rock about 2 miles south of Dean' (U. S. Geol. Survey fossil locality 5113). They are Cinnamomum mississippiensis? Lesquereux, Ficus praetrinervis Knowlton, Palmocarpon palmarum Lesquereux, and Rhamnus cleburni Lesquereux. Still farther north for about 7 miles west of Spanish Peaks the Vermejo and associated formations were not seen. The sedimentary formations have doubtless been disturbed by intrusions of igneous rock and the surface is covered with rock débris from the Spanish Peaks and is more or less forested.

\section{IA VETA DISTRICT.}

GENERAL FEATURES.

The sedimentary rocks north of Spanish Peaks near the western outcrop of the coal beds are isolated from those of all other parts of the field. Except at the northern end of

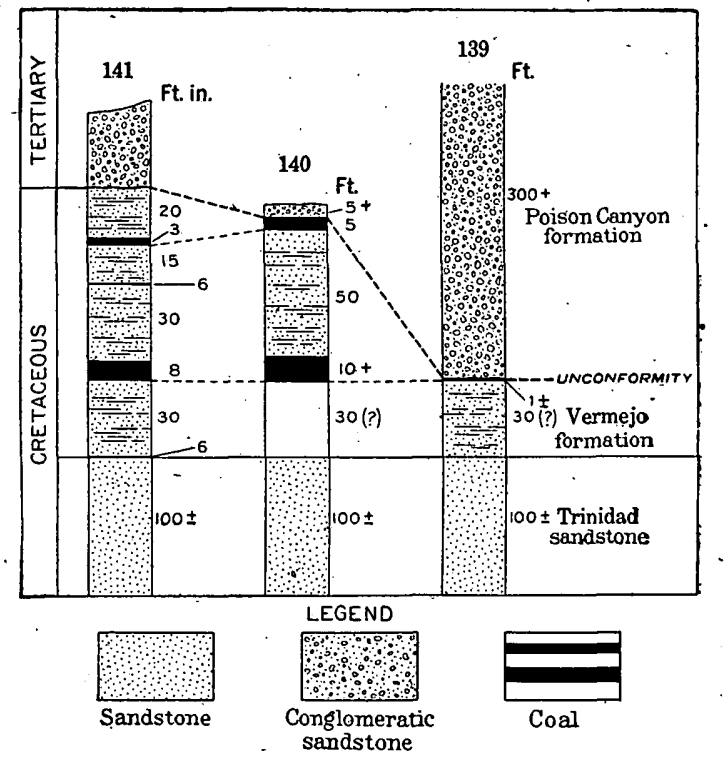

FIGURE 9.-Columnar sections measured in the La Veta district, Colo

the district, where a minor fold is developed, they are upturned here as they are south of Spanish Peaks, and in general they dip northeast. Apparently the coals were once continuous with those just described farther south, but their continuity was broken by the igneous intrusions of the Spanish Peaks. Also there is no reason to doubt that the coals are the same as those mined in the vicinity of Walsenburg and that they extend eastward under cover of the younger rocks and reappear at the eastern margin of the Trinidad field. The Pierre shale and the Trinidad sandstone 
occur in this district in characteristic development, and although there is little doubt that the coal beds belong to the Vermejo formation, some doubt exists as to the relation of these rocks to those overlying them. It is difficult in some places to distinguish between the Vermejo and the Raton where the two formations occur together, and possibly both will yet be found in this district, though no convincing evidence of the presence of the Raton has been obtained. The Poison Canyon formation seems to rest unconformably on the Vermejo. (See fig. 9.)

\section{CUCEARA RIVER.}

. LOCALITY 137.

On South Fork of Cuchara River (locality 137), about 7 miles southwest of La Veta, at the point where the outcrop of the the coal beds crosses the river, the sedimentary rocks dip $43^{\circ} \mathrm{E}$. The Trinidad sandstone was recognized and its thickness estimated to be about 100 feet. Two beds of coal observed above this sandstone obviously belong in the Vermejo formation, but their stratigraphic positions within this formation could not be definitely determined, though they are believed to be the same as the coals farther north that occur about 30 feet and 80 feet, respectively, above the Trinidad.

Conglomeratic sandstone. occurs a few feet stratigraphically above the higher coal, but it does not resemble the basal conglomerate of the Raton formation as developed to the south beyond Spanish Peaks or to the east near Walsenburg. It is lithologically similar to the typical beds of the Poison Canyon formation near La Veta and seems to be their westward extension.

\section{LOCALITY 138.}

An unsuccessful attempt was made to measure a section of the rocks exposed on Middle Fork of Cuchara River, about 4 miles north of locality 137 . The Trinidad sandstone was recognized, and two coal beds (probably the same as those noted on the South Fork) were found, but the rocks in which they occur are not well exposed and could not be completely mensured.

In the rock above the upper coal bed (U. S. Geol. Survey fossil locality 5675) a few fossil plants of Ficus praetrinervis Knowlton were found. The base of the conglomeratic sandstone described on the Cuchara farther south lies about 15 feet stratigraphically above this coal bed and seems to be traceable continuously eastward to the undoubted Poison Canyon beds in the vicinity of La Veta.

IOCALITY 139.

The next point toward the north at which the rocks were examined in detail is on the North Fork of the Cuchara, about 4 miles north of locality 138 and 6 miles northwest of La Veta. The rocks have been folded, and a small body of the coal measures has been preserved from erosion in an unsymmetrical syncline lying west of the main mass of the formation. The coal beds described on South and Middle forks of the Cuchara were traced nortbward to North Fork, and about a mile south of the river one of these beds (but which one was not determined) contains 4 feet 8 inches of coal separated into two benches by a shale parting, ${ }^{225 \mathrm{c}}$ but north of the North Fork of the Cuchara very little coal has been found at the western outcrop of the main body of the coal measures, although careful search has been made for it by the mining company operating in this district. Several old prospect openings were examined, but in only one, just north of the river at locality 139 , was coal found. In this one an entry has been driven about 50 feet on the coal bed, which varies in thickness from an inch or less to about 1 foot. A coarse-grained, white, conglomeratic sandstone rests with uneven base upon the coal. About 300 feet of this conglomerate is exposed in the hillside immediately above the coal bed, and in the walls of North Fork of Cuchara River an enormous thickness of it is visible. This same conglomeratic sandstone obviously continues uninterruptedly eastward to La Veta and is a part of the Poison Canyon formation. Apparently, then, in this prospect entry the Poison Canyon formation may be seen resting on the Vermejo. The coal bed is the lowest one found in the coal-bearing rocks and is supposed to be the coal that is worked in Oakdale mine, about a mile to the northwest. The typical Pierre shale occurs at this locality, ard also the Trinidad sandstone with its characteristic Halymenites major Lesquereux. 


\section{LOCALITY 140.}

At the Oakdale mine, about a mile northwest of locality 139 , coal is mined from a bed which, according to the mine superintendent, is $10^{\prime}$ to 14 feet thick. The base of the coal measures is not exposed near the mouth of the mine, and certain faults known to exist near. this locality render doubtful the tracing of the coal bed to a locality where its horizon can be determined. Richardson ${ }^{225}$ states that the bed is about 30 feet above the top of the Trinidad sandstone. A higher coal bed overlain by conglomerate was penetrated in a diamonddrill hole about one-fourth mile northwest of the mouth of the mine. The drill record was not

\section{LOCALITY 141.}

South and west of the Oakdale mine the coal beds were observed at the outcrop at short intervals around the southern extremity of the isolated body of coal-bearing rocks to the Occidental mine (locality 141), where the beds are practically vertical. (See fig. 10.) The Pierre shale is exposed to the west and the. Trinidad sandstone with its characteristic Halymenites forms a ridge that runs parallel with the outcrop of the coal: East of this ridge the coalbearing rocks and the overlying conglomerate found at the last two localities and described as probably belonging to the Poison Canyon are well exposed. At this mine a tunnel,

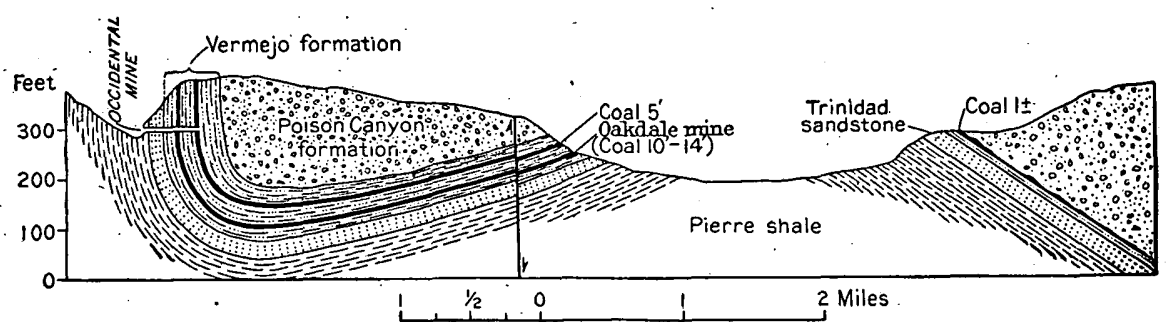

FraURE 10.-Sketch section showing the unconformable relations between the Vermejo and Poison Canyon formations near Oakdale, Colo.

seen by the writer, but the man who superintended the work furnished the following section from memory:

Record of a drill prospect near Oakdale mine.

Conglomerate. ......................... $5+$

Coal, coked......................... 5

Sandstone, white, granular, shaly in some places... . 50

Coal (the bed worked in Oakdale mine) . . . . $10+$

The lower bed of coal is supposed to be the same as the thin bed described at locality 139, on which the conglomeratic sandstone (obviously the same as the conglomerate of the drill record) rests unconformably. If this correlation is correct, the upper coal and the sandstone between it and the lower coal was eroded away at locality 139 previous to the deposition of the conglomerate. (See fig. 9.)

A few fossil leaves belonging to the Vermejo flora were found at this locality between the two beds of coal.

\section{Fossil plants collected at Oakdale, Colo.}

[U. S. Geol. Survey fossil locality 5672.]

Fious wardii Knowlton.

Sequoia obovata Knowlton. .

Sequoia reichenbachi (Geinitz) Heer.

Woodwardia crenata Knowlton. started west of the ridge formed by the Trinidad sandstone, was driven eastward through this sandstone and into the coal-bearing rocks, penetrating two beds of coal. The coal-bearing rocks penetrated by this tunnel were measured by D. E. Winchester. ${ }^{1}$ The thickness of the Trinidad sandstone was estimated by the writer, who also found the conglomerate to be 20 feet above the 3 -foot bed of coal about onefourth mile south of the mine. These facts are embodied in the following section:

Section of rocks measured at locality 141, Occidental mine, .northwest of La Veta, Colo.

Poison Canyon (?) formation:

Conglomerate.

Unconformity.

Vermejo formation: $\quad F t$. in.

Sandstone and shale $\ldots \ldots \ldots \ldots \ldots \ldots \ldots \ldots, 20,0 . \ldots \ldots$ Coal............................ 30

Sandstone, shaly..................... $15 \quad 0$ Coal........................... 6

Sandstone, shaly ...................... $30 \quad 0$ Coal........................... $8{ }^{2} 0$

Sandstone, shaly................... $30 \quad 0$ Coal $\overline{107 \quad 0}$ 
Trinidad sandstone:

Sandstone containing Halymenites major Pierre shale.

Lesquereux . Feet: $207+$

The conglomerate is upturned to practically the same degree as the underlying beds, but at this locality it is 20 feet above the conl bed (apparently the coal bed on which it rests at Oakdale, less than a mile to the northeast). This fact considered in connection with the obviously unconformable relations described from locality 139 . indicates that there is a slight angularity between the planes of bedding of the Vermejo and the Poison Canyon formations, but that there is no conspicuous overlap of the Poison. Canyon beds upon the older rocks at these localities $47019^{\circ}-17-11$ such as might be expected, and that there is no known reason for suspecting that the Raton beds, which do not appear at the outcrop, would be found under the Poison Canyon formation very close to the western margin of the La Veta district. However, this formation, which is nearly 800 feet thick near Walsenburg, about 12 miles to the east, must extend westward for a considerable distance under the Poison Canyon.

A few rather poorly preserved fossil plants, Myrica torreyi Lesquereux and Sparganium? sp., were collected near the Occidental mine. Some were found in the shale overlying the highest bed of coal and others in rock that came from the mine (U. S. Geol. Survey fössil localities 5673 and 5674). 


\section{CHAPTER 4.-CORRELATION OF FORMATIONS WITH THOSE OF OTHER REGIONS.}

CANON CITY FIELD.

PREVIOUS INVESTIGATIONS.

The Canon City coal field lies at the eastern base of the Rocky Mountains in south-central Colorado, about 40 miles from the Trinidad field. (See Pl. XXI.) The Canon City field is about 12 miles long and 6 miles wide, and the coal measures owe their preservation partly to the fact that they occupy the trough of a syncline. They are underlain by Pierre shale and by a massive sandstone which corresponds in stratigraphic position, lithologic character, and contained fossils to the Trinidad sandstone of the Raton Mesa region.

The occurrence of coal in this field was known as early as 1820 , when the field was visited by Maj. Long's party, ${ }^{3}$ members of which described the sandstone of the coal measures and stated that coal is generally found along the mountain front wherever the "gray sandstone" is met with. In 1865 Owen and Cox ${ }^{16}$ : referred to the coal. In 1869, Hayden, after examining the coal beds, ${ }^{29}$ referred them to the Tertiary. R. Neilson Clark ${ }^{27}$ followed in 1873 with a description of " the Tertiary coal beds of Canon City." About the same time Lesquereux, ${ }^{32}$ after examining some of the fossil plants from these coal beds, referred them to the Eocené.

In 1874 Cope, who had come to regard some of the western coals as Cretaceous, reviewed the evidence of age of the Canon City coal beds ${ }^{34}$ and attributed to Hayden the opinion that they are younger than the Cerrillos coal beds of central New Mexico, but that both are of Tertiary age. During the same year Stevenson ${ }^{50}$ announced that the coal. measures of the Canon City field contain marine fossils of Cretaceous age, and the following year he published a fuller description of the field..$^{58}$

In 1876 Hayden ${ }^{62}$ reviewed the evidence of age of the Lignitic group,. in which he included the Canon City coal beds, and argued that the group should be regarded as a transition from Cretaceous to Tertiary. A year later 162
Endlich ${ }^{73}$ followed Hayden in an argument that the coal beds at Canon City and others, then regarded as equivalent in age, should be regarded as neither Cretaceous nor Tertiary, but as an intermediate transitional group. In 1878 Lesquereux ${ }^{81}$ included the Canon City field in an outline of the geology of localities where fossil plants had been found, described the fossils, and reviewed the evidence of the age of the beds in an effort to support his contention that the coal measures were of Tertiary age. His effort was not successful, for Stevenson ${ }^{80}$ later referred to the Laramie the coal beds of the Raton Mesa region and correlated them with those of the Canon City field on the one hand and those of the Cerrillos field on the other. The reference of these beds to the Laramie (which was gradually becoming recognized as a Cretaceous formation) was not openly challenged (though Lesquereux and a few others never ac-knowledged them to be Cretaceous), nor was any serious objection to calling them Laramie raised for about 30 years. However, during most of this period a large collection of fossil plants, known as the Hadden collection, many of which are of species only recently described, had lain almost unnoticed in the National Museum, as well as another collection, made by Hadden for Newberry, in the museum of Columbia University; but although these fossils came from rocks supposed to be of Laramie age, they seemed not to belong to what had come to be known as the Laramie flora. The localities where they were found were in doubt, and furthermore the name Laramie seems to have become so firmly attached to the coal measures that little attention was given to the collections. In 1909 C. W. Washburne ${ }^{226}$ examined the coal beds of the Canon City field and followed the long-established custom of referring them to the Laramie. Through Washburne's efforts it was ascertained that the Hadden collection came-from near Coal Creek; and as the mines at Coal Creek, of which Mr. Hadden was superintendent, are in the lower part of the formation, it was naturally assumed that the fossil plants; which are of Montana age and are in- 


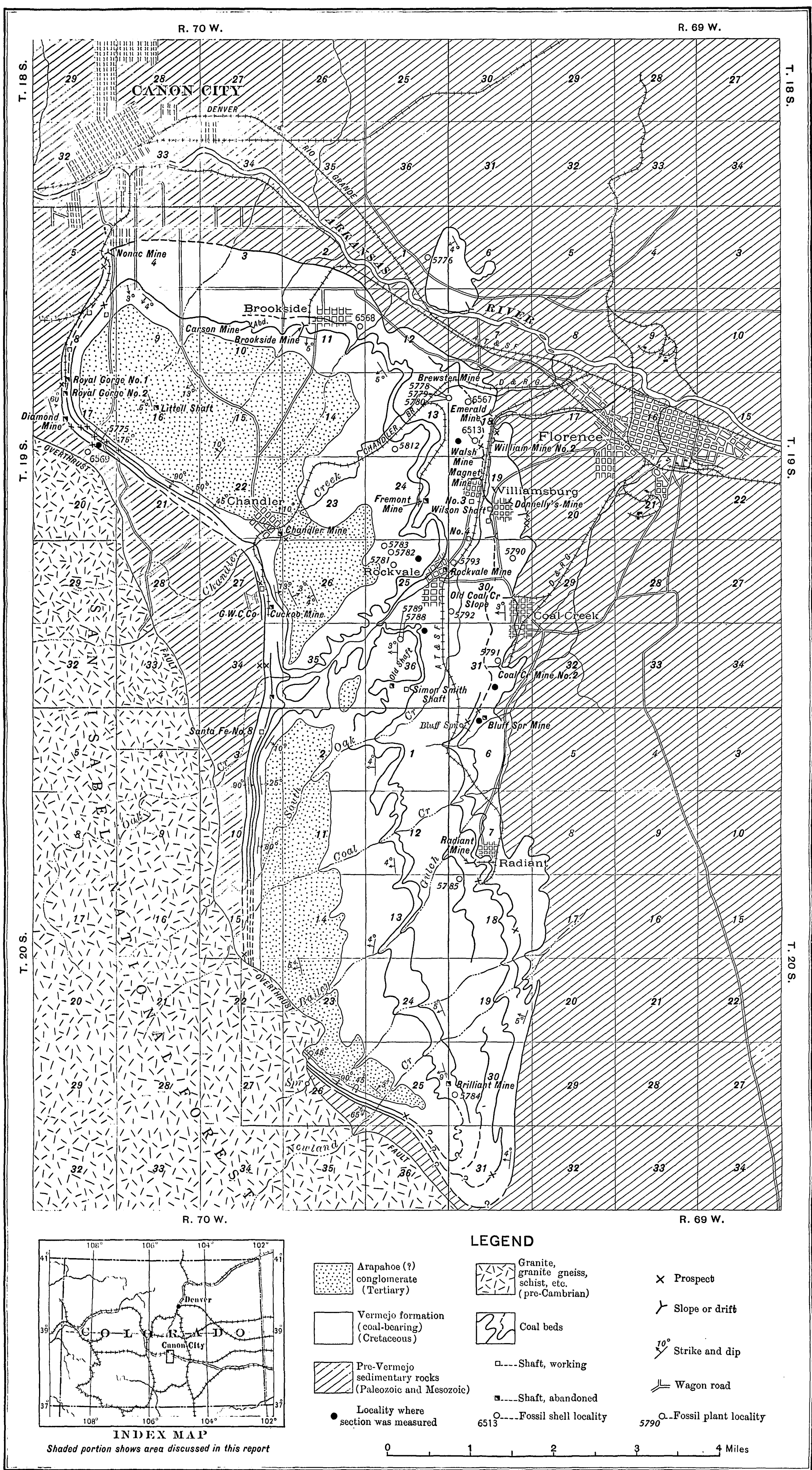

MAP OF CANON CITY COAL FIELD, COLO. 
cluded in the Vermejo flora in the present paper, came from the lower part; but when the present writer visited this field, in the summer of 1910, and collected the data presented in this paper, he found, by comparison of the materials collected at several horizons with that of the Hadden. collection and by the testimony of men at Coal Creek who had worked with Mr. Hadden, that the horizon of many, if not all, the plants in the National Museum collected by him and also those collected for Prof. Newberry came from the upper part of the formation, about halfway between the Rockvale sandstone and the "rim rock." The fossils of these collections have been studied and are described in the accompanying paper by Knowlton (pp. 223-349).

As the details on which depends the correlation of the formations in the Canon City field with those of the Raton Mesa region are not voluminous, they are here placed in their normal position preceding the discussion of general relations. For convenience of description formation names explained later will be used.

hocal featutres in DetaIL.

RADIANT.

The rocks are not well exposed in the southern part of the Canon City field and no satisfactory sections of them were measured. On Newland Creek the Trinidad sandstone contains great numbers of Halymenites major Lesquereux and some smaller forms about one-fourth inch in diameter. Petrified wood, described as Cupressinoxylon coloradense Knowlton, was found near the Brilliant mine a few feet above the Trinidad sandstone (U. S. Geol. Survey, fossil locality 5784).

Near the town of Radiant the rocks are better exposed than they are farther south. One-fourth mile southwest of the Radiant mine Sequoia reichenbachi (Geinitz) Heer was found a few feet below the Rockvale sandstone (U. S. Geol. Survey fossil locality 5785). There are some indications that the coal measures below this sandstone may be thicker in the southern part of the field than in the northern part. Washburne ${ }^{220}$ states that the Radiant mine is on a bed 200 to 250 feet above the base of the coalbearing formation, and yet, according to his map, this bed of coal is not the highest in the lower coal group. If he is correct, the lower group is thicker here than it is at Bluff Springs and at Coal Creek but is about the same thickness as at Rockvale.

\section{BLUFF SPRINGS.}

A short section was measured by Washburne ${ }^{220}$ at the Bluff Springs mine, about 4 miles southwest of Florence, Colo. The lower 80 feet.of the section (see Pl. XXII) was measured in an air shaft of the mine and the remainder at the outcrop. The lowest coal bed of the section, according to Washburne, is the Rockvale, or lowest coal in the field. However, he shows by his section that the top of the Rockvale sandstone is about 226 feet above this coal bed, whereas at the Rockvale mine, less than 2 miles north of Bluff Springs, the top of this sandstone is 323 feet above this coal, ${ }^{228}$ and at the Fremont mine, 21 miles north of Bluff Springs, the shaft between the outcrop of this sandstone and the first coal bed above it reaches the Rockvale coal bed, according to Washburne, ${ }^{227}$ at a depth of 402 feet. From these facts it seems probable either that the Bluff Springs section does. not include the Rockvale coal bed or that the sandstone at the top of the section is at some horizon below the Rockvale sandstone.

\section{COAL CREEK.}

There is a good exposure of a part of the lower group of coal-bearing rocks in the gulch a few hundred feet south of Coal Creek mine No. 2. The Rockvale coal bed, in which the Coal Creek mine is developed, is exposed in the bottom of the gulch, and above it lies a Halymenites-bearing sandstone which seems to be the Rockvale. The relations are shown in the section below.

Section of the lower part of the Vermejo formation measured in the gulch south of Coal Creek mine No. 2 .

[For graphic section see Pl. XXII.]

Sandstone, hard, yellow (Rockvale (?) sandstone).

Sandstone, more or less nodular and softer than Ft. in. the sandstone above, yellow................. $20 \quad 0$

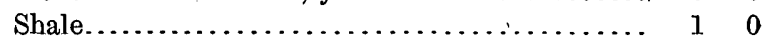

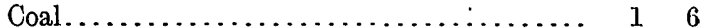

Shale, sandy, yellow..................... $12 \quad 0$

Sandstone, soft, friable, white................. $10 \quad 0$

Shale, with thin irregular layers of sandstone.... 00 Coal............................... $3 \quad 0$

Shale, sandy.............................. 0 Coal.............................. $2 \quad 0$ Shale, dark, containing gypsum and alkali....... $20 \quad 0$ Coal............................... $2 \quad 6$ 
$\begin{array}{lrr}\text { Shale, containing crystals of gypsum......... } & 35 & \text { Ft. }\end{array}$ Sandstone, soft, massive, white........... $15 \pm$

Coal (Rockvale bèd) $\begin{array}{r}4 \quad 0 \\ \hline\end{array}$

Fossil plants are abundant neàr Coal Creek in the lower part of the Vermejo formation. The following collection was made from the rock dump of the mine and another from rocks exposed at the surface:

Fossil plants from the rock waste of Coal Creek mine No. 2.

[U. S. Geol. Survey fossil locality 5791.]

Anemia supercretacea Hollick.

Amelanchier obovata Knowlton.

Asplenum coloradense? Knowlton.

Canna sp.

Ficus leei Knowlton.

Myrica torreyi Lesquereux.

Osmunda hollicki Knowlton.

Sabal montana Knowlton.

Fossil plants collected at the base of the Vermejo formation, about half a mile north of Coal Creek, Colo.

[U. S. Geol. Survey fossil locality 5790.]

Cupressinoxylon? vermejoensis Knowlton.

Ficus curta Knowlton.

Ficus praetrinervis Knowlton.

Ficus speciosissima Knowlton.

Ficus regularis Knowlton.

Ficus sp.

Phaseolites leei Knowlton.

Pteris erosa Lesquereux.

Viburnum? hesperium Knowlton.

Viburnum problematicum Knowlton.

ROCKVALE.

Another "short section of the rocks somewhat younger than those just described at Coal Creek was measured in a steep bluff about a mile south of Rockvale. In this bluff occurs a layer of fine-grained sandstone varying in color from pink to light yellow and ashen gray, from which a large number of fossil. plants have been collected both here and in Rockvale Canyon. From this sandstone Hadden collected many fossil plants (p. 163). Mr. Hadden was formerly superintendent of the Coal Creek and Rockvale mines, and men now living at these places who knew him personally state that he frequently went to the hillsides where this layer of yellowish-pink sandstone is exposed to collect fossils. By means of this sandstone the section is correlated with those measured at Rockvale and Williamsburg. The section follows:
Section of rocks measured near the top of Vermejo formation, about a mile south of Rockvale, Colo.

[For graphic section see PI. XXII.]

Feet.

Sandstone, with partings of sandy-shale............ 25

Sandstone, massive......................... 18

Shale..................................... 15

Sandstone, shaly ........................... 3

Shale, sandy, drab........................ 14

Sandstone, massive; containing fossil palm leaves

Ficus praetrinervis Knowlton and Sabal montana

Knowlton (U. S. Geol. Survey fossil locality

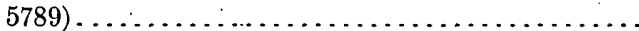

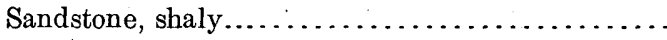

Shale, reddish.............................

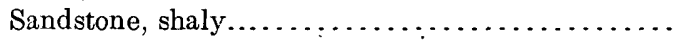

Shale, sandy. .

Shale, pink and somewhat sandy, interbedded with

lenses of yellow shale, coal bearing............

Sandstone, shaly, containing shaly layers at top

(U. S. Geol. Survey fossil locality 5788); with the following fossil plants: Sabal montana Knowlton, Salix plicata Knowlton, Ficus praetrinervis Knowlton, and Viburnum montanum Knowlton. .

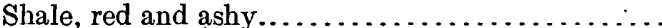

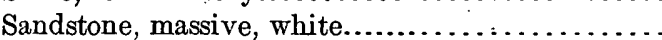

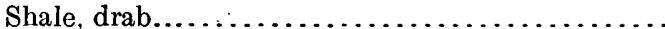

Sandstone, concretionary in some places, yellow...

Shale, brown, with thin beds of coal..............

Sandstone, massive soft, white....................

Shale.

Washburne ${ }^{228}$ has published a section measured north of Rockvale (see Pl. XXII) that is correlated with the Williamsburg section by means of the highest sandstone, which Washburne states is a part of "the big barren series" and which therefore corresponds with the base of the cliff-making sandstone which is well developed farther north and is locally known as the "rim rock.". A collection of fossil plants was made in Rockvale Canyon from pink sandstone which occurs about 135 feet below the base of the "big barren series" of Washburne. It is this fossiliferous sandstone that affords the means of correlating the Rockvale section with the section measured farther south and with the Williamsburg section farther north. As many of the fossils collected by Hadden and Newberry came from this horizon (U. S. Geol. Survey fossil locality 5781), the present writer collected only enough material to identify the horizon. In his material were found Anemia supercretacea Hollick and Salix plicata Knowlton.

Halymenites major Lesquereux occurs in the sandstone a few feet above the horizon at which these plants were found, and about 100 


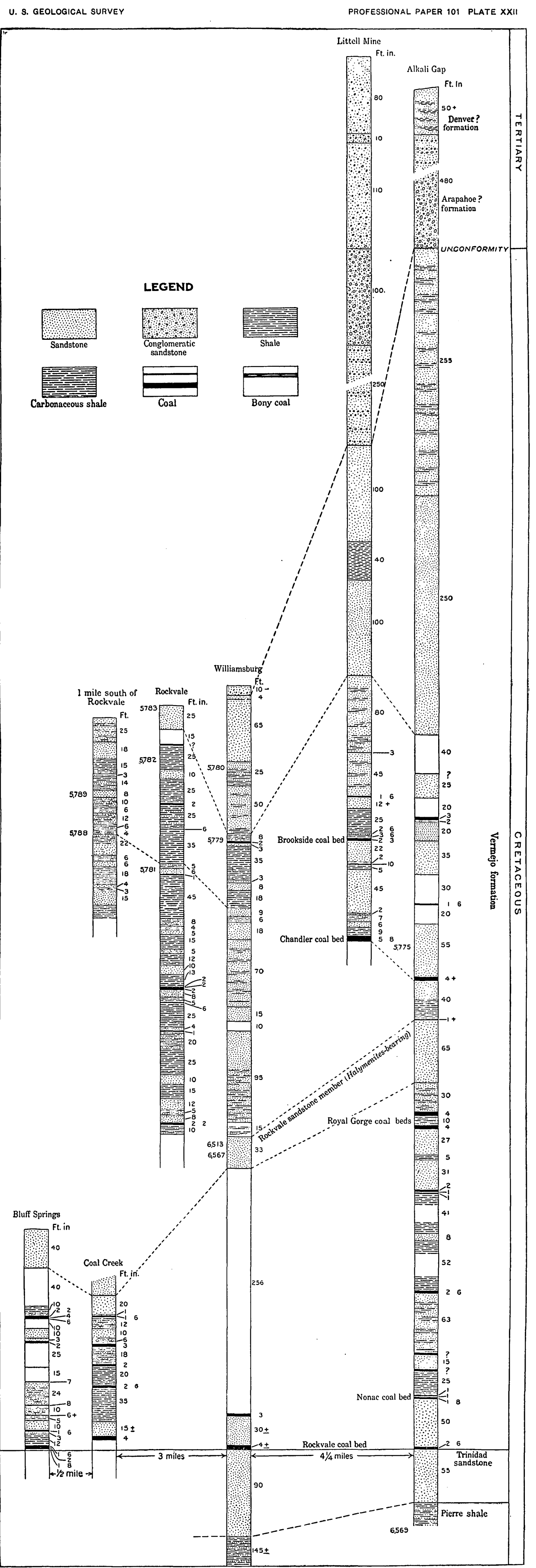

COLUMNAR SECTIONS MEASURED IN THE CANON CITY COAL FIELD, COLO. 
feet higher (U. S. Geol. Survey fossil locality 5782) Pterospermites undulatus Knowlton and Viburnum montanum Knowlton were found. Still higher in the section, near the base of the "rim rock," Ficus leei Knowlton, Ficus wardii Knowlton, and Myrica torreyi Lesquereux were found (U. S. Geol. Survey fossil locality 6783).

The following plants were collected from the rock waste of the Rockvale mine, said to come from the roof of the lowest bed in the coal measures:

\section{Fossil plants collected near Rockvale, Colo. [U. S. Gool. Survey fossillocality 5793.] \\ Asplenium? coloradense Knowlton.' \\ Canna magnifolia Knowlton. \\ Ficus speciosissima Knowlton. \\ Osmunda hollicki Knowlton.}

\section{WILIIAMSBURG.}

The rocks from the Rockvale sandstone up to the "rim rock" are well exposed in the point of the mesa about a mile north of the town of Williamsburg. (See Pl. XXIII.) The Pierre shale and the Trinidad sandstone are also exposed here, but the lower group of coalbearing rocks is not well enough exposed for detailed examination. The rocks dip $4^{\circ}-13^{\circ}$ W., and by computation from these dips and the horizontal distance measured across the space occupied by the poorly exposed rocks, a thickness of about 300 feet was obtained for the lower group. The thickness of these beds as measured in the shaft of the Rockvale mine is 323 feet. The Rockvale sandstone contains great numbers of Halymenites major Lesquereux, and near the top of it there are many lenticular masses of pink sandstone which contain the marine invertebrates named in the following section:

Section of rocks measured at the point of the mesa north of Williamsburg, Colo.

[For graphic section see Pl. XXII.]

Sandstone, coarse, locally conglomeratic; probably base of Arapahoe (?) formation:..

Unconformity.

Vermejo formation:

Sandstone, friable .....................

Sandstone, massive, coarse grained, cliff making, yellowish white; forms cliff at the top of mesa. .......................

Sandstone, shaly, thin bedded; contains many impressions of palm leaves, Sabal montana Knowlton (U. S. Geol. Survey fossil locality 5780) and several nettedveined leaves too poorly preserved for identification
Vermejo formation-Continued.

Sandstone, massive, with partings of shaly sandstone, yellow. Coal beds near the base..............................

Shale containing fossil plants near the top: Ficuis praetrinervis Knowlton, Sabal montana Knowlton, Sequoia obovata? Knowlton, Sequoia reichenbachi (Geinitz) Heer, Viburnum montanum Knowlton (U. S. Geol. Survey fossil locality 5779)........

Coal............................

Sandstone, soft, yellowish white...........

Shale, drab to brown. . ..................

Sandstone, nodular, yellow..............

Sandstone, soft, massive, white...........

Shale, brown, with thin beds of coal ........

Sandstone, massive, yellowish white; contains near the base fossil plants of the same species as were found in the pink sandstone west of Rockvale, and Halymenites major Lesquereux at the top..................

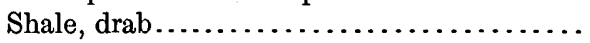

Sandstone, concretionary, yellow...........

Sandstone, shaly, with a thin bed of coal 6 feet from the base. ...................

Sandstone, massive .....................

Covered; probably shale or shaly sandstone.

Sandstone, massive; yellow to white, weathering to a reddish brown. The upper 40 feet forms a prominent shelf and contains Halymenites major Lesquereux. . . ........

Shale, sandy, not continuously exposed.....

Sandstone (Rockvale member), massive, yellow to brown, containing Halymenites major Lesquereux and the marine invertebrates Avicula linguiformis Evans and Shumard, Lucina? sp., Mactra warrenana Meek and Hayden, Mactra sp., Tellina scitula Meek and Hayden, and Thracia subgracilis Whitfield (U. S. Geol. Survey fossil localities

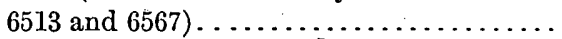

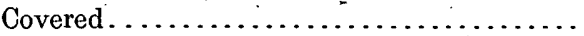
Coal ...............................

Sandstone, massive.................... Coal (Rockvale bed)...............

Trinidad sandstone:

Sandstone, massive, brown.............

Feet.

50

Pierre shale:

Shale with thin layers of sandstone (transitional zone), containing Halymenites major Lesquereux and fragments of nettedveined leaves.

Shale.

$$
1,030 \pm
$$

For a considerable distance above the Rockvale sandstone the rocks are soft and no complete exposure of them was found. They are coal bearing, and, according to Washburne's map of this field (here reproduced as $\mathrm{Pl}$. XXI, p. 162), this poorly exposed part of the section contains two coal beds of considerable 
horizons, one about 110 feet and the other about 230 feet above the Rockvale sandstone. The upper horizon is the same as the one described as occurring about 135 feet below the "rim rock" in Rockvale Canyon, where also the fossil plants occur below the Halymenites zone.

The cliff or "rim rock" consists of two strata of hard, massive sandstone, separated by about 25 feet of softer sandstone; shaly in places and containing fossil plants, chiefly large palm leaves. The upper stratum is very resistant and forms a nearly perpendicular cliff. It is here only 65 feet thick and is evidently. the lower part of the great sandstone möre than 500 feet thick that forms the hogback at Alkali Gap, about 4 miles farther west. Gravels that seem to belong to the conglomerate which lies unconformably on the Vermejo in the center of the field occur at the top of the section.

NORTHERN PART OF FIELD.

The Rockvale sandstone. is well exposed between Rockvale and Brookside. In a gulch half a mile east of Brookside it forms a cliff (see Pl. XXIV) and contains great numbers of Halymenites major Lesquereux. In it are large concretions of sandstone that weather to a pink color like those just described north of Williamsburg. Some of these concretions contain Mactra warrenana Meek and Hayden and Mactra sp. (U. S. Geol. Survey fossil locality 6568). A bed of coal which occurs immediately above the sandstone is believed to be the same as the thin bed below the Chandler coal of the Alkali Gap section.

A small area of coal-bearing rocks north of Arkansas River is underlain by the Trinidad sandstone, which is here more prominent than it is farther south and forms a conspicuous cliff, the most prominent part of which is locally. known as the Castle. It contains Halymenites major Lesquereux and great numbers of fragmentary plants, but half a day's search resulted in finding only two leaves, Ficus praetrinervis Knowlton and Dryophyllum bruneri Ward, that were perfect enough for specific identification (U. S. Geol. Survey fossil locality 5776). The presence of fossil seaweeds in the sandstone, together with the fragments of land plants, suggests that the sandstone was deposited near the shore and that the plants were washed in to the sea from land that was near by.
ALKALI GAP.

West of Brookside the rocks are not well exposed and no single bed was traced by the writer, but Washburne traced the coal developed in the Brookside mine west and south to Alkali Gap, where the longest section of the Canon Gity field was measured. Fossils were collected at this locality from several horizons and observations were made looking toward the correlation of the various rocks with those examined along the eastern margin of the field. The measurements made by the writer correspond in general with those previously published by Washburne $e^{226}$ and his measurements are used for plotting the section in Plate XXII (p. 164). However, to the section as published by Washburne have been added the fossils collected by the writer, who also is responsible for the correlations shown on this plate. The section follows:

Section of rocks measured in Alkali Gap.

[For graphic section see Pl. XXII.]

Sandstone, tuffaceous, and bright-colored clay, nearly horizontal, probably Denver Ft. in. formation........................ $50 \quad 0$

Not exposed, horizontal distance 325 feet, dip unknown.

Conglomeratic sandstone, dip $75^{\circ} \mathrm{E}$. (possibly equivalent in age to Arapahoe formation) . . $\quad 160 \quad 0$

Unconformity.

Vermejo formation:

Sandstone, soft, with streaks of sandy shale, nearly vertical..................... 255 0

Sandstone, strong, massive, makes crest of ridge........................... $250 \quad 0$

Not exposed, probably mostly soft sandstone, some fire clay at top............ $40 \quad 0$ Coal, thin bed.

Sandstone......................... $25 \quad 0$

Not exposed, soft rocks. .............. 20 : 0 Coal, probably. Brookside bed......... $3 \quad 0$

Shale. . . ........................ 2 0

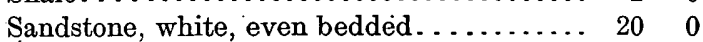

Sandstone, soft...................... 350

Not exposed..................... $30 \quad 0$ Coal, in black shale............... $1 \quad 6$

Not exposed ....................... $20 \quad 0$

Sandstone, with fossil leaves at base: Ficus speciosissima Knowlton, Myrica torreyi Lesquereux, Palaeoaster inquirenda Knowlton (U. S. Geol. Survey fossil locality 5775)... $55 \quad 0$

Coal; Chandler hed, in an open cut: ....... $\dot{4}-5.0$

Sandstone and shale................... $40 \quad 0$ Coal, top not exposed.............. 1+

Sandstone, coarse grained, massive, with iron concretions, weathers yellow, contains Halymenites major Lesquereux near the top.... 65 ' 0 


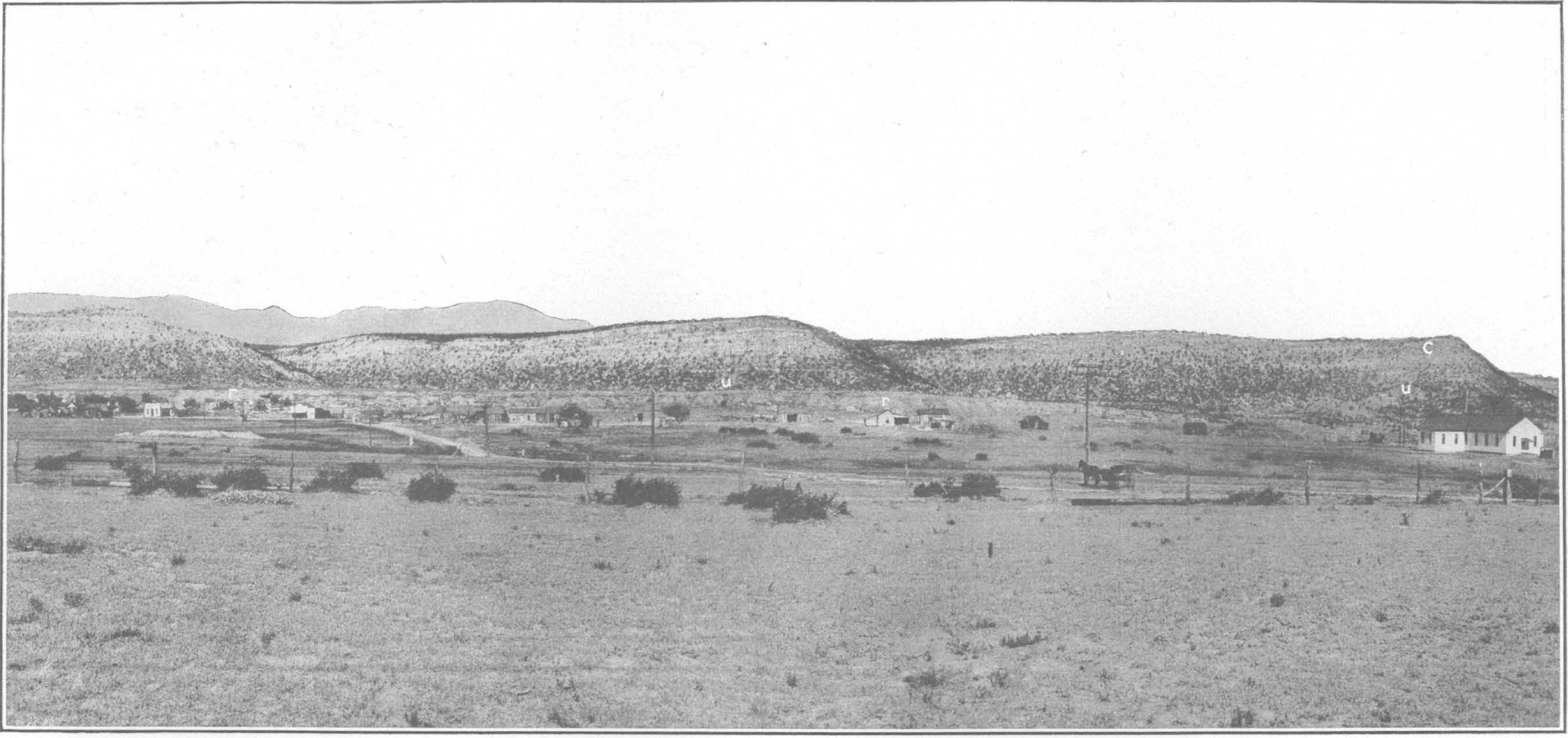

ESCARPMENT AT EASTERN MARGIN OF CANON CITY COAL FIELD, NORTH OF ROCKVALE, COLO.

C. Cliff-making sandstone, capped with Arapahoe (?) conglomerate; u, upper coal group of the Vermejo formation: $r$ Rockvale sandstone member of the Vermejo formation. 


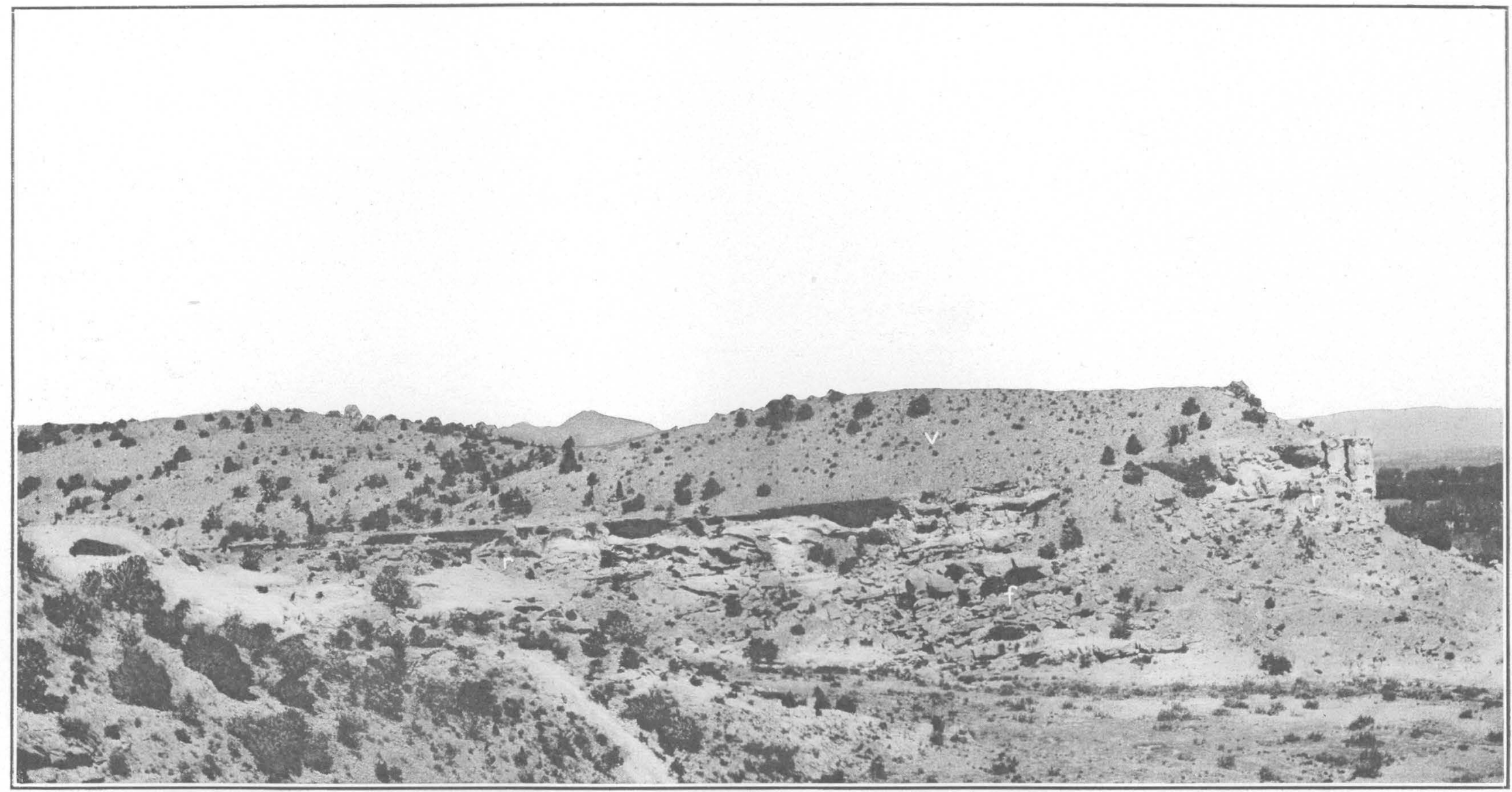

ROCKVALE SANDSTONE MEMBER OF THE VERMEJO FORMATION NEAR BROOKSIDE, COLO

$V$, Lower part of upper coal group; $r$, Rockvale sandstone member; $f$, locality where fossil invertebrates were collected. 
Vermejo formation-Continued.

Sandstone, shaly.................... Coal, upper Royal Gorge bed......... Shale, hard, sandy.................. Coal, bloom, lower Royal Gorge bed...

Sandstone, soft, white.................

Shale, with coaly streaks...............

Sandstone, soft, gray.................

Coal ..........................

Shale........................

Coal ...........................

Not well exposed, probably mostly shale...

Sandstone, hard......................

Not well exposed, mostly shale.......... Coal.

Sandstone and shale, with a nonworkable bed of coal near base................. Coal............................

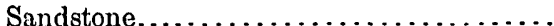
Coal...........................

Shale.............................

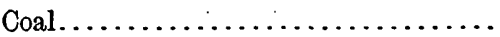

Shale............................

Coal............................

Sandstone, coarse white.................

Coal, Rockvale bed................

Trinidad sandstone.

Pierre shale:

Shale, blue, sandy..................

Sandstone...........................

Shale............................

Sandstone, massive..................

Shale,-blue, sandy, with thin partings of sandstone........................

Shale, sandy, yellow, containing large concretions with Pierre fossils.............

Shale, blue, sandy, with concretions......

Sandstone, soft, shaly.................

Shale, sandy, blue, yellow, white........

Shale, blue; containing at the base concretions (U. S. Geol. Survey fossil locality 6569) with Lucina occidentalis (Morton), Syncyclonema rigida Hall and Meek, Inoceramus sagensis Owen, Leda evansi Meek and Hayden, Nucula sp., Sphaeriola? sp., Mactra? sp., Baculites compressus Say, Scaphites nodosus Owen...........

Shale, blue-black, with thin indurated sandy layers containing comminuted plant fragments. . ..................

Shale, clayey, dark, slickensided.

IITTELI MINE.

$5,490+$

About three-fourths mile northeast of Alkali Gap a mine shaft has been sunk to a depth of more than 1,000 feet. It penetrated the Arapahoe (?) conglomerate and the upper part of the coal measures (Vermejo formation). The record of the shaft has been published by Washburne, ${ }^{220 a}$ from whose description the graphic section of the Littell mine was plotted in Plate XXII. The lowest coal bed included in the section is supposed to be the one in which the Chandler mine is developed, and this gives a convenient means of correlating the section with that of Alkali Gap.

\section{AGE RELATIONS.} PIERRE SHALE.

The fossils named in the Alkali Gap section from the upper part of the marine shale are regarded as sufficient evidence for correlating this shale with the Pierre of the Raton Mesa region. The correlation is strengthened by the practical continuity of the lower part of the shale between the Canon City and Trinidad fields, a distance of about 40 miles, although the upper part of the shale and such coal-bearing rocks as may have existed between the two have been eroded away.

The top of the Pierre shale is sandy, consisting of alternating layers of sandstone and shale like the transitional zone of the Raton Mesa region. Some of the sandstone layers contain great numbers of leaf fragments. Halymenites major Lesquereux is common.

A massive sandstone, similar in lithologic character and general appearance to the Trinidad sandstone of the Raton Mesa region, occurs above the transitional zone. The similarity of this sandstone to the one holding the same stratigraphic position in the Raton Mesa region was pointed out by Stevenson ${ }^{50}$ in 1874 . Washburne ${ }^{220}$ also correlated it in a general way with the Trinidad, although he found no fossils in it and expressed the opinion that it and the Trinidad "may not be precisely synchronous deposits." Though the Halymenites that characterize the Trinidad of the Raton Mesa region are not so generally distributed in the Canon City field, great numbers of the typical Halymenites major Lesquereux were found in places, especially in the southern part of the field, together with a smaller but otherwise similar form. As the outcrops in the two fields are only 40 miles apart, and as the sandstones are similar in lithologic character, hold the same stratigraphic position, and contain the same fossils the name Trinidad sandstone is here extended to the Canon City field. 


\section{VERMEJO FORMATION.}

The coal-bearing rocks of the Canon City field contain fossil plants that correlate them with the Vermejo formation of the Raton Mesa region so definitely that the name Vermejo is here extended to include them. The plantbearing beds are separated into two groups by a sandstone of marine origin that contains invertebrates of Fox Hills type and great numbers of Halymenites major Lesquereux, a form which seems to have culminated in Fox Hills time and apparently to have become extinct soon afterward. This fossil is also found at several horizons within the upper coal group. The invertebrates and Halymenites tend to correlate the Vermejo of this field with the Fox Hills farther north, and the other fossil plants tend to show its connection with the Mesaverde. From the Vermejo formation of the Canon City field, 57 fossil plants have been described, of which 23 are from the lower coal group. (See p. 54.) No definite locality is given for 21 of the plants and doubtless many of them come from the lower group.

The sandstone separating the two groups of coal beds is here named the Rockvale sandstone member of the Vermejo formation, from its typical development near Rockvale. It is of marine origin and contains the following fossils:

\section{Fossils collected from the Rockvale sandstone in the Canon City. field, Colo.}

[U. S. Geol. Survey fossil localities 6567,6513 , and 6568.]

Avicula linguiformis Evans and Shumard. Lucina? sp.

Mactra warrenana Meek and Hayden. Mactra sp.

Tancredia americana Hall and Meek.

Tellina scitula Meek and Hayden.

Thracia subgracilis Whitfield.

Halymenites major Lesquereux.

T. W. Stanton, who identified these fossils, says:

Some of them are identical with Fox Hills species, but the evidence is not sufficient for stating positively that the horizon is that of the Fox Hills sandstone, though the difference in age can not be very great. We know that many species of the Fox Hills fauna have a considerable range within the Montana group and are found in beds of similar lithologic character several hundred feet below the true Fox Hills.

As these forms elsewhere range downward in the Montana their occurrence here between beds yielding a Montana flora would seem to warrant placing the Vermejo of this field at least as low in the time scale as Fox Hills as developed in the Denver Basin and would not invalidate its reference to a place in the middle of the Montana, as some of the fossil plants seem to demand.

The upper coal group has yielded a large flora: (See table of Vermejo flora, p. 54.) Twenty of the species named are known to come from this group and probably a large proportion of the 21 others whose horizon is not definitely known were also found there. The fossil plants of this group, according to Knowlton, indicate Montana age and, like those from the lower group, belong to the Vermejo flora. Also the presence of Halymenites, a fossil of marine habitat, near the top of the coalbearing rocks, indicates that these beds belong at least as low in the time scale as the Fox Hills of Denver Basin. For these reasons all the coal-bearing rocks of this field are here placed in the Vermejo. No evidence was found that any of these rocks are equivalent in age to the Laramie of the Denver region.

The upper part of the Vermejo formation consists of massive sandstone that is about 500 feet thick in the western part of the field. It thins toward the east, probably because its top was eroded away previous to the deposition of the younger beds. However, in the eastern . part of the field it forms a cliff 100 to 150 feet high, which is.locally known as the "rim rock." It seems to be perfectly continuous with the underlying coal measures and is therefore included in the Vermejo.

\section{ARAPAHOE (?) AND DENVER (?) FORMATIONS.}

Resting unconformably on the Vermejo and upturned to a nearly equal degree is a conglomerate, overlain by still younger beds that are less sharply upturned. These have been doubtfully correlated with the Arapahoe and Denver formations by Washburne, ${ }^{226}$ and the present writer has no information that tends to invalidate this correlation.

SUMMARY.

The age relations of the formations in the Canon City field may be briefly summed up as follows: The Pierre shale of this field is the time equivalent of the Pierre of the Raton Mesa region, and, like the latter, may not be the full equivalent of the original Pierre: The Trinidad sandstone of the Raton Mesa region 
seems to be equivalent to the Trinidad of the by the unconformity between it and the VerCanon City field; hence the same name is mejo is comparable to that of the Raton Mesa used in both regions. The floras of the Ver- region on the south and to that of the Denver mejo of the two fields are similar, indicate region on the north. (See fig. 11.)

Montana age, and tend to correlate the Vermejo with the Mesaverde. The invertebrates, however, tend to place it somewhat higher in the time scale and correlate it with the Fox Hills of the areas farther north. According to Stanton, faunas from the upper part of the Pierre of these fields indicate horizons near the top of that formation. On the other hand, if the Vermejo flora is more closely allied to that of the Mesaverde than it is to younger floras, as Knowlton believes, the top of the Pierre shale of these fields must be placed somewhat lower than the top of the Pierre in the time scale. Other reasons for this assumption have been given in a paper already published. ${ }^{249}$ If younger Cretaceous rocks were formed in the Canon City field they were eroded away previous to the deposition of the Arapahoe (?) conglomerate. If this conglomerate is the time equivalent of the Arapahoe of the Denver Basin the hiatus represented

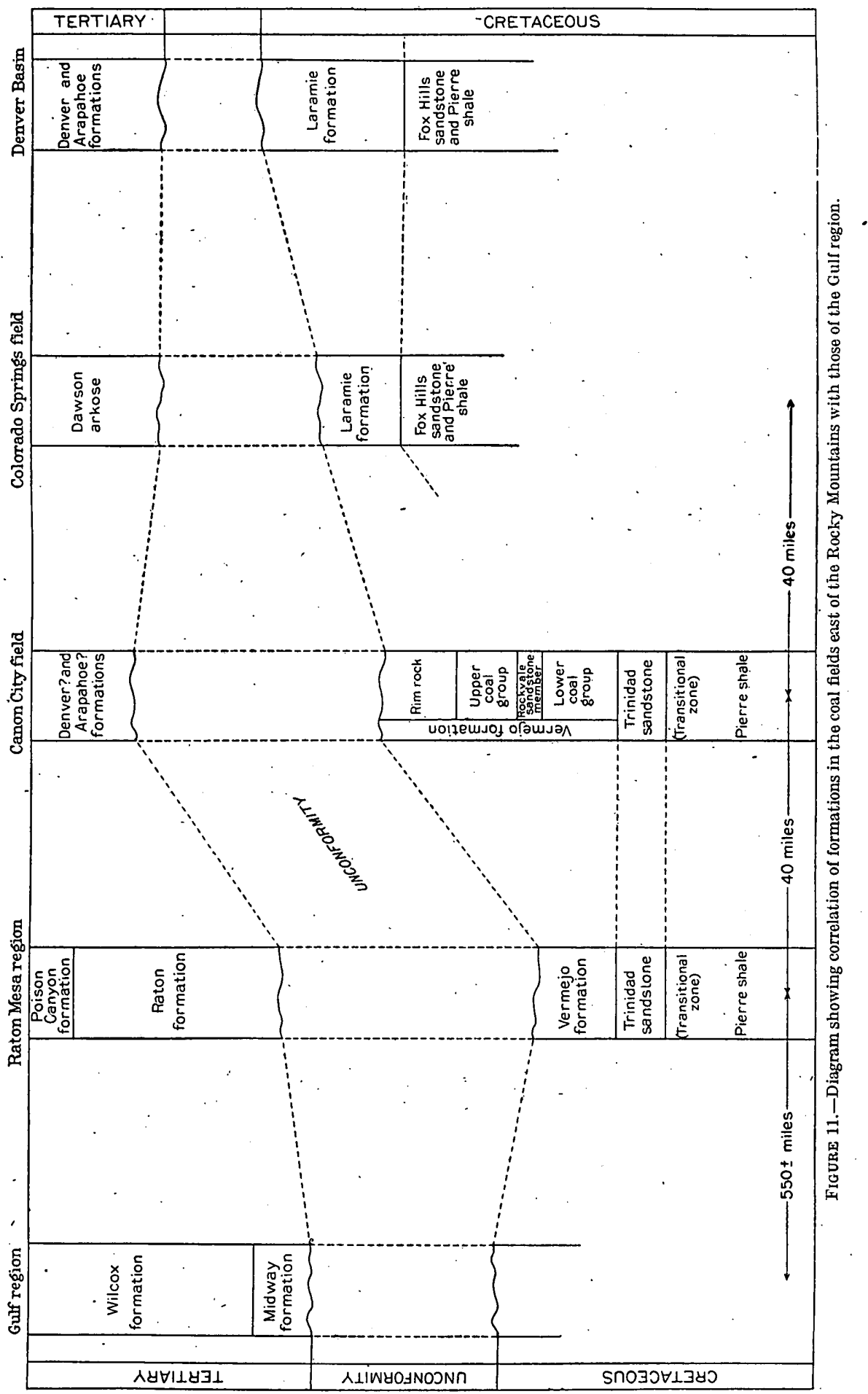


GULF REGION.

The Eocene deposits of the Gulf coast are divisible into four groups, which are, in ascending. order, (1) the Midway, (2) the Wilcox, (3) the Claiborne, and (4) the Jackson. These groups are locally subdivided into a number of formations, or in areas where not subdivisible the group name is employed in a.formational sense. There is a general unconformity by erosion between the Midway and the underlying Cretaceous, but it is usually concealed or inconspicuous because of the similarity of the Eocene and Cretaceous sediments. In northeastern Arkansas the Midway overlaps the Cretaceous and rests upon a Paleozoic floor. The Midway and Wilcox sediments are in part marine and contain a distinctively Eocene fauna and in part nonmarine and contain plants that Berry regards as indicative of lower Eocene. ${ }^{250}$

The Wilcox group overlies the Midway and in some places is unconformable with it. Some of the sediments are of marine or brackishwater origin and contain invertebrates, but most of them are nonmarine and contain beds of lignite. The Wilcox has yielded a large. flora which has been studied by E. W. Berry. Of the 59 species of plants in the Raton flora having outside distribution, 29 have already been found in the Wilcox formation. (See table, p. 60.) Also, there are many forms in the Wilcox flora which differ slightly in specific character from certain Raton species, but which nevertheless are so similar that they strengthen the correlation of the Wilcox with the Raton formation.

The correlation of the Raton formation with the lower Eocene beds of the Gulf region rests mainly on the stratigraphic position of the beds, on their structural relations to the older formations, and on the fossil plants. As the Midway formation is the oldest Eocene of the Gulf region and rests unconformably on the Cretaceous, it is possible that it is equivalent in part to the Raton formation. But there are no invertebrates in the Raton with which those of the Midway can be compared, and the Midway flora as now known is too meager for satisfactory correlation.

The Wilcox formation is lignite bearing, as is also the Midway in some places, and this character suggests comparison with the Raton formation, but the Eocene of the Gulf region is separated by about 550 miles from the Raton
Mesa region, a distance so great that lithologic similarity is of little value in correlation.

As plants are the only, fossils available for directly correlating the Raton with formations in the Gulf region, it follows that although the Raton may be in part the time equivalent of the Midway, as stratigraphic and structural evidence would indicate, the fossils are found principally in the Wilcox.

COLORADO SPRINGS AREA AND DENVER BASIN.

The coal field near Colorado Springs is about 40 miles from the Canon City field and about 80 from the Trinidad field. The most recent studies of this field ${ }^{248}$ show that the Pierre shale is overlain by the Fox Hills sandstone, and this in turn is surmounted by 250 to 300 feet of coal-bearing rocks that constitute the southward continuation of the Laramie formation of the Denver Basin. Lying unconformably on the Laramie is the Dawson arkose, ${ }^{234}$ a formation of recognized Tertiary age.

The Dawson arkose contains fossil plants and bones of a mammal and of dinosaurs, but as few fossils other than plants have been found in beds with which it is here correlated farther south these correlations must rest for the present on plants, stratigraphic position, and structural relations. Layers of shale occur between the massive beds of arkose, and some of these layers contain great numbers of fossil plants. A collection of 14 described and several unidentified species was made farther north near Sedalia, Colo., several years ago, from rocks then supposed to be Arapahoe. Richardson ${ }^{245}$ has recently shown that these rocks belong to the Dawson arkose. The plants therefore belong to the Dawson flora, which, as now known, consists of 45 forms.

Plants from the Dawson arkose.

[Identified by F. H. Knowlton.]

Acer trilobatum productum? (Alexander Braun) Heer.

Acorus brachystachis Heer.

- Anemia subcretacea (Gardner) Ettingshausen.

Artocarpus, probably A. similis Knowlton. ${ }^{1}$

Berchemia multinervis (Alexander Braun) Heer. ${ }^{1}$

Cinnamomum affine? Lesquereux.

Cissus laevigata Lesquereux. ${ }^{1}$

Cissus lobatocrenata Lesquereux.

Cornus studeri Heer of Lesquereux. ${ }^{1}$

Dicksonia n. sp.

Dombeyopsis obtusa Lesquereux.

1 Species common to Dawson arkose and Raton formation. 
Dombeyopsis trivialis Lesquereux.

Dryopteris lakesiana (Lesquereux) Knowlton.

Dryopteris lesquereuxii Knowlton.

Equisetum sp.?

Ficus denveriana Cockerell. ${ }^{1}$

Ficus planicostata latifolia? Lesquereùx. ${ }^{1}$

Ficus planicostata Lesquereux.

Ficus tiliaefolia Alexander Braun.

Ficus sp.?

Sabalites grayanus (Lesquereux) Lesquereux.

Geonomites tenuirachis Lesquereux.'

Hedera n. sp.

Hicoria sp. Knowlton.

Laurus primigenia Unger.

Laurus socialis Lesquereux. ${ }^{1}$

Laurus weediana? Knowlton.

Nelumbo lakesiana (Lesquereux) Knowlton. ${ }^{1}$

Nelumbo n. sp.

Palmocarpon palmarum (Lesquereux) Knowlton. ${ }^{1}$

Phyllites n. sp.

Platanus rhomboidea Lesquereux. ${ }^{1}$

Plátanus raynoldsii Newberry. ${ }^{1}$

Platanus haydenii Newberry.

Populus nebrascensis? Newberry.

Populus sp.?

Pteris erosa Lesquereux. ${ }^{1}$

Pteris undulata Lesquereux.

Quercus n. sp.

Rhamnus goldianus Lesquereux. ${ }^{1}$

Sapindus caudatus Lesquereux. ${ }^{1}$

Viburnum marginatum Lesquereux.

Viburnum n. sp.

Vitis olriki? Lesquereux. ${ }^{1}$

Woodwardia latifolia Lesquereux.

On the basis of these plants, the stratigraphic position of the formation, and its structural relations to the older rocks, the Dawson arkose is correlated with the Raton formation.

The formations of the Colorado Springs area extend continuously northward through the Denver region, which has come to be the recognized home of the Laramie and which is well known through the writings of Emmons, Cross, and Eldridge. ${ }^{133}$ Recent work in the southern part of the region by Richardson ${ }^{234,245}$ indicates that the Dawson arkose, which has a maximum thickness of about 2,000 feet, includes in it rocks equivalent in age to both the Arapahoe and Denver formations of the Denver Basin. "The plane of separation between the Dawson and the Laramie is the post-Laramie unconformity of the Denver Basin.

The correlation of the formations as indicated by the stratigraphic and structural relations is confirmed by some of the fossils. Dinosaurs have long been known to occur in the post-Laramie beds of the Denver Basin, and

I Species common to Dawson arkose and Raton formation. principally, if not wholly, because of them these beds have been regarded by many geologists as Cretaceous in age. However, dinosaur bones have been found in the Dawson arkose ${ }^{238}$ associated with a mammal and plants of Tertiary age. The dinosaurs are not specifically identifiable; hence, the correlation by fossils of the Dawson arkose with the Denver and Arapahoe formations depends on plant remains. According to Knowlton the Dawson flora is of essentially the same age although less numerous than the Denver flora. It contains 137 species, of which 98 have been described and 35 (of the 98) are known to occur in the Raton formation of the Raton Mesa region. (See table, p. 60.) In brief, the stratigraphic and structural relations, as well as all of the known paleontologic evidence, found in the Dawson, Denver, and Arapahoe formations tend to prove that the lower part of the Dawson arkose is essentially equivalent to the Arapahoe formation, and that the Denver formation is equivalent to the higher parts of the Dawson. By means of the fossil plants these formations are correlated with the Raton formation of the Raton Mesa region and with the Wilcox group of the Gulf const and are therefore to be referred to the early Eocene. (See fig. 11, p. 169.)

\section{AREAS WEST OF THE ROCKY MOUNTAINS} FIELD INVESTIGATIONS.

After having determined that the coalbearing rocks of the Raton Mesa region are divisible into two formations, one of Montana and the other of Eocene age, it seemed desiruble to determine the relations of these to similar formations west of the Rocky Mountains in southern Colorado and northern New Mexico where two coal-bearing formations occur. The younger had previously been correlated, though somewhat doubtfully, with the Laramie; and the older, or Mesaverde, has long been assigned to the Montana. It is separated from the socalled "Laramie" by a thick formation of marine shale-the Lewis. During the summer of 1911 observations were made in these western fields and the results were published ${ }^{235}$ during the following year. Areas were examined near Durango, in southwestern Colorado, in the type area of the Mesaverde formation; in several places in the eastern part of the San Juan Basin, including Pagosa Junction, Dulce, 
Monero, Cuba, and Cabezon; in the Rio Puerco field; the Tijeras field; the Hagan field; and the Cerrillos field. (See fig. 12, p. 173.) In the summer of 1912, the writer, accompanied by T. W. Stanton, made a tour of investigation from Albuquerque to Lumberton, N. Mex., when data were obtained that supplement those previously published. Other data have since been gathered. The information given in this paper, ${ }^{235}$ revised and brought up to date, is given in the following pages.

\section{GEOLOGIC FORMATIONS.} GENERAL FEATURES.

The formations of northwestern New Mexico and southwestern Colorado, described in this part of the paper, and their age relations, are shown in a general way in tabular form below. Certain questionable relations and modifications will be described beyond.

\section{Age relations of the Cretaceous and Tertiary formations of north-central and northwestern New Mexico and south- western Colorado.}

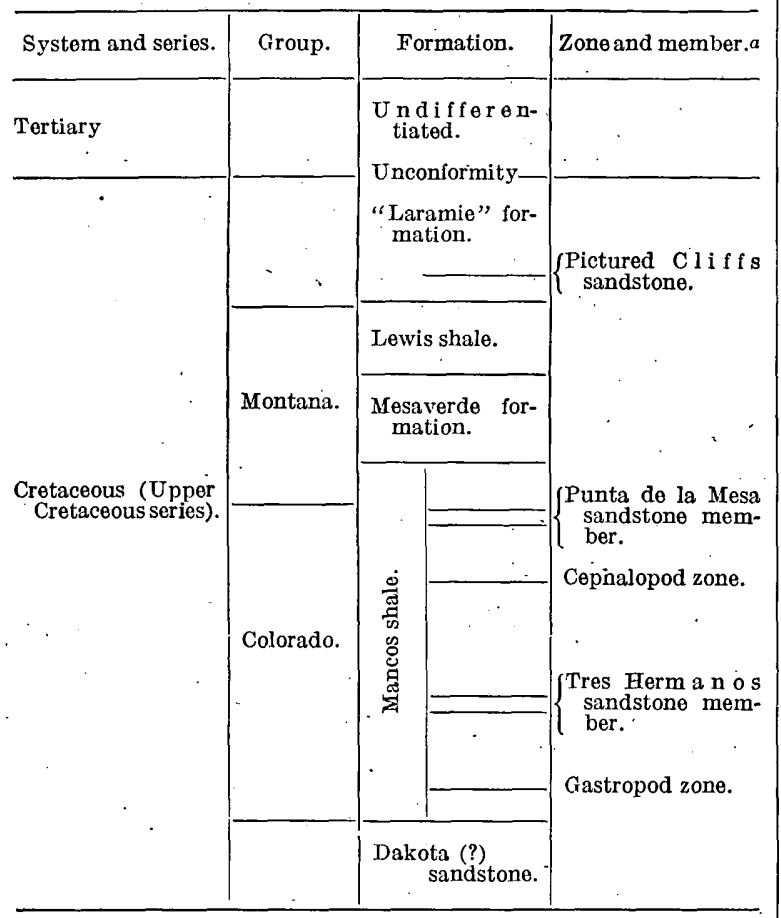

a Names of zones and

DAKOTA (?) SANDSTONE.

A quartzose sandstone, locally oonglomeratic, occurs at the base of the Cretaceous system in north-central and northwestern New Mexico. No fossils were found in it, but because of its stratigraphic position and its lithologic character it is here referred provisionally to the Dakota.

The so-called Dakota sandstone east of the Rocky Mountains in Colorado consists of two sandstones separated by a thin shale. This shale, together with the underlying sandstone, has been proved to be of Washita (Comanche) age, leaving only the upper sandstone in the Dakota. ${ }^{187}$, 233 The writer has observed similar relations as far south as Las Vegas, $N$. Mex. However, no rocks of Lower Cretaceous age are known to exist west of the mountains (unless the Morrison formation be of Lower Cretaceous age), and the sandstone between the Morrison and the lowest shale of the Mancos constitutes the Dakota in this part of the field. This sandstone was, found in all of the coal fields here described, and the few observations made on it are presented in the following pages devoted to the presentation of details.

\section{MANCOS SHALE.}

The Mancos shale of central New Mexico includes the rocks; mainly shale, intervening between the Dakota sandstone and the Mesaverde formation. According to Schrader, ${ }^{200}$ Gardner, ${ }^{212,222}$ and others who have traced the Cretaceous formations from the Durango region eastward and southward through the San Juan River region this formation is essentially equivalent to the Mancos of southwestern Colorado. ${ }^{141}$ The present writer examined it at three localities in the San Juan Basin-near Durango, in southwestern Colorado, and near Monero and at Cabezon, in New Mexico. It is continuously exposed between Cabezon and the Rio Puerco field, but east of the Rio Puerco. it disappears under Tertiary and Quaternary sand and gravel in the Rio Grande valley, and nothing is known there of its occurrence and extent. East of the Rio Grande the surface is occupied by Paleozoic and older rooks of the Sandia Mountain block, on the eastern slope of which the Màncos and younger rock formations reappear so little changed from their appearance on the Rio Puerco that even without the aid of fossils it would be difficult to believe that the formations were not once continuous. between the two fields. This similarity in the lithologic and stratigraphic succession is. confirmed by fossils and leaves little doubt that 
the sea in which the Mancos shale was deposited | of new names and to make use of the zonal extended from the San Juan Basin eastward over the Hagan-Cerrillos region.

When detailed observations are made on the Mancos of central and western New Mexico it will probably be subdivided into at least three formations, but for the purposes of this paper it will be preferable to avoid the introduction names adopted by Herrick and Johnson, ${ }^{46}$ as follows:

The gastropod zone occurs near the base of the Mancos in a shale formation 35 to 100 feet thick, which, in the Rio Puerco field, contains lenses and concretions of earthy limestones that carry. great numbers of fossils. This shale, is

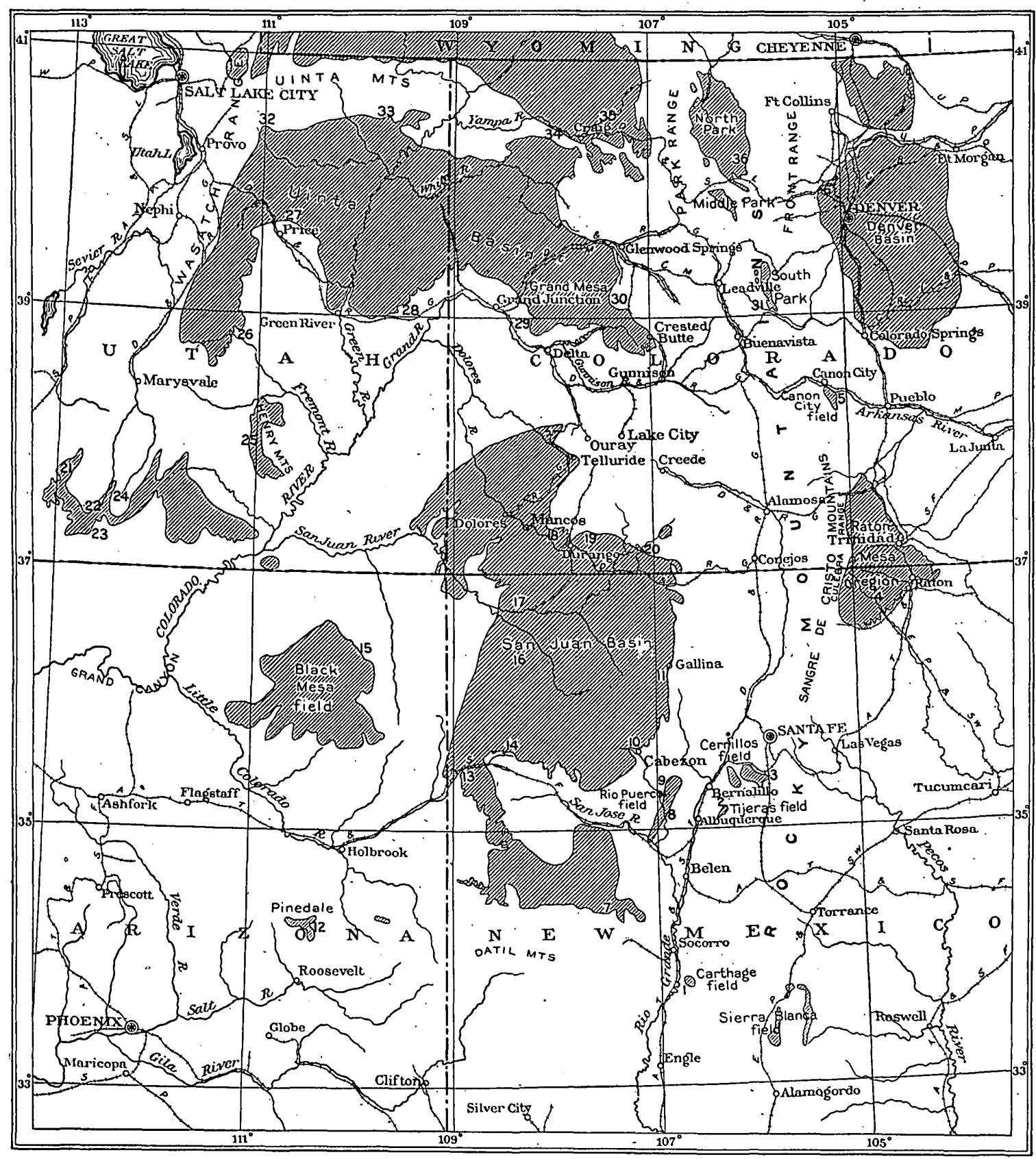

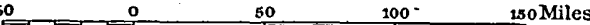

Figure 12.-Map of parts of Colorado, New Mexico, Utah, Arizona, and Wyoming, showing the positions of the coal fields described. The large numbers refer to localities of sections that have been correlated in another paper (Relation of the Cretaceous formations to the Rocky Mountains in Colorado and Now Mexico: U. S. Geol. Survey Prof. Paper 95, pp. 27-58, 1916). 
readily recognized in the other coal fields west of the mountains here described but is not so abundantly fossiliferous. In the Cerrillos field it contains thin beds of coal near its base and in the Rio Puerco field oarbonaceous shale. It seems probable that this may be the horizon of some of the so-called Dakota coal of the southwest.

A series of yellow sandstones alternating with gray shale lying above this shale is about 150 feet thick on the Rio Puerco and thinner in some of the other fields. It thickens westward and thins eastward. Herrick and Johnson called it the Tres Hermanos sandstone, and this name may be used to designate the zone containing the yellow sandstone that occurs near the base of the Mancos in all of the fields described in oentral New Mexico west of the mountains.

The principal part of the Mancos shale occurs above the Tres Hermanos sandstone member. It is a more or less homogeneous shale 1,200 to 2,000 feet thick in the Durango region, about 1,000 feet thick in the Rio Puerco field, and considerably thicker in the fields. east of the Rio Grande. It is not divisible lithologically, but the fossils prove that it contains time equivalents of the Benton, the Niobrara, and some of the Pierre.

The determination of the top of the Man$\cos$ in the time scale involves some difficult questions. In its type area in southwestern Colorado the Mancos includes at its top rocks of supposed Pierre age. ${ }^{140}$ In the Cerrillos field the shale below the coal-bearing rocks seems to have about the same range, but in the Rio Puerco field the upper part of the Mancos is arenaceous, the lowest sandstone member above the Tres Hermanos being the Punta de la Mesa sandstone. This sandy portion of the Mancos has not been separated from the overlying Mesaverde, and it was described by the writer in his former paper ${ }^{235}$ as the basal member of the Mesaverde on the assumption that this formation extended downward to include all of the massive sandstones. However, later investigations show that the Punta de la Mesa sandstone occurs several hundred feet below: the top of the Mancos shale as developed farther north.

East of the Rio Grande the. Mancos shale is much thicker than it is in the Rio Puerco field. At Hagan it has a measured thickness of 2,116 feet. A characteristic Benton fauna occurs in its lower 700 feet or more, but its upper part seems to be younger than the upper part of the principal shale body of the Mancos in the Rio Puerco field, for it contains fossils that range upward through the Mesaverde. The few fossils found at the top of the Mancos near Hagan were close to the basal sandstone of the Mesaverde, but in the Cerrillos field this fauna seems to extend downward several hundred feet into the shale. In this latter field the Mesaverde has a measured thickness of about 2,400 feet. The lower part of the Mancos is clearly of Benton age and some of the rocks are probably of. Niobrara age. The upper part contains a great number of fossils that belong in the fauna of the lower Montana. This occurrence of Montana fossils below the Mesaverde necessitates the reference of the rocks containing them to a horizon near the base of the Pierre.

The fossil invertebrates of the Mancos are included with those of the Mesaverde and Lewis in the following table, and their general distribution is indicated therein. Unfortunately a great many of the species have never been described, and their generic names as published in the table are of little value in. correlation.

The table contains only the names of fossils identified by T. W. Stanton from collections made principally by the writer, and in small part by J. H. Gardner and others. The fact that many of these species have never been described may be of no serious consequence for the purposes of this paper, for they seem to have a somewhat restricted geographic distribution in New Mexico, and, according to Stanton, their nearest known allies occur far to the southeast in Texas; but it is hoped that so well developed a fauna will be made available by proper description and illustrations for purposes of correlation as stratigraphic work is extended in the New Mexico coal fields. Some additional species from this area have been described by Herrick and Johnson, by W. D. Johnson, and by Shimer and Blodgett, but they are omitted from the following table unless they are represented by identified specimens in the collections of the United States Geological Survey.

In a report on the fossils collected by the writer Stanton makes the following statement covering both the Mancos and the Mesaverde faunas: 
The distribution of the faunas agrees with the field determination that the coal-bearing rocks of the Cerrillos, Hagan, Tijeras, and Rio Puerco fields all belong to one formation. In the Tijeras and Rio Puerco fields the marine fauna associated with the coal occurs in rocks lying above part of the coal beds as well as immediately beneath them [as described by Lee; who collected the fossils]. This fauna is closely related to the Cretaceous faunas of the Gulf and Atlantic borders and is especially related to the fauna which occurs a short distance beneath the coal at San Carlos near the Rio Grande in western Texas. It apparently does not extend far. northward, the most northern point at which it has been found being in the neighborhood of Cabezon. It is of course true that there are some similar and perhaps a few identical species in the Montana group faunas of Colorado and more northern areas, but the general association of forms and most of the species are entirely different. Its horizon is that of the lower part of the Montana group not far above the horizon of the Austin chalk and the Niobrara limestone, and hence apparently somewhat lower than the upper part of the Mancos as developed in southwestern Colorado. It is my judgment, therefore, that the base of the coal-bearing rocks in the central New Mexican fields mentioned is lower, perhaps by several hundred feet, than the base of the Mesaverde in the neighborhood of Durango, Colo. It is worthy of note that W. T. Lee's collections show a good development of the Benton fauna in the beds underlying those containing the fauna associated with the coal, and that this Benton fauna is with some additions essentially the same as that in the lower $\mathbf{4 0 0}$ feet of the Mancos shale in its type area and also in the Benton east of the mountains, in Colorado.

Distribution of Cretaceous invertebrates from southern Colorado and northern New Mexico.

[Identified by T. W: Stanton.]

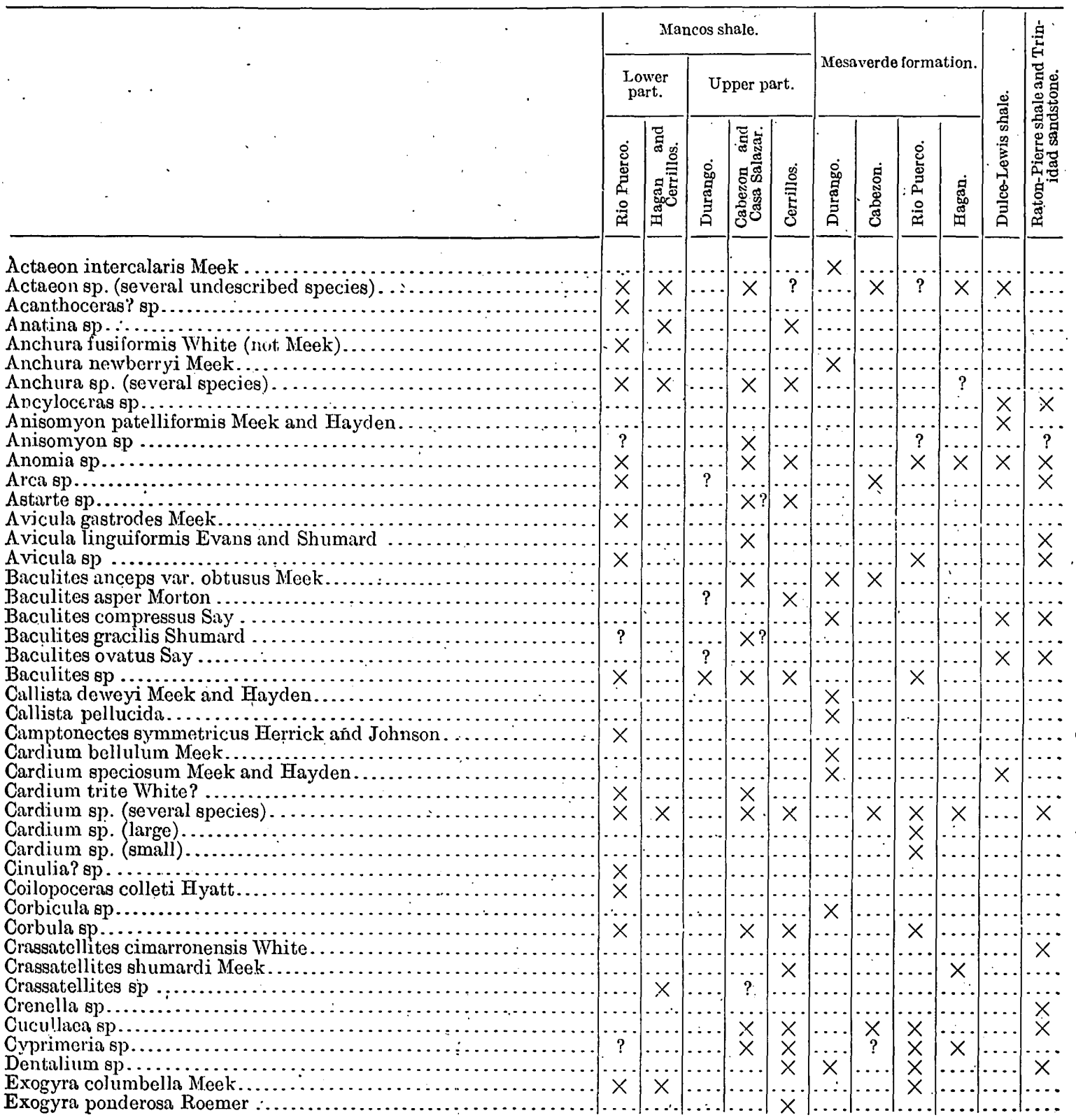


Distribution of Cretaceous invertebrates from southern Colorado and northern New Mexico-Continued.

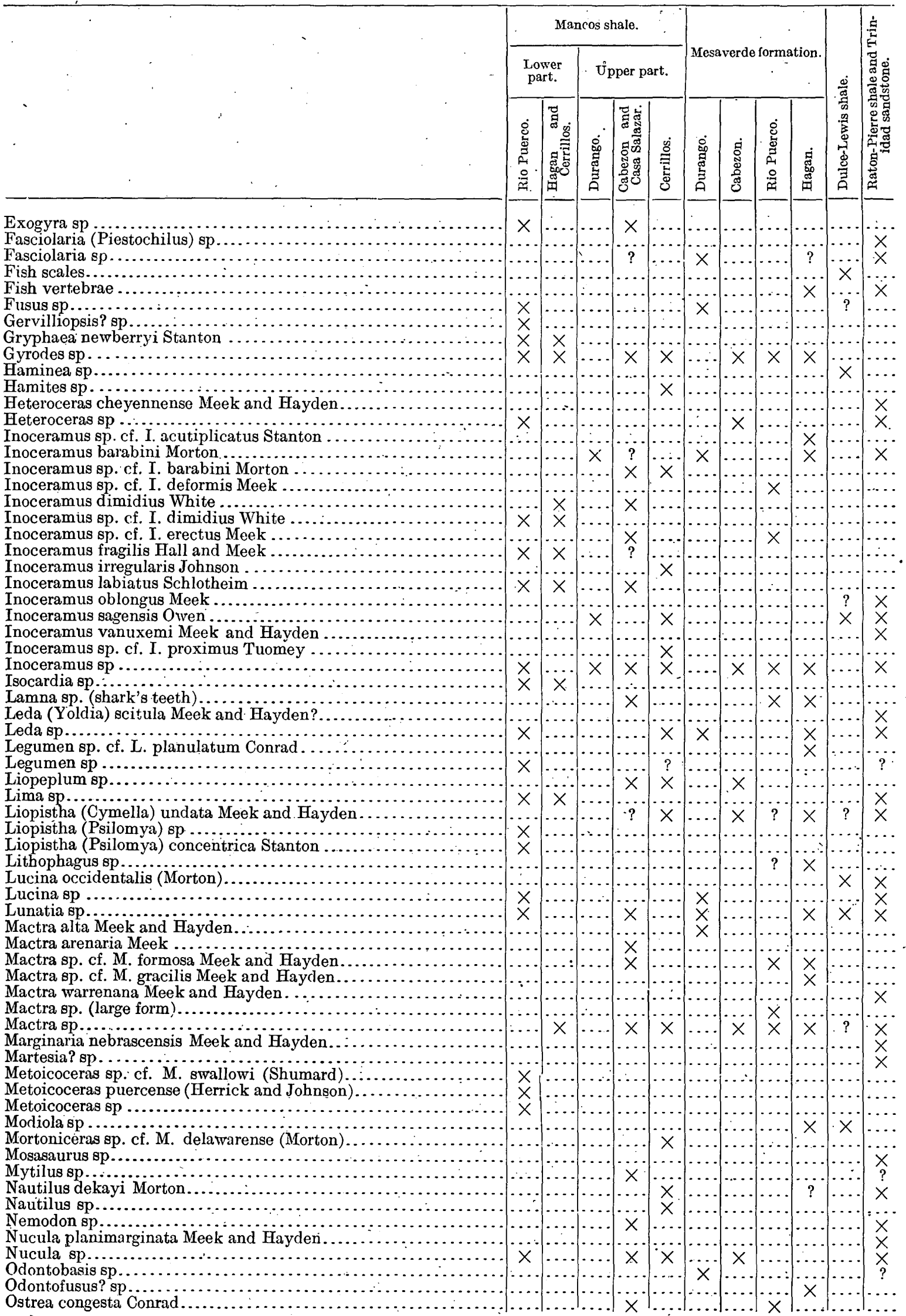


nistribution of Cretaceous invertebrates from southern Colorado and northern New Mexico-Continued.

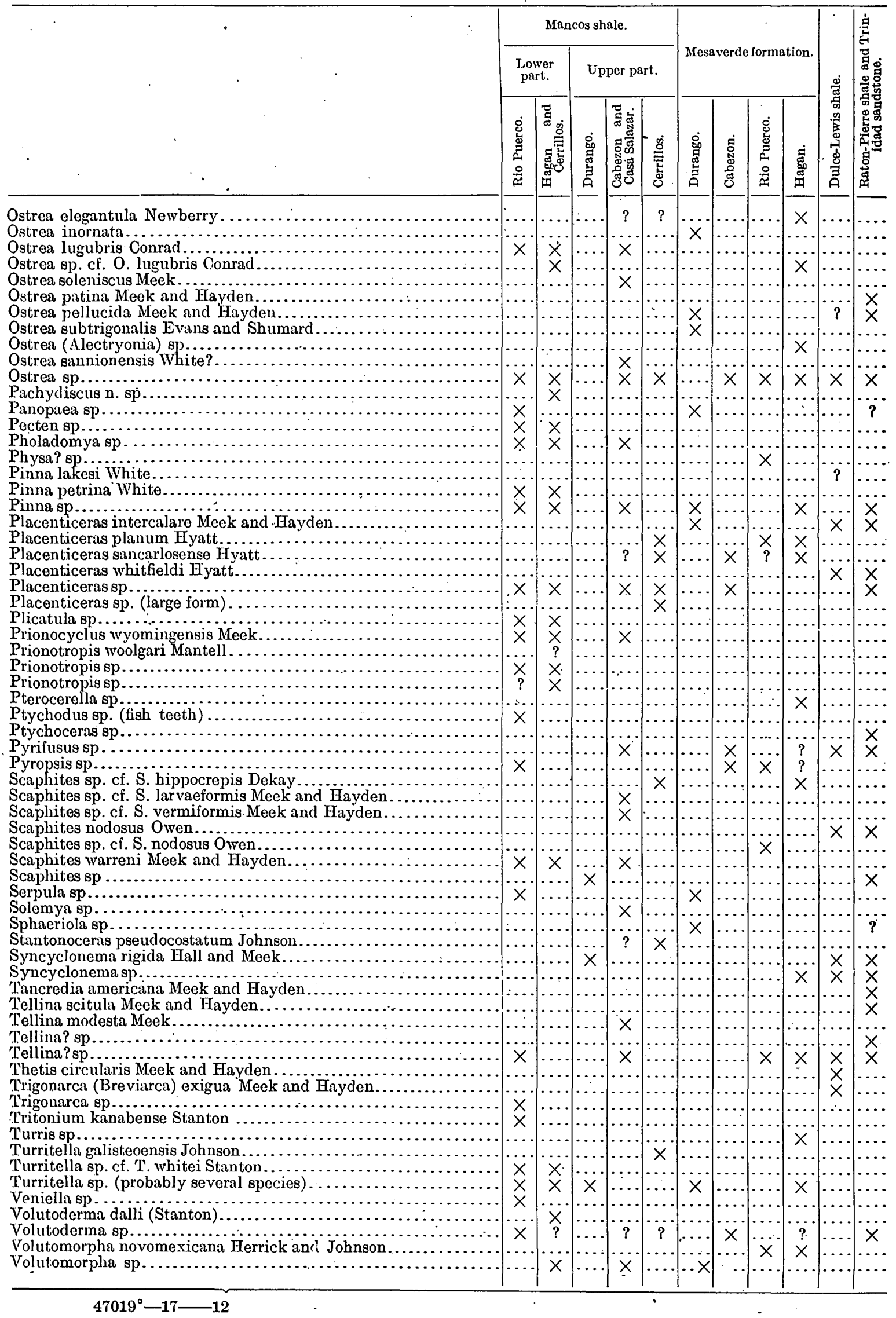




\section{MESAVERDE FORMATION.}

The Mesaverde consists principally of sandstone, shale, and coal. It is 423 feet thick near. Durango, Colo., and about the same at Monero, N. Mex., but is very much thicker farther south. Most of the sandstone is yellow and occurs in beds some of which are massive and thick, alternating with shale. In .some places the sandstone is more or less lenticular and contains irregular masses of impure limestone with great numbers of marine invertebrates. Some of the shale also contains marine fossils. These rocks alternate with those containing beds of coal and fossil plants.

Fossils were collected from the Mesaverde at many localities. Those collected where the sections were measured are denoted by lot numbers which identify them in the collections of the United States Geological Survey, and the same numbers are placed in the generalized sections in figure 13 to mark the horizons from which they came. Those collected at a distance from the measured sections are described apart from the sections. The species of each lot are named in the descriptions of the several fields (pp. 185-217), and their general grouping is presented in the preceding table.

Fossil plants occur at certain horizons in the Mesaverde of all coal fields in central New Mexico and in some places are numerous and well preserved, but they seem to be rare in the Mesaverde of northern New Mexico and southern Colorado. A large part of the flora consists of undescribed species and the lack of specific names in the table (pp. 175-177) is indicative not of poor material but of undescribed material, which in reality comprises beautifully preserved plants. Unlike the invertebrates whose nearest allies occur far south, some of the plants although not named are probably specifically identical with those from some of the coal fields to the north and east, and others are so similar to species found in those fields that they indicate essentially the same age.

The correlation by means of fossil plants of the Vermejo formation of the Raton Mesa region with the coal-bearing formations west of the mountains is discussed by Knowlton as follows:
The fossil plant material from the areas west of the mountains is very extensive but is not yet fully worked up, in fact is largely new to science, which accounts for the short list of species. However, it is not probable that any material change of opinion as regards stratigraphic position will result from the complete elaboration of the material, but rather that existing opinion will be strengthened by the recognition of a greater number of species common to the several areas.

Bearing in mind the above limitations, we may first consider the Vermejo flora of the Raton Mesa region. If, as has been suggested, the beds immediately below the Trinidad sandstone are to be correlated with the Lewis shale of the San Juan Basin, then the overlying coalbearing rocks might on stratigraphic grounds be presumed to belong to the Laramie. The plants found in these beds do not bear out this contention, for they have almost no affinity with the typical Laramie of the Denver Basin, only one species being common to the two. On the other hand, this flora has a positive and unmistakable affinity with the flora of the Mesaverde of the western slope of the mountains, and, to go farther afield, with the flora of the Rock Springs coal group (Mesaverde) of Point of Rocks, Wyo. When we find that such well-marked and hence unmistakable species as Sequoia obovita, Woodwardia crenata, Ficus speciosissima, Ficus praetrincrvis, Ficus wardii, Ficus starkvillensis, Sabal? ungeri (Geonomites of some writers), and Myrica torreyi, and a number of others, equally well marked but unnamed, are common to the floras of the Raton Mesa region and to one or the other of the areas above mentioned, we are inevitably led to the conclusion that they are essentially of the same age.

On the west side of the mountains, in the Cerrillos, Hagan, Tijeras, Rio Puerco, and Cabezon coal fields, the floras under discussion occur mainly in coal-bearing beds 400 to 600 feet above the base of the Mesaverde of this region, though some of them also range somewhat higher in the Montana, especially in the Durango field to the north. The relationship between these floras and that at Point of Rocks; Wyo., is rendered even closer than that already mentioned between the Raton Mesa region and Point of Rocks by the addition of such forms as Nelumbo intermedia, Trapa microphylla, Salix stantoni?, etc. There can be no doubt, it seems to me, that the floras of the Raton Mesa region, of the central and western New Mexican fields, and of the Point of Rocks field are essentially identical and hence perforce are of essentially the same age.

Collections of plants obtained near Dulce, N. Mex., and near Pagosa Junction and Durango, Colo., from coalbearing rocks above the Lewis shale have been referred to the so-called "Laramie" of this region. "These collections are very full and embrace a number of easily recognized species; hence their identification is satisfactory and complete. They prove clearly that these beds do not belong, to the Laramie, for so far as known to the writer not a single species in them has ever been found in beds of Laramie age. On the other hand, the plants beyond question belong to the Montana, for they include, for instance, Ficus speciosissima, Ficus praetrinervis, Ficus starkvillensis, and Sabal montana, which link them with the Mesaverde floras to the south and with the Vermejo 
flora already discussed in the Raton Mesa region. (See p. 54.) Associated with these, however, and tending to give them a slightly higher position although still within the Montana, are such forms as Brachyphyllum, Cunninghamites, Geinitziä, and Sequoia, all of which. are beyond doubt Montana types never found in the Laramie.

A number of collections were made by J. H. Gardner in the Ignacio quadrangle, east of Durango,. Colo., from beds regarded as the "Laramie" of that area. The plants in these collections, almost species by species, are identical with the forms from Dulce and near Durango, and I have no hesitation in saying that they occupy the same stratigraphic position and are the same in age, viz, Montana.

The lower Montana age of the principal coalbearing formation indicated by the fossil shells has already been stated in the quotation from Stanton (p. 175). The fossil plants indicate the same age, although some of the species occur at Coalville, Utah, in rocks generally regarded as older than Mesaverde and others in the socalled "Laramie" above the Lewis shale.

An effort was made to ascertain the relation of the coal-bearing rocks of central New Mexico to the Mesaverde formation of southwest Colorado, where this formation was originally named. Schrader traced the typical Mesaverde from Durango eastward and southward around

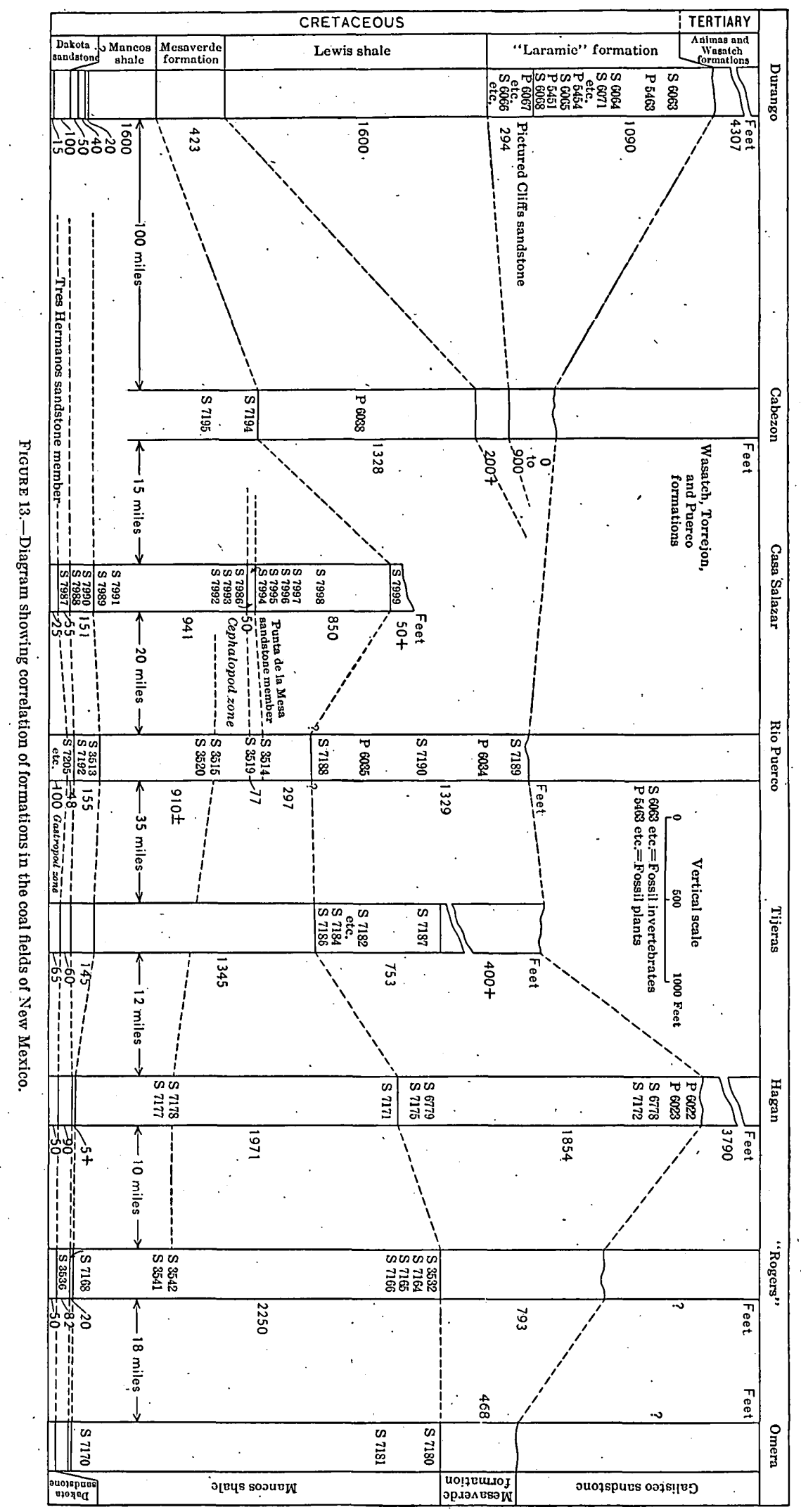


the San Juan Basin, but, not being satisfied that the coal-bearing rocks near Cabezon are to be correlated directly with the typical Mesaverde, he described them as the "lower Montana coal group; relation to Mesaverde unknown." However, Gardner, who later examined the same rocks, referred them definitely to the Mesaverde. ${ }^{212,222, ~ 223}$

The present writer visited the Durango region for the purpose principally of acquainting himself with the rocks originally named Mesaverde. It was thought that this region would be favorable for the collection of fossil plants, the Mesaverde coals having been extensively mined there. He also examined the coalbearing formation at Monero, N. Mex., and was convinced, as others have been, that it is equivalent to the Mesaverde of the Durango region. However, it was noted that the Mesaverde at Monero is only a few hundred feet thick (probably about the same as in the Durango region, where it is only 423 feet), and that the Mesaverde of Gardner's Arroyo Torreones section, ${ }^{222}$ measured a few miles northwest of Cabezon, is more than 1,300 feet thick.

It seems evident that the Mesaverde of the Torreones section includes more than the Mesaverde of the Monero section. It has been shown elsewhere in this paper that the basal sandstone of the Mesaverde is probably the same in both places and that the upper part of the Mesaverde of the Torreones section is probably the time equivalent of the lower part of the Lewis shale of the Monero region.

A somewhat hasty examination of the rocks between Monero and Cabezon. convinced the writer that the base of the Mesaverde as described by Schrader and Gardner is essentially the same at both localities, and that the upper part of it near Cabezon is probably equivalent in age to the lower part of the Lewis shale as developed near Monero. This has been described in a paper by the writer previously published. ${ }^{245}$ The coal-bearing formation of the Rio Puerco field is essentially equivalent in age to the Mesaverde of the San Juan Basin but is underlain by sandstone and sandy shale, formerly. included in the Mesaverde but now known by lateral tracing to be equivalent in age to the upper part of the Mancos shale. In brief, it may be stated that, except for the variations noted in the upper and lower limits of the formation, the lower group of coal-bearing rocks of all the fields here described that lie in central New Mexico west of the mountains is stratigraphically identical with the Mesaverde of the San Juan Basin. 
Distribution of fossil plants Jrom the Mesaverde and so-called "Laramie" formations of central and western New Mexico and southwestern Colorado. [Identified by F. H. Knowlton.]

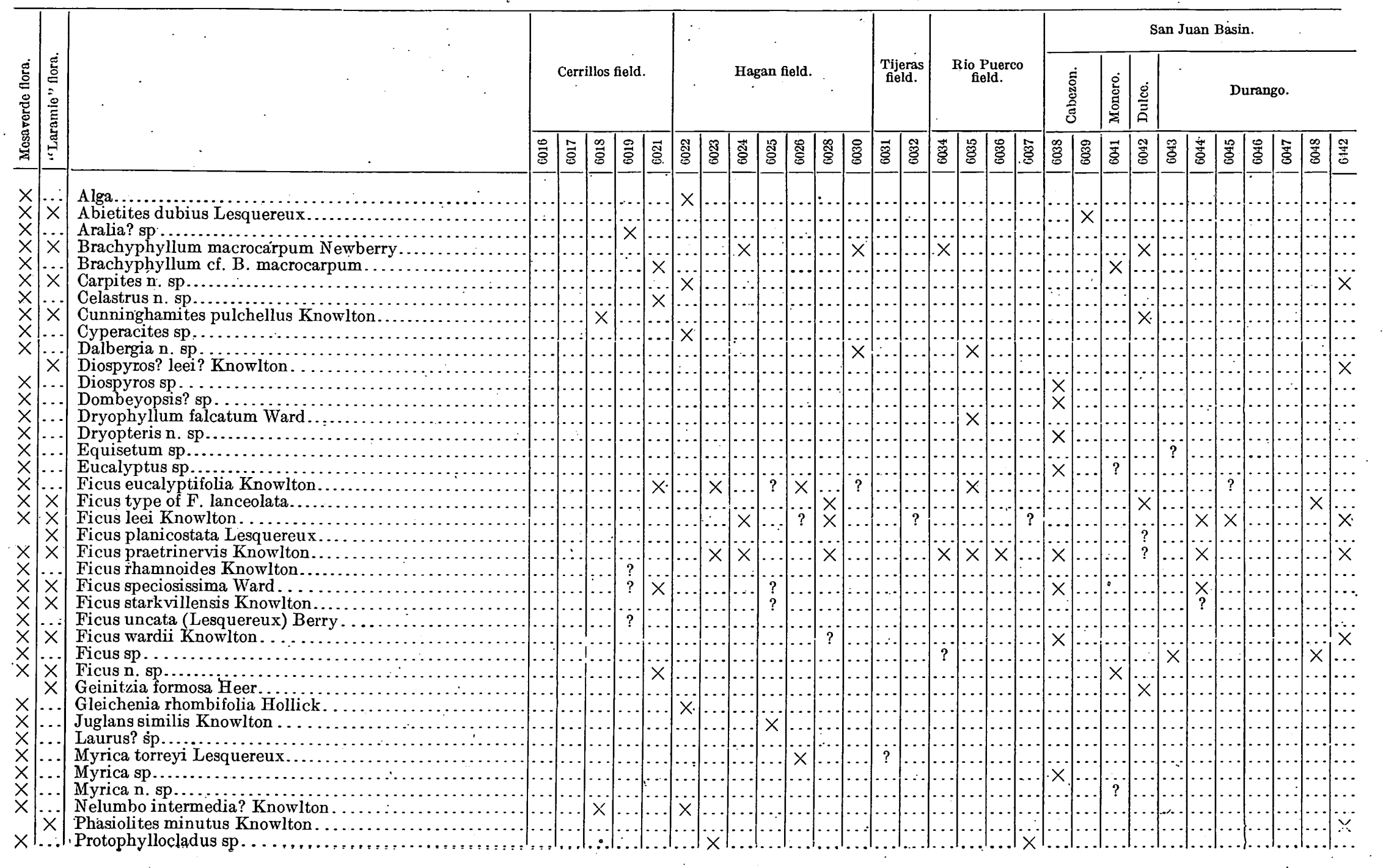


Distribution of fossilplants from the Mesaverde and so-called "Laramie". formations of central and western New Mexico and southwestern Colorado-Continued.

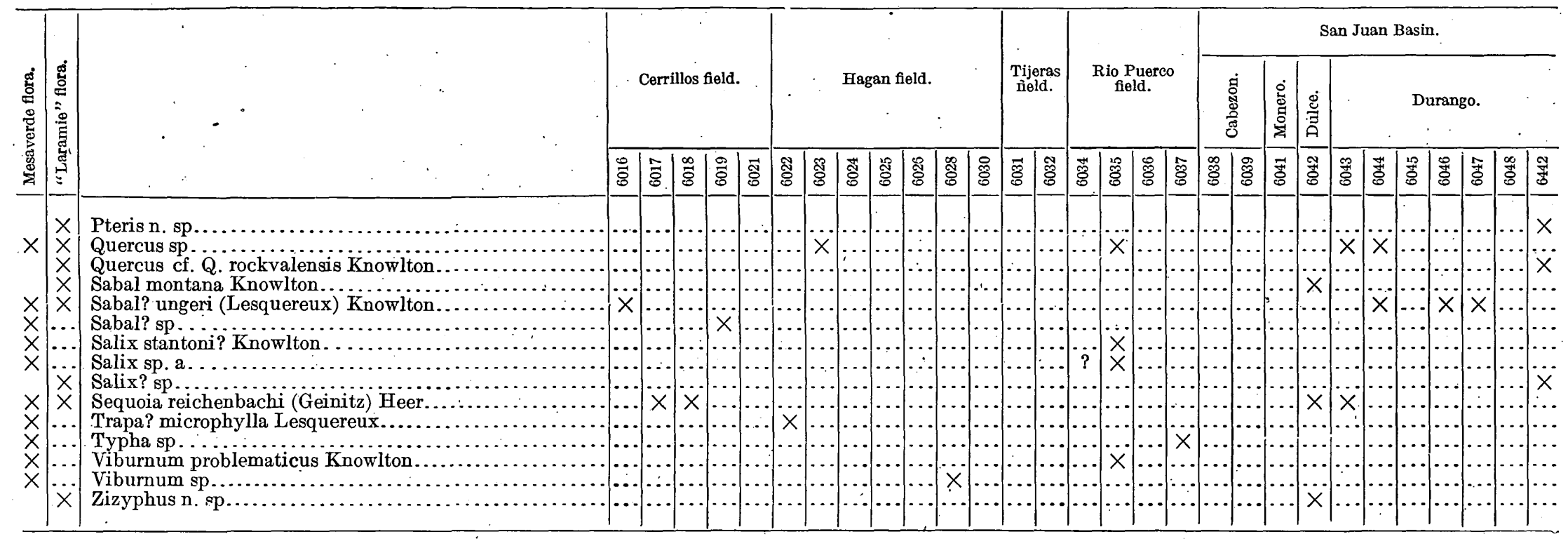


LEWIS SHALE.

The Lewis shale is known to occur in the region described in this paper in the San Juan Basin only. It is 1,600 feet thick near Durango on the northern rim of the basin and is possibly thicker in some other places. According to Schrader ${ }^{200}$ its maximum thickness is 2,500 - feet. It thins sharply southward, and at its outcrop in the southern parts of the basin is about 200 feet thick.222 Gardner ${ }^{212}$ states that it is 2,000 feet thick near Gallina" and that on the Arroyo Torreones, about 30 miles southwest of Gallina, it is only 250 feet thick." No explanation of this great variation in thickness can be given, but the suggestion previously noted seems pertinent, that the Lewis may become sandy and coal bearing to the south and may thus be equivalent in age to the upper part in the Mesaverde of the Cabezon region. In this connection it may be noted that a shale of marine origin nearly twice as thick as the Lewis of the Arroyo Torreones section occurs in the midst of the Mesaverde in the Rio Puerco field and that a sandy shale of marine origin of nearly the same thickness occurs in the Tijeras field above the principal group of coals. Because the fossils from these shales do not differ notably from those of the coal-bearing rocks above and below them the shales are regarded as probably parts of the Mesaverde formation. However, it is entirely possible that when the faunas and floras of this region are better known some of the rocks here described as Mesaverde may. prove to be equivalent in age to a part of the Lewis shale.

Few fossils have hitherto been collected from the Lewis shale of the southwest. Baculites asper ${ }^{141}$ was found in it in southwest Colorado, and a few fossil shells were found by Gardner southeast of Raton Springs. These, together with the shells collected by the present writer near Dulce (localities 7200 and 7201), àre sufficient to make rather definite the correlation of the Lewis shale with the top of the Pierre of the Raton coal field. The fossils are named and their relation to those collected in the Raton field indicated in table of invertebrates (pp.175-177):

$$
\text { "LARAMIE" FORMATION. }
$$

The "Laramie" formation occurs within the area described in this part of the paper only in the San Juan Basin. It is 600 feet thick near Durango and nearly as thick in the southern rim of the basin, ${ }^{212}$ but is thinner in the eastern rim, probably owing to post-Cretaceous erosion. At Dulce it is only 225 feet thick. This formation lies conformably on the Lewis shale, and (probably for this reason more than for any other) it has been called Laramie, although Cross ${ }^{141}$ several years ago called attention to the fact that investigation had "failed to bring to light valid ground for assigning any of the beds in question to the Laramie, while there is some reason to believe that more than the lower sandstone belongs to the Montana group." Since that time a considerable number of fossils, both invertebrates and plants, have been collected from these beds in the Durango region. The base of the formation, the Pictured Cliffs sandstone, contains marine and brackish-water invertebrates, and the lower part of the coal-bearing rocks above this sandstone contains brackish-water and fresh-water invertebrates. Several of these fossils occur in the Mesaverde of other fields. But higher in the formation the writer found fresh-water: invertebrates which Stanton regards as Laramie, together with fossil plants which Knowlton regards as older than Laramie. The fossil plants have been included in the table on pages 181-182, from which and from the accompanying statement by Knowlton it will be seen that the flora differs but little from that of the Mesaverde and is regarded as indicating Montana age.

The name "Laramie" is here used for this formation, not because the writer wishes to argue for the Laramie age of the rocks, but because the name is in use and because in this part of the paper he is intentionally avoiding the introduction of: new formation names. It must be noted, however, that though the formation is called "Laramie," it contains a flora which, according to Knowlton, denotes Montana age and includes nothing in common with the Laramie flora of the Denver Basin.

Whether the formation will eventually be called Laramie or be designated in some other way depends largely on the final use of that somewhat migratory name. But in view of the fact that many of the species of marine and brackish-water invertebrates from the lower part of the formation occur in the Mesaverde of other localities,' as for example in 
the Grand Mesa field of western Colorado; that many of the invertebrates are species of fresh-water origin which many geologists regard as unreliable for purposes of correlation; and that the plants are of Montana types, serious doubt is cast on the Laramie age of the formation. ${ }^{1}$

\section{TERTIARY AND LATER FORMATIONS.}

It is not the purpose of the writer to enter at this time into a discussion of the Tertiary and later formations of New Mexico further than is necessary to show that in all of the coal fields described rocks of probable Tertiary age lie unconformably on rocks of unquestioned Cretaceous age. In the Durango region the "Laramie" is overlain unconformably by the Animas formation, which has been regarded generally as the time equivalent of the Denver. This correlation places the Animas formation at the base of the Tertiary according to the classification advocated in this paper, and the writer has accepted this correlation because of the structural relations. ${ }^{249}$. Rocks that seem to be equivalent in age to the Animas rest unconformably on the "Laramie" near Pagosa Junction, Colo., and at Dulce, N. Mex. Farther to the south in the San Juan basin the oldest known Tertiary rocks-the Puerco formationlie unconformably on the "Laramie" in some places and on the Lewis shale in other places. ${ }^{223}$

In the Rio Puerco field rocks that are lithologically similar to the Wasatch of the San Juan basin lie unconformably on the Mesaverde. They are varicolored, with yellow, pink, and red shales predominating, and although they have never been measured they are comparable in thickness to the Tertiary formations of that basin. Thiese rocks consist of sandstone, conglomerate, and shale, all of which are poorly consolidated. The upper part is light colored and seems to be referable to the

I Since this paper was written detailed work has been done in small area in northwestern New Mexico that includes the so-called

"Laramie" formation. The rocks were subdivided by Bauer, 251 who gave local names to the subdivisions. The fossil dinosaurs collected by Bauer's party have been studied by Gilmore, 251a who concludes that the beds are older than Lance and probably synchronous with the Judith River and Belly River formations. Stanton 2 itb has studied the fossil invertebrates and states that the beds "may include the equivalents of everything from the Fox Hills to the Lance, inclusive." Knowlton 2510 has studied the fossil plants and concludes that the plant-bearing beds, "the Fruilland and Kirtland formations, are of Montana age."
Santa Fe marl, the type locality of which is a few miles east of the Rio Puerco field.

No rocks referable to the Tertiary were found in the Tijeras field, but in the Hagan field a series of beds comparable in thickness, lithologic character, and general appearance to the Tertiary of the Rio Puerco field rest unconformably on the Mesaverde. These beds contain great quantities of petrified wood, but no other fossils were found in them that make possible the determination of their age. The Hagan and Rio Puerco fields are only about 30 miles apart, and it is difficult to believe that the rocks of these two fields, which are comparable in every other way, differ in age to any great extent.

In the Cerrillos field, rocks that are lithologically similar to the Tertiary rocks of the Hagan and Rio Puerco fields and the San Juan basin," lie unconformably on the Mesaverde. They constitute a formation known as the Galisteo sandstone, the lower part of which consists of conglomeratic sandstone and shale identical in character and appearance to those of the Hagan field 10 miles to the west, but the upper parts are coarser and contain large angular blocks of many kinds of rock, including quartzite and crystalline rocks such as are now exposed in the mountains a few miles to the northeast, limestone containing Carboniferous fossils and sandstone. Rock formations, from which these blocks were probably derived, are now found upturned and eroded on the flanks of the mountains. The Galisteo sandstone is many hundreds of feet in thickness and may include two or more formations, but it has not been studied with a view to subdividing it into formations or of making exact correlations with formations of other fields. The Galisteo is the so-called "Cretaceous red beds" of the Cerrillos region. Hayden, ${ }^{29}$ who named the formation, regarded it as Tertiary, and correlated it with the "Monument Creek" of the Denver region, the lower part of which has recently been named the Dawson arkose ${ }^{234}$ and correlated with the Arapahoe and Denver formations. J. J. Stevenson ${ }^{89}$ failed to separate the Galisteo from the underlying coal measures and referred both formations to the Laramie. D. W. Johnson ${ }^{161}$ also failed to recognize the unconformity at the base and included the lower part of the Galisteo sand- 
stone in his Madrid group; which he referred to the Fox Hills. He referred the upper part of the Gralisteo to the Laramie. Little has been found in the Gralisteo to establish its geologic age. It contains great numbers - of petrified logs, which are beautifully preserved in external form, but the cellular structure of the wood is not well retained and no specific identifications have been made. The best-known locality at which these logs occur is a few miles east of Cerrillos in the so-called petrified forest, where there are many logs 25 to 75 feet or more in length. Logs have been found in this formation in many other places in a much better state of preservation. Fossil leaves have also been found in a few places, but their preservation is poor and few have been specifically identified. All things considered, it is probable that the Galisteo sandstone should be correlated with Tertiary formations farther west that are similar to it in character and stratigraphic position. (See fig. 13, p. 179.)

\section{LOCAI FEATURES IN DETAIL. \\ DURANGO.}

In 1899 Whitman Cross ${ }^{141}$ published a section of the Cretaceous rocks that has become the standaid for southwestern Colorado and western New Mexico. The section divides the Cretaceous into Dakota sandstone, Mancos shale (equivalent in age to Benton; Niobrara, and a part of the Pierre), Mesaverde formation, Lewis shale, Pictured Cliffs sandstone, and a series of coal-bearing rocks which had previously been referred to the Laramie formation, but whose identification was questioned by Cross. ${ }^{1}$ The Pictured Cliffs sandstone is now regarded as the basal member of the "Laramie" formation. The Animas formation, lying unconformably on the so-called Laramie, was correlated with the post-Laramie formations of the Denver Basin and elsewhere which were then generally referred to the Cretaceous, but which are now referred to the Tertiary.

This subdivision of the Cretaceous finds expression in a section measured by J. H. Gardner a few miles east of Durango for use in the Ignacio folio of the United States Geological Survey, now in preparation. At the writer's request Gardner prepared the following section:

\footnotetext{
1 See footnote, p. 184 .
}

Section of rocks measured on Florida River near Durango, Colo. (except the Wasatch, which was measured farther east).

Wasatch formation:

[Data furnished by J. H. Gardner.]

Sandstone, massive ledges, coarse grained, tan-colored, with thin beds of shale..... Sandstone alternating with beds of shale..

Sandstone, massive, tan-colored...........

Shale, variegated, and thin sandstone......

Sandstone, massive, coarse grained, gray..

Shale, gray and drab..................

Sandstone, tan-colored, coarse grained, with lenses of colored quartz and chert, about the size of a bird egg............

Shale, variegated, with lenticular beds of brown and gray sandstone.............

Shale, variegated with benches of gray sandstone and thin ferruginous sandstone and sandy shale...............

Sandstone, massive, soft, gray..........

Shale, variegated . . . . . . . . . . . . . . .

Sandstone, massive, coarse grained, dark gray but locally purplish-brown.........

Shale, variegated with brown, reddish, gray, and drab, with thin beds of brown and gray sandstone . ................

Shale, brownish and reddish, with lenses of conglomeratic sandstone; pebbles of colored quartz and chert chiefly ........ Shale, yellowish and gray............... Sandstone with small pebbles of quartz.... Shale, yellowish, drab, and gray..........

Shale, tan-colored and reddish at the base, containing Platanus raynoldsii Newberry? at the base (U. S. Geol. Survey fossil locality 5666)......................

\begin{tabular}{rr}
$250 \quad 0$ \\
\hline $2,275 \quad 0$ \\
\hline
\end{tabular}

Lithologic contrast; unconformity not perceptible where section was measured.

Animas formation:

Sandstone, massive, tan-colored, micaceous with greenish igneous débris, alternating with yellowish shale.................

Shale, brown, drab, gray, and some reddish.

Sandstone, tan-colored, alternating with heavy beds of brown, greenish, drab, and yellowish shale, containing Ficus sp., Laurus sp., Platanus cf. P. guillelmae Göppert, 109 feet from the top (U. S. Geol. Survey fossil locality 5455), and Artocarpus lessigiana (Lesquereux) Knowlton and Nyssa racemosa? Knowlton, 275 feet from the top (U. S. Geol. Survey fossil

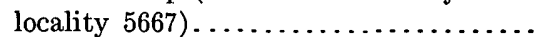

Sandstone, greenish gray, with small igneous pebbles one-fourth inch in diameter in irregular zones. . . . . . . . . . . . . . . . Shale and sandstone, greenish, locally conglomeratic......................

\begin{tabular}{rr} 
Ft. & in. \\
80 & 0 \\
70 & 0 \\
20 & 0 \\
100 & 0 \\
30 & 0 \\
50 & 0 \\
& \\
20 & 0 \\
& \\
400 & 0 \\
& \\
& \\
660 & 0 \\
20 & 0 \\
50 & 0 \\
& \\
4 & 0 \\
& \\
& \\
325 & 0 \\
& \\
\hline 85 & 0 \\
.50 & 0 \\
1 & 0 \\
60 & 0
\end{tabular}

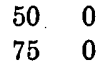

8550

$\cdot 50 \quad 0$

$250 \quad 0$ 
Animas tormation-Continued.

Shale, greenish.......................
Sandstone, greenish and pink with pebbles of schist and quartzite chiefly; pebbles 1 to 10 inches. . . . . . . . . . . . . . . . .

Shale, greenish..................... Sandstone, greenish gray, coarse, friable...

- Shale, greenish, and conglomeratic sandstone.

Shale, carbonaceous..................

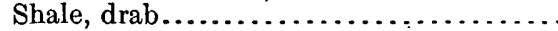

Shale, carbonaceous...................

Shale, greenish, with silicified wood ......

Sandstone, gray and ferruginous, with sandstone concretions....................

Shale, dark red, bluish, and drab..........

Sandstone, argillaceous, with andesite and other igneous pebbles and tuffs........

Sandstone and shale with igneous matrix and pebbles.

Shale, greenish and purple.............

Sandstone, yellowish....................

Shale, greenish, purple, and bluish.......

Sandstone, massive, poorly consolidated, yellowish-white, and cross-bedded; contains Ficus planicostata Lesquereux at the base (U. S. Geol. Survey fossil locality 5456)

Sandstone, argillaceous, and some shale; igneous matrix

Tuff, coarse fragments of different composition ..............................

Shale, reddish alternating with dark conglomerate and sedimentary débris......

Tuff, reddish and pìnk, coarse grained....

Sandstone, brown, fine grained; with round sandstone concretions...................

Shale, irregularly bedded, gray, friable...

Sandstone, brown, coarse grained; igneous matrix.

Sandstone, yellowish and locally reddish.

Sandstone, drab-colored, weathers reddish; igneous matrix

\begin{tabular}{rr}
15 & 0 \\
\hline 2,091 & 8 \\
\hline
\end{tabular}

Unconformity by erosion, and discordance of dip.

"Laramie" formation (upper part):

Shale, yellowish, with sometimes a white sandstone near the top.

Shale, drab-colored, with some thin sandstone.

Sandstone, massive, light colored.........

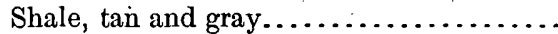

Sandstone, massive, soft, gray...........

Shale and soft sandstone containing at the base (U. S. Geol. Survey fossil 6063) Unio holmesianus White, Unio sp., Corbicula sp., Corbula subtrigonalis Meek and Hayden, Tulotoma thompsoni White, Goniobasis? sp., Campeloma? sp............

100
20
12

20
Ft. in. "Laramie" formation (upper part)-Contd.

$60 \quad 0$. Sandstone, massive, rather hard, gray ..... Shale, brownish, and thin, soft sandstone. Sandstone, friable, gray................. Sandstone, brown, containing Brachyphyllum macrocarpum Newberry and Sequoia reichenbachi (Geinitz) Heer (U. S. Geol. Survey. fossil locality 5462$). . . \ldots \ldots \ldots$. Sandstone, gray ........................ Shale and some thin sandstone........... Shale and thin sandstone, containing Sequoia reichenbachi (Geinitz) Heer, Carpites sp., Juglans sp., Salix sp.? (U. S. Geol. Survey fossil locality 5463). Coal bed.

Shale and thin sandstone.................

Sandstone, soft in several beds.............

Shale.............................

Coal bed C.........................

Shale, carbonaceous................... Coal bed..

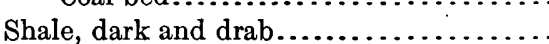

Sandstone, massive, gray with calcareous

layer near base.....................

Sandstone and shale, containing Pholas? sp., Goniobasis? sp., Campeloma? sp., Viviparus sp., 43 feet above the base (U. S. Geol. Survey fossil locality 6064) and fossil plants at the base.................

Shale, containing both fresh-water and brackish-water invertebrates as follows: Unio brachyopisthus White, Unio holmesianus White, Unio 2 undescribed (?) species, Sphaerium sp., Martesia? sp.; Viviparus sp., Campeloma? sp.; Tulotoma thompsoni White, Ostrea sp., Corbicula sp. related to C. subelliptica Meek and Hayden, Corbicula sp., Corbula sp., Melania sp. (U. S. Geol. Survey fossil localities 6071, 6072, and 6074)........ Coal bed B......................

Shale and thin sandstone, containing, 15 feet from the top (U. S. Geol. Survey fossil locality 6065), Ostrea sp., Anomia sp., Modiola laticostata White, Corbula subtrigonalis Meek and Hayden?, 20 feet from the base (U. S. Geol. Survey fossil locality 5453) are the fossil plants Sequoia reichenbachi (Geinitz) Heer, Quercus sp., and at the base (U.S. Geol. Survey fossil locality 6068) both shells and plants, Anomia sp., Corbula subtrigonalis Meek and Hayden?, Cypris? sp., and Melania sp. and (U.S. Geol. Survey fossil locality 5451) Brachyphyllum macrocarpum Newberry, Geinitzia formosa Heer, Sequoia. reichenbachi (Geinitz) Heer............

Coal bed A. . . . . . . . . . . . . . . . .

Shale, dark and drab................. $4 \quad 4$
Ft. in:

200

$320 \quad 0$

6

$2{ }^{-} 0$

150

$30 \quad 0$

$150 \quad 0$

100

$12 \quad 2$

190

110

350

.80

$\begin{array}{ll}3 & 1\end{array}$

150

$20 \quad 0$

$50 \quad 0$ 
Pictured Cliffs sandstone member of "Laramie" formation:

Sandstone, gray, massive, top of Pictured Cliffs sandstone (U. S. Geol. Survey fossil localities 6067, 6069, 6070), containing both invertebrates and plants, Ostrea sp., Inoccramus barabini Mortimer, Cardium speciosum Meek and Hayden, Tellina scitula Meek and Hayden, Anomia sp., Corbula subtrigonalis Meek and Hayden?, and (U. S. Geol. Survey fossil localities 5446 and 5448) Geinitzia formosa Heer?, Abietites dubius Lesquereux.............

Shale, drab..........................

Sandstone, massive, brownish...........

Shale, carbonaceous and coaly.............

Shale, drab.........................

Sandstone, massive, gray..............

Sandstone, massive, gray, with some alternating shale beds, bottom of Pictured Cliffs sandstone (U. S. Geol. Survey fossil locality 6066), containing at the base Ostrea sp., Inoceramus sp., Corbula sp., Odontobasis? sp.....................

Transition sandy shales with beds of sandstone 6 inches to 1 foot thick.

Lewis shale

Mesaverde formation:

Sandstone, massive, light gray. .........

Shale and sandstone.....................

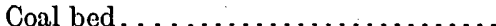

Sandstone and shale....................

Sandstone, massiye, gray................

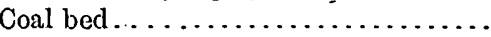

Shale and sandstone................. Coal bed. . . . . . . . . . . . . . . .

Shale. . . ........................... Coal bed.........................

Shale. . . . . . . . . . . . . . . . . . . Coal bed. . . . . . . . . . . . . . . . .

Shale and sandstone................... Coal bed. . . . . . . . . . . . . . . . .

Shale...........................

Coal streak sometimes present here.

Sandstone, massive, gray; containing Ficus lanciolata? Heer.

Mancos shale:

Shale with transitional beds of thin sandstone and shale at the top, containing Gryphaea newberryi Stanton, 1,200 to 2,000 feet thick; 60 feet above the base.. 1, 600

Dakota sandstone and sandstones at base of Mancos:

Sandlstone, massive, gray, quartzose.......

Shale, dark and gray, with local thin coal beds and some shaly sandstone. . . . . ....

Sandstone, massive, gray, quartzose.......

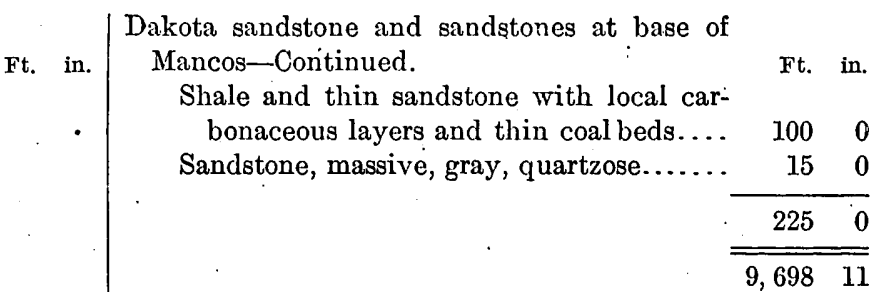

In order to correlate the formations described from central New Mexico with those of the Durango region the writer made a somewhat hasty trip to Durango, where the Cretaceous formations are well exposed along Animas River. Careful search was made for fossils in the Mesaverde, Lewis, and "Laramie" formations. None was found in the Lewis, and the Mesaverde was disappointing collecting ground, although a few shells and poorly preserved fossil plants were found in it. Half a mile west of Twin Buttes, at the mouth of the gulch entering Lightner Creek from the west (U. S. Geol. Survey fossil locality 6043), Equisetum sp., Sequoia reichenbachi (Geinitz) Heer, fern, Quercus sp., Quercus n. sp., palm, and Ficus sp. were found, but most of them are too poorly preserved to be specifically identified. In this gulch, half a mile farther west, Baculites anceps var. obtusus Meek was found above the main coal beds. A single palm; Sabal? ungeri (Lesquereux) Knowlton was found on the dump of an old mine in the Mesaverde coal, which opens in the gulch about a mile south of the Durango smelter (U. S. Geol. Survey fossil locality 6046); and on the dump of another mine in Horse Gulch, in the same coal measures, about half a mile. east of Durango (U. S. Geol. Survey fossil locality 6048), Ficus type of F. lanceolata Heer and Ficus sp. were found. The fossil plants seemed to be confined to very restricted zones closely associated with the coal. Baculites anceps var. obtusus Meek was found in the Mesaverde above the coal in several places near Durango. Such limited observi tions as were made in this region gave the impression that the Mesaverde is here essentially a marine formation, and this seems to be verified by the work of other geologists.

Fossils collected from the Mesaverde several years ago and identified by Stanton are as follows: 
Mesaverde fossils from southwestern Colorado. [Collected by Robert Forrester.]

Anchura newberryi Meek:

Acteon intercalaris Meek.

Baculites anceps var. obtusus Meek.

Baculites compressus Say.

Callista deweyi Meek and Hayden.

Cardium bellulum Meek.

Cardium speciosum Meek and Hayden.

Dentalium sp.

Fasciolaria sp.

Fusus sp.

Inoceramus barabini Morton.

Lucina sp.

Lunatia sp.

Odontobasis sp.

Ostrea subtrigonalis Evans and Shumard.

Pinna sp.

Panopaea sp.

Placenticeras intercalare Meek and Hayden.

Serpula sp.

Sphaeriola sp. .

Turritella sp.

The coal-bearing formation above the Lewis shale, near Durango, has somewhat generally been regarded as Laramie because of its stratigraphic position. These beds were found to be very fossiliferous in some places. Some of the fossils throw doubt on the Laramie age of the formation, but for the purposes of this paper it will be called "Laramie" in order to avoid introducing a new name. Gardner found several fossils in it. The best collection obtained from it by the writer contains both plants and invertebrates, found in the west wall of Animas Canyon, half a mile south of Carbon Junction, about 200 feet above the lowest or principal bed of coal. A few fossil plants were collected from lower horizons in the same formation near this locality by J. A. Taff in 1906 and by J. H. Gardner in 1909. In order to make the flora of this locality complete, these have been included in the following list and are marked *:

Fossils collected from the "Laramie" on or near Animas River, in the Durango region, Colo.

Plants (U. S. Geol. Survey fossil localitys 6044):

Ficus speciosissima Ward.

Ficus praetrinervis Knowlton.

Ficus leei Knowlton.

Ficus starkvillensis? Knowlton.

Quercus n. sp.

Sabal? ungeri (Lesquereux) Knowlton.

*Abietites dubius Lesquereux.

*Brachyphyllum macrocarpum Newberry.

${ }^{*}$ Carpites sp.

*Geinitzia formosa Heer.

*Sequoia reichenbachi (Geinitz) Heer.
Shells (U. S. Geol. Survey fossil locality 7197):

Unio holmesianus White.

Unio sp. related to U. aldrichi White.

Unio sp.

Neritina sp.

Tulotoma thompsoni White?

Campeloma? sp.

Viviparus sp.

In commenting on the age of these fossils Knowlton says of the plants: "Notwithstanding the fact that this collection is from rocks generally regarded as of Laramie age, there is not a single species in it that suggests the Laramie [of the Denver Basin]. It is the same flora as that at Point of Rocks, Wyo., and so far as I can see is of the same age, namely, Montana."

The shells collected by the writer are beautifully preserved, but they are of fresh-water species. Stanton says of them: "I consider this a Laramie fauna. The unios are Lance types and the gastropods are of types that range from Mesaverde to Lance."

In addition to the fossils named above, a number of invertebrates have been collected from the "Laramie" of southwest Colorado by Robert Forrester ${ }^{218}$ and J. A. Taff. Their collections have been joined with those of the writer and of Gardner in the following list, which . includes all the invertebrates known from the "Laramie" of southwest Colorado. The marine forms come from the Pictured Cliffs sandstone member and the brackish-water forms mainly from the lower part of the overlying shaly portion of the "Laramie" formation, above the principal coal bed. The fresh-water forms collected by the writer were found above the principal beds of coal, but Gardner reports many of them in close association with the coals.

Fossil invertebrates of the "Laramie" formation of south. west Colorado.

Anomia sp. related to A. micronema Meek.

Anomia sp.

Campeloma? sp.

Cardium speciosum Meek and Hayden.

Corbicula sp. related to C. subelliptica Meek and Hayden.

Corbicula occidentalis Meek and Hayden.,

Corbicula sp.

Corbula undifera Meek.

Corbula subtrigonalis Meek and Hayden.

Corbula sp.

Cypris? sp.

Goniobasis? sp. 


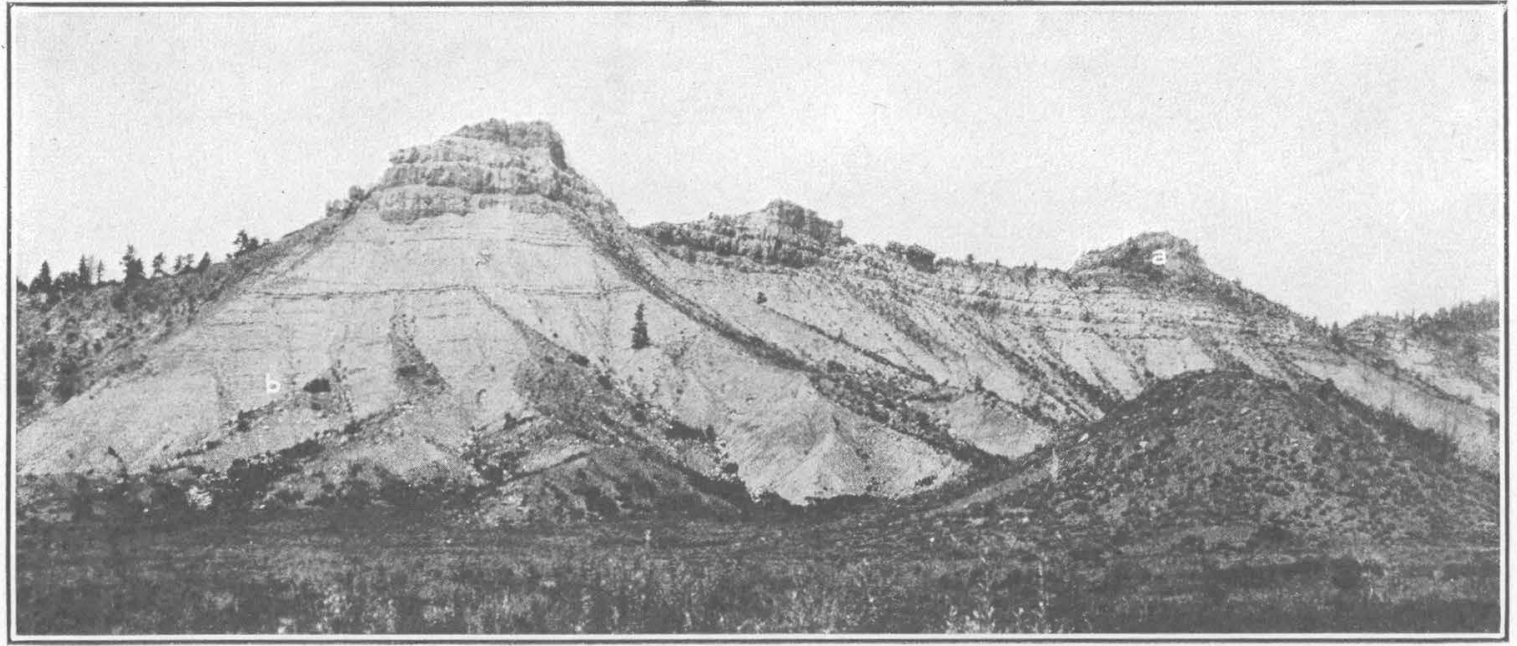

A. LEWIS SHALE AND "LARAMIE" FORMATION NEAR DULCE, N. MEX.

$a$, Coal bed, fossil plant locality; $b$, locality yielding fossil marine invertebrates.

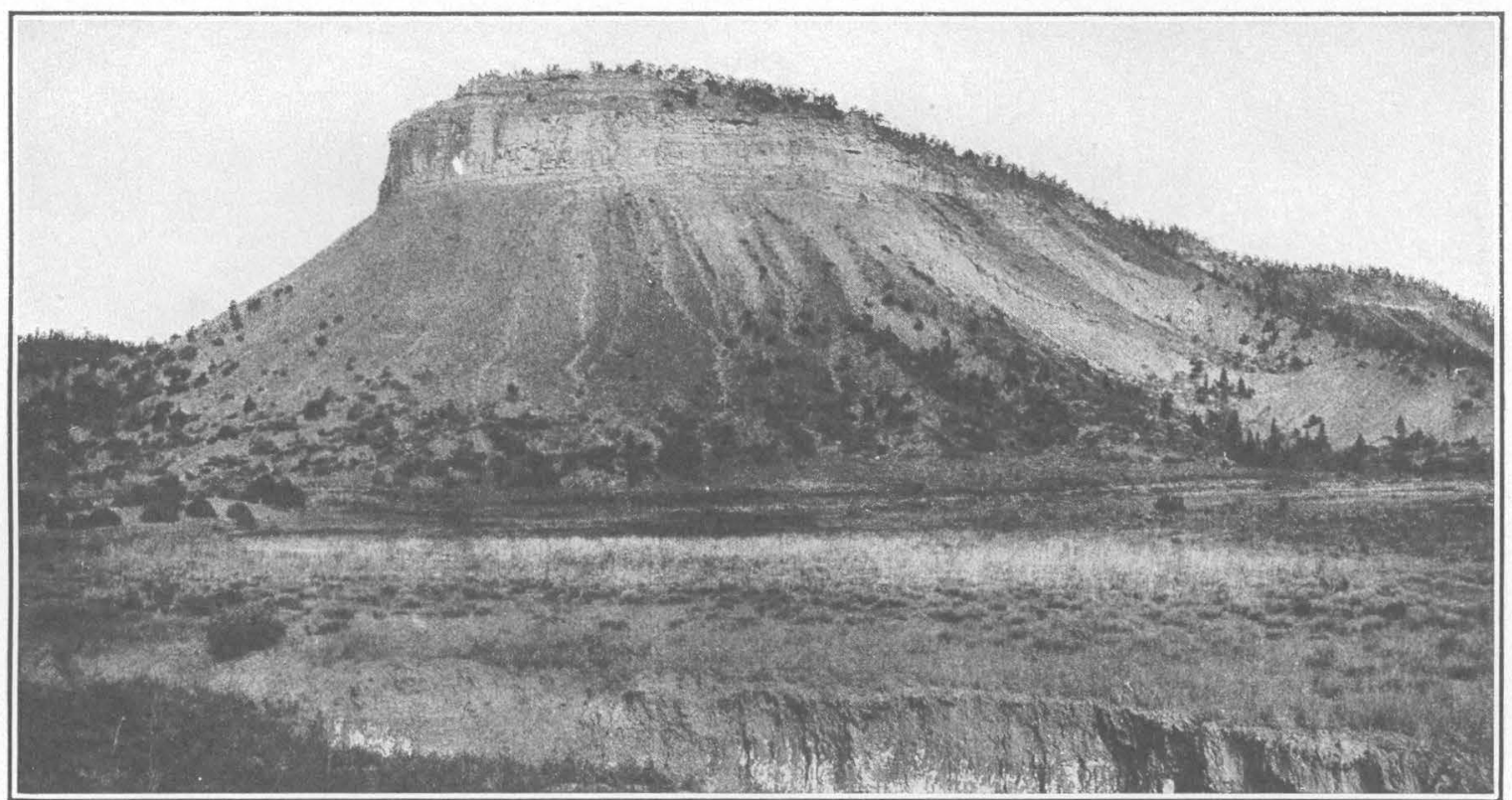

B. MANCOS SHALE AND THE BASAL SANDSTONE OF THE MESAVERDE FORMATION NEAR EL VADO, N. MEX.

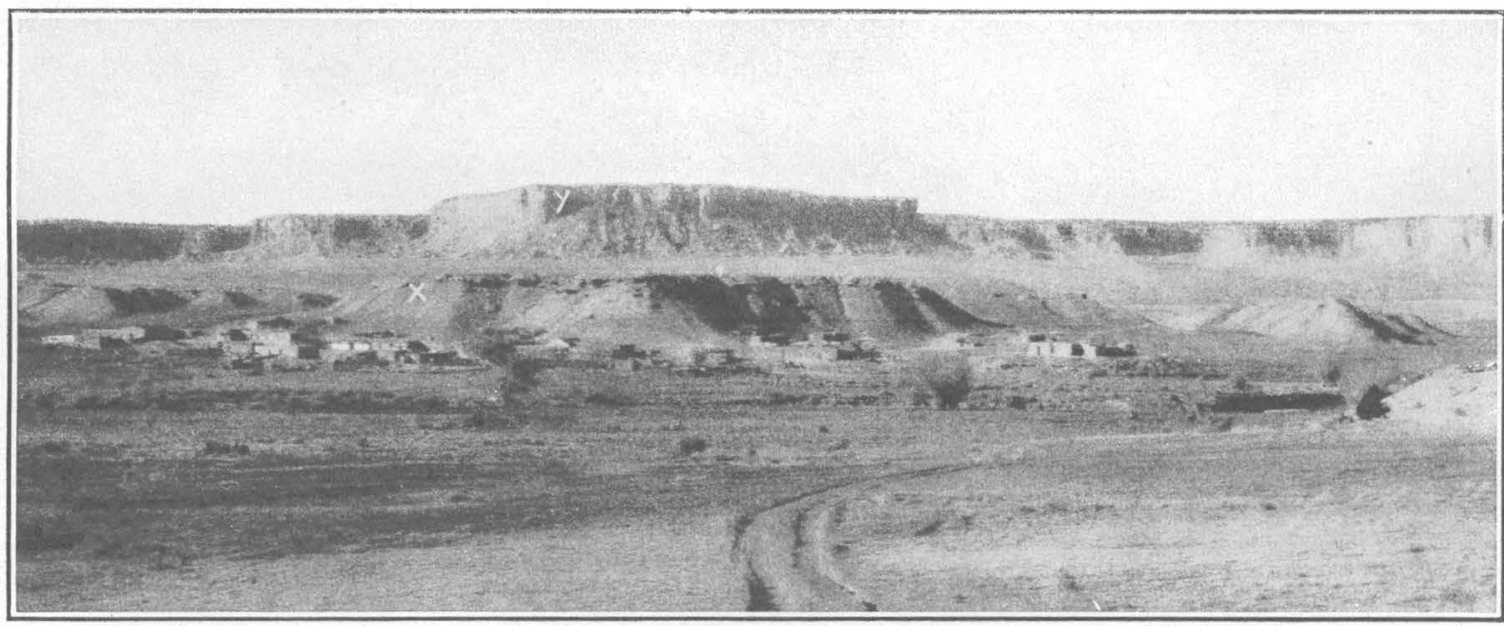

c. TOP OF MANCOS SHALE AND BASAL SANDSTONE OF THE MESAVERDE FORMATION, CABEZON, N. MEX.

$x$, Locality yielding fossils, lot $7195 ; y$, Mesaverde formation. 
Inoceramus barabini Morton.

Inoceramus sp.

Martesia? sp.

Melania wyomingensis Meek?

Melania sp.

Modiola laticostata White.

Neritina sp.

Ostrea sp.

Pholas? sp.

Sphaerium sp.

Tellina scitula Meek and Hayden.

Tulotoma thompsoni White.

Unio holmesianus White.

Unio brachyopisthus White.

Unio verrucosiformis Whitfield?

Unio sp. related to U. aldrichi White.

Unio sp. rundescribed; possibly 2 species.

Viviparus sp.

The relation of the so-called "Laramie" formation to the younger formations exposed along Animas River is not yet satisfactorily determined. Several hundred feet above the horizon of the fossils collected by the present writer there is a distinct change in lithology. A hard, massive, cliff-making sandstone rests with uneven base on shale, and in the lower part of this sandstone was found a large bone, apparently a shoulder blade, of which only a small part was obtained. On examination it proved to be a dinosaur bone, but no more defi- nite identification was possible. This sandstone was not observed over a wide enough area to demonstrate that it rests unconformably on the "Laramie," but the abrupt change in lithology and the uneven base of the sandstone suggests that it may be the base of the Tertiary beds. This sandstone does not seem to be present on Florida River, where Gardner measured his section, unless the white sandstone (not always present) at the top of his

- "Laramie" represents it.

MONERO AND DULCE.

About 2 miles southeast of Chama, in the northeastern part of the San Juan Basin on the Denver \& Rio Grande Railroad in northern Now Mexico, the Dakota sandstone was observed in a small canyon. The Mancos shale occupies a broad valley between Chama and Monero, and a sandy zone near its base probably represents, in a general way, the Tres Hermanos sandstone member typically developed farther south. The writer collected no fossils from the Mancos in northern New Mexico, but Schrader obtained Inoceramus fragilis Hall and Meek, Scaphites warreni Meek and Hayden, and Prionocyclus wyomingensis Meek from a locality on Chama River 2 miles northwest of Elvado, N. Mex., at a horizon estimated by him to be about the middle of this shale. According to Stanton these fossils denote upper Benton age.

Just east of Monero the railroad passes through a sharp canyon, in which the basal sandstone of the Mesaverde forms conspicuous cliffs. The westward dip of the rocks brings the coal beds that overlie this basal sandstone down to the level of the railroad at Monero, where the coal has been mined for many years. The Mesaverde, which, according to Schrader ${ }^{200}$ was traced from Durango to Monero, does not here differ notably in character from the Mesaverde of the Durango region.

A few very poorly preserved plants, Brachyphyllum cf. B. macrocarpum Newberry, Myrica or Eucalyptus n. sp., and Ficus n. sp., were found associated with the Mesaverde coals near Monero (U. S. Geol. Survey fossil locality 6041). The fossil plants seem to be restricted to very narrow zones. The sandstone both below and above the coal beds contains marine fossils. Ostrea sp., Pecten sp., Inoceramus barabini Morton, and Baculites anceps var. obtusus Meek were collected near Monero from a sandstone a few feet above the highest bed of coal (U.S. Geol. Survey fossil locality 7206).

The Lewis shale occupies a broad valley between Monero and Dulce. Its thickness was estimated at 1,000 feet, but this estimate may be too low, for its measured thickness both west and south of Monero is 2,000 to 2,500 feet. ${ }^{200,212}$ Schrader traced it continuously around the northern rim of the San Juan Basin and proved it to be the eastward extension of the typical Lewis shale. About half a mile north of Dulce it is very fossiliferous. The following shells were collected from it at two horizons, in limestone concretions distributed somewhat sparingly through the upper half of the shale, which is perfectly exposed in a steep barren slope. (See Pl. XXV, A.) The first lot of the following list is from the upper 100 feet (7200) and the second lot is from a horizon 300 to 500 feet below the top of the shale (7201). 
Fossils collected from the Lewis shale about half a mile north of Dulce, N. Mex.

[U: S. Geol. Survey fossil localitios 7200 and 7201.]

\begin{tabular}{|c|c|c|}
\hline & 7200 & 7201 \\
\hline Ostrea pellucida Meek and Hayden?. & & $x$ \\
\hline Ostrea $\mathrm{sp} \ldots \ldots \ldots \ldots \ldots \ldots \ldots \ldots$ & $x$ & ᄉ \\
\hline 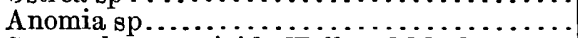 & & $x$ \\
\hline Syncyclonema rigida Hall and Meek. & & $\hat{x}$ \\
\hline 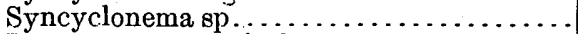 & $x$ & \\
\hline Inoceramus sagensis Owen.... & x & $x$ \\
\hline Inoceramus oblongus Meek?. & & $\hat{x}$ \\
\hline Modiola sp . . . . . . . . . . . & X & $\cdots$ \\
\hline Cardium speciosum Meek and Hayden. & $x$ & \\
\hline Pinna lakesi White?............... & & $x$ \\
\hline Trigonarca (Breviarca) exigua Meek and & & \\
\hline Lucina occidentalis(Morton) $\ldots \ldots \ldots \ldots$ & & $\hat{x}$ \\
\hline Thetis circularis Meek and Hayden....... & $x$ & $\hat{x}$ \\
\hline Pyrifusus sp . . . . . . . . . . . . & & $x$ \\
\hline 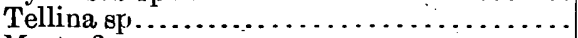 & $x$ & $\ldots$ \\
\hline Mactra? sp . . . . . . & X & \\
\hline Liopistha undata Meek and Hayden?.. & x & $\ldots$ \\
\hline 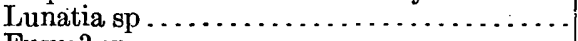 & $x$ & \\
\hline 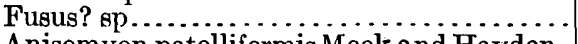 & x & $X$ \\
\hline Anisomyon patelliformis Meek and Hayden. & & X \\
\hline Actaeon sp $\ldots \ldots \ldots \ldots \ldots$ & $x$ & X \\
\hline Haminea sp....... & $\ldots$ & X \\
\hline Baculites ovatus Say..... & & X \\
\hline Baculites compressus Say. & $\cdots$ & $X$ \\
\hline Ancyloceras sp . . . . . . . & 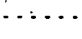 & X \\
\hline Scaphites nodosus Owen . . . . . . & & X \\
\hline Placenticeras whitfieldi Hyatt...... & X & X \\
\hline $\begin{array}{l}\text { Fracenuceras incercalare meek and } \\
\text { Fish scales..................... }\end{array}$ & & $x$ \\
\hline & & \\
\hline
\end{tabular}

Above the Lewis shale lies a series of rocks not less than 1,000 feet thick, somewhat shaly in the lower part, where a thin bed of coal occurs, but consisting principally of massive sandstone more or less conglomeratic throughout. Apparently some of the older geologists referred this whole series to the Laramie. Others referred some of it to the Laramie and some to the Tertiary. Schrader ${ }^{200}$ described the lower or coal-bearing portion as Laramie? and proved, by tracing the beds, that it is identical with the so-called Laramie of the Durango region. The following fossil plants were found by the present writer a few feet above the coal both north and south of the railroad near Dulce.

Fossil plants collected from the "Laramie" formation near Dulce, N. Mex.

[U. S. Geol. Survey fossil locality 6042. Those marked * occur also in the "Laramie" near Durango, Colo.]

* Brachyphyllum macrocarpum Newberry.

* Sequoia reichenbachi (Geinitz) Heer.

Cunninghamites pulchellus Knowlton.

* Geinitzia formosa Heer.

Ficus planicostata? Lesquereux (same as species at Point of Rocks).
* Ficus praetrinervis Knowlton.

* Ficus type of F. lanceolata Heer. Sabal montana Knowlton.

Zizyphus n. sp.

The flora is essentially the same as that described from the "Laramie" of the Durango section and confirms the statement that the beds are of the same age. It also strengthens Knowlton's opinion (p. 179) that the beds may be older than the Laramie of the Denver Basin, for two of the species are found at Point of Rocks, Wyo., in a formation regarded as older than Laramie, and others are found in the Mesaverde at the localities farther south described in this paper. In commenting on these plants, Knowlton says: "Their age is essentially Montana and not Laramie. If I were uninfluenced by their apparant stratigraphic position I should incline to place them in the Mesaverde, but since they are above Lewis they obviously can not be Mesaverde, though they can be, and in my opinion are, still Montana."

In the Dulce area the rocks above the Lewis shale that are referable to the Cretaceous are only about 225 feet thick, including the basal sandstone, which is 60 feet thick. A section of them and of the rocks overlying them was measured in the steep canyon wall about a mile northwest of Dulce. At this locality a conglomerate that varies greatly in thickness and character within short distances rests unconformably upon the coal-bearing rocks. For about 75 feet above this basal conglomerate the rock is variable in lithologic character and consists of friable granular sandstone and shale, irregularly intermingled and containing many lenses and irregular masses of conglomerate. The whole mass is dark and gives the impression of being the erosional product of dark igneous rock. It is the same material as that from Pagosa Junction, described on page 191 as consisting largely of andesitic material.

Section of rocks measured about a mile northwest of Dulce, N. $M e x$.

Formation not named (regarded by the writer as basal Tertiary):

Feet. Sandstone, conglomeratic, brown......... $80+$

Sandstone, slightly shaly, with greenish tint at base; massive, yellow above........... 44

Shale and sandstone, yellow............ 121

Sandstone, shaly, greenish................ 6

Conglomerate with pebbles principally of chert, up to one-half inch in diameter... 12 
Formation not named (regarded by the writer as basal Tertiary)-Continued.

Sandstone; shaly, gray.................. Conglomerate with chert pebbles up to threefourths inch in diameter................ Shale, sandy, yellow...................

Sandstone, white....................... Shale, sandy, yellow......................

Conglomerate with chert pebbles up to threefourths inch in diameter................

Shale, sandy, yellow................... Sandstone, massive, coarse grained, yellow..

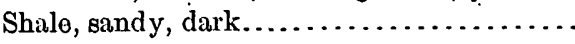
Sandstone, friable, dark. . . . . . . . . . . . Sandstone, coarse grained, conglomeratic, with pebbles mostly of cheri up to an inch or more in diameter...................

Unconformity by erosion.

"Laramie" formation:

Shale, sandy, carbonaceous; contains fossil plants (U. S. Geol. Survey fossil locality 6042)..............................

Coal, coke, and intruded igneous rock..... Sandstone, coarse grained, light colored.......

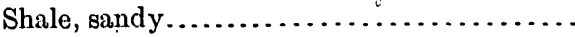

Sandstone, massive, light colored ...........

Lewis shale:

Shale, fossiliferous (U. S. Geol. Survey fossil

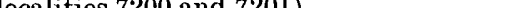

$\frac{300+}{1,059}$

The formations just described are well exposed north of Pagosa Junction, Colo., about 15 miles northwest of Dulce, in the gap eroded through the hogback formed by the upturned sedimentary rocks, but no section of them was measured. The Lewis shale was observed and the basal sandstone of the "Laramie" formation was found to contain Halymenites major Lesquereuxas it does also at Dulce. The "Laramie" near Pagosa Junction is much thicker than it is farther east, the estimated thickness being 600 feet. Two coal beds near the base of the formation have been opened at the Talian mine. The lower one is 3 feet thick and the upper 4 feet, and they are separated by 20 feet of sandy shale. From between these two beds a few miles to the west Gardner collected the following invertebrates:

Fossils collected from the "Laramie" formation in the SE. $\frac{1}{\frac{1}{4}}$ sec. 19, T. 34 N., R. 4 W., near Pagosa Junction, Colo., 5 feet above "Laramie" coal No. 1.

Ostrea subtrigonalis Evans and Shumard. Anomia sp. cf. A. micronema Meek. Corbicula cytheriformis Meek and Hayden. Corbula undifera Meek.
From a layer of fissile sandstone about 15 feet above the upper bed of coal the writer collected the following fossil plants:

Fossils collected from the "Laramie" formation at the Talian mine near Pagosa Junction, Colo.

[U. S. Geol. Survey fossil locality 6442.]

Ficus praetrinervis Knowlton.

Ficus wardii Knowlton.

Ficus leei Knowlton.

Ficus n. sp.

Pteris n. sp.

Quercus cf. Q. rockvalensis Knowlton.

Carpites sp.

Salix sp.

Phaseolites minutus Knowlton.

Diospyros? leei? Knowlton.

In his comments on these plants Knowlton says their age "is undoubtedly Montana, the several identified species being all present. in the Vermejo. The flora also closely resembles that of the Mesaverde."

The upper part of the "Laramie" is a soft sandy shale, usually covered at the surface with débris but well exposed in a railroad cut north of Pagosa Junction, at the controt with the overlying rocks, which the writer regards as Tertiary. The base of the overlying rocks is a coarse massive conglomerate, in which were found several varieties of pebbles, all well rounded, whose maximum diameter is 3 to 4 inches.

Thin slides of rook from this basal conglomerate north of Pagosa Junction were examined by E. S. Larsen, who states that the matrix is clearly derived from andesitic rocks. It is made up largely of crystal fragments of plagioclase feldspar with some grains of the groundmass of andesitic rocks and a few grains of quartz, secondary chlorite, and other minerals. The pebbles consist of several sorts of rock, including sandstone, quartzite, quartz, and igneous rocks partly or wholly decomposed. Some of them appear to be highly altered andesites. The specimens examined suggest that the conglomerate consists of washed andesitic tuff, in which was embedded waterworn pebbles derived from consolidated rock, although the impression gained from field examination was that the matrix, as well as the pebbles, was derived by erosion from consolidated rocks. The andesitic character of the rocks strengthens the suspicion, gained from the stratigraphic position of the beds and from fossils at higher horizons in the same 
formation, that it is equivalent in age to the Animas formation as developed near Durango.

The basal conglomerate of the supposed Tertiary forms the crest of the hogback but disappears southward beneath friable sandstone and coal-bearing shale 1,000 feet or more in thickness. In one exposure of strata about 400 feet thick were found eight coal beds ranging in thickness from a few inches to a foot. Fossil plants are abundant in this formation. Collections were made at three localities, one near the base of the coal-bearing rocks and two about 400 feet stratigraphically higher. They are as follows:

Fossils collected in a railway cut one-half mile downstream from Pagosa Junction, Colo.

[U. S. Geol. Survey fossil locality 6309.]

Ficus pseudopopulus Lesquereux.

Castalia cf. C. leei Knowlton.

Viburnum cf. V. antiquum (Newberry) Hollick and V. perfectum Ward.

Juglans cf. J. berryi Knowlton.

Fossils collected about 400 feet stratigraphically above the horizon of Pagosa Junction, Colo.

[Those from U. S. Geol. Survey fossil locality 6443 are from a mile northeast of the junction and those from 6444 are from a mile north west of the junction.]

\begin{tabular}{|c|c|c|}
\hline . & 6443 & 6444. \\
\hline 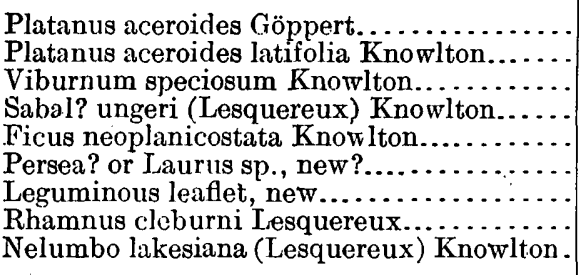 & $\begin{array}{c}x \\
x \\
x \\
x \\
x \\
x \\
\cdots\end{array}$ & $\begin{array}{l}x \\
x \\
x \\
x \\
x \\
x \\
x\end{array}$ \\
\hline
\end{tabular}

The writer found no fossil vertebrates in this region, but J. H. Gardner has kindly furnished the following information in a letter dated December 26, 1911:

I have carried a reconnaissance survey around the north side of the San Juan Basin, and have done the detail of the Ignacio folio which lies to the west but on the rim of the same basin. There is no doubt in my mind, based on reconnaissance mapping and lithologic similarity, that the beds [above the unconformity] are Animas * * *. The heavy conglomerate beds at the base of the Animas are in the form of a lentil which thins out away from the Animas Valley. The beds above this consist of tan-colored and greenish shale alternating with coarse-grained tancolored sandstone containing grains of igneous origin * * *. The beds which are intruded with sills along the canyon west of Dulce and crosscut by dikes [the upper
461 feet of the Dulce section] are of the same nature and apparently connect with the upper beds of the Animas, * * * and contain remains of Triceratops.

\section{CABEZON.}

Gardner ${ }^{222}$ correlates the rock formations exposed near Cabezon directly with those of the Durango section, and gives them the same names, viz, Mancos, Mesaverde, Lewis, and "Laramie." His correlation was based on the tracing of the outcrops around the San Juan Basin from their type locality in southwest Colorado. They are described as more or less continuously exposed on the west. and south sides of the basin, but for a few miles to the west of the Nacimiento Mountains they are covered by overlapping Tertiary rocks. However, in spite of the great length of outcrop around the basin to the west and the area of obscured outcrops on the east side, Gardner seems to have felt confident that the formations near Cabezon are to be correlated directly with those of the Durango section, and the writer in a somewhat rapid reconnaissance of this region saw nothing to cause him to question these correlations. The lower part of the Mesaverde at Cabezon seems to be equivalent in age to the Mesaverde at Monero (Pls. XXV, $B, C$, p. 188), but it may not be out of place to call attention to the fact that the Mesaverde at Monero is very thin, and that, according to Gardner, ${ }^{222}$ it has near Cabezon a thickness of more than 1,300 feet. On the other hand, the same writer ${ }^{222}$ shows that the Lewis shale near Cabezon is only about 250 feet thick, and that in the same basin farther north ${ }^{222}$ it is 2,000 to 2,500 feet thick. Southwest of Gallina this shale was found to change in thickness from 250 to about 2,000 feet in 30 miles. ${ }^{212}$

Gardner ${ }^{212}$ also described a sandstone near the top of the Mancos shale in the vicinity of Gallina which he suggests may be the attenuated edge of a coal-bearing member of the Mancos on the southern side of the basin.

The differences in thickness of the formations and the possibility of a change in lithologic character suggest that some of the upper part of the Mesaverde near Cabezon may be equivalent in age to the lower part of the Lewis shale farther north. ${ }^{248}$

Gardner collected fossils in the vicinity of Cabezon from both the Lewis shale and the Mesaverde formation. They are among the United States Geological Survey collections and 
have been identified by T. W. Stanton. Two collections were obtained from the Lewis as follows:

Invertebrates collected by J. H. Gardner, about 6 miles southviest of Raton Springs, N. Mex., from about 100 feet below the top of the Lewis shale.

[U. S. Geol. Survey fossil locality 4455.]

Ostrea sp.

Cardium speciosum Meek and Hayden.

Legumen sp.

Liopistha undata Meek and Hayden.

Lunatia sp.

Melania?sp.

Invertebrates collected from the Lewis shale by $J$. H, Gardner;, $2 \frac{1}{2}$ miles southeast of Cuba, N. Mex.

[U. S.'Geol. Survey fossill locality 4452.]

Inoceramus barabini Morton.

Baculites compressus Say.

Placenticeras intercalare Meek and Hayden.

The Mesaverde fossils collected by Gardner near Cuba are as follows:

Invertebrates collected near the base of the Mesaverde formation, three-quarters of a mile north of Copper City, N. Mex.

[U. S. Geol. Survey fossillocality 4453.]

Nucula sp.

Cucullaea sp.

Arca sp.

Cardium sp.

Cyprimeria? sp.

Liopistha undata Meek and Hayden.

Mactra sp.

Gyrodes sp.

Pyrifusus? sp.

Volutoderma sp.

Actaeon sp.

Baculites anceps var. obtusus Meek.

Placenticeras intercalare Meek and Hayden.

Placenticeras sp.

Helicoceras sp.

Scaphites sp. related to S. larvaeformis Meek and Hayden.

While in the field the present writer assumed that the Mesaverde age of the coal measures near Cabezon was established, and he visited the locality to collect.fossils for the purpose of correlating the Mesaverde with the coal-bearing rocks which, in the fields farther east, contain similar fossils. A large number of petrified logs and stumps and some leaf impressions were found in the lower part of the Mesaverde north of Cabezon, but most of these were too poorly preserved for identification. However, beautifully preserved leaves were found in a $47019^{\circ}-17-13$ thin layer of fine-grained sandstone about 400 feet above the lowest bed of coal, about 5 miles northwest of Cabezon, in a steep bluff half a mile north of a small artificial lake. The species collected are as follows:

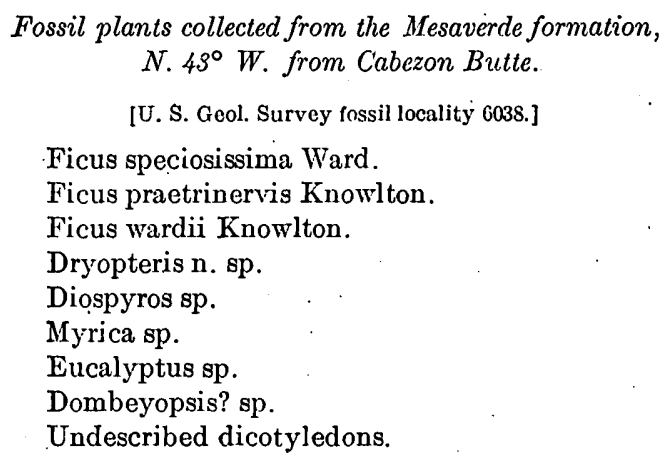

Fragments of palm leaves were found 50 to 100 feet above the bed yielding these plants; but no fragment had the parts necessary for the identification of species. Still higher in the formation, at the east end of Chacra Mesa (U. S. Geol. Survey fossil locality 6039), several conifers of Abietites dubius Lesquereux were found.

Two small collections of shells were made from the Mancos shale near Cabezon. One collection was obtained from the sandy layers at the top of the formation in the transitional zone between the Mancos and the basal sandstone of the Mesaverde, at the point where the wagon road leading northwestward from Cabezon crosses the top of the Mancos shale. They are as follows:

Fossils from the top of the Mancos shale, northwest of Cabezon. [U. S. Geol. Survey fossil locality 7194.]

Ostrea elegantula Newberry?

Anomia sp.

Pinna sp.

Cardium sp.

Cyprimeria sp.

Tellina sp.

Liopistha undata Meek and Hayden?

Mactra sp., related to M. formosa Meek and Hayden.

Corbula sp.

Gyrodes sp.

Actàeon sp.

Placenticeras-sancarlosense Hyatt?

The second collection was obtained from the low hill back of Cabezon at a horizon several hundred feet below the top of the Mancos shale. The rocks containing them are somewhat sandy, and this fact may serve to explain the resem- 
blance of the fauna to that yielded by the sandstones of the Mesaverde. The fossils follow:

Fossil shells collected at Cabezon, N. Mex.

[U. S. Geol. Survey fossil localities 7195 and 8000 .]

Exogyra sp.

Anomia sp.

Avicula linguiformis Evans and Shumard.

Inoceramus barabini Morton?

Mytilus sp.

Cucullaea sp.

Crassatellites? sp.

Cyprimeria sp.

Gyrodes sp.

Volutomorpha sp.

Volutoderma? sp.

Liopeplum sp.

Pyrifusus? sp.

Placenticeras sancarlosense Hyatt?

Stantonoceras pseudocostatum Johnson?

Lamna sp.

Ostrea sp.

Nemodon sp.

Tellina sp.

Pholadomya sp.

Lunatia sp.

Fasciolaria? sp.

Actaeon sp.

Baculites anceps var. obtusus Meek.

CASA SaLAzar.

The upper part of the Mancos shale forms the surface for a considerable distance south of Cabezon, the Mesaverde having been generally eroded away. However, a remnant of the Mesaverde has been preserved in Cabezon Butte (see Pl. XXVI, $A$ ), and the basal sandstone was observed for a considerable distance to the south in the west face of Prieta Mesa (see Pl. XXVII, $B$ ). Thus, the Mancos is continuously exposed between the San Juan Basin and the Rio Puerco field, and the continuity of the Mesaverde is interrupted by only three short gaps.

North of Cabezon the upper part of the Mancos is a shale that differs little from the shale of the lower part, but southward from Cabezon the upper part of the Mancos becomes increasingly more sandy. In the Rio Puerco field it is not possible, without further investition, to draw a definite line between Mancos and Mesaverde, and in the vicinity of Datil Mountains, 70 miles farther south, the Mancos is more or less sandy throughout. ${ }^{248}$. This is shown graphically in figure 13.

A section was measured and fossils collected by T. W. Stanton and the writer in 1912 near Casa Salazar, N. Mex., about halfway between
Cabezon and the Rio Puerco field. The information thus obtained aids materially in showing the relations of the formations of the San Juan Basin to those of the Rio Puerco field. The thicknesses were determined by Locke level and checked by aneroid barometer. The lower part of the section up to the top of the Tres Hermanos sandstone was measured about 5 miles south of Casa Salazar, at the locality shown in Plate XXVII, $B$. A mile farther north the rocks were measured between this sandstone and the Scaphites zone of the following section. This Scaphites zone was recognized at Casa Salazar, and the part of the section between it and the Punta de la Mesa sandstone was measured at the locality shown in Plate XXVI, $B$. The part above this sandstone was measured about a mile farther north. The combined section follows:

Section measured in the eastern face of Prieta Mesa, near Casa Salazar, N. Mex.

Mesaverde formation:

Sandstone, yellow, massıve, cliff making, containing (U. S. Geol. Survey locality 7999) Ostrea sp., Inoceramus sp., Cyprimeria sp., Gyrodes sp., Pyrifusus sp., Pyropsis sp., Volutomorpha sp., Liopeplum sp., Placen- Feet. ticeras sp............................ $50+$

(The slope above this sandstone is covered with débris from the sheet of igneous rock that caps the mesa.)

Mancos shale:

Not exposed . . . . . . . . . . . . . . . . 100

Shale and friable sandstone, buff-colored, containing, 450 feet from base (U. S. Geol. Survey locality 7998), Inoceramus sp., Baculites sp.; 150 to 250 feet from base (U. S. Geol. Survey locality 7997), Ostrea congesta Conrad, Inoceramus sp., Scaphites sp., related to Scaphites vermiformis Meek and Hayden; 100 feet from base (U. S. Geol. Survey locality 7996), Inoceramus sp., Baculites sp.; 50 feet from base (U. S. Geol. Survey locality 7995), Ostrea soleniscus Meek, Inoceramus sp........ 750

Sandstone, massive (Punta de la Mesa member). 50 Shale, sandy at the top, containing (U. S. Geol. Survey locality 7994) Prionotropis sp........ 350

(The talus from this sandstone about 3 miles farther south yielded (U. S. Geol. Survey locality 7986) Inoceramus sp., related to Inoceramus erectus Meek, Inoceramus labiatus Schlotheim?, Mactra arenaria Meek, and Gyrodes sp.)

Sandstone, fissile, and sandy limestone (Scaphites zone) containing (U. S. Geol. Survey locality 7993) Ostrea lugubris Conrad, Inoceramus dimidus White, Prionocyclus sp.,. Scaphites warreni Meek and Hayden........ $10+1$ 


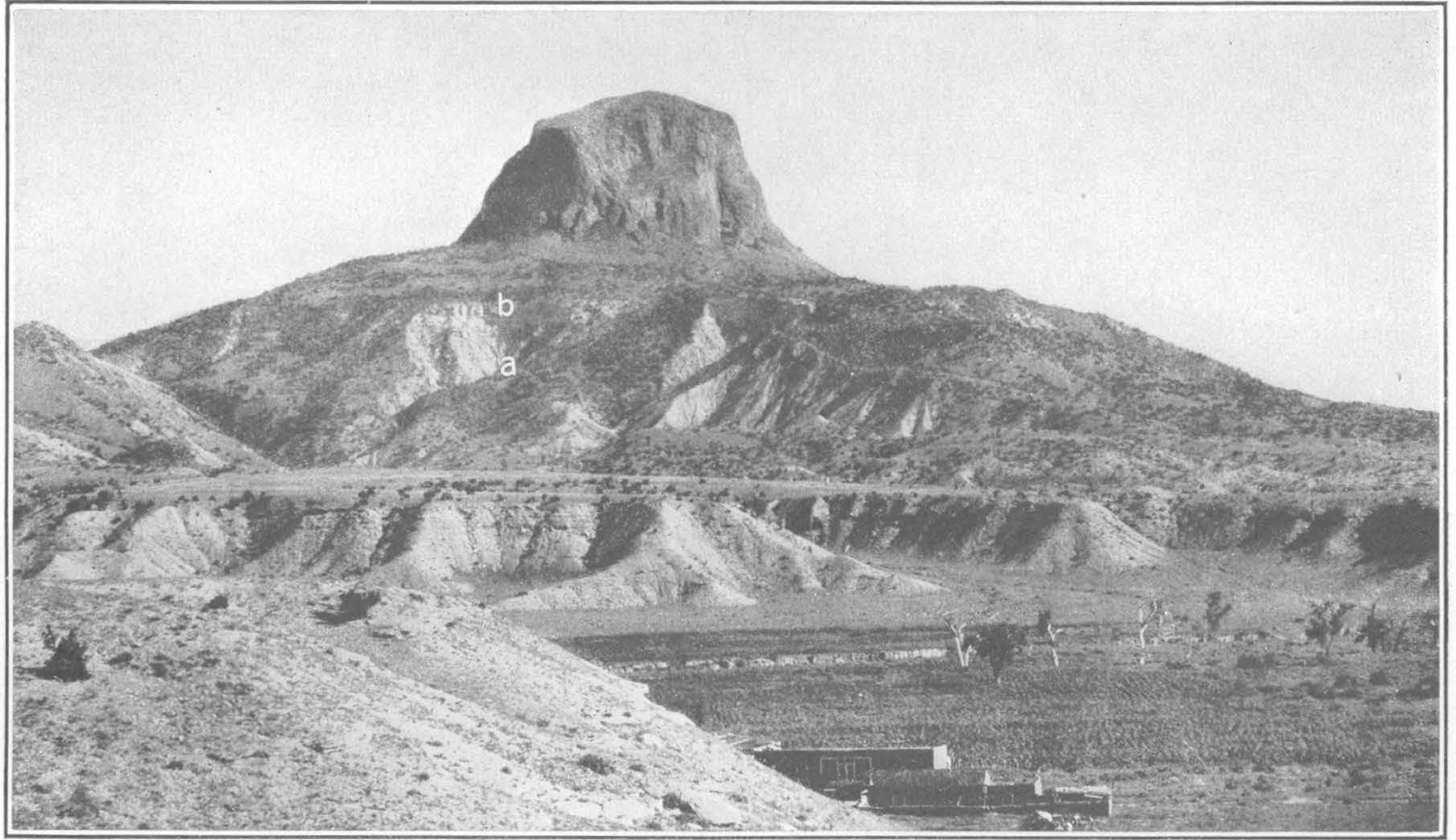

A. CABEzon butte, a large Volcanic plug, from CABEZON, N. MEX.

Showing the upper sandy part of the Mancos shale (a) and the basal sandstone of the Mesaverde formation (b).

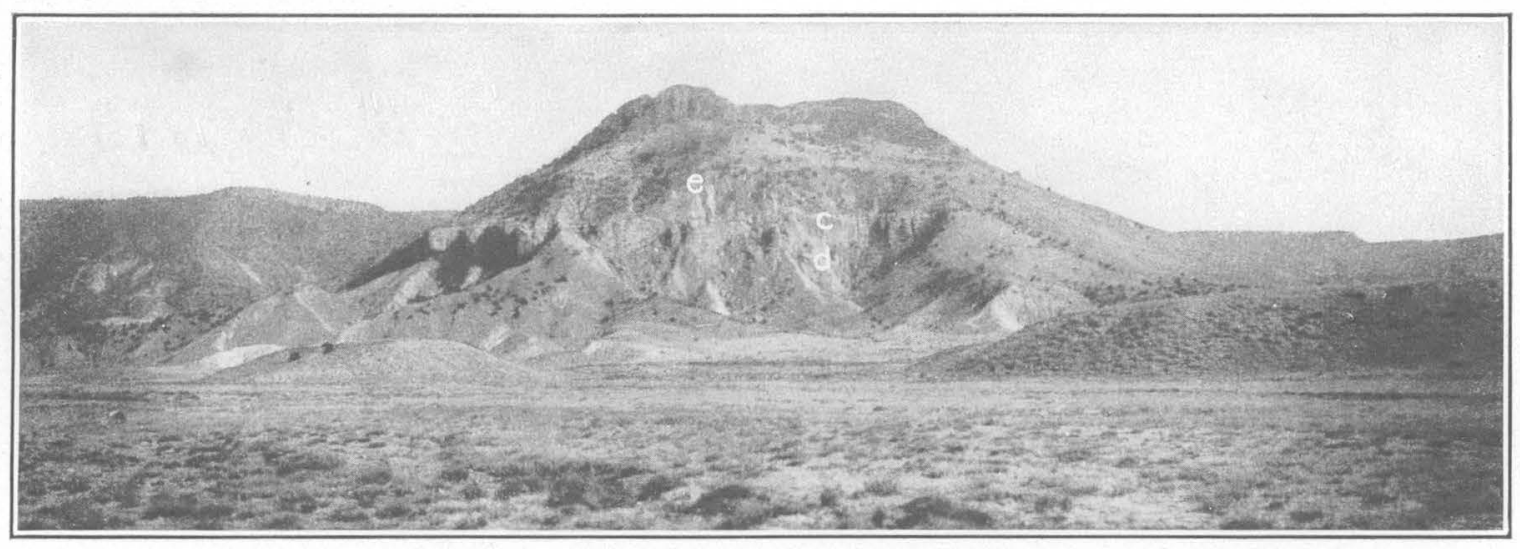

B. Volcanic plug about a mile west of CASA salazar, N. mex.

Showing the Punta de la Mesa sandstone member of the Mancos shale (c), the dark shale (d) below, and the light-colored sandy portion (e) of the Mancos above.

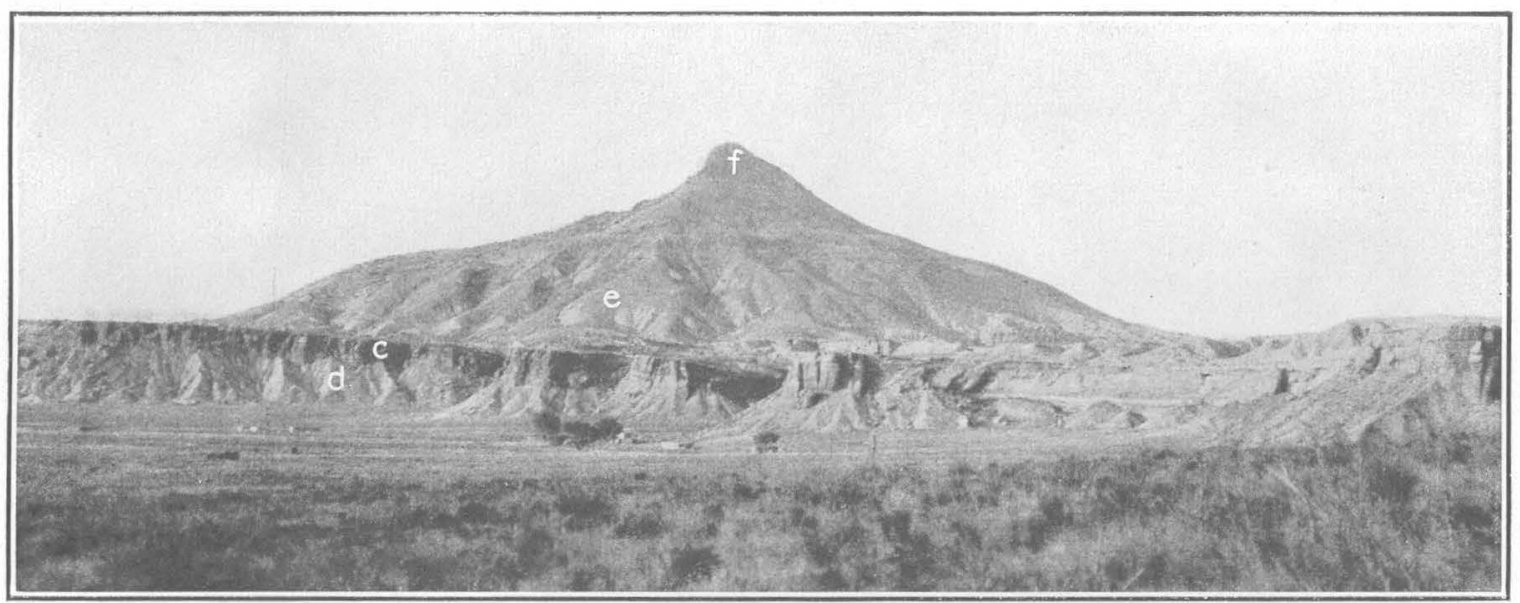

C. VOLCANIC PLUG NORTH OF CASA SALAZAR, N. MEX.

Showing the dark shale of the lower part of the Mancos (d), the Punta de la Mesa sandstone member (c), the sandy portion of the Mancos shale (e), and the top of the plug (f). 


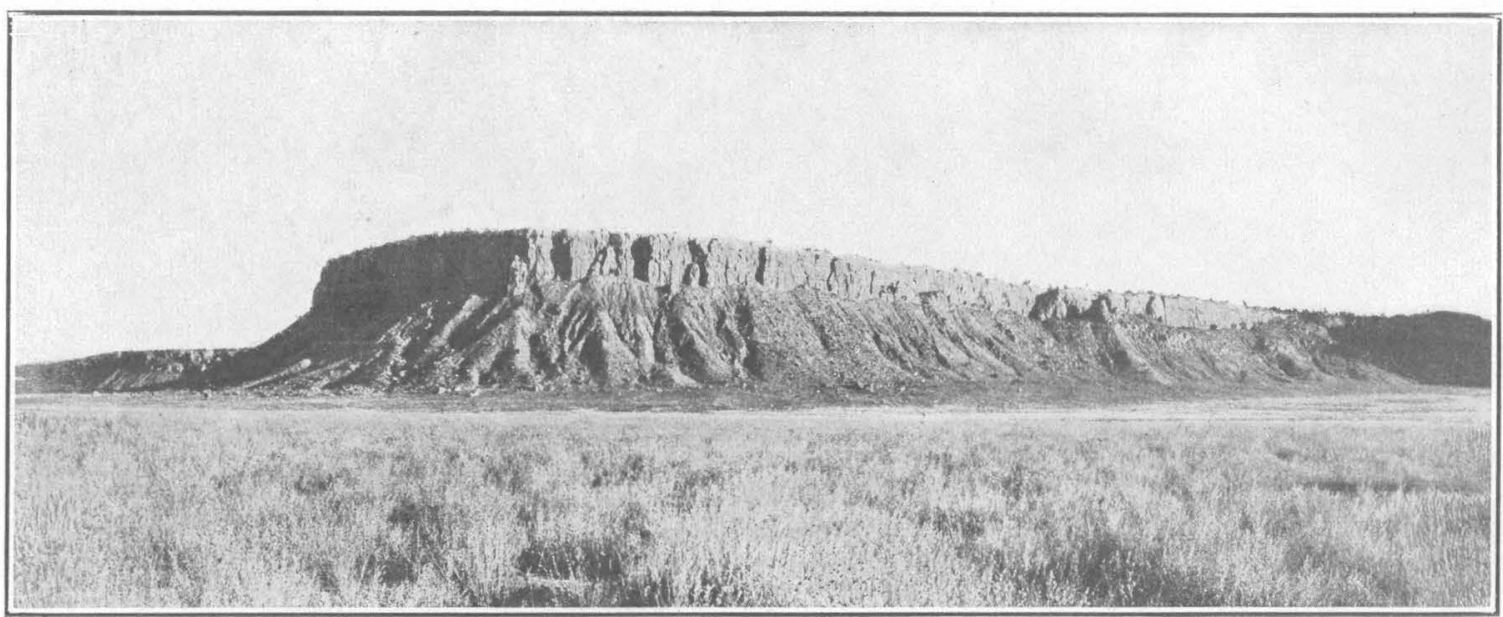

A. PUNTA DE LA MESA, NEAR SAN YGNACIO, N. MEX.

Type locality of the Punta de la Mesa sandstone member of the Mancos shale.

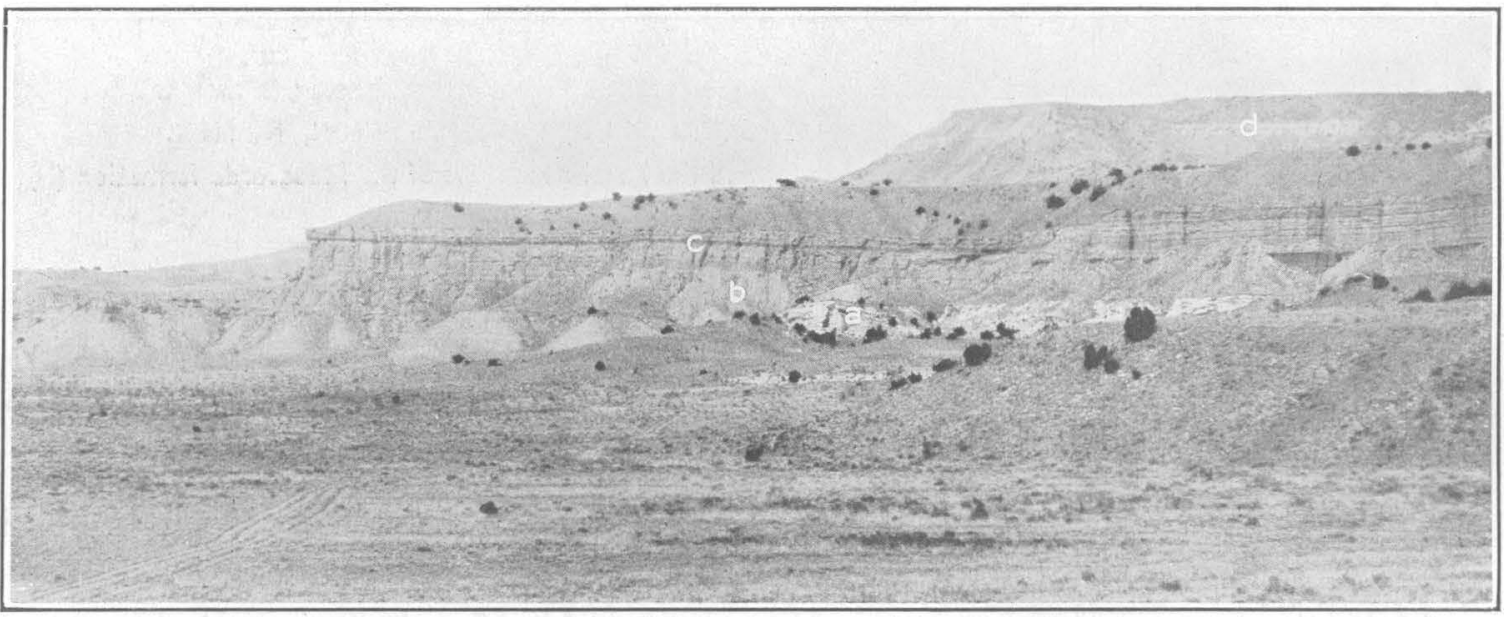

B. WEST SLOPE OF PRIETA MESA, ABOUT 5 MILES SOUTH OF CASA SALAZAR, N. meX.

Showing light-colored sandstone supposed to be of Morrison age (a); the Mancos shale, including at its base the gastropod zone (b) and the Tres Hermanos sandstone member (c); and the basal sandstone of the Mesaverde formation (d) in distance, under capping of igneous rock near top of mesa.

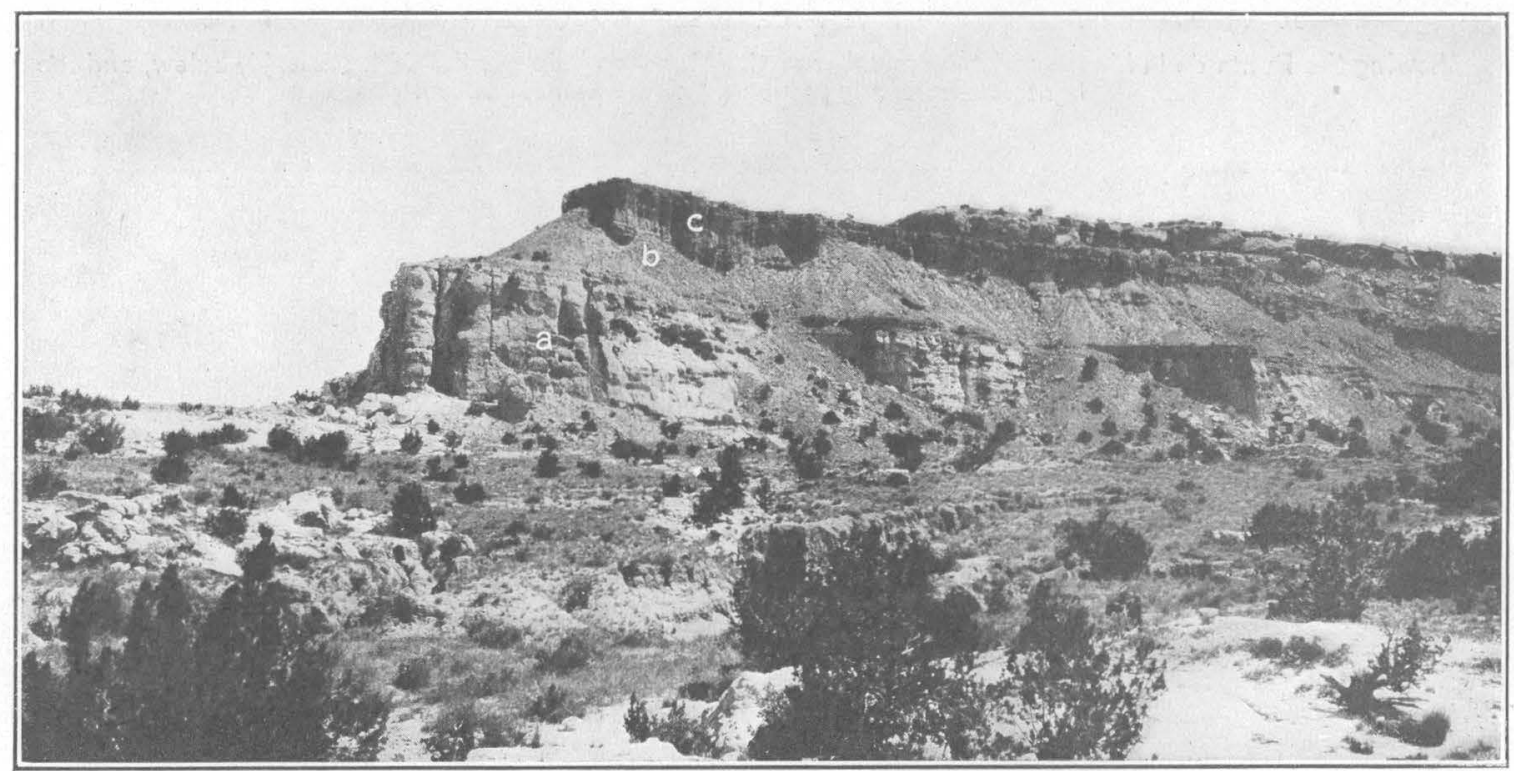

C. VALLEY OF RIO PUERCO NORTH OF SAN FRANCISCO, N. MEX.

Showing sandstone supposed to belong in the Morrison formation (a), and the lower part of Mancos shale, including the gastropod zone (b) and Tres Hermanos sandstone member (c). 
Mancos shale-Continued.

Sandstone and shale in thin layers..........

Shale, with concretions of limestone in upper half (cephalopod zone), containing (U.S. Geol. Survey locality 7992) Pinna sp., Turritella sp., Metoicoceras sp., Coilopoceras colletti Hyatt..........................

Shale, dark..........................

Shale with thin layers of limestone; containing (U. S. Geol. Survey locality 7991) Gryphaea newberryi Stanton, Inoceramus labiatus Schlotheim......................

Shale, dark..........................

Limestone, granular, irregularly bedded .....

Shale, dark...........................

Sandstone, yellow, massive (upper plate of Tres Hermanos sandstone), containing (U. S. Geol. Survey locality 7989) Gryphaea newberryi Stanton, Exogyra sp., Pinna petrina White?, Cardium trite White, Anchura sp., Pyropsis sp. (U.S. Geol. Survey locality 7990), Avicula gastrodes Meek............

Shale, dark........................

Sandstone, yellow, coarse grained (lower plate of Tres Hermanos sandstone), containing (U. S. Geol. Survey locality 7988) Exogyra columbella Meek, Avicula sp., Pinna petrina White, Isocardia sp., Cyprimeria sp., Tellina sp., Liopistha (Psilomya) sp., Turritella sp.

Shale, light yellow and sandy above, containing (U. S. Geol. Survey locality 7987) Exogyra columbellaMeek; Lima sp.,Camptonectes symmetricus Herrick and Johnson, Isocardia sp., Gyrodes? sp., Turritella sp., Anchura fusi- formis White (not Meek); and dark below..

Dakota sandstone:

Sandstone, conglomeratic, weathers dark and

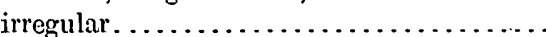

Shale, sandy, dark...................

Sindstone, friable, light colored ............

Morrison formation

Shale and sandstone, variegated.

Feet.

60 of the annotated list of publications ${ }^{146}$ on pages 17-37. These zones were found convenient for use by the present writer and are here used in a quotational manner.

The Cretaceous rocks of this field dip toward the east, the degree varying greatly from place to place, and disappear under a cover of Tertiary and Quaternary rocks in the valley of the Rio. Grande. A section showing the main features of the sedimentary rocks from the Morrison formation to the Punta de la Mesa sandstone was measured near San Francisco. The line along which the measurements were made extends southward across the gently dipping strata from the Rio Puerco, northwest of San Francisco, to Punta de la Mesa.

No place was found in the Rio Puerco field where a complete detailed section of the rocks. above this sandstone could be measured. The beds are well exposed in only a few places, and where exposed some of them are so warped that it is difficult to trace individual beds for any considerable distance and others are faulted so that certain beds are duplicated. Also, some of the upper part of the formation was removed by erosion previous to the deposition of the overlying Tertiary sediments. A generalized section was measured and many fossils were collected east of the Rio Puerco about 3 miles north of San Ygnacio; and a section of the upper part of the coal-bearing rocks -was measured in detail about a mile farther north, by L. C. Chapman, who was assisting the writer in the field. Where the part of the section north of San Ygnacio was measured faulting has rendered doubtful the relation of the Meșaverde to the Tertiary. But near the northern end of the Rio Puerco field an exposure was found of rocks that appeared to be undisturbed by faulting, where the basal conglomerate of the Tertiary with pebbles of quartzite, some of them 6 inches in diameter, rests upon the Mesaverde. The following section is the result of the observations made north of San Ygnacio:

Section of rocks measured near San Ygnacio, N. Mex.'

Tertiary:

Sandstone, locally conglomeratic, and shale; poorly consolidated, varicolored, with reds predominating below and milder shades above. (Many hundreds of feet.) Unconformity.
Aside from brief references, in the accounts of early explorations, to the occurrence of coal, the first geologic information of the Rio Puerco coal field was given by Herrick and Johnson. ${ }^{148}$ The zones described by them, and the fossils 
Mesaverde formation:

Shale with thin beds of coal; absent in some places ...........................

Sandstone, massive, yellow, calcareous, and shaly in places; contains (U. S. Geol. Survey fossil locality 7189) Ostrea sp., Anomia sp., Inoceramus sp. (thick shelled), Cucullaea sp., Cardium sp. (large form), Cardium sp. (slender form), Tellina sp., Cyprimeria sp., Liopistha undatá Meek and Hayden?, Corbula sp., Mactra sp. related to M. formosa Meek and Hayden, Mactra sp. (large form), Dentalium sp., Gyrodes sp., Physa? sp., Volutomorpha novimexicana Herrick and Johnson, Pyropsis sp., Actaeon? sp., Scaphites sp. related to S. nodosus Owen, Placenticeras sancarlosense Hyatt?, Placenticeras planum Hyatt?.

Shale, sandy, containing (U. S. Geol. Survey fossil locality 6034) Brachyphyllum macrocarpum Newberry, Ficus praetrinervis Knowlton, Ficus sp., Salix? sp. (large leaf) ...................

Shale, carbonaceous. Coal.

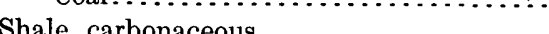

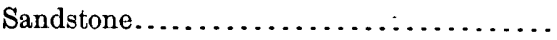

Shale, carbonaceous................... Coal............................

Shale, carbonaceous.

Sandstone.

(n)

Shale, carbonaceous.

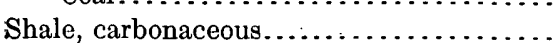
Coal...................

Shale, carbonaceous

Sandstone..........................

Shale.

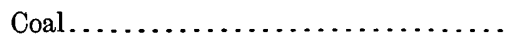

Shale, carbonaceous.................. Coal...........................

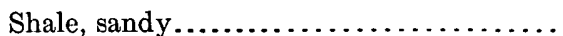
Coal......

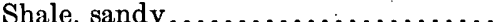

Shale............................. Coal.

Shale, carbonaceous....................

Shale............................ Coal..............................

Shale, carbonaceous...................

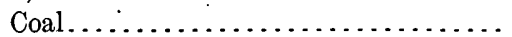

Shale, carbonaceous.................. Coal.............................

Shale, carbonaceous....................

Sandstone, coarse grained.

Shale, carbonaceous................... Coal.

Shale, carbonaceous.................. Coal.

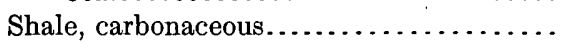

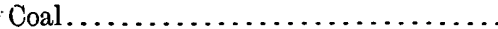

Shale, sandy, carbonaceous.............. Shale, sandy

\begin{tabular}{|c|c|c|c|}
\hline & Mesaverde formation-Continued. & Ft. & \\
\hline Ft. in. & Shale, carbonaceous............. & 2 & \\
\hline $10 \pm$ & Sandstone, coarse-grained, gray............ & 3 & 0 \\
\hline & Shale, carbonaceous, chocolate colored.... & 5 & 0 \\
\hline & Shale, carbonaceous, chocolate-colored.. & $1^{\circ}$ & 6 \\
\hline & Sandstone, coarse grained, massive, gray.. & 30 & 0 \\
\hline
\end{tabular}

Shale, with layers and lenses of yellow sandstone and earthy limestone, containing (U. S. Geol. Survey fossil locality 7190) Halymenites major Lesquereux, Ostrea congesta Conrad, Inoceramus sp., Lithophagus sp., Lamna sp............ Sandstone, coarse grained, yellow to gray, contains (U. S. Geol. Survey fossil locality 6035) the following fossil leaves: Quercus sp. serrate new, Ficus praetrinervis Knowlton, Ficus eucalyptiffolia Knowlton, Dryophyllum falcatum Ward (occurs at Point of Rocks), Dalbergia n. sp. (same as Hagan 6030), Salix stantoni? Knowlton (same as from Coalville, Utah), Salix sp. a, Viburnum? problematicum Knowlton..

Shale, containing one bed of coal 6 feet thick and several thin beds

Sandstone with layers of shale and lenses of impure limestone, fossiliferous, but no collections made.....................

Sandstone, massive, gray, with lenses of impure limestone near the top; containing (U. S. Geol. Survey fossil locality 7188) Ostrea sp., Inoceramus sp. (very thick shelled form), Cucullaea sp., Cardium sp., Tellina sp., Liopistha undata Meek and Hayden, Mactra sp. related to $M$. formosa Meek and Hayden, Mactra sp. large form, Volutomorpha novimexicana Herrick and Johnson, Baculites sp., Placenticeras planum Hyatt, Lamna sp..

Shale, carbonaceous, chocolate-colored.... Mancos shale (?):

Sandstone, yellow, and shale in alternating layers....................... 297-850 0

Sandstone, massive, yellow (Punta de la Mesa member), containing (U. S. Geol. Survey fossil localities 3514 and 3519) Inoceramus deformis Meek?, Inoceramus erectus Meek?, Avicula sp., Mactra sp., Cardium sp., Anisomyon? sp., Cyprimeria?

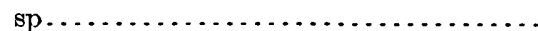

Shale, sandy at top..................

Limestone, shaly, containing (U. S. Geol. Survey fossil locality 3515) Exogyra columbella Meek, Pecten sp.; Pinna petrina White, Isocardia sp., Liopistha (Psilomya) sp., Anchura sp............ Shale.

Shale with limestone concretions (cephalopod zone) containing (U. S. Geol. Survey fossil locality 3520) Pinna petrina White?, Pecten sp., Trigonarca sp., Isocardia sp., Veniella? sp., Cardium sp., Turritella sp., Rostellites sp., undetermined gastropods, Metoicoceras sp. related to $M$. swallowi

. (Shumard), Metoicoceras sp............. 10 10
$25 \pm$

$100 \pm$

1720

$110 \quad 0$

$27 \quad 0$

$77 \quad 0$

$240 \pm$

$10 \pm$

500 
Mancos shale (?)-Continued.

Shale. In the lower part (U. S. Geol. Survey fossil lacality 7191) were found Ostrea sp., Avicula gastrodes Meek, Pinna petrina White, Veniella sp., Pholadomya sp., Turritella sp. related to T. whitei Stanton, Metoicoceras sp.....................

Sandstone, shaly, with impure limestone in lenses and concretions. (This sandstone and the limestone concretions above and below it seem to constitute the concretion (Septaria) zone of Herrick and Johnson.) It contains (U. S. Geol. Survey fossil localities 7192 and 3513). Ostrea sp., Exogyra columbella Meek, Anomia sp., Avicula gastrodes Meek, Cardium sp., Legumen sp., Pecten sp., Pinna petrina White, Isocardia sp., Liopistha (Psilomya) sp., Anchura. sp., Prionotropis sp., Acanthoceras? sp....... Shale alternating with layers of yellow sandstone........................

Shale, carbonaceous, dark; has general aspect of the shale associated with the coal beds of the Mesaverde in this field..

Sandstone, coarse grained above, shaly below, weathers to irregular, rounded masses; contains Halymenites similar to H. major Lesquereux, worm borings, and a variety of indefinite markings...........

Shale, dark (gastropod zone), containing (U. S. Geol. Survey fossil localities 7205 , 3517, and 3518) Ostrea sp., Exogyra columbella Meek, Camptonectes symmetrica Herrick and Johnson, Plicatula sp., Gervilliopsis? sp., Pinna petrina White, Pinna sp., Liopistha (Psilomya) sp., Arca sp., Trigonarca sp., Cardium sp., Lucina sp., Turritella sp., Anchura . fusiformis White (not Meek), Anchura sp., Cinulia? sp., Serpula sp...............

Sandstone, soft, friable, contains small pebbles principally of quartz and chert.. Sandstone, yellow

Dakota sandstone (?) and Morrison formation:

Sandstone, conglomeratic, absent. in some places............................

Sandstone, gray to pink; varies greatly from place to place in thickness, composition, and color. This sandstone may be $\mathrm{Da}$ kota, but its color and variable character are suggestive of Morrison..............

Sandstone and shale, variegated (Morrison).

No definite line of separation between the Mancos and Mesaverde has been drawn in this field. The rocks between the 27-foot shale of this section and the Punta de la Mesa sandstone consist of sandstone and sandy shale and doubtless have about the same thickness as that shown in the Casa Salazar section (850 feet), although the measurement made in the
350

$.5 \quad 0$

80

$20 \pm$

100
Ft. in | unfarorable circumstance presented in the Rio Puerco field indicated only 297 feet. East of the southerm end of Prieta Mesa, about 5 miles northeast of San Francisco, the fossils of lot 7981 (p. 198) were collected from the lower part of this sandy portion of the Mancos shale from a sandstone which may be the Punta de la Mesa. Concerning the age relations of these fossils Stanton says: "This lot seems to belong to the Colorado fauna, though a few of the forms suggest a somewhat later age."

Two collections of fossils were made by the writer east of the Rio Puorco about 3 miles north of San Francisco. The first is from a zone of limestone-concretions that seems to occupy a horizon about 50 feet above the top

$50+$ of the Tres Hermanos sandstone, although 78 the fossils indicate a higher horizon. The following species were collected from it :

Fossil shells collected east of the Rio Puerco, about $s$ miles north of San Francisco. N. Mex.

[U. S. Geol. Survey fossillocality. 7204.]

Ostrea sp.

Pinna petrina White.

Cardium sp.

Lunatia sp.

Turritella sp.

Prionotropis sp.

Metoicoceras sp.

Coilopoceras colleti Hyatt:

The second collection is from an exposure about half a mile east of the first and estimated to be stratigraphically higher by about 50 feet. The strata here dip very slightly to the east,

and the rocks are covered with soil in most places. The shells collected are as follows:

Shells collected cast of the Rio Puerco, about, \& miles north of Sin Francisco, N. Mex.

[U. S. Geol. Survey fossil locality 7193.]

Ostrea lugubris Conrad.

Anomia sp.

Inoceramus fragilis Fall and Meek.

Anchura sp.

Anisomyon? sp.

Baculites gracilis Shumard?

Prionocyclus wyomingensis Meek.

Scaphites warreni Meek and Hayden.

Ptychodus sp.

These shells indicate horizons near the cephalopod zone, but their apparent position as observed in the field is near the base of the Mancos. This may be due to faulting, though little indication of it was noted near these localities. 
During the summer of 1912 the writer, in company with ' $\mathrm{T}$. W. Stanton, revisited this region and collected fossils from places a few miles north of those just described. They are reported by stanton as follows:

Fossils collected about 5 miles east of Rio Puerco on road from Albuquerque to Casa Salazar, $N$. Mex., in shale underlying Punta de la Mcsa sandstone (?).

[U. S. Geol. Survey locality 7980.]

Inoceramus sp.

Nucula sp.

Cardium sp.

Corbula sp.

Gyrodes sp.

$\Lambda$ nchura sp.

Baculites sp.

Prionotropis sp.

Fossils collected from Punta de la Mesa (?) sandstone.

[U. S. Geol. Survey locality 7981 (same as 7980).]

Ostrea soleniscus Meek.

Ostrea sannionenis White?

Ostrea sp.

Inoceramus sp. related to I. erectus Meek.

Nucula sp.

Astarte? sp.

Cardium sp.

Tellina modesta Meek.

Solemya sp.

Mactra arenaria Meek.

Mactra sp.

Corbula sp.

Anchura sp.

Anisomyon sp.

Gyrodes sp.

Baculites sp.

Scaphites warreni Meek and Hayden?

Fossits collected about 2 miles east of Rio Purco on road from Albuquerque to Casa Salazar, N. Mex., in bank of arroyo below ranch.

[U. S. Geol. Survey locality 7982.]

Gryphaea sp.

Exogyra sp.

Cardium trite White?

Inoceramus sp. related to I: frayilis Hall and Meek.

Anchura sp.

Fossils collected in arroyo south of road from Albuquerque to Casa Salazar, N. Mex., about $2 \frac{1}{2}$ miles east of wost boundary of Albuquerque quadrangle, apparently only about 50 feet above Tres Hermanos sandstone.

$$
\text { [U. S. Geol. Survey locality 7983.] }
$$

Ostrea lugubris Conrad?

Pholadomya sp.

Turritella sp.

Volutoderma sp.

Acanthoceras sp.

Placenticeras sp.

Metoicoceras puercense (Herrick and Johnson).

Mstoicoceras sp.
Fossils collected from same locality as 7983 in shale 100 feet thick overlying "cephalopod zone.".

[U. S. Geol. Survey locality 7984.]

Ostrea lugubris Conrad.

Inoceramus dimidius White.

Astarte? sp.

Anchura sp.

Anisomyon? sp.

Baculites gracilis Shumard?

Scaphites warreni Meek and Hayden.

Prionocyclus wyomingensis Meek.

Fossils collected from same locality as 7983 but lower in section from 50 feet of shale overlying Tres Hermanos sandstone.

[U. S. Geol. Survey fossil locality 7985.]

Exogyra sp.

Plicatula sp.

Lunatia sp.

Prionotropis? sp.

More detailed investigation of the Mancos from Rio Puerco westward is necessary before its subdivisions and their relations to each other and to neighboring formations can be properly understood. The rocks dip at low angles and broad grassy valleys occur at the outcrops of the shale. The rocks are faulted and warped in some parts of this field, and in these broad valleys it is difficult to find a place where there is no liability of error in measuring the shale.

\section{TIJERAS FIELD.}

The Tijeras coal field is in central New Mexico, about 14 miles south of Hagan and 20 miles east of Albuquerque, on the eastern slope of the Sandia Mountains. The coal-bearing rocks occupy the center of a syncline of irregular outline about 5 miles long and 2 miles wide (see fig. 14), which is bounded on the west by the Sandia uplift, on the northeast by the South Mountain'uplift; and on the southeast by a broad but less well defined uplift due to a fault that (in the area mapped) brings the Carboniferous red beds in contact with the Mancos shale. The coal-bearing rocks are much disturbed by faulting, warping, and crushing, but in general dip from all directions toward the center of the syncline. Along the western margin of the field the strata are upturned to nearly vertical. The part of the section below the coal beds was measured across the edges of these upturned beds at San Antonio, for although these rocks lie more or less horizontal in the central part of the syncline, they are there warped, faulted, and crushed to such an 
extent that any measurement is likely to be deceptive. The part of the section above the Mancos shale was measured in a canyon at Holmes mine near the center of the syncline, where these rocks seem to be disturbed less than they are in some other places. Nevertheless, the section is given here with some hesitancy; because the measured thickness may prove to be very different from the thickness of the beds as originally laid down.

Section of rocks measured in the Tijeras coal field, $N$. Mex.

Mesaverde formation, including possibly younger beds:

Sandstone, coarse grained (not continuously exposed; thickness estimated)

Sandstone, gray, coarse grained, fria-ble, contains Laurus? sp. (U. S. Geol. Survey fossil locality 6033)...

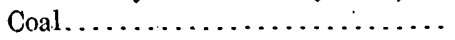

Not exposed $\ldots \ldots \ldots \ldots \ldots \ldots \ldots \ldots$ Coal........................

Not exposed . ....................

Sandstone, coarse grained, hard, cliff making (thickness estimated)....... ( $\mathrm{Abrupt}$ change in lithology.)

Shale and yellow sandstone. The shale predominates in the lower part and the sandstone above; contains (U. S. Geol. Survey fossil locality 7187) Ostrea sp., Inoceramus barabini Morton?, Cucullaea sp., Cyprimeria sp., Legumen? sp., Gyrodes sp., Volutomorpha novimexicana Herrick and Johnson?, Fusus? sp., Odontofusus?

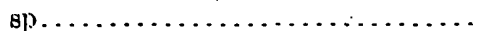

Shale, with many thin layers of yellow flagry sandstone................

Sandstone, massive; contains (U. S. Geol. Survey fossil localities 7182 and 7185) Ostrea sp., Inoceramus sp., Cucullaea sp., Cyprimeria sp., Volutomorpha sp., Pyropsis sp., Placenticeras planum Hyatt, Placenticeras sancarlosense Hyatt, Baculites. sp., Sphenodiscus sp., Lamna?• sp. Coal with a thin layer of shale containing Ficus sp. above it.......

Shale........................ Coal........................

Shale, not continuously exposed...... Sandstore, massive; contains (U. S. Geol. Survey fossil locality 7184) Ostrea sp., Cucullaea sp., Cucullaea? sp., Cardium sp., Cyprimeria sp., Mactra sp., Gyrodes sp., Volutomorpha novimexicana Herrick and Johnson, Placenticeras sancarlosense Hyatt.

Shale, with Myrica torreyi? and other plants (U. S. Geol. Survey fossil locality 6031$) \ldots \ldots \ldots \ldots \ldots \ldots \ldots$

Mesaverde formation, including possibly. younger beds-Continued.

Shale and sandstone. with thin layers of coal; contains (U. S. Geol. Survey fossil locality 7183) Cucullaea sp. and Cardium sp....................... Coal. .......................

Sandstone, massive, cliff making; contains (U. S. Geol. Survey fossil locality 7186) Cardium sp., Callista? sp., Volutomorpha sp..............

Mancos shale:

Shale, dark, sandy at top ........... 1,345. $\quad 0$

Sandstone (Tres Hermanos member), hard, quartzose; contains worm borings and indefinite markings of various kinds .....................

Shale, dark, with limestone concretions (gastropod zone)............

Dakota sandstone.

$\begin{array}{ll}\text { Ft. } & \text { in. } \\ 20 & 0 \\ & 2 \pm\end{array}$

1150 $145 \cdot 0$

$60 \quad 0$

$65 \quad 0$

Morrison formation:

Sandstone and shale, variegated.

150

25

$3 \pm$

?

$50 \quad 0$

390

50

the shale containing the gastropod zone. No

$55 \pm$ fossils were found in it, but it is stratigraphi1士 cally and lithologically the same as the Tres 150 Hermanos sandstone of the other fields de0-2 \pm scribed in this paper.

The principal mass of the Mancos shale is thinner in the Tijeras field than it is in the Hagan and Cerrillos fields, but this may be due in part to mechanical thinning which may.have taken place during the disturbance which upturned the rocks. On the other hand, the shale may have originally thinned toward the south as it does toward the west, but the distance of \begin{tabular}{cl|l}
10 & 0 & 10 miles between the fields is scarcely enough \\
1 & 8 & to render this hypothesis tenable.
\end{tabular} 
No fossiliferous lenses of yellow sandstone lie below the coal beds in the Tijeras field as they do in the Hagan field. It has not been determined whether this absence is to be explained on the assumption that the top of the Mancos shale of the Tijeras field is equivalent to the sandstone lenses of the Hagan field, or whether

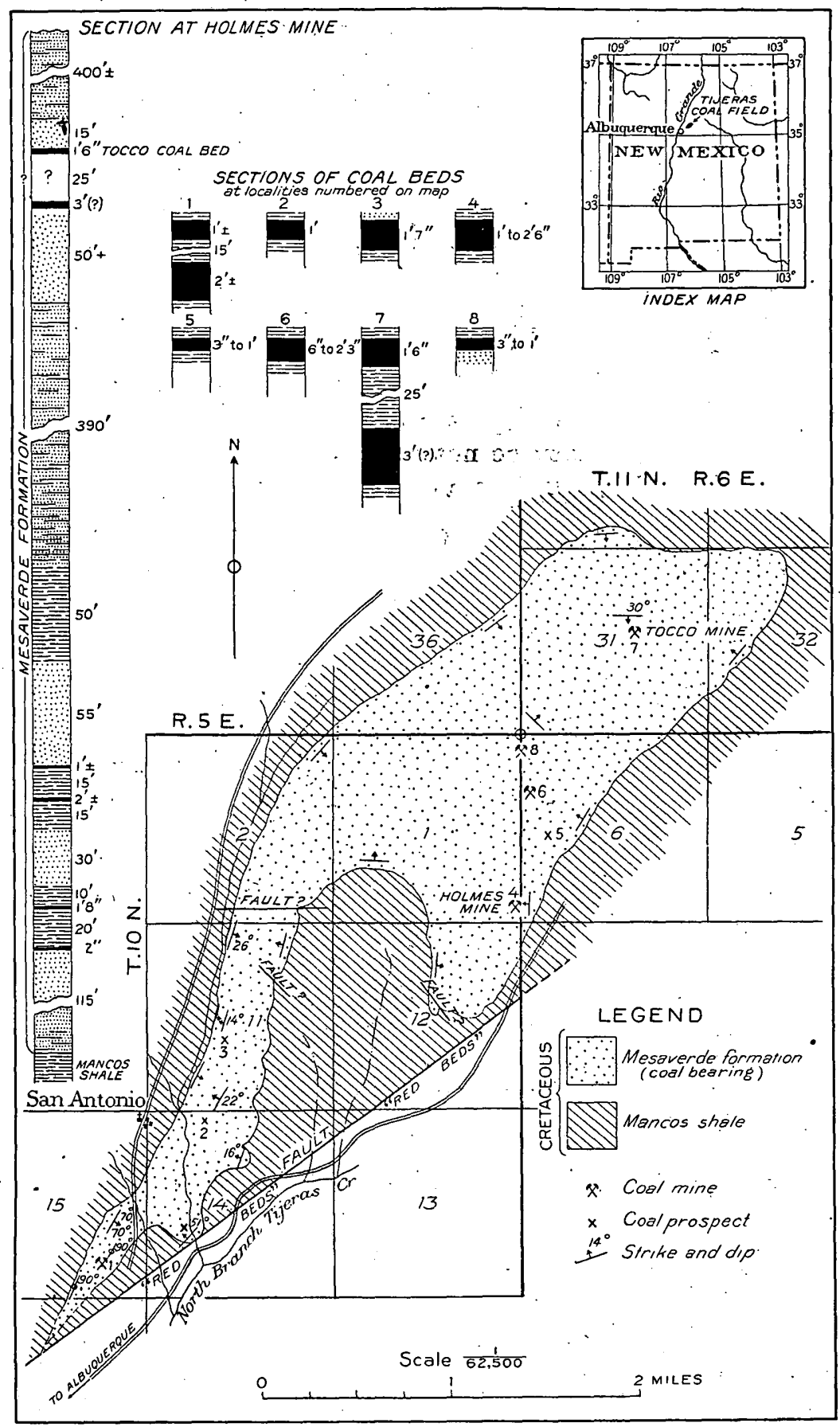

FIGURE 14,-Map and sections of the Tijeras coal field, N. Mex. the coal-bearing rocks of the Tijeras field are equivalent in age to the lenses of the Hagan field and therefore older than the Hagan coals. In many places in the Tijeras field the basal sandstone of the Mesaverde contains marine shells of species identical with those found in the sandstone below the coal in the Hagan field. Coal lies immediately above this sandstone, and associated with it are fossil leaves, but only a few poorly preserved specimens were found. The Mesaverde of the Tijeras field is essentially a marine formation and yielded shells at several horizons, as indicated in the section.

A zone of shale and sandstone above the principal coal beds contains marine fossils and may be the equivalent of the Lewis shale of the southern part of the San Juan Basin described by Gardner. ${ }^{222}$ It is somewhat thicker than the Lewis in the southeastern part of this basin, the locality at which the Lewis is known to occur nearest to the Tijeras field. The fossils named in the section indicate clearly the marine character of these beds, and if the Tijeras section were compared only with the sections measured in the Hagan and Cerrillos fields to the north it would seem proper to correlate the coal-bearing rocks with the coal measures of the Hagan and Cerrillos sections and refer the marine beds above them to a higher horizon, not now represented in the Hagan and Cerrillos fields. On the other hand, if the Tijeras section be compared with that of the Rio Puerco field the rocks con- 
taining these marine shells appear to represent one of the marine horizons in the Mesaverde in that field. The fossil shells seem to favor the latter correlation, for they are not characteristic Lewis species. They do not differ materially from those found at several horizons within the Mesaverde, and because of this fact these rocks are included in the Mesaverde.

These marine beds are overlain by a coarsegrained hard, cliff-making sandstone, which differs in character and appearance from the sandstone below to such an extent that it suggests the beginning of a new formation. This in turn is overlain by coal-bearing sandstone and shale. If the underlying beds containing the fossils of marine origin prove to be Lewis the higher beds may prove to be equivalent to the "Laramie".. of the San Juan Basin. No fossils except a few poorly preserved leares were found in them, and these proved insufficient for age determination.

These younger coal-bearing rocks are confined to the center of the synclinal basin and occupy an area of only a few acres. Coal occurs near their base, but the rocks intervening between it and the cliff-making sandstone, which is relatively hard, consist of soft sandstone and shale, so poorly exposed that the thickness could not be measured. Two coal beds 25 feet apart are known to occur in this upper coal-bearing part of the formation and were observed at the Tocco coal mine. The rocks above them consist principally of coarsegrained friable sandstone and, like the basal sandstone just described, are very different in appearance from any of the sandstones associated with the lower coal beds in this field or in the Mesaverde formation of the neighboring fields. For this reason these rocks are regarded as possibly younger than Mesaverde, but in the absence of definite evidence they are here assigned with doubt to the Mesaverde.

\section{HAGAN FIELD.}

The Hagan coal field lies east of the Rio Grande between the Sandia and the Ortiz Mountains. The Hagan coal mine, from which this field derives its name, is located about 14 miles southwest of Cerrillos. The mine has been described by M. R: Campbell ${ }^{203}$ and the coal beds correlated by him and others with those opened in the same field at the Sloan and the Pina Vititos mines. The rocks of this field $\operatorname{dip} 15^{\circ}-35^{\circ} \mathrm{E}$. and disappear under accumu-

lations of rock débris of comparatively recent origin. A section of the Cretaceous rocks at Hagan was measured with tapeline across the strike in an east-west direction, and the thicknesses obtained were corrected for dip. The rocks lying stratigraphically below the Dakota were described by the writer ${ }^{210}$ a few years ago, the top of the section measured at that time ending where the base of the present section begins. These two may be combined to make a complete section of the sedimentary rocks exposed east of the Sandia Mountains.

Scction of rocks measured near Hagan, N. Mex.

Quaternary(?):

Conglomerate consisting of pebbles and boulders up to several feet in diameter (several hundred feet).

Unconformity.

Tertiary:

Shale and friable sandstone, highly colored in many shades of purple, blue, green, yellow, etc....................

Sandstone, conglomeratic, with partings of red shale; a coarse conglomerate occurs at the base. Sandstone is all coarse grained, granular, and friable...........

Shale, sandy in some places, gypsiferous; highly colored, like the shale above....

Sandstone, yellow, conglomeratic at the base with pebbles up to 4 inches in diameter in a matrix of loose, friable sandstone. Pebbles consist principally of quartz, quartzite, chert, jasper; sandstone like those of lower horizons; and fragments of petrified wood. Sandstone is very coarse grained and more or less friable throughout, and contains great numbers of petrified logs, some of which seem to be of palm wood. Concretions of pink sandstone occur in the lower part...............................

Unconformity.

Foet. 2,500

Mesaverde formation:

Shale, sandy, with soft, friable sandstone. The shale is carbonaceous with thin seams of coal in many places, and several coal beds 1 to 6 inches thick occur near the top. Large concretions of yellow and chocolate-colored calcareous sandstone, yellow cone-in-cone structure limestone, and ironstone throughout. The following fossil leaves were found at the top of this shale half a mile north of Hagan (U. S. Genl. Survey fossil locality 6030): Brachyphyllum sp., Ficus sp., and Dalbergia n. sp.....................

Sandstone in thick, massive plates; forms the crest of the ridge at Hagan mine; fossiliferous 
Mesaverde formation-Continued.

Shale, sandy; contains crystals of gypsum (selenite) and fossiliferous concretions of sandstone. Fossil leaves at the top (U. S. Geol. Survey fossil locality 6022) are Alga, Cyperacïtes sp:, Gleichenia rhombifolia Hollick, Trapa microphylla Lesquereux, Nelumbo intermedia? Knowlton, and Carpites n. sp.......... Coal. .......................... Shale, chocolate-colored.............. Coal...........................

Sandstone, gray to brown, hard, fine grained; in layers alternating with shale.

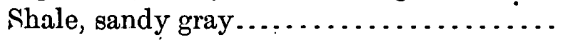
Coal............................

Sandstone and shale in alternating layers; contains (U. S. Geol. Survey fossil locality 6023) Protophyllocladus sp., Ficus lanceolata Heer, Ficus praetrinervis Knowlton, Quercus sp ...................

Sandstone, massive, gray, coarse grained, cross-bedded; contains petrified wood; lies with uneven contact on coal, 5 to 15 feet...........................

Coal (Hagan mine) . . ..............

Shale, carbonaceous, chocolate-colored.... Sandstone, shaly, and carbonaceous shale.. Sandstone, calcareous, chocolate-colored .. Shale, sandy.

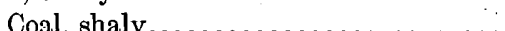

Shale................................

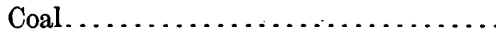

Covered (thin beds of coal occur at this horizon one-half a mile farther north)...

Sandstone, massive, friable, light gray.....

Not well exposed. There are several small ridges formed by, the outcropping of sandstone layers in which are concretions of chocolate-colored sandstones and fossiliferous limestones; contains (U. S. Geol. Survey fossil localities 6778 and 7172) Ostrea elegantula Newberry, Ostrea sp., Anomia sp., Syncyclonema sp., Modiola sp., Inoceramus barabini Morton, Inoceramus sp., Lithophagus sp., Leda sp., Cucullaea sp., Cardium sp., L $L$ gumen sp. related to $L$. planulatum Conrad, Liopistha undata Meek and Hayden, Tellina sp.; Mactra sp. related to M. formosa Meek and Hayden; Mactra sp. related to $M$. gracilis Meek and Hayden, Mactra sp., Turritella sp., Gyrodes sp., Lunatia sp., Pterocerella sp., Fasciolaria? sp., Turris sp., Pyrifusus? sp., Pyropsis? sp., Volutomorpha nolimexicana Ferrick and Johnson, Actaeon sp., Placenticeras whitfieldi Hyatt, Placenticeras intercalare Meek and Hayden, Placenticeras sancarlosense Hyatt, Placenticeras planum Hyatt, Scaphites sp. related to $S$. hippocrepis Dekay, Lamna sp. (shark teeth), fish vertebrae...........
Feet. Mesaverde formation-Continued.

Shale and sandstone not well exposed..... Sandstone with a subordinate amount of shale. The sandstone occurs in large lenticular masses and contains irregular masses of brownish-yellow to chocolatecolored, fossiliferous limestone. Gastropods are most numerous near the base. Contains (U.S. Geol. Survey fossil localities 6779 and 7175) Ostrea sp. related to O. lugubris Conràd, Ostrea (Alectryonia) sp., Inoceramus barabini Morton, Inoceramus sp., related to $I$. acutiplicatus Stanton, Pinna sp., Cucullaea sp., Cardium sp., Crassatellites shumardi Meek, Cyprimeria sp., Tellina sp., Turritella sp., Anchura? sp., Gyrodes sp., Turris sp., Pyrifusus? sp., Volutomorpha novimexicana Herrick and Johnson, Pyropsis? sp., Odontofusus? sp., Volutoderma? sp., several undetermined gastropod genera, Nautilus dekayi Morton?, Placenticeras sancarlosense Hyatt, Placenticcras intercalare Meek and Hayden, Lamna sp. (shark teeth), fish vertebrae ...........................

Mancos shale:

Shale with a few layers and concretions of limestone. The upper part: 100 to 200 feet thick, is sandy and yellowish in color and contains (U. S. Geol. Survey fossil localities 7171 and 7173) Anomia sp., Inoćramus sp. related to $I$. acutiplicatus Stanton; Inoceramus sp. related to $I$. sagensis Owen, Cardium sp., Gyrodes sp., Pyropsis? sp., Volutomorpha novimexicana Herrick and Johnson; but the principal part is dark and contains few fossils except a very large species of Inoceramus. Thin layers of fossiliferous limestone occur near the base and contain (U. S. Geol. Survey fossil locality 7178) Inoceramus labiatus Schlotheim, Inoceramus fragilis Hall and Meek, Prionocyclus uyomingensis Meek...................

Shale with fossiliferous limestone concretions at the top, containing (U. S. Geol. Survey fossil locality 7177) Ostrea lugubris Conrad, Ostrea sp., Inoceramus labiatus Schlotheim, Inoceramus fragilis Hall and Meek, Pecten sp., Pinna petrina White, Cardium sp., Isocardia sp., Anatina sp., Pholadomya sp., Mactra? sp., Turritella sp. related to T. whitei Stanton, Gyrodes sp., Volutoderma dalli (Stanton), Actaeon sp., Placenticeras sp., Prionotropis (two or more species)..........

Jimestone containing Inoceramus labiatus Schlotheim....................... Shale
Feet. 415

$1,854 \pm$ 
Mancos shale-Continued.

Sandstone (Tres Hermanos), quartzose, consisting of thin, contorted layers with numerous worm borings and markings of many kinds; also poorly preserved gastropods and other shells.................

Shale (gastropod zone) .................

Dakota sandstone:

Sandstone, white, friable, cross-bedded, locally conglomeratic ................ Morrison formation:

Shale, variegated, and sandstone.........

Foet. the base of the shale is full of shells of Inoceramus labiatus, a characteristic fossil of the Greenhorn limestone. A zone lying about 400 feet above this limestone has been called the cephalopod zone by Herrick. ${ }^{148}$ It is characterized by numerous limestone concretions, which are very fossiliferous and yielded the fossils (lot 7177) named in the section.

The Dakota sandstone is massive, conglomeratic, quartzitic in some places and friable in others, and its thickness changes from 15 to 50 feet or more in relatively short distances. No fossils were found in it, and its reference to the Dakota is based on its similarity in lithologic character and stratigraphic position. to the Dakota of neighboring regions.

The Mancos shale here; as elsewhere in the areas described in this paper, includes several more or less well defined zones that can be recognized over wide areas by their lithologic characters and by characteristic fossils. The lowest or gastropod zone, so called by. Herrick and Johnson ${ }^{140}$ in the Rio Puerco fie!d, is found in a dark shale 90 feet thick, and here as elsewhere in central New Mexico contains limestone concretions. However, these are not so fossiliferous as are those of the gastropod zone on the Rio 'Puerco. A few imperfect shells, mostly of the genus Inoceramus, were seen in it, but none were collected.

The Tres Hermanos sandstone ${ }^{146}$ is recognizable in this field, but it is only 5 feet thick where the section was measured. However, it increases to 15 or 20 feet in some places near by. It was observed along the outcrop from 凡 point about 2 miles south of Hagan for about 8 miles northward to Pina Vititos; where it disappears under surface débris. It contains a few poorly preserved gastropods and fragments of other shells.

The main body of the Mancos shale overlies the Tres Hermanos sandstone. It was measured and examined with much care near Hagan. Its lower half is a dark shale containing thin layers and concretions of limestone. Its upper half is more or less sandy and weathers to brownish yellow. These two subdivisions were readily recognized throughout the Hagan field. A thin limestone about 175 feet above
In the lower part of this concretion zone a petrified log 10 inches in diameter was found. The interior portions of it are silicified, and the silica center is surrounded by an envelope of coal about half an inch thick. Seventy-five feet above the top of the concretion zone the shale contains thin layers of dark limestone containing fossils (lot 7178 in the section). These shells, together with those from the concretion zone below them, belong to the Benton fauna. Several of the species are the same as those that Johnson ${ }^{161}$ included in his Benton. The writer visited Johnson's locality near the smelter of Cerrillos and is convinced that the horizon represented there is about the same as that indicated in the section 75 feet above the cephalopod zone.

At still higher horizons the Mancos shale contains specimens of Inoceramus 18 inches or more in length. The shells are fragile and crumble so easily that none were collected: They appear to be the same species that the writer has observed in many places near the center of the Mancos shale west of the Rocky Mountains and near the middle of the Pierre shale east of these mountains.

The. upper part of the Mancos consists of sandy shale about 700 feet thick, which may be the time equivalent of the sandy transitional beds at the top of the Mancos in other places. On the other hand, it is possibly more-appropriate to regard this sandy shale as the lower part of the Mesaverde, for the fossils contained in it (7171 and 7173) do not differ from those of the overlying Mesaverde formation.

The line of separation between the Mancos and the Mesaverde formation is here drawn at the base of the massive yellow sandstones below the coal beds. (See Pl. XXVIII, A.) The lower part of the Mesaverde is not continuously exposed at Hagan. It consists of sandstones that form prominent ridges separated by depressions, in which softer rocks, presumably shale, are poorly exposed. The sandstones are more or less lenticular, and no one of them 
has been traced for any considerable distance. They weather to rusty yellow and contain irregular masses of earthy limestone, in which were found great numbers of fossil shells (see section) that do not differ materially from those found in the shale below. In other words, the rocks here referred principally on lithologic character to the top of the Mancos are faunally not divisible from those referred to the base of the Mesaverde.

The upper part of the coal-bearing rocks of the Mesaverde are well exposed near Hagan mine and contain several beds of coal, two of which have been opened at the mine. Alternating with these beds are layers of carbonaceous shale and chocolate-colored sandstone in which are fossiliferous concretions of yellow calcareous sandstone similar in general appearance to the concretions that contain the marine shells at lower horizons. The concretions lying just above the principal opening of the Hagan mine yielded the fossil plants of Mesaverde age (lot 6023) named in the section. Leaves and large petrified tree trunks occur at somewhat lower horizons.

The shale between the coal beds contains large crystals of selenite. This shale, as well as the sandstone associated with it, does not differ in general aspect from the beds of marine origin immediately below the coal.

The 600 feet of shaly rocks above the main coal beds are more variable in constitution than those at lower horizons. In their lower part they contain great numbers of concretions of earthy limestones; near the top they are more carbonaceous and in some places contain several thin beds of coal. These beds have been prospected, but no coal more than a few inches thick was observed, although much carbonaceous shale was seen.

The measured thickness of 600 feet is probably more than the normal thickness of this shale. The measurement was made across the trough of a tilted syncline, and it is possible that the shale has been mechanically thickened. - Farther north it is not so well exposed and no measurement of its thickness was made, although the interval occupied by it was estimated at considerably less than 600 teet. The rocks at Pina Vititos, which probably represent this shale, measured 460 feet.

Lying unconformably upon these highest coal-bearing rocks is a conglomerate that con- stitutes the base of an extensive series of rocks younger than the Mesaverde. These rocks are highly colored and consist of shale, sandstone, and conglomerate that are similar in many wavs to the Galisteo sandstone of the Cerrillos coal field but that differ from the typical Galisteo in being much more shaly. Their conglomerates, too, consist of well-rounded pebbles of hard rock, whereas those of the Galisteo sandstone near Cerrillos contain many angular and slightly worn blocks of relatively soft rock. Howevier, the pebbles of the lowest conglomerates near Cerrillos are similar to those in the Hagan field and the larger and more angular ones are toward the top of the formation. On the other hand, these colored rocks in the Hagan field are very similar in composition, color, and general appearance to the Tertiary rocks of the Rio Puerco field, 30 miles to the west, and hold the same stratigraphic position. Although it seems probable that these rocks will eventually prove to be the time equivalent of some of the Tertiary formations of the San Juan River region farther west, they are provisionally correlated with the Galisteo sandstone. No fossils except petrified wood were found in them. (See Pl. XXVIII, B.) This occurs in the formation at. all horizons in the form of tree trunks 1 to 5 . feet or more in diameter, and in the conglomeratic part as well-worn pebbles, probably derived from tree trunks that were formerly embedded in the eroded portions of the underlying coal measures.

The youngest rocks near Hagan are coarsely conglomeratic and lie with conspicuous angular unconformity on the eroded edges of the red beds northeast of Hagan (Galisteo sandstone?), on the Mesaverde near Hagan, and on the Mancos shale and older rocks farther to the south. They consist principally of blocks of igneous rock derived in recent geologic time mainly from the Ortiz Mountains and constitute part of the beds which in the Cerrillos region were referred by Johnson ${ }^{161}$ to the Santa Fe marl, which, according to his definition, included, with the Tertiary, all rocks of the region younger than Tertiary. They are the rocks that form the aggraded parts of what has been described in this region as the high-altitude conoplain.

The Sloan mine is located in the Hagan field about 3 miles north of Hagan mine, and the formations of the Hagan section are all exposed there. The coal beds have been described by 


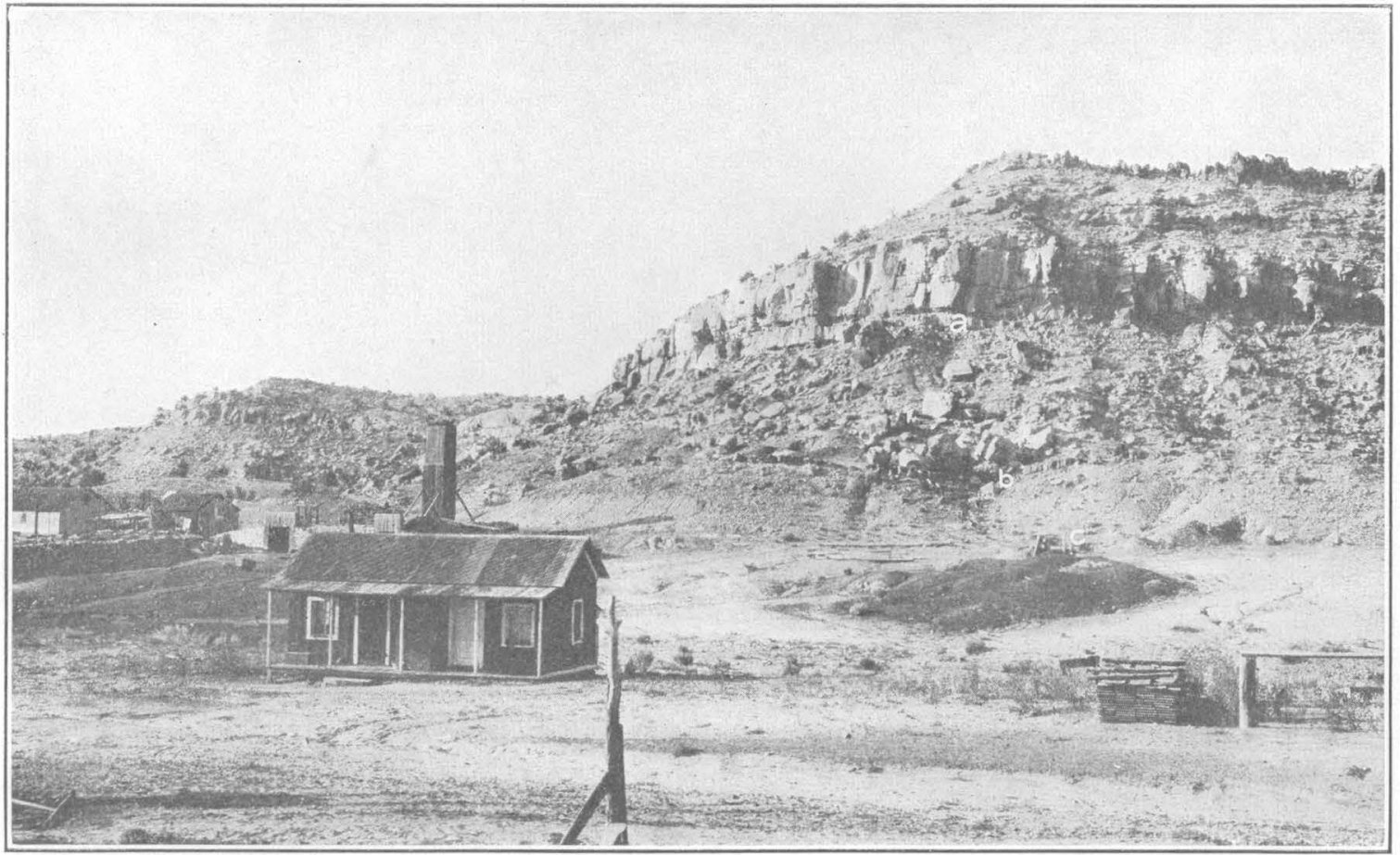

A. COAL-BEARING PORTION OF MESAVERDE FORMATION AT HAGAN, N. MEX a, Fossil plant locality 6022; b, fossil plant locality 6023; c, principal coal bed.

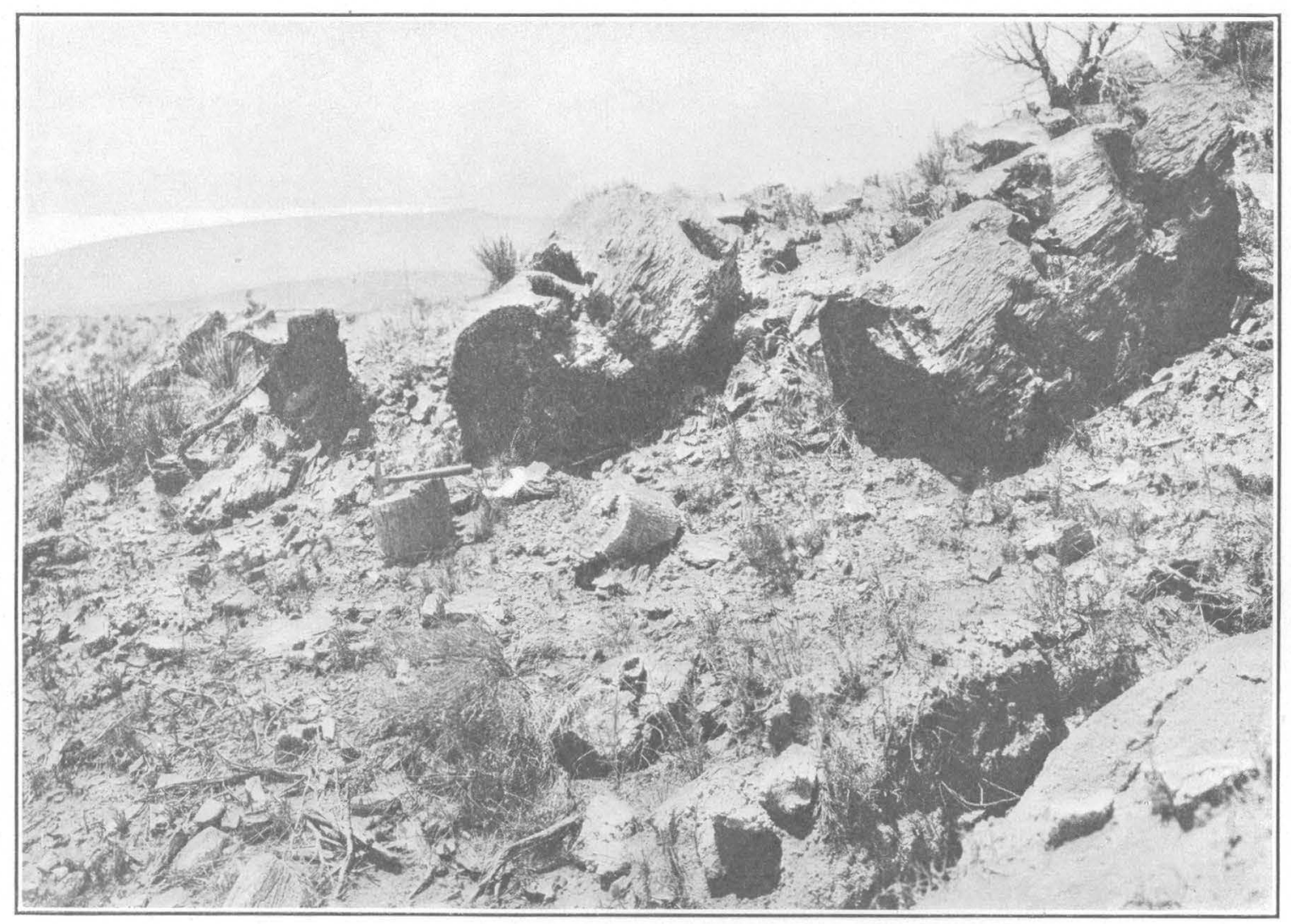

B. FOSSIL WOOD IN TERTIARY DEPOSITS, NEAR PINA VITITOS, HAGAN FIELD, N. MEX. 
M. R. Campbell, ${ }^{203}$ who quotes. a section of the coal-bearing rocks measured by $C$. $R$. Keyes. The Mancos shale below and the Galisteo (?) sandstone overlying the Mesaverde are present and are characterized by the same fentures as those described from Hagan and from Pina Vititos.

The Mesaverde is fossiliferous at several horizons. The massive sandstone underlying the principal coal beds contains Halymenites major Lesquereux, and some of the species of shells that were found in the Mesaverde at Hagan. Fossil plants-Ficus leei Knowlton, Ficus eucalyptifolia Knowlton, Myrica torreyi Lesquereux, and several undescribed forms-were found in the white sandstone overlying the main bed of coal (U. S. Geol. Survey fossil locality 6026). These species were found again at about the same horizon in a gulch half a mile south of the Sloan mine.

Pina Vititos is the name of a coal mine at the north end of the Hagan field, about 3 miles north of the Sloan mine and about 14 miles west of Cerrillos. All of the formations from Dakota to Tertiary are well exposed in the gulch in which the mine is located. They all dip about $30^{\circ} \mathrm{E}$. and pass under a cover of surface débris. Those below the Mesaverde do not differ in kind or character from the Mancos at Hagan and were not examined in detail. A section of the Mesaverde and younger rocks was measured with tapeline in the gulch and the measurements corrected for dip.

Section of rocks measured at Pina Vititos, N. Mex. Quaternary (?):

Conglomerate and breccia, containing a few pebbles of quartz, chert, etc., but consisting principally of blocks of igneous rock up to 5 feet or more in diameter, cemented to a resistant mass (many hundred feet).

Sandstone composed principally of igneous Feet. material............................. 165

Unconformity,

Galisteo (?) sandstone:

Sandstone, friable, slightly colored........ $\quad 330$

Conglomerate, composed principally of colored chert up to 3 inches in diameter..........

Sandstone, shaly, friable; variegated in color, shades of pink and yellow predominating..

Sandstone, friable, shaly, varicolored, with irregular masses of conglomerate at many horizons consisting principally of pebbles of $\mathrm{chert}$; contains great numbers of petrified logs............................ 1, 125

Sandstone, friable, white to light pink in color; contains pebbles of chert throughout......
Galisteo (?) sandstone-Continued. . Feot.

Sandstone, shaly, dark red.............. 400

Conglomerate......................... . 25

Sandstone, shaly, locally conglomeratic, pink to white in color...................... 330

Conglomerate, massive.................. 25

Sandstone, shaly, locally conglomeratic, pink 525

Conglomerate, coarse, massive........... $\quad 10$

Sandstone, shaly, friable, varicolored, conglomeratic at many horizons...............

Sandstone, conglomeratic at the base, more or less shaly above, with conglomerate at many horizons; petrified logs 1 to 6 feet in diameter are numerous................ 1, 120

Unconformity.

Mesaverde formation:

Shale and sandstone with ironstone concretions............................ 460

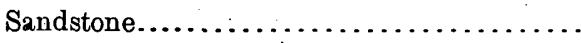

Shale with sandstone concretions, 1 foot 6 inches of coal near the top; contains at the base (U. S. Geol. Survey fossil locality 6028) Ficus sp. type of $F$. lanceolata Heer, Ficus wardii? Knowlton, Ficus praetrinervis Knowlton, Ficus leei Knowlton, Viburnum sp., and undescribed dicotyledons........ Coal...............................

Shale................................... 200

Shale...............................

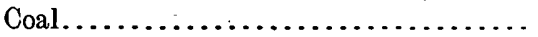

Shale................................

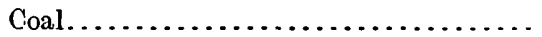

Shale................................

Sandstone, massive gray..................

Shale, sandy in the upper part, with lenses and concretions of sandstone.

Mancos shale.

The Mancos shale is well exposed west of the outcrop of the Mesaverde and does not differ in any essential manner from the Mancos of the Hagan section. As at Hagan, the lower part consists mainly of dark shale and the upper part of sandy shale which weathers to yellowish brown and contains fossiliferous concretions of impure limestone. No coal or carbonaceous shale was found below the sandstone that is here regarded as the base of the Mesaverde; the sandy shale is regarded as the transitional zone at the top of the Mancos, although it is quite possible it may be the equivalent in time of the lower part of the Mesaverde of other localities.

At the base of the measured section occurs a massive sandstone that appears to be at the same horizon as that at the base of the Mesaverde at Hagan. Five coal beds exposed in the mine entries, now abandoned; and several 
prospect openings were observed above this massive sandstone. The coals apparently hold the same position as those previously described from the Sloan and Hagan mines. Fossil plants were found at several horizons closely associated with the coal beds, and several (lot 6028 in section) were collected principally from the sandstone and shale overlying the main coal bed.

A series of shales and sandstones above the coal-bearing rocks contain ironstone concretions and may be the time equivalent of the rocks constituting the highest shaly member of the Mesaverde at Hagan.

On these shales and sandstone there rests unconformably, as at Hagan, the basal conglomerate of the colored beds which are correlated in a general way with the Galisteo. sandstone of the Cerrillos field. They contain great numbers of petrified logs, some of them very large, but most of them so poorly preserved that no specific determinations have been made. No identifiable fossils have been found in these colored rocks, and their geologic age is not known.

The coarse conglomerate which overlies the colored beds is composed principally of igneous material derived from the Ortiz Mountains in angular blocks from a few inches to several feet in diameter. The material is irregularly bedded and the beds dip $30^{\circ} \mathrm{E}$., about the same as the underlying rocks. The thickness, obtained by correcting for dip the distances measured across the strike in the upper part of the gulch locally known as Devils Canyon, is about 3,000 feet, but this may be in excess of the actual thickness, for the bedding is too irregular to admit of accurate determinations. It is certain, however, that this conglomerate is many hundreds of feet in thickness. It is the same as the youngest conglomerate of the Hagan section that was described as lying. unconformably on the Galisteo (?), Mesaverde, and Mancos formations.

\section{CERRILLOS FIELD.}

The Cerrillos coal field is better known than those just described, mainly because of the productive mines which have been operated in it for many years. The coal-bearing rocks occupy a syncline between the Ortiz Mountains and Galisteo Creek and extend from Galisteo westward for about 14 miles. The syncline is unsymmetrical and the rocks are warped and faulted in many places, but in general they dip from all directions toward the center of the syncline. The general geology of this field has been described by D. W. Johnson ${ }^{101}$ and will be considered in this paper no further than is necessary for an understanding of the age and structural relations of the Cretaceous and younger formations. The coalbearing rocks are referred to the Mesaverde and are correlated with those of the Hagan, Tijeras, Rio Puerco, and Cabezon fields. (See fig. 13 , p. 179.)

The principal coal beds of the upper part of the Mesaverde formation have been opened at Madrid, and their thickness, character, and stratigraphic position are well known from mining operations. Coal has been mined from three beds, the lowest of which, known as the Cook \& White coal bed, averages 3 feet in thickness. One hundred feet stratigraphically above this is the Peacock coal bed, averaging 1 foot 8 inches in thickness, and 22 feet higher is the White Ash bed, which normally contains coking bituminous coal averaging 5 feet 6 inches in thickness. Near Madrid the White Ash coal has been changed to anthracite by the intrusion above the bed of a sheet of igneous rock 400 to 500 feet thick. The anthracite coal averages 3 . feet in thickness. From data obtained in mining and kindly furnished to the writer by Mr. G. A. Kaseman, a section of the coal-bearing rocks at Madrid has been constructed. This section probably furnishes the best standard with which to compare others measured in the Cerrillos coal field, although fossils are so scarce as to be of little assistance in correlation.

\section{Section of rocks exposed at Madrid, N. Mex.}

¿[For graphic section see fig. 15, p. 208.]

Intrusive igneous rock.

Shale containing fossil plants, Sequoia reichenbachi (Geinitz) Heer (U: S. Geol. Survey fossil locality 6071) ........................... Coal (White Ash bed) $\ldots \ldots \ldots \ldots \ldots \ldots$

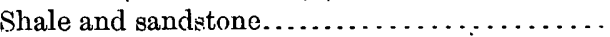
Coal (Peacock bed) .................... Shale and sandstone.......................

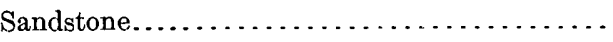

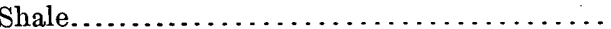

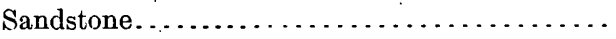

Shale with thin seams of coal..............

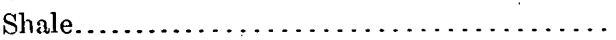

Sandstone.
Ft. in. $5 \pm$ 56 220 18 80 $20 \quad 0$ $20 \quad 0$ 200 20 60

200 


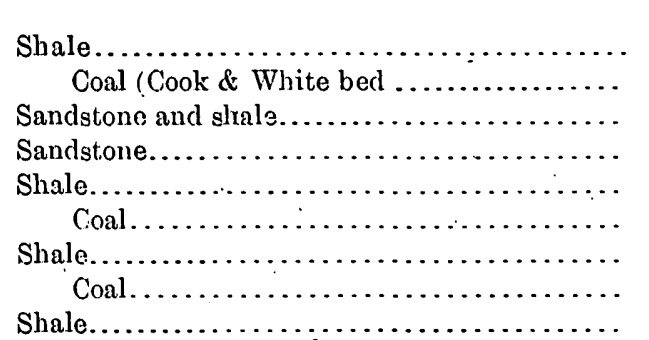

Few fossils were found in the coal-bearing rocks at Madrid, although careful search was made for them. The shale beds overlying the coal in the mines near Madrid yielded fossils at only one locality-about a mile south of Madrid in the roof of a prospect opening in the White Ash conl bed, where conifers (Sequoia reichenbachi (Geinitz) Heer) were found. Where the Cook \& White bed crosses Coal Gulch north of Madrid this coal bed is overlain by a massive sandstone containing pinkish-brown sandstone concretions, in one of which were found impressions of shells similar in appearance to some of the shells of marine origin that occur so abundantly in the sandstones at the base of the Mesaverde. The writer found no other shells above the coal beds near Madrid, but J. J. Stevenson ${ }^{89}$ reports the occurrence of Inoceramus and Ostrea in the coal-bearing rocks.

The rocks at Madrid dip about $15^{\circ} \mathrm{E}$. and the mine entries have been driven down this dip under an intrusive sheet of igneous rock which forms the crest of a hill east of the town. Above this sheet, in a gulch about half a mile enst of Madrid, coal-bearing rocks are exposed near the mouth of an abandoned mine. A section measured by D. W. Johnson ${ }^{161}$ at this locality was later confirmed by the present writer, who added fossil plants to those already reported.

Secition of rocks measured at an abandoned coal mine half a mile east of Madrid, N. Mex.

[For graphic section seo fig. 15, p. 208.]

Loose sand, upper part concealed..............

Intruded lava sheet.....................

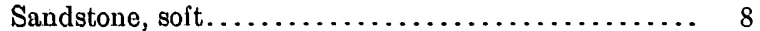

Intruded lava sheet...................... 3

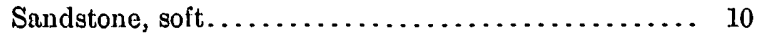

Sandstone, indurated, containing (U. S. Geol..Survey fossil locality 6019) Ficus rhamnoides? Knowlton, Ficus uncata? Lesquereux, Ficus speciosissima? Ward, Sabal? sp., Quercus? sp., Aralia? sp ........ 9 Shale, carbonaceous..

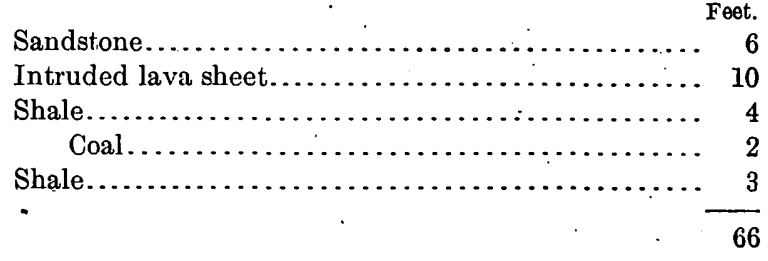

The rocks of this section lie stratigraphically below the Galisteo sandstone and above the intrusive sheet of igneous rock that overlies the highest or White Ash coal bed at Madrid. The thickness of this intruded rock is shown in drillhole records. 'In one hole sunk in the gulch a few hundred feet northeast of the old mine just mentioned and about 4,500 feet east of the principal opening at the outcrop of the White Ash coal bed the drill penetrated something like 75 feet of rock that seems to belong to the Galisteo sandstone before it reached the coalbearing rocks of the Mesaverde and encountered beds that seem to be equivalent to those of the section just given. After passing through the igneous rock a group of coal beds were encountered that doubtless are the same as those opened at Madrid. The record follows:

Section of rocks penetrated by diamond drill 4,500 feet east of the line of outcrop of the White Ash.coal bed at Madrid, N. Mexx.

(The rocks dip $15^{\circ} \mathrm{E}$. The measurements made of the core taken from the vertical hole are slightly in excess of the true thicknesses of the rocks. For graphic section see fig. 15, p. 208.]

Galisteo sandstone:

Shale, brown

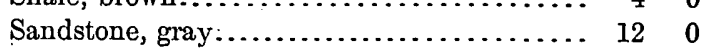

Shale......................... $7{ }^{0}$

Sandstone, gray..................... 50

Shale, gray to red..................... $22 \quad 0$

Sandstone, gray to red................ $19 \quad 0$

Shale, gray to red...................... $22 \quad 0$

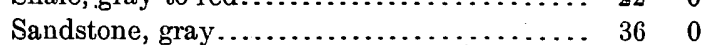

Shale, gray to red................... 80

Sandstone..................... $7 \quad 0$

Mesaverde formation:

Shale, gray. to red.................... $28 \quad 0$

Shale, carbonaceous with thin seams of coal. 30

Shale, dark........................ 120

Coal...................... 6

Shale, carbonaceous.................. $4 \quad 6$

Igneous rock....................... $425 \quad 0$

Shale, dark..................... 80

Coal....................... 12

Shale, dark..................... $6 \quad 10$

Coal...................... 1.2

Shale, dark....................... 20

Coal.............................. 10

Shale, dark.................... 29

Coal....................... 1 


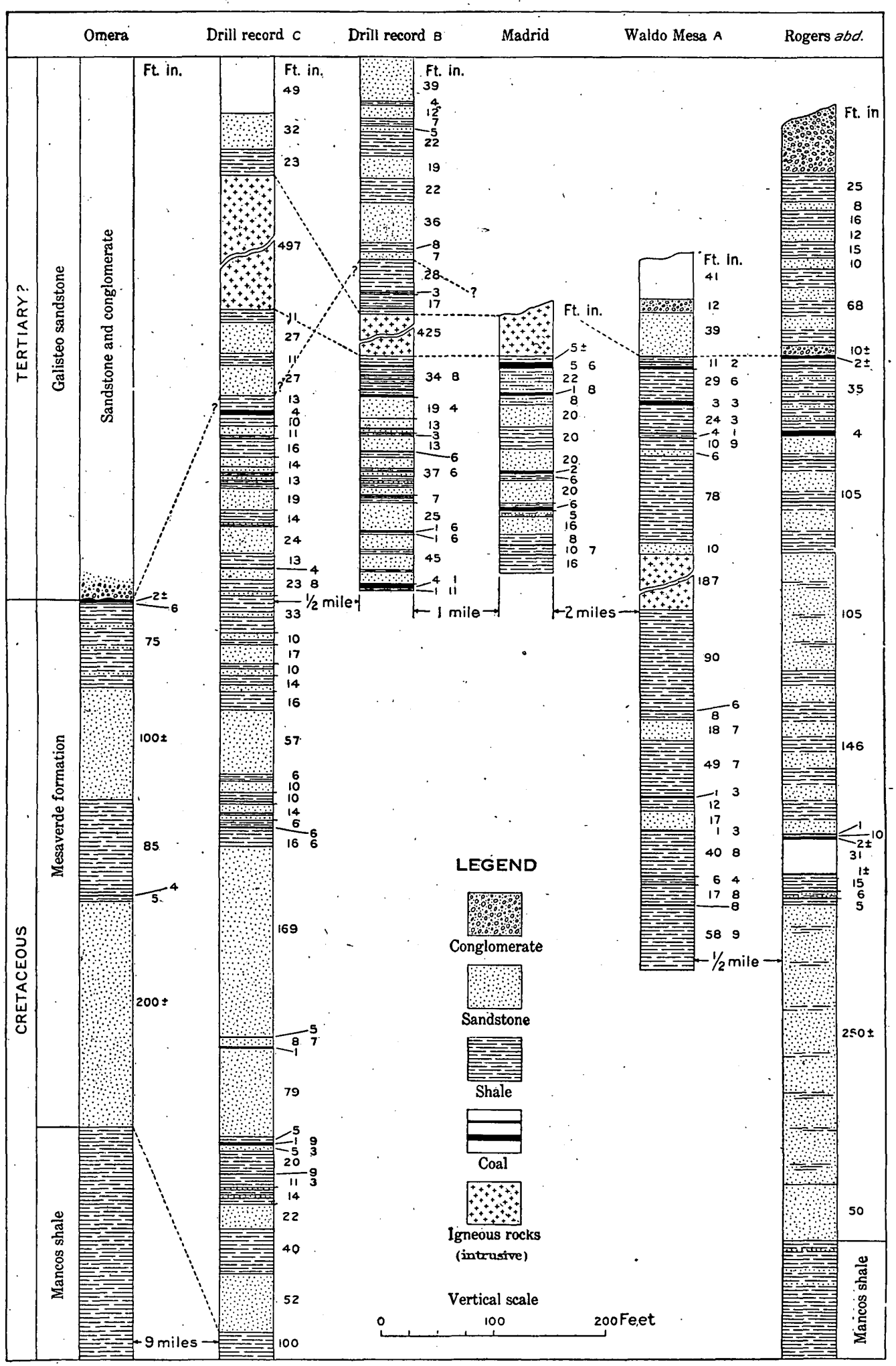

FIGURE 15.-Geologic sections and drill records in the Cerrillos coal field, N. Mex. 
Mesaverde formation-Continued. Shale, dark.

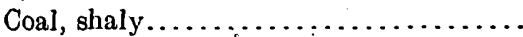
Shale, dark

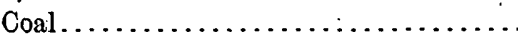

Sandstone, shaly

Sandstone...........................

Coal.

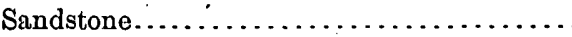

Shale, dark

Sandstone...........................

Coal.

Shale, dark.

Sandstone.

Shale, dark.

Sandstone.

Shale, dark.

Shale, dark...........................

Sandstone, brown.........................

Shale; dark.

Coal...

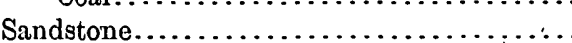

Shale, dark..........................

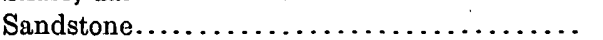

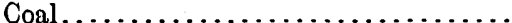

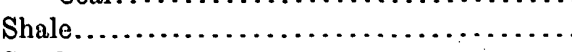

Sandstone...........................

Shale...................................

Sandstone........................... 14

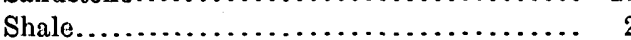

Sandstone........................... 11

Coal..............................

Shale.

8610

In a second drill hole put.down 6,800 feet east of the outcrop of the White Ash coal bed the drill reached a depth of 1,602 feet and penetrated not only the beds represented in the first record but also those of stratigraphic horizons considerably lower. The Galisteo sandstone occupies the surface in this region, but nothing in the record indicates its thickness at this locality except its red or variegated color which, however, may be caused by the metamorphic action of the intrusive igneous rock. As no coal is known to occur in the Galisteo sandstone, it seems safe to draw the line of separation between this formation and the Mesaverde above the highest coal. bed. (See fig. 15.) This record shows the occurrence of three groups of coals. The highest group obviously corresponds to that represented by the beds underneath the sheet of intrusive rock in the first record and to those of the Madrid section. The two lower groups probably correspond in stratigraphic position $47019^{\circ}-17-14$ to those described later near Omera farther east and to the lower coals near "Rogers" west of Madrid. The record follows:

Section of rocks penetrated by diamond drill 6,800 feet east of the line of outcrop of the White Ash coal bed, near Madrid, N. Mex.

(The rocks dip $15^{\circ} \mathrm{E}$. Measurements made of the core taken from the vertical hole are slightly in excess of the true thicknesses of the rocks. For graphic section see fig. 15, p. 208.]

Galisteo sandstone:

Gravel and boulders.

n..........

(n)

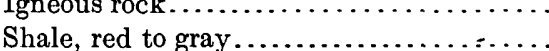

Sandstone, variegated in color.............

Shale, dark.

\section{Ft. in.}

$\begin{array}{ll}49 & 0\end{array}$

320

$23 \quad 0$

$497 \quad 0$

111

$27 \quad 0$

II 0

Mesaverde formation:

$650 \quad 1$

Sandstone, gray $\ldots \ldots \ldots \ldots \ldots \ldots \ldots \ldots . \ldots 27 \quad 0$

Shale................................ . $13 \quad 0$

Coal, anthracite.................... 40

Shale.............................. $10 \quad 0$

Sandstone, dark.................. $8 \quad 8 \quad 0$

Shale............................. $\quad 2 \quad 0$

Coal.......................... 10

Shale.............................. 160

Sandstone......................... 90

Sandstone, light...................... 5

Coal....................... 8

Shale................................... 14

Sandstone.......................... 4. 0

Shale..............................

Coal.............................

Shale...............................

Sandstone.........................

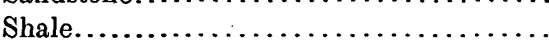

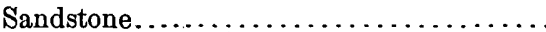

Shale...............................

Sandstone, shaly......................

Shale, sandy...

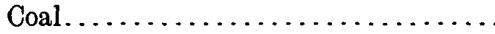

Sandstone.............................

Shale

Sandstone...........................

Shale. . .

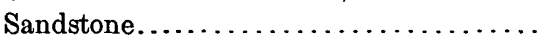

Shale.

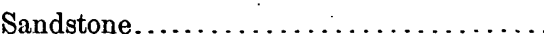

Shale.

Sandstone

Shale.............................

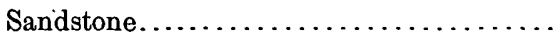

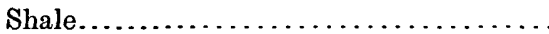

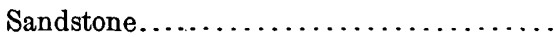

Shale..............................

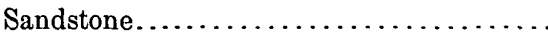

Shale.............................

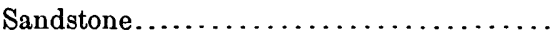

Shale:.

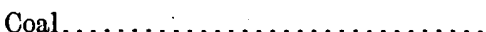




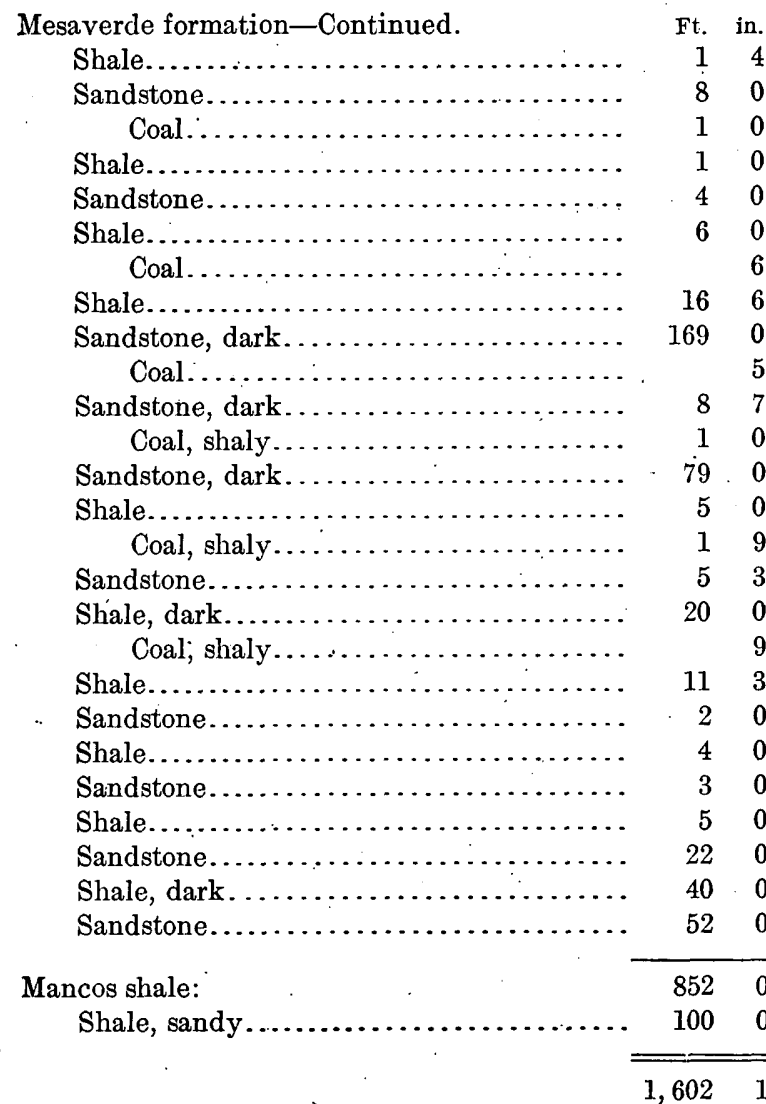

The dip of the rocks, which is $15^{\circ} \mathrm{E}$. at Madrid, if unchanged, would within a short distance carry a given bed to a considerable depth. However, the dip no doubt lessens eastward toward the center of the basin, and it is probable that the 1,602-foot hole passes entirely through the Mesaverde formation. The surface in the center is occupied by the Galisteo sandstone and younger rocks, but the underlying Mesaverde reappears from beneath them with opposite dip at the eastern extremity of the basin and was observed near Galisteo, although no details of it were obtained there. However, at the southeastern extremity of the basin, one of the Mesaverde coals has been developed at Omera mine; where a section was measured. The dip is low, and the thicknesses given were obtained by pacing across the outcrop and correcting for dip. Hence, the section is approximately correct and is presented to show the relation of the Mesaverde formation to the underlying Mancos shale and to the overlying Galisteo sandstone.
Section of rocks measured at Omera mine, about 18 miles southeast of Cerrillos, N. Mex.

[For graphic section see fig. 15, p. 208.]

Galisteo sandstone:

Conglomerate.

Unconformity.

Mesaverde formation: Ft. in

Coal (Omera mine)..................... $2 \pm$

Shale, carbonaceous.................... 6

Shale, with some layers of sandstone and cone-in-cone structure limestone (not continuously exposed) $\ldots \ldots \ldots \ldots \ldots \ldots \ldots \ldots, 75 \quad 0$

Sandstone......................... 100土

- Shale, carbonaceous in some places, with lenses and concretions of sandstone and cone-in-cone structure limestone. Fossil plants at the base.................... 85

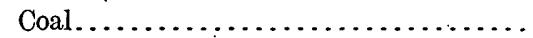

Shale................................

Sandstone, massive, yellow, contains fossil shells............................. 200t

Mancos shale:.

Shale with a sandy transitional zone at the top. Concretions of . fossiliferous limestone occur 100 to 150 feet from the top. These contain (U. S. Geol. Survey fossil locality 7180) Exogyra ponderosa Roemer?, Anomia sp., Inoceramus sagensis Owen?, Inoceramus sp., Cucullaea sp. Cyprimeria sp., Volutoderma? sp., Nautilus sp., Baculites sp., Mortoniceras sp. related to $M$. delawarense (Morton), Placenticeras sancarlosense Hyatt, Placenticeras sp. (very large specimens apparently distinct from either of the foregoing). A few hundred feet lower in this shale (U.S. Geol. Survey fossil locality 7181) the following fossils occur: Crassatellites shumardi Meek?, Mactra sp., Gyrodes sp., Volutoderma? sp., Actaeon? sp.

Comparison seems to show that the lowest bed of coal, which is only 4 inches thick where this section was measured but which is somewhat thicker in other places, corresponds in stratigraphic position with the lowest coal beds represented in the 1,602-foot drill record (p. 209); that the 100-foot sandstone finds its counterpart in the 169-foot sandstone of the drill record; and that the coal developed in the Omera mine corresponds in position with the middle group of the drill record and with the lowest developed coal of the Rogers section. (See fig. 15.) If this correlation is correct, it is evident that a large part of the Mesaverde for- 
mation as represented in other parts of the Cerrillos coal field is not present at Omera, and that the unconformity above the Omera coal represents an erosion interval of long duration.

The conglomerate of the Galisteo sandstone (see section, p. 210) rests in some places directly upon a coal bed, which varies considerably in thickness within short distances. Where shale intervenes between it and the overlying conglomeratic sandstone, the coal bed is 4 to 5 feet thick; but where the conglomeratic sandstone rests upon the coal bed, the coal is thinner and in some localities is entirely replaced by the sandstone, as is well illustrated in the mineworkings. J. H. Gardner states in his unpublished notes of the Omera mine that 560 feet down an old slope the coal abruptly disappears against a face of sandstone showing.no evidence of faulting. He found that this disappearance was due to total erosion of the coal bed previous to the deposition of the sandstone. He also states that at one locality near the Omera mine he found two coal beds separated by 9 feet of sandstone, the lower one 3 feet thick and the upper 4 feet 6 inches thick. At one of the prospect entries, a few rods from the place where the section given above was measured, the present writer observed two coal beds, as follows:

Section of rocks measured near Omera mine.

Conglomerate with pebbles of several kinds of rock including angular fragments of coal.

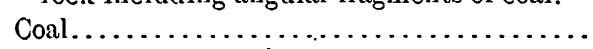

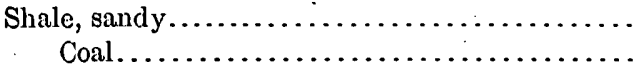
Shale.

The conglomerate shown at the top of this

The conglomerate shown at the top of this section constitutes the base of the Galisteo sandstone. In it were found pebbles and boulders, some as much as 6 inches or more in diameter, consisting of quartz, chert, sandstone, limestone, petrified wood, coal, and the like. This formation is exposed continuously from Omera northward to Galisteo Creek and westward to Madrid.

Below the Mesaverde the Mancos shale occurs in characteristic development. Great numbers of fossils, especially cephalopods, occur in concretions of limestone near the top of the formation. (See section, p. 210.)

The thickness of the Mancos was estimated to be about the same as that given for it in the Rogers section, but no attempt was made to measure it. It dips gently west and occupies the broad valley on either side of the New Mexico Central Railroad. At the eastern side of this valley, about 3 miles east of the town of Galisteo (U. S. Geol. Survey fossil locality 7170), the following Benton fossils were collected: Ostrea sp., Inoceramus fragilis $\mathrm{Hall}$ and Meek, Prionotropis sp., and undetermined casts of pelecypods and gastropods.

About 2 miles south of the locality where these fossils were collected the Tres Hermanos sandstone was recognized, also the shale between this sandstone and the Dakota, which contains the gastropod zone at the localities described farther west. Below the Mancos shale is a hard conglomeratic sandstone which, on the basis of lithologic character and stratigraphic position, is referred to the Dakota, and under it are variegated sandstone and shale that probably are Morrison.

- The rock formations above the Morrison in this eastern limb of the syncline correspond closely to those in the western limb, but those below the Morrison seem to be different. East of Omera a massive cliff-making pink to. red sandstone about 100 feet thick occurs below the Morrison and lies unconformably on the deep red and purple sandstone and shale of the typical red-bed formation of this region. This sandstone has the appearance of the Exeter sandstone ${ }^{158 \mathrm{~b}}$ of eastern New Mexico and holds' the same stratigraphic position. On sheet 13 of the Santa Fe Route guidebook ${ }^{1}$ this sandstone is called Wingate (?). Below this sandstone east of Omera occur red rocks similar to the red beds of the Manzano group that outcrop in the Sandia Mountains to the west.

The line of outcrop of the coal beds extends northwest from Omera and seems to pass around the northern base of the Ortiz Mountains to the coal in the vicinity of Madrid, but in the intervening space the coal is covered with débris from the mountains. North of Omera the coal beds were displaced by the intrusion of the igneous rock of Cerro Pelon, which rests on the basal sandstone of the Mesaverde at its southern end and on Mancos shale farther north. This shale and basal sandstone were observed underlying the Galisteo sandstone north of Cerro Pelon in the vicinity_ of Galisteo, but no indication was found that any coal occurs there. It seems probable that the 1 U. S. Geol. Survey Bull. 613, 1915. 
- erosion which preceded the formation of the Galisteo sandstone removed all rocks that may have existed above the basal sandstone of the Mesaverde in the vicinity of Galisteo. Little was seen of the Mesaverde or of the older rocks. between Galisteo and Cerrillos, they being, covered, for the most part, by younger rocks, but near Cerrillos the Mancos and Mesaverde reappear in vertical position, upturned by the intrusion of the igneous rocks of the mountains to the north:

West of Cerrillos the rocks dip steeply to the south and Galisteo Creek flows in a gorge cut along the strike partly in the Mancos shale and partly in the basal sandstone of the Mesaverde formation. About $1 \frac{1}{2}$ miles west of Cerrillos the rocks are well exposed south of Galisteo Creek, and a section was examined carefully for the purpose of locating the coal beds which have been developed at Rogers, a coalmining camp west of Madrid, now abandoned: At the horizons where the main beds should occur coal was found, but the beds are thin, possibly due to crushing at the time the rocks were upturned. Otherwise the section at this locality. does not differ materially from the Rogers section (below), except that in it the base of the Galisteo sandstone is more coarsely conglomeratic, consisting of hard quartzose sandstone containing pebbles principally of quartz and chert an inch or more in maximum diameter.

Fossil plants were found about 325 feet above the top of the basal sandstone of the Mesaverde in shale in a railroad cut on the branch line from Waldo to Madrid. They are as follows:

Fossil plants collected in the Mesaverde formation in a railroad cut $1 \frac{1}{2}$ miles west of Cerrillos, N. Mex. [U. S. Geol. Survey fossil locality 6021.]

Brachyphyllum cf. B. macrocarpum. Newberry.

Celastrus n. sp.

Ficus speciosissima Ward.

Ficus lanceolata Heer.

Ficus eucalyptifolia Knowlton.

Ficus n. sp.

Farther south and west the rock formations are well exposed and were traced to Rogers, on the western limb of the syncline. The rocks strike nearly north and south and dip $9^{\circ} \mathrm{E}$. A section was measured by tapeline from the old Rogers mine westward across the strike of the upturned rocks to a point at the base of the Cretaceous, about a mile south of Galisteo Creek. This section may be combined with the Galisteo Canyon section of the Manzano group published by the writer several years ago. 216 .

Section of rocks measured near Rogers, 2 miles southwest of Cerrillos, N. Mex.

[For graphic section sce fig. 15, p. 208.]

Conglomerate.

Galisteo sand̦stone:

Shale, sandy...................

Sandstone, yellow................. 8

Shale, sandy, yellow................ $\quad 16$

Sandstone, massive................ 12

Shale, sandy, light colored............. $\quad 15$

Sandstone, massive, gray............... 10

Shale andsandstone in alternating layers. $\quad 68$

Sandstone, massive, coarse grained, friable, loose textured to quartzose; locally conglomeratic; variable in thickness and character; contains (U. S. Geol. Survey fossil localities 6016 and 6020) Sabal? ungeri (Lesquereux) Knowlton and Dryopteris? sp.........

Unconformity by erosion.

Mesaverde formation:

Coal, thickness irregular, due to erosion; absent in some places....

Sandstone, shale, and thin beds of coal in alternating layers; contains (U. S. Geol. Survey fossil locality 6018) Abietites dubius Lesquereux, Sequoia reichenbachi (Geinitz) Heer, Cunninghamites pulchellus Knowlton, and Nelumbo intermedia? Knowlton....... Coal (Rogers opening)..............

Shale and sandstone; the shale carbonaceous in some places with thin seams of coal. ........................

Sandstone in massive layers separated by thin beds of shale; forms the crest of a ridge..........................

Sandstone and shale in alternating layers; contains concretions of brown sand-

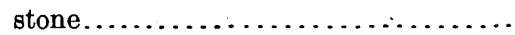

Coal.............................

Shale (0 to 10 inches)............. Coal...........................

Coviered...........................

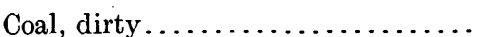

Shale with yellowish limestone concretions, containing (U. S. Geol. Survey fossil locality 7167) fossil oysters (Ostrea sp. related to $O$. soleniscus Meek).....

Coal...........................

Sandstone and shale.................. Coal........................... Shale..........................

Sandstone, principally massive, light gray, friable; in some places with brown flinty concretions. Thickness varies from place to place but the lower 
Mesaverde formation-Continued.

50 feet or more forms a prominent cliff, the basal sandstone of the Mesaverde, and contains Halymenites major Lesquereux, Mactra sp. related to $M$. alta Meek and Fayden, and several gastropods and other shells similar to those found below the basal sandstone....... Mancos shale:

Shale with thin layers of gray sandstone; constitutes the transition zone from the shale below to the base of the Mesaverde; contains (U. S. Geol. Survey fossil localities 71.64 and 7165) Ostrea elegantula Newberry?, Anomia sp., Inocercmus sp. related to $I$. proximus Tuomey, Inoceramus sp. related to $I$. barabini Morton, Cucullaea sp., Cardium sp., Cyprimeria sp., Legumen? sp., Corbula sp., Mactra? sp., Anatina sp., Dentalium sp., Turritella galisteoensis Johnson, Volutomorpha sp., Volutoderma? sp., Nautilus dekayi Morton?; Scaphites sp. related to $S$. hippocrepis DeKay, Baculites sp., Placenticerás sancarlosense Hyatt, Placenticeras planum Hyatt.......................

Shale, dark, with fossiliferous concretions of limestone near the top and near the bottom ......................

Sandstone ('Tres Hermanos), hard, quartzose, in thin, irregular layers; weathers to yellowish brown; contains (U. S. Geol. Survey fossil locality 7168) shells, numerous worm borings; and indefinite markings of various kinds; also Halymenites major Lesquereux, Pinna petrina White?, Pecten sp., Gyrodes sp., Turritella sp......................

Shale, dark, with dark-brown concretions

. of impure limestone (gastropod-zone) and a stratum of "crinkly" sandstone a foot thick near the middle..........

Conglomerate containing pebbles of quartz and chert up to an inch in diameter..........................

Shale, carbonaceous, with coal a few inches thick near the top............

Dakota sandstone:

Sandstone, hard, quartzose, massive, cross-bedded, locally conglomeratic near the base......................

Morrison formation :

Sandstone, white, more evenly bedded than the hard sandstone overlying it..

Shale and sandstone, variegated in color.

Conglomerate, cross-bedded, massive; pebbles an inch or more in diameter..

Shale, variegated, and sandstone, thickness estimated....................
The variegated sandstone and shale at the base of the section has been referred to the Morrison on lithologic and stratigraphic grounds, though no fossils have been found in it in this region. The lower pari, 200 feet or more in Feet. thickness, consists of soft shale and friable $300 \pm$ sandstone of many shades of color. This character has been noted in so many places that it has come to be regarded as more or less diagnostic of the Morrison formation. Above these softer beds is a coarse conglomerate 10 feet thick overlain by 80 feet of variegated sandstone and shale. Were it not for the color of the beds above it this "conglomerate might be regarded as the base of the Dakota. However, although conglomerate is rare in the Morrison, the reference of the 10 -foot conglomerate to this formation seems inevitable. Also the overlying thin-bedded sandstone, although white, probably belongs in the Morrison. Between it and the overlying conglomerate, which is here referred to the Dakota, an uneven line of separation, more or less conspicuous, may mark an unconformity. The writer has for-

2, 100 merly shown ${ }^{218}$ that in the Galisteo Canyon the Morrison apparently lies unconformably upon older rocks.

Above the rocks here referred to the Morrison is a sandstone about 50 feet thick, conglomeratic near the base, and otherwise similar in character and appearance to the basal sandstone of the Purgatoire formation as observed throughout the southern Rocky Mountain region. Until fossils of Comanche age were found in and above this sandstone east of the mountains it was regarded as a part of the Dakota sandstone. No fossils were found in it near Cerrillos, and its reference to the Dakota is based on its lithology and stratigraphic position.

Carbonaceous shale in which thin seams of coal occur in some places was found above the Dakota sandstone. Both shale and coal are irregular in thickness and character. The coal was observed in several places and was found to range in thickness from a mere film to about 6 inches. A conglomerate above the coal also varies in thickness and character and is absent in places. Apparently this carbonaceous shale, coal, and conglomerate belong in the Mancos shale and are not to be included with the Dakota. The only place at this locality where a line of separation can rationally be drawn between the Dakota sandstone and the Mancos 
shale is at the base of this carbonaceous shale, where there is an abrupt change from the shale to the quartzose sandstone below. On the other hand, there is a tendency on the part of some observers of Rocky Mountain geology to call any coal near this horizon "Dakota coal," and it is probable that although the coal in the Galisteo region clearly lies above the base of the Mancos shale it may be the equivalent in age of some of the so-called Dakota coal of the southern Rocky Mountain region. At other localities in the Cerrillos and Hagan fields neither the coal nor the overlying conglomerate could be found. It is evident that both the coal-bearing shale and the conglomerate are local in occurrence and of very restricted distribution.

The shale overlying the conglomerate is ordinary dark clay shale of marine origin. A few shells of the genus Inoceramus were found near the base. A stratum of sandstone and a zone of concretions of impure limestone occur midway of the shale and contain fossils, but none were collected. The limestone concretions probably represent the gastropod zone of the Rio Puerco field.

The Tres Hermanos sandstone, at this locality only 20 feet thick, overlies the shale containing the gastropod zone. It is very resistant and forms a hogback more prominent than that of the Dakota. It consists of thin irregular layers of sandstone an inch or less in thickness, on whose faces are ripple marks, worm tracks, and markings of many kinds. The sandy layers are separated in some places by films of shale. A few imperfect casts of gastropods were found in this sandstone, and impressions supposed to be Halymenites major are abundant in some places. The species named in the section (lot 7168) were found in blocks of sandstone at the base of a cliff of Tres Hermanos sandstone where the section was measured. The sandstone is unlike any other rocks near it and has a peculiar appearance that makes its recognition easy.

At a horizon estimated to be 100 feet stratigraphically above the Tres. Hermanos sandstone, there is a small ridge formed by a limestone about 3 feet thick, which presumably represents the Greenhorn limestone. It contains great numbers of Inoceramus labiatus Schlotheim. At a higher horizon, estimated as 500 feet above the base of the Cretaceous,
Inoceramus labiatus Schlotheim and Prionocyclus wyomingensis Meek were found in a limestone having a strong odor of petroleum. These fossils are among those collected by D. W. Johnson at the town of Cerrillos near the smelter and determined by him as belonging to the Colorado fauna. ${ }^{1{ }^{11}}$ They are as follows:

Fossils collected near the smelter at Cerrillos, N. Mex.

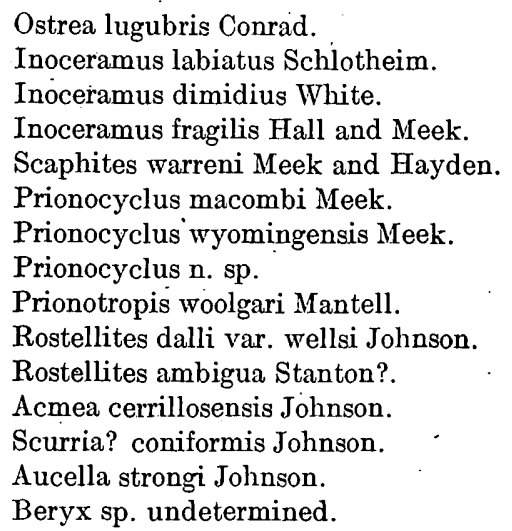

The Mancos shale of this section is particularly rich in fossils at the top. In its upper 200 feet were found the species (lots 7164 and 7165) named in the section measured near Rogers (p. 212). Another collection was made at approximately the same horizon north of Galisteo Creek. In commenting on these fossils Stanton says: "The horizon is believed to be a short distance above that of the Austin chalk and the Niobrara limestone-that is, in the lower part of the Montana group."

The base of the Mesaverde formation in the Cerrillos field consists of a massive cliff-making sandstone overlain by other sandstones which are softer and somewhat shaly in places. (See Pl. XXIX, A.) These sandstones form the surface of a dip slope that is unevenly eroded, and their measured thickness is open to question. The 300 feet given in the section was obtained by measuring with tapeline across the strike of rocks dipping only $5^{\circ}$ to $8^{\circ}$ and computing the thickness from the tip and horizontal distance measured. It is not certain that the dip is constant nor that no faults occur. No coal was found in this lower 300 feet of the Mesaverde, but at neighboring localities thin beds of coal occur in rocks that are probably equivalent. The sandstone contains large yellow concretions of calcareous sandstone in which marine fossils were found: Some shale occurs, but it seems to be very sub- 


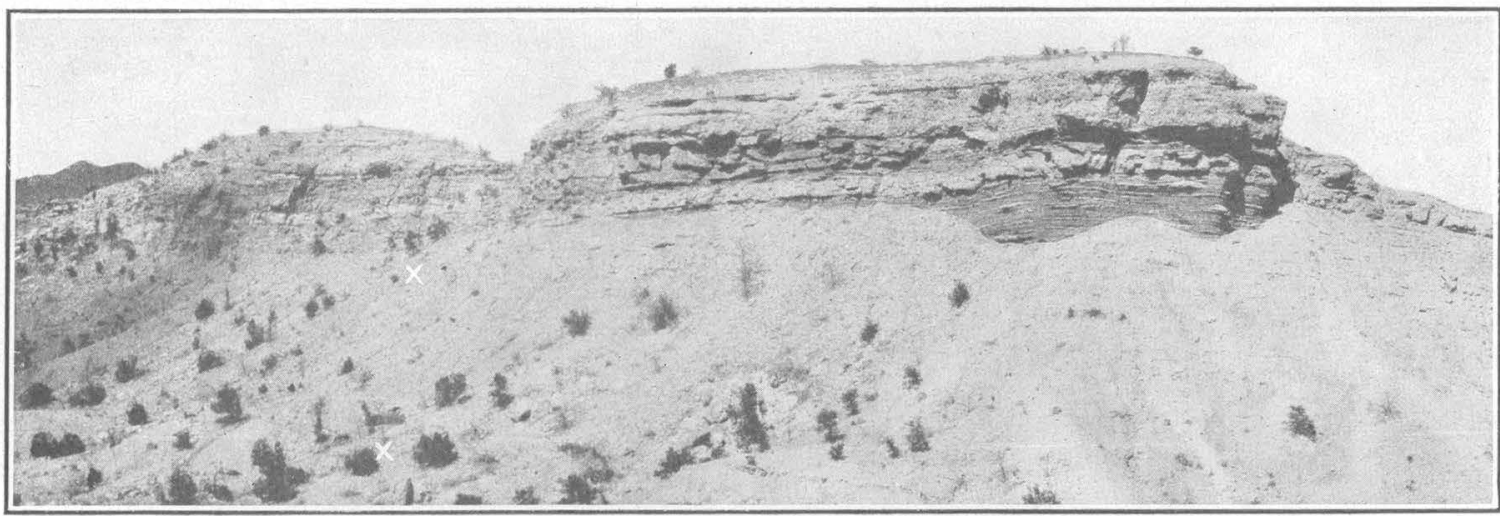

A. TOP OF MANCOS SHALE AND BASAL SANDSTONE OF MESAVERDE FORMATION WEST OF MADRID, N. MEX.

$x \times$, Fossil localities 7164 and 7165 .

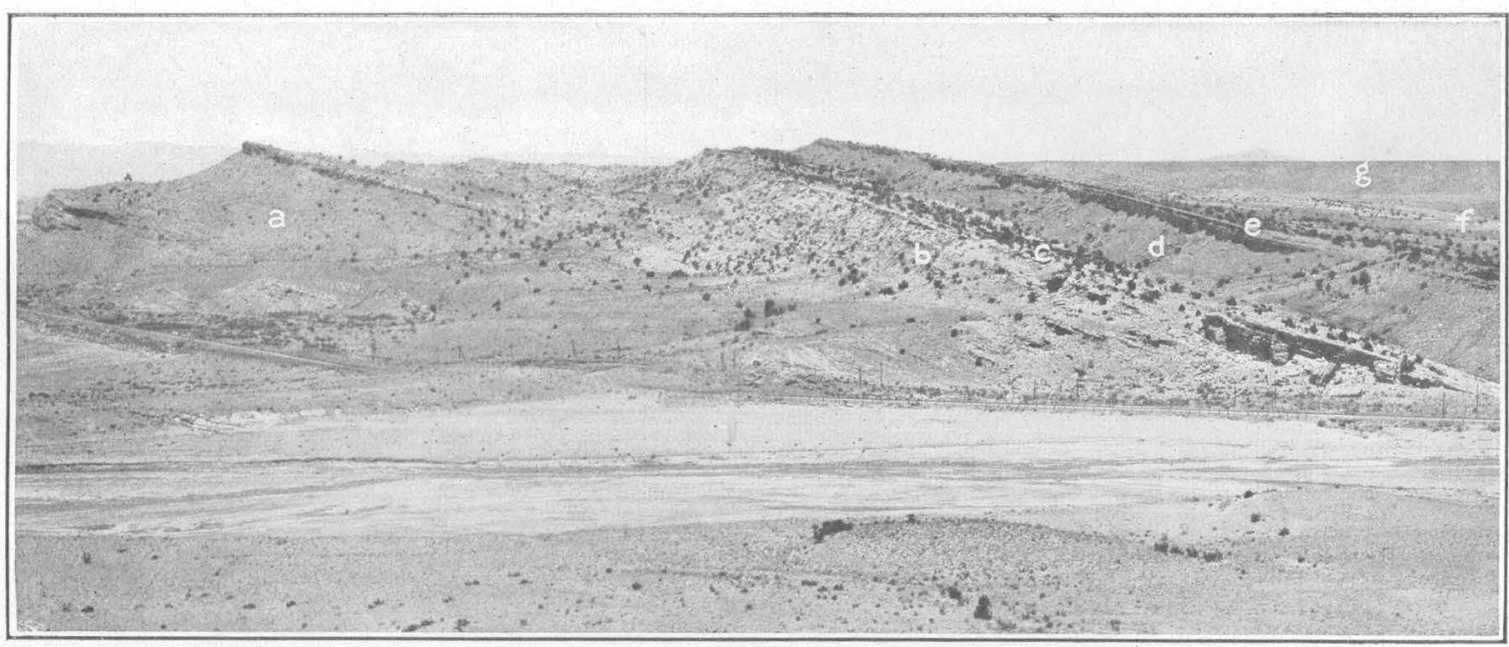

B. EASTWARD-DIPPING FORMATIONS NORTH OF GALISTEO CREEK, N. MEX.

a, Gypsiferous red beds; b, Morrison formation; c, Dakota sandstone; d, gastropod zone at base of Mancos shale; e, Tres Hermanos sandstone member of Mancos shale; $f$, main body of Mancos shale; g, Santa Fe marl.

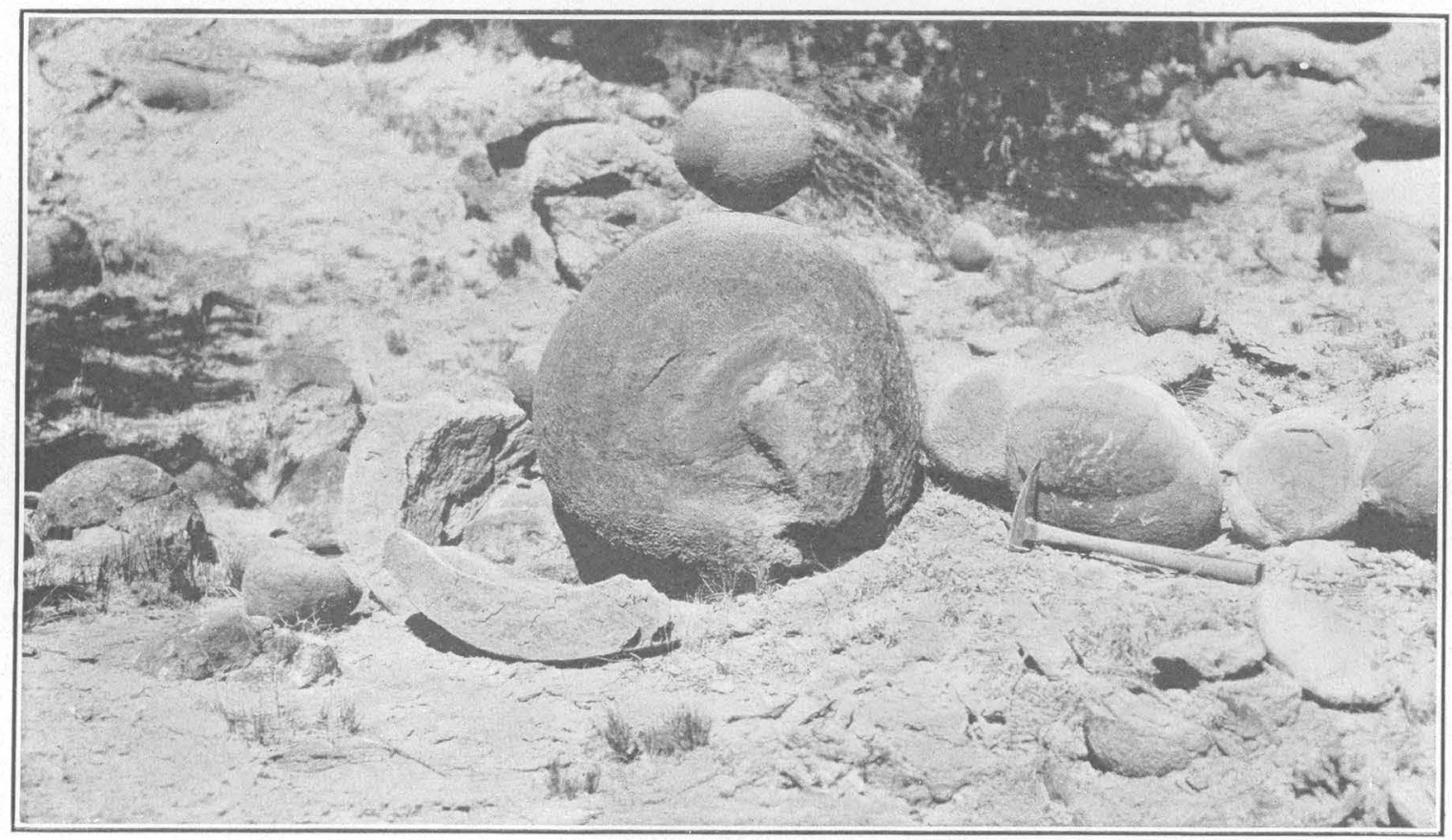

C. SANDSTONE CONCRETIONS IN THE GALISTEO SANDSTONE, NEAR MADRID, N. MEX. 
ordinate in amount. Apparently this $300 \pm$ feet of sandstone corresponds to the part of the 1,602-foot drill record (see fig. 15) included between the lower shale and the top of the 169 foot sandstone. This drill record shows thin beds of coal which are supposed to occur in the lower part of the Rogers section but which were not found where the section was measured. The Mesaverde formation at Rogers contains two groups of developed coal beds, the upper probably equivalent to the group described at -Madrid and the lower to the coals at Omera and to the middle group shown in the 1,602 -foot drill record. These relations are best shown in figure 15 (p. 208).

No fossil leaves were found in the Mesaverde; near Rogers, but oyster shells identified as Ostrea sp. related to $O$. soleniscus Meek were found about half a mile south of the line along which the section was measured. They occur in yellow concretions similar to those in the basal sandstone of the Mesaverde which yielded gastropods and other marine fossils. ' (See section, p. 212.) They occur about 50 feet stratigraphically above the lowest coal observed at this locality. The oyster shells are large, and no complete ones could be found, but fragments an inch or more in thickness and 10 inches long were obtained.

There is good evidence at Rogers of an unconformity between the Mesaverde and the overlying Galisteo sandstone. A coal bed which occurs about 65 feet stratigraphically above the coal at the old Rogers opening is 3 feet or more in thickness in some places and in other places is entirely absent. This variation in thickness is due to irregularities of the upper surface obviously caused by erosion. Upon this unevenly eroded surface lies a light-colored, coarse-grained, locally conglomeratic sandstone, above which no coal nor dark shale such as is associated with the coal lower in the section was observed. The rocks above it are pink, blue, and green and gradually. merge into the undoubted Galisteo sandstone typically developed farther to the east.

A few poorly preserved fossil plants named in the section were found in this basal member of the Galisteo at Rogers, but they are not of such character as to determine the age of the rocks.
Section of rocks penetrated by diamond drill in Waldo Mesa, about a quarter of a mile south of the old Rogers mine.

[The rocks dip $9^{\circ} \mathrm{E}$. The measurements made of the core taken from the vertical hole are slightly in excess of the true thicknesses of the rocks. For graphic section see fig. 15, p. 208.]

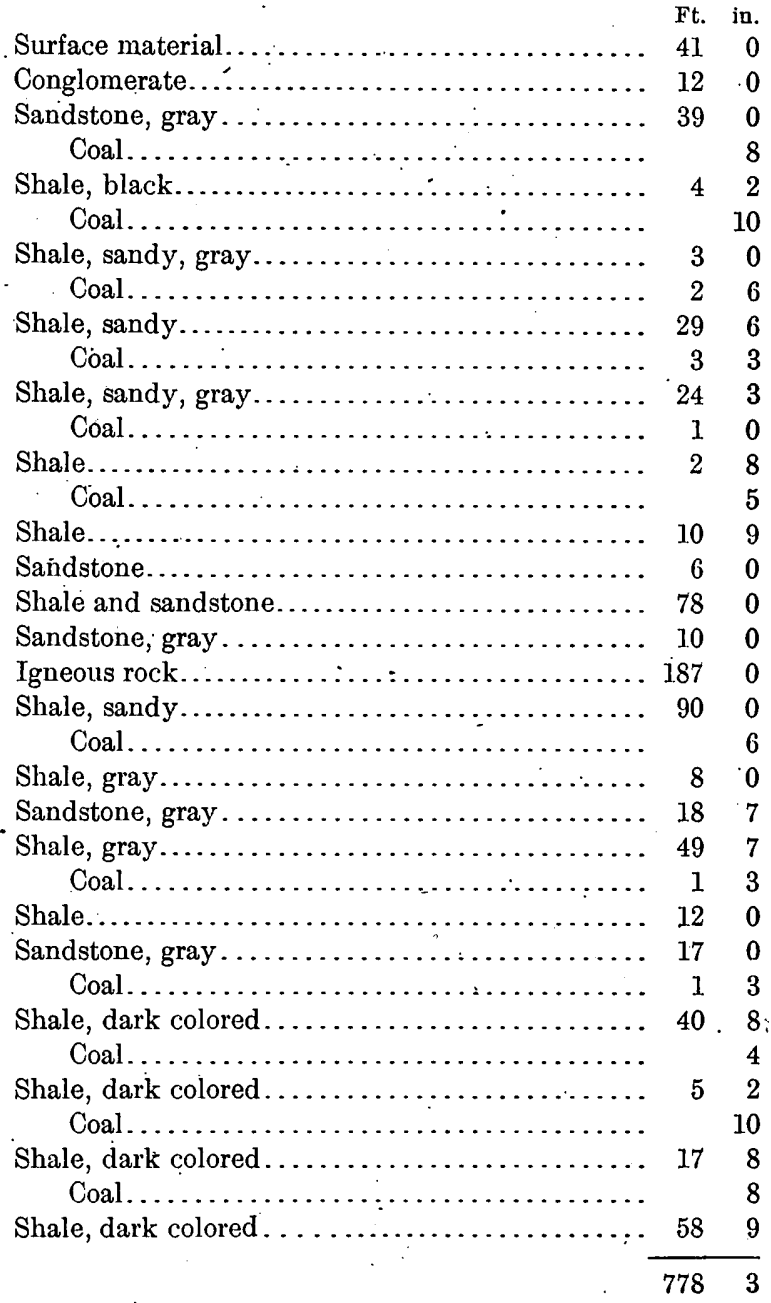

The diamond-drill prospect recorded above was made on Waldo Mesa about half a mile south of the old Rogers mine. The diill passed. through a group of coal beds that is obviously the same as the upper group of the Rogers section and then penetrated 187 feet of igneous rock. This rock is a part of a great intrusive sheet, which is very prominent farther south but which does not extend northward to the Rogers mine. Apparently it is not the intrusive sheet of the two drill records previously given, but one at a lower horizon. It underlies the coal beds at Madrid, as is well shown in Johnson's section. ${ }^{101 a}$ 
A second group of coal beds, penetrated by. the drill below the sheet of igneous rock, seems to be the same as the lower group of developed coals of the Rogers section and the middle group of the 1,602-foot drill record. . This correlation of the groups of coal beds at the several localities described seems relatively simple, but it is not so easy to correlate the individual beds. The upper group of the Waldo Mesa drill record corresponds in a general way to the group of coals developed at Madrid, but for some unknown reason there are fewer coal beds than at Madrid. It is possible, on the one hand, that the Waldo Mesa coal beds represent those near the horizon of the Cook \& White coal of the Madrid section and that the higher beds were eroded previous to the deposition of the Galisteo sandstone at the Waldo Mesa locality. On the other hand, it seems probable that the Waldo Mesa coals may correspond in position with the higher ones of the Madrid section and that the lower beds of Waldo Mesa may have been destroyed by the intrusion of the igneous rock.

The rock formations near the base of the Cretaceous are well exposed in Canyon del Yeso about 2 miles north of Galisteo Creek (Pl. XXIX, $B$ ), where the following section was measured and fossils collected. That part of the Mancos shale lying stratigraphically above this section was found to be fossiliferous in many places, but it does not lend itself readily to measurement.

Section of rocks measured in Canyon del Yeso, about 2 miles north of Galisteo Creek.

Mancos shale:

Limestone and shale in alternate layers, containing Inoceramus labiatus Schlotheim (horizon of Greenhorn limestone) ............. 15

Shale containing Prionotropis sp............ 100

Sandstone (Tres Hermanos), hard, quartzose, with sparkling sand grains, brown to yellow; in thin, irregular layers, with numerous worm borings and various indefinite markings. In the lower 10 feet the layers of sandstone are separated by thin layers of shale...........

Sandstone, containing Inoceramus sp. and Pinna sp...............................

Shale (gastropod zone), dark, with concretions of earthy limestone 20 feet from the top. Some of the concretions are fossiliferous and weather to a rusty yellow powder around the fossils, rendering specific identification difficult. From these concretions (U. S. Geol. Survey locality 3536) were obtained Ostrea sp., Exogyra columbella Meek, Plicatula sp., Lima sp., Pinna sp., Anchura sp...........
Dakota formation: Feet. Sandstone, conglomeratic at the base........ 40 Shale, sandy near the top................. 10 Sandstone, coarse grained, cross-bedded, white. $\quad 70$ Morrison formation:

Sandstone and shale, variegated.

340

An effort was made to recognize in this section the several zones described from the lower part of the Rogers section 3 miles farther south. The sandstone and shale here referred to the Morrison is similar lithologically to the variegated beds below the 10-foot conglomerate in the Morrison of the Rogers section. The 40foot conglomeratic sandstone is referred to the Dakota and the lower sandstone 70 feet thick is probably also Dakota, although it may be equivalent to the beds of the Rogers section lying below the conglomeratic Dakota and there referred with some doubt to the Morrison because it differed lithologically from the overlying Dakota. The rocks above the Dakota in Canyon del Yeso are the same as those similarly situated in the Rogers section. The 70foot shale corresponds in position to the shale containing the gastropod zone and the 35 feet of sandstone above it to the Tres Hermanos sandstone of the Rio Puerco field. The Greenhorn limestone horizon was recognized by its characteristic fossil Inoceramus labiatus. Two hundred feet or more stratigraphically higher in the section there is a zone about 50 feet thick containing large concretions of limestone, many of which are fossiliferous (U. S. Geol. Survey fossil locality 480) and contain Inoceramus fragilis Hall and Meek, Rostellites sp.?, Prionotropis sp., Pachydiscus n. sp. Some of the ammonites are very large: Pachydiscus, the largest found, probably measured 2 to 3 feet across when complete, but only a small part of it was obtained. About 100 feet stratigraphically above the concretion zone some thin layers of limestone (U. S. Geol. Survey fossil locality 3542) in the shale yielded Ostrea sp., Inoceramus fragitis Hall and Meek, Inoceramus sp. related to I. dimidius White, Scaphites warreni Meek and Hayden, and Prionotropis sp.

East of the Canyon del Yeso locality the surface is nearly level and the shale is more or less covered with soil. However, in a small ridge about 1,800 feet to the east, at a somewhat higher horizon, a few poorly preserved specimens of Inoceramus (either Inoceramus 
deformis Meek or a variety closely resembling it) were found. This fossil is considered definite enough to correlate the rocks yielding it with. the Niobrara. About a mile farther east and at a still higher horizon the shale contains numerous very fossiliferous limestone concretions, which probably represent the zone of concretions near the top of the Mancos shale that yielded the fossils (lots 7164 and 7165) named in the Rogers section. The following species were collected from these concretions:

Fossils collected about 5 miles northwest of Cerrillos, N. Mex.

[U. S. Geol. Survey fossil localities 3532 and 7166.]

Ostrea sp.

Exogyra ponderosa Roemer.

Inoceramus sagensis Owen.

Inoceramus irregularis Johnson.

Inoceramus sp.

Leda sp.

Cucullaea? sp.

Nucula sp.

Cardium sp.

Astarte sp.

Crassatellites shumardi Meek.

Cyprimeria sp.

Liopistha undata Meek and Hayden.

Corbula sp.

Mactra? sp.

Gyrodes sp.

Anchura sp.

Nautilus dekayi Morton.

Baculites asper Morton.

Hamites sp.

Placenticeras planum Hyatt.

Placenticeras rotundatum Johnson.

Placenticeras sancarlosense Hyatt.

Placenticeras sp.

Stantonoceras pseudocostatus Johnson.
In commenting on the age relations of these fossils, Stanton states that they are about the same as those from the top of the Mancos near Rogers, of which he says:

The fauna is related to the Gulf and Atlantic coast Cretaceous faunas more closely than to those of the Rocky Mountain region. Its horizon is believed to be a short distance above that of the Austin chalk and the Niobrara limestone; that is, in the lower part of the Montana group.

- This locality is near the place at which Johnson ${ }^{83}$ collected the fossils described by him as Pierre:

Two miles southwest of Santa Rosa Mountain, where the main wagon road leaves the basalt-capped mesa for the valley below, there are exposed in the valley at the foot of the mesa. fossiliferous shales and sandstones. The exposure is not large, but a small arroyo has removed some of the looser shales, leaving still in place the calcareous nodules in which the fossils are most abundant.

The following species were collected at this locality: Ostrea congesta Conrad??

Protocardia rara Evans and Shumard?

Astarte evansi Hall and Meek.

Nucula subplana Meek and Fayden.

Solen cuneatus Gabb?

Lingula subspatulata Hall and Meek.

Tritonium kanabense Stanton:

Natica sp. undet.

Baculites anceps Lamarck.

Helicoceras pariense White?

Beryx sp. undet.

Arca madridensis Johnson?

Cyprimeria? sulcata Johnson.

Turritella galisteoensis Johnson.

Admetopsis? elevata Johnson.

As no sandstone was found by the writer at this locality, it is probable that the fossils collected by him are slightly lower in the section than those collected by Johnson. 


\section{CHAPTER 5.-SUMMARY OF STRATIGRAPHIC AND STRUCTURAL RELATIONS.}

That the Vermejo formation of the Raton Mesa region and the Canon City field is of Montana age and essentially equivalent to the Fox Hills of the Denver Basin seems to be well established. If the Fox Hills sandstone of this basin is equivalent in time to the typical Fox Hills of North Dakota, and if the Vermejo is essentially equivalent in age to the Mesaverde of western Colorado as shown in this paper, this relation becomes somewhat difficult of comprehension, but may still be correct, as the writer has shown, ${ }^{249}$ on the principle that beds may be homogenetically equivalent and yet different in actual age. On the other hand, it is possible (1) that the so-called Fox Hills of the Denver Basin is somewhat older than typical Fox Hills, and (2) that the Fox Hills may not be as near the top of the Cretaceous in the time scale as has generally been supposed. In attempting to correlate the Cretaceous formations from the Denver Basin around the north end of the southern Rocky Mountains Heroy ${ }^{247}$ reached the conclusion that the so-called Fox Hills of the Denver Basin is essentially equivalent to the Mèsaverde of southern Wyoming. The latter, in turn, is practically continuous with the Mesaverde of west-central Colorado, which the writer regards as younger than typical Mesaverde and as equivalent, at least homogenetically, to the Fox Hills and Laramie of the Denver Basin. ${ }^{249}$ This correlation is not generally accepted at present and the Laramie of the Denver Basin is usually regarded as the youngest possible Cretaceous. However, the upper surface of this formation is one of erosion, and it is evident that what is left of the formation belongs, in the theoretical time scale, somewhere below the top of the Cretaceous-how much below remains for future investigation.

Another method of correlating the beds of the several fields surrounding the mountains is based on the theory that the formations were once continuous over the mountain region and that the stratigraphic succession on opposite sides should be comparable. This theory has been developed by the writer in a separate paper. ${ }^{249}$ The relation between the Raton Mesa region and the San Juan Basin is illustrated in the section shown in figure 16.

The invertebrates from the upper part of the Pierre shale in the Raton Mesa region denote Pierre age, although not certainly the latest Pierre. Stanton says of this fauna, "While it is typical of the Pierre shale it has a considerable range within it. From the material at hand it is not possible to recognize definite restricted zones.". This fauna is similar to that of the Lewis shale as represented at Dulce, N. Mex., and tends to correlate the Lewis with the upper part of the Pierre of the Raton Mesa region, but as this fauna has a considerable range within the Pierre the similarity of the faunas can not be regarded as invalidating other evidence.

The typical Mesaverde of the northern part of San Juan Basin has yielded a few invertebrates, which are only sufficient to show that they belong to the fauna of the Montana group. In the Mesaverde of the southeastern part of this basin and in the coal fields farther south in north-central New Mexico the rocks here classed as Mesaverde contain a fauna which is not yet fully studied, but which, according to Stanton, is closely related to the fauna of the Gulf coast, especially as developed in southwestern Texas. As this fauna is not known north of New Mexico, it is not available for correlation with formations in other parts of the Rocky Mountain region.

The Trinidad sandstone of the Raton Mesa region has yielded a few fossils, but these are not sufficiently characteristic for a positive determination of age. Some of them differ but little from those of the underlying Pierre shale. Others tend to show that the sandstone is of Fox Hills age.

The Vermejo formation of the Raton Mesa region has yielded practically no invertebrates, 
but a few have been found in the Canon City field. The occurrence of these shells in the middle of the Vermejo tends to strengthen the evidence of the plants that this formation is of Montana age.

A considerable number of invertebrates have been collected from the "Laramie" of the northern part of the San Juan Basin. Here again there is apparent conflict between the evidence of the invertebrates and of the plants. The age of the "Laramie" formation of this basin has an intimate bearing on the length of time represented by the unconformity at the top of the formation. If the Animas formation is of Tertiary age, as the writer believes, and the "Laramie" is of Montana age, as the plants indicate, the unconformity must represent a greater hiatus than it would if the so-called "Laramie" were of Laramie age-that is, youngest Cretaceous. The importance of this question in the present discussion warrants comparison with the nearest coal field to the north, namely, the Grand Mesa field, ${ }^{237}$ although it has already been described in some detail in a previously published paper. ${ }^{249}$

The Grand Mesa field lies in the southern part of Uinta Basin and about 100 miles north of the San Juan Basin. The two basins are similarly situated with respect to the mountains, and although they are now separated by uplifted areas from which such younger Cretaceous rocks as may have existed have been removed by erosion, there is no evidence that they were separate basins of deposition, and there are some indications ${ }^{241}$ that the rock formations in these basins once extended continuously over the intervening area.

The "Laramie" formation of southwestern Colorado, consisting of a basal sandstone (the Pictured Cliffs sandstone), containing marine invertebrates and overlain by coal-bearing shale and sandstone that contain brackishwater invertebrates-neglecting for the present other fossils-is comparable both lithologically and faunally to the Rollins sandstone of the Grand Mesa field with its marine invertebrates overlain by coal-bearing sandstone and shale (the Bowie shale member of the Mesaverde with its marine and brackish-water invertebrates). The writer, who has examined these formations in both basins, has been impressed with the

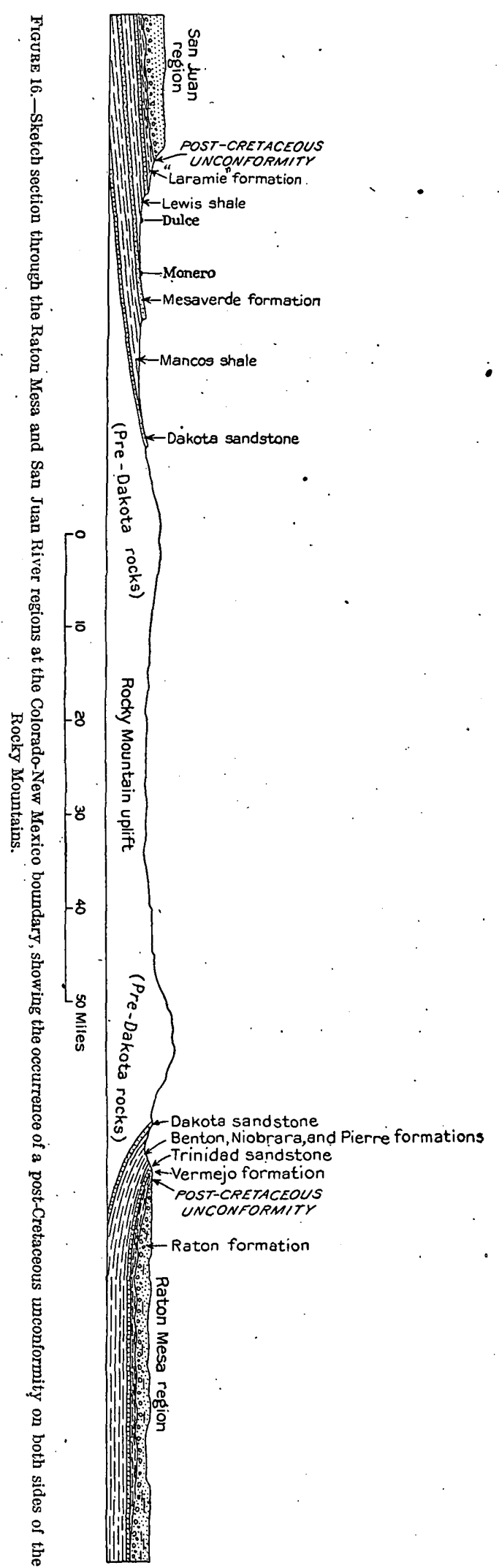


similarity between the "Laramie" of southwestern Colorado and the lower part of the socalled Mesaverde of the Grand Mesa field (the Rollins sandstone and Bowie shale).. Although a number of fossils were found in the Rollins sandstone few are specifically identifiable and must be neglected in comparing the faunas of the Grand Mesa Mesaverde with the "Laramie" of the San Juan Basin. Of the 26 fossil forms from the Bowie shale ${ }^{237} 15$ are specifically identified and are therefore available for comparison. Of this fauna Stanton says:

They consist of (1) marine Cretaceous fossils belonging to the fauna of the Montana group; most of the species have a considerable vertical range, many of them occurring in both the upper part of the Mancos and the lower part of the Mesaverde, so that there is no sharp faunal distinction between Mancos and the marine portions of the Mesaverde; (2) brackish-water species-types that occur in the Laramie and also in lower horizons like the Mesaverde and Judith River in the Montana group.

Of these 15 species 9 have been found in the "Laramie" of southwestern Colorado but few of them in the typical Mesaverde. The absence of many of them from the original Mesaverde may'be due to the want of favorable conditions of preservation, but there is at least a temptation to regard the similarity between the faunas as indicating that the so-called Mesaverde of Grand Mesa is more closely related to the "Laramie" of the San Juan Basin than to the typical Mesaverde of this basin. Furthermore, if the Bowie fauna of Grand Mesa indicates Montana age the same fauna from the "Laramie" should indicate Montana age and thus agree with the flora of the "Laramie" of southwestern Colorado, which Knowlton maintains is Montana. ${ }^{1}$

In all the areas here described rocks of undoubted Cretaceous age are separated by an unconformity from later rocks, which the writer regards as Tertiany, ${ }^{249}$ although no evidence of Tertiary age has been found in some of them aside from the lithologio character and their conformable relations with the Cretaceous in the Hagan, Cerrillos, and Rio Puerco fields. These latter beds rest on the Mesaverde. In the San Juan Basin they rest on "Laramie" or older formations, according to location. (See fig. 13, p. 179.) In the fields described east of the mountains the Tertiary lies unconformably on the Vermejo formation, Trinidad sandstone, and Pierre shale. (See Pl. V, p. 56, and fig. 11,

1 See footnote, p. 184. p. 169.) So far, therefore, as can be determined by correlation of formations, the erosion resulting in the unconformity on either side of the mountains took place at the same time and is therefore to be regarded as the same unconformity. Furthermore, this unconformity has been shown ${ }^{250}$ to be approximately equivalent in time to the unconformity in the Gulf Coast region, which has been established in a marine section ${ }^{242}$ and is accepted by all geologists as marking the separation between Cretaceous and Tertiary.

The correlation indicated by fossil plants between the early Tertiary formations of the Gulf coast and the Raton formation is in harmony with the principles of diastrophism that seem to be applicable and effective in establishing the line of separation between Cretaceous and Tertiary in the Rocky Mountain region, where the significance of other criteria has been seriously questioned.

Some of the broad phases of the relation of the Cretaceous and early Tertiary formations to the Rocky Mountains have been described by the writer in a paper already published, ${ }^{249}$ although it deals with data assembled mainly for the present one. In that paper it was shown that the Cretaceous formations probably extended at one time continuously over the present site of the southern Rocky Mountains, and that similar formations on opposite sides of the mountains may be more nearly time equivalents than has been supposed hitherto; also that aside from minor warpings of the surface that may have caused differences in the thickness of the Cretaceous sediments there were probably no orogenetic disturbances in the southern Rocky Mountain region during Upper Cretaceous time that left any notable imprint on the stratigraphic record that has yet been recognized.

The principle is generally accepted that the uplift in western America which drained the continent and culminated in the formation of the mountains marks the division of time between Cretaceous and Tertiary, but there is no general agreement in applying this principle. It is a matter of common knowledge that there are conspicuous unconformities at many horizons within the Tertiary deposits of the mountain region, and there is a tendency on the part of some geologists to regard the most obvious unconformity as marking the 
separation between Cretaceous and Tertiary. This tendency has been expressed by Ransome, ${ }^{240}$ when he suggests that the dividing line should be drawn at the top of the Fort Union.

In this connection it seems appropriate to call attention to the fact that the most conspicuous unconformity is not necessarily the most significant. In the writer's opinion the first of a series of movements that followed a long period of quiescence and ushered in a period of crustal disturbances like that of the Tertiary is more significant in delimiting periods of geologic time than the greatest movement of this series. Accepting this principle it is evident that the first well-marked unconformity above rocks of undoubted Cretaceous age in the Rocky Mountain region should constitute the line of separation between Cretaceous and Tertiary. This lowest unconformity in Colorado and New Mexico is described in this paper as the post-Cretaceous unconformity. In few places is it as conspicuous as some of the later ones, but this could scarcely be otherwise. The mountains did not spring into existence in a day. Their gradual and intermittent rise, which culmi- nated in the present mountains-if indeed a culmination has yet been reached-was naturally accompanied by the deposition of sediments (such as those of the Raton formation and others described as early Tertiary in this report), which indicate processes in a sense transitional between the quiescent marine conditions of Cretaceous time and the obviously violent processes of Tertiary time. In the writer's opinion the change in character from sedimentary rocks mainly of marine origin to those of nonmarine or upland type that occurs at the unconformity here designated as postCretaceous in all of the fields described is sufficient in itself to indicate a common cause. This, taken in connection with the structural, paleontologic, diastrophic, and paleophysiographic evidence, is regarded as sufficient to warrant placing the division between the Cretaceous and the Tertiary systems at the lowest unconformity, as has been done in this paper. A further refinement may be applied if occasion arises for apportioning the time represented by the unconformity, for the early part of this time would naturally be included in the Cretaceous period and the later part in the Tertiary. 



\title{
FOSSIL FLORAS OF THE VERMEJO AND RATON FORMA- TIONS OF COLORADO AND NEW MEXICO.
}

\author{
By F. H. Kinowlton.
}

CHAPTER 1.-INTRODUCTION.

PREVIOUS PALEOBOTANIC WORK.

As Mr. Lee has presented in the first part of this report a very complete historical review of geologic and paleontologic activities in the Raton Mesa region of Colorado and New Mexico, only a brief summary of the paleobotanic work within the area is here necessary.

So far as I. know the first fossil plants obtained in the Raton Mesa region were collected in January, 1846, by Lieut. T. W. Abert. ${ }^{1} \mathrm{He}$ noted the presence of coal beds near the Raton and states that he searched diligently for ferns, which he presumed would be similar to the ferns associated with the Carboniferous coals with which he was familiar in Missouri. But "after a long search he was obliged to confess that there were none," and he was forced to be content with bringing back a few dicotyledonous leaves. ${ }^{2}$ These were studied but not even generically named by $\mathrm{T}$. W. Bailey, who made no age determination other than to state that they were "decidedly far more recent" than the Carboniferous.

The first fossil plants from this area to come under scientific eyes were obtained in July, 1867 , by Le Conte, ${ }^{3}$ while serving as geologist on the Union Pacific Railroad survey from Smoky Hill River, Kans., to the Rio Grande. They came from the upper end of Purgatoire Canyon (near what is now the mouth of Riley Canyon) and from Raton Pass, about $1 \frac{1}{2}$ miles south of Trinidad. Their age was thought by Le Conte to be Cretaceous.

1 Abert, T. W.; Examination of New Mexico in the years 1846-47: 30th Cong., 1st soss., S. Doc. 23, pp. 3-130, 1848; Ex: Doc. 41, pp. 417-546, 1848 .

Tho threo leaves figured seem to be identifiable as follows: Fig. 1 (plato opposite p. 522) is a narrow leaf, apparently a Salix; fig. 2 (op. cir.) is apparontly a largo leaf of Ficus schimperi Lesquereux; fig. 2 (opposite p. 547) is tho samo as the last.

8 Lo Conte, J. L., Notes on the geology of the survey for the extension of tho Union Pacific Railway, E. D., from the Smoky Hill River, Kans., to the IRio Grande, pp. 18-26, Philadelphia, 1868.
The Le Conte plants were submitted for study to Lesquereux, whose report on them was first published in 1868 in the form of a letter by Hayden ${ }^{4}$ and was reprinted without change in $1873 . .^{5}$ From the Raton Pass material Lesquereux reported four species, two of which (Berchemia parvifolia and Abietites dubius) he named and imperfectly characterized; the. other two (Echitonium sophiae Weber and Cinnamomum affine Lesquereux) were previously known. From the upper end of Purgatoire Canyon he reported a single species, which he named Rhamnus obovatus, but it was not described and figured until many years later. Lesquereux concluded that the plants indicated Tertiary age.

The next collections of fossil plants from the Raton Mesa region were obtained by Hayden in the summer of 1869 . His account of their occurrence, together with a description of the general geology of the areas, was published in $1873 .^{\circ}$ These plants also were studied by Lesquereux. As they were the first considerable collections from the region it is important to fix as nearly as possible their exact stratigraphic position. Hayden first visited the Canon City coal field. At a point about 10 miles below Canon City he examined ${ }^{7}$ a section in which he found a layer "full of impressions of deciduous leaves, like Salix, Platanus, Thuya, and a broad flaglike plant." These, as is now known, belong to the Vermejo formation. Of the Trinidad region he writes: 8

On the hills surrounding Trinidad are great quantities of deciduous leaves in the rocks. The most conspicuous, as well as, abundant fossil, is a species of fan palm, undoubt-

Hayden, F. V., Notes on the lignite deposits of the West: $\mathrm{Am}$. Jour. Sci., 2d ser., vol. 45, pp. 207, 208, 1868.

5 Hayden, F. V., U. S. Geol. Survey Terr. First, Second, and Third Ann. Repts., pp. 195-197, 1873.

${ }^{6}$ Idem, pp. 147-158.

7 Idem, p. 150.

8 Idem, p. 154. 
edly Sabal campbelli [now called Sabal? ungeri], which occurs in the lignite beds on the upper Missouri. This tree would seem to have formed the dominant tree in ancient times, much like the palmetto of South Carolina. In some places the sandstones are filled with this plant for miles. There are also in considerable abundance leaves of the Magnolia, Platanus, Laurus, etc., and, so far as I can determine, identical with the species found on the upper Missouri. I do not doubt for a moment that all the coal beds of the Raton Mountains are Tertiary and belong to the great coal system which has already been traced over such a wide area.

The plants collected, which without doubt are the ones labeled "Fischers Peak, Raton Mountains," are thus seen to have come from above the unconformity, from beds now referred to the Raton formation, a position corroborated by the finding of the same species by later students in beds of this formation only.

Lesquereux's account of these plants was not published until 1872. He enumerated 21 species, 6 of which he regarded as new to science. (The present disposition of these species is shown on p. 226.) He recognized at once the Tertiary facies of these plants and their undoubted affinity with the Tertiary flora of Mississippi. On this latter point he says: ${ }^{1}$

With the Mississippi Tertiary flora it has as identical sp:cies *** eight species. If we consider that this id ntity is ior representatives of genera of distant affinity, wlich at the same time are all, except Cinnamomum, characteristic of our present flora-Populus, Quercus, Magnoli i, Juglais, even palms; if we consider still that this icies. tity is $\mathbf{r}$-ndered positive by the peculiar and easily ascertained characters of the species, we can but see here and acknowledge an evident proof of the homogeneity of the North American Tertiary flora in comparing it even at great distances under the same latitude. The difference between the two points of comparison is about $15^{\circ}$ of longitude.

In the summer of 1872 Lesquereux himself was commissioned by Hayden to make explorations and collections in the west with the "view of positively ascertaining the age of the Lignitic formation." His investigations extended from the Raton Mountains, Colo., through the Trinidad, Canon City, Colorado Springs, and Denver fields, and thence along the Union Pacific Railroad as far west as Evanston, Wyo. From the locality which he gives simply as "Raton Mountains," but which from his report appears to be confined to the immediate vicinity of Trinidad, he men-

1 U. S. Geol. Survey Terr. Fifth Ann. Rept., for 1871, Suppl., p. 19, 1872. 2 U. S. Geol. Survey Terr. Sixth Ann. Rept., for 1872, pp. 318-322, 1873. tions only 6 species from the upper or Raton formation, none of which was an addition to those previously known from the collections of Le Conte and Hayden. However, within a mile or two northwest of Trinidad he discovered a locality, evidently in the lower beds, where a heavy Haggy sandstone, resting conformably on the surface of "the black shale No. 4 of the Cretaceous" (= Pierre), was filled with fucoidal remains. As regards the age of this hard white sandstone, which is undoubtedly what is now known as the Trinidad sandstone, Lesquereux was in some doubt but concluded that it occupied a "kind of debatable ground, dubiously referred either to the Cretaceous or Tertiary.", 3 From this horizon he described seven species of fucoids and a single. doubtful fungus, all but one being new to science. ${ }^{4}$

In 1878 Lesquereux ${ }^{5}$ published his work on the Tertiary flora, which was really a contribution to the Tertiary flora of the western Territories. So far as regards the area under consideration this volume was based on the material already known from the collections of Le Conte, Hayden, and Lesquereux himself: This material was simply more fully described and was for the first time illustrated. In discussing the age of the beds involved Lesquereux again correctly referred the upper coal measures (now the Raton formation) to the Tertiary, and in reviewing the evidence concerning the white fucoidal sandstone from near Trinidad, he presumed that Cretaceous No. 5 (Fox Hills) was absent from the section and concluded that these beds were probábly best regarded as forming the basal member of the upper series and hence were also of Eocene age. It may be added that in his treatment of the species previously enumerated from the Raton-Trinidad area, he omitted several which were probably merged with other forms and made no clear record of such disposition; and he also changed the generic and specific designation of a number of others. A record of these emendations and omissions will be found on page 226 .

From 1878 to about 1905, when interest in the field was renewed, work on the paleobotany of the Raton Mesa region was desultory and

3 Op. cit., p. 319.

4 Op. cit., pp. $372-375$.

5 Contributions to the fossil flora of the western Territories; the Tertiary flora: U. S. Geol. Survey Terr. Rept.; vol. 7, 1878. 
relatively unimportant. In 1883 Newberry ${ }^{1}$ named and described four species of plants from Vermejo Canyon, Fisher's [Fisher] Peak, and North Branch of Purgatoire River, respectively. These were more fully described and figured in 1898. ${ }^{2}$ In 1883 the age of the bods had come to be regarded as Laramie, and Nowberry so reforred them, apparently on the mistaken assumption that they were of the same age as the coal-bearing rocks of the Denver Basin, which had come to be known as Laramie. From that time until the work was done that has resulted in the present paper no critical study was made of the fossil plants, and this erroneous assumption remained unchallonged.

The only other paleobotanic work done in this field is my own. In the course of this work I have made a number of preliminary reports at the instance of several geologists connected with the United States Geological Survey. Thus in 1909 W. T. Lee ${ }^{3}$ published a paper, in which, after describing the physical evidence for an unconformity in the so-called Laramie of the Raton coal field, he presented a tabular list of the plants from the beds below and above the unconformity, and reached the tentative conclusion that the lower beds are older and the upper beds younger than the Laramie.

In 1908 G. B. Richardson ${ }^{4}$ investigated the conl of the Trinidad field for land-classification purposes and made brief mention of the fossil plants of the region. He noted the conglomerate now known to mark the unconformity but questioned its significance and referred the whole of the coal-bearing rocks tentatively to the Laramie, pending the paleobotanic study.

As it has been decided to include the consideration of the Canon City field with that of the Raton Mesa region brief mention may be made of the paleobotanic activities within this field. Although both Hayden and Lesquereux visited the Canon City field and mentioned the abundant occurrence of fossil plants neither appears to have made collections; in any event, they re-

1 Nowberry, J. S., Brief descriptions of fossil plants, chiefly Tertiary, from western North America: U. S. Nat. Mus. Proc., vol. 5, pp. 502-514, 1853 .

2 Nowberry, J. S., The later extinct floras of North America: U. S. Geol. Survey Mon. 35, 1898.

\& Unconformity in tho so-called Laramie of the Raton coal field, New Mexico: Geol. Soc. America Bull., vol. 20, pp. 357-368, 1909.

- U. S. Geol. Survey Bull. 381, pp. 379-446, 1910. $47019^{\circ}-17-15^{\circ}$ corded none. About $1885 \mathrm{Mr}$. George Hadden, sometime superintendent of the coal mines at Coal Creek and Rockvale, made a very considerable collection of plants which he sold to Mr. R. D. Lacoe, of Pittston, Pa., who later donated it to the United States National Museum. This collection was studied by Lesquereux, who prepared a voluminous report on it, which, however, was never published. This material, together with the Lesquereux manuscript, has been available.

At apparently about the same time Mr. Hadden made another and still larger collection for Newberry, who partly studied it. The duplicate material was sent to the United States National. Museum, where it now is and the other and undoubtedly better portion was retained and is now in the New York Botanical Garden, Bronx Park, New York City. Nothing. has been done with this collection since Newberry's death except that the forns were worked up and described by Hollick. ${ }^{5}$ The species established by Hollick are included in the present paper, but the bulk of the collection remains unstudied.

In 1908 C.W.Washburne ${ }^{6}$ spent some months in the study of the coal and oil resources of the Canon City field and made fragmentary collections of plants. These were identified, so far as possible, by me, and I then reached the conclusion that the lower coal beds belonged to the Montana and the upper beds, above the Rockvale sandstone member of the Vermejo formation, probably to the Laramie. They were all referred to the Laramie by Washburne, who concluded that there was "no good reason for separating these lower beds from the Laramie, even though they contain an upper Montana flora." Subsequent investigations have shown that the whole series is referable to the Montana.

In the following year (1909) I spent several days in collecting in the Canon City field, especially in the vicinity of Rockvale, and was able to obtain sufficient material to fix the exact horizon whence came the Hadden collections (previously in doubt), and to make certain that the whole section is part of the Montana.

5 Hollick, Arthur, Fossil ferns from the Laramic group of Colorado: Torreya, vol. 2, pp. 145-148, pls. 3, 4, 1902 .

○ U. S. Geol. Survey Bull. 3s1, pp. 341-37s, 1910. 


\section{SYNONYMS AND CHANGES OF INTERPRETA- TION.}

As a considerable number of changes in the names and disposition of species have been made in the present paper, the following list of such changes is presented for the convenience of users of earlier literature:

Araucarites reichenbach $i$ Geinitz $=$ Sequoia reichenbachi. Asplenium erosum (Lesquereux) Knowlton=Pteris erasa . Asplenium magnum Knowlton. Hollick, Torreya, vol. 2, p. 146 , pl. 4, figs. 1, 2, 1902=Asplenium? coloradense.

Berchemia parvifolia Lesquereux $=$ Berchemia multinervis.

Carex berthoudi Lesquereux, U. S. Geol. and Geog. Survey Terr. Ann. Rept., 1872, p. 377 [1873]. Apparently referred by error to Raton Mountains.

Carpolithus spinosus Newberry $=$ Carpolithes spinosus.

Ceanothus fibrillosus Lesquereux $=Z$ izyphus fibrillosus.

Ceanothus meiggsii Lesquereux $=Z i z y p h u s$ meiggsii.

Delesseria incrassata Lesquereux $=$ Caulerpites incrassatus.

Delesseria lingulata Lesquereux, U. S. Geol. and Geog. Survey Terr. Ann. Rept., 1872, p. 374 [1873]=Caulerpites incrassatus.

Dombeyopsis occidentalis Lesquereux $=$ Ficus occidentalis .

Ficus arenacea brevipetiolata Lesquereux $=$ Ficus uncata .

Ficus gaudini Lesquereux = Ficus uncata.

Ficus irregularis (Lesquereux). - Lesquereux, U. S. Geol. Survey Terr. Rept., vol. 7, p. 196, pl. 63, fig. 9 (not of pl. 34, figs. '4-7), $1878=$ Ficus coloradensis Cockerell, in part $=$ Ficus regularis.

Ficus planicostata latifolia Lesquereux $=$ Ficus latifolia.

Ficus spectabilis Lesquereux $=$ Ficus denveriana .

Ficus ulmifolia Lesquereux $=$ Ficus uncata.

Flabellaria? longirachis? Unger. Lesquereux, U. S. Geol. and Geog. Survey Terr. Ann. Rept., 1873, p. 396 $[1874]=$ Geonomites tenuirachis.

Geonomites ungeri Lesquereux $=$ Sabal? ungeri.

Halymenites minor . Fischer-Ostheim. Lesquereux $=$ Haly menites major.

Juglans smithsoniana Lesquereux =Ficus? smithsoniana .

Magnolia attenuata Weber. Lesquereux, U. S. Geol. Survey Terr. Rept., vol. 7, p. 250, pl. 45, fig. 6 , $1878=$ Magnolia angustifolia.

Magnolia laurifolia Lesquereux, Am. Philos. Soc. Trans., vol. 13, p. 421, pl. 20, fig. 2 [not fig. 1], 1869=Magnolia hilgardiana.

Magnolia tenuinervis Lesquereux = Magnolia magnifolia.

Nelumbium lakesianum Lesquereux $=$ Nelumbo lakesiana

Pecopteris sepulta Newberry. Hollick, Torreya, vol. 2,

$\therefore$ p. 147, pl. 3, figs. 5, 5a, 1902=Osmunda hollicki.

Persea lancifolia Lesquereux $=$ Nectandra lancifolia .

Platanus aceroides Göppert. Heer, Flora tertiaria Helvetiae, vol. 2 , p. 71 , pl. 88 , figs. $13,14,1856=$ Platanus guillelmae heerii.

Populus monodon Lesquereux, U. S. Geol. Survey Terr. Rept., vol. 7, p. 180, pl. 24, figs. 1, 2, 1878=Ficus uncata

Populus mutabilis repando-crenata Heer. Lesquereux, U. S. Geol. Survey Terr. Ann. Rept., 1871, Suppl., p. $13,1872$.

Quercus chlorophylla Unger. Lesquereux $=$ Quercus chlorophylloides.

Quercus moorii Lesquereux $=$ Dryophyllum moorii.
Quercus nerïfolia Alexander Braun. Lesquereux, U. S. Geol. Survey Terr. Rept., vol. 7, p. 150, pl. 19, fig. 5, $1878=$ A pocynophyllum lesquereuxii.

Quercus platania? Heer. Lesquereux, U. S. Geol. Survey Terr. Ann. Rept., 1871, Suppl., p. 16, 1872. A mere fragment not afterward recognized.

Rhamnus deletus? Heer. Lesquereux, U. S. Geol. Survey Terr. Ann. Rept.., 1871, Suppl., p. 15, 1872. (Not afterward referred to by Lesquereux.)

Rhamnus rectinervis Heer. Lesquereux, U. S. Geol. Suryey Terr. Rept., vol. 7, p. 279, 1878. Incidentally mentions its occurrence in Raton Mount'ains, but not supported by specimens.

Sabal communis Lesquereux = Flabellaria eocenica .

Sabal campbelli Newberry $=$ Sabal? ungeri.

Sabal grandifolia Newberry $=$ Sabal? ungeri.

Sabalites fructifer Lesquereux, U. S. Geol. Survey Terr. Rept., vol. 7, p. 114, pl. 11, fig. 3a and fruit on fig. 3, $1878=$ Nyssa? racemosa.

Sábalites grayanus Lesquereux, U. S. Geol. Survey Terr. Rept., vol. 7, pl. 12, fig. 1 [not pl. 12, fig. 2], 1878=Sabal montana.

Sequoia brevifolia Heer. Lesquereux, U. S. Geol. Survey Terr. Rept., vol. 7, pl. 61, figs. 25-27, 1878=Sequoia obovata.

Sphacria lapidea Lesquereux $=$ Rosellinites lapideus.

Sphaerites lapideus (Lesquereux) Meschinelli=Rosellinites lapideus.

Terminalia radobojensis Heer. Lesquereux, U. S. Geol. Survey Terr. Ann. Rept., 1871, Suppl., p. 15, 1872= Magnolia angustifolia:

Viburnum anceps Lesquereux $=$ Platanus rhomboidea .

Viburnum marginatum Lesquereux, U. S. Geol. Survey Terr. Rept., vol. 7, pl. 38, fig. 2, 1878=Viburnum con tortum.

Viburnum platanoides Lesquereux $=$ Platanus platanoides . Viburnum whymperi Heer. Lesquereux, U. S. Geol. Survey Terr. Rept., vol. 7, p. 225, pl. 61, fig. 23, 1878= Viburnum anomalinervum.

Zizyphus distortus Lesquereux, U. S. Geol. Survey Terr. Rept., vol. 7, p. 275 , pl. 51, fig. 7 [not figs. 8, 9], 1878= Zizyphus fibrillosus.

\section{THE VERMEJO FLORA.}

STRATIGRAPHY.

GENERAL CONSIDERATIONS.

For almost a quarter of a century previous to the beginning of detailed work (see p. 224) the coal-bearing rocks of the Raton Mesa region of Colorado and New Mexico were supposed to belong to a single geologic formationthe Laramie. The demonstration of a widespread unconformity in the midst of this supposedly continuous sequence naturally brought into question the correctness of the reference of these rocks to a single formation, and it became necessary to interrogate all possible sources of information as to their bearing on the point at issue. It was for this purpose, 
therefore, that the present paleobotanic investigation was undertaken, and, without unduly anticipating, it may be stated that it has furnished a very complete demonstration of the distinctness of the age of the beds separated by the unconformity.

The present study is based on most of the original material collected by Le Conte, Hayden, and Lesquereux and reported on by Lesquereux, and on the collections recently made by Lee, Richardson, St. John, and others, which are the most extensive and in many respects the finest material thus far brought together from any horizon within the Rocky. Mountain area.

The flora of the coal-bearing rocks below the unconformity-now called the Vermejo formation-comprises 108 species and, as will be brought out subsequently, presents a remarkably distinct and characteristic aggregation of plant forms. From accurate stratigraphic data now for the first time available, it appears that only about seven species of plants contained in the old collections as studied by Lesquereux came from horizons now known with reasonable certainty to be below the unconformity, and most of these are from the Trinidad sandstone. As all these are more or less problematic organisms, supposed to belong to Fungi and Algae, only one of which (Halymenites) has ever been found a second time either within or without the Raton Mesa region, their influence in settling the age of the beds whence they came has been relatively slight. Lesquereux regarded them as probably transitional between Cretaceous and Tertiary but finally referred them to the basal Eocene. It was not until the present collections were studied that satisfactory conclusions were at all possible.

\section{SPECIES.}

As a preliminary to the discussion of the Vermejo flora the following list of species is presented:

\section{Forms known from the Vermejo formation.}

[*Species found in the Raton Mesa region. + +Species found in the Canon City field.]

*Rosellinites lapideus (Lesquereux) Knowlton.

*†Halymenites major Lesquereux.

*Halymenites striatus Lesquereux.

*Chondrites bulbosus Lesquereux.

*Chondrites subsimplex Lesquereux.

*Caulerpites incrassatus (Lesquereux) Lesquereux. $\dagger$ Acrostichum haddeni Hollick.

†Polystichum hillsianum Hollick.

$*+$ ?Pteris russellii Newberry.

*†Pteris erosa Lesquereux.

*Pteris? sp.

*†Asplenium? coloradense Knowlton, n. sp.

†Asplenium sp.

*Woodwardia crenata Knowlton.

†Stenopteris? cretacea Hollick.

†Osmunda hollicki Knowlton, n. sp.

†Gleichenia rhombifolia Hollick.

†Gleichenia delicatula? Heer.

†Anemia robusta Hollick.

†Anemia supercretacea Hollick.

*Brachyphyllum cf. B. macrocarpum Newberry.

*Abietites dubius Lesquereux.

*Geinitzia formosa Heer.

* +Sequoia reichenbachi (Geinitz) Heer.

*†Sequoia obovata Knowlton, n. sp.

*Widdringtonia? complanata Lesquereux.

*Taxodium? sp.

*+Cupressinoxylon coloradense Knowlton, n. sp.

†Cupressinoxylon? vermejoense Knowlton, n. sp.

*Sparganium? sp.

* Sabal mon tana Knowlton, n. sp.

*Sabal? ungeri (Lesquereux) Knowlton, n. comb.

*†Canna magnifolia Knowlton, n. sp.

- †Canna? sp.

†Juglans coloradensis. Knowlton, n. sp.

†Juglans similis Knowlton, n. sp.

*†Myrica torreyi Lesquereux.

†Myrica coriacea Knowlton, n. sp.

*Salix gardneri Knowlton, n. sp.

* †alix plicata Knowlton, n. sp.

*Salix sp. a.

*Salix sp. b.

†Salix sp. c.

*Populus? neomexicana Knowlton, n. sp.

*Quercus gardneri Knowlton; n. sp.

†Quercus rockvalensis Knowlton, n. sp.

†Dryophyllum bruneri Ward.

- Ficus dalmatica Lesquereux

*†Ficus haddeni Knowlton, n. sp.

†Ficus eucalyptifolia Knowlton, n. sp.

*†Ficus leei Knowlton, n. sp.

*Ficus minima Knowlton, n. sp.

$\dagger$ Ficus newberryana Knowlton, n. sp.

*Ficus? starkvillensis Knowlton, n. sp.

* + Ficus praetrinervis Knowlton, n. sp.

$\dagger$ Ficus regularis Knowlton, n. sp.

$\dagger$ Ficus rhamnoides Knowlton.

†Ficus rockvalensis Knowlton, n. sp.

* †Ficus speciosissima Ward.

†Ficus tessellata Knowlton, n. sp.

* †Ficus wardii Knowlton.

*Ficus gigantea Knowlton, n. sp.

$\dagger$ Ficus curta Knowlton, n. sp.

$\dagger$ Ficus sp.

*Artocarpus dissecta Knowlton, n. sp.

${ }^{*}$ Credneria protophylloides Knowlton, n. sp.

†Laurus coloradensis Knowlton, n. sp.

*Liriodendron alatum Newberry.

†Platanus? sp. 
†Amelanchier obovata Knowlton, n. sp. $\dagger$ Phaseolites crassus Knowlton, n. sp. $\nmid$ Phaseolites leei Knowlton, n. sp. *Phaseolites minutus Knowlton, $\mathbf{n}$. sp. *Colutea speciosa Knowlton, n. sp. †Celastrus haddeni Knowlton, n. sp. †Celastrus? hesperius Knowlton, n. sp. *Celastrus? sp.

* †Rhamnus salicifolius Lesquereux. *Zizyphus paliurifolius Knowlton, n. sp.

*Sterculia coriacea Knowlton, n. sp.

* Pterospermites undulatus Knowlton.

*Pterospermites wardii Knowlton.

*Pterospermites nervosus Knowlton, $\mathrm{n}$. sp.

*Hedera rotundifolia Knowlton, n. sp.

*Vitis? fragmenta Knowlton, n. sp.

*Cissites panduratus Knowlton, n. sp.

*Diospyros? leei Knowlton, n. sp.

*Fraxinus? sp.

*Viburnum anomalinervum Knowlton, n. sp.

†Viburnum? hesperium Knowlton, n. sp.

*+Viburnum montanum Knowlton.

†Viburnum? problematicum Knowlton.

†Viburnum simile Knowlton, n. sp.

*Viburnum crassum Knowlton, n. sp.

*Viburnum rhamnifolium Knowlton, n. sp.

†Viburnum sp.

* Palaeoster inquirenda Knowlton, n. gen. and sp.

*Seedling plant?

*Phyllites aurantiacus Knowlton, n. sp.

*Phyllites leei Knowlton, n. sp.

*Phyllites nanus Knowlton, n. sp.

*Phyllites populoides Knowlton, n. sp.

tPhyllites protophylloides Knowlton, n. sp.

*Phyllites rosaefolius Knowlton, n. sp.

*Phyllites sapindus Knowlton, n. sp.

$\nmid$ Phyllites castalioides Knowlton, n. sp.

*Phyllites walsenburgensis Knowlton, n. sp. .

*Phyllites vermejoensis Knowlton, $n$. sp.

*Phyllites ratonensis Knowlton, n. sp.

Of the 108 forms $^{1}$. comprising the Vermejo flora 14 are more or less fragmentary and have not been given specific names, and no less than 61 are regarded as being new to science. The remaining 33 forms were previously known, and most of them have been found outside the Raton Mesa region.

The Vermejo flora is unmistakably Cretaceous in aspect. Thus, there may be noted such distinctively Cretaceous forms as Halymenites major, ${ }^{2}$ Brachyphyllum macrocarpum, Geinitzia formosa, Sequoia reichenbachi, Woodwardia crenata, Widdringtonia complanata, the genera Credneria, Gleichenia, Pterospermites,

1 The list includes a few forms from the Trinidad sandstone that are so closely related to those of the Vermejo that it has been deemed wise to include them in the Vermejo flora.

2 This form occurs below but nowhere higher than the Upper Cretaceous, cxcept in the Cannonball member of the Lance formation. Its maximum distribution is in or near the Fox Hills. etc. So far as known not one of these forms has been found above the Cretaceous or, for that matter, above the Montana.

Following is a list of Vermejo species, ${ }^{3}$ most of which occur at Point of Rocks and on the Laramie Plains in Wyoming, at Coalville in Utah, and elsewhere outside the Raton Mesa region.

Vermejo plants vith outside distribution.

Halymenites major.

Woodwardia crenata.

Pteris erosa.

Anemia supercretacea.

Brachyphyllum macrocarpum.

Geinitzia formosa.

Sequoia reichenbachi.

Sequoia obovata.

Widdringtonia? complanata.

Sabal montana.

Sabal? ungeri.

Myrica torreyi.

Juglans similis.

Ficus dalmatica.

Ficus wardii.

Ficus regularis.

Ficus rhamnoides.

Ficus speciosissima.

Ficus eucalyptifolia.

Rhannus salicifolius.

Pterospermites undulatus.

Pterospermites wardii.

Viburnum montanum.

Viburnum problematicum.

The geologic positions of the localities with which the Vermejo flora has species in common are as follows: Point of Rocks, Wyo., belongs to the Almond coal group of Schultz ${ }^{4}$ and is referred to the upper part of the Mesaverde formation. The locality at Rock Springs, Wyo., which has afforded a number of very characteristic forms is in the Rock Springs coal group of Schultz ${ }^{5}$ and is also referred to the Mesaverde formation, but lies perhaps 1,000 feet below the Almond. The plant beds at Coalville; Utah, according to Stanton, ${ }^{6}$ are overlain by. 1,800 feet of marine Cretaceous strata and are referred by him to the Montana. The localities on the Laramie Plains, Wyo.; are also referred ${ }^{7}$ to the Cretaceous in the approximate position of the Mesaverde.

3 Knowlton, F. H., Flora of the Montana formation: U. S. Geol. Survey Bull. 163, 1900.

4 Schultz, 'A. R., U. S. Geol. Survey Bull. 381, 'p. 223, 1910.

5 Idem, p. 224

6 Stanton, T. W., U. S. Geol. Survey Bull, 106, pp. 43-44, 1893.

'Stanton, T. W., and Knowlton, -F. H., Geol. Soc. America Bull., vol. 8 , pp. 137-143, 1897 . 
There can, of course, be no doubt as to the correctness of the reference of the above-mentioned localities to the Cretaceous, and, moreover, to that portion of the Montana group that has either been directly assigned to the Mesaverde formation or is acknowledged to be in the approximate stratigraphic position of this formation. Therefore, as fully 90 per cent of the Vermejo flora enjoying an outside distribution occurs at these localities and as, further, the affinities of a majority of the species described as new point in the same direction, it naturally follows that the beds containing this flora must occupy a similar stratigraphic position.

In this connection it will perhaps be of some interest to compare the Vermejo flora of the Raton Mesa region with the flora of beds in a similar stratigraphic position on the west side of the mountains. It has long been Lee's contention that the stratigraphic sequence is essentially identical on-opposite sides of the mountains, and in proof of this he was able in 1911 and 1912 satisfactorily to correlate certain of the formations of the Raton Mesa region as well as the unconformity separating them around the southern end of the mountains and thence up the west side to Durango, Colo. ${ }^{1}$

Thus the following Montana species are now known to be common to the east and west sides of the mountains, but it is to be added that the collections from the various areas on the southern and western sides of the mountains are very large and up to the present.time have been only hastily examined. When their study is completed many other species common to both sides will doubtless be found.

Vermejo species occurring west of the Rocky Mountains.

Abietites dubius.

Brachyphyllum macrocarpum.

Geinitzia formosa.

Sequoia reichenbachi.

Sequoia obovata.

Gleichenia rhombifolia.

Woodwardia crenata.

- Sabal montana.

Sabal? ungeri.

Myrica torreyi.

Juglans similis.

Ficus rhamnoides.

Ficus speciosissima.

Ficus eucalyptifolia.

1 Geol. Soc. America Bull., vol. 23, pp. 571-686, 1912.
Ficus leei.

Ficus wardii.

Ficus praetrinervis.

Ficus starkvillensis.

Viburnum? problematicum

Viburnum anomalinervum.

The remaining previously named speciesabout a dozen in number-are apparently confined to the Raton Mesa area, not having thus far been identified outside.

Although new species as such may have little or no value in fixing the age of the beds in which they occur their obvious affinities may lead to important deductions: Thus Juglans similis is related to $J$. rugosa, which has a wide range in Cretaceous and lower Tertiary. Myrica coriacea is most closely related to $M$. torreyi, a Vermejo and in general an Upper. Cretaceous form. Ficus haddeni is of the type of $F$. praetrinervis and is not greatly different from it. Ficus leei, one of the handsomest and most abundant species in this flora, is very close to and, in many cases, is almost indistinguishable from Ficus speciosissima, a highly characteristic Montana species. Ficus newberryana is of the type of $F$. planicostata. Ficus starkvillensis is evidently related to $F$. lanceolata, a form commonly found in. the Laramie of the Denver Basin. Ficus praetrinervis is close to $F$. trinervis; and $F$. rockvalensis is quite similar to certain leaves from Point of Rocks, Wyo., referred by.Lesquereux to $F$. dalmatica. Ficus tessellata is related to $F$. navicularis. Artocarpus dissecta, which comes only from Walsenburg, is most nearly related to $A$. Zessigiana from the Laramie of the Denver Basin yet differs essentially: Credneria protophylloides is hardly to be distinguished from C. integerrima Zenker, from the Quadersandstein of Blankenburg. Laurus montanensis in the matter of nervation approaches very closely to $L$. primigenia Unger as figured by Lesquereux but differs from it in size and shape. It is perhaps the same as specimens reported from Point of Rocks under the name of $L$. primigenia. Liriodendron alatum Newberry is apparently identical with leaves reported from the Eagle sandstone of Montana. Phaseolites crassus appears to approach most closely to $P$. elegans Hollick from the Raritan formation of $\mathrm{New}$ York. Sterculia coriacea is of the same type as S. reticulata Lesquereux, from the Dakota sandstone of Kansas, and S. rigida Lesquereux, from 
the Miocene of Florissant, Colo., though differing essentially from each. Diospyros? leei is of the same type as $D$. ficoidea Lesquereux, from Black Buttes and Hodges Pass, Wyo., but differs from it in being more nearly elliptical in shape and in having lower-angled secondaries. Viburnum anomalinervum is the same as a leaf from Point of Rocks, Wyo., that was referred by Lesquereux to $V$. whymperi Heer, but that is quite distinct from that species. Viburnum simile was associated with and is undoubtedly most closely related to $V$. montanum Knowlton, a species from Point of Rocks. Viburnum rhamnifolium is very close to V.problematicum as described in this report from Rockvale, Colo.

\section{FLORAS OF THE CANON CITY AND RATON MESA} FIELDS.

Although the present investigation is primarily concerned only with the Raton Mesa area it has been thought best to include with it a consideration of the Canon City field, especially as the relations between them have been found to be intimate. The Canon City field is north of and in a way intermediate between the Raton Mesa field and that of the Colorado Springs and the Denver Basin areas.

The Canon City coal measures were once supposed to be of Laramie age (p. 225) and even as late as 1910 were so referred by Washburne, ${ }^{1}$ notwithstanding the fact that I had already pointed out that at least the lower 400 feet of beds (all below the Rockvale sandstone member) contained a Montana flora. Subsequently much more complete and better collections, made by Lee, Stanton, and Knowlton, showed that the entire coal measures section, at least up to and including the so-called rim rock, belongs in the Montana. Halymenites major, which is held always to indicate marine conditions, is especially abundant in the upper portion of the Rockvale sandstone, as well as in its stratigraphic equivalent on the west side of the basin, and is now known to occur in the upper coal group nearly to the base of the rim rock near Rockvale. Ficus speciosissima and its near ally, F. leei, also occur throughout the section, and other of the most characteristic Montana forms are found both above and below the Rockvale sandstone. Therefore, the propriety of in-

1 U. S. Geol. Survey Bull. 381, p. 348, 1910. cluding all in the Montana is no longer questioned.

The complete list of the Vermejo flora on pages 227-228 shows the species common to the Raton Mesa and Canon City fields, and though these are not numerous (less than a dozen) most of them are important forms not likely to be misidentified.

\section{FLORAS OF THE VERMEJO AND RATON FOR-} MATIONS.

Naturally, much interest attaches to the relation between the floras of the beds below and above the unconformity, that is, between those of the Vermejo and Raton formations. The paleobotanic differences between them - are striking, for at present only four species (Pteris erosa, Sabal? ungeri, Ficus praetrinervis, and Palaeoaster inquirenda) are known to cross the line.

The last-named species is very close to the line on either side. In the Vermejo formation it is found at Alkali Gap, in the Canon City field, 35 feet above the highest Halymenites zone, and at Walsenburg above the highest bed of the lower coal group. In the Raton formation it occurs at the Bowen mine, near Trinidad, only a few feet above the conglomerate.

There are, however, one or two other species that may ultimately prove to be common to the two formations when fuller collections are available. Thus, what has been described as new under the name of Artocarpus dissecta from Walsenburg (based on a single example) may prove to be identical with Artocarpus similis or A. lessigiana. Myrica torreyi occurs elsewhere in beds corresponding in age to the Raton formation. Some of the species of Ficus of the type of $F$. planicostata may occur in both formations but at present are not known to doso.

Aside from the fact that the two floras have only four species in common, theyshow marked and striking differences. For example, the Algae, represented in the Vermejo by the genera Halymenites, Chondrites, and Caulerpites, are unknown in the Raton formation. The Palmaceae, represented in the Raton by five genera and nine species and occurring at practically every locality in which collections were made, are reduced to a single genus and two species in the Vermejo and are known to occur in less than a dozen localities. The 
Coniferae, abundant in genera and species in the Vormejo formation, are without known representation in the Raton formation. The Platanaceae, represented in the Raton formation by seven forms and a great many specimens, have a single very doubtful representation in the Vermejo formation. The Magnoliaceae are exceedingly abundant in the Raton formation but are without a species of Magnolia in the Vermejo formation. The Cornaceae have two species in the Raton formation but are not known in the lower beds.

In addition Acrostichum, Polystichum, Woodwardia, Gleichenia, Sparganium, Canna, Pterospermites, Cissites, Diospyros, Credneria, Liriodendron, and Colutea, all Vermejo genera, are not present in the Raton formation; and similarly, Alismaphyllites, Phragmites, Fagus, Castanea, Aristolochia, Castalia, Nelumbo, Cinnamomum, Liquidambar, Rhus, Ceanothus, Acer, Sapindus, Paliurus, Apeibopsis, Cissus, Aralia, Nyssa, Andromeda, Chionanthus, and Apocynophyllum, all Raton genera; are not represented in tho Vermejo.

VERMEJO AND LARAMIE FLORAS OF THE DENVER BASIN:

As the coal-bearing rocks of the Raton Mesa region were regarded-until the beginning of the present investigation - as belonging to the Larnmie, it will be of interest to compare the floras of the beds below the unconformitythe flora of the Vermejo formation-with the flora of the Laramie in its typical area. As the unconformity that separates the Laramie from the overlying Arapahoe and Denver formations in the Denver Basin is the same as that delimiting the Vermojo formation from the overlying Raton formation, it might seem a priori that the two floras should have much in common and perhaps should be identical. Critical study, howover, failed signally to confirm this supposition. At first it was thought that only a single spocies (Rhamnus salicifolius) was common to the two formations. Since 1913, when the present paper was completed, a thorough revision has been made of the Laramie flora in the Denver Basin, and this discloses that there are five or six species that occur in both. But as there are 106 species in the Vermejo flora and 129 in the Laramie flora, the relationship obviously is not very strong. The species in common aro as follows:
Sequoia reichenbachi (Geinitz) Heer.

Sabal montana Knowlton.

Myrica torreyi Lesquereux.

Ficus dalmatica? Ettingshausen.

Ficus trinervis Knowlton.

Rhamnus salicifolius Liesquereux.

A brief discussion of the above species may be of interest.

Sequoia reichenbachi has an almost worldwide distribution and ranges in áge from Jurassic to Upper Cretaceous and is, therefore, of no importance as a close horizon marker. The known presence of this species in the Laramie rests on a few more or less doubtful fragments, though if correctly identified its rarity has of course no particular bearing in the present consideration. Sabal montana is a very large leaved species, perhaps the largest known in the Rocky Mountain region, and as a consequence it is rare to find it preserved in condition that will permit certain identification. It is fairly abundant in the Vermejo formation and has probably been correctly identified in the Laramie, though the specimens are fragmentary. Myrica torreyi, though occurring mainly in the Montana, is a widely ranging form and has even been found in beds above the unconformity. Rhamnus salicifolius was originally described from the Laramie and has subsequently been found at a number of horizons both above and below the unconformity. The two species of Ficus are fairly well marked species that have probably been correctly identified in both the Vermejo and Laramie.

The Vermejo flora, as already pointed out (p. 230), is distinctively Montana in aspect, and although the Laramie flora is obviously related to the Montana flora, it is distinctly different, and with adequate collections there should be no difficulty in separating them. It appears that the erosion producing the unconformity, which is regarded by many as profound and which in any event was very considerable, has left some 1,200 feet or less of Laramie in the Denver Basin, and that in the Colorado Springs area, the southernmost point at which the Laramie has thus far been recognized, it has reduced the thickness of the Laramie to a maximum of 375 feet where the overlying beds (Dawson arkose) transgress everything perhaps down to the Cambrian. In the Trinidad field the Laramie, if ever present, has been entirely removed, and the erosion has cut the Vermejo to a little 
over 400 feet in thickness. In other parts of the Raton Mesa region, as Lee has shown, the Vermejo and the underlying Trinidad sandstone have both been removed and the Raton formation rests directly on Pierre shale. This explanation of the physical history is supported by the paleobotany.

SPECIES TRANSGRESSING THE GREAT UNCONFORMITY ELSEWHERE.

As already pointed out, the unconformity which separates the Vermejo and Raton formations in the Raton Mesa region is the same as that in the Colorado Springs region, where it separates the Dawson arkose from all underlying beds, and as that in the Denver Basin, where it separates the remnant of the Laramie from the overlying Arapahoe and Denver formations. It is also believed to be essentially the same as that in Carbon County, Wyo., where it separates the most complete section of Laramie known $(5,000 \pm$ feet) from the overlying dinosaur-bearing beds-that is, that separates the "Lower Laramie" from the "Upper Laramie" of Veatch. Likewise it is believed to represent the time interval in eastern Wyoming, the Dakotas, and Montana, which is believed to everywhere separate the Lance formation from underlying beds (Fox Hills, Pierre, etc.).

In this connection it may be of interest briefly to review the species of plants that are known or supposed to cross the line of this unconformity.

Only four species (p. 230) are known to be common to the Vermejo and Raton formations in the Raton Mesa region, and only six species (p. 231) to the Laramie of the Denver Basin and the Raton formation. At one time or another about 11 species have been reported as passing from Laramie to Denver, 5 or 6 from Laramie to the dinosaur-bearing beds in Carbon County, Wyo., and 16 from Cretaceous (Montana and Laramie) to the Lance. On eliminating duplications in the several lists as well as the few species which fuller information has shown to have been incorrectly identified in one or the other horizon, there remains a total of about 21 or 22 species that are known to cross the line of this unconformity throughout its whole areal extent, from New Mexico on the south to the Canadian border on the north. The combined floras of the beds (Vermejo, Mon- tana, Judith River, Laramie; etc.) below the line of the unconformity throughout the same areal extent contain about 350 known species; and the combined floras in the beds above the break (Raton, Dawson, Arapahoe, Denver, Lance, etc.) contain over 700 known species. If out of 350 species below the line and 700 species above it, only 21 or 22 are known to transgress it, the distinction between the rocks below and above would appear to be sharp. In fact, the only wonder is that more species do not cross the line. If the known number should be even doubled by future work (a condition which, according to present knowledge, is improbable) the difference would still be very marked.

\section{BIOLOGIC CONSIDERATIONS.}

The complete flora of the Vermejo formation, to which has been added that of the Trinidad sandstone, comprises 108 species. (See p.227.) It is believed that this enumeration is really very conservative, for it omits the many fragmentary forms that are always present but that can not be adequately characterized, and includes only those that are capable of being figured or described so that they may subsequently be recognized. The number accepted is doubtless far short of the actual number that lived during Vermejo time, for no matter how careful the exploitation, each new collection is almost certain to bring to light forms previously unknown or unrecognized.

The vast group of Thallophytes is, as might be expected, but sparsely represented in this flora. The fungi comprise only a single rather insufficiently characterized bark-inhabiting species, and this, of course, must give a very inadequate idea of this group as it doubtless existed at the time. The Algae are represented by three genera and five nominal species, but as most of these are preserved simply as rough sandstone casts of stems or portions of fronds they are not in a shape that will permit adequate biologic comparison, and about all that can be said of them is that they appear to be properly referable to the group.

With the Pteridophyta, however, the case is entirely different, at least four families being identifiable with a fair degree of certainty. The largest representation is in the Polypodiaceae, which embrace six genera (Acrostichum, Polystichum, Pteris, Asplenium, Wood- 
wardia, and Stenopteris?) and nine species. The Osmundaceae are represented by a single species ( $O$. hollicki), and the Gleicheniaceae and Schizaeaceae by two species each.

In the Spermatophyta the Coniferales are abundantly represented, not only by genera and species but by individuals. The recently established family Brachyphyllaceae, which has apparently no very close living relatives, contains in this flora a single species, which is probably the same as Brachyphyllum macrocarpum Newberry, though, as the material is not very well preserved, the specific identification has been questioned. The Pinaceae, however, are abundantly represented by six genera and eight species. Of these the most abundant are the sequoias, which represent both the living types of the genus, Sequoia reichenbachi, corresponding to $S$. washingtoniana, and $S$. obovata, corresponding to the living S. sempervirens. It is possible that the two species described under the name of Cupressinoxylon may represent the wood of some form described also from the foliage; but this can not be proved at present.

The.Monocotyledonae were but sparsely represented in the collections, there being a single doubtful species of Sparganium, two species of Sabal, and two that apparently belong to Canna. It is of course probable that there were many more monocotyledons in this flora, but as most of them were inconspicuous small forms without deciduous foliage the chances of their being preserved were relatively remote:

Many orders of the Dicotyledonae are well represented. Thus, the Juglandales are represented by the Juglandaceae with two species, the Myrtales by two species of Myrica, and the Salicales by five forms of Salix and a single doubtful species of Populus, and the Fagales by two species of Quercus. The largest and most important dicotyledonous order is the Urticales and family Moraceae, with no less than 17 species referred to Ficus. and 1 to Artocarpus. Ficus must have been' exceedingly abundant and conspicuous, for there is hardly a collection without one or more species of it, and some have as many as half a dozen. Individuals are also abundant, some species, such, for instance, as in Ficus leei, being represented by literally dozens of leaves, so many that it has been possible to work out their range in size and individual variations.
In the order Ranales the Lauraceae are represented by a single species of Laurus and the Magnoliaceae by a well-marked species of Liriodendron. The Rosales are comprised in three families-the Platanaceae with a single doubtful fragment of Platanus, the Rosaceae with a species that apparently belongs to Amelanchier, and the Papilionaceae by a number of leaflets referred to Phaseolites and Colutea. The order Sapindales, family Celastraceae, has had referred to it three forms of Celastrus; and the order Rhaminales, family Rhamnaceae, is represented by a single species each of Rhamnus and Zizyphus.

Another fairly well represented order is the Malvales, there being one species of Sterculia, three of Pterospermites, and one of Hedera referred to the family Sterculiaceae, and one species each of Vitis and Cissites referred to the Vitaceae. These are followed by two relatively unimportant orders, the Ebenales with a single species of Diospyros and the Gentianales with a very doubtful leaflet of Fraxinus. The remaining order of particular importance in this flora is the Rubiales, which comprises eight more or less well characterized species of Viburnum.

The remaining constituents of this flora are of uncertain systematic position. They comprise the peculiar organism, perhaps a capsule, described under the name of Palaeoaster. inquirenda, and two species segregated under the form genus Phyllites.

Briefly to recapitulate: The Vermejo flora comprises 108 forms distributed among the several groups as follows: Fungi, 1 genus and species; Algae, 3 genera, 5 species; Pteridophyta, 4 families, 9 genera, and 14 species; Coniferales, 2 families, 7 genera, and 9 species; Monocotyledonae, 3 families, 3 genera, and 5 nominal species; Dicotyledonae, 13 orders, 17 families, and 60 species.

\section{ECOLOGIC CONSIDERATIONS. '}

From the biologic aspects of the Vermejo flora some tentative conclusions may be drawn, with a fair degree of probability, as to the ecologic conditions under which this flora existed. In drawing conclusions from individual organisms in an inquiry of this kind dependence must of course be placed on our knowledge of the present-day requirements of similar species, and the results must always be subject to possibility of error from two sources-first, from 
the incorrect placing biologically of the organism and, second, from the fact that its requirements in past geologic time may not have been the same as these which now dominate the life activities of its supposed analogue. However, when all of the elements of a flora appear to point in the same direction the liability to serious error is minimized if not eliminated.

The presence of numerous large coarse-growing algae is interpreted as bespeaking shallowwater marine conditions for the beds in which they are now found entombed. Algae of this kind are present sparsely in the lower portion of the Vermejo formation and more numerously in the underlying Trinidad sandstone, which for convenience has been included in this enumeration. Halymenites major occurs abundantly both in the Trinidad and in the Canon City areas. In other areas, where this form has a wide geographic range, it has been found on occasion in association with various invertebrates, all of them of marine shallowwater types. Although comparatively few invertebrates have been found in company with the Halymenites within this area it is safe to say that the sea had access to the region, either temporarily or permanently, during the time of its existence.

The evidence to be derived from the ferns is not very impressive and is somewhat conflicting. The genera Acrostichum, Woodwardia, Osmunda, and Anemia are distinctly swamploving forms, but Dicksonia, as known at the present day, is distinctly xerophytic, though not necessarily living at any great distance from or above sea level. The genus Pteris is also found usually in drier situations, and Asplenium and Polystichum are not out of place in either swampy or drier habitats.

The conifers, however, afford much more definite and valuable criteria for the inquiry in hand. Take first the two species of Sequoia, which, as already stated, represent both the living types of the genus. The redwood ( $S$. sempervirens) is confined to the coast range of California and the extreme southwestern corner of Oregon, and ranges from near sea level to approximately 2,500 feet elevation, mainly on the seaward side of the mountains within the fog belt. Here it is subjected to frequent and heavy sea fogs and to typically moist soil and air. The annual precipitation ranges between 20 and 60 inches, and the temperature between $15^{\circ}$ and $100^{\circ}$, with an annual average of $50^{\circ}$ to $60^{\circ} \mathrm{F}$.

The big tree (S. washingtoniana) occurs now in the interior valleys of California at elevations of from 5,000 to 8,500 feet and is tolerant of cooler and drier conditions than the redwood. The range in temperature is between $-12^{\circ}$ and about $100^{\circ} \mathrm{F}$., with a precipitation of 18 to over 60 inches. Probably the genera Abietites and Geinitzia should be considered with Sequoia -in any event they do not greatly differ from it in foliar and other characters.

The genus Cupressinoxylon, which is believed to represent the wood of Cupressinae, affords valuable data regarding climatic conditions. Of the two species described from the Vermejo flora one is entirely without growth rings, and the other exhibits a very slight ring in which only three or four rows of cells are slightly thickened and thus mark the brief period of rest. A single species of dicotyledonous wood, so poorly preservied that it could hardly be figured or described with satisfaction, exhibits but slight trace of growth rings, at least so far as can be made out.

Widdringtonia, which is now represented by three or four species, natives of the warm, moist regions of South Africa and Madagascar, argues-if it has been correctly identified-for a warm, moist climate.

On the whole it would appear that the conifers indicate the absence of marked seasonal changes and the presence of moist, relatively warm climatic conditions.

The Monocotyledonae are unimportant but, so far as they may be interpreted, indicate marshy or swamp conditions. Palms, though present, were unimportant in species, though abundant in individuals.

The Dicotyledonae are the most abundant and conspicuous elements of the Vermejo flora. The genera Juglans, Myrica, Salix, Populus, and Quercus are poorly and in some cases doubtfully represented in the flora. These are relatively large genera that are mainly of northern range, though representatives of all or nearly all are found as far or farther south than the area under consideration. The most important genus both as regards species and individuals was Ficus, of which 17 forms have been delimited. Ficus is a vast genus of more than 600 living species, widely distributed in the tropical and subtropical regions of the 
world. There is also a fine species of Artocarpus, a genus which, although once living as far north as Greenland, is now confined to the Old World within $20^{\circ}$ of the Equator. The genera Laurus and Liriodendron are now growing under warm or at least temperate conditions. The several genera of Papilionaceae (Phaseolites, Colutea) are not sufficiently well determined to be of value in this consideration. Celastrus, with the exception of a single North American species, is a native of the warm portions of enstern Asin, Australia, and Madagascar. Rhamnus is also a native at present of warm and temperate regions, and $Z i z y p h u s$ is mainly found in the tropical portions of America, eastern Asia, southern Africa, and Australia. Sterculia is now confined to the tropics of both hemispheres, and Hedera is mainly tropical. Cissus is a very large genus of the tropics with a few species extending into the subtropics. Viburnum is also extensive, häing over 100 species, most of which are natives, of subtropical portions of eastern Asia and North America, with, for example, two species in the island of Jamaica.

From the several forms of plant life considered above that are likely to afford information of interest or value a picture of the ecologic conditions as they probably existed during Trinidad and Vermejo time may be drawn.

During at least the close of Trinidad time, and locally in the earlier stages of Vermejo time, the sea had access to the region, probably as a broad shallow bay or arm. In the warm waters existed the several species of large coarse algae, whose stems and foliar expansions were cast on the beach to be covered by the sand and preserved in the form of casts and impressions. That there was a contemporary land flora is of course more than probable, but it has not been preserved in this area.

Subsequently the seas was excluded, though perhaps never to any great distance, giving place probably to a series of great low-lying swamps and marshes wherein grew much of the vegetation of the time. In the pools and slowmoving streams were Sparganium, and on the surface floated the rosettes of Trapa? microphylla. About the edges grew Canna?, Acrostichum, Woodwardia, and doubtless certain figs and an occasional palm. In the denser swamps were found the cypress-like Cupressinoxylon, Widdringtonia, Sterculia, and many species of
Ficus, with here and there a breadfruit tree. On higher ground were sequoias, oaks, walnuts, laurels, ivies, and grapes.

From the abundance and proportion of the plant types it may be presumed that there was an abundance of moisture, from the absence of marked growth rings that there was no sharp differentiation of seasons, and from the general facies of the whole flora that the climate was warm temperate and perhaps even subtropical.

\section{THE RATON FLORA.}

\section{STRATIGRAPHIC CONSIDERATIONS.}

The Raton formation, as the conl-bearing portion of the section above the unconformity in the Raton Mesa region is now called, has been considered-largely on account of its supposed stratigraphic relations-as belonging to the Laramie. However, the demonstration of this widespread unconformity made it necessary to investigate the upper beds with extreme care, and the result has been to show that from the paleobotanist's point of view they are distinctively post-Laramie in age.

As a preliminary to the discussion of the Raton flora, the following is given as a complete list of the forms known:

Forms known from the Raton formation.

Dryopteris? cladophleboides Knowlton, n. sp.

Dryopteris? sp.

Pteris erosa Lesquereux.

Pteris russellii Newberry.

Pteris linearis Knowlton, $\mathbf{n}$. sp.

Asplenium? primero Knowlton, n. sp.

Anemia occidentalis Knowlton, n. sp.

Alismaphyllites crassifolium Knowlton, n. gen. and $\mathrm{sp}$.

Phragmites oeningensis Alexander Braun.

Oreodoxites plicatus Lesquereux.

Sabalites grayanus Lesquéreux.

Sabal inquirenda Knowlton, n. sp.

Sabal? rugosa Knowlton, n. sp.

Sabal? leei Knowlton, n. sp.

Sabal? ungeri (Lesquereux) Knowlton, n. comb

"Geonoma" gigantea Knowlton, n. sp.

Geonomites tenuirachis Lesquereux.

Palmocarpon palmarum (Lesquereux) Knowlton.

Juglans acuminata Alexander Braun.

Juglans nigella Heer.

Juglans minutidens Knowlton, n. sp.

Juglans berryi Knowlton, n. sp.

Juglans rugosa Lesquereux.

Juglans rhamnoides Lesquereux.

Juglans sapindiformis Knowlton, n. sp.

Juglans sapindoides Knowlton, n. sp.

Juglans schimperi Lesquereux.

Populus neotremuloides Knowlton, n. sp. 
Populus, female ament.

Fagus papyracea Knowlton, n: sp.

Castanea intermedia Lesquereux.

Quercus fisheriana Knowlton, n. sp.

Quercus simplex Newberry.

Quercus? neomexicanus Knowlton, n. sp.

Quercus? ratonensis Knowlton, n. sp.

Dryophyllum tennesseensis Berry.

Dryophyllum aquamarum? Ward.

Dryophyllum moorii (Lesquereux) Berry.

Ulmus sp.

Ficus artocarpoides Lesquereux.

Ficus aguilar Knowlton, n. sp.

Ficus uncata Lesquereux.

Ficus duplicata Knowlton, n. sp.

Ficus occidentalis (Lesquereux) Lesquereux.

Ficus harrisiana Hollick.

Ficus denveriana Cockerell.

Ficus neoplanicostata Knowlton, n. sp.

Ficus planicostata latifolia Lesquereux.

Ficus planicostata clintoni (Lesquereux) Knowlton.

Ficus pseudopopulus Lesquereux.

Ficus praetrinervis Knowlton n. sp.

Ficus schimperi Lesquereux.

Ficus? smithsoniana Lesquereux.

Ficus richardsoni Knowlton, n. sp.

Ficus minutidens Knowlton, $\mathrm{n}$. sp.

Ficus ratonensis Knowlton, n. sp.

Artocarpus similis Knowlton, n.. sp.

Aristolochia? elongata Knowlton, n. sp.

Castalia leei Knowlton, n. sp.

Nelumbo lakesiana (Lesquereux) Knowlton, n. comb.

Magnolia angustifolia Newberry.

Magnolia laurifolia Lesquereux.

Magnolia hilgardiana Lesquereux.

Magnolia magnifolia Knowlton, n. sp.

Magnolia leei Knowlton, n. sp.

Magnolia lesleyana Lesquereux.

Magnolia regalis? Heer.

Magnolia rotundifolia Newberry.

Magnolia cordifolia Lesquereux.

Laurus? caudata Knowlton, n. sp.

Laurus ratonensis Knowlton, $\mathrm{n}$. $\mathrm{sp}$.

Laurus? coloradensis Knowlton, n. sp.

Laurus pedatus? Lesquereux.

Laurus socialis Lesquereux.

Laurus utahensis Lesquereux.

Nectandra lancifolia (Lesquereux) Berry.

Oreodaphne? ratonensis Knowlton, n. sp.

Cinnamomum? ficifolium Knowlton, n. sp.

Cinnamomum linifolium Knowlton, n. sp.

Cinnamomum mississippiense? Lesquereux.

Liquidambar cucharas Knowlton, n. sp.

Platanus aceroides Göppert.

Platanus aceroides cuneata Knowlton, n. var.

Platanus aceroides latifolia Knowlton, n. var.

Platanus guillelmae Göppert.

Platanus guillelmae heerii Knowlton, n. var.

Platanus platanoides (Lesquereux) Knowlton.

Platanus raynoldsii Newberry.

Platanus rhomboidea Lesquereux.
Platanus? regularis Knowlton, n. sp.

Cercocarpus orestesi Knowlton, n. sp.

Prunus coloradensis Knowlton, n. sp.

Leguminosites arachioides Lesquereux.

Sophora nervosa Knowlton, n, sp.

Cassia richardsoni Knowlton, n. sp.

Cassia sapindoides Knowlton, n. sp.

Cassia fisheriana Knowlton, n. sp.

Inga heterophylla Knowlton, n. sp.

Carapa eolignitica? Berry.

Xanthoxylum dubium Lesquereux.

Euphorbocarpum richardsoni Knowlton, n. gen. and sp.

Rhus viburnoides Knowlton, n. sp.

Celastrus serratus Knowlton, n. sp.

Celastrus? sp.

Euonymus splendens Berry.

Acer fragilis Knowlton, n. sp.

Sapindus caudatus Lesquereux.

Sapindus affinis Nèwberry.

Sapindus rocklandensis Knowlton, n. sp.

Rhamnus cleburni Lesquereux.

Rhamnus goldianus? Lesquereux.

Rhamnus? woottonensis Knowlton, n. sp.

Rhamnus obovatus Lesquereux.

Rhamnus fischeri Lesquereux.

Berchemia multinervis (Alexander Braun) Heer. Paliurus zizyphoides Lesquereux.

Zizyphus fibrillosus (Lesquereux) Lesquereux.

Zizyphus meiggsii (Lesquereux) Berry.

Apeibopsis? neomexicanus Knowlton, n. sp.

Tilia speciosissima Knowlton, n. sp.

Sterculia berryana Knowlton, $\mathbf{n}$. sp.

Dombeyojpsis magnifolia Knowlton, n. sp.

Vitis olriki Heer.

Vitis leei Knowlton, n. sp.

Vitis inominata Knowlton, n. sp.

Vitis? platanifolia Knowlton, n. sp.

Cissus grossedentata Knowlton, n. sp.

Cissus laevigata Lesquereux.

Aralia coloradensis Knowlton, n. sp.

Aralia? serrata Knowlton, n. sp.

Hedera rotundifolia Knowlton, n. sp.

Cornus neomexicana Knowlton, n. sp.

Cornus studeri? Heer.

Nyssa lanceolata Lesquereux.

Nyssa? racemosa Knowlton.

Andromeda lanceolata Knowlton, n. sp.

Andromeda scripta Knowlton, n. sp.

Chionanthus membranaceus Knowlton, n. sp.

A pocynophyllum lesquereuxii Ettingshausen.

A pocynophyllum wilcoxensis Berry.

A pocynophyllum linifolium Knowlton, n. sp.

Viburnum contortum Lesquereux.

Viburnum speciosum Knowlton, n. sp.

Viburnum magnum Knowlton, n. sp.

Viburnum woottonianum Knowlton, n. sp.

Viburnum lakesii Lesquereux.

Palaeoaster inquirenda Knowlton, n. sp.

Carpites coffeaeformis Lesquereux.

Carpolithes spinosus Newberry.

Phyllites retusoides Knowlton, n. sp. 
Aside from the biologic relationships of this florn the interest naturally centers on the data it affords regarding the age position of the beds in which it occurs.

Over the unconformity separating the Raton and Vermejo formations pass only four species, namely:

Species common to the Raton and Vermejo formations.

Pteris erosa.

Sabal? ungeri.

Ficus practrinervis.

Palaeoaster inquirenda.

As there are 148 species in the Raton flora and 108 in the Vermejo flora, the presence of only four species in common shows conclusively that there is no real relationship between them. A full discussion of the further differences between the two floras will be found on page 230 .

Species common to the Raton and Laramie formations of the Denver Basin.

Ficus? smithsoniana.

Paliurus zizyphoides.

The Laramie of the Denver Basin affords, as at present understood, about 129 species of plants. As only 2 species found in the Raton flora occur also in the Laramie, the relationship is not very close.

Species common to the Raton and Arapahoe formations. ${ }^{1}$

Pteris erosa.

Berchemia multinervis.

Cissus laevigata.

Nelumbo lakesiana.

As the Raton formation occupies the same stratigraphic position in regard to the unconformity at the top of the Vermejo as does the Arapahoe formation of the Denver Basin in regard to the post-Laramie unconformity it is of interest to compare their flora. Four species, all of which are found also in the Denver formation, are common to the two formations. The flora of the Arapahoe is supposed to number about 30 species, but of late some doubt has arisen as to the correctness of referring certain of the supposed Arapahoe localities to this formation; in fact, Richardson ${ }^{2}$ has expressed the tentative opinion that the Arapahoe may be only a

\footnotetext{
1 Sinco this section was written it appears to have been demonstrated by Richardson that the supposed plant-bearing Arapahoe locality should bo roferred to either the Denver formation or the Dawson arkose.

2 Geol. Soc. America Bull., vol. 23, p. 274, 1912 .
}

depositional phase of the Denver. Be this as it may, there is evidently not a very strong relation between the Raton and Arapahoe as at present understood.

Species common to the Raton and Denver formations.

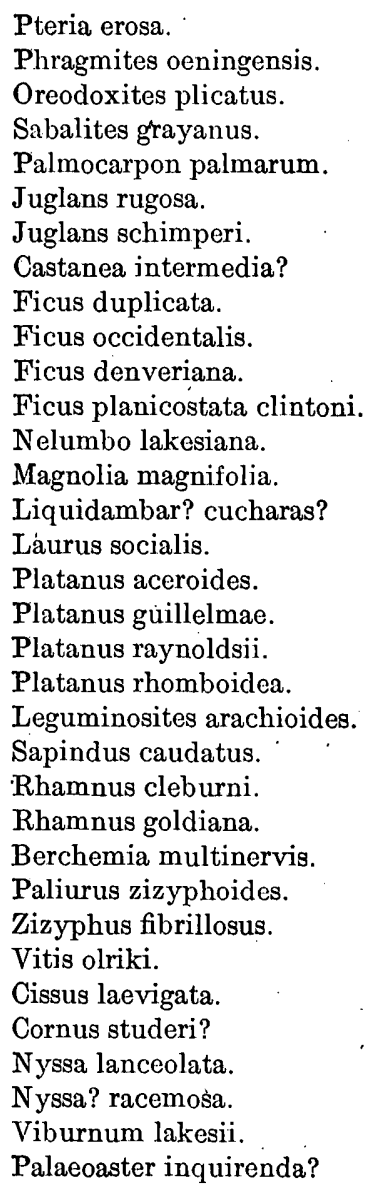

From the beginning of the critical study of the Raton flora it has been increasingly evident that its closest affinity is with the Denver flora. From the above list it appears that at least 34 species are common to the two floras. Put in another way it means that 43 per cent of the Raton flora having an outside distribution is found also in the Denver; and as the total published Denver flora embraces 98 species, it follows that more than one-third of these occur in the Raton formation. It is but fair to add that the known new species from the Denver, not published, will bring its total flora up to at least 137 species. Even including these, however, more than one-fourth of the total is found also in . the Raton formation. 
Species common to the Raton and Wilcox formations.

Sabalites grayanus.

Juglans berryi.

Juglans schimperi.

Dryophyllum moorii.

Dryophyllum tennesseensis.

Ficus schimperi.

Ficus uncata. ${ }^{1}$

Ficus occidentalis.

Ficus denveriana.

Ficus harrisiana:

Ficus neoplanicostata.

Ficus pseudopopulus.

Ficus latifolia. ${ }^{1}$

Ficus artocarpoides.

Magnolia angustifolia.

Magnolia leei.

Magnolia lesleyana. ${ }^{1}$

Magnolia hilgardiana. ${ }^{1}$

Magnolia cordifolia. ${ }^{1}$

Laurus pedatus. ${ }^{1}$

Laurus ratonensis. ${ }^{1}$

Cinnamomum mississippiensis.

Nectandra lancifolia.

Zizyphus meiggsii.

Euonymus splendens.

Cornus studeri?

Carapa eolignitica.

Leguminosites? arachioides.

Apocynophyllum wilcoxensis.

In a recently issued work Berry ${ }^{2}$ gives the following list of Wilcox species that are represented by closely related forms in the Raton formation:

Anemia eocenica.

Asplenium hurleyensis.

Pteris pseudopinnaeformis.

Chamaedorea danai.

Canna eocenica.

Dryophyllum puryearensis.

Artocarpus wilcoxiana.

Cinnamomum oblongatum.

Cassia glenni.

Sophora henryensis.

Sapindus eoligniticus.

1 E. W. Berry and I have been in constant consultation regarding the relations between the floras of the Raton and Wilcox formations, and though we are in absolute accord as to the above-listed plants being common to the two formations, we are not altogether agreed as to the names they shall bear. Some of the disagreement resulted from differences in nomenclatorial interpretation and others from differences as to biologic allocation. In order that there may be a minimum of confusion in comparing the two lists the names adopted by $\mathrm{Mr}$. Berry that differ from those employed in the present work are given below, his names following mine.

Ficus uncata $=$ Ficus monodon.

Ficus latifolia $=$ Ficus planicostata latifolia

Magnolia lesleyana = Terminalia lessleyana.

Magnolia hilgardiana $=$ Terminalia hilgardiana .

Magnolia cordifolia= Combretum ovalis.

Laurus pedatus $=$ Osmanthus pedatus.

Laurus ratonensis $=$ Ficus pseudolmediafolia.

2 Berry, E. W., The lower Eocene floras of southeastern North

America: U. S. Geol. Survey Prof. Paper 91, p. 148, 1916.
Concerning this and the preceding list Berry says:

This is an imposing array of identical or closely related forms and indicates that the two floras can not differ very materially in age; that is, that one can not be Eocene and the other Cretaceous. The Wilcox differs from the Raton flora in the large number of Leguminosae and Lauraceae and in the presence of many genera whose representatives still live in the tropical and subtropical regions of America. * * * The fact that the commonest and not the most significant forms usually occur in remote areas leads me to the conclusion that the Wilcox flora is somewhat younger than the Raton flora, to which it bears the same relation that it does to the Midway (?) flora. This conclusion is also influenced by the stratigraphic relations in the embayment area, and the result is that I consider the Midway as in whole or in part synchronous with the Raton. I have seen a large amount of the Raton material in connection with my Wilcox studies and have also visited the area and feel entirely justified in the conclusion that it is of Eocene age and slightly older than the Wilcox.

As this is the first time, at least in recent years, that this portion of the Rocky Mountain section has been intimately compared with a definitely placed eastern section, a brief description of the latter and what it signifies may be of interest.

The Wilcox formation ${ }^{3}$ takes its name from Wilcox County, in south-central Alabama, where its beds are characteristically developed. It extends as a broad coastal belt, exposed or covered, from Georgia well into eastern Texas, being especially well exposed and characterized at many points in Alabama, Mississippi, and Louisiana. It has a maximum thickness of 800 to 900 feet and is composed of "dark, finely laminated sands and clays containing much vegetable matter either scattered through the mass or accumulated in lignite beds, and occasional layers containing marine-shells." 4 In some localities it contains a bed of lignite 6 to 7 feet thick near its base and another in its upper portion.

The Wilcox formation is underlain by the marine Eocene Midway formation and overlain

${ }^{3}$ Owing to the fact that the limits of the several Upper Cretaceous and Tertiary formations of the Gulf region are more or less obscured by overlap and by lithologic similarity and have been inadequately studied paleontologically, there have been many differences of interpretation. What is now accepted as the Wilcox formation has been known as the "Sabine" formation (from a typical development along Sabine River in Sabine County, Tex.) and the "Chickasaw" group, these being its direct equivalents. In whole or in part it has been called "Lignitic," "Eo-Lignitic," "Mansfield," "Camden," "Lagrange," and "Timberbelt or Sabine River beds," these now being abandoned for one reason or another. For discussion of the synonymy of the Wilcox or "Sabine" formation, see Veatch, A. C., U. S. Geol. Survey Prof. Paper 46, pp. 34-35, 1906; and Willis, Bailey, U. S. Geol. Survey Prof. Paper 71, pp. 25, 726, 1912.

4 Veatch, A. C., op: cit., p. 35. 
by the Claiborne group, which is also of marine origin. Its position is definitely fixed, therefore, by the underlying marine Eocene as well as by intercalated layers that contain marine Eocene invertebrates.

The first contribution to the flora of the Wilcox formation (then called the "Lignitic") was made by Lesquereux ${ }^{1}$ in 1869 , when he described and figured 30 species. The exact localities whence they came are given by Lesquereux as follows: Hurley's schoolhouse, now known as Flat Rock Church, Benton County; Colemans Mill, near New. Prospect, Winston County; and Oxford, Lafayette County, all in Mississippi.

The next report was also by Lesquereux ${ }^{2}$ and was on two small lots of plants, one from Campbell's quarry at Cross Lake, near Shreveport, and the other from McLees, 2 miles north of Mansfield, both in Louisiana. This paper enumerates 17 species, 15 of which are new to this flora, though common to the Denver, Green River, and other deposits of the Rocky Mountains.

The third paper dealing with this flora is one by Hollick ${ }^{3}$ on plants from the vicinity of Shreveport. Hollick enumerates 36 forms, 7 being regarded as new to science.

Combined, the forms given in these three papers make a nominal list of 76 species representing the flora of the Wilcox formation, but duplications and misidentifications reduce the number to about 65 .

During the 15 years that have elapsed since Hollick's report was published very extensive collections have been obtained during the work incident to the Coastal Plain investigations under the direction of Dr. T. W. Vaughan. This material has been elaborated by $\mathrm{E}$. W. Berry, with the result that the flora of the Wilcox has now been increased to about 330 species, of which about 250 have proved to be new to science. This great increase in the Wilcox flora is largely due to the fact that especial attention was given to the collecting of small, generally overlooked forms, of which there are great numbers, particularly among the Leguminosae. The fact that the fine-grained

\footnotetext{
1 Lesquereux, Loo, On species of plants from the Tertiary of the Stato of Mississippi: A m. Philos. Soc. Trans., vol. 13, pp. 411-430, pls. 14-22, 1869.

2 U. S. Nat. Mus. Proc., vol. 11, pp. 24, 25, 1888.

3 Roport on a collostion of fossil plants from northwestern Louisiana: Louisiana Gool. Survoy Rept. 1889, pp. 270-288, pls. 32-48, 1900.
}

clays in which this flora is largely preserved are especially favorable to the preservation and subsequent successful study of the numerous small leaves and leaflets, and that the sandstones and conglomeratic matrix holding the Raton flora are not so well fitted to preserve small things accounts for some of the difference between the two floras. But undoubtedly much of it is to be attributed to the fact that the Wilcox is mainly a strand flora and the Raton largely a swamp flora.

Species common to the Raton and Fort Union formations.

$$
\begin{aligned}
& \text { Juglans nigella. } \\
& \text { Juglans rugosa. } \\
& \text { Ficus artocarpoides. } \\
& \text { Magnolia hilgardiana. } \\
& \text { Platanus aceroides. } \\
& \text { Platanus guillelmae. } \\
& \text { Platanus raynoldsii. } \\
& \text { Leguminosites arachioides. } \\
& \text { Sapindus affinis. } \\
& \text { Berchemia multinervis. }
\end{aligned}
$$

The Fort Union flora is very large, numbering perhaps 500 species, and consequently the above list of 10 species is not remarkable; yet it shows, when taken in conjunction with the other Tertiary floras, that there is an appreciable relation between the Raton and the Fort Union. The latter flora is much in need of critical revision, and when this can be done it will doubtless disclose more in common. Certain of the species common to the two, such as Ficus artocarpoides, Platanus raynoldsii, Leguminosites arachioides, are a very important element in the Fort Union flora:

\section{ECOLOGIC CONSIDERATIONS.}

The caution that is necessary to be observed in treating the probable ecologic conditions under which a flora now fossil may have lived has already been discussed (p. 233) and need not be repeated.

The large, coarse marine algae which formed such an important ecologic feature in Vermejo time are of course absent from the beds of the Raton formation, for the close of the Cretaceous witnessed the permanent withdrawal of the sea from the Raton region. No remains of conifers have thus far been found in the Raton formation, and although it seems probable that they were present it is certain that they did not exist in conspicuous numbers.

The ferns of the Raton formation are few in number and all belong to a single family 
(Polypodiaceae), and so far as can be made out they might have been at home in or along the borders of swamps.

Undoubtedly one of the most conspicuous and dominant elements in this flora was the palms, of which (see p. 287) there were at least six genera and nine species, some of them being exceedingly abundant in individuals. Knowledge of the habitat enjoyed by the living forms to which the Raton forms appear to be related indicates that they required a relatively moist, warm situation whose temperature did not fall much if any below $42^{\circ} \mathrm{F}$.

The amentiferous trees were apparently abundant, as there were no less than nine walnuts (Juglans), two poplars (Populus), one beech (Fagus), one chestnut (Castanea), and six or seven oaks (Quercus, Dryophyllum). At the present time these genera enjoy a wide range of climatic conditions, but as a majority of the fossil forms under consideration are of types that are found in temperate or warmtemperate habitats, it seems safe to assume such conditions for their. predecessors.

The 15 species of figs (Ficus), as well as the 3 breadfruit trees (Artocarpus), undoubtedly argue for a warm climate. Magnolias were also abundant and likewise predicate a warm habitat, as do the laurels (Laurus), cinnamons (Cinnamomum), and related forms (Nectandra, Oreodaphne, etc.). Sycamores were not only numerous in species but were abundant in individuals and appear to call for warm-temperate conditions. The Leguminosae are represented by several types such as Sophora, Cassia, Inga, etc., which have similar requirements. The sumac (Rhus), bittersweet (Celastrus), spindle tree (Euonymus), redroot (Ceanothus), and buckthorn (Rhamnus) are mainly of temperate or warm-temperate distribution. A similar story is told by such forms as Berchemia, Paliurus, Zizyphus, Stercutia, Cissus, Hedera, and Aralia. Vitis, Andromeda, and Viburnum preferred rather cooler climates.

The physical conditions under which the Raton flora existed do not appear to differ greatly from those which existed in Vermejo time. There is no evidence that the sea occupied this area after the close of the Cretaceous, but much of the country must have remained at or near water line for very long periods, this baing abundantly attested by the numerous thick beds of coal. As in the case of the
Vermejo, a series of great swamps and marshes may be imagined, in and around which grew much of the plant life of the time. In the shallow open waters there were water lilies of the familiar types. In the marshes grew the tall, reedlike grass, Phragmites, and doubtless several of the small ferns. About the edges of the marshes were palms, figs, cinnamons, and breadfruit trees. In the denser swamps there were probably figs, magnolias, sweetgums, sycamores, and certain of the climbing vines. On higher and drier ground were oaks, walnuts, beeches, viburnums, and grapes.

The presence of the numerous coal veins as well as the character and luxuriance of the vegetation indicates that moisture was abundant, and the known distribution of the living representatives of the Raton flora make it more than probable that the climate was at least warm temperate, perhaps not unlike that now prevailing in South Carolina and Georgia. In fact there is no evidence that the physical and climatic conditions had changed from those of Vermejo time.

\section{AGE OF'THE RATON FORMATION.}

The evidence on which the Raton formation is believed to be referable to the Tertiary may be summarized as follows:

That the underlying Vermejo is of Cretaceous age is established by its stratigraphic position, its invertebrate fossils, and especially. by its plants, which correlate it with the Montana in the approximate position of the Mesaverde formation. The Vermejo is terminated by an unconformity which is correlated with the time interval separating the Dawson arkose from underlying beds, the Arapahoe from the true Laramie in the Denver Basin, the "Upper Laramie" of Veatch from the so-called "Lower Laramie," in eastern Wyoming, and I believe it to be represented between the Lance formation and underlying beds (Fox Hills and Pierre).

So far as is at present known only 4 of the 108 Vermejo species pass over the unconformity between the Vermejo and the Raton. This distinction is further emphasized by the fact that of the 49 Vermejo genera the 28 following do not appear in the Raton:

Rosellinites.

Halymenites.

Chondrites.

Caulerpites. 
Acrostichum.

Polystichum.

Woodwardia.

Stenopteris.

Osmunda.

Gleichenia:

Brachyphyllum.

Abietites.

Geinitzin

Sequoia.

Widdringtonites.

Taxodium.

Sparganium.

Myrica.

Salix.

Credneria.

Liriodendron.

Amelanchier.

Phaseolites.

Sterculia.

Pterospermites.

Cissites.

Diospyros.

Fraxinus.

It is of course true that certain of these genera appear in the Tertiary of other areas, but a considerable proportion of them are exclusively Cretaceous. The differences in the floras of the two formations are not such as might be explained by differences in physical conditions, for, as shown in the ecologic discussion if the two floras, these are practically idenical. The conclusion is therefore reached that the hiatus between the Vermejo and Raton Aoras can be explained only by the lapse of a very long period of time.

The Raton formation is to be correlated with the Wilcox, and probably with the Midway formation of the Gulf region, though the latter is mainly marine, and contains only 10 species of plants, 8 of which, however, occur in the Raton. The Tertiary age of the Midway and
Wilcox formations is not questioned. The Wilcox contains a flora of about 330 species, of which number only about 80 have outside distribution. Of the Raton flora of 148 species 38 are either identical with or very closely related to Wilcox species. Most of the species held in common are the abundant and characteristic forms that occur, some of them in great numbers, in both areas. There can be no doubt, at least in the author's opinion, in correlating the two horizons. Of the 80 Wilcox species having outside distribution about 45 are common to the Raton, Denver, or Fort Union, and not one is known from the Cretaceous anywhere.

The Tertiary age of the Raton is further attested by the presence in it of the following genera which have not been reported in older beds:

\author{
Alismaphyllites. \\ Oreodoxites. \\ Geonoma. \\ Castanea. \\ Ulmus. \\ Cercocarpus. \\ Leguminosites (fruit). \\ Sophora. \\ Xanthoxylum. \\ Euphorbocarpum. \\ Euonymus. \\ Berchemia. \\ Chionanthus. \\ Palmocarpon?
}

On the basis of the plants the Raton formation is also correlated with the Arapahoe and the Denver formations of the Denver Basin; and the latter is now known to be correlated with, and in fact to be practically continuous with, the Dawson arkose. The conclusion is reached that all these formations are Tertiary (Eocene) in age. 


\section{CHAPTER 2.-FLORA OF THE VERMEJO FORMATION. ${ }^{1}$}

\section{THALLOPHYTA.}

FUNGI.

\section{Family SPHAEREACEAE.}

\section{Rosellinites lapideus (Lesquereux) Knowlton.}

Spheria lapidea Lesquereux, U. S. Geol. Survey Terr. Ann. Rept., 1872, p. 373, 1873; U. S. Geol. Survey Terr. Rept., vol. 7 (Tertiary flora), p. 34, pl. 1, fig. 3, 1878.

Rosellinites lapideus (Lesquereux) Knowlton, U. S. Geol. Survey Bull. 152, p. 204, 1898.

Sphaerites lapideus (Lesquereux) Meschinelli, Sylloge fungorum fossilium, p. 30, 1892.

Lesquereux's description is as follows:

Perithecea round, highly convex, 1-2 millimeters broad, growing in lineal series from under the bark and piercing it before opening; borders irregularly lacerated; color whitish.

The type and only known specimen of this species is preserved in the. United States National Museum (No. 3). It is obscure and of little value, either geologically or biologically.

Occurrence: Trinidad sandstone (Cretaceous); near Trinidad, Colo., collected by Leo Lesquereux in 1871.

\section{ALGAE:}

Halymenites major Lesquereux.

Halymenites major Lesquereux, U. S. Geol. Survey Terr. Ann. Rept., 1872, pp. 373, 390, 1873; idem, 1873, pp. 379, 384, 386, 1874; idem, 1876, p. 496, 1878; U. S. Geol. Survey Terr. Rept., vol. 7 (Tertiary flora), p. 38, pl. 1, figs. 7, 8, 1878.

Eldridge, Am. Jour. Sci., 3d ser., vol. 38, p. 317, 1889; Stevenson, Geol. Soc. America Bull., vol. 1, p. 532, 1890.

Stanton and Knowlton, Geol. Soc. America Bull., vol. 8, p. $154,1897$.

Knowlton, U. S. Geol. Survey Bull. 163, p. 17, 1900. Haiymenïtes minor Fischer-Ostheim. Lesquereux, U. S. Geol. Survey Terr. Ann. Rept., 1872, p. 373, 1873; idem, 1876, p. 496, 1878; U. S. Geol. Survey Terr. Rept., vol. 7 (Tertiary flora), p. 39, pl. 1, fig. 9, 1878.

Halymenites major is one of the most abundant and widely distributed fossil organisms known in the Rocky Mountain region. It has

1 The localities of most of the fossil plants described in this paper are indicated by means of the lot catalogue numbers on the map of the region (Pl. I) a cylindrical or slightly flattened stem or "frond," usually about 2 centimeters in diameter, and is dichotomously or pinnately branched or is sometimes divided into shorter and smaller branches. In length the pieces observed are diverse, some being only a few centimeters long, others extending over or through the matrix for a distance of nearly or quite a meter and showing numerous forkings. The surface is covered with round elevated or half-globular tubercles 2 to 5 millimeters broad and equally thick. These tubercles are either distant and separate or crowded and connected at the borders and are more or less irregular, even on the same fragment, but are always present. This roughened or tuberculate appearance has given rise to the colloquial name "fossil corn cob," by which they are known in many places. The cylindrical organism itself is easily detached from the matrix and when removed leaves behind the deep, irregular pits or impressions of the tubercles, and this is perhaps the commonest condition under which it is observed or collected.

The presence of Halymenites major is held to indicate marine conditions, for wherever it is found in association with invertebrates they are always of marine types. It is also believed to indicate relatively shallow water and nearshore conditions. For example, Halymenites was not present, so far as now recalled, in the deep sea during and at the close of the Pierre; but during the succeeding Fox Hills epoch, the shaly sandstones of which give evidence of littoral conditions, it was exceedingly abundant. In fact, it is so abundant and almost universal in the Fox Hills that it may almost be said to be characteristic of that epoch; yet this is not quite true, for it occurs sparingly in beds at perhaps the middle of the Colorado group, at several horizons in the Montana group, and possibly as high as the lower portion of the true Laramie formation. This latter horizon, however, may be referable to the extreme upper portion of the Fox Hills sandstone, and not to the Laramie at all. 
Occurrence: Trinidad sandstone (Cretaceous); Trinidad, Colo., collected by G. B. Richardson (51.08); Spring Canyon, Willow Canyon, N. Mox., collocted by Orestes St. John in 1902; Vermojo Park, N. Mox., collected by Orestes St. John, 1894. Rockvale sandstone,-member of Vermejo formation, Rockvale, Colo., collected at various dates by Washburne, Knowlton, Stanton, and Lee. Near top of coalbearing rocks just below the "rim rock" near Rockvale, Colo., collected by W. T. Lee.

Halymenites striatus Lesquereux.

Halymenites striatus Lesquereux, U. S. Geol. Survey Terr. Ann. Rept., 1872, p. 373 , 1873; idem, 1873 , p. 373 , 1874; iclem, 1876, p. 496, 1878; .U. S. Geol. Survey Terr. Rept., vol. 7 (Tertiary flora), p. 37, pl. 1, fig. 6, 1.878.

The type specimens of this species are all No. 4 of the United States National Museum collection. They are all mere fragments, scarcely 3 inches long, and seem inadequate for the proper characterization of a species. However, judging from the original mention of the species, Lesquereux must have had much better material, for he speaks of their "penetrating the sandstone in every direction and in such a -way that, as the remains are extremely abundant, it is very difficult to separate them, even in small fragments." They differ from other similar forms in having the stems smooth or more or. less regularly striate. No additional spocimons appear to have been obtained.

Occurrence : Trinidad sandstone (Cretaceous), Raton Mountains, N. Mex., collected in 1872 by Loo Lesquereux.

\section{Chondrites bulbosus Lesquereux.}

Chondrites bulbosus Lesquereux, U. S. Geol. Survey Terr. Ann. Rept., 1872, p. 373', 1873; U.'S. Geol. Survey Terr. Rept., vol. 7 (Tertiary flora), p. 42, pl. 1, fig. 14, 1878.

The original description is as follows:

Frond flattened irregularly, subpinnately divided in opposite or alternate branches, close to each other, or distant, short, inflated, some of them irregular tubercles.

This species was fairly well described and figured by Lesquereux. It was not noted in any of the recent collections from the area. The types do not appear to be preserved in the United States National Museum.
Occurrence: Trinidad sandstone(Cretaceous); near Trinidad, Colo., collected in 1871 by Leo Lesquereux.

\section{Chondrites subsimplex Lesquereux.}

Chrondrites sutsimplex Lesquereux, U. S. Geol. Survey Terr. Ann. Rept., 1872, p. 373, 1873; idem, 1876, p. 497, 1878; U. S. Geol. Survey Terr. Rept., vol. 7 (Tertiary flora), p. 41, pl. 1, fig. 13, 1878.

Lesquereux's description and accompanying remarks concerning this species are as follows:

Frond cylindrical, more or less flattened by compression, with rare, dichotomous, long, flexuose branches, mostly of the same size in their whole length.

This species is found generally flattened, with its expanded, long, flexuose branches covering large slabs of passing across layers of shaly sandstone. Sometimes the filaments or fronds appear simple, linear; * * * rarely they branch by simple forking of the main axis, preserving? the same size; some of the divisions, however, gradually decrease in size to a round point half as broad as the main stem. The surface is irregularly roughened, especially slightly wrinkled along tl:e borders, and the middle is generally marked by a depression which seems to indi. cate a fistulose character of the stem and its divisions.

The type specimens of this species are preserved in the United States National Museum (No. 6), but no additional examples have been positively identified in recent years. A number of fragmentary. stemlike bodies that may have been referable to this form have been observed in the lower beds, but none was sufficient for positive determination.

Occurrence: Trinidad sandstone (Cretaceous); near Trinidad, Colo, , collected in 1871 by Leo Lesquereux.

Caulerpites incrassatus (Lesquereux) Lesquereux.

Delesseria incrassata Lesquereux, U. S. Geol. Survey Terr. Ann. Rept:; 1872, p. 374, 1873; idem, 1873, p. 379, 1874.

Caulerpites incrassatus (Lesquereux) Lesquereux, U. S. Geol. Survey Terr. Rept., vol. 7 (Tertiary flora), p. 40, pl. 1, figs. 11, 12, 1878 .

The type specimens of this species are preserved in the United States National Museum (Nos. 7, 8), and represent, so far as known, the only ones thus far obtained. In view of its nature the species has been well characterized and illustrated by Lesquereux.

Occurrence:Trinidad sandstone(Cretaceous); near Trinidad Colo., collected in 187.1 by Leo Lesquereux. 


\section{PTERIDOPHYTA.}

Order FILICALES.

Family POIYPODIACEAE.

Acrostichum haddeni Hollick.

Acrostichum haddeni Hollick, Torreya, vol. 2, p. 146, pl. 4, figs. 3, 4, 5, 6, 1902.

Hollick describes the species as follows:

General form of frond unknown; pinnae (?) apparently 20 centimeters or more in lenoth by about 3 centimeters fn maximum width, narrowed to acute tips and with coarsely crenulate serrate margins; nervation consisting of a series of alternate pinnately arranged veins, extending from the rachis to the extremities of the serrations, with the spaces between occupied by a network of fine nerves.

This species is based on four figured specimens, three of which (figs. 3, 5, and 6) came from "grayish sandstone, Walsenburg, Colo.,". and the fourth (fig. 4); from "gray shale, Florence, Colo." As this species was not contained in any of the collections recently obtained its exact stratigraphic position is unknown and it can not be employed as an horizon marker.

As set forth under Anemia supercretacea and $A .^{-}$robusta, it is probable that the specimen labeled as having come from Florence, Colo., came from the vicinity. of Rockvale, Colo., and the description of the matrix as a "gray shale" suggests the possibility that it is from below the top of the Rockvale sandstone member of the Vermejo formation; but obviously this position can not be fixed until the species is again collected from beds of known position.

The types of Acrostichum haddeni are in the paleobotanic museum of the New York Botanical Garden.

Occurrence: Vermejo formation (Cंretaceous); "grayish sandstone, Walsenburg, Colo." (figs. 3, 5, 6); "gray shale, Florence, Colo." (fig. 4); exact stratigraphic position unknown.

Polystichum hillsianum Hollick.

Polystichum hillsianum Hollick, Torreya, vol. 2, p. 146, pl. 4, fig. 7, 1902.

The single specimen on which the present species was based is said to have come in readish shaly sandstone from Florence, Colo., though, as set forth under several of the preceding species, it seems probable that the locality is the cliff-forming sandstone near Rockvale, Colo., which, in places, is shaly and reddish in color and is known to be abundantly plant bearing. However, this species is not contained in any of the recent collections from the region and consequently it can not be employed in exact stratigraphic work. The type is in the New York Botanical Garden.

Occurrence: Vermejo formation (Cretaceous); "in reddish shale, Florence, Colo."; presumably about 250 feet above the Rockvale sandstone member of the Vermejo formation at or near Rockvale, Colo.

\section{Pteris erosa Lesquereux.}

Pteris erosa Lesquereux, U. S. Geol. Survey Terr. Ann Rept., 1871, Suppl., p. 12, 1872; U. S. Geol. Survey Terr. Rept., vol. 7 (Tertiary flora), p. 53 , pl. 4, fig. 8, 1878; idem, vol. 8 (Cretaceous and Tertiary floras), p: 121, pl. 19, fig. 1, 1883.

Asplenium erosum (Lesquereux) Knowlton, U. S. Geol. Survey Bull. 152, p. 45, 1898.

The type locality of this fine species is given as Fishers Peak, Raton Mountains, where it was first collected by Hayden, in 1867. It was subsequently found in the Denver formation at Golden, Colo., as recorded by Lesquereux in "The Cretaceous and Tertiary floras," and occurs in many of the recent collections from that place. In a collection from a locality supposed to be in the Arapahoe formation (now known to be Dawson arkose), near Sedalia, Colo., there was found a fine fruiting example, which served as the basis for transferring the species to the genus Asplenium. Subsequent study of this fruiting specimen, together with very completely preserved sterile material, has led to the conclusion that though undoubtedly asplenoid in character it is not properly referable to Asplenium. It is to be made the basis of a new genus, and a characterization is already in writing, but as extensive synonymy and a large series of figures will be necessary to make the matter clear, the present is not deemed a satisfactory place and it has been considered under its original name of Pteris erosa.

This species is one of the very few that apparently cross the line from the Vermejo to the Raton formation. The type locality was apparently in the Raton formation, but notwithstanding the extensive collections that have been made in recent years from this formation it is not contained in any of them. It has, however, been found in two of the collections from the Canon City field in the Vermejo formation. Outside the areas under 
consideration it has been found most abundantly in the Denver formation at Golden, Colo.

Occurrence: Raton formation (Tertiary) type, Fishers Peak, Raton Mountains, Colo., collected by F. V. Hayden in 1867. Vermejo formation (Cretaceous), Canon City coal field Colo. (sec. 30, T. 19 S., R. 69 W.), collected by W. T. Lee (5790); dump of Rockvale mine; Rockvale, Colo., F. H. Knowlton, collector. Denver formation (Tertiary), Golden, Colo.

\section{Pteris russellii Newberry.}

Pteris russellii Newberry, U. S. Nat. Mus. Proc., vol. 5, p. 503, 1883; U. S. Geol. Survey Mon. 35, p. 7, pl. 6.1, figs. 1.,.1a, 1898 .

The description written by Newberry follows:

Frond large, pinnate; pinnae crowded, linear in outline, narrow, long-pointed above, attached to rachis by entire base; decurrent; length 16 to 20 centimeters; width 10 millimeters; margins undulate below, irregularly and coarsely toothed above; nervation fine but distinct; branches all forked, leaving midrib at an angle of about $45^{\circ}$, all twice or three times forked.

This species was first described by Newberry from material obtained by I. C. Russell in Vermejo Canyon, N. Mex. The exact position of the beds containing it is unknown according to present standards, but from the fact that Newberry also mentions having the same fossil from Walsenburg, Florence, and Golden, Colo., it seems probable that the beds belong to the Vermejo formation. It was not detected in any of the recent collections from the region.

Occurrence: Vermejo formation (?) (Cretaceous), Vermejo Canyon, N. Mex., collected by I. C. Russell; reported by Newberry from Walsenburg, Florence, and Golden, Colo., but specimens not seen by me. Raton formation (?).

\section{Pteris? sp.}

Plate XXX, figure 3.

In a small collection from the lower coal group at Cuatro, Colo., there are several fragments of a fern that appears referable to Pteris ns it is usually defined in the fossil state. The fragment figured is the largest one observed, but it is quite impossible to form any adequate ider of its size and complete outline. It was about 2 centimeters wide and apparently had an entire margin. The midvein is relatively thick. The veins are close, parallel, at a low angle, forking at or very near the midvein and a few of them beyond the middle. It has some resemblance to Pteris erosa Lesquereux $b_{u t}$ is smaller, entire instead of erose-dentate, and with the veins at a slightly sharper angle of divergence.

Occurrence: Vermejo formation (Cretaceous), Cuatro, Colo.

Asplenium? coloradense Knowlton, n. sp.

Plate XXX, figures $1,2$.

Asplenium magnum Knowlton. Hollick, Torreya, vol. 2, p. 146, pl. 4, figs. 1, 2, 1902.

Outline and size of frond unknown, but probably of large sizé and apparently twice pinnatifid, thick and coriaceous in texture; pinnae approximate(?), long, narrowly lanceolate in outline, broadest near or just above the base, thence tapering to a long slender apex, cut nearly to the rachis into numerous triangular falcate sharp-pointed pinnules, those at base on one side being larger and less scy the shaped than the others; nervation consisting of a strong midvein passing to the apex of the pinnules and about eight or nine pairs of veins which fork once just above the midvein, and terminate in the margin; fruit unknown.

This species, which I have ventured to describe as new, is represented in the recent collections by two excellent specimens figured and by a number of smaller fragments. Though none is of sufficient completeness to indicate the full outline and habit the position of the two pinnae shown in figure 1 leads one to suspect that the frond was large and probably at. least twice pinnatifid, and that these were attached to a general rachis. The fact that. the basal pinnules on one side are uniformly longer and straighter than any of the others: lends weight to this supposition, since it is. well known that many compound fronds show more or less marked inequality in the basal pinnae or pinnules, the upper being usually the larger.

The finely preserved specimens figured by Hollick, which I now refer to the present species, were referred by him to Asplenium magnum Knowlton, which comes from breccias of Fort Union age in the Yellowstone National Park. ${ }^{i}$ As Hollick pointed out, his Colorado specimens have the pinnae more deeply dissected and the pinnules somewhat more

1 Knowlton, F. H., Fossil flora [Yellowstono National Park]: U. S. Geol. Survey Mon. 32, pt. 2, p. 667, pl. 79, figs. 5-8, 1899. 
pointed and falcate than those of $A$. magnum. Asplenium magnum is regarded as having a simple frond, for in neither the large number of specimens studied nor in those figured were any found either attached or in any way indicating a compounding. The basal pinnules are of approximately the same size and shape on either side of the rachis, and moreover in some of the specimens, for example that shown in figure 7., the stipe is preserved for a length of nearly 1 centimeter. The difference in the dissection of the pinnae in the two species is very marked; $A$. coloradense being cut nearly to the rachis and $A$. magnum rarely below the middle and usually much less. On the whole, considering the above-mentioned differences as well as the stratigraphic discordance the two forms seem sufficiently distinct.

The only other Amerioan fossil species with which it is necessary to compare the present species is Aspidium (now Dryopteris) kennerlyi Newberry ${ }^{1}$ from the Cretaceous of Nanaimo, -Vancouver Island. Although in general appearance Dryopteris kennerlyi is somewhat similar to Asplenium? coloradense, it differs in its larger size and longer, less falcate pinnules, which are obtuse instead of ovate at the apex and finely serrate.

Occurrence: Vermejo formation (Cretaceous). The material described and figured by Hollick (under the name of Asplenium magnum Knowlton) is said to have come from Florence, Colo., figure 1 from "reddish shaly sandstoné" and figure 2 from "black carbonaceous shale." As pointed out under the discussion of Anemia robusta this material is without reasonable doubt from Rockvale, Colo. Recent material collected by W. T. Lee is from the dump of the Coal Creek mine near Rockvale, Colo.; the dump of the Rockvale mine, Rockvale, Colo. (5793); the roof of the Rockvale mine, which communicates with the Coal Creek mine (5791); and the dump of the Rockländ mine, 3 miles southwest of Walsenburg, Colo., about 70 feet below the top of the Vermejo formation (5677).

\section{Asplenium sp.}

\section{Plate XXX, figure 4.}

The material from the vicinity of Rockvale, Colo., contains a single fragment of a large fern of the type of Pteris erosa, but it is too imper-

\footnotetext{
1 Newberry, J. S., The later extinct floras of North America: U. S. Geol. Survey Mon. 35, p. 11, pl. 16, figs. 4, 5, 1899.
}

fect to be positively identified. It is about 3 centimeters wide and shows the strong midvein and the numerous strong nerves, which fork just above the point of origin.

Occurrence: Vermejo formation (Cretaceous); Coal Creek (Rockvale), Colo., collected by George Hadden (U. S. Nat. Mus., 51255).

\section{Woodwardia crenata Knowlton.}

Woodwardia crenata Knowlton, U. S. Geol. Survey Bull. 163, p. 22 , pl. 3 , fig. 3,1900 .

This species was described originally from the Montana. group at Point of Rocks, Wyo., and was not again obtained until 1910, when W. T. Lee found a single small fragment between the lower coal beds near La Veta, Colo. This later.specimen is even smaller than the type and adds nothing to our knowledge of the species. It was found in association with Sequoia obovata, S. reichenbachi, and Ficus wardii.

Occurrence: Vermejo formation(Cretaceous); Oakdale mine, locality $140,{ }^{2}$ near La Veta, Colo., between first and second coal beds, collected by W. T. Lee (5672).

\section{Stenopteris (?) cretacea Hollick.}

Steno'pteris (?) cretacea Hollick, Torreya, vol. 2, p. 148, pl. 3 , fig. 2, 1902.

The original description is as follows:

General form of frond unknown but apparently large and strong; each pinna or branch consisting of a broadwinged rachis, with relatively remote, entire, strapshaped pinnules, each of which is traversed by a strong midvein from base to apex; secondary nervation unknown.

Occurrence: Vermejo formation (Cretaceous); "in reddish shaly sandstone, Florence, Colo."; exact horizon not stated, but without doubt it came from the shaly rocks above the Rockvale sandstone member of the Vermejo at or near Rockvale, Colo.

\section{Family OSMUNDACEAE.}

Osmunda hollicki Knowlton, n. sp. Plate XXX, figure 6.

Pecopteris (Cheilanthes) sepulta Newberry (?). Hollick, Torreya, vol. 2, p. 147, pl. 3, figs. 5, 5a, 1902.

Frond small, delicate, outline of whole frond unknown but at least twice pinnate and probably deltoid in shape; main rachis slender; pinnae opposite, apparently deltoid or broadly triangular in outline; pinnules alternate, lance-

${ }^{2}$ Locality numbers refer to positions on the map (Pl. I). 
olate in shape, entirely free at base, rather sharp apex, the margins deeply cut at base then undulate and finally nearly entire, the lobes in all cases rounded and obtuse; nervation strong and well marked, consisting of a rather strong midvein and numerous lateral veins which are usually twice forked, once near the midvein and again about half the distance between midvein and margin.

In a paper on a number of fossil ferns from the supposed Laramie formation 'of 'Colorado, published in 1902, Hollick described and figured a small fern supposed to be from Walsenburg, Colo., which he identified.provisionally with Pecopteris (Cheilanthes) sepulta Newberry. That species, which came from the Green River formation at Green River, Wyo., was described by Newberry ${ }^{1}$ as being pinnate and as having its lower pinnae attached to the rachis by the whole width of the base. As set forth in the dingnosis the fern under discussion differs from Newberry's species in two important characters, for it is at least twice pinnate and has the pinnae all free at base. The specimen figured by Hollick did not happen to be complete enough to show its twice pinnate character, but the basal pinnules are free as he pointed out. The specimen obtained by Lee (Pl. XXX, fig. 6) is smaller than the one figured by Hollick but otherwise does not appear to differ from it essentially. It seems not unlikely that the upper portion of Hollick's specimen, which was not obtained, was of about the same size as the larger one found by Lee, which is clearly from the apical portion of the frond.

Hollick's material was associated with material collected by Hadden for Newberry, but its locality label was lost before it came to be. studied, and from the resemblance of the matrix on which it is preserved to the "grayish sandstone" of the collections from Walsenburg, Colo., Hollick referred it with question to this locality. It was not found in any of the recent collections from Walsenburg but only in a grayish sandstone from the dump of the Coal Creek mine near Rockvale, Colo. It is therefore reasonably probable that the Hollick material came from Coal Creek, where the collector; George Hadden, was the mine superintendent, and not, as surmised, from the vicinity of Walsenburg.

\footnotetext{
1 Nowberry, J. S., op. cit., p. 12, pl. 62, figs. 5, 5a, 6, 1898.
}

Occurrence: Vermejo formation (Cretaceous); collected by George Hadden and referred by Hollick to Walsenburg (?), Colo.; thought to be probably from Coal Creek, Colo.; present material collected in 1910 by W. T. Lee, from the dump of the Coal Creek mine, near Rockvale, Colo., hence below the Rockvale sandstone member of the Vermejo (5793); dump of Coal Creek mine, Rockvale, Colo., collected by W. T. Lee (5791).

\section{Family GLEICHENIACEAE.}

Gleichenia delicatula (?) Heer.

Gleichenia delicatula Heer, Flora fossilis arctica, vol. 3, Abt. 2, p. 54, pl. 9, fig. 1.le; pl. 10, figs. 16, 17, 1874. Hollick, Torreya, vol. 2, p. 14.7, pl. 3, fig. 4, 1902.

This species was identified with question by Hollick as coming from the beds now known to be near Rockvale, Colo. It is not contained in any of the recently collected material from this region.

As originally described by Heer it came from the Komé beds (Neocomian) of Greenland; and as Hollick suggests, this implies a very wide vertical range for the species, and he did well to question the identification. Though the fragment certainly does closely resemble the figures given by Heer it is without nervation, and better material might show more or less marked differences.

Occurrence: Vermejo formation (Cretaceous); "reddish sandstone, Florence, Colo.," = near Rockvale, Colo.; the reddish sandstone is about 250 feet above the Rockvale sandstone member of the Vermejo.

Gleichenia rhombifolia Hollick.

Gleichenia rhombifolia Hollick, Torreya, vol. 2, p. 147, pl. 3, fig. 3, 1902.

This species, of which but a single specimen has been described, occurs, according to its author, in "reddish shaly sandstone, Florence, Colo.," but, as indicated under a number of other species of ferns from this locality, its exact position is not known, though not improbably it may have come from the plant-bearing sandstone of this character near Rockvale, Colo., about 3-miles north of Florence. It was not found by any of the recent workers in this field. The type is preserved in the New York Botanical Garden.

Occurrence: Vermejo formation (Cretaceous); "in reddish shaly sandstone, Florence, 
Colo."; exact horizon not stated, but with little doubt is in the sandstones about 250 feet above the Rockvale sandstone member of the Vermejo, Rockvale, Colo., or vicinity.

\section{Family SCHIZAEACEAE.}

Anemia robusta Hollick.

Anemia robuista Hollick, Torreya, vol. 2, p. 145, pl. 3, fig. 1, 1902.

The original description reads as follows:

General form of frond, also nervation, unknown; pinnae (?) linear in outline, about 3 centimeters in width, pinnules entire, ovate to subspatulate, with blunt wedgeshaped tips, about 2.5 centimeters in length by 12 millimeters in width, more or less confluent or decurrent along the rachis, each one provided with a weak midvein.

The type locality of this species is given as Florence, Colo., "in grayish sandstone." As set forth under the preceding species, the material of which this forms a part was collected by George Hadden, then superintendent of the Coal Creek mine near Rockvale, Colo., which is at least 3 miles from Florence, which latter place was doubtless only the shipping point. The precise horizon which supplied the type of Anemia robusta is unknown, but from the fact, ascertained by Lee, that there is a grayish plant-bearing sandstone in the roof of the Coal Creek mine, it seems reasonably probable that the type may have come from this place, where it would have been likely to have attracted Hadden's attention. Unfortunately it is not contained in any of the recent collections from the region and remains unique.

Occurrence: Vermejo formation (Cretaceous); "in grayish sandstone, Florence, Colo."; thought probably to be in the grayish plantbearing sandstone in the roof of the Coal Creek mine near Rockvale, Colo.

\section{Anemia supercretacea Hollick.}

Plate XXX, figure 5.

Anemia supercretacea Hollick, Torreya, vol. 2, p. 145, pl. 3, figs. 6, 7, 1902 .

The original description is as follows:

General form of frond, also nervation, unknown; pinnae delicate, narrowly conical in outline, gradually tapering to the tips; pinnules entire, lower ones spatulate, distinct, somewhat decurrent along and forming acute angles with the rachis, upper ones often more pointed or becoming confluent and forming toothed or crenulated tips to the pinnae.

This species was described from material collected by Mr. Hadden, sometime superintend- ent of the Coal Creek mine near Rockvale, Colo., and transmitted through R. C. Hills, of Denver, Colo., to the late J. S. Newberry. The locality is given as Florence, Colo., "in reddish shaly sandstone," but the exact point at which it was obtained is unknown, though it is probable that Florence was merely the shipping point and that it came from somewhere near Rockvale, which was the scene of Mr. Hadden's activities. The only clue to the precise horizon is afforded by the matrix, and this would appear to place it somewhere within several hundred feet of the top of the Rockvale sandstone member of the Vermejo formation. Above this sandstone are several hundred feet of hard, shaly, often reddish sandstones, which together form rugged cliffs just back of the town of Rockvale. This sandstone is prolifically plant bearing at many points, and so far as may be judged from the description of the matrix bearing this Anemia it might well have come from any one of 50 localities within this zone. Apparently the exact point in the beds whence it came can never be known, and the only manner in which it can be made of positive stratigraphic value is by its identification in beds of known position. Fortunately the collections made by W. T. Lee contain unmistakable examples of this species from the roof of the Coal Creek mine, at a horizon about 160 feet below the top of the Rockvale sandstone and consequently about 200 feet below the beds indicated by the matrix alone. It is not contained in the large collections (now in the United States National Museum) made from the reddish sandstone by Hadden nor in collections made by the writer in this general region in 1909. The greatest - value, therefore, attaches to the specimens collected by Mr. Lee, which are of known stratigraphic position.

The type specimens are in the paleobotanic museum of the New. York Botanical Garden.

In figure 5 is shown a specimen that is referred with some doubt to the present species. The best preserved of the specimens figured by Hollick (fig. 6) has the rachis strong and undiminished in size, but the specimen figured here is undoubtedly the apical portion and has the rachis very slender and delicate. The two lower pinnules have strongly toothed margins, which is some indication that the teeth, or the cutting, may lower down become as prominent as shown in Hollick's figures. There is nothing 
in the collections, however, that quite connects the two, but the presumption seems to favor their belonging to a single species. The present specimen came from the same locality as the others collected by W. T. Lee.

Occurrence: Vermejo formation(Cretaceous); "in reddish shaly sandstone, Florence, Colo.," believed to be from the reddish shaly sandstone about 250 feet above the top of the Rockvale sandstone member of the Vermejo, near Rockvale, Colo.; additional specimens collected by W. T. Leefrom dump of Coal Creek mine (equivalent to the roof of the Rockvale coal) near Rockvale, Colo: (5791), and in north wall of Rockvale Canyon (sec. 25, T. 19 S., R. 70 W.), 100 feet below base of the rim rock (5781).

\section{SPERMATOPHYTA.}

Order CONIFERALES.

Family BRACHYPHYLLACEAE.

Brachyphyllum cf. B. macrocarpum Nèwberry.

Plate XXXI, figure 4.

This is a single specimen of Brachyphyllum from Hunts Canyon, Cimarron, N. Mex. It consists of a portion of a thick stem or branch between 3 and 4 centimeters in length and over 1 centimeter in width, with five lateral branches, each bearing a number of thick irregular branchlets or ultimate divisions. Its matrix is a hard coarse-grained sandstone, and practically all trace of the leaves or scales has been obliterated. So far as can be determined from the size, shape, and general appearance this specimen is indistinguishable from what has usually been referred to Brachyphyllum macrocarpum of Newberry ${ }^{1}$ from the Raritan formation of New Jersey. It is, for instance, apparently the same as what I have described and figured under this name ${ }^{2}$ from a point near Harper station on the Union Pacific Railroad and on the north fork of Dutton Creek, Laramie Plains, Wyo., from beds referred to the Mesaverde formation, or in any event. to the upper part of the Montana group. Also, it is not greatly different from $B$. crassicaule Fontaine, as recently shown by Berry ${ }^{3}$ from the Lower Cretaceous of Maryland and Virginia. Brachyphyllum obesum Heer,

${ }^{1}$ Newberry, J. S., The florn of the Amboy clays: U. S. Geol. Survey Mon. 26, p. 51 (footnote), 1895.

' Enowiton, F. T., Flora of the Montana formation: U.S. Geol. Survey Bull. 163, p. 29, pl. 4, figs. 5, 6, 1900.

3 Berry, E. W., Systematic palcontology of the Lower Cretacecus doposits of Maryland: Maryland Geol. Survey, Lower Cretaceous, p. 393, pl. 64, figs. 1-6, 1911. from the Albian of Portugal, belongs to the same group.

The form under discussion is apparently the same as that from the Ignacio quadrangle collected by J. H. Gardner, and from near Dulce, N. Mex., obtained in 1911 by W. T. Lee, both from beds which are usually referred to the Laramie formation, but which I regard as obviously. of Montana age. It is not impossible that several species in the Cretaceous have been more or less confused, a condition that can only be completely elucidated by a series of wellpreserved specimens, and this, it appears, is very difficult to procure.

In one of the small collections from Powell Arroyo, near Trinidad, Colo., there is a single very poorly preserved. specimen that quite clearly belongs to Brachyphyllum but is too obscure either to figure or describe adequately. From the fact that Brachyphyllum macrocarpum Newberry has been found in beds of similar stratigraphic position south of Durango, Colo., it is to be presumed that this is the species under consideration, but it is too indistinct to venture a positive determination.

Occurrence: Vermejo formation (Cretaceous); Hunts Canyon, Cimarron, N. Mex.; collected by Orestes St. John, 1902; about 100 feet above the Trinidad sandstone, Powell Arroyo, at locality 107, 4 miles northwest of Trinidad, Colo., collected by G. B. Richardson's party (5110).

\section{Family PINACEAE:}

\section{Abietites dubius Lesquereux.}

Abietites dubius Lesquereux, Am. Jour. Sci., vol. 45, p. 207 (nomen nudum), 1868; U. S. Geol. Survey Terr. Ann. Rept., 1869, reprint, p. 196, 1873; idem, 1872, p. 374, 1873; U. S. Geol. Survey Terr. Rept., vol. 7 (Tertiary flora), p. 81, pl. 7, figs. 19-24, 1878.

Remains of this species were first obtained in 1867 by Le Conte ${ }^{4}$ in the Raton Pass, about $1 \frac{1}{2}$ miles from Trinidad. They came from between two coal beds in a "stratum of gray clayey rock containing leaves and stems badly preserved," which seems to place them rather definitely in the Vermejo formation.

Abietites dubius was named by Lesquereux ${ }^{5}$ in 1868 , and was first really described in 1872 from material obtained by Lesquereux himself

- Le Conte, J. L., Notes on the geslogy of the survey for the extension of the Union Pacific Railway, E.D., from Smoky Hill River, Kans.; to the Rio Grande, Philadelphia, p. 19, 1868 .

5 Hayden, F. H., Notes cn the lignita deposits of the West: Am. Jour. Sci., $2 \mathrm{~d}$ ser., vol. 45 , p. $207,1868$. 
the previous year at a locality which he thought was "probably at the same place where Dr. Le Conte obtained his specimens." He does not clearly mention just what he found associated. with these specimens, except fragmentary material which he referred to Phragmites oeningensis, but apparently they are associated , with dicotyledons that are known only from the upper beds.

This species was figured for the first time in 1878, in "The Tertiary flora"; these specimens are preserved in the United States National Museum (Nos. 65-68, 77), and they undoubtedly came from the Raton Mesa field, though sometimes erroneously recorded ${ }^{1}$ as having come from "Spring Canyon, near Fort Ellis, Mont."

On looking again at the type specimens I find preserved on one of them (No.65) a dicotyledonous leaf that apparently belongs to Ficus praetrinervis (p. 263), whioh is another argument for presuming that they came from the lower instead of the upper beds. The only specimens, and these poorly preserved, in the recent collections, are from Powell Arroyo, 4 miles northwest of Trinidad, in the Vermejo formation. These agree satisfactorily with the type specimens and must be considered as identical.

Some years ago I proposed ${ }^{2}$ to divide this species, retaining figures 19,23 , and 24, Plate VII, of "The Tertiary flora," under Abietites dubius and referring the others $(20,21,21 \mathrm{a})$ to Sequoia reichenbachi; but since that time, having had a wide experience with the latter species, I am inclined to doubt the validity of such a transfer. They are all now included under Abietites dubius. Sequoia reichenbachi has the leaves short, at a low angle, thick at base, much arched upward and acute at the apex, and in Abietites dubius the leaves are much larger, at an acute angle, thin and pointed, but not arched upward.

\section{Sequoia reichenbachi (Geinitz) Heer.}

Araucarites reichenbachi Geinitz, Charakteristik der Schichten und Petrefacten des sächsisch-böhmischen Kreidegebirges, Heft 3, p. 98, pl. 24, fig. 4, 1842.

Sequoia reichenbachi (Geinitz) Heer, Flora fossilis arctica, vol. 1 , p. 83 , pl. 43 , figs. 1d, 2 b, 5a, 1868 .

Occurrence: Vermejo formation (Cretaceous); collected by W. T. Lee-Radiant, Colorado? (5785); between first and second coal beds,

1 U. S. Nat. Mus. Bull. 53, pt. 2, p. 87, 1907.

2 U. S. Geol. Survey Bull. 152, p. 24, 1898.
Oakdale mine at locality 140 , northwest of La Veta, Colo. (5672); Rockland mine, about 3 miles southwest of Walsenburg, Colo. (5677); roof of old mine at locality 108, 2 miles west of Bowen, Colo. (5694); dump of Starkville mine, Starkville, Colo. (5707); 1 mile east of Kohler, N. Mex., at locality 31 (5811); Canyon City coal field (sec. 18, T. 19 S., R. 69 W.) from base of "rim rock" (5779); Ponil Canyon, N. Mex., 1 mile west of locality 11, near top of Vermejo formation (5829).

Sequoia obovata Knowlton, n. sp.

Plate XXX, figure 7.

Sequoia brevifolia Heer. Lesquereux, U. S. Geol. and Geog. Survey Terr. Bull., vol. 1, 1875, p. 365, 1876; U. S. Geol. and Geog. Survey Terr. Ann. Rept. 1874, p. 298, 1876; idem, 1876, p. 500, 1878; U. S. Geol. Survey Terr. Rept., vol. 7 (Tertiary flora), p. 78, pl. 61, figs. 25-27, 1878.

Knowlton, U. S. Geol. Survey Bull. 163, p. 27, pl. 4, figs. 1-4, 1900; U.' S. Geol. Survey Prof. Paper 98, p. $333,1916$.

Branchlets alternate or opposite on the branches, slender and delicate, producing a flat "spray"; leaves of two forms, those on the branches when young being small, scale form, appressed, abruptly pointed, while the regular foliage leaves are close, distichous, short, linear-oblong or slightly obovate, usually enlarged in the middle, abruptly narrowed to an obtusely pointed apex, or rarely obtuse, narrowed below, gradually decreasing in length toward the top and base of the branchlets.

This fine species, to which I have ventured to give a new name, has long been known in this country under the name Sequoia brevifolia Heer. It was described by Heer from the socalled Miocene of Atanekerdluk, North Greenland, and was subsequently detected by him in collections of the same age from Spitzbergen and the Baltic. Heer rightly states that his S. brevifolia appears to be most closely related to $S$. langsdorfii, of which he was at first inclined to regard it as merely a variety (and to which Schenk ${ }^{3}$ would still refer it), but he finally concluded that it differed uniformly by its much shorter, more wedge-shaped leaves. It must be confessed that it is not easy to draw a satisfactory line between the American specimens and Heer's. In the absence of actual specimens of $S$. brevifolia for com-

${ }^{3}$ Zittel, K. A.von, Handbuch der Palaeontologie, Abt. 2, p. 298, 1890. 
parison dependence must be placed entirely on Heer's figures. On carefully comparing these with the American material it appears that the Greenland form has the leaves more scattered, more obtuse, and little if any enlarged in the middle. In view of these facts, and in view of the marked difference in geologic position, it would seem improbable that the Greenland and American specimens are identical, and the latter have consequently been given a new name.

Sequoia obovata is very closely related, indeed possibly identical, wich $S$. cuneata Newberry ${ }^{1}$ from the Upper Cretaceous of Nanaimo; Vancouver Island. The latter is based on fragments of branchlets only, and hence the general disposition of the branchlets as well as the character of the leaves on the branches, if any, can not be ascertained and compared. The shape of the leaves in the two forms is very similar, though in $S$. cuneata they are larger than in the one under consideration.

The American species is also similar to certain of the forms referred to the well-known Cretaceous species S. heterophylla; ${ }^{2}$ in fact, it appears beyond reasonable question that there are a number of species of Sequoia that await full collections for comparison before their status can be regarded as fixed.

The species now to be known as Sequoia obovata was first detected by Lesquereux in the Montana group at Point of Rocks; Wyo. It was also found at this place by Ward in 1882 and was subsequently obtained by the writer in the same region. The only other place at which it had previously been found was in the adjacent Rock Springs area, where it occurs in beds of the same age as at Point of Rocks. Its discovery at numerous localities in the Raton Mesa region is of interest and tends to prove the identity of the age of the Raton Mesa region and the Wyoming localities.

Occurrence: Vermejoformation (Cretaceous); collected by W. T. Lee-between first and second coal beds at Oakdale mine, locality 140, northwest of La Veta, Colo. (5672); dump of McAinlly mine, Walsenburg, Colo. (5676); dump of No. 6 mine, Forbes; Colo. (5691); dump of Starkville mine, Starkville, Colo.

1 Newberry, J. S., Tho later extinct floras of North America: U. S. Geol. Survey Mon. 35, p. 18, pl. 14, figs. 3-4a, 1898.

2 Volenovsky, J., Gymnospermen der böhmischen Kreidéformation, pl. 13 , fig. 2,1885 .
(5707); dump of Morley mine, Morley, Colo. (5709); Custro, in Tercio Park, Colo. (5805); Vermejo Park, N. Mex., locality 123 (5810); Dawson, N. Mex., locality 24, 36 feet above Trinidad sandstone (5153); Ponil Canyon, $\mathrm{N}$. Mex., 1 mile west of locality 11, near top of Vermejo formation (5829). Collected by George Hadden: Coal Creek (Rockvale), Colo. (51260, 51234, 61261).

\section{Geinitzia formosa Heer.}

Plate XXXI, figures 1-3.

Geinitzia formosa Heer, Neue Denkschr. allg. schweiz. Gesell., Band 24 (Beiträge zur Kreideflora von Quedlinburg), p. 6, pl. 1, fig. 9; pl. 2, 1871.

Newberry, Flora of the Amboy clays: U. S. Geol. Survey Mon. 26, p. 51, pl. 9, fig. 9, 1895 [1896].

Knowlton, U. S. Geol. Survey Bull. 163, p. 28, pl. 5, figs. 1, 2, 1900; U. S. Geol. Survey Prof. Paper 98, p. 333 , pI. 85 , fig. 3,1916 .

Although this species has been found at many widespread localities in the Montana group, it has been detected only near Walsenburg, Colo., within the area under consideration in this report. Fortunately the material at this locality was ample, and, as may be seen from the three figures given, is exceptionally well preserved.

Many isolated or individual branchlets of this species are distinguished with difficulty from those of Sequoia reichenbachi (Geinitz) Heer, and quite probably some specimens of it have been erroneously recorded by that name. In general, S. reichenbachi may be distinguished by its more slender branchlets with leaves that are decurrent, rigid, strongly incurved, and acuminate at apex, whereas Geinitzia formosa has thicker branchlets, with decurrent, arched; not very rigid leaves, and with smaller intermediate scalelike leaves. When the leaves of G. formosa have fallen the scars or bolsters are almost regularly quadrangular. The cones of the two species of course differ markedly and are easily separated when sufficiently well preserved to be made out with reasonable certainty.

Occurrence: Vermejo formation (Cretaceous); 3 miles south of Walsenburg, Colo., 130 feet above the base of the Vermejo and 50 feet below the basal conglomerate of the Raton formation, collected by J. H. Gardner (for G. B. Richardson) (5131). Montana group (Cretaceous); Harper station on Union Pàcific Railroad, Laramie Plains, Wyo. 


\section{- Widdringtonia? complanata Lesquereux.}

Plate XXXII, figures 4, 5 .

Widdringtonia? complanata Lesquereux, U. S. Geol: and Geog. Survey Terr. Bull., 1875, vol. 1, p. 336, 1876; U. S. Geol. and Geog. Survey Terr. Ann. Rept., 1874 , p. 299 , 1876; idem, 1876 , p. 499, 1878; U. S. Geol. Survey Terr. Rept., vol. 7 (Tertiary flora), p. 72 , pl. 62 , figs. $13,14,1878$.

Knowlton, Flora of the Montana formation: U. S. Geol. Survey Bull. 163, p. 30, 1900.

The status of this species, including a discussion as to its probable or possible affinities up to the present time, has been fully set forth by me. The present specimens, two fragments collected 3 miles south of Walsenburg, Colo., are believed to be the second occurrence of the species that has been recognized. They are not very well preserved, and the individual leaves are made out with difficulty, though in strong light they are plainly visible. Obviously they add nothing to existing knowledge as to their systematic position.

Occurrence: Vermejo formation (Cretaceous); 3 miles south of Walsenburg, Colo., 130 feet above the base of the Vermejo and 50 feet below the basal conglomerate of the Raton formation, collected by J. H. Gardner (for G. B. Richardson). (5131), found with Geinitzia formosa and Ficus praetrinervis.

Taxodium? sp.

Plate XXXII, figures 1, 2.

In one of the collections from Vermejo Park, N. Mex., there are several fragments of a conifer that appears to belong to the genus Taxodium. This material is so poorly preserved that under ordinary circumstances it would hardly merit mention much less figuring, but conifers are so very rare in these beds that the present specimens are presented to call attention to their existence. The branchlets evidently formed a flat spray with the numerous linear, acute, onenerved, apparently short petioled leaves disposed alternately along the slender branchlets. The details of the insertion of the leaves and their configuration at base are obscure. It is hoped that this may be sufficient to attract the attention of subsequent workers in this field.

Occurrence: Vermejo formation (Cretaceous); locality 124, Spring Canyon, Vermejo Park, N. Mex., collected by W. T. Lee (5240).
Cupressinoxylon coloradense Knowlton, n. sp.

Plate XXXIII, figures 1-4; Plate XXXIV, figure 1; Plate XXXV, figures 1-6.

Transverse section: Growth rings of different widths but on the whole rather narrow, about sixteen being in a radial extent of 25 millimeters. Tracheids in regular, radial rows, usually very even in size, twenty to thirty in each row, mainly rectangular in shape. The thickened wood of the ring involves usually three or four cells, never-or very rarely-more than six. Resin passages absent; resin cells fairly abundant, scattered irregularly throughout the summer wood, usually smaller than the cells of the summer wood. Radial section: Ray cells of one kind only; short, covering one to three tracheids, straight; upper and lower walls thin, apparently not pitted; terminal walls thin, usually oblique, not pitted; lateral walls obscure but apparently with occasional large oval pits, about two per tracheid. Bordered pits usually in a single row, occasionally in two rows, the central pore large. Resin cells fairly numerous, short, thick walled, central mass black carbonaceous. Tangential section: Rays numerous, in a single series of one to as many as twenty, average perhaps six to ten. Resin cells as in the radial section.

The fossil wood here described is based on sections cut from small pieces broken from large trunks or fragments of trunks that are abundant in certain localities. In some places of similar age but outside the present area these aggregations of trunks may reach the dignity of socalled fossil forests. As these woods when made available by study may prove valuable as close stratigraphic marks, the several species, where sufficiently well preserved for adequate investigation, are presented with the other plant remains. Through lack of time the specimens have not been studied exhaustively from the biologic standpoint but are figured and so far described as to make the wood available for stratigraphic purposes.

The present species, which is based on material from the Canon City and Trinidad frelds, belongs clearly to the genus Cupressinoxylon. It is, for instance, quite similar to Cupressinoxylon elongatum Knowlton ${ }^{1}$ from the Fort

\footnotetext{
1 U. S. Nat. Mus. Proc., vol. 11, p. 7, pl. 3, figs. 1-4, 1888.
} 
Union formation of Montana, which, however, has a greater number of cells involved in the fall wood and in almost all specimens has two rows of bordered pits on the rachial walls of the - summer tracheids.

Occurrence: Vermejo formation (Cretaceous) (Pl. XXXIII, figs. 1-3; Pl. XXXV, figs. 1-3, 5) ; south of Trinidad, Colo. (sec. 25; T. 38 S., R. 64 W.), collected by W. T. Lee (5706); (Pl. XXXIII, fig. 4; Pl. XXXIV, fig. 1; Pl. XXXV, fig. 4.), Newland Creek, Canon City field, Colo. (sec. 19, T. 20 S., R. 69 W.), collected by W. T. Lee (5784).

Cupressinoxylon? vermejoense Knowlton, n. sp.

Plate XXXIV, figures 2, 3; Plate XXXV, figure 7 .

Transverse section: Growth ring absent, at least none appears in a radial extent of over 25 millimeters. Tracheids small, thin walled, approximately square, and of nearly the same size throughout. Resin passages and resin cells apparently both absent. Radial section: The elements as seen in this view are exceedingly obscure, owing to distortion during or after fossilization. The ray cells are apparently thin walled and very long, but the markings, if ever present, are not to be ascertained. The bordered pits on the walls of the summer tracheids can not be made out. Tangential section: Rays numerous, in a single series of one to seven, usually three or two.

This material is so poorly preserved that many of the essential characters can not be made out, and figuring would not have been attempted did not the characters that can be observed differ so markedly from those of Cupressinoxylon coloradense. The annual ring appears to be entirely absent, and the medullary rays are never more than seven and are usually only three or four cells high. It is probable that from these characters alone it could be distinguished in future. In the absence of exact information regarding certain essential particulars it is impossible to enter into a comparison with other named species. It is quite probable that it may be found not to belong to Cupressinoxylon.

Occurrence: Vermejo formation (Cretaceous) (Pl. XXXIV, figs. 2, 3; Pl. XXXV, fig. 7); Canon City field, Colo. (sec. 30, T. 19 S., R. 69 W.), collected by W. T. Lee (5790).
ANGIOSPERMAE. MONOCOTYLEDONAE. Order PANDANALES. Family TYPHACEAE.

Sparganium? sp.

Plate XXXII, figure 6.

In the small collection from the Occidental mine, near La Veta, Colo., is the little specimen here figured. It is a small capitulum about 7 or 8 millimeters in diameter, borne by a slender peduncle or stalk 15 millimeters in length. It is not sufficiently well preserved to permit making out its full structure, but so far as, can be noted it appears to be referable to the genus Sparganium. It also somewhat resembles Liquidambar, but on the whole seems best referred as above. There are no foliar organs in the collection with it that could be referred to either genus.

Occurrence: Vermejo formation (Cretaceous); roof of upper coal bed, Occidental mine, locality 141, near La Veta, Colo., collected by W. T. Lee (5673).

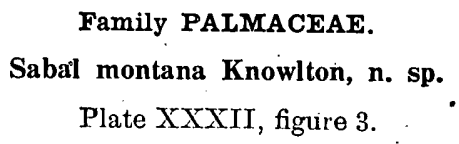

Sabalites grayanus (Lesquereux) Lesquereux, U. S. Geol. Survey Terr. Rept., vol. 7 (Tertiary flora), p. 11.2, pl. 12, fig. 1 (not pl. 12, fig. 2), 1878 .

Sabal montana Knowlton, U. S. Geol. Survey Prof. Paper 98, p. 335, pl. 85, fig. 2, 1916.

Leaves of very large size, perhaps the largest in the area, palmate, with approximately ninety rays or folds; petiole unarmed; apparently rounded on both surfaces, 5 or 6 centimeters broad, prolonged at apex into a relatively short triangular point not more than 10 or 15 centimeters long, in many specimens only 8 centimeters.

This species is still very imperfectly known, but its immense petiole (fully 6 centimeters broad) and the great breadths of its folds (4 centimeters or more) mark it as probably the largest land species known from the region or indeed from anywhere in the Rocky Mountain area.

This species is based jointly on specimens from the Colorado area obtained by Lee and figured on Plate XXXII, figure 3 , and the large specimen.from the Montana group at Point of Rocks, Wyo., described by Lesquereux ${ }^{1}$ under 1 U. S Geol. Survey Terr. Rept., vol. 7 (Tertiary flora), p. 112, pl. 12,
fig. 1, 1878. 
the name of Sabatites grayanus (No. 108, U. S. Nat. Mus. coll.). As shown in the discussion under Sabal? ungeri (p. 289) it seems impossible that this Point of Rocks specimen should be the same as the original form which was described ${ }^{1}$ from the "Eo-lignitic" of Mississippi. . The former is not only three times the size of the type but differs markedly in the shape and character of the apex of the petiole. In 1896 I obtained from Point of Rocks a fine specimen, which is hardly to be distinguished from that from the same locality figured by Lesquereux. It is even larger than Lesquereux's specimen but hardly adds to our knowledge, as it simply exhibits a little more of the blade of the leaf.

Occurrence: Vermejo formation (Cretaceous; collected by W. T. Lee; Canon City field, dump of coal mine near Rockvale, Colo., type (5791); 1 mile south of Rockvale, Colo. (5789) ; sec. 18, T. 19 S., R. 69 W., Canon City field, Colo. (5778) ; sec. 18, T. 19 S., R. 69 W., Canon City field, Colo. (5780); 1 mile south of Rockvale, Colo. (5788); top of cliff west of Florence, Colo.? (5812); dump of Starkville mine, Colo., at base of Vermejo formation (5707); dump of Coal Creek mine, Rockvale, Colo. (5791); Forbes, Colo., roof of second bed of coal in south wall of North Fork of Purgatoire River, locality 136, Colorado (5800) ; Vermejo Park, N. Mex., locality 123 (5810). Also found in the Montana group at Point of Rocks, Wyo.

Sabal? ungeri (Lesquereux) Knowlton, n. comb.

This species is mainly found in the Raton formation, the present specimens being the only ones that have with certainty been found in the Vermejo formation. For synonymy and full discussion see page 289 .

Occurrence: Vermejo formation (Cretaceous) ; Ponil Canyon, N. Mex., 1 mile west of locality 11, near top of Vermejo formation, collected by W. T. Lee (5829). Raton formation (Tertiary). (See p. 290.)

\section{Order SCITAMINALES.}

Family CANNACEAE.

Canna? magnifolia Knowlton, n. sp.

Plate XXXVI, figure 3.

Leaf of large size and firm texture, apparently broadly lanceolate with an acute apex;

1 Am. Philos. Soc. Trans., vol. 13, p. 412, pl. 14, flgs. 4-6, 1869. margin entire; midrib very strong, about 1 . centimeter thick, not greatly reduced at apex; nerves arising from the midrib at a very acute. angle, close, parallel, unforked, ending in the margin; cross veinlets numerous, close, parallel, and at right angles to the veins.

This splendid leaf, which unfortunately is represented by fragments only, was of great. size, being probably not much if any under 50 centimeters in length and 16 to 20 centimeters in width. The configuration of its base and of its extreme tip are both somewhat conjectural, though in the specimen figured the upper portion is narrowing as if to produce an acute termination, and in a fragment from Rockvale, Colo., the base appears to be wedgeshaped. The midrib was very strong, being in some of the fragments fully 1 centimeter in thickness. The numerous close, parallel, unforked veins rise from the midrib at an angle of about $70^{\circ}$ and run straight up to the margin. These veins are nearly equal in size, though: here and there one is slightly stronger than the others; there seems to be no regularity as to the number of the intermediate veins. The close, parallel cross veins are nearly as strong as the main veins and produce a checkered appearance, even to the naked eye, though the figure does not adequately bring out this feature.

The only described species with which this may be compared is Musophyllum complicatum Lesquereux, ${ }^{2}$ from Green River station, Wyo., but that it is even congeneric with it is doubtful. The two forms differ markedly, In Lesquereux's species the veins, which are nearly at right angles with the midrib, are thinner, at least where they reach the margin, and are more or less forking, especially near the margin, but the cross veins, which are so conspicuous in Canna? magnifolia, are entirely absent in Musophyllum complicatum.

There is a single specimen, even more fragmentary than the type material, from the Rockvale mine at Rockvale, Colo., that agrees in every particular with the Walsenburg material. It is evidently from the part near the base of the leaf and. shows a portion of the margin that indicates that the base would be wedgeshaped.

Occurrence: Vermejo formation (Cretaceous); collected by W. T. Lee-type, dump of Rock-

${ }^{2}$ Lesquereux, Leo, The Tertiary flora: U. S. Geol. Survey Terr. Rept., vol. 7, p. 96 , pl. 15 , figs. $1-6,1878$. 
land mine, locality 120, from about 170 feet below the top of the Vermejo formation, 3 miles southwest of Walsenburg, Colo. (5677); roof material of Rockvale mine, Rockvale, Colo., in the Canon City field (5793).

\section{Canna? sp.}

A single fragment in the material from the roof of the coal mine at. Rockvale, Colo., may be referred provisionally to the genus Canna, though it is very unlike Canna? magnifolia. The fragment, probably from near the middle of the leaf, is about 12 centimeters in length and about 9 oentimeters in width. It has the same thick midrib and apparently entire margin of the other but differs from it in having the veins arise at a slightly lower angle and without cross veinlets. Its nervation is very obscure, however, and it may be that it is identical with $C$. magnifolia; but in the absence of proof it seems best to retain them apart, at least for the present. It is too poor to be satisfactorily figured.

Occurrence: Vermejo formation: (Cretaceous); dump of Coal Creek mine, Rockvale, Colo., col- lected by W. T. Lee (5791).

\section{Subclass DICOTYLEDONAE.}

Order JUGLANDALES.

Family JUGLANDACEAE.

Juglans coloradensis Lesquereux (MS.), n. sp.

Plate XXXVI, figure 1.

Leaflet large, coriaceous in texture, lanceolate, gradually narrowed from the middle to the slightly unequal-sided base, alternate but not decurring in joining the petiolule; midrib very strong, straight; secondaries strong, numerous-about 9 pairs-irregular, mainly alternate, at an acute angle of divergence, following the borders in marginal loops or anastomosing with the one next above; nervilles very distinct, transverse, cut in the middle or continuous; areolae square or polygonal. Type, United States National Museum (No. 34469).

This species was indicated by Lesquereux as new in the manuscript list accompanying the collection of plants from Coal Creek (near Rock- vale), Colo., made by George Hadden for R. D. Lacoe, now the property of the United States National Museum. The description with slight modification is Lesquereux's, as is also the name given it. The type specimen, which lacks the upper portion, is about 9 centimeters in length when perfect and 3.5 centimeters in width near the middle. It has a rather abruptly narrowed base and apparently a rather obtuse apex. It was also somewhat unequal-sided. The nervation is very strongly and deeply impressed, consisting as stated of the thick midrib and about nine pairs of mainly alternate secondaries. The nervilles are especially strong.

This species is compared by Lesquereux with Juglans ventricosa Brongniart, as figured by Ludwig, ${ }^{1}$ and it also suggests certain of the leaves referred to Juglans rugosa Lesquereux?,2 especially by its strongly impressed nervation. Occurrence: Vermejo formation (Cretaceous); Coal Creek (Rockvale), Colo., collected by George Hadden.

\section{Juglans similis Knowlton, n. sp. \\ Plate XXXVI, figure 2.}

Leaflet membranaceous in texture, ovatelanceolate in outline, abruptly wedge-shaped at base, prolonged above into an acuminate apex; margin entire; midrib thin, straight; secondaries ten or twelve pairs, thin, alternate, slightly curved upward, camptodrome, and curving just within the border to join the one next above; finer nervation obsolete.

This fine little species is well represented by the example figured. This is narrowly ovatelanceolate in shape, being about 7.5 centimeters in length and 3.25 centimeters in width in the middle. The nervation is well shown in the figure.

. This species is of the type of certain of the leaflets often referred to Juglans rugosa Lesquereux, but differs from it in having a more narrowly lanceolate shape, larger acuminate apex, and thinner nervation at a slightly more. acute angle of divergence.

Occurrence: Vermejo formation (Cretaceous); Coal Creek (Rockvale), Colo., collected by George Hadden (U. S. Nat. Mus., 51332).

1 Palaeontographica, vol. 4, p. 139, pl. 57, figs. 3, 3a, 5; pl. 58, 1861.

2 Lesquereux, Leo, op. cit., p. 286, pl. 55, fig. 5, etc., 1878. 
Order MYRICALES.

Family MYRICACEAE.

Myrica torreyi Lesquereux.

Plate XXXVII, figures 2-4.

Myrica torreyi Lesquereux, U. S. Geol. Survey Terr. Ann. Rept., 1872, p. 392, 1873; U. S. Geol. and Geog. Survey Terr. Ann. Rept., 1873, p. 399, 1874; idem, 1876 , p. 503, 1878; U. S. Geol. Survey Terr. Rept., vol. 7 (Tertiary flora), p. 129, pl. 46, figs. 3-10, 1878.

Knowlton, Flora of the Montana formation: U: S. Geol. Survey Bull. 163; p. 34, pl. 6, figs. 1-3, 1900; U. S. Geol. Survey Prof. Paper 98, p. 336, pl. 86, fig. 1, 1916.

The type locality of this species is given as Black Buttes, Wyo., though it was not observed in an exhaustive collection made at this locality in 1909 by A. C. Peale and the writer. All but two of the type specimens are preserved in the United States National Museum (Nos. 138-142). This species was well described and figured by Lesquereux, and none of the material since obtained adds materially to knowledge of it.

Since the original finding at Black Buttes this species has been reported at several additional localities, all in lower beds. Thus Ward found it ${ }^{1}$ at Point of Rocks, Wyo., in strata now known to be of Montana age. These specimens were illustrated in my "Flora of the Montana formation," and though the leaves shown in figures 1 and 2 of that report probably belong to the species, that shown in figure 3 is somewhat doubtful; its margin is similar to that of certain of the type specimens, but it appears to lack the intramarginal vein; it is not well preserved and had perhaps best be separated. What was apparently this species was found by Knowlton, Stanton, and Knight in the Montana group at Dunn's ranch, 30 miles north of Laramie, Wyo., and at Harper station, on the Union Pacific Railroad about 6 miles west of Laramie. It has also been detected in beds of Laramie age at Crow Creek, Colo. It has also been noted near Newcastle, Meeker, and Rio Blanco and in the Grand Mesa region, Colo., at Book Cliffs, Utah, in the San Juan basin, N. Mex., and elsewhere, all in late Cretaceous beds. Thus, though it appears to have been described from postLaramie beds, all, or nearly all, its subsequent occurrences seem to have been in older beds.

In the collections from the Rockland mine; near Walsenburg, Colo., there is a single ex-

1 Knowlton, F. H., Flora of the Montana formation: U. S. Geol. Survey Bull. 163, p. 34, pl. 6, figs. 1-3, 1900. ample, the one here figured (Pl. XXXVII, fig. 4) that appears referable to this species. In size, shape, and marginal dentation it agrees perfectly with some of the smaller leaves of $M$. torreyi, but there is almost no nervation preserved except the midrib. Such of the finer nervation as can be faintly discerned appears to be that of this species, but the intramarginal vein is obscure.

In the material from the reddish sandstone below the rim rock at Rockvale, Colo., are a number of fragmentary leaves that undoubtedly belong to this species, though they are smaller than is usual. Three examples from the south wall of the gap at Tercio, Colo., also agree in size, shape, and marginal teeth, and, so far as can be made out, in the nervation.

Occurrence: Vermejo formation (Cretaceous); collected by F. H. Knowlton-first hill south of Rockvale, Colo., opposite ball grounds, 1909 (5477); collected by W. T. Lee-Alkali Gap, Colo., Canon City field (5775); dump of Coal Creek mine, Rockvale, Colo. (5791); Occidental mine, locality 141, northwest of La Veta, Colo. (5673) ; Bowen mine, locality 109, near Trinidad, Colo. (5692); dump of McAnily . mine, Walsenburg, Colo. (5676); Rockland mine, locality 120, southwest of Walsenburg; Colo. (5677); dump of mine 6, Forbes, Colo., near top of Vermejo formation (5691); Canon. City field, Colo., north wall of canyon near Rockvale (sec. 25, T. 19 S., R. 70 W.) (5783).

\section{Myrica coriacea Knowlton, $n$. sp.}

Plate XXXVII, figure 5.

Leaf very coriaceous in texture, narrowly ovate-lanceolate in shape, broadest about onefourth the length from the base, whence it is rather abruptly narrowed to the base, apparently to a rather acute apex; margin entire; midrib very thick, especially below; secondaries very obscure but apparently numerous, fine, irregular, and terminating in a wellmarked inträmarginal vein.

The leaf figured, which is the best observed, was about 10 centimeters in length and 3.25 centimeters in width. It is lanceolate, or very narrowly ovate-lanceolate, with rounded wedge-shaped base and apparently a rather long acuminate apex. The nervation, with the exception of the midrib, is very obscure, but apparently it consists of numerous, thin, irregu- 
lar $\cdot$ veins which terminate in a pronounced intramarginal vein.

This species is most closely related to Myrica torreyi Lesquereux, from which it differs in being relatively broader and in having the margin entire instead of markedly serrate. So far as can be made out the nervation is identical. It may be that the specimen is merely. an entire-margined leaf of Myrica torreyi, but in the absence of intermediate forms it is best to regard it as belonging to a distinct species.

Occurrence: Vermejo formation (Cretaceous); Conl Creek (Rockvale),Colo., collected by George Fadden (U. S. Nat. Mus., 51372).

\section{Order SALICALES.}

\section{Family SALICACEAE.}

Salix gardneri Knowlton, n. sp.

Plate XXXVII, figure 1.

Leaves linear-lanceolate, broadest about the middle, thence tapering gradually to the long wedge-shaped lower portion and in about equal degree to the acuminate apex; margin perfectly entire; midrib fairly strong; secondaries numerous, about twelve pairs, alternate, at an angle of about $45^{\circ}$, very much curved upward, each joining the one next above, the lower ones by a series of several loops, the upper ones making themselves a series of conspicuous loops; nervilles prominent, approximately at right angles to the midrib.

This handsome little species is represented by the nearly perfect example figured as well as several more or less fragmentary specimens. The figured specimen is 7 centimeters long and 1 centimeter wide; the others are slightly smaller.

This species is undoubtedly most closely related to Salix plicata, with which it agrees closely in size and shape but from which it differs in the disposition of the less numerous secondaries; the finer nervation is also a more conspicuous feature in the present species. It is named in honor of the collector, $\mathrm{Mr}$. J. H. Gardner, formerly a member of the United States Geological Survey and later connected with the Kentucky Geological Survey.

Occurrence: Vermejoformation (Cretaceous); Trinidad coal field, Colo., near base of Vermejo formation, at Simpson's mine, 3 miles south of Walsenburg (SE. SE. 1 sec. 21, T. 28 S., R. 66 W.), 3 feet above coal and 10 feet $47019^{\circ}-17--17$ above the Trinidad sandstone, collected by G. B. Richardson's party (5130).

Salix plicata Knowlton, n. sp.

Plate XXXVII, figures $6-\overline{8}$.

Leaves evidently thick and coriaceous in texture, narrow, linear or linear-lanceolate, long and narrowly wedge-shaped at base, narrowed to the apex (destroyed); margin entire throughout; petiole evidently short; midrib very thick, deeply impressed; secondaries very. numerous, at a low angle, abruptly curved upward well inside the border and joining the one next above, thus forming a series of intramarginal loops far inside the margin; intermediate secondaries occasional; finer nervation deeply impressed, forming irregularly quadrangular areas.

This little species is represented by a large number of specimens which are very perfect so far as they go, though curiously enough there is none with the tip preserved, and very few that retain the base. 'They are narrow, linear; and entire, with a very short petiole. The length varies from 5 to about 10 centimeters and the width from about 6 to a maximum of 18 millimeters, average 10 or 12 millimeters.

In range of size, shape, and general appearance this species is perhaps closest to Salix angusta Alexander Braun, as figured by $\mathrm{Heer}^{1}$ from the Swiss Miocene, but it differs absolutely in nervation and can hardly be in any way related. The coriaceous character of the leaves and the strongly impressed nervation prcduce a very well marked species, which is easily recognized even in fragmentary material.

.This species was indicated as new by Lesquereux in a manuscript report on a collection from "Coal Creek, Colo.," made by George Hadden for R. D. Lacoe, and by him donated to the National Museum: It is all in the reddish shaly sandstone so characteristic of the bluffs (so-called rim rock) about Rockvale, Colo. There are about a dozen examples in the Hadden collection, and it was also obtained by Lee in 1910 and by me in 1909 .

Occurrence: Vermejo formation (Cretaceous); "Coal Creek, Colo.," collected by George Hadden, without doubt from the rim rock near Rockvale; first hill south of Rockvale and opposite ball grounds, about 150 feet above top

1 Heer, Oswald, Flora tertiaria Helvetiae, vol. 2, p. 30, pl. 69, figs. 1-11, 1858 . 
- of Rockvale sandstone member of the Vermejo, collected by F. H. Knowlton, 1909 (5477); 1 mile south of Rockvale, Colo., collected by W. T. Lee, 1910 (5788); Rockvale Canyon, about 100 feet below lower cliff of rim rock, collected by W. T. Lee (5781); in roof of Cameron mine, 3 miles south of Walsenburg, Colo. (5044), collected by George B. Richardson.

Salix sp. a.

Plate XXXVIII, figure 1.

Salix sp. $a$ Knowlton, U. S. Geol. Survey Prof. Paper 98, p. 337, pl. 86, fig. 9, 1916.

In one of the collections from Vermejo Park, N. Mex., there are several small leaves that appear reférable to Salix, but beyond the fairly clear outline of the leaf there is little that can be made out with absolute certainty. They are lanceolate in shape, slightly curved, and unequal sided, and measure about 8 centimeters in length and 2 centimeters in width; their margin is perfectly entire. The nervation consists of a rather slender midrib and numerous pairs of slender secondaries, which arise at an acute angle and apparently curve upward for a considerable distance.

Occurrence: Vermejo formation (Cretaceous); locality 125, west of Vermejo Park, N.Mex., near the middle of the Vermejo formation, collected by W. T. Lee (5809).

Salix sp. b.

Plate XXXVIII, figure 2.

In one of the small collections from Ponil Canyon, N. Mex., there is found the single leaf here figured. It is narrowly lanceolate, broadest just above the base, and apparently slenderly acuminate at apex. The length is about 11 centimeters and the width 1.8 centimeters; the margin is perfectly entire. The nervation is not well preserved, consisting of a relatively strong midrib and numerous pairs of thin, apparently camptodrome secondaries.

It is usually so difficult to satisfactorily identify small, narrow leaves of this type that beyond placing it under Salix, where it appears to belong, it has not been thought worth while to give it a specific name. It is very similar to a number of described species, such, for example, as Salix media Heer, ${ }^{1}$ from the Swiss

1 Heer, Oswald, op. cit., pl. 68, figs. 14-19, 1856.
Miocene, but it would require more and better material before it could be described and characterized properly.

Occurrence: Vermejoformation (Cretaceous); Ponil Canyon, N. Mex., 1 mile west of locality 11 , at top of Vermejo formation, collected by W. T. Lee (5829).

Salix sp. c.

The collections from the Canon City field contain a number of long, narrow leaves that are probably correctly referred to the genus Salix. The leaf is linear-lanceolate, 12 centimeters in length and about 2.5 centimeters in width at the widest point, whence it tapers upward to the slender apex and more gradually downward to the base. The nervation is obscurely preserved, consisting of a rather thick midrib and numerous' secondaries, but the details are somewhat obscured.

This leaf, in size and shape, approaches closely what was called ${ }^{2}$-probably erroneously - Salix angusta Alexander Braun, from Coalville, Utah, and Point of Rocks, Wyo., though the secondary nervation appears to differ somewhat. This species is principally Tertiary in distribution, and its identification in the several lower horizons whence it has been reported is probably due to error. On account of the greater or less uncertainty which attaches to the identification of willow leaves of this general type I have preferred not to attach a specific name to it, rather than risk the possibility of misidentification with an existing species.

Occurrence: Vermejo formation (Cretaceous); Rockvale, Colo., Newberry collection, probably made by George Hadden.

Populus? neomexicana Knowlton, n. sp.

Plate LIII, figure 3 .

Leaf apparently rather membranaceous in texture, broadly.ovate in shape, about 7 centimeters in length and 6 centimeters in width, broadly truncate to the slightly decurrent base, rather obtusely acuminate at apex; margin entire at base, apparently crenate above; nervation three ribbed from the base of the blade, midrib strong, straight, with a single pair of subopposite secondaries in the upper portion;

2 Knowlton, F. H., Flora of the Montana formation: U.S. Geol. Sur vey Bull. 163 , p. 38 , pl. 7 , fig. 6,1900 . 
lateral ribs as strong as midrib, at an angle of about $45^{\circ}$, much curved upward, each with several pairs of secondary branches on the outside; finer nervation not retained.

This leaf is not well preserved, in fact, the base and a small portion of one side is all that is retained of the true margin. It appears, however, to have been broadly ovate with a rounded truncate base, which is slightly decurrent along the petiole. It is remarkable for having only one pair of secondaries on the extreme upper portion of the midrib.

The reference of this leaf to Populus is uncertain, but in general it seems not greatly unlike leaves of many later formations that have been so identified. It may belong to Ficus, but its poor preservation precludes certainty.

Occurrence: Trinidad sandstone (Cretaceous); 1 mile south of Raton, N. Mex., collected by W. T. Lee (5145).

\section{Order FAGALES.}

Family FAGACEAE.

Quercus gardneri Knowlton, n. sp. Plate XXXVIII, figure 3.

Leaf coriaceous in texture, elliptical in general outline, obtuse and rounded at apex, abruptly rounded and slightly decurrent into the short, and rather stout petiole at base; margin deeply sinuate lobed, both lobes and sinuses being obtuse and rounded; midrib rather thick; secondaries in three pairs, thin, subopposite, ending. in the obtuse lobes; nervilles irregular, mainly broken.

This very handsome little species is for. tunately preserved almost entire. It is 4 centimeters long, exclusive of the petiole, which is nearly 1 centimeter in length, and 23 millimeters broad between the points of the lobes.

This species does not appear to be especially closely related to any fossil form thus far described from this country, but among living species it seems perhaps closest to Quercus undulata Torrey. This species is usually a shrub, occasionally becoming a small tree, and ranges from the eastern foothills of the Rocky Mountains in Colorado to western Texas and thence to southern Utah and south into Mexico.

Occurrence: Vermejo formation (Cretaceous); 2 miles south of Walsenburg, Colo., 130 feet above the base of the Vermejo formation and 50 feet below the basal canglomerate of the Raton formation, collected by J. H: Gardner (for G. B. Richardson) (5131).

Quercus rockvalensis Knowlton, n. sp. Plate XXXVIII, figure 4.

Leaf small, elliptical in general outline, obtusely wedge-shaped at base, pinnately five lobed, the lobes obtuse and rounded and separated by shallow, rounded sinuses; the terminal lobe largest and the basal pair slightly smaller than the upper pair; midrib rather strong; secondaries three pairs, opposite, terminating in the lobes; finer nervation not retained.

The only example observed is the one here figured. It is 4.5 centimeters long and about 3 centimeters between the tips of the larger lobes;

Occurrence: Vermejo formation (Cretaceous). Rockvale, Colo., Newberry collection.

\section{Dryophyllum bruneri Ward. ' Plate LIII, figure 5.}

Dryophyllum bruneri Ward, U.S. Geol. Survey Sixth Ann. Rept., p. 551; pl: 37, figs. 6-9, 1886; U. S. Geol. Survey Bull. 37, p. 27, pl. 10, figs. 5-8, 1887.

In a small collection from the Trinidad sandstone of the Canon City field there is found the single leaf here figured, which appears to be identical with Ward's Dryophyllum bruneri. This species came from Point of Rocks and Hodges Pass; Wyo., and especially resembles figure 8 (above quoted). In shape it is perhaps rather closer to $D$. falcatum Ward, ${ }^{1}$ from Hodges Pass, but this has the margin undulate rather than toothed, and all things considered it is thought to be nearer to D. bruneri.

Occurrence: Trinidad sandstone(Cretaceous); Canon City field, Colo. (sec. 1, T. 19 S., R. 70 W.), collected. by W. T. Lee, No. 694 (5776).

\section{Order URTICALES.}

Family MORACEAE.

Ficus dalmatica Ettingșhausen.

Ficus dalmatica Ettingshausen. Lesquereux, U. S. GeoI. and Geog. Survey Terr. Ann. Rept., 1874, p. 303, 1875; U. S. Geol. Survey Terr. Rept., vol. 7 (Tertiary flora), p. 199, pl. 63, figs. 3-5, 1878.

Knowlton, U. S. Geol. Survey Bull. 163, p. 51, pl. 8, fig. 4, 1900.

Occurrence: Vermejo formation (Cretaceous); Coal Creek (Rockviale), Colo., collected by George Hadden (U. S. Nat. Mus., 51167).

1 Ward, L. F., Synopsis of the flora of the Laramie group: U. S. Geol. Survey Sixth Ann. Rept., p. 551, pl. 37, fig. 10, 1886. 
Ficus eucalyptifolia Knowlton, n. sp.

Plate XLIV, figures 1, 2.

Ficus eucalyptifolia Knowlton, U. S. Geol. Survey Prof. Paper 98, p. 340, pl. 87, figs. 1, 2, 1916.

Leaf coriaceous, lanceolate, gradually narrowed from near the middle to the wedgeshaped base and upward to the narrow acuminate apex; margin entire; midrib very thick, straight; secondaries numerous, about fifteen 'pairs, thin, alternate, parallel, reaching close to the margin; finer nervation obsolete.

This species is represented by several fairly well preserved thick coriaceous leaves, narrowly lanceolate in shape and slightly unequalsided, about 14 centimeters long and 3 centimeters wide. Their most marked feature is the very thick midrib (and petiole) and the rather close, numerous, parallel secondaries.

Long narrow leaves of this general type are very difficult to identify satisfactorily, as there are so many forms to which they could seemingly belong. They are, for instance, very much like what has been described as Apocynophyllum wilcoxensis (p. 345), at least so far as regards size, shape, and thick midrib; but they differ in the secondary nervation and in the absence of the intramarginal vein. In size, shape, and thick midrib the present form is hardly to be separated from a number of species of Ficus-such, for example, as $F$. proteoides Lesquereux and $F$. berthoudi Lesquereux, especially the latter; from the Dakota sandstone of Kansas ${ }^{1}$ - but it shows slight differences in the secondary nervation. It is also very similar in size and shape to Laurus knowltoni Lesquereux ${ }^{2}$ but differs slightly from this also in the secondary nervation. "It also approaches very closely to some of the leaves referred by Lesquereux ${ }^{3}$. to Ficus lanceolata Heer, about the only difference being in its thicker midribthe finer nervation not being comparable. This comparison could be extended further, but it is hardly. worth while, and it seems best to give the Colorado leaves a new name, which they may retain until it can positively be shown that they belong elsewhere.

Occurrence: Vermejo formation (Cretaceous); - Rockvale, Colo., Newberry collection, probably made by George Hadden.

\footnotetext{
1 Lesquereux, Leo, The flora of the Dakota group: U. S. Geol. Survey Mon. 17, pl. 12, figs. 2, 3, 1890.

2 Idem, pl. 50, fig. 4.

${ }^{3}$ Lesquereux, Lea The Tertiary flora: U. S. Geol. Survey Terr. Rept., vol. 7 , p. 192, pl. 28 , ngs. $1-3,1878$.
}

Ficus haddeni Knowlton, n. sp.

Plate XXXVIII, figures 6, 7.

Leaves firm in texture, ovate, narrowed below to a decurrent base, rather obtuse at apex; margin entire; nervation triple nerved from the decurrent basal portion; midrib strong, straight, with five or six pairs of mainly alternate secondaries which are camptodrome and arch by a series of loops well inside the margin; lateral ribs arising with the midrib, thinner than the midrib, passing up about parallel with the lowest pair of secondaries for nearly one-half the length of the blade, camptodrome, each with three or four secondary branches on the outside; nervilles thin, obscure.

This species is represented by five or six fairly well preserved leaves, the larger of which is about 6 centimeters long and 3.5 centimeters wide and the smallest only about 3 centimeters long and a little less than 2 centimeters wide; average, about 5 by 2.5 centimeters.

This species is of the type of Ficus praetrinervis, with which it agrees closely in shape and triple-nerved appearance. It differs from this, however, in having lateral ribs lighter than the midrib and in these not passing up parallel with the midrib to the upper part of the blade; the secondaries in the midrib are also different. Ficus haddeni also differs of course similarly from the allied $F$. trinervis. Remotely it resembles $F$. planicostata Lesquereux, but from this it is known at once by the decurrent base.

These specimens all passed through Lesquereux's hands and were by him identified as a form of Populus mutabilis Heer, which they somewhat resemble in the shape and appearance and nervation of the upper portiou, but from which they differ essentially in the outline and nervation of the basal portion.

Occurrence: Vermejoformation (Cretaceous) ; Coal Creek (Rockvale), Colo., collected by George Hadden, for whom it is named; roof of Cameron mine, 3 miles south of Walsenburg, Colo., collected by G. B. Richardson's party (5044).

Ficus minima Knowlton, n. sp.

Plate XXXVI, figure 4; Plate XXXVIII, figure 5.

Leaf small, thick, lanceolate, apparently rather abruptly rounded to both base and apex; margin perfectly entire; midrib exceedingly thick; secondaries strong, numerous; probably 
twonty pairs, close, parallel, emerging at a right angle, then considerably curved upward, each joining the one next above just inside the margin, thus producing a continuous loop; intermediate secondaries occasional; nervilles very strong, unbroken.

The little leaf figured, which unfortunately lacks both base and apex, was apparently about 5 centimeters long and 1.75 centimeters wide. It is remarkable for the extremely thick midrib and numerous strong secondaries which arise at a right angle and, curving slightly upward, form a continuous loop just inside the margin.

Occurrence: Vermejo formation (Cretaceous); dump of McAnily mine, Walsenburg, Colo., colected by W. T. Lee (5676).

Ficus newberryana Knowlton, n. sp.

Plate XXXVIII, fgure 8.

Leaf thick in texture, broadly ovate, abruptly rounded to the truncate base (apex destroyed); margin entire; three nerved from the base of the blade; midrib thin, straight; secondaries only two or three pairs, alternate, lowest pair high above the base, at an angle of about $45^{\circ}$, apparently running to the margin; lateral ribs of the same size as the midrib, running straight to the margin, each with four or five tertiary branches on the outside, nearly at right angles to the midrib, apparently ending in the margin; nervilles few, strong, percurrent.

The figured example, the most perfect observed, is far from complete, lacking all of the apical portion and most of one side. The total length is uncertain but probably exceeds 10 centimeters; the width is about 9 centimeters.

This species is of the type of Ficus planicostata Lesquereux; in fact, it is distinguished with difficulty, from what Lesquereux ${ }^{1}$ has called F. planicostata goldiana from the Denver formation of the Denver Basin, Colo. In general, however, the present species seems to have been a thicker loaf than the Denver species, with the secondaries strikingly alternate instead of opposite or subopposite, and fewer tertiary branches for the lateral ribs; the nervilles are more nearly at right angles to the secondaries than to the midrib.

Occurrence: Vermejo formation (Cretaceous); Rockvale, Colo., Canon City field, Newberry collection, probably made by George Hadden.

I Lesqueroux, Leo, op. cit., p. 202, pl. 33, figs. 1-3, 1878
Ficus leei Knowlton, n. sp.

Plate XXXIX, figures 1-6; Plate XI, figures 1, 2.

Ficus leei Knowlton, U. S. Geol. Súrvey Prof. Paper 98, p. 338 , pl. 90 , fig. $2,1916$.

Leaves very thick and fleshy in texture, the nervation strongly impressed; shape broadly elliptical, ovate-elliptical or sometimes nearly orbicular, the base from rounded and truncate to deeply cordate-auriculate, the apex abruptly rounded and obtuse or sometimes slightly pointed; margin entire or occasionally very slightly undulate; petiole short, thick; nervation strong, the midrib straight or at most slightly flexuose, with from three to six pairs of strong secondaries, the lowest pair arising at the base of the blade, of the same size as the midrib and together producing a three-ribbed effect; the lowest pair of secondaries (or ribs) with from three to as many as ten tertiary branches on the outside, the lowest of these in the larger leavesnearly at right angles to the midrib-with a number of quaternary branches on the lower side, which supply the extreme basal portion of the blade; the secondaries on the midrib are usually remote, alternate, or subopposite, and sometimes with a few branches on the outside; all nervation camptodrome and arching just inside the margin; nervilles numerous, strong, mainly unbroken; finer nervation producing an abundance of irregularly quadrangular areolae.

This fine species is represented in collections from numerous localities and by a great number of specimens, of which enough have been figured to show the range in size, configuration of the base, and consequent differences in the nervation. The largest specimens are 12 to 16 centimeters. long and 8 to 12 centimeters wide; the smallest leaf observed (shown in fig. 4) is less than 2 centimeters long and is 1.25 centimeters wide. Another small leaf (fig. 3 ) is 4 centimeters long and 2.75 centimeters wide; and many are 8 to 9 centimeters long and 6 to 7 centimeters wide. In the smaller leaves (see fig. 3) the base is rounded or at most truncate; as the size increases (figs. 2, 5), it becomes slightly heartshaped and finally more marked (fig. 6); and ultimately it is deeply heart-shaped, which brings it to an auriculate form (figs. 1 and 2, Pl. XL).

In all these leaves the nervation is essentially the same. Thus, regardless of size, all are three- 
ribbed from the very base of the blade, and all show the same camptodrome secondaries or their branches, with the same strong, mainly unbroken nervilles. As the leaves become more deeply heart-shaped at base the secondary and tertiary nerves which supply the basal portion of the blade become more and more branched.

It is with a good deal of hesitation that this species is described as new: If it were not for the fact that an almóst unbroken gradation can be shown from the small truncate leaves on one hand to the large cordate-auriculate leaves on the other it might not be doing great violence to say that the series representing this species begins with Ficus speciosissima Ward, and ends with Ficus planicostata Lesquereux; in fact, if these extremes had not all been found in a single locality and collection, it is quite possible that they would have been so identified. So far as can be mado out at present, about the only difference between the largest of the leaves, here called F. leei, and F. speciosissima is in their size, for even the largest of $F$. leei are considerably smaller than $F$. speciosissima, and the average-sized leaves of $F$. leei are only about half as large. The task of separating the smaller truncate leaves of $F$. leei from $F$. planicostata is even more difficult. The leaves of F. leei appear to be thicker and to have a stronger nervation and are perhaps slightly more pointed at the apex, but at best these differences are not great. It is difficult to escape the conviction that all these leaves belong to a single species, and that for the present it is best considered as new, for if an attempt was made to divide them into two forms it would be practically impossible to draw any satisfactory line between them.

Occurrence: Vermejo formation (Cretaceous); collected by W. T. Lee-(fig. 4), Rockland mine, locality 120,3 miles southwest of Walsenburg, Colo. (5677); (fig. 6), dump of Coal Creek mine, Canon City field, near Rockvale, Colo. (5791); dump of Morley mine, Morley, Trinidad coal field, Colo., base of Vermejo formation (5709); in Canon City field near Rockvale, Colo. (sec: 25, T. 19 S., R. 70 W.) (5783); south wall of North Fork of Purgatoire Canyon, locality 136, above second coal bed from base of Vermejo formation (5800); Cimarron Canyon, N. Mex., locality 9, near top of Vermejo formation (5828); Ponil Canyon,
1 mile west of locality 11 , near top of Vermejo formation (5829).

\section{Ficus speciosissima Ward.}

Ficus speciosissima Ward, U. S. Geol. Survey Sixth Ann. Rept., p. 552, pl. 45, fig. 1, 1886; U. S. Geol. Sur'vey Bull. 37, p. 39, pl. 21, fig. 3, 1887.

This species, which has been so well described and figured by Ward, was described from Point of Rocks, Wyo., in beds then thought to be of Laramie age but which are now known to belong to the Montana group (Mesaverde formation). Since its original discovery it has been found at a number of widespread localities in Montana, Wyoming, and Colorado, and always within the Montana. It has been identified at several localities within the area covered by the present report. At first it was confused with certain of the larger examples that are now referred to Ficus leei, from which, as already pointed out, it is hardly to be distinguished except by size. In one of the collections-that from Cokedale near Trinidad - there is a large array of specimens that are referred after deliberation to this species. In size and in the configuration and nervation of the basal portion they are indistinguishable from $F$. speciosissima, but in the upper portion they are somewhat more elongated than in the original figure. It is not believed, however, that the difference is suffcient to exclude them from this species.

Occurrence: Vermejo formation (Cretaceous); dump of Cokedale mine, Cokedale, Colo., collected by W. T. Lee (5698); at locality 124, Spring Canyon, Vermejo Park, N. Mex. (5237); dump of mine 6 at Forbes, Colo. (5691); east wall of Vermejo Park, N. Mex., near locality 123, 25 feet below top of Vermejo formation, collected by W. T. Lee (5810); Bowen mine, locality 109, near Trinidad, Colo. (5692); Canon City field (sec. 30, T. 19 S., R. 69 W.) (5790); dump of Rockvale mine, Rockvale, Colo. (5793); Alkali Gap, Canon City field, Colo. (5775); Rockvale, Colo., near reservoir, collected by F. H. Knowlton.

\section{Ficus? starkvillensis Knowlton, n. sp.}

Plate XXXVIII, figure 9.

Leaf thick in texture, narrowly lanceolate, long. wedge-shaped at base to the thick petiole (apex destroyed); 'margin perfectly entire; 
nervation all effaced except the relatively thick midrib.

The figured specimen is the best of the two or three available but lacks all of the upper third or more of the blade. Its width is 1.75 centimeters and its length apparently about 10 centimeters. Another very fragmentary specimen is 2.5 centimeters wide.

It is really hardly worth while to name this form, as it is so broken and has only the midrib preserved, but it seems best to call attention to the fact that a leaf of this character is present. It is of about the same shape and size as certain American specimens from the Laramie formation of the Denver Basin, referred by Lesquereux ${ }^{1}$ to Ficus lanceolata Heer (now called. Ficus navicrilaris Cockerell), but the absence of nervation makes it impossible to authenticate this identification: There is also great uncertainty as to whence the specimens figured by Lesquereux actually came, though the same forms have been found in the Laramie by subsequent investigators.

Occurrence: Vermejoformation (Cretaceous); collected by W. T. Lee-dump of Starkville mine, Starkville, Colo. (5707), in association with Sequoia obovata, S. reichenbachi, eto.; dump of mine 6 at Forbes, Colo. (5691); dump of Gray Creek mine, about 40 feet above the base of Vermejo formation (5710).

Ficus praetrinervis Knowlton, n. sp.

Plate XILI, figures 1-4; Plate XIII, figure 1.

Leaves of firm texture, broadly ovate in shape, more or less abruptly rounded below to the decurrent base, and apparently rather obtuse above; margin perfectly entire; three ribbed from the base of the decurrent or wodge-shaped basal portion of the blade; central rib (midrib) straight, terminating in the tip of the blade, with two or three pairs of secondaries in the upper portion; lateral ribs nearly or quite equal in size to the midrib, equally dividing the distance between midrib and the margin of the blade, curved and becoming approximately parallel to the midrib, thin above and apparently lost before reaching the upper third of the blade, each with two to four secondary branches on the outside, these being camptodrome and arching well inside the margin; finer nervation obsolete.

1 Lesquereux, Leo, The Tertiary flora: U. S. Geol. Survey Terr. Rept., vol. 7, pl. 28, figs. 1-5, 1878.
This species is represented by a great number of specimens, showing a considerable range in size. The larger examples are about 10 centimeters long and about 7 centimeters wide; smaller ones not more than 6 or 7 centimeters long and 4 centimeters wide. An average size is about 8 by 5 centimeters.

In the Newberry material, now the property of the United States National Museum, there are some especially well preserved examples which exhibit the whole length of the petiole. In a few specimens (see fig. 3) the petiole is from a third to almost half as long as the blade, and the three principal ribs run clear to the very base, being compressed and lying side by side in the lower part.

This species is very closely allied to and has frequently been confused with Ficus trinervis Knowlton, which in turn was for many years confounded with Cinnamomum affine Lesquereux. The status of these two species, which I have previously set forth at length, may be briefly recapitulated. ${ }^{2}$ Cinnamomum affine was first described from the true Laramie formation at the Marshall mine, near Denver, Colo., and was subsequently reported from a number of localities near Golden, Colo., presumably from the Laramie, though this can not be positively ascertained.

The species was figured by Lesquereux, ${ }^{3}$ but the source and location of the figured specimens are uncertain. In later work, however, it has come to be pretty generally recognized that Cinnamomum affine Lesquereux belongs to the Laramie, its presence in beds older than this being uncertain or incorrect.

Ward obtained some very fine material from Black Buttes, Wyo., which he referred to Cinnamomum affine Lesquereux. ${ }^{4}$ These specimens agree perfectly with one of the Lesquereux figures (5) but are wholly unlike what may be called typical $C$. affine as depicted in figures 1-4, 7. It was these Black Buttes specimens as figured by. Ward, together with Lesquereux's figure 5 above mentioned, that were made the basis of Ficus trinervis Knowlton. This latter species is very abundant at Black Buttes, in beds which are regarded by the author as of post-Laramie age, and it has

2 Knowlton, F. H., Flora of the Montana formation: U. S. Geol. Survey Bull..163, p. 42, 1900 .

${ }^{8}$ Lesquereux, Leo, The Tertiary flora: U. S. Geol. Survey Terr. Rept. vol. 7, pl. 37, figs. 1-5, 7, 1878

- Ward, L. F., op. cit., pl. 47, figs. 1-3. 
since been reported from a number of horizons in Wyoming; Montana, and Colorado, though probably not always correctly.

Ficus trinervis was admitted into the Montana flora ${ }^{1}$ on the basis of several very poor specimens (U. S. Nat. Mus., Nos. 312 a, b, c) from Point of Rocks, Wyo. It is probable that these should now be referred to Ficus praetrinervis, but they are too poor to be of much value in any connection. Ficus trinervis was not noted at or near Point of Rocks nor in any recent material.

As already stated Ficus praetrinervis is very closely related to $F$. trinervis, the difference being in the lateral ribs and their running to the base of the very long petiole. In F. trinervis these ribs, which of course arise at the same point as the midrib in the wedge-shaped basal portion of the blade, are practically straight or even arch slightly. outward, and join with the lowest pair of secondaries on the midrib. In $F$. praetrinervis the lateral ribs, though they arise in much the same manner as in the older species, are uniformly curved so that they shortly become parallel to the midrib and appear to be lost in the upper part of the blade; or may reach nearly or quite to the upper margin. Although this difference is not great it appears to be constant and may serve to distinguish the two forms.

Ficus praetrinervis is a very abundant species in the Canon City, Colo., field, where it was identified by Lesquereux as Cinnamomum affine.

I have also figured from Riley Canyon, Colo., another nearly perfect specimen from above the conglomerate and hence in the Raton formation. It is the only specimen in this collection and is rather larger than usual. There is also a single example of this species in one of the large collections from Wootton, Colo., and thus in the upper beds. It was probably a specimen similar to this that was once identified by Lesquereux as his Cinnamomum mississippiense, which it much resembles.

Occurrence: Vermejo formation (Cretaceous); Canon City field, Colo., Coal Creek, near Rockvale, collected by George Hadden; Newberry collection, from same locality and presumably by same collector; 1 mile south of

1 Knowlton, F. H., op. cit., p. 43.
Rockvale, Colo., collected by W. T. Lee (5789); Canon City field (sec. 30, T. 19 S., R. 69 W.), collected by W. T. Lee (5790); Canon City field (sec. 18, T. 19 S., R.69 W。) (5779); following localities, all by W. T. Lee-Spring Canyon, locality 124, Vermejo Park, N. Mex. (5237); locality 136, near La Veta, Colo. (5675); Starkville, Colo. (5707); dump of mine 6, Forbes, Colo. (5691); dump of Gray Creek mine, Colo. (5710); Cuatro, in Tercio Park, Colo. (5805); Spring Canyon, locality 124, Vermejo Park, N. Mex. (5807); following localities, by G. B. Richardson's party-Simpson's mine, 3 miles south of Walsenburg, Colo. (5130); roof of Cameron mine, 3 miles south of Walsenburg, Colo. (5044). Raton formation (Tertiary); Riley Canyon, one-half mile north of Cokedale, Colo., 100 feet above the base of the Raton formation, collected by W. T. Lee (5699); Wootton, Colo., 50 to 100 feet above Wootton coal, collected by W. T. Lee (5712); hogback, 2 miles southeast of Dean, Colo., in slide rack, collected by G. B. Richardson's party (5113).

Ficus regularis Knowlton, n. sp.

Ficus irregularis (Lesquereux) Lesquereux (in part), U. S. Geol. and Geog. Survey Terr. Bull., vol. 1, 1875, p. 368, 1876; U. S. Geol. Survey Terr. Rept., vol. 7 (Tertiary flora), p. 196, pl. 63, fig. 9, excl. pl. 34, figs. 4-7, 1878; (Ulmus? irregularis Lesquereux, U. S. Geol. Survey Terr. Ann. Rept., 1871, p. 378, 1872), not $F$. irregularis Miquel, Ann. Mus. Bot. Lugduno Batavum, vol. 3, p. 224, 1867.

Ficus coloradensis Cockerell (in part), Torreya, vol. 10, p. $223,1910$.

Similar in size and shape of leaf to F. irregularis but with the secondary nerves regular in size and spacing instead of irregular.

In the several collections, but especially in those from the Canon City field, there are a number of rather large thick leaves that are very close to the leaves of $F$. irregularis. They are presumably the same as the single leaf figured by Lesquereux from Point of Rocks, Wyo., under this name. The Canon City specimens are preserved on a coarse-grained matrix and it is somewhat difficult to make out the characters.

Occurrence: Vermejo formation (Cretaceous); Canon City field, Colo., north of Coal Creek (sec. 30, T. 19 S., R. 69 W.), collected by W. T. Lee (5790). Montana group; Point of Rocks, Wyo. 
Ficus rhamnoides Knowlton.

Ficus rhamnoides Knowlton, U. S. Geol. Survey Bull. 163, p. 47, pl. 10, figs. 1-3; pl. 11, fig. 1, 1.900; U. S. Geol. Survey Prof. Paper 98, p. 339, pl. 86, fig. 10, 1916.

This species, described originally from the Montana group at Point of Rocks, Wyo., is represented by one nearly perfect example and by several more fragmentary specimens.

Occurrence: Vermejo formation (Cretaceous); Coal Creek (Rockvale), Colo., collected by George Hadden (U. S. Nat. Mus., 51168).

Ficus rockvalensis Knowlton, n. sp.

Plate XL, figures 3,4 .

Lerves small, thick and coriaceous in texture, ovate-lanceolate or slightly obovate-lanceolate, acuminate, rather abruptly rounded to the slightly unequal sided base; margins perfectly entire; nervation very deeply impressed, consisting of a very strong, perfectly straight midrib and five or six pairs of strong secondaries, which arise at an acute angle, are alternate below and subopposite above, and curve inward just at the margin; nervilles numerous, very strong, approximately at right angles to the midrib, usually broken, occasionally precurrent; finer nervation producing large quadrangular areas.

The smaller of the two specimens figured is ovate-lanceolate in shape, being about 6 centimeters in length and a little over 2 centimeters in width. It is characterized by its small sizc, unequal-sided base, deeply impressed nervation with especially strong nervilles. In this latter feature it suggests the genus $R$ hamnus, especially $R$. cleburni and $R$. goldianus of the Denver formation, though of course the shape, size, and secondary nervation in these species are totally different. On the whole it is best referred to Ficus, being, for instance, very similar to certain of the leaves from the Montana group at Point of Rocks, Wyo., that have been referred to $F$. dalmatica Ettingshausen. ${ }^{1}$ Though similar in size, shape, and general appearance, it differs in the regular close, parallel secondaries at an acute angle and in the marked appearance of the nervilles. In other words, the nervation is light in $F$. dalmatica and very strongly impressed in F. rockvalensis.

1 Lesquereux, Leo, The Tertiary flora: U. S. Geol. Survey Terr. Ropt., vol. 7, p. 199, pl. 63, fig. 4, 1879.
The other specimen referred here with some hesitation is slightly obovate-lanceolate or elliptical in shape with a nearly equal base and an acuminate apex.

Occurrence: Vermejo formation (Cretaceous); low hill opposite the baseball park, Rockvale, Colo., about 100 feet above the Rockvale sandstone member of the Vermejo, collected by F. H. Knowlton, 1909 (5477).

\section{Ficus gigantea Knowlton, n. sp.}

Plate XLIII.

Leaf of very large size, ovate or ovateelliptical, rounded, and obtuse at apex, apparently abruptly rounded or truncate at base; margin entire; nervation very strong, consisting of a thick straight midrib and seven or eight pairs of strong, alternate secondaries at an angle of about $45^{\circ}$, the lower ones occasionally branched, all camptodrome and forming loops near the margin; nervilles numerous, very strong, mainly unbroken, and at right angles to the secondaries.

This species is represented by two well-preserved leaves-the larger of which is figuredand a few fragments. The smaller unfigured leaf is 15 centimeters in length and about 12 centimeters in width; the larger one is about 24 centimeters long and about 18 centimeters wide; but it unfortunately lacks the basal portion and most of the margin on one side. Both are very well marked by the strong nervation.

The smaller leaf somewhat resembles Ficus spectabilis Lesquereux, ${ }^{2}$ from the Denver formation, but it is proportionately broader, has fewer secondaries, and a somewhat flexuose midrib. The figured specimen does not resemble closely any species with which I am familiar. The extreme upper part is quite like $F$. speciosissima Ward; but the basal part differs markedly. It is much larger than the latter species and is about twice the size of any other species reported from this area.

Occurrence: Vermejo (?) formation (Cretaceous); south side of Santa Clara Canyon, near water-tank of Rouse mine, Colorado, collected by W. T. Lee (5685), on same stone with Credneria protophylloides. 
Ficus tessellata Lesquereux (MS.), n. sp.

Plate XLI, figure 5.

Leaves coriaceous in texture, lanceolate, equally narrowed upward from the middle to an acute point and downward to the base; margin entire or slightly undulate; midrib thin but very distinct, straight; secondaries ten or twelve pairs, at an acute angle $\left(20^{\circ}\right)$ of divergence, equally spaced, parallel, camptodrome, following the borders in large marginal loops; nervilles strong, at right angles to the secondaries, simple and continuous, forming large square meshes.

This species is represented in the earlier collections by two specimens, the best of which is here figured. This leaf is nearly perfect, lacking but a small portion of the tip. It is about 11 centimeters long and a little more than 2.5 centimeters wide. The less perfect specimen is apparently slightly shorter but of about the same width.

This species, as Lesquereux points out, is perhaps closest to Ficus lanceolata Heer, ${ }^{1}$ yet differs in being much narrower and in having a more regular nervation, the secondaries being at a more acute angle, and the aerolation more pronounced. It also has some resemblance to leaves usually referred to Rhamnus salicifolius Lesquereux, from which it appears to differ in having fewer more uniform secondaries and a different aerolation.

Occurrence: Vermcjo formation (Cretaceous); Coal Creek (Rockvale), Colo., collected by George Hadden (U. S. Nat. Mus., 51169).

\section{Ficus wardii Knowlton.}

Plate XLII, figure 2.

Ficus' wardii Knowlton, U. S. Geol. Survey Bull. 163; p. 48 , pl. .9 , fig. 1,1900 .

The type of this species, came from Point of Rocks, Wyo., in beds of the Rock Springs coal group (in the Mesaverdeformation). The example here figured is not so large as the original specimen, but it does not otherwise differ from it. At first sight it somewhat resembles small leaves of Ficus speciosissima and F. leei, but it is separated at once by having five instead of three ribs.

Occurrence: Vermejo formation (Cretaceous); Oakdale mine, locality 140 , northwest

1 Heer, Oswald, Flora tertiaria Helvetiae, vol. 2, pl. 81, figs. 3-5, 1855. of La Veta, Colo., collected by W. T. Lee (5672), associated with Woodwardia crenata, Sequoia obovata, and S. reichenbachi; McAnily mine, Walsenburg, Colo., collected by W. T. Lee (5676); Simpson mine, 2 miles south of Walsenburg, Colo. (sec. 21, T. 28 S., R. 66 W.), collected by G. B. Richardson's party (5130); roof of deserted mine, locality 108, near Bowen, Colo., collected by W. T. Lee (5694); Rockvale, Colo., in Canon City field (in sec. 25, T. 19 S., R. 70 W.), collected by W. T. Lee (5783).

Ficus curta Knowlton, n. sp.

Plate XLII, fig. 5.

Ficus curta? Knowlton, U. S. Geol. Survey Prof.. Paper 98, p. 338, pl. 88, fig. 3, 1916.

Leaves thick in texture, ovate in shape, abruptly rounded to the decurrent base (apex destroyed); petiole rather slender; midrib slender, straight; secondaries about three pairs, lowest pair arising at the base of the blade, at an acute angle, passing high up, each with two or three tertiary branches on the outside; upper secondaries remote, opposite, slightly curved upward, apparently camptodrome; all finer nervation obsolete.

These leaves are about 7 centimeters in length and 4.5 centimeters in width; the petiole is preserved for 1.5 centimeters and is probably not quite complete. The matrix is so coarse grained that only the primary nervation can be made out.

This species undoubtedly approaches closely to Ficus planicostata goldiana Lesquereux, ${ }^{2}$ from the Denver formation of the Denver Basin, but it appears to be a thicker leaf with a more decurrent base and to have fewer tertiary branches on the lower secondaries.

Occurrence: Vermejo formation (Cretaceous), Canon City field, Colo., 1 mile east of Rockvale (sec. 30 , T. 19 S., R. 69 W.), collected by W. T. Lee (5790).

\section{Ficus sp.}

Plate XLV, figure 1.

In the collections from the Canon City field $I$ find a fragmentary. leaf-the one here figured-that evidently belongs to the genus Ficus but is too imperfect to admit of proper characterization. It was a large leaf, probably 12 centimeters or more in length and about 10

${ }^{2}$ Lesquereux, Leo, op. cit., pl. 33, figs., 1, 2. 
centimeters in width, and was evidently very thick. The nervation is very thick and heavy, consisting of a straight midrib and at least three pairs of secondaries, the lowest pair bcing provided with about six tertiary branches on the lower side. At base the leaf is rounded truncate, and judging from the appearance of the secondary nerves it seems not. improbable that it was lobed above, but this is impossible of verification. In some respects it suggests Dombeyopsis platanoides Lesquereux, ${ }^{1}$ from the lower coal-bearing portion of the Livingston formation of Montana but differs from it in several points.

Occurrence: Vermejo formation(Cretaceous); Canon City field, Colo., 1 mile east of Rockvale, at base of coal-bearing rock (sec. 30, T. 19 S., R. 69 W.), collected by W. T. Lee (5790).

\section{Artocarpus dissecta Knowlton, n. sp.}

Plate XLII, figure 6.

Leaf of large size and firm texture, deeply cut into at least three pairs of opposite lobes, the upper ones separated by broad rounded sinuses, the lower pair remote from the ones next above and connected with them by an exceedingly narrow wing which is hardly more than the petiole; lower lobes nearly at right angles, irregularly ovate-lanceolate, apparently obtuse, the blade cut away on the lower side nearly to the midrib; upper lobes at an angle of about $45^{\circ}$, spreading, acute; each lobe with a midrib, which has several camptodrome branches on the lower side and an additional rib above the midrib; a short secondary from the main midrib passes up to and forks just under the sinuses in the upper part of the leaf; finer nervation irregular.

Unfortunately the specimen figured is the only one observed of this particular form and is far from perfect, lacking all of the upper portion as well as the tips of the lobes. Its size can not of course be ascertained, though it was presumably at least 18 to 20 centimeters long and about 16 centimeters broad between the points of the lower lobes.

This leaf is very remarkable in that it has the lower pair of lobes separated from the ones above by a distance of nearly 2 centimeters of practically bare midrib-that is, the wing connecting the two is so reduced as to be almost nonexistent. The lower lobes are also curiously cut into almost to the midrib on the lower side, whereas on the upper side it is attached by the whole base. Otherwise this leaf is undoubtedly most closely related to Artocarpus lessigiana (Lesquereux) Knowlton, ${ }^{2}$. from the Laramie formation of the Denver Basin. The general shape, number, configuration, and type of nervation of the lobes is practically the same in both, and it may well be that a series of leaves would show their identity; but as the facts now stand they are best considered apart.

Occurrence: Vermejo formation (Cretaceous); dump of McAnily mine, Walsenburg, Colo., collected by W. T. Lee (5676).

\section{Family CREDNERIACEAE. \\ Credneria protophylloides Knowlton, n. sp. Plate XLVI.}

Leaf of large size, evidently thick and firm in texture, apparently nearly orbicular in shape, about equally rounded to both base and apex; margin perfectly entire; petiole short, very stout, and thick, especially at the point of attachment; midrib very thick, thus directly continuing the petiole; secondaries about three pairs opposite, the lowest pair as strong as the midrib, arising high above the base of the lamina, considerably curved upward, each with five or six strong tertiary branches on the outside, these often again bearing outside branches, all camptodrome and forming broad bows just inside the margin; midrib between lowest pair of secondaries and the base of the lamina with two or three strong branches at right angles to it; nervilles very prominent and strong, mainly unbroken, nearly at right angles to the secondary or tertiary branches which they connect.

The leaf figured is the best preserved of any that belongs with certainty to this species, but it lacks much of one side and the apex. As far as can be made out it was nearly orbicular in shape, being probably about 20 centimeters long and about as much wide. The petiole is nearly 4 centimeters long and fully 5 millimeters thick at its point of attachment. Another still larger leaf was 28 to 30 centimeters long and 22 to 24 centimeters wide. These leaves are very strongly marked by the fact that the lowest pair of secondaries rises high above the base of the blade and runs up 
nearly to the apex of the leaf, each being provided with several strong, often branched tertiaries on the outside. Below the lower pair of strong secondaries there are two or three strong branches on the midrib which supply the basal portion of the blade. The nervilles, as already pointed out, are especially strong and prominent.

In the preliminary examination and without extensive study and comparison, it was thought that this leaf should be referred to the genus Protophyllum, which embraces so many large and striking leaves found in the Dakota sandstone. The resemblance was especially marked in the basal portion of the blade with its peculiar nervation, in the thick petiole, and in the numerous strong nervilles. That it can not belong to this genus, however, is shown by several essential points of disagreement: No known species of Protophyllum has its leaves three ribbed from above the base of the blade; normally Protophyllum has its leaves perfoliate; Protophyllum has the margin of the blade undulate or more or less toothed and the nervation craspedodrome. This genus may therefore be dismissed as untenable for the leaf under consideration.

The next genus naturally suggested is Ficus, of which many large, strongly nerved species have been described, but, so far as can be recalled, all have the secondaries or ribs-often from three to five or even seven-arising at the very base of the blade. The upper part of the specimen leaf has a strong resemblance to certain large species of Ficus, as, for instance, to $F$. speciosissima Ward, and it is not improbable that in previous studies portions of the species under examination may have been so referred. When the basal portion is present such reference is of course impossible.

The leaf under consideration is so unmistakably similar to the several forms ascribed to the genus Credneria, that there can be no doubt as to the correctness of its reference to this genus. Except as regards size it is hardly to be distinguished from Credneria integerrima Zenker ${ }^{1}$ from the Quadersandstein of Blankenburg, which, by the way, is the type of the genus. It also resembles in the basal portion certain other species from the same locality, as $C$. subtriloba Zenker and C. biloba Zenker, but

1 Zenker, J. C., Beiträge zur Naturgeschichte der Urwelt, pl. 2, fig. F, Jena, 1833. these latter seem to differ from it in the upper portions. $^{2}$

Occurrence: Vermejo formation (?) (Cretaceous); south side of Santa Clara Canyon, near water tank of Rouse mine, Colorado, collected by W. T. Lee (5685).

\section{Order RANALES}

Family LAURACEAE.

Laurus coloradensis Knowlton, n. sp.

Plate LXV, figure 3.

Laurus coloradensis Knowlton, U. S. Geol. Survey Prof. Paper 98, p. 340, pl. 88, figs. 4, 5, 1916.

Leaf narrowly lanceolate, tapering in about equal degree to both base and apex; petiole short (?), thick; midrib relatively very thick below but becoming very thin above; secondaries numerous, a dozen or more pairs, subopposite, much curved upward, camptodrome, arching near the margin and each joining the next above by a series of loops; intermediate secondaries frequent, usually joining the secondary next below; secondaries strong, oblique to the secondaries; finer nervation not. preserved.

The leaf here figured as the type of this species is narrowly lanceolate in shape, being about 11 centimeters in length and 2.5 centimeters in width; the petiole is preserved for a. length of 0.5 centimeter but probably is not. complete.

In the matter of nervation the present species approaches very closely to Laurus primigenia Unger, as figured by Lesquereux, ${ }^{3}$ but it differs. from this in size and to some extent in shape, being much larger and narrower, especially at. the base. Its thick petiole and thick basal portion of the midrib constitute other minor differences.

The species here described is probably the same as that reported from Point of Rocks, Wyo., under the name of Laurus primigenia, ${ }^{4}$ but which was so poorly preserved as to make the determination uncertain.

Occurrence: Vermejo formation (Cretaceous); Rockvale, Colo.; Newberry collection, probably made by George Hadden.

\footnotetext{
${ }^{2}$ Idem, pl. 3, fig. C; pl. 2, fig. A.

${ }^{3}$ Lesquereux, Leo, The Tertiary flora: U. S. Geol. Survey Terr. Rept., vol. 7 , pl. 36 , fig. 6,1878

4 Knowlton, F. H., Flora of the Montana formation: U. S. Geol. Survey Bull. 163, p. $58,1900$.
} 
Family MAGNOLIACEAE.

Liriodendron alatum Newberry (MS.).

Plate XLVIII, figure 3.

Liriodendron alatum Newberry MS. Hollick, Torrey Bot. Club Bull., vol. 21, p. 468, pl. 220, 1894.

Knowlton, U. S. Geol. Survey Bull. 163, p. 13, pl. 1, fig. 6, 1900.

Following is the original description as given by Hollick:

Leaves 4-5 inches wide, oblong or ovate in outline, rounded or somewhat cordate at base; deeply emarginate at apex, lobed or constricted at sides, or merely with wavy margins; petiole long, stout, and conspicuously winged; nervation characteristic of the genus, consisting of two sets of parallel secondaries, one strong, connecting near the margins in festoons, the other weaker and intermediate with the former.

The material upon which this species was founded was collected under the direction of R. C. Hills at Walsenburg, Colo., in beds supposed to be Laramie in age. The species was subsequently detected by the writer in a collection from the right bank. of Missouri River, 7 miles below the Conl Banks, near Virgelle, Mont., in the Eagle sandstone. The two or three somewhat fragmentary examples in the present collection are from Walsenburg, Colo., and doubtless came from or near the type locality. They are apparently not quite so large as the type specimen, the one figured being noticeably smaller, but in the shape of the base of the leaf and the size and appearance of the winged petiole they are indistinguishable.

Occurrence: Vermejo formation (Cretaceous) : dump of McAnily mine, Walsenburg, Colo.; collected by W. T. Lee (5676); Walsenburg, Colo., types, collected for R. C. Hills. Eagle sandstone, right bank Missouri River, 7 miles below Coal Banks, near Virgelle, Mont.

Order ROSALES.

\section{Family PLATANACEAE?}

Platanus? sp.

Plate XiLII, figure 3.

The collection from Rockvale, Colo., contains a single small, distorted leaf (fig. 3), probably stipular in position, that is presumed to belong to some species of Platanus. It is ovate in shape and very unequal sided. The margin is strongly toothed, with the secondaries (or, in the lower part, the tertiaries) entering the teeth. The nervilles are strong, mainly precurrent and platanoid in appearance.

Occurrence: Vermejo formation (Cretaceous) ; Canon City field, Rockvale; Colo., Newberry collection, presumably obtained by George Hadden.

\section{Family ROSACEAE. \\ Amelanchier obovata Knowlton, n. sp.}

Plate XLII, figure 4.

Leaf small, membranaceous in texture, obovate in shape, being rounded and obtuse at apex and obtusely wedge shaped at base; margin slightly toothed, the teeth remote, low; midrib thick, straight; secondaries about seven pairs, opposite, at an angle of about $40^{\circ}$, slightly curved upward, camptodrome; nervilles numerous, thin, approximately at right angles to the secondaries.

This little leaf, the only one observed, is regularly obovate in outline, 4 centimeters long and about 2.5 centimeters wide; it has a short portion of the petiole preserved. It is clearly rosaceous in character and agrees well with Amelanchier, being, for example, not greatly unlike $A$. alnifolia Nuttall, the familiar service berry of the Northwest. It is not like any of the fossil forms referred to this genus.

Occurrence: Vermejo formation (Cretaceous); dump of Coal Creek mine, Canon City field, Coal Creek, Colo., collected by W. T. Lee (5791).

\section{Family PAPILIONACEAE.}

Phaseolites crassus Knowlton, n. sp.

Plate XLV, figure 5.

Leaflet of firm texture, ovate-acuminate in. shape, rounded to the obtusely wedge-shaped base; margin perfectly entire; petiole nearly 1 centimeter long, exceedingly thick; midrib relatively strong, particularly just above the base of the blade; secondaries about eight pairs, alternate, arising at an angle of about $35^{\circ}$, curved upward, camptodrome, arching very near the border of the blade; nervilles numerous, fine, mainly precurrent and slightly oblique to the secondaries.

This handsome little leaflet is nearly perfect, lacking only a small portion of the apex. It has the blade about 6 centimeters long and 2.75 centimeters wide and a petiole nearly 1 centimeter long and more than 2 millimeters 
thick. The leaflet is slightly curved and unequal sided. It is well marked by this thick petiole and by the alternate, much-curved secondaries with the fine, slightly oblique nervilles.

Among the described species referred to this rather poorly defined genus the present species appears to approach most closely to Phaseolites elegans Hollick, ${ }^{1}$ from the Raritan formation at Brooklyn, N. Y. . With this it agrees very well in size and shape, though not so markedly falcate, and appears to differ principally in the very thick petiole. The secondaries also appear to be more numerous, more curved upward, and more markedly camptodrome, though this feature is not very well shown in the eastern species.

Occurrence: Vermejo formation (Cretaceous); Canon City field, Rockvale, Colo., Newberry collection, probably made by George Hadden.

Phaseolites leei Knowlton, n. sp.

Plate XLV, figure 6 .

Leaflet narrowly ovate-lanceolate in shape, broadest below the middle, thence rounded to the base and to the slender acuminate apex; margin entire; petiole short, very thick; midrib strong, especially below; secondaries about five pairs, at an angle of about $45^{\circ}$, curved upward, camptodrome; all finer nervation obliterated.

The leaflet figured is absolutely perfect. It is 7.5 centimeters in length and a little over 2 centimeters in width. As it is preserved on a coarse-grained sandstone, all traces of the finer nervation are obliterated and even the major nervation is none too clearly preserved. 'This species is similar to $P$. crassus but is longer, much narrower, and more symmetrical instead of slightly unequal-sided. It has also fewer secondaries.

Occurrence: Vermejo formation (Cretaceous); Canon City field, Colo., 1 mile east of Rockvale (sec. 30, T. 19 S., R. 69 W.), at base of coal-bearing rocks, collected by W. T. Lee (5790).

Phaseolites minutus Knowlton, n. sp.

Plate LIII, figure 4.

Leaflet of small size and evidently firm texture, slightly obovate-elliptical in outline, broadest near the middle, whence it rounds in

1 Hollick, Arthur, The Cretaceous flora of southern New . York and New England: U. S. Geol. Survey Mon. 50, p. 85, pl. 32, fig. 4, 1906. about equal degree to both base and apex; margin entire; midrib relatively thick, straight; secondaries apparently about three pairs but very obscurely preserved.

This little leaflet-the only one observed-is about 4 centimeters long and nearly 2 centimeters wide. The nervation other than the thick midrib is obscure, though apparently there are about three pairs of secondaries.

Occurrence: Trinidad sandstone (Cretaceous); 1 mile south of Raton, N. Mex., collected by W. T. Lee (5145).

Colutea speciosa Knowlton, n. sp. Plate XLIK, figure 4.

Texture of leaf firm, shape transversely elliptical, broader than long (4.5 centimeters wide, 3.5 centimeters long), about equally rounded to the emarginate apex and below to the small, abruptly decurrent base; margin perfectly entire; midrib thick below, straight, becoming very thin above; secondaries thin, about four pairs, at a very low angle, much curved upward, especially the uppermost pair, which turn in well toward the midrib; finer nervation obscure.

The little leaflet figured is the only one noted in these collections and is fortunately almost perfect, lacking only a very small portion of one margin. It is regularly rounded above to the emarginate apex, the sinus being sharp though not very deep. It was apparently thick in texture, as shown by the thick midrib and very faintly impressed secondaries; the latter are opposite or subopposite and curve sharply upward after starting nearly at right angles to the midrib. The leaflet appears certainly to be congeneric with various leaflets referred by Heer and others to Colutea. It is, for instance, very similar in shape to $C$. macrophylla and $C$. salteri ${ }^{2}$ from the Miocene of Switzerland, but it is very much larger and proportionately much broader than either. In the character of the emarginate apex it is like C. primordiales Heer, ${ }^{3}$ from the Upper Cretaceous of Greenland, but differs markedly from it in shape as well as in size.

Occurrence: Vermejoformation (Cretaceous); locality 125, west of Vermejo Park, N. Mex., in middle of Vermejo formation, collected by W. T. Lee (5809). 2 Heer, Oswald, Flora tertiaria Helvetiac, vol. 3, pl. 132, figs. 46, 47-57,
1859 .

${ }^{3}$ Heer, Oswald, Flora fossilis arctica, vol. 6, pl. 27, figs. 7-11, 1880. 
Order SAPINDALES.

Family Celastraceat.

Celastrus haddeni Knowlton, n. sp.

Plate XLV, figure 2.

Leaf small, firm in texture, narrowly and obliquely obovate, rounded above and narrowed below to the long wedge-shaped unequalsided base; margin perfectly entire; midrib relatively very strong, with five pairs of alternate, acute-angled secondaries, the lower pair arising at the very base of the blade and producing a three-ribbed effect; the lowest secondary on the broad side of the blade with several tertiary branches on the outside, these and all the upper secondaries camptodrome, arching just within the margin; finer nervation obscure.

This little leaf, the only one observed in the collection, is obovate in shape, being 4 centimeters in length and 2 centimeters in width at the broadest point, which is well above the middle. The leaf appears to be three ribbed from the base, but really the lowest pair of secondaries arise near the base of the midrib, thus simulating a true three-ribbed appearance. The nervation is well brought out in the figure and need not be further described. So far as known to me, there is nothing in the present collections to which this can be closely compared.

Occurrence: Vermejo formation (Cretaceous); Canon City field, Coal Creek (Rockvale), Colo., collected by George Hadden (U. S. Nat. Mus., 51373).

Celastrus? hesperius Knowlton, n. sp.

Plate XLIV, figure 5.

Leaf small, ovate or ovate-elliptical, rather abruptly narrowed to a wedge-shaped base and to the obtuse apex; margin undulate-toothed throughout; midrib relatively strong, straight; secondaries about five pairs, alternate, at an angle of about $45^{\circ}$, apparently camptodrome, but this and the finer nervation obscure.

This little leaf, the only one observed in the collections, is hardly worthy of a name, yet it appears to be different from anything previously noted. It is 4.5 centimeters long and about 3 centimeters wide.

Occurrence: Vermejo formation (Cretaceous); Canon City field, Coal Creek (Rockvale), Colo., collected by George Hadden (U. S. Nat. Mus., 51254).

Celastrus? sp.

Plate XLVII, figure 6.

The mere fragment figured is all that was found of this form, and if it were not apparently a well-marked type it would hardly be worthy of mention. It was probably elliptical in shape, about 10 centimeters long and 7 centimeters wide, with the margin provided with numerous relatively large round-pointed teeth. Very little of the nervation beyond the thick midrib and a few delicate secondaries can be ascertained. It appears to possess characters that would place it in Celastrus, but this is very uncertain, and it is presented simply to call attention to the fact that there is a large, peculiarly toothed leaf present in these beds.

Occurrence: Vermejo formation (Cretaceous); locality 125, west of Vermejo Park, N. Mex., collected by W. T. Lee (5809).

\section{Order RHAMNALES. \\ Family RHAMNACEAE.}

Rhamnus salicifolius Lesquereux.

Rhamnus salicifolius Lesquereux, Am. Jour. Sci., $2 \mathrm{~d}$ ser. vol. 41, p. 206, 1868; U. S. Geol. Survey Terr. Ann. Rept., p. 196, 1869; idem, 1872, p. 400, 1873; U. S. Geol. and Geog. Survey Terr. Ann. Rept., 1873, p. 382, 1874; idem, 1876, p. 517, 1878; U. S. Geol. Survey Terr. Rept., vol. 7 (Tertiary flora), p. 282 , pl. 53, figs. $9,10,1878$.

Knowlton, U. S. Geol. Survey Bull. 163, p. 70, 1900.

The type locality for this species is Marshall's coal mine, Boulder County, Colo., in beds of true Laramie age. Of the two examples figured by Lesquereux as types of the species, the original of figure 9 is the specimen above mentioned from Marshall's, and the original of figure 10 is said to have come from Black Buttes, Wyo. Neither of these specimens can now be found in the collections of the United States National Musuem, where they are supposed to be; and as the species has not been subsequently detected at Black Buttes, its occurrence at this locality is for the present held to be questionable. The species has proved to be more or less abundant in the Laramie formation of the Denver Basin, occurring at Coal Creek, Boulder County, Erie, and at Golden. It has subsequently been iden- 
tified with some question in the Montana group near Harper station; Wyo., and is now known to be fairly common in beds of similar age near Rock Springs, Wyo.

In the material from Coal Creek (Canon City field), Colo., collected by Hadden and studied by Lesquereux in the Lacoe collection, are two leaves which were regarded by him as representing a new species of Rhamnus. They are rather fragmentary, lacking both base and apex, but so far as can be made out they do not differ from the smaller of the two leaves figured by Lesquereux as types of Rhamnus salicifolius and they are so referred.

Occurrence: Vermejo formation (Cretaceous); Canon City field, Coal Creek (Rockvale), Colo., collected by George Hadden (U. S. Nat. Mus., $51219,51220)$; ? 2 miles west of Trinidad, Colo., near locality 106 (sec. 15, T. 33 S., R. 64 W.), 70 feet above base of Vermejo formation, collected by G. B. Richardson's party (5098).

Zizyphus paliurifolius Knowlton, n. sp.

Plate XLVII, figures 1-4.

Leaves variable in size, membranaceous in texture, ovate or ovate-elliptical in shape, about equally rounded to both base and apex; margin perfectly entire; nervation triple ribbed from the base of the blade, the rib of about equal strength, the lateral ones at an acute angle and passing up nearly or quite to the apex; midrib straight, with one or two pairs of alternate secondaries, usually in the upper portion only; lateral ribs with four or five pairs of secondary branches on the outside, these being simple in the smaller leaves and forked in the larger ones, camptodrome; nervilles strong, at right angles to the midrib.

There are seven specimens in the small collection representing this locality, which, although differing greatly in size, appear to belong together. The smallest leaf (fig. 1) is 4 centimeters long and about 2.5 centimeters wide, and the largest (fig. 4) probably was not far from 12 to 14 centimeters long and 10 centimeters wide. The most perfectly preserved example (fig. 2) is 4.5 centimeters long and a little over 3.5 centimeters wide. Others of intermcdiate size are about 10 centimeters long and 7 centimeters wide.
At first sight these leaves appear very different, but they all have the same peculiar nervation, and when arranged in a series on the basis of size it seems impossible to draw any satisfactory line between them. It would seem that they may either be referred to one species or to almost as many as there are leaves.

The species appears to be related to $Z i z y p h u s$ distortus Lesquereux ${ }^{1}$ or $Z$. fibrillosus Lesquereux, both from the Denver formation of the Denver Basin of Colorado.' From Z. fibrillosus it differs in the base and moré particularly in the absence of the peculiar nervilles, and from $Z$. distortus in size and in certain details of nervation; it is, however, closer to $Z$. distortus than to $Z$. fibritlosus.

The small leaves of this species (particularly fig. 2) are very similar to those of Paliurus colombi Heer, as identified for instance by Lesquereux ${ }^{2}$ from the lower Tertiary of Carbon County, Wyo., but even the smallest is considerably larger than any of the Carbon County leaves: They also show differences in the nervation, the secondaries, for instance, passing nearly or quite to the margin and there joining a marginal vein instead of being plainly camptodrome and curving some distance below the margin.

Occurrence: Vermejo formation (Cretaceous); Vermejo Park, N. Mex., locality 123, near top of Vermejo formation, collected by W. T. Lee (5810).

Order MALVALES.

Family STERCULIACEAE.

Sterculia coriacea Knowlton, n. sp.

Plate LXVIII, figure 1.

Leaf coriaceous in texture, cuneate at base, palmately three lobed, the lobes cut nearly to the base, narrowly lanceolate, acuminate; margins perfectly entire; petiole long and very strong; nervation consisting of a midrib for each lobe, those for the lateral lobes joining the one for the central lobe well about the base of the blade; additional nervation now obsolete.

This very characteristic leaf is 8 centimeters long from the top of the petiole to the apex of

${ }^{1}$ The Tertiary flora: U.S. Geol. Survey Terr. Rept., vol. 7, p. 275, pl. 51 , figs. 7-9, pl. 52 , figs. $1-6,1878$.

2 Idem, pl. 50, figs. 13-17. 
the central lobe and nearly 9 centimeters wide between the tips of the lateral lobes. The lobes are 4 to 5 centimeters long and nearly 1.5 centimeters wide at the base. The petiole is 3.5 centimeters long and is relatively very strong. The lateral lobes stand nearly at an angle of $45^{\circ}$ with the central lobe. The only nervation, at least the only nervation preserved, is the rather light midrib for each lobe.

This species is of the same type as Sterculia reticulata Lesquereux, ${ }^{1}$ from the Dakota sandstone of Kansas, and S. rigida Lesquereux, ${ }^{2}$ from the Miocene of Florissant, Colo. It is, however, considerably larger than either of these species; it differs from the first in having acuminate instead of obtuse lobes and absence of reticulate nervation, and it differs markedly from the second in having the lobes more than twice as broad and the base more broadly cuneate. The petiole is very like that of $S$. reticulata.

Occurrence: Vermejo formation (Cretaceous) locality 124; Spring Canyon, Vermejo Park, N. Mex, at top of Vermejo formation, collected by W. T. Lee (5237).

\section{Pterospermites undulatus Knowlton.}

Pterospermites undulatus Knowlton, U. S. Geol. Survey Bull. 163, p. 67, pl. 16 (fig. 3), pl. 17 (fig. 2), pl. 18 (fig. 4), 1900.

Several rather imperfect leaves that are referred to this species are contained in collections from the vicinity of Rockvale, Colo., and it is present in material collected by Lee in Vermejo Park, N. Mex.

Occurrence: Vermejo formation (Cretaceous); Canon City field, Còal Creek (Rockvale), Colo., collected by George Hadden (U. S. Nat. Mus. 51328, 51330); Vermejo Park, N. Mex., near locality 123 , collected by W. T. Lee (5810); near Rockvale, Colo., in the Canon City field (sec. 2S, T. 19 S., R. 70 W.), near base of rim rock, collected by W. T. Lee (5782).

\section{Pterospermites wardii Knowlton.}

Pterospermites wardii Knowlton, U. S. Geol. Survey Bull. 163 , p. 66 , pl. 16, fig. 1, 1900 .

In the material from Walsenburg, Colo., there is a single leaf that appears to belong to

IIesquereux, Leo, The flora of the Dakota group: U. S. Geol. Survey Mon. 17, pl. 34, fig. 10, 1892.

2 Lesquereux, Leo, The Cretaceous and Tertiary floras: U. S. Geol. Survcy Terr. Rept., vol. 8, pl. 34, fig. 12, 1883. this species. It is so badly preserved that it adds nothing to our knowledge of the species, and consequently it has not been figured. It is of about the same size as the figure above quoted. and appears to agree with it in all essential characters of margin and primary and finer nervation.

Occurrence: Mesaverde formation (Cretaceous) ; Point of Rocks, Wyo. Vermejo formation (Cretaceous); dump of McAnily mine, Walsenburg, Colo., collected by W. T. Lee (5676).

Pterospermites nervosus Knowlton, n. sp.

Plate XLVIII, figure 4.

Leaf large, apparently of nearly regular elliptical outline, very obtuse at apex and apparently truncate or rounded at base; margin perfectly entire; midrib straight, very thick, grooved; principal secondaries about eight pairs, thin, alternate, at irregular distances, the two lowest pairs arising at the same point high above. the base of the blade, one pair at right angles to the midrib, the other pair (and all above it) at an angle of about $45^{\circ}$, camptodrome, forming broad loops just below the margin; one or two pairs of thinner secondaries below the principal ones supply the basal portions of the blade; nervilles numerous, thin, very irregular and broken, the finer nervation forming rather large; irregularly quadrangular areolae.

The specimen figured, which lacks all, or nearly all, of the basal margin, is the only one observed in the collections. It was apparently nearly regularly elliptical in shape and was about 13 centimeters long and 11 centimeters wide.

In some respects, particularly in its upper portion, this leaf suggests Magnotia, but the peculiar disposition of the nerves in the basal portion precludes its reference to this genus. Its basal nervation suggests ProtophyПlum, but from this genus it is excluded by the fact that in all 'species of Protophyllum the secondary nervation is craspedodrome; ending in the margin, or, more commonly, in marginal teeth. The present leaf is perfectly entire and the nervation camptodrome, which admits it to the genus Pterospermites. The configuration of the base is not known, but the arrangement of the basal nervation agrees well with that of several described species, such, for instance, as $47019^{\circ}-17-18$ 
$P$. dentatus Heer, ${ }^{1}$ from the Miocene of the Mackenzie River region; it differs from this, however, in having marginal teeth.

Occurrence: Vermejo formation (Cretaceous) ; Rockland mine, locality 120, 3 miles'southwest of Walsenburg, Colo., near top of Vermejo formation, collected by W. T. Lee (5677).

Hedera rotundifolia Knowlton, $n$. sp.

Plate XLVII, figure 8.

Leaf thickish in texture, orbicular in shape, rounded and very slightly heart-shaped at -base, rounded and obtuse at apex; margin perfectly entire; nervation relatively strong, three ribbed from the top of the petiole; midrib with one pair of secondaries in the upper part; lateral ribs at an angle of about $45^{\circ}$, slightly curved upward, each with three or

four secondary branches on the outside, standing at right angles to the midrib; finer nervation not preserved.

This little leaf is about 3.5 centimeters long and 4.5 centimeters broad. As the matrix in which it is preserved is very coarse grained all trace of the finer nervation has been obliterated, so that beyond the three principal ribs and the few secondary branches it is not possible to go. It can not be made out whether the secondaries are camptodrome or craspedodrome, though presumably the former.

Occurrence: Vermejo formation (Cretaceous); locality 129, south of Francisco Pass, west of Raton, N. Mex:, at the base of the Vermejo formation, where it is associated in the same hand specimens with marine invertebrates, such as Tellina scitula Meek and Hayden, and Panopaea? sp., colliected by W. T. Lee (5806).

\section{Family VITACEAE.}

Vitis? fragmenta Knowlton, n. sp.

Plate XLVII, figure 7.

Leaf rather coriaceous in texture, outline unknown but presumably nearly. circular, very deeply heart-shaped at base, the lobes broad, rounded, and nearly overlapping; margin apparently coarsely toothed, but this point is obscure; nervation three ribbed from the top of the petiole, the midrib strong, with at least one pair of nearly opposite secondaries; lateral ribs at an angle of about $45^{\circ}$, nearly as strong as the midrib, slightly curved upward,

1 Heer, Oswald, Flora fossilis arctica, vol. 1, pl. 22, figs. 6, 7, 9, 1868. each with several secondary branches on the outside which supply the cordate base.

A single fragment is all that was found of this form. It is impossible to determine its exact size, though it appears to have been about 7 centimeters long and about 6 centimeters wide. The margin in the lower portion appears to be coarsely toothed, but the matrix is a rough sandstone and it is difficult to be certain of the true margin.

This specimen is so fragmentary that were it not from the lowest beds of the Vermejo formation it would hardly be worthy of name and description. It appears to resemble the genus Vitis most closely, but its reference thereto may not be correct.

Occurrence: Trinidad sandstone (Cretaceous); 1 mile south of Raton, N. Mex., collected by W. T. Lee (5145).

\section{Cissites panduratus Knowlton, n. sp.}

Plate LXIX, figure 10.

Leaf membranaceous in texture, very broadly ovate or nearly circular in general outline, truncate at base, deeply cut by broad rounded sinuses into five large lobes; middle lobe obovate, probably with two or three small lobes; next pair of lobes symmetrical, unequal sided, somewhat obovate, obtuse; lowest pair of lobes symmetrical, smaller than the others, nearly at right angles to the midrib, obtuse; nervation five palmate from the top of the petiole, the ribs straight, terminating in the apex of the lobes; middle rib with about five pairs of slender secondaries; lateral ribs near upper margin of the lobes, each with two or three pairs of slender alternate secondaries, except the lower pair, which has the secondaries on the lower side only.

This species is represented at present only by the splendid specimen figured, which is nearly perfect. It is about 7 centimeters in length and 7 centimeters between the points of the lower lobes and a little less between the tips of the middle lobes. The slender petiole is preserved for 2.5 centimeters and was probably a little longer when perfect. The sinuses, as will be noted in the figure, are very broad and rounded; under each of the upper ones there is a secondary branch of the midrib which forks and passes in either direction just within the border. Aside from the few secondary 
branches shown in the figure, the finer nervation is not preserved.

The species appears at first sight to be related to a number of forms among living and fossil species. It suggests certain deeply lobed leaves of Acer, but its lobes are all entire or, in any event, are without the sharp teeth and lobes usually characteristic of the maples. It also remotely resembles certain of the very deeply lobed leaves of Liriodendron, and the position of its ribs near the upper margin of the lateral lobe is not unlike the conditions in this genus, but its facies is on the whole different. It also suggests certain species of Vitis and $C i s s u s$, though the resemblance is not particularly close in any living species noted in the National Herbarium. On the whole it seems to be most like the genus $C$ issites, being, for instance, strongly suggestive of $C$. formosus Heer, as figured by Lesquereux. ${ }^{1}$ The latter, however, is only three lobed and the present form is not conspecific with it.

Occurrence: Vermejo formation (Cretaceous); locality 120, Rockland mine, 3 miles southwest of Walsenburg, Colo., collected by W. T. Lee, 1910 (5677); dump of McAnily mine, Walsenburg, Colo., collected by W. T. Lee (5676).

Order EBENALES.

Family EBENACEAE.

Diospyros? leei Knowlton, n. sp.

Plate XLVIII, figure 2.

Leaf evidently of thickish texture, elliptical or slightly obovate-elliptical, broadest above the middle, thence rounded to the slightly pointed apex and below to the short thick petiole; midrib extremely thick below, becoming almost effaced before reaching the apex; secondaries seven or eight pairs, alternate, at an angle of about. $30^{\circ}$, somewhat curved upward near the margin; upper pairs of secondaries very thin and almost obsolete; finor nervation not well preserved.

This handsome little leaf is practically perfect. It is 6 centimeters in length and 4.5 centimeters in width. A little more than 5 millimeters of the petiole is preserved. This leaf is notable for its elliptical outline and extremely thick midrib.

It is perhaps uncertain that it belongs to Diospyros, and the generic reference is conse-

1 Lesquereux, Leo, The flora of the Dakota group: U. S. Geol. Survey Mon. 17, p. 161, pl. 21, fig. 5, 1891. quently questioned. It is of the type and general appearance of $D$. ficoidea Lesquereux, ${ }^{2}$ from Black Buttes and Hodges Pass, Wyo., from which it differs in being more nearly elliptical with very slightly pointed apex. The secondaries are at a lower angle and not branched.

Occurrence: Vermejo formation (Cretaceous); Vermejo Park, N. Mex., nearest locality 123, near the middle of the Vermejo formation, collected by W. T. Lee (5809).

\section{Order GENTIANALES. \\ Family OLEACEAE? \\ Fraxinus? sp. \\ Plate XLIX, figure 1.}

The collections from the Gray Creek mine, near Gray Creek, Colo., include a single specimen (fig. 1) that appears to belong to the genus Fraxinus but that is so fragmentary that I. have not ventured to name it. It was evidently an ovate-lanceolate, entire-margined leaf about 9 centimeters in length and 3.25 centimeters in width. It had about seven pairs of alternate acute-angled secondaries. Its finer nervation is obscure.

In some ways this leaf suggests Rhamnus salicifolius Lesquereux, but it is rather broader and has fewer more acute-angled secondaries. In shape it suggests certain leaves that have been referred to Ficus lanceolata Heer, but here again the nervation is more acute angled.

Occurrence: Vermejo formation (Cretaceous) ; dump of coal mine, at Gray Creek, Colo., collected by W. T. Lee (5710), found with Ficus praetrinervis, Viburnum anomalinervum, etc.

\section{Ordẹ RUBIALES. \\ Family CAPRIFOLIACEAE.}

Viburnum anomalinervum Knowlton, n. sp.

Plate XLV, figure 4.

Viburnum whymperi Heer. Lesquereux, U. S. Geol. Survey Terr. Rept., vol. 7 (Tertiary flora), p. 225, pl. 61, fig. 23, 1878.

Leaf small, ovate in outline, truncate at base, and slightly decurrent on the petiole, obtusely pointed above; margin toothed from just above the base, the teeth usually rather large, obtuse; nervation strong, deeply impressed, consisting of a midrib which is two or three

${ }^{2}$ Lesquereux, Leo, The Tertiary fiora: U. S. Geol. Survey Terr. Rept., vol. 7 , pl. 40 , figs. $5,6,1878$. 
times forked, and two ribs nearly as strong that arise in the decurrent base of the blade and that in many specimens pass up nearly to the top of the leaf, each with several forking branches on the outside, all craspedodrome, and ending in the marginal teeth; nervilles strong, mainly forked or broken.

The specimen figured is nearly perfect. It is 3.5 centimeters long and 2 centimeters wide. The shape is regularly ovate. The nervation is very strong and deeply impressed for so small a leaf, and is in effect three ribbed from the base, for what may be called the lowest pair of secondaries is of about the same strength as the midrib, arises with it at the very base of the blade, and runs for some distance nearly parallel to it; each of these secondaries has several craspedodrome branches.

It has for a long time been apparent that the little leaf from Point of Rocks, Wyo., referred by Lesquereux to Heer's Viburnum whymperi, could not belong to that species; and I have ventured to refer it to the present species. It is of about the same size as the present specimen and is like it in its slightly decurrent base, three-ribbed nervation, and other details. There can be no reasonable doubt as to its identity.

Occurrence: Vermejo formation (Cretaceous); type, dump of mine at Gray Creek, Colo., collected by W. T. Lee (5710). Montana group, Mesaverde formation (Cretaceous), Rock Springs coal group, Point of Rocks, Wyo.

Viburnum? hesperium Knowlton, n. sp.

Plate XLIX; figure 2.

Leaf evidently rather thick, ovate, truncate at base, abruptly narrowed to an acuminate apex above; margin apparently sharply serrate, at least above (margin obscurely preserved); midrib thick, perfectly straight; secondaries about six pairs, opposite, lowest pair arising at top of the petiole, each with four or five tertiary branches on the outside, other secondaries close, parallel, apparently ending in the teeth; finer nervation obsolete.

This little leaf, which is broadly ovate with abruptly truncate base, is 5.5 centimeters long and about 4.5 centimeters wide. As it is preserved on very coarse grained sandstone, the details of exact outline and nervation are to be made out with difficulty. It appears to be entire along the base and serrate, with rather small, sharp teeth above. So far as can be made out the secondaries and tertiaries pass directly to the margin. The whole nervation is very regular and straight.

Viburnum rotundifolium Lesquereux, ${ }^{1}$ from the Laramie and Denver formations, approaches the species in some respects but differs from it in being rounded and obtuse at apex, in having coarser marginal teeth, and in having fewer curving secondaries and tertiaries.

Occurrence: Vermejo formation (Cretaceous); Canon City field, Colo., 1 mile east of Rockvale (sec. 30, T. 19 S., R. 69 W.), at base of coal-bearing rocks, collected by W. T. Lee (5790).

Viburnum montanum Knowlton.

Plate LII, figure 2.

Viburnum montanum Knowlton, U. S. Geol. Survey Bull. 163, p. 73, pl. 19, figs. 1; 2, 1900.

In the reddish fine-grained sandstone below the rim rock at Rockvale, Colo., are numerous leaves that are referred without hesitation to Viburnum montanum. As pointed out in the original discussion, this species has considerable resemblance to Viburnum marginatum Lesquereux, ${ }^{2}$ especially in the basal portion, but differs from it in shape, being narrower and not so expanded above. These specimens all passed through 'Lesquereux's hands and were identified by him as Viburnum marginatum, V. anceps, and V.platanoides, but there is no doubt that they belong to $V$. montanum. Occurrence: Vermejo formation (Cretaceous); collected by W.T. Lee-Canon City field, Coal Creek (Rockvale), Colo., 1 mile south of Rockvale, Colo., 1910 (5788); Canon City field (sec. 18, T. 19 S., R. 69 W.) (5779); south wall of Spring Canyon in Vermejo Park, N. Mex., locality 124, at top of Vermejo formation (5237) near Rockvale, Colo., in Canon City field (sec. 25, T. 19. S., R. 70 W.), near base of rim rock (5782).

Viburnum? problematicum Knowlton.

Plate XI,IX, figure 9.

Viburnum? problematicum Knowlton, Flora of the Montana formation: U. S. Geol. Survey Bull. 163, p. 71, pl. 19, fig. 4, 1900.

In the collections from the Canon City field I find several leaves that are apparently the same as the specimen figured as the type of this

1 Lesquereux, Leo, The Tertiary flora: U. S. Gool. Survey Terr. Rept., vol. 7 , pl. 38 , fig. 10,1878 .

2 Idem, p. 223, pl. 38, figs. 1,4 . 
species from beds believed to be of Montana age at Coalville, Utah, but it is doubtful if they are the same as the single leaf of Viburnum marginatum Lesquereux, which I referred to V. problematicum in the "Flora of the Montana formation." The latter is from a much higher horizon (Black Buttes, Wyo.) and has a margin provided with more numerous and much smaller teeth.

Occurrence: Vermejo formation (Cretaceous); Canon City field, Colo., 1 mile east of Rockvale (sec. 30 , T. 19 S., R. 69 W.) at base of coalbearing rocks, collected by W. T. Lee (5790). Beds believed to be of Montana age, Coalville, Utah.

Viburnum simile Knowlton, n. sp.

Plate XLIX, figure 3.

Leaf coriaceous in texture, elliptical in outline, abruptly rounded to the slightly decurrent base; margin entire for lower third, thence provided with low sharp teeth; midrib strong, straight; secondaries about eight pairs, opposite or subopposite, lowest pair arising well above the base, each with seven or eight tertiary branches on the outside, these camptodrome or subcraspedodrome; other secondaries straight, at an angle of about $45^{\circ}$, occasionally forked, ending in the marginal teeth; nervilles numerous, prominent, at right angles to the secondaries.

The example figured, which is the most perfect one observed, is about 7.5 centimeters in length and 3.5 centimeters in width. It. is associated with, and most closely related to, Viburnum montanum Knowlton; in fact, it may be only a small narrow leaf of that species. It differs, however, in being smaller, elliptical instead of ovate, and in having the lowest pair of secondaries arising above the base of the blade instead of at or near the base. It is also slightly unequal-sided, as well as decurrent at base. The type and general appearance of the nervation is very much the same.

Occurrence: Vermejo formation (Cretaceous); Canon City field, Rockvale, Colo., Newberry collection, probably made by George Hadden.

Viburnum rhamnifolium Knowlton, n. sp.

Plate XLVII, figure 5.

Leaf ovate-lanceolate, broadest just below the middle, where it tapers to a wedge-shaped base below and to an acuminate apex above; margin entire below, then irregularly sharply serrate above; nervation pinnate; the midrib straight; secondaries about ninè or ten pairs, alternate, at an acute angle, craspedodrome, entering the slightly larger marginal teeth; nervilles numerous, very strong, mainly unbroken, and at right angles to the midrib.

The specimen figured, which is the best preserved of the two representing this species, is about 6 centimeters long and a little over 2 centimeters wide. It is entire for perhaps onefourth the length of the blade, thence sharply toothed, the teeth entered by the secondaries being considerably larger than the others. The number of smaller teeth between the larger ones is usually three. The marked appearance of the leaf is due to the numerous prominent, mainly simple nervilles, which are approximately at right angles to the midrib.

This species is of the same type as a leaf from Rockvale described in this report as Viburnum? problematicum Knowlton, but differs from it in being much narrower and more pointed at apex and in having more numerous secondaries and conspicuous nervilles. It also has some resemblance to V. simile, described from Rockvale, but the latter is larger and has the lower pair of secondaries arising above the base, with several branches on the outside. The teeth in $V$ : simile are usually without the intermediate smaller ones between those entered by the secondaries.

Occurrence: Vermejo formation (Cretaceous); locality 124, Vermejo Park, N. Mex., in Spring: Canyon 2 feet above the highest coal bed of the Vermejo formation, $\cdot$ collected by W. T. Lee (5807).

Viburnum crassum Knowlton, n. sp.

Plate LII, figures 3,4 .

Leaves of medium size, very thick and firm in texture, very broadly obovate wedge-shaped in general outline, apparently truncate above but with apparently about five low, broad, obtuse lobes; margin of long wedge-shaped base perfectly entire; but margin of lobes apparently sparsely toothed; nervation very strong, consisting of a thick midrib and three pairs of secondaries, the lowest pair nearly as strong as the midrib and arising with it at the base of the blade; upper secondaries alternate, the lowest forked; basal secondaries-or ribs-with several branches on the outside; nervilles numerous, very strong, mainly unbroken, and at right angles to the midrib or secondaries. 
This species is represented by several examples, none of which, however, is well preserved. In one of the specimens here figured (fig. 4) the basal portion is well preserved; in the other (fig. 3) the base is only partly retained; but the upper portion is better shown. The leaf appears to be truncate above, with several low, rounded obtuse lobes, but the nature of the matrix makes the real margin uncertain. The nervation is particularly strong.

This species is of the type of certain leaves of Viburnum montanum Knowlton, ${ }^{1}$ at least as regards the nervation of the basal portion, but it differs widely from these in shape and in the apparent configuration of the upper portion. Its nervation is also much stronger.

Viburnum crassum is also of the type of $V$. marginatum Lesquereux ${ }^{2}$ (or Platanus marginata as it is often called), but it is a much thicker leaf with stronger nervation and moreover appears to differ essentially in the outline of its apical portion.

Occurrence: Trinidad sandstone (Cretaceous); 1 mile south of Raton, N. Mex., collected by W. T. Lee (5145).

\section{Viburnum sp.}

Plate XLIV, figure 3.

The collections from Coal Creek (Rockvale) include a small fragmentary leaf that was described in manuscript by Lesquereux as a new species of Ficus, but that appears to me to belong rather to Viburnum. The only specimen noted (fig. 3 ) is too fragmentary for proper characterization, though it is perhaps sufficient to permit its recognition should it again be found. It was apparently broadly ovate in general shape, about 4 centimeters long and about 3 centimeters wide, and was possibly slightly unequal-sided. The margin is irregularly dentate, the teeth being scattered and low. The midrib is unusually strong, with about six pairs of secondaries, which arise at an acute angle and either enter the teeth or supply a series of bows which in turn supply the teeth. The nervilles; which are very prominent and strong, are very oblique to the secondaries.

Occurrence: Vermejo formation (Cretaceous); Canon City field, Coal Creek (Rockvale), Colo.,

1 Knowlton, F. H., Flora of the Montana formation: U. S. Geol. Survey Bull. 163, pl. 19, figs. 1, 2, 1900.

2 Lesquereux, Leo, The Tertiary flora: U. S. Geol. Survey Terr. Rept., vol. 7 , pl. 38 , figs. $1,4,1878$. collected by George Hadden (U.S. Nat. Mus. 51316).

INCERTAE SEDIS.

Palaeoaster inquirenda, n. gen. and sp.

Plate XLIX, figures 5,6 .

Organism consisting of a whorl or rosette of eight to twelve thick, sessile, linear-lanceolate, acuminate, erect, one-nerved "leaves," but without trace of internal organization.

This organism, whatever its exact nature may be, is very peculiar and is highly characteristic of the beds in which it occurs. It consists, as stated in the diagnosis, of eight to twelve, usually about nine, narrow, erect "leaves" or members 3.5 to about 4.5 centimeters long and 6 to 10 millimeters wide in the middle. They are slightly narrowed to the sessile base where they are in contact, though evidently perfectly free from each other. Above they are narrowed to a very slender acuminate point, usually somewhat incurved. The segments are thick and leathery, if not indeed woody, and are traversed dorsally by a deep median furrow. These specimens, preserved in rather coarse sandstone, show very little trace of structure other than the median rib; but specimens preserved in finer-grained material, where the substance has been transformed into a thick coaly layer, show a series of fine, approximately parallel lines at right angles to the median rib and extending between it and the margin. Faint traces of this transverse marking may be noted, or perhaps imagined, even in the sandstone specimens, though it is doubtful if they would have been seen if attention had not been especially called to them by their observed presence in the coaly specimens.

It seems probable that these organisms were terminal, for there is some evidence of the presence of a scar or point of attachment at the base, but no axis on which they might have stood has ever been noted. They are certainly not leaves whorled around a stem, for had they been some trace of the stem should have been detected in some of the numerous specimens. It appears much more likely that they were capsular. in nature, for if the nowspreading segments were brought together they would apparently make a tightly closed "capsule." The incurved tips of the segments lend support to this view, though no evidence of seeds nor of any interior structure has been 
observed. If the segments were uniform in number in all specimens the argument for a capsule would be strengthened; though lack of uniformity in this respect is not, of course, a fatal objection, as many plants have capsules with a varying number of segments.

These organisms were assuredly veryrigid and resistant when entombed, for most of them have not been at all distorted. I have seen a single piece of matrix less than 30 centimeters long and perhaps 15 centimeters in the other dimensions, which contained four of these organisms, all lying in different planes and none showing much if any distortion. As the matrix is a fairly coarse grained sandstone this retention of form could not have occurred had it been other than leathery or perhaps woody. A few are somewhat flattened, but this is exceptional. Still more rarely isolated and detached segments are found.

This organism has been shown to a number of botanists, in the hope that its affinities might be recognized, but the results are not very satisfactory. To one it suggested the flowers of Calycanthus, and to another the fruit of Liriodendron or the flowers of Magnolia, but none of these suggestions can be seriously entertained. It does, indeed, bear considerable resemblance to certain flowers of Williamsonia, but this can hardly be considered more than an accidental resemblance, especially as no trace of essential organs has been found.

This form has been supposed for a long time to be identical with Eriocaulon? porosum Lesquereux, ${ }^{1}$ which was described originally from the Arapahoe or the Denver formation on Sand Creek, in or near Denver, Colo., and was later obtained from the Laramie formation of the Denver Basin, the Book Cliff coal field, Utah, and near Lay post office, in Routt County, Colo., the two latter localities being somewhat in question.

A careful comparison of all the specimens involved leads me to the conclusion that Lesquereux's specimen and possibly some of the others are not conspecific and possibly not congeneric. The type of Eriocaulon? porosum (U. S. Nat. Mus. 137) is preserved in a piece of soft, fine-grained clay and has been fairly well described and figured by Lesquereux. It is partly wrapped around the end of the piece 1 Losquereux, Leo, The Tertiary flora: U. S. Geol. Survey Terr. Rept.,
vol. 7, p. 106, pl. 16, figs. 2, 2a, 1878. of matrix, and its several leaves do not lie in the same plane. It appears, however, as Lesquereux supposed, that they were disposed in a circle, possibly around a stem, though no trace of a supporting axis is preserved. The nervation of the segments or leares in this specimen is uncertain. There is clearly a very strong central rib or midrib and apparently about two thinner ribs or veins on each side, but the remainder is obscure and more or less in doubt. The leaves were evidently very thick and leathery, and the more or less wrinkled surface shows numerous obvious joint checks, so that any actual nervation is difficult to make out.

Among the several lots of specimens from the Raton Mesa region there is one from the McAnily mine near Walsenburg that consists of a number of detached leaves or segments. Only three or four leaves are preserved on any piece of matrix, but these seem to arise from a central point, as in the other examples and as in the type of Eriocaulon? porosum. The leaves in these Walsenburg specimens are rather longer and narrower than common, and they appear, if anything, to have been thicker, as shown by the layer of carbonaceous matter remaining in favored places. The midrib is very deeply impressed-channeled, in fact-and at right angles to it there are minute parallel lines connecting with the margin. It will be seen that these specimens appear to approach most closely to Eriocaulon? porosum, and it may be necessary ultimately to separate these specimens (from Walsenburg, Colo.) and to place them directly with Lesquereux's species.

The type specimen's of Palaeoaster inquirenda are contained in a large collection from Alkali Gap in the Canon City field and are in association with an especially fine lot of leaves of Ficus leei. They have been fully described and illustrated above.

Occurrence: Vermejo formation (Cretaceous); types, Alkali Gap, Canon City coal field, Colo., 35 feet above the highest Halymenites zone, collected by W. T. Lee (5775); dump of McAnily mine, near Walsenburg, Colo., collected by W. T. Lee (5676). Raton formation (Tertiary); Bowen mine, locality 109, Colorado, a few feet above the basal conglomerate, collected by W. T. Lee (5794); locality 30 , southwest of Koehler, N. Mex., in slide rock. 
Seedling plant?

Plate XLIX, figure 4.

In the material from Cuatro, Colo., in beds belonging to the lower coal group, there was found the specimen here figured, which seems to belong to a seedling plant. It has a relatively long thick stem, or caulicle, as it should be called, if this interpretation be the correct one, bearing at the top two opposite, thick leaves or cotyledons, between which and continuing the axis of growth is what is in the position of, and apparently represents, the plumule. The "cotyledons" are provided with short petioles, which are strictly opposite in insertion, and each blade has a midrib, the left one with a faint indication' of several secondary branches. The stem (caulicle) is the thickest below and appears to split at the point where the "cotyledons" arise, the continuing axis being much reduced in size.

No attempt has been made to seek possible affinities for this plant, for if it really represents a seedling it is of the same general appearance as very many dicotyledonous types and could hardly be identified with any degree of certainty.

Occurrence: Vermejo formation (Cretaceous); Tercio Park, at Cuatro, Colo., in the Vermejo formation, collected by W. T. Lee (5805).

Phyllites aurantiacus Knowlton, n. sp.

Plate L, figure 5.

Leaf small, 4 centimeters long, 2.5 centimeters broad, coriaceous in texture, ovate or ovateelliptical, abruptly rounded to the slightly wedge-shaped base, obtuse at apex; margin undulate; petiole short, strong; nervation obscure, consisting of a thin midrib and presumably several pairs of very thin secondaries, which, however, are so obscured by the thick substance of the leaf as to be almost obsolete.

This little leaf is so obscure as regards the nervation that it is impossible to compare it satisfactorily with described species.

Occurrence: Vermejo formation (Cretaceous); 3 miles south of Walsenburg, Colo., 50 feet below the top of Vermejo formation, collected by J. H. Gardner (for G. B. Richardson) (5131), on the same stone with Widdringtonia? complanata.
Phyllites leei Knowlton, n. sp.

Plate XLIX, figure 8.

Leaf of small size, ovate, abruptly wedgeshaped at base, obtuse at apex; margin entire below, slightly cuneate toothed above, the teeth very low, obtuse; petiole relatively strong; midrib relatively strong below; much thinner above; secondaries three pairs, the lowest arising at the base of the blade, producing a three-ribbed appearance, running up for a long distance; nervilles strong, mainly unbroken.

This little leaf, which is 3.5 centimeters long and 2.25 centimeters wide, is regularly ovate in shape, with a very'abruptly wedge-shaped base and obtuse apex; the margin is very obscurely toothed from a point. well above the base.

Occurrence: Vermejo formation (Cretaceous); dump of McAnily mine, Walsenburg, Colo., collected by W. T. Lee (5676).

\section{Phyllites nanus Knowlton, n. sp.}

Plate L, figures 3, 4.

Leaf small, ovate, broadest at about the middle, thence about equally tapered to both base and apex; margin entire; petiole short (6 millimeters); midrib relatively strong, straight; secondaries four pairs, the lowest pair arising at the base of the blade, producing a pseudotrinerved appearance, others remote, subopposite, at an angle of $45^{\circ}$, slightly curved upward, all apparently craspedodrome, or effaced just below the margin; finer nervation not preserved.

Occurrence: Vermejo formation (Cretaceous); collected by W. T. Lee-locality 125 , west of Vermejo Park, N. Mex., near middle of the Vermejo formation (5809); locality 129, San Francisco Pass, N. Mex., at base of Vermejo formation (5806), with Tellina scitula Meek and Hayden and Panopaea? sp.

\section{Phyllites populoides Knowlton, n. sp.}

Plate I, figures 1, 2.

Leaves firm in texture, orbicular or orbicularovate, rounded and obtuse above, truncate or slightly heart-shaped at base; margin entire or very slightly undulate; nervation rather light, three ribbed from the extreme base of the 
blade, the midrib being perfectly straight and the lateral ribs starting at an angle of about $45^{\circ}$ and running thence nearly straight to the margin, each with three or four secondary branches on the outside, the midrib with three or four subopposite secondaries; all secondaries and their branches apparently craspedodrome; nervilles numerous, mainly unbroken.

This species is represented by three or four specimens, none of which, however, is very well preserved. The smaller of the two specimens figured was about 6 centimeters in length and 7 centimeters in width; the larger is of unknown length and about 8 centimeters in width.

Occurrence: Vermejo formation (Cretaceous); Tercio, Colo., south wall of gap near top of Vermejo formation, collected by W. T. Lee (5804).

Phyllites protophylloides Knowlton, n. sp.

Plate L, figure 6 .

Leaf firm in texture, outline unknown but apparently narrowly ovate or ovate-lanceolate, deoply heart-shaped or almost perfoliate at base, the basal lobes broadly rounded; margin entire so far as known; midrib thick and strong; secondary thin, irregular, at a low angle, about three pairs approximate at the base, one pair at right angles, the lower pair supplying the basal lobes; all secondaries camptodrome forming broad loops far within the margin; nervilles strong, mainly broken.

This species is represented by three or more specimens, but none of them shows more than what is probably the basal third of the blade; hence the length can. not be satisfactorily estimated; the width is about 3 centimeters. The characters derived from the basal portionincluding outline and nervation-are so peculiar in this species that it will probably not be difficult to recognize in future.

I have been constrained to give these leaves the nondescript name Phyllites because of the uncertainty, with the fragments at hand, in fixing the genus. In many respects they are strongly suggestive of certain of the Dakota sandstone species of Protophyllum, such for example as $P$. praestans Lesquereux, ${ }^{1}$ though of course in size and character of margin they are very different. In nervation and the basal arrangement of the secondaries they are not

1 Lesquereux, Leo, The flora of the Dakota group: U. S. Geol. Survey Mon. 17, pl. 41, fig. 2, 1872. unlike other species of Protophyllum, but under the circumstances it seems best to put them under Phyllites until the full characters can be ascertained.

Occurrence: Vermejo formation (Cretaceous); Canon City field, Rockvale, Colo., Newberry collection, probably made by George Hadden.

Phylites rosaefolius Knowlton, n. sp.

Plate XLIX, figure 7.

Leaf very small, obovate, broadest well above the middle, whence it is rounded to the acute apex and downward to the wedge-shaped base; margin entire; midrib very slender, straight; secondaries about six pairs, opposite, very slender, at a low angle, apparently camptodrome but very obscure.

This little leaf is regularly obovate in shape, being about 3.5 centimeters in length and a little less than 2.5 centimeters in width. The nervation is almost effaced and its full details are made out with difficulty; apparently it consists of a slender, straight midrib and about six pairs of opposite or subopposite thin, apparently camptodrome secondaries.

Occurrence: Vermejo formation (Cretaceous); locality 125, west of Vermejo Park, N. Mex., near middle of Vermejo formation, collected by W. T. Lee (5809).

\section{Phyllites sapindus Knowlton, n. sp. \\ Plate $\mathrm{L}$, figure 7 .}

Leaf evidently very thick in texture, elliptical or elliptical-lanceolate in general outline, strongly unequal sided at base, being abruptly rounded on one side and long and wedge-shaped on the other; apex destroyed; margin perfectly entire; petiole strong, 2 centimeters long; midrib strong, especially below; secondaries strong, about five or six pairs, very irregular, emerging at various angles; those on the broad side of the leaf ranging from $10^{\circ}$ to $45^{\circ}$, those on the narrow side at about $45^{\circ}$, all strongly camptodrome, each joining the one next above, usually with large loops; finer nervation not preserved.

This is a peculiar leaf. It lacks only the apical portion, a portion evidently not great in extent, and was probably about 10 centimeters in length when complete and is 3.5 centimeters in maximum width. It may readily be recognized by its markedly unequal-sided 
blade with strong petiole and midrib and strong camptodrome-arched secondaries.

I do not recognize the affinities of the leaf. Diospyros haguei Knowlton, ${ }^{1}$ from breccias of Fort Union age in the Yellowstone National Park, somewhat resembles it but differs in being smaller (only 7 centimeters long and 3.3 centimeters wide), more nearly elliptical in outline, and not at all unequal at base. The thick petiole and midrib and irregular method of branching and looping of the secondaries is very similar in both forms, which may be generically but obviously are not specifically related. If this is the habitual form of the leaf-and there is no evidence that it is distorted-it should prove a good horizon marker.

In some ways the leaf also suggests Sapindus; but if it belongs to that genus it. should, of course, be considered a leaflet.

Occurrence: Vermejo formation (Cretaceous); locality 125, west of Vermejo Park, N. Mex., near the middle of the Vermejo formation collected by W. T. Lee (5809).

Phyllites vermejoensis Knowlton, n. sp.

Plate. LII, figure 1.

Leaf membranaceous in texture; orbicular in outline, about equally rounded to both base and apex; margin entire; midrib relatively strong, straight; secondaries four pairs, alternate, middle ones forked, all campiodrome, finer nervation obsolete.

This little leaf, the only one of the kind observed, is nearly perfect. It is a little over 4 centimeters in length and a little over 3.5 centimeters in width.

Occurrence: Vermejo formation (Cretaceous); locality 124, Spring Canyon, Vermejo Park, N. Mex., at the top of the Vermejo formation, collected by W. T. Lee (5240).

Phyllites walsenburgensis Knowlton, n. sp. Plate LI.

Leaf large, ováte-elliptical, truncate at base (apex and margin unknown), petiole long, slender; nervation strong, pinnate, consisting of a relatively thick midrib and about 8 or 9 pairs of secondaries, the three lowest pairs arising very close together near the base of the

1 Knowlton, F. H., Fossil flora [Yellowstone Park]: U. S. Geol. Survey Mon. 32, pt. 2, pl. C, fig. 3, 1899. blade, whence they radiate outward, the middle and upper pair of the three with several tertiary branches on the outside; upper secondaries parallel, opposite, at an angle of about $45^{\circ}$, straight, apparently craspedodrome.

This large leaf is unfortunately so poorly preserved that it can not be- satisfactorily determined and is presented simply to call attention to the fact that a large, long-petioled leaf is present at this horizon. It was probably 16 centimeters or more in length and 12 centimeters or more in width. The petiole is preserved for 3.5 centimeters.

Occurrence: Vermejo formation (Cretaceous); dump of McAnily mine, Walsenburg, Colo., collected by W. T. Lee (5676).

Phyllites castalioides Knowlton, n. sp.

Leaf large, evidently membranaceous in texture, outline unknown, apparently broadly ovate, very deeply heart-shaped at base, the lobes possibly overlapping; leaf nine ribbed, the ribs or veins all arising at the same point and about equally dividing the blade into the several areas; midrib and next pair strongest, the former with several pairs of strong, alter-. nate, remote secondaries; second pair about at right angles to the midrib, the other pairs successively smaller, supplying the basal lobes; finer nervation obsolete.

It is unfortunate that this leaf is not suffi-. ciently well preserved to permit a more satisfactory diagnosis, for it is the only one observed and was evidently of large size and striking appearance. The only portion of the margin retained is a small part of the basal lobe, where it appears to be entire. There is some evidence to show that the remainder of the blade above the basal portion was deeply lobed, but the preservation is so poor that this feature is uncertain. The width of the blade at the base exceeded 12 centimeters, but it is quite impossible to form an accurate idea as to the total length.

The affinity of this leaf is of course uncertain, as it is so poorly preserved that important characters can not be made out. At first sight the numerous ribs and deeply lobed base suggest Castalia, but critical features that would prove this reference are obscure. It is also very suggestive of certain species of Ficus, for example, such as F. speciosissima Ward, 
and other deeply heart-shaped leaves, but the number and disposition of the ribs make this reference questionable: It has some resemblance to the genus Menispermites but hardly sufficient to warrant placing it under this heading. On the whole it seems best to put it under Phyllites until better material can be obtained. It is evidently easily recognizable and so shnuld furnish a valuable stratigraphic marker.

Occurrence: Vermejo formation (Cretaceous); Canon City field, Rockvale, Colo., Newberry collection, probably made by George Hedden.

Phyllites ratonensis Knowlton, n. sp.

Plate LIIII, figures 1, 2.

Leaves thick in texture, obovate or slightly obovate-elliptical in outline, obtusely wedgeshaped at base, abruptly rounded above to a low, obtuse point; margin perfectly entire; petiole long ( 5 centimeters), thick, and strong; midrib very strong, somewhat flexuose; secondary nervation somewhat irregular, in some specimens with three or four pairs, the lowest pair arising with the midrib at the top of the petiole, in other specimens strongly irregular and alternate; upper secondaries mainly alternate, apparently camptodrome; lower secondaries with several branches on the outside.

This species is represented by several specimens, not all, however, being very well preserved. The best (fig. 1) has the petiole preserved for 2.5 centimeters. Its blade is 8.5 centimeters long and about 5 centimeters wide. The other figured specimen is larger, having a. blade about 10 centimeters long and nearly 6 centimeters wide and a petiole fully 5 centimeters long.

Occurrence: Trinidad sandstone (Cretaceous); 1 mile south of Raton, N. Mex., collected by W. T. Lee (5145). 


\section{CHAPTER 3.-FLORA OF THE RATON FORMATION.}

\section{PTERIDOPHYTA.}

Order FILICALES.

\section{Family POLYPODIACEAE.}

Dryopteris? cladophleboides Knowlton, n. sp.

Plate LIV, figure 1.

Outline of frond unknown, pinnae linear, slender, cut nearly to the rachis into numerous small, confluent, oblong, or ovate-lanceolate, obtuse, or somewhat acute pinnules; midvein of pinnules strong, straight; nervation obscure, apparently consisting of several pairs of thin forking branches.

This species is represented by. several fragmentary pinnae, the best preserved of which is figured. As this specimen is about 7 centimeters in length and 1.5 centimeters in width, and as, though both ends are broken, it shows little or no diminution in width, it is probable that it was. not much if any under 10 centimeters in length when perfect. The pinnules do not seem to be the same shape on the two sides of the rachis, though this appearance may be due in part to distortion. On the one side they are short, oblong, obtuse and slightly cyathiform, and on the other side they are lanceolate and very acute with no upward turn at the tips. The nervation with the exception of the rather thick midrib is obscure and difficult of discernment; it -appears to be thin and once forking.

Occurrence: Raton formation (Tertiary); Tercio, Colo., about 200 feet above the top of the basal conglomerate of the Raton formation, collected by W. T. Lee (5803) on same stone with Oreodoxites plicatus.

\section{Dryopteris? sp.}

In one of the small collections from the vicinity of the Yankee mine, near Raton, there are several fragments of a small fern that are referred provisionally to the genus Dryopteris. The pinnae are lanceolate, more than 6 centimeters long and 2 centimeters wide at base, cut nearly to the rachis into numerous, proximate, scythe-shaped, acute pinnules, in which only a strong central nerve is preserved. 284
These fragments are too indistinct to w arran figuring.

Occurrence: Raton formation (Tertiary), mine No. 5, locality 85, Yankee, N. Mex., collected by W. T. Lee (5137).

\section{Pteris erosa Lesquereux.}

This is one of the species supposed to occur in both Raton and Vermejo formations. (See p. 244.)

Occurrence: Raton formation? (Tertiary), type, Fishers Peak, Raton Mountains, Colo., collected by F. V. Hayden, 1867.

Pteris russellii Newberry.

The status of this species is not settled. Its type locality is Vermejo Canyon, N. Mex., in beds now thought probably to belong to the Vermejo formation. It was not found in any of the recent collections, in either the Raton Mesa or Canon City fields, though Newberry ${ }^{1}$ states that he has had it from Walsenburg, Florence, and Golden. As the exact locality at Walsenburg is not known it might have been in either the Vermejo or Raton formations. The Florence locality, if correctly stated, should be in the Vermejo formation. The Golden locality, might be in either the Laramie or the Denver formation.

The only time I have seen this species was in a collection máde by Lee, 4 miles southeast of Palisades, Colo., in beds belonging to what has been designated the Paonia shale member of the Mesaverde formation, which in. the writer's opinion corresponds approximately to the Raton formation, being above an unconformity in that region.

Occurrence: Raton formation? (Tertiary) and Vermejo formation? (Cretaceous).

\section{Pteris linearis Knowlton, n. sp.}

Plate LIV; figure 3.

Outline of frond unknown, at least once pinnate; main (?) rachis strong, ridged; pinnae alternate, sessile, linear in shape, slightly nar-

1 Newberry, J. S., The later extinct floras of North America: U. S. Geol. Survey Mon. 35, p. 7, pl. 61, figs. 1, 1a, 1898. 
rowed at base, entire margined, apex probably abruptly acuminate; midvein exceedingly strong, strongly three grooved; veins regular, nearly. at right angles to the midvein, apparently once forked at or just above the midvein.

This species is represented by half a dozen or more specimens, but unfortunately all are so fragmentary-being for the most part only fragments of pinnae-that it is impossible to form an adequate idea of the perfect frond. The specimen figured is in some respects the best, for it shows portions of three pinnae approximately in place, one being still attached to the rachis. The pinnae are narrowly linear in shape, being only slightly narrowed to the sessile base. The length of the pinnae was at least 9 or 10 centimeters, and the width of the frond must have been about 20 centimeters (if simply once pinnate); the width is 11 or 12 millimeters. No specimen has the apex preserved, but as the largest shows no diminution in width it is to be presumed that it was rather - abruptly acuminate. The nervation is not well preserved, but so far as can be made out the reins fork once at or near the midvein; they emerge nearly at a right angle with the midvein and run straight to the margin.

Occurrence: Raton formation (Tertiary); floor of Fishers Peak mine, Fishers Peak, 3 miles southeast of Trinidad, Colo., collected by G. B. Richardson's party (5099).

\section{Asplenium? primero Knowlton, n. sp.}

\section{Plate LIV, figure 4.}

Frond broadly lanceolate in general outline, twice pinnatified; pinnae alternate, approximate; the lower ones lanceolate, the middle and upper ones linear, all decurrent on the rachis; lower pinnae deeply cut into numerous acute teeth, these becoming less and less marked until in the upper part they are merely slight indentations or at the extreme tip are wholly absent; nervation relatively simple, consisting of a strong midrib or seccundary rachis in the pinnae, from which arise secondary branches passing to the tips of the segments or teeth, each of these again with from two to four pairs of simple branches.

This is a handsome fern of which, unfortunately, only the specimen figured was obtained. The size and outline of the whole frond is not known, but, assuming from the example present that it is complete, it was broadly lance- olate in shape and twice pinnate. The length is 10 centimeters and the width approximately 4 centimeters at the broadest point, whence it tapers to an acuminate apex. The outline of the pinnae and the simple nervation are well shown in the figure.

In the absence of fruit some uncertainty attaches to the generic reference for this fern. In its̀ general aspect it resembles Asplenium, and among living species it finds a very close approximation in outline and type of nervation to Asplenium lineatum Swartz, from Malacca, and it is referred provisionally to this genus.

No American fossil species hitherto described seems very closely related to the present species.

Occurrence: Raton formation (Tertiary); dump of mine at Primero, Colo., collected by W. T. Lee (5798).

\section{Family SCHIZAEACEAE.}

Anemia occidentalis Knowlton, n. sp. Plate LIV, figure 2.

Frond at least once and probably twice pinnate, apparently triangular-lanceolate in general outline; rachis slender, ridged; pinnules alternate, usually remote, strongly decurrent, at an angle of about $60^{\circ}$, long linearlanceolate; slenderly acute at apex, slightly narrowed at base, the margin cut by numerous strong, sharp, upward-pointing teeth, these diminishing toward the apex and in the upper part of the frond; midvein relatively strong, grooved; veins at an acute angle, numerous, close, parallel, forking once just above the base.

Ferns of the type usually referred by paleobotanists to the genus Anemia are of widespread vertical and geographic range in this country, and especially in the Rocky Mountain region, but are usually represented in collections by few examples from one locality and most frequently by specimens of small sizethat is, it is rather rare to find specimens which show the full size and general habit, perhaps the majority consisting of single or at most of only a few associated pinnules. It is with some hesitation that the present form is described as new, but the conviction has been growing of late that too diverse forms have been crowded into the few thus far named species, with the result that none seemed to have much geologic value. It must be confessed, however, 
that the differences that could be made out from the material available are not great, a fact that accounts for the unsatisfactory status of many species of the genus.

The present species is based on material from four localities, though only one has more than a single example. The largest and in some respects the best specimen (fig. 2) shows a frond at least 15 centimeters long. and more than 20 centimeters wide, which would seem to indicate that it was much larger than the portion shown.' The lower pinnules preserved were about 12 centimeters in length and about 1.5 centimeters in width; the upper ones are of course shorter and narrower. The nervation is very obscurely preserved in this specimen, though faint indications can be made out.

Another specimen, nearly as large, is not figured. It is a fragment about 12 centimeters long and a little more wide, evidently from the upper portion of a frond that could hardly have been much under 30 centimeters in length. It well shows the erect, strict nature of the frond and the strongly decurrent form of the pinnules. Fortunately the nervation is quite well preserved in this specimen. It consists of a strong grooved midvein or secondary rachis with the numerous, close, parallel, once-forked and acute-angled veins.

The two other' specimens which have not been figured are of single pinnules and show the nervation well preserved.

Anemia occidentalis is perhaps most closely related to and in the past has undoubtedly been most frequently identified with Anemia perplexa Hollick. ${ }^{1}$ The name Anemia perplexa was substituted by Hollick for Sphenopteris (Asplenium) elongatum Newberry, 1863, which was held to be preoccupied by the living Asplenium elongatum Swartz, 1806. The species is the same as Anemia subcretacea (Saporta) Gardner and Ettingshausen, 1880 (Asplenium subcretaceum Saporta, 1868), and is probably the same as Gymnogramma haydenii Lesquereux, 1871 (1872). In late years it has been most widely known as Anemia subcretacea. It has been identified by Newberry from the Cretaceous of Orcos Island, Bellingham Bay, Wash., from the Laramie formation at Erie, Colo., and from the Montana group at Point of Rocks, Wyo. It seems probable, however,

1 Newberry, J. S., op. cit., p. 3, pl. 15 (figs. 1, 1a), pl. 16 (fig. 3), pl. 63 (figs. 1-4). that two species have been confused by. Newberry, for certainly the plants shown on his Plates XV and XVI are not conspecific with these shown on his Plate.LXIII: The localities whence he obtained his specimens are not definitely stated, though presumably the originals of Plate LXIII are the Washington specimens. From these Anemia occidentalis differs markedly, for though some of its pinnules are cut into prominent teeth they are never cut into definite lobes, each with its separate midvein and distinct nervation. The figures on Newberry's Plates XV and XVI are not greatly unlike $A$. occidentalis, but they appear to represent a thicker, coarser plant with more prominent teeth and stronger nervation. They must certainly be kept apart from $A$. occidentalis until more $A$. perplexa material is available for comparison.

In habit $A$. occidentalis is similar to the abundant English form referred by Gardner and Ettingshausen to Anemia subcretacea, but it is apparently larger, has more prominent teeth, and a nervation which springs from the central rachis of the pinnules. The English forms were regarded by Newberry as similar to or at. most only varietally different from $A$. perplexa.

Occurrence: Raton formation (Tertiary); near locality 106, Colorado (sec. 9, T. 33 S., R. 64 W.), collected by W. T. Lee (5697); 4 miles. north of Trinidad, Colo., near locality 109, 200 feet above the lowest bed of coal, collected by G. B. Richardson's party (5102); Riley Canyon, 2 miles above Cokedale, Colo., collected by G. B. Richardson's party (5103); Honeyfield mine near Yankee, N. Mex., collected by W. T. Lee. (5140).

\section{SPERMATOPHYTA. Class ANGIOSPERMAE. Subclass MONOCOTYLEDONAE. Order NAIADALES. Family ALISMACEAE? \\ Genus ALISMAPHYLLITES Knowlton, n. gen.}

Stems thick, fleshy, longitudinally striate, covered by the more or less sheathing bases of the fleshy, acrodrome leaves.

Alismaphyllites crassifolium Knowlton, n. sp.

Plate LV, figure 1.

Leaves evidently thick and somewhat fleshy, variable, from elliptical-lanceolate to spatulatelanceolate, obtusely acuminate at apex, narrowed at base and apparently sheathing the 
stem; nerves all or nearly all arising at the base of the blade and there very close together, then spreading and running quite to the tip of the blade.

In view of its evidently fleshy nature this specimen is reasonably well preserved. It consists of a fleshy stem about 4 centimeters long and about 7 millimeters thick, with three leaves still attached and evidence of the existence of a fourth. The leaves appear to be sheathing or partly continuous with the stem. The nerves all arise at the base of the blade and are pressed closely together, those in the middle continuing close together and producing a kind of false midrib for more than half the blade's length, but one after another they spread off on the outside as the blade broadens, filling the blade with the nerves about 1 millimeter apart. They all curve inward again and become closely approximated at the tip.

There is considerable range in size among these leaves, perhaps due to age. Thus the smallest is only 6 centimeters long and 2 centimeters broad, and the largest is almost. 12 centimeters long and 3 centimeters broad. Still another is 4 centimeters broad and probably at least 10 centimeters long.

Occurrence: Raton formation (Tertiary); Fishers Peak mine, Fishers Peak, 3 miles southeast of Trinidad, Colo., collected by G. B. Richardson's party (5099).

\section{Order GRAMINALES.}

\section{Family POACEAE.}

Phragmites oeningensis Alexander Braun.

Phragmites oeningensis Alexander Braun, in Stizenberger

- Uebersicht der Versteinerungen des Grossherzogthums Baden, p. 75, 1851.

Lesquereux, U. S. Geol. Survey Terr. Ann. Rept., 1871, Suppl., p. 13, 1872.

This species was reported by Lesquereux from Fishers Peak, Raton Mountains, but has not since been noted.

Occurrence: Raton formation (Tertiary); Fishers Peak, Raton Mountains, Colo., collected by F. V. Hayden, 1869.

\section{Order ARECALES.}

\section{Family PALMACEAE.}

Of the many families that may be recognized among the fossil remains in the area covered by this report the Palmaceae is perhaps the most abundant and widely distributed. Remains of palms are present in the collections from 40 to 50 localities, distributed from one end of the field to the other, and according to Lee, who collected most of the material, the presence of a few fragments in a lot may not be by any means an indication of the relative abundance at that place. In fact, they were so abundant that unless exceptionally fine specimens could be obtained only enough to show their presence were usually collected. In certain coal mines, such, for example, as the Sugarite mine near Raton, N. Mex., the roof for a considerable area is completely covered by masses of great palm leaves, some of which are practically complete and unbroken. As these can rarely be removed without serious breakage, recourse should be had to photographing them in place.

With such a wealth of available material it was presumed that the obvious confusion that had existed could be reduced to some sort of order. The result, however, is somewhat disappointing, for only one pinnate species, represented by less than half a dozen examples from a single locality, was found, all the rest belonging to the palmate type, and, as is well known, comparatively few palmate-leaved palms have leaf characters that alone serve for satisfactory differentiation. However, as the leaves are almost the only parts preserved the best must be made of the material available, and careful study has shown that most specimens possess some characters which ally them more or less conclusively to living genera.

Oreodoxites plicatus Lesquereux.

Plate LXIII, figure 1.

Oreodoxites plicatus Lesquereux, U. S. Geol. Survey Terr. Rept., vol. 8 (Cretaceous and Tertiary floras), p. 122, pl. 18, figs. 1-4, 1883.

In one of the collections from Tercio, Colo., from about 200 feet above the conglomerate, there is a single fragment that appears with little doubt to belong to this well-known Denver species. It is from the basal portion of a leaf and is indistinguishable in charaoter from Lesquereux's figure 2. The fragment is, perhaps, too imperfect to be worth figuring, for it can add nothing to what is already known. Occurrence: Raton formation(Tertiary); Tercio, Colo., about 200 feet above the top of the basal conglomerate of the Raton formation, collected by W. T. Lee (5803). Denver formation (Tertiary); Golden, Colo. 
Sabalites grayanus (Lesquereux) Lesquereux.

- Sabal grayana Lesquereux, Am. Philos. Soc. Trans., vol. 13, p. 412, pl. 14, figs. 4-6, 1869.

Sabalites grayanus (Lesquereux) Lesquereux, U. S. Geel. Survey Terr. Rept., vol. 7 (Tertiary flora), p. 112, pl. 12, figs. 1, 2, 1878.

This species was described originally from the "Eo-lignitic" (Wilcox group) of Mississippi, and according to Berry has been found at several localities in the Wilcox group. It is undoubtedly closely related to what has usually been called Flabellaria eocenica Lesquereux, a species found first at Black Buttes, Wyo., and subsequently in the Denver formation at Golden, Colo. What is believed to be this species has been detected at two localities in the Raton Mesa area.

Occurrence: Raton formation (Tertiary); west side of Dillon Canyon, near Blossburg, N. Mex., collected by W. T. Lee (5147); hillside just west of south entrance to Raton tunnel, 6 miles north of Raton, N. Mex., collected by F. H. Knowlton (5464).

Sábal inquirenda Knowlton, n. sp. Plate LVI.

Leaves relatively small, probably 1.5 meters or less in diameter, palmate, with 40 to 50 folds which are much compressed at the point of attachment and rapidly widen outward (apex not known); petiole unarmed, rounded both above and below; or at least. not conspicuously concave above; about 2 to 3 centimeters broad; apex of petiole rounded on the upper side of the leaf and prolonged on the under side into a spine or "midrib" 6 to 12 centimeters in lengtin.

This species has, with the exception of Sabal? rugosa, the smallest leaves of any of the forms here differentiated, the diameter being probably little if any in excess of a meter. The rays are in the main small, crowded, and flat, in which respect they differ from those of $S$. rugosa. The petiole, as it enters the base of the blade, is well shown in the plate.

Occurrence: Raton formation (Tertiary); Sugarite mine, 4 miles northeast of Raton, N. Mex., collected by F. H. Knowlton, 1909 - (5467); Old Wagon mine, 4 miles northeast of Raton, N. Mex., collected by W. T. Lee, 1908 . (5143).
Sabal? rugosa Knowlton, n. sp.

Plate LVIII.

Leaves of small size, 1 meter or less in diameter, palmate, truncate at base, with about 40 rays or folds; petiole about 2 centimeters broad, unarmed, not grooved nor ridged, obtuse on the upper side, the rays nearly all arising from it, on the lower side prolonged into a short point about 8 centimeters long.

This species is well represented by the two fine examples, which fortunately represent both upper and lower surfaces, thus showing the apex of the petiole above and below and the character of the rays and their insertion. The rays are very strongly folded and have sharp keels, whence the local name of "fossil washboards," by which they are known to the miners. Aside from the strong midrib or keel to the folds the nervation is not preserved.

This species is not likely to be confused with either of the forms described and figured in this report, being perhaps nearest to Sabal? in quirenda as regards size but differing from it in its fewer rays, their more strongly plicate character, and in the details of the apex of the petiole. From Sabal? ungeri it differs in having only forty instead of from eighty to ninety rays and in the much shorter extension of the petiole on the lower side.

The present form approaches most closely to what Lesquereux ${ }^{1}$ has called Flabellaria eocenica, from the Denver formation of the Denver Basin; Colo.; and the Black Buttes coal group of Black Buttes, Wýo. (regarded by the author as of post-Laramie age); in fact, it is probable that no great harm would be done if the two were combined. Lesquereux's type specimens are fragments showing the apex of the petiole in both upper and under surfaces and the origin of the rays. No good characters can be observed in these parts which will serve to separate it from S. rugosa; the outer extensions of its rays, however, are described as being very flat and open, whereas in $S$. rugosa they are strongly compressed even near the tips. The nervation in S. rugosa is obsolete, so these features in the two forms can not be compared. It is therefore best to keep them separated until absolute proof

1 Lesquereux, Leo, The Tertiary flora: U. S. Geol. Survey Terr. Rept., vol. 7., p. 111, pl. 13, figs. 1-3, 1878 . 
of their identity is forthcoming, as it will be very easy to combine them at any time in the future.

Occurrence: Raton formation (Tertiary); locality 85, near Yankee, N. Mex. (sec. 29, T. 32 N., R. 25 E.), collected by W. T. Lee, 1909 (5142).

Sabal? leei Knowlton, n. sp.

Plate LX.

Leaves of large size, probably nearly or quite two meters in longest diameter, wedge-shaped at base, then palmately spreading; petiole very strong, unarmed and unkeeled, 3.5 centimeters broad, narrowed from the base of the blade and prolonged above into a long slender point 25 to 30 centimeters in length; rays or folds very numerous, about fifty or sixty on each side:of the prolonged midrib or petiole, arising at an angle of about $45^{\circ}$, and only 2 to 4 millimeters wide at the point of attachment; margin not seen but widest folds preserved are about 2 centimeters.

This species, which I have ventured to describe as new, is well represented by the single example figured. It was clearly a leaf of large size, being probably not much, if any, under-2 meters in length. The part exposed is thought to be the under (outer) side-that is, the side away from the axis of growth. The petiole was rounded and unarmed and unkeeled.

This species appears to differ from all the other examples in the collections by its markedly wedge-shaped base and by its extremely numerous, narrow, compact rays, which arise at an angle of about $45^{\circ}$. It is somewhat difficult to count the number of rays, but there appear to be fifty to sixty on each side, or 100 to 120 for the whole leaf.

Occurrence: Raton formation (Tertiary); 3 miles southeast of Walsenburg, Colo., and oneeighth of a mile northeast of Rockland mine, locality 120, on north side of Cucharas Canyon, collected by W. T. Lee (5679); Canadian Canyon near mouth of Jones Canyon, Raton field, N. Mex., collected by G. B. Richardson's party (5235); about 3 miles north of Trinidad, Colo., near locality 109 (5094).

$47019^{\circ}-17-19$
Sabal? ungeri (Lesquereux) Knowlton, ǹ. comb.

Plates LVII, LIX.

Sabal campbelli Newberry (in part), Boston Jour. Nat. Hist., vol. 7, p. 515, 1863.

Sabal campbelli Newberry. Lesquereux, Illustrations of Cretaceous and Tertiary plants, pl. 10, U. S. Geol. and Geog. Survey Terr., 1878.

Geonomites ungeri Lesquereux, U. S. Geol. Survey Terr. Rept., vol. 7 (Tertiary flora), p. 118, pl. 11, fig. 2, 1878.

Sabal grandifolia Newberry, U. S. Geol. Survey Mon. 35, p. 28 , pl. 63 , fig. 5 (not pl. 25 or pl. 24 , figs. 2 , 2a), 1898 .

Leaves of large size, probably 2.5 to 3 meters in diameter, with seventy to ninety folds; petiole 3 to 4.5 centimeters wide, flat, or slightly ridged above but without a keel above or below; margins of petiole unarmed, terminating on the upper side in an arch from which the folds radiate; on the underside prolonged into a spine or midrib 15 to 20 centimeters or more in length.

The above description is with some essential modifications that given by Newberry for his Sabal grandifolia, of which he figured one specimen from the Fishers Peak region. Whether or not the other specimens figured and described by Newberry under this name are conspecific is not here considered, but there can be no doubt that his Fishers Peak specimen is identical with Lesquereux's Geonomites ungeri from the same region.

The fragment upon which Lesquereux based his Geonomites ungeri (U. S. Nat. Mus. Coll. 106) comes, as is now known, from the underside of a large leaf and shows the spikelike prolongation of the petiole into what may be called a sort of false midrib, such as characterizes the underside of the leaf in many large palmateleaved living palms. He mistook this for the upper side of the leaf and hence concluded that the shape of the perfect leaf was flabellatopinnate or broadly linear-lanceolate. It was for this reason that he placed it in Geonomites, since in the living genus Geonoma, on which it is based, the leaves are somewhat of this character. As the leaves under discussion are clearly circular in outline and have the rays or folds palmate in origin it has been necessary to transfer it to $S a b a l$, which seems to combine the 
characters exhibited by the fossil leaves; and as Lesquereux's specific name has priority over any others given it the species is now called Sabal? ungeri.

Notwithstanding the comparatively large number of specimens now available for study I am still somewhat in the state of uncertainty concerning them that Newberry acknowledged himself to be. He says: ${ }^{1}$

In the great number of the remains of palms found in the Tertiary and Cretaceous rocks of the West-trunks, leaves, and fruit-it has been very difficult to define distinct species, and it is probable that many years will elapse before perfect order can be brought out of the present confusion. The species now under consideration may, however, be identified by the large size of its leaf, its plain unkeeled petiole drawn out into a long acute spine on the underside, the very numerous folds, and the crowded subequal nervation.

The species from outside the area under consideration to which the present form is most closely related is. Sabalites grayanus of Lesquereux. This was described originally, ${ }^{2}$ under the name of Sabal, from the "Eo-lignitic"" (Wilcox formation) of Mississippi and, although a mere fragment, is distinguished from $S a b a l$ ? ungeri with difficulty if at all. Subsequently leaves that have been identified as Sabalites grayanus have been found at many localities ranging in age from Montana to Eocene, but most of these are very fragmentary, and it is extremely doubtful if they have been correctly referred to this species. For example, the huge specimen figured by Lesquereux ${ }^{3}$ came from the Montana group at Point of Rocks, Wyo., where other similar specimens have been since found, but it is totally different in size and appearance from the "Eo-lignitic" type. On the same plate Lesquereux has figured as Sabalites grayanus a section of a petiole (U. S. Nat. Mus. coll. 109) from the Denver formation near Golden, Colo., but there is not the slightest valid reason for referring it to this species, and it might as well have belonged to any one of several large-leaved palms. If this strongly keeled petiole could really be proved to belong to Sabalites grayanus it would in itself be a sufficient character to separate it

\footnotetext{
1 Newberry, J. S., The later extinct floras of North America: U. S. Geol. Survey Mon. 35, p. 28, 1898.

2 Lesquereux, Leo, On species of fossil plants from the Tertiary of the State of Mississippi: Am. Philos. Soc. Trans., n. ser., vol. 13, p. 412, pl. 14, figs. 4-6, 1869.

${ }^{8}$ Lesquereux, Leo, The Tertiary flora: U. S. Geol. Survey Terr. Rept., vol. 7, pl. 12, fig. 1, 1878.
}

from Sabal ungeri, in which there is no evidence that the periole was either grooved or keeled.

It may be that the original "Eo-lignitic" types are the same as the leaves under discussion, but it is practically certain that most if not indeed all of those later referred to $S$. grayanus are not conspecific with the present specimens, and in the absence of convincing proof it is best to keep them distinct.

Sabal ungeri is the most abundant and widely distributed of all the forms it is attempted to delimit in this paper: It undoubtedly approaches most closely Sabal inquirenda, and unless specimens are of sufficient size and perfection to show well their character they can not be separated with absolute certainty. Sabal inquirenda, however, may be known in general by its small size-not exceeding 1.5 meters in diameter-and its forty to fifty instead of seventy to ninety folds. Sabal rugosa is smaller and has more strongly ribbed and plicated rays, which do not exceed forty in number. Sabal leei, also a large-leaved form, may be distinguished from $S$. ungeri by its wedgeshaped base and its great number of very closely appressed, obliquely inserted rays.

Occurrence: Raton formation (Tertiary); collected by W. T. Lee-Raynolds mine, near Yankee, N. Mex. (5133); Yankee, N. Mex., locality 85 (5142); south entrance to Raton tunnel, north of Raton, N. Mex. (5146); junction of Dillon and Coal canyons, near Blossburg, N. Mex.; same (5150); south end Raton tunnel (5155); south wall of Purgatoire Canyon, at mouth of Riley Canyon, near Cokedale, Colo. (5704); locality 106 (sec. 9, T. 33 S., R. 64 W.), near Trinidad, Colo. (5697); Riley Canyon near Cokedale, Colo. (5701); same (5703); same (5795); Vermejo Valley, N. Mex., near Salyers Creek (5826); same (5827); Ute Park, N. Mex. (5830); collected by or for George B. Richardson-4 miles north of Trinidad, near locality 109 (5102); Riley Canyon, 2 miles above Cokedale. (5103); Powell Arroyo, Trinidad field (5112); Cokedale, Colo. (5096); 3 miles north of Trinidad, near locality 109 (5094); North Fork of Purgatoire River, between Vigil and Wood's ranch (5114); collected by Orestes St. John-Long. Canyon, N. Mex., 900 feet \pm above Trinidad sandstone; near Raton, N. Mex., 350 feet above Trinidad sandstone; Spring. Gulch, Wilson Arroyo, N. Mex.; York Canyon, N. Mex.; collected by F. H. Knowlton-Bowen mine, 4 
miles north of Trinidad, Colo. (5496); Sugarite mine (Old Wagon mine), 4 miles northeast of Raton, N. Mex. (5467). Type of species (U.S. Nat. Mus. Coll. 106), Raton Mountains, Colo. Vermejo formation (Cretaceous); Ponil Canyon, N. Mex., 1 mile west of locality 11, near top of Vermejo formation, collected by W. T. Lee (5829); 1 mile south of Shumway, Colo. (5680).

\section{“Geonoma" gigantea Knowlton, n. sp. Plate LXI.}

Leaves pinnate, of large size, probably 3 meters or more in length and 1 meter in width; petiole within the limits of the leaf about 2 centimeters broad, rounded, striate; leaflets opposite, at an angle of about $45^{\circ}$, slightly constricted at point of attachment, slightly enlarging upward (apex not seen); width at point of attachment about 2 centimeters, greatest width about 3.5 centimeters; each leaf with a distinct midrib, and three or four thinner vieins, about equally dividing the space between midrib and margin on either side; intermediate veins present though obscure.

This splendid species is represented by three or four specimens, all from the same locality, the largest and best being figured. It is a pinnate-leaved form, that from the proportions noted between leaflets and petiole in certain living species must have been at least 3 meters in length and probably more than 1 meter in width. The generally good state of preservation clearly indicates that it was of strong coriaceous character and was quite comparable in this respect to many large-leaved living species.

Though palmate-leaved palms are of common and widespread occurrence in certain American Mesozoic and Tertiary strata, pinnate-leaved types are exceedingly rare. The species with which the present form would naturally be first compared is Calamopsis danai Lesquereux, ${ }^{1}$ from the Wilcox formation of Mississippi; in fact before it had been carefully studied it was presumed to be a large species of Calamopsis. Investigation shows, however, that it can hardly be congeneric with Calamopsis, for in addition to being much larger it has a round instead of a keeled petiole and thicker leaflets with distinct midribs.

1 Lesqucreux, Leo, On species of plants from the Tertiary of the State of Mississippi: Am. Philos. Soc. Trans., vol. 13, p. 411, pl. 14, figs. 1-3, 1869. It is probable that Calamopsis danai should be referred to the genus Chamaedorea.
An undescribed species of Calamopsis is known to the writer from the Denver formation of Middle Park, Colo., but it is somewhat fragmentary and apparently differs but little from C. danai.

Several species have been described by Lesquereux under the name Geonomites on the presumption that they were pinnate, but as will be shown later at least two of the "species" are really palmate forms and belong to Sabal. No restudy has been made of the remaining species of Geonomites, but in any event they are very unlike the form under consideration and can not be congeneric with it.

Oreodoxites plicatus Lesquereux, from the Denver formation, is another pinnate-leaved species, but it has short, elliptical, strongly plicate leaves that are totally unlike the Colorado species and that likewise can not be congenerio with it.

Among the great number of living palms with pinnate leaves it is a matter of some difficulty to determine the genus to which the present specimens are most.closely related. After a careful review of the material in the National Herbarium it appears to be nearest to Geonoma sp. of Jamaica. This species, known as the long thatch palm, is so exactly similar to the fossil that they are separated with great difficulty. About the only difference noted is in the petiole, which in the living species is approximately triangular in cross section, and in the fossil species is apparently rounded, though the incidents attending fossilization may possibly account for this apparent difference.

Occurrence: Raton formation (Tertiary); oneeighth of a mile northeast of Rockland mine, locality 120, north side of Cucharas Canyon, near Walsenburg, Colo., collected by W. T. Lee, 1910 (5679).

\section{Geonomites tenuirachis Lesquereux.}

Plate LXII

Flabellaria? longirachis? Unger. Lesquereux, U. S. Geol. Survey. Terr. Ann. Rept., 1873, p. 396, 1874.

Geonomites tenuirachis Lesquereux, U.' S. Geol. Survey Terr. Rept., vol. 7 (Tertiary flora), p. 117, pl. 11, fig. 1, 1878.

Notwithstanding the fact that the specimen here figured is much larger and móre nearly complete than the single fragment made the basis of Lesquereux's name, there is still doubt 
as to the full size and shape of the species. Following is Lesquereux's comment on the type specimen:

It appears to represent the upper part of long, linearlanceolate frond, palmato-pinnate, with a very narrow rachis, to which the rays are attached at an acute angle of divergence, scarcely $20^{\circ}$. The rachis is about $2 \mathrm{~mm}$. thick, smooth, and grooved in the middle. The rays, obtusely carinate; narrow, about 1 centimeter wide, including both faces, become flat and slightly decurrent toward the rachis, curve inward in narrowing, and seem to become free from each other toward their points.

The type specimen, which is scarcely 10 centimeters in length, might well have come either from the middle or upper portion of a specimen like the one here figured, in which the rachis is preserved for a length of 36 centimeters, and when unbroken was doubtless three times as long, for a specimen photographed by Lee in the roof of the Sugarite mine at Raton, N. Mex., had a rachis more than a meter in length. There can be no doubt, however, that the specimen here figured is identical with the fragment figured by Lesquereux, and it is consequently referred under his name.

Occurrence: Raton formation (Tertiary); ridge east of Yankee mine, near Yankee, $\mathrm{N}$. Mex., locality 85, collected by W. T. Lee (5139).

Palmocarpon palmarum (Lesquereux) Knowlton.

Carpolithes palmarum Lesquereux, U. S. Geol. Survey Terr. Ann. Rept., 1871, Suppl., p. 13, 1872; idem, 1872, pp. 382, 403, 1873; U. S. Geol. and Geog. Survey Terr. Ann. Rept., 1873, p. 385, 1874; idem, 1876, p. 503, 1878.

Palmocurpon palmarim (Lesquereux) Knowlton, U. S. Geol. Survey Bull. 152, p. 158, 1898.

Palmocarpon commune Lesquereux, U. S. Geol. Survey Terr. Rept., vol. 7 (Tertiary flora), p. 119, pl. 13, figs. 4-7, 1878; U. S. Geol. and Geog. Survey Terr. Ann: Rept., 1876, p. 503, 1878.

The type specimens of this species and a large number of recently collected examples are preserved in the United States National $\mathrm{Mu}$ seum. The species was first described from Fishers Peak, Raton Mountains, Colo., and has since been obtained at other localities within the type area and elsewhere, but particularly at South Table Mountain, near Golden, Colo. The recent collections from the Denver formation at Golden contain a large number of specimens, but notwithstanding the abundant material now in hand nothing has been found to throw additional light on its affinity.

From the Lance formation of Converse County, Wyo., there is a single fruit, apparently of this species, which occurs in the midst of other coarse particles of sand inside a large dinosaurian bone. It is nearly circular in shape, much flattened and not much wrinkled. Its upper surface shows faint close lines which give it the appearance of having been fibrous coated.

Occurrence: Raton formation (Tertiary); types, Fishers Peak, Raton Mountains, Colo.; collected at the following localities by W. T. Lee-junction of Dillon and Coal canyons, near Blossburg, N. Mex. (5148); locality 124, in Spring Canyon, Vermejo Park, N. Mex. (5236); south wall of Purgatoire Canyon, mouth of Riley Canyon, Colo. (5795); Ute Park, N. Mex. (5830); collected by G. B. Richardson's partynear Trinidad, Colo,, near locality 106 (5097); $2 \frac{1}{2}$ miles north of Trinidad, Colo., near locality 109 (5094); 4 miles north of Trinidad, Colo., near locality 109 (5102); Riley Canyon, Colo., $2 \frac{1}{2}$ miles above Cokedale (5105); hogback north of Stonewall, Colo. $(5110,5113)$; 2 miles southeast of Dean, Colo.; Trinidad field, Colo., 7 miles southwest of Berwind, Colo., 400 feet above supposed base of Poison Canyon formation (5121); collected by Orestes St.JohnDutchman-Dillon divide, N. Mex., $500+$ feet above Trinidad sandstone.

Subclass DICOTYLEDONAE. Order JUGLANDALES.

Family JUGLANDACEAE.

Juglans acuminata Alexander Braun. Plate LXV, figure 1.

Juglans acuminata Alexander Braun, Neues Jahrb., 1845, p. 170.

Lesquereux, U. S. Geol. Terr. Ann. Rept., 1872 p. 416 (in list), 1873.

I am not able to distinguish this from leaves so referred by other students.

Occurrence: Raton formation (Tertiary); dump of mine at Primero, Colo., collected by W. T. Lee (5798).

\section{Juglans nigella Heer.}

Plate LV, figure 2; Plate LXIII, figure 2.

Juglans nigella Heer, Flora fossilis ärctica, vol. 2, p. 38, pl. 9, figs. $2-4,1869$.

Lesquereux, U. S. Geol. Survey Terr. Rept., vol. 8 (Cretaceous and Tertiary flora), p. 234, pl. 46A, fig. 11, 1883.

The fine specimen here figured, which is from Web Canyon near Weston, Colo., appears to be indistinguishable from Heer's Juglans nigella 
from the Eocene (Kenai formation) of Alaska, and it has also been reported by Lesquereux from the Fort Union formation of North Dakota. It is particularly close to Heer's figure 4 but differs from it slightly in being a little broader and in having its marginal teeth proportionately a trifle larger. In the disposition and direction of the secondaries as well as in the numerous strong nervilles it is practically identical. There is only the single leaflet in this collection, and a series might of course develop recognizable differences, which, however, in any event would be extremely slight.

The additional leaflet figured is from another locality, but it does not differ essentially from the first and seems best referred to this species.

Occurrence: Raton formation (Tertiary); Web Canyon, about 5 miles northwest of Weston, Colo., 50 to 100 feet below the supposed base of the Poison Canyon formation, collected by W. T. Lee (5799); Apishapa Canyon, one-half mile east of Abeton, Colo., collected by W. T. Lee (5686); Sopris, Colo., collected by G. B. Richardson's party (5100).

Juglans minutidens Knowlton, n. sp.

Plate LV, figure 3.

Leaflet obovate-lanceolate in shape, taper pointed above, obtusely wedge shaped and unequal sided below; margin entire below, then finely serrate, the teeth. small, sharp, and turned upward; midrib rather strong; secondaries about fourteen pairs, thin, alternate, at a very low angle of emergence, camptodrome, curved upward near the margin; finer nervation not retained.

The specimen figured is nearly perfect, lacking only the basal portion on one side. It is rather narrowly obovate-lanceolate, its length being 11 centimeters and its width about 4.5 centimeters near the middle, whence it is narrowed below to the obtusely.wedge-shaped base and rounded above to the abruptly taperpointed apex. For about 4 centimeters from the base the margin is entire, and thence it is fincly and sharply serrate.

Occurrence: Raton formation (Tertiary); dump from the Turner mine, $1 \frac{1}{2}$ miles north of Wootton, Colo., collected by W. T. Lee (5714) on same stone with Magnolia lesleyana, Laurus socialis, and others.
Juglans berryi Knowlton.

Plate LXIII, figure 3; Plate LXIV, figure 3; Plate LXXIII, figure 3.

Juglans berryi Knowlton, in Berry, U. S. Geol. Survey Prof. Paper 91, p. 183, 1916.

Leaflets membranaceous in texture, the terminal leaflet ovate, equal sided, broadest near the middle, whence it narrows in about the same degree to both base and apex; margin entire; petiole short, slender; secondaries, ten or twelve pairs, mainly alternate, considerably curved upward, camptodrome; lateral leaflet larger, ovate-lanceolate, strongly unequal sided; margin slightly undulate; petiole slender; secondaries, probably about fourteen pairs, alternate, camptodrome; nervilles mainly unbroken, oblique to the secondaries.

This species is represented by several examples, two being figured which are thought to represent the lateral and terminal leaflets, respectively. The terminal leaflet is 9 centimeters long and about 4 centimeters wide; the petiole is preserved for a length of 8 or 9 millimeters. The lateral leaflet was probably 13 or 14 centimeters long and 5.5 centimeters wide; it has the petiole for a length of more than 1 centimeter.

I take pleasure in naming this species in honor of Mr. Edward Wilber Berry, of Johns Hopkins University; who has done so much toward the elucidation of the fossil floras of the Atlantic Coastal Plain.

Occurrence: Raton formation (Tertiary); Primero, Colo. (Pl. LXXIII, fig. 3), collected by W. T. Lee (5798); Wootton, Colo. (Pl. LXIII, fig. 3), collected by W. T. Lee (5714). Lagrange formation (Tertiary, in beds of Wilcox age), Wickliffe, $\mathrm{Ky}$.

\section{Juglans rugosa Lesquereux. \\ Plate CXII, figure 4.}

Juglans rugosa Lesquereux, Am. Jour. Sci., 2d ser., vol. 45, p. 206, 1868; U. S. Geol. Survey Terr. Rept., vol. 7 (Tertiary flora), p. 286, pl. 83 , figs. 4, 5; pl. 84, figs. 1-9; pl. 85, figs. 1, 2, 1878.

This. species, as may be noted from Lesquereux's figures, is very variable, showing considerable range in size and configuration of base. The specimen figured herewith agrees remarkably well with Lesquereux's figures 5 
and 7 , and there can be no doubt as to the correctness of this identification.

Occurrence: Raton formation (Tertiary); oneeighth mile northeast of Rockland mine, locality 120, north side of Cucharas Canyon, Colo., collected by W. T. Lee (5679); Yankee, N. Mex., locality 85 (5142); Apishapa Canyon, one-half mile west of Abeton, Colo. (5686); locality 106, near Trinidad, Colo. (5697); Wootton, Colo. (5711); same (5712); same (5714); dump of mine at Primero, Colo. (5798); Wet Canyon near Weston, Colo. (5799); Tercio, Colo. (5802).

\section{Juglans rhamnoides Lesquereux.}

Plate LXVI, figure 1.

Juglans rhamnoides Lesquereux, U. S. Geol. Survey Terr. Ann. Rept., 1871, p. 294, 1872; idem, 1872, pp. 382, 400, 402, 1873; U. S. Geol. and Geog. Survey. Terr. Ann. Rept., 1874, p. 307, 1876; idem, 1876, p. 517, 1878; U. S. Geol. and Geog. Survey Terr. Bull.,vol. 1, 2 d ser., No. 5, p. 370, 1876; U. S. Geol. Survey Terr. Rept., vol. 7 (Tertiary flora), p. 284, pl. 54, figs. 6-9, 1878; idem, vol. 8 (Cretaceous and Tertiary flora), p. $235 ; 1884$.

Dawson, Roy. Soc. Canada Trans., vol. 3, sec. 4, p. $31,1886$.

Lesquereux, U. S. Nat. Mus. Proc., vol. 11, p. 22, 1888; Harvard Coll. Mus. Comp. Zoology Bull., vol. 16, p. 56,1888 .

Knowlton, U. S. Geol. Survey Bull. 105, p. 58, 1893.

Rhamnus rossmässleri Unger. Lesquereux, U. S. Geol. and. Geog. Survey Terr. Ann. Rept., 1874, p. 314, 1876; U. S. Geol. and Geog. Survey Terr. Bull., vol. 1, 2d ser., No. 5, p. 388, 1876; U. S. Geol. Survey Terr. Rept., vol. 7 (Tertiary flora), p. 283 , pl. 54, fig. 4, 1878.

The present status of this species is involved in more or less uncertainty. It appears first to have been described in 1871, based on specimens said to have come from Evanston, Wyo., below the main coal. In the following year it was mentioned by Lesquereux as occurring at. Golden, Colo., and Black Buttes and Evanston, Wyo., and in 1875 a single small leaf was referred to it from Point of Rocks; Wyo. None of these specimens, at least under this name, is now to be found in the collections of the United States National Museum, and it seems more than likely that they were transferred to other forms without a record being made of such transfer, as was Lesquereux's occasional custom: In "The Tertiary flora," which was supposed to represent, Lesquereux's mature judgment regarding all previously described forms falling within its scope, the only local- ities mentioned are Spring Canyon, Mont., and Black Buttes and Point of Rocks, Wyo. Cf the four examples he figures, all of which are before me, three came from Black Buttes and one from Spring Canyon. In preparing my "Flora of the Montana formation," which includes all the plant horizons at Point of Rocks, -Wyo., I did not find a single specimen that could be referred to Juglans rhamnoides, and consequently excluded this species from that. work. In speaking of its presence here, Lesquereux says: ${ }^{1}$

A small leaf of this species, which is not yet, however, definitively. limited, as seen from the description in Dr. F. V. Hayden's Report for 1871 (p. 294), and which may be identical with Juglans leconteana Lesquereux and Cornus acuminata Newberry. Though it may be of the value of the species the leaf from Point of Rocks is identical in all its characters, even in its size, with some of those found in the burned beds of red shales at Black Butte.

It appears probable, as above hinted; that this Point of Rocks specimen was later merged in some other species and no record made of such disposition.

When I reviewed the fossil plants of the Bozeman, Mont., coal field, ${ }^{2}$ I was not able to find the figured specimen from that area, but it has since come to light, preserved.on the same stone with a figured specimen of Cinnamomum. But very few additional specimens have been found in the abundant material subsequently obtained from the Bozeman field.

This species was also reported by Lesquereux ${ }^{3}$ from the Tertiary beds at Cherry Creek, Oreg., but in working over his material ${ }^{4} I$ did not recognize it as present within that area. Two specimens were referred to this species by Lesquereux, but they could not subsequently be so recognized.

Lesquereux has several times referred to the presence of Juglans rhamnoides in the Denver formation at Golden, Colo. None of this material is now preserved in the United States National Museum, nor has it been found in the abundant recent. collections from the Denver Basin. The specimens so referred are the

1 On some new species of fossil plants from the Lignitic formations: U. S. Geol. and Geog. Survey Terr. Bull., vol. 1, 2d ser., No. 5, p. 370, 1876.

2 Knowlton, F. H., The Laramie and the overlying Livingston formation in Montana: U. S. Geol. Survey Bull. 105, p. 58, 1893.

3 Recent determinations of fossil plants from Kentucky, Louisiana, Oregon, California, Alaska, etc.: U.S. Nat. Mus. Proc., vol. 11, p. 22, 1889 . 4 Knowlton, F. I., Fossil flora of the John Day Basin, Oreg.: U. S. Geol. Survey Bull. 204, 1902. 
property of the Hiarvard College Museum of Comparative Zoology and I have not seen them.

This again brings up the consideration of the localities whence came the figured examples of Juglans rhamnoides, namely Black Buttes, Wyo., and Spring Canyon, near Bozeman, Mont., these being the only localities mentioned. in the earlier literature that $I$ am at present prepared to admit for this species.

In the collections made by W. T. Lee in Spring Canyon, Vermejo Park, N. Mex., is the single example here figured, which is indistinguishable from one of Lesquereux's types of this species (fig. 6). Thus the species becomes again known from a definitely fixed horizon.

After some consideration I have reduced Lesquereux's determination of Rhamnus rossmässleri Unger to the present species. The presence of this European species in American strata (at Black Buttes, Wyo.), depends on a single rather poorly preserved specimen, the original of Lesquereux's figure 4 , which is preserved in the United States National Museum (No. 450). It has, it is true, a strong resemblance to certain of the European figures of this species, but it has also just as strong a likeness to Juglans rhamnoides of Liesquereux, which is found in comparative abundance at the same locality, and, as already pointed out the latitude in the characterization of Juglans rhamnoides will permit of the reception of the so-called Rhamnus rossmässleri.

Occurrence: Black Buttes coal group (regarded by the author as of post-Laramie age); types; Black Buttes, Wyo. Livingston formation (regarded by the author as Tertiary); type, " "Spring Canyon, Mont." (=Hodsons coalmine on Meadow Creek, 12 miles southeast of Bozeman, Mont.), collected by A. C. Peale, 1872; same locality, collected by Knowlton and Peale, 1887. Raton formation (Tertiary); Spring Canyon, north of Vermejo Park, N. Mex., collected by W. T. Lee (5236).

Juglans sapindiformis Knọwlton, n. sp. Plate LXV, figure 3.

Leaflet narrowly ovate-lanceolate, very obtusely wedge shaped, and apparently slightly unequal sided at base, apex apparently acute; margin perfectly entire; midrib strong; secondaries numerous, about sixteen or eighteen pairs, thin, irregularly spaced; emerging at a very low angle ( $30^{\circ}$ or less), not much curved upward, strongly camptodrome, arching far inside the margin and each joining the one next above, sometimes with one or more additional loops; finer nervation not preserved.

The example here figured is the only one of this type observed in the collections. It was probably about 12 centimeters long when perfect, but only 10 centimeters is now preserved; it is 3.5 centimeters wide. It is well marked by its narrowly ovate-lanceolate outline and strongly camptodrome nervation.

This species is quite similar to Juglans vetusta Heer, ${ }^{1}$ as figured from the Swiss Miocene, and also to $J$. acuminata Heer, from the same horizon. ${ }^{1}$ From the former it differs in its larger size, more wedge-shaped base, and more numerous secondaries, and from the latter in its narrower shape, though a fow specimens referred to it are very similar in outline. It also has some resemblance to certain species of Sapindus, though not so close a one as it has with Juglans.

Occurrence: Raton formation (Tertiary); Raynolds mine near Yankee, N. Mex. (sec. 30, T. 32 N., R. 25 E.), collected by W. T. Lee (5133).

Juglans sapindoides Knowlton, n. sp.

- Plate LXV, figures 4, 5 .

Leaflets subcoriaceous in texture, narrowly lanceolate, rather abruptly narrowed to the slightly unequal sided base and more gradually. to the acuminate apex; margin perfectly entire; midrib strong, straight; secondaries about eight, pairs, alternate, at a low angle below, becoming more acute above, all much curved upward, camptodrome; finer nervation obsolete. This species is represented by a considerable number of specimens, two of which are figured. Of these, one is presumed to be lateral and the other terminal. The lateral leaflet (fig. 4) is 9 or 10 centimeters long and from 2.5 to 3.25 centimeters wide, and the one thought to be the terminal leaflet is 7.5 centimeters long and 3 centimeters wide.

It is with some hesitation that this is described as a new species and it is uncertain that it is referred to the proper generic type. For instance, it is not greatly unlike leaflets that have been at times referred to Juglans rugosa Lesquereux; and its basal portion as well as its nervation suggests Juglans schim-

\footnotetext{
1 Flora tertiaria Helvetiae, vol. 3, pls. 127 (figs. 40-45) and 128, is59.
} 
peri Lesquereux, ${ }^{1}$ from the Denver and Green River formations, though from this it differs in being shorter and much less prolonged above. It also suggests certain forms of Sapindus such as $S$. affinis Newberry and $S$. grandifoliolus Ward, from the Fort Union formation, and for this reason it has been given the specific name sapindoides.

Occurrence: Raton formation (Tertiary); Wootton, Colo., 50 to 100 feet above the Wootton coal bed, collected by W. T. Lee (5711).

\section{Juglans schimperi Lesquereux.}

Plate LXIV, figure 1.

Juglans schimperi Lesquereux, U. S. Geol. Survey Terr. Ann. Rept., 1871, Suppl., p. 8, 1872; U. S. Geol. Survey Terr. Rept., vol. 7 (Tertiary flora), p. 287, pl. 56, figs. 5-10, 1878 .

Knowlton, U. S. Geol. Survey Mon. 32, pt. 2, p: 688, 1899; U. S. Geol. Survey Bull. 204, p. 34, 1902.

Hollick, A report on a collection of fossil plants from northwestern Louisiana: Louisiana Geol. Survey Special Rept. 5, p. 280, pl. 33, figs. 1, 2, 1899.

Penhallow, Report on Tertiary plants of British Columbia, p. 60, Canada Geol. Survey, 1908.

Berry, U. S. Geol. Survey Prof. Paper 91, pp. 182-183, pl. 18, figs. 3-5; pl. 19, fig. 5, 1916.

The collections from Green Canyon, near Aguilar, contain a specimen-the one here figured-that is certainly the same as, one of the two leaflets (fig. 1) figured by Hollick under this name from the "Eo-lignitic" (Wilcox formation) of Coushatta, La. It is of the same size, the same configuration at base, and, so far as can be made out, has the same nervation. It also has the same shaped base as several of the leaflets figured by Lesquereux but is not as slenderly acuminate as some of the other leaflets there shown. In this respect Hollick's leaflet, with which it is being compared, also differs from the other one he figures. It may ultimately be necessary to separate them from Lesquereux's species, but in the absence of complete series of specimens from both localities it is best to refer them as above.

Occurrence: Raton formation (Tertiary); dump of Green Canyon mine, locality 119, near Aguilar, Colo., collected by W. T. Lee (5684); south side of Dillon Canyon, N. Mex., near Blossburg, collected by W. T. Lee (5147); hillside just west of south end of Raton tunnel, north of Raton, N. Mex., collected by F. H.

1 The Tertiary flora: U. S. Geol. Survey Terr. Rept.; vol. 7, p. 287, pl. 56, figs. 5-10, 1878 .
Knowlton (5464); Wootton, Colo., collected by Orestes St. John; south ranch, South Raton Canyon, N. Mex., $950 \pm$ feet above Trinidad sandstone, collected by. Orestes St. John. Wilcox formation (Tertiary); common.

\section{Order SALICALES.}

Family SALICACEAE.

Populus neotremuloides Knowlton, n. sp.

Plate LXVI, figure 2.

- Leaf of large size, clearly coriaceous in texture, nearly circular in general outline, cordate at base, rounded and abruptly acuminate at apex; margin entire at base, becoming remotely and but slightly toothed or merely undulate in the extreme upper portion; midrib very thick and strong, slightly flexuose; secondaries four pairs, the lowest pair very strong, alternate, much curved upward, one arising nearly at the base of the blade and the other a short distance above, each with about four camptodrome branches on the lower side, which curve upward and join by a broad bow well inside the margin and send slender tertiary branches to the low teeth; next secondaries strong, arising at an angle of about $45^{\circ}$, much curved upward and provided with two or three camptodrome branches on the lower side; upper branches remote, thin, joining the lower pair; nervilles strong, mainly percurrent, and at right angles with the midrib; finer nervation not retained.

This splendid species is represented by the single leaf figured. It is approximately circular in outline, or possibly a little broader than long. Its length is 11 centimeters and its width probably a little greater. Its petiole is not preserved, but the midrib indicates that it was undoubtedly very thick and strong.

This species is not only referred without hesitation to the genus Populus, but it is very closely related indeed to the living $P$. tremuloides Michaux, the well-known aspen. Most leaves of $P$. tremuloides are much smaller than those of $P$. neotremuloides, but some on vigorous sprouts are as large, or even larger. The smaller ordinary living leaves are regularly and finely toothed, but the larger leaves are only remotely toothed and in some speoimens are only undulate, thus agreeing perfectly with those of the fossil. The thick midrib, the three or four pairs of camptodrome secondaries, and the arrangement of tertiary branches and 
nervilles are all strikingly similar to those of the fossil species.

In size and general appearance this species is quite like certain leaves referred to Vitis crenata Heer, such, for instance, as that figured by Heer ${ }^{1}$ from the Eocene (Kenai formation) of Alaska, and it would seem that this latter should more properly be referred to Populus, being especially like P. richardsoni.

Occurrence: Raton formation (Tertiary); dump of mine at Primero, Colo., collected by W. T. Lee (5798).

\section{Populus, female ament. \\ Plate LXVI, figure 3.}

In close association with certain leaves of poplar there is the fruiting ament, with its counterpart, that is here figured. Its length is about 6 centimeters. The numerous capsules, which are disposed along a rather thick axis, are ovate in shape (about 6 or 7 millimeters long) and are apparently two valved, though this last observation is not very well authenticated. It is not sufficiently well preserved to permit very full or satisfactory description, and it is presented here merely to show that this type is present in these beds and thus lend support to the correctness of the identification of foliar organs.

Occurrence: Raton formation (Tertiary); dump of Green Canyon mine, locality 119, near Aguilar, Colo., collected by W. T. Lee (5684).

\section{Order FAGALES.}

Family FAGACEAE.

Fagus papyracea Knowlton, n. sp.

Plate LXVIII, figure 1.

Leaf large, membranaceous in texture, ovate in outline, abruptly rounded to the acute apex (base not seen); margin sinuate toothed, the teeth low, acute, or nearly blunt, separated by very shallow sinuses; midrib slender; secondaries mainly alternate, rather thin, at an angle of about $45^{\circ}$, little curved upward, occasionally once or twice forked, craspedodrome, and ending in the marginal teeth; finer nervation not retained.

The single broken example figured is all that has been observed of this species. It was probably about 12 centimeters or more in length and about 7 centimeters in width, and

1 Flora fossilis arctiça, vol. 2 (Flora fossilis alaskana), pl. 8, fig. 6, 1896. is unequal sided, one side being much the wider and having smaller, lower, and slightly sharper teeth.

Occurrence: Raton formation (Tertiary); Green Canyon mine, locality 119, near Aguilar, Colo., collected by W. T. Lee (5684).

Castanea intermedia Lesquereux.

- Plate LXVIII, figure 2.

Castanea intermedia Lesquereux, U. S. Geol. and Geog. Survey 'Terr. Bull., vol. 1, 2d ser., No. 5, p. 386, 1876, U. S. Geol. and Geog. Survey Terr. Ann. Rept., 1874; 1876; U. S. Geol. Survey Terr. Rept., vol. 7 (Tertiary flora), p. 164, pl. 21, fig. 7, 1878.

This species is said to have come from Middle Park, Colo., in beds there thought to be Green River in age, but it has not since been reported from there, and from later knowledge of the geology of Middle Park it seems reasonably probable that it came from beds of Denver age. The present specimen agrees perfectly with the figured type except that the marginal teeth are not quite so sharp; the margin, however, is not well preserved.

Occurrence: Raton formation (Tertiary); Wootton, Colo., 50 to 100 feet above the Wootton coal bed, collected by W. T. Lee (5712).

Quercus fisheriana Knowlton, n. sp. Plate LXVIII, figures 3, 4 .

Leaves rather small, membranaceous in texture, oblong in general outline, apparently wedge shaped at base, strongly five lobed, the lateral lobes at an angle of about $45^{\circ}$, acute, separated by broad rounded sinuses; terminal lobe largest, very acute; midrib light, straight; secondaries two pairs, thin, at an angle of $45^{\circ}$, craspedodrome, ending in the tips of the lateral lobes; nervilles strong.

This species is represented by four leaves, all, unfortunately, too fragmentary to give a thoroughly satisfactory conception of the complete form. It appears that the leaf was, broadly speaking, oblong in general outline and was at least five lobed - that is, it had two lobes on each side and a stronger central one. Its length was about 8 or 9 centimeters and its width between the tips of the upper lobes about 4 centimeters. The lower lobe, in the only specimen in which it can be approximated, was at least 2 centimeters wide. In one specimen, in. which the three upper lobes are well preserved, the lower lobes appear 
very much larger; but this appearance may be due to overlap by another leaf so closely matched that it is difficult to discriminate it. If this lateral lobe really belongs to the specimen the leaf is very much larger than other specimens indicate. This species is not well established, but it can be recognized in future by the well-preserved upper portion, which is shown in the figures.

This species undoubtedly belongs to the red oak (rubra) type of living leaf.

Among American fossil oaks Q. fisheriana is perhaps closest to what Lesquereux has identified as $Q$. angustiloba Alexander Braun, from the Laramie formation at Golden, Colo., but Q. fisheriana is smaller and has very much shorter and more obtuse lobes. The nervation is much the same in both.

Occurrence: Raton formation (Tertiary); floor of . Fishers Peak mine, 3 miles southeast of Trinidad, Colo., collected by G. B. Richardson's party (5099).

\section{Quercus simplex Newberry.}

Plate LXX, figure 3.

This leaf appears to approach most closely to Quercus simplex Newberry ${ }^{1}$ from Bridge Creek, Oreg., except that it is twice as large. It has absolutely no nervation, except the midrib. Another leaf from the same place is very much like the type.

In the collection from the canyon west. of Old Rouse, Colo., there are several other specimens that are certainly referable to $Q$. simplex. They are much smaller than the Vermejo Creek specimens and but little larger than the type figure and have the secondary nervation well preserved. They agree in this respect with the type.

Occurrence: Raton formation (Tertiary); Vermejo Valley near the mouth of Salyers Creek, N. Mex., collected by W. T. Lee (5826); canyon west of old town of Rouse, Colo., about 300 feet above the base of the Raton formation, collected by W. T. Lee (5683).

Quercus? neomexicana Knowlton, n. sp.

Plate LXX, figure 5.

Leaf thick in texture, broadly ovate or orbicular-ovate in outline, abruptly rounded

1 Newberry, J. S., The later extinct floras of North America: U. S. Geol. Survey Mon. 35, pl. 63, fig. 6, 1898. and truncate at base, apparently obtusely pointed at apex; margin entire at base, then undulate toothed, the teeth low and rounded and the sinuses shallow; midrib very thick, especially below; secondaries eight or nine pairs, mostly alternate, at almost a right angle, considerably curved upward, apparently craspedodrome but obscure on this point; finer nervation not retained.

The single example figured is all that has been discovered, but fortunately it is nearly perfect and thus gives a fairly good idea of the species. It was evidently a thick leaf, broadly ovate in shape, with truncate base and apparently pointed apex. The length was about 12 centimeters and the width 8.5 centimeters.

Occurrence: Raton formation (Tertiary); near Yankee (sec. 29, T. 32 N., R. 25 E.), N. Mex., locality 85, collected by W. T. Lee (5142).

Quercus? ratonensis Knowlton, n. sp。

Plate LXIX, figures 6, 7.

Leaf ovate-lanceolate, abruptly rounded to a very obtusely wedge-shaped base, long and taper pointed above; midrib very thick, especially below; secondaries thin, numerous (fifteen to twenty pairs), alternate, at an angle of about $45^{\circ}$, curving upward, camptodrome, arching well inside the margin and joining the one next above, with a series of loops outside; nervilles numerous, irregular.

This speciès is represented by two fragmentary specimens only, which fortunately show both basal and apical portions. The leaf was apparently ovate-lanceolate with a rounded and obtusely wedge-shaped base and a narrowly acuminate or taper-pointed apex. The nervation is rather striking, consisting of a very thick midrib and very numerous thin camptodrome secondaries. In the narrowed apical portion of the blade the secondaries run up for long distances before joining the ones next above. The length of the leaf was apparently 18 or 20 centimeters and the width about 6 centimeters.

The reference of these leaves to the genus Quercus is extremely doubtful, though they are certainly very similar to certain of the entire leaves referred to $Q$. lyelli Heer, ${ }^{2}$ from the upper Atanekerdluk of Greenland. They are, however, much larger and broader than Q. lyelli and

2 Flora fossilis arctica, vol. 7, pl. 72, figs. 1-10, 1883. 
have more regular secondaries, though the type of these as well as the irregular character of the finer nervation is very much the same.

In certain respects the two leaves figured have some resemblance to Juglans schimperi Lesquereux, ${ }^{1}$ but they are much larger, broader, aind apparently not at all unequal sided.

Occurrence: Raton formation (Tertiary); Honeyficld mine near Yankee, N. Mex., 75 feet above the base of the Raton formation, collected by W. T. Lee (5140). Wilcox formation (Tertiary); near Coushatta, La.

Dryophyllum aquamarum? Ward.

Plate LXX, fig. 2.

Dryophyllum aquamarum Ward, U. S. Geol. Survey Sixth Ann. Rept., p. 551, pl. 37, figs. 3-5', 1886; U. S. Geol. Survey Bull. 37, p. 27, pl: 10, figs. 2-4, 1887.

The example here figured from Wootton, Colo., appears to belong to Ward's Dryophyllum aquamarum, but as the margin is so poorly preserved as to be made out with difficulty the reference has been questioned. In size, apparent shape, and nervation this leaf is undoubtedly similar to Ward's figure 4. The species was described originally from Black Buttes, Wyo., in the Black Buttes coal group, regarded by the author as post-Laramic in age; it is perhaps identical with Dryophyllum subfalcatum Lesquereux.

Occurrence: Raton formation (Tertiary); Wootton, Colo., 50 to 100 feet above the Wootton coal bed, collected by W. T. Lee (5712).

Dryophyllum moorii (Lesquereux) Berry.

Plate LXX, figure 1.

Quercus moorii Lesquereux, Am. Philos. Soc. Trans., vol. 13 , p. 415 , pl. 16, figs. 1-3, 1869; U. S. Nat. Mus. Proc., vol. 11, p. 31, 1888.

Dryophyllum moorii (Lesquereux) Berry, U. S. Geol. Survey Prof. Paper 91, pp. 190-191, pl. 22, fig. 1; pl. 23, figs. 1, 2, 1916.

This species was described by Lesquereux as follows:

Leaves coriaceous, oblanceolate or ovate-oblong, elongate, subobtuse; margins remotely and slightly toothed; secondaries at a low angle of emergence, curved, craspedodrome.

To this it may be added that the lower secondaries are nearly opposite and at almost a right angle, and that above they become alter-

1 Tho T'ertiary flora: U. S. Geol. Survey Terr. Rept., vol. 7, pl. 56, :Ags. 5, 9, 1878. nate and much more distant. The nervilles are very strong, at right angles to the secondaries, and mainly unbroken.

The leaf here shown is almost perfect, lacking only the apical portion. It is comparable with the larger of the three figured types, and is presumably of about the same shape, though the type is fragmentary below. In the matter of outline, remotely toothed margin, numerous close-parallel craspedodrome secondaries, and strong nervilles they agree satisfactorily.

Occurrence: Wilcox formation (Tertiary); types, Mississippi. Raton formation (Tertiary); Vermejo Creek, locality 23a, about 3 miles northwest of Dawson; N. Mex., collected by W. T. Lee (5827), on same stone with Sabal? ungeri.

\section{Dryophyllum tennesseensis Berry.}

Plate LXIX, figures 3-5.

Dryophyllum tennesseensis Berry, U. S. Geol. Survey Prof. Paper 91, p. 192, pl. 19, fig. 6; pl. 20, figs. 1-3; pl. 2l, figs. $1,4,5$; pl. 22 , fig. 2,1916 .

Leaves coriaceous, linear-lanceolate, long and wedge shaped at base, acuminate at apex; margin entire for a short distance at base then sharply serrate; midrib relatively strong; secondaries very numerous, about fifteen or twenty pairs, mainly alternate, at an angle of $60^{\circ}$ or $70^{\circ}$, straight, occasionally forked, craspedodrome, ending in the marginal teeth; finer nervation not retained.

This fine little species is represented by a large number of specimens, but most of them are badly broken. The length is from 8 to 10 centimeters and the width from 6 to 11 millimeters. It is well marked by its extremely long narrow shape, finely serrate margin, and numerous acute-angled secondaries.

This species is undoubtedly most closely-related to Quercus breweri Lesquereux, ${ }^{2}$ which was once merged with $Q$. consimilis Newberry, ${ }^{3}$ from the Clarno formation (Eocene) of the John Day Basin, Oreg. It differs slightly from Q. breweri, however, in its generally narrower shape, fewer and rather larger teeth, and more acute-angled secondaries.

Occurrence: Raton formation (Tertiary); 1 mile southwest of Rugby, Colo., 170 feet above

2 The Cretaceous and Tertiary floras: U. S. Geol. Survey Terr. Rept., vol. 8, p. 246, pl. 54, figs. 5-8, 1883.

3 T'he later extinct floras of North America: U.S. Geol. Survey Mon. 35, p. 71, pl. 43, figs. 2-5, 1898. 
the Trinidad sandstone, collected by G. B. Richardson's party (5128). Wilcox formation (Eocene); Mississippi, Arkansas, Tennessee, and Kentucky.

\section{Order URTICALES. \\ Family ULMACEAE: \\ Ulmus sp. \\ Plate LXX, figure 4.}

In the material from Powell Arroyo, near Bowen, Colo., a single fragmentary example was found, which with little doubt belongs to Ulmus. It is evidently unequal sided, about 6 centimeters long and 3 centimeters wide, and has its margin coarsely toothed with rather blunt teeth. There was probably about eight pairs of alternate rather strong secondaries, which end in the teeth and send short forks to the sinuses.

This form, so far as can be ascertained, was about the same size as Olmus tenuinervis Lesquereux ${ }^{1}$ and has much the same nervation but much coarser teeth.

Occurrence: Raton formation (Tertiary); Powell Arroyo, 3 miles west of Bowen, Colo., collected by W. T. Lee (5695).

\section{Family MORACEAE.}

Ficus artocarpoides Lesquereux.

Plate LXXI, figure 3.

Ficus artocarpoides Lesquereux, U. S. Geol. Survey Terr. Rept., vol. 8 (Cretaceous and Tertiary floras), p. 227, pl. 47, figs. 1-5, 1883.

Berry, U. S. Geol. Survey Prof. Paper 91, p. 200, pl. 34, fig. 2, 1916.

Lesquereux's original description is as follows:

Leaves large, subcoriaceous, oval, obtuse, or blunt at the apex, rounded or subcordate at base; median nerve thick, enlarged at base and passing into a very thick long petiole; secondary nerves narrow, at an acute angle of divergence, camptodrome, with few branches; nervilles close, simple or rarely forked.

The types of this species are described as being from 10 to 15 centimeters in length and 7 or 8 centimeters in width, with 4 centimeters of the petiole preserved. The leaf from Wootton that is here figured was probably fully 15 centimeters in length and about 8.5 centimeters in width; and the petiole, 6 centimeters long and 4 millimeters thick, is preserved in its entirety.

1 The Tertiary flora: U. S. Geol. Survey Terr. Rept., vol. 7, pl. 26, fig. 3,1878 .
Occurrence: Raton formation (Tertiary); Wootton, Colo., 50 to 100 feet below the Wootton coal, collected by W. T. Lee (5711). Wilcox formation (Tertiary); Coushatta, La.

Ficus aguilar Knowlton, n. sp.

Plate LXXI, figure 1.

Leaves large, very thick and coriaceous in texture, oblong-lanceolate in shape, rather abruptly rounded to the extremely thick petiole (apex unknown); margin perfectly entire; midrib unusally thick-5 millimeters at base-perfectly straight but slightly thinner above; secondaries numerous (probably eighteen or twenty pairs), at somewhat irregular distances, emerging at a very low angle, considerably curved upward, apparently ending in or very near the margin; finer nervation obscure, nervilles apparently numerous, unbroken, and at right angles to the secondaries.

The specimen figured is all that can certainly be referred to this species. The full length of the leaf can not be ascertained, for its upper portion is missing; but there is no indication of narrowing in the part preserved, and it was probably at least as long again, or about 24 centimeters; its width is 9 centimeters. About. 1 centimeter of the petiole is preserved but part. is clearly missing.

This leaf is remarkable for its large size, oblong-lanceolate outline, exceedingly thick petiole and midrib, and numerous thin lowangled secondaries, and by these characters is shown to be of the type of the living Ficus. elastica Linné. Among fossil species there. are many with which it may be compared. Thus Ficus glascoena Lesquereux, ${ }^{2}$ from the Dakota sandstone of Kansas, has approximately the same size and shape and the same exceedingly thick midrib but differs distinctly in its secondaries, of which it has more than twice as many. The secondaries in F. glascoena. are also thinner and little if any curved upward near the margin.

F. aguilar is perhaps closer to Ficus ungeri. Lesquereux, from the Green River formation of Wyoming, but differs from it in its larger size, its. much thicker midrib and petiole, and its rather fewer, relatively stronger secondaries.

2 The flora of the Dakota group: U. S. Geol. Survey Mon. 17, p. 76, pl. 13, figs. 1, 2, 1892. 
Occurrence: Raton formation (Tertiary); dump of Green Canyon mine, locality 119, near Aguilar, Colo., collected by W. T. Lee (5684).

Ficus uncata Lesquereux.

Plate LXXVI, figure 2.

Ficus ulmifolia Lesquereux, U. S. Geol. Survey Terr. Ann. Rept., 1871, Suppl., p. 14, 1872.

Ficus gaudini (not Ettingshausen), Lesquereux idem, p. 300 .

Ficus uncata Lesquereux, U. S. Geol. Survey Terr. Rept., vol. 7 (Tertiary flora), p. 197, pl. 35, figs. 1, 1a, 2, 1878.

Ficus arenacea brevipetiolata Lesquereux, U. S. Geol. Survey Terr. Rept., vol. 7 (Tertiary flora), p. 195, pl. 29 , figs. 2, 3, 5, 1878 .

Populus monodon Lesquereux, idem, p. 180, pl. 24, figs.1, 2. Ficus 'monodon (Lesquereux) Berry; U. S. Geol. Survey Prof. Paper 91, p. 201, pl. 32, fig. 2; pl. 33, fig. 2 1916.

Leaves large, coriaceous in texture, quite entire, broadly lanceolate or ovate-lanceolate, acuminate, rounded to the base, with thick petiole grooved in many specimens, midrib broad and thick and grooved in many specimens; secondaries numerous, strong, subequidistant, parallel, camptodrome; nervilles strong, largely unbroken.

As may be seen from the extensive synonymy above recorded, very great confusion has existed regarding the leaves here brought together under the name of Ficus uncata, and it is by no means certain that they are even now finally allocated, and in addition there is more or less uncertainty regarding localities, as will be pointed out later.

The type specimens of Ficus uncata are preserved in the United States National Museum (Nos. 298, 299, 300). In the original description (published under the preoccupied name of Ficus ulmifolia), these specimens are said to have come from "Fishers Peak, Raton Mountains, N. Mex.," being so recorded in the $\mathrm{Mu}$ seum catalogue in Lesquereux's handwriting; and there is no reason to doubt the correctness of the statement, as the matrix agrees perfectly with that of others from thatlocality. In" "The Tertiary flora" (p. 197, Pl. XXXV) the originals of figures 1 and 2, shown above to be the types, are said to have come from Carbon, Wyo., having been found "in the shale above the main coal," and figure 3 (probably fig. 1a, there being no Ficus on this plate with the No. 3 ) is alone said to be from the Raton Mountains. This statement is certainly wrong, and is so shown to be not only by the specimens theinselves and by the entry in the Museum catalogue but by the original description, which clearly proves that these are the specimens figured. The species has never been found at Carbon, Wyo., and is undoubtedly from the Raton Mountains.

Ficus arenacea brevipetiolata Lesquereux is represented by three figures in "The Tertiary flora" (PI. XXIX, figs. 2, 3, 5), and by two original specimens in the United States $\mathrm{Na}$ tional Museum.(Nos. 260, 260a). These leaves (described under the preoccupied name of Ficus gaudini) are preserved on a "hard, shaly, fine-grained whitish sandstone" and are from.an unknown locality of which Lesquereux ${ }^{1}$ says: "The precise locality is unknown, the labels having been lost or forgotten." This locality was viguely conjectured to be in the Green River formation, and the specimens were subsequently so assigned without further question. It is highly improbable that they really came from the Green River, for the species has not been found in that formation; and the finding of what is undoubtedly this species in the Raton Mesa region makes it reasonably probable that the original horizon was not far away, though the original locality will probably always remain unknown. In any event it seems impossible to distinguish these leaves from those of Ficus uncata. They have the same rounded form at base, the same thick midrib, and the same close parallel secondaries. Ficus uncata is said to be especially characterized by the short hooked petiole, but this is manifestly a character of little value, for the position of the leaf on the branch would largely determine the shape of the petiole and easily account for its hooked form.

Populus monodon Lesquereux ${ }^{2}$ was described originally from the "Eo-lignitic" (Wilcox formation) of Mississippi, and is figured and described by its author as having the margins undulate or even somewhat toothed. In "The Tertiary flora" (Pl. XXIV; figs. 1, 2) two leaves are figured from Fishers Peak, Raton Mountains, under the name of Populus monodon, but, as may be seen on comparing these figures with

1 Fossil flora: U. S. Geol. Survey Terr. Ann. Rept., 1871, pt. 3, p. 300, 1872.

2 Lesquereux, Leo, On species of fossil plants from the Tertiary of the State of Mississippi: Am. Philos. Soc. Trans., vol. 13, p. 413, pl. 15, figs. $1,2,1869$. 
the originals from Mississippi, they can hardly be considered as conspecific, and with very little doubt they are correctly referable to Ficus uncata. Both are preserved in the United States National Museum (Nos. 217, 218 ), and the matrix is seen to be absolutely the same as that bearing the types of $F$. uncata. One of the figures (fig. 1) is not quite accurate, the apparent sinus on the side being simply a broken place and not showing true margin.

The leaf here figured from near Abeton, Colo., is not to be distinguished from one of the leaves figured by Lesquereux as Ficus uncata brevipetiolata. It is smaller than the three figured types of $F$. uncata, but it is of the same type.

Occurrence: Raton formation? (Tertiary); types, "Fishers Peak, Raton Mountains, N. Mex." Raton formation (Tertiary); Apishapa Canyon, about 4 miles northeast of Abeton, Colo., near top of Raton formation, collected by W. T. Lee (5689).

Ficus duplicata Knowlton, n. sp.

Plate LXXIV, figure 1.

This species is very closely similar to and may possibly be the same as Ficus aguilar from the same locality. It differs from that form apparently in being slightly ovate-lanceolate and in having a much thinner petiole and midrib, although both are relatively strong. The secondaries are of about the same number, though they emerge at a much greater angle and are not much curved upward.

Occurrence: Raton formation (Tertiary); dump of Green Canyon mine, locality 119, near Aguilar, Colo., collected by W. T. Lee (5684).

Ficus occidentalis (Lesquereux) Lesquereux.

Plate LXXII, figure 1.

Dombeyopsis occidentalis Lesquereux, U. S. Geol. Survey Terr. Ann. Rept., 1872, p. 380, 1873.

Ficus occidentalis (Lesquereux) Lesquereux, U. S. Geol. Survey Terr. Rept., vol. 7 (Tertiary flora), p. 200, pl. 32, fig. 4, 1878; Harvard Coll. Mus. Comp. Zoology Bull., vol. 16, p. 50, 1888.

The type of this species from the Denver formation at Golden, Colo., is preserved in the United States National Museum collections (No. 281). It appears to be rather rare, although Lesquereux records the presence of five specimens in the large collections which he identified for the Harvard College Museum of Comparative Zoology, at Cambridge, and the writer found another much smaller but otherwise well-marked specimen in recently studied collections. The collection from Dillon Canyon, N. Mex., contains two examples, one of which certainly belongs here. The one figured is a little larger than Lesquereux's type but otherwise agrees with it perfectly. Occurrence: Denver formation (Tertiary); type, Golden, Colo. Raton formation (Tertiary); west side of Dillon Canyon, near Blossburg, N. Mex., 1 mile north of mouth of Coal Canyon, collected by W. T. Lee (5147). Ackerman formation (Tertiary); Hurleys, Benton County, Miss. Midway formation? (Tertiary); Earle, Tex.

\section{Ficus harrisiana Hollick?}

Ficus harrisiana Hollick, A report on a collection of fossil plants from northwestern Louisiana: Louisiana Exper. Sta., pt. 5, p. 281, pl. 46, fig. 2, 1899.

Berry, U. S. Geol. Survey Prof. Paper 91, p. 201, pl. 34, fig. 1, 1916.

A single example from Dillon Canyon, $\mathrm{N}$. Mex., is probably best referred to this form. It is very closely related to and was at first referred to Ficus occidentalis Lesquereux, but it is maintained as distinct by Berry in his recent work:

Occurrence: Raton formation (Tertiary); west side of Dillon Canyon, N. Mex., 1 mile north of mouth of Coal Canyon, collected by W. T. Lee (5147). Wilcox formation (Tertiary); Vineyard Bluff, Shreveport, La.

\section{Ficus denveriana Cockerell.}

Plate LXXV, figures 1, 2.

Ficus spectabilis. Lesquereux (homonym, Ficus spectabilis Kunth and Bouché, Amnales sci. nat., 3d ser., vol. 7, p. 235, 1847), U. S. Geol. Survey Terr. Ann. Rept., 1872, p. 379, 1873; U. S. Geol. Survey Terr. Rept., vol. 7 (Tertiary flora), p. 199, pl. 33, figs. 4-6, 1878; Harvard Coll. Mus. Comp. Zoology Bull., vol. 16, p. 50, 1888; U. S. Nat. Mus. Proc., vol. 11, p. 25, 1888.

Ficus denveriana Cockerell, Torreya, vol. 10, p. 224, 1910 Berry, U. S. Geol. Survey Prof. Paper 91, p. 198, 1916.

This fine species has the Denver formation at Golden, Colo., as its type locality, and all subsequent collections from this area show it to be a rather common form. It has also been reported from several other localities, all approximately in the same stratigraphic position. Thus Cannon found it on Sheriff Creek, near Hot Sulphur Springs, in Middle Park, Grand 
County, Colo., in beds referred to the Denver; Brown obtained a doubtful specimen from the Lance formation of Weston County, Wyo., and Peale and Goldman found it at several points near Colorndo Springs, Colo., in beds of postLarnmie age.

Ficus spectabilis has also been reported by Lesquereux from two localities in Louisiana in beds said to be the equivalent of the La Grange group of Safford, hence probably in the Wilcox formation and thus in the approximate position of the Denver. Its appearance in the post-Laramie beds of the Raton Mesa field, being intermediate between the northern and southern localities, was to have been expected. The Jeaf figured, which is fairly perfect, is not to be distinguished from certain of the leaves of this species from the Denver Basin.

Occurrence: Denver formation (Tertiary); types, Golden, Colo. Raton formation (Tertiary), collected by W. T. Lee-Norman's ranch, 12 miles east of Raton, N. Mex. (5132); Yankee, locality 85, N. Mex. (5137); near Yankee, N. Mex. (5142); Vermejo Valley, near mouth of York Canyon, N. Mex. (5241); mesa north of Raton, N. Mex. (5132); Apishapa. Canyon, near Abeton, Colo. (5689); Apishapa Canyon, one-half mile west of Abeton, Colo. (5686); near Suffield mine, Colo. (5693); Wootton, Colo., 50 to 100 feet above Wootton coal (5712); Vermejo Creek, N. Mex. (5826); collected by G. B. Richardson's partyFishers Peak mine, 3 miles southeast of Trinidad, Colo. (5099); 7 miles southwest of Berwind, Colo. (4121); 5 miles above Aguilar, Colo. (5122); collected by Orestes St. JohnWootton, Colo.; Long Canyon, N. Mex.; 900 feet above Trinidad sandstone. Wilcox formation (Tertiary); several localities in Arkansas. and Louisiana. Midway formation (Tertiary).

Ficus neoplanicostata Knowlton, n. sp.

Plate LXXIII, figure 4; Plate LXXIV, figures 2, 3; Plate LXXVI, figure 4.

Leaves thick in texture, ovate, broadest at or just below the middle, whence they are rounded to the obtusely wedge-shaped base and above to the acuminate apex; margin perfectly entire; nervation strong, pinnate, the lowest pair of secondaries nearly as stong as the midrib and arising at or more frequently just above the base of the blade, this producing a pseudo three-ribbed appearance; midrib with four or five pairs of secondaries, which are slightly curved upward and arch just inside the margin; basal pair of secondaries (ribs) with some seven or eight camptodrome branches on the outside; nervilles numerous, strong, mainly unbroken.

This form is represented by a number of wellpreserved leaves of different sizes, all regularly ovate with an obtusely wedge-shaped base and an acuminate apex. The smallest leaf noted is 4 centimeters long and 3 centimeters wide, and the longest is 10 centimeters long and 5.5 centimeters wide. The nervation is very well shown in the figures and need not be further described.

This species is undoubtedly of the type of and most closely related to Ficus planicostata Lesquereux ${ }^{1}$ of the Black Buttes coal group of Black Buttes, Wyo., regarded by the author as of post-Laramie age. It differs from this, however, in several particulars, being distinctly ovate-acuminate instead of elliptical with a rounded apex; and obtusely wedge shaped at base instead of rounded or truncate; the nervation is of the same type in both.

Occurrence: Raton formation (Tertiary); one-eighth mile northeast of Rockland mine, locality 120, north side of Cucharas Canyon, near Walsenburg; Colo., collected by W. T. Lee (5679).

Ficus planicostata clintoni (Lesquereux) Knowlton. Plate LXXVI, figure 3.

Ficus clintoni Lesquereux, U. S. Geol. Survey Terr. Ann. Rept., 1872, p. 393, 1873.

Ficus planicostata clintoni (Lesquereux) Knowlton, U. S. Geol. Survey Bull. 152, p. 103, 1898.

Ficus planicostata var. goldiana Lesquereux, U. S. Geol. and Geog. Survey Terr. Ann. Rept., 1873, p. 399, 1874; U. S. Geol. Survey Terr. Rept., vol. 7 (Tertiary flora), p. 202 , pl. 33 , figs. $1-3,1878$.

Thè specimen, although not very well preserved, appears to be referable to F.planicostata clintoni. It is rather shorter than is usual but otherwise does not appear essentially different.

Occurrence: Raton formation (Tertiary); Norman's ranch, about 12 miles east of Raton, N. Mex., near locality 92 , collected by W. T. Lee (5132). Denver formation (Tertiary); types, Golden, Colo.

1 The Tertiary flora: U. S. Geol. Survey Terr. Rept., vol. 7, pl. 31, figs. 1-8, 10-12, 1878 . 
Ficus latifolia? (Lesquereux) Knowlton. ${ }^{1}$

Ficus planicostata latifolia Lesquereux, U. S. Geol. Survey. Terr. Ann. Rept., 1872, p. 393, 1873; U. S. Geol. Survey Terr. Rept., vol. 7, Tertiary flora, p. 202, pl. 31, fig. 9, 1878.

Ficus latifolia (Lesquereux) Knowlton, U. S. Geol. Survey Bull. 152, p. 102, 1898 .

In one of the collections from the vicinity of Trinidad I find a single very fragmentary specimen that appears to belong to this species. Only a portion of the base is preserved, but so far as can be made out it does not appear to differ from the figure given by Lesquereux.

Occurrence: Laramie formation (Cretaceous); type, Golden, Colo. Raton formation (Tertiary); Trinidad field; Colo., 7 miles southwest of Berwind (S. $44^{\circ}$ W. from NE. corner of T. 32 S., R. 66 W.), collected by G. B. Richardson's party (5045). Wilcox formation (Tertiary); Shreveport, La.

Ficus pseudopopulus Lesquereux.

Plate LXXII,' figüres 2-4; Plate LXXIII, figures 1, 2; Plate CXII, figure 3 .

Ficus pseudopopulus Lesquereux, U. S. Geol. Survey Terr. Bull., vol. 1, 2d ser., No. 5, p. 387, 1876; U. S. Geol. and Geog. Survey Terr. Ann. Rept., 1874, p. 313, 1876; U. S. Geol. Survey Terr. Rept., vol. 7 (Tertiary flora), p. 204, pl. 34, figs. 1a, 2, 1878.

Berry, U. S. Geol. Survey Prof. Paper 91, p. 200, pl. 37, figs. 3-5, 1916.

Lesquereux's original description is as follows:

Leaves of medium size, oval, pointed or acuminate, entire, narrowed downward to a long petiole, palmately three nerved from the base; lateral primary veins at an acute angle of divergence, ascending to above the middle; secondary veins two or three pairs, parallel to the primary ones but at a great distance above them; divisions all camptodrome.

The size was given as 8 to 10 centimeters long and 3 to 4 centimeters wide. The original locality, given as unknown, was conjectured to be in the Green River formation of Wyoming, but later the species was found in the lower Tertiary at Evanston, Wyo.

The fine leaf here figured is referred to this species with a little hesitation. It is of the same shape, though much larger; being about 14 centimeters long and 7 centimeters wide, and has the lateral ribs at a very slightly more acute angle. Owing to the coarseness of the

1 This name is preoccupied and will bechanged in a later publication, in which the data making the change necessary will be presented in full. matrix on which it is preserved none of the finer nervation has been retained.

As regards the affinities or apparent affinities of this species Lesquereux says: "This species is a remarkable one, resembling a $\mathrm{Cin}$ namomum by its principal nervation, a $Z i z y$ phus by the form of the leaves, a Populus by its entire borders and long petiole, and a Ficus by the areolation."

Occurrence: Raton formation (Tertiary); collected by W. T. Lee-near Yankee, N. Mex. (5142); Spring Canyon, north of Vermejo Park, N. Mex. (5236); Vermejo Valley, near mouth of York Canyon, N. Mex. (5241); collected by G. B. Richardson's party-Trinidad field, locality 110 , near northeast corner sec. 23 , T. 32 S., R. 64 W. (5101); 4 miles southwest of Berwind, Colo., mine No. 37 (5120); collected by Orestes St. John-Wootton, Colo., about 1,050 feet above the Trinidad sandstone. Lagrange formation (in beds of Wilcox age) (Tertiary); Puryear, Henry County, and Hatchie River, near Shandy, Hardeman County, Tenn.

\section{Ficus praetrinervis Knowlton, n. sp.}

This species occurs also in the Vermejo formation and for the full description, discussion of relations, and reference to figures, see page 263.

Occurrence: Raton formation (Tertiary); Riley Canyon, one-half mile north of Cokedale, Colo., collected by W. T. Lee (5699); Wootton, Colo., 50 to 100 feet above the Wootton coal, collected by W. T. Lee (5712); hogback 2 miles southeast of Dean, Colo. (T. 32 S., R. 68 W.) in slide rock 200 feet above lowest coal, collected by G. B. Richardson's party (5113). Vermejo formation (Cretaceous); see page 263.

Ficus schimperi Lesquereux.

Plate LXXV, figs. 3,4 .

Ficus schimperi Lesquereux, Am. Philos. Soc. Trans., vol. 13, p. 407; pl. 18, figs. 1-3, 1869.

Berry, U. S. Geol. Survey Prof. Paper 91, p. 204, pl. 31, figs. 1-3, 1916.

The leaf here figured, although lacking all its upper portion, appears to be referable to this species. It is of the same size and shape and has practically the same type of primary nervation, though the lowest pair of secondaries arise lower down than in the leaf shown in Lesquereux's figure 3 , the one that this leaf 
most resembles. Even more closely resembling the type specimens are several fairly well preserved examples from Vermejo Creek, N. Mex.

Occurrence: Raton formation (Tertiary); collected by W. T. Lee-near Yankee, N. Mex., locality 85 (5142); Green Canyon mine, locality 119, near Aguilar, Colo. (5684); near Trinidad, Colo., locality 106 (sec. 9, T. 33 S., R. 64 W.) (5697); Vermejo Valley, near the mouth of Salyers Creek, N. Mex. (5826).

Ficus? smithsoniana (Lesquereux) Lesquereux.

Juglans smithsoniana Lesquereux, U. S. Geol. Survey Terr. Ann. Rept., 1871, Suppl., p. 16, 1872.

Ficus? smithsoniana (Lesquereux) Lesquereux, U. S. Geol. Survey Terr. Rept., vol. 7 (Tertiary flora), p. 200, pl. 32, fig. $5,1878$.

Lesquereux describes this as follows:

Lenf coriaceous, smooth; lanceolate, gradually tapering upward from above the base and acuminate; borders entire and undulate; middle nerve flat and broad; lower pair of lateral veins more oblique and ascending higher; nervation camptodrome.

The type of this species is now in the United States National Museum, being preserved on the same stone with the type of Sabal? ungeri. It is said to have come from "Fischers [Fishers] Peak, Raton Mountains, N. Mex.," and although it is not known to have come from above the unconformity, the appearance of the matrix, as well as its association with a wellknown species which has been found only in the upper beds, makes it reasonably certain that such is its position. It has been fairly well described and figured by Lesquereux. - Its length is about 13 centimeters and its width about 4 centimeters. The nervilles are numerous, rather strong, and mainly broken; the finer nervation produces rather large quadrangular areas.

Occurrence: Raton formation (Tertiary); Fishers Peak, Raton Mountains, Colo., type, on same stone with type of Sabal? ungeri.

Ficus richardsoni Knowlton, n. sp. Plate LXXVI, figure 1.

Leaf thick in texture, broadly ovate in shape, abruptly rounded to a slightly decurrent base, apex probably rather obtusely pointed; margin entire or slightly flexuose; petiole slender; palmately five ribbed from the top of the petiole; midrib much the stronger, straight, with six or seven pairs of slender, alternate $47019^{\circ}-17-20$ secondaries which curve upward along the lateral ribs, those from the middle and upward reaching the upper margin; middle pair of ribs nearly as strong as the midrib, reaching to within one-third the length of the blade from the apex, each with about ten secondary branches on the outside which are approximately at right angles to the midrib, curving upward and joining the one next above near the margin; lowest pair of ribs . very slender, passing up for about one-third the length of the blade and there joining with a secondary from the middle pair of ribs; finer nervation not preserved.

This fine large leaf, the only one of the kind thus far observed, was about 13 or 14 centimeters long and 8 centimeters broad at the broadest point, which is about one-fourth the length of the blade from the base. It is remarkable for its thick midrib with its several pairs of alternate, irregularly spaced secondaries, which begin just above the base and supply the whole of the space between the next pair of ribs; it has also a few intercalated or intermediate secondaries which disappear within short distances. The lateral strong ribs pass high up in the blade and have numerous secondary branches on the outside which are at a very different angle to those on the midrib. The lowest or outer pair of ribs is very slender, being hardly more than secondary branches from the extreme base of the middle pair of ribs, yet they run up for some distance and are joined by several of the secondaries.

This species resembles more or less closely a number of described fossil species (for example, Ficus praetrinervis, p. 263), with some of which it agrees perfectly in size, shape, and general appearance, but from which it differs in having the secondary branches on the midrib filling the whole space between the next pair of lateral ribs, and also in the position of the lowest or outer pair of thin ribs.

Occurrence: Raton formation (Tertiary); 5 miles above Aguilar, Colo:, collected by G. B. Richardson's party (5046).

Ficus minutidens Knowlton, n. sp.

Plate LXXI, figure 2.

Leaf very thick in texture, ovate, apparently truncate or slightly heart-shaped at base and obtuse at apex; margin with few, remotr, very small teeth; nervation strong, consisting 
of a strong, straight midrib and four or five pairs of nearly as strong alternate secondaries, which curve upward (some of the upper ones branched), the lower pair with six or seven branches on the outer side ending in the minute teeth or camptodrome below; nervilles numerous, very strong, mostly unbroken and at right angles to the secondaries.

The specimen figured is the only one thus far observed in the collections. It is fragmentary, lacking both base and apex as well as most of one side. It appears to have been 10 or 11 centimeters in length and about 9 centimeters in width. It is remarkable for the strong Ficus-like nervation and its remotely and minutely toothed margin.

At first sight this leaf appears to belong to the type of Ficus planicostata Lesquereux and $F$. latifolia (Lesquereux) Knowlton, both of which are so abundànt at Black Buttes, Wyo.; and in fact it does agree with this type in size, shape, and nervation but differs absolutely in the character of its margin. In the lower part of the margin it shows only faint indications of teeth in the form of slight undulations, but above it has definite though small and scattered teeth which are entered by the secondaries or branches from them.

Occurrence: Raton formation (Tertiary); Wootton, Colo., 50 to 100 feet below the Wootton coal, collected by W. T. Lee (5711).

Ficus ratonensis Knowlton, n. sp.

Plate LXXIV; figure 4.

Leaf firm in texture, ovate in shape, abruptly rounded to a truncate, slightly heart-shaped base (apex destroyed, apparently acuminate); nervation palmately five or seven ribbed from the top of the petiole, midrib strongest; straight, with three or four pairs of alternate, remote, thin camptodrome secondaries; next pair of ribs emerging at an angle of about $45^{\circ}$, curving upward and joining the lowest pair of secondaries; next pair of ribs arising nearly at a right angle with the midrib, then much curving upward and joining the ribs above, these ribs with three or four secondary branches on the lower side, the first one arising at the very base and thus giving the leaf a seven-ribbed appearance; all ribs and secondaries camptodrome, often with a series of large loops on the outside; nervilles prominent, strong, mainly unbroken and at right angles to the secondaries or the lateral ribs.

This species unfortunately is represented only by the single, very imperfect exámple figured. It is, as may be seen from the illustration, a regular ovate with a rounded, then slightly heart-shaped base. The length, so far as can be made out, was about 9 centimeters and the width about 7 centimeters.

Occurrence: Raton formation (Tertiary); Honeyfield mine near Yankee, N. Mex., 75 feet above the base of the Raton formation, collected by W. T. Lee (5140).

\section{Artocarpus similis Knowlton, n. sp.}

Plate LXXVII; Plate LXXVIII, figures 1; 2.

Leaf of large size, coriaceous in texture, apparently long elliptical in general outline, deeply cut into two or more pairs of opposite or subopposite large lobes which are rather broad and acute or obtusely acute, separated by broad rounded sinuses; terminal lobe ovate; or ovate-elliptical, apparently rather obtuse, lower lobes progressively smaller toward the base; nervation rather slender, craspedodrome, the thin secondaries ending in the lobes; intermediate secondaries passing up to and forking just under the sinuses.

As indicated above, this leaf was undoubtedly of large size, the portion preserved being nearly 18 centimeters long. The whole leaf could hardly have been less than 25 centimeters in length. The width between the tips of the lobes is 12 to 14 centimeters. This specimen is not well preserved and lacks the basal portion and practically all of the nervation except the midrib and the secondary branches passing to the tips of the lobes.

This species is mostly closely related to forms from the Denver Basin, which are now believed to represent two species. These are Artocarpus lessigiana (Lesquereux) Knowlton ${ }^{1}$ (originally described as Myrica? lessigiana) and Artocarpus pungens (Lesquereux) Knowlton (first named Aralia pungens). At one time I.was inclined to unite these forms, ${ }^{2}$ but from evidence now at hand it seems best to consider them distinct, though their differences are not very great. Artocarpus lessigiana is much the larger and has very, broad, relatively obtuse lobes and

1 Science, vol. 21, p. 24, 1893

2 Knowlton, F. H., A catalogue of the Cretaceous and Tertiary plants of North America: U. S. Geol. Survey Bull. 152, p. 42, 1898. 
exceptionally strong midrib and secondaries; its terminal lobe, if the one preserved represents this, was broadly ovate and presumably rounded. A. pungens, however, has its lateral lobes at a more acute angle, larger, and narrower; its terminal lobe is also narrower and pointed, and its nervation, although rather strong, is much weaker than that of $A$. lessigiana.

Artocarpus similis is, in a way, intermediate between $A$. lessigiana and $A$. pungens. It has the narrow acute-pointed and acute-angled lobes of $A$. pungens, and the ovate, obtuse terminal lobe of $A$. lessigiana. It differs from both apparently in having much slenderer nervation. The differences separating the three species are not very marked, and it is quite possible that with a fair series of specimens from both localities they might be found to be indistinguishable. Leaves of Artocarpus are always rare and; being of large size, are infrequently preserved entire. Notwithstanding all the collecting that has been done in the Denver Basin less than half a dozen examples have come to the writer's attention, and in the immense collections under consideration from southern Colorado there are only seven or eight specimens, all fragmentary. The present form has; however, been found at no less than six localities in this area, all the specimens, so far as can be made out, being referable to a single species, which, as stated above, appears to differ slightly from the forms known farther north.

Occurrence: Raton formation (Tertiary); collected by W. T. Lee-type, Wet Canyon, about 4 miles northwest of Weston, Colo. (5799); railroad cut about one-half mile north of Wootton, Colo. (5711); dump of mine at Delagua, Colo. (5690); 1 mile north of Trujillo Plaza, Colo., about 100 feet below supposed base of Poison Canyon formation (5687); one-eighth mile northeast of Rockland mine, locality 120 , near Walsenburg, in Cucharas Canyon, Colo.' (5679); near Strong, Colo. (5682) (supposed in the field to belong to the Vermejo formation, but now presumed, as the stratigraphic relations are uncertain and as the single fragmentary specimen agrees absolutely with all the others, to belong to the higher beds); Wootton, Colo., 50 to 100 feet-above the Wootton coal (5712) ; collected by G. B. Richardson's partyRiley Canyon, near Cokedale, Colo. (5104).
Order ARISTOLOCHIALES:

Family ARISTOLOCHIACEAE.

Aristolochia? elongata Knowlton, n. sp.

Plate LXXVIII, figure 3.

Fruit flattened, narrowly elliptical or long oblong in outline, rounded and very obtuse at the distal extremity, abruptly rounded to a very short pedicel at base, 28 millimeters long, 10 to 11 millimeters broad; marked with two rather prominent longitudinal ribs which divide the surface into four approximately equal areas.

The two fruits figured are all that has been observed of this form. From the position they now occupy it seems probable that they were attached to an axis, now disappeared, by the very short pedicel preserved. Although now compressed to a thickness of only 2 to 3 millimeters, they were probably little flattened when perfect. From the presence of two longitudinal ribs, it is inferred that they were six ribbed.

This species most closely resembles Carpites pealei Lesquereux, ${ }^{1}$ from the Miocene lake beds at Florissant, Colo., but differs from it in its much larger size, short-pediceled base, and lack of fine, parallel striae.

In a general way, these fruits are also like those of: Aristolochia oeningensis Heer, ${ }^{2}$ except that they are longer, narrower, and have finer striae. As they seem at least to be congeneric I have placed them in the genus Aristolochia rather than in the nondescript Carpites.

Occurrence: Raton formation (Tertiary); 4 miles southwest of Berwind, Colo., collected by G. B. Richardson's party (5120).

Order RANALES.

Family NYMPHAEACEAE.

Castalia leei Knowlton, n. sp.

Plate LXXIX, figure 3.

Leaf firm in texture, apparently nearly orbicular in outline, deeply cordate-reniform at base, the sinus open and the basal lobes rounded; margin perfectly entire; nervation palmately radiate, nine ribbed from the top of the petiole; midrib probably with one or more pairs of secondaries, all the other ribs forking about half the distance between petiole, or point of origin, and the margin, the branches nearly equal and apparently passing thence straight to the margin; finer nervation not retained.

1 The Tertiary flora: U. S. Geol. Survey Rept., vol. 7, p. 306, pl. 60,

fig. 31, 1878.
2 Flora tertiaria Helvetio, vol. 3, p. 189, pl. 154, fig. 8, 1859. 
This splendid species is represented only by the example figured, which unfortunately lacks most of one side and all of the apical portion. The base and all of one side are present and exhibit well the general outline and characteristic nervation. It appears that the leaf was nearly orbicular with a transverse diameter of about 12 centimeters; but as its midrib does not fork or branch within as short a distance as do the other ribs, the leaf may possibly have been slightly pointed or.prolonged, as in certain living species of the genus Castalia. In some respects this leaf seems to combine the characters of the leaves of both Castalia and Nelumbo. The orbicular or orbicular-ovate shape and deeply lobed base with the basal lobes rounded are characters indistinguishable from those of Castalia but at variance with those of Nelumbo; in which the leaves are centrally peltate. In Castalia, however, the midrib is always distinct, and usually has several pairs of opposite forking secondaries; the other ribs radiate from its base. In Nelumbo the equally strong ribs all radiate from the depressed center of the blade. In the present leaf the midrib is not wholly preserved, but the portion retained shows no indication of branches or secondaries, though there doubtless were such in the upper portion. In the living Castalia the midrib and lateral ribs all arise at the extreme base of the blade, but in the fossil $C$. leei the ribs arise a short but appreciable distance above the base of the lamina. On the whole, however, this leaf appears to be closest to Castalia and may be so considered until further information is available. It is a well-marked form that can be identified in the future with certainty, provided sufficiently well-preserved material is at hand.

Occurrence: Raton formation (Tertiary); oneeighth mile northeast of Rockland mine, near Walsenburg, north side of Cucharas Canyon, Colo., collected by W. T. Lee (5679).

Nelumbo lakesiana (Lesquereux) Knowlton, n. comb.

Nelumbium lakesianum Lesquereux, U. S. Geol. Survey Terr. Ann. Rept., 1873, p. 403, 382, 1874.

Knowlton, U. S. Geol. Survey.Bull. 152, p. 151, 1898. Nelumbium lakesii Lesquereux, U. S. Geol. Survey Terr. Rept., vol. 7 (Tertiary flora), p. 252, pl. 46, figs. 1, 2, 1878; U. S. Geol. and Geog. Survey Ann. Rept., 1876, p. 514, 1878; Harvard Coll. Mus. Comp. Zoology Bull., vol. 16, p. 53, 1888.

The type specimens of this beautiful species are preserved in the United States National
Museum. (Nos. 370, 371), with a number of others more recently found. The originals are from the Denver formation at Golden, Colo., and although the large collections made at the same locality in 1890 by Arthur Lakes do not contain this species, it was present in the collection determined by Lesquereux for the Harvard College Museum of Comparative Zoology, at Cambridge, Mass.

In the collections also made by Lakes in 1890 near the Douglass coal mine, Sedalia, Colo., there were found no less than five more or less perfect specimens that are.referred with much certainty to this species. They have the same thick ribs, producing, when preserved on simi. lar material, the rough appearance described. by Lesquereux. The number of ribs is usually 14 , although one has but 13 , the number described as present in $N$. tenuifolia. One specimen shows the under surface of the leaf and a small portion of the petiole, which is 3.5 millimeters in diameter, or about the size of the petiole in the living $N$. lutea of eastern North America, although the leaf appears to have been rather smaller than the usual size of that living species. The margin is not well enough preserved to show with certainty the manner in which the nerves enter it.

This species is obviously most closely related to $N$. tenuifolia, from which it appears to differ, as pointed out by Lesquereux, by its evidently thinner texture and the lighter character of its ribs. These differences, however, are not great and may be entirely due to the age of the leaf, as Berry has said regarding the supposed differences between certain species of the Atlantic Coastal Plain.

So far as can be ascertained $N$. lakesiana is also very close to $N$. arctica Heer, ${ }^{1}$ from the Atane beds of Greenland. The Arctic species is, however, only a small fragment of the entire leaf; it has 13 thick ribs radiating from a common center, but the finer nervation is obsolete.

In one of the large-collections from the Fishers Peak region I have found a single specimen that appears to belong to $N$. lakesiana. It is very fragmentary, lacking all of the margin and a portion of one side, but in the manner of the insertion of the petiole and the radiation of the thirteen or fourteen ribs it is identical.

1 Flora fossilis arctica, yol. 6, Abt. 2, p. 92, pl. 40, f.g. 6, 1882. 
Occurrence: Denver formation (Tertiary); Golden, Colo. Dawson arkose (Tertiary); 3,000 feet east of the Douglass coal mine, near Sedalia, Colo. Raton formation (Tertiary); Fishers Peak mine, 3 miles southeast of Trinidad, Colo., collected by G. B. Richardson's party (5099).

Family MAGNOLIACEAE.

Magnolia angustifolia Newberry.

Plate I.XXIX, figure 1.; Plate IXXX; Plate LXXXI, figure 1.

Terminalia radobojensis Heer. Lesquereux, U. S. Geol. Survey Terr. Ann. Rept., 187l, Suppl., p. 15, 1872.

Magnolia angustifolic Newberry, U. S. Nat. Mus. Proc., vol. 5, 1882, p. 513, 1.883 .

Berry, U. S. Geol. Survey Prof. Paper 91, p. 214,.1916. Magnolia attenuata Weber. Lesquereux, U. S. Geol. Survey Terr. Rept., vol. 7 ('Tertiary flora), p. 250, pl. 45 , fig. 6, 1.878 .

Leaves evidently thick in texture, narrowly lanceolate or slightly obovate-lanceolate in shape, from 16 to 20 centimeters long, 4 to 5 centimeters wide, with an acuminate apex and a long narrowly wedge-shaped base; midrib relatively very thick, particularly below, much more slender above; secondaries about twelve to fourteen pairs, rather slender, alternate, at an angle of about $45^{\circ}$, considerably curved upward near the margin, camptodrome; finer nervation not retained.

This species is represented by a number of very well preserved leaves from several localities, four of the best of which are figured. The very perfect example shown in Plate LXXX, figure 2 , is fully 20 centimeters long and about 4.5 centimeters wide and has a rather slender acuminate apex. The other specimens figured are from a different locality and are equally perfect, especially that shown in Plate LXXX, figure 1.

The basal portion of these leaves is indistinguishable from the portion figured by Lesquereux from Fishers Peak, Raton Mountain, under the name of Magnolia attenuata Weber. This name was changed by Newberry to $M$. angustifolia, on the ground that it was not the same as the European leaves so called. - It is evident that Newberry had material from Fishers Peak. when he made the change in names, for his description agrees perfectly with the leaves here described and figured from the same general region, except that he gives the size as slightly larger than any I have observed.
Magnolia angustifolia is suggestive of $M$. laurifolia Lesquereux, from the Wilcox formation of Mississippi, from which it differs in having the finer secondaries at a more acute angle in the basal portion. In shape it agrees with $M$. lanceolata Lesquereux (now $M$. dayana Cockerell, ${ }^{1}$ from the auriferous gravels (Miocene) of California, but differs from it in having much less numerous secondaries set at a slightly different angle.

Occurrence: Raton formation (Tertiary); collected by W. T. Lee-type, Fishers Peak, Colo., Yankee, locality 85, N. Mex (5142); onehalf mile north of Brilliant, Colo. (5154); Rouse, Colo. (5683); Green Canyon mine, locality 119, near Aguilar, Colo. (5684); Apishapa Canyon, Colo. (5686); same (5689); mine at Delagua, Colo. (5690); near Trinidad, Colo., locality 106 (sec. 9, T. 33 S., R. 64 W.), (5697); south wall of Purgatory Canyon at mouth of Riley Canyon, near Cokedale; Colo., 50 to 150 feet above base of Raton formation (5704); one-half mile south of Starkville, Colo. (5797); Wootton, Colo., 50 to 100 feet above Wootton coal (5712); dump of Turner mine, $1 \frac{1}{2}$ miles north of Wootten, Colo. (5714); Wet Canyon, 4 miles northwest of Weston, Colo. (5799); Tercio, Colo., about 200 feet above top of basal conglomerate (5803); Vermejo Valley near mouth of Salyers Creek, N. Mex. (5826); Ute Park, N. Mex. (5830); collected by G. B. Richardson's party-5 miles above: Aguilar, Colo. (5122); 3 miles above Aguilar, Colo. (5118); one-fourth mile southeast of Santa Clara, Colo. (5126); collected by F. H. Knowlton-Hillside just west of south end of Raton tunnel, north of Raton, N. Mex. (5464); collected by Orestes St. John-Wootton, Colo., Long Canyon, N. Mex.; Smith's ranch, South Raton Canyon, N..Mex. Wilcox formation (Tertiary); near Coushatta, La., and Puryear, Henry County, Tenn.

\section{Magnolia laurifolia Lesquereux.}

Plate LXXXV, figure 2; Plate CVI, figure 2.

Magnolia laurifolia Lesquereux, Am. Philos. Soc. Trans., vol. 13, p. 421; pl. 20, fig. 3 (not fig. 2), 1869 .

In one of the large collections from above Aguilar I find the specimens here figured, neither of which can be distinguished from Lesquereux's Magnolia laurifolia, originally found

${ }^{1}$ Am. Naturalist, vol. 44, p. 35, 1910. 
in the Wilcox formation of Mississippi. One of the specimens is the basal portion of a fine leaf similar in every respect to the smaller of the two figures given. by Lesquereux. It was probably about 15 centimeters in length when perfect and is 5 centimeters broad at the broadest point. The extremely thick midrib and numerous close, parallel, thin secondaries are identical.

Occurrence: Wilcox formation (Tertiary); types; Mississippi. Raton formation (Tertiary); 5 miles above Aguilar, Colo., collected by G. B. Richardson's party (5046).

Magnolia hilgardiana Lesquereux.

Plate LXXIX, figure 2; Plate LXXXV, figure 1.

Magnolia hilgardiana Lesquereux, Geol. Recon. Arkansas Second Rept., p. 31.9, pl. 6, fig. 1, 1860; Am. Philos. Soc. Trans., vol. 13, p. 421, pl. 21, fig. 1, 1869; U. S. Geol. Survey Terr. Ann. Rept., 1871, Suppl., pp. 12, 15, 1872; U. S. Geol. and Geog. Survey Terr. Ann. Rept., 1873, pp. 382; 385, 1874; idem, 1876, p. 513, 1878; U. S. Geol. Survey Terr. Rept., vol. 7 (Tertiary flora), p. 249 , pl. 44, fig. 4, 1878; idem, vol. 8 (Cretaceous and Tertiary flora), p. 233, 1883; U. S: Nat. Mus. Proc., vol. 11, p. 29, 1888.

Hollick, A report on a collection of fossil plants from northwestern Louisiana: Louisiana Exper. Sta., pt. 5 , p. 282 , pl. 39,1899 .

Magnolia laurifolia Lesquereux, Am.. Philos. Soc. Trans., vol. 13, p. 421, pl. 20, fig. 2 (not fig. 3), 1869.

Terminalia hilgardiana (Lesquereux) Berry, U. S. Geol. Survey Prof. Paper 91, p. 325, pl: 92, fig. 2, 1916.

Berry has recently united Lesquereux's Magnolia laurifolia with Magnolia hilgardiana Lesquereux under the name of Terminalia hilgardiana. A reexamination of the figures convinces me that, though it may be correct to regard Lesquereux's figure 3 as identical with Magnolia hilgardiana, his figure 2 is distinct and is entitled to separate recognition. I think there can be no doubt as to the identity of Lesquereux's figure 3 of Magnolia laurifolia and the well-preserved leaves here figured from Aguilar, Colo. I also doubt the propriety of referring these leaves to Terminalia, and for the present, at least, I prefer to keep them in Magnotia.

This species was first described and figured by Lesquereux in 1860, in the second Report of the Geological Reconnaissance of Arkansas. As there stated, however, the specimens did not come from Arkansas but "from the chalk banks of the Mississippi and from the red shales of Tennessee." As the other two species de- scribed with it are accredited to Tennessee, M. hilgardiana remains as the only one which must have come from the "chalk banks of the Mississippi." The State whence it came is not actually named, but the fact that nine years later Lesquereux again records and figures the same specimen among the "Fossil plants from the Tertiary of Mississippi" " makes it probable that it actually came from Mississippi.

Magnolia hilgardiana was next reported (1872) as doubtfully contained in a collection from above the coal at Evanston, Wyo. The specimen on which this determination was based showed, according to Lesquereux, "the middle part only of a large leaf with undulate entire borders and the nervation of this species." It was never afterward mentioned by Lesquereux and was either discarded altogether or was united with some other form; the species has not since been found at this locality.

In the same volume ${ }^{3} M$, hilgardiana was reported from "Fishers Peak, N. Mex." This specimen is preserved in the United States National Museum (No. 365) and is the original of Plate XLIV, figure 4, of "The Tertiary flora." Although it is a mere fragment from the part near the middle of a large leaf, with hardly an inch of the true margin preserved, it agrees fairly well with the type figures of this species as well as with a number of extremely well preserved leaves in W. T. Lee's collections from the same region.

Magnolia hilgardiana has also been accredited to the Fort Union formation ${ }^{4}$ on the basis of a statement made by Lesquereux ${ }^{5}$ that "a fine, fully preserved leaf of this species is in Prof. Winchell's collection from the. Yellowstone Valley." This specimen was not figured nor is its location now known, and I can only say that $I$ have not detected it in any of the extensive collections that have passed through my hands from these beds.

The final mention of this species in the literature is by Hollick, who reports and figures it from the vicinity of Coushatta, La., in beds presumed to belong to the Wilcox formation ("Eo-lignitic" of older writers).

1 Am. Philos. Soc. Trans., vol. 13, p. 421, pl. 21, fig. 1, 1869.

2 U. S. Geol. Survey Terr. Ann. Rept., 1871, Suppl., p. 12, 1872.

3 Idem, p. 15.

${ }^{4}$ Cf. Ward, L. F., Synopsis of the flora of the Laramie group: U. S. Geol. Survey Sixth Ann. Rept., p. 529, 1886 .

5 The Cretaceousand Tertiary floras: U. S. Geol. Survey Terr. Rept. vol. 8 , p. 233,1883 . 
This leaf, $\cdot$ a nearly perfect specimen, agrees closely with Lesquereux's original figures of the species and is undoubtedly identical with the leaf here figured from the Rockland mine, Cucharas Canyon, Colo., in the Raton formation.

From the aoove exposition it appears that this species may fairly be assumed to enjoy a very wide distribution and to have been found only in rocks of lower Tertiary age.

Occurrence: Wilcox formation (Tertiary); type, Mississippi and near Coushatta, La. Fort Union formation? (Tertiary). Valley of Yellowstone River, Mont. Raton formation (Tertiary); one-eighth mile northeast of the Rockland mine, locality 119 , north side of Cucharas Canyon, near Walsenburg, Colo., collected by W. T. Lee .(5679); Yankee, locality 85 , N. Mex., collected by W. T. Lee (5142); also the following, all collected by G. B.

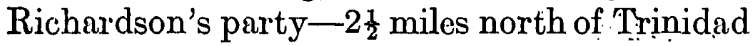
field, locality 110, near northeast corner sec. 23, T. 32 S., R. 64 W. (5101); near locality 109, Trinidad, Colo. (5094); 4 miles north of Trinidad, Colo., near locality 109 (5102); Riley Canyon, 2 miles above Cokedale, Colo. (5105); Riley Canyon, Colo. (5103); 5 miles, above Aguilar, Colo. (5122).

- Magnolia magnifolia Knowlton, n. sp. Plate LXXXIV.

Magnolia tenuinervis Lesquereux, U. S. Geol. Survey Terr. Rept., vol. 7 (Tertiary flora), p. 24.9, pl: 44, figs. 5, 6, pl. 45, figs. 1-3 (not pl. 45, figs. 4, 5), 1878 .

Leaves generally of large size, evidently subcoriaceous in texture, broadly lanceolate, broadest near or just above the middle, rather obtusely pointed at apex and wedge shaped at base (petiole not observed); midrib very thick below, becoming much thinner above; secondaries about twelve or fourteen pairs, strong, alternate, somewhat irregular, especially in the middle of the blade, curving upward well inside the margin; nervilles mainly percurrent and at right angles to the secondaries.

Magnolia tenuinervis was named, though not adequately described, by Lesquereux in 1868, from material obtained in. "Lignite beds near Golden City, Colo.,". and hence presumably in the true Laramie formation, as the Denver formation has not been found coal bearing at this locality. Its next mention in 1869 (reprint 1873) is a verbatim copy of the first article and without additional information. In the report for 1870 it is simply given in a list and referred to the locality mentioned above, and in the report for 1876 it is also mentioned in a list without indication of locality, though probably it was based on the same material. It does not appear to have been properly described and figured until the publication of "The Tertiary flora," though in the Hayden 1 report for 1872 specimens from Black Buttes, Wyo., that were later referred to this species, were described under Heer's name of Magnolia inglefieldi. Of the specimens of this species figured in "The Tertiary flora" (Pl. XLV), all but two of the "types" are preserved in the United States National Museum, but there appears to have been some confusion as to the localities whence some of them came. Thus, the original of figure 3 , Plate $\mathrm{XLV}$, is recorded in the Museum catalogue (No. 368) as coming from Golden, Colo., but the matrix proves beyond reasonable doubt that it came from Black Buttes, Wyo.; and the same is true of another duplicate specimen (No.366) of this species. The original of figure 2 is undoubtedly from the Denver formation at Golden, Colo. (U. S. Nat. Mus., 367), and that of figure 5 from Bridger Pass, Wyo. (No. 369), although this latter locality was once erased from the Museum catalogue. The originals of figures 1 and 4 can not now be found, nor can that of figure 6, Plate XIX, of "The Cretaceous and Tertiary floras," though the original of figure 4 is, according to Lesquereux, one of the specimens upon which Magnolia tenuinervis was founded, and hence is the real type of the species. The original of figure 5, Plate XLIV, of "The Tertiary flora" can not now be found, nor is it known whence it came; there is no evidence to show that it was ever the property of the United States National Museum. The original of figure 6, Plate XLIV, of "The Tertiary flora" is No. 366 of the Museum collections, and is recorded as having come from Golden, though the matrix would seem to indicate that it comes from Black Buttes, Wyo. The only localities given by Lesquereux in "The Tertiary flora" are Golden and Black Buttes.

I have given at length the intricate and complicated history of what, for more than 40 years,

I U. S. Geol. Survey Terr. Ann. Rept., 1872, p. 396, 1873. 
has been passing under the name of Magnolia tenuinervis Lesquereux, and the result is seen to be a nearly hopeless tangle. For more than 10 years after it was named it remained a nomen nudum, and even when it was described and figured it was based on such a heterogeneous assemblage of forms that are obviously not conspecific and may not all be congeneric, from unknown or doubtful localities, that it seems best to abandon the current acceptance of this "species" and start afresh. The difficulties into which this miscellaneous aggregation has led subsequent writers is shown by the fact that it is supposed to have a vertical range from the Mesaverde formation to the Denver formation, or even later. But, as the rules of nomenclature do not permit the abandonment of a name so long as it can not be clearly referred to another earlier species, it is proposed hereafter to restrict the name Magnolia tenuinervis to figure 6 , Plate $\mathrm{XLV}$, of "The Tertiary flora," for this, so far as can be made out, is the figure of the specimen from "Golden City, Colo.," upon which the "species" was based. It is a mere fragment of the upper portion of a leaf that can not.be positively identified with anything and may not be a Magnolia. The type specimen itself is lost, and it can not be determined whether it belongs to the Laramie or the Denver formation, and it must serve as an unhappy heritage to hold the name and prevent further confusion and misuse of Lesquereux's species.

Lesquereux appears at first to have inclined to the opinion that figure 5 , Plate XLV, of "The Tertiary flora," said to be from Bridgers Pass, was not conspecific with the other leaves he figured as Magnolia tenuinervis. I agree with this view and believe it should be removed and given another name. ${ }^{1}$ I formerly identified as Magnolia tenuinervis a leaf from Coalville, Utah, on the basis of its resemblance to Lesquereux's figure 5, above discussed. ${ }^{2}$ As pointed out at the time this Coalville leaf does not agree perfectly with Lesquereux's, and I am now convinced that it should be removed from $M$. tenuinervis and given another name. ${ }^{3}$

There remains Plate XLIV, figures 5 and 6 , and Plate XLV, figures 1 and 3; of "The Ter-

\footnotetext{
1 This may be called Magnolia? inquirenda $\mathrm{n}$. sp.

2 Flora of the Montana formation: U. S. Geol. Survey Bull. 163, p. 55, pl. 14, fig. 1, 1900.

8 This may be known as Magnolia? coalvillensis n. $\mathrm{sp}$.
}

tiary flora," and these may, without obvious violence, be considered conspecific, though three of these $(5,6$, and 3$)$ are mere fragments and confessedly of little value. So far as known they come from the Black Buttes coal group of Black Buttes, Wyo. (regarded by the author as of post-Laramie age), and the Denver formation at Golden, Colo. These five figures are here transferred to Magnolia magnifolia.

Magnolia magnifolia is apparently the largestleaved fossil species thus far described from American rocks, the maximum length observed approximating 30 centimeters and the width 10 or 12 centimeters. The characters are excellently well shown in the nearly perfect example here figured. Among living species it appears to be most closely related to a species cultivated in the parks of the District of Columbia under the name of $M$. mexicana, from which its leaf differs mainly in having a more wedge-shaped base.

Magnolia magnifolia is perhaps the most abundant and widely distributed species thus far observed in the post-Laramie rocks of the Raton Mesa region, though few specimens of it are perfectly preserved. It may be known by its large size, rather obtuse apex, wedge-shaped base, and especially by the irregular spacing of its secondaries near the middle of the blade. Almost all specimens have a short intermediate secondary between these widely spaced secondaries.

Occurrence: Denver formation (Tertiary), Golden, Colo. Black Buttes coal group (regarded by the author as of post-Laramie age), Black Buttes, Wyo. Raton formation (Tertiary); collected by W. T. Lee-type, dump of Delagua mine near Delagua, Colo. (5690); junction of Dillon and Coal canyons, near Blossburg, N. Mex. (5149); Norman's ranch, 12 miles east of Raton, N. Mex., near locality 92 (5132); one-half mile north of Brilliant, Colo. (5154); 3 miles southwest of Walsenburg, Colo., near locality 120 (5678); Green Canyon mine, locality 119, near Aguilar, Colo. (5684); Apishapa Canyon, Colo. (5686); 1 mile north of Trujillo Plaza, Colo. (5687); Apishapa Canyon, Colo. (5687); Apishápa Canyon, Colo. (5689); locality 106, near Trinidad; Colo. (5697); near Cokedale, Colo. (5702); Wootton, Colo. (5712); Wet Canyon, 4 miles north of Weston, Colo. (5799); North Fork of Purgatoire River, Colo., locality 136. (5801); Tercio, Colo. (5803); 
Vermejo Valley near the mouth of Salyers Creek, N. Mex. (5826); Raton field, Canadian Canyon, 1 mile east of Jones Canyon (5291); collected by or for G. B. Richardson's partyPowell Arroyo, near locality 107, near Trinidad, Colo. (5111); south side of Apishapa River, Colo. (5119); 5 miles above Aguilar, Colo. (5122); onèhalf mile north of North Fork of Purgatoire River, between Virgil's and Wood's ranches (5114); collected by Orestes St. John-Wootton, Colo., Smith ranch, South Raton Canyon, N. Mex.; Morley coal district, Colo.; collected by F. H. Knowlton-south end of Raton tunnel, 6 miles north of Raton, N. Mex. (5464).

\section{Magnolia leei Knowlton.}

Plate LXIV, figure 2; Plate LXV, figure 2; Plate LXXXI; figure 2 .

Magnolia leei Knowlton, in Berry, U. S. Geol. Survey Prof. Paper 91, p. 215, pl. 43, figs. 1, 2, 1916.

Leaves small or medium, elliptical or elliptical-lanceolate in shape, more or less wedge shaped at base, long taper pointed at apex; margin entire, slightly undulate; midrib strong, straight; secondaries about nine pairs in the smaller leaves and eighteen to twenty pairs in the larger leaves, alternate, irregular, somewhat curved upward, camptodrome, forming broad loops near the margin; finer nervation obscure."

Three of the best specimens are figured. Of these the largest is about 23 centimeters long and nearly 6.5 centimeters wide at a point just below the middle. The next in size is about 14 centimeters long and the same width as the largest, and the smallest is 13 centimeters long and 5.5 centimeters wide. The long, slender apex is well shown in two of these specimens; in the third it is somewhat shorter and is perhaps not all preserved.

It is with some hesitation that this is described as a new species, especially when there are so many species already named from these beds. It is perhaps most closely related to Magnolia magnifolia and M. hilgardiana, but differs from M. magnifolia in size, somewhat in shape, and in its taper-pointed apex, and from $M$. hilgardiana in size, in its taper-pointed apex, and slightly in the disposition of its secondaries.

- Occurrence: Raton formation (Tertiary), Vermejo Park, N. Mex., collected by W. T. Lee (5826); dump from mine at Primero; Colo., collected by W. T. Lee (5798). Ackerman formation, Hurleys, Miss. Lagrange formation (in beds of Wilcox age), Puryear, Tenn.

Magnolia lesleyana Lesquereux.

Plate LXXXII, figures 1, 2.

Magnolia lesleyana Lesquereux, Fossil plants from the Tertiary of Mississippi: Am. Philos. Soc. Trans., vol. 13, p. 421, pl. 21, figs. 1, 2, 1869; U. S. Geol. Survey Terr. Ann. Rept., 1870, p. 382, 1871; idem, 1871, Suppl., p. 14, 1872; U. S. Geol. and Geog. Survey Terr. Ann. Rept., 1873, pp. 382, 403, 1874; idem, 1876, p. 513, 1878; U. S. Geol. Survey Terr. Rept., vol. 7 (Tertiary flora), p. 248, pl. 44, figs. 1-3, 1878. Terminalia lesleyana (Lesquereux) Berry, U. S. Geol. Survey Prof. Paper 91, p. 323, pl. 89, 1916.

Leaves large, coriaceous in texture, obovate, rather abruptly narrowed from above the middle to a rather obtuse apex and to a wedgeshaped base; midrib extremely thick, especially below; secondaries about twelve pairs, alternate, distant, irregular; finer nervation mostly obsolete.

Magnolia lesleyana was originally described from the "Eo-lignitic" (Wilcox formation, Eocene) of Mississippi, and the type specimens are presumably preserved in the Museum of the State University at Oxford.

This species was subsequently reported by Lesquereux from Fishers Peak in the Raton Mountains, N. Mex.; the specimens on which his determination was based are preserved in the United States National Museum (Nos. 364, 6 specimens, 772, 925). In "The Tertiary flora," figure 3, Plate XLIV, is a copy of Plate XXI, figure 2, of the "Fossil plants from the Tertiary of Mississippi," but the original can not be found. The original of figure 1 is from Fishers Peak, N. Mex., and is in the museum collection. The original of figure 2 can not be found; it has somewhat the appearance of being the counterpart of Plate XXI, figure 1, of the "Fossil plants from the Tertiary of Mississippi," but this is merely surmise.

Though none of the specimens from Fishers Peak is perfect they are undoubtedly the same as the leaves from Mississippi. As Lesquereux has said, the species is well characterized by the very large, entire leaves, obovate-spatulate in shape, enlarged above the middle, from which point they narrow to a short thick petiole and upward to an obtuse rounded point. The lateral nerves are distant, strong, and camptodrome. 
The United States National Museum contains a specimen (No. 925) recorded as doubtfully from Evanston, Wyo. It is similar to the leaves from Fishers Peak and is preserved on a hard fine-grained gray sandstone, unlike the usual matrix at Evanston. It seems hardly likely that it could have come from that place, but it is impossible to be positive regarding its habitat.

A single specimen, much broken ánd doubtfully identified with this species, is reported from Golden, Colo., but it can not now be found, and no others appear to have been obtained from this locality.

The recent collections made by W. T. Lee contain a number of specimens of this species and appear to settle more clearly than ever the identity with the Mississippi types. They also settle beyond reasonable doubt that the material studied by Lesquereux from Fishers Peak was from beds in the same stratigraphic position as the collections made by Mr. Lee.

Occurrence: Wilcox formation (Tertiary); types, Mississippi. Raton formation (Tertiary); Fishers Peak, Raton Mountains, N. Mex., Lesquereux's material in United States National Museum; collected by W. T. Leenear Trinidad, Colo., at locality 106 (5697); south wall of Purgatoire Canyon at mouth' of Riley Canyon near Cokedale, 50 to 150 feet above the basal conglomerate (5704); Turner mine $1 \frac{1}{2}$ miles north of Wootton, Colo. (5714); Wet Canyon; 4 miles northwest of Weston, Colo. (5825); collected by G. B. Richardson's party-Bear Canyon near Berwind, Colo. (5095); Riley Canyon, Colo. (5105); collected by Orestes St. John, Wootton, Colo.; South Raton Canyon.

\section{Magnolia regalis? Heer.}

Plate LXXXVII.

Magnolia regalis Heer, Flora fossilis arctica, vol. 4, Abt. ], p. 81, pl. 20,1877 .

In the collections from Wet Canyon, near Weston, Colo., is the single large leaf figured, which is thought probable to be the same as Heer's Magnolia regalis, from Cape Lyell, Spitzbergen. Heer's type specimen is only a fragment from the middle of the leaf, the remainder being. restored as it was thought to have been. It was somewhat larger than the present leaf, being about 20 centimeters long and 18 centimeters wide, whereas the one from Weston is only about 16 centimeters long and about 13 centimeters wide. Very little of the margin is preserved in the present specimen, but so far as can be made out it was somewhat undulate. The secondaries are numerous-about a dozen pairs-alternate, and at about the same angle as in $M$. regalis. Most of the few nervilles shown in Heer's figure are once forked but appear to have been fewer, at least as preserved, than in the present specimen, in which the nervilles are very numerous and uniform, and are mainly percurrent. They are nearly at right angles to the secondaries, suggesting the genus Ficus, but until more and better preserved material is available the specimen should be referred to $M$. regalis.

Occurrence: Raton formation (Tertiary); Wet Canyon, 4 miles northwest of Weston, Colo., collected by W. T. Lee (5799).

\section{Magnolia rotundifolia Newberry.} Plate LXXXIII.

Magnolia rotundifolia Newberry, U. S. Nat. Mus. Proc., vol. 5, p. 513, 1883; U. S. Geol. Survey Mon. 35, p. 95 , pl. 59, fig. ], 1898 .

This species was described by Newberry as followș.:

Leaves petioled, large $(8$ inches in length by 6 inches in width), round-ovate in outline, rounded or blunt pointed above and slightly wedge shaped below; margins entire; nervation open and delicate; four to six lateral branches given off from the midrib at remote and irregular distances, curving gently upward and forming festoons near the margin.

After comparing this species with Magnotia regalis Heer and $M$. nordenskiöldi Heer and pointing out wherein they differ from it Newberry continues:

A number of specimens in the collection show some diversity of form, and it is possible that the leaf figured is more rounded and less pointed than the average, but unless there should be very great departure from this standard there is little probability of this species being united with any other.

On tentatively restoring the apex of the example figured by Newberry in accordance with the apparent direction of the margins and the nervation, it would seem to be more pointed than either description or figure would now indicate, and this is made the more probable by the additional remarks concerning other specimens in the collections before him.

The leaf here figured is very imperfect below but is very well preserved above. It is of 
about the same size and configuration as the lenf figured by Newberry, but its apex is rather abruptly pointed, much as it is presumed the other was when perfect. The light, irregular, scattered, secondary nervation is about the same as shown in the original figure. The base is wanting or is so obscured that it can not be made out with any certainty.

The type of Magnolia rotundifolia came from Fishers Peak, Colo., but with no precise information as to whether it was from above or below the unconformity, though the presumption is very strong that it came from above. From the appearance of the matrix as well as the plant associations it is not thought probable that any of the older material came from the lower (Montana) beds.

Occurrence: Raton formation? (Tertiary); Fishers Peak, Colo., type: Raton formation (Tertiary); dump of the Turner mine, $1 \frac{1}{2}$ miles north of Wootton, Colo., collected by W. T. Lee (5714), on the same stone with Andromeda? lanceolata; Green Canyon mine, locality 119, near Aguilar, Colo. (5684).

Magnolia cordifolia Lesquereux.

Plate LXXXVI; Plate LXXXVIII, figure 1.

Magnolia cordifolia Lesquereux, Am. Philos. Soc. Trans.', vol. 13, p. 422 ; pl. 22, figs. 1, 2, 1869.

This species is relatively large, broadly ovate or broadly ovate-elliptical in shape, with a truncate or slightly cordate base and a short acuminate apex. The petiole is not preserved in any of the Colorado examples, but in the Mississippi specimens it is very thick, the midrib is relatively strong and has about nine. or ten pairs of mainly alternate secondaries at a low angle, these arching some distance inside the margin.

Magnotia cordifolia was described by Lesquereux from the so-called "Eo-lignitic" (Wilcox formation) of Mississippi. The Trinidad specimens, one of the best of which is here figured (Pl. LXXXVI, fig. 1), appear to agree in every essential particular with those from Mississippi and are referred without hesitation to Lesquereux's species. An additional finely preserved example from Green Canyon near Aguilar, which has also been figured (Pl. LXXXVIII, fig. 1), agrees perfectly, so far as can be made out, with Lesquereux's figure 2 and description. In the Green Canyon specimen figured the apex is rather abruptly but distinctly pointed. 'In the Mississippi specimen the extreme apex is not preserved, but from its configuration in the upper portion it seems practically certain that it also was provided with an acuminate apex. The larger specimen figured by Lesquereux (fig. 1) appears also to have an acuminate apex, but Berry, ${ }^{1}$ who has had access to the original specimen, says: "By chipping away more of the matrix in the type specimen it was found that the distal margin was abruptly rounded off." Be this as it may, I am firmly convinced that the Colorado specimen is conspecific with the smaller of the two Mississippi specimens figured by Lesquereux.

Recently Berry ${ }^{1}$ has combined Lesquereux's Magnolia ovalis and Magnolia cordifolia under the name Combretum ovalis (Lesquereux), on the ground that they can not be separated and that they show affinity to Combretum rather than to Magnolia. His description in part is as follows:

Leaves relatively large, elliptical or orbicular in general outline, the apex rounded or bluntly pointed, and the base very broadly rounded or truncate. Length ranges from 12 to 15 centimeters. Maximum width, in the middle part of the leaf, ranges from 5.5 to 12 centimeters, averaging about 9 centimeters. Margins entire, full, and rather evenly rounded. Leaf substance thin but apparently subcoriaceous. Petiole very stout and curved. Midrib very stout, curved. Secondaries relatively thin, not prominent. Their spacing variable, in general rather remote; they branch from the midrib at angles of $45^{\circ}$ or more, pursue a regularly curved subparallel course, and are camptodrome in the marginal region. There are usually about eight subopposite to alternate pairs. Tertiary venation entirely obsolete.

This description appears to have been drawn, in large part at least, from the leaves figured by Lesquereux as Magnolia ovalis and specimens probably conspecific with them, and does not altogether fit the description and figures of Magnolia cordifolia. I have not seen all of the Wilcox material and therefore am not in position to pass critical judgment on the matter, but I can not escape the conviction that possibly two forms have been confused under the one name. Berry has given two figures of Combretum ovalis, of which his Plate XCIV, figure 1, is a reproduction of Lesquereux's figure 2 of Magnolia cordifotia, and his Plate XCV, figure 1, is the original of Lesquereux's figure 3 of Magnolia ovalis. $M$.

1 Berry, E. W., The lower Eocene floras of southeastern North America: U. S. Geol. Survey Prof. Paper 01, p. 321, 1916. 
ovalis is a much longer leaf with the secondaries much thinner and more remote. In general appearance these leaves appear quite different and at least for the present I propose to maintain them as distinct. The question of its reference to Combretum will not be discussed at present.

Occurrence: Raton formation (Tertiary); near Trinidad, Colo., locality 106, collected by W. T. Lee (5697); dump of Green Canyon mine, locality 119, near Aguilar, Colo., collected by W. T. Lee (5684). Wilcox formation (Tertiary); Mississippi and Louisiana.

Family LAURACEAE.

Laurus? caudata Knowlton, n. sp.

Plate LXXXIX, figure 1.

Leaf large, coriaceous in texture, slightly obovate-lanceolate in shape, broadest at or slightly above the middle, thence narrowed regularly to the wedge-shaped base, and above rather abruptly rounded into the exceedingly long, slenderly acuminate tip; margin slightly undulate; midrib very thick below, then becoming very thin above; secondaries irregular, about seven or eight pairs; strongly alternate, emerging at a very low angle, then strongly curved upward, especially on one side, where they run along well inside the margin for long distances, all camptodrome; intermediate secondaries occasional: finer nervation not retained.

This splendid leaf is nearly perfect, lacking only a very small portion of the base. Its length is 23 centimeters and its width nearly 7 centimeters. It is well characterized by its large size, obovate-lanceolate shape with long, obtusely wedge-shaped base and exceedingly long, slender, acuminate apex and irregular secondary nervation, with the middle secondaries especially curved upward for very long distances.

The basal half of this fine leaf is strongly suggestive of leaves that have usually-been referred to Magnotia, such for instance as that here described as M. magnifolia or certain of the broader forms of $M$. angustifolia. It differs, however, in its long slender tip and in the secondary nervation. Unless this nervation is abnormal, of which there is no particular evidence, this leaf can hardly be referred to Magnolia.
Occurrence: Raton formation (Tertiary); Wootton, Colo., 50 to 100 feet above Wootton coal bed, collected by W. T. Lee (5712).

\section{Laurus ratonensis Knowlton, n. sp.}

Plate XCI, figs. 1-4.

Ficus pseudolmediafolia Berry, U. S. Geol. Survey Prof. Paper 91, p. 205, 1916.

Leaves evidently.coriaceous in texture, narrowly lanceolate, rather abruptly rounded and obtuse at base, acuminate at apex; margin entire or slightly undulate; midrib relatively strong; secondaries numerous, fifteen or eighteen pairs, mostly alternate, at a very low angle, arching well below the margin and joining the one next above in a broad loop; intermediate secondaries occasional; finer nervation producing a close, delicate, irregular areolation.

This species is represented by fifteen or twenty leaves, many of them nearly perfect. They are narrowly lanceolate-acuminate with a rounded, somewhat obtuse base, and entire or very slightly undulate margin. Their length is about 10 centimeters and the width 2 to 2.5 centimeters; none has the petiole preserved.

This species is certainly very close to if not identical with what Lesquereux ${ }^{1}$ identified as Laurus primigenia Unger, from Evanston, Wyo. Unfortunately none of the Evanston material, figured or otherwise, can now be found in the collections of the United States National Museum, nor is there evidence to show that it was ever there. We must therefore depend entirely upon Lesquereux's figures. His originals were found in the same beds with and are certainly very close to Laurus socialis Lesquereux, ${ }^{2}$ being, according to Lesquereux, "narrowly lanceolate, more distinctly acuminate, and narrowly cuneate," all comparative or relative characters which are really of very little weight: The specimens under consideration are certainly very similar to Lesquereux's figures of Laurus primigenia.

That Laurus primigenia is a very polymorphic species is indicated by the forms that have been referred to it by various European paleobotanists, but it is hard to reconcile Lesquereux's figures with any of them, though it is not greatly unlike those of some of the narrow

\footnotetext{
1 The Tertiary flora: U. S. Geol. Survey Terr. Rept., vol. 7, pl. 36, figs. $5,6,8,1878$.
}

2 Idem, pl. 36, figs. 1-4, 7 . 
lenves of the European forms, such, for instance, as those figured by Unger ${ }^{1}$ from Sotzka.

Lesquereux's Evanston leaves are very unlike many that have been subsequently referred to $L$. primigenia, such, for example, as those given by Ward ${ }^{2}$ from Carbon and Point of Rocks, Wyo., and by Hollick ${ }^{3}$ from the "Eo-lignitic" (Wilcox formation) of Coushatta, La. It seems more than probable that the Evanston leaves belong to an unnamed species of Laurus and not to L. primigenia, and the question arises as to whether they might not be referred to the same species as the Raton leaves under discussion, namely, to $L$. ratonensis. However, in the absence of either type or subsequently collected material for comparison it has seemed as well to leave them distinct, at least for the present. They are, if anything, a little larger than the Evanston leaves and rather more abrupt at base, but these differences are but slight.

In 1888 Lesquereux ${ }^{4}$ reported the presence of $L$. primigenia in the Denver formation at Golden, Colo., but his specimens have not been seen by the writer, so it is not possible to tell whether they are of the type of the Evanston leaves or of the European forms. The large recent collections from Golden do not seem to contain the species.

The species under consideration has also some resemblance to one of the leaves of Tetranthera sessiliflora Lesquereux, ${ }^{5}$ now Malapoenna weediana (Knowlton) Knowlton, ${ }^{6}$ from the Livingston formation of Montana, but the leaves are larger and longer, and the nervation, though of the same type, is at a more acute angle.

Laurus ratonensis may also be compared with Quercus simplex Newberry, ${ }^{7}$ from the Eocene of the John Day Basin, Oreg., but it is much larger and has a slightly different secondary nervation.

1 Unger, F., Dio fossile Flora von Sotzka, pl. 19, figs.1-4, 1850.

\& Ward, I. F., Types of the Laramie flora: U. S. Gcol. Survey Bull. .37 , pl. 23, figs. 8-10, 1887.

8 T. Tollick, Arthur, $A$ report on a collection of fossil plants from northwestern Louisiana: Louisiana Exper. Sta., pt. 5, p. 284, pl.41, figs. 1, 2, 1899.

1 Jarvard Coll. Mus. Comp. Zoology Bull., vol. 16, p. 50, 1888.

- The Tertiary flora: U. S. Geol. Survey Terr. Rept., vol. 7, pl. 35 fig. 0, 1878.

O A catalogue of the Cretaceous and Tertiary plants of North America: U. S. Gicol. Survey Bull. 152, p. 142, 1898

${ }^{7}$ Newberry, J. S., The later extinct floras of North America: U. S. Geol. Survey Mon. 35, pl. 63, fig. 6, 1898.
Laurus ratonensis is found also, according to Berry, in the Wilcox formation, where it is relatively abundant. $\mathrm{He}$ has, however, described it under the name of Ficus pseudolmediafolia.

Occurrence: Raton formation (Tertiary); Honeyfield mine neạr Yankee, N. Mex., 75 feet above the base of the Raton formation, collected by W. T. Lee (5140). Wilcox formation (Tertiary); Tennessee and Arkansas.

Laurus pedatus? Lesquereux.

Laurus pedatus Lesquereux, Am. Philos. Soc. Trans., vol. 13 , p. 418, pl. 19, fig. 1, 1869.

The collections from above the conglomerate, but more particularly the one from Green Canyon near Aguilar, contain a number of leaves that are apparently referable to this species. They are long and narrowly lanceolate or obovate-lanceolate, with a very large wedgeshaped base and extremely thick midrib. As the leaves are so thick in texture and the nervation is so obscurely preserved it is made out with the greatest difficulty, but so far as can be seen it appears to be about the same as that shown in the type figures. It was described originally from the "Eo-lignitic" (Wilcox formation) of Mississippi.

Berry. ${ }^{8}$ has transferred the Laurus pedatus of Lesquereux to the genus Osmanthus, on the ground of its apparent resemblance to the living Osmanthus americanus Bentham and Hooker.

Occurrence: Raton formation (Tertiary); dump of Green Canyon mine, locality 119, near Aguilar, Colo., collected by W. T. Lee (5684). Wilcox formation (Tertiary); Mississippi.

\section{Laurus socialis Lesquereux. Plate XCr, 'figure 5.}

Laurus socialis Lesquereux, U. S. Geol. Survey Terr. Rept., vol..7 (Tertiary flora), p. 213, pl. 36, figs $1-4,7,1878$.

The type and all the figured specimens of this species are said to have come from Evanston, Wyo., in beds then regarded as Laramie in age but now believed to be younger. Only three of the type specimens are now in the United States National Museum, so it is impossible to ascertain whether they all really came from the same locality.

${ }^{8}$ Berry, E. W., The lower Eocene floras of southeastern North America: U. S. Geol. Survey Prof. Paper 91, p. 341, pl. civ, fig. 1, 1016. 
The example here figured agrees in all essential particulars with certain of the smaller of the figured types, and there is no reasonable doubt regarding their identity.

Occurrence: Raton formation (Tertiary); dump of mine at Delagua, Colo., collected by W. T. Lee (5690), on same stone with Magnotia magnifolia, $M$. angustifolia, and Zizyphus fibrillosus; Vermejo Valley near mouth of York Canyon, N. Mex. (5241); 5 miles above Aguilar, Colo., collected by G. B. Richardson (5046).

\section{. Laurus utahensis Lesquereux.}

Plate XC, figure 4.

Laurus utahensis Lesquereux, U. S. Geol. Survey Terr. Reṕt., vol. 7 (Tertiary flora), p. 216, pl. 26, fig. 11, 1878.

The leaf figured; which lacks a small portion only of the base and 'apex, I am unable to distinguish from the Laurus utahensis of Lesquereux, which came originally from Bridger Pass, Wyo., in beds of Tertiary, probably Fort Union, age. It is a little larger than the type specimen, being about 11 centimeters long and 5 centimeters wide as compared with 9.5 and 4 centimeters, respectively, and it is also slightly more wedge shaped at base. Otherwise neither in shape nor in details of nervation are the two distinguishable. This species has also been reported from the Wilcox formation of Louisiana.

Occurrence: Raton formation (Tertiary); Wet Canyon, about 4 miles northwest of Weston, Colo., 50 to 100 feet below base of Poison Canyon formation, collected by W, T. Lee (5799). Wilcox formation (Tertiary); Louisiana.

\section{Nectandra lancifolia (Lesquereux) Berry.}

Plate XC, figures 1, 2.

Persea lancifolia Lesquereux; Am. Philos. Soc. Trans., vol. 13, p. 419 , pl. 19, fig. 4 , 1869.

Nectandra lancifolia (Lesquereux) Berry, U. S. Geol. Survey Prof. Paper 91, p. 308, pl. 85, fig. 2, 1916.

The leaf here figured is not to be distinguished irum the smaller of the two type specimens of this species as figured by Lesquereux. Heretofore it has been known only from the type locality, which is in the Wilcox formation of Mississippi.

Occurrence: Wilcox formation (Tertiary); types, Mississippi. Raton formation (Tertiary); collected by W. T. Lee-Vermejo Valley, near mouth of Salyers Creek, N. Mex., about 1,000 feet above the base of the Raton formation (5826); Wet Canyon, 4 miles northwest of Weston, Colo. (5825); Green Canyon mine, locality 119, near Aguilar, Colo. (5684).

Oreodaphne? ratonensis Knowlton, n. sp.

Plate LXXXVIII, figure 2.

Leaf of medium size, coriaceous in texture, ovate broadest near the middle, whence it tapers in about the same degree to the wedgeshaped base and the acuminate apex; petiole short; midrib quite strong below, much thinner above; secondaries about seven pairs, the strongest pair arising some distance above the base, at an angle of about $45^{\circ}$, camptodrome and joining the lowest tertiary branch on the next higher pair of secondaries, each with five or six tertiary camptodrome branches on the outside; two pairs of light secondary branches. below the principal pair and about five pairs abore, each usually with outside camptodrome. tertiary branches; nervilles fairly numerous, unbroken, and at right angles to the secondary or tertiary branches between which they run.

This splendid, nearly perfect leaf is unfortunately the only one found in the collections. It is about 14 centimeters in length and 5.5. centimeters in width; the petiole is nearly 1 centimeter in length and-probably is not completely preserved.

It is with some hesitation that this species is referred to the genus Oreodaphne, but it undoubtedly ha's a lauraceous facies and on the whole seems to be at least generically related to the recently described $O$. aitabamensis Berry ${ }^{1}$ from the Mesozoic of Texas. In any event, it is a well-marked species for stratigraphic uses.

Occurrence: Raton formation (Tertiary); 1 mile north of Trujillo Plaza, Colo., collected' by W. T. Lee (5687).

Cinnamomum? ficifolium Knowlton, n. sp.

Plate XC, figure 3.

Leaf apparently membranaceous in texture, ovate or ovate-elliptical, base rather abruptly. and obtusely wedge shaped (apex destroyed); petiole very long and slender; nervation light. and delicate, equally three ribbed from the apex of the petiole in the very base of the

1 Berry, E. W., Contributions to the Mesozoic flora of the AtlanticCoastal Plain: Torrey Bot. Club Bull., vol. 39, p. 400, pl. 32, fig. 1, 1912. 
blade, the lateral ribs at a very acute angle of divergence, running close to the midrib high up near the apex of the blade, each with several delicate secondary camptodrome branches on the outside; finer nervation not preserved.

This leaf-the only one observed-is unfortunately very imperfect, lacking all of the upper portion; the basal portion, however, is so very remarkable that $I$ have ventured to describe it as new. Its length when complete was probably about 8 centimeters and its width 4 centimeters. The slender petiole is over 2.5 centimeters in length. The striking feature of this leaf is the splitting of the petiole at the base of the blade into three slender ribs of equal strength, the lateral ones arising at a very acute angle and passing up almost parallel to the midrib nearly to the apex of the blade. The midrib was doubtless provided with secondary branches in the extreme upper portion, but they are not preserved.

It is with some hesitation that this leaf is referred to the genus Cinnamomum, for while the leaves in this genus are triple ribbed, the lateral ribs ordinarily arise some distance above the base of the blade. However, a number of fossil leaves referred to this genus have the lateral ribs arising with the midrib in the very base of the blade, as in the present specimen. For instance, Cinnamomum buchi Heer, ${ }^{1}$ from the Swiss Miocene, is occasionally shown with ribs of this character, though most commonly they are figured as arising well above the top of the petiole. Cinnamomum elongatum Saporta, ${ }^{2}$ of the travertins of Aix-enProvence, has very much the appearance of the leaf under consideration but is much narrower and has a less delicate nervation. - A leaf from Evanston, Wyo., referred by Lesquereux ${ }^{3}$ to C. lanceolatum Heer?; has very similar ribs but is narrower and apparently more pointed. Certain other forms-Ficus praetrinervis, for example (see p. 263) -a.lso suggest $C$. ficifolium, but do not possess its.long, slender petiole and delicate straight ribs.

Occurrence: Raton formation (Tertiary): Apishapa Canyon, one-half mile west of Abeton, Colo., collected by W. T. Lee (5686).

1 Flora tertiaria Helvetiac, vol., 2, pl. 105, fig. 7, 1856.

2 Saporta, G. de, Dornieres adjonctions il la flore fossile d'Aix-enProvence, pl. 6, fig. 3, 1889 .

${ }^{8}$ Tho Tertiary flora: U. S. Geol. Survey Terr. Rept., vol. 7, pl. 36, fig. $12,1878$.
Cinnamomum linifolium Knowlton, n. sp.

Plate LXXXVIII, figures 3-7.

Leaves firm in texture; from linear to linearlanceolate, long and narrowly wedge shaped at base, apparently rather obtuse at apex; nervation triple ribbed from the very top of the petiole, midrib the stronger, straight; lateral ribs more. slender, ascending nearly or quite to the apex of the blade (additional nervation not observable).

This form is represented by a dozen or more leaves, of which a series of four is figured in Plate LXXXVIII to show the range in size. The smallest (fig. 7) was probably about 6 centimeters long and 1 centimeter wide. The next (fig. 6) is 3.5 centimeters long and 1 centimeter wide, with a petiole about 4 millimeters long; this leaf may not be quite normal in that it is more obtuse than the others would appear to have been. Figure 4 shows a leaf 6 centimeters long and 1.5 centimeters broad. The largest (fig. 3 ) is about 7 centimeters long and 2.25 centimeters wide, with a petiole about 6 millimeters long. As regards the nervation it is altogether probable that there were secondary branches on both the midrib and the lateral ribs, but beyond the triple-ribbed arrangement nothing is now discernible; all traces of the still finer nervation is of course obsolete.

It is with some hesitation that these leaves are referred to the genus Cinnamomum on account of the fact that the three ribs all arise at the very top of the petiole instead of an appreciable distance above, as in most leaves of the genus. Occasionally, however, a leaf referred to this genus is depicted as having the ribs running quite to the base of the blade, and in exceptional cases leaves of living species are found in which this condition obtains. In all the leaves of this form the ribs run to the top of the petiole, and hence this feature can not be considered sporadic.

In size and shape the leaves approach most closely to certain of the narrow forms of Cinnamomum salicifolium Staub and C. Zanceolatum Unger, ${ }^{4}$ but differ from those species in being less pointed at the apex, usually more narrowly wedge shaped at the base, and in having a much shorter petiole; the details of

4 Staub, M., Die Geschichte des genus Cinnamomum, pl. 12, figs. 7-14 
nervation can not be compared. In size, shape, and the basal origin of the three ribs the leaves well agree with certain living species of Ceanothus, as, for example, C. ovatus Desfontaines of the eastern United States, but they differ in the margin, that of the living species being more or less conspicuously serrate.

An additional specimen (fig. 5) recently found in a small collection from near Dawson, N. Mex., is about the size and shape of the leaf shown in figure 4.

Cinnamomum linifolium is exceedingly close to a new species described by Berry from the Wilcox formation.

Occurrence: Raton formation (Tertiary); railroad cut one-half mile south of Starkville, Colo., collected by W. T. Lee (5796); Vermejo Creek, locality 23a, near Dawson, N. Mex., collected by W. T. Lee (5827):

Cinnamomum mississippiense? Lesquereux.

Plate LXXXIX, figure 2.

Cinnamomum mississippiense Lesquereux, Am. Philos. Soc. Trans., vol. 13, p. 418, fig. 2, 1869.

Berry, U. S. Geol. Survey Prof. Paper 91, p. 298, pl. 37, fig. 2, 1916.

It is with some hesitation that the leaf here figured is identified with the Cinnamomum mississippiense of Lesquereux, and there is more or less doubt as to the distinctness of this from the earlier $C$. affine Lesquereux. In "The Tertiary flora" (p. 220) Lesquereux made the following observations regarding the relationship between these two forms:

I have been for a long time undecided in regard to the possible identity of this northern species with the beautiful Cinnamomum mississippiense Lesquereux. * * * From the larger size of the Mississippi leaf, more enlarged below the middle, its more rugose nervation, and the greater distance of the lateral nerves from the borders, I came to the conclusion that the leaves of Golden did represent a new species, or at least a diminutive variety of C. mississippiense. This may be an error.

At one time ${ }^{1} \mathrm{I}$ was of the opinion that. the Mississippi leaf should be placed under C. affine, but as its status is so unsettled it has seemed best to retain both until further information is available. That they are extremely close, if not identical, is certain.

The specimen from Apishapa Canyon is precisely similar in shape to $C$. mississippiense, but is conspicuously larger, being 13

1 Knowlton, F. H., A catalogue of the Cretaceous and Tertiary plants of North America: U. S. Geol. Survey Bull. 152, p. 68, 1898. centimeters long and 6.5 centimeters wide as compared with 10 and 5 centimeters, respectively, in the other. The nervation is also slightly different: The lateral pairs of ribs in the Apishapa Canyon specimen arise almost at the base of the blade instead of a little higher and run nearly straight to the margin and do not curve inward as in $C$. mississippiense; the remainder of the nervation is the same in both. The specimen may not be $C$. mississippiense-in fact, it may not be a Cinnamomum-but for the present it is tentatively referred to this species.

Specimens from Cucharas Canyon have recently been detected, one of which is even larger than the one from Apishapa Canyon, being fully 15 centimeters long and 7 to 8 centimeters wide. They do not differ from it essentially, though they have more the facies of Ficus.

Occurrence: Raton formation (Tertiary) ; collected by W. T. Lee-Norman's ranch, 12 miles east of Raton, N. Mex., near locality 92 (5132); locality 85, near Yankee, N. Mex. (5135); one-eighth mile northeast of Rockland mine, locality 120, north side of Cucharas Canyon, near Walsenburg, Colo. (5679) ; Apishapa Canyon, 3 miles northeast of Abeton, Colo. (5688); Ute Park, N. Mex. (5830); collected by G. B. Richardson's party -2 miles southeast of Dean, Colo. (5113); 4 miles north of Trinidad, Colo., locality 109 (5102); collected by F. H. Knowlton-Sugarite mine (Old Wagon mine), 4 miles northeast of Raton, N. Mex. (5467); collected by Orestes St. John-?Wootton, Colo. Wilcox formation (Tertiary); types, Mississippi.

\section{Order ROSALES.}

\section{Family HAMAMELIDACEAE.}

Liquidambar? cucharas Knowlton, n. sp.

Plate XCI, figure 6.

Leaf broadly ovate in general outline, broad and somewhat heart-shaped at base, palmately three and probably five lobed, the lowest lobe small, upper lobes prominent, very sharp pointed, apex prolonged and sharp pointed; margin perfectly entire or at most slightly undulate; nervation well marked, palmately five ribbed, lowest pair of ribs nearly. at right angles to the midrib; middle pair at an angle 
of about $45^{\circ}$, ending in the sharp tip of the lobes; midrib with two or three pairs of alternate, remote secondaries strongly camptodrome, arching far inside the margin and joining the one next above; nervilles strong, mainly unbroken.

The leaf figured, which is unfortunately the only one of this type observed in the collections, lacks more than half its blade. As near as can be made out it was about 11 or 12 centimeters long and 13 centimeters wide, the apparent distance between the upper lobes being 12 centimeters. That the leaf was five lobed is not certain, though probable, for the side whence it would show if present is broken. The lower rib, which should enter the lobe if present, is camptodrome and arches around to join a secondary branch on the middle rib. The secondaries, whether on the midrib or on the rib entering the lateral lobe, are markedly camptodrome, usually arching some distance inside the margin.

This is on the whole a well-marked leaf, and, although so fragmentary, it ought to be readily recognizable in future. Whether it is correctly referred to Liquidambar is perhaps open to some question,. though the shape, lobation, and strongly camptodrome secondary nervation certainly suggest this genus. It is so fragmentary that it is hardly worth while to attempt to compare it with other fossil species.

Occurrence: Raton formation (Tertiary); oneeighth mile northeast of Rockland mine, locality 120, north side of Cucharas Canyon, near Walsenburg, Colo., collected by W. T. Lee (5679).

\section{Family PLATANACEAE.}

Platanus aceroides Göppert.

Plate LXIII, figure 4; Plate XCVII, figures 2, 3.

Platanus aceroides Göppert, Deutsche geol. Gesell. Zeitschr., vol. 4, p. 492, 1.552.

Lesquereux, Am. Jour. Sci., 2d ser., vol. 45, p. 206, I869; U. S. Geol. Survey Terr. Rept., vol. 7 (Tertiary flora), p. 184, pl, 25, fig. 4, 1878.

Occurrence: Raton formation (Tertiary); collected by W. T. Lee-Riley Canyon near Cokedale, Colo. (5701); Wootton, Colo., 50 to 100 feet above Wootton coal (5712); railroad cut about a mile south of Morley, Colo. (5715); Vermejo Valley, near mouth of Salyers Creek, N. Mex. (5826); south entrance to Raton tunnel, north of Raton, N. Mex. (5146); Raton-

$$
47019^{\circ}-17-21
$$

field, Canadian Canyon, 1 mile east of Jones Canyon (5291).

Platanus aceroides cuneata Knowlton, n. var.

Plate CXIII, figure 1.

A leaf of the general type of Platanus aceroides but differing in its smaller size and cuneate base. Most leaves of the typical form are broad and more or less nearly truncate at base, but a few, as for instance that figured by Heer ${ }^{1}$ from the Swiss Miocene, approach the present form. The lateral lobes are set at a more acute angle than in the typical form, but the central lobe is identical as are the strong, sharp teeth.

Occurrence: Raton formation (Tertiary); South Raton Canyon, N. Mex., collected by Orestes St. John.

Platanus aceroides latifolia Knowlton, $n$. var.

Plate XCII; Plate XCIII, figure 3; Plate XCIV.

Similar to the type but proportionately broader and shorter; margin provided with numerous small, rather blunt teeth.

This form, which I have ventured to describe as new, is the most abundant and widely distributed (within the area) of any member of the genus. For instance, in the collection from near Wootton there are upward of a hundred specimens, some of them absolutely perfect, showing the leaf in a variety of sizes and shapes.

Platanus aceroides is very abundant in the Tertiary of both this country and Europe, and though there is naturally considerable variation in the size and even in the shape of the leaves that have been referred to it there is a general consensus of agreement. It is of the type of the living P. occidentalis and is described as being of medium size, three ribbed and three lobed, the base truncate, slightly cordate or rarely more or less subcuneate, the lobes broadly triangular with the margins unequally dentate, the middle lobe with 2 to 4 teeth and the lateral lobes with a few more, the teeth usually strong; in many specimens curved or even slightly hooked, and invariably sharp pointed.

Heer ${ }^{2}$ has figured sereral leaves from the Swiss Miocene which well illustrate the usual

1 Flora tertiaria Helvetiae, vol. 2, pl. s8, fig. 14, 1856. 2 Idem, pls. 87 and 88. 
range of variation in $P$. aceroides. They all show the teeth to be prominent and very sharp pointed, and the teeth and secondaries to be the same or nearly the same in number. In the middle lobe there are usually four pairs of secondaries and an equal number of teeth; and in the lateral lobes there are 8 to 10 secondary branches on the outside and the same number of large teeth.

The form which I have here named latifolia is similar in shape to the typical leaves of $P$. aceroides, except that it perhaps averages a little broader at the base. Its middle lobe has usually about four pairs of secondary branches, but its lateral lobes have only five or six secondary branches on the lower side of the lateral rib. The most marked difference, however, is in the marginal teeth. Instead of having a large tooth for each secondary, latifolia has one to three or even four smaller teeth, all small and rather blunt, between each of the teeth entered by a secondary. Many of its large leaves have a tertiary branch, and some of them two branches, which pass to the intermediate teeth.

The marginal dentition in latifolia makes it possible to distinguish it from the typical form at a glance, but otherwise its general appearance is much the same. The dentition can hardly be an individual variation, for it occurs in numerous specimens from very widely separated localities.

These leaves were first identified with Platanus haydenii Newberry, ${ }^{1}$ one of the most abundant species of the Fort Union formation. As Newberry pointed out in his original description, $P$. haydenii is very closely related to $P$. aceroides but differs in its marginal teeth and slightly in its nervation. Thus he says: "In $P$. aceroides they [the teeth] are few, long, and acute, sometimes even uncinate, while in $P$. haydenii they are more numerous, less prominent, and always obtuse, sometimes merely giving a wavy outline to the margin of the leaf."

His figured type specimen of this species is preserved in the United States National Museum collection (No. 565 ${ }^{\mathrm{a}}$ ) and a reexamination of it shows that the margin is not preserved except in a single minute space, and here the teeth are distinctly sharp, the rounded

1 Newberry, J. S., The later extinct floras of North America: U. S. Geol. Survey Mon. 35, p. 103, pl. 36, 1898. outline of the teeth as shown in the figure being due to injury. If this character can be shown to hold for all the Fort Union leaves referred to $P$. haydenii it will naturally bring them closer to $P$. aceroides, and it is possible that it may be best ultimately to regard it as a varietal form only. In the meantime, however, it may remain under Newberry's name.

Occurrence: Raton formation (Tertiary); collected by W. T. Lee-types, railway cut one-half mile north of Wootton, Colo. (5713); $1 \frac{1}{2}$ miles southwest of mine at Rugby, Colo. (5696); Wootton, Colo., 50 to 100 feet above Wootton coal (5712); Tercio, Colo., about 400 feet above basal conglomerate (5802); canyon west of old town of Rouse, Colo., about 300 feet above base of Raton formation (5683); dump of mine at Delagua, Colo. (5690); south end of Raton tunnel, north of Raton, N. Mex. (5155); Vermejo Valley, near mouth of Salyers Creek, N. Mex. (5826); collected by G. B. Richardson's party-4 miles above Aguilar, Colo. (5123); near Berwind, Colo. (5107); collected by F. H. Knowlton-hillside just west of south end of Raton tunnel, 6 miles north of Raton, N. Mex. (5464); collected by Orestes St. John-Wootton, Colo.; Smith ranch, South Raton Canyon, N. Mex.

\section{Platanus guillelmae Göppert.}

Plate XCIII, figure 1.

Platanus guillelmae Göppert, Deutsche geol. Gesell. Zeitschr., vol. 4, p. 492, 1852; Tertiäre Flora von Schossnitz in Schlesien, p. 21., pl. 11, figs. 1, 2, 1855.

Lesquereux, U. S. Geol. Survey Terr. Ann. Rept., 1871, Suppl., p. 14, 1872.

In the material from Tercio, but also from many other localities, there are a number of well-preserved leaves that I am unable to distinguish from the usual figures given for Platanus quillelmae, such for example as those by $\mathrm{Heer}^{2}$ from the Tertiary of Greenland. They are small (8 to 9 centimeters long and 9 to 10 centimeters broad), nearly circular in general outline, palmately three ribbed from the base of the blade, and three lobed, the middle lobe deltoid in shape and relatively large and the lateral lobes very small, hardly more than large teeth. The base of the leaf is truncate and entire for some distance, then provided with small, even, low teeth.

2 Flora fossilis arctica, vol. 7, p. 96, pl. 97, f.g. 6; pl. 99, fig. 1, 1883. 
Lenves of this species somewhat resemble very small leaves of $P$. aceroides latifolia, at least in the basal portion, but they differ markedly above, having only very slight lateral lobes when $P$. aceroides latifolia has pronounced strong lobes; the teeth are also of different character in the two forms.

Occurrence: Raton formation (Tertiary); collected by $\mathbf{W}$. T. Lee-Norman's ranch, 12 miles north of Raton, N. Mex., near locality 92 (5132); ? Honeyfield mine, near Yankee, N. Mex., 200 feet above base of coal rocks (5141); ?near Yankee mine, locality 85, N. M.cx. (5138); south end Raton tunnel, north of Raton, N. Mex. (5155); Tercio, Colo., about 400 feet above basal conglomerate (5802); one-half mile north of Vermejo Gap', at locality 127, N. Mex. (5239); Vermejo Valley, near the mouth of Salyers Creek, N. Mex. (5826); collected by F. H. Knowlton-hillside just west of south end of Raton tunnel, 6 miles north of Raton, N. Mex. (5464); collected by G. B. Richardson's party-112 miles southwest of Berwind, Colo. (5107); 5 miles above Aguilar, Colo. (5046); collected by Orestes St. JohnWootton; Colo., 700 feet above the Trinidad sandstone; South Raton Canyon, N. Mex., $950 \pm$ feet above the Trinidad sandstone; collected by F. V. Hayden, 1869-Fishers Peak, Colo.

Platanus guillelmae heerii Knowlton, n. var.

Plate XCVI, figure 5; Plate XCVII, figure 1; Plate XCVIII, figure 2 .

Platanus guillelmaie Göppert. Heer, Flora fossilis arctica, 13and 2, $\mathrm{bbt} .4$ (Contributions to the fossil flora of North Greenland); excerpt, Roy. Soc. London Philos. Trans., vol. 159, pt. 2 , p. 473 , pl. 47, figs. $1-3$; pl. 48, fig. 4, 1869.

Platanus aceroides Göppert. Heer, Flora tertiaria Helvetiae, vol. 2, p. 71, pl. 88, figs. 13, 14, 1856.

Lenves of medium size, 12 to 15 centimeters long and 9 to 12 centimeters wide, undivided, long wedge-shaped at base in many specimens, unequal sided, apex deltoid, moderately acute; margin entire along the wedge-shaped basal portions, otherwise rather coarsely and sharply toothed; petiole long, 5 centimeters or more; nervation strong, consisting of a relatively strong midrib and about 5 pairs of alternate or subopposite secondaries at an angle of about $60^{\circ}$ or $65^{\circ}$, ending in marginal teeth; lowest pair of secondaries, strongest, arising at or a little above the top of the petiole; each with some five or six acute-angled tertiary branches on the outside; finer nervation strong, consisting of numerous, often broken, nervilles, very platanoid in appearance.

In the ample collections from Tercio, Colo., there are several specimens, three of which are here figured, that are made the basis of the present variety. Though they agree fairly well with what at times have been identified by various authors as Platanus guillelmae or $P$. aceroides, they do not agree with what may be considered as the typical forms of either of these species, and it seems best to designate them as at least of varietal rank. Thus the leaves from Tercio differ from typical $P$. guillelmae by their larger size, acutely wedgeshaped instead of truncate base, and in more acute-angled secondaries and branches; and from $P$. aceroides they differ by their usually larger size, wedge-shaped base, and much smaller teeth.

This supposed new form is of the same type with, and in fact was at first identified as, Platanus marginata (Lesquereux) Heer [Viburnum marginatum Lesquereux], with which it agrees in the shape of the base as well as in the entire system of nervation. The principal difference, however, is in the apical portion, which, in $P$. marginata, is rounded above or has a very short acuminate point, but in the leaves under consideration the apex is markedly prolonged. The teeth are sharp but not prolonged, and small intermediate teeth uppear in places between the larger ones, a feature not noted in any of the figures of $P$. marginata given by Lesquereux or Heer.

Occurrence: Raton formation (Tertiary); Tercio, Colo., 400 feet above the top of the basal conglomerate of the Raton, collected by W. T. Lee (5802).

\section{Platanus platanoides (Lesquereux) Knowlton.}

\section{Plate XCV, figure 4.}

Viburnum platanoides Lesquereux, U. S. Geol. and Geog. Surv. Terr. Ann. Rept., 1874, p. 314, 1876; U. S. Geol. Survey Terr. Rept., vol. 7 (Tertiary flora); . p. 224 , pl. 38 , figs. $8,9,1878$.

Platanus platanoides (Lesquereux) Knowlton, U. S. Geol. Survey Bull. 152, p. 171, 1898.

The nearly perfect specimen here figured appears to be referable to Viburnum platanoides Lesquereux, though it does not quite agree with it in all particulars. It is a little more wedge shaped at base than the type 
specimens and has its marginal teeth somewhat smaller, but otherwise in size, shape, and character of nervation it is practically the same. In some particulars it agrees with Platanus marginata Lesquereux, especially in the shape of the base and in the margin and general nervation, but differs from it in having its upper portion much more pointed. At first it was thought probable that it was an extreme form of $P$. aceroides, but it has a more wedge-shaped base than typical aceroides, and it lacks the lateral lobes of that species. In his discussion of $P$. platanoides, Lesquereux points out that it is obviously related to both $P$. aceroides and $P$. marginata, but it differs especially from the latter by its usually larger size, coarser appearance, and more wedgeshaped base, which last, however, as pointed out above, appears to break down. Without a larger series of specimens for comparison, it is perhaps as well to place it under the present species with a mark of interrogation.

The type specimens of Platanus platanoides. came from Black Buttes, Wyo., in beds regarded by the writer as post-Laramie in age, and it has also been reported from the "Lower Laramie" of Carbon County, Wyo., and elsewhere.

Occurrence: Raton formation (Tertiary); canyon west of the old town of Rouse, Colo., about 300 feet above the base of the Raton formation, collected by W. T. Lee (5683). Black Buttes coal group (regarded by the writer as of post-Laramie age); types, Black Buttes, Wyo.

\section{Platanus raynoldsii Newberry.}

Plate XCV, figure 1.

Plaianus raynoldsii Newberry, Iyceum Nat. Hist. New York City Annals, vol. 9, p: 69, 1868; U. S. Geol. Survey Mon. 35, p. 109, pl. 35, 1898.

Lesquereux, U. S. Geol. Survey Terr. Rept., vol. 7 (Tertiary flora), p. 185, pl. 27, fig. 2, 1878.

The present collections from southern Colorado contain a single example-the one here figured-that is referred without hesitation to Newberry's Platanus raynoldsii. Although the leaf lacks much of its upper portion, its lower portion is unmistakably similar to that of raynoldsii as figured by both Newberry and Lesquereux. The type specimens came from the Fort Union formation on the lower reaches of the Yellowstone River, Mont., and subse- quent investigation has shown it to be one of the most abundant and widely distributed species known from this formation.

The specimen figured by Lesquereux (Tertiary flora, pl. 27, fig. 2) is preserved in the United States National Museum (No. 248) and is from the Denver formation near Golden, Colo. It is practically identical in every particular with the specimen here figured.

In the collections from Yankee, N. Mex., there is a single fragmentary specimen that is referred with some hesitation to this species. It is also the basal portion of a leaf, but is without margin and hence can not be positively determined.

Occurrence: Raton formation (Tertiary); railway cut about a mile south of Morley, Colo., collected by W. T. Lee (5715). Riley Canyon near Cokedale, Colo. (5700); mouth of 'York Canyon, in Vermejo Valley, N. Mex. (5241); ? Wootton; Colo., collected by Orestes St. John.

\section{Platanus rhomboidea Lesquereux.}

Platanus rhomboidea Lesquereux, U. S. Geol. and Geog. . Survey Terr. Ann. Rept., 1873, p. 400, 1874; U. S. Geol. Survey Terr. Rept., vol. 7 (Tertiary flora), p. 186, pl. 26 , figs. $6,7,1878$.

Viburnum anceps Lesquereux, U. S. Geol. Survey Terr. Rept., vol. 7 (Tertiary flora), p. 227 , pl. 38, fig. 11, 1878.

Leaves small or medium sized ( 7 to 12 centimeters long, 5 to 9 centimeters broad), subcoriaceous in texture, rhomboidal in general outline; three ribbed and in some specimens slightly trilobate, being broadest at about the middle, from . which point they are narrowed and entire to the wedge-shaped base and about equally narrowed above where they are more or less deeply-usually sharply-dentate; lateral nerves (secondaries) at an acute angle of divergence, parallel, the lower pair being a little the longer and entering short acute lobes, each with three or four branches on the outside, which also pass to marginal teeth; nervilles nearly at right angles to the midrib, mostly percurrent; finer nervation quadrangular.

The two figured type specimens of Platanus rhomboidea are preserved in the United States National Museum collection (Nos. 245, 246) and are from the characteristic andesitic material of the Denver formation at Golden, Colo. They were the only specimens recorded in the museum catalogue that were so identified by Lesque- 
reux; but in the large lot of specimens ${ }^{1}$ at Cambridge, studied by Lesquereux ${ }^{2}$ in $1888^{\circ}$, no less than six additional examples were detected, and in the collections made by.Arthur Lakes in 1890, and studied by the writer, a small number of characteristic specimens were found. The species has since been detected in the Lance formation in Weston County, Wyo., and in certain beds southwest of Rawlins, Wyo., which are regarded by the author as of postLaramie age.

In the material from southwestern Colorado Platanus rhomboidea is represented at Wootton, Colo., by several specimens, one of the best of which is figured. It has also been identified, but with some doubt, on the mesa north of Raton, N. Mex. After a careful examination of the type of Viburnum anceps Lesquereux (U. S. Nat. Mus., 326) I am unable to find any characters that will separate it from Platanus rhomboidea. The single specimen upon which it was founded is a fragment representing the upper portion of a leaf of the same size as the smaller of the two types of $P$. rhomboidea.' The general shape of the leaves as well as the nervation is precisely the same, the only difference being that in the so-called Viburnum anceps the teeth are not quite so prominent nor sharp, a character manifestly of little importance as compared with that of nervation.

Occurrence: Raton formation (Tertiary); collected by W. T. Lee-mesa north of Raton, N. Mex., at top of Raton formation (5152); Vermejo Valley near the mouth of York Canyon, N. Mex. (5241); railway cut one-half mile north of Wootton, Colo., 50 to 100 feet below Wootton conl (5711); Wootton, Colo., 50 to 100 feet above Wootton conl (5712); collected by Orestes St. John-North Raton Canyon, Morley coal district, Colo.

\section{Platanus? regularis Knowlton, n. sp.}

Plate CXIII, figure 4.

Leaf of medium size, evidently of firm texture, broadly ovate in general outline, abruptly truncate, perhaps somewhat heart shaped at base, rather obtusely pointed at apex; margin coarsely toothed throughout, rather acute, separated by shallow sinuses; petiole strong;

\footnotetext{
1 Harvard Coll. Mus. Comp. Zool. Bull., vol. 16, p. 49, 1888.

2 U. S. Geol. Survey Terr. Rept., vol. 7 ('Tertiary flora), pl. 26, 'fig. 7 , 1878 .
}

midrib rather slender for the size of the blade, perfectly straight; secondaries five or six pairs, the lowest pair opposite, arising at the base of the blade, at an angle of about $50^{\circ}$, with six or more often forking tertiary branches on the outside, all entering marginal teeth; upper secondaries subopposite or alternate, entering the marginal teeth; finer nervation not retained.

This fine leaf was about 12 centimeters long and 10 centimeters wide, and is remarkable for its broadly ovate shape, coarsely toothed margin, and relatively light nervation.

No further comparisons will be instituted regarding this species, as in some unaccountable manner the specimen has been misplaced since the figure was made. Without the specimen in hand it is impossible to ascertain the precise locality, though it is somewhere within the Raton Mesa region.

Occurrence: Raton formation? (Tertiary); localitv unknown.

Family ROSACEAE

Cercocarpus orestesi Knowlton, n. sp.

Plate XCV, figure 2.

Leaf small, coriaceous in texture, obovate in outline, long and regularly wedge shaped at base, apparently rather obtuse at apex; margin entire for one-third of the basal portion, thence slightly toothed; midrib moderately slender, straight; secondaries numerous, about ten pairs, close, parallel, straight, at an angle of about $50^{\circ}$, craspedodrome, deeply impressed; nervilles obscure.

The single example figured is all that has been noted of this species. It is about 6 centimeters in length and 2.5 centimeters in width, and is well characterized by its wedge-shaped base, entire below, dentate above, and numerous, close, parallel, deeply impressed secondaries.

This species is most closely related to Cercocarpus antiquus Lesquereux, ${ }^{3}$ described originally from the auriferous gravels of California. It differs, though but slightly, in its larger size, longer wedge-shaped portion, and more numerous, sharper angled, and deeper impressed secondaries.

I take pleasure in naming this fine little species in honor of the veteran geologist Mr. Orestes St. John, who collected it in June, 1904.

${ }^{8}$ The Cretaceous and Tertiary floras: U. S. Geol. Survey. Terr. Rept., vol. 8 , pl. $45-B$, figs 2,1883 
Occurrence: Raton. formation (Tertiary); leaf ledge just above Șmith house, south of Raton Valley, N. Mex., collected by Orestes St. John, June, 1904.

\section{Prunus coloradensis Knowlton, n. sp.}

Plate XCVI, figure 2.

Leaf apparently rather thick in texture, elliptical-lanceolate in shape, obtusely wedge shaped at base, apparently rather abruptly acuminate at apex; margin finely and evenly serrate throughout, the teeth very sharp and upward pointing; midrib fairly strong, straight; secondaries exceedingly thin and obscure, apparently alternate and curving abruptly upward well inside the margin.

The leaf figured is the only one observed in the collections. It is about 10 centimeters long and 3.25 centimeters wide, and was evidently petioled, but the petiole has been destroyed. The margin to within a short distance of the base is finely and sharply serrate. The nervation, with the exception of the midrib, is very obscurely preserved, but so far as can be made out the secondaries are few, very thin, and arching very well inside the margin.

The leaves seem most closely related among living species to those of Prunus serotina Ehrhart, of the eastern. United States, but they differ in being elliptical-lanceolate rather than ovate-lanceolate. The marginal teeth in both species are the same.

Occurrence: Raton formation (Tertiary); dump of the Turner mine, $1 \frac{1}{2}$ miles north of Wootton, Colo., collected by W. T. Lee (5714), on same stone with Magnolia rotundifolia.

\section{Family LEGUMINOSAE?}

Leguminosites? arachioides Lesquereux.

Leguminosites? arachioides Lesquereux, U. S. Geol. Survey Terr. Rept., vol. 7 (Tertiary flora), p. 301, pl. 59, figs. 13, 14, 1878 .

Berry, U. S. Geol. Survey Prof. Paper 91, p. 249, p1. 48, fig. 9, 1916.

In one of the collections from near Berwind; Colo., there is a poorly preserved specimen showing a cluster of four thick striated fruits that appear to belong to Lesquereux's wellknown species. It is a little smailer than the original figures and is preserved on a coarsegrained matrix that does not well bring out the structure; but so far as can be made out it otherwiśe agrees-satisfactorily. It has not been figured as it would not add to our knowledge of this form.

Occurrence: Tertiary; types, Evanston, Wyo. Denver formation (Tertiary); Golden, Colo. Fort Union formation (Tertiary); Clear Creek, near Glendive, Mont. Raton formation (Tertiary); Trinidad, field, Colo., 7 miles southwest of Berwind, Colo. (S. $44^{\circ} \mathrm{W}$. of northeast corner T. 32 S.; R. 66 W.), collected by G. B. Richardson's party (5121). Lagrange formation (in beds of Wilcox age), Puryear, Tenn.

\section{Sophora nervosa Knowlton, n. sp.}

Plate XCV, figure 3.

Leaflet small, of rather thick texture, elliptical, abruptly rounded below to a heart-shaped base, obtuse and rounded at apex; midrib extremely thick, straight; secondaries numerous, strong, alternate, at a very low angle of divergence, camptodrome, with one or two series of very large areolae outside the line of the secondaries; finer nervatioń obscure.

This little leaflet is extremely well marked. In shape it is regularly elliptical with a strongly cordate base and an obtuse and rounded apex. The length is 4 centimeters and the width a little over 2.5 centimeters. Its midrib is relatively very thick, and its secondaries, which arch and join less than halfway to the margin, are succeeded outside by one or two series of large loops or irregular areas.

This species does not appear to be very closely related to any with which I am familiar; in nervation it is not greatly unlike Leguminosites reticulatus Heer ${ }^{1}$ from the Swiss Tertiary; but it differs widely from that species in size and shape. On the whole, it appears to be most closely related to Sophora henryensis Berry of the Wilcox formation, than which, however, it is much larger.

This collection consists of only two specimens, S." nervosa and a rolled-up leaf of Artocarpus similis. In the field the beds whence they came were supposed to belong to the Vermejo formation, but as the stratigraphic relations are obscure and the Artocarpus is elsewhere found only in the upper beds, it presumably belongs in the Raton formation.

Occurrence: Raton formation? (Tertiary); near Strong, Colo., collected by W. T. Lee (5682).

1 Flora tertiaria Helvetiac, vol. 3 , pl. 88, fig. 49, 1859. 
Cassia richardsoni Knowlton, n. sp.

Plate XCIII, figure 2.

Leaflet small, evidently firm in texture, ovate, abruptly rounded at base, obtusely acuminate at apex; petiole short; midrib straight, secondaries about five pairs, opposite or subopposite, considerably curved upward, camptodrome; nervilles few, thin, approximately at right angles to the secondaries.

This little species is represented by several examples, one of the most perfect being figured. It is 4.5 centimeters long and nearly 2.5 centimeters wide.

This species is very similar to Cassia berenices Heer, from the Swiss Miocene, being indeed of the same shape but having fewer, more acuteangled secondaries.

Occurrence: Raton formation (Tertiary); Berwind, Colo., collected by G. B. Richardson's party (5107).

\section{Cassia sapindoides Knowlton, n. sp.} Plate XCVI, figure 1.

Leaflet small, lanceolate or slightly ovate or elliptical-lanceolate, slightly unequal sided at the wedge-shaped base (apex destroyed); petiole short; midrib thick below, very slender above; secondaries about six or seven pairs, alternate, thin, at a low angle, much curved upward near the margin, camptodrome.

The only specimen noted is the one here figured. It is about 6 centimeters long and nearly. 2 centimeters wide, and is well shown in the figure. As the apex is absent it is impossible to know whether it was emarginated or pointed, though probably the former. It is very close to Cassia glenni Berry, a very common Wilcox species from Mississippi.

Occurrence: Raton formation (Tertiary); Wootton, Colo., collected by W. T. Lee (5714).

\section{Cassia fisleriana Knowlton, n. sp.}

Plate LXXVIII, figure 4.

Leaflet membranaceous in texture, ovate or almost ovate-triangular, abruptly rounded at base, obtusely acuminate at apex; margin perfectly entire; midrib thin, straight; secondaries six pairs, very thin, at an angle of about $30^{\circ}$, camptodrome; finer nervation obsolete. This leaflet is 5 centimeters long and nearly 3 centimeters wide at the broadest point, which is only about one-fourth its length above the base.
This leaflet is very similar in size, shape, and secondary nervation to certain of those referred to Cassia berenices Heer, ${ }^{1}$ from the Miocene of Switzerland.

Occurrence: Raton formation (Tertiary); Fishers Peak mine, 2 miles southeast of Trinidad, Colo., collected by J. B. Mertie for G. B. Richardson (5099).

Inga heterophylla Knowlton, n. sp. Plate LIV, figure 5.

Leaflet membranaceous in texture, ovateacuminate, very unequal sided, abruptly truncate at base, acuminate at apex; petiole short, stout; midrib straight, very strong below, becoming much thinner above; secondaries thin, few-about five pairs-serrate, alternate, emerging at a low angle, much curved upward.

The leaflet figured is 7 centimeters long and 3.5 centimeters wide, the width on the upper side being more than twice that on the lower side, which of course makes it very unequal sided. The lowest pair of secondaries emerge nearly at a right angle but curve upward well inside the margin and join the pair next above. The other secondaries are subopposite, emerge at a slightly greater angle, and join the ones next above. The finer nervation is not retained.

This species has a general resemblance to Juglans rugosa Lesquereux, ${ }^{2}$ but differs from it in the strongly inequilateral shape of the leaflet as well as in the character of the nervation.

Occurrence: Raton formation (Tertiary); Wootton, Colo., 50 to 100 feet above the Wootton coal, collected by W. T. Lee (5712).

\section{Carapa eolignitica Berry?}

Plate LXIX, figure 2.

Carapa eolignitica Berry, U. S. Geol. Survey Prof. Paper 91, p. 253, pl. 29, fig. 4, 1916.

In one of the small collections from Rugby, Colo., there are a number of leaves that appear to belong to this species: They are not very completely preserved, in fact little more than their outline remains, but so far as can be made out they may be doubtfully referred to this species with no great violence.

Occurrence: Raton formation (Tertiary); 1 mile southwest of Rugby, Colo., collected by G. B. Richardson's party (5128).

1 Flora tertiaria Helvetiae, vol. 3, pl. 133, figs. 42-56, 1856.

2 U. S. Geol. Survey Terr. Rept., vol. 7 (Tertiary flora), p. 286, pl. 55, figs. 1-9, 1878 . 
Order GERANIALES.

Family RUTACEAE.

Xanthoxylum dubium Lesquereux.

Xanthoxylum dubium Lesquereux, U. S. Geol. Survey Terr. Ann. Rept., 1871, Suppl., p. 15, 1872.

Of this species Lesquereux says:

A small oblong leaf 3 centimeters long, 1.5 centimeters broad, with borders entire or wavy crenulate, nearly parallel in the middle, rounded downward, with an abrupt, short, descending curve to the base of the median nerve; secondary veins parallel, eight pairs, open (angle of divergence, $60^{\circ}$ ), abruptly curving near the borders, camptodrome. The point of the leaf is destroyed. Related to $X$. dentatum Heer (Flora tertiaria Helvetiae, vol. 3, pl. 127, fig. 21).

The status of this species is exactly the same as that of Rhamnus fischeri-that is, it was named and described as above but so far as now known was not afterward referred to.

Occurrence: Raton formation (Tertiary); "Fischers [Fishers] Peak, Raton Mountains, N. Mex." collected by F. V. Hayden, 1869.

Family EUPHORBIACEAE?

Genus EUPHORBOCARPUM Knowlton, n. gen.

Fruit of large size, composer of numerousprobably seven to nine-woody, compressed, wedge-shaped, apparently indehiscent carpels, disposed around a central axis.

Euphorbocarpum richardsoni Knowlton, n. sp.

Plate XCVI, figures $3,4$.

This remarkable species is founded, as may be seen from the figures, on three huge, ligneous, somewhat kidney-shaped or wedgeshaped carpels, which are so disposed as forcibly to suggest that there were originally at least seven, and probably as many as nime, in the complete fruit. The diameter of the complete fruit was at least 4 centimeters and the height 2.5 centimeters. One of the carpels, which is now detachable, has a thickness at the back of 13 millimeters and is wedge-shaped where it reaches the central axis. The surfaces where it was in contact with its fellows are plane and flat, and each is the same by mutual compression. The back of each carpel is rounded and the distance to the point where they are flattened by the mutual pressure is about 5 millimeters. It is difficult accurately to describe or figure this specimen but perhaps enough has been said to convey an idea of its original appearance. It is certainly unlike anything in a fossil state with which the writer is familiar in this country, and it should prove a good horizon marker if subsequently found.

From its rather striking resemblance to that of the well-known tropical euphorbiaceous tree; Hura crepitains, I have ventured to give it a new generic name implying relationship with the family Euphorbiaceae. It might have been given the nondescript name of Carpites or Carpolithes, but rather than add to these already overburdened "generic" groups it has seemed best to give it a distinctive name even if the apparent affinities have not been correctly interpreted. The Euphorbiaceae is of course a vast group, exhibiting great diversity of form and structure. The predominant type of fruit is composed of three carpels, but the number may range all the way from one to as many as nine in Anisonema or Thula or to fifteen in Hura. As already pointed out, there may well have been nine carpels in the present fruit.

A very great number of types of leaves are preserved in the beds in which the new fruit is found, and it is not impossible that some of them may represent the tree which bore it, but if so, the fact has not been detected.

I take pleasure in naming this remarkable fruit in honor of the collector, Mr. George B. Richardson, of the United States Geological Survey.

Occurrence: Raton formation (Tertiary); 5 miles south of Aguilar, Colo., collected by G. B. Richardson (5046).

\section{Order SAPINDALES,}

\section{Family ANACARDIACEAE.}

Rhus? viburnoides Knowlton, n. sp.

Plate XCVIII, figure 5.

Leaflets firm in texturé, obovate or obovateoblong, more or less unequal sided; margin entire below, doubly serrate above, the teeth sharp and upward pointing; midrib straight; secondaries about four or five pairs, at an acute angle, ending in the longer teeth, the lowest pair with two or three branches on the outside; finer nervation obscure.

This species is represented by a number of examples, one of which is figured. The larger is 4.5 centimeters in length and 2.5 centimeters in width, while the smaller one is 3.5 centi- 
meters long and barely 1.5 centimeters wide. The latter is markedly unequal sided and, moreover, lies in association with what appears to be a small piece of the general rachis.

I am uncertain as to the generic reference of these specimens. The smaller seems with little doubt to be a leaflet of Rhus, but the larger, though it resembles the other more or less closely in essential character, has less the general facies of the genus. For instance, it somewhat resembles certain small-leaved species of Viburnum, especially in the teeth, and it is possible that the two are not congeneric.

Occurrence: Raton formation (Tertiary); railway cut about one-half mile northwest of Wootton; Colo., 50 to 100 feet below the Wootton conl, collected by W. T. Lee (5711).

Family CELASTRACEAE.

Celastrus serratus Knowlton, n. sp.

Plate XCंVIII, figure 3; Plate XCIX, figure 4; Plate $\mathrm{C}$, figure 1.

Leaves of firm texture, ovate or ovate-oblong in outline, slightly cordate and unequal sided at base and apparently obtusely acuminate at apex; margin entire at base; thence provided with numerous, relatively small, sharp, upward-pointing teeth; petiole and midrib very strong; secondaries strong, about ten pairs, the lower ones opposite and emerging nearly at right angles, the upper ones alternate and emerging at an angle of about $45^{\circ}$, all more or less curved upward and most of them with two or three branches on the lower outer side which enter the teeth, or the secondaries arching and joining, and sending outside branches to the teeth. Nervilles numerous, oblique to the sccondaries and approximately at right angles to the midrib; fine nervation consisting of very small areolae.

This species is represented by several very well preserved leaves, the three specimens figured representing the extremes in size. The largest leaf is about 18 centimeters long and 12 centimeters wide and the smaller one about 9 centimeters long and 5.5 centimeters wide. The petiole, of which only. a small length remains in the larger specimen, is nearly 4 millimeters in thickness. In the additional specimen figured from Wootton the petiole reaches the extraordinary length of 11 centimeters. Severnl specimens of intermediate size have not been figured.
The present species is undoubtedly very closely related to Celastrus ferrugineus Ward, from the Fort Union formation of Montana; in fact, the smaller of the two leaves here figured is hardly to be distinguished from Ward's figure 13. Aboùt the only difference that can be readily observed is the greater size and sharper-pointed form of $C$. serratus. However, the largest leaf of the latter species is, very much larger than the largest specimen of $C$. ferrugineus figured by Ward; in fact, it is more than twice its size. In the absence of complete proof of the identity of the two species, the one under consideration has been given a new name.

Occurrence: Raton formation (Tertiary); dump of mine at Primero, Colo., collected by W. T. Lee (5798) on same stone as Asplenium? primero and Eucalyptus leei, Wootton, Colo., 50 to 100 feet above the Wootton coal, collected by W. T. Lee (5712).

\section{Celastrus sp.}

\section{Plate XCVIII, figure 1.}

The collection from near Yankee, N. Mex., contains a single fragment, here figured, that appears best referred to the genus Celastrus. It is so fragmentary that a clear idea of its size and distal configuration can not be obtained. It was apparently elliptical-lanceolate in outline, with abruptly rounded base and finely serrate margin. The nervation consists of a strong midrib and probably about a dozen pairs of thin, parallel, camptodrome secondaries.

Occurrence: Raton formation (Tertiary); Honeyfield mine near. Yankee, N. Mex., collected by W. T. Lee (5140).

Euonymus splendens Berry.

Plate LXIX, figure 1.

Euonymus splendens Berry, U. S. Geol. Survey Prof. Paper 91, p. 267 , pl. 61 , fig. 6 ; pl. 62 , figs. $1-5,1916$.

Leaf apparently coriaceous in texture, broadly ovate-lanceolate, 14 centimeters long, 6.5 centimeters wide, abruptly rounded and truncate at base, acuminate at apex; margin finely crenate-serrate throughout except near the base; midrib very strong; secondaries numerous, about fourteen pairs, strong, emerging at a very low, almost a right, angle below, but

1 Ward, L. F., Synopsis of the fora of the Laramie group: U. S. Geol. Survey Sixth A.nn. Rept., p. 555, pl. 52, figs. 11-14, 1886. 
about $45^{\circ}$ in the upper part, mainly alternate, somewhat curved upward, occasionally forked, apparently craspedodrome; finer nervation obsolete.

This leaf is fortunately nearly perfect, lacking only a small portion of the upper extremity, and is well characterized by its broadly ovatelanceolate shape, finely undulate-serrate margin, and numerous low-angled secondaries. The petiole is preserved for a length of 5 . millimeters.

This species is at first sight strongly suggestive of what Lesquereux has identified as Quercus haidingeri Ettingshausen, ${ }^{1}$ from the Green River formation, but differs from it in its larger size, obtusely rounded instead of obtusely wedge-shaped base, and lower angled secondaries.

Occurrence: Raton formation (Tertiary); southern end of Raton tunnel, north of Raton, N. Mex., collected by W. T. Lee (5155). Wilcox formation (Tertiary); the commonest species in the Wilcox.

\section{Family ACERACEAE.}

Acer fragilis Knowlton, n. sp.

Plate CI, figures 1, 2.

Leaves evidently membranaçeous in texture, broadly deltoid in general outline, truncate at base, palmately seven ribbed and apparently seven lobed; lower lobes largest, acute, supplied by the ribs; upper pair small, obtusely acute, supplied by secondary branches from the midrib; sinuses rounded; nervilles obscure, apparently mainly broken.

This species is represented by several specimens, but all are so much broken that it is almost impossible to get a clear idea of the shape and appearance of the leaf. It is clearly truncate at base and seven ribbed and is apparently seven lobed, the lower lobes being entered by the lateral ribs and the upper pair by secondary branches from high up on the midrib. The terminal lobe is acuminate and the others are rather obtusely acuminate; none, so far as seen, is toothed. The leaves are all so fragmentary that it is impossible to get any accurate measurements, though the length appears to range from 7 to 10 centimeters and the width from 6 to 8 centimeters.

1 U. S. Geol. Survey Terr. Rept., vol. 7 (Tertiary flora), pl. 20, figs $9,10,1878$.
This species, it is admitted, is not well founded, and it is presented simply to call attention to the fact that such an aceroid type of leaf is present in these beds. Additional collections will be necessary before it can be made out with full satisfaction. This being the case it seems hardly worth while to institute comparisons with either living or fossil species.

Occurrence: Raton formation (Tertiary); floor o? Fishers Peak mine, 3 miles southeast of Trinidad, Colo., collected by G. B. Richardson's party (5099); Sugarite mine, 4 miles northeast of Raton, N. Mex., collected by F. H. Knowlton (5467).

\section{Family SAPINDACEAE.}

Sapindus caudatus Lesquereux.

Plate C, figure 2.

Sapindus caudatus Lesquereux, U. S. Geol. Survey Terr. Ann. Rept., 1872, p. 380, 397, 1873; U. S. Geol. and Geog. Survey Terr. Ann. Rept., 1873, p. 382, 1874; idem, 1.876, p. 51.5, 1878; U. S. Geol. Survey Terr. Rept., vol. 7 (Tertiary flora), p. 264, pl. 48, fig. 6 , 1878; Harvard Coll. Mus. Comp. Zool. Bull., vol. 16, p. $54,1888$.

Nyssa lanceolata Lesquereux, U. S. Geol. Survey Terr. Ann. Rept., 1872, p. 407, 1873; U. S. Geol. Survey Terr. Rept., vol. 7 (Tertiary flora), p. 245, pl. 35, fig. 5 [not figs. 6, 6a], 1878.

Leaf subcoriaceous in texture, broadly lanceolate or elliptical-lanceolate in shape, inequilateral, narrowed to the petiole on one side, rounded to it on the other side, tapering above into a long acuminate point; margin perfectly entire; midrib strong; secondaries about twelve pairs, mostly alternate, unequally distant, the lowest one more open, curving to and along the borders and anastomosing with shorter intermediate ones; upper ones camptodrome, curving along. the borders; nervilles rather oblique to the secondaries; finer nervation copious, producing a fine irregular network.

In size these leaves are remarkably uniform, the usual length being between 7 and 10 centimeters, exceptionally 11 centimeters, and the usual width about 4 centimeters; they are quite strongly unequal sided and the tip is prolonged into a long, slender point.

The type specimen of this fine species is preserved in the United States National Museum (No: 386) and has been well described and figured by its author. It appears to be a rather rare species, for in the large collection 
identified by Lesquereux for the Harvard College Museum of Comparative Zoology he found only one specimen, and in the recent collections made by Lake only a very few examples were found, one of which, however, is exceptionally complete and perfect.

This species is reported by Lesquereux ${ }^{1}$ from Campbell's quarry, Cross Lákes, La. (U. S. Nat. Mus. 2601), but the specimen can not now be found. The material is a very hard sandstone and most of the other leaves preserved on it are only in fragments. Though it is, of course, impossible to say how this particular specimen is preserved, it is more than probable that it was also fragmentary and hence open to question. More material must be obtained before its reference can be positively settled.

After consideration I have concluded that it is imperative to refer what Lesquereux named Nyssa lanceolata, to Sapindus caudatus, although at one time I was inclined to regard it as belonging to Juglans rugosa.". Nyssa lanceolata was described originally from " 6 miles above Spring Canon, Mont.," but neither this nor any other specimen from there appears to have been in the United States National Museum, and it is quite possible that the locality of the type was wrongly recorded. The leaf Lesquereux figures in "The Tertiary flora" (U. S. Nat. Mus. 303) comes from the andesitic beds at Golden, Colo. This specimen agrees so well with the original description as to suggest the suspicion that it is the original type and never came from the Bozeman coal field at all, but there is no possible manner in which this supposition can be proved or disproved. As rather militating against this view it may be stated that in Lesquereux's final pronouncement on the subject ${ }^{3}$ he still retains the species as coming from Spring Canyon but adds "in small fragments of leaves."

In any event, specimen No. 303, which is the figured type of so-called Nyssa lanceolata, comes from Golden, Colo., and is nothing more nor less than the basal portion of a leaf that previously had been named Sapindus caudatus, as may be seen by comparing the figures in "The Tertiary flora." In the collections from the vicinity of Raton, N. Mex., I have found

\footnotetext{
1 U. S. Nat. Mus. Proc., vol. 11, p. 24, 1888.

2. Knowlton, F. H., A cataloguc of the Cretaceous and Tertiary plants of North America: U. S. Geol. Survey Bull. 152, p. 153, 1898.

${ }^{8}$ Lesquercux, Leo, The Tertiary flora: U. S. Geol. Survey Terr. Rept., vol. 7, p. 246, 1878.
}

the single example here figured, which is not to be distinguished from Lesquereux's Sapindus caudatus, the only difference being the very slightly greater angle of its secondaries.

Occurrence: Denver formation (Tertiary); type, Golden, Colo. Livingston formation? "Six miles above Spring Canon, Mont.," original specimen lost and none since obtained. Raton formation (Tertiary); locality 85, near Yankee, N. Mex., collected by W. T. Lee (-5142). Wilcox formation? (Tertiary); Campbell's quarry, Cross Lakes, near Shreveport, La.

\section{Sapindus affinus Newberry. \\ Plate XCIX, figure 3.}

Sapindus affinis Newberry, Lyceum Nat. Hist: New York City Annals, vol. 9, p. 51, 1868; U. S. Geol. Survey Mon. 35 , p. 116, pl. 30, fig.: 1; pl. 40, fig. 2, 1898.

Ward, U. S. Geol. Survey Sixth Ann. Rept., p. 554, pl. 50, figs. 2, 3, 1886; U. S. Geol. Survey Bull. 37 , p. 67 , pl. 30, figs. 1, 2, 1887.

This specimen is perhaps the most abundant and widely distributed form thus far discovered in the Fort Union formation, and it is of interest that it should be found in the Raton formation so far to the south of its previously known range. In the specimens figured from Primero there is a single nearly perfect leaflet and fragments of two or three others.

Occurrence: Raton formation (Tertiary); dump from mine at Primero, Colo., collected by W. T. Lee (5798). Fort Union formation ('Tertiary).

\section{Sapindus rocklandensis Knowlton, n. sp. Plate XCVIII, figure 4.}

Leaflet coriaceous in texture, ellipticallanceolate in outline, abruptly wedge-shaped at base, rather obtusely pointed at apex; petiole apparently short; midrib straight; secondaries about ten pairs, irregular, opposite above and below and alternate in the middle, emerging at a very low angle, then much curved upward, camptodrome, occasionally with only two camptodrome forks on the outside; finer nervation not retained.

The present example is nearly perfect and is about 8.5 centimeters in length and 2.5 centimeters in width. It is slightly unequal sided at base and has a little of the petiole preserved. It may be known by its ellipticallanceolate shape and numerous irregular camptodrome secondaries. 
This species is not greatly different from certain leaflets referred to Sapindus grandifoliolus. Ward ${ }^{1}$ from the Fort Union formation of Montana. and Wyoming, but it differs by its narrower and more elliptical shape and its less markedly camptodrome secondaries.

Its basal portion resembles certain leaflets of Juglans schimperi Lesquereux ${ }^{2}$ from the Denver and Green River formation, but its upper portion is quite different. It also suggests leaflets that have sometimes been placed in Juglans rugosa Lesquereux, but the agreement is not very close.

Occurrence: Raton formation (Tertiary); one-eighth mile northeast of Rockland mine, locality 120, north side of Cucharas Canyon, near Walsenburg, Colo., collected by W. T. Lee (5679).

\section{Order RHAMNALES.}

Family RHAMNACEAE.

\section{Rhamnus cleburni Lesquereux.}

Plate CXIII, figure 3.

Rhamnus cleburni Lesquereux, U. S. Geol. and Geog. Survey Terr. Ann. Rept.; 1873, p. 381, 1874; U. S. Geol. Survey Terr. Rept., vol. 7 (Tertiary flora), p. 280, pl. 53, figs. 1-3, 1878.

The material from Wootton, Colo., contains the single finely preserved example of this species that is here frgured. It is nearly perfect, lacking only a little of its upper part. It is about 13 centimeters in length and 5.5 centimeters in width, and is indistinguishable from the type figures given by Lesquereux.

Occurrence: Raton formation (Tertiary); collected by W. T. Lee-Canadian Canyon, N. Mex., 1 mile east of Jones's Canyon (5291); dump from Turner mine, $1 \frac{1}{2}$ miles north of Wootton, Colo. (5714); railway cut one-half mile north of Wootton, Colo. (5711); Wet Canyon, 4 miles northeast of Weston, Colo. (5825); one-eighth mile northeast of Rockland mine, locality. 120, north side of Cucharas Canyon near Walsenburg, Colo. (5679); Spring Canyon, north of Vermejo Park, N. Mex. (5236); collected by G. B. Richardson's party $\rightarrow 2$ miles southeast of Dean, Colo. (5113); one-half mile southwest of Berwind, Colo. (5107); 5 miles above Aguilar,

1 U. S. Geol. Survey Sixth Ann. Rept., p. 554, pl. 4, figs. 4-8, 1886.

2 The Tertiary flora: U. S. Geol. Survey Terr. Rept., vol. 7, p. 287, pl. 56 , fig. 10,1878 .
Colo. (5046); collected by F. H. Knowltonhillside just west of south end of Raton tunnel, 6 miles north of Raton, N. Mex. (5464); collected by Orestes St. John-Wootton, Colo.

Rhamnus goldianus? Lesquereux.

Plate CI, figure 4; Plate CXII, figure 5.

Rhamnus goldianus Lesquereux, U. S. Geol. Survey Terr. Ann Rept., 1872, p. 381, 1873; U. S. Geol. Survey Terr. Rept., vol. 7 (Tertiary flora), p. 281, pl. 53, figs: $4-8,1878$.

The specimen here figured appears to be properly referable to this species, though it is preserved on such a coarse-grained matrix that its character can not always be made out with satisfaction. It is about the same size and shape as the medium-sized leaves of $R$. goldianus and has about the same number of close parallel secondaries. It has also the slightly heart-shaped base, but its lowest pair of secondaries does not appear to be supplied with tertiary branches. The nervilles, though faintly preserved, appear to be of the same character as in typical $R$. goldianus. It is possible that the specimen under consideration is not quite the same, but it is obviously very close, and rather than make it a new species the identification has been questioned.

Occurrence: Raton formation. (Tertiary); Wootton, Colo., 50 to 100 feet below the Wootton coal, collected by W. T. Lee (5711); dump of Green Canyon mine, locality 119, near Aguilar, Colo., collected by W. T. Lee (5684).

Rhamnus? woottonensis Knowlton, n. sp.

Plate CI, figure 6.

Leaf firm in texture, elliptical-lanceolate in shape, obtusely wedge shaped at base, apparently acuminate at base; margin entire below, thence slightly undulate or in a few places toothed, the teeth few, scattered, low; midrib fairly strong, perfectly straight; secondaries nine or ten pairs, alternate, at. an angle of $45^{\circ}$, slightly. curved upward, a few near the middle with two or three tertiary branches on the outside; nervilles thin, mainly prominent.

The specimen figured is the best observed, but it lacks a portion of the side and the extreme apex. The length is about 17 centimeters and the width 7 centimeters. It is very difficult to be certain of the exact configuration of the margin, but it is certainly entire for perhaps a fourth of its length from 
the base; thence to the apex it appears to be slightly undulate or in places obscurely toothed. The only really distinct tooth appears to be entered by a small branch from a secondary; the other secondaries appear to be camptodrome, but it is impossible to be certain of just how they terminate.

Occurrence: Raton formation (Tertiary); dump of Turner mine, $1 \frac{1}{2}$ miles north of Wootton, Colo., collected by W. T. Lee (5714), on same stone with a fragment of Andromeda? lanceolata.

\section{Rhamnus obovatus Lesquereux.}

Rhamnns obovalus Lesquereux, Am. Joür. Sci., \&d ser., vol. 45, p. 207, 1.868 (nomen nudum); U. S. Geol. Survey Terr. [Third] Ann. Rept., p. 97, 1869 (reprint, p. 1.97, 1873); idem, 1871., Suppl., p. 15, 1872; idem, 1872, pp. 381., 402, 1873; U. S. Geol. and Geog. Survey Terr. Ann. Rept., 1873,.pp. 382, 385, 1874; idem, 1876, p. 51.7, 1878; U. S. Geol. Survey Terr. Rept., vol. 7 (Tertiary flora), p. 281, pl. 54, figs. 1, 2, 1.878; U. S. Nat. Mus. Proc., vòl. 11, p. 20, 1888.

This was one of the three species collected in 1867 by J. L. Le Conte and the only one coming from the locality given as "upper end of Purgatoire Canyon, N. Mex." It was subsequently reported by Lesquereux from Golden, Colo., and Evanston, Wyo., but the type specimens, together with all other original specimens, are now lost or at least their present location is unknown. The records of the United States National Museum do not show that any of these specimens have ever been in its possession.

Rhamnus obovatus is not contained in any of the recent collections from the Raton Mesa region, but, as may be seen from Lesquereux's figures of it; it is too definite and well marked to be ignored.

Occurrence: Raton formation (Tertiary); type, upper end of Purgatoire Canyon, Colo., collected July, 1867, by J. L. Le Conte. Denver formation? (Tertiary); Golden, Colo. See Lesquereux.

\section{Rhamnus fischeri Lesquereux.}

Rhamnus fischeri Lesquereux, U. S. Geol. Survey Terr. Ann. Rept., 1871, Suppl., p. 51, 1872.

Lesquereux says:

Leaves thickish, large, 4 inches long, 3 inches broad, rhomboidal, obtuse and entire; median nerve thick, :grooved, secondary nerves open (angle of divergence, $60^{\circ}$ ), oquidistant, ten to twelve pairs, parallel, straight to the borders where they abruptly curve, camptodrome. By the form of the leaves and the straight secondary veins this species is related to Rhamnus aizoon Heer. The nervation is not distinguishable.

So far as known to the writer this species was not subsequently referred to by its author. It does not appear in "The Tertiary flora," which was the formal summing up of available data to 1878 , and it seems probable that it was merged with some other species or type, though there is no evidence to support this view. In the absence of information as to its disposition it seems best to retain it as left by Lesquereux.

Occurrence: Raton formation (Tertiary); "Fischers Peak, Raton Mountains, Colo.," collected by F: V. Hayden, 1869.

Berchemia multinervis (Alexander Braun) Heer.

\section{Plate CI, figure 5 .}

Berchemia parvifolia Lesquereux, Am. Jour. Sci., vol. 45, p. 207, 1868; U. S. Geol. Survey Terr. [Third] Ann. Rept., p. 96, 1869, reprint, p. 196, 1873; idem, 1870, p. 382 , 1871; idem, 1871, Suppl., p. 15, 1872; U. S. Geol. and Geog. Survey Terr. Ann. Rept., 1873, p. $382,1874$.

Berchemia multinervis (Alexander Braun) Heer. Lesquereux, U. S. Geol. Survey Terr. Rept., vol. 7 (Tertiary flora), p. 277, pl. 52, figs. 9, 10, 1878; U. S. Geol. and Geog. Survey Terr. Ann. Rept., 1876 , p. 517, 1878; U. S. Nat. Mus. Proc., vol. 11, p. 16, 1888.

Neither of the figured American "types" of this species are now, nor apparently have ever been, in the United States National Museum collection. As indicated by the synonymy Lesquereux first called this form Berchemia parvifolia, but when he prepared "The Tertiary flora" he decided that it was not sufficiently distinct from the well-known European plant, a view of which all later collections appear to sustain. The earlier specimens are said to have come from Raton Pass in the Raton. Mountains, N. Mex., but they are not in the United States National Museum and their whereabouts can not be ascertained. Later specimens, however, have been reported from several localities in or about the Denver formation of Colorado.

This species as found in American strata is undoubtedly closely allied to Rhamnus goldianus, from which it differs, according to Lesquereux, in never exhibiting the lowest pair of secondaries branched on the outside. This 
character Ward ${ }^{1}$ does "not regard as of sufficient weight to be treated as generic," and it is a slight character to attach such importance to. But, as Lesquereux says, all of the leaves of Rhamnus goldianus, regardless of size, have the lower secondaries branched, and as none of the leaves of Berchemia show this branching it perhaps becomes a generic character.

Much more difficult, it appears to me, is the task of discriminating between $B$. multinervis and the small leaves of Rhamnus cleburni, which are frequently associated with it. Rhamnus cleburni differs from $R$. goldianus in being usually of larger size and in not having the lower pair of secondaries branched, which is sufficient where the leaves are large, but when they are smaller it is impossible to separate them from $B$. multinervis. They can only be unsatisfactorily separated by the fact that $B$. multinervis is nearly elliptical and $R$. cleburni more pointed.

According to the facts above presented, the leaf from Golden, Colo., referred by Ward to Berchemia multinervis, ${ }^{2}$ will have to be referred to Rhamnus goldianus. It is no smaller than a number of leaves referred to this latter species by Lesquereux, being only a little more wedge shaped at base.

The recent collections from the Denver Basin embracing this species come from the south face of South Table Mountain, Golden, Colo., and from 3,000 feet east of the Douglass coal mine, west of Sedalia, Colo. The species has also been reported from the Fort Union formation near the mouth of Yellowstone River.

The single specimen here figured from New Mexico is nearly perfect so far as regards outline and the principal nervation, and it is referred to this species with little hesitation. It is preserved on such a coarse-grained sandstone that the peculiar, fine nervation is almost obliterated, though careful study discloses a few nervilles. It is a little more nearly elliptical than the two examples figured by Lesquereux, but it is exactly duplicated by some of the leaves figured by $\mathrm{Heer}^{3}$ from the Swiss Miocene. The finding of this species again in the Raton region is of importance in confirm-

\footnotetext{
1.Ward, L. F., Types of the Laramie flora: U. S. Geol. Survey Bull, 37, p. 73,1887 .

2 Ward, L. F., op. cit., p. 73, pl. 33, fig. 2.

8 Flora tertiaria Helvetiae, vol. 3 , pl. 123, 1859.
}

ing Lesquereux's original reference, though his specimens are now lost.

Occurrence: Raton formation (Tertiary); Raton Pass, Raton Mountains, N. Mex., type locality of Berchemia parvifolia Lesquereux, mine No. 5 , locality 85, near Yankee, N. Mex., collected by W. T. Lee (5134). Denver formation (Tertiary); Golden, Colo., Dawson arkose, near Douglass mine, west of Sedalia, Colo. Fort Union formation (Tertiary); mouth of Yellowstone River, Mont.

\section{Paliurus zizyphoides Lesquereux.}

Plate CIV, figure 2.

Paliurus zizyphoides Lesquereux, U. S. Geol. Survey Terr. Ann. Rept., 1872, p. 384, 397, 1873; U. S. Geol. and Geog. Survey Terr. Ann. Rept., 1873, p. 382 , 1874; idem, 1876, p. 516, 1878; U. S. Geol. Survey Terr. Rept., vol. 7 (Tertiary flora), p. 274, pl. 51, figs. 1-6, 1878; Harvard Coll. Mus. Comp. Zool. Bull., vol. 16, 1888, p. 55 .

Four of the six figured types of this species. are preserved in the United States National Museum (fig. 1, No. 416; fig. 4, No. $416^{6}$; fig. 5; No. 418; fig. 6, No. $416^{a}$ ), as are also a number of other specimens marked as types. which do not appear to be such, and it is possible that the two missing ones may be in the collection under wrong numbers.

This species. was first described from Erie, near Golden, Colo, but the specimen (or specimens) can not now be found and none have since been obtained from the locality. A single specimen in the collection (No. 417) from Sand Creek, Colo., is marked as a type, but it can not be identified with any of the figures. It is not well preserved and does not. appear to agree closely with the typical forms. It seems to be more closely related to Rhamnus. and may belong to this genus.

Most of the specimens representing the species. come from Black Buttes, Wyo., but a few appear to have been found at Golden, Colo. The Black Buttes specimens as figured differ considerably among themselves. They measure 2 to 7 centimeters each way, for they are nearly round or sometimes approximately oval. At first sight it seems hardly possible that they belong to one species, yet in nervation they certainly appear very similar. The thick midrib is "abruptly inflated above the base of" the leaves and the two or three pairs of pri- 
mary nerves are successively attached to it, the inner ones at the top of the inflated part, the others lower." It is probable that if a larger series can ever be obtained it will be found possible to divide them up.

The specimen figured, which is from southeastern Colorado, agrees most closely with figure 6 of the original illustrations. It lacks all of the upper portion (as does also the figure with which it is compared), but so far as can be made out the differences are not essential.

Occurrence: Raton formation (Tertiary); Wootton, Colo., 50 to 100 feet above the Wootton coal, collected by W. T. Lee (5712). Black. Buttes coal group (regarded by the author as post-Laramie); Black Buttes, Wyo. Denver formation (Tertiary); Golden, Colo. Laramie formation (Cretaceous); Erie and Sand Creek, Colo.

Zizyphus fibrillosus (Lesquereux) Lesquereux. Plate CII, figure 1.

Ceanothus fibrillosus Lesquereux, U. S. Geol. Survey Terr. Ann. Rept., 1872, p. 381, 1873; U. S. Geol. and Geog. Survey Terr. Ann. Rept., 1873, p. 404, 1874.

Zizyphus fibrillosus (Lesquereux) Lesquereux, U. S. Geol. Survey Terr. Rept., vol. 7 (Tertiary flora), p. 276, pl. 52, figs. 1-6, 1878; Harvard Coll. Mus. Comp. Zoology Bull., vol. 16, p. 55, 1888.

Zizyphus distortus Lesquereux, U. S. Geol. Survey Terr. Rept., vol. 7 (Tertiary flora), p. 275, pl. 51, fig. 7 (not figs. 8, 9), 1878.

The figured type specimens of this species, together with a number of others, are preserved in the United States National Museum (Nos. 425-429). Though none of these specimens is absolutely perfect, the different parts are so well represented that a fairly good idea of the appearance of the leaf may. be gained from them.

This species was first reported by Lesquereux as rare, but subsequent collections have shown it to be one of the most abundant and characteristic plants of the Denver formation, to which it has been supposed to be confined. The collections elaborated by Lesquereux for the Harvard College Museum of Comparative Zoology contained some specimens, and the collections made at Golden by the United States Geological Survey contain about 40 more or less perfect examples. From a study of all these leaves it appears that some are very broad
( 8 centimeters), with a round, subcordate base and in a few specimens with seven nerves, though normally with only five and exceptionally with only three. Others are round or subtruncate at base and are prolonged above into a rather slender acuminate apex. They ordinarily range from 5 to 8 centimeters in width and 7 to 12 centimeters in length. The petiole is preserved in some leaves for 2.5 to 3 centimeters; it is narrow below and broadens slightly where it expands into the laminae. The nervilles are very close, distinct, simple, at right angles to the midrib and more or less oblique to the lateral nerves and their branches. One of the figured types of Lesquereux's Zizyphus distortus $^{1}$ shows no essential difference from the present species and has accordingly been transferred to it. Very probably the other leaves figured under $Z$. distortus should also be transferred to $Z$. fibrillosus, but there are some reasons for. keeping the two species distinct, and they may so remain for the present.

Lesquereux's statement ${ }^{2}$ that this species has been found at Black Buttes, Wyo., appears to be in error, as no known specimens show such distribution.

The specimen here figured from the Raton Mesa region is an exceptionally well preserved leaf; at least as regards the basal portion and petiole, and is seen to belong to the broader seven-ribbed type above described. The nervilles, although obscure, are really well preserved, and can be made out with a low-powered microscope. This. specimen, so far as known, is the first one found outside of the Denver Basin.

An exceptionally large leaf of this species occurs in a collection from Vermejo Creek, $\mathrm{N}$. Mex. It is fully 12 centimeters long and 9 centimeters broad but is not figured, as it is somewhat imperfect on the margins.

Occurrence: Denver formation (Tertiary); types, Golden, Colo. Raton formation (Tertiary), collected by W. T. Lee-Apishapa Canyon, 3 miles northeast of Abeton, Colo. (5688); dump of mine at Delagua, Colo. (5690); Vermejo Valley, near the mouth of Salyers Creek, N. Mex. (5826); junction of Dillon and Coal canyons, near Blossburg, $\mathrm{N}$. Mex. (5149); near Yankee, N. Mex. (5142); col-

1 Lesquereux, Leo, The Tertiary flora: U. S. Geol. Survey Rept., vol. 7 , p. 275 , pl. 51 , fig. 7,1578 .

2 Idem, p. 270 
lected by G. B. Richardson's party -5 miles above Aguilar, Colo. (5046); collected by Orestes St. John-Wootton, Colo.

\section{Zizyphus meiggsii (Lesquereux) Schimper.}

Plate XCIX, figures 1, 2; Plate C, figure 3.

Ceanothus meiggsii Lesquereux, "Am. Philos. Soc. Trans., vol. 13, p. 419 , pl. 19 , figs. $5-7,1869$.

Zizyphus meiggsii (Lesquereux), Schimper, Paléontologie végétale, vol. 3 , p. 223, 1874.

Berry, U. S. Geol. Survey Prof. Paper 91, p. 278, pl. 70, figs. 3-5, 1916.

The two specimens figured are from Vermejo Creek. They are very fragmentary but seem to be indistinguishable from this species. They have the same broadly ovate outline, finely and evenly serrate margin, and tripleribbed primary nervation. The lateral ribs with their numerous outside branches extend nearly to the upper point of the blade; and the midrib bears numerous thin secondary branches. Whether or not the apex was prolonged into the slender tip, as shown in one of the type specimens, can not be ascertained, for the leaf is broken just at this point, but from the appearance of the midrib it is extremely probable that it was prolonged to some extent at least.

A specimen believed to belong to this species was detected in the collections from the vicinity. of Yankee. It is indistinguishable from the larger of the two from Vermejo Creek.

Occurrence: Raton formation (Tertiary), collected by W.T. Lee-Vermejo Valley, near the mouth of Salyers Creek, N. Mex. (5826); section near mine No. 5, locality 85, Yankee, N. Mex: (5137). Wilcox formation (Tertiary); types, Mississippi.

\section{Order MALVALES.}

Family TILIACEAE.

Apeibopsis? neomexicana Knowlton, n. sp.

Plate CI, figure 3 .

Leaf of firm texture, ovate-lanceolate, truncate at base (apex destroyed); margin strongly undulate; petiole strong; midrib very strong, especially below; secondaries about six or seven pairs, alternate; arising, at very irregular distances, at an angle of about $45^{\circ}$, somewhat curved upward, camptodrome, arching well inside the margin, often with large loops; finer nervation obsolete.
The example figured is the only one observed of this form; it is nearly perfect, lacking only a small portion of the apex. The length was presumably about 8 centimeters, and the width is nearly 4 centimeters. The outline of the leaf and the rather peculiar nervation are well shown in the figure.

This leaf appears to be related to A peibopsis? discolor Lesquereux, ${ }^{1}$ from the Black Buttes coal group (regarded by the author as of postLaramie age) at Black Buttes, Wyo., but is quite distinct from it. It also resembles Nyssa buddiana Ward ${ }^{2}$ from the supposed Laramie at Hodges Pass, Wyo., but is easily distinguished from it.

Occurrence: Raton formation (Tertiary); locality 85, near Yankee, N. Mex., collected by W. T. Lee (5142).

Tilia speciosissima Knowlton, n. sp. Plate LXVII.

Leaf of large size and very firm texture, broadly ovate in shape, deeply cordate at base, the lobes rounded, apex rather obtuse; petiole very long, slender; margin undulate, toothed, or seemingly almost entire; nervation strong; three ribbed from the top of the petiole, the midrib straight, with about three pairs of strong alternate secondaries at an angle of about $45^{\circ}$, slightly curved upward, ending in the margin or slightly below it; lateral ribs nearly as strong as the midrib, running up for two-thirds the length of the blade, slightly curved upward, each with numerous (eight or nine) secondary branches on the outside, the lowest pair-which arise with the midrib and lateral ribs at the base of the blade and giving a five-ribbed appearance to the leaf-with several (about eight) tertiary branches which supply the basal lobes; nervilles numerous, strong, usually somewhat oblique to the secondaries.

The splendid leaf here figured, together with its counterpart, is almost perfectly preserved. It is broad-ovate in shape, being about 14 centimeters long and 12 centimeters wide; its petiole is preserved for a length of 7.5 centimeters and clearly is not all present. The nervation is so well shown in Plate LXVII that it is not necessary further to describe it.

1 The Tertiary flora: U. S. Geol. Survey Terr. Rept., vol. 7, p. 259, pl. 44, fig. 6, 1878 .

2 Synopsis of the flora of the Laramie group: U. S. Geol. Survey Sixth Ann. Rept., pl. 47, fig. 7, 1880. 
This species seems with reasonable certainty to belong to the genus Tilia, being, for example, quite like some of the larger leaves of the living T. americana Linne, the common linden or basswood. Ordinarily the leaves of all the living species of Titia are more or less unequal sided at base, but there are many in which this inequality is slight and some in which it can not be detected. The present leaf is not quite perfectly preserved at base, but so far as can be made out it is slightly inequilateral. The long strong petiole is the same as in Titia, and the manner in which the strong lateral ribs originate is the same as in T.americana. The márgin in living linden leaves is usually sharply serrate, though in certain large leaves, especially those from suckers, the teeth are less numerous and less sharp. The margin in the fossil leaves is obscurely preserved but apparently is not strongly toothed; in fact, it is almost entire. The nervation agrees almost perfectly with that of $T$. americana.

Tilia speciosissima bears much resemblance to certain fossil leaves that have been referred to the genus Populus. P. Tatior cordifolia Heer, ${ }^{1}$ from the Swiss Miocene, is even larger, though of quite different shape. Populus laevigata Lesquereux, ${ }^{2}$ from the Laramie Plains of Wyoming, is also similar, as is P.genatrix Newberry, from the Fort Union formation of the Yellowstone Valley, Mont. On the whole, however, the specimens undoubtedly resemble Tilia more closely than Populus.

Occurrence: Raton formation (Tertiary); oneeighth mile northeast of the Rockland mine, locality 120, north side of Cucharas Canyon, near Walsenburg, Colo., collected by W. T. Lee (5679).

\section{Family STERCULIACEAE.}

Sterculia berryana Knowlton, n. sp. Plate CII, figures 3,4 .

Leaf small, coriaceous, truncate to a slightly decurrent base, palmately fir lobed, palmately three ribbed from the top of the petiole; lobes lanceolate, acuminate, the central lobe much the larger, the lowest ones very small; margin otherwise perfectly entire; central lobe with three or four pairs of alternate, strong secondary branches, the lowest entering and running

1 Flora tertiaria Helvetiae, vol. 2, 'pl. 55, figs. 1, 2, 1858.

2 Tho Tertiary flora: U. S. Gcol. Survey Terr. Rept., vol. 7, pl. 21, Ag. 9,1878 . nearly to the tip of the lateral lobes, the others much curved upward and running along the margin; lateral ribs with about two secondary branches on the lower side only, one entering the tip of the lower lobe and the other running nearly to the tip of the lateral lobe; finer nervation not retained.

This fine species is represented by several specimens, of which the best preserved is figured (fig. 3). It is about 9 or 10 centimeters long and 8 centimeters between the tips of the lateral lobes. The central lobe is about 4.5 centimeters long and 3 centimeters broad, the lateral lobes only 2.5 centimeters long, and the basal lobes less than 1 centimeter long.

Among the other more or less fragmentary specimens is one which was at first mistaken for a Platanus. It was probably 15 centimeters long and 12 centimeters or more broad. The specimen shown in figure 4 was probably fully as large, and it well shows the truncate character of the base and the abruptly decurrent portion which follows the thin ribs to their junction with the top of the petiole.

This species is of the same type as Stercuitia mucronata Lesquereux and $S$. snowii Lesquereux; from the Dakota sandstone of Kansas, ${ }^{3}$ from which, however, it differs in its generally smaller size, its relatively much larger central lobe, and markedly in its nervation. It is wholly unlike any of the few American Tertiary forms thus far referred to this genus.

Among foreign Tertiary species $S$. berryana is of the same type as several-for example, S. labrusca Unger, as figured by Engelhardt, and S. majolana Massalongo. ${ }^{4}$

This species is named in honor of Edward W. Berry.

Occurrence: Raton formation (Tertiary); mine No. 5, locality 85, near Yankee, N. Mex., collected by W. T. Lee (5134).

Dombeyopsis magnifolia Knowlton, n. sp.

Plate CII, figure 2.

In one of the collections from Ute Park, N. Mex., a specimen was found (figure 2) which appears to belong to the genus Dombeyspsis, though unfortunately it is so fragmentary that it is perhaps unwise to give it a new

${ }^{3}$ Lesquereux, Leo, The flora of the Dakota group: U. S. Geol. Survey Mon. 17, pl. 30, figs. 1-4, and pl. 31, figs. 2, 3, 1892.

- Massalongo, A. B., Synopsis florae fossilis Senegalliensis, pl. 20, fig. 3, 1858 : 
specific name. In size it is probably nearest to Dombeyopsis obtusa Lesquereux,${ }^{1}$ from the Denver formation at Golden, Colo.; it is, however, larger, being fully 14 centimeters long and 13 centimeters wide. Its margin is undulate, in which particular it agrees better with either $D$. trivialis Lesquereux, ${ }^{2}$ from the Laramie at Golden, Colo., or with $D$. platanoides Lesquereux, ${ }^{2}$ from beds at Spring Canyon, Mont., that are regarded by the author as of postLaramie age. It is larger than either of these species and is proportionately longer, its length exceeding its width. It was at least four lobed on each side and was probably deeply heart shaped at base. This form probably can be recognized in future from the fragment figured and should be a good horizon marker.

Occurrence: Raton formation (Tertiary); Ute Park, N. Mex., on road to Ponil Park, collected by W. T. Lee (5830).

\section{Family VITACEAE. \\ Vitis olriki Heer.}

Vitis olriki Heer, Flora fossilis arctica, vol. 1, p. 120, pl. 48 , fig. 1, 1868.

Lesquereux, U. S. Geol. Survey Terr. Ann. Rept., 1871, Suppl. p. 12, 1872; U. S. Geol. and Geog. Survey Terr. Ann. Rept., 1873, p. 385, 1874; idem, 1876, p. 512, 1878; U. S. Geol. Survey Terr. Rept., vol. 7 (Tertiary flora), p. 241, pl. 41, fig. 8, 1878.

The single example upon which Lesquereux based his determination of this species in American strata is preserved in the United States National Museum (No. 351). It agrees closely with the original Greenland leaf as figured by Heer, being only a little coarser toothed and having fewer secondaries on the midrib. The specimen described and figured by Lesquereux comes from.Evanston, Wyo., "above the coal." It was not observed in the recent collections from this locality.

Lesquereux states that this species had been found in the Raton Mountains, but no specimen from this locality was contained in the collections of the United States National Museum. It is therefore a pleasure to be able to announce that a single example with its counterpart occurs in the present collections from the mesa north of Raton. It is fragmentary, lacking all of the upper portion, but the base is well shown and agrees with the figure given

1 Lesquereux, Leo, The Tertiary flora: U.S. Geol. Survey Terr. Rept.; vol. 7 , p. 255 , pl. 47 , figs. $4,5,1878$

${ }^{2}$ Idem, pl. 47, figs. 1, $2,3$. by Lesquereux, except that it is a little larger. It has not been figured, as it can add nothing to our knowledge of the form.

Occurrence: Beds regarded by the author as Tertiary; Evanston, Wyo. Raton formation (Tertiary); mesa north of Raton, N. Mex., at top of Raton formation, collected by W. T. Lee (5152).

Vitis leei Knowlton, n. sp.

Plate LXVI, figure 4.

Leaf membranaceous in texture, nearly circular in outline, slightly heart shaped at base, apparently rounded at apex; petiolo strong, at least 2.5 centimeters long and probably much longer; margin entire for a short distance at base, thence regularly and evenly serrate, the teeth strong, sharp, and outward pointing; nervation palmate, five ribbed from the top of the petiole, the lower pair nearly at right angles to the midrib, with several Tertiary branches on the lower side that enter the marginal teeth; next pair of ribs at an angle of about $45^{\circ}$, craspedodrome, each with four or five branches on the outside that enter the teeth; midrib with three or.four pairs of craspedodrome secondary branches; nervilles thin, usually unbroken.

The specimen figured is the only one observed. It is nearly circular in outline, the length reaching 6.5 or 7 centimeters and the width about 8 centimeters. The petiole, as stated above, is preserved for 2.5 centimeters and was apparently considerably longer.

This leaf, fortunately nearly perfect, appears to be certainly referable to the genus Vitis, it being clearly of the type of the living $V$. labrusca Linné, the common fox grape of the East. It is also similar to $V$. cinerea Engelmann, the downy grape of the Middle West. The present species has much the same shape and marginal toothing as these living species but is less deeply heart shaped at base and has the ribs very little arched upward. Its general appearance, however, is quite that of Vitis.

At first it was thought that this species might be referable to Populus. It agrees very well with Populus latior cordifolia $\mathrm{Heer}^{3}$ in shape, configuration of base, marginal teeth, and palmate origin of the principal ribs, but it differs from it in size and essentially in nervation, all the ribs and secondaries being craspedodrome instead of camptodrome. Populus grewiopsis

3 Flora tertiaria Helvetiae, vol. 2, pl. 55, fig. 2, 1856. 
Ward, ${ }^{1}$ from the Fort Union formation of Montana, is closer to it in size and shape, but differs from it in having its base truncate instead of heart shaped and its principal nervation less markedly palmate in origin, though craspedodrome. Hardly to be distinguished from $P$. grewiopsis is Grewiopsis populifolia Ward, ${ }^{2}$ also from the Fort Union; the two are certainly congeneric.

Occurrence: Raton formation (Tertiary); dump of Green. Canyon mine, locality 119, near Aguilar, Colo., collected by W. T. Lee (5684).

Vitis? platanifolia Knowlton, n. sp.

Plate CIII, figure 2.

Leaves of medium size, coriaceous in texture, obtusely wedge shaped and entire below, threelobed above, the lobes obtusely triangular in shape, of nearly equal size, margin of lobes with obtuse teeth; the three ribs arising at the base of the blade, of equal strength; midrib with about four pairs of alternate secondaries which pass to marginal teeth; lateral ribs with four or five secondary branches on the lower side and three or four on the upper side; finer nervation obsolete.

This form is represented by a number of leaves, but all are more or less fragmentary, making it difficult to determine the characters. The best example (fig. 2) is about 8 centimeters long and about 11 centimeters broad; other specimens are a little larger, but the average size is apparently as stated.

This species appears to be most closely related to Vitis bruneri Ward ${ }^{3}$ from Carbon, Wyo., being of about the same size, though more wedge shaped at base and less inclined to be five ribbed. In $V$. bruneri, however, the five-ribbed facies is more apparent than real, for the lowest pair of "ribs" is simply produced by the lower secondaries, which in some specimens branch off near the base of the real lateral ribs.

The upper portion of Vitis carbonensis Ward, ${ }^{4}$ also from Carbon, Wyo., is perhaps more like this portion of $V$. platanifolia, but its basal portion as well as the major nervation is sufficient to separate the two.

1 Ward, L. F., Synopsis of the flora of the Laramie group: U. S. Geol. Survey Sixth Ann. Rept., pl. 36, fig. 6, 1886.

2 Idem, pl. 55, fig. 8.

8 Idem, pl. 51, figs. 4, 5

- Idem, pl. 51, flg. 6.
Occurrence: Raton formation (Tertiary); Riley Canyon near Cokedale, Colo., collected by W. T. Lee (5701).

Vitis inominata Knowlton, n. sp.

Plate CVII, figure 1.

Leaf rather thin in texture, apparently nearly circular in general outline, deeply heart shaped at base, apparently rounded at. apex; margin regularly and coarsely toothed, teeth low, outward pointing; nervation strong; palmately five ribbed from the extreme base of the blade; midrib with two or possibly three pairs of remote alternate secondaries; lateral pair of ribs arising at an angle of approximately $45^{\circ}$, slightly curved upward, each with four or five secondary branches on the outside; the two lower with two or three tertiary branches on the lower side; basal pair of ribs emerging nearly at right angles with the midrib; slightly curved upward, each with about six tertiary branches on the lower side which supply the rounded basal lobes; finer nervation not preserved.

This species, represented by a single example, lacks the apical portion and much of one side, but as nearly as can be made out it was approximately circular in general outline. The length was about 10 centimeters and the width about the same.

That this leaf is properly referred to the genus Vitis there is no reasonable doubt as proclaimed by its size, general shape, marginal dentation, and above all by the nervation. Among living species it is strikingly similar to $V$. aestivalis Michaux, the common summer grape of eastern North America, in which the leaves are normally strongly three lobed but are exceptionally scarcely lobed at all. It is the unlobed leaves that most resemble the fossil under consideration.

Among fossil species Vitis inominata is perhaps closest to $V$. olriki Heer, as figured by Lesquereux ${ }^{5}$ from Evanston, Wyo., "above the coal," but it differs from this in its complete lack of lateral lobes and in its more numerous and smaller teeth.

Occurrence: Raton formation (Tertiary); Trinidad coal field, one-eighth mile northeast of Rockland mine, locality 120, north side of

6 The Tertiary flora: U. S. Geol. Survey Terr. Rept., vol. 7, p. 241, pl. 42 , fig. $8,1878$. 
Cucharas Canyon, 3 miles southwest of Walsenburg, Colo., collected by W. T. Lee (5679).

\section{Cissus grossedentata Knowlton, n. sp. Plate CIV, figure 1.}

Leaf of large size and firm texture, broadly ovate, rather abruptly rounded below to a slightly decurrent basal portion, acuminate above; margin entire at base, then strongly few toothed, the teeth large, rather obtuse, separated by broad shallow sinuses; midrib strong below, becoming thin above; secondaries five or six pairs, at an angle of $45^{\circ}$ or $50^{\circ}$, the lowest pair much the stronger, arising well above the decurrent portion of the blade, each with four or five tertiary branches on the out. side which are much curved upward and pass to the marginal teeth; other.secondaries nearly opposite, terminating in the large teeth; finer nervation obsolete.

This splendid leaf is nearly perfect, lacking but a very small portion of one margin. It is about 14 centimeters long and slightly over 8 centimeters wide. The decurrent basal portion is about 1 centimeter long and a little more than this in width where it turns downward from the basal line of the blade. The petiole is preserved for less than 1 centimeter. The basal pair of secondaries is almost as strong as the midrib and as they originate well above the base of the blade the leaf appears to be three ribbed.

This species seems to be most closely related to Cissus parrotiaefolia Lesquereux ${ }^{1}$ from which it differs in its larger size, much more pointed apex, decurrent basal portion, and in having its lowest pair of secondaries arising well above the base instead of at or near the top of the petiole. Cissus parrotiaefolia was described originally from beds supposed to be of Green River age, but-careful reading of the original reference shows that they are from an unknown locality, for it appears that the "labels had been lost or misplaced." The particular specimen above referred to came from Medicine Bow, Wyo., in beds now known to belong to Veatch's "Upper Laramie," which is regarded by the author as the equivalent there of the Lance formation. This species has also been found by Lesquereux ${ }^{2}$ from the Denver formation at Golden, Colo.

1 Idem, p. 239, pl. 42, fig. 1.

? Harvard Coll. Mus. Comp. Zool. Bull., vol. 16, p. 52, 1888.
It is possible that a large series of specimens might show that what is here described as a new species is not to be separated from $C$. parrotiaefolia, for the differences are not very great.

Occürrence: Raton formation. (Tertiary); Morley, Colo., collected by Orestes St. John, 1897.

\section{Cissus laevigata Lesquereux. \\ Plate CIII, figure 1.}

Cissus lacvigata Lesquereux, U. S. Geol. Survey Terr. Ann. Rept., 1872, p. 380, 1873; U. S. Geol. and Goog. Survey, Terr. Ann. Rept., 1873, p. 382, 1874; idem, 1876, p. 512, 1878; U. S. Geol. Survey Terr. Rept., vol. 7 (Tertiary flora), p. 238, pl. 40, figg. 12, 13, 1878.

Leaf membranaceous, broadly oval in outline, narrowing in a broad curve to the short petiole; three nerved from the base or slightly above it, the lateral ribs running nearly straight to about the middle of the blade, branching on the outside; secondaries alternate. or subopposite, parallel; nervilles prominent, percurrent, approximately at right angles to midrib; areolation quadrangular.

This species, according to Lesquereux, was founded on two specimens, both of which lacked the upper portions. Only one of these types (No. 347), the original of Lesquereux's figure 13 , is now to be found. in the collections of the United States National Museum. Both are said to have come from the same locality, namely the Denver formation at Golden, Colo., together with a number of smaller fragments, but none appears to have been obtained in the type area in recent years.

In working up some of the later collections from the Denver area, two specimens were found near the Douglass coal mines, west of Sedalia, Colo., that agree in every particular with the figures of the original specimens. Like the types, they lack the upper portions of the blade, although one has fully two-thirds of the lamina preserved. Lesquereux thought it probable that these leaves would be obscurely trilobate at the apex, but the Sedalia examples did not bear this out.

The specimen here identified with Cissus laevigata is the most complete of any thus far obtained, but it also lacks the extreme point. The bäse of this specimen agrees perfectly with the types; but the upper portion is rather longer, and the leaf more nearly ovate, than was anticipated from examples previously studied. It was apparently about 10 centi- 
meters long, and 6.5 centimeters wide and has the petiole preserved for nearly 2 centimeters. There were about three pairs of rather slender secondary branches on the midrib above the basal pair of ribs. The finer nervation is obscure, but so far as can be made out it agrees with the type specimen.

Occurrence: Denver formation (Tertiary); types, Golden, Colo. Dawson arkose (Tertiary); 3,000 feet east of the Douglass coal mine, near Sedalia, Colo. Raton formation (Tertiary); Apishapa Canyon, northeast of Abeton, Colo., collected by W. T. Lee (5689).

\section{Order UMBELLALES.}

Family ARALIACEAE.

Aralia coloradensis Knowlton, n. sp.

Plate CVII, figure 2.

Leaf of large size, coriaceous in texture, palmately strongly three ribbed from the very base of the blade, five lobed, central lobe and upper pair of lateral lobes long-lanceolate in shape; basal pair of lobes small, apparently lanceolate; at right angles to the midrib; margin of lobes toothed, the teeth remote, shallow; the three upper lobes with ten to twelve pairs of mainly alternate secondaries that end in the marginal teeth; midrib of lower pair of lobes arising from the lateral pair some distance above the base of the blade; nervilles strong, mainly percurrent.

The leaf figured, the only one noted in the collections, was about 20 centimeters in length and 16 to 18 centimeters broad between the points of the large lateral lobes. The central lobe is largest, being fully 12 centimeters long and about 55 centimeters broad at base. The lateral lobes were apparently about 10 centimeters long and 4.5 centimeters broad at base. The basal lobes are too fragmentary to give reliable measurements.

It is with some hesitation that this is described as new, but it is so broken that it is somewhat hazardous to identify it positively with any described species, and it is left to the future to secure more material and settle its status. It is undoubtedly most closely related to Aralia notata Lesquereux, ${ }^{1}$ - from the Fort Union and Denver formations, from which it differs in having the lobes relatively longer,

Tho Tertiary flora: U. S. Geol. Survey Terr. Rept., vol. 7, p. 237, pl. 39, figs. 2-4, 1878. lanceolate and acute, and the margins toothed. The secondaries are also fewer and craspedodromes in termination.

This species is also similar to what Newberry has described under the name of Platanus nobilis ${ }^{2}$ from the Fort Union formation but which is thought by some to be the same as Aralia notata Lesquereux. According to Lesquereux, however, there are characters which separate them. The form under consideration differs from $P$. nobilis in its longer, regularly narrowed lobes and fewer secondaries.

It is to be confessed that the present species does not differ very greatly from either of the above-mentioned forms and that a series of specimens may well show that it belongs to one or the other, but until this ean be proved it seems best to keep them separate.

Occurrence: Raton formation (Tertiary); Riley Canyon, near Cokedale, Colo., collected by W. T. Lee..(5700).

\section{Aralia? serrata Knowlton, n. sp. \\ Plate CVIII, figure 4.}

Leaf large, coriaceous in texture, obtusely wedge shaped at base, strongly three ribbed and three lobed; middle lobe smallest, lanceolate, lateral lobes large-lanceolate, apparently acute; margin entire at base, then coarsely toothed, the teeth very sharp, slightly upward pointing; lateral lobes. with a dozen or more secondaries on the lower side of the thick midrib, fewer on the upper side; secondaries in middle lobe apparently about ten or twelve, somewhat curving upward; nervilles numerous, percurrent.

This species is represented by the single example figured. It is considerably broken, but so far as can be made out its length was about 20 centimeters and its width about 12 to 15 centimeters. The lateral lobes were about 8 to 9 centimeters long and about 5 centimeters wide at base.

It is with hesitation that this is described as new, as it is represented by a single specimen only and is moreover in association with the preceding species (A. coloradensis), from which it seems to differ in being wedge shaped at base and plainly three lobed instead of five lobed. The marginal teeth are also much stronger in the present form.

\footnotetext{
2 Newberry, J. S., The later extinct floras of North America: U. S.
} Geol. Survey Mon. 35, p. 106, pl. 34, 1898. 
Aralia coloradensis is distinctly aralioid in appearance, particularly in the manner of branching of the lateral ribs, and $A$. serrata is decidedly more platanoid. It is more wèdge shaped at base, lacks the branches on the lateral ribs and has large, Platanus-like teeth. It is quite possible that the specimens should bé referred to Platanus, but in the absence of sufficient material to determine its range in variation it is thought best to retain them under Aralia.

Occurrence: Raton formation (Tertiary); Riley Canyon, near Cokedale, Colo., collected by W. T. Lee (5700); Vermejo Valley near the mouth of Salyers Creek, N. Mex. (5826).

\section{Family CORNACEAE.}

Cornus neomexicana Knowlton, n. sp.

Plate CIX, figure 1.

Leaves of medium size, firm in texture, elliptical in outline, broadest at or near the middle, thence rounded in about the same manner to both base and apex, the latter in particular being obtuse; midrib very strong, especially below, perfectly straight; secondaries numerous (ten or eleven pairs), close, parallel, mainly alternate, considerably curved upward, the upper pair curving in and joining the midrib; nervilles apparently numerous, close, mainly unbroken and approximately at right angles to the secondaries.

This species is represented by several examples, one of the best being the one here figured. It is a little over 12 centimeters long and 7 centimeters wide. Another specimen (not figured) was probably about 14 centimeters long and 6.5 centimeters wide. and has 1.75 centimeters of the petiole preserved.

The moderate size of these leaves combined with the regularly elliptical outline, obtuse apex, inarched upper secondaries, and regular mainly simple nervilles all indicate with relatively little question that they are correctly referred to the genus Cornus.

Among fossil species, at least those from this country, Cornus neomexicana, approaches most closely to $C$. impressa Lesquereux ${ }^{1}$ from the Denver formation; in fact, it is perhaps doubtful if they should be held distinct. The two are of exactly the same shape and type of

1 The Tertiary flora: U. S. Geol. Survey Terr. Rept., vol. 7, p. 243, pl. 42 , fig. $3,1878$. secondary nervation, the difference being mainly one of size. Thus $C$. impressa is about 7 centimeters long and 4.5 centimeters broad, and $C$. neomexicana is 12 to 14 centimeters long and 6.5 to 7 centimeters broad. Cornus neomexicana, however, has a greater number of secondaries, as might perhaps be expected from its larger size. Its nervilles are slightly different, being nearly at right angles to the secondaries instead of markedly oblique to them, as in C. impressa.

Cornus impressa is rather rare. It was described from a single specimen coming from Mount Bross, Middle .Park, Colo. Another specimen from Golden that undoubtedly belongs to it, was described by Ward under the name of $C$. emmonsi, ${ }^{2}$ and an additional one was found in the later collections from Golden.

In size and shape this species is much like one of the leaves formerly referred to Magnolia tenuinervis Lesquereux ${ }^{3}$ and now named Magnolia? inquirenda (p. 312), which; however, differs from it in having fewer, 'more irregularly spaced, and often forked secondaries, none of which curve in and join the midrib, as the upper ones do in $C$. impressa.

Occurrence: Raton formation (Tertiary); Vermejo Valley near the mouth of Salyers Creek, N. Mex. (sec..36, T. 30 N., R. 19 E.), collected by W. T. Lee (5826).

\section{Cornus studeri? Heer.}

Plate CIX, figure 2.

Cornus studeri? Heer. Lesquereux, U. S. Geol. Survey Terr. Rept., vol. 7 (Tertiary flora), p. 244, pl. 42, figs. 4, 5, 1878.

Berry, U. S. Geol. Survey Prof. Paper 91, p. 331, pl. 68, fig. 3, 1916.

The status of Cornus studeri, as then understood, was fully set forth by me in $1900 .^{4}$ Although the species was then accepted for both the Denver formation at Golden, Colo., and for the Montana group at Point of Rocks, Wyo., it was pointed out that there were recognizable differences between them, and the opinion was expressed that ultimately they should probably be separated; furthermore, their reference to the genus Cornus was en-

2 Ward, L. F., Synopsis of the flora of the Laramie group: U. S. Geol. Survey Sixth Ann. Rept., p. 553, pl. 48, fig. 2, 1886.

3 The Tertiary flora: U. S. Geol. Survey Terr. Rept., vol. 7, pl. 45 fig. $5,1878$.

- Knowlton, F. H., Flora of the Montana formation: U.S. Geol. Survey Bull. 163, p. 68, 1900 . 
larged upon. Material examined in recent years makes it more than probable that the leaves from the two localities should be held as distinct, but a complete revision will not be attempted at this time. There can be no doubt, however, that the specimen in hand is identical with the figure of Cornus studeri given by Lesquereux from Golden, Colo., and the question of its identity with the European types is left for future work when the Denver flora comes to be finally revised. The possibility of all being referred to Ficus is also to be considered.

Occurrence: Denver formation (Tertiary); types, Golden, Colo. Raton formation (Tertiary), 5 miles above Aguilar, Colo., collected by G. B. Richardson's party (5046).

Nyssa lanceolata Lesquereux.

Plate CVIII, figure 1; Plate CXIII, figure 2.

Nyssa lanceolata Lesquereux, U. S. Geol. Survey Terr. Ann. Rept., 1872, p. 407, 1873; U. S. Geol. Survey Terr. Rept., vol. 7 (Tertiary flora), p. $245 ;$ pl. 35 , fig. 6 [not fig. 5], 1878.

Knowlton, U. S. Geol. Survey Bull. 105, p. 56, 1899

The type locality of this species is supposed to have been "Spring Canyon, Mont." (= Meadow Creek, 12 miles southeast of Bozeman, Gallatin County), in beds presumed to belong to the Livingston formation, but the type specimen is lost and no additional material has since been obtained in this area. The species has also been reported from the Denver formation of Golden, Colo., and specimens in the collection of the United States National $\mathrm{Mu}$ seum bear out the report.

The first specimen referred to this species (Pl. CXIII, fig. 2) agrees well with the type figure in size, shape, and general character of the nervation but differs from it in the slightly more acute divergence of its lower secondaries. The other specimen (Pl. CVIII, fig. 1) is slightly more wedge shaped at base but does not markedly differ from the first.

Occurrence: Raton formation (Tertiary); canyon west of Mayne, Colo:, about 300 feet above the base of the Raton formation, collected by W. T. Lee (5683); Purgatoire Canyon at mouth of Riley Canyon, Colo., collected by. W. T. Lee (5704). Livingston formation? (Tertiary); Spring Canyon, Mont.
'Nyssa? racemosa Knowlton.

Sabalites fructifer Lesquereux, U. S. Geol. Survey Terr. Rept., vol. 7 (Tertiary flora), p. 114, pl. 11, fig. 3a and fruit on fig. 3,1878 .

Nyssa? racemosa Knowlton, U. S. Geol. Survey Bull. 152, p. 153,1898 .

Fruits in a compound raceme, the rachis or axis being very thick and strong; individual fruits 10 to 16 millimeters long, 4 to 7 millimeters in diameter, erect, short pediceled, oblong, acute at both ends or sometimes somewhat rounded, provided with probably 12 or 15 faint longitudinal striae or ribs and very numerous delicate transverse striae.

These fruits were first detected by Lesquereux. He assumed, because they were found on the same piece of matrix as a palm leaf, that they belonged together. The type specimen upon which this determination is based is fortunately preserved in the United States National Museum under the name of Sabalites fructifer. A glance at it, or indeed at the wellexecuted figure, shows at once that there is no organic connection between them but simply close association. The name, therefore, was retained for the palm and the fruits given a new designation. The part figured by Lesquereux consists of the upper portion of a raceme with three characteristic fruits attached.

The single detached fruit described by Lesquereux as Carpites oviformis ${ }^{1}$ from the Denver formation at Golden, Colo., may possibly belong to this species, but as the evidence is not conclusive it is retained as indicated by its describer.

It is with much uncertainty and reserve that these fruits and those from near Raton are referred to the genus Nyssa, for this, of course, implies a more or less close relationship to the living Nyssa, and it has been done mainly on account of their undoubted resemblance to certain fossil fruits that have been so designated. I have sought long and widely among living plants for evidences of close affinity, but having failed I have been forced to refer them to the fossil forms which they most resemble, hoping that in the future someone may be able to interpret them more correctly.

The fossil species with which they are possibly related is Nyssa arctica Heer, ${ }^{2}$ from the

1 The Tertiary flora: U. S. Geol. Survey Terr. Rept., vol. 7, pl. 30 fig. $6 \mathrm{a}, 1878$.

2 Flora fossilis arctica, vol. 4, p. 80, pl. 19, figs. 1-10, 1877. 
Miocene or Eocene of Cape Lyell, Spitzbergen, which differs from them in being much larger (17 to 21 millimeters long and 8 to 11 millimeters wide) and in having more numerous and much more prominent longitudinal striae or ribs; the transverse striae are of about the same character in both. There is no evidence that $N$. arctica had the fruits arranged in.a compound raceme although several are figured as having two fruits sessile on the top of a short pedicel, much as in the modern Nyssa. Some of the elongated fruits of Nyssidium ekmani Heer ${ }^{1}$ from Cape Staratschin, Spitzbergen, are also similar to $N$. racemosa, from which they differ mainly in being smaller and apparently without transverse striae. A number of other fruits are described by Heer from the same locality under the name of Nyssidium, but though all of these resemble in a general way the fruits of Nyssa? racemosa none of them resemble it very closely.

The fruits of the living species of Nyssa, it must be confessed, are considerably unlike the fossil forms and probably are not closely related to them. However, as stated above, the specimens have only provisionally been placed in this genus.

The fruits from near Raton agree with the type specimens perfectly in general character and appearance but are slightly smaller than most specimens from the type locality though not smaller than a few of them. One of these Raton specimens is covered with a coaly layer about 2 millimeters thick, thus apparently showing that a thick flesh covered the hard "stone." The transverse lines show very plainly under the coaly layer.

Occurrence: Denver formation (Tertiary); type, Golden, Colo. Raton formation (Tertiary; near No. 5 mine, locality 85 near. Yankee, N. Mex., collected by W. T. Lee (5137). Black Buttes coal group (regarded by the author as of post-Laramie age); Black Buttes, Wyo.

Order ERICALES.

Family ERICACEAE.

Andromeda? lanceolata Knowlton, n. sp.

Plate CIX, figure 3; Plate CX, figure 1.

Leaves narrowly lanceolate, or almost linearlanceolate, tapering from or above the middle to the very long narrowly wedge-shaped base, and above to the acuminate apex; margin perfectly entire; petiole exceedingly stout; midrib remarkably thick below but becoming in the upper half of the leaf very much thinner; secondaries about eight or nine pairs, alternate, at an acute angle, running up for long distances nearly straight, then slightly curved upward and camptodrome; finer nervation not observed.

This fine species is represented by several specimens of which two representing the extremes in size are figured. Of these the larger is 20 centimeters in length and 4 centimeters in width at a point a little above the middle; the smaller is about 16 centimeters long and little less than 3 centimeters wide near the middle. The petiole was apparently very short and thick and passes without diminution of size into the blade, where it continues for nearly half the length of the blade as one of the most extraordinarily thickened midribs observed in so narrow a leaf.

Although there may perhaps be a question as to the advisability of referring these leaves to the genus Andromeda, there can be no reasonable doubt, I think, as to their being congeneric with certain similar leaves that have been so referred. Thus, what Lesquereux ${ }^{2}$ has identified as Andromeda pfaffiand Heer, from the Dakota sandstone of Kansas, is wholly similar to $A$. lanceolata in general appearance, though it differs in size and to a lesser degree in shape. Similarly, Andromeda flexuosa Newberry, ${ }^{3}$ from the Raritan formation of New Jersey, is of the same general type but differs in several minor particulars.

Occurrence: Raton formation (Tertiary); dump from the Turner mine, $1 \frac{1}{2}$ miles north of Wootton, Colo., collected by W. T. Lee (5714).

Andromeda scripta Knowlton, n. șp.

Plate CXII, figures 1, 2 .

Leaves apparently rather thick, ovate in general outline, rather abruptly rounded at base, acuminate at apex; margin perfectly entire; petiole short, slender; midrib slender, suraight; secondaries from six to eight. or nine pairs, alternate, slender, at an angle of about $45^{\circ}$,

2 Lesquereux, Leo, The flora of the Dakota group: U. S. Geol. Survey Mon. 17, p. 116, pl. 18, figs. 7, 8, 1892 .

${ }^{3}$ Newberry, J. S., The flora of the Amboy clays: U. S. Geol. Survey Mon. 26; p. 121, pl. 34, figs. 1, 5, 1895. 
little curved upward, camptodrome; nervilles few, at right angles to the secondaries.

The two little leaves figured appear to belong to the same species. The smaller is about 7 centimeters long and 3 centimeters wide, and the larger about 9 centimeters long and nearly 4 centimeters wide. They are fairly well shown in the figures.

Occurrence: Raton formation (Tertiary); (fig. 1) 1 mile southwest of Rugby, Colo., 52 feet above mine at Wichita, 170 feet above Trinidad sandstone, collected by G. B. Richardson's party (5128); (fig. 2) one-eighth mile northeast of Rockland mine, locality 120, north side of Cucharas Canyon, near Walsenburg, Colo., collected by W. T. Lee (5679).

\section{Order GENTIANALES.}

\section{Family OLEACEAE.}

Chionanthus membranaceus Knowlton, n. sp.

Plate CVIII, figure 2.

Lenf membranaceous in texture, broadly ovate-lanceolate, obtusely wedge shaped at base (apex broken); margiii entire, slightly undulate; petiole short, stout, midrib straight, strong below, becoming thin above; secondaries thin, about six pairs, alternaté, at a low angle, camptodrome, curving near the borders; finer nervation not retained.

The single leaf figure is all that was observed of this species, and this lacks the apex and much of one side. It was about 12 centimeters in length and 6 centimeters in width, with a petiole a little over 1 centimeter in length.

This species appears to be rather closely related to Chionanthus virginicus Linné; the common fringe tree of eastern North America, its small leaves having much the same shape and its primary nervation well agreeing. It also suggèsts certain species of Diospyros, such for instance as $D$. copeana Lesquereux, ${ }^{1}$ from Elko station, Nev., which, however, is smaller, more nearly obovate in shape, and has a greater number. of secondaries.

Occurrence: Raton formation (Tertiary); dump of Green Canyon mine, locality 119, near Aguilar, Colo., collected by W. T. Lee (5684).

1 'Tho Tertiary flora: U. S. Geol. Survey Terr. Rept.; vol. 7, pl. 40, fig. $11,1578$.
Family APOCYNACEAE.

Apocynophyllum lesquereuxii Ettingshausen.

Quercus neriifolia Alexander Braun. Lesquereux, U. S. Geol. and Geog. Survey Terr. Ann. Rept., 1873, p. 413, 1874; U. S. Geol. Survey Terr. Rept., vol. 7 (Tertiary flora), p. 150, pl. 19, fig. 5, 1878.

Apocynophyllum lesquereuxii Ettingshausen, K. Akad. Wiss. Wien Denkschr., vol. 47, p. 32, 1883; Tertiary flora of Australia: Geol. Survey New South Wales Mem., Paleontology, No. 2, p. 51, 1888.

The original of Lesquereux's figure 5 (from Fishers Peak, Raton Mountains) is preserved in the United States National Museum (No. 171). It is a mere fragment as figured, but by further uncovering the specimen nearly the complete apex was brought to light. It is narrowly lanceolate, being broadest above the middle and tapering thence to the base and to the apparently acuminate apex. It is about 12 centimeters long and a little over 3 centimeters wide. It has an extremely thick midrib, but beyond that its nervation is very obscure. In Lesquereux's figure the secontaries are shown as numerous, close, parallel, and at a low angle; and this is probably correct, though I am not able fully to confirm this feature. The secondaries are extremely thin and delicate.

It is of course evident to any one that it would be extremely hazardous to identify this fragment, particularly with the well-known European Quercus neriifolia; and, as Ettingshausen long ago pointed out, it appears, to be much more probably referable to Apocynophyllum than to Quercus; hence Ettingshausen's name is employed.

Occurrence: Raton formation? (Tertiary); Fishers Peak, Raton Mountains, Colo., collected by Leo Lesquereux about 1871; Norman's ranch, 12 miles east of Raton, N. Mex., near locality 92 , collected by W. T. Lee (5132).

Apocynophyllum wilcoxensis Berry.

Plate CIII, figure 3; Plate CV, figures 1, 2; Plate CVI, figure 1 .

Apocynophyllum wilcoxensis Berry, U. S. Geol. Survey Prof. Paper 91, p. 342, pl. 103, figs. 2, 3; pl. 108, fig. 4, 1916.

Leaves thick and coriaceous in texture, narrowly lanceolate in shape, more or less unequal sided and slightly falcate, broadest near the middle, thence tapering upward to the 
long slender apex and downward to the long, narrowly wedge-shaped base; midrib very strong, especially below, straight; secondary nervation thin, delicate, more or less uneven, consisting of numerous, rather close, parallel secondaries which emerge at an angle of about $20^{\circ}$ and run nearly straight almost to the margin, each joining the one next above, thus producing a somewhat irregular intermarginal "stitch."

This species is represented by numerous specimens, several of the best of which have been figured. All the leaves are long, narrowly lanceolate, commonly more or less unequal sided, and all or nearly all are obviously falcate. The length ranges between 16 and 20 centimeters, with a few reaching perhaps 23 centimeters. The width at the broadest point is between 2.5. and 3.75 centimeters. The difference in the width of the laminae on opposite sides of the midrib is clearly shown in several of the figures. The nervation, with the exception of the strong midrib, is obscure, and has been made out in only a few favorable. places. In fact, it is so obscure that the photographic process employed failed to reproduce it, except very faintly. In certain of the figures enough of this has been added to show its character, though the penciled lines are of necessity somewhat stronger than the actuality on the specimens. In some of the larger leaves, that seem at first sight to be quite destitute of nervation, the presence of a few secondary branches from the midrib can usually be detected.

Although the intramarginal vein; held to be characteristic of most living leaves of Eucalyptus, is rather obscure in the leaves under consideration, it is present in effect, being formed by the arching of the numerous close parallel secondaries some distance inside the margin. In general facies these leaves strongly suggest the genus Eucalyptus, being obviously coriaceous in texture, narrowly lanceolate, unequal sided, and more or less strongly falcate, all characters that are present in living species of this genus.

Occurrence: Raton formation (Tertiary); (Pl. CIII, fig. 3; Pl. CV, fig. 2); dump of mine at Primero, Colo., collected by W. T. Lee (5798); (Pl. CVII, fig. 1) Riley Canyon, near Cokedale, Colo., collected by W. T. Lee (5701); (Pl. CV, fig. 1), Powell Arroyo, 5 miles north of
Trinidad, Colo., collected by J. B. Mertie for G. B. Richardson (5111). Wilcox formation (Tertiary), Oxford, Miss., Puryear, Tenn., and Naborton, La.

Apocynophyllum linifolium Knowlton, n. sp.

Plate CIV, figure 3.

- Similar to the last but larger, being fully 24 centimeters in length and 2.5 centimeters in width; very narrowly ovate-lanceolate; broadest below the middle, thence rather abruptly narrowed to the base and upward to the acuminate apex; not obviously unequal sided or falcate. The midrib, though strong, is not so thick as that of the smaller leaves of $A$. leei, but the secondaries are rather stronger and slightly farther apart. However, these differences are not great and a full series of specimens might well demonstrate that only a single species is represented.

Occurrence: Raton formation (Tertiary); dump of Green Canyon mine, locality 119, Aguilar, Colo., collected by W. T. Lee (5684).

Order RUBIALES.

Family CAPRIFOUIACEAE.

Viburnum contortum Lesquereux.

Plate CVIII, figure 3.

Viburnum contortum Lesquereux, U. S. Geol. Survey Terr. Ann. Rept., 1872, p. 396, 1873.

Viburnum marginatum Lesquereux, U. S. Geol Survey Terr. Rept., vol. 7 (Tertiary flora), p. 223, pl. 38, fig. 2 (not fig. 3), 1878.

Viburnum contortum was described originally from Black Buttes, Wyo., where it was found in association with such well-known forms as Ficus planicostata and. Ficus latifolia. At the time it was founded Lesquereux stated that it might perhaps be considered as nearly a variety of Viburnum marginatum (= Platanus marginata); and in "The Tertiary flora" he so considered it and merged the name of $V$. contortum in marginatum and placed two specimens figured (the types of contortum) under that name. This disposition by Lesquereux has been accepted until the present time, though all who have compared the figures given under Viburnum marginatum could hardly have failed to note the marked difference between them, particularly in shape, the one being broadly obovate with a truncate or rounded apex and the other with an acuminate apex. 
If leaves of the contortum type were only found in direct association with the marginatum type, it might perhaps be permissible to allow them to remain together, but where leaves that are obviously of the type of contortum are found at widely distant points where they are not associated with the marginatum type, it seems best to regard them as specifically distinct.

The leaf here referred to $V$. contortum, it will be observed, is almost exactly similar to Lesquereux's figure 2, the only difference being its fewer, rather larger, teeth.

Occurrence: Raton formation (Tertiary); one-eighth mile northeast of Rockland mine, locality 120, north side of Cucharas Canyon, Colo., collected by W. T. Lee (5679).

\section{Viburnum speciosum Knowlton, n. sp.}

\section{Plate CXI, figures 1-5.}

Leaves of medium size for the genus; of firm texture, lanceolate-ovate to ovate or very slightly obovate, wedge shaped at base, similarly narrowed to an acuminate apex; petiole slender; margin entire at base and for one-third or more above, then coarsely few toothed, the teeth sharp and upward pointing; midrib strong, straight; secondaries five pairs, strong, alternate, at an acute angle, craspedodrome, ending in the large teeth; finer nervation not retained.

This species is represented by a dozen or more specimens, five of which are here figured. They are 8 to 10 centimeters in length and from 3 to 4.5 centimeters in width; two of them have the petiole preserved for 1 centimeter or a little more.

This species appears to be very closely related to Viburnum contortum Lesquereux ${ }^{1}$ from Black Buttes, Wyo., in beds regarded by the author as post-Laramie in age, but it differs in having unbranched secondaries and much fewer and larger marginal teeth.

It is also similar to a leaf which has been identified (p. 276) as Viburnum (?) problematicum Knowlton, from the lower beds at Rockvale, Colo., but which is more deltoid in shape and has numerous small marginal teeth.

Occurrence: Raton formation (Tertiary); Riley Canyon, near Cokedale, Colo., collected by W. T. Lee (5701).

1 The Tertlary flora: U. S. Geol. Survey Terr. Rept., vol. 7, pl. 38, figs. $2,3,1878$.
Viburnum magnum Knowlton, n. sp.

Plate CX, figure 2.

Leaf coriaceous in texture, broadly lanceolate in shape, abruptly narrowed below, apparently acuminate at apex; margin dentate from above the base, the teeth rather large, obtuse; midrib straight, strong; secondaries seven to eight pairs, alternate, at an acute angle of divergence, occasionally forked, especially below, craspedodrome, all secondaries and their branches entering the teeth; nervilles obscure, apparently percurrent and at right angles to the secondaries.

The specimen figured is about 15 centimeters in length and 5 centimeters in width, and is well shown in the figure. It is of the type of several of the Fort Union species, such for instance as Viburnum newberryanum Ward. However, it is much larger than some of the largest leaves of this species, narrower and is provided with coarser teeth, and its secondaries are fewer and somewhat less branched.

Occurrence: Raton formation (Tertiary); Wootton, Colo., 50 to 100 feet below the Wootton coal, collected by W. T. Lee (5711); oneeighth mile northeast of Rockland mine, locality 120, north side of Cucharas Canyon, near Walsenburg, Colo., collected by W. .T. Lee (5679).

Viburnum woottonianum Knowlton, n. sp.

Plate CXI, figure 6.

Leaf coriaceous in texture, oblong in outline; about equally rounded at both base and apex, margin entire for lower half or more, then coarsely, sharply toothed; midrib very strong, straight; secondaries six or seven pairs, alternate, at an acute angle of divergence, ending in the large teeth; nervilles numerous, close, parallel, at right angles to the secondaries.

This well-marked species is represented by two nearly perfect specimens, the smaller of which is figured, and by a few more fragmentary specimens. The figured leaf is nearly regularly oblong in shape, 6.5 centimeters long and a little more than 3 centimeters wide; the unfigured specimen is about 9 centimeters long and 5 centimeters wide, with a petiole 1.5 centimeters long. The species is peculiar in that

2 Ward, L. F., Synopsis of the flora of the Laramie group: U. S. Geol Survey Sixth Ann. Rept., p. 557, pl. 44, figs. 10-12, pl. 45, figs. 1-3, 1886. 
its secondaries are at an acute angle and reach the margin at or above the middle of the leaf, at which point the marginal teeth begin. In this feature this species resembles Viburnum cuneatum Newberry ${ }^{1}$ from the Fort Union formation of. Tongue River, Mont., but the latter differs in being, as the name indicates, markedly wedge shaped at base; otherwise the two are quite similar.

Occurrence: Raton formation (Tertiary); dump of Turner mine, $1 \frac{1}{2}$ miles north of Wootton, Colo., collected by W. T. Lee (5714).

\section{Viburnum lakesii Lesquereux.}

Plate CX, figures 3,4 .

Viburnum lakesii Lesquereux, U. s. Geol. Survey Terr. Ann. Rept., 1872, pp. 382, 401, 1873; U. S. Geol. and Geog. Survey Terr. Ann. Rept., 1876, p. 511, 1878; U. S. Geol. Survey Terr. Rept., vol. 7 (Tertiary flora); p. 226, pl. 37, fig. 13, 1878.

Dawson, Roy. Soc. Canada Trans., 1883, pl. 4, p. 32.

Leaf medium sized, coriaceous, rounded, broadly obovate in shape, distinctly trilobate, round-truncate to the petiole, lobes deltoid, central one slightly larger than the lateral ones; margin nearly or quite entire below, finely toothed above; nervation strong, palmately three ribbed from the base of the blade, midrib strong, straight, with three or four pairs of alternate or subopposite secondaries, some of which fork above and end in the marginal teeth; lateral ribs at an angle of about $45^{\circ}$ ending in the lateral lobes, with about five strong secondary branches on the outside, the lowest with several Tertiary branches, all oraspedodrome; nervilles numerous, distinct, both broken and unbroken.

The type of this species is preserved in the United States National Museum (No. 319). As shown in Lesquereux's figure only its lower portion is preserved, but in even this fragment the character of the nervation and the presence of a rounded sinus in the upper part indicates that it is trilobate. Fortunately, another speoimen, found in recent collections from the type locality, has the upper portion preserved and proves it to be distinctly trilobate. It also appears that the upper portion is provided with small, sharp, upward-pointing teeth as described and figured for the lower portion. The secondaries are frequently diohotomous in

Newberry, J. S. The later extinct floras of North America: U. S. Geol. Survey Mon. 35, p. 130, pl. 57, fig. 2, 1898. the upper portions, the branches entering the marginal teeth, as is normal in Viburnum.

The species appears to be closely related to the living Viburnum acerifolium Linné, of eastern North America, especially some of the less strongly lobed forms. The living leaf differs, however, in being generally broader with more prominent lobes, larger teeth, and less oblique nervation. The finer nervation is the same in each.

Viburnum lakesii was thought by Lesquereux to be somewhat closely allied to his $V$. platanoides (now referred to Platanus), but it differs essentially from this in its distinctly trilobate form, ooriaceous substance, and upward-pointing teeth. It is undoubtedly best retained in Viburnum.

An undescribed species from the Livingston formation of Montana is also closely related to the present species. The specimen here figured from Morley, Colo., is absolutely identical with the type and with the specimens from Golden. It shows the slightly trilobate upper portion perfectly.

Ocourrence: Denver formation (Tertiary); type, South Table Mountain, Golden, Colo. Raton formation (Tertiary); Morley, Colo., collected by Orestes St. John (No. 345), 1897.

\section{INCER,TAE SEDIS.}

Palaeoaster inquirenda Knowlton, n. gen, and n. sp.

This species also occurs in the Vermejo formation. (See p. 278.)

Occurrence: Raton formation (Tertiary); Bowen mine; locality 109, north of Trinidad, Colo., near base of Raton formation, collected by W. T. Lee (5794). Vermejo formation (Cretaceous).

\section{Carpites coffeaeformis Lesquereux.}

Carpites coffeaeformis I,esquereux, U. S. Geol. Survey Terr. Rept., vol. 7 (Tertiary flora), p. 303, vol. 60, figs. 6,7, 1878 .

- In one of the collections from Brilliant there are several oval, peculiarly grooved fruits that are not to be distinguished from Lesquereux's species, described originally from the Denver formation at Golden, Colo. They are, if anything, slightly larger, and, as Lesquereux stated, they very much resemble the thick; centrally grooved fruits of the coffee tree, though it is of course not to be presumed that this resem- 
blance is really a mark of kinship. Their true affinity is, and of oourse probably must remain, unknown.

Occurrence: Denver formation (Tertiary); types, Golden, Colo. Raton formation (Tertiary); half a mile north of Brilliant, N. Mex., collected by W. T: Lee (5154) on same stone with many leaves of Magnolia magnifolia.

\section{Carpolithes spinosus Newberry.}

Carpolithus spinosus Ne wberry, U. S. Nat. Mus. Proc., vol. 11. p. 514, 1888 .

Carpolithes spinosus Newberry, U. S. Geol. Survey Mon. 35 , p. 1.38, pl. 68, figs. 2, 3, 1.89s.

Following is Newberry's original description:

Fruit inclosed in an exocarp composed of three elliptical or lentiform segments, furrowed along the middle line of the dorsum and bristling with erect, acute spines 6 to 8 millimeters long; peduncle cylindrical, strong, 1 inch or more in length.

The type and only known specimen of this curious fruit is preserved in a fossil-plant collection deposited in the New York Botanical Garden. It was collected July 31,1878 , on the north branch of Purgatoire River, Colo. (stated by Newberry to be in New Mexico), by I. C. Russell while engaged in explorations west of the 100th meridian. It bears a printed number, (3861), which is probably the serial number of the collection of this Survey.

In the description Newberry states that the fruit is "composed of three elliptical or lentiform segments," but a careful study of the type leads me to believe that there were at least four segments, and, as Hollick suggests, probably five. No affinity has been suggested for the anomalous plant.

Occurrence: Raton formation? (Tertiary?); North Branch of Purgatoire River, Colo., collected by I. C. Russell, 1878.

Phyllites retusoides Knowlton, n. sp.

Plate CII, figure 5.

Outline of leaf unknown, apical portion truncate, strongly retuse; margin perfectly entire; nervation thin, consisting of a straight midrib. and at least four pairs of camptodrome secondaries, the two upper pairs being much curved around and nearly or quite joining the top of the midrib.

Unfortunately this leaf is so fragmentary that it can not be satisfactorily characterized, at least as regards size and general outline, and indeed it would hardly have been necessary to mention it at all were it not for the peculiar configuration of its apex. It may be of course that the apical portion has been deformed by injury when young, but it is so regular and the secondaries are arched in such an apparently normal manner that it is described and figured for what it is worth. If it proves to be normal it will make an excellent horizon marker.

Occurrence: Raton formation (Tertiary); railway about one-half mile north of Wootton, Colo., 50 to 100 feet below the Wootton coal, collected by W. T. Lee (571i). 



\section{I}

PLATES XXX-CXIII. 


\section{1}

\section{PLATE XXX.}

Figures 1, 2. Asplenium? coloradense Knowlton. n. sp. (U. S. Nat. Mus. catalogue Nos. 34453, 34554)........ 245

3. Pteris? sp. (U. S. Nat. Mus. catalogue No. 34455)............................... 245

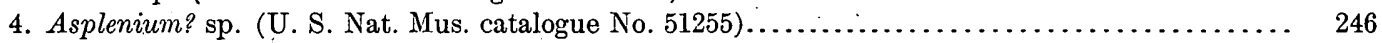

5. Anemia supercretacea Hollick (U. S: Nat. Mus. catalogue No. 34457$) \ldots \ldots \ldots \ldots \ldots \ldots \ldots \ldots \ldots \ldots \ldots$

6. Osmunda? hollicki Knowlton, n. sp. (U. S. Nat. Mus. catalogue No. 34458) .............. 246

7 Sequoia obovata Knowlton, n. sp. (U. S. Nat. Mus. catalogue No. 34456 )................... 250 


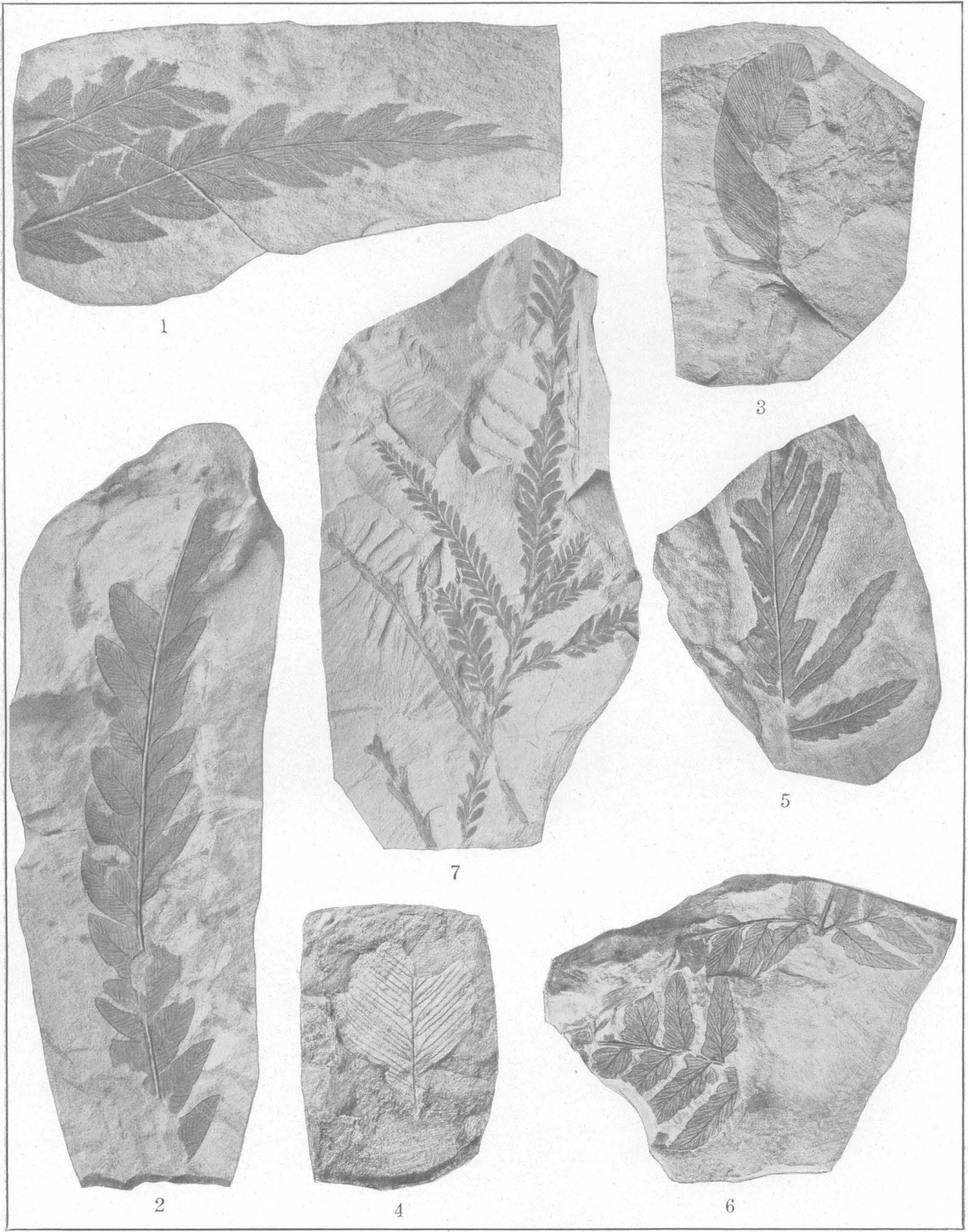

$47019^{\circ}-17-23$

FLORA OF THE VERMEJO FORMATION. 


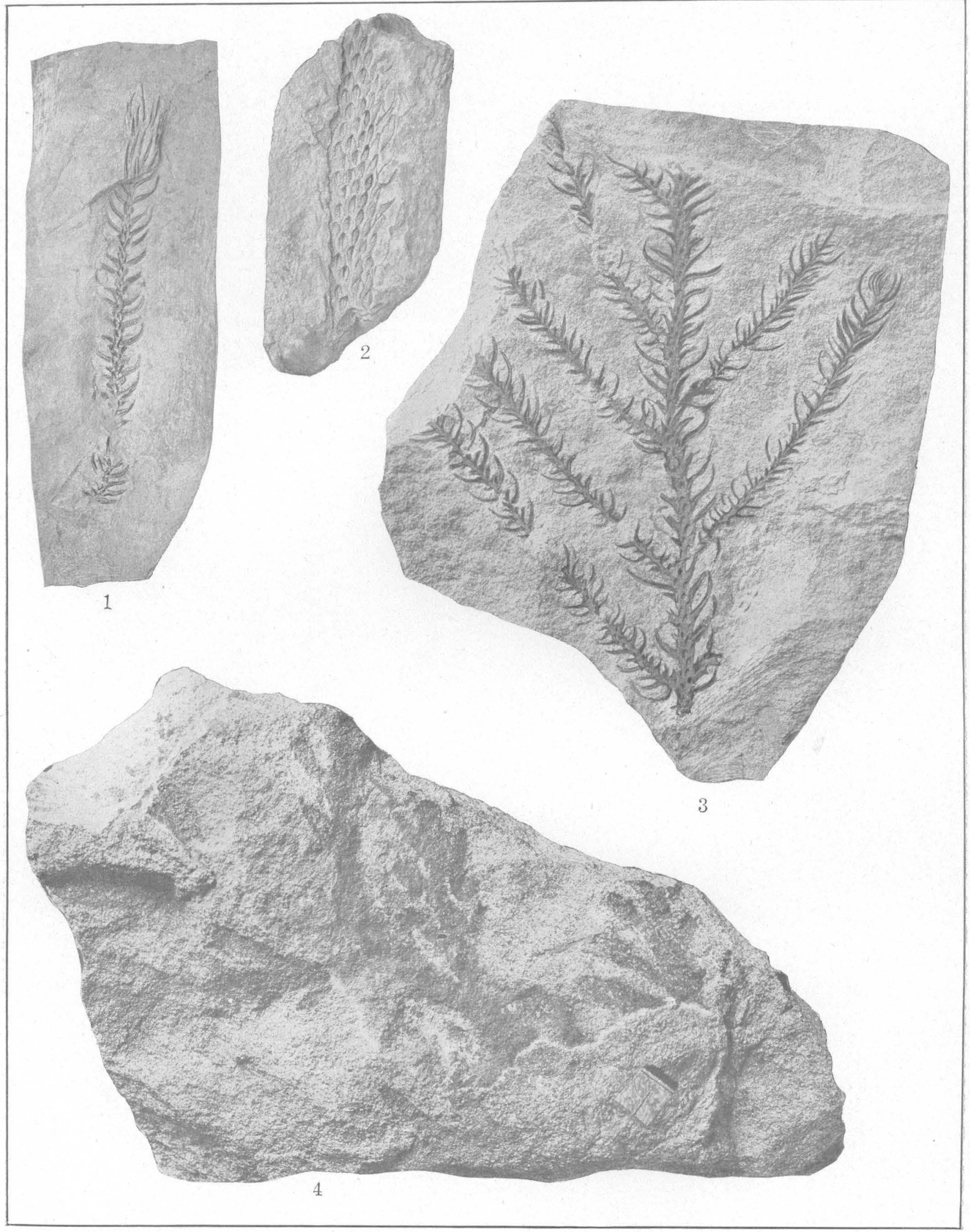

FLORA OF THE VERMEJO FORMATION. 


\section{PLATE XXXI.}

Fraure 1 3. Geinitzin formosa Heer (U. S. Nat. Mus catalogue Nos, 34459, 34460, 34461) .

4. Brachyphyllum ci. B. macrocarpum Newberry (U. S. Nat. Mus. catalogue No. 34462)............ 249 . 


\section{PLATE XXXII.}

Figures 1, 2. Taxodium? sp. (U. S. Nat. Mus. catalogue Nos. 34463, 34464) . . . . . . . . . . . . . . . . . . . 252

3. Sabal montana Knowlton, n. sp. (U. S. Nat. Mus. catalogue No. 34465) _... . . . . . . . . . . . 253

4, 5. Widdringtonia? complanata Lesquereux (U. S. Nat. Mus. catalogue Nos. 34466, 34467) . . . . . 252

6. Sparganium? Knowlton, sp. (U. S. Nat. Mus. catalogue No. 34468) ..................... 253 354 


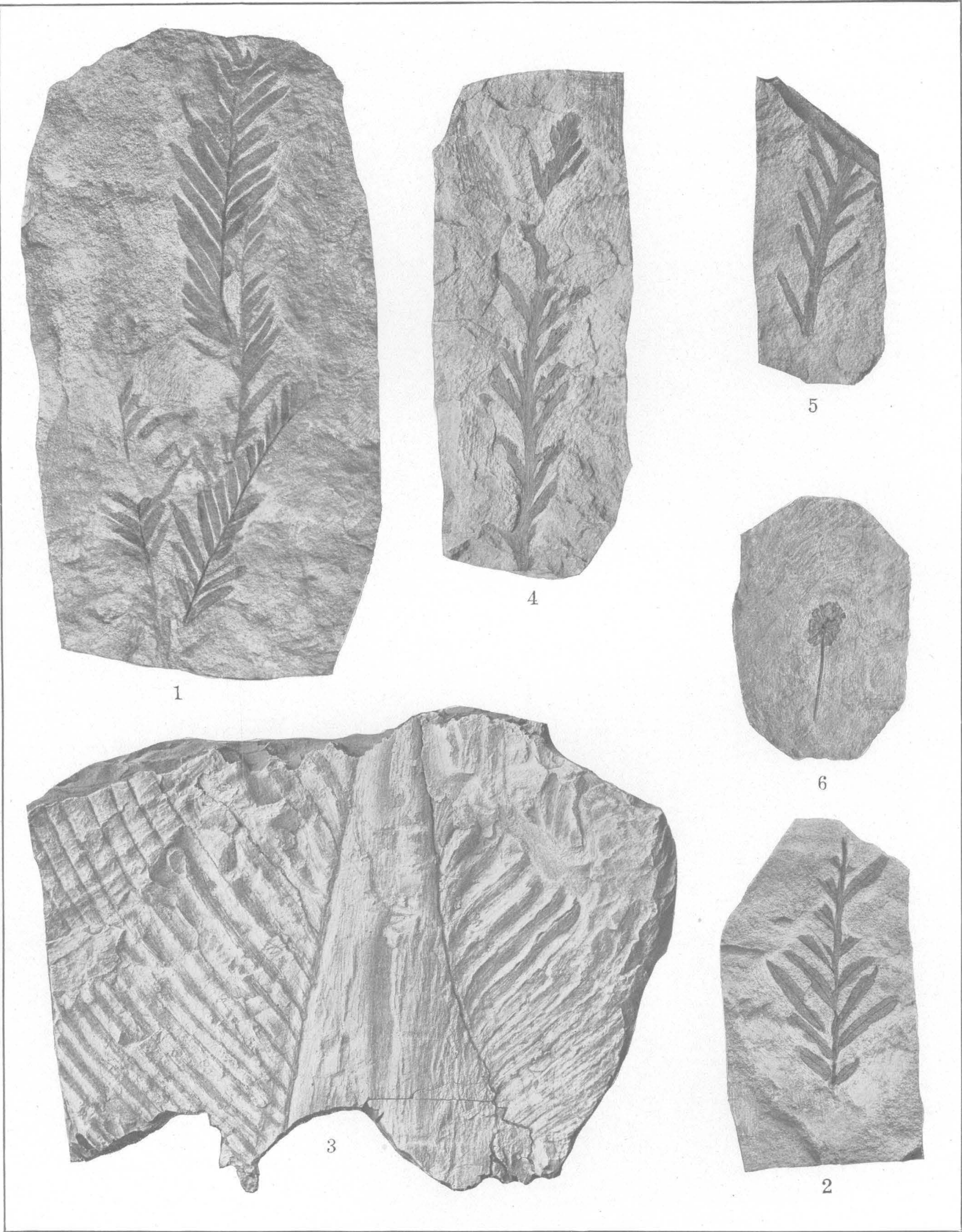

FLORA OF THE VERMEJO FORMATION. 


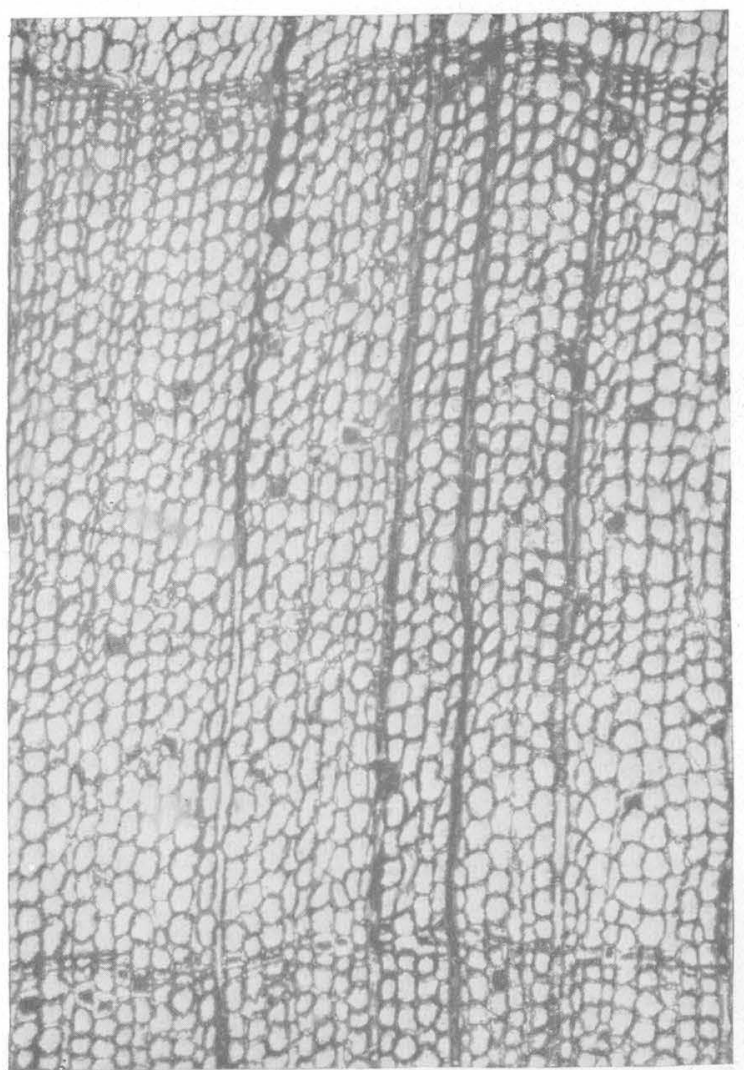

$$
1
$$

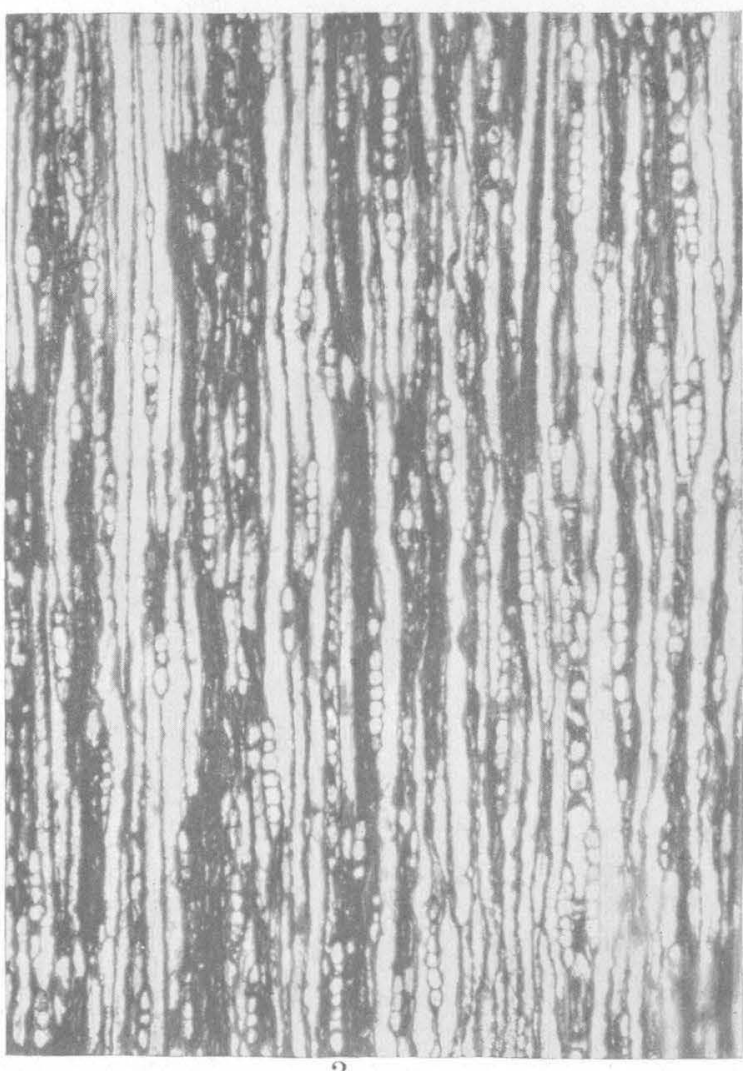

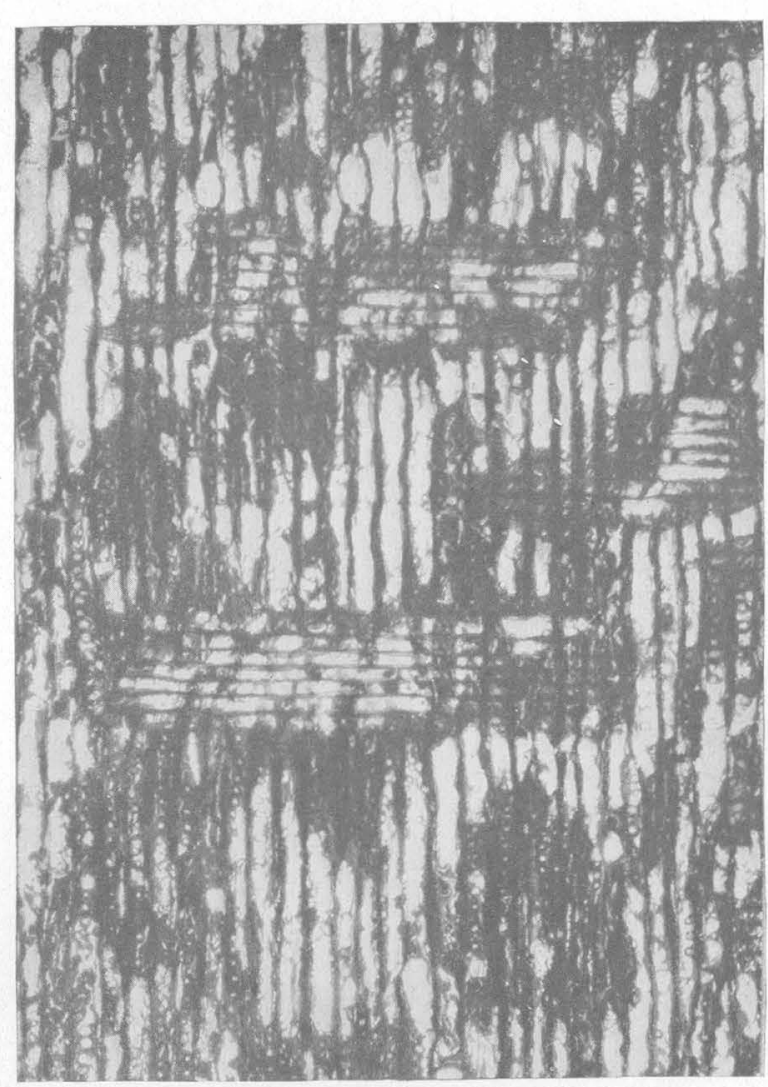
2

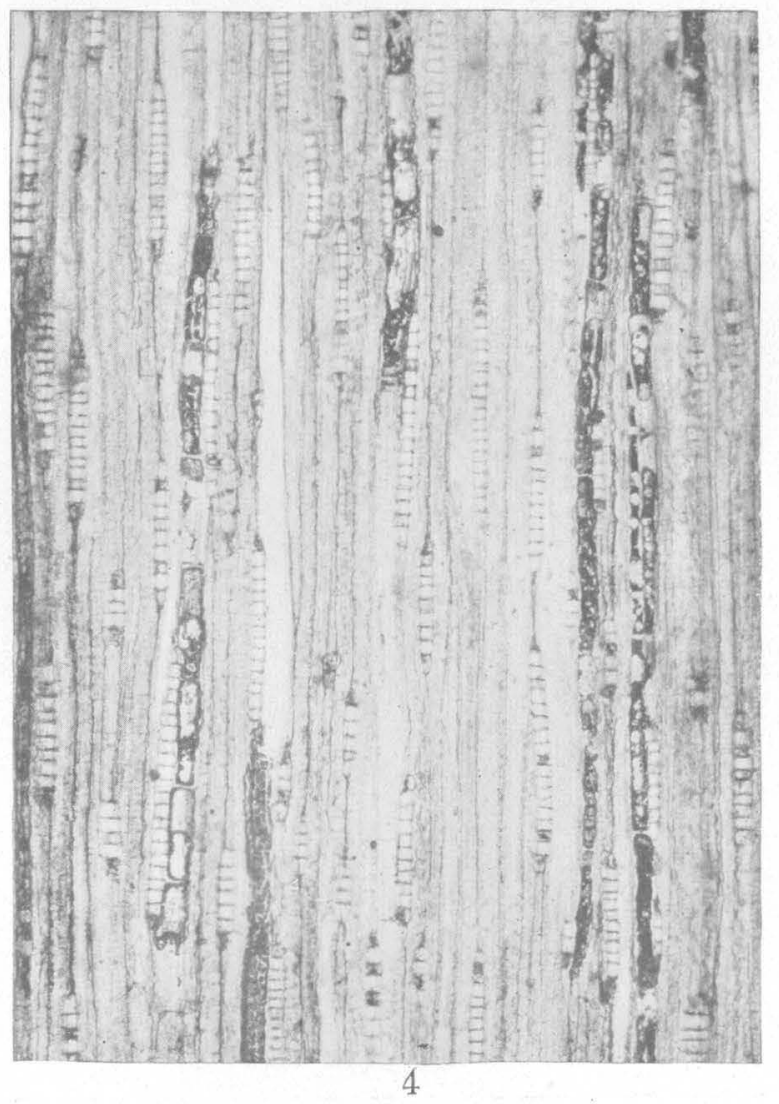




\section{PLATE XXXIII.}

Cupressinoxylon coloradense Knowlton, $\mathbf{n}$. sp.:

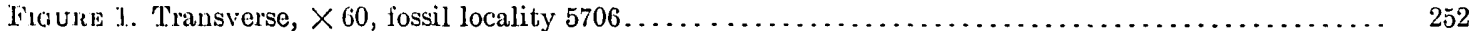

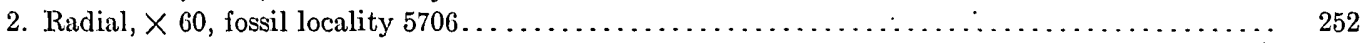

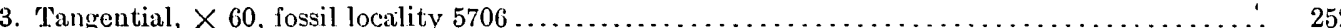

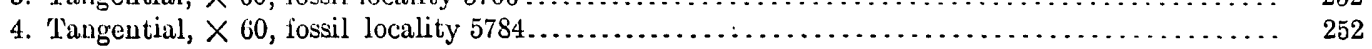




\section{PLATE XXXIV.}

Cupressinoxylon coloradense Knowlton, $\mathbf{n}$. sp.:

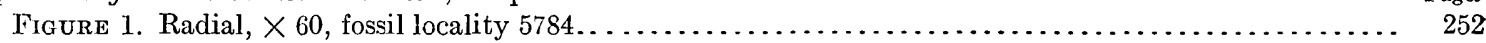

Cupressinoxylon? vermejoense Knowlton, n. sp.:

Fig'ure 2. Transverse, $\times 60$, fossil locality 5790

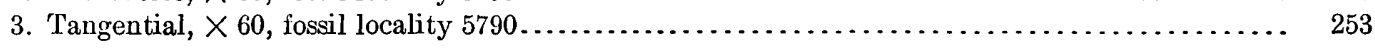

356 

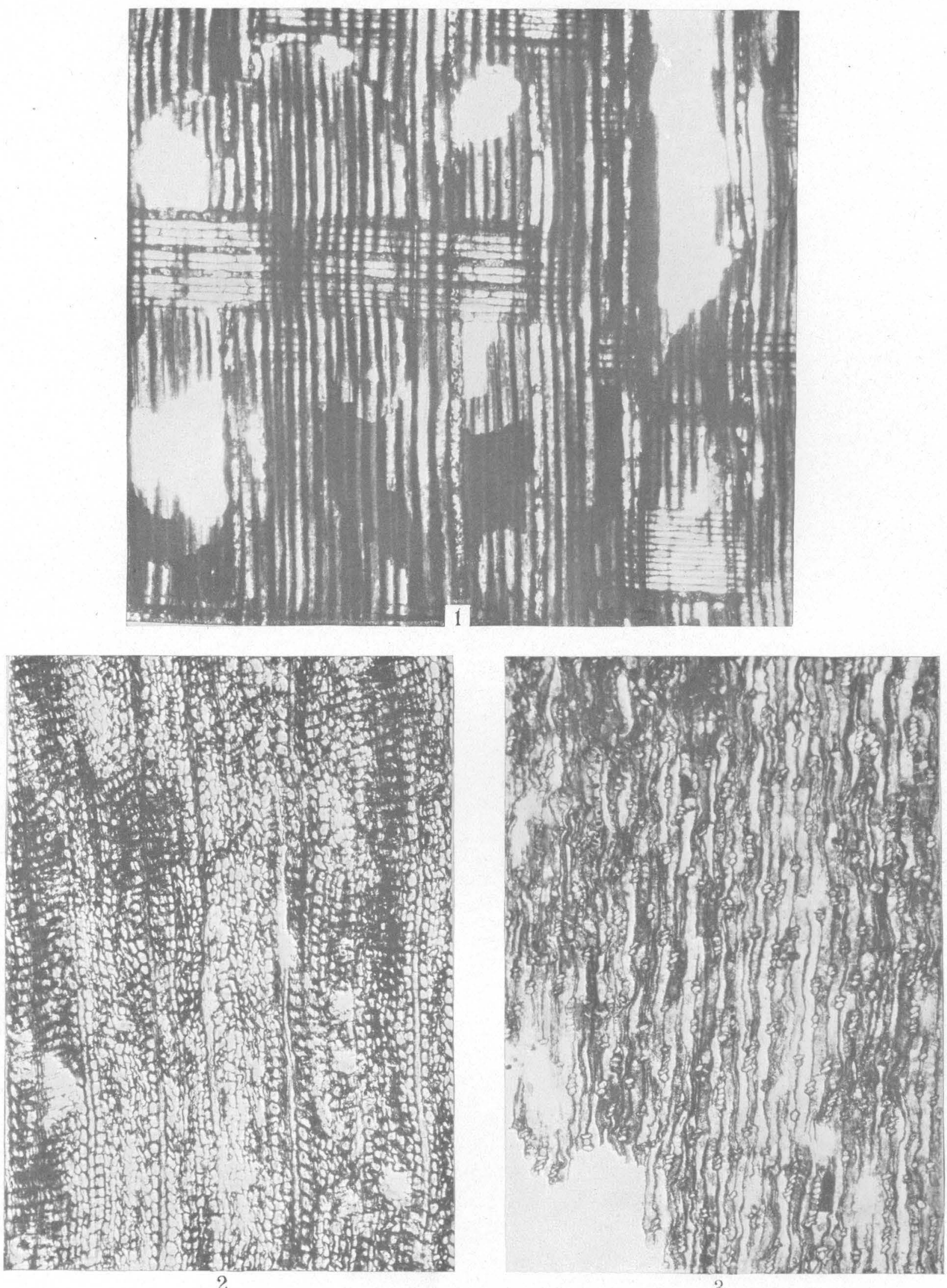

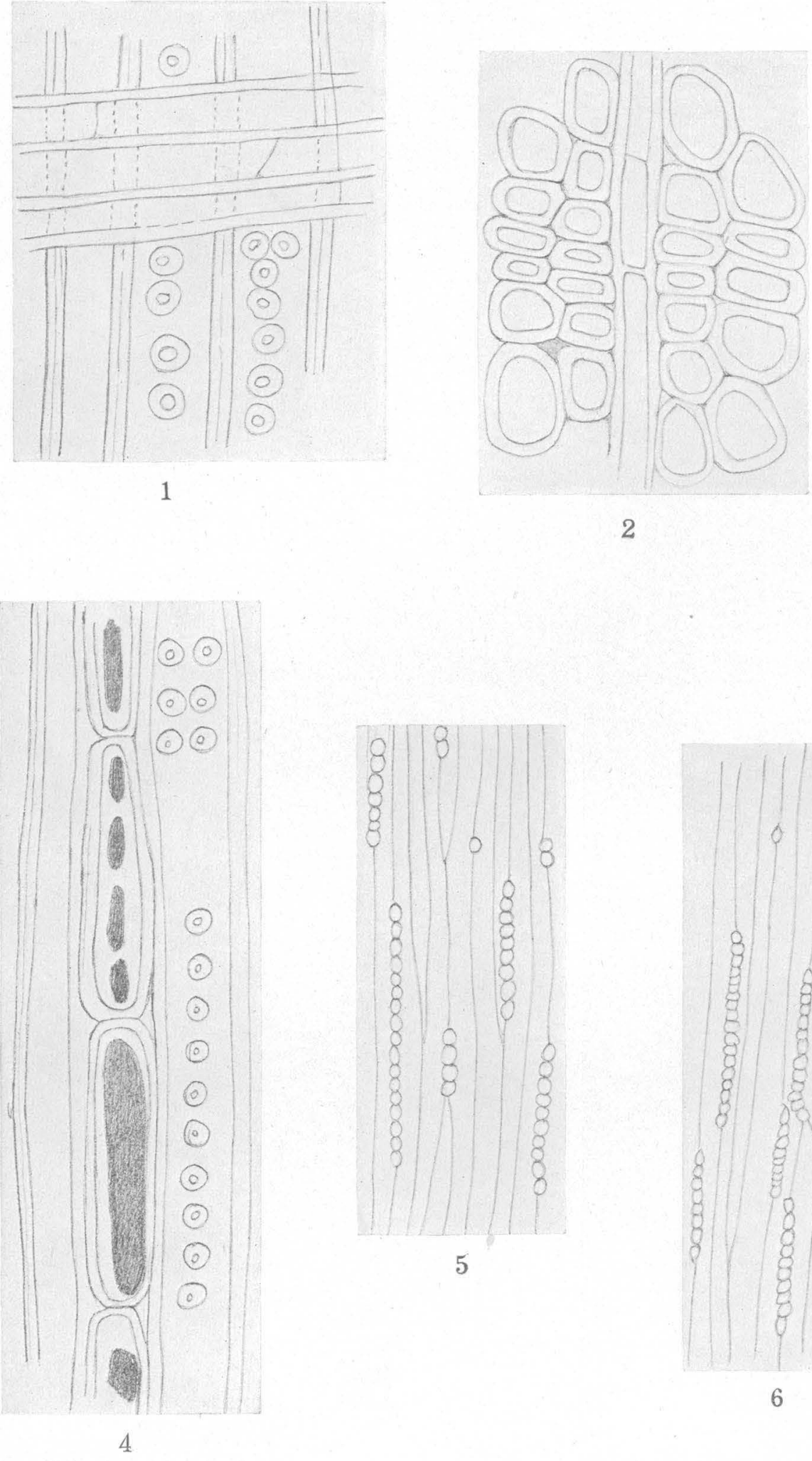
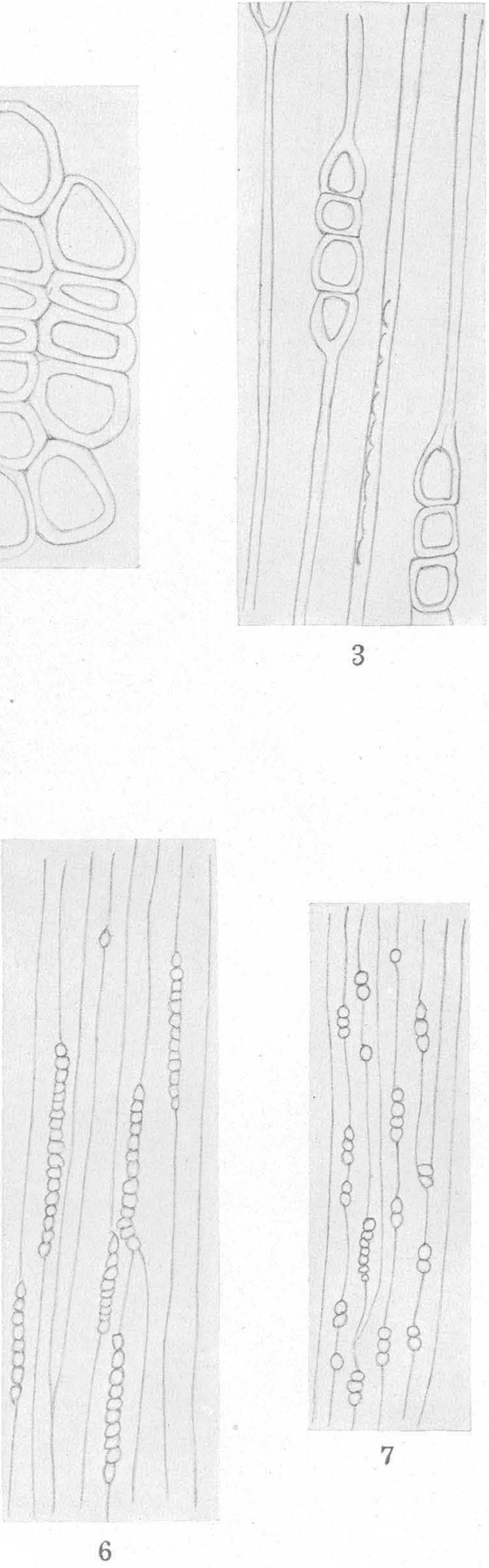


\section{PLATE XXXV.}

Cupressinoxylon coloradense Knowlton, $\mathrm{n}$. sp.:

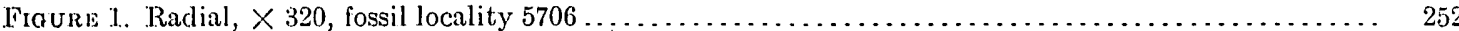

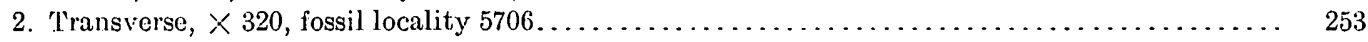

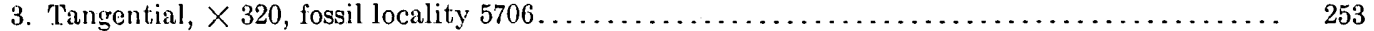

4. Radial showing resin cell and pitted tracheid, $\times 320$, fossil locality $5784 \ldots \ldots \ldots \ldots \ldots \ldots .252$

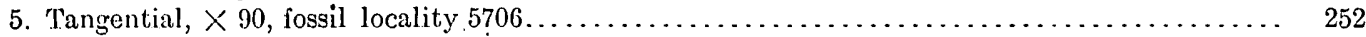

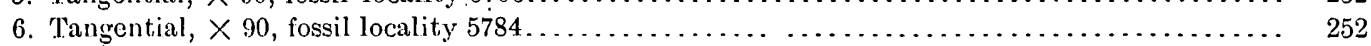

Cupressinoxylon? vermejoense Knowlton, n. sp.:

Fraure 7. Tangential, $\times 90$, fossil locality 5790 . 
PLATE XXXVI.

-FIgURE 1. Juglans coloradensis Lesquereux (MS.), n. sp. (U. S. Nat. Mus. catalogue No. 34469) ............. 255

2. Juglans similis Knowlton, n. sp. (U. S. Nat. Mus. catalogue No. 51332 ) .................. 255

3. Canna? magnifolia Knowlton, n. sp. (U. S. Nat. Mus. catalogue No. 34470) ................... 254

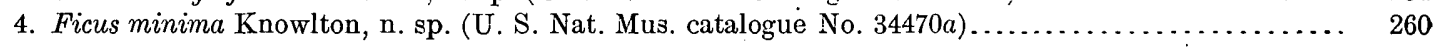




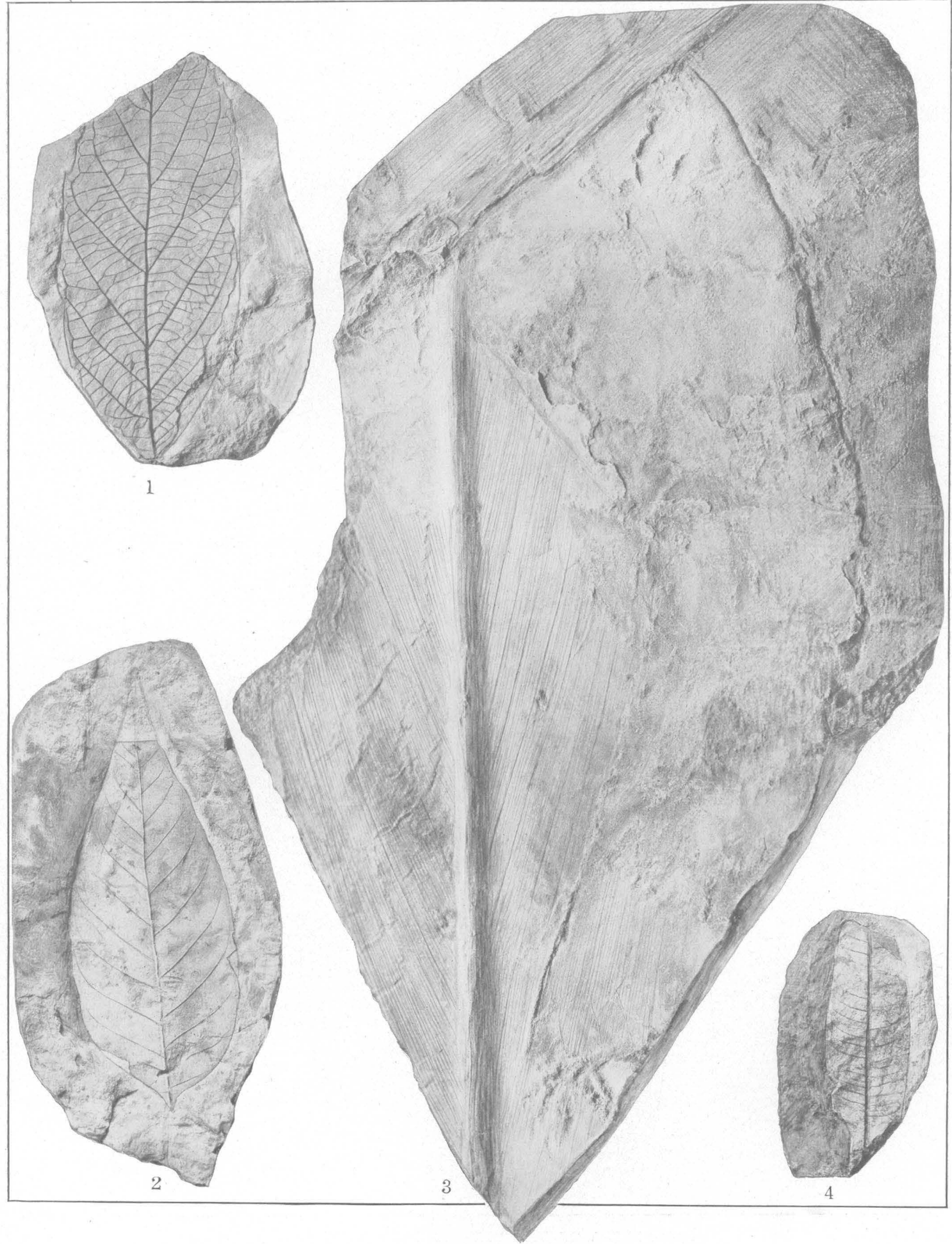

FLORA OF THE VERMEJO FORMATION. 


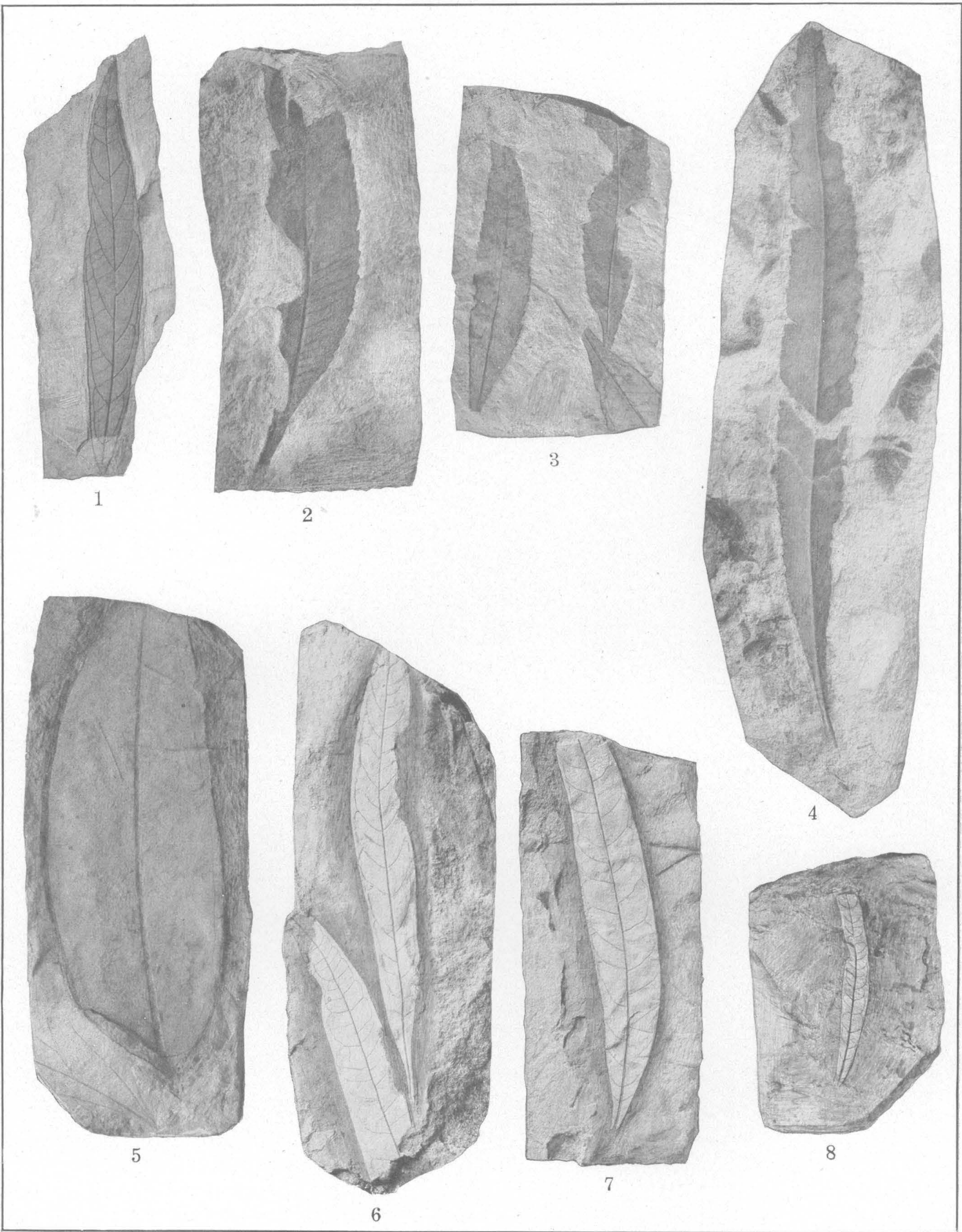

FLORA OF THE VERMEJO FORMATION. 


\section{PLATE XXXVII}

Fraure 1. Salix gardneri Knowlton, n. sp. (U. S. Nat. Mus. catalogue No. 34471.).................. 257

2-4. Myrica torreyi Lesquereux (U. S. Nat. Mus. catalogue Nos. 34472, 34473, 34474) . . . . . . . . . 256

5. Myrica coriacea Knowlton, n. sp. (U. S. Nat. Mus. catalogue No. 51372 ) . . . . . . . . . . . 256

6-8. Salix plicata Knowlton, n. sp. (U. S. Nat. Mus. catalogue Nos. 34475, 34476, 51178) . . . . . . . . 257 


\section{PLATE XXXVIFI.}

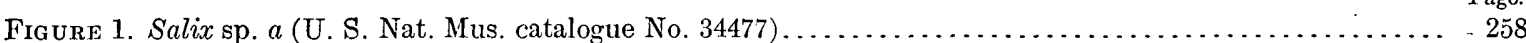

2. Salix sp. $b$ (U. S. Nat. Mus. catalogue No. 34478) .............................. 258

3. Quercus gardneri Knowlton, n. sp. (U. S. Nat. Mus. catalogue No. 34479) .................... 259

4. Quercus rockvalensis Knowlton, n. sp. (U. S. Nat. Mus. catalogue No. 34480) . . . . . . . . . ... 259

5. Ficus minima Knowlton, n. sp. (U. S. Nat. Mus. catalogue No. 34481) ....................... 260

6-7. Ficus haddeni Knowlton, n. sp. (U. S. Nat. Mus. catalogue Nos. 511.87, 51.189) ................ 260

8. Ficus newberryana Knowlton, n. sp. (U. S. Nat. Mus. catalogue No. 34482) ................... 261

9. Ficus? starkvillensis Knowlton, n. sp: (U. S. Nat. Mus. catalogue No. 34483) .................. 262

360 


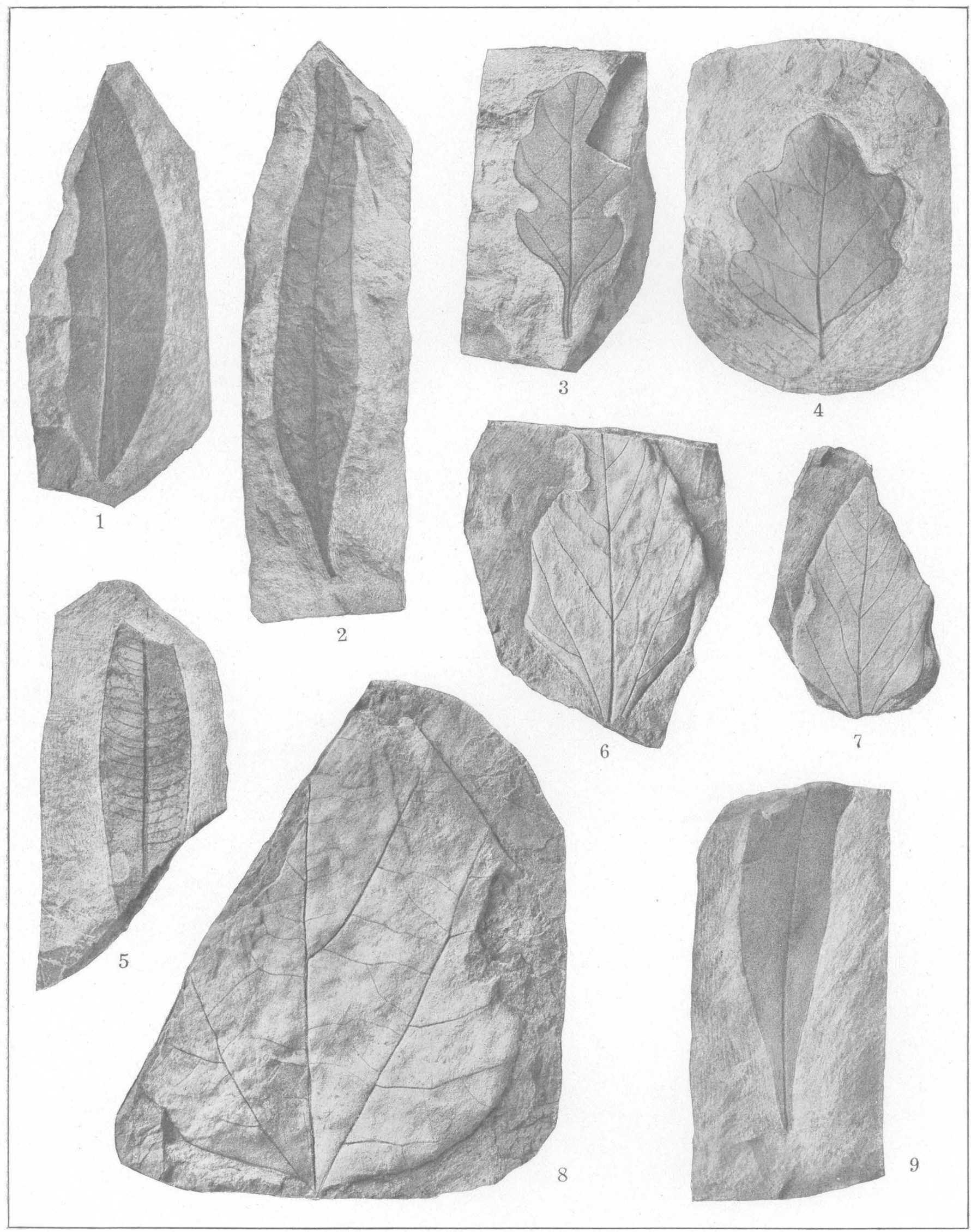




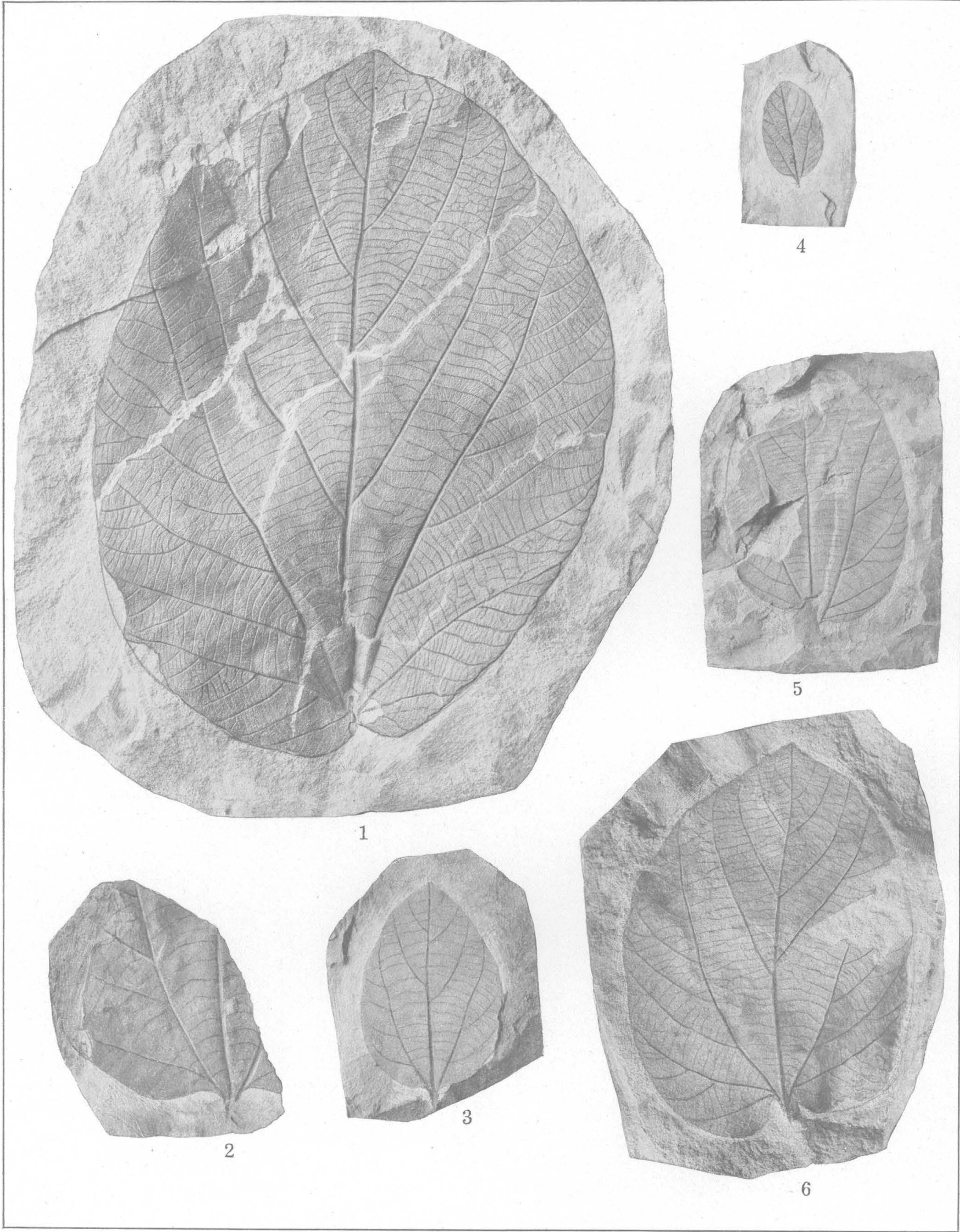

FLORA OF THE VERMEJO FORMATION. 
PLATE XXXIX.

Fiounas $1-6$. Pimus loci 


\section{PLATE XL.}

FIGUREs 1, 2 Ficus leei Knowlton, n sp. (U. S. Nat Mus catalogue Nos 34490, 34491) . . . 3, 4. Ficus rockvalensis Knowlton, n. sp. (U. S. Nat. Mus. catalogue Nos. 34492, 34725) . . . . . . . 265 362 


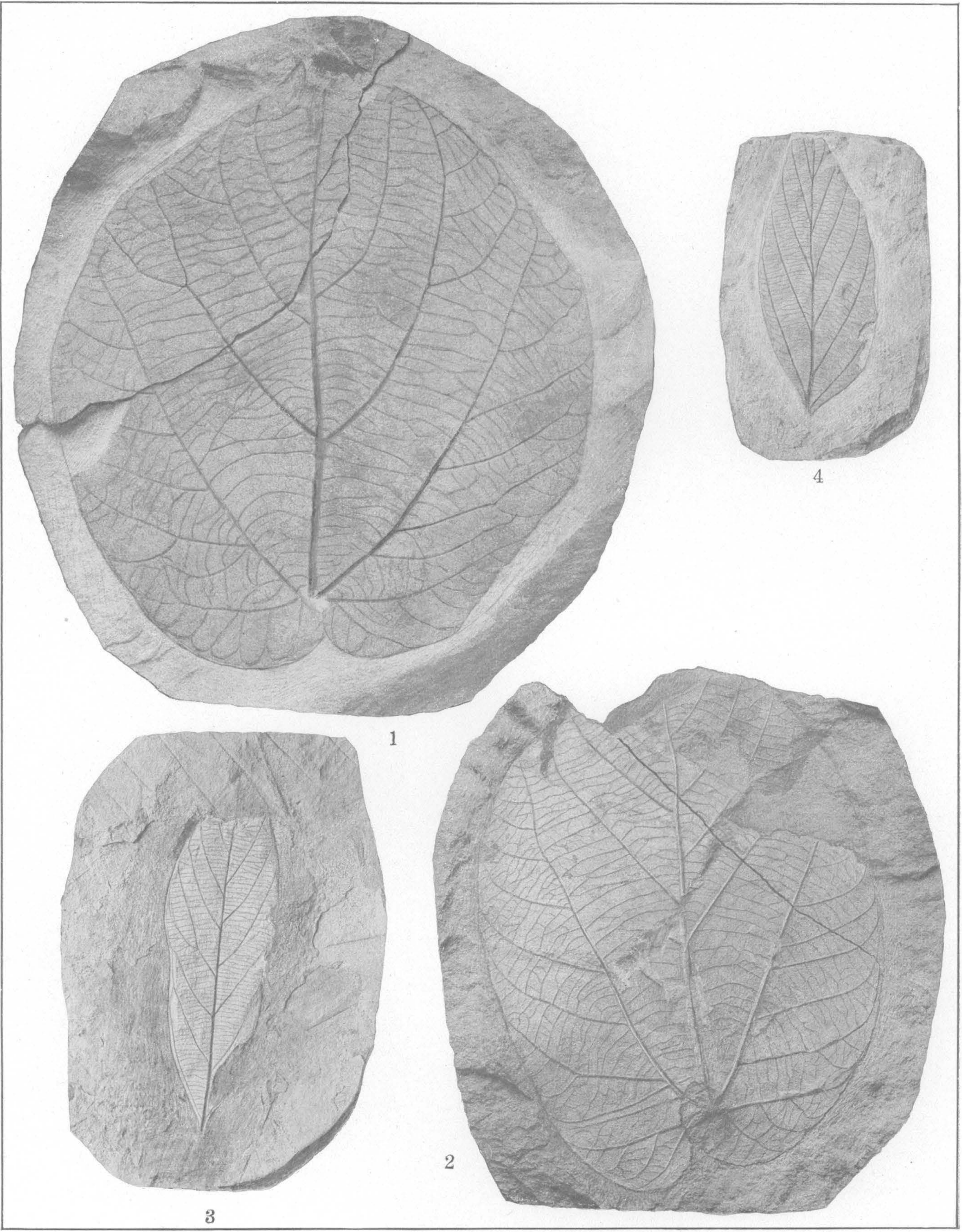

FLORA OF THE VERMEJO FORMATION. 


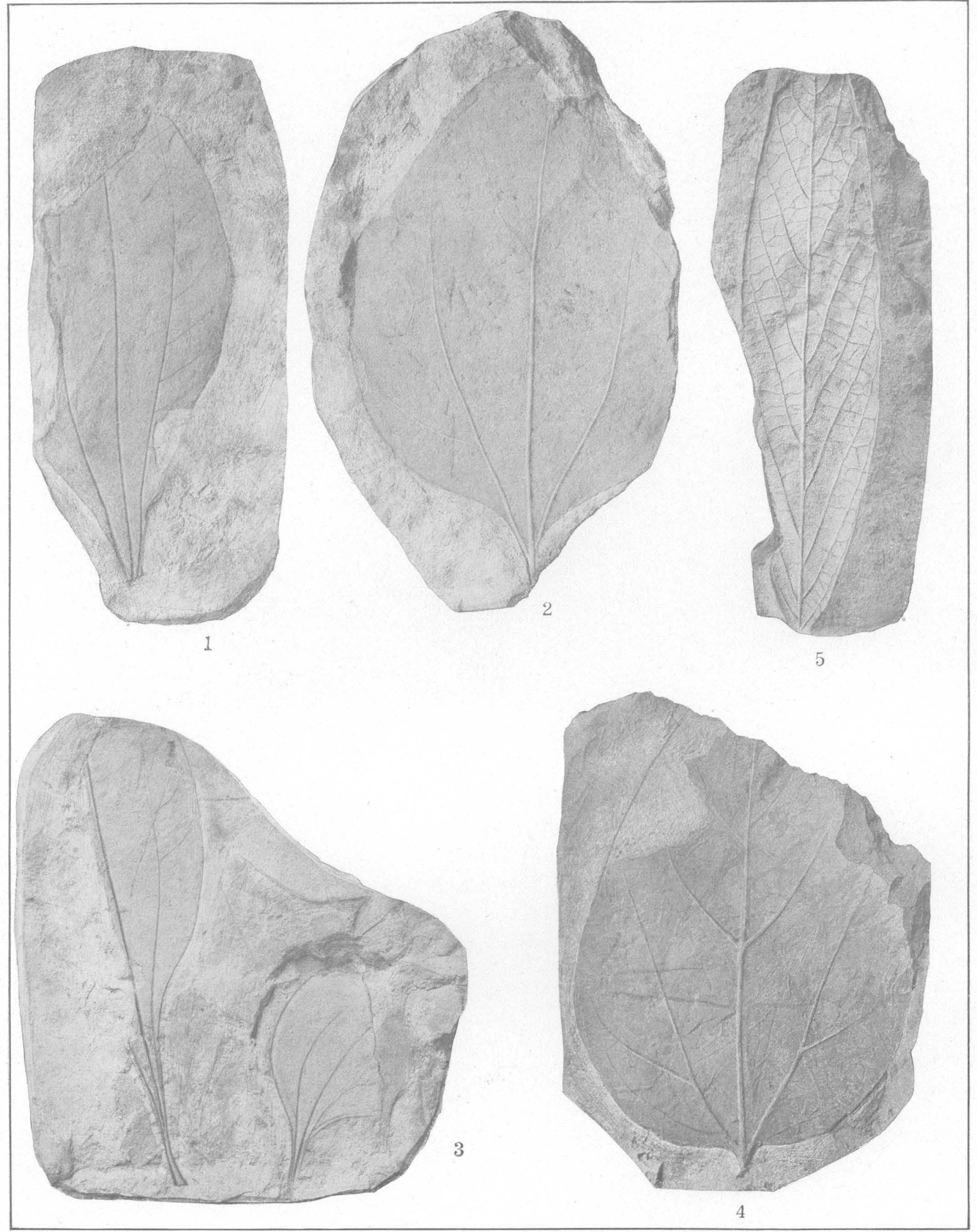

FLORA OF THE VERMEJO FORMATION. 
PLATE XLI.

Figures 1-4. Ficus prcetrincrvis Tinowlton n. sp. (U. S. Nat. Mus catalogue Nos. $34493,34494,34405,51135$ ).

5. Ficus lessellala Lesquereux (MS.), n. sp. (U. S. Nat. Mus. catalogue No. gil169) .......... 266 
Figure 1. Ficus praetrinervis Knowlton, n. sp. (U. S. Nat. Mus. catalogue No. 51384) . . . . . . ......... 263

2. Ficus wardii Knowlton (U. S. Nat. Mus. catalogue No. 34496) . . . . . . . . . . . . . . . . . . 266

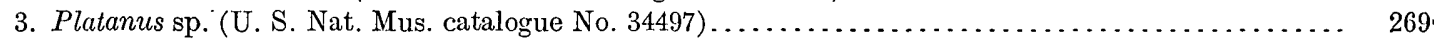

4. Amelanchier obovata Knowlton, n. sp. (U. S. Nat. Mus. catalogue No. 34498) . . . . . . . . . . . 269

5. Ficus curta Knowlton, n. sp. (U. S. Nat. Mus. catalogue No. 34499) . . . . . . . . . . . . . . . . 266

6. Artocarpus dissecta Knowlton, n. sp. (U. S. Nat. Mus. catalogue No. 34500) . . . . . . . . . . . 267

364 

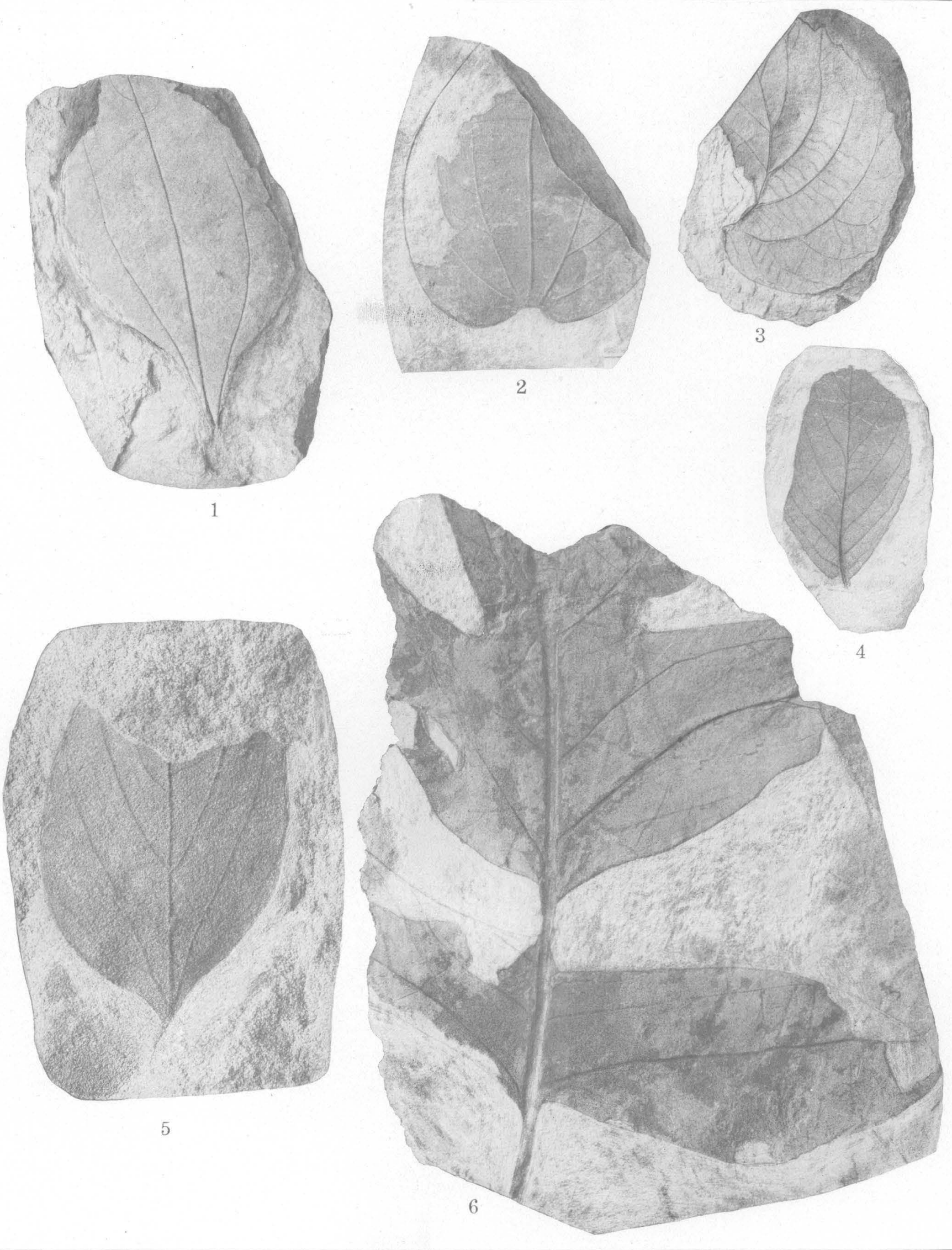

FLORA OF THE VERMEJO FORMATION. 


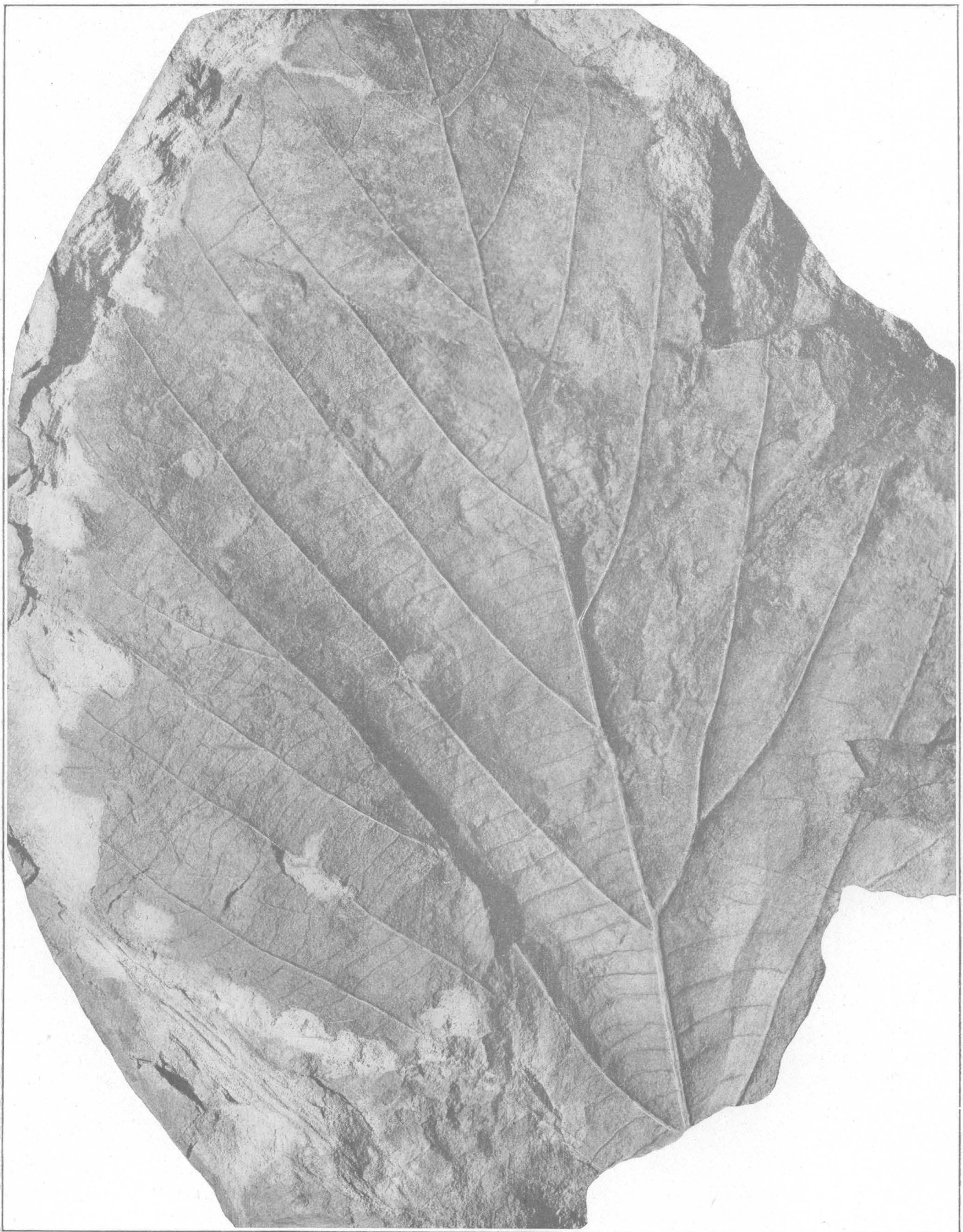

FLORA OF THE VERMEJO FORMATION. 


\section{PLATE XLIII}




\section{PLATE XLIV.}

Figures 1, 2. Ficus eucalyptifolia Knowlton, n. sp. (U. S. Nat. Mus. catalogue Nos. 34502, 34503) . ....... 260

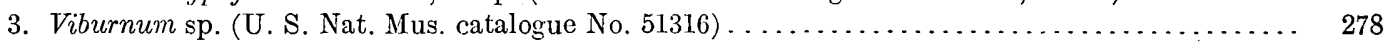

4. Colutea speciosa Knowlton, n. sp. (U. S. Nat. Mus. catalogue No. 34504) ................. 270

5. Celastrus? hesperius Knowlton, n. sp. (U. S. Nat. Mus. catalogue No. 51254) . . . . . . ..... 271 366 


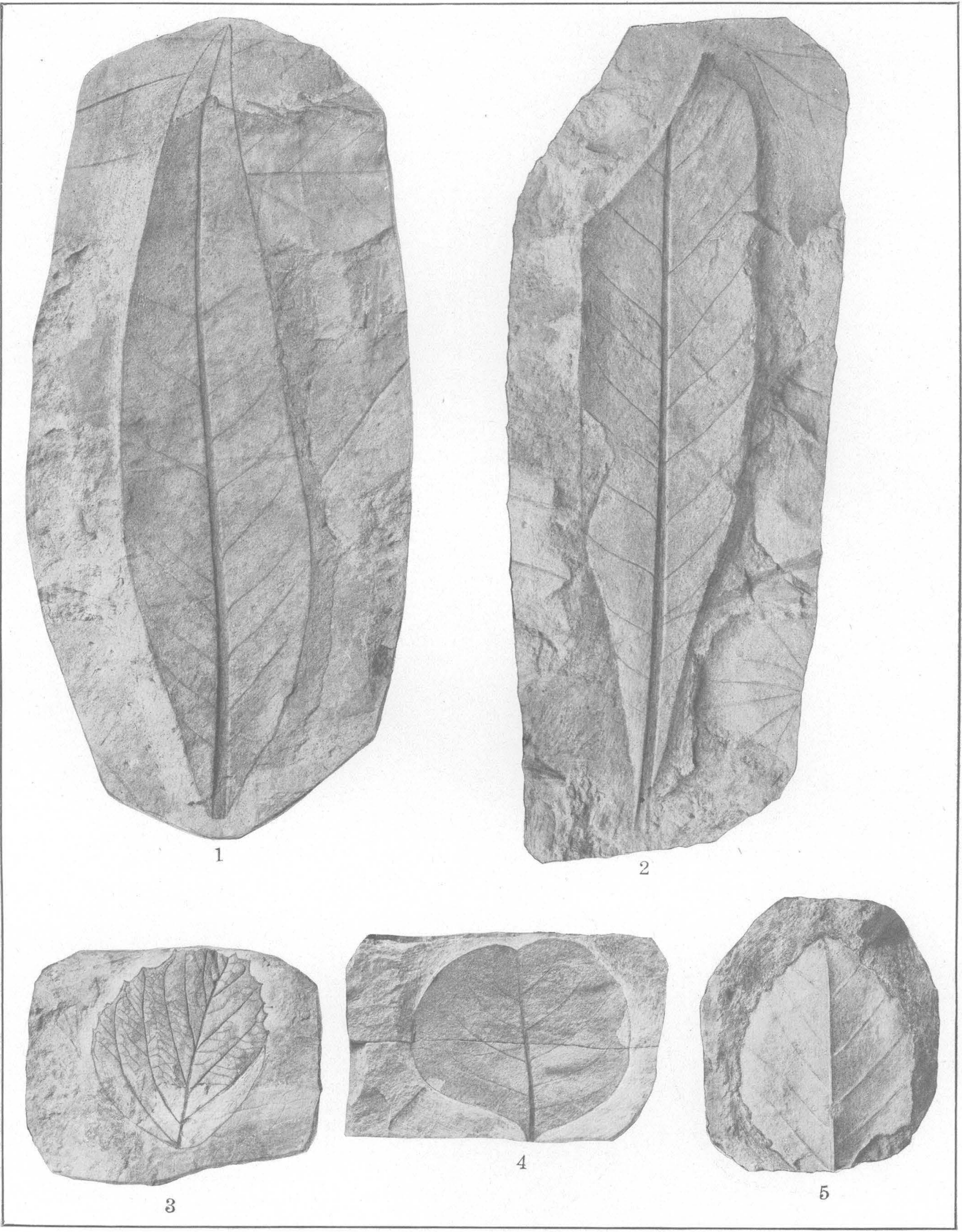

FLORA OF THE VERMEJO FORMATION. 


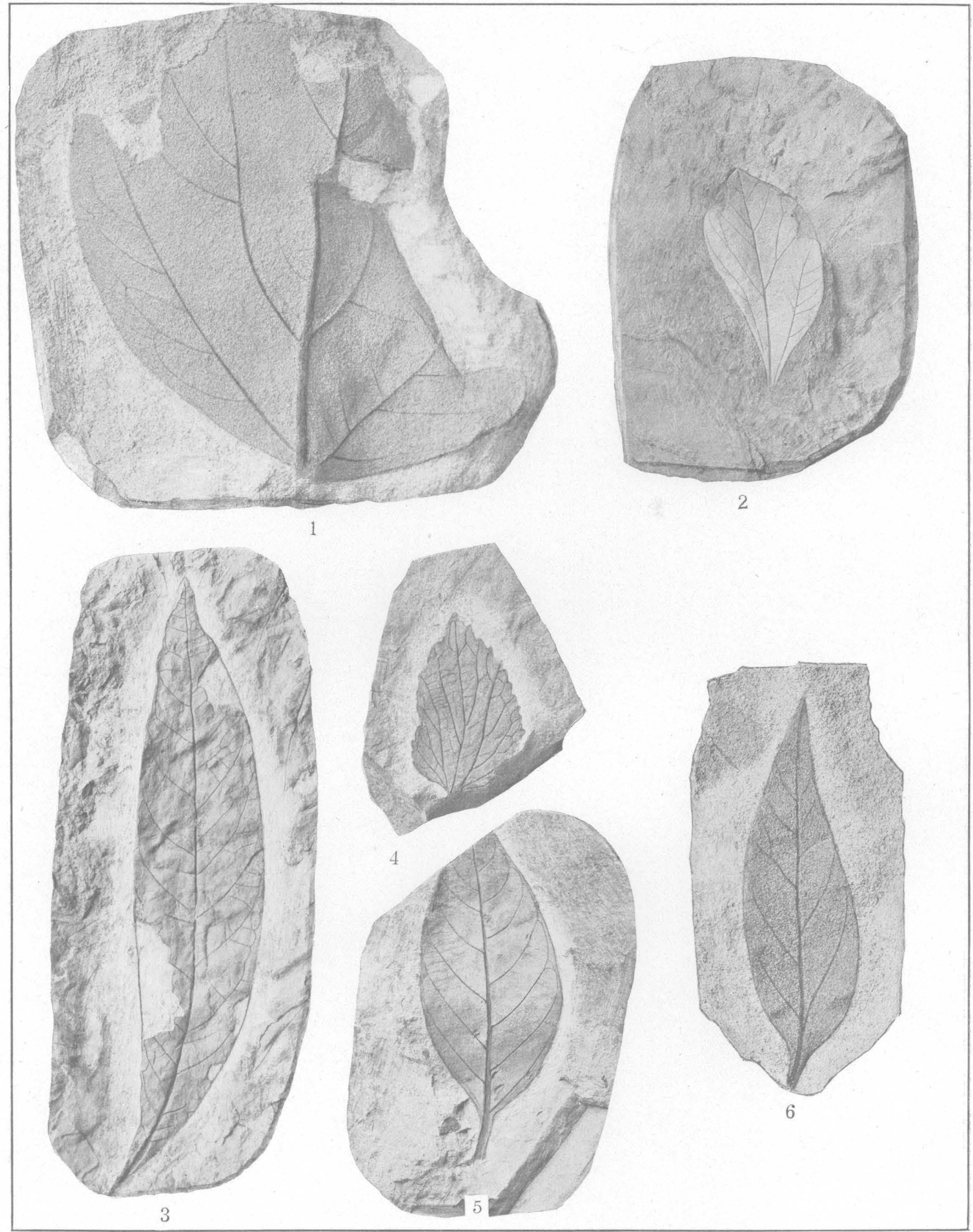

FLORA OF THE VERMEJO FORMATION. 


\section{- PLATE XLV.}

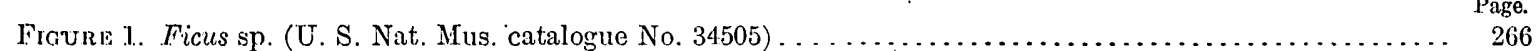

2. Celastrus haddeni Knowlton, n. sp. (U. S. Nat. Mus. catalogue No. 51373) ................... 271

3. Laurus coloradensis Knowlton, n. sp. (U. S. Nat. Mus. catalogue No. 34506) . . . . . . . ..... 268

4. Viburnum anomalinervum Knowlton, n. sp. (U. S. Nat. Mus. catalogue No. 34507) . . . . . . . . . 275

5. Phaseolites crassus Knowlton, n. sp. (U. S. Nat. Mus. catalogue No. 34508) . . . . . . . . . . . . 269

6. Phaseolites leci Knowlton, n. sp. (U. S. Nat. Mus. catalogue No. 34509) . ................... 270 
PLATE XLVI.

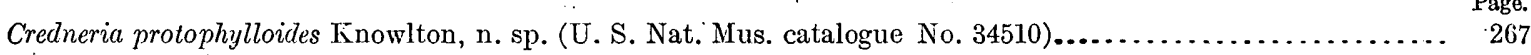
368 


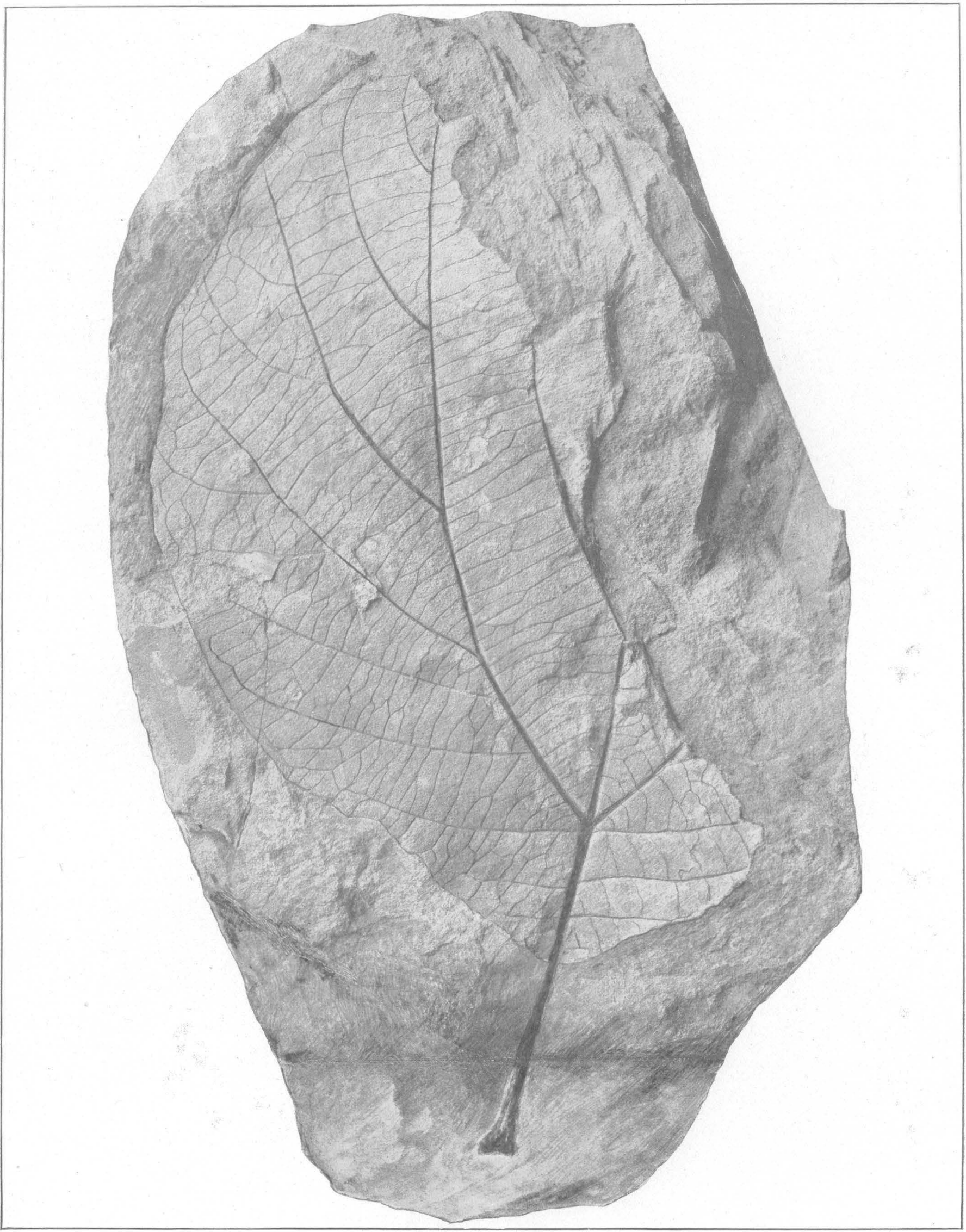




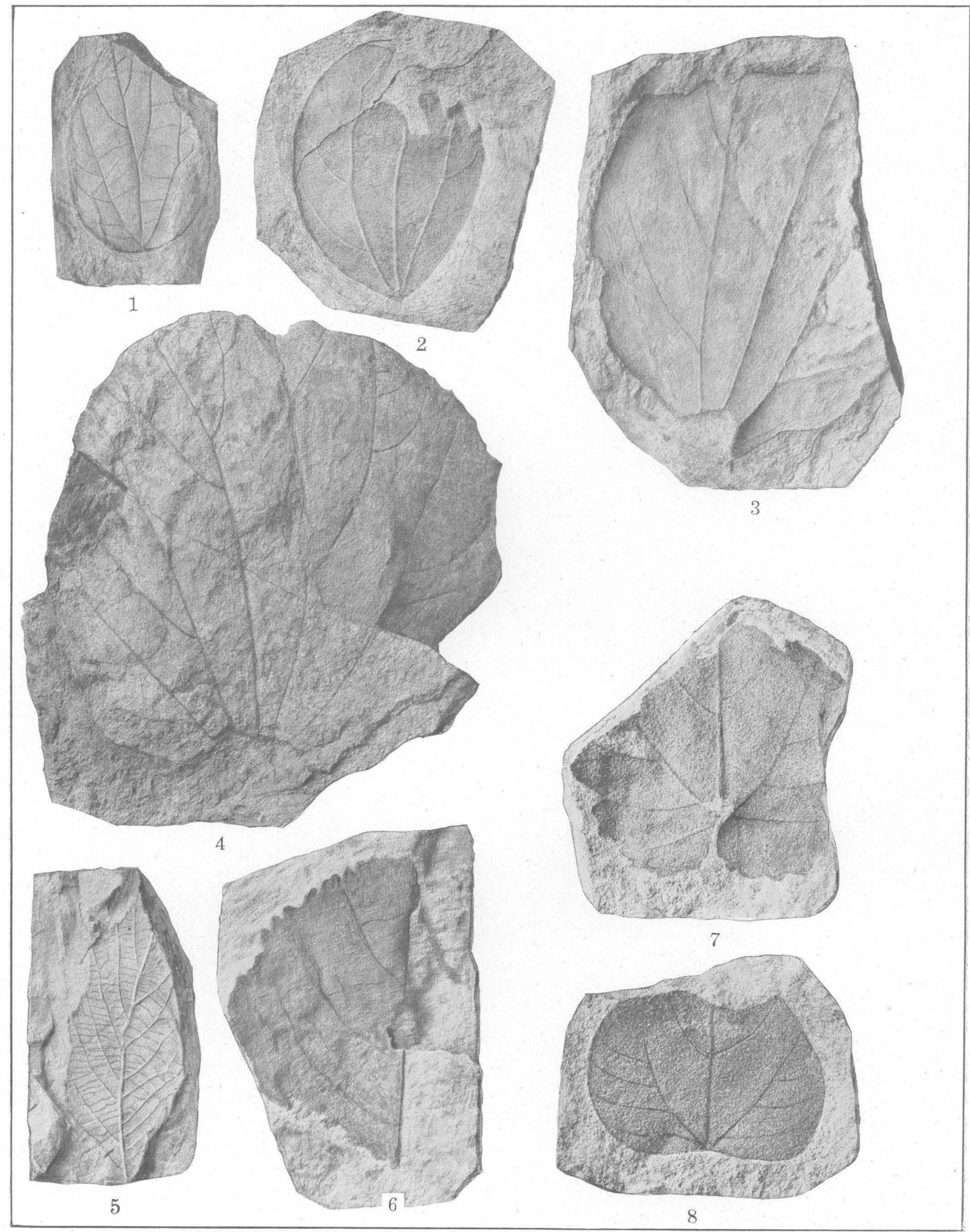

FLORA OF THE VERMEJO FORMATION. 


\section{PLATE XLVII.}

Figures 1-4. Zizyphus paliurifolius Knowlton, n. sp. (U. S. Nat. Mus. catalogue Nos. 34511-34514) ........ 272

5. Viburnum rhamnifolium Knowlton, n. sp. (U. S. Nat. Mus. catalogue No. 34515 ) ............. 277

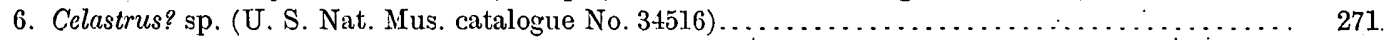

7. Vitis? fragmenta Knowlton, n. sp. (U. S. Nat. Mus. catalogue No. 3451.7) .................... 274.

8. Hedera rotundifolia Knowlton, n. sp. (U. S. Nat. Mus. catalogue No. 34518) . . . . . ........ 274. 


\section{PLATE XLVIII.}

FraURE 1. Sterculia coriccea Knowlton, n. ap. (U. S. Nat. Mrus. catalogue No. 34519)

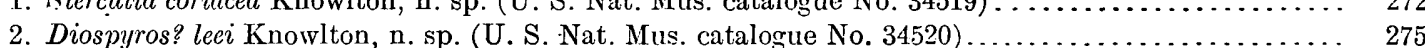

3. Liriodendron alatum Newberry (MS.) (U. S. Nat. Mus. catalogue No. 34521) .................. 269

4. Pterospermites nervosus Knowlton, n. sp. (U. S. Nat. Mus. catalogue No. 34522) ................ 273 370 


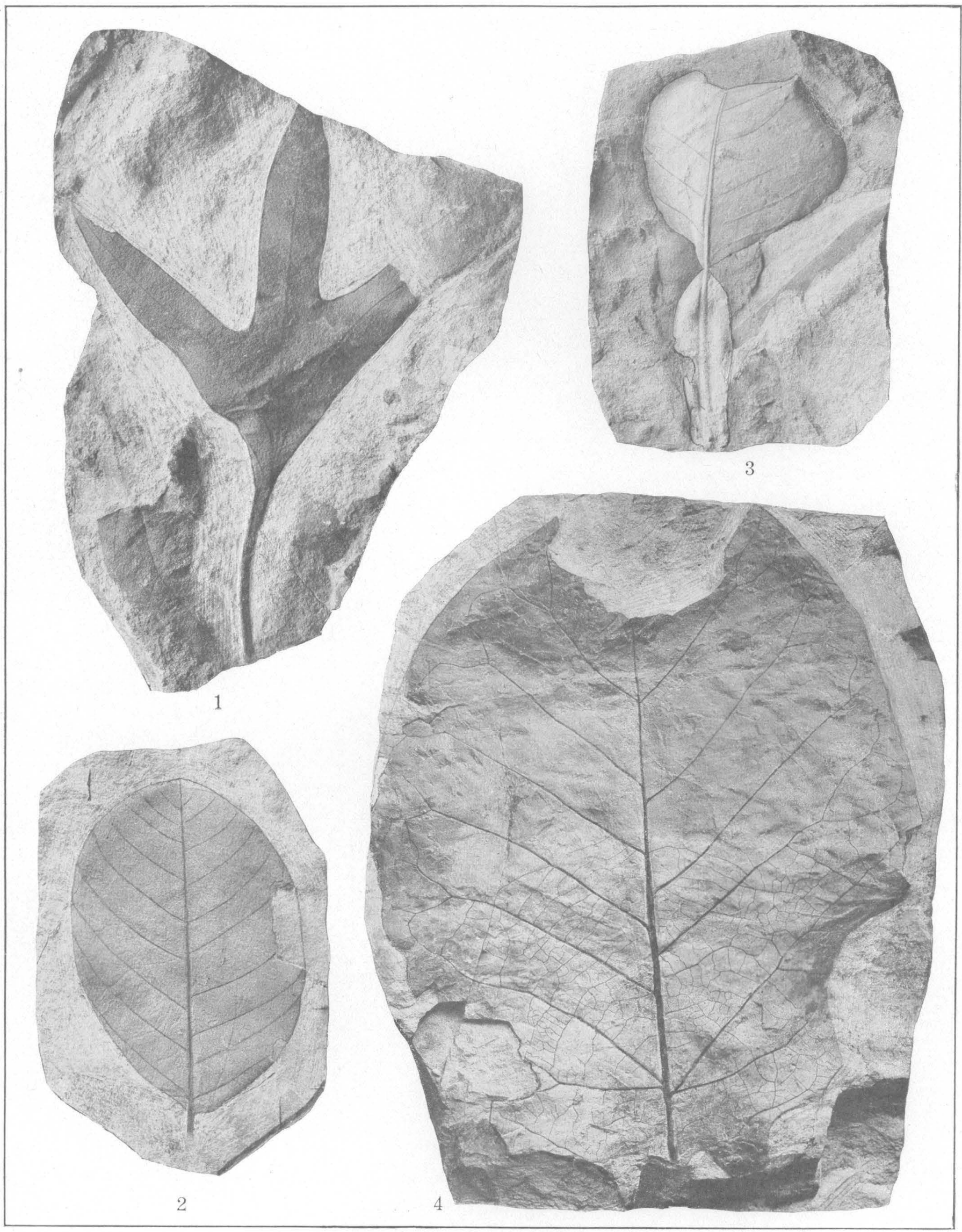

FLORA OF THE VERMEJO FORMATION. 


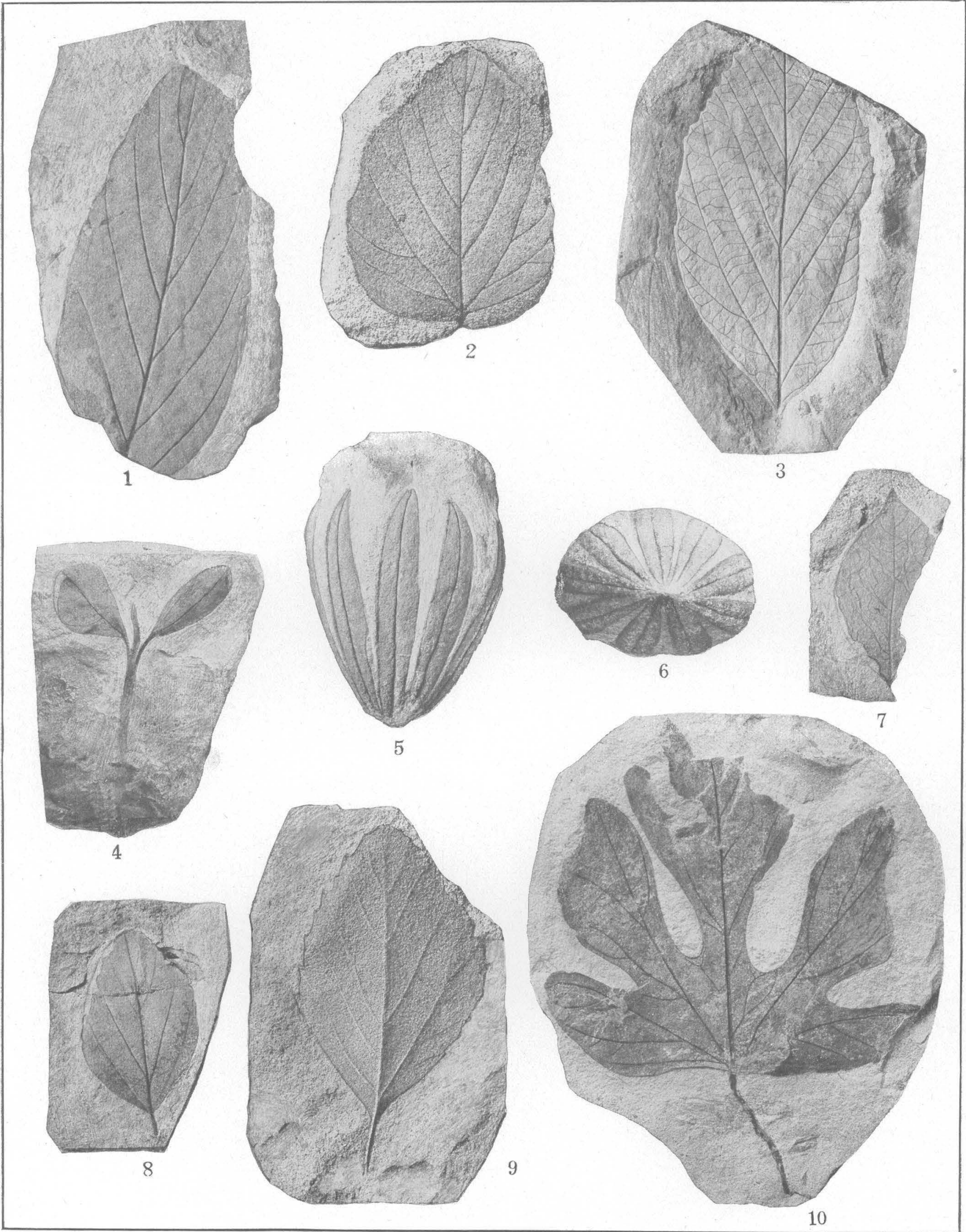

FLORA OF THE VERMEJO FORMATION. 


\section{PLATE XLIX.}

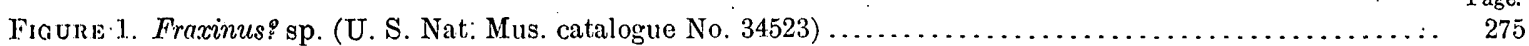

2. Viburnum? hesperium Knowlton, n. sp. (U. S. Nat. Mus. catalogue No. 34524) .............. 276

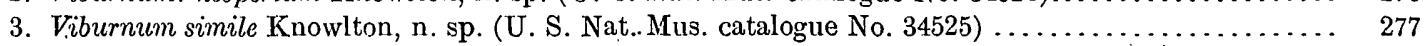

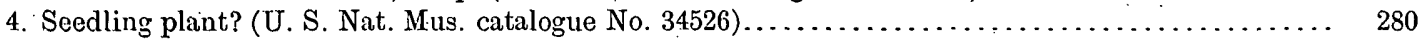

5, 6. Palaeoaster inquirenda Knowlton, n. gen. and sp. (U. S. Nat. Mus. catalogue No. 34527$) \ldots \ldots \ldots \ldots 278$

7. Phyllites rosaefolius Knowlton, n. sp. (U. S. Nat. Mus. catalogue No. 34528)................ 281

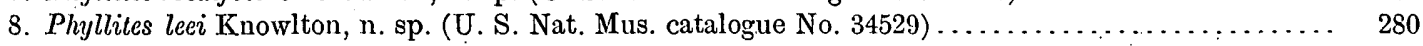

9. Viburnum? problematicum Knowlton (U. S. Nat. Mus. catalogue No. 34530) ................... 276

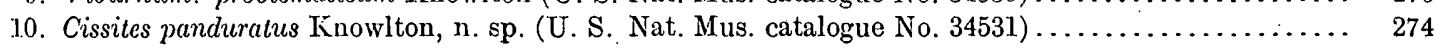




\section{PLATE L.}

Figures 1,2.. Phyllites populoides Knowlton, n. sp. (U. S. Nat. Mus. catalogue Nos. 34532,34533 ) 3, 4. Phyllites nanus Knowlton, n. sp. (U. S. Nat. Mus. catalogue Nos. 34534,34535 )............ 280

.5. Phyllites aurantiacus Knowlton, n. sp. (U. S. Nat. Mus. catalogue No. 34536)............... 280

6. Phyllites protophylloides Knowlton, n. sp. (U. S. Nat. Mus. catalogue No. 34537) ... ....... 281

7. Phyllites sapindus Knowlton, n. sp. (U. S. Nat. Mus. catalogue No. 34538) ............... 281 372 


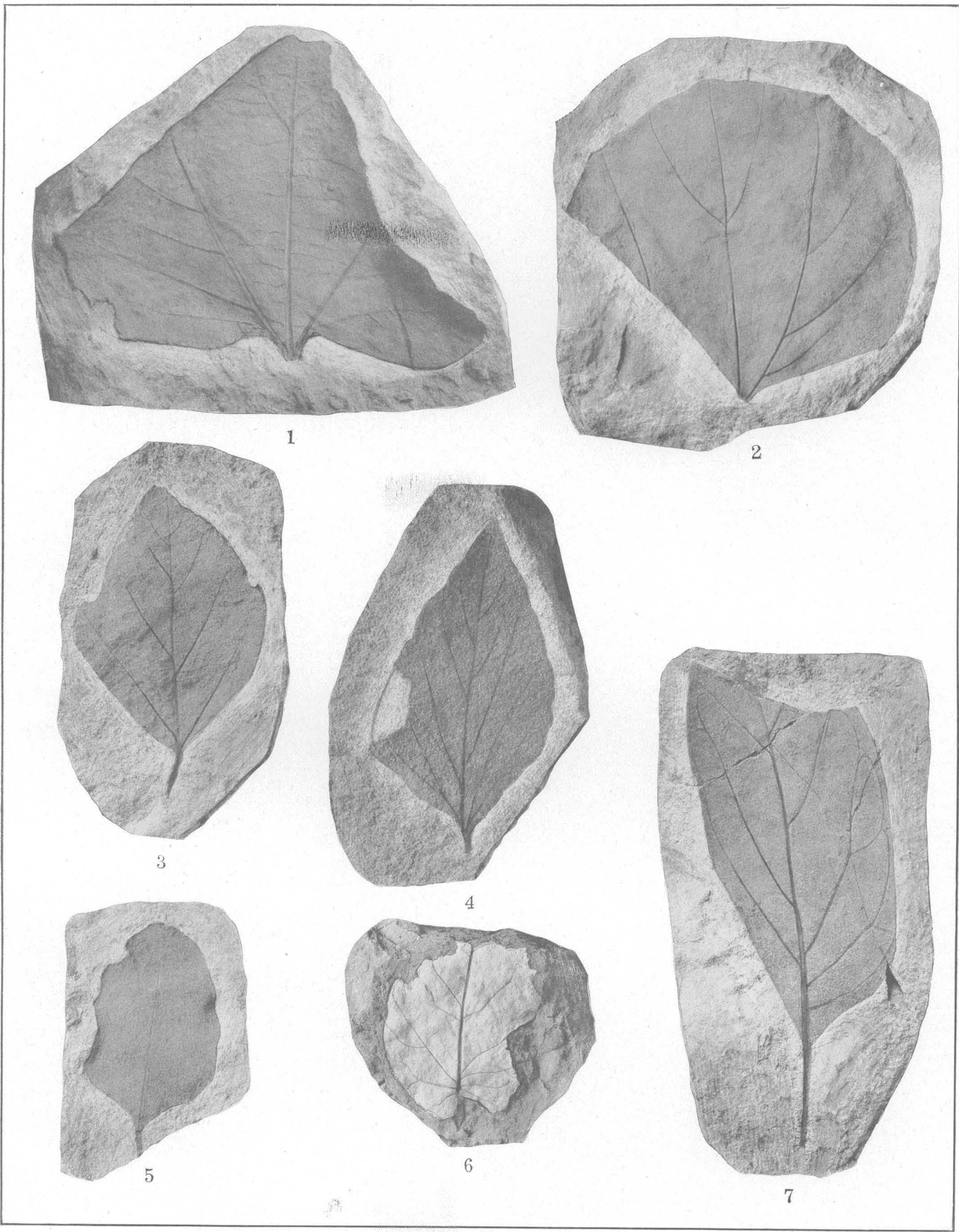

FLORA OF THE VERMEJO FORMATION. 


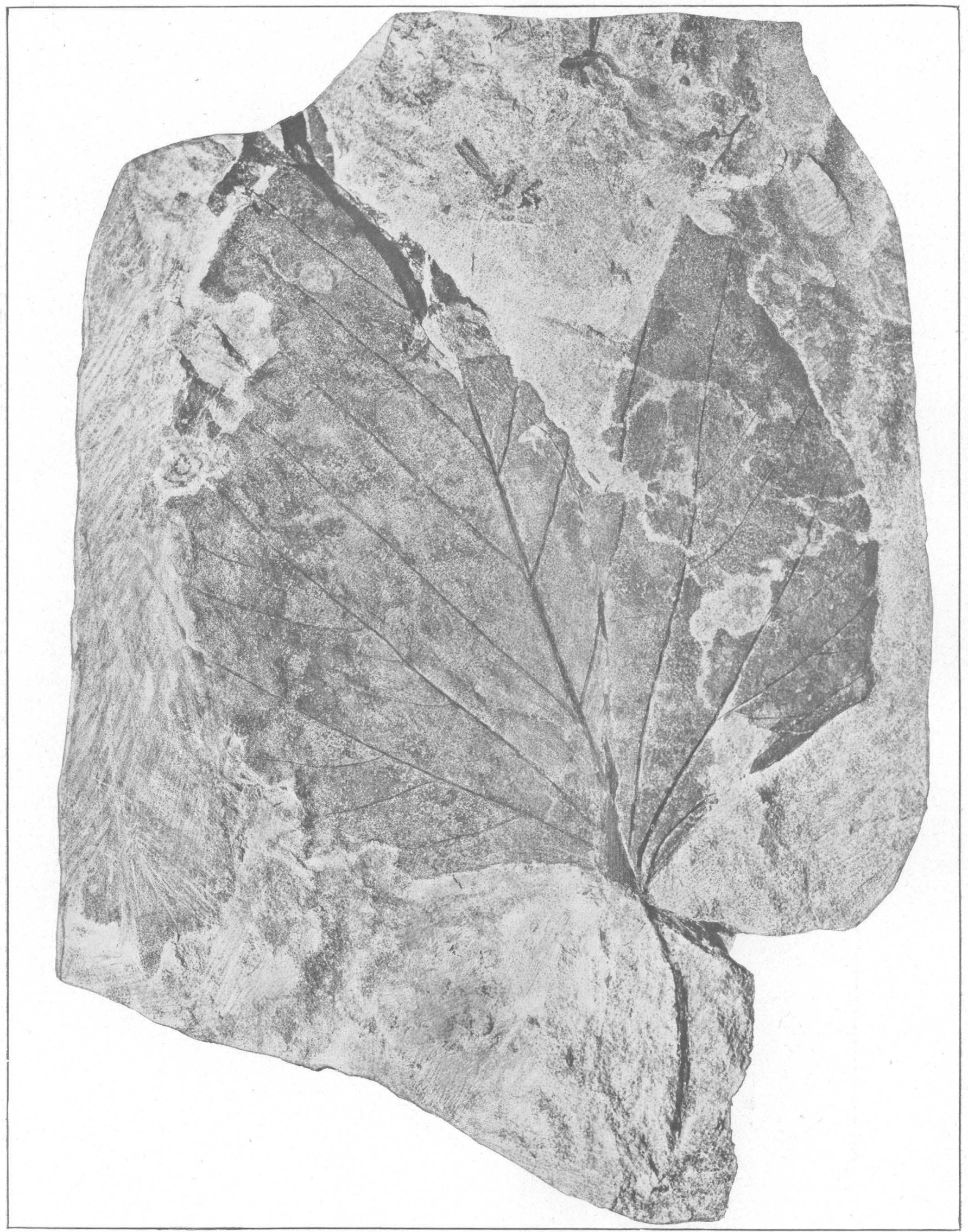

FLORA OF THE VERMEJO FORMATION. 
PLATE LI.

Phyllites walsenburgensis Knowlton, n. sp. (U. S. Nat. Mus. catalogue No. 34539)..................... 282 
PLATE LII.

Page.

Figure 1. Phyllites vermejoensis Knowlton, n. sp. (U. S. Nat. Mus. catalogue No. 34540)................. 282

2. Viburnum montanum Knowlton (U. S. Nat. Mus. catalogue No. 34541) ..................... 276

3, 4. Viburnum crassum Knowlton, n. sp. (U. S. Nat. Mus. catalogue Nos. 34542,34543$) \ldots \ldots \ldots \ldots \ldots \ldots .277$ 374 


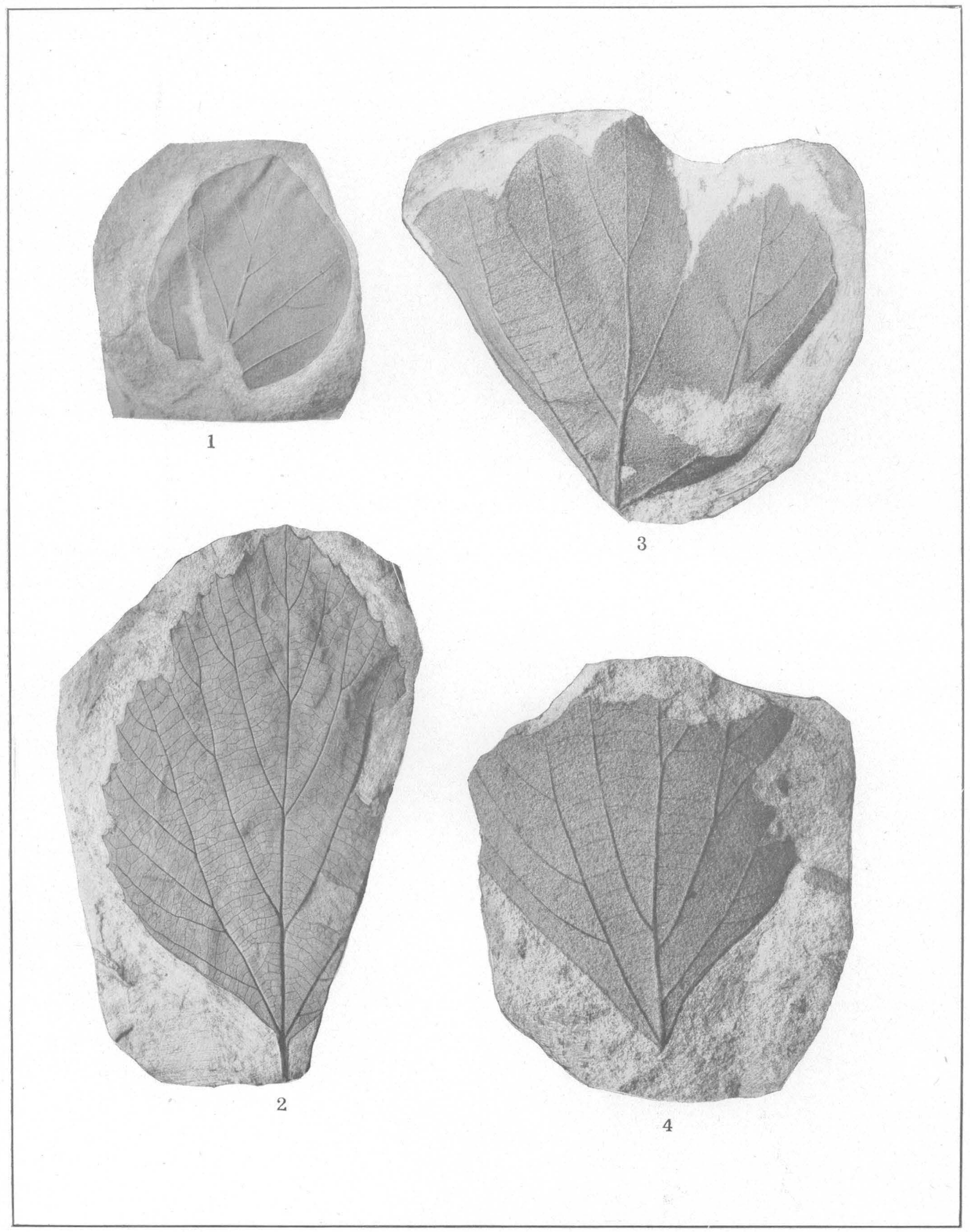

FLORA OF THE VERMEJO FORMATION. 


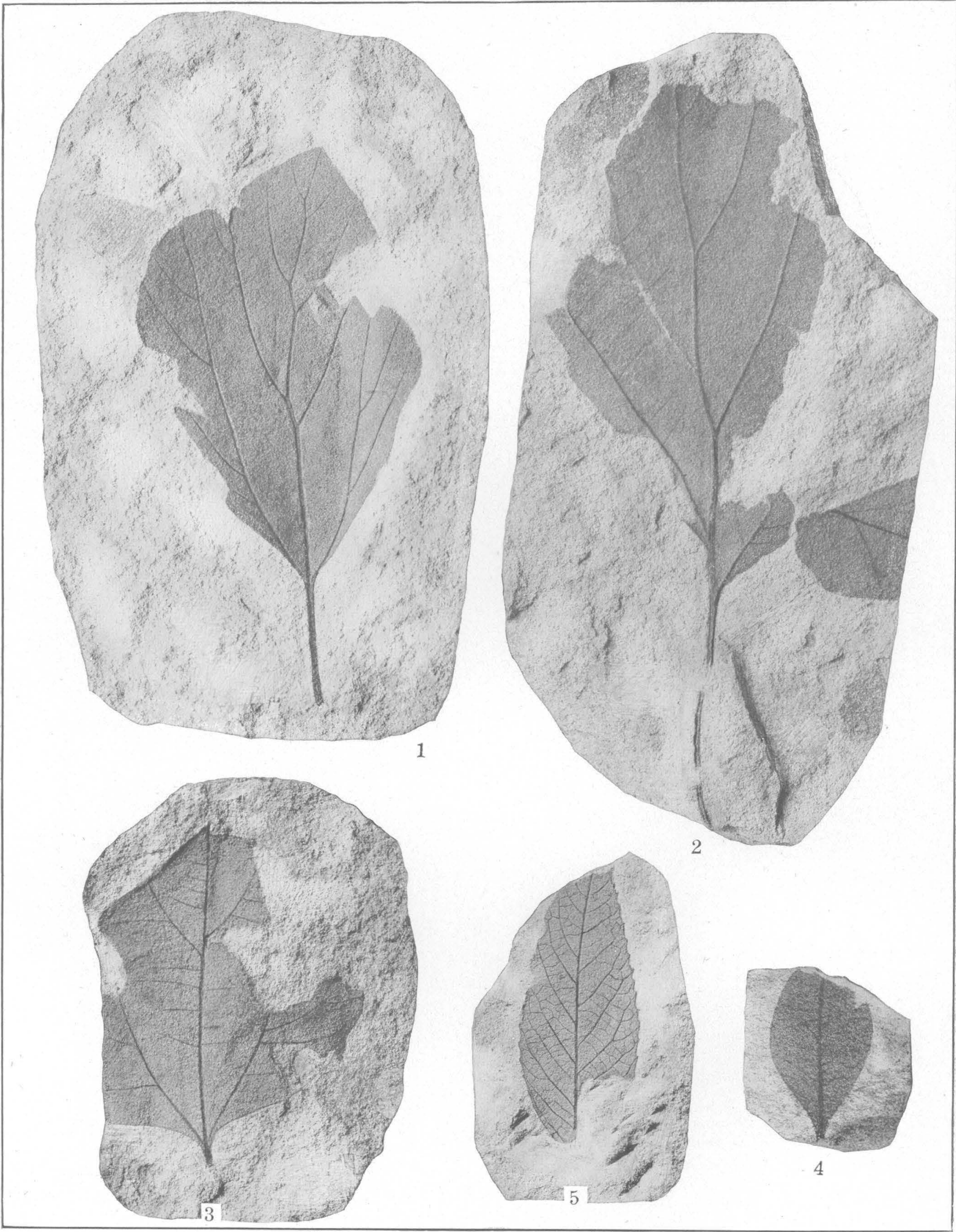

FLORA OF THE VERMEJO FORMATION. 


\section{PLATE LIII.}

Page.

Frgures 1. 2. Phyllites ratonensis Knowlton, n. sp. (U. S. Nat. Mus. catalogue Nos. 34544, 34545) ........... 283

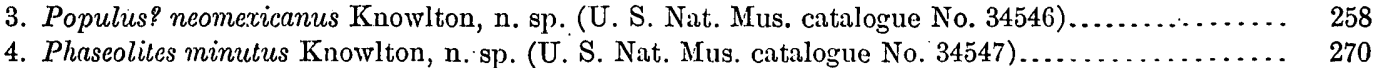

5. Dryophyllum bruneri Ward (U. S. Nat. Mus. catalogue No. 34735) .................... 259 
PLATE LIV.

Figure 1. Dryopteris? cladophleboides Knowlton, n. sp. (U. S. Nat. Mus. catalogue No. 34548)............. 284

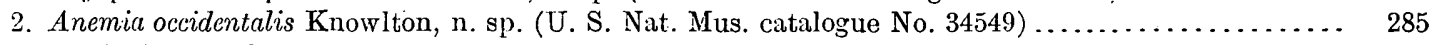

3. Pteris linearis Knowlton, n. sp. (U. S. Nat. Mus. catalogue No. 34550)................... 284

4. Asplenium? primero' Knowlton, n. sp. (U. S. Nat. Mus. catalogue No. 34551 ) . . . . . . . . . . . 285

5. Inga heterophylla Knowviton, n. sp. (U. S. Nat. Mus. catalogue No. 34552).................. 327 376 


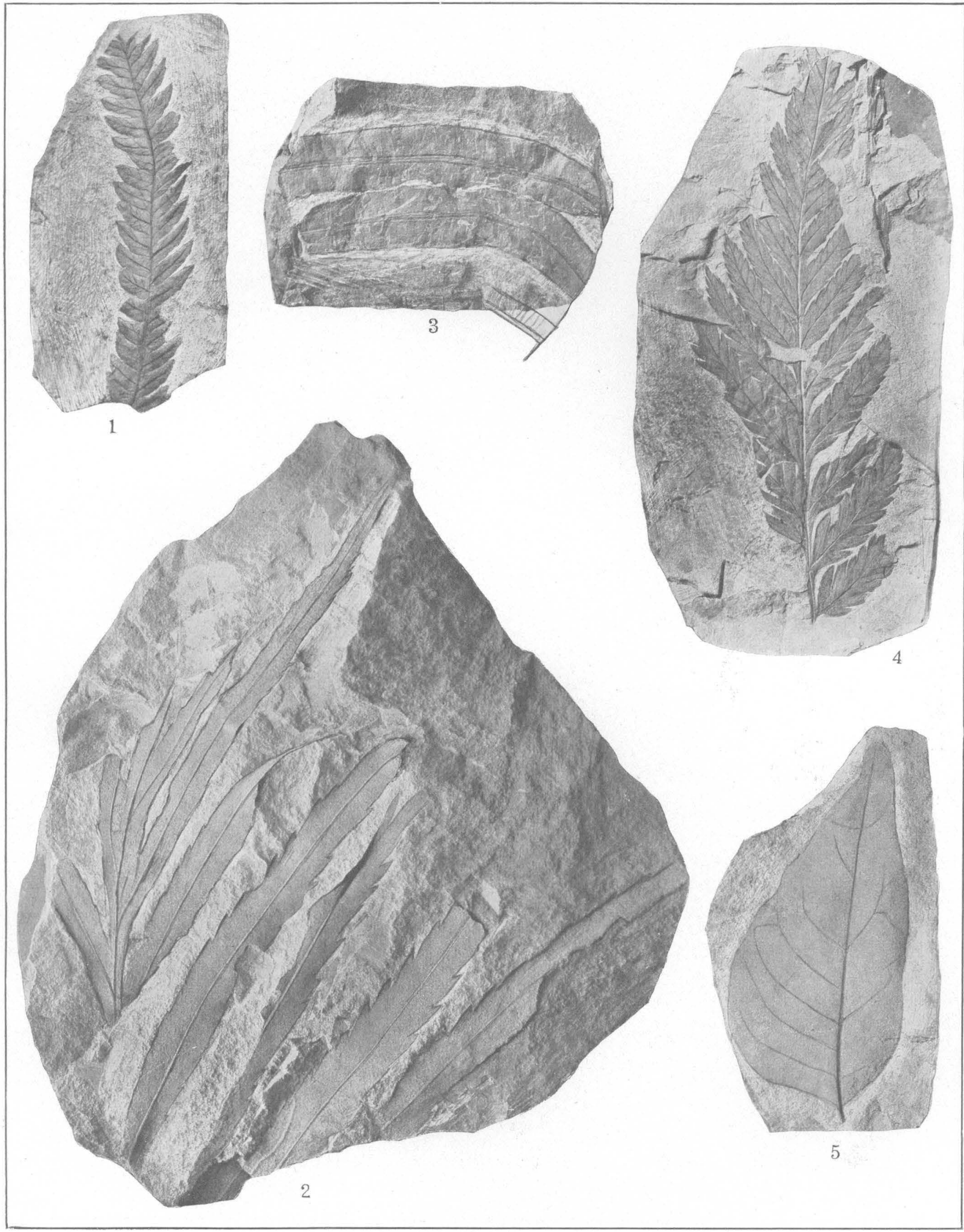

$47019^{\circ}-17-26$ 


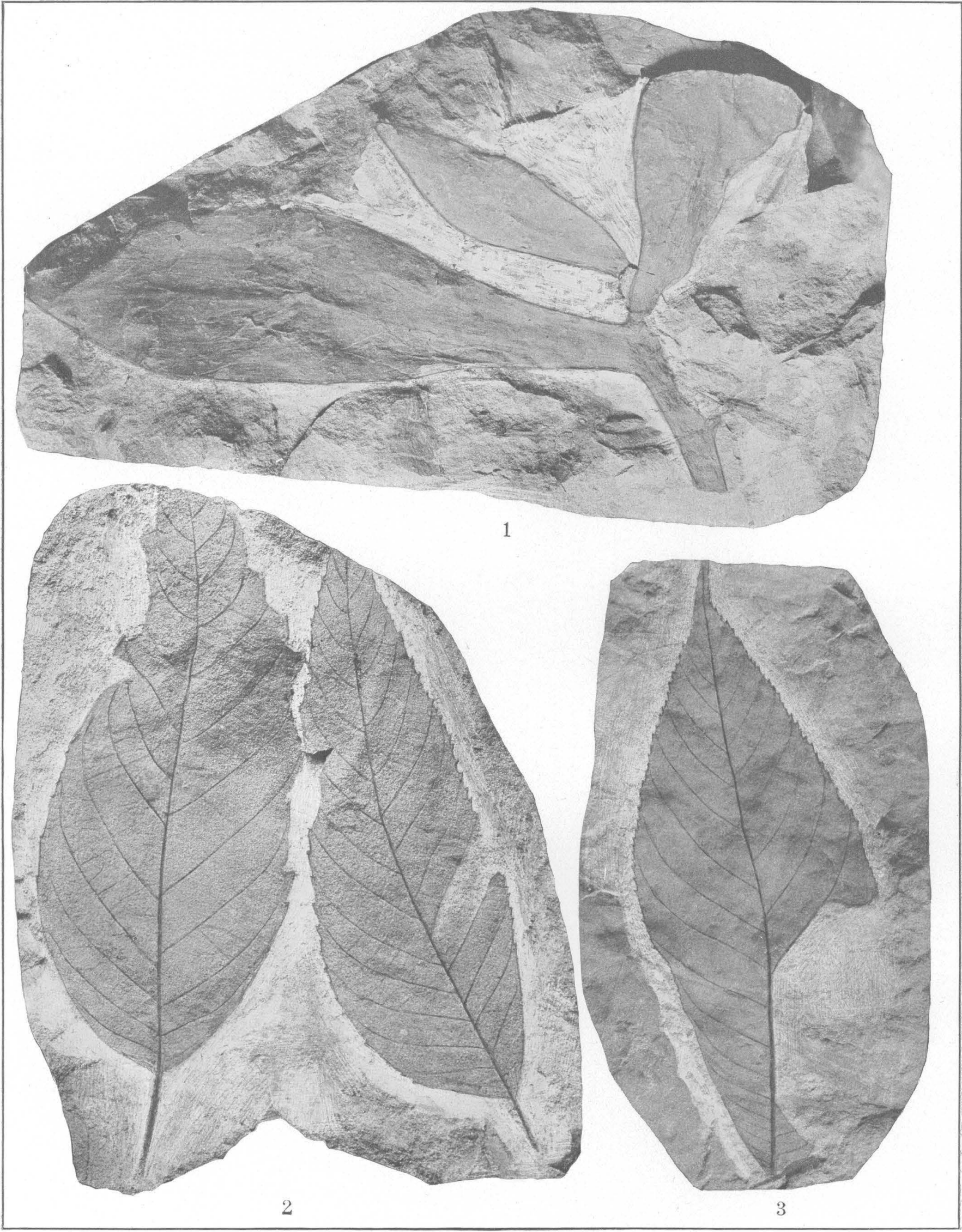

FLORA OF THE RATON FORMATION. 


\section{PLATE LV.}

Figure 1. Alismaphyllites crassifolium Knowlton, n. gen. and sp. (U. S. Nat. Mus. catalogue No. 34553)...... 286

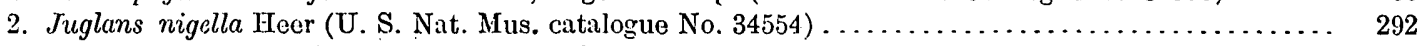

3. Juglans minutidens Knowlton, n. sp. (U. S. Nat. Mus. catalogue No. 34555) ................ 293 


\section{PLATE LVI.}

Sabal inquirenda Knowlton, n. sp. (U. S. Nat. Mus. catalogue No. 34726).

(1) 


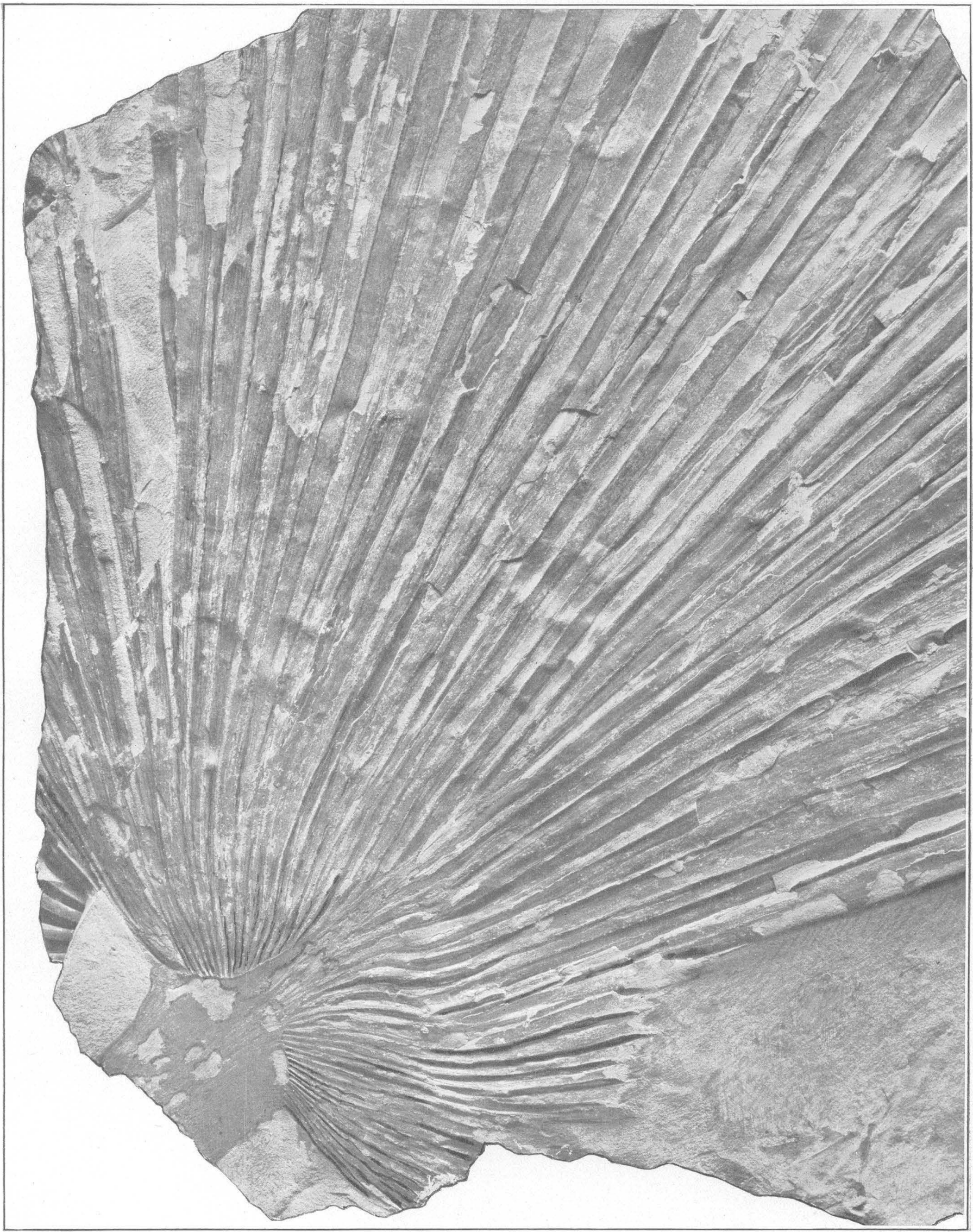

FLORA OF THE RATON FORMATION. 


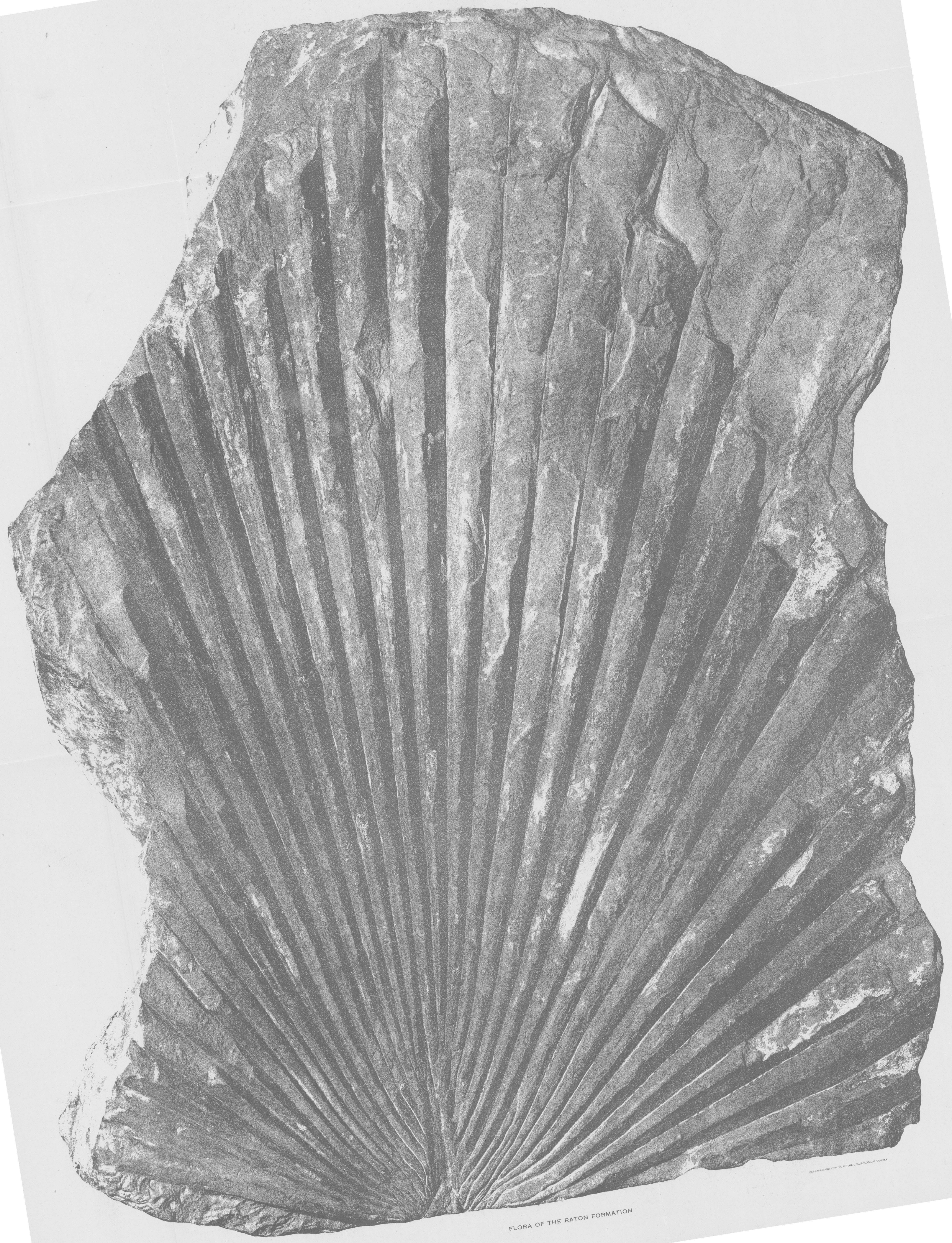


PLATE LVII.

Sabal? ungeri (Lesquereux) Knowlton, n. comb. (U. S. Nat. Mus. catalogue No. 34727)................ Paga. 289

379 
PLATE LVIII. 


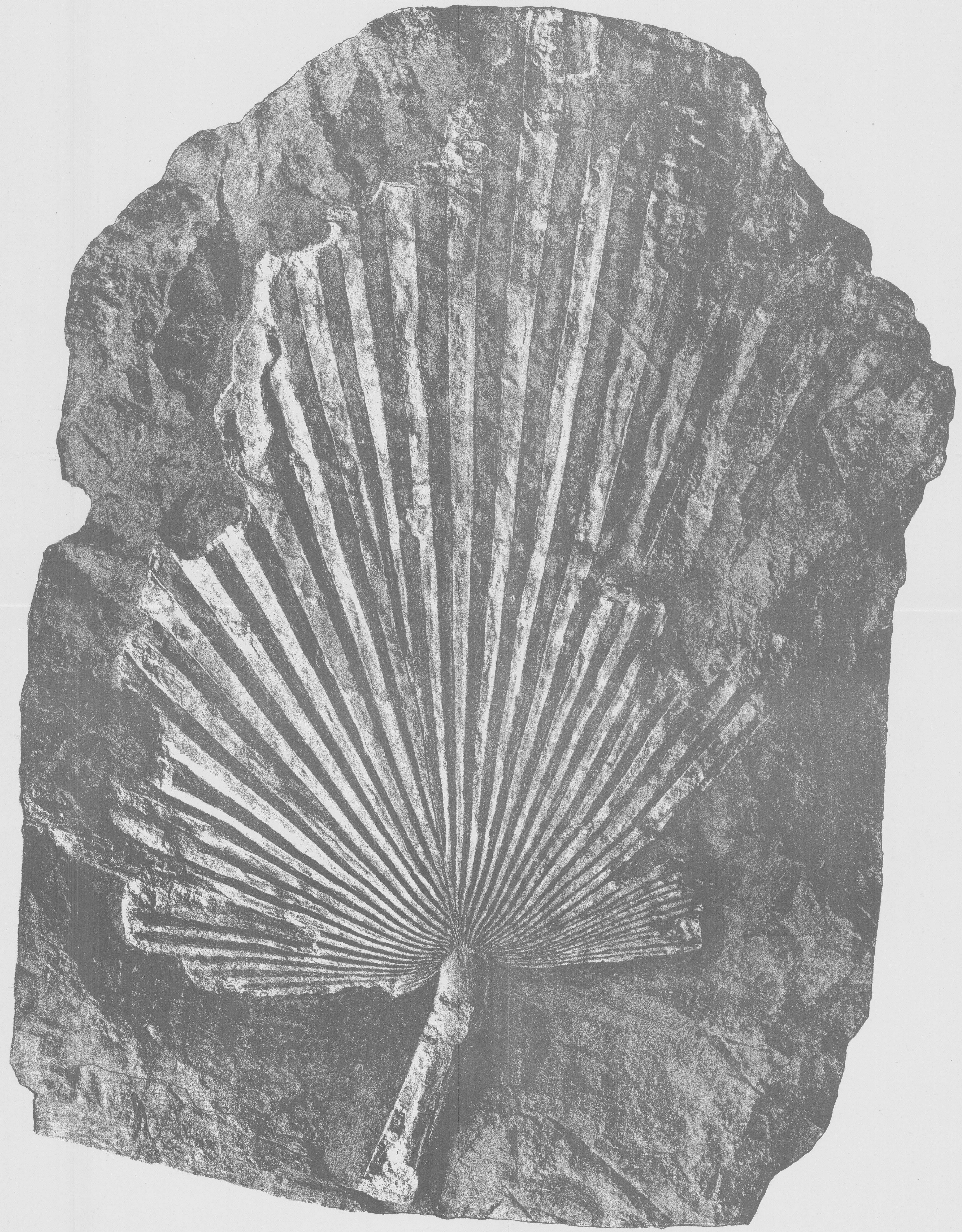




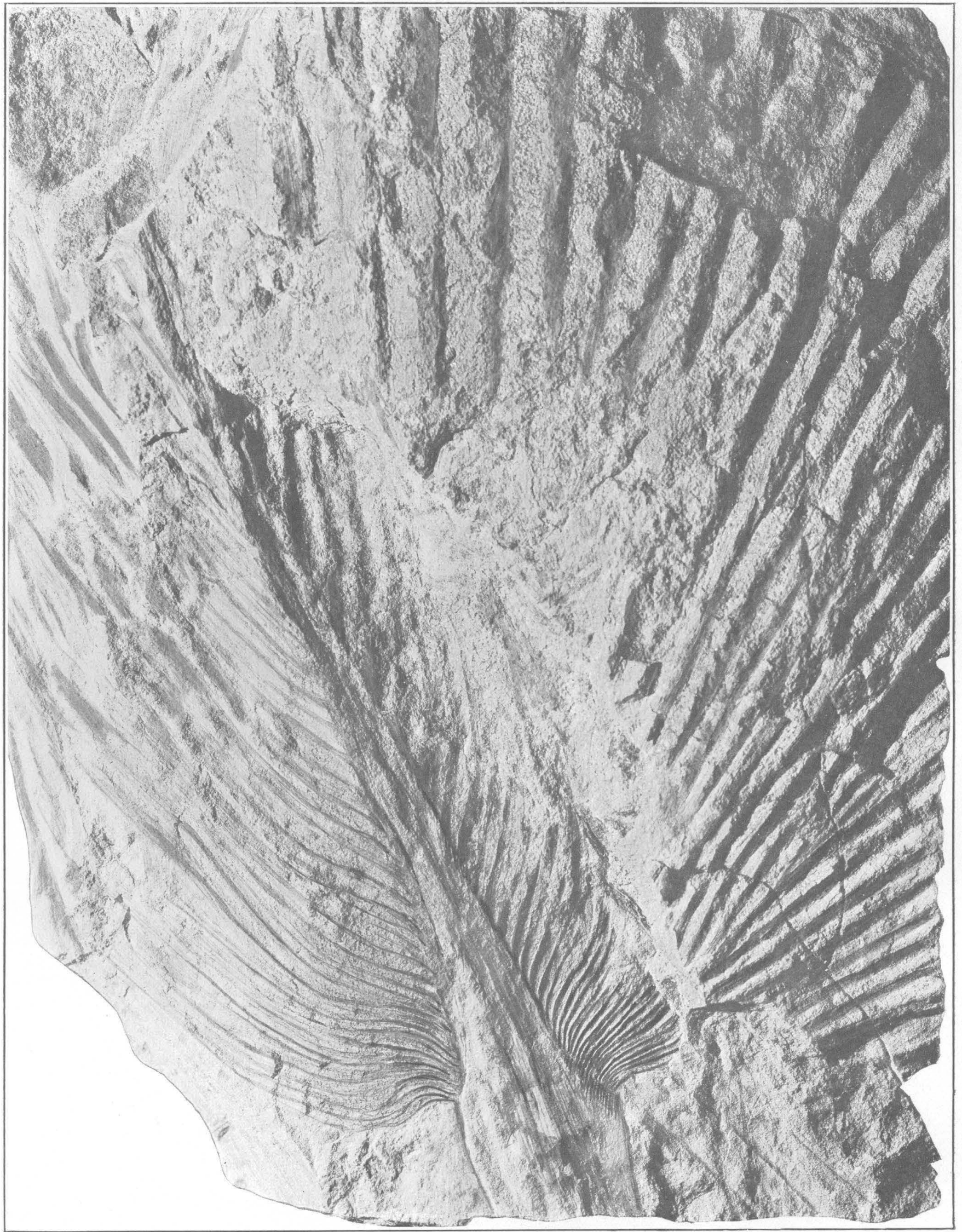

FLORA OF THE RATON FORMATION. 


\section{PLATE LIX.}


PLATE LX.

Sabal? leei Knowlton, n. sp. (U. S. Nat. Mus. catalogue No. 34730). 


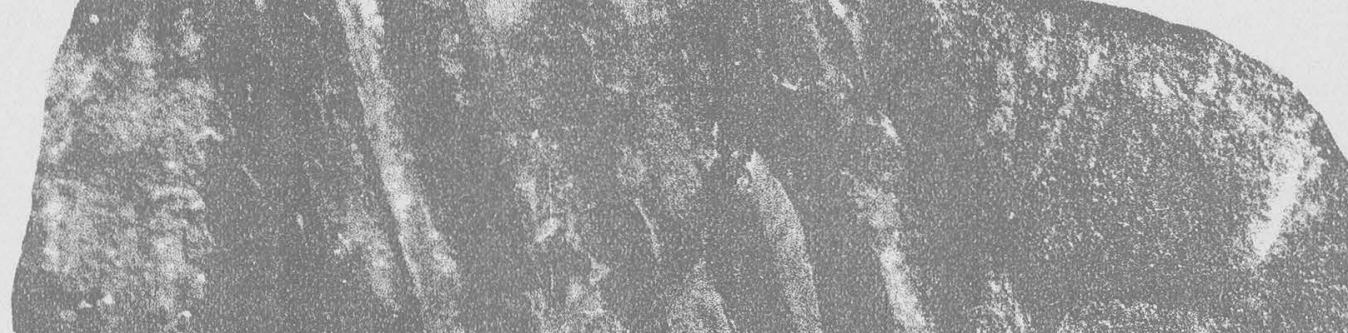

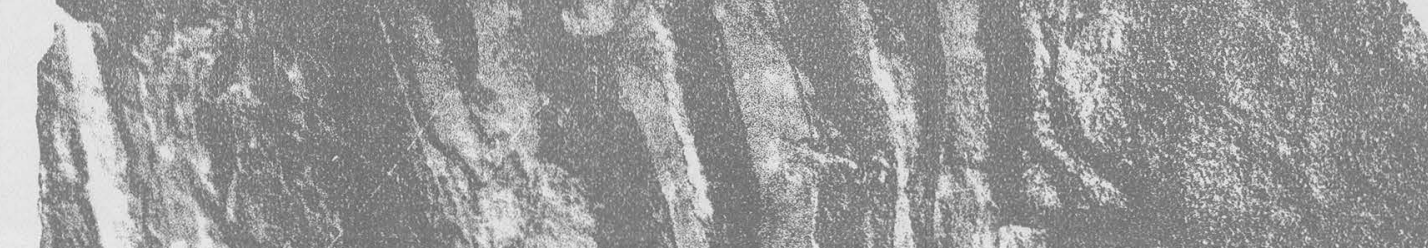

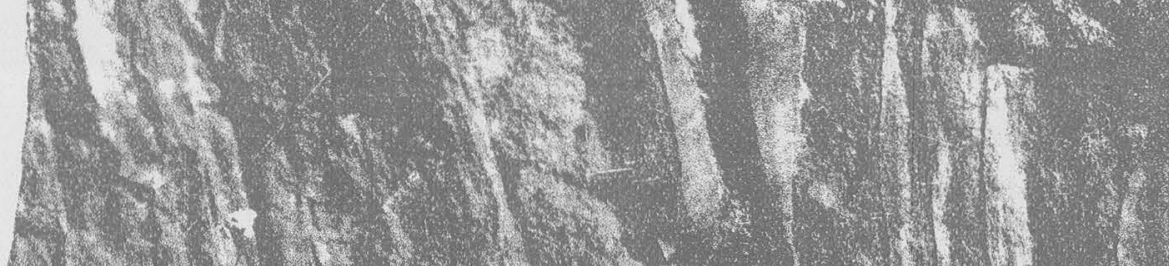

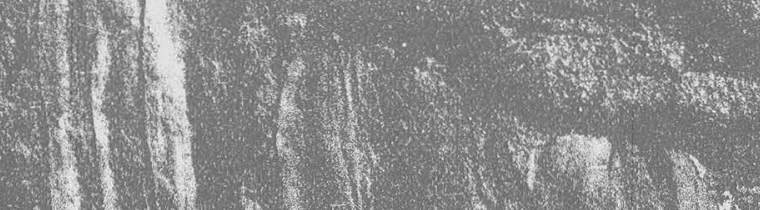

W.

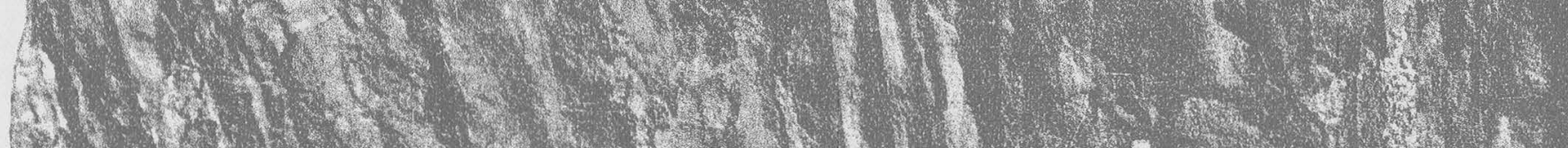

Ax). A.

(1)

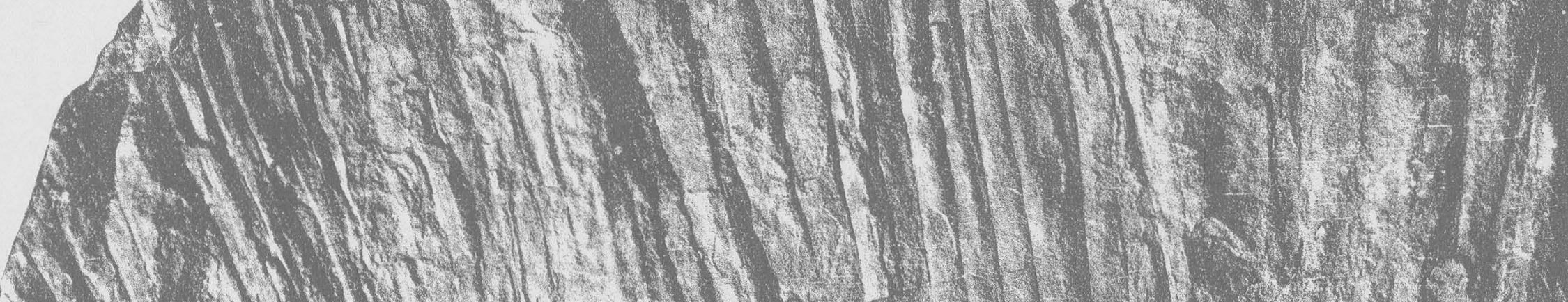

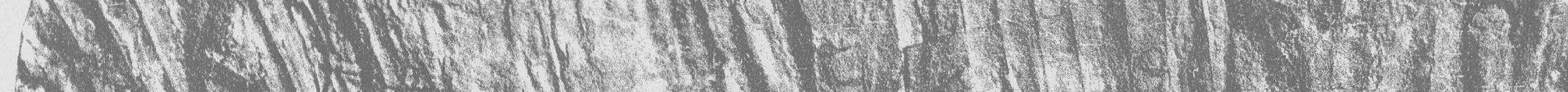

A. 1 Wh W

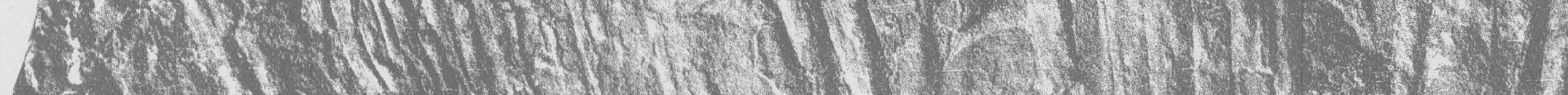

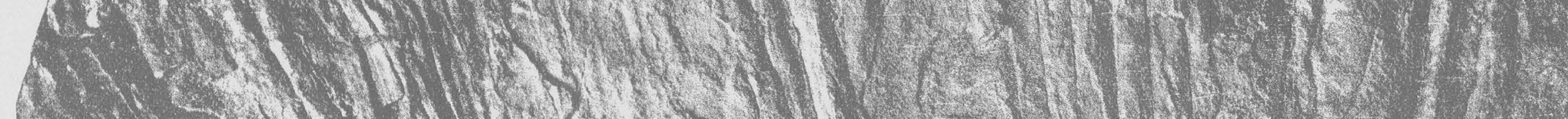

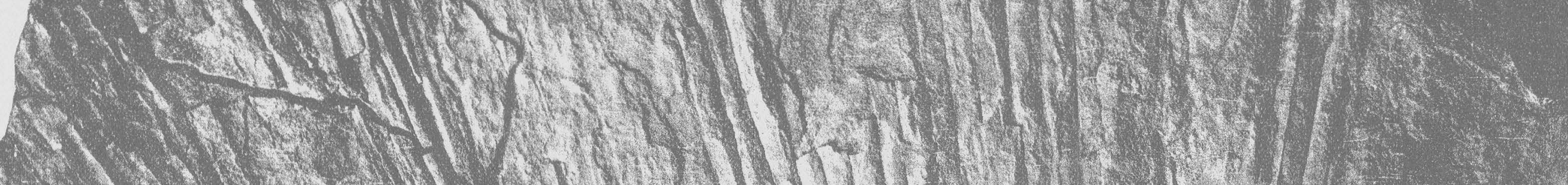

(1)

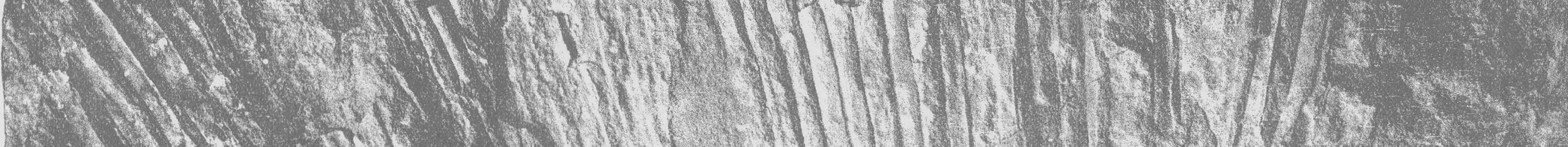

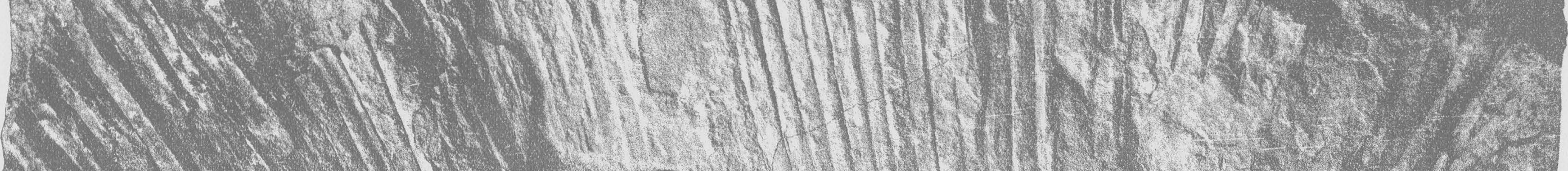

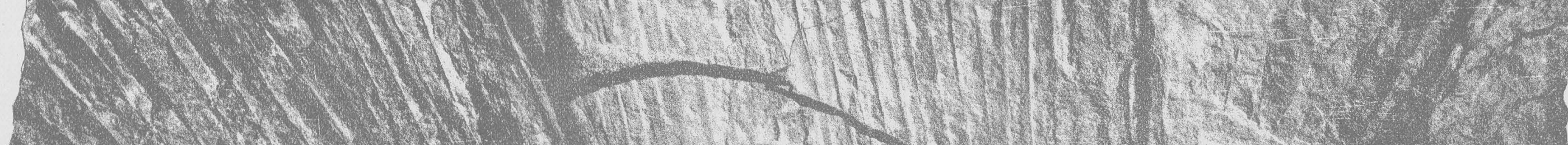

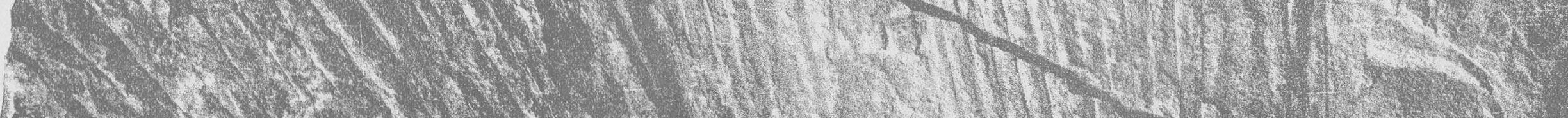

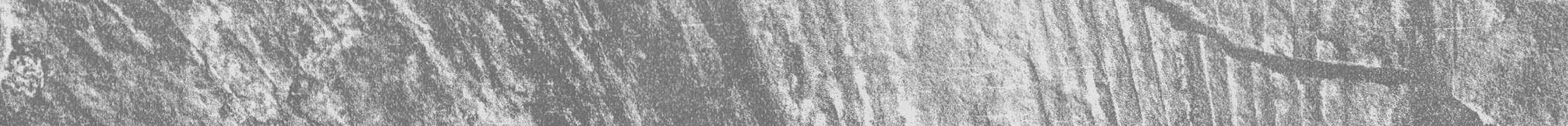

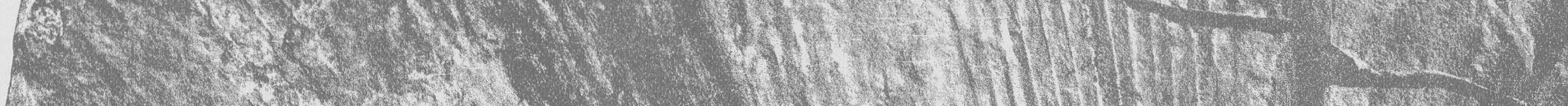
a

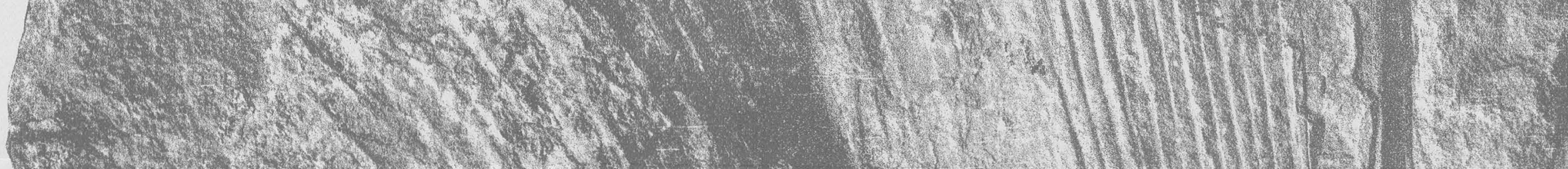

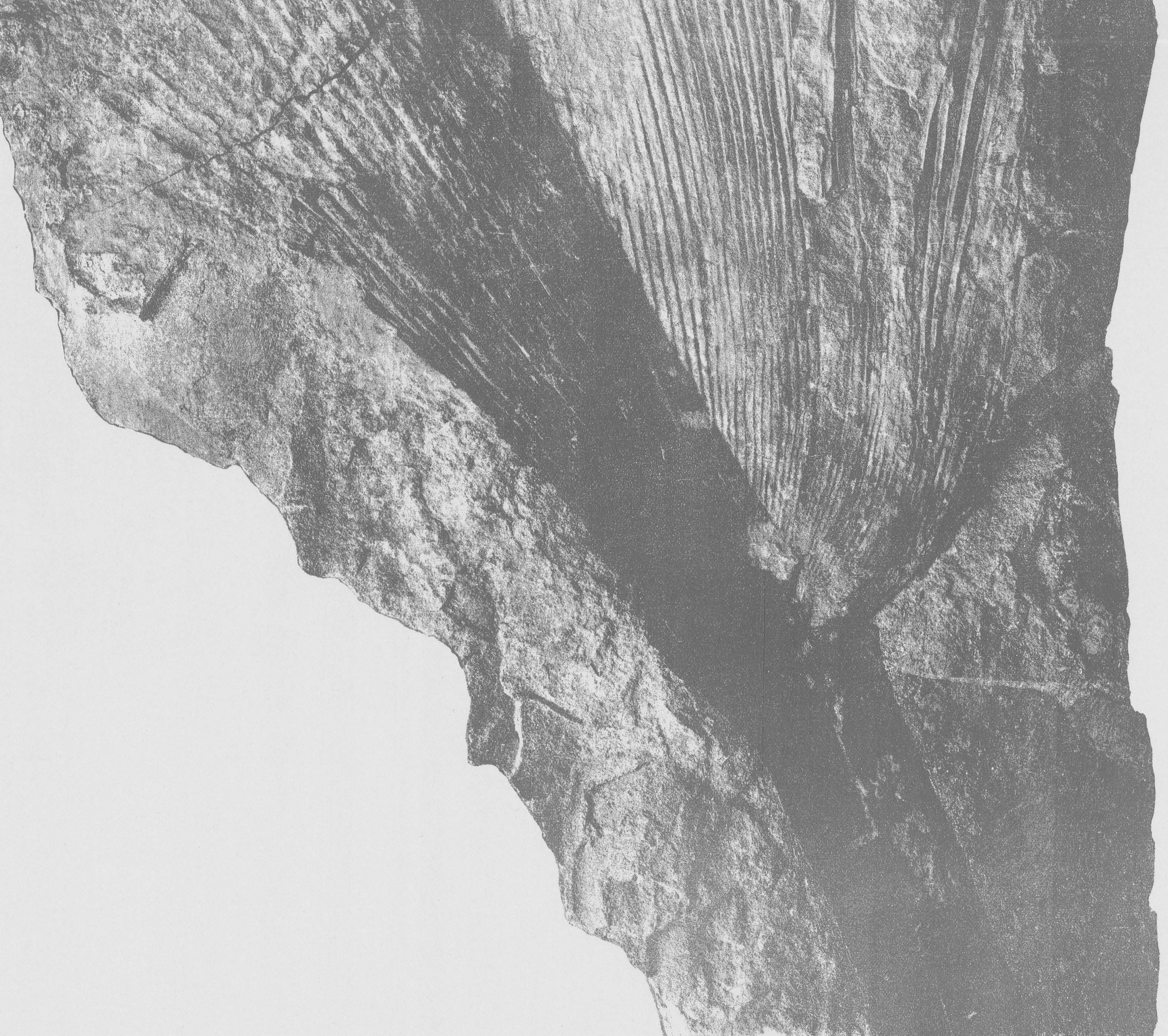




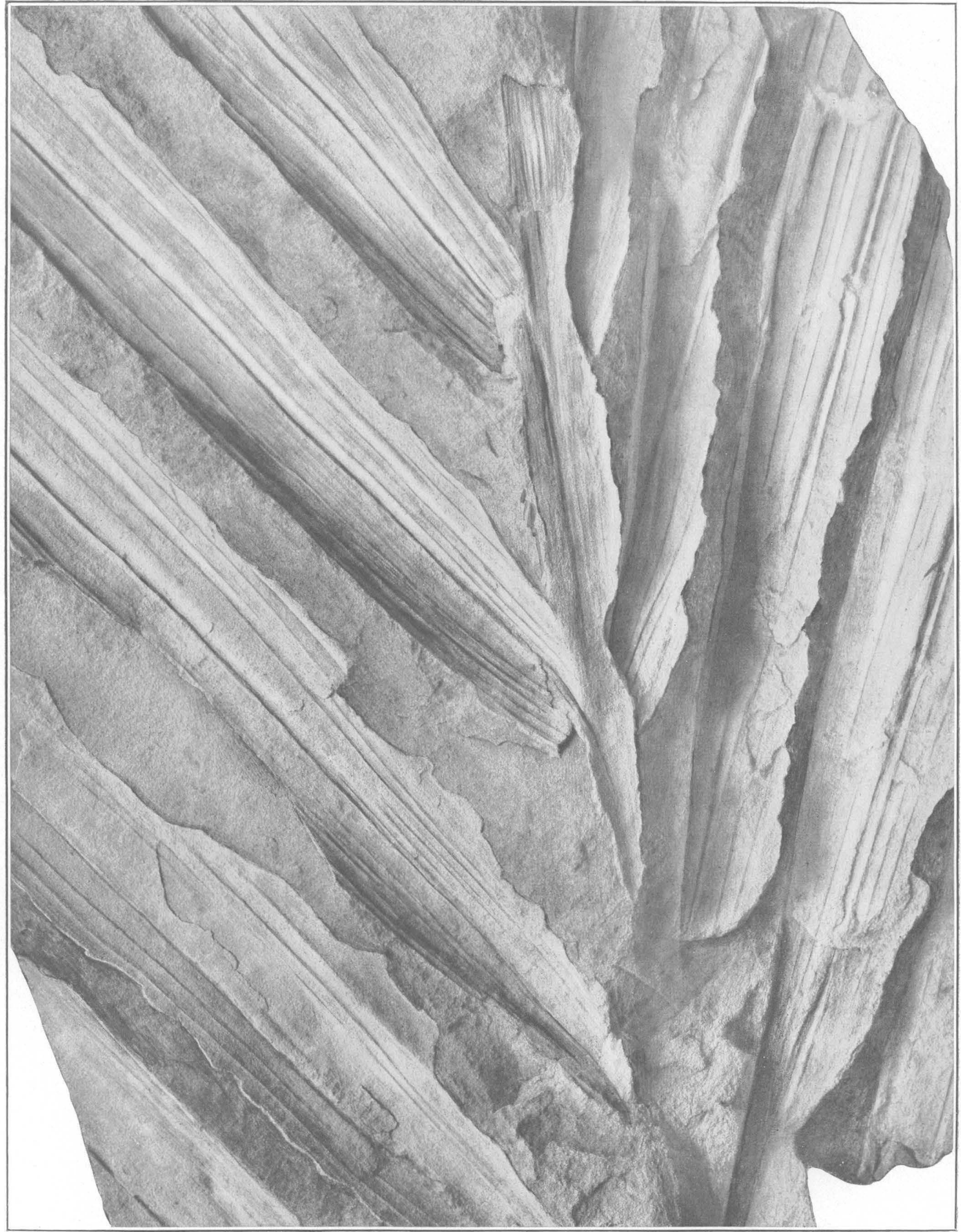

FLORA OF THE RATON FORMATION. 
PLATE LXI.

"Geonoma" gigantea Knowlton, n. sp. (U. S. Nat. Mus. catalogue No. 34731). 
PLATE LXII.

Page.

Geonomites tenuirachis Lesquereux (U. S. Nat. Mus. catalogue No. 34732)

291 384 


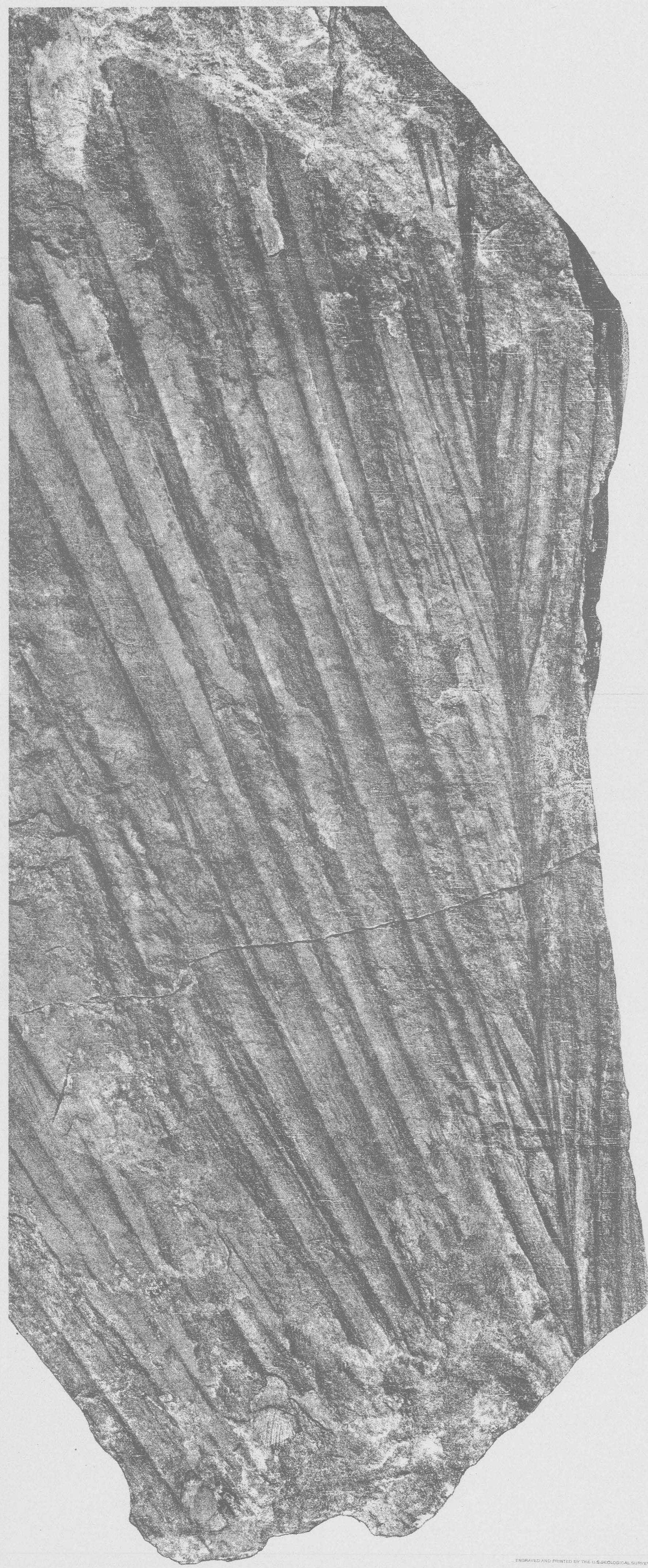

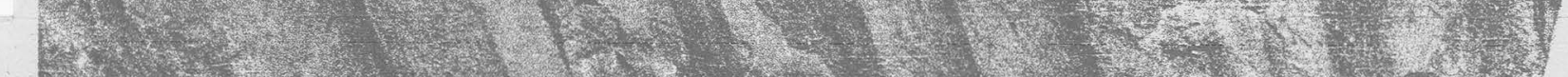

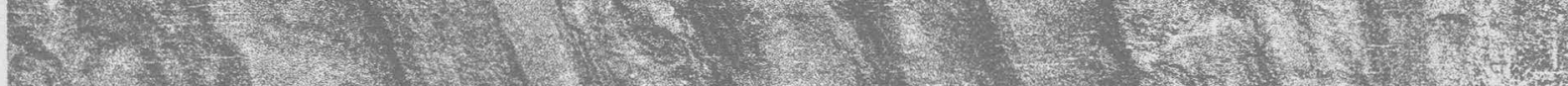

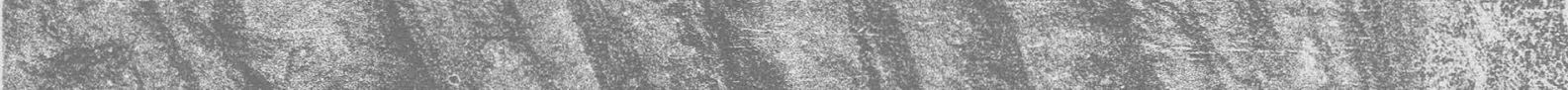

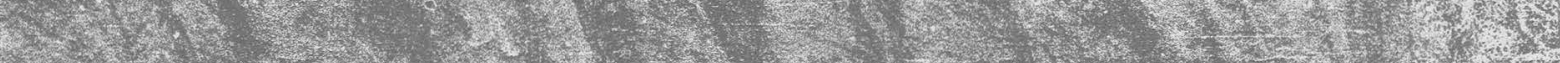

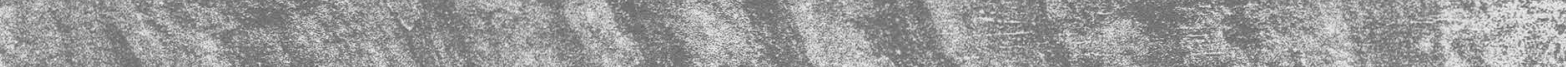

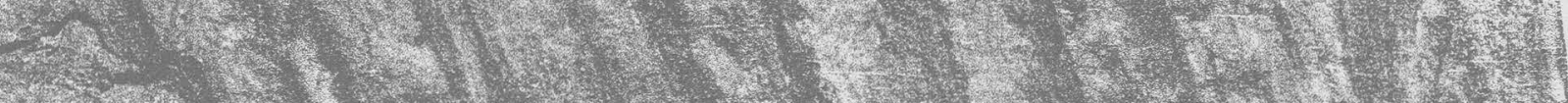

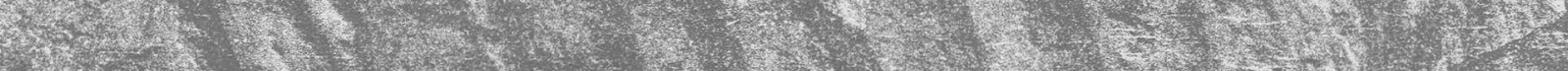

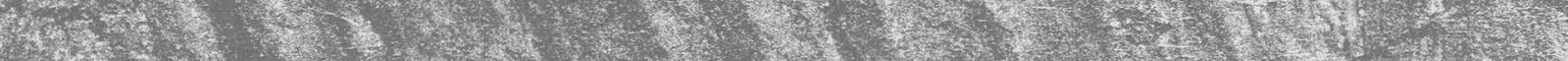

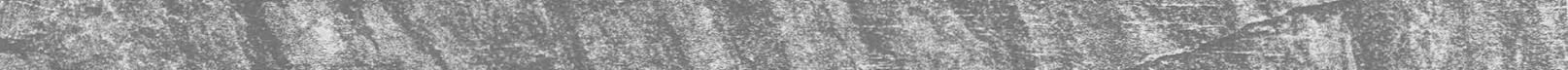
1.

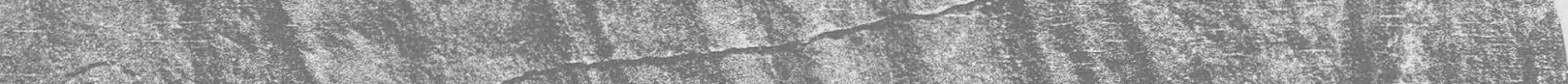

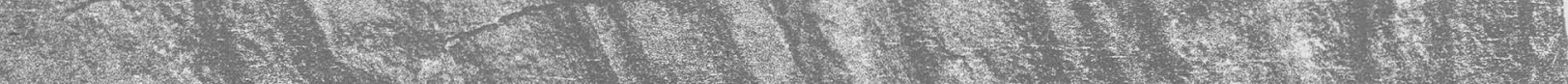

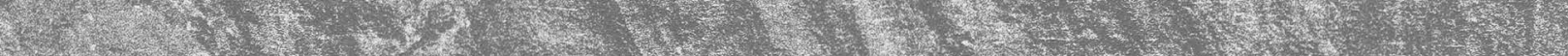

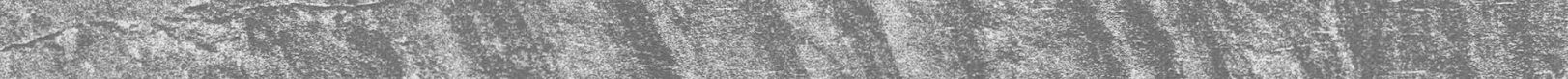

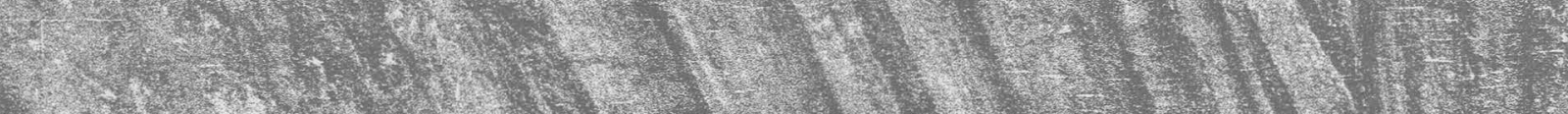

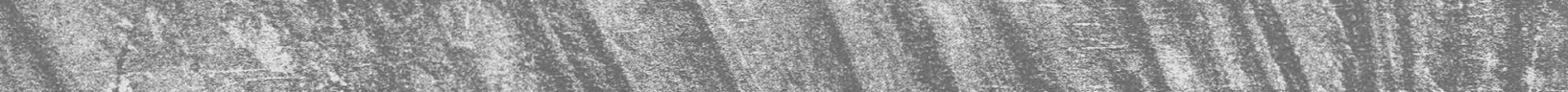

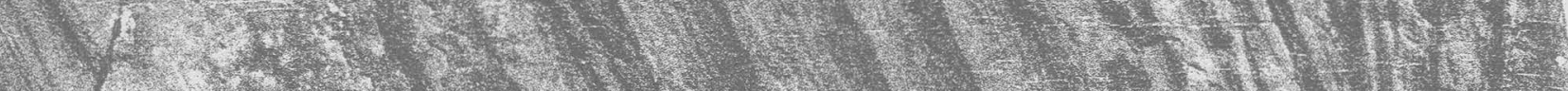

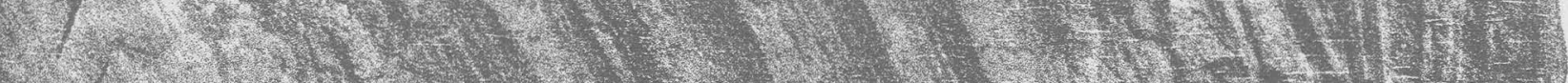
th

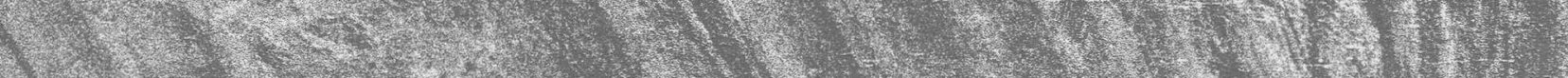

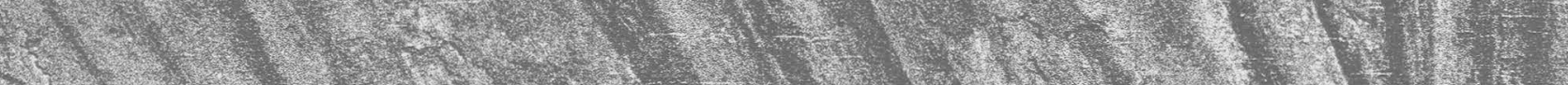

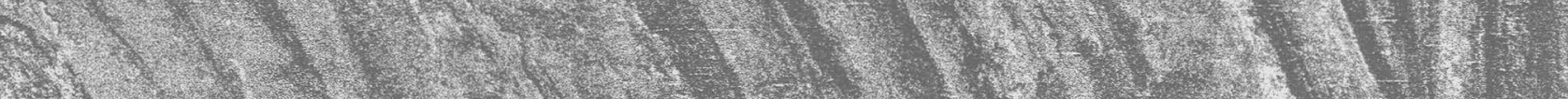

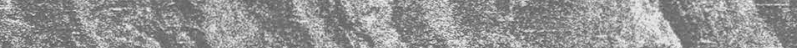
m.

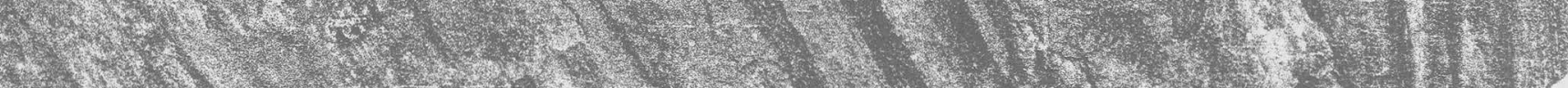

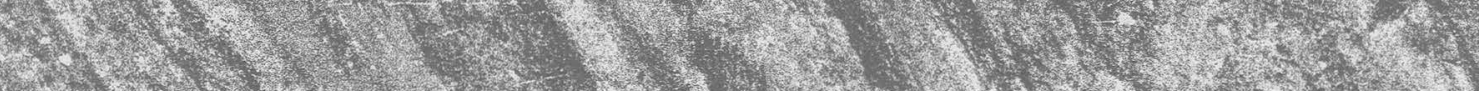

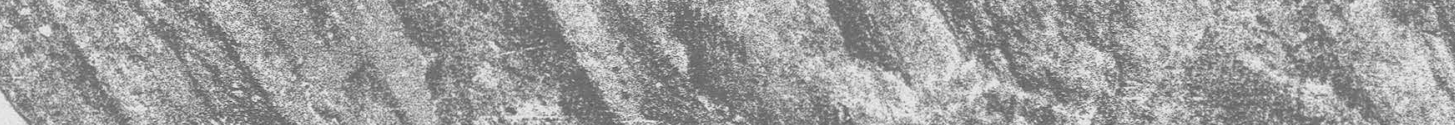
1.

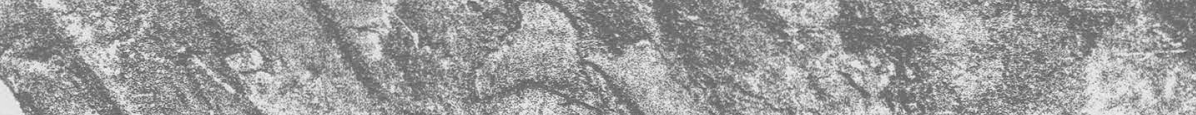

FLORA OF THE RATON FORMATION 


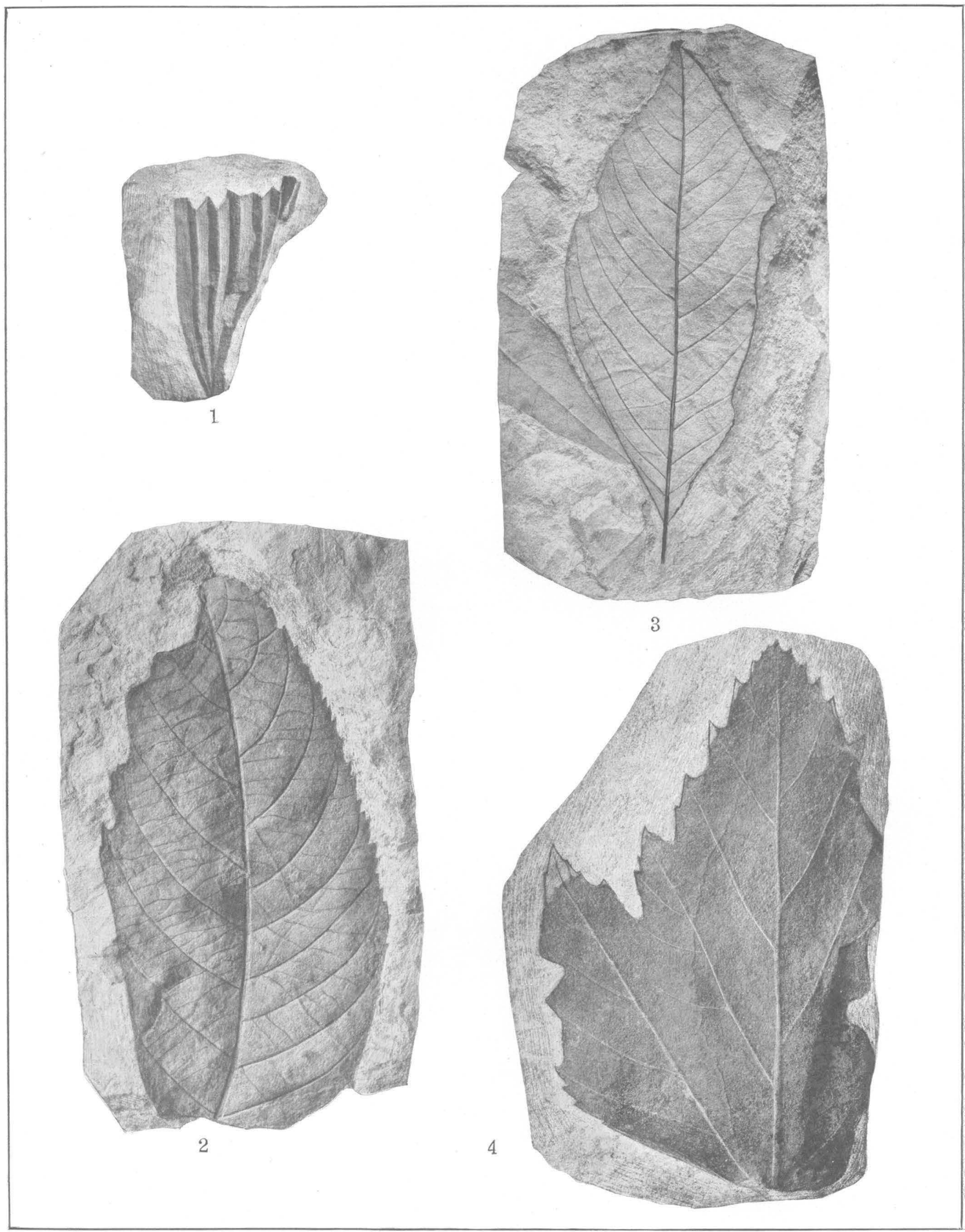

FLORA OF THE RATON FORMATION. 


\section{PLATE LXIII.}

Fraure 1. Oreodoxites plicatus Lesquereux (U. S. Nat. Mus. catalogue No. 34556)....................... 287

2. Juglans nigella Heer (U. S. Nat. Mus. catalogue No. 34557) .............................. 292

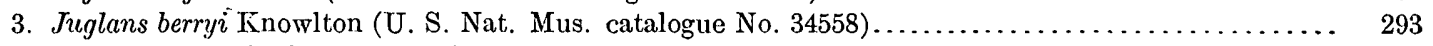

4. Platanus aceroides Göppert (U. S. Nat. Mus. catalogue No. 34559) . . . . . . . . . . . . . . . 321 
PLATE LXIV.

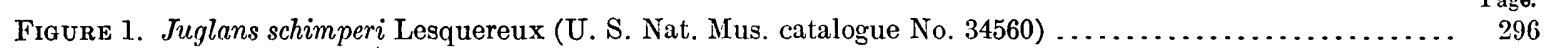

2. Magnolia leei Knowlton, n. sp. (U. S. Nat. Mus. catalogue No. 34561) ...................... 313

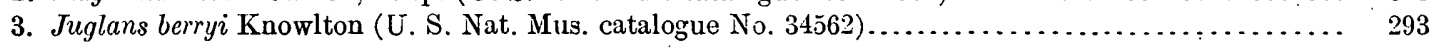
386 


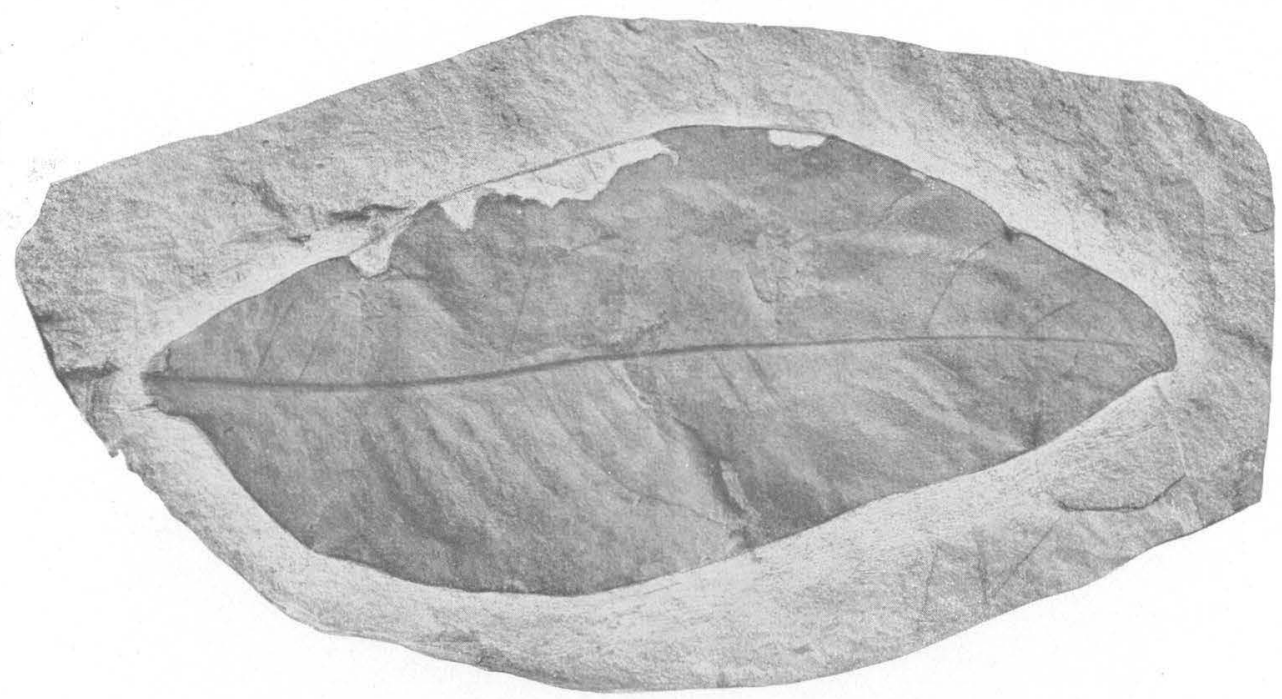

1
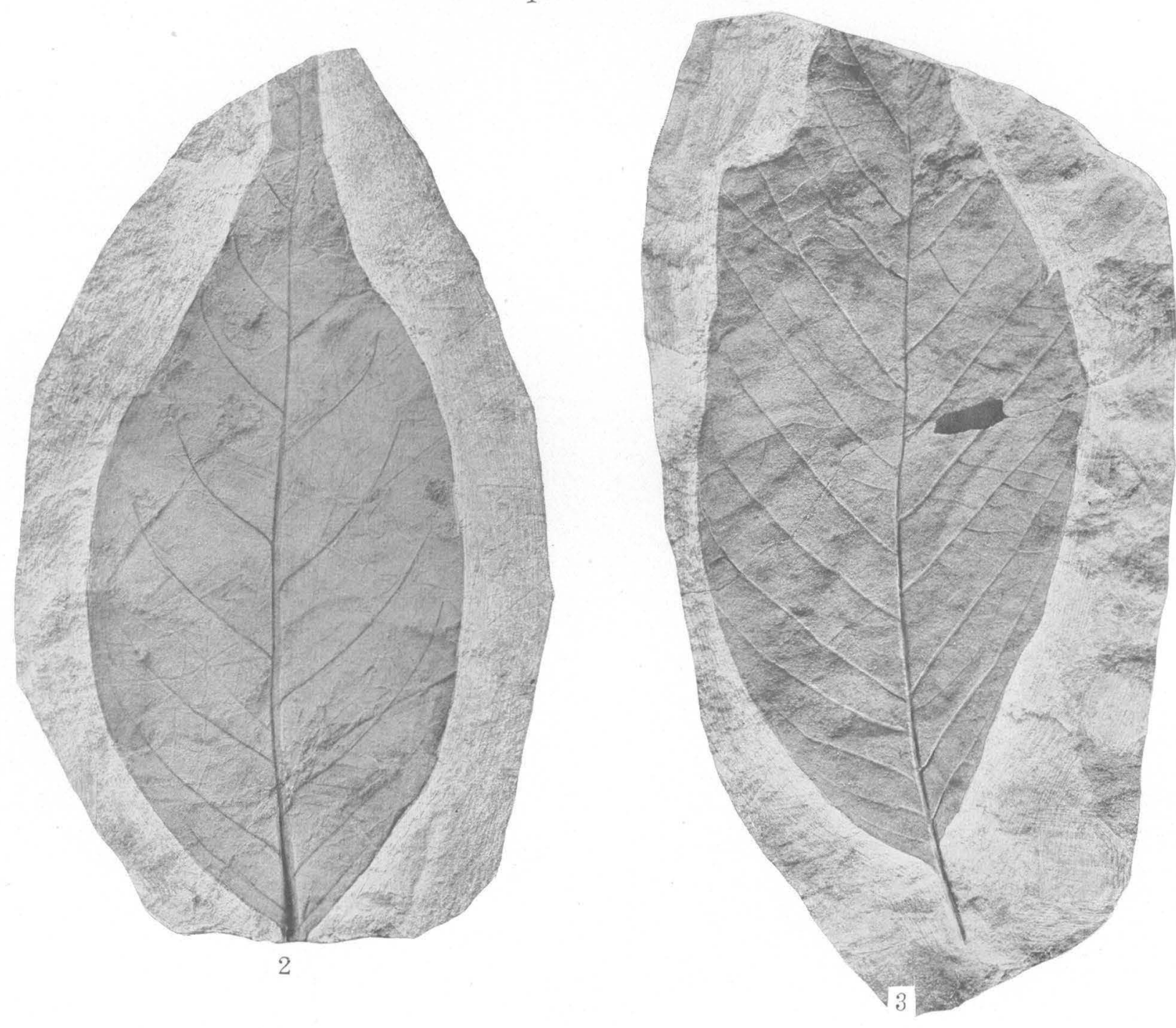

FLORA OF THE RATON FORMATION. 


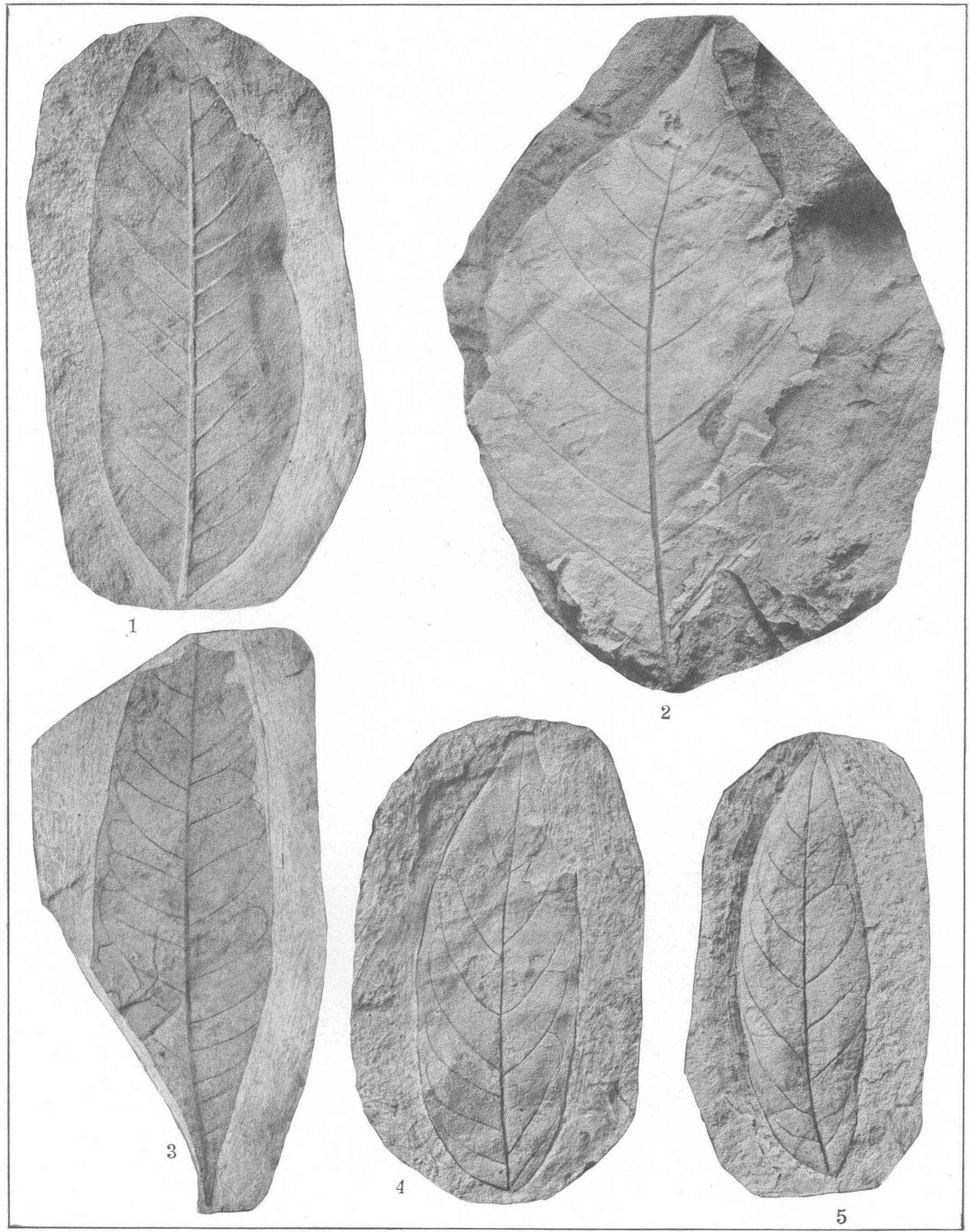

FLORA OF THE RATON FORMATION. 


\section{PLATE LXV.}

Fioure 1. Juglans acuminata Alexander Braun (U. S. Nat. Mus. catalogue No. 34563)................... 292

2. Magnolia leei Knowlton n. sp. (U. S. Nat. Mus. catalogue No. 34564) ..................... 313

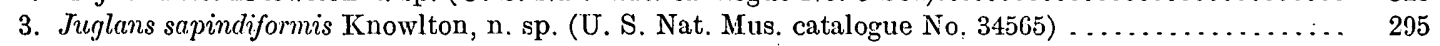

4, 5. Juglans sapindoides Knowlton, n. sp. (U. S. Nat. Mus. catalogue Nos. 34566, 34733) .......... 295 


\section{PLATE LXVI.}

Figure 1. Juglans rhamnoides Lesquereux (U. S. Nat. Mus. catalogue No. 34567) . . . . . . . . . . . . . . . 294

2. Populus neotremuloides Knowlton, n. sp. (U. S. Nat. Mus. catalogue No. 34568) . . . . . . . . . 296

3. Populus, female ament (U. S. Nat. Mus. catalogue No. 34569) . . . . . . . . . . . . . . . . 297

4. Vitis leei Knowlton, n. sp. (U. S. Nat. Mus. catalogue No. 34570 ) . . . . . . . . . . . . . . . 338 388 


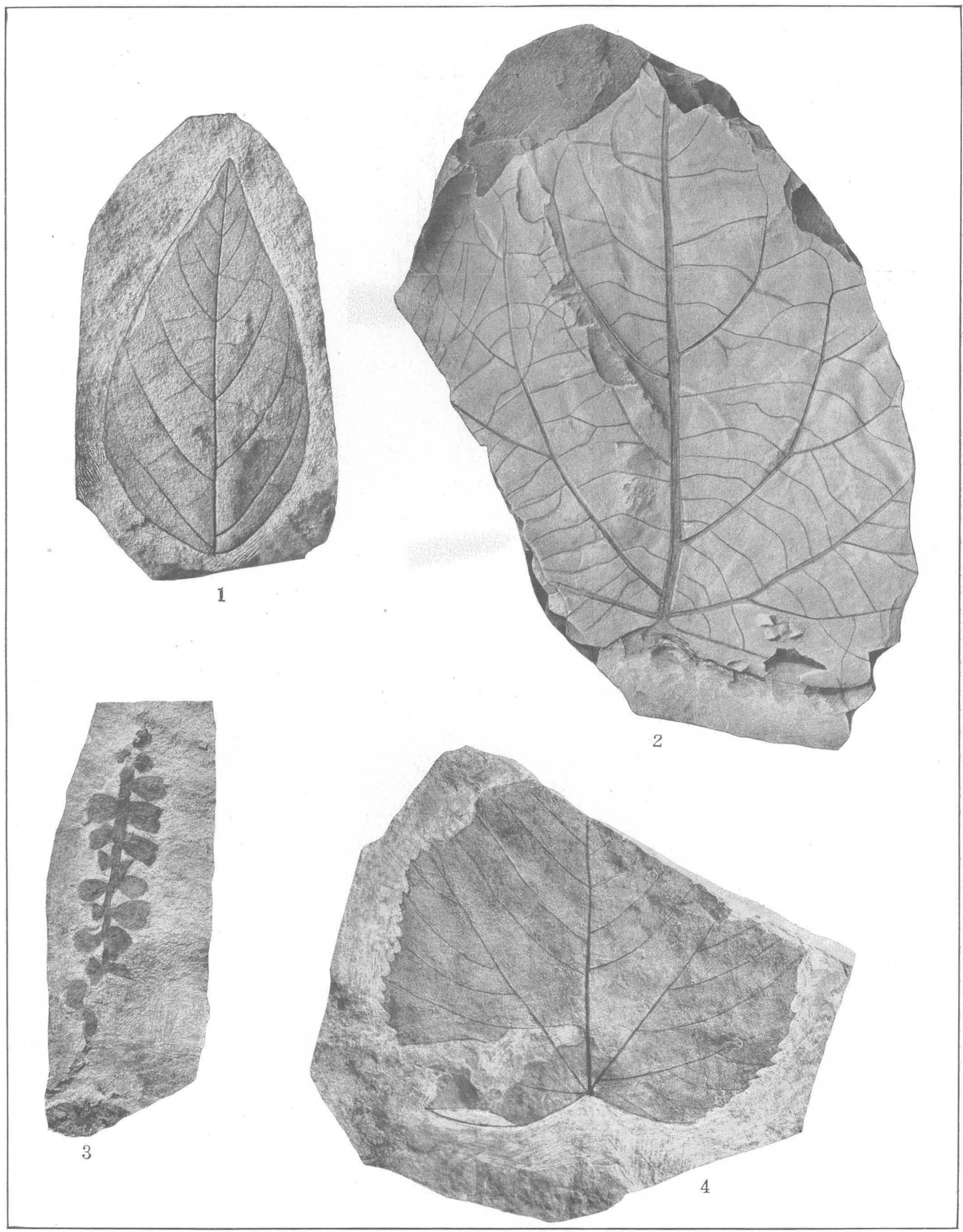

FLORA OF THE RATON FORMATION. 


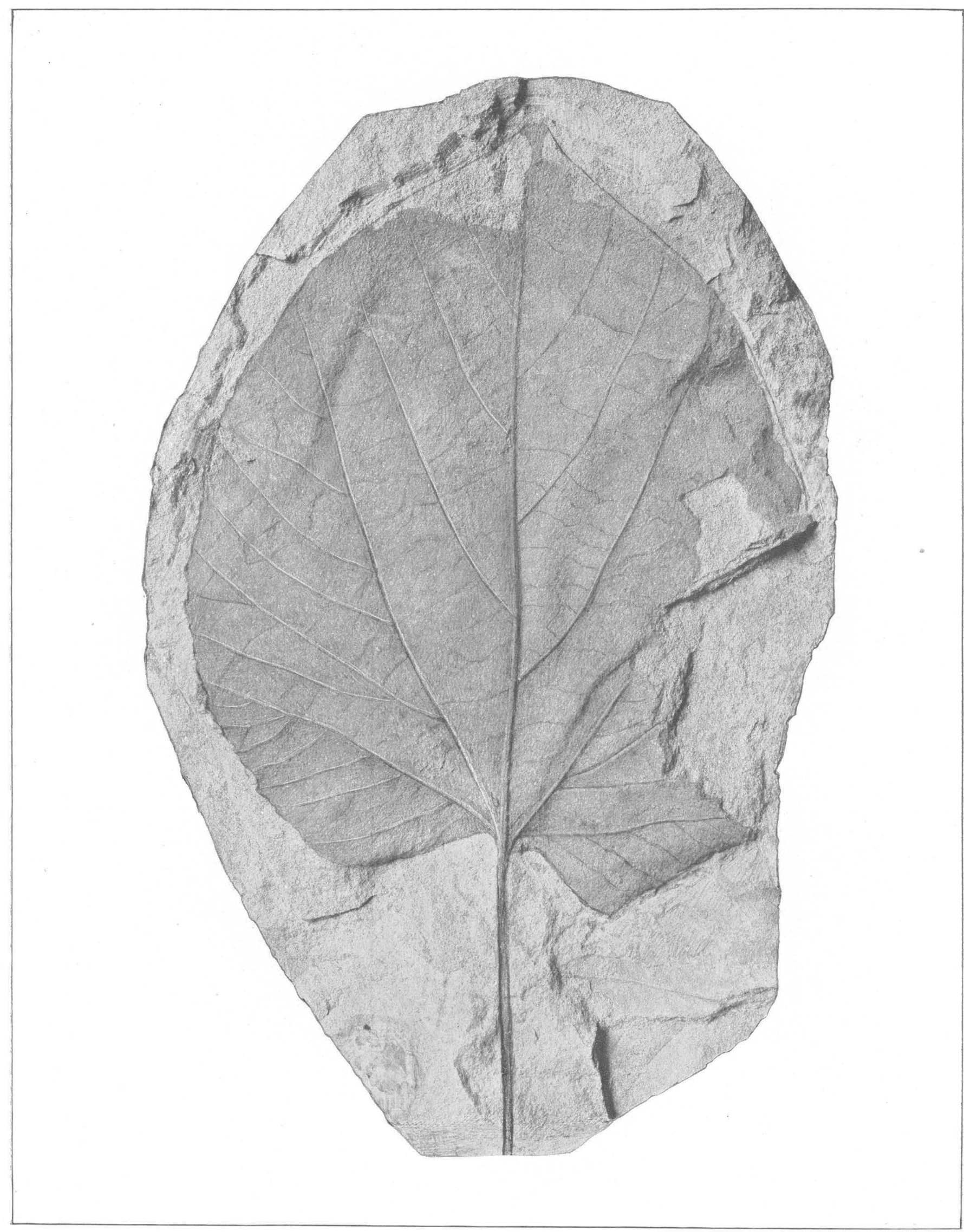

FLORA OF THE RATON FORMATION. 
PLATE LXVII.

Tilia speciosissima Knowlton, n. sp. (U. S. Nat. Mus. catalogue No. 34571). 
PLATE LXVIII.

Pagre.

Figure 1. Fagus papyracea Knowlton, n. sp. (U. S. Nat. Mus. catalogue No. 34572)..................... 297

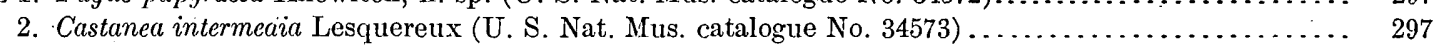

3, 4. Quercus fisheriana Knowlton, n. sp. (U. S. Nat. Mus. catalogue Nos. 34574, 34575)............. 297 390 


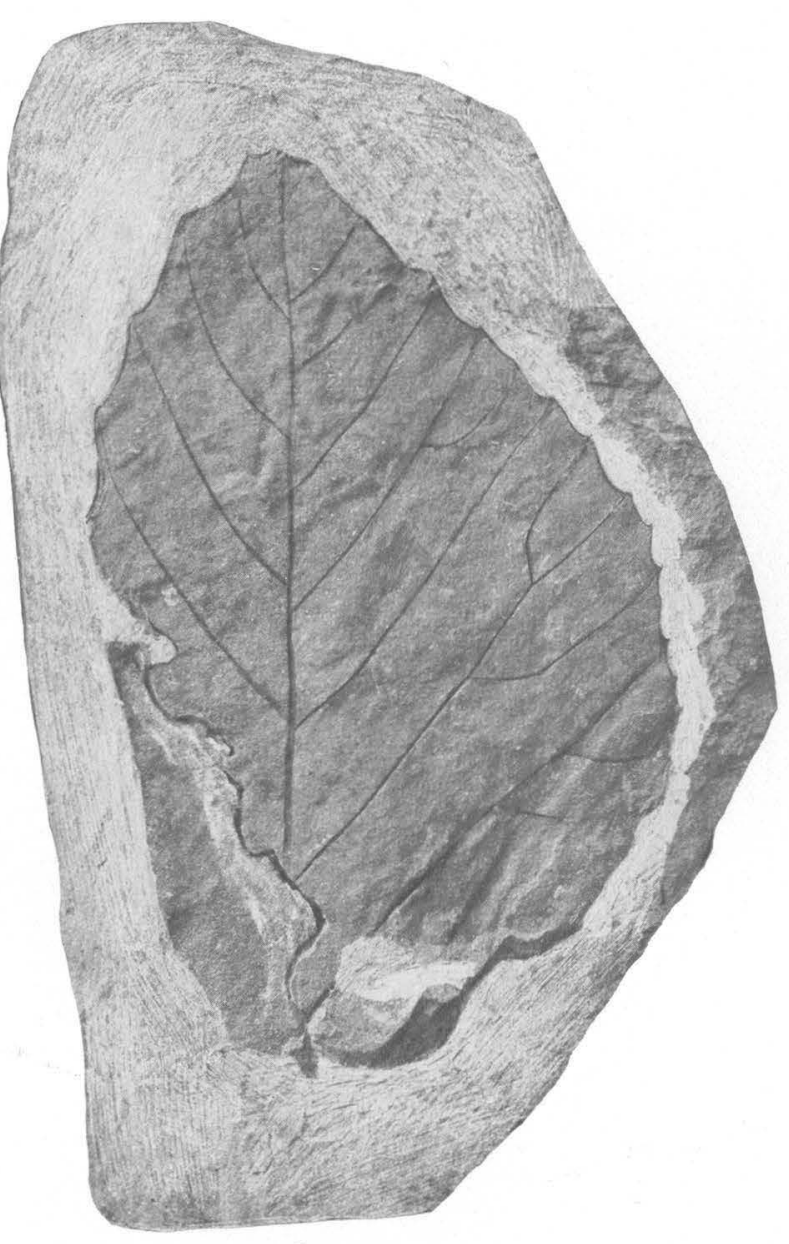

1

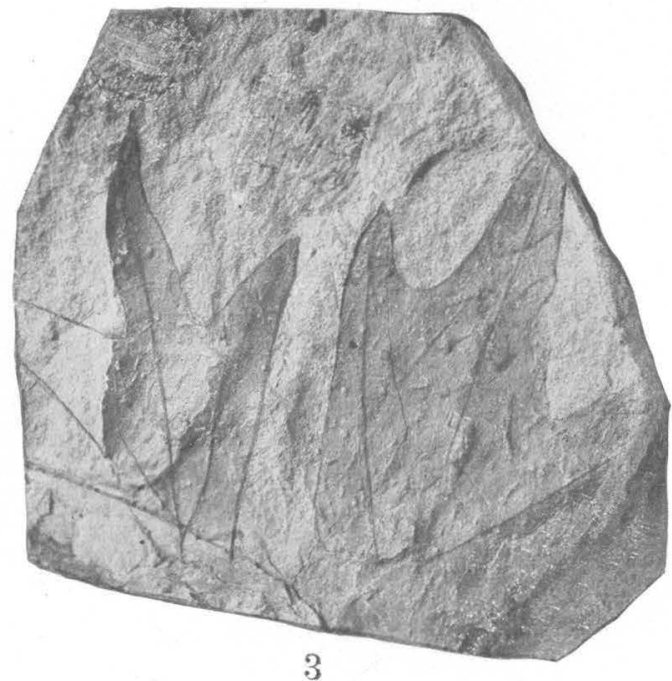

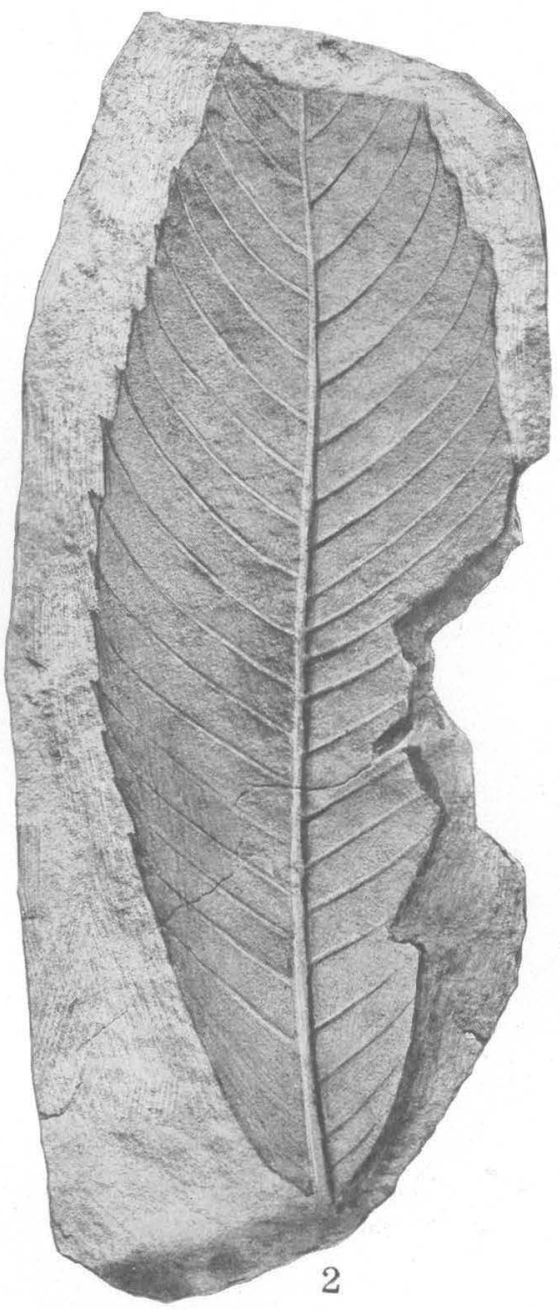

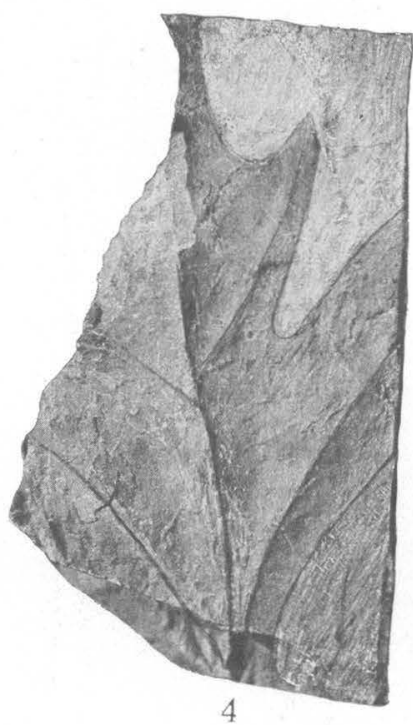




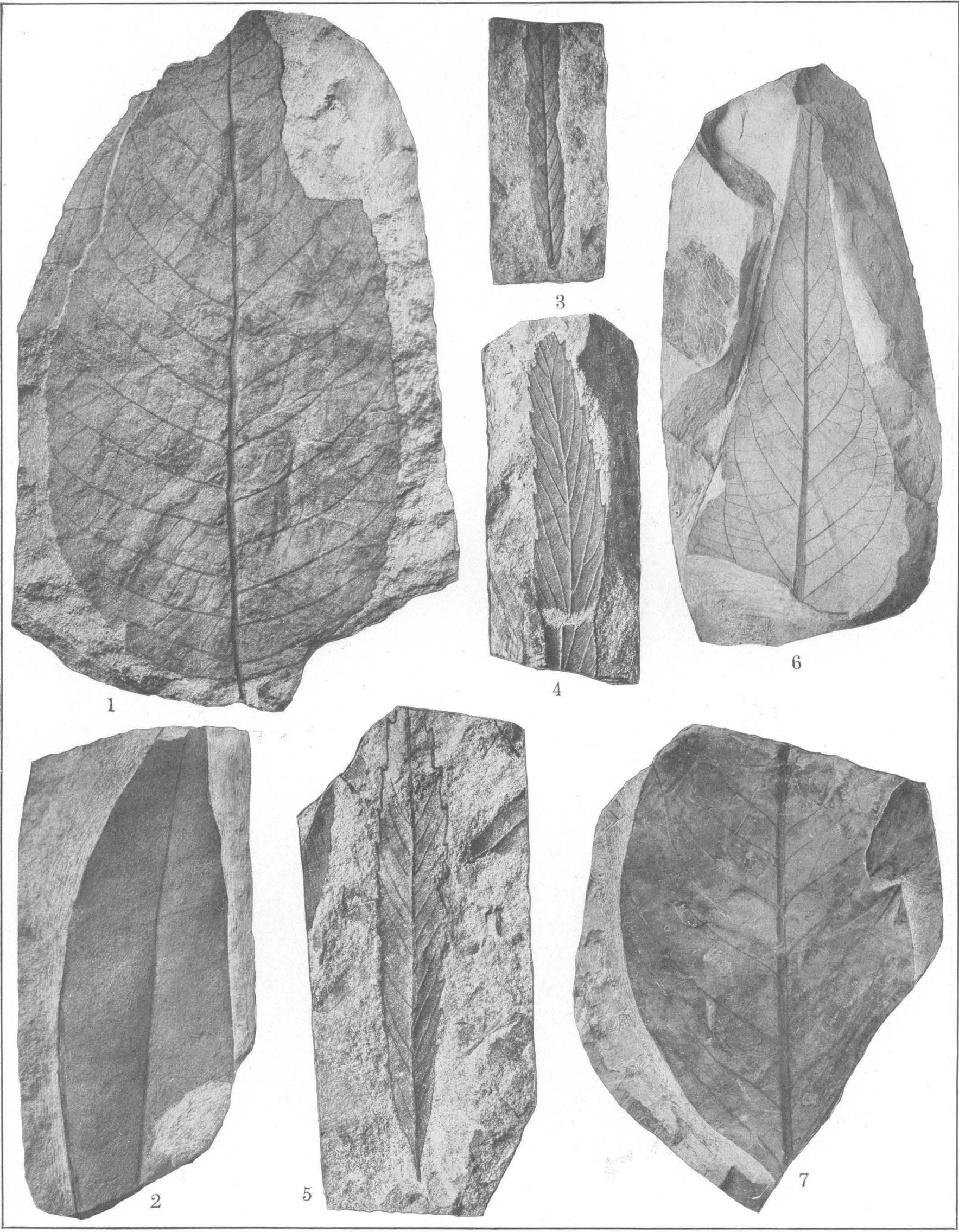

FLORA OF THE RATON FORMATION. 


\section{PLATE LXIX.}

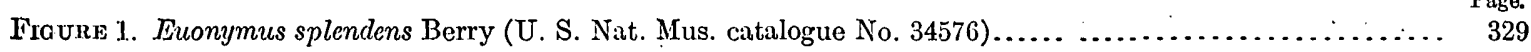

2. Carapa eolignitica Berry? (U. S. Nat. Mus. catalogue No. 34577 ) . ..................... 327

3-5. Dryophyllum tennesseensis Berry (U. S. Nat. Mus. catalogue Nos. 34578, 34579, 34580)......... 299

6, 7. Quercus? ratonensis Knowlton, n. sp. (U. S. Nat. Mus. catalogue Nos. 34581, 34582) . . . . . . . . . 298 


\section{PLATE LXX.}

Fig URE 1. Dryophyllum moorii (Lesquereux) Berry (U. S. Nat. Mus. catalogue No. 34583) ................. 299

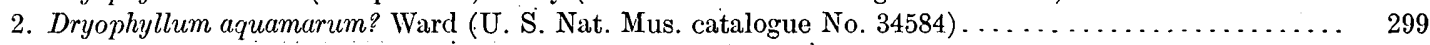

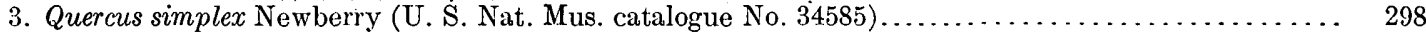

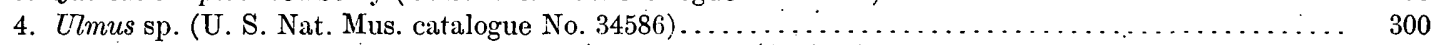

5. Quercus? neomexicana Knowlton, n. sp. (U. S. Nat. Mus. catialogue No. 34587 )................ 298 392 


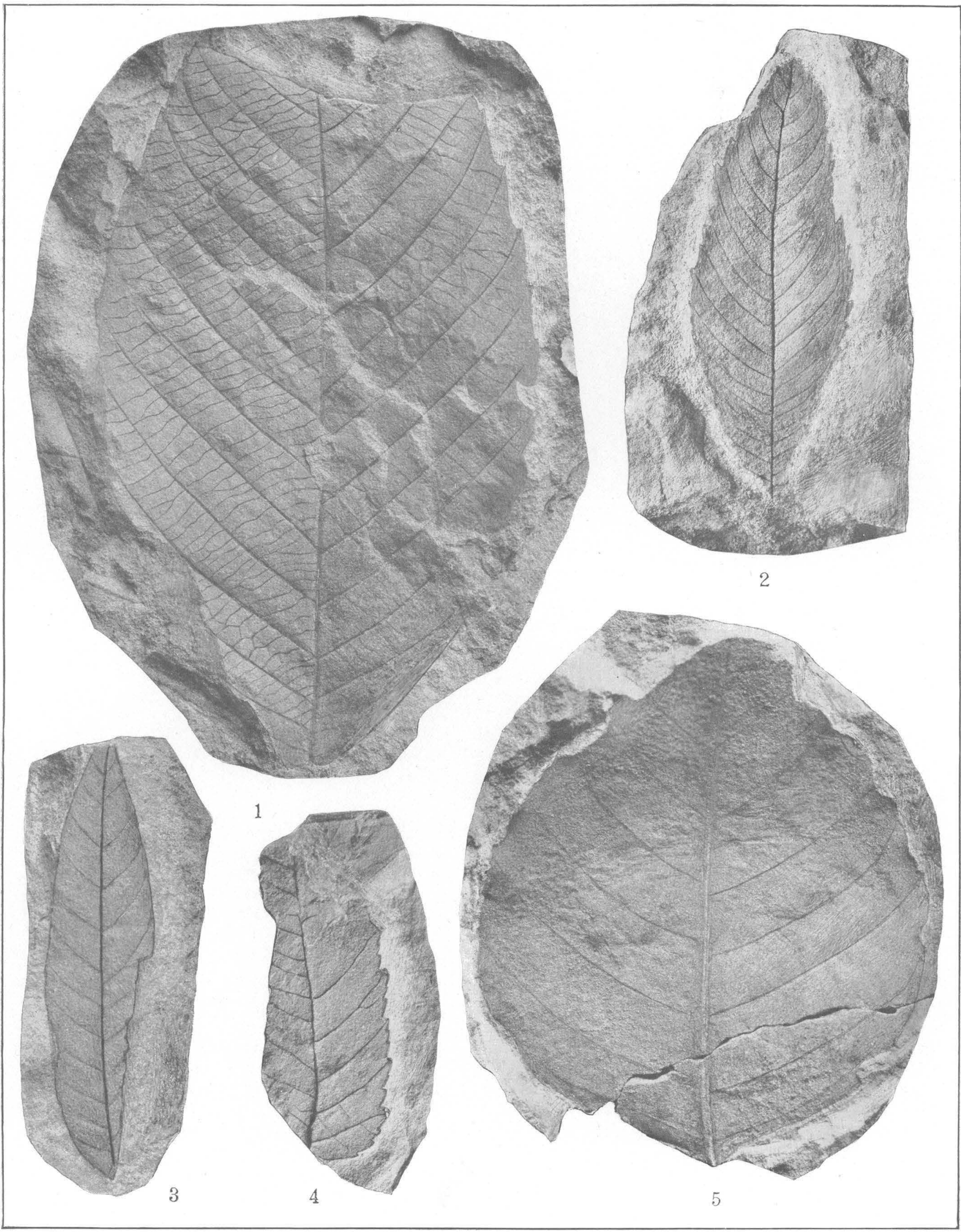




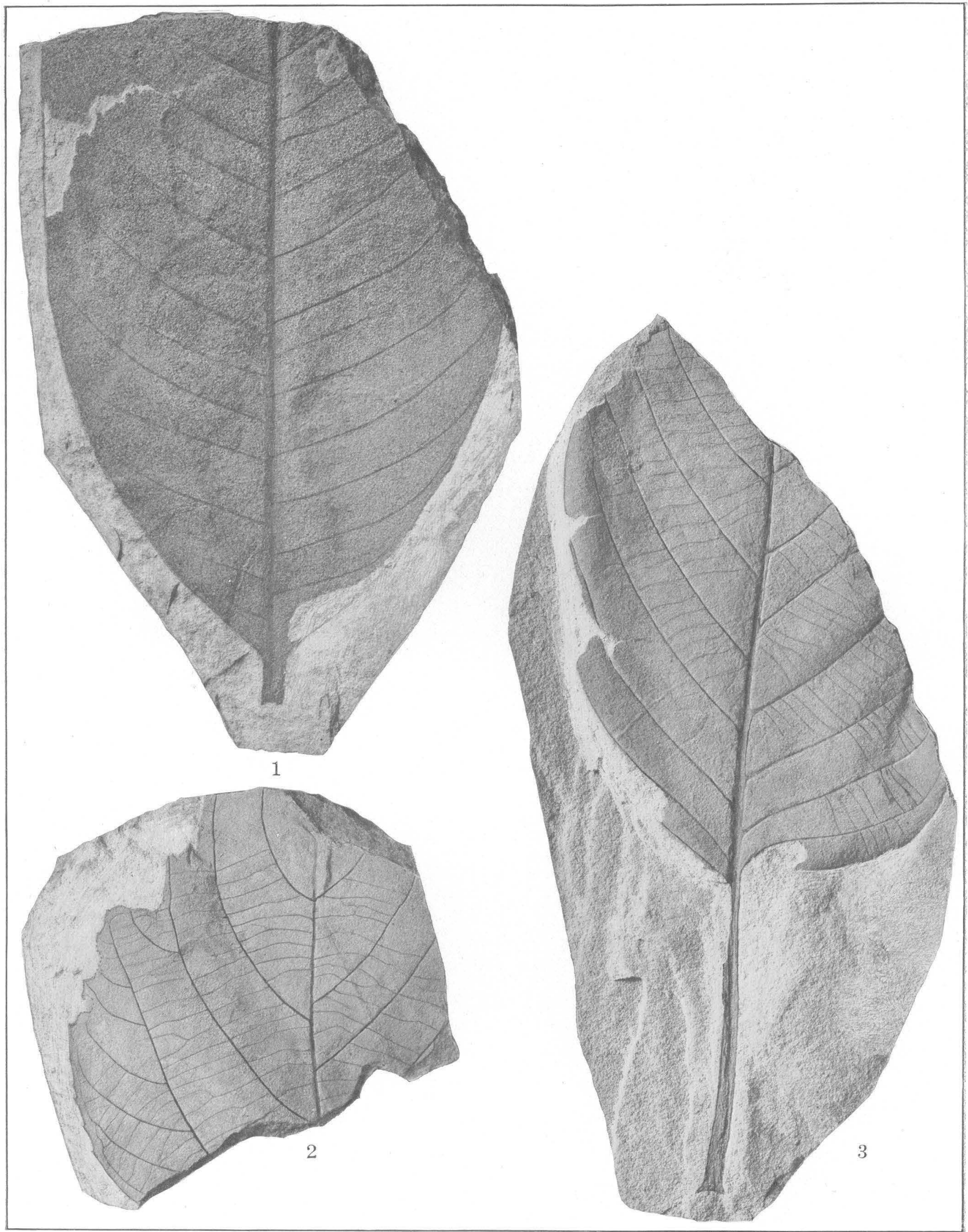

FLORA OF THE RATON FORMATION. 
PLATE LXXI.

Page.

Frgure 1. Ficus aguilar Knowlton, n. sp. (U. S. Nat. Mus. catalogue No. 34588) .................. 300

2. Ficus minutidens Knowlton, n. sp. (U. S. Nat. Mus. catalogue No. 34589).................. 305

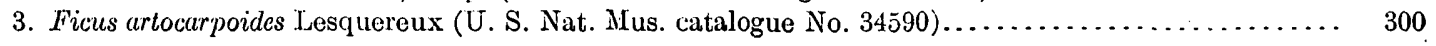


PLATE LXXII.

$\begin{array}{r}\text { Figure 1. Ficus occidentaiis (Lesquereux) Lesquereux (U. S. Nat. Mus. catalogue No. } 34591 \text { ).............. } \\ \text { 2-4. Ficus pseudopopulus Lesquereux (U. S. Nat. Mus. catalogue Nos. } 34592,34593,34594) \ldots \ldots \ldots \ldots \\ \hline\end{array}$ 394 


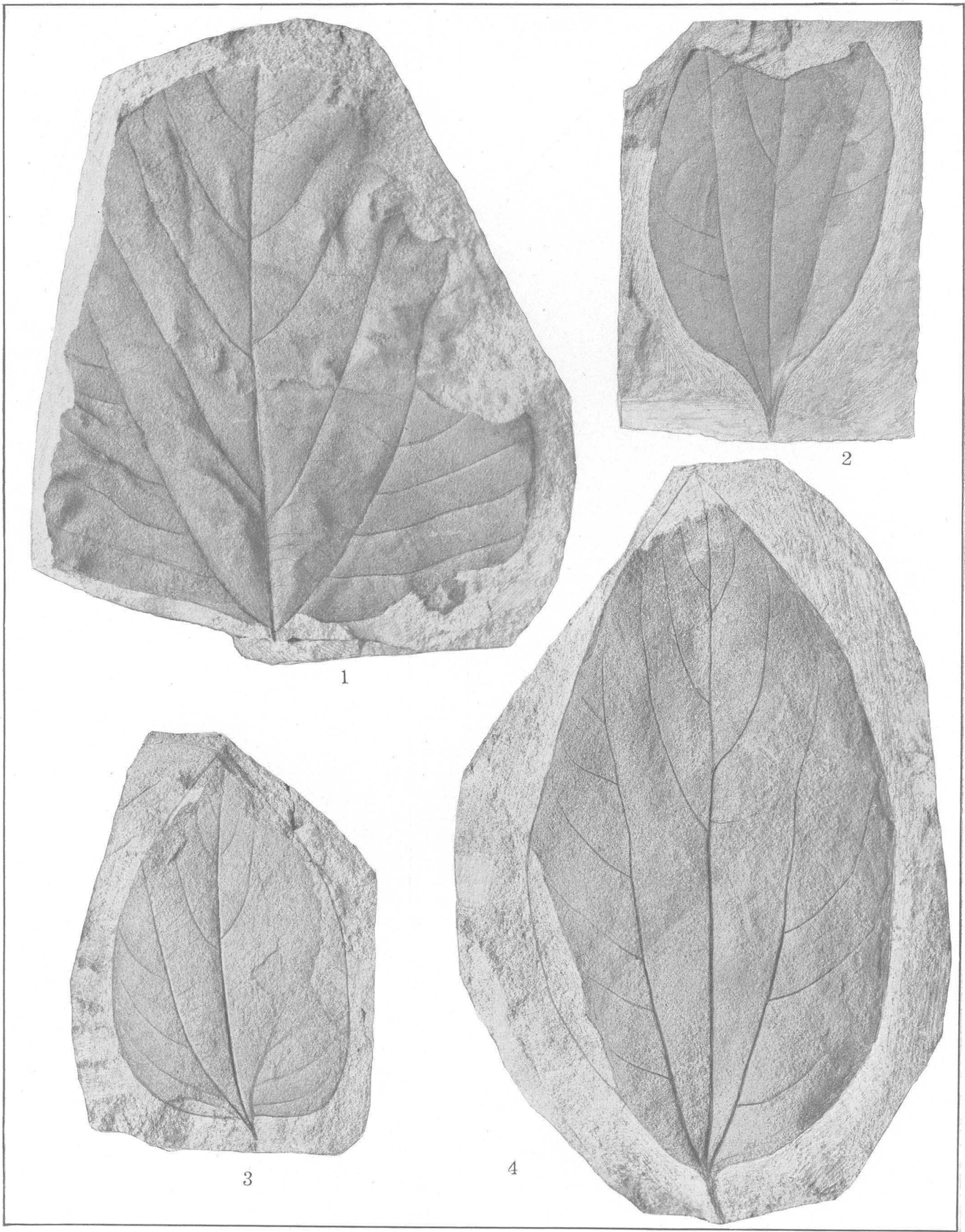

FLORA OF THE RATON FORMATION. 


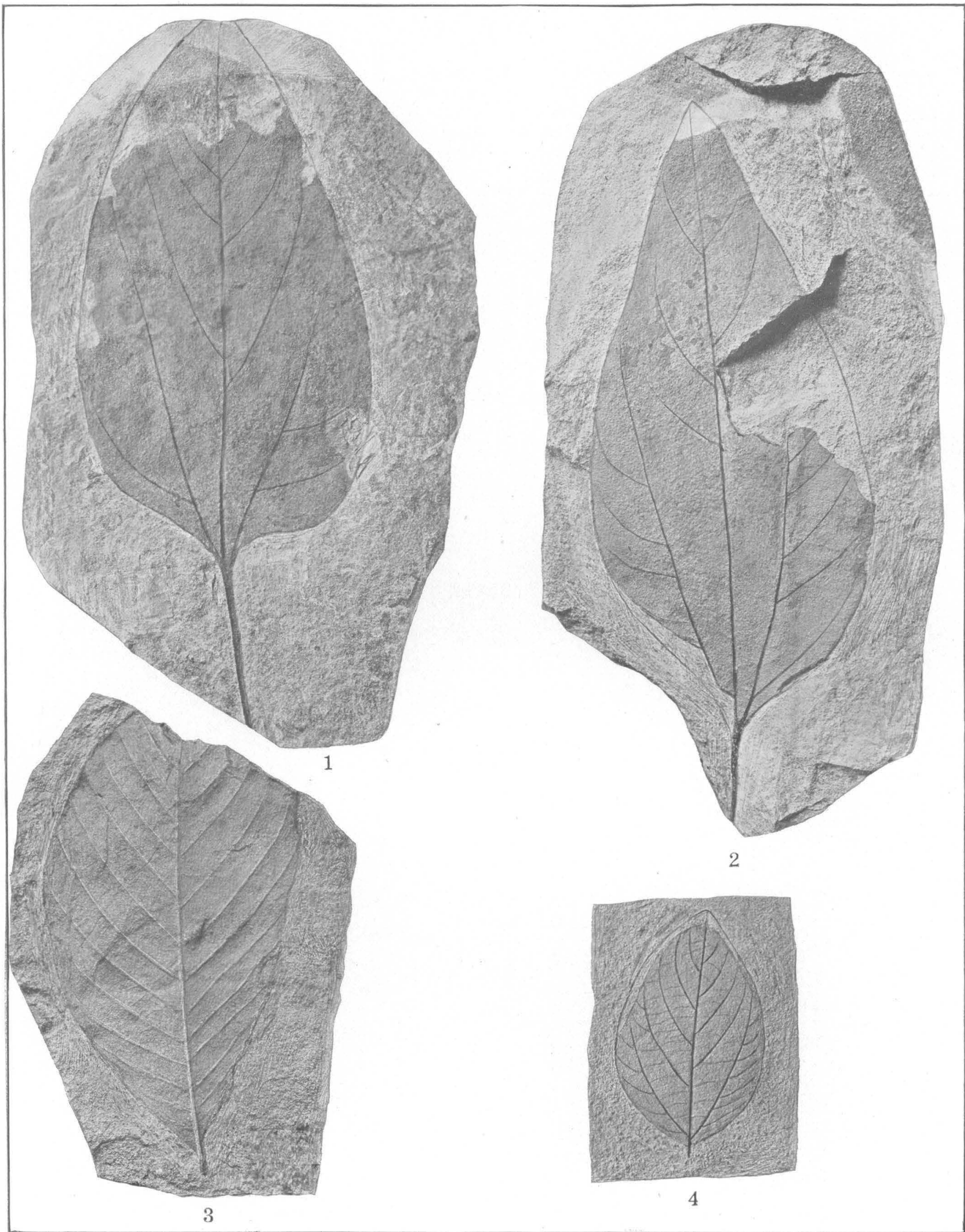

FLORA OF THE RATON FORMATION. 


\section{PLATE LXXIII.}

Fraures 1., 2. Ficus pseudopopulus Lesquereux (U. S. Nat. Mus. catalogue Nos. 34595, 34596).............. $\begin{array}{r}\text { Page. } \\ 304\end{array}$

3. Juglans berryi Knowiton (U. S. Nat Mus catalogue No. 34597)

4. Ficus neoplanicostata Knowlton, n. sp. (U. S. Nat. Mus. catalogue No. 34598$) \ldots \ldots \ldots \ldots \ldots \ldots \ldots \ldots \ldots$ 


\section{PLATE LXXIV.}

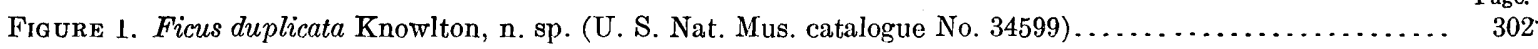

2, 3. Ficus neoplanicostata Knowlton, n. sp. (U. S. Nat. Mus. catalogue Nos. 34600, 34601) ........... 303 .

4. Ficus ratonensis Knowlton, n. sp. (U. S. Nat. Mus. catalogue No. 34602) .................... 306 . 396 


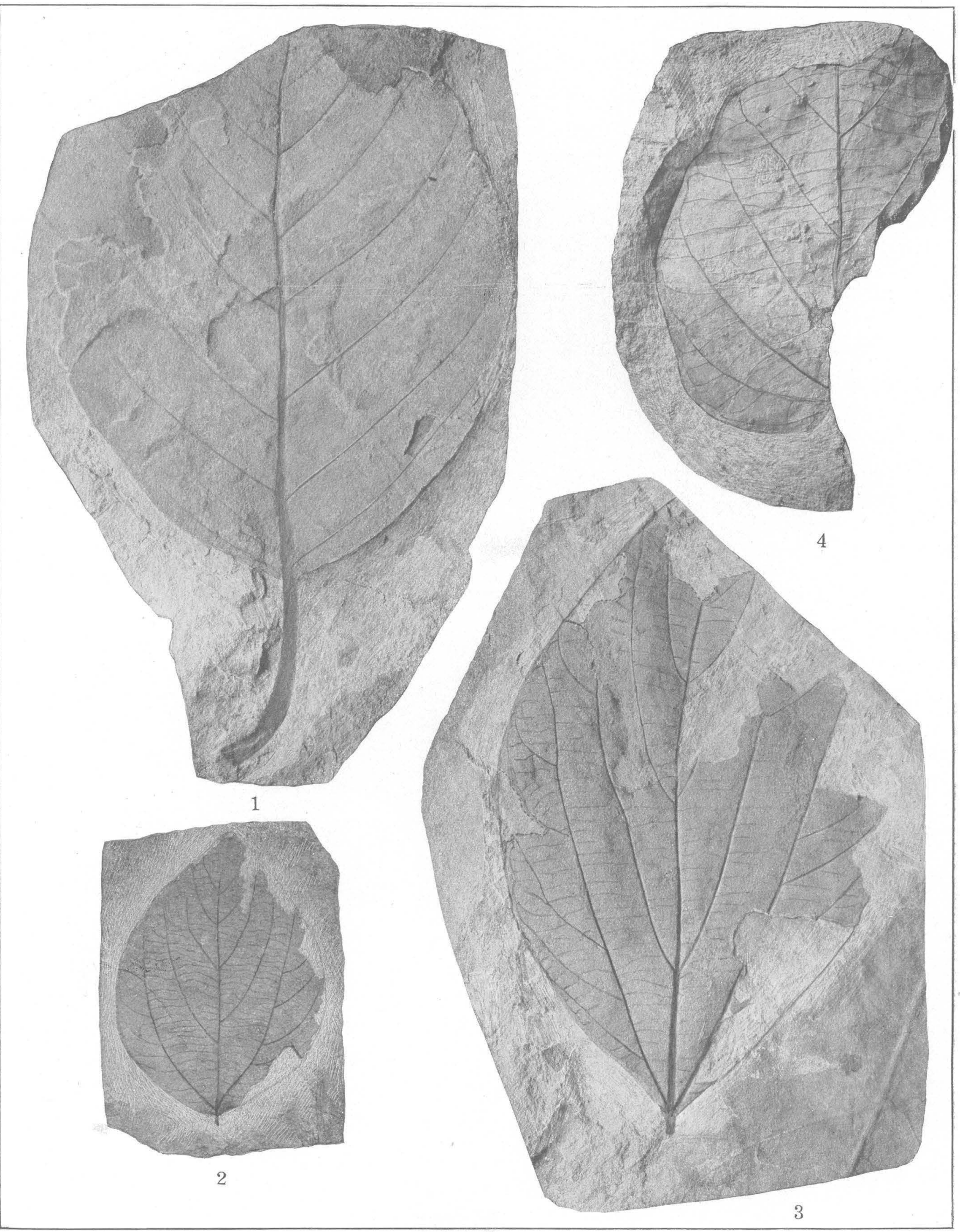

FLORA OF THE RATON FORMATION. 


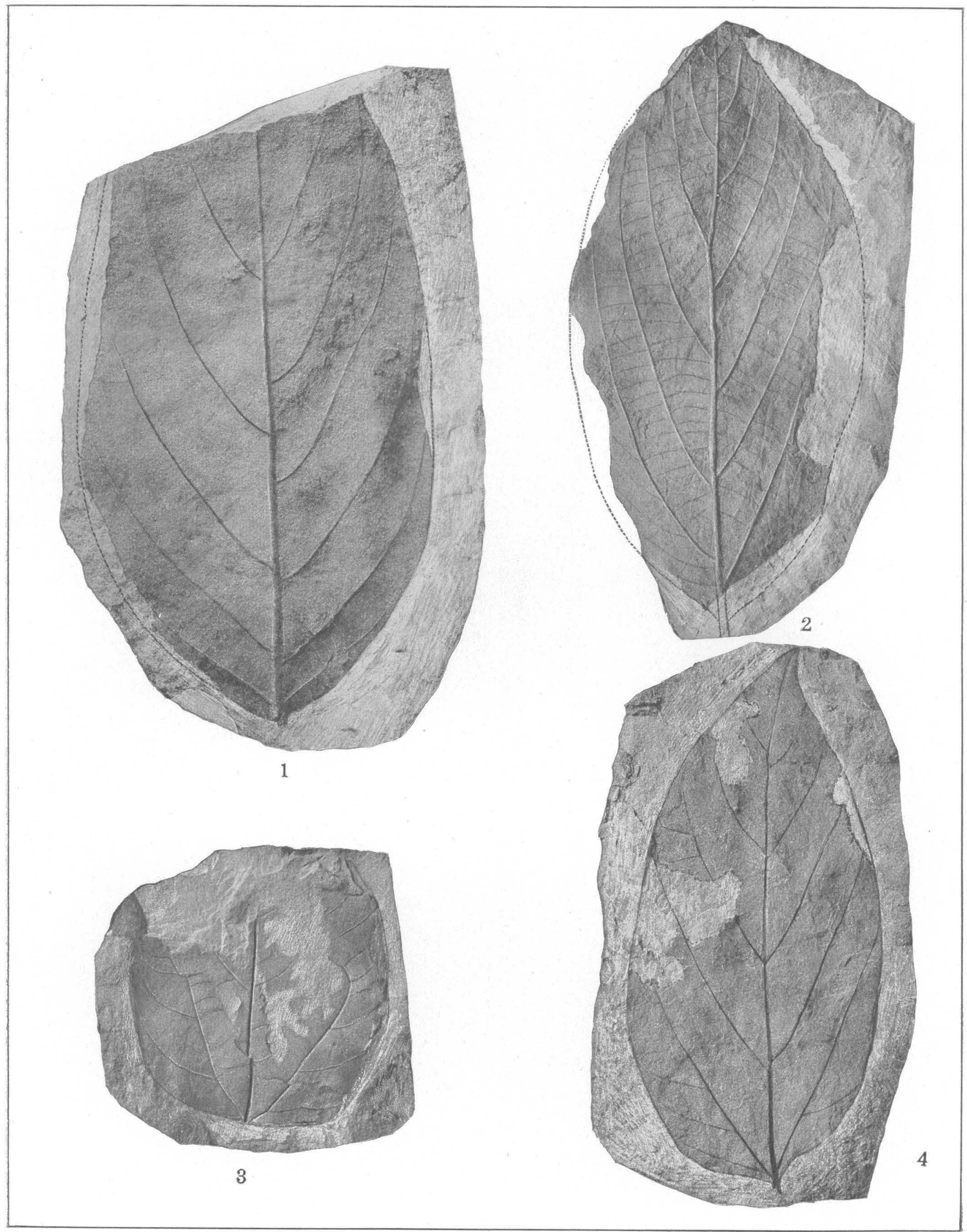

FLORA OF THE RATON FORMATION. 


\section{PLATE LXXV.}

Troures 1,2 Picuge. 1., 2. Micus denveriana Cockorell (U. S. Nat. 3, 4. Ficus schimperi Lesquereux (U. S. Nat. Mus. catalogue Nos. 34605,34606 ) 


\section{PLATE LXXVI.}

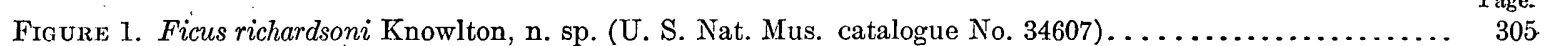

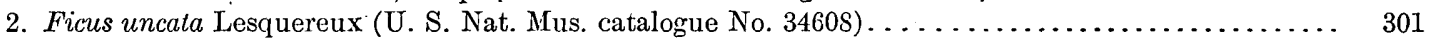

3. Ficus planicostata clintoni (Lesquereux) Knowlton (U. S. Nat. Mus. catalogue No. 34609)....... 303

4. Ficus neoplanicostata Knowlton, n. sp. (U. S. Nat. Mus. catalogue No. 34610).............. 303 398 


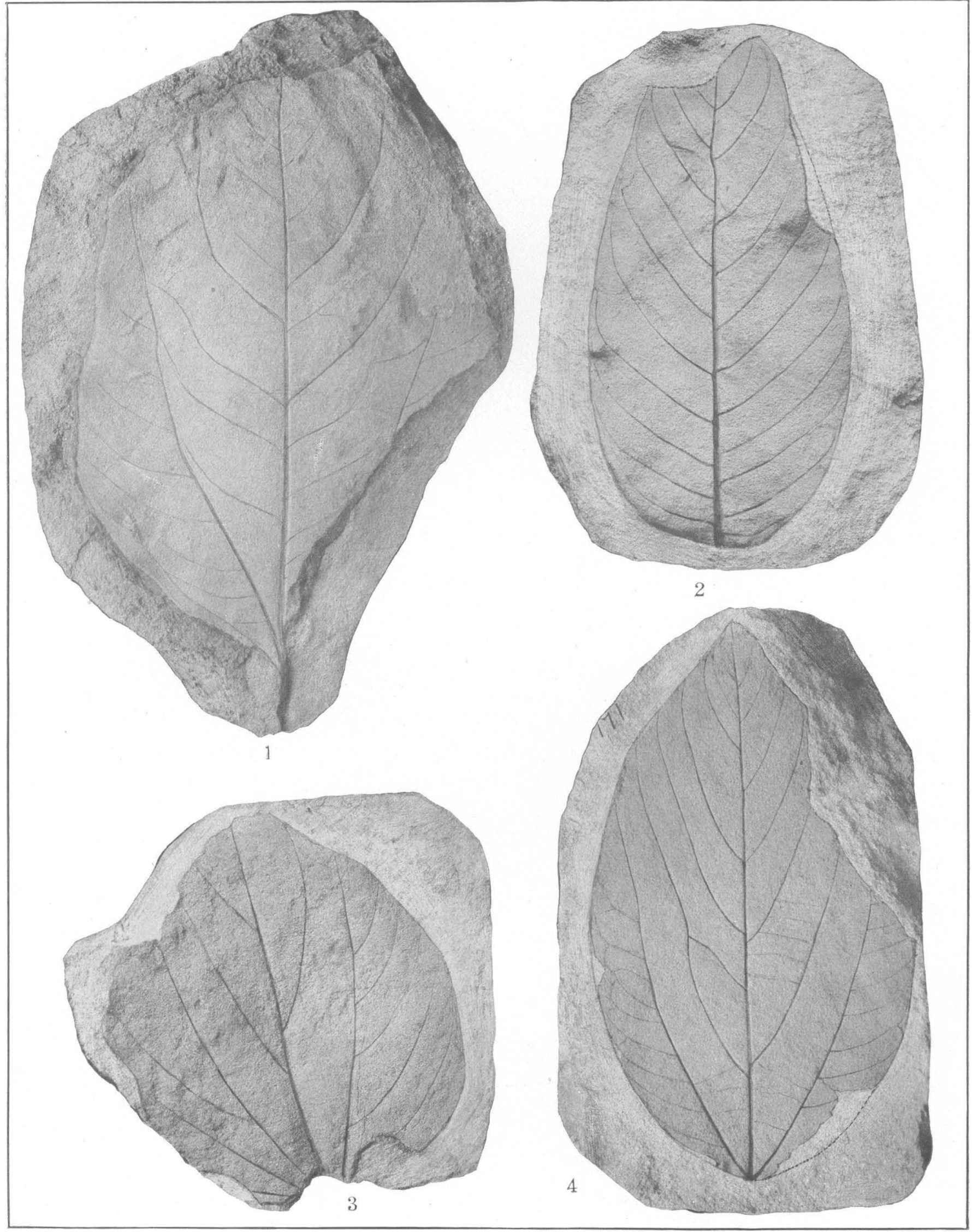

FLORA OF THE RATON FORMATION. 


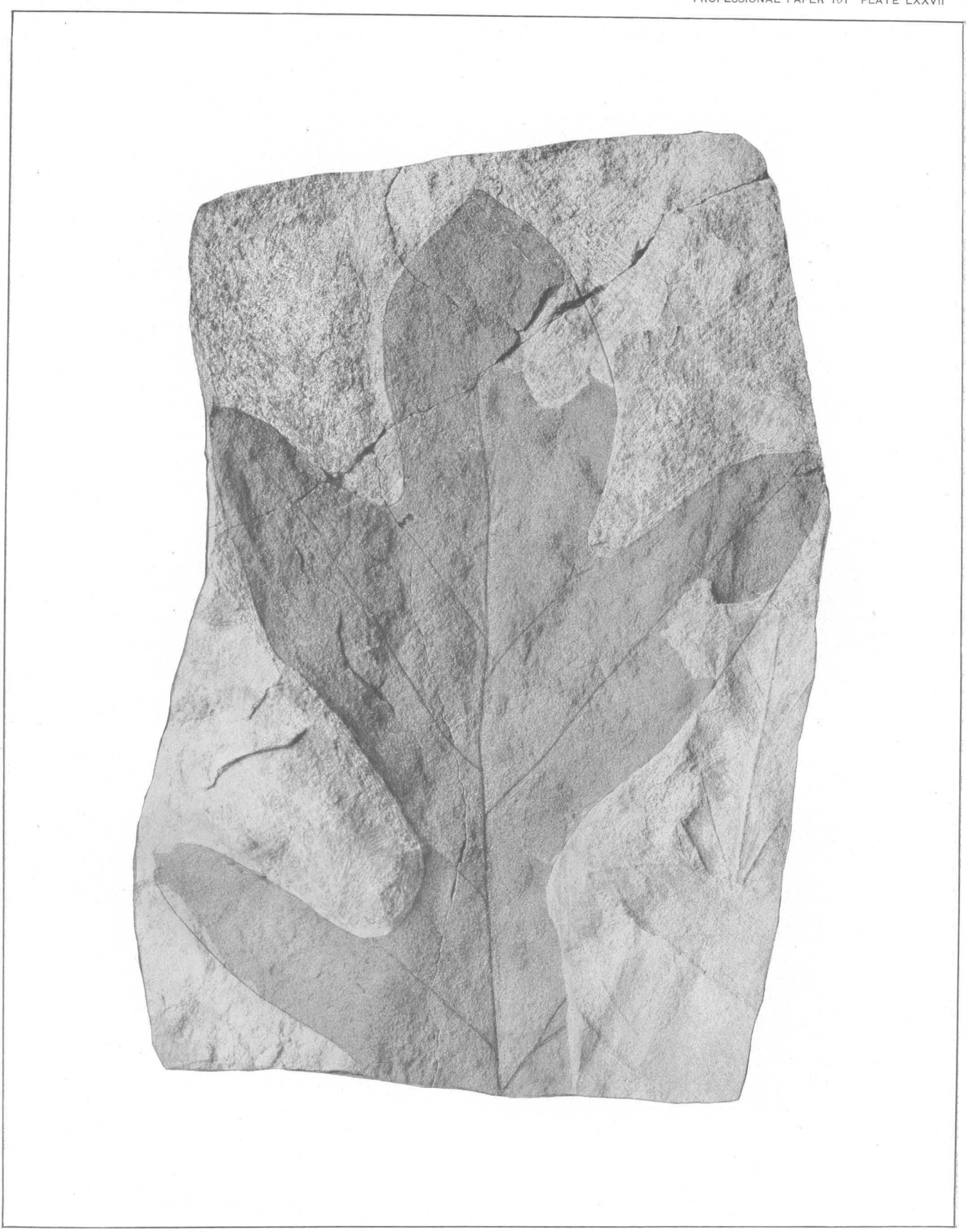

FLORA OF THE RATON FORMATION. 
PLATE IXXXVII.

Page.

Artocarpus similis Knowlton, n. sp. (U. S. Nat. Mus. catalogue No. 34611) 


\section{PLATE LXXVIII.}

FIgUres 1, 2. Artocarpus similis, Knowlton, n. sp. (U. S. Nat Mus catalogue Nos 34612 34613)

3. Aristolochia? elongata Knowlton, n. sp. (U. S. Nat. Mus. catalogue No. 34614)................. 307

4. Cassia fisheriana Knowlton, n. sp. (U. S. Nat. Mus. catalogue No. 34615) . . . . . . . . . . . 327 400 


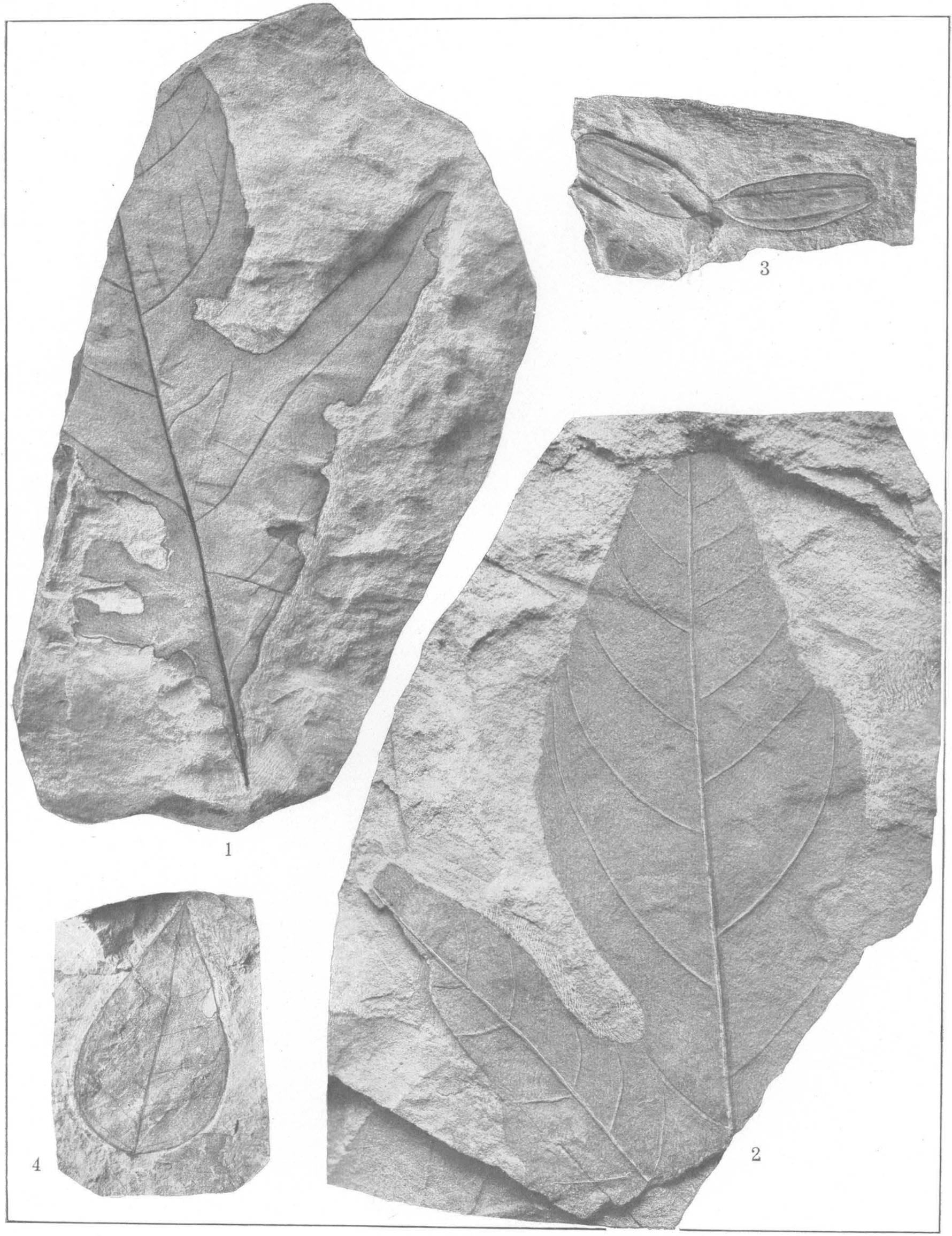




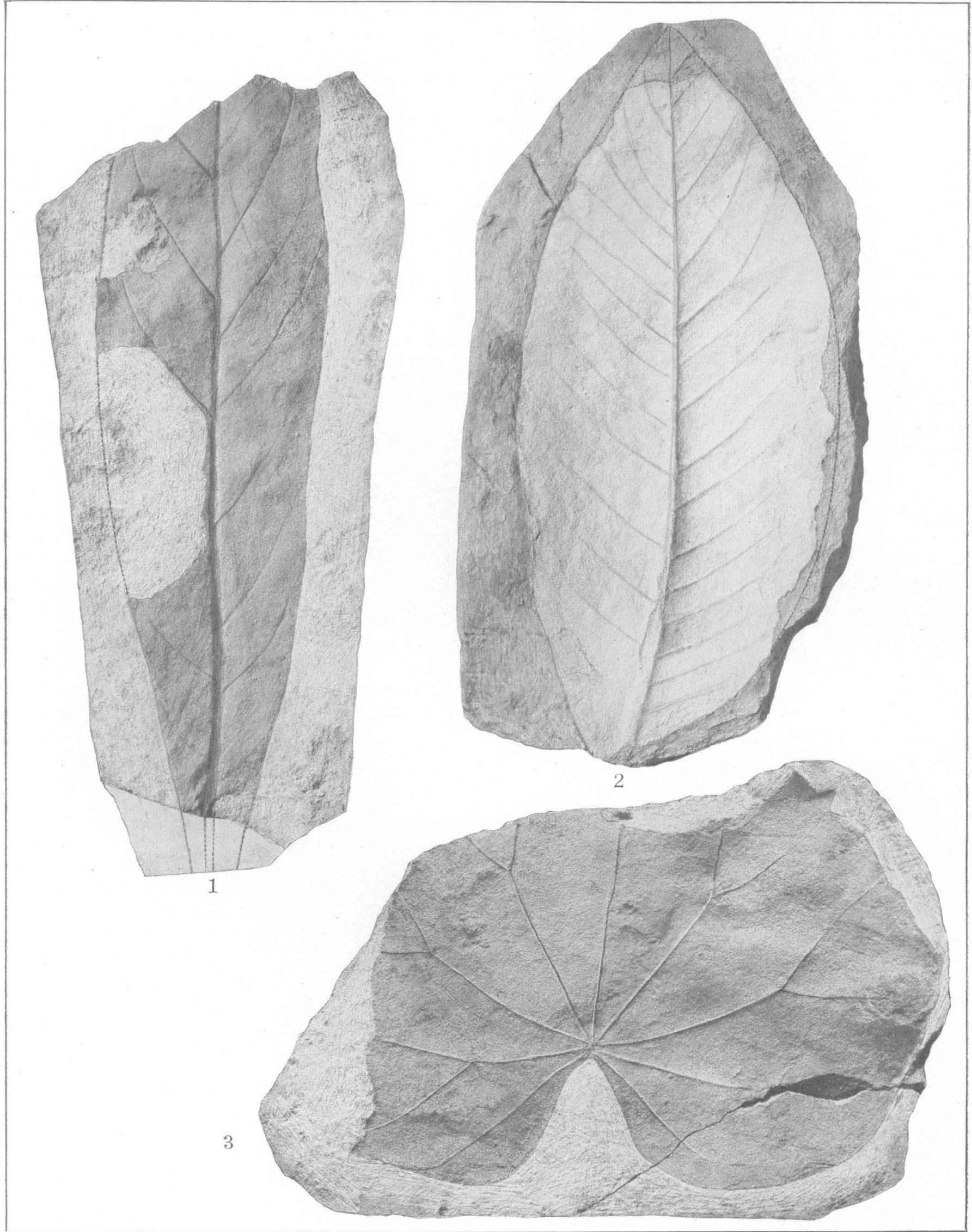

FLORA OF THE RATON FORMATION. 


\section{- PLATE LXXIX.}

Figure 1. Magnolia angustifolia Newberry (U. S. Nat. Mus. catalogue No 34616)

2. Magnolia hilgardiana Lesquereux (U. S. Nat. Mus. catalogue No. 34617 . . . . . . . . . . . . . . 310

3. Castalia leei Knowlton, n. sp. (U. S. Nat. Mus. catalogue No. 34618) . . . . . . . . . . . . . . 307 


\section{PLATE LXXX.}

Figures 1, 2. Magnolia angustifolia Newberry (U. S. Nat. Mus. catalogue Nos. 34619, 34620) . . . . . . . . . 


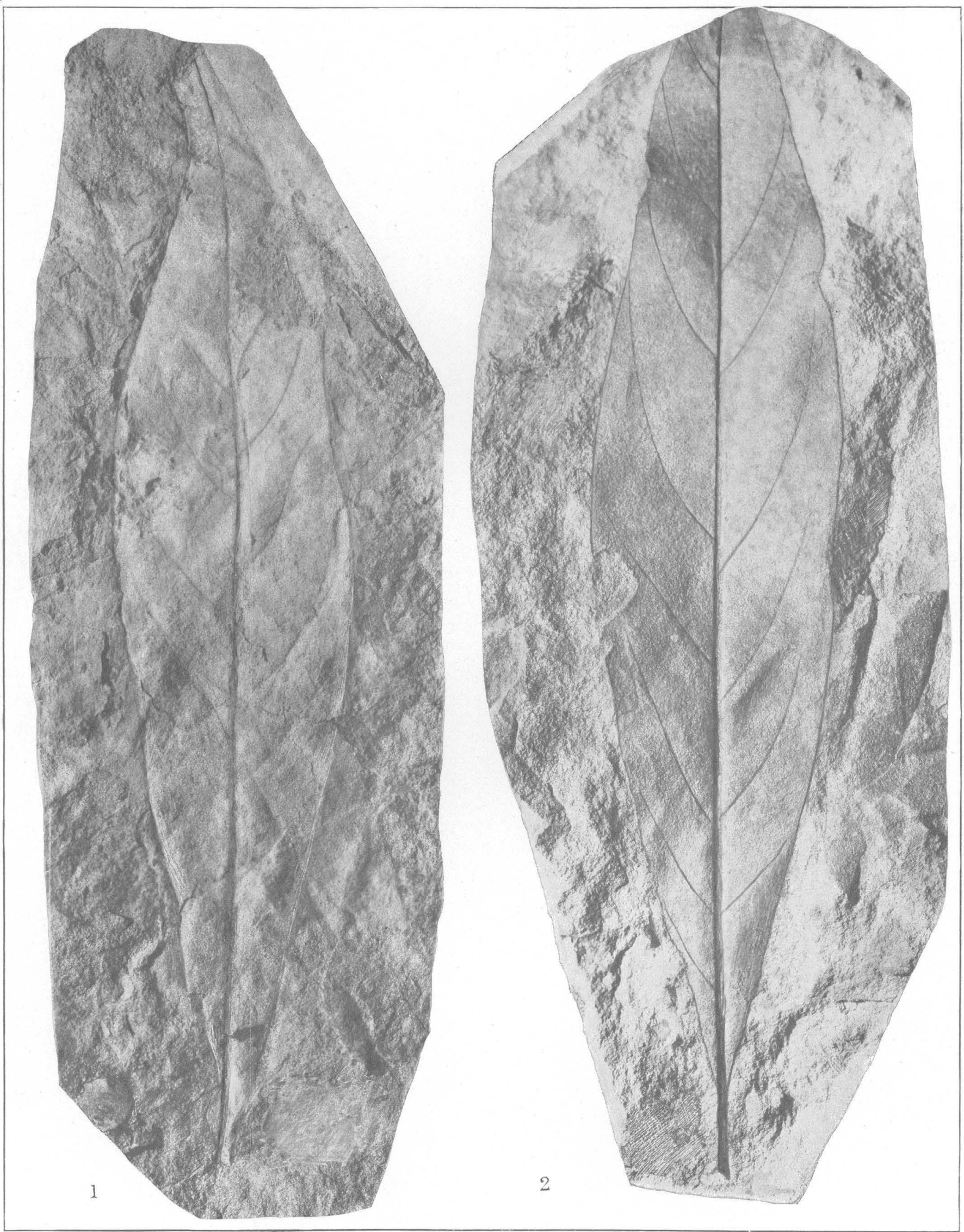

FLORA OF THE RATON FORMATION. 


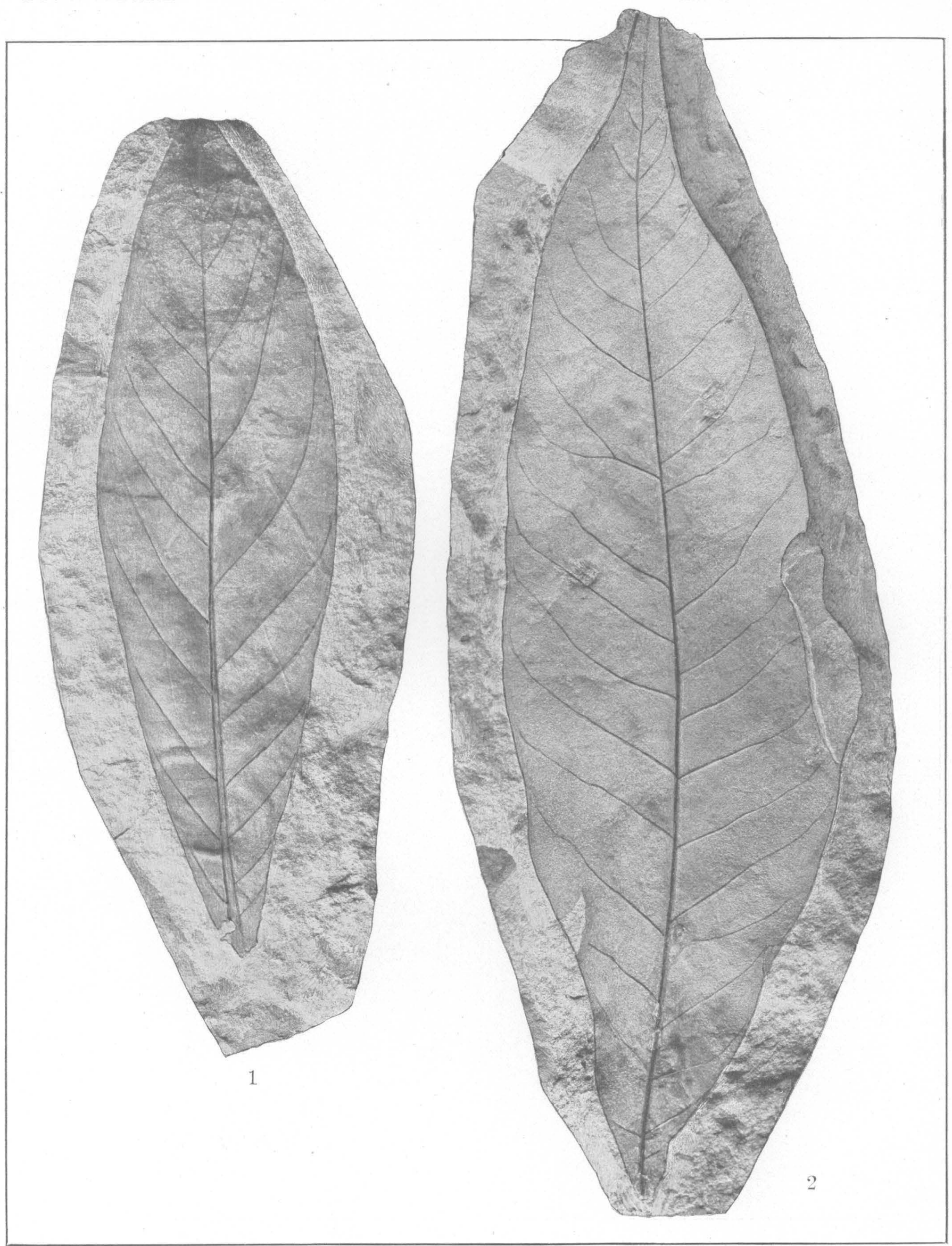

FLORA OF THE RATON FORMATION. 
PLATE LXXXI.

Page.

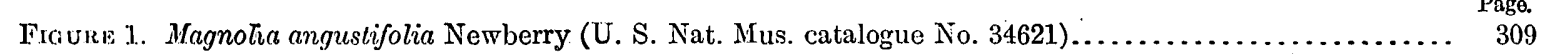

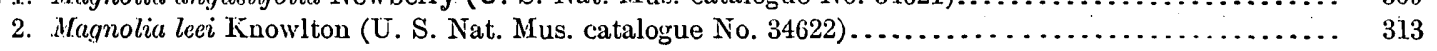

403 


\section{PLATE LXXXII.}

Figures 1, 2. Magnolia lesleyana Lesquereux (U. S. Nat. Mus. catalogue Nos. 34623, 34624)............ 313 404 


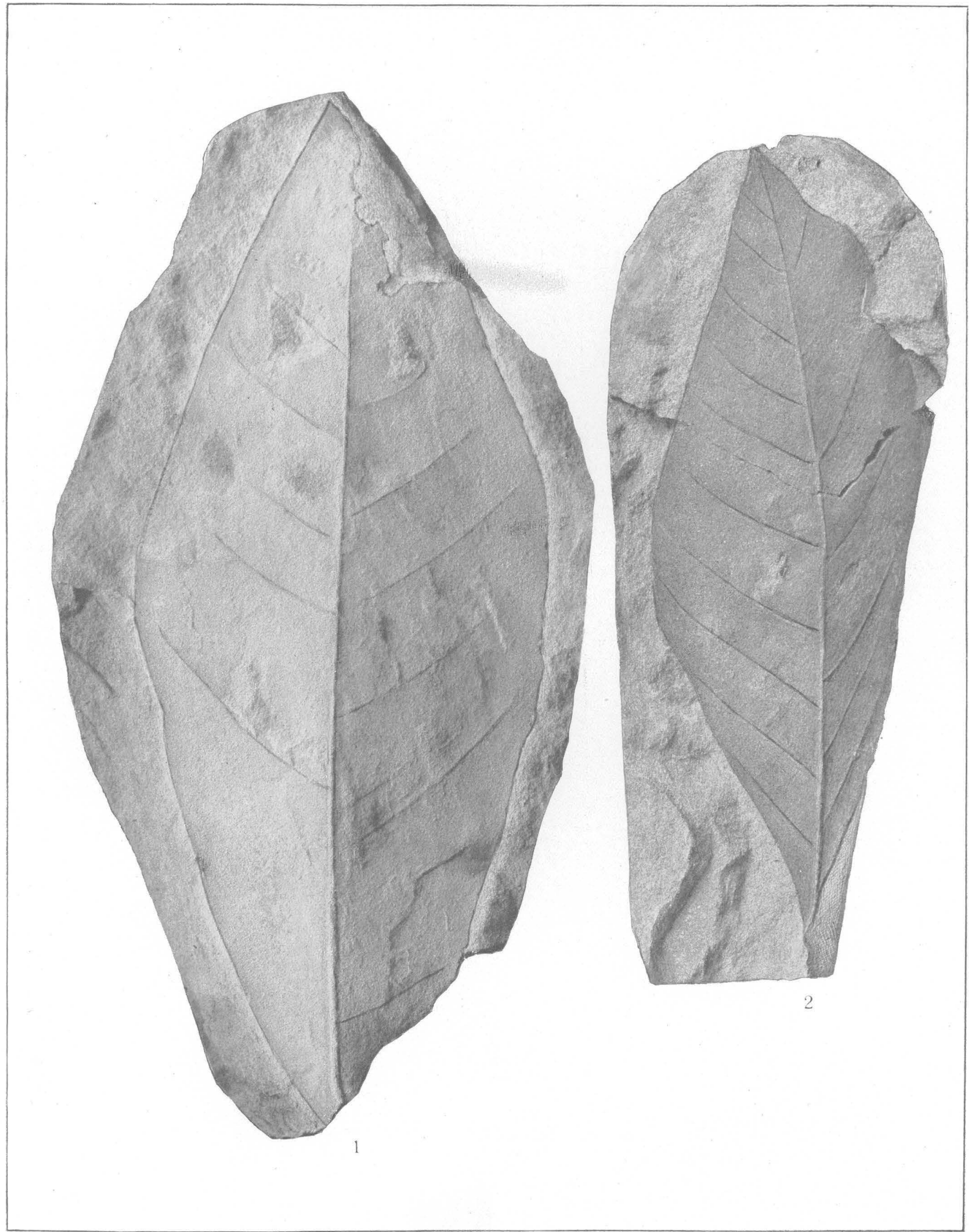

FLORA OF THE RATON FORMATION. 


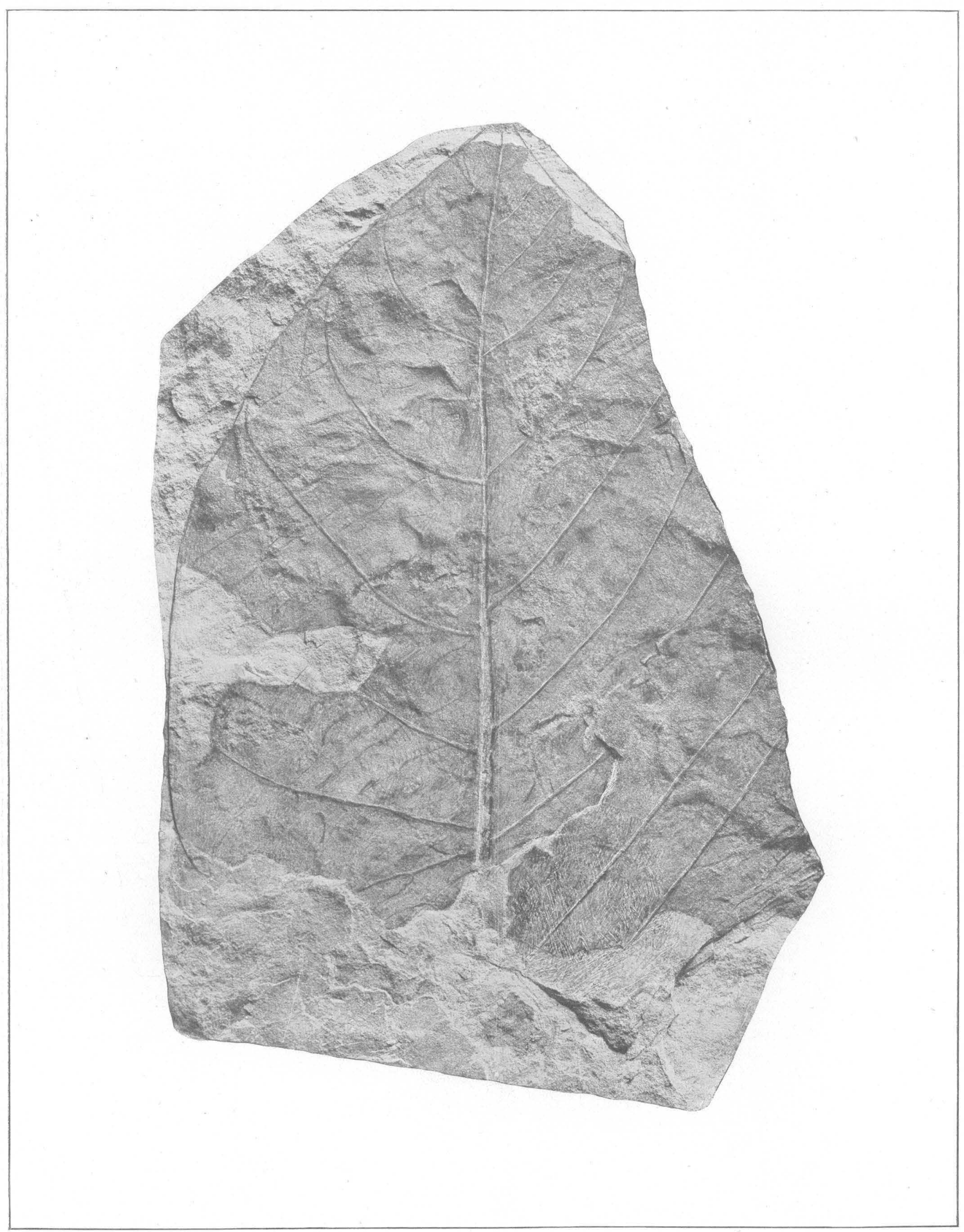

FLORA OF THE RATON FORMATION. 


\section{PLATE LXXXII}




\section{PLATE LXXXIV.}

Magnolia magnifolia Knowlton, n. sp. (U. S. Nat. Mus. catalogue No. 34626); reduced about one-quarter ...... 311 406 


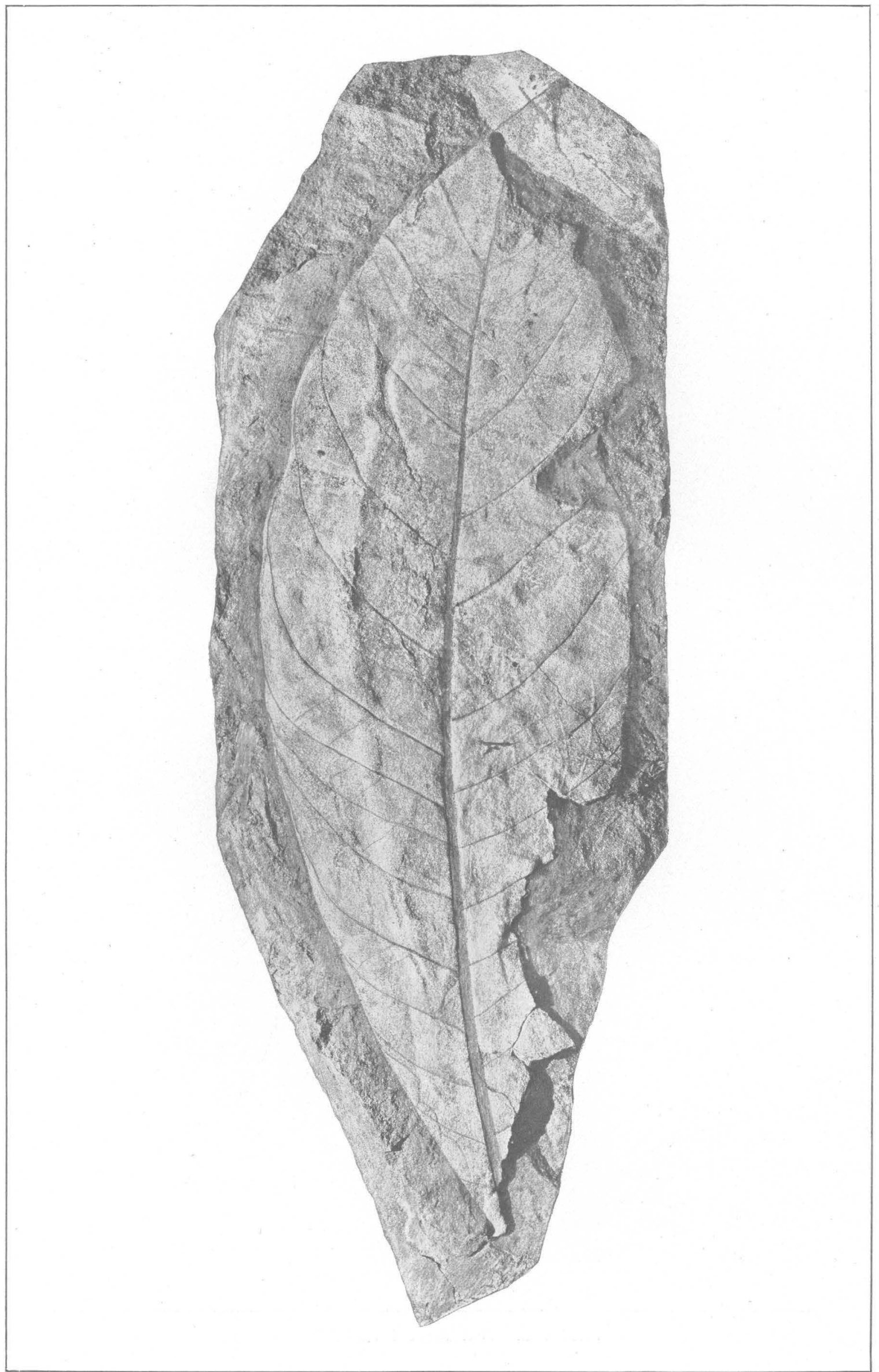

FLORA OF THE RATON FORMATION. 


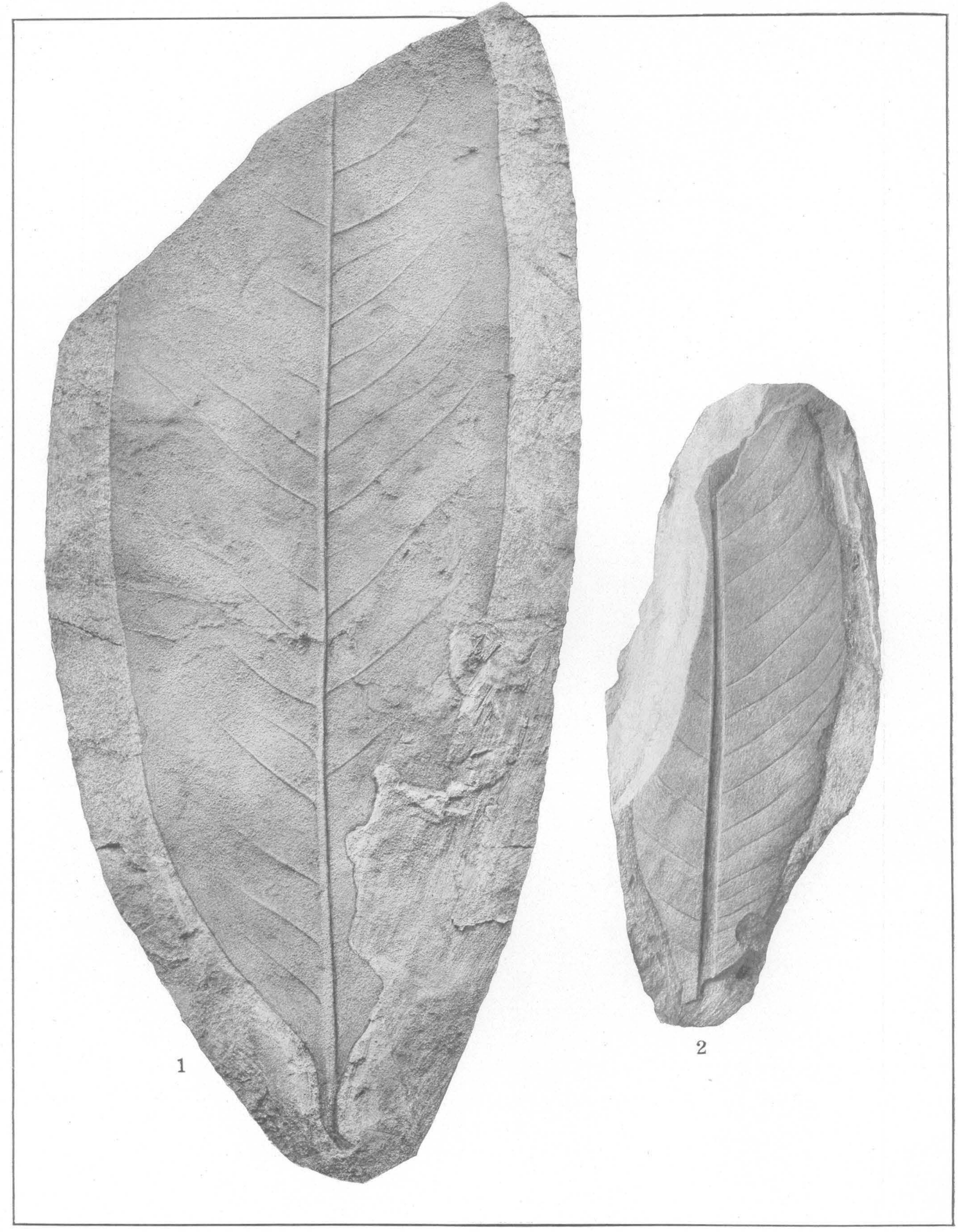

FLORA OF THE RATON FORMATION. 
PLATE LXXXV.

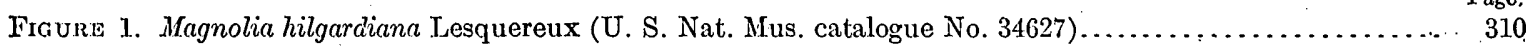
2. Magnolia laurifolia Lesquereux (U. S. Nat Mus. catalogue No. 34628) ........................ 309

407 


\section{PLATE LXXXVI.}

Magnolici cordifolia Lesquereux (U. S: Nat. Mus. catalogue No. 34629).

408 


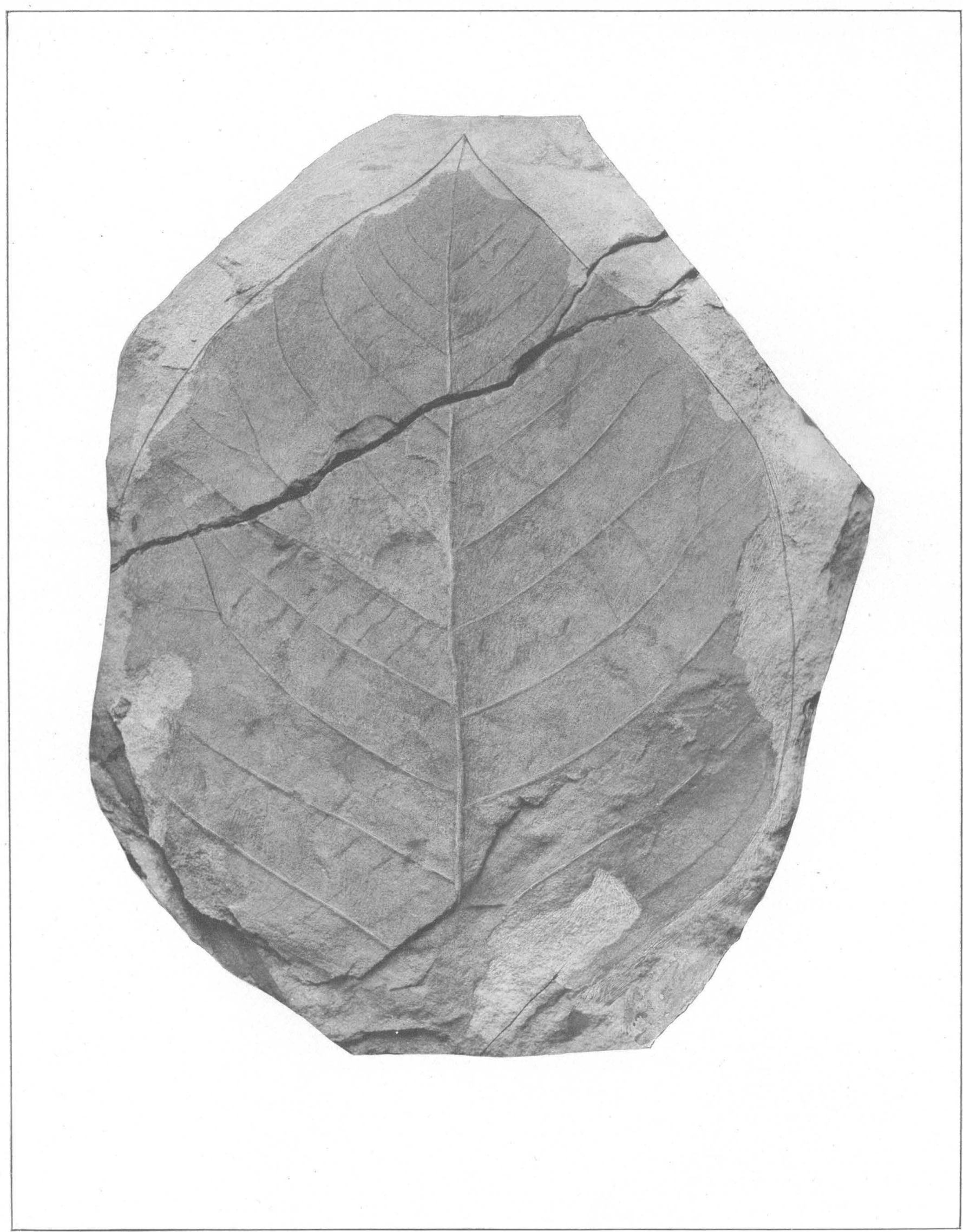




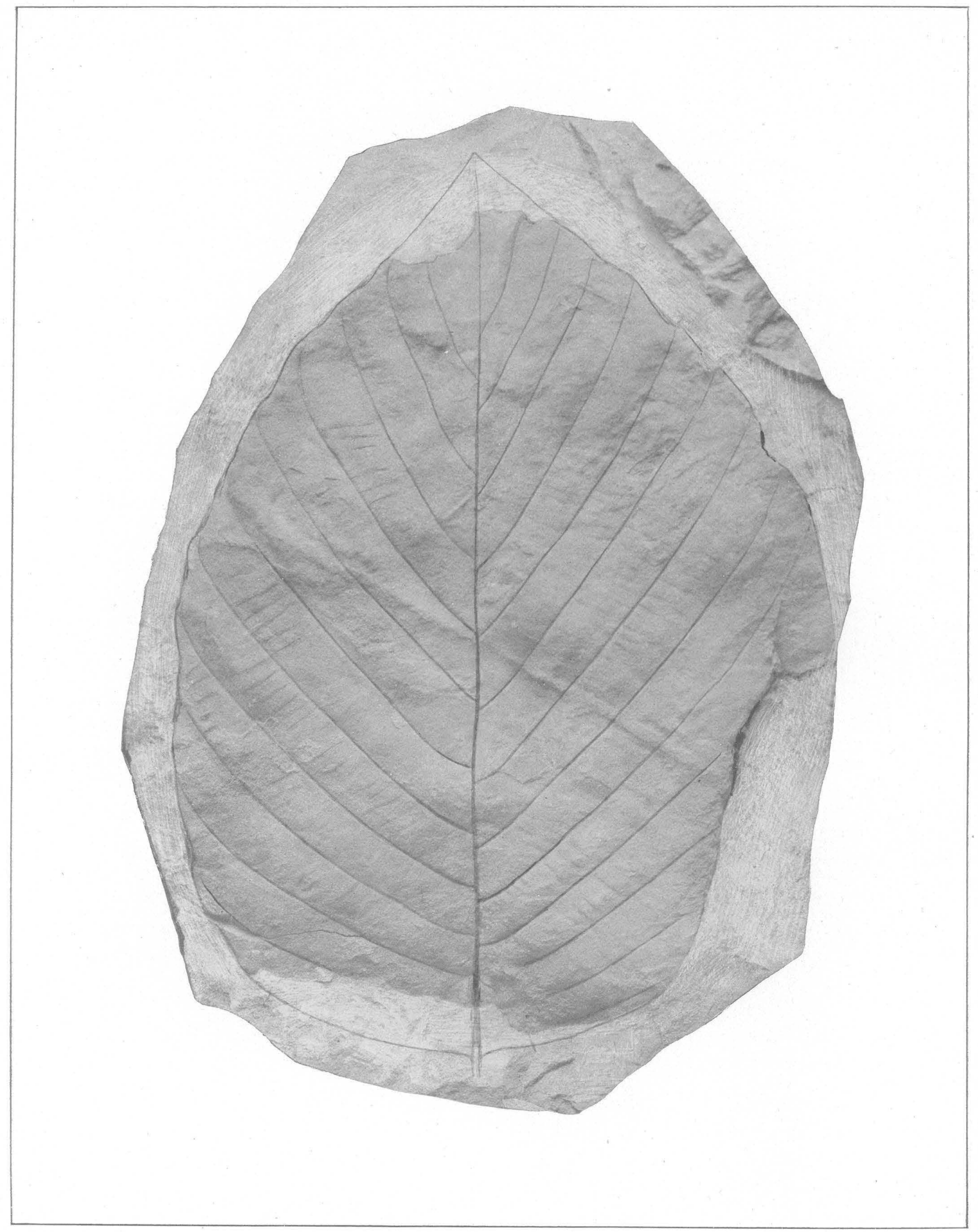

FLORA OF THE RATON FORMATION. 
PLATE LXXXVII.

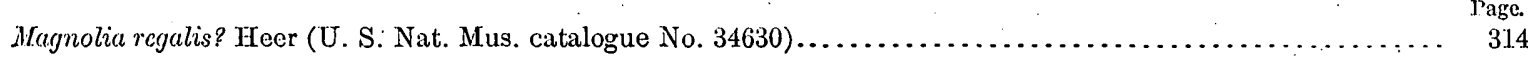

409 


\section{PLATE LXXXVIII.}

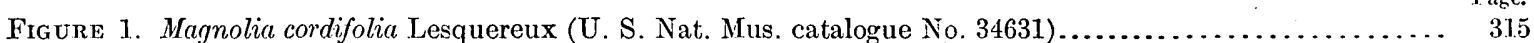

2. Oreodaphne? ratonensis Knowlton, n. sp. (U. S. Nat. Mus. catalogue No. 34632) ............... 318 3-7. Cinnamomum linifolium Knowlton, n. sp. (U. S. Nat. Mus. catalogue Nos. 34633-34637) ......... 319 410 


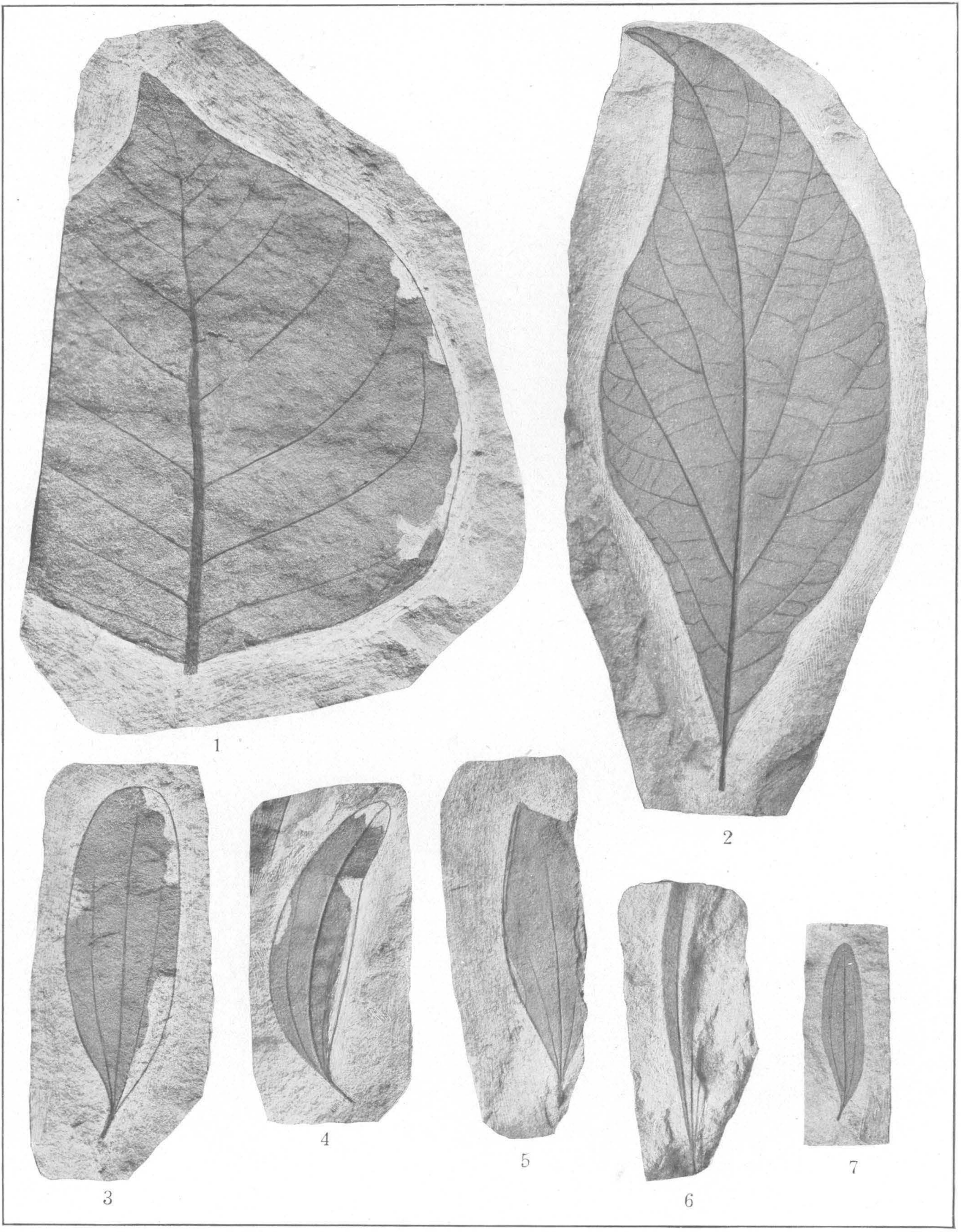

FLORA OF THE RATON FORMATION. 


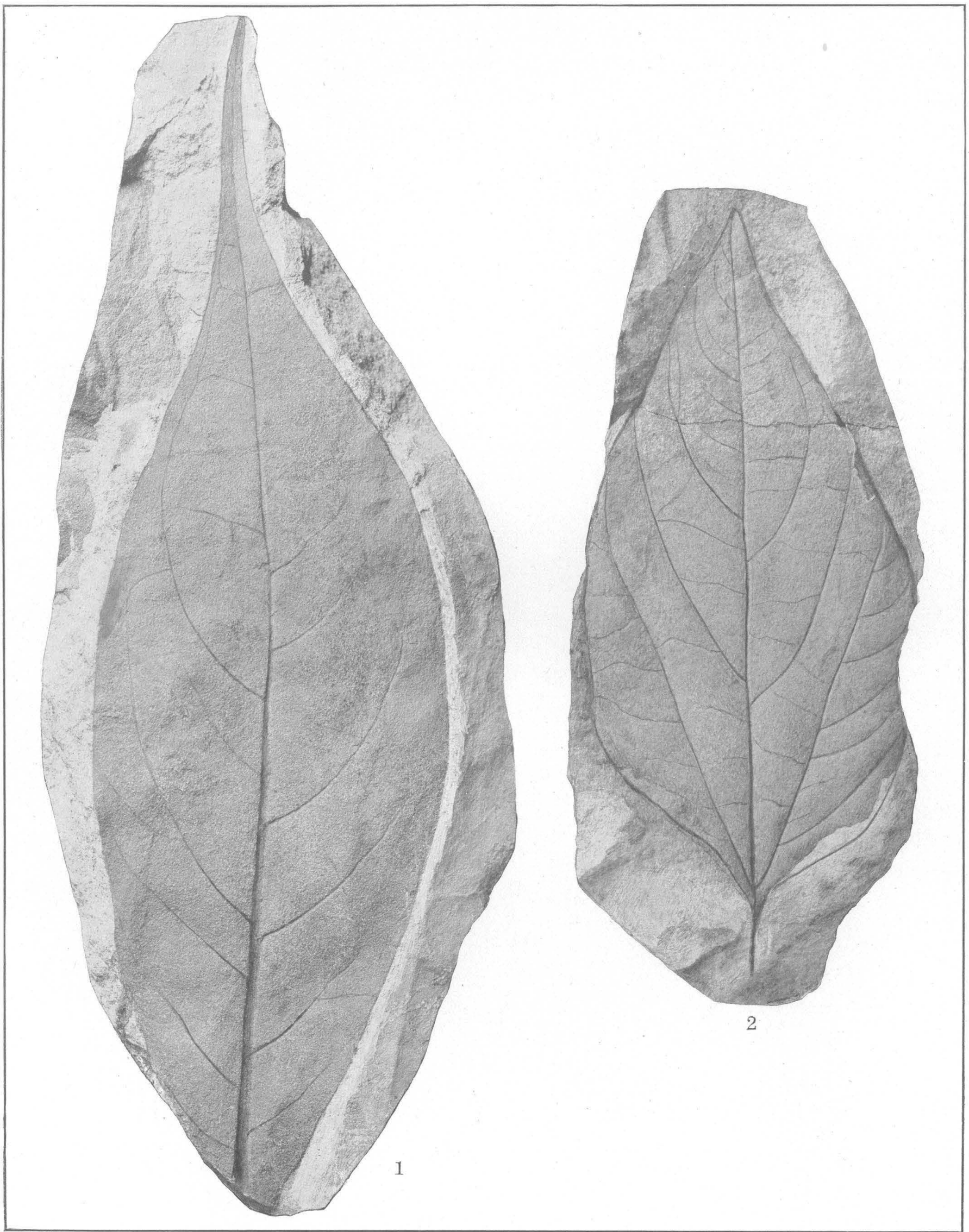

FLORA OF THE RATON FORMATION. 


\section{PLATE LXXXIX.}

Fraure 1. Laurus? caudata Knowlton, n. sp. (U. S. Nat. Mus. catalogue No. 34638)................

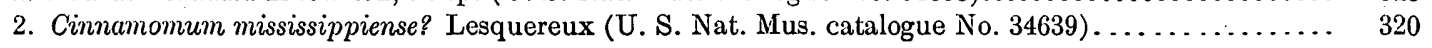


PLATE XC.

Figures 1, 2. Nectandra lancifolia (Lesquereux) Berry (U. S. Nat. Mus. catalogue Nos. 34640, 34641)........ 318

3. Cinnamomum? ficifolium Knowlton, n. sp. (U. S. Nat. Mus. catalogue No. 34642) ............ 318

4. Laurus utahensis Lesquereux (U. S. Nat. Mus. catalogue No. 34643)...................... 318

412 


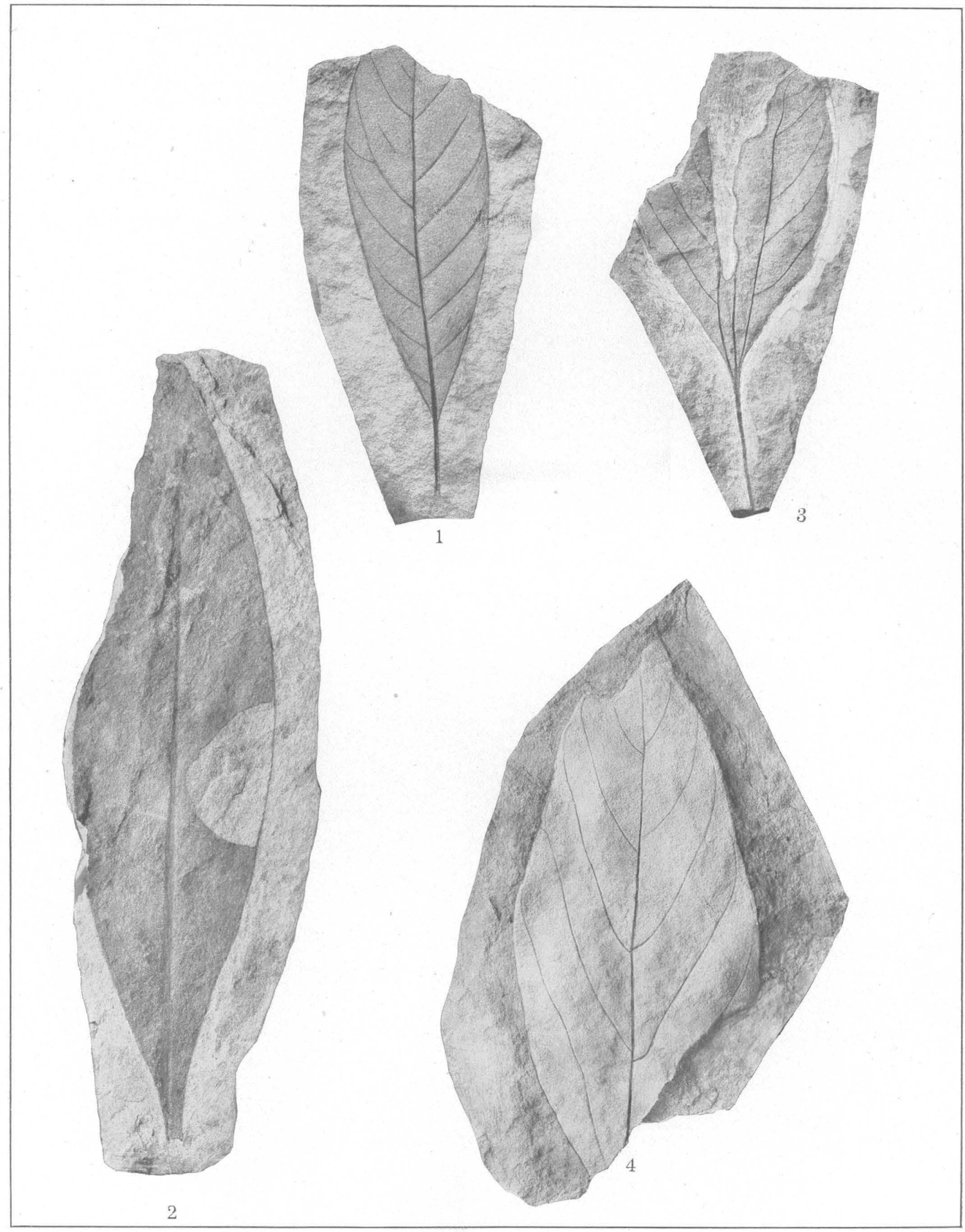

FLORA OF THE RATON FORMATION. 


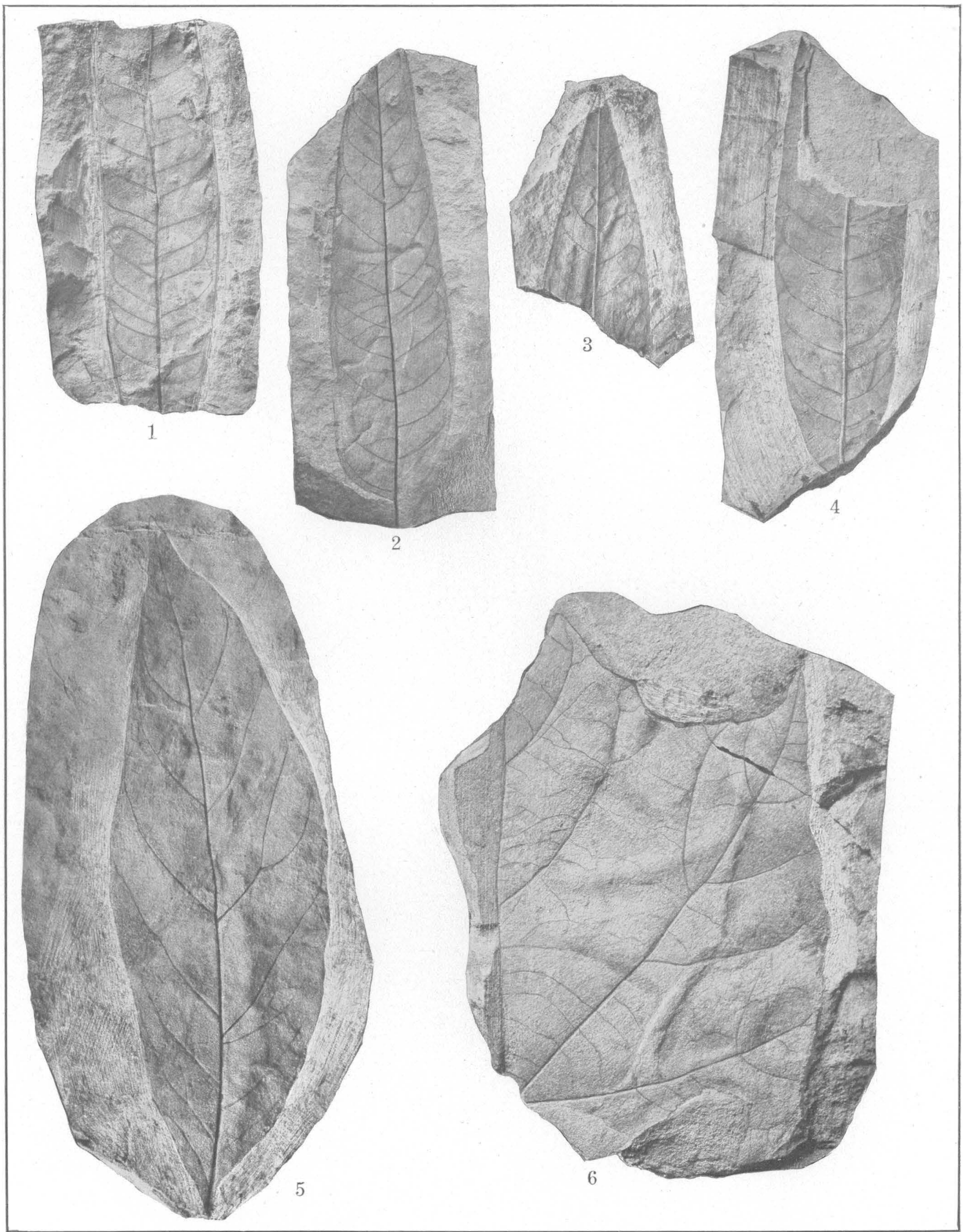

FLORA OF THE RATON FORMATION. 
PLATE XCI.

Ficures 1.4. Laurus ratonensis Knowlton, i. sp. (U.S. Nat. Mus. catalogue Nos. 34644, 34645, 34646) . . . . 316

5. Laurus socialis Lesquereux (U. S. Nat. Mus. catalogue No. 34647) .................... 317

6. Liquidambar? cucharas Knowlton, n. sp. (U. S. Nat. Mus. catalogue No. 3464S).

320 


\section{PLATE XCII.}

Platanus aceroides latifolia Knowlton, n. var. (U. S. Nat. Mus. catalogue No. 34649) 


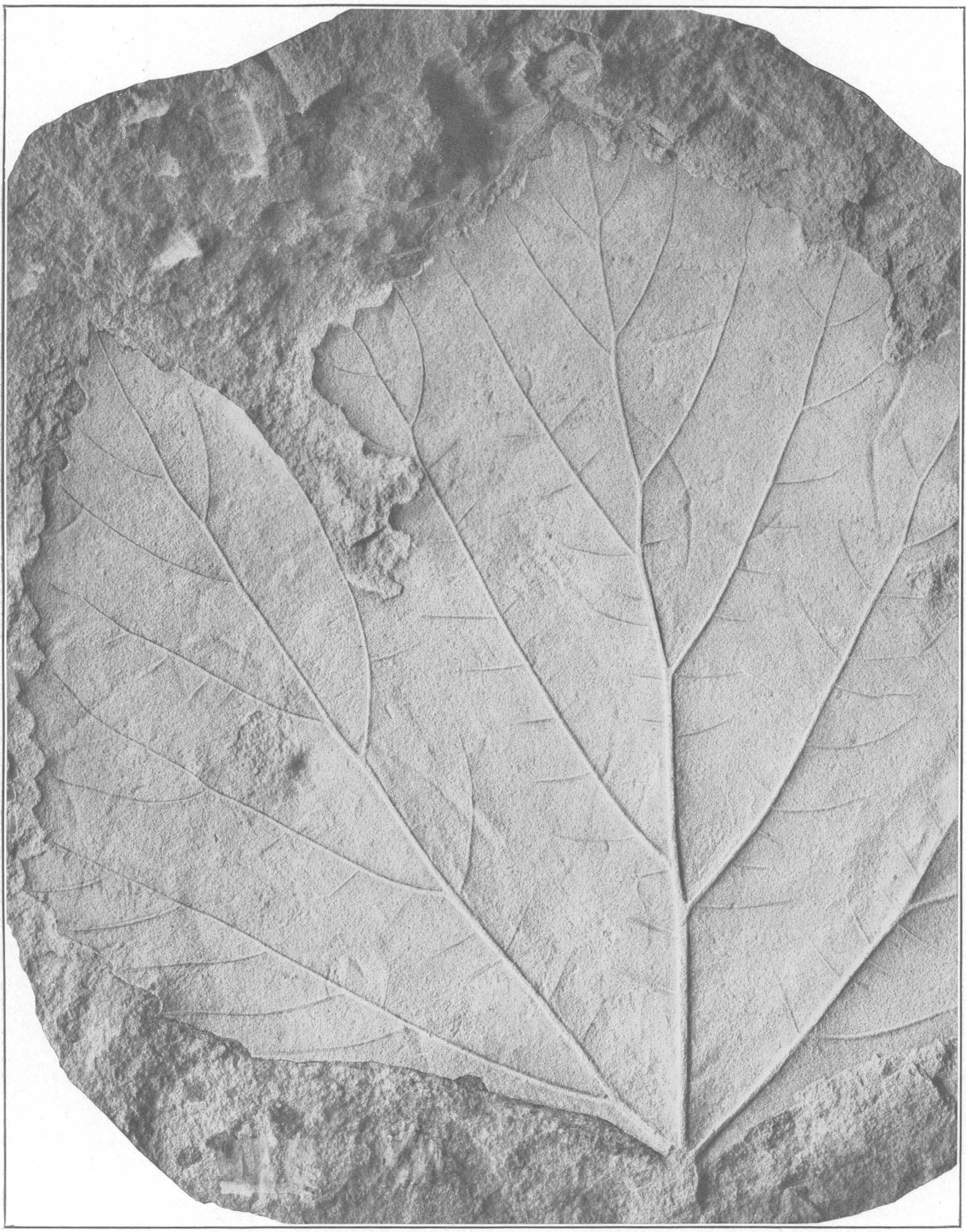

FLORA OF THE RATON FORMATION. 


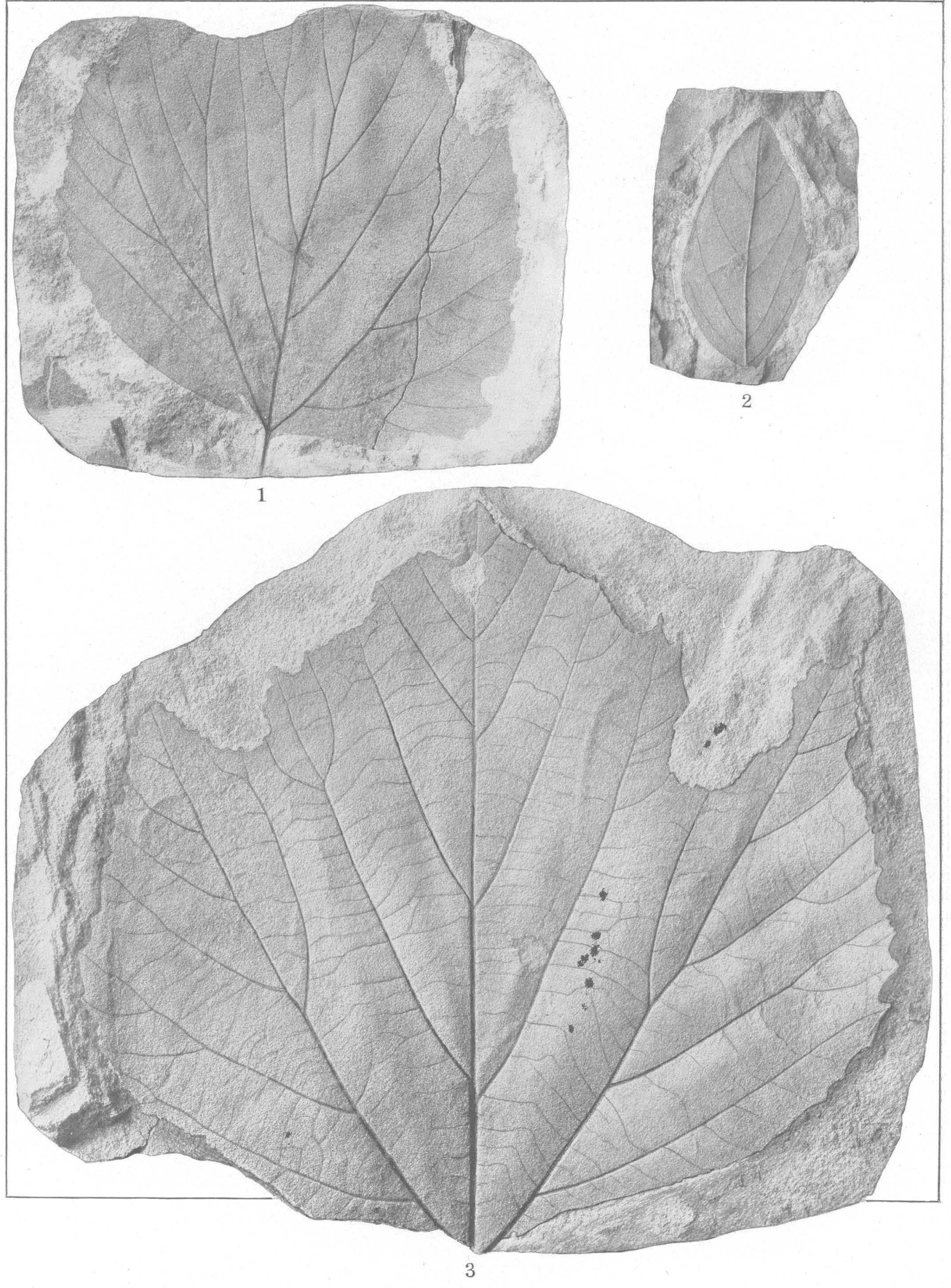

FLORA OF THE RATON FORMATION. 


\section{PLATE XCIII.}

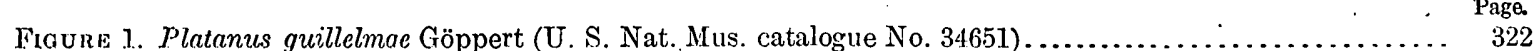

2. Cassia richardsoni Knowlton, in. sp. (U. S. Nat. Mus. catalogue No. 34652 ) ................. 327

3. Platanus aceroides latifolia Knowlton, n. var. (U. S. Nat. Mus. catalogue No. 34650)............... 321

415 
PLATE XCIV.

Platanus aceroides latifolia Knowlton, n. var (U. S. Nat. Mus. catalogue No. 34653)................... 321 416 


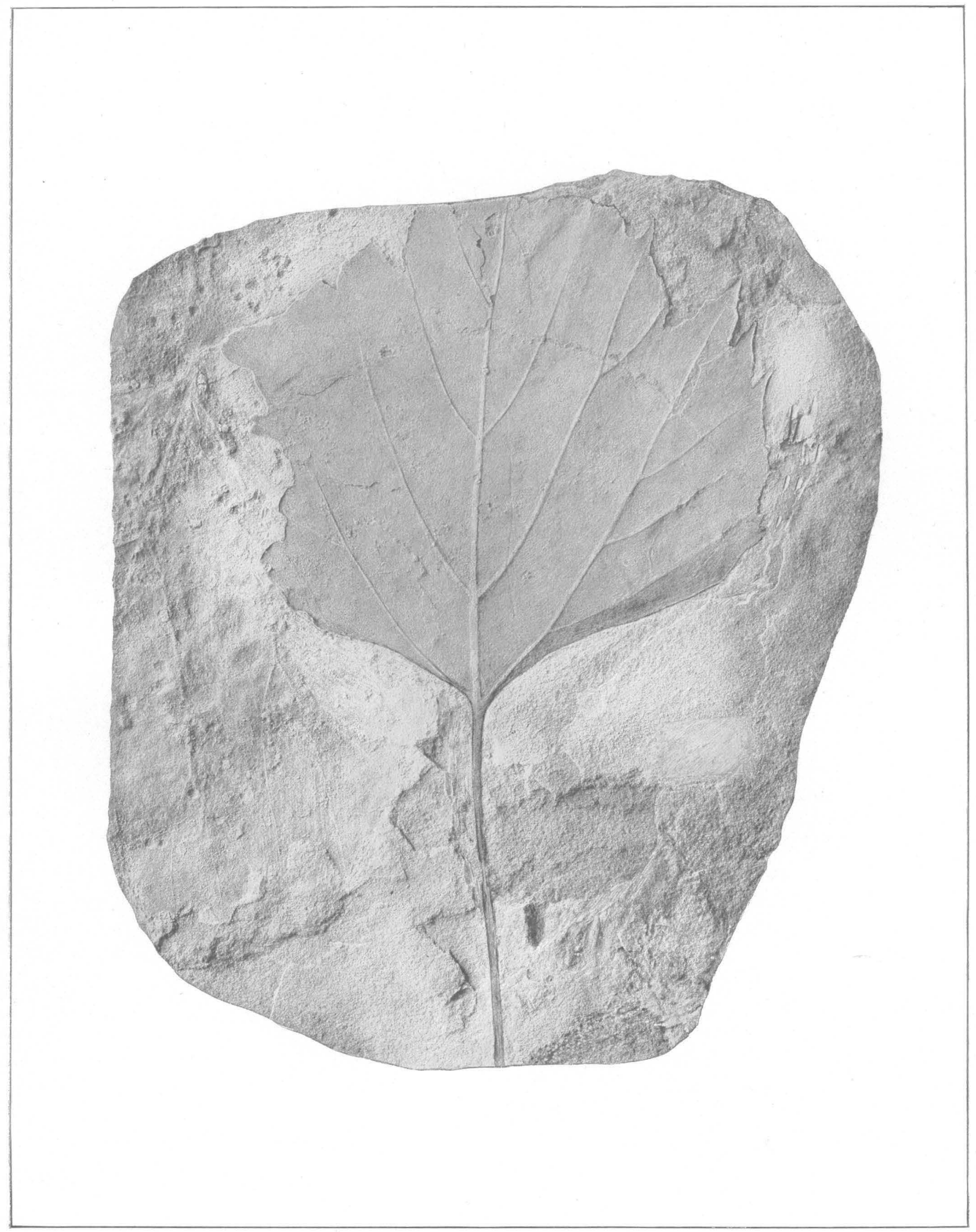

$47019^{\circ}-17-31$ 


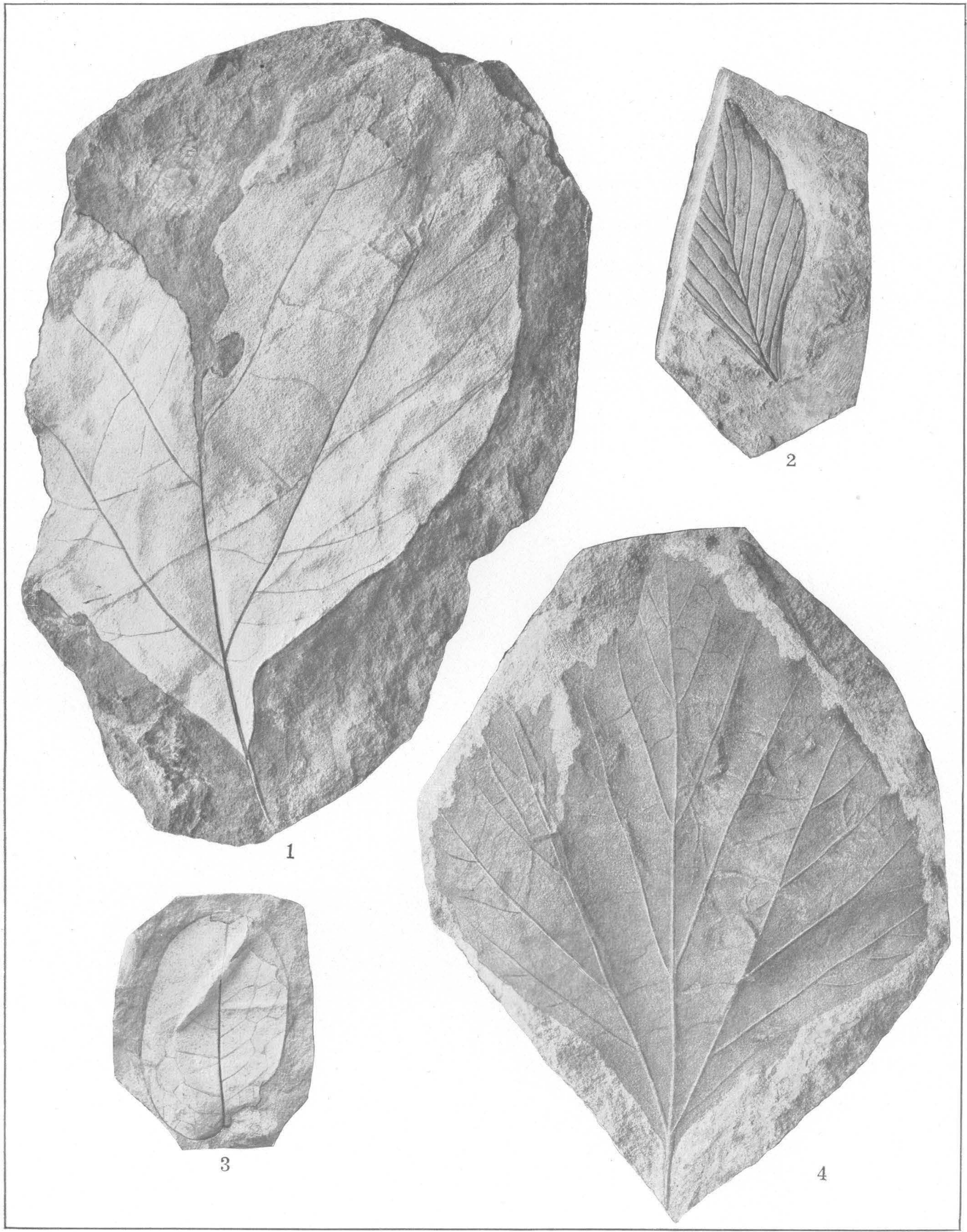

FLORA OF THE RATON FORMATION. 


\section{PLATE XCV.}

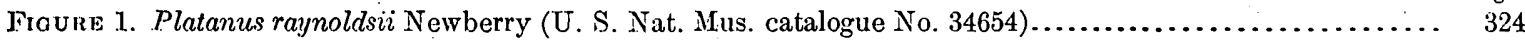

2. Cercocarpus orestesi Knowlton, n. sp. (U. S. Nat. Mus. catalogue No. 34655) . . . . . . . . . . . . 325

3. Sophora nervosa Knowlton, n. sp. (U. S. Nat. Mus. catalogue No. 34656) . . . . . . . . . . . . 326

4. Platanus platanoides (Lesquereux) Knowlton (U. S. Nat. Mus. catalogue No. 34657)........... 323 


\section{PLATE XCVI.}

Figure 1. Cassia sapindoides Knowlton, n. sp. (U. S. Nat. Mus. catalogue No. 34658)...................... 327

2. Prunus coloradensis Knowlton, n. sp. (U. S. Nat. Mus. catalogue No. 34659) ................. 326

- 3, 4. Euphorbocarpum richardsoni Knowlton, n. gen. and sp. (U. S. Nat. Mus. catalogue No. 34660)..... 328

5. Platanus guillelmae heerii Knowlton, n. var. (U. S. Nat. Mus. catalogue No. 34661) ............. 323 418 


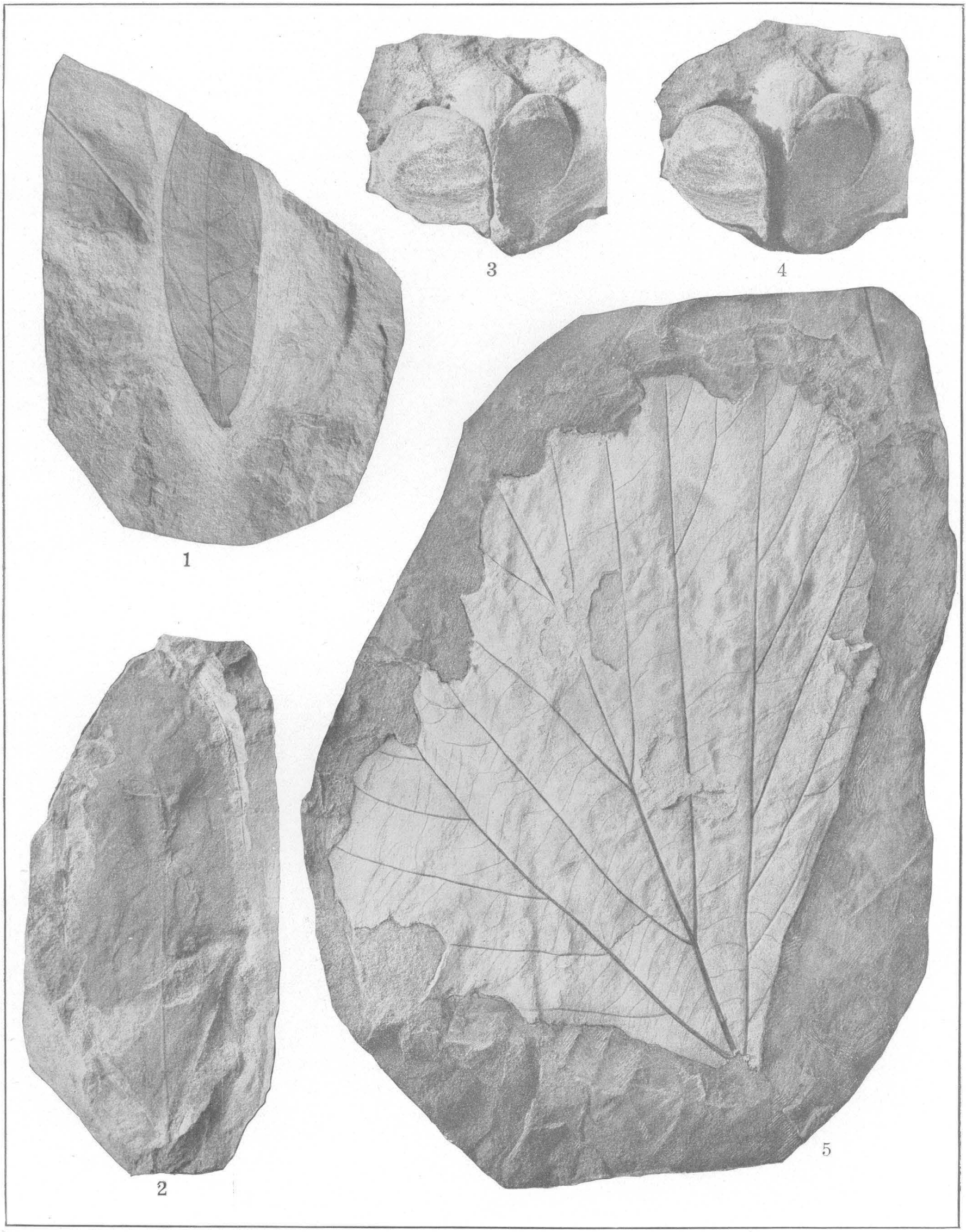

FLORA OF THE RATON FORMATION. 


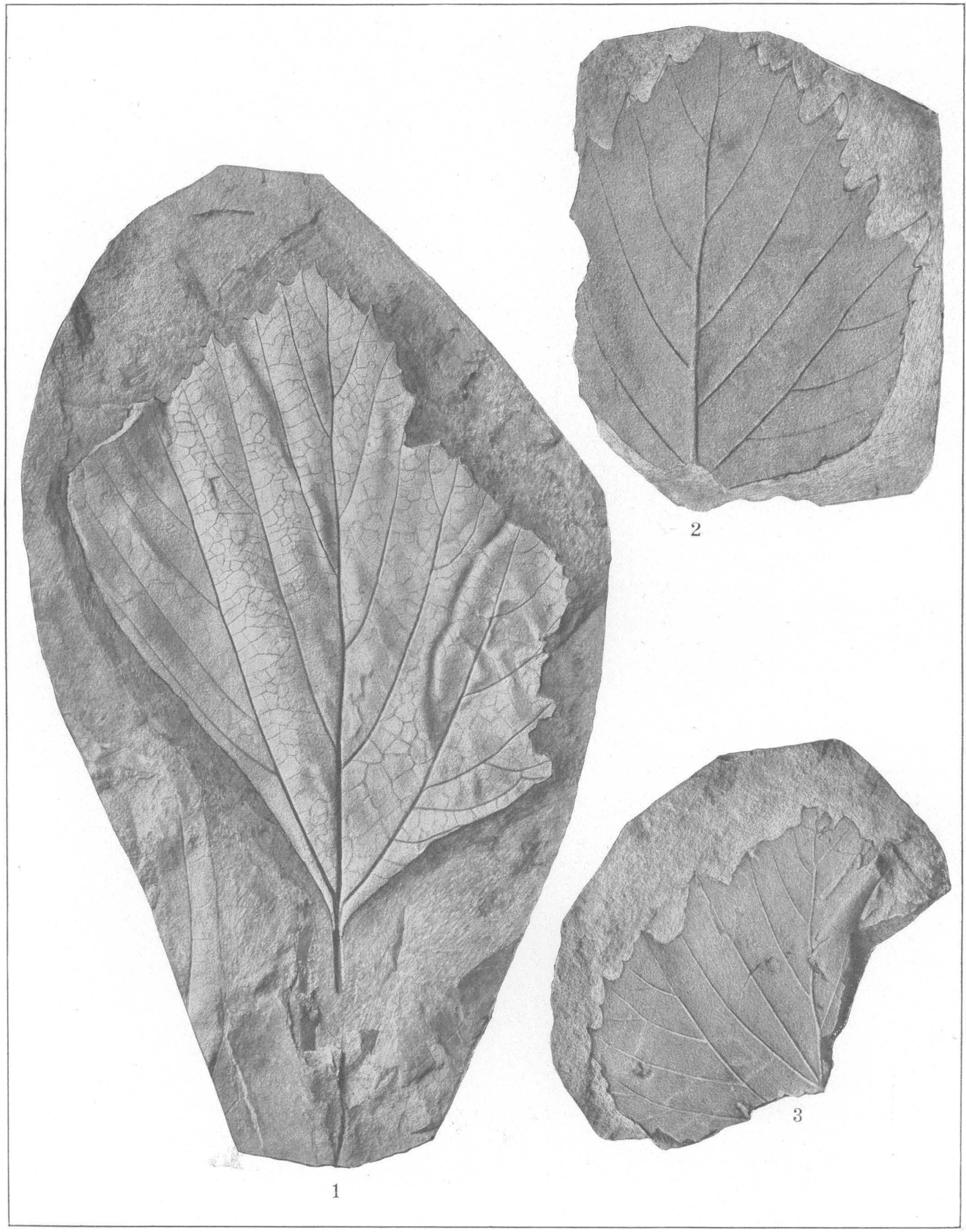

FLORA OF THE RATON FORMATION. 


\section{PLATE XCVII.}

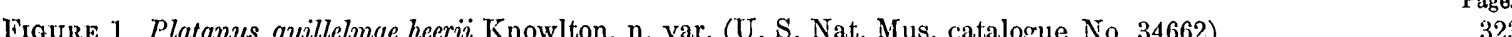
2, 3. Platanus aceroides Göppert (U. S. Nat. Mus. catalogue Nos. 34663,34664$) \ldots \ldots \ldots \ldots \ldots \ldots \ldots \ldots . \ldots \ldots \ldots \ldots$ 


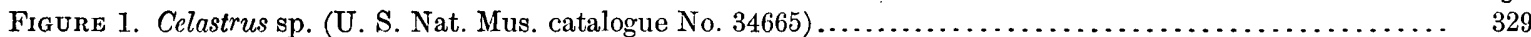

2. Platanus guillelmae heerii Knowlton, n. var. (U. S. Nat. Mus. catalogue No. 34666)............... 323

3. Celastrus serratus Knowlton, n. sp. (U. S. Nat. Mus. catalogue No. 34667) .................... 329

4. Sapindus rocklandensis Knowlton, n. sp. (U. S. Nat. Mus. catalogue No. 34668)............... 331

5. Rhus? viburnoides Knowlton, n. sp. (U. S. Nat. Mus. catalogue No. 34669$) \ldots \ldots \ldots \ldots \ldots \ldots \ldots \ldots \ldots$ 420 


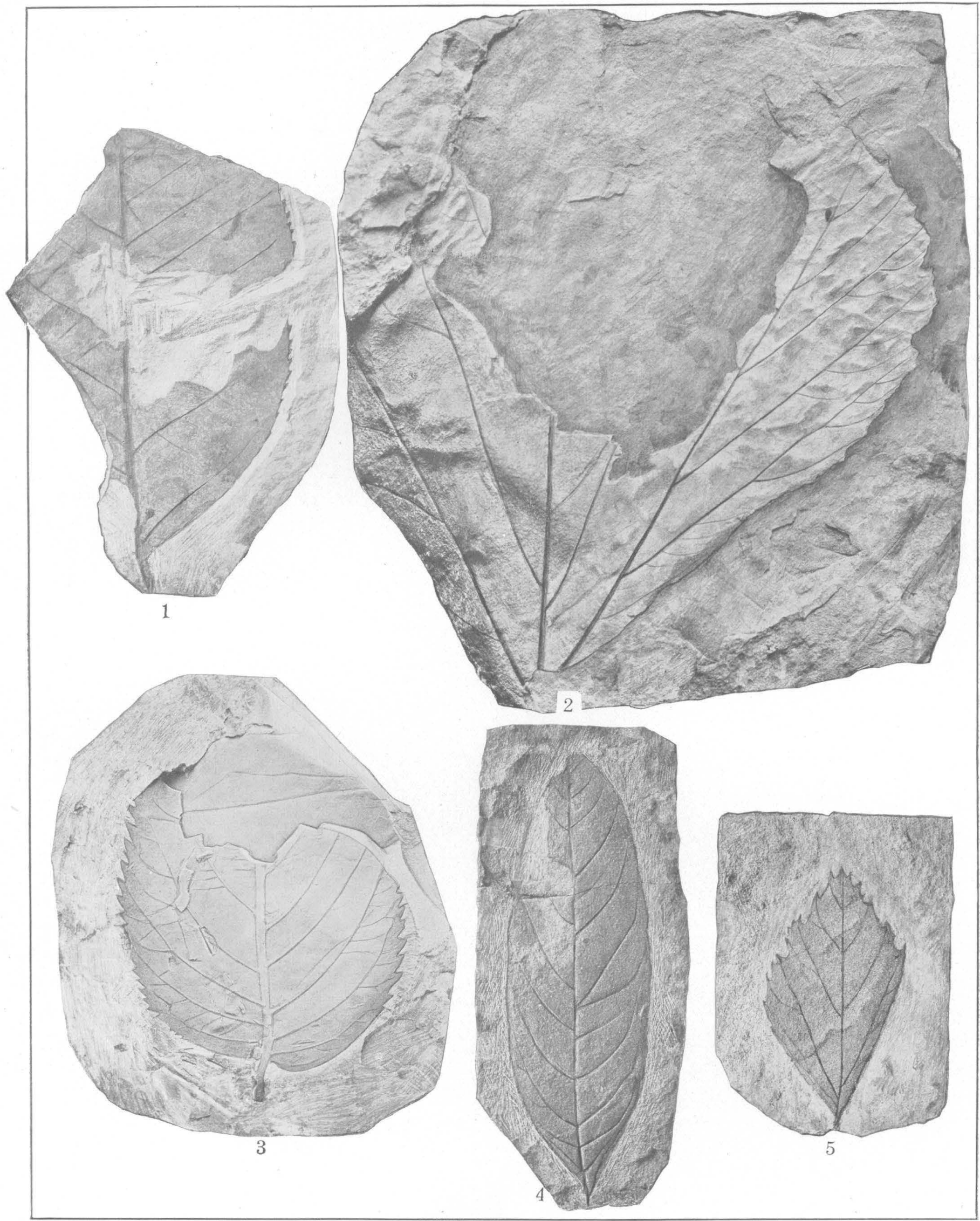

FLORA OF THE RATON FORMATION. 


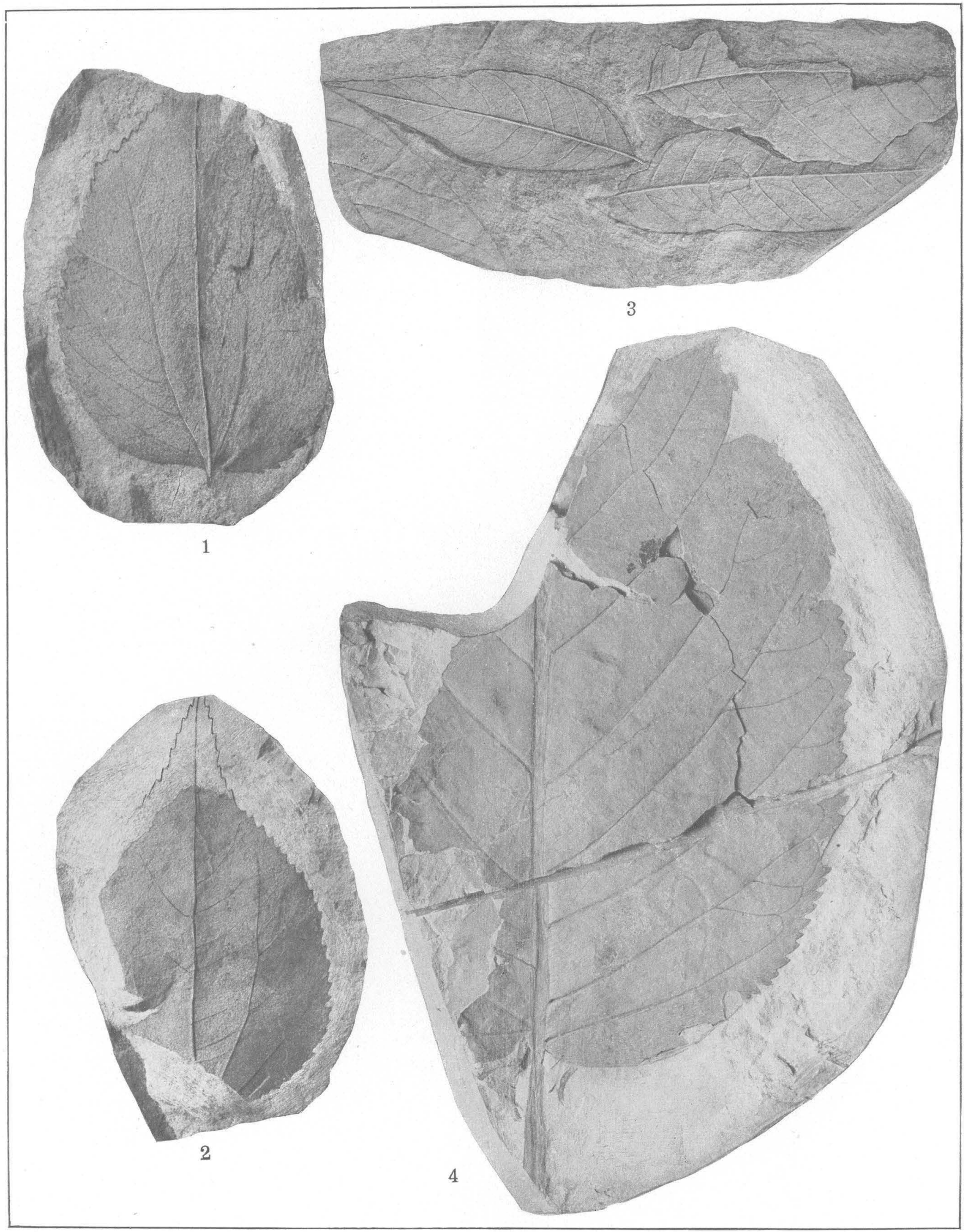

FLORA OF THE RATON FORMATION. 


\section{PLATE XCIX.}

Figures 1, 2. Zizyphus meiggsii (Lesquereux) Schimper (U. S. Nat. Mus. catalogue Nos. 34670, 34671) ........ 336

3. Sapindus afinis Lesquereux (U. S. Nat. Mus. catalogue No. 34672) .................... 331.

4. Celastrus serratus Knowlton, n. sp. (U. S. Nat. Mus. catalogue No. 34673) .................. 329 


\section{PLATE C.}

Page.

FIgUre 1. Celastrus serratus Knowlton, n. sp. (U. S. Nat. Mus. catalogue No. 34674) . . . . . . . ........... 329

2. Sapindus caudatus Lesquereux (U. S. Nat. Mus. catalogue No. 34675) .................... 330

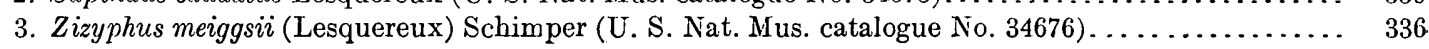
422 


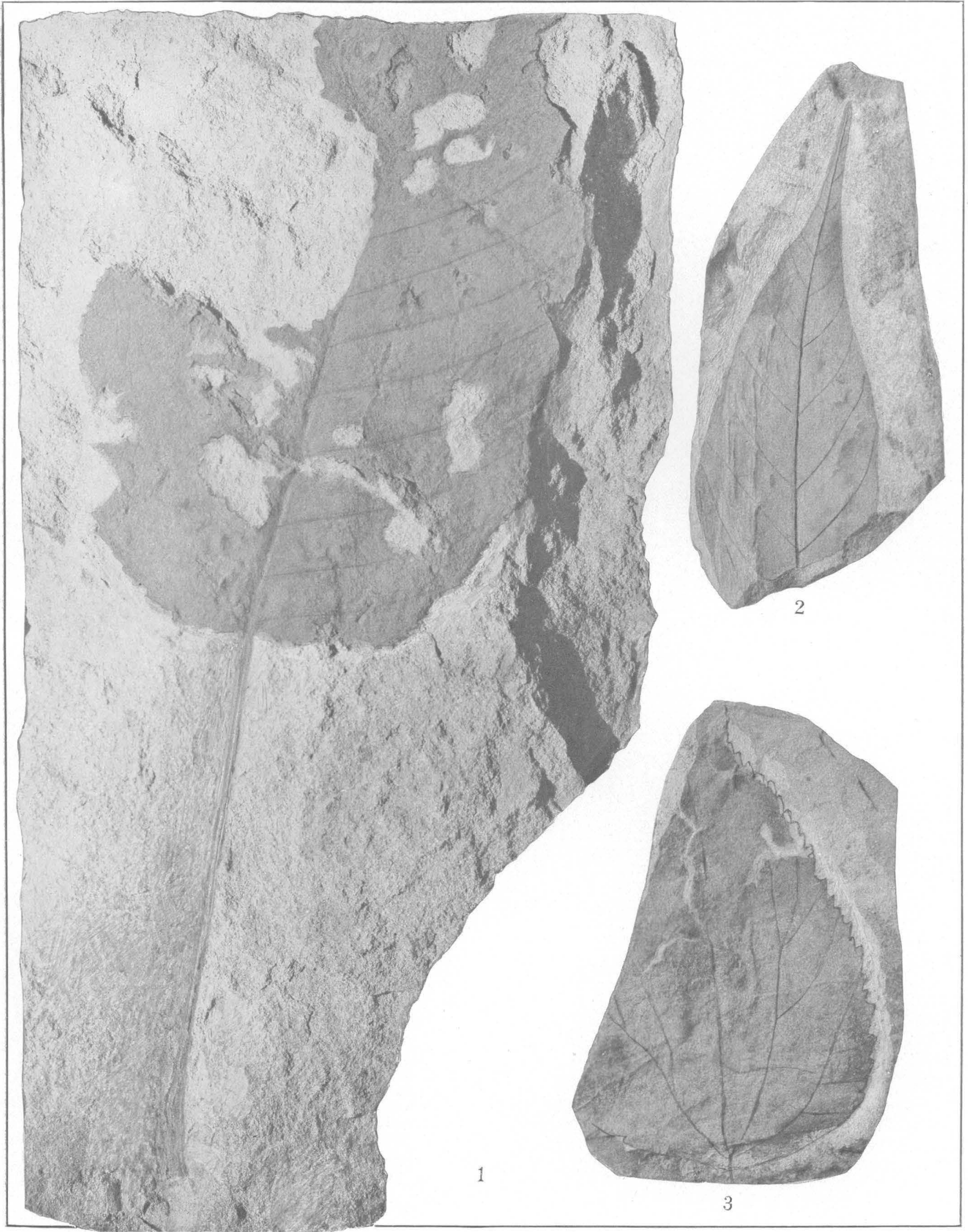

FLORA OF THE RATON FORMATION. 


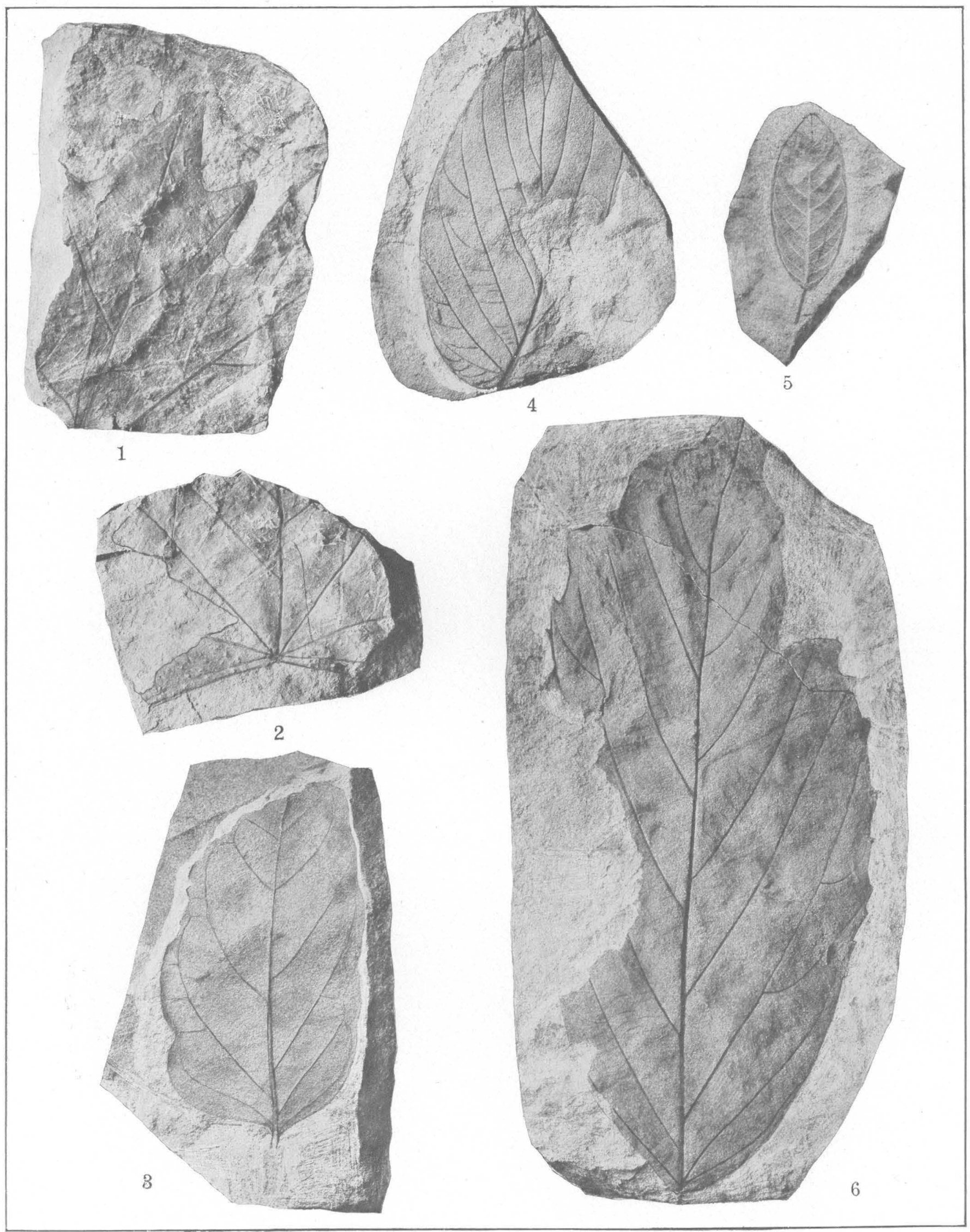

FLORA OF THE RATON FORMATION. 


\section{PLATE CI.}

Ficures 1, 2. Acer fragilis Knowlton, n. sp. (U. S. Nat. Mus. catalogue Nos. 34677,34678 ) ................ 330

3. A peibopsis neomexicana? Knowlton, n. sp. (U. S. Nat. Mus. catalogue No. 34679).............. 336

4. Rhamnus goldianus? Lesquereux (U. S. Nat. Mus. catalogue No. 34680).................. 332

5. Berchemia multinervis (Alexander Braun) Heer (U. S. Nat. Mus. catalogue No. 34681) . . . . ... 333

6. Rhamnus woottonensis? Knowlton, n. sp. (U. S. Nat. Mus. catalogue No. 34682)................ 332 


\section{PLATE CII}

Figure 1. Zizyphus fibrillosus (Lesquereux) Lesquereux (U. S. Nat. Mus. catalogue No. 34683).............. 335

2. Dombeyopsis magnifolia Knowlton, n. sp. (U. S. Nat. Mus. catalogue No. 34684) .............. 337

3, 4. Sterculia berryana Knowlton, n. sp. (U. S. Nat. Mus. catalogue Nos. 34685,34686 ) ............ 337

5. Phyllites retusoides Knowlton, n. sp. (U. S. Nat. Mus. catalogue No. 34687) .................... 349 424 


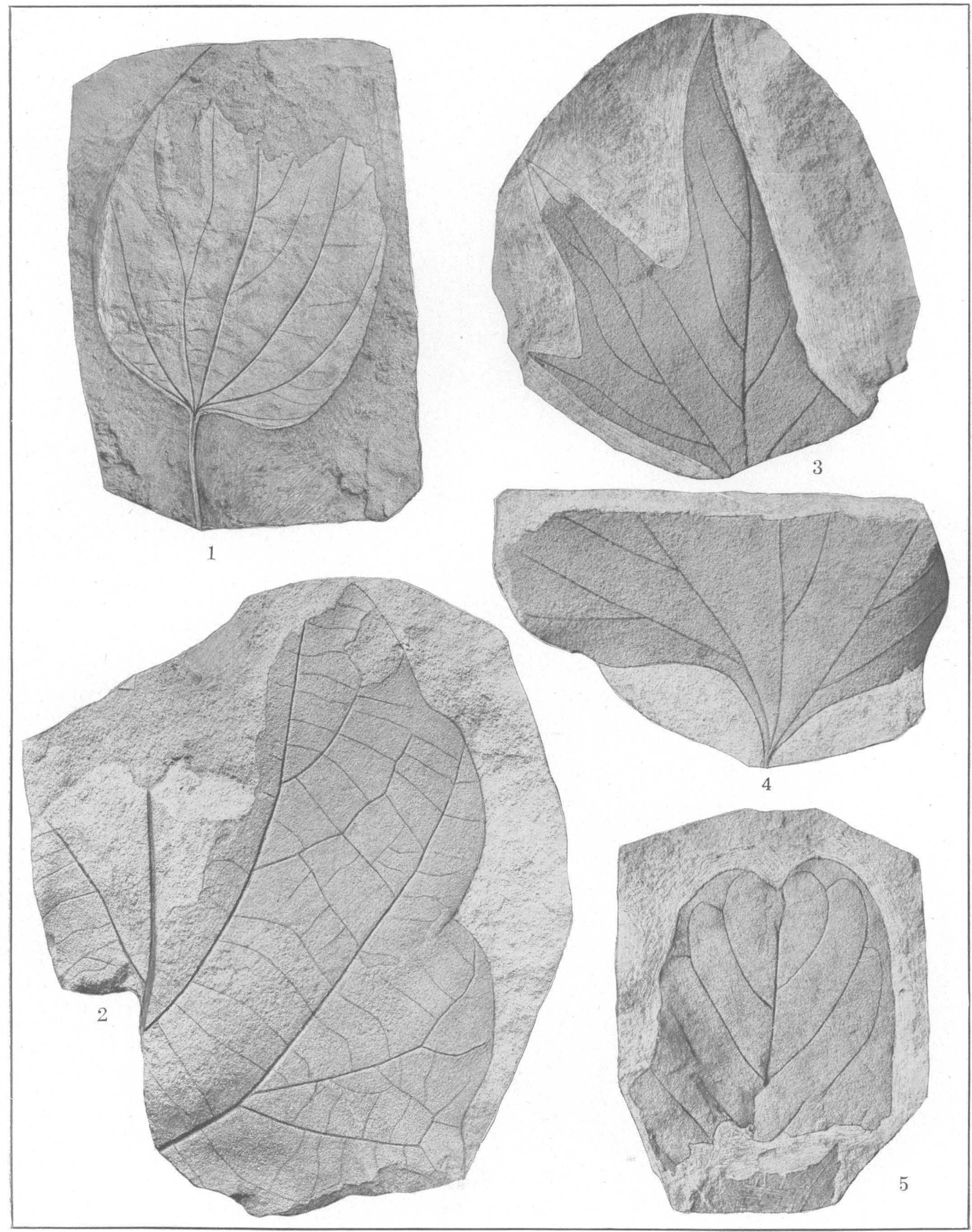

$47019^{\circ}-17-32$

FLORA OF THE RATON FORMATION. 


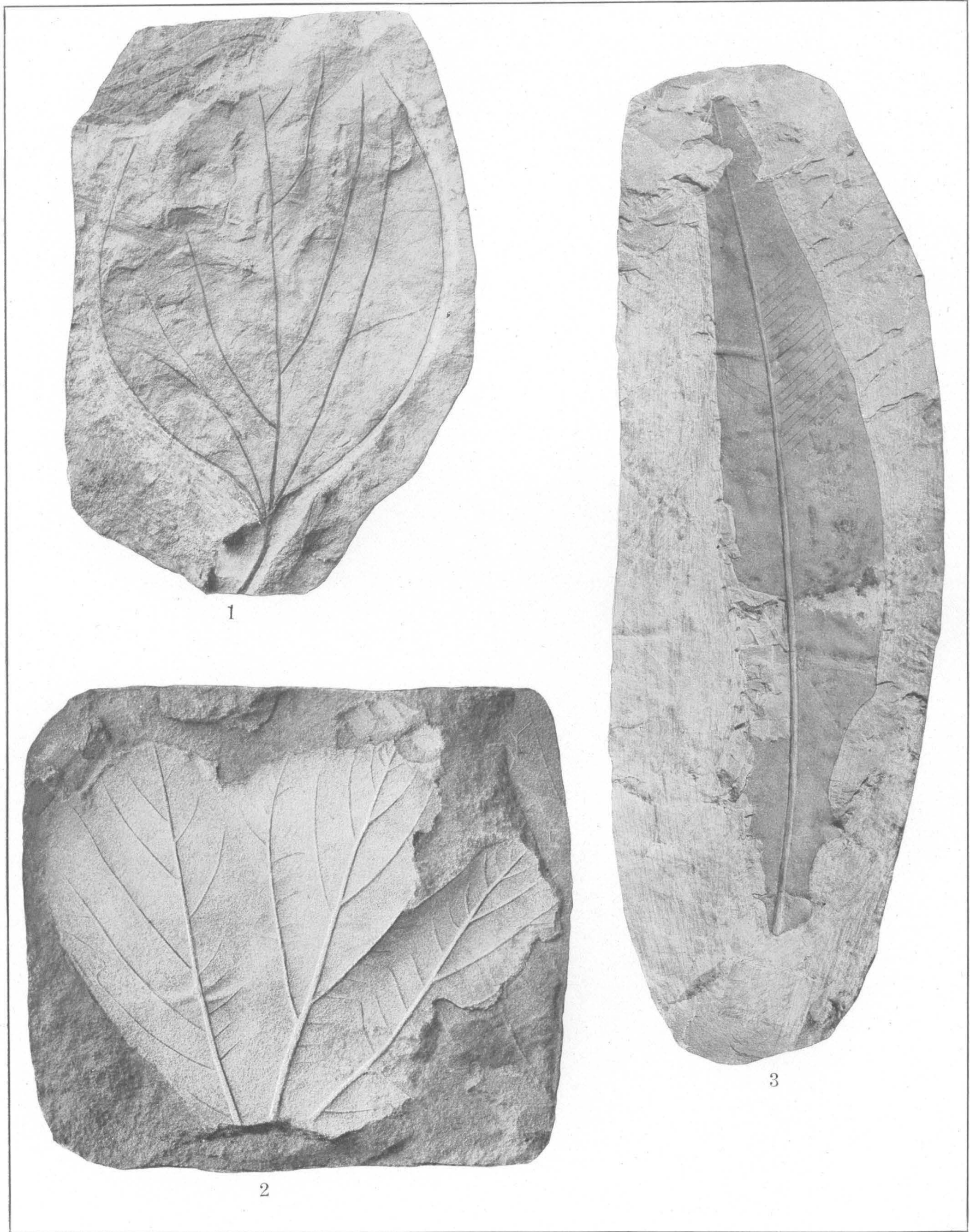


PLATE CIII.

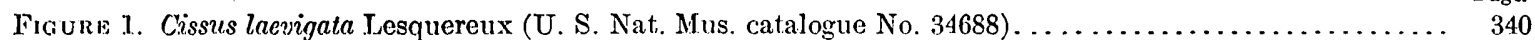

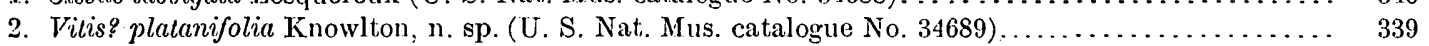

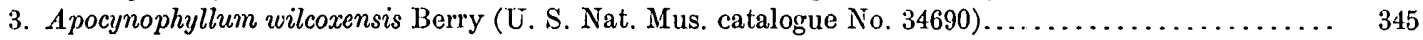




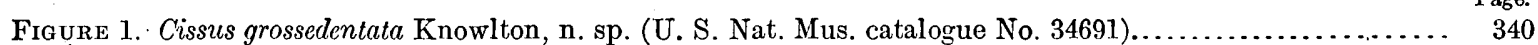

2. Paliurus zizyphoides Lesquereux (U. S. Nat. Mus. catalogue No. 34692) ................... 334

3. Apocynophyllum linifolium Knowiton, n. sp. (U. S. Nat. Mus. catalogue No. 34693)............. 346 426 


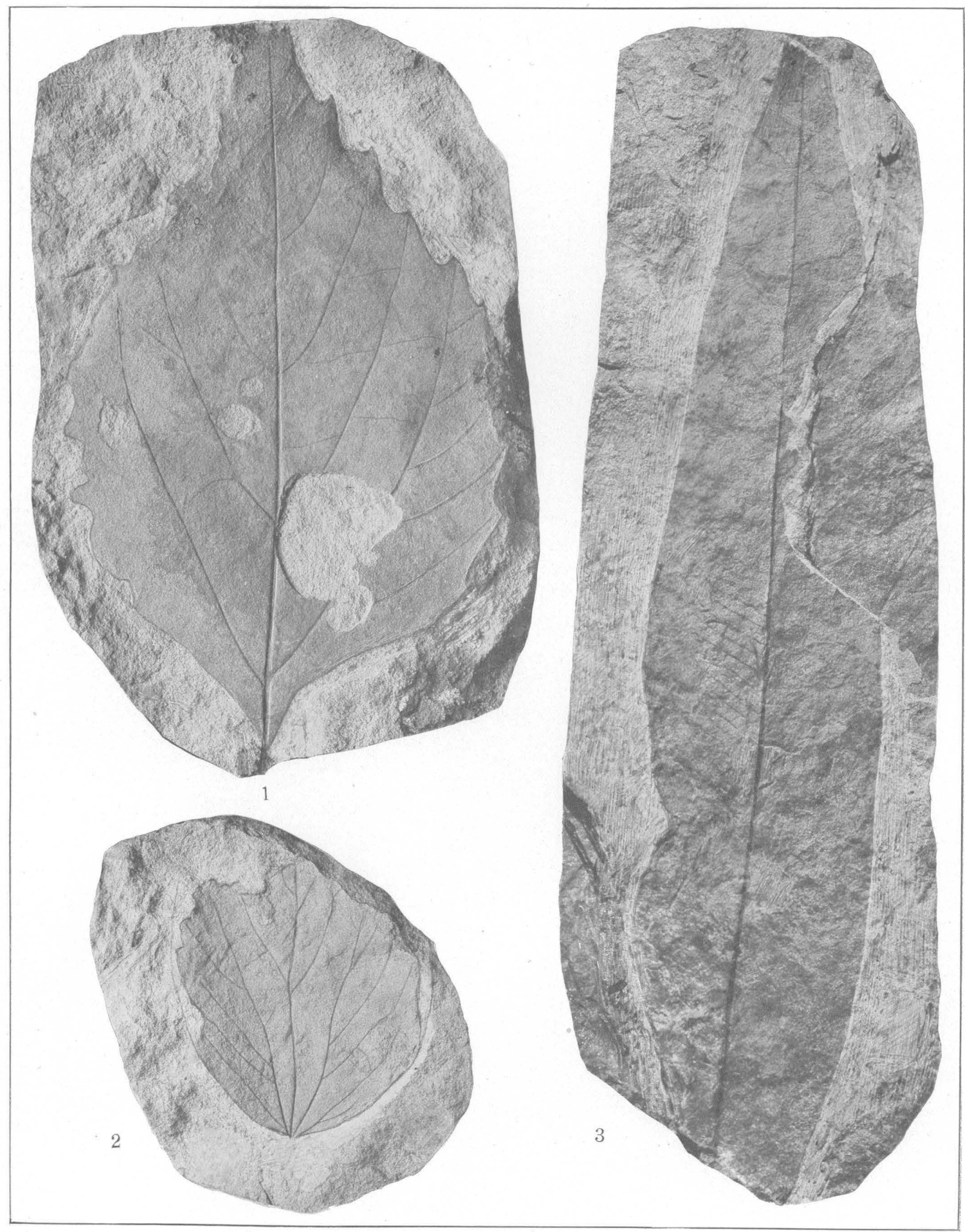

FLORA OF THE RATON FORMATION. 


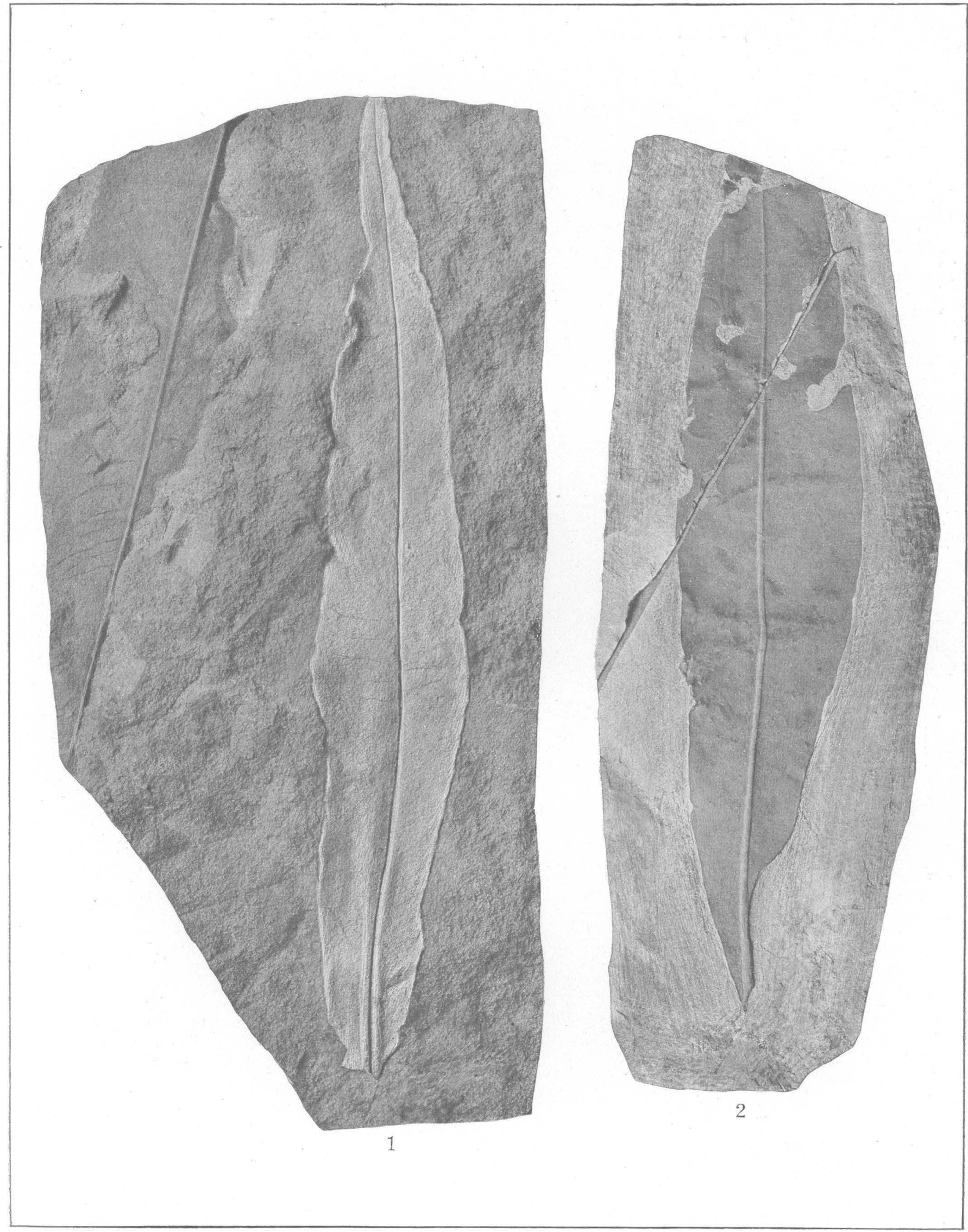

FLORA OF THE RATON FORMATION. 
PLATE CV.

Figures 1, 2. Apocynophyllum wilcoxensis Berry (U. S. Nat. Mus. catalogue Nos. 34694, 34695).......... 345 


\section{PLATE CVI.}

FigUre 1. Apocynophyllum wilcoxensis Berry (U. S. Nat. Mus. catalogue No. 34696).................. 345

2. Magnolia laurifolia Lesquereux (U. S. Nat. Mus. catalogue No. 34697) .

300

428 

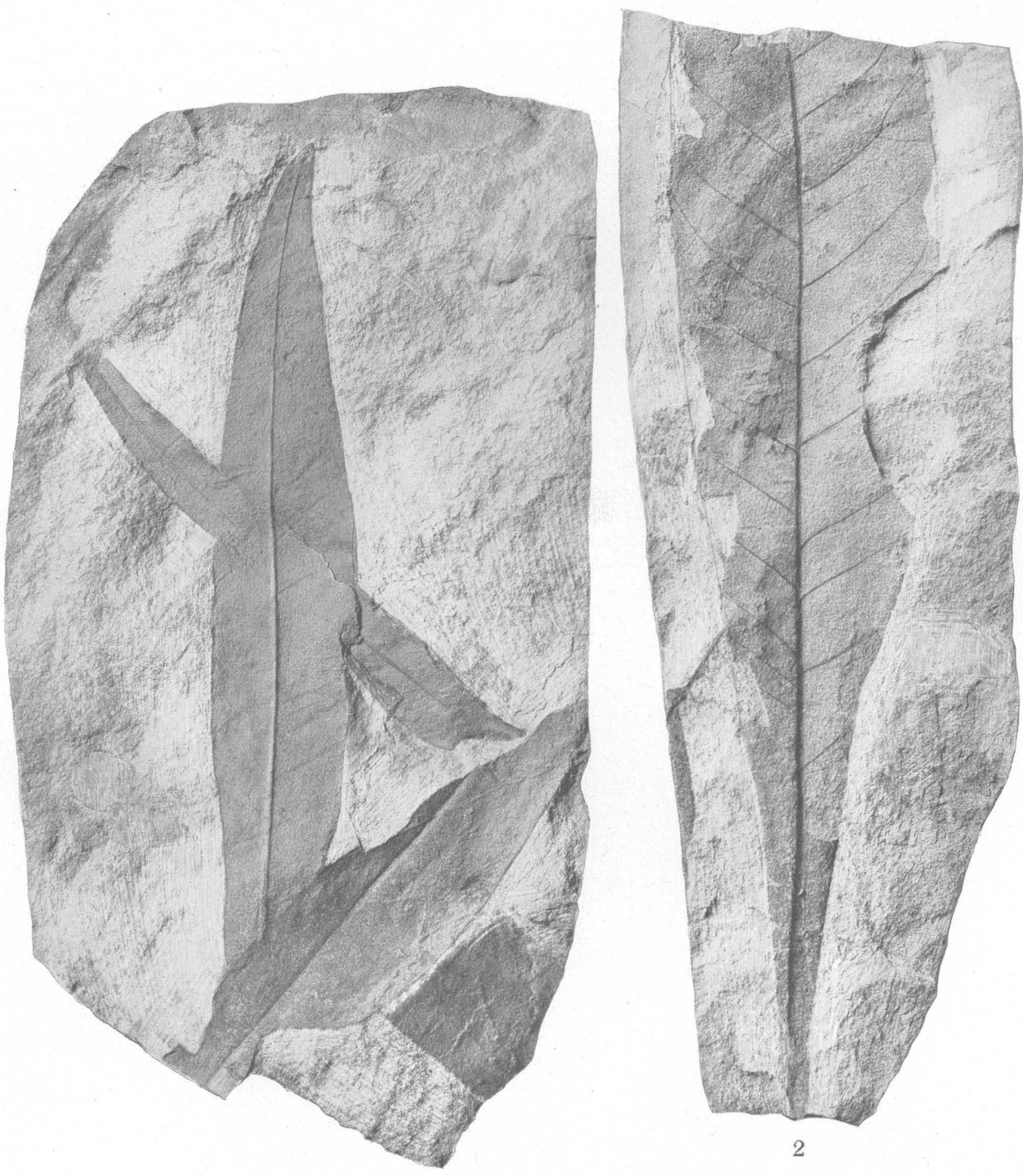

1 


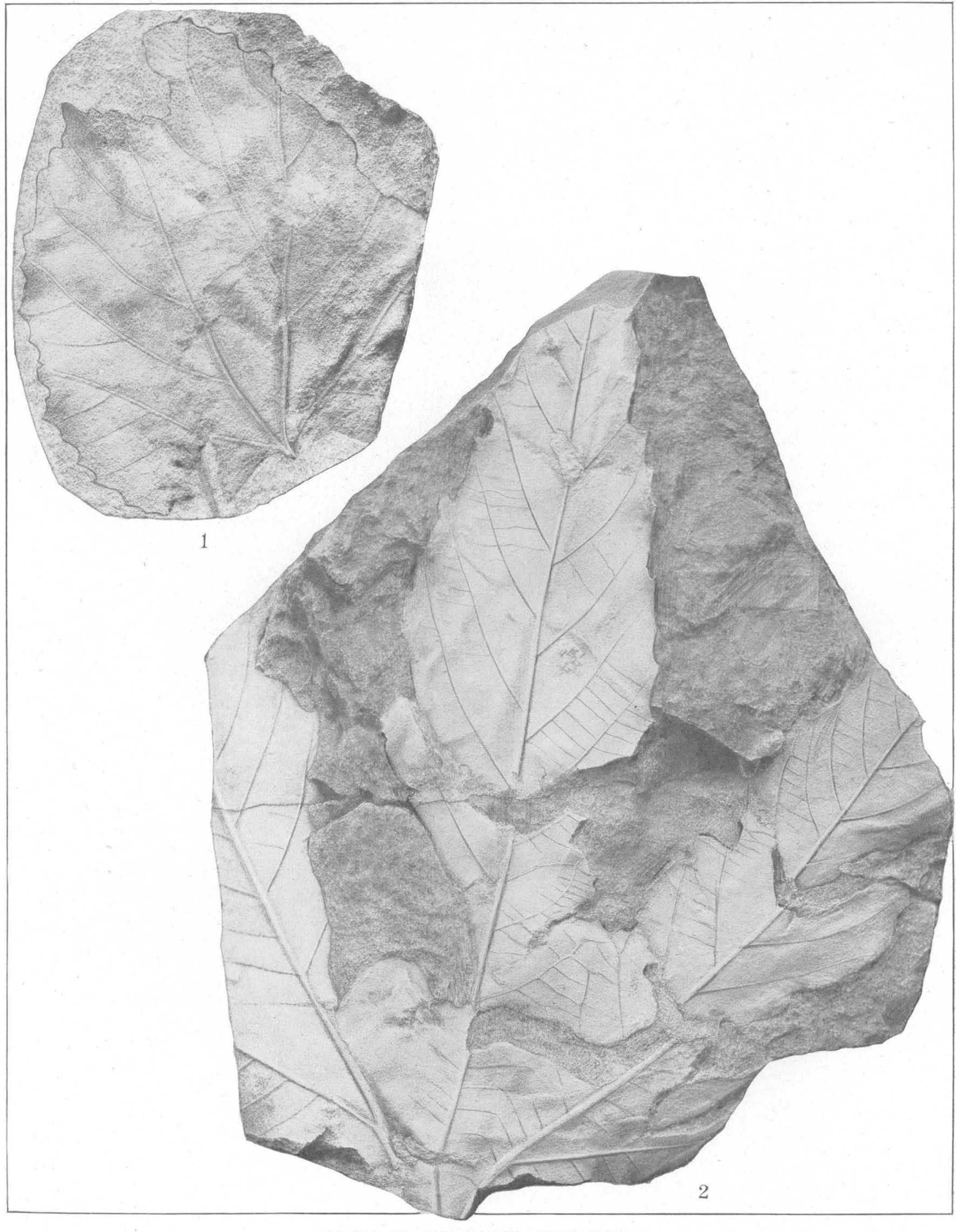

FLORA OF THE RATON FORMATION. 


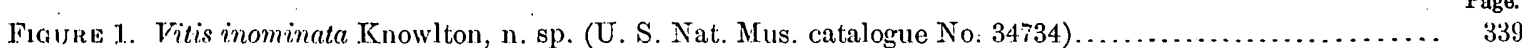

2. Aralia coloradensis Knowlton, n. sp. (U. S. Nat. Mus. catalogue No. 34698)................... 341 


\section{PLATE CVIII.}

Figure 1. Nyssa lanceolata Lesquereux (U. S. Nat. Mus. catalogue Nó. 34699)......................... 343

2. Chionanthus membranaceus KnowIton, n. sp. (U. S. Nat. Mus. catalogue No. 34700)........... . 345

3. Viburnum contortum Lesquereux (U. S. Nat. Mus. catalogue No. 34701)................... . . 346

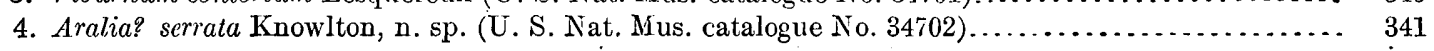

430 


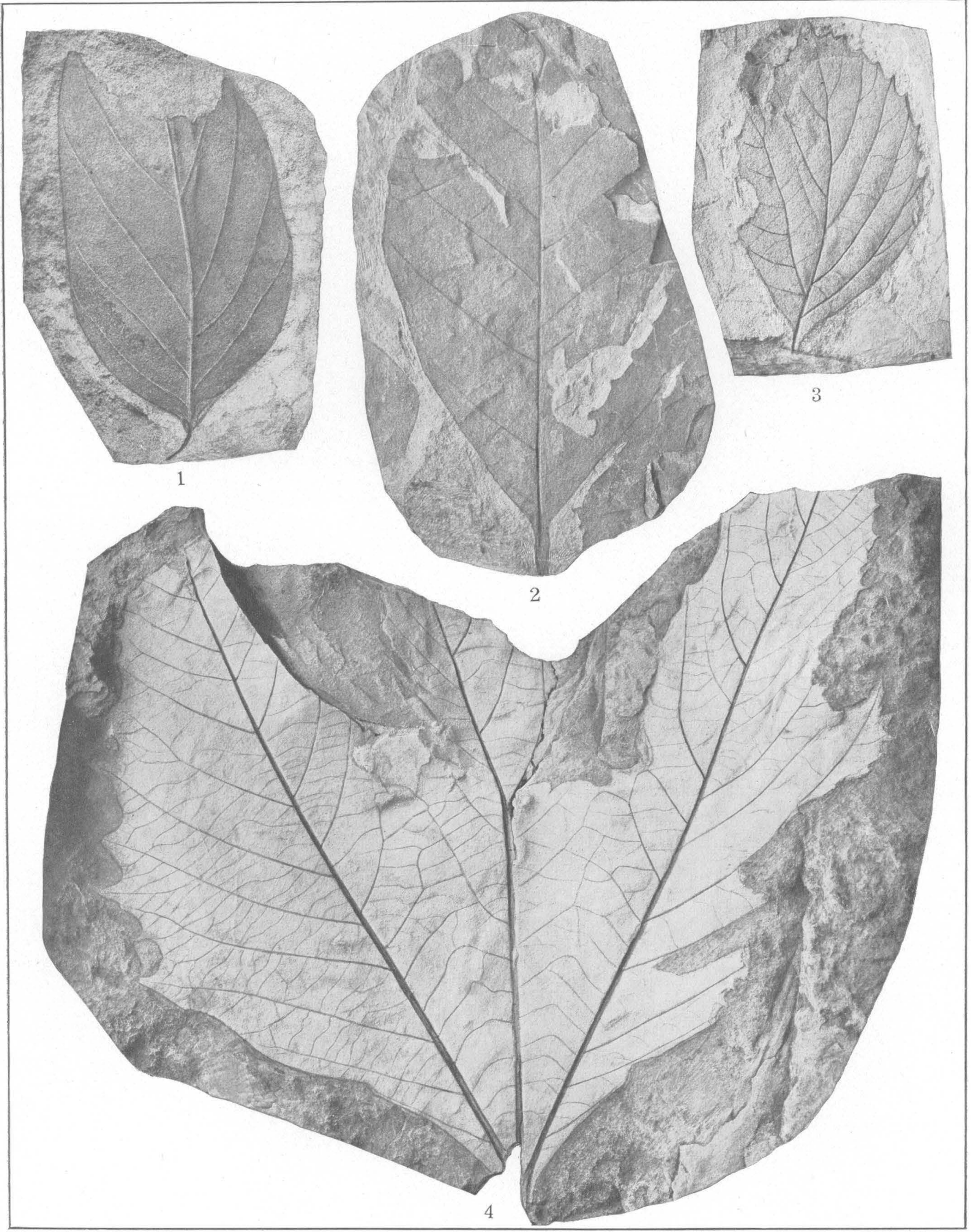

FLORA OF THE RATON FORMATION. 


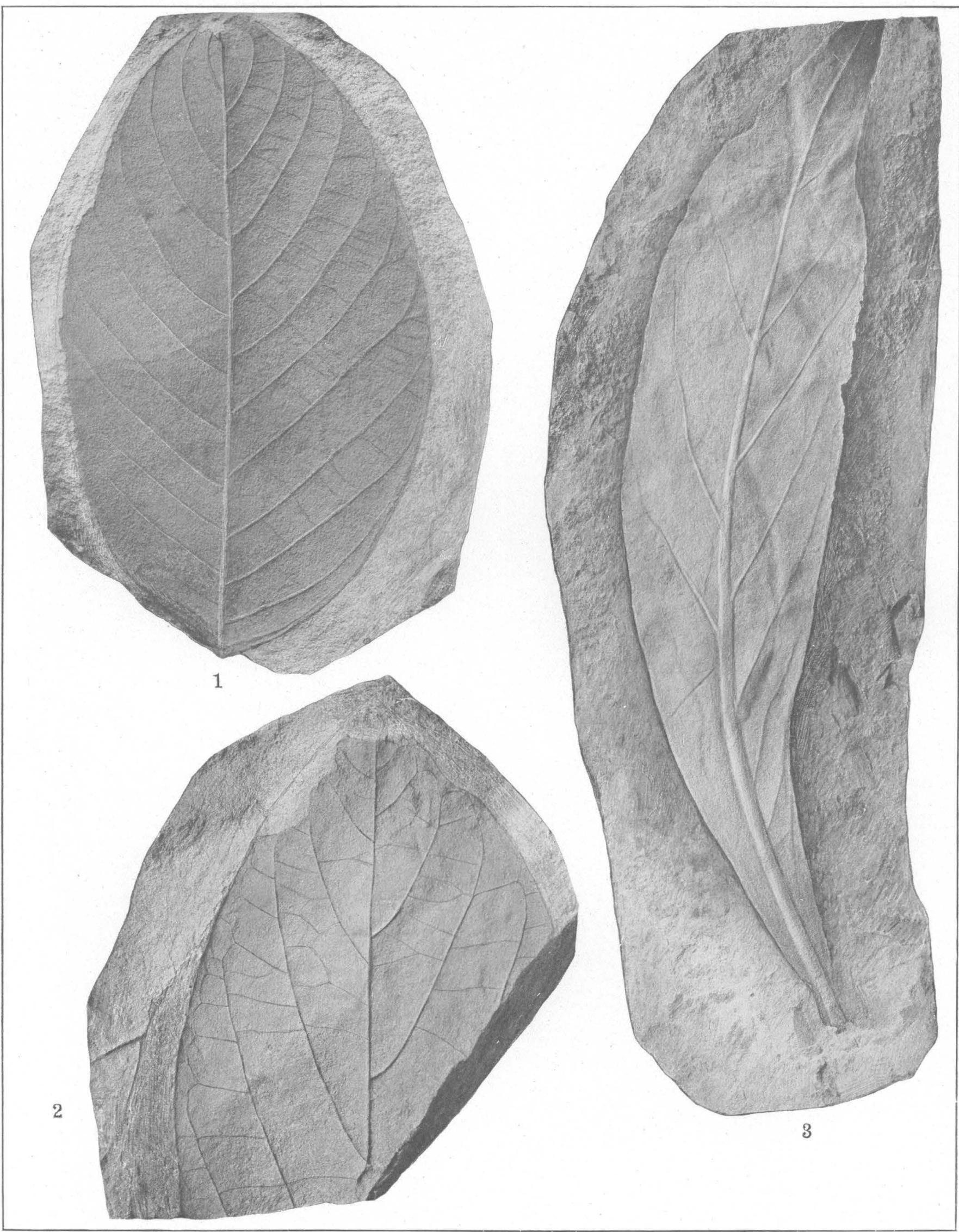

FLORA OF THE RATON FORMATION. 
PLATE CIX.

Figure 1. Cornus neomexicana Knowlton, n. sp. (U. S. Nat. Mus. catalogue No. 34703)................... $\begin{array}{r}\text { Page. } \\ 342\end{array}$

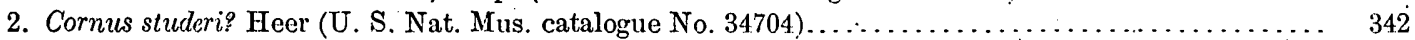

3. Andromeda? lanceolata Knowlton, n. sp. (U. S. Nat. Mus. catalogue No. 34705) .................. 344 
PLATE CX.

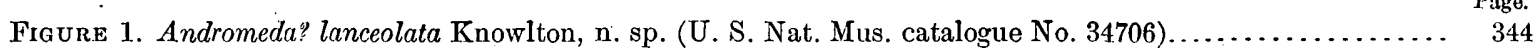

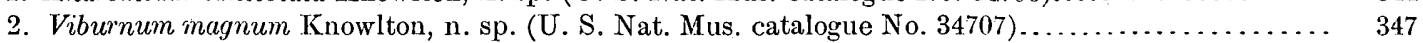

3, 4. Viburnum lakesii Lesquereux (U. S. Nat. Mus. catalogue Nos. 34708, 34709)................ 348 432 


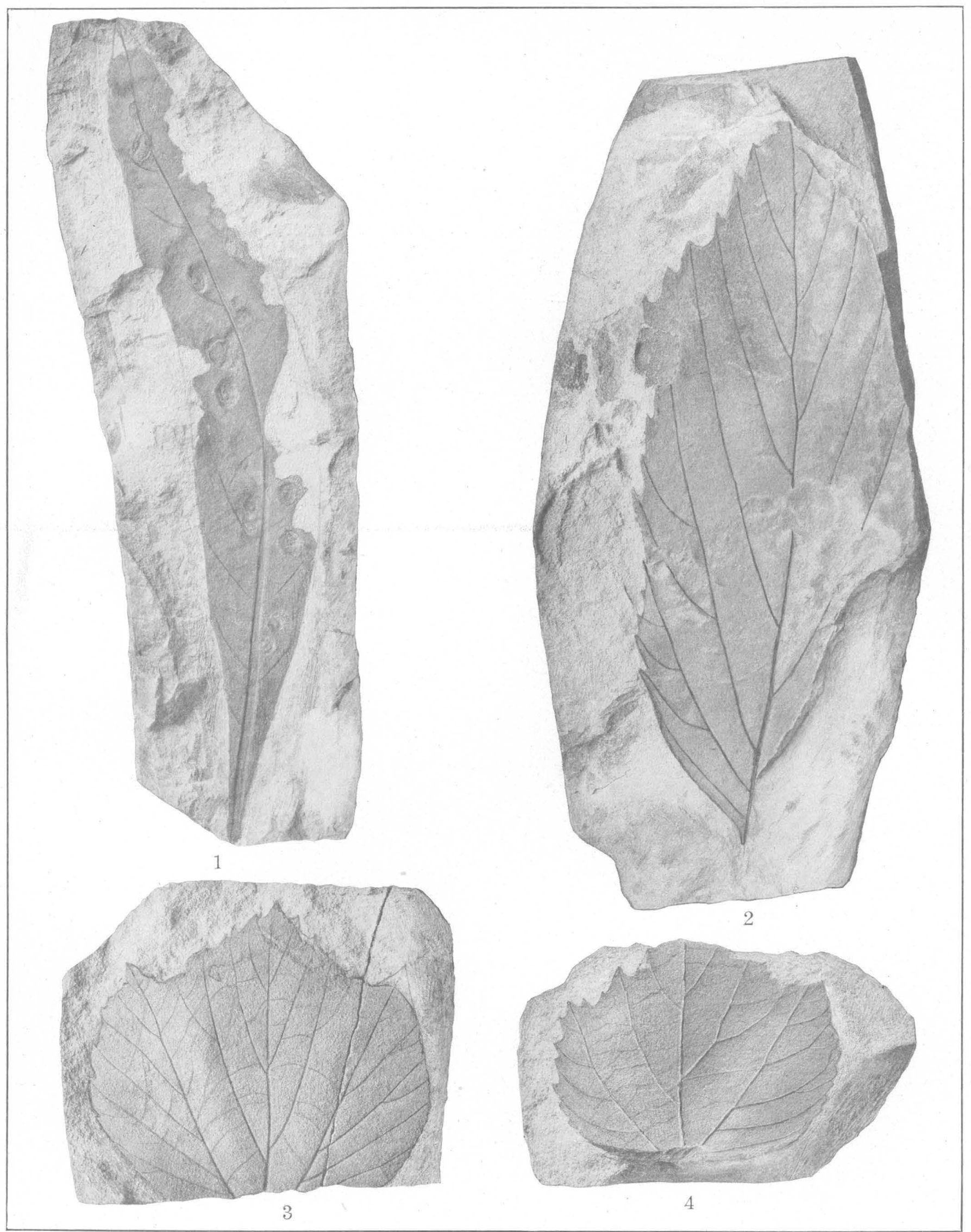

$47019^{\circ}-17-33$

FLORA OF THE RATON FORMATION. 


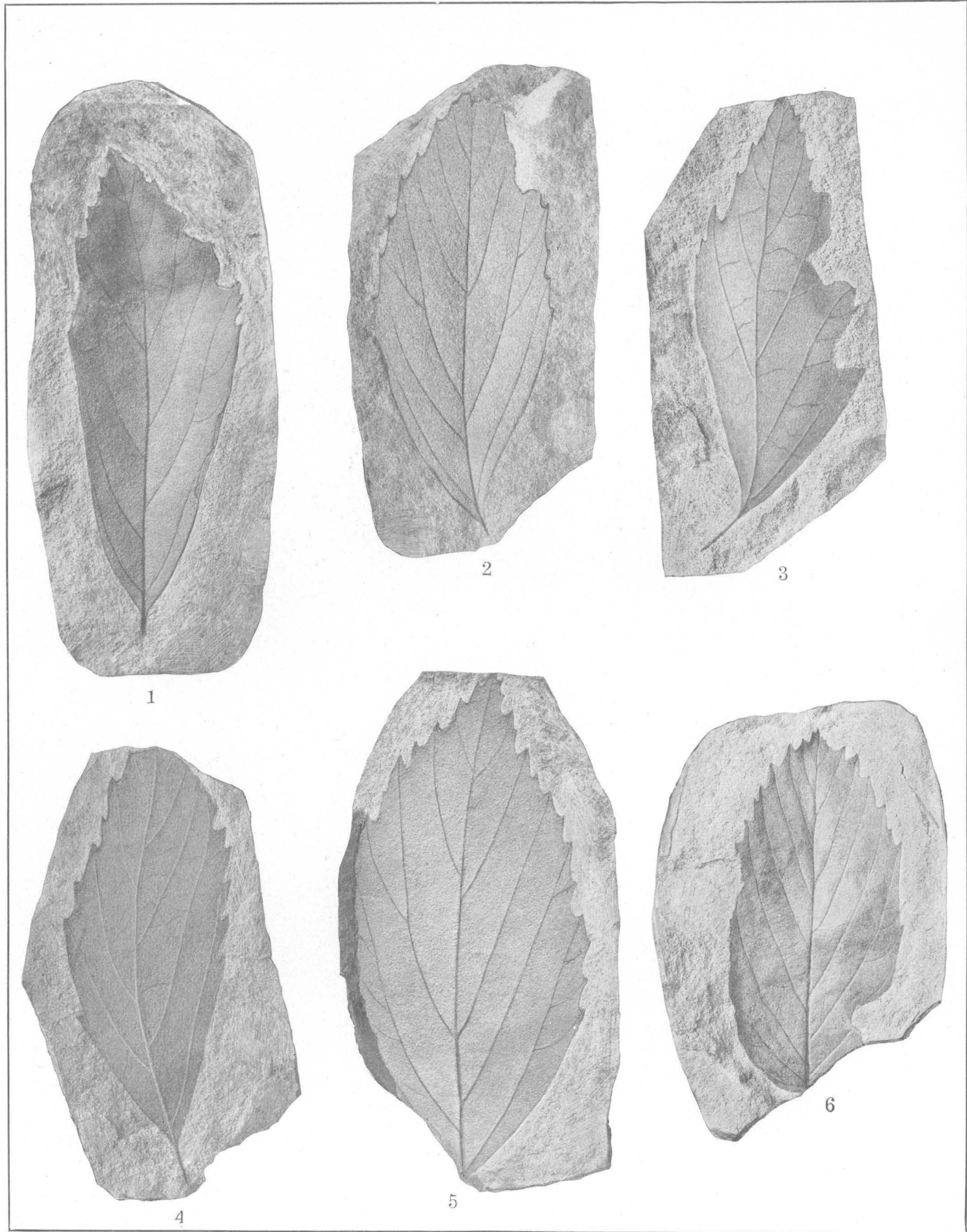

FLORA OF THE RATON FORMATION. 


\section{PLATE CXI.}

Fiaures 1.-5. Viburnum speciosum Knowlton, n. sp. (U. S. Nat. Mus. catalogue Nos. 34710-34714).......... Page. 347

6. Viburnum woottonianum Knowlton, n. sp. (U. S. Nat. Mus. catalogue No. 34715)............ 347 


\section{PLATE CXII.}

Figures 1, 2. Andromeda scripta Knowlton, n sp. (U. S Nat Mus catalogue Nos 34716, 34717).

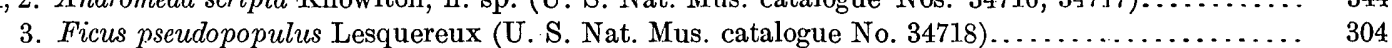

4. Juglans rugosa Lesquereux (U. S. Nat. Mus catologue No. 34719) .....

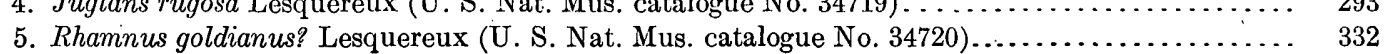

434 


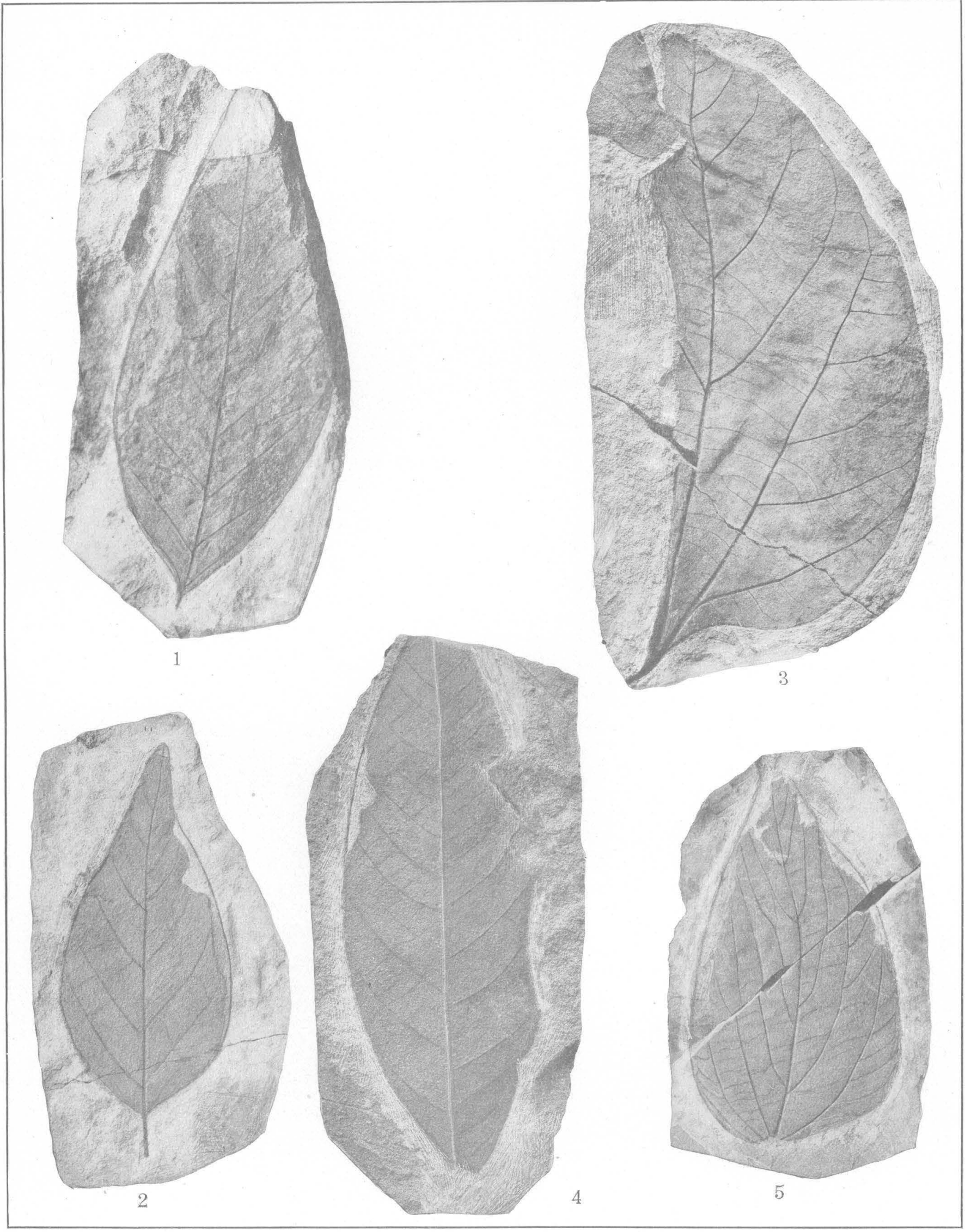

FLORA OF THE RATON FORMATION. 


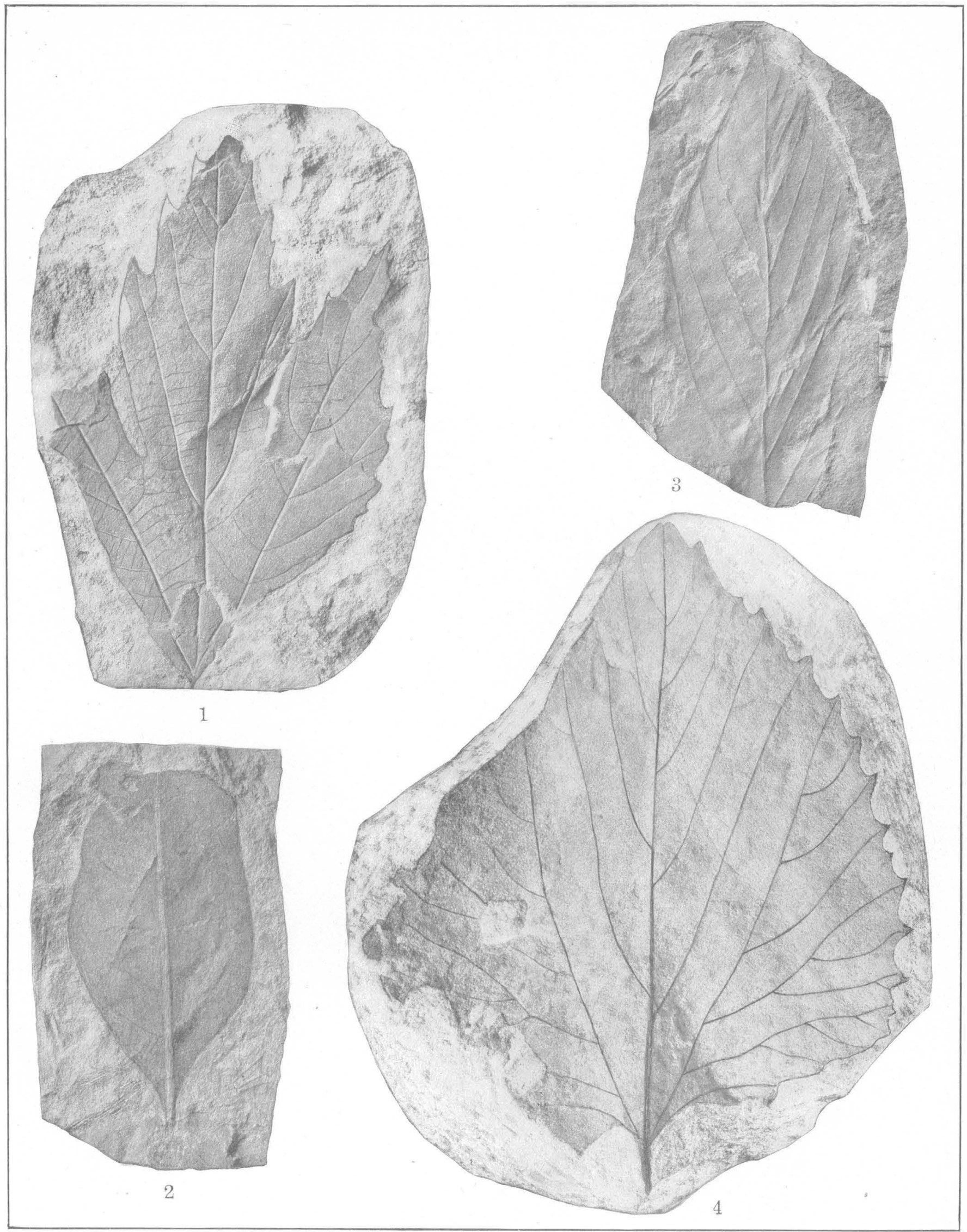

FLORA OF THE RATON FORMATION. 


\section{PLATE CXIII.}

Fraure 1. Platanus aceroides cuncata Knowiton, n. var. (U. S. Nat. Mus. catalogue No. 34721 )................... 321

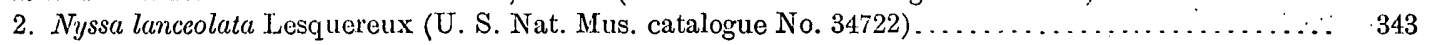

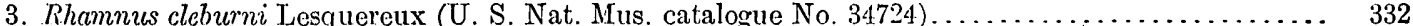

4. Platanus? regularis Knowlton, n. sp. (U. S. Nat. Mus. catalogue No. 34723 )................ 325 



\section{N D EX.}

Names in italic are synonyms; figures in black face refer to descriptions; figures in italic denote illustrations.

\begin{tabular}{|c|c|}
\hline Page. & \\
\hline$\therefore 13,17,223$ & Apeibopsis . \\
\hline ........ & $\ldots \quad 336$ \\
\hline (n......................... & $61,113,236,3336,428$ \\
\hline$\ldots \ldots \ldots \ldots \ldots 234,241, \mathbf{2 4 9}-\mathbf{2 5 0}$ & Apishapa Canyon, Colo., fossils from. \\
\hline $3,212,223,227,229,249-250$ & Apocynaceac.. \\
\hline ... $175,197,198$ & Apocynophyllum \\
\hline$\ldots 231,330$ & .................. \\
\hline $236, \mathbf{3 3 0}, 429$ & $\ldots .61,114,226,236,345$ \\
\hline$\ldots \ldots \ldots$ & $\ldots \ldots \ldots 61,135,236, \mathbf{3 4 6}, 426$ \\
\hline ...............330 & $6,237,260,345-346,485,487,488$ \\
\hline$\ldots \ldots \ldots \ldots \ldots 32,214$ & Aporrhais biangulata. \\
\hline ............. 170 & $32,181,207,231,240, \mathbf{3 4 1}-\mathbf{3 4 2}$ \\
\hline $232,234,235,241,244$ & .. $61,125,236,341,429$ \\
\hline $54,227,244$ & n................... 341 \\
\hline $94,196,202,210$ & 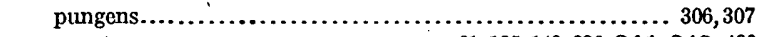 \\
\hline$\ldots \ldots 175,188$ & $\ldots \ldots \ldots \ldots \ldots \ldots \ldots, 61,125,143,236,341-342,430$ \\
\hline$\ldots \ldots \ldots \ldots .32,217$ & .......... 341-342 \\
\hline$\ldots \therefore: \ldots \ldots \ldots+\ldots, \ldots, \ldots$ & ormation, correlation of . ................... 168, 169, 171,241 \\
\hline$\ldots \ldots \ldots \ldots \ldots \ldots \ldots \ldots \ldots \ldots \ldots \ldots \ldots$ & f, chart showing $\ldots \ldots \ldots \ldots \ldots \ldots \ldots \ldots \ldots \ldots \ldots \ldots \ldots$ \\
\hline$\ldots \ldots 13$ & (n.............. \\
\hline ........ & 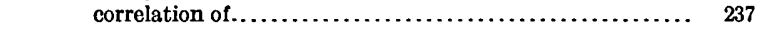 \\
\hline …...... 177, 202 & 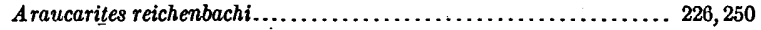 \\
\hline$\ldots \ldots \ldots \ldots \ldots \ldots \ldots \ldots 181,202$ & $\ldots \ldots \ldots \ldots \ldots \ldots \ldots \ldots \ldots \ldots \ldots, 29,175,193,197,217$ \\
\hline$\ldots \ldots 230,232,233,234,242-243$ & .................. \\
\hline$\therefore \ldots \ldots \ldots \cdot 286-287$ & $\ldots \ldots \ldots \ldots \ldots 287-292$ \\
\hline$\ldots \ldots \ldots \ldots 231,241,286-287$ & $\ldots \ldots \ldots \ldots \ldots \ldots \ldots 231,307$ \\
\hline $86-287 ; s ; \gamma$ & $60,133,236,307,400$ \\
\hline 176 & 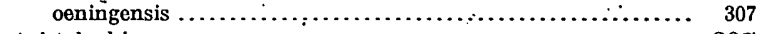 \\
\hline ….... 166-167 & $\because \ldots \ldots .307$ \\
\hline$\ldots \ldots \ldots \ldots \ldots 166-167$ & $(\ldots \ldots \ldots \ldots \ldots \ldots \ldots \ldots \ldots \ldots \ldots \ldots, 307$ \\
\hline .............. & 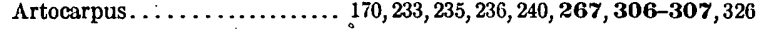 \\
\hline ta........... & 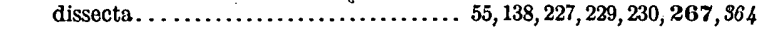 \\
\hline$\therefore \ldots \ldots \ldots \ldots \ldots \ldots \ldots \ldots$ & a. $\ldots \ldots \ldots \ldots \ldots \ldots \ldots \ldots \ldots \ldots \ldots, 181,229,230,267,306,307$ \\
\hline (n. & 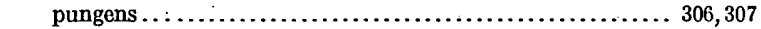 \\
\hline$\ldots \ldots \ldots \ldots \ldots \ldots 228,233,241,269$ & $\because 60,121,125,133,139,141,157,170,230,306-307,326,999,400$ \\
\hline (n................. & $\cdots \cdots \cdots$ \\
\hline$\ldots \ldots \ldots \ldots 55,164,269,864$ & ennerlyi........ \\
\hline$\ldots \ldots \ldots \ldots \ldots, 328-329$ & $\ldots \ldots \ldots \ldots \ldots \ldots \ldots \ldots \ldots 5,227,232,234, \mathbf{2 4 5}-\mathbf{2 4 6}, \mathbf{2 8 5}$ \\
\hline$\ldots \ldots \ldots \ldots 29,175,202,213$ & $\ldots \ldots \ldots \ldots 54,138,164,165,226,227, \mathbf{2 4 5}-\mathbf{2 4 6}, 352$ \\
\hline$\ldots \therefore 175,195,196,197,198,202,216,217$ & 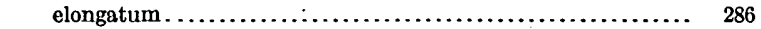 \\
\hline …......... 175,1 & $\ldots \ldots \ldots \ldots \ldots \ldots 226,244$ \\
\hline$\ldots \ldots \ldots \ldots \ldots \ldots, 17$ & .................. \\
\hline$\ldots \ldots \ldots \ldots 45,51,175,190$ & lineatum.................. \\
\hline$\ldots \ldots \ldots 231,240,344-345$ & 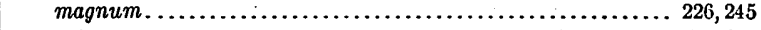 \\
\hline ........ & $\ldots \ldots \ldots \ldots 60,124,235,285,376$ \\
\hline $121,236,315, \mathbf{3 4 4}, 481,492$ & aceum $\ldots \ldots \ldots \ldots \ldots \ldots \ldots$ \\
\hline ............. & $\ldots \ldots \ldots \ldots 2,246,952$ \\
\hline , 236, 344-345 & (198, 217 \\
\hline $248-249,285-286$ & ............. 32,217 \\
\hline ............ & a concentrica...$\ldots \ldots \ldots \ldots$ \\
\hline$\ldots 102,113,125,127,130$ & ..................... \\
\hline $60 ; 235,285-286,976$ & $\ldots \ldots \ldots \ldots \ldots 32,214$ \\
\hline ................. & $\ldots \ldots \ldots \ldots \ldots 45,68 ; 71,175,196$ \\
\hline $227,244,248$ & $\therefore \ldots \ldots \ldots \ldots \ldots, 35,175,195,197$ \\
\hline .. 170,227 & linguiformis................................. 45, 106, 165, 168, 175, 194 \\
\hline $228,244,248-249,286,952$ & nebrascana........................ \\
\hline .. 253-278, 286-348 & 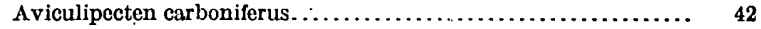 \\
\hline on; correlation of. & \\
\hline 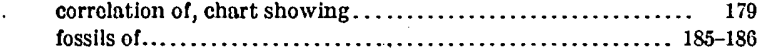 & B. \\
\hline$\ldots \ldots \ldots \ldots \ldots \ldots \ldots \ldots \ldots \ldots \ldots+185-186$ & Baculites..................29, 30,32, 175, 194, 196, 198, 199, 210, 213, 217 \\
\hline$\ldots .45,80,175,196,198$. & $\ldots 32,175,217$ \\
\hline & $\therefore 187,188,189,193,194$ \\
\hline 175,190 & ...... $29,30,175,183$ \\
\hline Anisonema........................... & compressus.......... $45,71,73,74,106,130,136,167,175,188,190,191$ \\
\hline $\begin{array}{r}\text { Anomia........... } \\
187,188,190,191,193,194,196,197,202,210,213\end{array}$ & 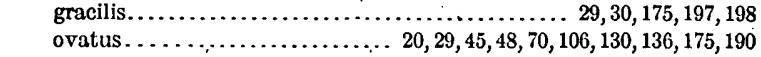 \\
\hline (n.................... & ailey, J. W., on fossils near Trinidad. \\
\hline
\end{tabular}


Page.

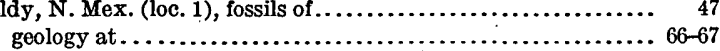
gold at...

section near, plate showing.

Baptemys.

Barilla Mesa, N. Mex.-Colo., section on sections on; plate showing.

Bartlett Mesa, N. Mex. (locs. 78-82), fossils from geology at. . sections in... plates showing

Bauer, C. M., on "Laramie" formation. . . . . . . . . . . . . . . . . 37,18

Bear Canyon, N. Mex., rocks in ........................... 115

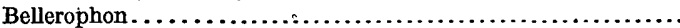
carbonarius montfortianus. percarinatus.

Benton formation, character and distribution of fossils of.

Berchemia multinervis...........6 61, 113, 170, 226, 236, 237, 239, 333-394, 428 parvifolia ................................. 223; 226, 333, 334

Berry, E. O., on Cretaceous-Tertiary boundary ............... 16 on Wilcox flora. .

Berwind, Colo. (loc. 113), fossils from near................. 132-133 geology at and near.............................. 132-133 section near. plate showing

Berwind-Aguilar area, Colo. (locs. 110-119), geology of ......... 130-136 sections in, plate showing.... See also Bowen; Majestic; Berwind; Aguilar; Gonzales Canyon.

Beryx...

Bibliography...

Blake, W. P., on coal near Cerrillos on geology of New Mexico.

Blodgett, M. E., and Shimer, H. W., on geology of Rio Puerco..

Blossburg, N. Mex. (locs. 61-67), fossils from. geology at and near. sections at and near

plate showing..

Bluff Springs, Colo., geology at. section at, plate showing. wen, Colo. (locs. 109, 110-111), fossils from..........47, 129-130,131

sections at and near

$128-130,130-131$ plate showing

Bowie shale, fossils of

Brachyphÿllaceao.

Brachyphyllum.

crassicaule.$$
\text { obesum. }
$$

$128,181,186,188,189,190,196,212,227,228,229,233,249$

$$
\text { sp... }
$$

Breviarca exigua

Brilliant, N. Mex., section near.

Broadhead, A. G., on Gonzalez Canyo section by...

Brookside, Colo., view near

Buchiceras swallovi.

\section{C.}

Cabezon Butte, view of

Cabezon field, N. Mex., formations of, correlation of formations of, correlation of, figure showing fossils of. view in

Calamopsis danai.

Callista. deweyi..

$$
\text { pellucida }
$$

Calycanthus.

Campbell, M. R., on coal of New Mexico....... 34, 204-205

Campeloma.

Campophyllum torquiun.................................. 42

Camptonectes. symmetricus.
Page. Canyon, N. Mex. (locs. 51-60), geology at and near.. 102-130 sections at and near.............................. 102, 103 geology of ......................................... 99-103 See also Cottonwood Canyon; Sugarloaf Mountain; Canadian Canyon.

Canna........................... 55, 164, 227, 231, 233, 235, 254-255 өocenica....................................... 238 magnifolia.......................55, 138, 165, 227, 254-255, 358 sp............................................... 255

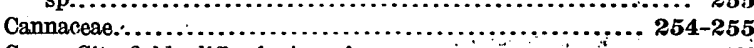

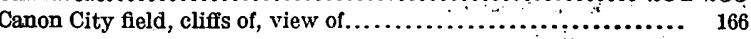
coal measures of..................................... 163 bibliography of.............................. 17, 18,27

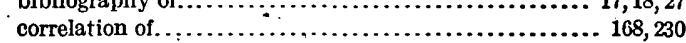
fossils of. See Vermejo formation.

formations of . . . . . . . . . . . . correlation of . ............................. 12, 20,162-169 figure showing ............................... 169 fossils of............................. 9, 12,54-55, 223-224, 227-228 investigations in.................................. 162-163

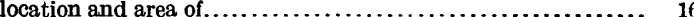
map of ............................................ 162

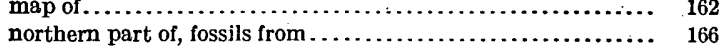

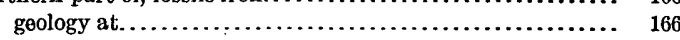
sections in, plate showing $. . \ldots \ldots \ldots \ldots \ldots \ldots \ldots \ldots \ldots \ldots . .164$ Canyon del Yeso, N. Mex., section in.................... 216 Caprifoliaceae................................ 275-278,346-348

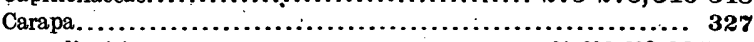
eolignitica................................ 1, 236, 238, 327, 391 Carboniferous system, deposition of occurrence and character of..................... 40 Cardium ..... 25, 26, 30, 35, 45, 49, 106, 175, 193, 196, 197, 198, 199, 202, 213, 217 bellulum......................................... 175, 188 pauperculum...................................... 30 speciosum.............................. 175, 187, 188, 190, 193

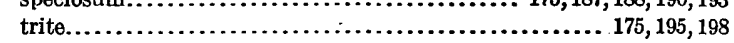

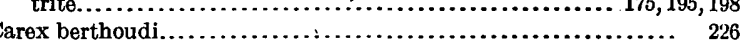
Carpites ....................... 181, 186, 188, 191.202,307,328, 348-349 coffeaeformis . . . . . . . . . . . . oviformis............................................. 343

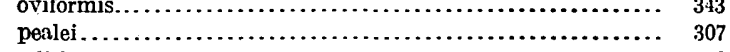

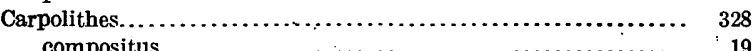

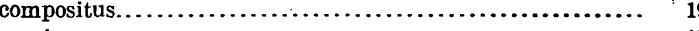
mexicanus........................................... 19 palmarum.................................... 292

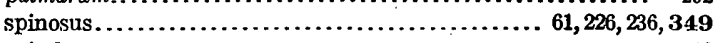
spirales........................................... 19

Carpolithus spinosus ..................................... 226

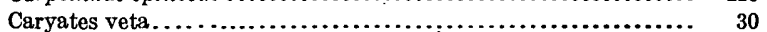

Caryophyllia johannis .............................. 47

Casa Salazar field, N. Mex., formations of, correlation of......... 194-195 formations of, correlation of, figure showing............. 179 fossils of...................................... 175, 194-195

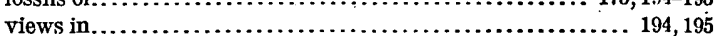
Cassia.................................................... 240 berenices.......................................... 327 fisheriana.............................. 61, 119, 327, 400 glenni ...............238, 327

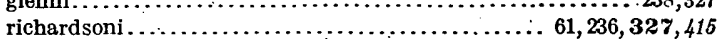
richardsoni $\ldots \ldots \ldots \ldots \ldots \ldots \ldots \ldots \ldots \ldots \ldots \ldots \ldots \ldots \ldots \ldots \ldots \ldots \ldots \ldots \ldots \ldots \ldots \ldots \ldots \ldots \ldots \ldots \ldots$
sapindoides...121, 236, 327, 418 Castalia ................................. 231, 282, 307-308 leei..........................60, 139, 192, 236, 307-308, 401 Castanea.................................. 231, 236, 240, 241, 297 intermedia.............................. 60, 121, 237, 297, 390 Caulerpites......................................... $230,241, \mathbf{2 4 3}$ incrassatus............................ 54, 226, 227, 243

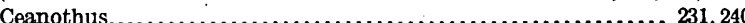

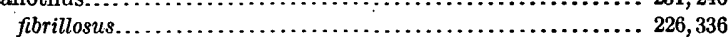
meiggsii ...................................... 226, 337

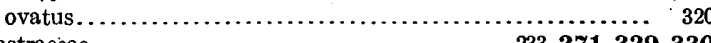
Celastraceae.............................. 233, 271, 329-330 Celastrus.............61, 113, 147, 181, 212, 228, 235, 236, 240, 271, 329 ferrugineus................................... 329

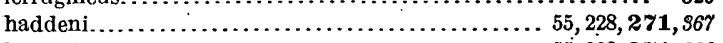
hesperius.............................. 55, 228, 271, 866 serratus...................... 61, 121, 124, 236, 329, 420, 421, 422 sp................................... 271, 329, 369,480 
Conozolc time, ovents in . ...........................64-65 Corcocarpus..................................... 241, 325-326 antiquus orestosi.

. 60, 236, 325-326, 417 coal beds or. bibliography of . . ................... 17, 18,19,20,21,22,27,29,31

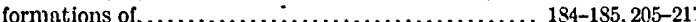
bibliography of . . . . . . . . . . . . . . . . corrolation of........................ 13,24, 25, 27,28, 29, 184 fossits of.............................. $32,175-177,206-207,210-217$ sections in.

figures showing.

(1)

Corrososo Canyon, N. Mex. (locs. 15-16), fossi.s from...........47, 78

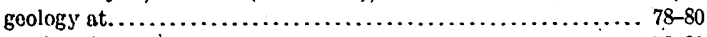
soctions in $\ldots \ldots \ldots \ldots \ldots \ldots \ldots \ldots \ldots \ldots \ldots \ldots \ldots \ldots \ldots \ldots \ldots, 78-80$ plate showing $\ldots \ldots \ldots \ldots \ldots \ldots \ldots \ldots \ldots \ldots \ldots \ldots \ldots, \quad 56$

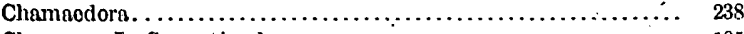

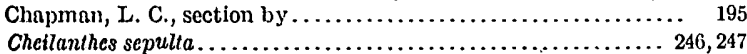

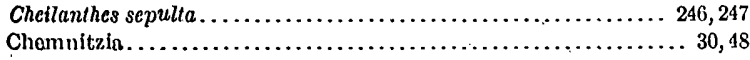

coalvillensis.

Chico Arroyo district, N. Mex., coal of ...

Chicorico Canyon, section in, plates showing ............. 56, 108

Chionanthus................................... 231, 241, 345 membranaceus........................ $61,135,236, \mathbf{3 4 5}, 480$ virginicus $\ldots \ldots \ldots \ldots \ldots \ldots \ldots \ldots \ldots \ldots \ldots \ldots \ldots \ldots \ldots \ldots \ldots, 345$

Chlamys nebrascensis. ............................. 45, 50,136

Chondrites .................................... 230, 240, 243

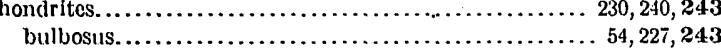
subsimplex $\ldots \ldots \ldots \ldots \ldots \ldots \ldots \ldots \ldots \ldots \ldots \ldots \ldots \ldots, 54,227, \mathbf{2 4 3}$

Chonetos mosolols.

Cimarron, N. Mex. (loc. 10), fossiis nt and near............ 47-48, 73, 74 geology at.................................... $72-74$ sections near

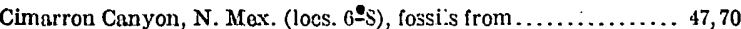
geology at.... geology

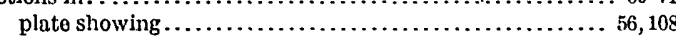
visws of....................................... 68,72

vlow in $\ldots \ldots \ldots \ldots \ldots \ldots \ldots \ldots \ldots \ldots \ldots \ldots \ldots \ldots \ldots \ldots \ldots \ldots, \quad 72$

Cimcrron River, N. Mex. (locs. 6-10), geo.ogy at............. 69-74 See also Cimarron Canyon; . Turkey Canyon; Cimarron.

Cinnamomum........................ 224, 231, 240, 304, 318-320 nfine................................ 170, 223, 263, 264,320 buchi.

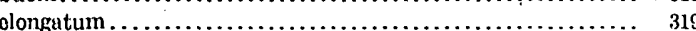
ncifollum........................... 60, 133, 236, 318-319, 418

lanceolatum . linifollum.......................... $60,86,123,236, \mathbf{3 1 9}-\mathbf{3 2 0}, 410$ mississipplense. $60,67,109,113,114,130,133,139,158,236,238,264,320,411$ oblongatum

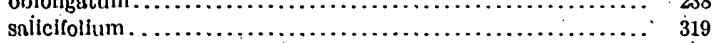

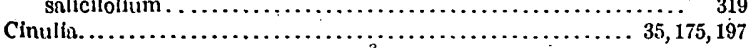

Çissitos.................................... 231, 233,241, 274-275 formosus... panduratus........................ 55, 138, 228, 274-275, $s 71$

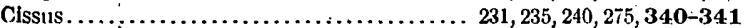
grossedéntata........................... $61,236,340,426$ laevigata....................... $61,133,170,236,237, \mathbf{3 4 0}-\mathbf{3 4 1}, 485$

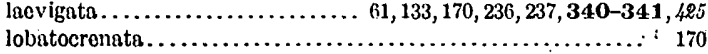
parrotinefolia..

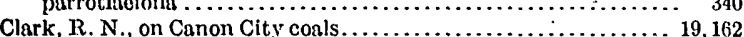

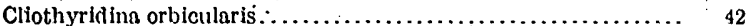

Conl, plate showing .................................... 146

Coal Crook, Colo., fossils from ....................... 162-163, 164 geology at...................................... 163-164 soction on ..................................... 163-164 plate showing $\ldots \ldots \ldots \ldots \ldots \ldots \ldots \ldots \ldots \ldots \ldots \ldots \ldots \ldots \ldots, 164$

Conl fields, map showing...................................

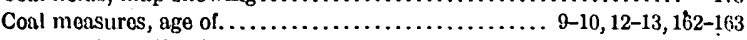
gge of, publications on . .............................. 17-34

publications on, review of ....................... 13-16

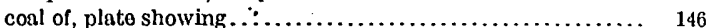
conl of, plate showing $. . \ldots \ldots \ldots \ldots \ldots \ldots \ldots \ldots \ldots \ldots \ldots \ldots, 146$ deposition of.

fossils in..........

See also particular fields; Raton formation; Vernaejo formation.
Coalville, Utah, fossils from ................................... Page.

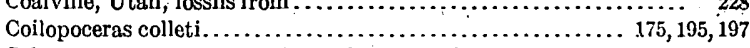

Co'orado group, occurrence and character of ................. 40

Colorado Springs area, Co.o.:

formations of ........... 170-171 corre.ation of ..................................... 171

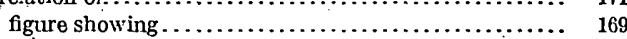

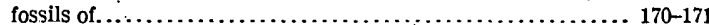
Colutea .................................... 231, 233, 235, 270 macrophylla ................................. $\quad 270$

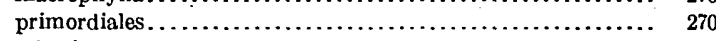
salteri......................................... 270 speciosa............................. 55, 147, 228, 270, 366

Combretum ....................................... 315-316 ovalis . . . . . . . . . . . . . . Composita subti.ita ................................... 42 Conglomerate at Cretaceous Tertiary contact. See Raton formation. ........... 231

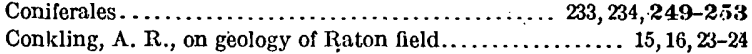
Cope, E. D., on coal measures............ 14, 20, 21, 22, 23, 25, 26, 27, 162 Corbicula......................................... 175, 186, 188 cytheriformis.................................... 191 occidentalis . . . . . . . . . . . . . . subelliptica. ................................. 186, 188

Corbula................................. 25, 35, 175, nematophora fitchi...................

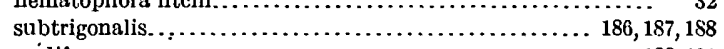
undifera..................................... 188, 191

Cornaceae................. 231, 342-344

Cornell, Colo. (locs. 133-134), geology at and near............. 156-157 sections at and near.............................. 156, 157

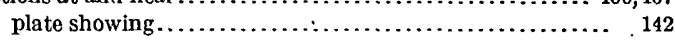

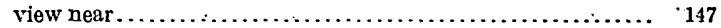

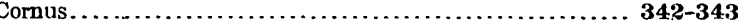
acuminata . ...................................... 342 emmonsi.............................................. 342

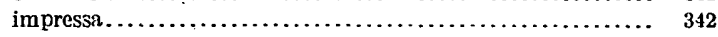
neomexicana........................... 61, 143, 236, 342, 481

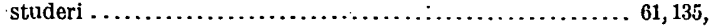
$170,236,237,238,342-343,481$

Correlation, of different regions........................... 162-217 of different regions, charts showing......................... 169, 179 principles of....................................... 112 See also particular formations, regions, etc.

Cottonwood Canyon, N. Mex. (locs. 48-49), geology at.......... 100-101 sections in ....................................... 100, 101

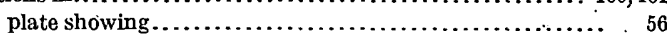
unconformity in $\ldots \ldots \ldots \ldots \ldots \ldots \ldots \ldots \ldots \ldots \ldots \ldots \ldots, 100$ figure showing . ................................ 100

Cox, E. T., and Owen, R. E., on mines of New Mexico........... 18

Crassatella cimarronensis................................ 48, 73

Crassatellites.................................... 175, 194

cimarronensis............................. 45, 71, 74, 175 shumardi............................. 175, 202, 210, 217

Credneria ................................. 228, 231, 241, 267-268

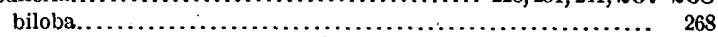
integerrima ................................ 229, 268 protophylloides............... 55, 135, 227, 229, 265, 267-268, 968 subtriloba......................................... 268

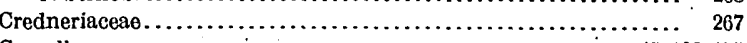
Crenella ............................................ $45,106,175$

Cretaceouls period, events in:............................ $62-64$

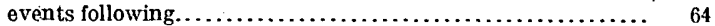
geologic quiescence in ............................. 11-64 Cretaceous sea, submergence by ........................... 59,63 withdrawal of...

Cretaceous system, boundary of Tertiary and................ 11 fossils of ....................................... 10

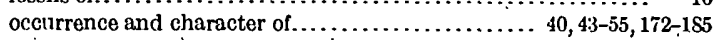

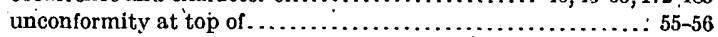
figures showing........................... 74, 96,97, 169 fossils transgressing........................ 232, 237, 240-241 Cross, Whitman, on geology of Colorado................... 28, 29, 185 on post-Cretaceous erosion........................... $\quad 59$ Crow Canyon, N. Mex., sections in ......................... 93-94 
Page. geology at. sections at.

Cuchara River, Colo. (locs. 120. 137-141), fossils from geology at.. sections at. figure showing

Cucullaea.

Culebra Range, rocks of sections in...

Cunninghamites... pulchellus.

Cupressinae.......

Cupressinoxylon coloradense.......... 55, 122, 123, 163, 227, 233, 252-253, $355,356,357$ elongatum . vermejoensis. (locs. 29-30), fossil from geology at. ections on plate showing

Cymella undata.

Cyperacites.

Cyprimeria sulcata. $45,136,175,193,194,196,199,202,210,213,217$ ... 138-139, 160 137-139, 159-161 137-138, 160-161 41- 41 178 12 Cypris 181,202

Dakota sandstone, character and distribution of $0,213,217$
$.32,217$ D. deposition of . correlation of, chart showing. section of.

.

Darton, N. H., on geology of New Mexico

Dawson, N. Mex. (locs. 20-26), fossils from geology at and near. sections at and near.

$$
\text { plates showing. }
$$
view near. See also Dawson; Saltpeter Creek; Saltpeter Mountain; Turkey Creek.

Dawson arkose, correlation of correlation of, chart showing. . fossils of..

Dead Easy mine, N. Mex

Delagua, Colo., fossils from

Delesseria incrassata.............................. 226, 243 lingulata

Dentalium...

Denver Basin, Colo, formations of formations of, correlation of . correlation of, flgure showing fossils of. . $45,106,175,188,196,21$ enver formation, correlation of ................................. correlation of, chart showing... fossils of . ............................................... $60-61,237$

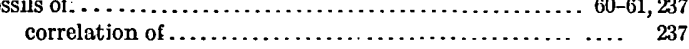
Derbya bennetti..................................... 42 crassa.

Diastrophism, correlation by

Dicksonia............. 170,234

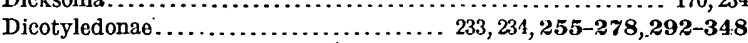

Dillon Canyon area, N. Mex., coal in .................... 103, 10

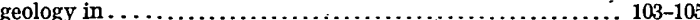
See also Blossburg.

Diospyros ....................... 181, 191, 193, 231, 233, 241, 275, 345 copeana. .................... 345

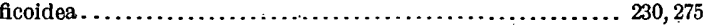

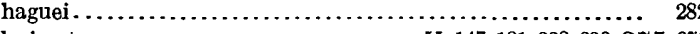
leei .......................... 55, 147, 181, 228, 230, 275, 370 Dombeyopsis............................ 61, 181, 193, 337-339 magnifolia........................... 67, 236, 337-339, 424 obtusa...................................... 170,338 occidentalis.................................... 226, 302 platanoides .................................... 267, 338 trivialis.
Dosinia.

Dryophyllum. ( bruneri............................... 166, 227, 259,375 falcatum................................. 181, 196, 259 moorii........................ 60, 86, 226, 236, 238, 299, s92 puryearensis. subfalcatum... 299 Dryopteris............................ 60, 113, 18i, 193, 212, 235, 284 cladophleboides.......................... 60, 155, 235, 284, 876 kennerlyi........................................ 246

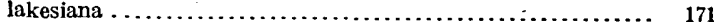
lesquereuxii $\ldots \ldots \ldots \ldots \ldots \ldots \ldots \ldots \ldots \ldots \ldots \ldots \ldots \ldots \ldots \ldots \ldots \ldots, 171$ sp.............................................. 284 Dulce, N. Mex., fossils from ....................... 175-177, 189-191 geology at . . . . . . . . . . . . . . .

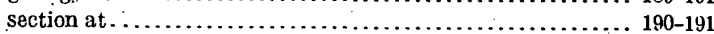

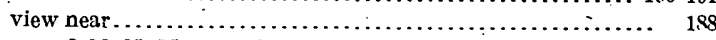
Durango field, N. Mex., cnal of .............................. formations of, correlation of . . . . . . . . . . . . . . chart showing. . . . . . . . . fossils of . . . . . . . . . . . . . . 175-177 section at. ........................................ 185-187 Dutchman Canyon, N. Mex., section in, plate showing......... 56

\section{E.}

Earle, C., and Osborn, H. F., on Puerco beds................ 29 Ebenaceae........................................ 275

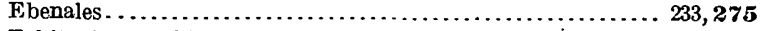

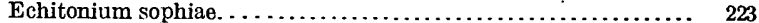

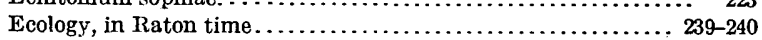
in Vermejo time.............................................. 234-235 Emmons, S. F., on coal measures...................... 28 on diastrophism in region ............................ 27

Emory, W. H., on coal near Trinidad................... 13, 17 Encenoso Creek (loes. $76-7 \delta$ ), geology at....................... 76-78 sections on. plate showing....

Endicott $J, D$, on a

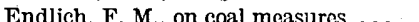

Endocostea brooksi......................................... 32

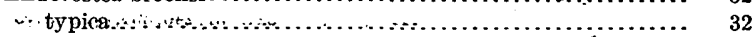

Engle, Colo. (loc. 97), fossils from ......................... 119 geology at. . . . section at. plate showing.

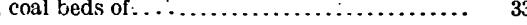
occurrem

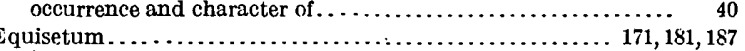

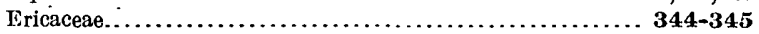

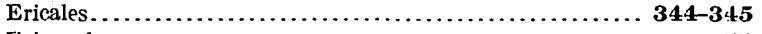

Eriocaulum porosum.............................. 279

Erosion, measure of . . . .

Eucalyptus.................................... 181, 189, 193, 346

Euonymus................................ 240, 241, 329-330 splendens......................61, 105, 236, 238, 329-330, 391 Euphorbiaceae.................................... 328 Euphorbocarpum................................ 241, 328 richardsoni . . . . . . . . .

Exogyra ................................... 176, 194, 195, 198 columbella........................ $30,35,175,195,196,197,216$ laeviuscula..................................... 30 ponderosa............................................ 175,217

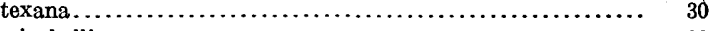
vinchelli.

\section{F}

Fagaceae.................................... 259, $297 \mathbf{7 9 0 0}$ Faga'es........................................ Fagus................................... 231, 236, 240, 297 papyracea.............................6. $60.135, \mathbf{2 9 7}, 390$ Fasciolaria........................ 45, 48, 74, 81, 176, 188, 194, 202 Field work, methods of ................................... 10-11 Fishers Peak mine, Colo., fossils from.:

30
30
98
75
59
92
38
99
99
4
6
46
71
71
194
91
91
188
33
87
79
77
56

.


Page. Ficus............... 55, 164, 171, 181, 185, 187, 189, 190, 191, 196, 201 $212,227,233,234-235,240,259-267,268,282,300-306,314$

aguilar $60,135,236,239,300-301,302,393$ arenacea brevipetiolato. artocarpoides. ........................... 60, 121, 236, 238, 300, 898 borthoudi.

clintoni. coloradensis. curta. dalmatica......................... 55, 227, 228, 229, 231, 259, 265 denveriana ............................60, 108, 113, 114, 119 $121,131,132,133,143,171,226,236,237,238,302-303,397$ cucalyptifolia................ 55, 181, 205, 212, 227, 228, $229, \mathbf{2 6 0}, 366$ gaudini.......................................... 226, 301

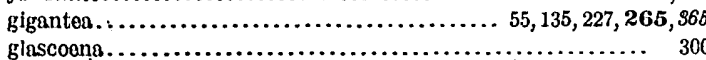

haddeni.

harrisiana.

$55,136,227,229,260,360$ lanceolata.....................181, 187, 190, 202, 205, 212,229, 260, 266, 275 latifolin..........................6 60,132, 226, 238, 304,306,346

leoi .................. 55, 71, 75, 120, 138, 157, 164, 165, 181 $188,191,205,227,229,230,233, \mathbf{2 6 1 - 2 6 2}, 266,279,860,361$ minima.......................... 55, 138, 227, 260-261, 358,360 minutidans.............................. 60, 121, 305-306, $\$ 99$ monodon .......................................... 238, 301 navicularis...................................... 229 neoplanicostata............6 60, 139, 192, 236, 238, 303, $395, .996,398$ nowberryiana........................... 55, 227, 229, 261, 860 occidentalis................... $60,104,226,236,237,238, \mathbf{3 0 2}, 394$ planicostata.... 171, 181, 186, 190, 229, 230, 236, 260, 261, 262,303,306, 346 clintoni.......................... 60, 114, 236, 237, 303, 398 goldiana................................... 261, 266,303 latifolia......................................171, 226, 236, 238, 306 prnetrinervis....... 55, 60, 118, 121, 123, 125, 131, 136, 153, 158, 159, 164, $165,166,17 \mathrm{~S}, 181,188,190,191,193,196,202,205,227,229,230$ 236, 237, 250, 252, 260, 263-264, 275, 304, 305, 319, 363, 364

proteoldes.

pseudolmediafolia................................... 238,316 pseudopopulus.

$113,131,137,143,146,182,236,238,305,994,995,434$ ratonensis.........60,113, 306, 396 regularis............................. 55, 164, 227, $228, \mathbf{2 6 4}$ rhamnoides................... 31-32,55, 181, 207, 227, 228, $229, \mathbf{2 6 5}$ richardsoni..........................60, 105, 135, 236, 305, 398 rockvalensis............................. 55, 227, 265, 968 schimperi................ 113, 127, 135, 143, 236, 238, 304-305, $\$ 97$ smithsoniana............................60, 226, 236,237,305 spociosissima.

$55,125,129,131,164,165,166,178,181,188,193$ $207,212,227,228,229,230, \mathbf{2 6 2}, 265,266,268,282$ spectabilis..............................226, 265, 302,303 starkvillensis..... 55, 118, 123, 131, 178, 181, 188, 227, 229, 262-263, 360 tessellata.............................. 55, 227, 229, 266, 369 tilinofolia.

trinervis. ulmifolia..................................... 226, 301 uncatr............... 32,60, 133, 181, 207, 226, 236, 238, 301-302, 398 brevipetiolata .................................. 302 ungeri.

wardli. $138,160,165,178,181,191,193,205,227,228,229,246, \mathbf{2 6 6}, 364$ sp.

Flabollaria longirachis . ........................... 244-248, 284-28

oocenica

Fleming, J. W.,.on coal mines................................ 29, 30

Fiorida River, Colo., section on ........................ 185-187

Forbes mine, Colo., fossils at........................... 131 geology at..

Fort Union formation, fossils of fossils of, corrolation of ................................ 239 Fossils, change in, at lowest unconformity................... 12 Sce also particular places, formations, etc.

Fraxinus............................... 55, 118, 228, 233, 241, 275 sp....................................... 275, 871
Tox Hills sandstone correlation of Page.

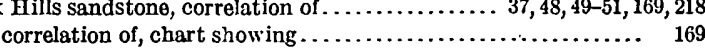
Fungi. .................................................. 232, 233, 242 Fusus................................... 35, 176, 188, 190, 199

Galisteo coal field, N. Mex. Bee Cerri.los field.

Galisteo Creek, N. Mex., rocks near, view of................. 214

Galiste $\sigma$ sandstone, character and relations of................. 184-185 correlation of..........................22, 23, 26,31,184-185, 206 fossils in ...................................... 185, 212

petrified $\operatorname{logs}$ in $\ldots \ldots \ldots \ldots \ldots \ldots \ldots \ldots \ldots \ldots \ldots \ldots \ldots \ldots \ldots \ldots \ldots, 185$ sections of............................... 205, 207, 209, 210, 212 figure showing. ................................... 208 views of......................................... 214 Gardiner, N: Mex., section near.......................... 103 plate showing .................................... $\quad 56$ See also Canadian Canyon.

Gardner, J. H., on coal of New Mexico..................... 34,35 on San Juan Basin.............................. 192-193

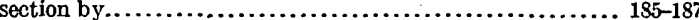
Gastropod zone, character and relations of............. 162,173-174 Geinitzia. . ................................ 178, 234, 241, 251 formosa....... 55, 136, 181, 186, 187, 188, 190, 227, 228, 229, 251, 252, 353 Gentianales................................ 233.275, 345-346

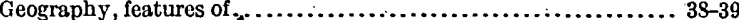

Geologic history, account of ................................... $61-65$

Geology, features.of........................................ $39-61$ rocks of ........................................ $41-61$

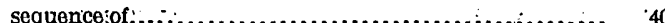
See also particular formations, etc.

Geonoma....................................... 241; 289,291 gigantea....................................60;139, 235, 291, 889 Geonomites............................... 178, 289, 291-292 tenuirachis.................. 60, 113, 171, 226, 235, 291-292,984 ungeri.......................................... 226,289

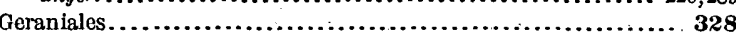

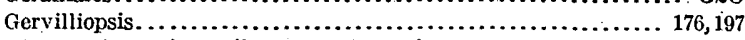
Gilmore, C. W., in fossils of the "Laramie"................. 37, 184 Girty, G. H., fossils determined by....................... 43 Gleichenia............................... 228, 231, 241, 24,7-248 delicatula..................................... 55,227,247 rhombifolia......................... 55, 181, 202, 227,229, 247-248 Gleichoniacea............................... 233, 247-248

Goat Hill, N. Mex., fossils from....................... 106 view of................................................ 110

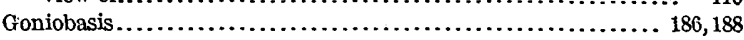
Gonzales Canyon, Colo. (loc. 119), fossils from .............. 135-136 geology at..................................... 133-136

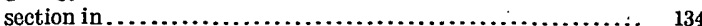
Gonzales Canyon, N. Mex., coal of ......................... 148

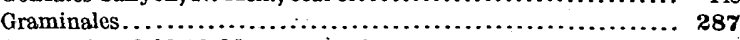
Grand Mesa field, N. Mex., rocks of ...................... 219 Gray Creek, Colo. (loc. 96), fossils from .................... 118 geology at............................................. 118

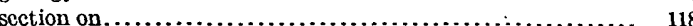

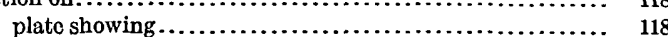

Green Canyon mines, Colo., fossils from................... 135

Greenhorn limestone, character and distribution of........... 44, 214

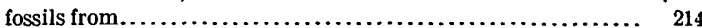

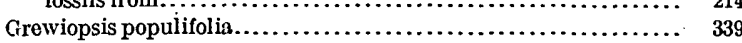
Gryphaea .......................................... 35, 198 newberryi................................ 29, 176, 187, 195 vesicularis . ......... 30 Gulf region, formations of ............................ 170 formations of, correlation of ............................ 170 figure showing ................................... fossils of ........................................60,170 Gymnogramma haydeni............................. 286 Gyrodes.................. 176, 193, 194, 195, 196, 198, 199, 202, 210, 213, 217 depressa........................................ 30

$\mathrm{H}$.

Hackberry Canyon, N. Mex., coal in......................... ' 81 Hadden, George, fossils collected by ................. 162-163, 164, 225 


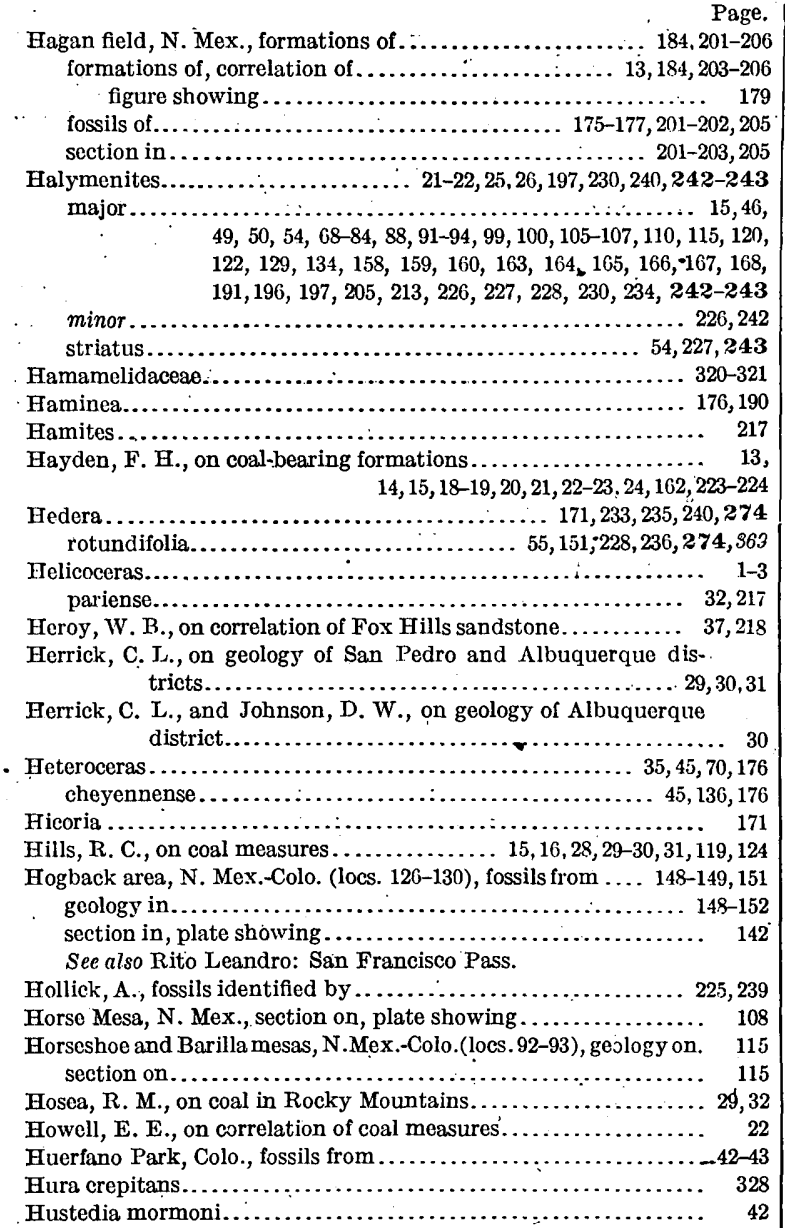

$49,50,54,68-84,88,91-94,99,100,105-107,110,115,120$, $122,129,134,158,159,160,163,164,165,166,-167,168$, $191,196,197,205,213,226,227,228,230,234, \mathbf{2 4 2}-\mathbf{2 4 3}$

Hills, R. C., on coal measures............ 15, 16, 28, 29-30,31,119, 124

Hogback area, N. Mex.-Colo. (locs. 126-130), fossils from .... 148-149, 151 geology in................................... 148-152 section in, plate showing .......................... 142 See also Rito Leandro: San Francisco Pass.

Hollick, A., fossils identified by

Horse Mesa, N. Mex., section on, plate showing

Horseshoe and Barilla mesas, N.Mex.-Colo.(locs.92-93), gejlogy on. 115 section on.

Hosea, R. M., on coal in Rocky Mountains................. 29, 32

Howell, E. E., on correlation of coal measures................. 22

Huerfano Park, Colo., fossils from ........................ $42-43$

Hura crepitans..

Hustedia mormoni.......................................

I.

Idonarca depress shumardi.

Incertae sedis............................... 278-283, 348-349

Inge ........ 240,327 heterophylla...................................... 121, 236, 327, 870 Inoceramus..................... $26,29,32,35,45,50,73,120,122,176$, $187,189,194,196,198,199,202,203,207,210,213,214,216,217$ acutiplicatus ......................................... 176, 202 balchii......................................... 32 barabini....................................
$105,106,130,136,176,187,188,189,193,194,199,202,213$ cripsi.............................................. 32 deformis $\ldots \ldots \ldots \ldots \ldots \ldots \ldots \ldots \ldots \ldots \ldots \ldots \ldots, 176,216-217$ dimidius........................... 29,32, 176, 194, 198, 214, 216 erectus................................48, 176, 194, 196, 198 fragilis................ 29, 30,32, 148, 176, 189, 197, 198, 202, 211, 214, 216 irregularis................................... 32, 176, 217 labiatus..................... 29,32,148, 176, 194, 195, 202, 214, 216 oblongus............................... 45, 72,73,74,176,190 sagensis ................................. 29,45,5), 51,70, simpsini ......................................... ' 32 vanuxemi....................... $32,45,48,51,66,74,99,122,130,136,176$ Isocardia. .......... 35, 176, 195, 196, 197, 20

\section{J.}

James, Edwin, on Maj. Long's expedition.

Johnson, D. W., on geology of Cerrillos Hills:..................

Johnson, D. W., and Herrick, C. L., on geology of Albuquerque district..

Johnson Mesa, N. Mex. (locs. 87-81), gẹology at................. 114-115

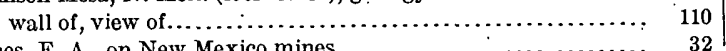

Page. Juglandaceae $\ldots \ldots \ldots \ldots \ldots \ldots \ldots \ldots \ldots \ldots \ldots \ldots \ldots \ldots \ldots \ldots \ldots \ldots \ldots \ldots \ldots \ldots \ldots \ldots$
Juglandales $\ldots \ldots \ldots \ldots \ldots \ldots \ldots$ Juglans ........................... 186, 224, 234, 255; 292-296 acuminata.........................60, 124, 235, 292,295, 387 berryi ....................60, 121, 124, 192, 235, 238, 293, 380, 395

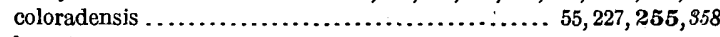

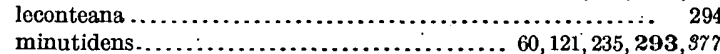
nigella ................ 60, 127, 133, 157, 235, 239, 292-293, $977-985$ rhamnoides.......................60, 146; 235, 294-295, 388 rugosa.............................6 $60,113,121,124,127,133,139$, $157,229,235,237,239,255,293-294,295,327,331,332,494$ sapindiformis ........................ sapindoides..........................6. $60,121,235, \mathbf{2 9 5}-\mathbf{2 9 6}, 987$ schimperi........ 60, 104, 105, 135, 235, 237, 238, 295, 296, 299, 332, 386 similis.......................... 55, 181, 227, 228, 229, 255, 358 smithsoniana ................................... 226, 305 ventricosa....................................... 255 vetusta.......................................... 295 Jurassic time, events in ...................................... K.

Kaseman, G. A., section by ............................ 206 Keyes, C. R., on Cretaceous coals............................ 32,33 Knowlton, F. H., fossils identified by ................. 16, 28, 190 on coal-bearing rocks.............................. 37 on fossils of Vermejo and Raton formations.............. 178-179, $184-188,223-435$ Koehler, N. Mex. (locs. $31-40$ ), canyon at, view in ................ fossils from................................... 47,90-91 geology at..................................... $90-94$ sections at and near ............................ 90-94 plate showing ..................................... 56

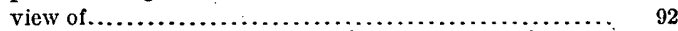
view near $\ldots \ldots \ldots \ldots \ldots \ldots \ldots \ldots \ldots \ldots \ldots \ldots \ldots \ldots \ldots \ldots \ldots \ldots, 74,92$ Koehler area, N. Mex. (locs. 29-40), geology in................ 89-93 See also Curtis Creek; Koehler.

L.

La Bella mine, Colo. (loc. 102), section at.................. 124

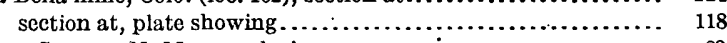
Lacy Canyon, N. Mex., rocks in ........................... 83 Lakes, Arthur, on coal fields........................31,32,33,36 on Colorado oil fields............................... 31 Lamna................................... 176, 194, 196, 199, 202 Laramie of Denver Basin, correlation of ................ 9,171, 218 correlation of, chart showing ....................... 169

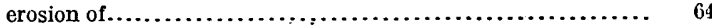

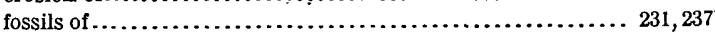
correlation of ................................ 231-232, 237 Laramie of Raton Mesa, divisibility of.................... 9,12

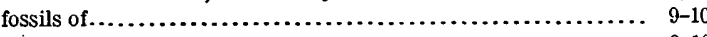
unconformity in See also Vermejo formation; Raton formation.

"Laramie" of San Juan Basin, character and re'ations of. . 183-184, 188 correlation of................ 9, 13,34-35, 171, 183, 188, 190-192, 219 figure showing. fossils of.

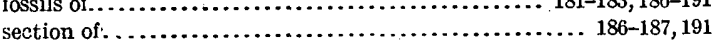
section of . . . . . . . . . . . . . . view of......................................... 188 Laramie Plains, Wyo., fossi.s of ......................... 228 Larsen, E. S., on "Laramie". . . .......................... 191-192 Lauraceae...................................... 268, 316-320 Laurus......................... 181, 192, 224, 233, 235, 240, 268, 316-318 caudata............................. 60, 121, 236, 316,411 coloradensis. . ....................... 55, 60, 227, 236, 268, 967 knowltoni....................................... 260

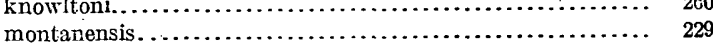
pedatus............................. 60, 135, 236, 23s, $\mathbf{3 1 7}$ primigenia............................. 171, 229, 269, 316-317 ratonensis . . . . . socialis.................. $60,133,135,143,171,236,237, \mathbf{3 1 7}-\mathbf{3 1 8}, 418$ socialis $\ldots \ldots \ldots \ldots \ldots \ldots \ldots(60,133,135,143,171,236,237, \mathbf{3 1 7}-\mathbf{3 1 8}, 418$
utahensis $\ldots \ldots \ldots \ldots \ldots \ldots \ldots \ldots \ldots \ldots \ldots \ldots \ldots 60,157,236, \mathbf{3 1 8}, 412$

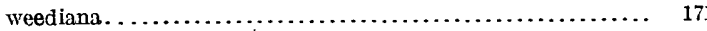

La Veta, Colo., geology at............................ 15s-161

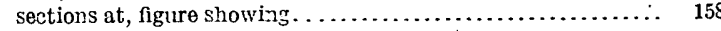
See also Cuchara River. 
Page.

Lo Conte, J. L., on age of conl-bearing rocks on conl of Now Mexico. $35,45,70,106,176,200,217$ ovansi. . . .

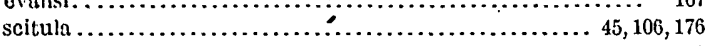

Leo, W. ' $\mathrm{T}$, on coal measures.......................... 15-16,33-36 on correlation.

on fossil dinosaurs.

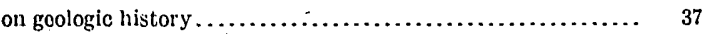
on geology of Colorado............................. 31, 37, 225 on goology of New Mexico...................... 34-35, 36, 37, 225 on geo!ogy of Raton Mosn region. . . . . . . . . . . . . . . . . on graphite noar Raton.............................. ${ }_{36}$ on Sangre de Cristo Range.......................... 31 Legumen. $45,50,176,193,197,199,202$ appressum planulatum..... Loguminosno

Loguminosites.............................................. 326 arnchioidos.....................60, 132, 236, 237, 238, 239, 326 reticulatus . .

Lesquereux, Leo, on fossils from Raton Mesa region........... 13-14, $15,19,20,24,162,223-224$ on Wilcox flora.

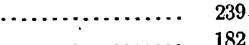
Lowis shale, character and relations of. correlation of. figuro showing.................................. 179 $183,190,192,200-201,218$ fossils of.............................. 175-177, 183, 189-190, 193 view of.

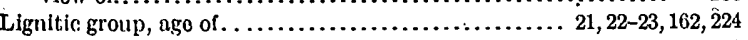
cossils of.

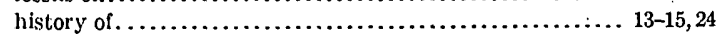

Limn. ...................................... 45, 72, 176, 216

Lingula subspatulata. ................................. 32,217

Liocloma...

Liopoplum. .

Liopisthn $\ldots \ldots \ldots \ldots \ldots \ldots .176,195,196,197$ concentrica. . . . . . . . . . . . . undata......................... 45, 72,176, 190, 193, 196, 202, 217

Liquidambar...........................60, 231, 253, 320-321 cuchnras. . .................... 139, 236, 237, 320-321, 418

Liriodendron..................... 231, 233, 235, 241, 269, 275, 279 alatum.......................... 55, 138, 227, 229, 269, 370 Literaturo, list of.

Lithology, correlation by.............................. $\quad 11$

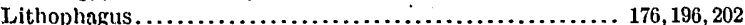

Littell mine, Colo., geology at.......................... 167 soction at, plato showing

Loew, Oscar, on anthracite coal. on fossil resin.

Iong, S. H., coal discovered by expedition of.

Tophophyllum profundum.

Censition of. ........................62-63 occurrence and character of:

$40,43-44$

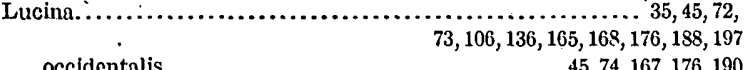
occidentalis Lunatia....................... 45, 48, 70, 176, 188, 190, 193, 194, 198, 202

\section{M.}

McAnily mine, Colo., fossils from..

Macfarlano, James, on cosl measures....

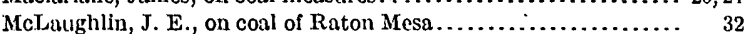
Mcl Laughtin mine, Colo., section at........................... 122-123

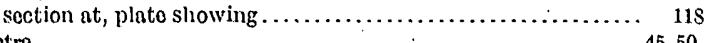

Mactrn............. alta........ $51,81,166,167,168,176,190,193,196,19 S, 199,202,210,213,217$

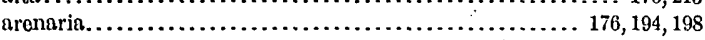
formosa................................. 176, 196, 202 gracilis........................................... 176, 202 subqundrata...................................... 30

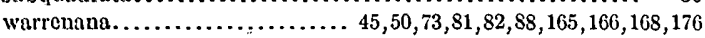
Madrid, N. Mex., sections at............................ 206-210 sections at, flguro showing.

Madrid cosl group' occurrence and character of.
Magnolia

Page. angustifolia.............60,67,104, 105, 113,121,123,127,133,135,136 $433,155,157,226,236,238,309,316,401,402,403$ attenuata ....................................226, 309 cordifolia.....................60, 127, 135, 236, 238, 315-316, 408,410 dayana. hilgardiana...................................6 60,125, $130,131,13 \overline{5}, 139,226,236,238,239, \mathbf{3 1 0}-311,313,401,40$

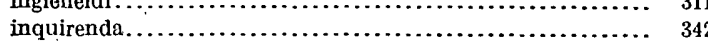
lancolata........................................ 309 laurifolia................... $60,135,226,236, \mathbf{3 0 9}-\mathbf{3 1 0}, 407,428$ leei $\ldots \ldots \ldots \ldots \ldots \ldots \ldots \ldots 6 . \ldots 6,124,143,236,238, \mathbf{3 1 3}, 386,887,403$ lesleyana..............60, 121, 124, 127, 157, 236, 238, 313-314., 404 magnifolia...... $60,101,104,105,110,114,121,124,125,127,128,133,135$, $139,143,155,157,158,226,236,237,238,311-313,316,400$

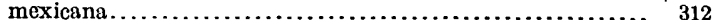
nordenskiöldi . . . . . . ovalis

regalis. . Magnoliaceae $\ldots \ldots \ldots \ldots \ldots \ldots \ldots \ldots \ldots \ldots \ldots .231,233, \mathbf{2 6 9}, \mathbf{3 0 9}-\mathbf{3 1 6}$

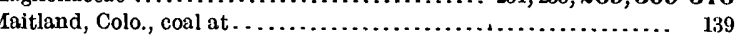
section near....................................... 139-140 Majestic, Colo. (loc. 112), fossils from...................... 131 geology at......................................... 131 section at. ....................................... 131-132 plate showing .......................................... 118 Malapoenna weediana................................ 317 Malvales............................. 233, 272-275, 336-341 Mancos shale, age of .................................... 174 character and relations of.................. 172-174, nassim 187-214 correlation of........................... 172-174, 192, 194, 200 figure showing............. 179 fossils of ................ 29, 175-177, 187-188, 193-203, 211, 213, 216 relations of, plates showing........................ 188, 214 sections of................... 194-195, 196-197, 199, 202-203, 213, 216 figures showing.............................. 188, 208, 214 views of........................................ 188 zones of Marcou, Jules, on coal measures............................ 18 Margarita........................................... 48 nebrascensis...................................45, 106 Marginaria nebrascensis................................ 176 Marginifera . ............................................. 42 wabashensis ............................................ Martesia..................................................... $43,186,189$ Mayne, Colo., fossils from ...............................

Meade, Frank, on coal of Pictou, Colo................ 30-31, 139-140 Meek, F. B., on correlation of coal measures.

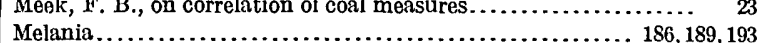

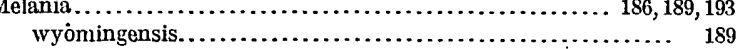
Menispernites....................................... 283 Metoicoceras.............................. 176, 195, 196, 197, 198 puercense.......................................... 176, 198 swallowi ......................................... 176, 196 Merriam, L. B., on coal of Colorado ...................... 32

Mesaverde formation, character and relations of. 178-180, passim, 203-214 coal measures of ............................. 206-211, 214 viow of........................................ 204 correlation of............ $34,169,171-172,178-180,187-189,192,194,218$ chart showing................................ 179 fossils from...................... 13,54-55, 175-177, 178, 179 $181-182,187,188,189,194,196,199,201-202,205,207,212,214$ relations of, plates showing....................... 188, 214 sections of............ 187, 194, 196, 199, 201-202, 205, 207-210, 212-213 figures showing ........................... 188, 208, 214

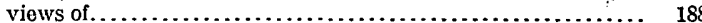

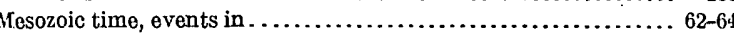
Modiola..........................................176,190, 202

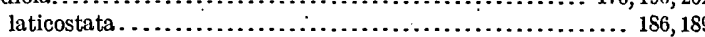
Monero, N. Mex., fossils from........................... 189 geology at............................................ 189

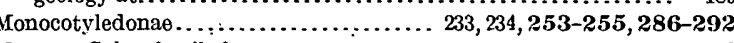
Monson, Colo., fossils from............................ 47, 136 Montana group, correlation of ........................... 171 occurrence and character of 


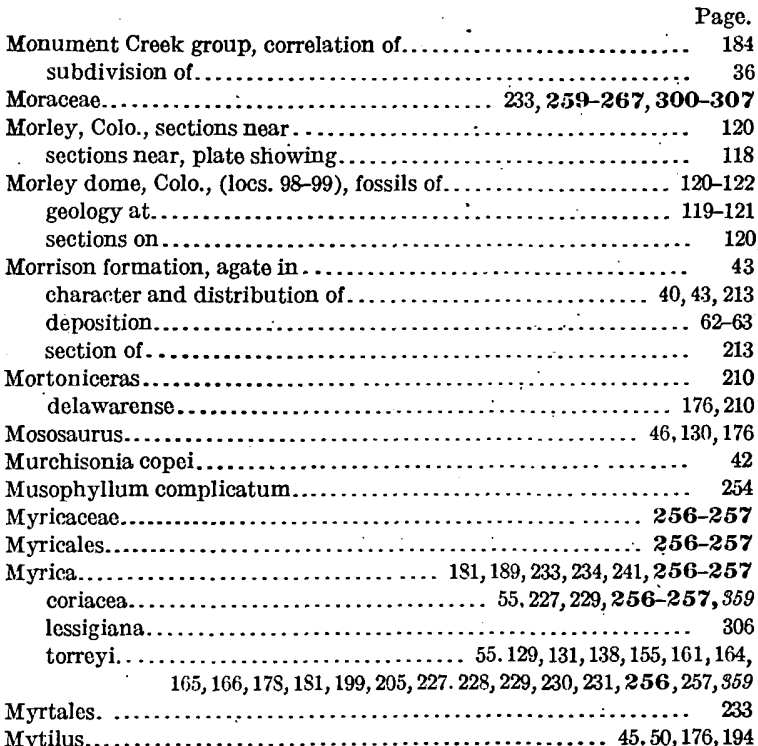

N.

Naiadales.........................................286-28 Natica.......................................... 32,217

Naticopsis altonensis ................................... altonensis gigantea................................ 42

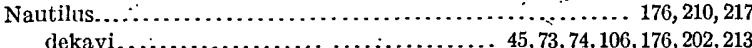
(1) lancifolia..................... $60,135,143,157,226,236,2388,318$, 442

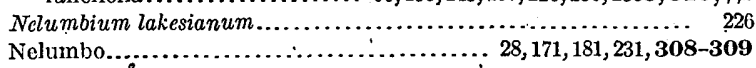

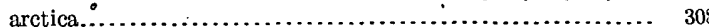
intermedia................................. 178, 202, 212 lakesiana.....................60,119, 171.192,226, 236, 237, 308-309

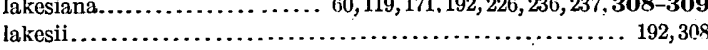

lutea.

tenuifolia.

Nomodon.

.

Newberry, J. S., on coal measures. ........... 14-15, 18, 19, 21, 23, 28, 225 on fossils from New Mexico...........................29, 225

North Curtis Creek, N. Mex., section on, plate showing........... 56

North Raton Creek, Colo., fossils from .................... 121-122

North Willow Canyon, N. Mex., section in . ............... 93 Nucula $45,106,170$ planimarginata........................... subplana. . ventricosa.

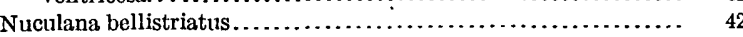
Nymphaeaceae.................................... 307-309

Nysse

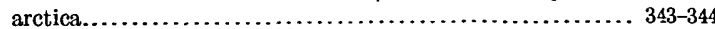
buddiana........................................ 330 lanceolata...................6 61, 124, 135, 236, 237, 330, 343, 490, 495 racemosa..................... $61,113,18 \overline{5}, 226,236,237,343-344$

Nyssidium.

\section{o.}

Oakdale, Colo., fossils from section at. ..

Vermiejo-Poison Canyon contact, figures showing Occidental mine, Colo., section at.

Odontobasis

Odontofusus.

Oleaceae.

Omera field, N. Mex , formations of ...................... 211 formations of, correlation of figure showing............... 179, 208 section in figure showing
Orbiculoidea convexa..................................... Page. missouriensis.....................................

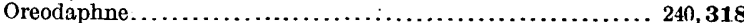

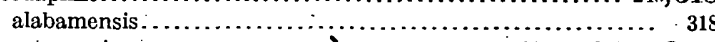
ratonensis............................. $60,133,236, \mathbf{3 1 8}, 410$ Oreodoxites................................. 235, 241, 287 plicatus.........................60, 155, 237, 284, 287, 291, 385

Osborn, H. F., and Earle, Charles, on Puerco beds...............

Osmanthus.......................................... 317 americanus........................................ 317

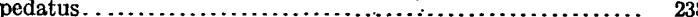
Osmunda. ..................................... 234, 241, 246-247

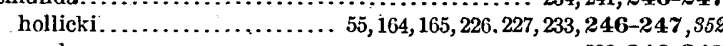
Osmundaceae................................. 233.246-247

Ostrea....................... 26, 46,47,50,72,130,136,177, 186, 187, $189,190,193,194,196,197,198,199,202,207,211,212,215,216,217$

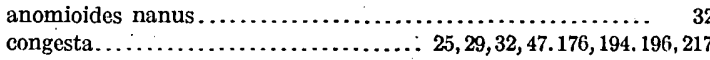
elegantula................................ 177, 193, 202,21 franklini ...................................... 30 glabra ........................................ 25, 31

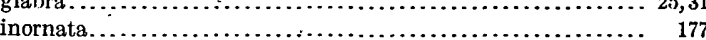
lugubris ..................... 29,30,32,148.177, 194,197,198, 202, 214 patina......................................46,51,177 pellucida............................46,50,106, 136, 177, 190 prudentia....................................... 30 sannionensis............................... 30,177, 198 soleniscus........................... 177, 194, 198, 212, 215 subtrigonalis.............................. 177, 18s, 191

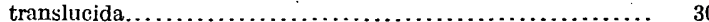
Owen, R. E., fossils collected by ..................... 15, 18 Owen, R. E., and Cox, E. T., on mines of New Mexico............. 18

Pachydiscus . ........................................ 177, 216 Pachythaerus cimarronensis............................. 48 Pagosa Junction, N. Mex., fossils from. ................ 191-192 geology at .................... 191-192 Palaeoaster.................................. 233, 278-279 inquirenda.... 55, 61, 90, 130, 138, 166, 228, 230, 236, 237, 278-279, 348 Paleontology, correlation by ............................. 11 See also Fossils.

Paleozoic time, events in............. 62

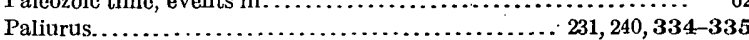
colombi. zizyphoides.... $61,121,236,237, \mathbf{3 3 4}-\mathbf{3 3 5}, 426$ Palmaceae............................. 230, 253-254, 287-292 Palmocarpon......................................... 241, $\mathbf{2 9 2}$

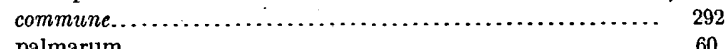

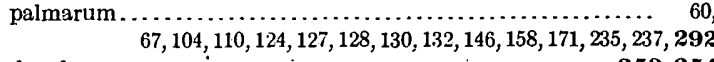

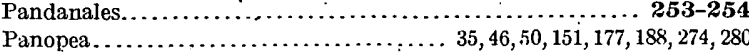
Panopea................................ $35,46,50,151,177,188,274,280$
Papilionaceat................................... 233. 269-270 Pecopteris sepulta.............................. 226, 246, 247 Pecten ............................... 35, 177, 189, 196, 197, 202, 213 Persea............................................... 192

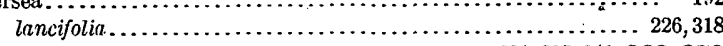

Phaseolites............................. 231, 235, 241, 269-270 crassus.......................... 55, 228, 229, 269-2 70, 367

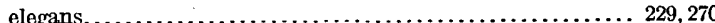

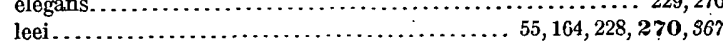
minutus........................... $55,105,181,191,228, \mathbf{2 7 0}, 375$ Phillipsia........................................ 42

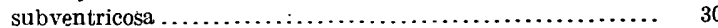
Pholas............................................. 186, 189 Phragmites............................................. 231, 287 oeningensis......................... 60, 235, 237, 250, 287

Phyllites . aurantiacus................................ $55,136,228, \mathbf{2 8 0}, 372$ castalioides............................... 55, 228, $\mathbf{2 8 2 - 2 8 3}$

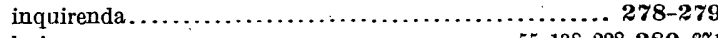
leei ................................55, 138, 228, 280, 871 nanus.......................... 55, 147, 151,228, 280, 372 neomericanus .................................... 
Phylltes populoides protophylloides. ratonensis... retusoides.

rosacfolius.

sapindus. vermojoansis. walsen burgensis

Physa.

Pictou, Colo., coal at. section noar.

Pictured Cliffs sandstone, correlation of. corrolation of, chart showing.

fossils of......

section of......

Pledmont mine, Colo. (loc. 101), section at. soction at, plate showing.

Piorre shale, character and distribution of corrolation of.

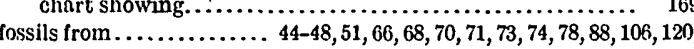
$129,130,136,144,145,148,158,161,165,167,175-177,217,218$ rolations of, plate showing sections of. $67,68-120,127-131,144-158$ plates

$67,68-120,127-131,144-158$

Piestochilus.

Pinaceavo...... Pinn Vititos mine, N. Mex., fossil wood near, view of.......... 204 $45,48,176$ section nt....................................... 205 Pinna.................. 30, 35, 46, 106, 177, 188, 193, 195, 196, 197, 202, 216 lnkesi 177,190 potrinn............................30,177, 195, 196, 197, 202, 213

Placenticeras................... 32, 46, 80, 88, 177, 193, 194, 202, 210, 217 costnto, intercalaro. intermedium placenta

planum.

rotundetum $32,46,80,88,177,193,194,202,210,217$ sancarlosanse................ 177, 193, 194, 196, 199, 202, 210, 213, 217 whitfigldi.

Placer Mountain. See Cerrillos field.

Platanaceno.......................... 231, 233, 269-270, 321-325

Platanus................... 55, 185; 223, 224, 227, 233, 269, 337, 342, 348 aceroides...............................60, 101, 105, 121, $125,143,192,226,236,237,239, \mathbf{3 2 1}, 322,323,324,885,419,485$ cuneatr..................................... 60, 236, 321

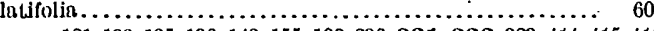
$121,133,135,136,143,155,192,236,321-322,323,414,415,416$ ................................. 19,60 $105,113,114,135,143,149,155,185,236,237,239,322-323,415$ heerii.....................60, 155, 226, 236, 323, 418, 419, 480 haydenil........................................ 171,322 marginata.................................. 278, 323,324,346 nobilis. occidentalis. piatanoides raynoldsii. . .........60,121,125, 143,171,185, 236,237, 239, 324,417 regularis ..........60, 236, 325, 495 rhomboidea ..............60, 108, 121, 143, 171, 226, 236, 237, 324-325 sp........................................... 269, 864 Plcurotomarin. perizomata.............

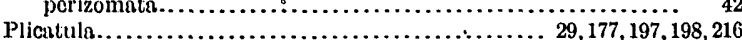
Ponceno... (287

Point of Rocks, Wyo., fossils from............................ 228

Poison Canyon formation, character and distribution of. $61,137,141,159,161$

correlation of

61

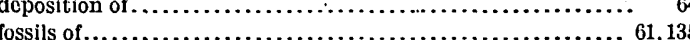
section of. 137,154

Polypodiaceao ...................... 232-233, 240, 244-246, 284-285

Polystichum............................. 231, 232, 234, 241, 244 hillsianum ................................... 227, 244

Ponil Canyon, N. Mox. (locs. 11-12), fossils from.............47, 75

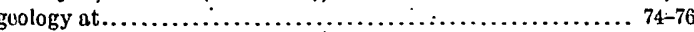
rocks in.

soction in.

plate showing
$\mathrm{P}$

Page.

297, 304,

balsamoides.................................... $\quad 19$

genatrix......................................... 337

grewiopsis...................................... 338-339

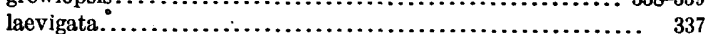

latior caudifolia ........................................ 337,338

monodon........................................... 226, 301

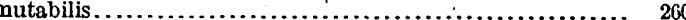

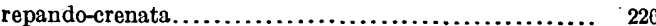

nebrascensis........................................ 171

neomexicana ......................... 55, 105, 227, 258-259, 375

neotremuloides.................60, 124, 135, 235, 296-297, 308

richardsoni....................................... 297

tremuloides........................................ 296

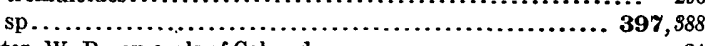

Potter, W. B., on coals of Colorado......................... 24

Powell Arroyo, Colo: (loc. 107-108), fossils from.................. 128

geology at...................................... 127-128

section in . ........................................... 128

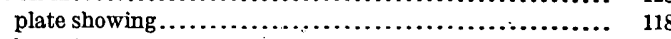

Prairie Crow Canyon, N. Mex., section in ....................... 91-93

Pre-Cambrian rocks, occurrence and character of .............. 40

Pre-Cambrian time, events in . .............................6.6.6. 61

Pre-Cretaceous rocks, fossils of ........................... 41-43 occurrence and character of ............................ 40-43 sections of ...................................... 41-42 See also Triassic; Carboniferous; Pre-Cambrian.

Prieta Mesa, N. Mex., section at. . ......................... 194-195

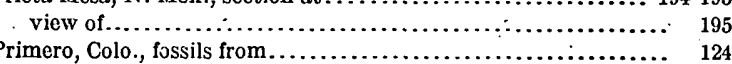
Prionocyclus...................................... 32, 194, 214 macombi................................... 29, 32, 214 wyomingensis................... 32, 148, 177, 189, 197, 198, 202, 214 Prionotropis.........................177, 194, 197, 198, 202, 211, 216 woolgari................................. 30, 32, 177, 214

Productus cora........................................ ${ }_{42}$ costatus........................................... 42 inflatus........................................... 42

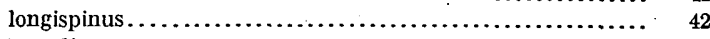

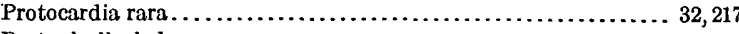

Protophyllocladus................................. 181, 202

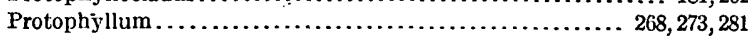
praestans ........................................... 281

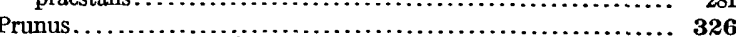
coloradensis . . . . . . . . . .

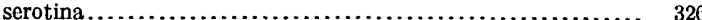

Pryor mines, Colo., fossils from ............................... 136 section in .......................................... 136

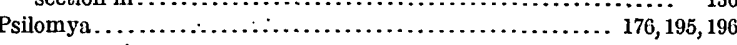
concentrica..................................... 35, 176

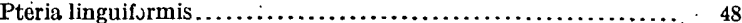

Pteridophyta.......................... 232-233, 244-249, 284-286 Pteris ................ 54, 153, 182, 227, 232, 234, 244-245, 284-285 crosa.... 54, 60, 164, 171, 226, 227, 228, 230, 235, 237, 244-245, 246, 284 linearis ...........................60, 119, 235, 284-285, 376 pseudopinnaeformis................................ 238

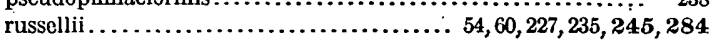
undulata......................................... 171 sp ......................................... 245,358

Pterocerella.................................... 177, 202 Pterospermites........................... 229, 231, 233, 241, 273-274

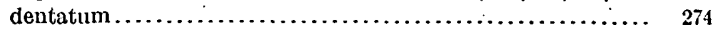
nervosus.......................... 55, 138, 228, 273-274, 870 undulatus............................ 51, 55, 165, 228, 273 wardii............................................... 228 Ptychoceras..............................46, 73, 74, 106, 177

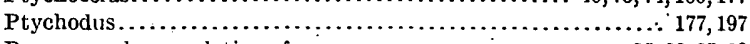
Puerco marls, correlation of ......................... 25, 26,27, 29 Punta de la Mesa sandstone, character and re'ations of .... 172, 174, 197 fossils from ...................................... 198

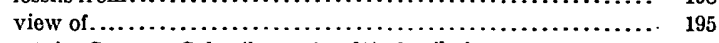

Purgatoire Canyon, Colo. (locs. 104-105), fossils from........... 42, 124 fossils from, bibliography of ........................ 1s geology at........................................ 126-127 sections in .............................. 41-42,126-127 views in ......................................... 124, 125 Purgatoire formation, character and distribution of........... 40,43-44 deposition of. 
Purgatoire River basin, Colo, fossils from geology at............................................... sections in. . . . . . . . . view in. . See also Purgatoire Canyon.

Purgatoire Valley area, Colo. (locs. 100-109), geology of........ 122-130 sections in, plates showing ........................ 118,142 See also Raton Canyon; Sopris; Reilly Canyon; Purgatoire Canyon; Trinidad; Powell Arroyo; Bowen.

Pyramidella

Pyrifusus............................... $46,72,73,177,190,193,194,202$ Pyropsis................................. 177, 194, 195, 196, 199, 202 bairdi.

Q.

Quaternary period, events in.......

Quercus...................... 31,32,171,182,186,187,188,191,202,207, $224,233,234,236,240, \mathbf{2 5 9}, \mathbf{2 9 7}-\mathbf{2 9 9}, 345$

angustiloba

breweri...

chlorophylla.

chlorophylloides.

consimilis

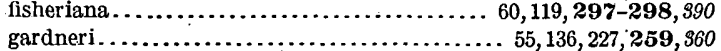

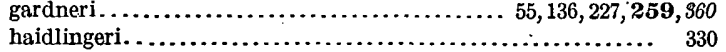

lyelli.

moorii.......................................... 226, 299

neomexicana......................... 60,113, 236, 298, 998

neriifolia .......................................... 226, 345

platania ....................................... 19, 226

ratonensis.......................... $60,113,236, \mathbf{2 9 8}-\mathbf{2 9 9}, 391$

rockvalensis ................... 55, 182, 191, 227, 259, 360

simplex........................ 60, 136, 143, 236, 298, 317, 392

undulata.

$R$.

Radiant, Colo., fossils from. geology at.

Rail Canyon, N. Mex., section in

Ranales.

.......

259

ex. (locs, 68-75), fossils from geology at..................................... 105-108 sections at and near.................................. 105-107 plate showing.

views near...

See also Raton; Bartlett Mesa; Sugarite Canyon.

Raton Canyon, Colo. (loc. 100), fossils from ................. 122-123 geology at.

$122-123$

section in.....

Raton coal, occurrence of

Raton field, N. Mex., coal of

fossils of

sections in, plates showing topography of

Raton formation, age of.

(a)

of. cliffs of, views of .................................. $68,94,110$ coal in. $49,59,70,86,88-90,95,104-118,134-135,137,147-148$ plate showing...

conglomerate at base of .............. 58,66-80,105-109, 118-158 coal in, plate showing............................ 146 gold in views of.

correlation of. chart showing.

$74,94,95,12$ deposition of... from $\ldots \ldots \ldots \ldots \ldots \ldots \ldots \ldots \ldots \ldots .12,60-61,67,86$, passim
$104-114,121-146,155,157,175-177,224,230-231,235-241,284-347$ correlation of, with Vermejo flora............ 230-231, 237-239 ecologic conditions of $\ldots \ldots . . . . . .239-240$

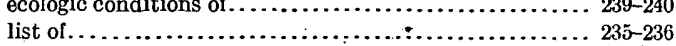

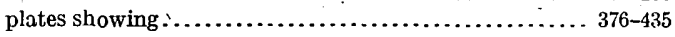

sections of.................................... $57,67,68-158$ plates showing........................56,108,118, 132, 142 unconformity at base of . ................... 55-56,96-97,99,100 figures showing...................... 74,96,97,99,100,169 fossils transgressing . . ...................... 231, 237, 240-241

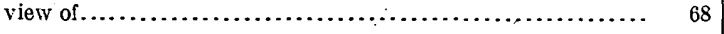

Raton Mesa colo. (locs. 94-97), Page. See also San Francisco Canyon; Gray Creek; Engle.

Raton Mesa region, Colo.-N. Mex., access to ................. 38 breaks of, view of $\ldots \ldots \ldots \ldots \ldots \ldots \ldots \ldots \ldots \ldots \ldots \ldots \ldots \ldots, \quad 38$ coal fields of ........................................... 38 geographic relations of $\ldots \ldots \ldots \ldots \ldots \ldots \ldots \ldots \ldots \ldots \ldots . .38-39$ See also Raton field; Trinidad field.

drainage of $\ldots \ldots \ldots \ldots \ldots \ldots \ldots \ldots \ldots \ldots \ldots \ldots \ldots \ldots \ldots, \quad 39$

formations of ............................ 162-217

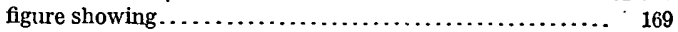

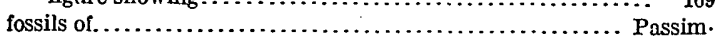

location of........................................ 39

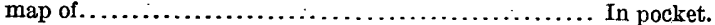

construction of ................. 10

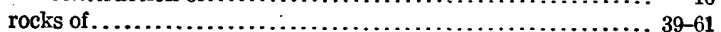

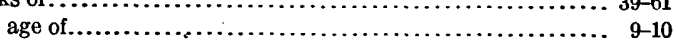

exposures of................................ 39

relations of, plates showing............... 48,74,95, 125, 136

sequence and character of ............................

See also Vermejo formation; Raton formation.

sections of, plate showing........................... In pocket.

topography of

Raton time, conditions in .................. 239-240

Raton tunnel, N. Mex., fossils from......................... 105

Raymond, R. W., on coal measures.............................. 19, 21

Reagan, A. B., on geology in New Mexico.................... ${ }_{32}$

Red beds, occurrence and character of ............................

Red River Canyon. See Canadian Canyon.

Red River Peak, N. Mex. (locs. 46-47), fossils from ............ 47,99 geology at..................................... $98-99$ sections on ...................................... 98,99

plate showing.................................. 56

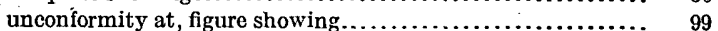

Reilly Canyon, Colo. (loc. 125), fossils from ..................... 125 geology at and near................................... 125-160 sections in ......

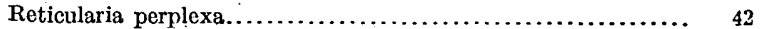

Rhamnaceae...................................... 271,332-336

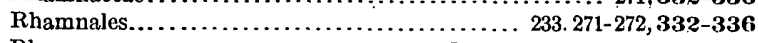

Rhamnus.......................... 233, 235, 240, 265, 271-272.334

aizoon

cleburni $105,121,135,139,146,157.158,192,236,237,265,332,334,435$

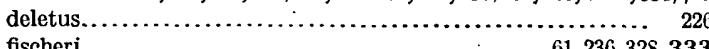
fischeri..............................66, 236, $328, \mathbf{3 3}$ goldianus............61,121, 135, 171, 236, 265, 332, 333-334, 429, 494 obovatus.............................. 61, 223, 236, 333

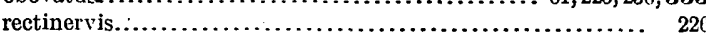
rossmässleri.............................................294, 295 salicifolius..................... 55, 127, 228, 231, 266, 271, 275 woottonensis $. \ldots \ldots \ldots \ldots \ldots \ldots \ldots \ldots \ldots \ldots .6 . \ldots 1,236, \mathbf{3 3 2 - 3 3 3}, 429$

Rhus................................. 231, 240, 328-329 viburnoides ........................ $611,21,236, \mathbf{3 2 8}-329,490$ Richardson, G. B., fossils collected by........... $50.119 ; 127,129-130,158$ map by

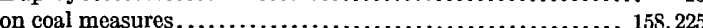
on geology of Trinidad field ............................. 16,35 on Monument Creek group .............................. on Trinidad sandstone...............................

Rio Puerco field, coal of bibliography of $\ldots \ldots 17,18,2$ coal-bearing rocks of................................ 195-198 correlation of................................. 13,29 formations of, correlation of....................... 184, 195 figure showing ................................... 179 fossils of ................................ 35, 175-177, 196-198 bibliography of.................................... 17,34,35 section in.................................... 195-190 view in ........................................... 195

Rito Leandro, N. Mex. (loc. 126-128), geology of. . ........... 149-151 sections near.................................. 149-151 plate showing .................................. 142 Rockland mine, Colo., fossils from............................ Rock Springs, Wyo., fossils from ........................ 228

Rockvale, Colo., fossils from......................... 164-165 geology at. ........................................ 164-165

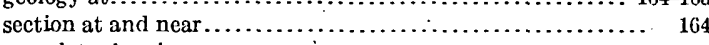
plate showing ..................................... 16

view of............................................ 160 
Rockvale sandstone, correlation of correlation of, chart showing occurrence and character of viow of.

Rocky Mountains, areas west of, formations of. formations of, correlation of fossils of. fossils east and west of, correlation of

Rocky Mountain region, submergence of unconformity cast and west of

Ragers field, $\mathrm{N}, \mathrm{Mox}$, formations of, corrclation of, figure showing....................................... 179, 208 section in.

Rollins sandstone, correlation of.

Rosaceac.

Rosales.

Rosellinites. lapideus.

$233,269,325-326$ ......................................... $54,226,227,242$ Rostcllarin texana.................................... ${ }_{32}$

Rostellites.......................................... 35, 196 ambigua.....................................30.32,214

.. 30,214 wellsi

Rotella verrucelifera.

Rouse, Colo., fossils from

Rubiales.

Rutacene. $233,275-278,346-348$

Solot

S.

Sabal communis grandifolia. inquirenda. Icci...... $109 . \ldots . .226 .289$ $0,101,130,139,235,289,290,388$ montana .................................. $51,55,120$, rugosa. ungeri. (1), $113,235,288-289,290,380$ $124,125,127,128,129,130,140,143,157,178,182,187,188,192,212$ 224, 226, 227, 228, 229, 230, 235, 237, 254, 289-291, 305, s79, 881

Sabalites. fructifer.

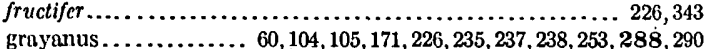

St. John, O. H., fossils collected by ......................25,47-48 on geology of Raton field............................... 15, 23 on Vermejo Park coals scetions by.

Salicnccae.

Salicaceao.

257-259, 296, 297

Salix .........55, 75, 147, 182, 186, 191, 196, 223, 227, 233, 234, 241, 257-258 angusta........................................... 257, 258 gardneri............................. 55, 136, 227, 257, 859 media.......................................... 258 plicata........................... 55, 136,164,227, 257-258, 359 stantoni.................................... 178, 182, 196 sp........

$\therefore 258,360$

Saltpeter Creek, N. Mex., geology on ...

Saltpeter Mountain, N. Mex. (loc. 27), fossils from................ 47, 88 gcology at...................................... 87-88 section on .............................................. 87-88 plate showing.

Salyers Creek, N. Mex. (loc 122); fossils from geology at........................................ 142-143 section on ................................... 85, 142-143 plate showing.

San Francisco, N. Mex., section at, plate showing. view near.

San Francisco Canyon, Colo. (locs 04-05), gavlogy at... scctions in ........................................ 116-117

San Francisco Pass, N. Mex.-Colo. (locs. 129-130), fossils from.... 47, 151 geology at...................................... 151-152 socticns in.

Sangre de Cristo Range. See Culebra Rangc.

Snn Miguel, Colo., section near. section near, plate showing.........

Santa Clara Creek, Colo., fossils from.... structural relations on, plate showing
Santa Fe, coal at, bibliography of ...................... Page. San Ygnacio, N. Mex., section near.................... 195-196

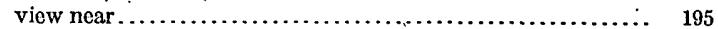
Sapindaceae. .................................... 330-331 Sapindales................................ 233, 271, 328-332 Sapindus ....................................... 231, 295, 296 affinis.......................... 61, 124, 236, 239, 296, 331, 481 caudatus..................... 61, 113, 171, 236, 237, 330-331, 428

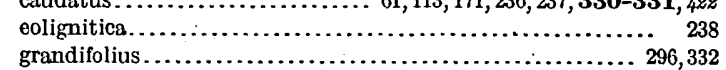
rocklandensis....................... 61, 139, 236, 331-332, 480 Scaphites..........................29, 30, 177, 193, 194, 196, 202, 213 hippocrepis $\ldots \ldots \ldots \ldots \ldots \ldots \ldots \ldots \ldots \ldots \ldots \ldots \ldots \ldots \ldots \ldots \ldots \ldots \ldots \ldots \ldots \ldots \ldots \ldots \ldots \ldots \ldots \ldots \ldots \ldots \ldots \ldots \ldots \ldots$
larvaeformis $\ldots \ldots \ldots \ldots \ldots \ldots$ nodosus............ 30,46, 48, 51, 72, 73, 106, 130, 136, 167,177, 190, 196 vermiformis.................................... 177, 194 - warreni....................... 29, 32, 177, 189, 194, 197, 198, 214, 216 Schizacaceae.............................. 233, 248-249, 285-286 Schizodus wheeleri.................................... 42 Schomberg Creek, N. Mex., geology near........................ Schrader, F. C., on coals of San Juan Basin................... 33-34 Scitaminales.............. 254-255 Scurria coniformis.................................... 32,214 Sedalia, Colo., fossils from............................... 170

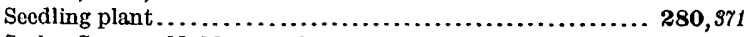
Seeley Canyon, N. Mex., geology at...................... 104 section in ...................................... 104

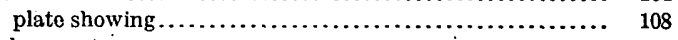
Seminula argentea $\ldots \ldots \ldots \ldots \ldots \ldots \ldots \ldots \ldots \ldots \ldots \ldots \ldots \ldots \ldots \ldots \ldots \ldots \ldots$
Sequoia.$\ldots \ldots \ldots \ldots \ldots \ldots$ Sequoia................................... 171, 241, 250-251 brevifolia ...................................... 226, 250 heterophylla................................... 251

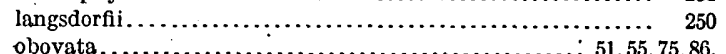
obovata............................... 227, 228, 229, 233, 246, 250-251, 263, 266, 358

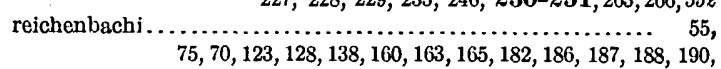
$75,70,123,128,138,160,163,165,182,186,187,188,190$
$207,212,266,227,228,229,231 ; 233,246,250,251,263,266$

sempervirens................................... 233, 234 washingtoniana ....................................... 233, 234 Serpula ............................... 48, 177, 188, 197 Shaler, M. K., on geology of San Juan Basin.................. 34 Sheridan, J. E., on coal mines of New Mexico.................... $34,35,86$ Shimer, H. W., and Blodgett, M. E., on geology of Rio Puerco... 34

Shumway, Colo., fossils from............................. 140-141 geology at....................................... 140-141 structural relations near, plate showing................... 130 Sigaretus textilis ................................... 30

Simpson, J. H., on coal on Rio Puerco, N. Mex............. 18

Sloan mine, N. Mex., rocks in........................... 204-205 Solemya............................................. 177, 198 Solen cuneatus.................................... 32,217 Soleniscus......................................... ${ }_{42}$

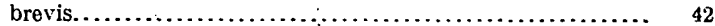

Sophora..................................... 240, 241, $3 \mathbf{2 6}$ henryensis................................... 238,326 nervosa................................. $141,236, \mathbf{3 2 6}, 417$

Sopris, Colo. (locs. 101-102), fossils from ................... 124 geology at................................. 123-124, 126 sections at and near......................... 123, 126-127 views near...................................... 124, 125 Sparganium ..................... 55, 161, 227, 231, 233, 235, 241, 253, 359 sp......................................... 25 Spencer, A. C., on Upper Cretaceous section.................... Spermatophyta.......................... 233, 249-278, 286-348 Sphaereaceae...................................... $\mathbf{2 4 2}$ Sphaeriola....................................... 167, 177, 188 Sphaeria lapidea...................................... 226, 242 Sphacrites lapideus.................................. 226, 242 Sphaerium.............................................. 186, 199 Sphaerodoma.................................................. ${ }_{42}$ texana $\ldots \ldots \ldots \ldots \ldots \ldots \ldots \ldots \ldots \ldots \ldots \ldots \ldots \ldots \ldots \ldots \ldots, 42$

Sphenodiscus...................................... 199 lenticularis.......................................... 30 Sphenopteris elongatum............................... 286

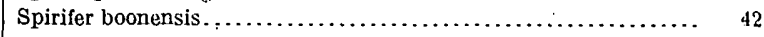

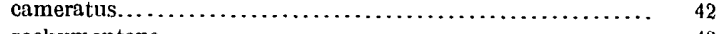
rockymontana................................. 42 


\begin{tabular}{|c|c|}
\hline & \\
\hline Spiriferina kentucl & ark, Colo. (locs. 130-133), geology in... \\
\hline Spironema.. & view in. \\
\hline Squamularia përplexa....... & See also Cuatro; Tercio; Cornell. \\
\hline Stanton, T. W., fossils determined by & Teredo. \\
\hline $98,217,218$ & Terminalla hilgardiana........ \\
\hline on Bowie shale fossils & lesleyana.. \\
\hline on Ceratops beds.. & radobnjensis... \\
\hline on Morrison formation & Tertiary period, events in. \\
\hline$\ldots \ldots \ldots \ldots \ldots \ldots$ & geologic violence in .......... \\
\hline$\ldots \ldots \ldots \ldots . . . . .$. & Tertiary system, character of... \\
\hline Stantonoceras guadalou pae........... & $\therefore 16,21,24,25 ; 58$ \\
\hline$\ldots \ldots \ldots \ldots 177,194,217$ & .. 184-185 \\
\hline$\ldots \ldots \ldots \ldots \ldots, 123$ & fossils of....... \\
\hline ........233, 241, 246 & fossil wood in, view of......... \\
\hline$\ldots \ldots \ldots \ldots 5,227,246$ & $\ldots \ldots .40,56-60$. \\
\hline ndary $\ldots \ldots \ldots \ldots \ldots 16,37$ & $11,55-50,220-221$ \\
\hline 3,$235 ; 240,241,272-273$ & $\ldots 74,96,97, \mathrm{i} 69$ \\
\hline$\ldots 61,113,236,337,424$ & $232,235,240-241$ \\
\hline$\ldots 55,228,229,272,370$ & Tetranthe \\
\hline 337 & $\ldots 232,242$ \\
\hline (n) & Thetis \\
\hline (n) & Thracias \\
\hline$\ldots \ldots \ldots \ldots \ldots \ldots+229$ & Thula. \\
\hline$\cdots \ldots \ldots \ldots \ldots \ldots$ & huya \\
\hline$\ldots \ldots \ldots \ldots \ldots \ldots, 337$ & bibliography of... \\
\hline 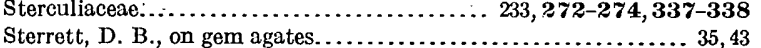 & $\ldots \ldots \ldots \ldots \ldots 198,201$ \\
\hline $\begin{array}{l}\text { gem agates.................................... } \\
\text { n coal measures. } 14,15,16,21-22,23,25-26,27,28,29,162\end{array}$ & $\cdots \cdots \cdots \cdots, \quad 200$ \\
\hline $\begin{array}{l}\text { asures. } 14,15,16,21-22,23,25-26,27,28,29,162 \\
\text { measures........................... } 25\end{array}$ & 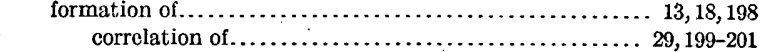 \\
\hline …..... 157 & 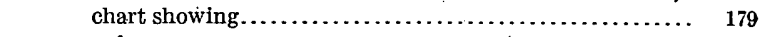 \\
\hline .............. & 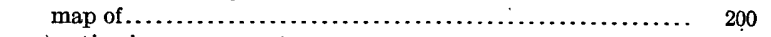 \\
\hline (locs. 134-136), geology in ............... 156-158 & $\ldots \therefore \ldots \ldots \ldots \ldots$ \\
\hline (n) & $\therefore \ldots \ldots \ldots \ldots$ \\
\hline ap., Colo. (loc. 135), fossils from ....................... & ….....336-337 \\
\hline (n) & $\ldots \ldots \ldots$ \\
\hline 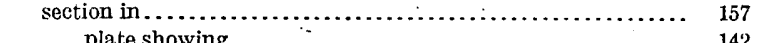 & , 236, 336-337 \\
\hline 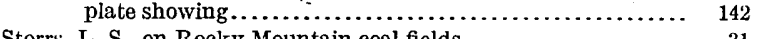 & Tiliace \\
\hline ocky Mountain coal fields..................... & art showing.................. \\
\hline 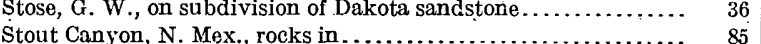 & $\ldots \ldots, 178,182,202,235$ \\
\hline 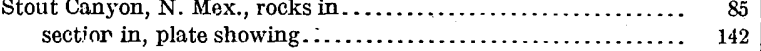 & $\begin{array}{l}.178,182,202,235 \\
\ldots \ldots \ldots \ldots\end{array}$ \\
\hline 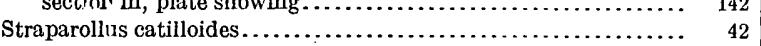 & 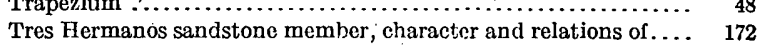 \\
\hline ( & $174,213-214$ \\
\hline 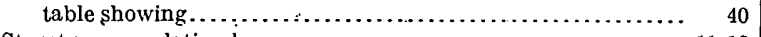 & $\ldots \ldots \ldots 213,214$ \\
\hline in by $\ldots \ldots \ldots \ldots \ldots \ldots \ldots \ldots \ldots \ldots \ldots \ldots \ldots \ldots \ldots \ldots \ldots \ldots, 11,12$ & ............ 203,214. \\
\hline$\ldots \ldots \ldots \ldots \ldots \ldots \ldots \ldots \ldots \ldots, 48,74,95,125,136$ & n......... \\
\hline ction at $\ldots \ldots \ldots \ldots \ldots \ldots \ldots \ldots \ldots \ldots \ldots \ldots \ldots, 131$ & nce and character of.. \\
\hline ing $\ldots \ldots \ldots \ldots \ldots \ldots \ldots \ldots \ldots \ldots \ldots \ldots \ldots \ldots \ldots \ldots, 118$ & ents in ......................... \\
\hline n, N. Mex. (locs. 83-84), fossils from.............. 110 & $\ldots \ldots \ldots \ldots \ldots \ldots \ldots \ldots \ldots$, \\
\hline (109-112 & a $\ldots \ldots \ldots \ldots \ldots \ldots \ldots \ldots \ldots \ldots \ldots \ldots \ldots \ldots \ldots \ldots \ldots \ldots \ldots \ldots \ldots \ldots, 196,197$ \\
\hline 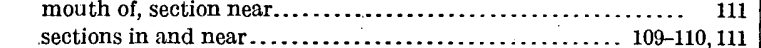 & $\ldots \ldots \ldots \ldots \ldots \ldots \ldots \ldots \ldots \ldots \ldots \ldots, 177,190$ \\
\hline 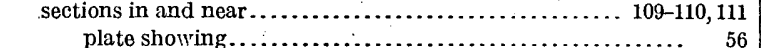 & ........... \\
\hline$\ldots \ldots \ldots+\cdots \cdots$ & . (loc. 10n), fossils from...... \\
\hline ce and character of ................... 104-118 & \\
\hline , N. Mex. (loc. 50), fossils of ............. 101-102 & 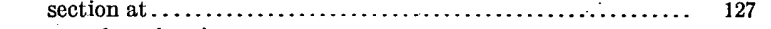 \\
\hline$\ldots \ldots \ldots \ldots \ldots \ldots, 101-102$ & 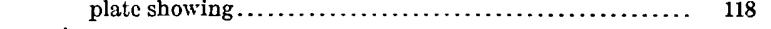 \\
\hline 101 & $\therefore \ldots \ldots \ldots+\ldots \ldots \ldots \ldots \ldots$ \\
\hline ( & bliography of........................ 17,24,27 \\
\hline 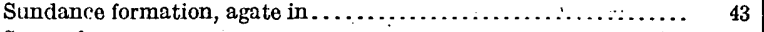 & n................... \\
\hline$\ldots \ldots \ldots .46,70,177,202$ & $\ldots \ldots \ldots \ldots \ldots$ \\
\hline $29,46,108,167,177,190$ & $\ldots \ldots+45-46,47$ \\
\hline (n) & 17 \\
\hline & ............ \\
\hline & ..... 118,132,133 \\
\hline (n) & $\ldots \ldots \ldots \ldots \ldots \ldots .38-39$ \\
\hline riformis.................................... & (n. \\
\hline Taxodium $. \ldots \ldots \ldots \ldots \ldots \ldots \ldots \ldots \ldots \ldots \ldots \ldots \ldots \ldots \ldots \ldots \ldots \ldots, 227,241, \mathbf{2 5 2}$ & Trinidad sandstone, age of ............. \\
\hline 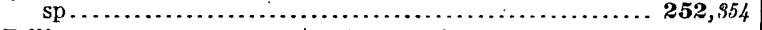 & distribution of $\ldots \ldots \ldots \ldots \ldots \ldots \ldots \ldots, 40,48-50,67-161$ \\
\hline$\ldots \ldots \ldots \ldots \ldots \ldots 25,46,50,81,177,190.193,194,195,196,202$ & 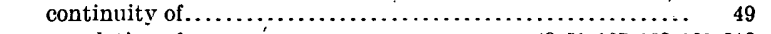 \\
\hline alis.............................................. & of $\ldots \ldots \ldots \ldots \ldots \ldots \ldots \ldots \ldots \ldots \ldots \ldots \ldots+48-51,167,168-169,218$ \\
\hline 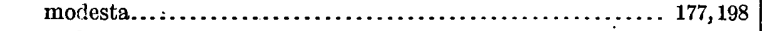 & owing.................... \\
\hline n.................. & (n) \\
\hline$\ldots 46,50,75,146,151,165,168,177,187,189,274,280$ & 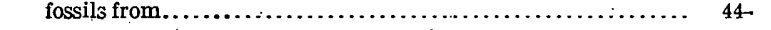 \\
\hline winslowi......... & $47,50,54-55$, passim $67-84,88,91-95,105,106,107$, \\
\hline oc. 132), fossils from. & 110. $120.122,1$ \\
\hline 5 & showing \\
\hline …... 15 & $\ldots 48,56,108,132,142$ \\
\hline & \\
\hline
\end{tabular}


Page. Tritonlum kanabense... Truj Illo, Colo., fossils from................................... Tulotoma...

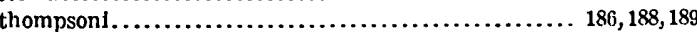

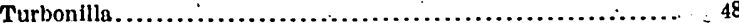

Turkoy Canyon, N. Mex. (loc. 9), fossils from.................. 71-72 goology at........................................ 71-72 section in.

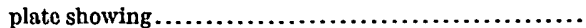

Turkey Creok, N. Mex. (loc. 28), fossils from.................. geology at ......................................... $88-89$ soction on$$
\text { plate showing }
$$

Turner mine, Colo., fossils from .................. 121

Turrilites............................................ 35

Turris.

$29,35,48,177,188,195,196,19 ?, 198,202,213$

Turritella.................. $29,35,48,177,188,19,190,197,198,22,213$

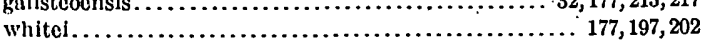
whitci

Typha.........

$177,197,202$

$\mathrm{U}$.

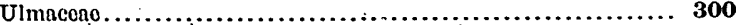

Ulmus.........................................60,128, 236.241,300 irregularis...................................... 204 tenuinervis $\ldots \ldots \ldots \ldots \ldots \ldots \ldots \ldots \ldots \ldots \ldots \ldots, 300$ sp ............................................ 300,998

Umbellales

Una dol Gato fiold, N. Mex., coal of ........................ 34

Unconformity, Crotaceous-Tertiary, bibliography of ...........34,35, 30 character of ................................. 55-50, 220-221 conglomerate at...................................... 10 correlation of ................................. 12.220-221 figuro showing $\ldots \ldots \ldots \ldots \ldots \ldots \ldots \ldots \ldots \ldots \ldots \ldots \ldots \ldots \ldots \ldots \ldots \ldots \ldots, 219$

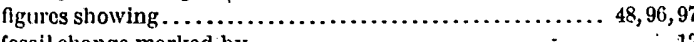

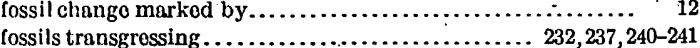

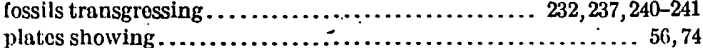

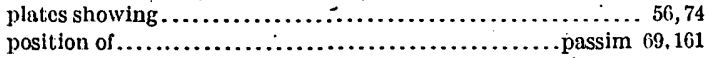
chart showing................................. 169

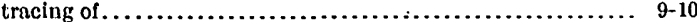

Unio....................................... 104, 186, 188, 189 aldrichi brachyopisthus...................................... 186, 189 holmesianus................................. 186, 188, 189

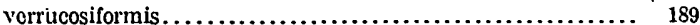

Upper Cretrceous series, disposition of ..................... 63-64 occurrenco and character of.

Urticales ...

Uto Irark, N. Mex. (locs. 2-5), $X$

fossils, at and near..... gcology at.................... 67-69 section, at and near..........................................6. $67-68$ plato showing $\ldots \ldots \ldots \ldots \ldots \ldots \ldots \ldots \ldots \ldots \ldots \ldots \ldots \ldots \ldots \ldots \ldots \ldots \ldots \ldots, 108$ V.

Van Bremmer Creek and Canyon, N. Mex. (locs. 17-18), fossils from.................................47, 80-82

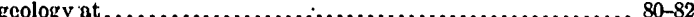
sections on ........ - plato showing..

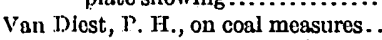

Van Frouten, N. Mex. (locs. 41-45), geology, at and near ........ 94-98 rocks near, views of ................ 94,95 sections at and near............................. 95, 97,98

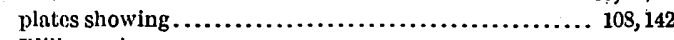
See Willow mine.

Van Houten area, N. Mex. (locs. 41-47), geology in ............. 94-99 Scc also Van Houten; Red River Peak.

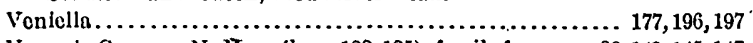

Vermejo Canyon, N. Mex. (locs. 122-125), fossils from.... 86, 143, 145-147 geology of ...................................... 141-148 sections in . . . . . . . . plate showing.................................. 142 Sce also Salyer's Creek; Vermejo Park.
Vermejo formation age of Page. distribution....................................... $51-54,62$ character and distribution of ............. 40,51-64,68-107, 117-160 coal of.... 49-50, 52-53, passim 72-77, 80-100, 103-107,117-141, 145, 161 faults in, figures showing.................... 96-97 correlation of $\ldots \ldots \ldots \ldots \ldots \ldots \ldots \ldots \ldots \ldots \ldots \ldots . .12,168,169,218-219$ chart showing ....................................... 169

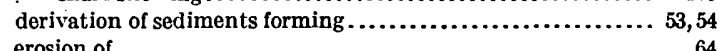
erosion of ....................................... fossils from..................................... 12R-131, 136-147, 153, 155, 158, $164-168,168,223,226-235,242-283$

biological relation s of . ......................... 232-233 correlation of ................................. 228-232 ecologic conditions of................................ 233-235

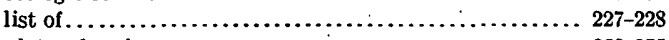
plates showing .............................. 352-375 relations of plates showing........................ 48, 125 sections of .......................... 51, 68-107,117-160, 163-167 plates showing .....................48, 56, 108, 118, 132, 142 unconformity at top of ..................... 74,55-56,96-97 figures showing $\ldots \ldots \ldots \ldots \ldots \ldots \ldots \ldots \ldots \ldots \ldots 48,74,96,97,169$ fossils transgressing....................... 232.237, 240-241 view of ......................................... 124 See also Rockvale sandstone member.

Vermejo Gap, N. Mex., hogback in, view of ................ 147 sections near.................................... 150-151 plate showing ................................ 142

Vermejo Park, N. Mex., (locs. 123-125), fossils from.... 45-46, 47, 144-147 geology at ................................... 143-148 sections in ................................... 143-140 plate showing.

Vermejo time, conditions in . . ............................ 234-235 Viburnum ...................... 55, 171, 182,192, 202, 228, 233, 235, 240

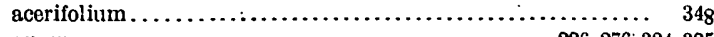
anceps................................. 226, 276; 324. 325 anomalinervum ............ 55, 118, 226, 228, 229, 230, 275-276, 367 antiguum..................................... 192 contortum.......................... $61,139,226,236, \mathbf{3 4 6}-\mathbf{3 4} 7,430$ crassum............................ 55, 228, 277-278, 974 cuneatum...................................... 348 hesperium................................... $55,164,228,276,87.1$ lakesii............................. $61,236,237,348,482$ magnum............................61,121, 139, 236, 347, 438 marginatum................... 171, 226, 276, 277, 278, 323, 346-347 montanum................. 55, 164, 165, 228, 230, 276, 277, 278, 374 newberryanum................................... 347

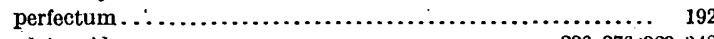
platanoides $. . \ldots \ldots \ldots \ldots \ldots \ldots \ldots \ldots \ldots \ldots \ldots \ldots 226,276,323,348$ problematicum...... 55, 164, 182, 196, 228, 229, 230, 276-277, 347, 571 rhamnifolium............................ 55, 228, 230, 277, 969 rotundifolium....................................... 276

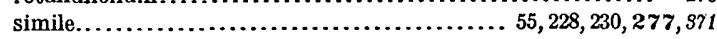
speciosum.........................61, 125, 192, 236, 347, 498 whympert. ................................. 226, 230,275 wootonianum.......................... $61,121,236,347-348,499$

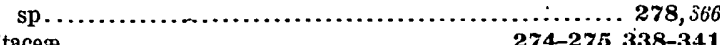
Vitaceæ............................... Vitis............................. 233, 240, 274, 275, 338-340 aestivalis..................................... 339 bruneri............................................ 339 carbonensis....................................... 339

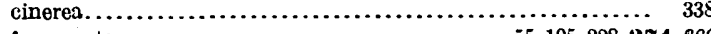
fragmenta........................... 55, 105, 228, 274, 369 inominata.............................. $61,139,236, \mathbf{3 3 9 - 3 4 0 , 4} 49$

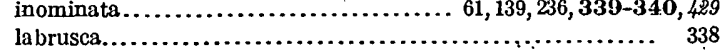

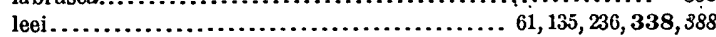
olriki.......................... 61, 108, 171, 236, 237, 338, 339 platanifolia............................. 61, 125, 236,339, 425 Viviparus......................................... 104, 186, 188, 189 Volcanic plugs, views of ................................... 194 Volutoderma.......................46,136, 177, 193, 194; 198, 210, 213 dalli..................177, 202

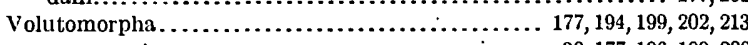

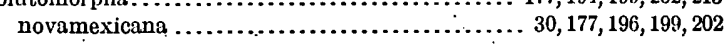


Page.

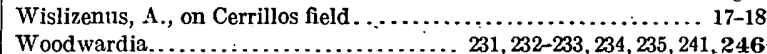
Woodwardia......................... 231, 232-233, 234, 235, 241, 246 crenata ....................... 55, 160, 178, 227, 228, 229, 216, 266 latifolia ......................................... 171

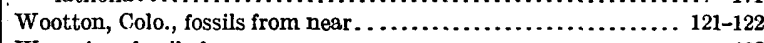

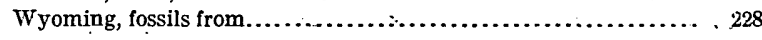
$\mathrm{x}$.

Xanthoxylum ........................................ 241, 328 dentatum...................................... 328

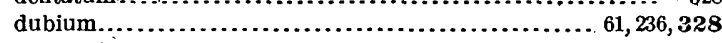

Y.

Yankee area, N. Mex. (locs. 84-93), coal of . . .............. 111-112 geology of ... view near.

See also Sugarite Canyon, mouth of; Yankee mines; Johnson Mesa; Horseshoe and Barilla mesas.

Yankee mines, N. Mex. (locs. 85-86), coal of.................. 112,113 fossils of .............................................

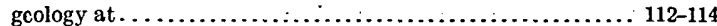
section at. ..................................... 112-113 Yoldia scitula........................................... $45,106,176$

' $\quad$ Z:

Zaphrentis

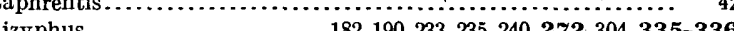
distortus...................................... 226, 272, 336 fibrillosus..... 61, 104, 113, 133, 135, 143, 226, 236, 237, 272, 335-336, 484 meiggsii.................... 61, 113, 143, 226, 236, 238, 336, 42t',422 paliurifolius........................... 51,55, 228, 272, 869 